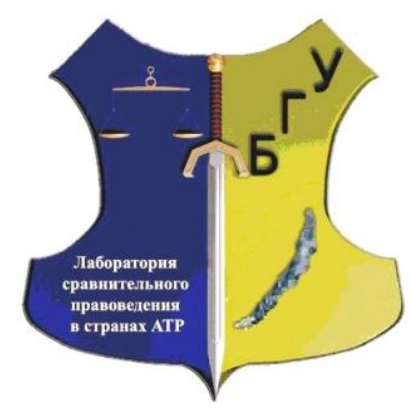


MINISTRY OF EDUCATION AND SCIENCE OF THE RUSSIAN FEDERATION BURYAT STATE UNIVERSITY

Laboratory of Comparative law in the Asia-Pacific region

Center of legal maintenance of interaction of the Russian Federation with the countries of APR

Faculty of Law

supported by

Supreme Court of the Republic of Buryatia,

China University of Political Science and Law,

University of Law Enforcement officers of Mongolia

\title{
COMPARATIVE JURISPRUDENCE \\ IN THE COUNTRIES OF ASIAN-PACIFIC REGION - VII
}

\author{
Materials of the international scientific conference young scientists, \\ postgraduate, masters and students
}

(Ulan-Ude, April, 15, 2016)

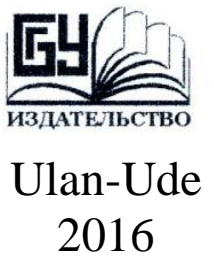


МИНИСТЕРСТВО ОБРАЗОВАНИЯ И НАУКИ РОССИЙСКОЙ ФЕДЕРАЦИИ БУРЯТСКИЙ ГОСУДАРСТВЕННЫЙ УНИВЕРСИТЕТ

Лаборатория сравнительного правоведения в странах Азиатско-Тихоокеанского региона

Центра правового обеспечения взаимодействия России со странами АТР

Юридический факультет при поддержке

Верховного суда Республики Бурятия, Политико-юридического университета КНР, Университета правоохранительной службы Монголии

\section{СРАВНИТЕЛЬНОЕ ПРАВОВЕДЕНИЕ В СТРАНАХ АЗИАТСКО-ТИХООКЕАНСКОГО РЕГИОНА - VII}

Материаль международной научно-практической конференциии молодых ученых, аспирантов, магистрантов и студентов

(Улан-Удэ, 15 апреля 2016 г.)

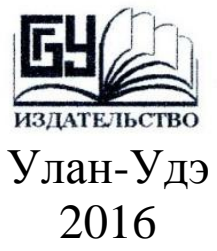




\author{
Ответственный редактор \\ Ю. П. Гармаев \\ доктор юридических наук, профессор
}

\section{Редакционная коллегия}

Ю. И. Скуратов, д-р юр. наук, проф.; К. А. Будаев, канд. юр. наук, доц.; В. М. Мельников, канд. психол. наук., доц.; Е. А. Мурзина, канд. юр. наук, доц.; Э. Л. Раднаева, канд. юр. наук, доц.; Н. Б. Садыков, доц.; Ю. Г. Хамнуев, канд. юр. наук, доц.; Ю. В. Хармаев, канд. юр. наук, доц.; С. Д. Хуташкеева, канд. ист. наук, доц.; О. В. Хыликтуев, канд. юр. наук, проф.; И. А. Шаралдаева, д-р экон. наук, проф.; Е. В. Гулина (отв. секретарь)

Текст печатается в авторской редакции

C 75 Сравнительное правоведение в странах Азиатско-Тихоокеанского региона-VII: материалы международной научно-практической конференции молодых ученых, аспирантов, соискателей, магистрантов и студентов (г. Улан-Удэ, 15 апреля 2016 г.) / отв. ред. Ю. П. Гармаев. - Улан-Удэ: Издательство Бурятского госуниверситета, 2016. -358 c.

ISBN 978-5-9793- 0882-1

SPLN 001-000001-3012-FT

DOI 10.18411/SBORNIK_ATR-7_2016

IDSP 000001:SBORNIK_ATR-7_2016

В настоящий сборник уже традиционно вошли статьи молодых ученых, аспирантов, магистрантов и студентов вузов России, Китая, Монголии, посвященные актуальным теоретическим и практическим проблемам сравнительного правоведения стран Азиатско-Тихоокеанского региона.

Сборник предназначен для ученых, студенческой молодежи и аспирантов, преподавателей вузов, юристов-правоприменителей, а также для широкого круга читателей, интересующихся сравнительным правоведением и правом стран АТР, международным сотрудничеством в различных сферах общественных отношений.

Comparative pravovedenie in the Asia-Pacific Region-VII: proceedings of the international scientific-practical conference of young scientists, graduate students, job seekers, graduates and students (Ulan-Ude, April 15, 2016) / resp. ed. Y. P. Garmaev. - UlanUde: Buryat State University Publishing Department, 2016. - 358 p.

ISBN 978-5-9793- 0882-1

SPLN 001-000001-3012-FT

DOI 10.18411/SBORNIK_ATR-7_2016

IDSP 000001:SBORNIK_ATR-7_2016

This collection has traditionally included articles of young scientists, graduate students, undergraduates and students of universities in Russia, China, Mongolia, on topical theoretical and practical problems of Comparative Law of the Asia-Pacific region.

The volume is intended for scientists, students and post-graduate students, university professors, lawyers, law enforcers, as well as for a wide range of readers interested in comparative law and the right of the Asia-Pacific countries, international cooperation in various spheres of public relations. 


\section{ПРЕДИСЛОВИЕ}

Как известно, Азиатско-Тихоокеанский регион объединяет 58 государств, расположенных по периметру Тихого океана, и многочисленные островные государства в самом океане. Принято также к региону относить Монголию, Непал, Союз Мьянма, Индию. Как верно отмечает Т. Я. Хабриева: «В связи с тем, что роль Российской Федерации в развитии азиатско-тихоокеанского сотрудничества возрастает, важно провести глубокий и всесторонний анализ экономических и особенно правовых проблем взаимодействия глобализационных и интеграционных процессов в данном регионе, что в конечном счете призвано обеспечить использование экономического, технологического и политического потенциала АТР для роста российской экономики, которому будут содействовать преимущества регионального интеграционного проекта. Правовые системы государств АТР имеют значительные особенности, они сохранили уникальные правовые традиции и прошли длительный путь развития. Однако эти обстоятельства не препятствуют формированию правовых механизмов долгосрочного торгового, экономического и инвестиционного сотрудничества. Задача юридической науки состоит в том, чтобы, учитывая юридико-цивилизационные особенности стран АТР, предлагать адекватные правовые решения для достижения консенсуса при определении механизмов устойчивого и справедливого развития всех государств региона» ${ }^{1}$.

Думается, что особая роль в сравнительно-правовых исследованиях должна принадлежать гордости и надежде любой нации - студенческой молодежи. Ведь именно ей в самом недалеком будущем придется взять на себя всю полноту ответственности не только за развитие собственной страны, но и за укрепление дружбы и сотрудничества во всем Азиатско-Тихоокеанском регионе, во всем мире.

Ежегодная Международная научно-практическая конференция молодых ученых, аспирантов, магистрантов и студентов, проводимая БГУ в апреле каждого года, в 2016 году предшествовала проведению еще более крупного научного мероприятия - Международного научного форума «Россия - Монголия - Китай: вопросы взаимодействия и сотрудничества в условиях XXI века», прошедшего 20-24 июня 2016 года на территории России и Монголии. В таком формате мероприятие было проведено впервые, собрало известных ученых, преподавателей права и практических работников, и стало одним из крупнейших событий в научной жизни юристов стран АТР. Трудно переоценить значение двух последовательно проводимых научных мероприятий в деле расширения и укрепления международного правового сотрудничества. При этом все было задумано и реализовано так, что результаты исследований и правоприменения старшего поколения активно подхватывает и развивает поколение молодое.

Если в первые годы проведения конференции, в силу новизны проекта, оргкомитет принимал практически все заявки, то сейчас у нас появилась объективная возможность вести отбор выступлений и тезисов. Эволюция компаративистики определяется необходимостью развивать дидактику, качество подготовки будущих юристов. Соответственно, оргкомитет конференции сделал акцент на более тщательном руководстве научной работой молодых ученых. Мы по мере сил помогали молодежи в их исследовательской деятельности

Хорошее знание языков стран АТР, владение законодательством России и других азиатских стран в сравнительно-правовом аспекте может дать будущим юристам высокие гарантии успешного трудоустройства и блестящей карьеры. Именно поэтому интерес к Международной молодежной конференции постоянно растет, а количество заявок на участие в ней год от года превышает самые смелые прогнозы. В этом году в адрес оргкомитета поступило 228 заявок на участие, в том числе, из Китая (города: Пекин, Маньчжурия, Харбин, Цицикар, Шанхай и др.) и Монголии (г. Улан-Батор). Были приняты доклады из 11 городов России: Владивосток, Екатеринбург, Ижевск, Иркутск, Москва, Нижний Новгород, Новосибирск, Симферополь, Смоленск, Улан-Удэ и Чита.

Теперь несколько слов о том, как была проведена конференция. На торжественном открытии международного молодежного научного форума с приветственным словом выступили: ректор БГУ, д-р техн. наук, професcop Н. И. Мошкин, председатель Верховного Суда Республики Бурятия, заслуженный юрист Республики Бурятия, канд. юр. наук А. А. Кириллова, старший научный сотрудник Центра правового обеспечения взаимодействия РФ со странами АТР БГУ, доцент Чаньчуньского политехнического университета КНР, д-р юр. наук, профессор Лян Миньянь, вице-консул Генерального консульства Монголии в г. Улан-Удэ Шаранжамц Амарсанаа, декан юридического факультета Новосибирского государственного технического университета, заведующий кафедрой уголовного права и процесса, канд. юр. наук, доцент С. А. Поляков, директор Департамента правовых исследований Байкальского филиала Гуманитарного института (г. Москва) Т. А. Осипова, зам. начальника уголовно-исполнительной инспекции Федеральной службы исполнения наказаний России по Республике Бурятия, полковник внутренней службы, канд. юр. наук А. А. Кочетов, декан юридического факультета БГУ, канд. психол. наук, доцент В. М. Мельников.

На пленарном заседании с докладами выступили участники конференции из Монголии, Китая и России, после чего конференция продолжила свою работу в пяти секциях:

\footnotetext{
${ }^{1}$ Хабриева Т. Я. Россия в Азиатско-Тихоокеанском регионе // Глобализация и интеграционные процессы в АзиатскоТихоокеанском регионе (правовое и экономическое исследование): монография / Н. М. Бевеликова [и др.]; под ред. Т. Я. Хабриевой. М.: ИЗиСП, ИНФРА-М, 2014. С. 5-6.
} 
Секция № 1: «Конституционно-правовые и административно-правовые институты стран АТР: сравнительно-правовой аспект». Ведущим секции выступил заслуженный юрист Российской Федерации и Республики Бурятия, канд. юр. наук, профессор БГУ К. А. Будаев. В рабочий президиум секции, которому было поручено заслушать и оценить доклады молодых ученых, вошли: зав. кафедрой конституционного, административного и муниципального права ЮФ БГУ, канд. юр. наук, доцент Ю. Г. Хамнуев; и.о. директора Бурятского филиала Академии труда и социальных отношений, канд. ист. наук, доцент С. Д. Хуташкеева; ст. преподаватель кафедры конституционного, административного и муниципального права ЮФ БГУ, канд. юр. наук Е. С. Алексеева; ст. преподаватель кафедры конституционного, административного и муниципального права ЮФ БГУ А. Г. Тышкенова; преподаватель кафедры конституционного, административного и муниципального права ЮФ БГУ С. В. Дагангаров; магистр юриспруденции, ассистент кафедры конституционного, административного и муниципального права ЮФ БГУ О. А. Гатаулина; ассистент кафедры конституционного, административного и муниципального права ЮФ БГУ Ж. А. Васильева.

Секция № 2: «Международное право и международные отношения». Ведущим секции выступил зав. кафедрой международного права и международных отношений ЮФ БГУ, заслуженный юрист Российской Федерации, канд. юр. наук, профессор БГУ О. В. Хышиктуев. В рабочий президиум секции вошли: доцент кафедры международного права и международных отношений ЮФ БГУ, канд. юр. наук, доцент Б. С. Семенов; заведующий кафедрой теории и истории государства и права, конституционного права ЮФ ВСГУТУ, канд. полит. наук, доцент П. Н. Дудин; директор Восточного института БГУ, доцент кафедры международного права и международных отношений ЮФ БГУ, канд. пед. наук, доцент И. Г. Актамов; ст. преподаватель кафедры международного права и международных отношений ЮФ БГУ, канд. юр. наук Е. О. Мадаев; преподаватель кафедры международного права и международных отношений ЮФ БГУ, канд. ист. наук, доцент Н. С. Баранова; старший преподаватель кафедры теории и истории права и государства ЮФ БГУ М. Д. Цыбикова; ассистент кафедры международного права и международных отношений ЮФ БГУ Е. И. Савицкая.

Секция № 3: «Гражданско-правовые проблемы сравнительного правоведения в странах АТР». Ведущими секции выступили зав. кафедрой гражданского права и процесса ЮФ БГУ, заслуженный юрист Республики Бурятия, канд. юр. наук, доцент Е. А. Мурзина и ст. преподаватель кафедры гражданского права и процесса ЮФ БГУ С. В. Доржиева. В рабочий президиум секции вошли: доцент кафедры гражданского права и процесса ЮФ БГУ, канд. биол. наук Р. А. Балдаева; ст. преподаватель кафедры гражданского права и процесса ЮФ БГУ, канд. юр. наук А. Х.-И. Шатуева; ст. преподаватель кафедры гражданского права и процесса ЮФ БГУ Д. К. Миронова; директор Департамента правовых исследований Байкальского филиала Гуманитарного института (г.Москва) Т. А. Осипова; ассистент кафедры гражданского права и процесса ЮФ БГУ Ж. Т. Ламбаев.

Секция № 4: «Уголовно-правовые и криминологические проблемы сравнительного правоведения в странах АТР». Ведущими секции выступили зав. кафедрой уголовного права и криминологии ЮФ БГУ, канд. юр. наук, доцент Э. Л. Раднаева и декан ЮФ Новосибирского государственного технического университета, канд. юр. наук, доцент С. А. Поляков. В рабочий президиум секции вошли: доцент кафедры уголовно-правовых дисциплин ЮФ ВСГУТУ, канд. юр. наук Е. И. Попова; доцент кафедры уголовного права и криминологии ЮФ БГУ, канд. юр. наук, доцент В. В. Иринчеев; доцент кафедры уголовного права и криминологии ЮФ БГУ, канд. юр. наук Т. И. Эрхитуева; заместитель декана ЮФ БГУ, канд. юр. наук, доцент А. В. Доржиев; доцент кафедры уголовного права и криминологии ЮФ БГУ А. Н. Мяханова; ответственный по научно-исследовательской работе студентов юридического факультета Новосибирского государственного технического университета О. А. Исаева.

Секция № 5: «Уголовно-процессуальные и криминалистические проблемы сравнительного правоведения. Правоохранительные органы в странах АТР». Ведущими секции выступили зав. лабораторией сравнительного правоведения в странах АТР, профессор кафедры уголовного процесса и криминалистики ЮФ БГУ, д-р юр. наук, профессор Ю. П. Гармаев и зав. кафедрой уголовного процесса и криминалистики ЮФ БГУ, заслуженный юрист Республики Бурятия, канд. юр. наук, доцент Ю. В. Хармаев. В рабочий президиум секции вошли: декан ЮФ БГУ, канд. психол. наук, доцент В. М. Мельников; доцент кафедры уголовного права и криминологии ЮФ БГУ, заслуженный юрист Республики Бурятия, канд. юр. наук, доцент С. К. Бураева; зав. лабораторией криминалистики, доцент кафедры уголовного процесса и криминалистики ЮФ БГУ, заслуженный юрист Республики Бурятия Н. Б. Садыков; ст. преподаватель кафедры уголовного процесса и криминалистики ЮФ БГУ, канд. юр. наук Б. Б. Самданова; ст. преподаватель кафедры уголовного процесса и криминалистики ЮФ БГУ, заслуженный юрист Республики Бурятия, заслуженный юрист Украины Е. Н. Науменко; преподаватель кафедры уголовного процесса и криминалистики ЮФ БГУ К. С. Латыпова; магистр юриспруденции, ассистент кафедры уголовного процесса и криминалистики ЮФ БГУ Н. И. Шаликова.

На заключительном пленарном заседании конференции были подведены итоги научного форума. Авторы лучших докладов по целому ряду номинаций были отмечены дипломами, благодарственными письмами и призами - комплектами редких изданий юридической литературы.

Мы гордимся молодыми учеными, показавшими глубокие знания в области сравнительного правоведения в странах АTP, блестящие навыки публичных выступлений! Вот они - надежда и гордость компаративистики: 


\section{Лучшие доклады в пленарном заседании}

Диплом І степени - Пыкина Татьяна Александровна, студентка 4 курса ЮФ БГУ (г Улан-Удэ, Россия); Диплом II степени - Линникова Надежда Витальевна, студентка 4 курса ИЮИ (ф.) АГП РФ (г. Иркутск, Россия);

Диплом III степени - Яковлев Олег Дмитриевич студент 3 курса ЮФ НГТУ (г. Новосибирск, Россия).

\section{Лучшие доклады в научной секции № 1}

Диплом І степени - Иринчеева Мэдэгма Сергеевна, студентка 4 курса ЮФ БГУ (г. Улан-Удэ, Россия); Диплом II степени - Васильева Надежда Леонидовна, студентка 2 курса ЮФ БГУ (г.Улан-Удэ, Россия); Диплом III степени - Санжицыбиков Константин Дугарович, магистрант 2 года обучения ЮФ БГУ (г.УланУдэ, Россия).

\section{Лучшие доклады в научной секции № 2}

Диплом І степени - Алексеева Валентина Андреевна, студентка 2 курса ЮФ БГУ (г.Улан-Удэ, Россия); Диплом II степени - Галецкая Галина Сергеевна, студентка 4 курса ЮФ БГУ (г. Улан-Удэ, Россия); Россия).

Диплом III степени - Дашиева Арюна Биликовна, магистрант 1 года обучения ЮФ ВСГУТУ (г. Улан-Удэ,

\section{Лучшие доклады в научной секции № 3}

Диплом І степени - Шакирова Ольга Камельяновна, студентка 4 курса ЮФ БГУ (г. Улан-Удэ, Россия); Диплом II степени - Пинигин Виктор Алексеевич, студент 3 курса ЮФ БГУ (г. Улан-У дэ, Россия); Диплом III степени - Шагдаров Тимур Намжалович, студент 3 курса ЮФ БГУ (г. Улан-Удэ, Россия).

\section{Лучшие доклады в научной секции № 4}

Диплом І степени - Доржиева Дари Сергеевна, студентка 2 курса ЮФ БГУ (г. Улан-Удэ, Россия); Диплом II степени - Телятников Евгений Викторович, студент 3 курса ЮФ НГТУ (г. Новосибирск, Россия); Диплом ІІІ степени - Зуев Павел Павлович, студент 3 курса ЮФ БГУ (г. Улан-Удэ, Россия).

\section{Лучшие доклады в научной секции № 5}

Диплом І степени - Бродникова Александра Васильевна, студентка 3 курса ЮФ БГУ (г. Улан-Удэ, Россия); Диплом II степени - Лумбунова Маргарита Эдуардовна, студентка 3 курса ЮФ БГУ (г. Улан-Удэ, Россия); Диплом III степени - Федоров Александр Константинович, студент 4 курса ЮФ БГУ (г. Улан-Удэ, Россия).

Благодарственные письма Верховного суда Республики Бурятия получили:

- Цыденова Валентина Станиславовна, студентка 4 курса ЮФ БГУ (г. Улан-Удэ, Россия);

- Чимитдоржиева Гэрэлма Тумэновна, студентка 2 курса ЮФ БГУ (г. Улан-Удэ, Россия);

- Дылыков Роман Игоревич, студент 2 курса ЮФ БГУ (г. Улан-Удэ, Россия);

Благодарственное письмо Адвокатской палаты Республики Бурятия получили:

- Юй Хай, магистрант 1 года обучения ИЭУ БГУ и Лумбунова Маргарита Эдуардовна, студентка 3 курса ЮФ БГУ (г. Улан-Удэ, Россия);

Благодарственное письмо Следственного управления СК РФ по РБ получил:

- Линник Сергей Андреевич, студент 4 курса ЮФ БГУ (г. Улан-Удэ, Россия).

Благодарственное письмо УФМС РФ по РБ получила:

- Туртуева Бальжима Вадимовна, студентка 3 курса ЮФ БГУ (г. Улан-Удэ, Россия).

Благодарственное письмо МВД РФ по РБ получил:

- Ижийт Баясгалан Баатар, заведующий кафедрой охраны и безопасности Института исполнения судебных решений Университета правоохранительной службы Монголии (г. Улан-Батор, Монголия).

Благодарственное письмо УФСИН РФ по РБ получил:

- Чимитов Жамсаран Цырендоржиевич, студент 4 курса ЮФ БГУ (г. Улан-Удэ, Россия).

Благодарственные письма Генерального консульства Монголии в г. Улан-Удэ получили:

- Сверкунов Сергей Петрович, студент 3 курса ЮФ БГУ (г. Улан-Удэ, Россия);

- Чимитдоржиева Виктория Жаргаловна, студентка 4 курса ЮФ БГУ (г. Улан-Удэ, Россия). 
Помимо этого, каждому участнику конференции был вручен сертификат, подтверждающий участие в научном форуме.

Интересной и разнообразной была и культурная программа конференции. Для участников и гостей был организованы экскурсии по г. Улан-Удэ, посещение Иволгинского дацана (буддистский храм - центр традиционной буддийской сангхи (общины) России), а также выезд на оз. Байкал (п. Горячинск).

Организаторы и члены президиумов секций конференции, все участники научного форума отметили высокий научно-теоретический уровень и прикладную значимость большинства докладов, заслушанных на пленарном и секционных заседаниях, хорошие навыки публичных выступлений, проявленные выступавшими. Отмечены обширная «география» и качественный состав участников конференции, представленный молодыми специалистами в области сравнительного правоведения в странах АТР.

Все участники научного форума сошлись во мнении о том, что сравнительно-правовые исследования в странах АТР необходимо продолжать и популяризировать, причем, прежде всего, именно в молодежной среде. Студентам, аспирантам, молодым ученым необходимо активизировать, прежде всего, прикладные исследовании в области сравнительного правоведения, включаться в работу по переводу законодательства стран АТР, глубоко изучать сравнительное правоведение как науку и учебную дисциплину, шире использовать возможности языковых и научных стажировок, участия в разнообразных молодежных форумах в странах региона.

Атмосфера молодежного форума демонстрировала глубокий, неподдельный интерес к изучению азиатских языков, к анализу законодательства России и других стран АТР в сравнительно-правовом аспекте. Учет этих приоритетов в научной и образовательной деятельности юридических вузов даст последним гарантии высокого рейтинга на образовательном рынке, а будущим юристам обеспечит успешное трудоустройство, блестящую карьеру, интересную и общественно полезную практическую и научную деятельность. По единодушному мнению конференция реализовала поставленные задачи. Оргкомитет конференции выражает надежду на то, что предложенная молодым ученым возможность знакомства, обмена мнениями, опытом исследований и установления творческих контактов с представителями других вузов России и стран АТР даст мощный стимул для дальнейшей плодотворной работы, будет содействовать укреплению дружбы и сотрудничества между странами региона.

Организаторы конференции выражают признательность Генконсульству Монголии в г. Улан-Удэ, Верховному Суду Республики Бурятия, Адвокатской палате Республики Бурятия, Следственному комитету Российской Федерации по Республике Бурятия, Управлению федеральной миграционной службы Российской Федерации по Республике Бурятия, Управлению федеральной службы исполнения наказаний России по Республике Бурятия, Министерству внутренних дел Российской Федерации по Республике Бурятия и всем, кто помог в организации и проведении конференции!

Заведуюший лабораторией

сравнительного правоведения в странах АТР Центра правового обеспечения взаимодействия РФ со странами АТP Бурятского государственного университета, доктор юридчческих наук, профессор Ю. П. Гармаев 


\title{
I. КОНСТИТУЦИОННО-ПРАВОВЫЕ И АДМИНИСТРАТИВНО-ПРАВОВЫЕ ИНСТИТУТЫ СТРАН АТР: СРАВНИТЕЛЬНО-ПРАВОВОЙ АСПЕКТ
}

\author{
Развитие страхования в Китае
}

\author{
(ㄷ Е. С. Алексеева \\ стариий преподаватель кафедры \\ конституционного, административного и \\ муниципального права юридического факультета \\ ФГБОУ ВО «Бурятский госуниверситет», \\ канд. юр. наук, \\ Россия, г. Улан-Удэ \\ Alslena22@yandex.ru
}

Первые страховые компании в Китае были образованы еще в 20-е гг. прошлого столетия. Они обслуживали в первую очередь внешнюю торговлю страны, и район их деятельности ограничивался приморскими городами и «открытыми портами». В силу длительных военных действий в стране в первой половине ХХ в. деятельность страховых компаний не получила должного развития. Во второй половине прошлого века правительство Китая взяло курс на объединение всех страховых фирм в единую КНСК (Китайская Народная Страховая Компания), которая осуществляла абсолютно все страховые выплаты в стране. КНСК впоследствии по мере усиления директивно-плановой системы фактически превратилась в отдел Народного банка Китая (НБК), а ее деятельность была сведена к страхованию морских и железнодорожных внешнеторговых грузов, и аккумуляции средств предприятий, перечисляемых по линии обязательного страхования (страхование жизни в ряде профессий, страхование сельскохозяйственных рисков). Данный шаг не принес каких-либо видимых результатов, заметно затормозив развитие рынка за счет монополизации. Период с 1984 по 1994 гг. представляет собой новый этап в развитии страхования, характеризующийся ликвидацией монопольного положения КНСК и появлением элементов рыночной конкуренции. КНСК снова была разделена на несколько автономных страховых компаний общенационального и регионального значения. Вместе с тем страховые предприятия Китая характеризовались невысоким уровнем качества услуг и беспорядочным менеджментом. В конце 80-х гг. на внутренний рынок Китая были допущены иностранные компании. Они стали активно внедрять в стране новые, современные виды страхования, а также модернизировать старые [1].

Быстрое развитие рынка страхования в первой половине 90-х гг. было вызвано усилением рыночных рычагов в регулировании экономики, увеличением потребности хозяйствующих субъектов в получении кредитов. Банки и прочие кредитные организации требовали определенных гарантий, которые могли быть даны за счет страхования. Возросла заинтересованность хозяйствующих субъектов в страховании имущества, а также гражданской ответственности.

В конце 1998 г. был образован Китайский комитет по страховому регулированию (ККСР), непосредственно подчиненный Госсовету КНР. Данный комитет помимо страхового надзора стал также рассматривать вопросы предоставления лицензий, совершенствования деятельности страховщиков.

Вопрос создания страховой компании в обязательном порядке утверждался Комитетом по контролю в сфере страхования, который выдавал лицензии на те или иные виды страховой деятельности. Получение лицензии являлось основанием для регистрации в Государственной торгово-промышленной администрации КНР, который и выдавал сертификат на осуществление страховой деятельности.

Высокие темпы роста страхования в Китае были достигнуты в основном за счет обязательного страхования. На этот вид страхования приходилось до 50\% прироста страховой премии по рынку. Осознавая безусловную важность обязательного страхования, приходилось констатировать, что основная движущая сила роста рынка страховых услуг - директивное, административное расширение сферы применения обязательного страхования. Необходимо также учитывать, что по каналам обязательного страхования циркулировали исключительно бюджетные деньги, не создавая инвестиционных возможностей для государства. Довольно высок был процент выплат по обязательному страхованию. По-видимому, обязательное страхование в Китае следует рассматривать как создание определенного компенсационного рискового фонда.

Характерной особенностью развития страхового сектора стал быстрый рост доли различных накопительных видов страхования (жизни, пенсионное страхование, создание специальных медицинских и образовательных страховых фондов).

Особенностью страхового дела в Китае было невычленение из отрасли «добровольных пенсионных фондов». Отделения КНСК, особенно в провинции, осуществляли страхование от всех рисков. В 1995 г. было принято решение о создании специализированных страховых компаний, занимающихся исключительно пенсион- 
ным и личным страхованием. Компаниям или филиалам, осуществляющим имущественное страхование, запрещалось проводить операции по медицинскому и возрастному страхованию.

Данный факт, помимо отмеченных выше особенностей текущей экономической обстановки, объяснялся тем, что в Китае наметилась тенденция к старению населения, особенно это касалось центральных городов, а также проводимой в стране реформой системы социального и пенсионного обеспечения.

В начале 2000-х гг. китайская система страхования претерпела сильные изменения. Новые правила значительно расширили сферу деятельности страховых компаний. Коммерческим страховщикам была предложена новая схема работы. Она позволила использовать как средства из фонда компании, так центрального и местных правительств. Новые правила способствовали укреплению страховых инвестфондов, модернизации промышленности и сельского хозяйства. Эксперты отрасли возлагали большие надежды на комплексный подход к страхованию.

Кроме того, страховой рынок больше не принадлежал исключительно государству. Эта реформа открыла путь на рынок сотням местных и иностранных предприятий, представляющим серьезную конкуренцию государственной страховой ассоциации, которой все же принадлежит около 70\% рынка.

В настоящий период нормативную правовую базу регулирования страхового рынка составляют:

- закон КНР «О страховании» от 30 июня 1995 г. (действует в редакции 2002 г.);

- правила заключения договоров страхования имущества (1981г.);

- временные правила по управлению страховыми компаниями (1985 г.);

- временные меры по управлению страховыми компаниями с иностранным капиталом в Шанхае (1992 г.).

Государственным органом, осуществляющим регулирование в сфере страховых услуг, является Комиссия KНР по регулированию страховой деятельности CIRC (China Insurance Regulatory Commission - CIRC).

Основными функциями Комиссии являются: разработка норм и правил регулирования страхового рынка, составление планов развития страховой индустрии, наблюдение за страховым бизнесом, применение санкций за нелегальную страховую деятельность, обеспечение честной конкуренции на рынке страховых услуг, выдача лицензий страховым компаниям.

С 1 ноября 2013 г. в КНР вступили в силу «Правила проведения разбирательств по страховым потребительским спорам», принятые Комиссией по регулированию страховой деятельности. Данные Правила устанавливают порядок рассмотрения жалоб потребителей на услуги организаций в сфере страхования.

В соответствии с принципом разделения основных видов страховой деятельности на страхование жизни и страхование имущества на китайском рынке страховых услуг представлены две группы компаний - по страхованию жизни и по страхованию имущества соответственно.

Сфера деятельности компаний по страхованию имущества включает в себя: страхование ущерба имуществу, страхование гражданской ответственности, страхование юридической ответственности, страхование кредитов и гарантий, сельскохозяйственное страхование, страхование иного имущества, краткосрочное медицинское страхование и страхование от несчастных случаев.

Сфера деятельности компаний по страхованию жизни включает в себя: страхование от несчастных случаев, медицинское страхование, традиционное страхование жизни, инновационные продукты страхования жизни, традиционные пенсионные продукты, инновационные пенсионные продукты и другие продукты по страхованию жизни.

Страховые компании, осуществляющие страховую деятельность на всей территории страны, должны зарегистрировать уставный капитал в размере не менее 500 млн. юаней. Страховые компании, осуществляющие страховую деятельность на определенной территории страны, - не менее 200 млн. юаней.

Закон предъявляет жесткие требования к составу персонала страховых компаний - 60 \% работников должны иметь высшее специальное образование и опыт работы в страховом бизнесе.

Особенностью функционирования страховых компаний в Китае является создание филиалов как обязательного условия их деятельности.

По опубликованным, ранее данным Министерства труда и социального обеспечения КНР, наиболее популярным видом страхования в Китае является накопление в пенсионный фонд, так называемое «страхование от старости». На втором месте по популярности - страхование имущества. Автомобильная страховка занимает последнее место в Китае и не является приоритетным пунктом страхования.

Больше всего денег страховым компаниям приносит страхование ответственности средних и больших предприятий перед партнерами и заключенными между ними контрактами. Китайский страховой сектор в последнее время переживает бурный рост - более 150 зарегистрированных иностранных и национальных игроков активно работают здесь. Больше половины рынка контролируют две основные страховые компании China Life Insurance и Ping An Insurance, входящие в десятку крупнейших страховых агентств мира по версии Forbes. По данным все того же Министерства труда и социального обеспечения КНР, всего на страховом рынке постоянно задействовано более 35000000 человек, из которых больше половины - страховые агенты, занимающиеся корпоративными продажами.

Что касается населения, то потребность в пенсионном страховании, страховании жизни и личного имущества стала расти под влиянием положительных изменений в экономической жизни.

Как и в большинстве стран, в Китае работает система обязательного социального страхования населения, представленная в 5 видах: Пенсионное страхование, Медицинское социальное страхование, Страхование жизни, страхование от производственных травм или другого ущерба, полученного на работе, Страхование от без- 
работицы, Страхование на рождение ребенка. Данные виды страхования распространяются на всех граждан без исключения и предоставляются только под эгидой государственной страховой ассоциации. Уровень охвата системой социального страхования пока еще не очень высок по причине огромной численности населения страны, но уровень социального страхования в городе значительно выше, чем был до начала реформы перехода к рыночной экономики. Поэтому можно с уверенностью сказать, что в Китае действительно реализуется модель развития «социализма с китайской спецификой» [3, с.72].

С китайских страховых компаний государство взимает налог в $33 \%$, с компаний с иностранной долей 15\%. Компании по страхованию жизни людей полностью освобождены от налогов.

2008 год можно отметить черным цветом в экономическом календаре китайского страхового рынка. Мировой финансовый кризис частично задел и Азию, когда, еще не оправившийся после внутренних экономических реформ, страховой рынок Китая получил новый удар. На протяжении нескольких лет страховой сектор восстанавливался, не без помощи государства, и уже с 2012 года начал показывать отличные финансовые результаты. Например, в Китае введена новая программы страхования, которая за семь лет вывела страну в число лидеров рынка страхования сельскохозяйственных рисков. К 2013 году страна вышла на второе место по мировым сборам страховых премий в сфере сельскохозяйственного страхования [2, с.202].

\title{
Литература
}

1. Жигулева В. В. Страховой рынок Китая // Финансы. 17.07.2000.

2. Иванова Т. А. Проблемы сельскохозяйственного страхования в Китае // Бизнес. Образование. Право. Вестник Волгоградского института бизнеса. 2015. ноябрь № 4 (33). С. 202-207.

3. Островский А.В. Решение социальных проблем в Китае в условиях перехода к рыночной экономике // Журнал Российского права. 2011. № 5. С.72-80.

\section{Сравнительно-правовой анализ конституционного статуса глав государств Республики Казахстан и Российской Федерации}

\author{
(С) Д. Б. Аюшиев \\ студент 2-го курса юридического факультета \\ ФГБОУ ВО «Бурятский госуниверситет» \\ Россия, г. Улан-Удэ \\ dayushiev@list.ru
}

Актуальность работы обусловлена тем, что в правовом государстве статус главы государства максимально точно определяется конституцией и принимаемыми на ее основе законами. Глава страны как лицо, занимающее высшее положение в государстве, имеет четкие права и обязанности и не может, выходить за установленные пределы, своими действиями, тем самым порождать угрозу конституционным правам и свободам граждан. Любое государство нуждается в существовании должностного лица, обеспечивающего конституционный порядок, устойчивость и преемственность механизма власти, а также высшее представительство в международных отношениях. Такое лицо и есть глава государства, который наделяется широкими полномочиями в сфере взаимоотношений с законодательной, исполнительной и судебной властью и выступающий как своеобразный символ государства и официальный представитель народа.

Институт президента в каждой стране является одним из самых важных в системе органов государственной власти, его рациональное устройство и функционирование, является важным условием обеспечения конституционализма в стране.

Правовой статус Президента России определяется в главе 4 Конституции РФ. Конституционный статус Президента Казахстана определяется в разделе 3 Конституции Казахстана. Мы считаем, что от баланса и гармонии между поведением главы государства и других органов власти в своей решающей степени зависит устойчивость конституционного строя, гражданский мир и реальность свободы народа.

Конституционный статус глав государств определяется их полномочиями, функциями и местом в системе государственных органов. Конституционные статусы Президентов в рассматриваемых странах примерно схожи по своей структуре, но имеются некоторые несущественные различия. Например, оба Президента не входят ни в одну ветвь власти, имеют весьма сходные полномочия и функции. Главы государства обеспечивают конституционный порядок, устойчивость самой власти, ее преемственность и согласованное взаимодействие, а также представительство государства внутри страны, (например, принятие в гражданство страны), и на международной арене (например, подписание международных договоров). Как в России, так и в Казахстане Президент выступает официальным представителем народа и символизирует единство государственной власти.

Одно из отличий заключается в том, что Президент Казахстана не представляет кандидатуры на должности судей. Он образует Высший Судебный совет, который представляет кандидатуры на должности судей Президенту Казахстана, последний их назначает по своему усмотрению. Другое важное отличие состоит в том, что Президент Казахстана может по представлению премьер-министра устанавливать оклад чиновников, содержащихся за счет бюджета Республики.

Рассмотрим процедуру отрешения от должности Президента в России и Казахстане. Основные положения одинаковы, но есть одно различие в Казахстане решение о выдвижении обвинения и его расследовании может 
быть принято большинством от общего числа депутатов не менее чем $1 / 3$ голосов, в то время как в Российской Федерации $2 / 3$ голосов.

В требованиях к кандидату в Президенты в Казахстане и России имеются различия. В Казахстане гражданин-кандидат должен проживать в этой стране не менее 15 лет, а в России кандидат должен проживать 10 лет. В Конституции Казахстана указано, что кандидат в Президенты должен быть не моложе 40 лет, в Российской Федерации 35 лет. Есть пункт, который отсутствует в РФ, но присутствующий в Конституции Казахстана гражданин, претендующий на должность Президента, не может быть служителем какого-либо культа. Есть различия в сроке Президентский полномочий, в Республике Казахстан он составляет 7 лет, а в РФ 6 лет.

Стоит отметить закон от 20 июля 2000 года №83-11 «О первом Президенте Республики Казахстан», который предоставил Нурсултану Назарбаеву еще больше полномочий и, можно сказать фактически даровал ему право до конца своей жизни управлять страной. Этот закон прямо нарушает основные принципы демократизма. На наш взгляд, такие законы могут повлечь огромные злоупотребления властью Президентом ради удовлетворения своих интересов.

И в России и в Казахстане существует республиканская форма правления. Ю. И. Лейбо считает, что республиканскую форму правления в России можно отнести к полупрезидентскому типу, хотя и с некоторыми оговорками [5, с.12 ]. И.Д. Хутинаев признает, что форма правления в России представляет собой смешанный тип, но не соглашается с классификацией его как полупрезидентского, а предполагает считать российскую форму правления индивидуальной (единичной) [6, с.34]. На наш взгляд в России и в Казахстане существует одна из разновидностей президентской формы правления, причем эта разновидность характеризуется особенно сильной президентской властью.

Таким образом, пост Президента как в России, так и в Казахстане занимает особое место в системе государственных органов. Отношения Президента и органов законодательной, исполнительной и судебной власти характеризуются не только правами, но и взаимной ответственностью. Необходимость в самом институте президентства вытекает из потребности обеспечить устойчивость сложной системы управления государственными делами. Институты власти в государстве нуждаются в авторитетном арбитре, который бы обеспечивал согласованное их взаимодействие. Президент призван обеспечить устойчивость самого механизма властвования, гарантировать устойчивость государства в целом, его суверенитет и государственную целостность.

\section{Литература}

1. Авакьян С. А. Конституционное право России: Учебный курс. 2-е изд., перераб. и доп.: в 2 т. М.: Юристъ, 2007.

2. Зуйков А.В. Институт президентства в России: конституционная модель, современные реалии и перспективы развития // Конституционный вестник. Специальный выпуск. 2008.

3. Конституционное право России: учебник / под ред. Г. Н. Комковой. М.: Юристъ, 2005.

4. Кубеев Е. К., Амандыкова С. К. Конституция Республики Казахстан. Теоретико-правовой анализ 2008.

5.Конституционное право зарубежных стран: учебник для вузов / под ред. М. В. Баглая, Ю. И. Лейбо, Э. М. Элтина. М.: Норма, 1999.

6. Хутинаев И.Д. Институт Президентства и проблемы формы государства. М., 1994.

\section{Проблемы развития демократии в конституционной доктрине США и Российской Федерации}

(C) P. A. Багдуев

магистрант 1 года обучения юридического факультета ФГБОУ ВО «Бурятский госуниверситет»

Россия, г. Улан-Удэ

Bagasan08@gmail.com

Актуальность данной работы обосновывается в особой роли конституции в становление и развитии демократии во многих странах современного мира. Ведь именно конституция закрепляет основополагающие конституционно-правовые нормы для демократического регулирования общественных отношений. Р. Даль утверждал: «Демократия более эластичная категория, чем право и процедура. Ее формы и содержание могут претерпевать значительные модификации, в то время как законодательство и процедура остаются сравнительно неизменными» [1].

Конституция же в свою очередь является политико-правовой формой выражения демократии. Она является важной составляющей частью юридического механизма самоорганизации демократического общества. По мнению В.А. Ершова именно конституция играет ключевую роль в функционировании любого общества и занимает особенное место в правовой системе «народовластного» государства и вызывает необходимость всестороннего изучения [3].

Целью данной работы является показать основные проблемы развития демократии на примере Соединенных Штатов Америки и Российской Федерации. Так как эти два государства играют важную роль на геополитической арене современного мира и имеют свои отличительные черты в становлении демократии. Первой созданной конституцией с современном ее понимании,-- то есть документ, описывающий и устанавливающий 
разделение властей и компетенцию каждой из них, закрепляющий основные права и свободы граждан, - является Конституция США, принятая в 1787 г., с ее дальнейшими поправками [6]. Именно этот документ заложил основы американской государственности, в нем были сформированы предпосылки для появления на свет юридического документа, который стал первой в истории человечества попыткой реализации идеи демократии в рамках целой страны, а также по сей день играющий важнейшую роль в жизни каждого американца и по мнению многих ученных может просуществовать еще десятки или даже сотни лет.

В свою очередь Конституция РФ не может похвастаться такой долгой историей как Конституция США, ведь она была принята не так давно - в 1993 г., после фундаментальных перемен, случившихся в жизни страны на рубеже 80-90-х гг. Однако именно современная Конституция РФ стала основой для построения демократии в России, после заката тоталитарной советской власти.

Но не смотря на принятие конституций в этих странах, становление демократии в них только зарождалось и имело множество препятствий и сложностей. Например, Конституция США далеко не самый демократичный документ, так как изначально в ней отсутствовали положения о правах и свободах человека и гражданина. Они были добавлены «Биллем о правах» в виде поправок к Конституции.

Однако в то же время в США существовало рабство, которое в современном мире никак не является элементом демократического государства, хотя и было отменено в дальнейшем [5]. Но и по сей день США встряхивают отголоски прошлых лет, несмотря на всю демократичность и толерантность соединенных штатов, особенно это связано с «чернокожим» населением страны, отношения к которым базируется на цвете их кожи [9].

Ежегодно в судах США рассматриваются десятки тысяч дел о нарушении прав и свобод в отношении афроамериканского населения со стороны представителей власти, а особенно сотрудников полиции. О чем свидетельствуют беспорядки в городе Фергюсоне, где сотрудник полиции застрелил безоружного чернокожего подростка. И на этом проблемы демократии в США не заканчиваются.

22 октября 2012 г. МИД РФ представил первый специальный доклад на тему о положении с правами человека в Соединенных Штатах Америки, вынеся его на слушания в Государственной Думе. Как подчеркнул представлявший доклад замминистра иностранных дел Сергей Рябков, «то, как в США обращаются с правами человека, далеко от идеала, а порой вообще из другой эпохи».

С. Рябков упомянул в докладе, что «среди наиболее серьёзных вызовов, которые стоят перед Америкой, растущее социальное неравенство, дискриминация по расовому, этническому и религиозному признакам, практика бессрочного содержания заключенных без предъявления им обвинений, предвзятость правосудия, функционирующие вне правового поля тюрьмы, применение пыток, воздействие государственных ведомств на судебные процессы, слабая пенитенциарная система, ущемление свободы слова, интернет-цензура, легализованная коррупция, ограничение избирательных прав граждан, проявление нетерпимости по признаку расы и национальности, нарушение прав детей, экстерриториальное применение американского законодательства, ведущее к нарушениям прав человека в других странах, похищение людей, слежение за инакомыслящими, непропорциональное применение силы по отношению к мирным демонстрантам, применение смертной казни по отношению к несовершеннолетним и душевнобольным. При этом международно-правовые обязательства США, по-прежнему, сводятся к участию лишь в трех из девяти основных договоров по правам человека, предусматривающих контрольные механизмы. США до сих пор не ратифицировали Международный пакт об экономических, социальных и культурных правах 1966 года, Конвенцию о ликвидации всех форм дискриминации в отношении женщин 1979 года, Конвенцию о правах ребенка 1989 года, Международную конвенцию о защите прав всех трудящихся-мигрантов и членов их семей 1990 года, Конвенцию о правах инвалидов 2006 гада и Международную конвенцию для защиты всех лиц от насильственных исчезновений 2006 года» [7].

Что касается РФ, то присущей спецификой данной конституции является приоритет прав и свобод человека что свидетельствует о демократической характеристики Конституции [4].

На сегодняшний день невозможно точно сказать, что Конституция РФ 1993 года работает на 100\%, так как на ее пути встречаются масса препятствий, которые порождаются экономическими, социальными, политическими и другими факторами. Что в свою очередь оказывает большое влияние на развитие демократии в стране. На демократическое развитие, бесспорно, влияет нерешенность многих задач и многие другие события, которые препятствуют демократизации России, такие как экономический кризис в конце 90-х гг., который резко ухудшил жизненное положение населения, регулярные задержки выплаты заработной плат, возрастающая коррупция среди государственных и муниципальных служащих, рост преступности и многие другие обстоятельства [8].

Г. Дилигенский считает, что одной из важнейших проблем российской демократизации является «дефицит демократического политического лидерства, связанный с отсутствием у российских политиков умения, навыков и воли к устойчивой политической самоорганизации, что привело к решающей роли не оправдавшего себя харизматического лидера, несостоятельность харизмы которого стала одной из причин дискредитации демократии в общественном сознании» [2].

Но не смотря на все эти проблемы в становлении и развитии демократии в США и РФ, нельзя не выделить несовершенства и очевидные недостатки самой демократии, которые препятствуют ее развитию не только в данных странах, но и во всем мире:

1. Огромная разновидность «подтипов» демократии, их примерно насчитывается порядка 550 разновидностей. И даже на примере США и РФ можно увидеть большие отличия в построении демократического государства (различия в избирательной системе, различия в иерархии нормативно-правовых актов и многое другое). 
2. Менталитет людей, который складывался на протяжении тысячелетий. Например, в РФ и США за употребление легких наркотических веществ, правонарушитель может отделаться административным наказанием (в РФ) или штрафом (США), а в то же время в Саудовской Аравии за употребление марихуаны можно попасть в тюрьму на долгий срок и при этом преступника предварительно выпарывают плетью, аналогичное наказание предусмотрено и в Индонезии, там за употребление даже легких наркотиков или лекарственных препаратов (которые разрешены на территории многих стран, в том числе России и США) минимальный срок 10 лет и там также как и в Саудовской Аравии преступника выпарывают плетью.

3. Для построения демократического государство нужно большое количество времени и специалистов (кадров). Например, после распада СССР и образования РФ, Россия выбрала путь построения демократического государства, и по мнению многих ученных она до сих пор находится на этом пути, во многом из-за того, что был резкий переход от тоталитарного режима к демократии, и страна просто на просто не была к этому готова.

Подводя итоги проделанной работы, хочу сделать вывод, что Конституция РФ - это документ своего времени, и он рассчитан, как минимум, на переходный этап в развитии России, о продолжительности которого ведутся жаркие дебаты. Одной из важнейших задач при разработке Конституции было, создание механизма, обеспечивающего устойчивость государственного, экономического, общественного строя именно в переходный период становления демократического государства.

Что касается США, то на сегодняшний день Конституция США выглядит как умеренно-демократический документ, во многом уступая в демократичности основным законам стран Западной Европы и прочих государств современного мира [11].

И все же для американцев Конституция - это больше, чем просто основной закон страны. Ее влияние на американцев настолько велико, что ее можно сравнить с Библией, которая является символом «слов Бога». В ней отражены все ценности общества, все приоритеты и формы этих приоритетов. Это особенно отражено в Преамбуле, где записаны цели Конституции, и в Билле о правах, провозглашающем права людей [10].

В заключении хотелось бы добавить, что основной проблемой США и РФ в развитии демократии - это не недостаток законодательной базы, а несовершенство ее реализации и контроля. Демократия не будет развиваться, пока она не «засядет» в сознании подавляющего числа населения (порядка 80-90\%) какого-либо государства, так как такие препятствия как коррупция, преступность, нищета и иные факторы будут замедлять ее развитие.

\section{Литература}

1. Даль Р. Демократия и ее критики / пер. с англ., под ред. М. В. Ильина. М.: РОССПЭН, 2003 [Электронный ресурс]. URL: http://lib.sale/politicheskie-ideologiya-politicheskaya/demokratiya-kritiki-per-angl-pod-red-mvilina.html (дата обращения: 12.04.2016).

2. Дилигенский Г.Г. Демократия на рубеже тысячелетий. Дубна, 2001. С.38-39 [Электронный pecypc]. URL: http://www.agitclub.ru/center/syst/parties05.htm (дата обращения: 12.04.2016).

3. Ершов В.А. Конституционное право зарубежных стран. М.: РОСБУХ, 2009. 144 с.

4. Конституция (Основной Закон) Российской Федерации (Принята общенародным голосованием в 1993г.) // Российская газета. 1993. № 248.

5. Конституция (Основной Закон) Соединенных Штатов Америки: [Принята Конституционным Конвентом в 1787г.] // 1787.

6. Мишин А.А. «Конституционное (государственное) право зарубежных стран: учебник. М., 1996.

7. Рябов С. О положении с правами человека в Соединенных Штатах Америки. М., 2012.

8. Оффе К. Дилемма одновременности: демократизация и рыночная экономика в Восточной Европе. СПб., М., Берлин, 2003. C.11.

9. Токвиль Алексис де. Демократия в Америке: пер. с франц. / предисл. Гарольда Дж. Ласки. М.: Прогресс, 1992.554 с.

10. Фридмен Л. Введение в американское право. М.,1993 [Электронный pecypc]. URL: http://www.juristlib.ru/book_10390.html (дата обращения: 12.04.2016).

11. Хантингтон С. Третья волна. Демократизация в конце XX века: пер. с англ. М., 2003. С. 338.

\section{Сравнительный анализ системы налогового администрирования Японии и Российской Федерации}

(C) C. A. Баиров

студент 4-го курса юридического факультета ФГБОУ ВО «Бурятский госуниверситет»

Россия, г. Улан-Удэ

Sergeo.94@mail.ru

Налоговая система России характеризуется достаточной гибкостью и изменчивостью. Это обусловлено участием государства в международных отношениях, что вызывает необходимость соответствовать существующим условиям. Система налогового администрирования России подвергается реформированию на протяжении последних двадцати лет.

Реформирование в России всегда опиралось на зарубежный опыт в целях соответствия мировым стандартам и улучшения эффективности национальной налоговой системы путем использования уже разработанных мето- 
дов. Как правило, российские реформаторы сравнивают Россию с преуспевающими странами Западной Европы. Однако некоторые страны Востока, являясь примером рационального построения системы налогового администрирования, заслуживают внимания наравне со странами Запада. Например, система налогового администрирования Японии сложилась достаточно давно и практически не подвергалась существенным переменам. Тем не менее, между Россией и Японией много общего.

Во-первых, управление налоговой системой Японии находится в юрисдикции Министерства финансов, что характерно и для России. Во-вторых, систему государственных налоговых органов Японии возглавляет центральный аппарат - Национальное налоговое управление (ННУ), на которое возложены все функции по начислению, сбору и пресечению случаев уклонения от уплаты всех общегосударственных налогов и сборов. В России таким органом является Федеральная налоговая служба (ФНС). ННУ, как центральный орган, имеет свои подразделения - секретариат и три управления, которые в свою очередь состоят из отделов [3, с. 43]. В состав ФНС России входят тринадцать управлений.

Национальное налоговое управление располагается в Токио. Его возглавляет начальник, который назначается на должность министром финансов. Руководитель ФНС назначается на должность Правительством Российской Федерации по представлению Министра финансов.

В-третьих, система налоговых органов Японии по признаку подчиненности составляет три уровня, что является характерной чертой Российской налоговой системы

Высший уровень по указанному признаку в Японии занимает Национальное налоговое управление. В подчинении Национального управления находятся Национальный налоговый трибунал, колледж, налоговый совет и Районные налоговые управления, включая Районное налоговое управление Окинавы.

Районные управления Японии занимают второй уровень. Как правило, управление состоит из пяти подразделений: управления согласования, управления налогообложения, управления доходов и сборов, управления уголовных расследований и проверок. Районные налоговые управления осуществляют консультирование, проверяют крупных налогоплательщиков и руководят работой налоговых инспекций [2].

Из общего числа выделено Районное управление Окинавы, которое было создано в 1972 году по причине отдаленности и достаточно обширной площади. Окинава - самый крупный остров Японии. Это самая южная префектура, которая состоит из сотен малых островов, образующих архипелаг Рюкю. В отличие от районных налоговых управлений районная налоговая служба Окинавы не имеет структурных подразделений.

Третий уровень занимают налоговые инспекции. Они являются непосредственными исполнителями налогового законодательства и выполняют функции налогообложения доходов и имущества. Как правило, она состоит из нескольких отделов, каждый из которых занимается администрированием конкретного налога или группы налогов.

В России высший уровень по принципу подчиненности занимает Федеральная налоговая служба. На втором уровне располагаются Управления ФНС, каждое из которых находится в одном из 84 субъектов России. Управления контролируют работу налоговых инспекций, которые соответствуют местному - третьему уровню подчиненности. Как и в Японии, в состав инспекций и Управлений ФНС входят структурные подразделения отделы [1].

Существенные различия между системами налогового администрирования исследуемых стран заключаются в организации налогового контроля. В частности, имеют место разные формы ответственности. Так, в России ответственность за нарушение налогового законодательства разграничивается на налоговую, административную и уголовную. Соответствующие нормы права содержатся в Налоговом и Уголовном Кодексах, а также в Кодексе об административных правонарушениях. В Японии за нарушение налогового законодательства наступает налоговая или уголовная ответственность, которая предусмотрена в многочисленных актах так называемого уголовно- административного законодательства. Среди них наиболее значимыми являются «Закон о взимании государственных налогов» 1959 года, «Закон о подоходном налоге» 1947 года, «Закон о налоге с юридических лиц» 1947 года [1]. При проведении расследования в целях привлечения к ответственности применяются нормы «Закона о контроле за нарушениями в сфере общегосударственных налогов».

Механизм выявления налоговых правонарушений построен в Японии иначе, чем в России. Разница заключается в том, что Районные управления в своем штате имеют специальных следователей, в обязанности которых входит сбор информации и выявление случаев нарушения налогового законодательства [2]. В России налоговые правонарушения выявляются посредством проведения специальных (выездных и камеральных) проверок. Управления ФНС следователей в своем штате не имеют, кроме того, основные функции Управления носят скорее надзорный характер. Расследования являются прерогативой органов внутренних дел.

Налоговые органы России имеют большую свободу действий и независимость от других органов правосудия. Следователи Японии могут производить обыск помещений только при наличии санкции прокурора. По ст. 91 НК РФ уполномоченные должностные лица производят осмотр помещений налогоплательщика при предъявлении удостоверений и решения руководителя налогового органа.

Выявлением и расследованием фактов уклонения от уплаты налогов в Японии занимаются также штатные следователи. Для начала официального расследования должна быть существенная доказательная база, подтверждающая факты налогового правонарушения. Только тогда следователь получает судебный ордер как право на проведение углубленного расследования с привлечением свидетелей и помощников. Результаты расследования передаются Прокурору для рассмотрения уголовного дела в суде. В России привлечение к налоговой и административной ответственности производится на основании проведенной проверки либо по факту (например, не- 
представление декларации) без дополнительных санкций. Уголовное расследование проводится органами внутренних дел, а следственные действия производятся при получении соответствующих санкций суда или Прокуpopa.

Для обжалования актов Районных налоговых управлений в Японии существует специальный орган - налоговый трибунал. Российское законодательство предусматривает административное (в вышестоящем органе) и судебное обжалование. Более того, обжалование актов и решений налоговых органов производится сначала в административном, а затем в судебном порядке. Обжалование приговоров по уголовным делам производится только в суде высшей инстанции.

Следует отметить, что характерными чертами налоговой системы Японии являются весьма низкий уровень налогового бремени и жестко централизованная система сбора налогов. Японские налоговые органы соблюдают три основных принципа: уважение к законопослушному налогоплательщику, простота и доступность налоговой системы, примат доверия к налогоплательщику над стремлением к наказанию.

Уровень налогового бремени в России считается достаточно высоким. Кроме того, система налогового права построена таким образом, что фактически налогоплательщик считается заведомо виновным в правонарушении, о чем свидетельствует возможность налоговых органов списывать задолженность со счетов юридических лиц в бесспорном порядке. Безусловно, налогоплательщику направляется требование об уплате налога, однако, нередки случаи судебных споров на предмет незаконности остановки движения денежных средств по счетам и бесспорного списания задолженности.

Таким образом, благодаря наличию сходств в организационном построении вертикали налоговых органов, администрирование Японии может служить предметом научного исследования, которое окажется полезным для выбора путей реформирования российской системы. Налоговые органы России более независимы, по сравнению с налоговыми органами Японии, где закон в большей степени защищает налогоплательщика, указывая на обязательность формирования доказательной базы перед осуществлением официального расследования. Из системы налогового администрирования Японии следует позаимствовать принцип уважения налогоплательщика, который подразумевает его защищенность от необоснованного применения санкций. Ошибочное начисление пеней, штрафов следует свести к минимуму, поскольку от этого зависит отношение налогоплательщиков к органам государственной власти.

\section{Литература}

1. Налоговый кодекс Российской Федерации: Части первая и вторая: офиц. текст. М.: Проспект, КноРус, 2013. 832 с.

2. Отчѐт Национального налогового управления Японии 2012 года [Электронный ресурс]. Режим доступа. URL: http://www.nta.go.jp/foreign_language/Report_pdf/2013e.pdf. (дата обращения 2.07.2013).

3. Попова Л.В. Налоговые системы зарубежных стран: учеб.- метод. пособие / Л. В. Попова, И. А. Дрожжина, Б. Г. Маслов. М.: Дело и Сервис, 2008. 368 с.

\section{Бюджетный процесс в России и КНР}

(ㄷ) Ю. А. Баннова

студентка 4-го курса юридического факультета ФГБОУ ВО «Бурятский госуниверситет»

Россия, г. Улан-Удэ bja-5@ya.ru

Бюджет играет огромную роль в политической, экономической и хозяйственной жизни каждой страны, а модернизация бюджетного процесса - это важнейшая составная часть политики повышения конкурентоспособности государства и международной стабильности.

Бюджетный процесс представляет собой регламентированную законом деятельность органов государственной власти по составлению, рассмотрению, утверждению и исполнению центрального и местных бюджетов (в федеративных государствах также бюджетов членов федерации).

Правовое обеспечение бюджетного процесса в Российской Федерации на данном этапе в основном отвечает требованиям лучшей мировой практики, однако следует изучать опыт других ведущих стран мира для того, чтобы основным источникам бюджетного права России обеспечивались более стабильные условия существования.

Наиболее интересным является сравнение российского бюджетного процесса с бюджетным процессом Китая. Россия и Китай имеют схожие черты, они являются странами, которые изначально были крестьянскими, пережили социалистические революции, форсированными темпами произвели модернизацию экономик и т. д., однако при всем при этом они по-разному чувствуют себя в XXI веке.

Бюджетная система Российской Федерации состоит из трех уровней. Первый уровень составляют федеральный бюджет, а также бюджеты государственных внебюджетных фондов РФ. Второй - бюджеты субъектов РФ и бюджеты территориальных государственных внебюджетных фондов. Третий - местные бюджеты, в том числе бюджеты: муниципальных районов, городских округов, внутригородских муниципальных образований городов федерального значения (Москвы, Санкт-Петербурга и Севастополя).

Китай имеет пятиуровневую систему: Первый уровень составляет государственный бюджет (бюджет центрального правительства). Второй - это бюджеты провинций, а также бюджеты автономных районов и муници- 
палитетов, которые подчинены непосредственно центральному правительству. Третий уровень - бюджеты городов, которые имеют административно-территориальное деление на районы и префектуры. Четвертый - бюджеты уездов и городов, которые такого деления не имеют. И, наконец, пятый уровень - бюджеты небольших городов, поселков и национальных поселков [4, с. 169].

В бюджетном законодательстве Китая также говорится о бюджетах отделов и входящих в них подразделений органов власти, но они не включаются в бюджетную систему КНР, а являются частью общих бюджетов.

К органам, обладающими бюджетными полномочиями в КНР, относятся:

а) Всекитайское собрание народных представителей (ВСНП) и нижестоящие собрания народных представителей (СНП). В полномочия данных органов входит: проверка проектов и отчетов об исполнении бюджетов всех нижестоящих уровней, одобрение соответственно государственного бюджета или бюджетов соответствующих уровней.

б) Постоянный комитет ВСНП (ПК ВСНП) и постоянные комитеты нижестоящих СНП - занимаются проверкой и контролем исполнения бюджетов своего и нижестоящих уровней, проверкой и одобрением итогового отчета об исполнении соответствующих бюджетов.

в) Госсовет КНР - составляет государственный бюджет и итоговый отчет об его исполнении, отвечает за организацию исполнения государственного (центрального) и местных бюджетов, за контроль исполнения отделами центрального правительства и местными органами власти государственного бюджета, за доведение до ВСНП или ПК ВСНП результатов исполнения центрального и местных бюджетов.

г) Местные органы власти (все уровни власти, начиная от провинций) - в отношении соответствующих им и нижестоящих бюджетов имеют аналогичные полномочия с Госсоветом.

д) Финансовый отдел Госсовета и местные финансовые отделы - занимаются непосредственным составлением проектов соответствующих бюджетов и отчетов об их исполнении, а также отвечают за практическую организацию исполнения бюджета.

е) Государственное казначейство - отвечает за хранение и учет средств бюджета, организационно подчиняется Народному банку, но в своей деятельности руководствуется инструкциями Госсовета [5].

К участникам бюджетного процесса России относятся: Президент РФ, высшие должностные лица субъектов РФ, главы муниципальных образований, законодательные (представительные) органы государственной власти и представительные органы местного самоуправления, исполнительные органы государственной власти (исполнительно-распорядительные органы муниципальных образований), Центральный банк России, органы государственного (муниципального) финансового контроля, органы управления государственными внебюджетными фондами, главные распорядители (распорядители) бюджетных средств, получатели бюджетных средств [2, с. 185$]$.

Кроме названных участников бюджетного процесса к их числу также относятся и некоторые другие, например, главные администраторы (администраторы) доходов бюджета, главные администраторы (администраторы) источников финансирования дефицита бюджета.

В бюджетном процессе КНР, как и в бюджетном процессе России можно выделить 4 стадии: составление проекта, рассмотрение и утверждение бюджета, исполнение бюджета, которое завершается по окончании финансового года и, наконец, составление, внешняя проверка, рассмотрение и утверждение бюджетной отчетности.

Первая стадия в РФ начинается с того, что Президент РФ, не позднее марта года, предшествующего очередному финансовому году, направляет Федеральному Собранию бюджетное послание, в котором должна быть определена бюджетная политика Российской Федерации на очередной финансовый год и плановый период.

До начала рассмотрения проекта о бюджете на очередной финансовый год должен быть утвержден отчет об исполнении бюджета предыдущего года, который также служит источником информации при рассмотрении нового бюджета. Возможно использование иных программно-стратегических документов, например, прогноза научно-технического развития.

Составлением проекта бюджета занимается Правительство РФ и соответствующие органы исполнительной власти субъектов РФ и органов местного самоуправления, работу над проектом федерального бюджета должны начать не позднее, чем за десять месяцев до начала очередного финансового года.

Данная стадия завершается тем, что не позднее 26 августа года, предшествующего очередному финансовому году, Правительство РФ должно рассмотреть проект бюджета и иные сопутствующие ему материалы и документы, которые были предоставлены Министерством финансов РФ и другими федеральными органами исполнительной власти, и утвердить проект федерального закона о федеральном бюджете для внесения его в Государственную Думу.

В КНР составлением проекта бюджета занимаются финансовые отделы, которые обязаны учесть результаты исполнения бюджета прошедшего периода и реальную оценку прогноза поступления доходов будущего периода. Готовый проект представляется в соответствующий постоянный комитет для проверки за месяц до ежегодной сессии ВСНП или СНП.

Вторая стадия бюджетного процесса - это рассмотрение и утверждение бюджета.

В России, наряду с проектом федерального закона о федеральном бюджете, Правительство РФ вносит в Государственную Думу также проекты следующих федеральных законов: о бюджетах государственных внебюджетных фондов РФ; о внесении изменений и дополнений в законодательные акты РФ о налогах и сборах; о тарифах страховых взносов в государственные внебюджетные фонды на очередной финансовый год. 
Проект федерального закона о федеральном бюджете рассматривается Государственной Думой в трех чтениях.

После того, как Государственная Дума примет соответствующий проекта федерального закона к рассмотрению, он должен быть направлен в Совет Федерации, комитеты Государственной Думы, другим субъектам права законодательной инициативы для внесения замечаний и предложений, а также в Счетную палату РФ для его заключения.

Принятый федеральный закон о федеральном бюджете в течение пяти дней со дня его принятия должен быть передан в Совет Федерации на обязательное рассмотрение, которое длится 14 дней. Далее федеральный закон в течение 5 дней со дня одобрения Советом Федерации направляется Президенту РФ для подписания и обнародования [1].

В Китае данная стадия проходит в два этапа. В первую очередь, осуществляется доклад бюджета и его одобрение ВСНП или СНП. Во вторую, одобренный бюджет регистрируется в органе власти следующего по иерархии уровню. Для того чтобы снять разногласия при регистрации бюджета, законодатель предусмотрел согласительную процедуру, в пределах которой регистрирующий орган власти может направить специальный запрос в ПК СНП нижестоящего уровня [5].

Если бюджет не одобрен до начала бюджетного года (в КНР, как и в России, бюджетный год приравнен к календарному году), местные органы власти могут планировать свои расходы исходя из показателей прошлого года.

Третьей стадией бюджетного процесса в РФ является исполнение бюджета.

Организацией исполнения бюджетов, управлением счетами бюджетов и бюджетными средствами в России занимаются органы исполнительной власти, являющиеся кассирами всех распорядителей и получателей бюджетных средств и осуществляющие платежи за счет бюджетных средств от имени и по поручению бюджетных учреждений [1]. Данная стадия завершается 31 декабря.

За организацию исполнения местных бюджетов разных уровней в Китае ответственны финансовые отделы местных органов власти соответствующих уровней.

Местные органы власти соответствующего уровня обязаны наметить свои расходы согласно сумме бюджетных расходов предыдущего года сразу же после того, как начинается бюджетный год и до того момента, пока проекты местных бюджетов разного уровня не будут одобрены СНП соответствующего уровня. После одобрения такой бюджет требуется исполнить.

Казначейство должно быть создано для каждого бюджета уровня уезда и выше, а при наличии соответствующих условий их надлежит образовывать в каждом поселке, национальном поселке или небольшом городе.

Руководство делами Государственного казначейства осуществляет Народный банк КНР, местными казначействами - согласно положениям Госсовета[3].

Главными обязанностями казначейства является управление точным и своевременным сбором, а также распределением, сохранением и оборотом бюджетных доходов и назначением бюджетных расходов.

В России министр финансов в конце каждого финансового года должен издавать распоряжение о его закрытии и подготовке отчета об исполнении федерального бюджета, а также бюджетов каждого государственного внебюджетного фонда. Этим и начинается стадия подготовки, рассмотрения и утверждения отчета об исполнении бюджета, являющаяся завершающей.

На основании названного распоряжения всеми получателями бюджетных средств должны быть подготовлены годовые отчеты. Главные распорядители бюджетных средств обобщают и сводят отчеты подведомственных им бюджетных учреждений [1]. Бюджетный кодекс РФ утвердил положение о том, Правительство РФ обязано представить в Государственную Думу и Счетную палату РФ отчет об исполнении федерального бюджета за очередной финансовый год в форме федерального закона не позднее 1 июня. Далее, Счетная палата РФ должна провести проверку данного отчета и составить заключение, направляемое затем в Государственную Думу, которая после его получения обязана рассмотреть переданный Правительством РФ отчет в течение одного с половиной месяца. Рассматривая отчет, Государственная Дума должна заслушать доклады руководителей Федерального казначейства и министра финансов о результатах исполнения федерального бюджета, кроме этого доклад Генерального прокурора РФ о соблюдении законности в области бюджетного законодательства и заключение Председателя Счетной палаты РФ.

Рассмотрев отчет и заключение Счетной палаты РФ, Государственная Дума должна принять одно из следующих решений: об утверждении отчета об исполнении федерального бюджета или об отклонении отчета об исполнении федерального бюджета.

За составление проекта итогового отчета об исполнении бюджета в КНР отвечает финансовый орган соответствующего уровня, который затем передает его в ПК СНП. Затем уже готовый отчет передается в Госсовет, который проверяет его и направляет далее для проверки и одобрения в ПК ВСНП [3].

Итоговый отчет об исполнении бюджета, как и сам бюджет, передается для регистрации в органы государственной власти следующий по восходящей уровня.

Подходя к концу, необходимо также заметить, что Россия имеет трехчленную формулу баланса бюджетов и состоит из доходов, расходов и источников их финансирования дефицита бюджета, в КНР же бюджет двойной и являет собой баланс расходов и доходов. Здесь бюджет центрального правительства, в соответствии с бюджетным законодательством, аналогично государственному бюджету СССР, должен составляться бездефицит- 
ным. Это предполагает выравнивание всех возникающих диспропорций через перераспределение расходов и доходов на уровне вышестоящего бюджета.

Таким образом, несмотря на общую схожесть черт бюджетных процессов России и КНР, они имеют ряд различий, большая часть которых, обусловлена особенностями национального законодательства, а также государственного устройства и государственного строя, и связана с тем, что бюджетный процесс Китая более всего похож на бюджетный процесс СССР. Так, бюджет центрального правительства КНР составляется бездефицитным и объединяет в себе все бюджеты бюджетной системы, как это происходило и в СССР. Кассовым исполнением госбюджета СССР занимался Государственный банк СССР, а кассовым исполнением государственного бюджета КНР - Государственное казначейство, которое подчиняется Народному банку КНР. Похожими являются и полномочия их финансовых органов.

\section{Литература}

1.Бюджетный кодекс Российской Федерации [Электронный ресурс]: [Федеральный закон от 31.07.1998 N145-Ф3 (ред. от 15.02.2016)]. Режим доступа: http://base.garant.ru/12112604/

2.Бюджетный процесс: сущность, участники, этапы // Молодежный научный форум: Общественные и экономические науки: электр. сб. ст. по материалам XXIX студ. междунар. заочной науч.-практ. конф. 2015. № 10 (29) / [Электронный реcypc]. URL: http://www.nauchforum.ru/archive/MNF_social/ 10(29).pdf

3.Закон КНР «О бюджете Китайской Народной Республики» [Электронный ресурс]: [Принят 22 марта 1994 г.]. Режим доступа: http://law.uglc.ru/budget.htm

4.Казна и бюджет / Д. Л. Комягин [и др.]; отв. ред. Д. Л. Комягин. М.: Наука, 2014. 501 с.

5.0 бюджетной системе и современном бюджетном законодательстве Китая [Электронный ресурс]. Режим доступа: http://www.center-bereg.ru/o2618.html

\section{Сравнительно-правой анализ защиты социальных прав на примере Российской Федерации и КНР}

(C) К. М. Бернадская магистрант 1 года обучения юридического факультета ФГБОУ ВО «Бурятский госуниверситет»

Россия, г. Улан-Удэ german211093@mail.ru

Социальные права и свободы - это права, признаваемые за человеком как за участником гражданского общества, которые гарантируются государством. Социальные права - это права на участие в обеспечении достойных условий материального и физического существования. Социальные права и свободы обеспечивают свободу человека в экономической, социальной и культурной сферах и дает ему возможность защитить свои жизненные потребности. Данная группа прав неотчуждаема от личных и политических прав, поскольку все права и свободы взаимосвязаны и составляют единый правовой статус человека и гражданина. Однако, защита этих прав весьма затруднительна. Конституционное закрепление таких прав не является основанием для возбуждения дела. Например, в России - Федеральный закон от 15.12.2001 г. № 166-Ф3 «О государственном пенсионном обеспечении в Российской Федерации», Федеральный закон от 29.12.2012 г. № 273-Ф3 «Об образовании в Российской Федерации», Федеральный закон от 10.01.2002 г. № 7-Ф3 «Об охране окружающей среды» и др.

Таким образом, социальные конституционные права являются не столько юридическими нормами, сколько стандартом, к которому стремится государство в своей политике. Международный Пакт об экономических, социальных и культурных правах обязывает государства «принять в максимальных пределах имеющихся ресурсов меры к тому, чтобы обеспечить постепенное полное осуществление признаваемых в Пакте прав» (ч.1 ст.2) [1]. В целях защиты таких прав, в государствах существуют специальные органы защиты прав человека, в России данным примером может послужить Конституционный Суд Российской Федерации.

В ноябре 1991 г. китайским правительством была опубликована книга «Права человека в Китае», благодаря которой международное сообщество ознакомилось с основной позицией и практикой Китая в области прав человека. За последние четыре года Китай добился в этой области новых сдвигов.

С 1991 г. начинается важный исторический период - всестороннего осуществления в Китае восьмого пятилетнего плана народнохозяйственного и социального развития. В 1995 г. Китай осуществил стремительный рывок в области народнохозяйственного и социального развития и досрочно достиг намеченной на 2000 г. цели четырехкратного увеличения по сравнению с 1980 г. объема валовой национальной продукции. Жизненный уровень китайского населения заметно возрос, продолжается продвижение вперед к обеспечению уровня средней зажиточности населения. В настоящее время в Китае существует положительная социальная стабильность, экономического развития, социального прогресса, национального сплочения, народного благосостояния, всестороннего улучшения положения в области прав человека. Практика показывает, что приоритетное право народа на существование и развитие, всестороннее улучшение положения в области прав человека в условиях реформы, развития и стабильности соответствуют китайской реальности и отвечают коренным интересам всего китайского народа и вызывают одобрение со стороны мировой общественности [2]. 
Китай активно выступает в защиту целей и принципов Устава ООН, направленных на содействие правам и основным свободам человека, решительно выступает против применения некоторыми государствами двойных стандартов в области прав человека по отношению к другим, особенно развивающимся странам, против навязывания другим собственной модели, против гегемонистских попыток вмешательства во внутренние дела других стран под предлогом «проблемы прав человека». Принципиальная позиция Китая в вопросе прав человека завоевала поддержку со стороны многих стран мира. Он прилагает свои усилия в борьбе за мир, в содействии нормализации международной ситуации в области прав человека.

Желающим в обращении с обжалованием в суд, а также обеспечение процессуальных прав граждан Китая, вменяется в обязанности общественным организациям. Общественные организации имеют право по поручению истца выступать в суде в роли его представителя, иначе говоря, граждане могут осуществлять свои процессуальные права с помощью общественных организаций.

Для предоставления удобства гражданам, обращающимся в суд с жалобой, Верховный Народный Суд постановил, что для граждан-истцов, действительно испытывающих материальные затруднения, допускается отсрочка уплаты, частичное или полное освобождение от уплаты расходов на судопроизводство.

Китайскими властями была введена довольно таки действенная и всеохватывающая тенденция. Для обеспечения грамотности и юридической образованности широких масс населения, были разработаны образовательные программы с использованием литературы, печати, искусства, конкурсов-викторин, консультации специалистов, средства теле- и радиовещания и прочее.

В настоящее время, правительство Китая занимается разработкой девятого пятилетнего плана народнохозяйственного и социального развития и перспективного плана на 2016 г., согласно которым к 2017 г., когда численность населения Китая по сравнению с 1990 г. увеличится на 3000 млн. человек, валовой национальный продукт на душу населения возрастет по сравнению с тем же годом в четыре раза. К тому времени в Китае в основном будет ликвидирована бедность, и жизнь народа станет зажиточной. К 2016 г. ВНП увеличится в два раза по сравнению с 2006 г., и жизнь народа будет еще более зажиточной. Претворение в жизнь девятой пятилетки и перспективного плана на 2016 г. позволит китайскому народу пользоваться правом на существование и развитие на более высоком уровне и в более широких сферах [3].

Тем временем в России Конституционный принцип социального государства предполагает создание равных возможностей для всех членов общества, проведение социальной политики, признающей за каждым членом общества право на такой уровень жизни, который необходим для поддержания здоровья и благосостояния его самого и его семьи, когда он работает, а также в случаях безработицы, болезни, инвалидности, старости.

Различные научные деятели, сравнивают состояние социального государства Россию, с состоянием на уровне 1920-х годов. Одной из причин некой «отсталости» социальных механизмов, являются политико-социальные пережитки советского государства.

Основные социальные права неотчуждаемы и принадлежат каждому от рождения. Провозглашение Российской Федерации социальным государством предопределяет проведение социальной политики, направленной на признание и защиту социальных прав человека на основе принципов справедливости и в соответствии с общепризнанным международно-правовыми стандартами.

Защита социальных и экономических прав, является неотъемлемой и самой важной частью жизни общества. Нарушение данных прав встречаются в обыденной жизни практически повседневно, а механизм защиты социальных прав, не всегда является гарантом и в полной мере охватывающий данную группу прав. Это не только демонстрирует приверженность государства общечеловеческим ценностям и гуманистическим идеалам, что само по себе очень важно и характеризует качественное состояние государства, но и является фактором, обеспечивающим социальную безопасность, стабильность развития общества [5].

Конституционный Суд наряду с проведением единой политики защиты социальных прав, так же разрабатывает и правовые позиции, оказывающие существенное значение для законодательства в этой сфере.

В данной таблице наиболее подробно представлены сходства и различия социального законодательства двух огромных держав, Российской Федерации и КНР.

Сравнительный анализ социальных прав, закрепленных в конституции Российской Федерации и КНР.

\begin{tabular}{|c|c|}
\hline Китай & Россия \\
\hline \multicolumn{2}{|c|}{ право на труд, обязанность трудиться } \\
\hline $\begin{array}{l}\text { Статья } 42 \\
\text { Граждане КНР имеют право на труд и обязаны трудиться. } \\
\text { Государство создает условия труда, улучшает охрану труда. } \\
\text { Государство поощряет занятие граждан добровольным } \\
\text { безвозмездным трудом. Государство осуществляет необхо- } \\
\text { димое трудовое обучение граждан до устройства их на ра- } \\
\text { боту. }\end{array}$ & $\begin{array}{l}\text { Статья } 37 \\
\text { 1. Труд свободен. Каждый имеет право свободно распоря- } \\
\text { жаться своими способностями к труду, выбирать род дея- } \\
\text { тельности и профессию. } \\
\text { 2. Принудительный труд запрещен. } \\
\text { 3. Каждый имеет право на труд в условиях, отвечающих } \\
\text { требованиям безопасности и гигиены, на вознаграждение за } \\
\text { труд без какой бы то ни было дискриминации и не ниже } \\
\text { установленного федеральным законом минимального раз- } \\
\text { мера оплаты труда, а также право на защиту от безрабо- } \\
\text { тицы. } \\
\text { 4. Признается право на индивидуальные и коллективные } \\
\text { трудовые споры с использованием установленных феде- }\end{array}$ \\
\hline
\end{tabular}


на забастовку .

5. Каждый имеет право на отдых. Работающему по трудовому договору гарантируются установленные федеральным законом продолжительность рабочего времени, выходные и праздничные дни, оплачиваемый ежегодный отпуск.

Обязанность всех граждан трудиться прописана в конституции Китая. Конституция РФ закрепляет право на труд и свободу труда, раскрывая ее как право каждого свободно распоряжаться своими способностями к труду, выбирать род деятельности и профессию. Человек вправе как работать, так и не работать, не может быть и речи о привлечении к административной или уголовной ответственности за так называемое тунеядство, бродяжничество и т. д. Свобода труда связана с запретом принудительного труда. С правом на труд связано право трудящихся на забастовку. Конституция России устанавливают это право. В китайской конституции о нем не говорится, но также нет и запрета на забастовки.

право частной собственности, наследование

В Китае разрешается частная собственность, но основой экономики является всё же государственная собственность и собственность трудящихся. Государственная собственность находится под особой защитой. В России же наоборот, провозглашен принцип неприкосновенности частной собственности. В России собственник вправе совершать в отношении своего имущества любые действия, включая создание частных предприятий, фермерских хозяйств и другую экономическую деятельность.

право на социальное обеспечение, пенсии

Пенсии государственные и муниципальные, выплачиваются из государственного фонда. Социальное обеспечение также происходит за счет государства.
Пенсии государственные и муниципальные, выплачиваются из государственного фонда, состоящего из отчислений предприятий, работников и бюджетного фонда. Возможно социальное обслуживание инвалидов, престарелых. Также, пенсии выплачиваются фирмами на которых трудился человек.

Таким образом, модель социальной защиты, действующая сейчас в Китае, нацелена на запуск современных страховых механизмов и обеспечение необходимых стандартов социальной защиты. Важная роль отводится здесь традиционно-семейному фактору оказания социальной поддержки. Во всех этих процессах активно участвует государство, мотивируя развитие коллективных форм помощи и благотворительной деятельности. Сегодня приоритетной частью китайских реформ становится именно социальная сфера.

Китайская власть принадлежит народу. В этом основное значение и фундаментальный принцип государственного строя Китая, основная суть его социалистической и демократической системы правления. Народ осуществляет государственную власть через Всекитайское и местные Собрание народных представителей разных уровней. Что касается Российской Федерации, одной из основных частей конституции и задачами, поставленными перед государством. Поэтому эти права принадлежат защите в порядке конституционного судопроизводства Конституционным Судом Российской Федерации. Федеральный Конституционный Закон устанавливает критерии допустимости жалоб: подведомственность дел Конституционному Суду; как гарантии права на судебную защиту, ст. 46 (ч.1) Конституции Российской Федерации каждому гарантирует судебную защиту прав и свобод [6]. Конституционный Суд Российской Федерации является судебным органом конституционного контроля, самостоятельно и независимо осуществляющим судебную власть посредством конституционного производства. Защита основных прав и свобод человека и гражданина - одна из целей деятельности Конституционного Суда Российской Федерации, достигается им при разрешении дел в соответствии с его компетенцией. Она достигается Конституционным Судом Российской Федерации в контексте с другими целями, поставленными перед ним Конституцией Российской Федерации и Законом от 21 июля 1994 года - защитой конституционного строя, обеспечения верховенства и прямого действия Конституции Российской Федерации. Одновременное достижение этих целей обеспечивается принимаемыми Конституционным Судом Российской Федерации решениями [7].

\section{Литература}

1. Конституция Российской Федерации (Принята общенародным голосованием 12 декабря 1993г.) [Электронный ресурс]. Режим доступа: https://www.consultant.ru/document/cons_doc_LAW_28399/

2.Сошникова, Т.А. Правовой механизм защиты конституционных прав и свобод в сфере труда: дис. ...д-ра юр. наук (12:00:02, 12:00:05). М., 2005.

3.Прогресс Китая в защите прав человека (Белая книга) [Электронный ресурс]. Режим доступа: http://www.mfa.gov.cn/rus/ziliao/zt/zfbps/t25318.htm;

4.Российская газета // 31 декабря. 2014. № 299 (6571)

5.Федеральный Конституционный закон от 21.07.1994 № 1- ФКЗ (ред. От 14.12.2015) «О Конституционном Суде Российской Федерации» [Электронный ресурс]. Режим доступа: https://www.consultant.ru/document/cons_doc_LAW_4172/\$;

6. Режим доступа: http // studopedia.org/2-52883.html

7. Режим доступа: http://saint-petersburg.china-consulate.org/rus/zt/rqwt/t175676.htm. 


\title{
Сравнительный анализ валютного регулирования в России и Китае
}

\author{
(С) И. О. Будаева \\ студентка 4-го курса юридического факультета \\ ФГБОУ ВО «Бурятский госуниверситет» \\ Россия, г. Улан-Удэ \\ ira-budaeva@mail.ru
}

За последние 3 года в России произошло событие, усилившее общий интерес к вопросам валютной политики: курс рубля по отношению к доллару США резко снизился. Это событие произошло на фоне ускорения утечки капитала из страны. Но хотелось бы отметить, что аналогичные процессы происходят не только в России, но и в ряде зарубежных стран, где также наблюдается обесценивание национальных валют и значительный отток капитала[1,c.1].

В связи с этим возникает вопрос: достаточно ли на данный момент существующих мер экономической валютной политики для защиты национальной валюты, не следует ли подкрепить экономические стимулы временным восстановлением тех или иных административных барьеров?

Напомним, что в России с 2007 г. действует правовой режим совершения валютных операций, который можно определить как мягкое валютное регулирование[2, с.1]. Практически любые валютные операции разрешены, по крайней мере, международные. Единственное условие купли-продажи иностранной валюты - это совершение сделки через уполномоченный банк. Сохранено правило репатриации валютной выручки, но обязательная продажа иностранной валюты за рубли полностью отменена[3, с.1].

Поскольку Россия решает те же задачи в валютной сфере, что и большинство других стран, в том числе и Китай, следует разобраться, уникален ли наш российский опыт правового регулирования валютных операций, существенно ли отличается валютное законодательство Китая и России, и совпадает ли направление развития валютного законодательства.

Из множества стран для изучения был выбран именно Китай, так как, на наш взгляд, это позитивный пример последовательного эволюционного движения от валютной монополии к жесткому, а затем мягкому валютному регулированию, и в этом китайский опыт наиболее близок к российскому.

Китайская Народная Республика.

Для начала мы хотели бы рассмотреть, какие именно валютные ограничения характерны для КНР.

Основными принципами действующего валютного регулирования КНР являются:

1) практически полная свобода совершения текущих валютных операций;

2) сохранение ряда ограничений по капитальным операциям;

3) сохранение валютного контроля, осуществляемого финансово-кредитными учреждениями (аналог агентов валютного контроля) и Управлением валютного регулирования (орган валютного контроля);

4) допустимость применения мер валютного регулирования в экстренных случаях в экономике [4, с.2].

Базовым валютным ограничением, как и в Российской Федерации, в КНР служит сосредоточение всех валютных операций в уполномоченных банках, точнее финансово-кредитных учреждениях, к которым относятся собственно уполномоченные банки и валютные брокеры. Это касается как проведения расчетов, так и конверсионных операций.

Ограничения по текущим международным операциям в стране отсутствуют (ст. 5 Норм и правил). Кроме того, отменены репатриация валютной выручки резидентами и ее обязательная продажа. Теперь возврат выручки на территорию КНР или оставление ее за собой (либо продажа через уполномоченный банк) осуществляется по решению резидента (ст. 9 Норм и правил)[5,c.2].

Среди валютных ограничений валютных операций внутри страны можно назвать следующие.

1) Осуществление расходов в иностранной валюте осуществляется либо за счет собственной иностранной валюты, либо за счет валюты, приобретенной у финансово-кредитных учреждений на основании подтверждающих документов.

2) Установлен запрет обращения иностранной валюты на территории КНР, расчетов и установления цен в иностранной валюте. Однако Государственным советом КНР могут предусматриваться случаи, когда такие расчеты допускаются, например, на приграничных территориях.

3) Купля-продажа иностранной валюты осуществляется только через уполномоченные банки или специализированных валютных брокеров[6,с.3].

Если текущие валютные операции в КНР совершаются свободно (отчасти даже более свободно, чем в Российской Федерации, в связи с отменой требования репатриации валютной выручки), то регулирование операций движения капитала сохраняет рудименты режима жесткого валютного регулирования.

В КНР установлены следующие валютные ограничения для капитальных операций:

1) При осуществлении прямых инвестиций на территории КНР иностранные организации и частные лица после получения разрешения должны также зарегистрировать в Управлении валютного регулирования свою деятельность. 
2) Регистрация в Народном банке КНР также требуется для иностранных организаций в случае осуществления на территории Китая деятельности с ценными бумагами, выпуска и операций с производными финансовыми инструментами.

3) Резиденты, планирующие осуществлять инвестирование за пределами КНР, также должны оформить регистрацию.

4) Средства в иностранной валюте и юанях, полученные при конвертации иностранной валюты, на счете движения капитала должны использоваться по установленному назначению.

5) Предоставление банковским учреждением кредита за рубеж, в том числе резиденту, осуществляется с согласия Народного банка КНР[7,c.3].

Действующее законодательство не устанавливает ограничений на открытие валютных счетов внутри страны или за ее пределами.

Отменена обязательная проверка источников валютных поступлений для компаний, желающих инвестировать за рубеж.

Специальных ограничений на валютные операции с офшорными юрисдикциями Нормы и правила не устанавливают.

Полученную в юанях выручку иностранные инвесторы вправе использовать для приобретения иностранной валюты, также они могут репатриировать ее за рубеж, но только через посредство финансово-кредитного учреждения, осуществляющего обмен и продажу иностранной валюты.

Особую значимость представляет активное использование юаня и иностранных валют в международных расчетах, закрепляемое в соответствующих нормативных документах (приводимые положения не являются валютными ограничениями, однако устанавливают правовой режим в отношении ряда операций).

Определенные особенности в КНР так же имеет и валютный контроль

Законодательство КНР детально описывает полномочия субъектов, осуществляющих валютный контроль в КНР. Исходя из объема полномочий Управление валютного регулирования можно назвать органом валютного контроля, а уполномоченные финансово-кредитные учреждения - агентами валютного контроля. Оговоримся, что в Нормах и правилах термины «органы валютного контроля» и «агенты валютного контроля», характерные для российского законодательства, не используются [8, с.4].

Финансово-кредитные учреждения в КНР признаются агентами валютного контроля. При выявлении финансово-кредитными учреждениями, осуществляющими операции с иностранной валютой, противоправных действий клиентов с иностранной валютой они информируют об этом органы валютного регулирования (ст. 36 Норм и правил).

Указанные организации обязаны подавать в орган валютного регулирования (Управление валютного регулирования) информацию о платежах в иностранной валюте и об изменениях на счетах клиентов.

В основе валютного контроля в КНР лежат принципы законности всех операций и достоверности документов. Финансово-кредитные учреждения, осуществляющие валютные операции по поручению клиентов, продавая им валюту, должны принимать разумные меры для проверки документов, подтверждающих операции, а также их соответствие платежам в иностранной валюте. Орган валютного регулирования обеспечивает надзор и проводит проверку использования средств в иностранной валюте и в юанях, полученных при конвертации иностранной валюты, на счете движения капитала.

Для текущих операций также разработаны меры контроля финансово-кредитных учреждений за расходными операциями с использованием иностранной валюты. Такие расходы должны опираться на подтверждающие документы[9,с.5].

Законодательством предусмотрено право любого лица проинформировать орган валютного контроля о правонарушениях в сфере валютного регулирования (ст. 38 Норм и правил).

Так же устанавливается ответственность за нарушение валютного законодательства, в том числе за использование иностранной валюты при расчетах на территории КНР; конверсионные операции в обход финансовокредитных учреждений; самовольное изменение назначения использования средств в иностранной валюте или средств, полученных при конвертации иностранной валюты; проведение капитальных операций без соответствующих разрешений.

Ну и, конечно же, хотелось бы узнать насколько эффективной на данный момент является валютная политика в КНР.

Цель защиты национальной валюты объективируется в виде конкретных задач, о решении которых свидетельствует достижение определенных количественных показателей. Прежде всего, это стабильность курса национальной валюты, сохранение золотовалютных резервов и поддержание оптимальной структуры платежного баланса.

По нашему мнению, валютная политика КНР, сочетающая экономические меры, валютные ограничения и валютный контроль, демонстрирует довольно убедительный результат. На протяжении последних восьми лет, в течение которых действует управляемое плавание, наблюдается постепенное удорожание юаня по отношению к доллару США[10,c.5]. Интересно, что даже отказ от фиксированного курса юаня к доллару в 2005 г. не привел к резким колебаниям курса.

Отмена обязательной продажи валютной выручки в совокупности с отменой требования репатриации валютной выручки не привела, как можно было бы ожидать, к снижению золотовалютных резервов Народного банка КНР. Их величина в последние 10 лет растет и в 2013 г. составляла около 3,8 трлн. долл. США [11,с.6]. 
Полагаем, что Россия также могла бы последовательно двигаться в этом направлении. Ведь сохранение в нашем законодательстве требования репатриации выручки после отмены с 2007 г. обязательной продажи валютной выручки до некоторой степени утратило смысл.

Платежный баланс КНР характеризуется общим положительным сальдо, приток иностранной валюты в страну преобладает над оттоком как за счет торговых статей баланса, так и за счет операций с капиталом, сальдо составляет более 200 млрд. долл. США [12, с.6]. Заметим для сравнения, что положительное сальдо платежного баланса Российской Федерации сохраняется только благодаря перевесу экспортной выручки над платежами за импорт (положительное сальдо по счету текущих операций составляет примерно 29 млрд. долл. США). Напротив, баланс операций с капиталом дает отрицательный итог, который в 2013 г. едва не перевесил положительный итог внешнеторговых операций (около 28 млрд. долл. США) [13, с.6].

Система юридических валютных ограничений отсекает спекулятивное давление на курс и препятствует оттоку капитала. В условиях экономического роста это позволяет Народному банку КНР успешно реализовать денежно-кредитную и валютную политику посредством рыночных инструментов.

Проведенный анализ показал, что существующий в Российской Федерации правовой режим валютного регулирования имеет наибольшее количество общих черт с валютным режимом КНР. Однако в КНР, в отличие от России, последовательно отменены все ограничения текущих валютных операций (в том числе репатриация экспортной валютной выручки) при сохранении ограничений движения капитала.

На наш взгляд чем либеральнее валютное законодательство, тем лучший эффект оно дает с точки зрения обеспечения защиты национальной валюты. Чем меньше регулирования, тем лучше работает система. Этот парадокс объясняется просто: валютное регулирование - не причина, а следствие конкретного явления - ослабления национальной валюты; это лекарство, в котором нуждается слабая экономика, и надобность в нем отпадает по мере оздоровления ситуации.

Таким образом, сбалансированное валютное законодательство КНР позволяет государству получить все выгоды от развития частной инициативы, исключив негативное влияние сугубо спекулятивных валютных операций. В соответствии с этим, на наш взгляд, опыт КНР заслуживает детального изучения.

\title{
Литература
} № 1 .

1.Брюков В. Г. Реформирование системы валютного регулирования КНР // Международные банковские операции. 2010.

2. Режим доступа: http://chinalawinfo.ru/economic_law/.

3. Режим доступа: http://forbes.ua; http://www.forbes.ru/finansy/rynki/.

4. Режим доступа: http://forexaw.com/; http://ru.wikipedia.org/.

5. Режим доступа: http://lenta.ru/news/.

6. Режим доступа: http://rbcdaily.ru/world/.

7. Режим доступа: http://rusecuador.ru.

8. Режим доступа: http://www.cbr.ru/currency_base/dynamics.aspx.

9. Режим доступа: http://www.cbr.ru/statistics/.

10. Режим доступа: http://www.cbr.ru/statistics/; http://www.rosbalt.ru/business/.

11. Режим доступа: http://www.eclac.cl/.

12. Режим доступа: http://www.economywatch.com/economic-statistics/China/; http://www.b24.am/ru/economy/.

13. Режим доступа: http://www.forecast-chart.com.

\section{Источники иудейского права в системе религиозно-правовых источников мира}

\author{
(C) А. Н. Бужнинаев \\ магистрант 1 года обучения юридического факультета \\ ФГБОУ ВО «Бурятский госуниверситет» \\ Россия, г. Улан-Удэ \\ Gerrardc08@mail.ru
}

Исследуя понятие, источник еврейского права, следует понимать сам термин «источник». Во-первых это письменные источники права под которыми понимаются все письменно заверенные источники, которые распространяют свою причастность на данную ситуацию, например, сборники законов и постановлений, «Исторические источники права» это именно те источники, которые «в результате исторических процессов стали источником определенной правовой нормы» [3, с. 256]. В более широком значении к историческим источникам права можно причислить любой фактор - экономический, социальный, духовный, который влечет за собой возникновение новых правовых норм. А также «юридические источники права», «источники становления и образования права». Имея в виду те источники и пути, которые адаптируются самой судебной системой для придания законной силы определенной правовой норме [2, с.608].

В этой связи отметим, что в данном случае речь ведется не только о правовых религиозных источниках, а прежде всего о светском сионистском праве Израиля.

Источники иудейского права имеют существенный религиозный оттенок. С теоретической точки зрения, они определяются специалистами с одной стороны, как «точно переданные слова Бога», а с другой, - как их «божественно вдохновленная интерпретация»[4, с.89]. С древнейших времен, еврейское право было сугубо ир- 
рациональным, передавалось только в устной форме и было связано в основном с поиском истины. Например, пытки подозреваемых огнем и водой, обращение «к небесному голосу» в поисках доказательств и т.д. Однако по мере своего социального развития иудейское право начинало приобретать письменный характер и избавлялось от традиционной иррациональности. В последствие иррациональная техника добычи доказательств исчезла и появился рациональный способ правового сознания с соответствующими уже ему методиками добычи показаний. Логично, что пророчества и гадания с появлением рациональных источников ушли на второй план. Таким образом, священные правовые писания Моисея в системе источников права евреев приобрели доминирующий характер.[2, с.608]

В любой исторический период времени существования еврейского народа, значимость письменных источников еврейского права особенно подчеркивалась и сохранялась.

Например Библия. Важнейший источник права евреев. Он представляет собой «сборник разновременных религиозно правовых сочинений VIII в. до н.э. - II в. н.э.»[8, с. 457].

В словаре Вебстера поясняется, что под понятием Библия понимается священная книга христианства, состоящая из Ветхого Завета и Нового Завета; священная книга иудаизма, состоящая только из признаваемого иудеями Ветхого Завета; а «любое собрание священных писаний и книг, неразрывно связанных с постулатами той или иной религии»[7]. Таким образом, без сомнения издателей данного словаря Коран является Мусульманской библией.

По структуре Библия разделяется на две части Ветхий и Новый заветы.

Ветхий завет и по сей день является еврейской Библией. По традициям христианской литературы все ветхозаветные книги подразделяются на «законоположительно-исторические», «пророческие» и «поэтическо-назидательные» книги. Очевидно. что рассматривая формы и источники иудейского права особый интерес представляет первая группа священных книг - книги «законоположительно-исторические».

В еврейской религиозно-правовой традиции литература также делится на три части. Первая группа включает в себя свод законов жизни евреев-книги Моисея. Эту группу священных книг чаще всего называют Пятикнижием Моисея или же Торой. В иудейской правовой системе Тора выступает традиционно в качестве самостоятельного источника права [5, С. 299].

Вторая группа источников - Небиим, наследие оставленное пророками, а все остальные иудейские священные книги зовутся - Ктувим.

Как известно вплоть до II в. до н.э. Тора рассматривалась как одна книга. Затем, свод законов Моисея разделили на пять частей и стали величать Пятикнижием. Каждая из книг в последствии стала отличаться именно своим содержанием. Например, в книге «Бытие» повествуется о сотворении мира и появлении, сотворении человечества. Однако под человечеством в широком смысле здесь понимается лишь один народ израильтяне. Необходимо отметить, что в данной книге речь ведется как о бытии как таковом, так и о всеобщих законах евреев, в том числе правилах проживания, обычаях, традициях и прочих регуляторах повседневной жизни. [1, с.24]

Все это подтверждается и в остальных главах Пятикнижия. Например, в книге Второзакония, которая явила собой олицетворение всех еврейских законов собранных воедино старейшинами. В юридической литературе Второзаконие зачастую рассматривается как самостоятельный источник иудейского права. [4, с. 156]

Основное внимание во Второзаконии уделяется заповедям которые устанавливают определенные обязанности перед богом и заповеди которые регулируют общечеловеческие отношения. К примеру, заповеди запрещающие поклонения иным богам, запрещающие сотворение кумира, или же упоминать о боге понапрасну. Среди общечеловеческих законов выделить можно правила не убивай, не прелюбодействуй, не воруй, не доноси, уважай отца и мать.

Важное значение во Второзаконии придается постановлениям и законам. С их помощью в обществе евреев регулировались все сферы деятельности людей. Начиная отношениями рыночного характера и общественными нормами и заканчивая на более позднем этапе нормами процессуального права. Например, устанавливался порядок ведения дел в судах, а также порядок, ее судебного рассмотрения дела. «Если будет тяжба между людьми, - говорится в главе 25 Второзакония, - то пусть приведут их в суд и рассудят их, правого пусть оправдают, а виновного осудят»[6].

Таким образом, данные процессуальные нормы давали основание определить порядок сбора показаний и доказательств в суде. Например, если кто-то убьет человека, то убийцу следовало убить по показаниям свидетелей.

Подобный закон предусматривал и порядок исполнения наказания, «если виновный достоин будет побоев, то судья прикажет положить его и бить при себе, смотря по вине его, по счету». Отметим, что «отцы не должны быть наказываемы смертью за детей, а дети не должны быть наказываемы смертью за отцов; каждый должен быть наказываем смертью за свое преступление»[6].

Законы и постановления, содержащиеся в Пятикнижии, включая те, которые включены в содержание Второзакония, в исследовательской литературе называются «Законами Моисея».

Вплоть до XI в. считалось, что Моисей является автором всех законов евреев, лишь позже это удалось опровергнуть европейскими мыслителями.

Однако, в любом случае, Законы Моисея являются неразрывной частью современного израильского права. Всегда, и по сей день, существуя вместе, древние и современные законы, формируют религиозно-правовой характер и содержание современного законодательства государства Израиль. 


\section{Литература}

1.Библейский культурно-исторический комментарий: пер. с англ. СПб., 2003.

2.Марченко М. Н. Источники права: учеб. пособие. 2-е изд., перераб. М.: Норма: ИНФРА-М, 2014. 672 с. 1907.

3.Нечаев В. М. Источники права // Энциклопедический словарь Брокгауза и Ефрона : в 86 т. (82 т. и 4 доп.). СПб., 1890-

4.Пилкингтон С. М. Иудаизм / пер. с англ. Е. Г. Богдановой. М.: Фаир-пресс, 2002.

5.Саидов А. Х. Сравнительное правоведение: учебник / под ред. В. А. Туманова. М.: Юристъ, 2003. 320 с.

6.Сайт русской православной церкви. Режим доступа: http://www.patriarchia.ru/bible/deu/

7.Словарь Вебстер. Режим доступа: http://www.merriam-webster.com/dictionary/bible

8.Хубер В. Права человека и законодательство Библии // Права человека и религия: Хрестоматия. М., 2001.

\section{Административно-территориальное устройство КНР и РФ: сравнительно-правовой анализ}

(С) Н. Л. Васильева

студентка 2-го курса юридического факультета ФГБОУ ВО «Бурятский госуниверситет»

Россия, г. Улан-Удэ Orlivik90@mail.ru

Административно-территориальное устройство (деление) - это разделение территории унитарного государства или субъектов федеративного государства на определенные части: области, провинции, губернии, департаменты и т.д., в соответствии с которым строится и функционирует система местных органов государства [1, c.21].

КНР - унитарное государство, которое, согласно статье 30 Конституции Китайской Народной Республики, имеет следующее административно-территориальное деление:

1) вся страна делится на провинции, автономные районы и города центрального подчинения;

2) провинции, автономные районы делятся на автономные округа, уезды, автономные уезды и города;

3) уезды, автономные уезды делятся на волости, национальные волости и поселки [2].

Однако в провинциях и автономных районах Китая могут быть образованы национальные автономные территориальные образования - автономные округа и автономные уезды. Это является некой специфической особенностью административно-территориального устройства КНР. Создание национальных автономных территориальных образований является решением национального вопроса в КНР. В стране более 91 млн человек (около 9\% населения) являются представителями различных народностей, которым, согласно Конституции Китая, гарантированно право на сохранение и развитие традиций и обычаев. Статус данных образований регламентирован шестым разделом Конституции КНР и является несколько более высоким, относительно других местных образований.

Кроме того, в КНР есть Особые административные районы - это сравнительно новая разновидность территориальных единиц КНР, возникшая в результате возвращения под суверенитет Китая Гонконга (Сянгана) в 1997 г. и Макао (Аомэнь) в 1999 г. Гонконг и Макао обладают достаточно высокой самостоятельностью: имеют собственную социально-экономическую систему, судебную систему, законодательные и исполнительные органы власти.

На сложившуюся трехзвенную систему территориального устройства повлиял ряд различных факторов: исторических, социально-экономических, национально-демографических, наличие языково-диалектных барьеров, а также сложившиеся в Китае многовековые традиции государственного управления.

На данный момент территория КНР состоит из 23 провинций, 5 автономных районов, 4 городов центрального подчинения.

Единицами верхнего звена являются автономные районы. Среднее звено образуют автономные округа, уезды, автономные уезды и города. К низовым местным единицам относятся волости, национальные волости, поселки, города без районного деления, городские районы.

Изменения в территориальную организацию страны могут быть внесены исключительно по решению Всекитайского собрания народных представителей или Государственного совета Китая, на что имеется норма статьи 31 Конституции КНР.

Все территориальные единицы, входящие в состав КНР, обладают собственными органами власти, которые, в свою очередь, образуют единую, целостную систему. Это собрания народных представителей, их постоянные комитеты и народные правительства.

В соответствии с территориальным делением, СНП бывают провинциальными (автономных районов, городов центрального подчинения), уездными (городские) и волостными (поселковые). СНП является выборным органом. Срок полномочий собраний составляет пять лет. В их компетенции входят следующие вопросы:

1. обеспечение исполнения Конституции КНР и иных НПА на соответствующей территории;

2. рассмотрение и утверждение социально-экономического плана и бюджета своей территории;

3. формирование других местных органов государственной власти, отмена или изменение актов правительства подвластной территории;

4. поддержание общественного порядка, охрана прав и свобод граждан. 
Собрания народных представителей образуют постоянные комитеты, которые решают важные вопросы в период между сессиями СНП и контролируют работу некоторых органов, например, народных судов и прокуратур.

СНП на уровне провинции, автономного района, города центрального подчинения наделены правом нормотворчества местного значения.

Местные народные правительства всех ступеней являются местными административными органами государства, ответственными и подотчетными СНП соответствующего уровня и его постоянному комитету, а также вышестоящему народному правительству. Народные правительства выполняют задачи по охране общественного порядка, разрешают некоторые мелкие споры между жителями и т.д. Все местные правительства подчиняются Госсовету КНР.

Административно-территориальное устройство РФ представляет собой деление территории России и ее субъектов на структурные единицы - территориальные образования, которые выступают в качестве основы для функционирования органов государственной власти и местного самоуправления, участия граждан в управлении делами государства, рационального использования ресурсов, создания качественных условий для удовлетворения социально-экономических, политических, духовных и иных потребностей населения страны.

Как мы выяснили на примере Китая, унитарное государство само делится на территориальные единицы. В федеративном же государстве такое деление имеют лишь субъекты Федерации.

В России административно-территориальное устройство основывается на некоторых принципах.

Во-первых, это экономический принцип. Суть его заключается в том, что при образовании административно-территориальной единицы необходимо учитывать особенности хозяйственного профиля, направления развития хозяйства, плотность населения, наличие и состояние путей сообщения и т. д.

Во-вторых, значительную роль в административно-территориальном устройстве играет национальный принцип. Для сохранения и развития социально-культурных ценностей малочисленных наций и народностей, проживающих на территории нашего государства, необходим всесторонний учет национального состава.

В-третьих, принцип максимального приближения государственного аппарата и местного самоуправления к населению. Взаимодействие органов местного самоуправления и населения позволяет быстрее выявлять проблемы и нужды людей, следовательно, качественнее и эффективнее разрешать их.

Действующая на данный момент Конституция РФ не регулирует вопросы административно-территориального устройства. Они находятся в области деятельности субъектов Федерации. Каждый субъект решает такие вопросы самостоятельно, применительно к своим определенным условиям в конституциях республик в составе РФ и в уставах других субъектов.

В соответствии с Федеральным законом от 6 октября 2003 г. «Об общих принципах организации местного самоуправления в Российской Федерации», с 2006 г. введена новая система муниципальных образований, предполагающая новые параметры территориального устройства субъектов Российской Федерации:

- субъект РФ делится на территории муниципальных районов и городских округов;

- в состав муниципального района входят сельские и городские поселения;

- сельское поселение состоит из сельских населенных пунктов;

- городское поселение состоит из города или поселка, кроме того, возможно вхождение в его состав и сельских населенных пунктов;

- сельский населенный пункт - первичная территориальная единица в сельской местности;

- возможно деление крупных городов на районы (городские районы) [4].

Законодательством субъектов РФ об административно-территориальном устройстве определяется порядок образования, преобразования и упразднения административно-территориальных единиц.

Организация и осуществление власти в административно-территориальных единицах РФ базируется на принципе местного самоуправления.

Согласно ст. 130 Конституции РФ, местное самоуправление в Российской Федерации обеспечивает самостоятельное решение населением вопросов местного значения, владение, пользование и распоряжение муниципальной собственностью [3].

Местное самоуправление осуществляется гражданами путем референдума, выборов, других форм прямого волеизъявления, через выборные и другие органы местного самоуправления.

Ссылаясь на статью 12 Конституции РФ, органы местного самоуправления не входят в систему органов государственной власти [3], следовательно, хотя органы государственной власти и создают правовые границы для местного самоуправления, тем не менее, сами они не вправе его осуществлять.

Структура органов местного самоуправления определяется населением самостоятельно.

Структуру органов местного самоуправления составляют:

- представительный орган муниципального образования;

- глава муниципального образования;

- местная администрация;

- контрольный орган муниципального образования;

- иные органы и выборные должностные лица местного самоуправления, предусмотренные уставом муниципального образования и обладающие собственными полномочиями по решению вопросов местного значения.

Порядок формирования, полномочия, подотчетность, подконтрольность органов местного самоуправления, а также другие вопросы организации и функционирования указанных органов закреплены в уставе муници- 
пального образования. Наименование представительного органа муниципального образования, главы муниципального образования, местной администрации определяются законом субъекта РФ исходя из исторических и местных традиций.

Структура органов местного самоуправления определяется населением на местном референдуме (в муниципальном образовании с численностью жителей, обладающих избирательным правом, не более 100 человек на сходе граждан) или представительным органом муниципального образования и закрепляется в уставе муниципального образования.

Изменение структуры органов местного самоуправления осуществляется не иначе как путем внесения изменений в устав муниципального образования. При этом изменения вступают в силу не ранее чем по истечении срока полномочий представительного органа муниципального образования, принявшего данное решение.

Правовой основой деятельности местного самоуправления и его органов выступает Конституция (ст. 12 , 130-133), федеральный закон «Об общих принципах организации местного самоуправления в Российской Федерации», конституции, уставы, законы субъектов Российской Федерации. Кроме того, сохраняет силу закон РСФСР от 6 июля 1991 г. «О местном самоуправлении в РСФСР» в части, не противоречащей вышеназванным и другим правовым актам (с 1 сентября 1995 г. не действуют ст. 1-48, 77-79, 87-96 названного закона).

Для решения местных вопросов муниципальное образование должно иметь денежные средства, для чего формируется местный бюджет. Источниками доходов служат местные налоги и сборы, штрафы, отчисления от государственных налогов; поступления от сдачи имущества в аренду или от его приватизации; отчисления от прибыли муниципальных предприятий (торговых, бытовых, промышленных); различные дотации.

Итак, сравнив административно-территориальное устройство двух стран, можно выделить некоторые особенности.

Особенностью Китайской Народной Республики (КНР) в организации административно-территориального устройства можно считать опыт предоставления большого количества национальных автономий, а также выделение особых административных районов.

Кроме того, в области местного самоуправления Китай показывает постепенное, но не тотальное внедрение принципов местной власти, наряду с этим система местных народных правительств различных ступеней находится под централизованным руководством Госсовета КНР.

В России же местное самоуправление выделено из системы органов исполнительной власти. Вся деятельность органов местного самоуправления осуществляется самостоятельно, при этом роль его малозначительна.

Для того чтобы изменить данную ситуацию, следует повысить эффективность деятельности органов местного самоуправления. К примеру, одной из проблем органов местного самоуправления является ограниченность их собственного, муниципального бюджета. Так, районы Крайнего Севера формируют около трети национального дохода страны, но доля собственных доходов местных бюджетов в общем объеме доходов составляет не более 30-40\%. Как следствие, возникают финансовые проблемы, например, невозможность своевременного оснащения больниц оборудованием, ремонта дорог, модернизации коммунальных инфраструктур. Поэтому систему органов местного самоуправления необходимо развивать и реформировать в соответствии с данной ситуацией.

\title{
Литература
}

1.Большой юридический словарь / под ред. А. Я. Сухарева. 3-е изд., доп. и перераб. М.: ИНФРА-М, 2010. 858 с.

2.Конституция КНР [Электронный ресурс]. Режим доступа: http://chinalawinfo.ru/constitutional_law/ constitution/_ch1 [дата обращения: 08.04.2016].

3.Конституция Российской Федерации (Принята общенародным голосованием 12 декабря 1993г.) [Электронный ресурс]. - Режим доступа: https://www.consultant.ru/document/cons_doc_LAW_28399/ [дата обращения: 08.04.2016].

4.Федеральный закон от 06.10.2003 N 131-ФЗ (ред. от 15.02.2016) «Об общих принципах организации местного самоуправления в Российской Федерации» [Электронный ресурс]. Режим доступа: https://www.consultant.ru/document/ cons_doc_LAW_44571/ [дата обращения: 08.04.2016].

\section{Вопросы параллельного импорта в Евразийском экономическом союзе}

\author{
(C) О. А. Гатаулина \\ ассистент кафедры конституцчионного, \\ административного и муниципального права \\ юридического факультета \\ ФГБОУ ВО «Бурятский госуниверситет» \\ Россия, г. Улан-Удэ \\ Orlivik90@mail.ru
}

Для начала разберемся, что же понимается под импортом на территории Евразийского экономического сообщества. В 2014 году был подписан Договор о Евразийском экономическом союзе, где в Приложение № 7 к Договору о Евразийском экономическом союзе «Протокол о мерах нетарифного регулирования в отношении 
третьих стран» дается определение термина: «импорт»- ввоз товара на таможенную территорию Союза из третьих стран без обязательства об обратном вывозе» [2].

Данное определение по своему содержанию совпадает с понятием, закрепленным в Таможенном кодексе Таможенного союза (далее ТК ТС), однако термин «импорт» не встречается в ТК ТС, вместо этого термина используется понятие «выпуск для внутреннего потребления», обозначающий таможенную процедуру, при которой на территории Таможенного Союза иностранные товары находятся и используются без ограничений по их пользованию и распоряжению[3]. Важен тот факт, что данный термин и его содержание закреплены исключительно в интересах данного Договора, где оно содержится, поэтому его применение, например, к положениям Таможенного кодекса Таможенного союза, с юридической точки зрения, допустимо.

Национальное законодательство в п. 10 ст. 2 Федерального закона № 164-Ф3 от 08.12.2003 г. «Об основах государственного регулирования внешнеторговой деятельности» дает следующее определение: «импорт товара ввоз товара в Российскую Федерацию без обязательства об обратном вывозе» [4].

По нашему мнению, термин «импорт» шире понятия «выпуск для внутреннего потребления». Так последний, по нашему мнению, отражает в основном уже результат процесса приобретения иностранного товара, а термин «импорт» весь процесс - от заключения сделки на его приобретение, перемещения через таможенную границу, ввоза на таможенную территорию и последующего использования.

Несмотря на недостаточную урегулированность термина «импорт» на внутригосударственном и международном уровне, в данной статье мы будем использовать понятие импорт, как более широкое и отражающее действия при ввозе на таможенную территорию Таможенного Союза (далее ТС) или вывозе различными способами, предусмотренными ТК ТС и иными законодательными документами. Данные способы включают в себя и пересылку с помощью международной почтовой службы, использование трубопроводного транспорта и линий электропередач [3]. К указанным действиям также относится и ввоз товаров и транспорта с территории свободных таможенных зон и со свободных складов на остальную часть таможенной территории ТС.

Термин параллельный импорт не встречается в законодательстве ТС и Российской Федерации, но под параллельным импортом принято понимать ввоз товара без акцента правообладателя на территорию страны оригинального товара, защищенного товарным знаком.

В соответствии с Гражданским кодексом РФ юридические лица имеют исключительные права на результаты интеллектуальной деятельности и средства индивидуализации, которыми являются, в частности, фирменные наименования, товарные знаки и знаки обслуживания, коммерческие обозначения [1, ст. 1226].

Торговый знак представляет собой закрепленную в собственности компании совокупность обозначений (названий, логотипов, символов), благодаря которым она или ее продукты отличаются от других компаний и продуктов.

Таким образом правообладатель на законных основаниях может использовать свои результаты интеллектуальной деятельности и средства индивидуализации как он считает нужным, разрешать или запрещать другим лицам их использование (и в том числе импорт). То есть правообладатель имеет в России легальную монополию в отношении неопределенного круга лиц по распоряжению товаром, включающим охраняемые объекты интеллектуальной собственности.

С согласия правообладателя импорт его товара осуществляют его официальные дилеры (фирмы - посредники или представители). Обычно эти же фирмы занимаются и рекламой импортируемого товара, и последующим его обслуживанием: монтажом, гарантийным обслуживанием, ремонтом.

Так вот импорт товара, содержащего результаты интеллектуальной деятельности и средства индивидуализации, без согласия правообладателя общепринято называть параллельным импортом.

Возникают вопросы: при каких условиях параллельный импорт является законным, а при каких противозаконным? Ответить на эти вопросы можно только ответив на третий вопрос: когда и при каких условиях исключительное право правообладателя завершается?

На перечисленные вопросы можно ответить, рассмотрев, так называемый, принцип исчерпания (ограничения) исключительного права. который регламентирует исключительные права правообладателя.

Принцип исчерпания исключительного права состоит в том, что товар, введенный правообладателем в гражданский оборот, может затем беспрепятственно использоваться любым лицом. То есть исключительное право на результаты интеллектуальной деятельности и средства индивидуализации уже реализовано и потому исчерпано, поэтому товар можно свободно перепродавать и использовать. Разрешения правообладателя товара не требуется.

Принцип исчерпания исключительного права может быть национальным, региональным и международным.

Если страна применяет концепцию международного принципа исчерпания исключительного права (например, Китай), то при продаже правообладателем товара в любой стране, права интеллектуальной собственности считаются исчерпанными, и новые собственники имеют право распоряжаться товаром по своему усмотрению и в этом случае параллельный импорт в любую страну разрешен.

При региональном принципе исчерпания исключительного права импорт товара в одну часть региона (например, любую страну Евросоюза) приводит к исчерпанию прав во всём регионе и товар может свободно перемещаться между странами Евросоюза, но при этом параллельный импорт в данный регион запрещен.

В России принцип исчерпания исключительного права отражен в ст. 1487 Гражданского кодекса РФ, согласно которому в нашей стране действует национальный принцип исчерпания исключительного права [1, ст. 1487]. В соответствии с этим законом коммерческая фирма не может купить за границей какой-либо товар и 
импортировать его в Россию без получения согласия от владельца товарного знака, нанесенного на этот товар, даже если этот товар был неоднократно продан за рубежом. Если же правообладатель товарного знака продал товар в России, то после этого он не имеет права препятствовать дальнейшей его торговле на ее территории.

По законам России импортеру необходимо заручаться согласием правообладателей на ввоз, хранение и продажу товаров. Такие разрешения оформляются в виде соглашений (об уступке права, либо о выдаче лицензии). Если же товары в незначительном количестве ввозятся физическими лицами или пересылаются по межнациональной почте и предназначены не для последующей продажи, а для личных и семейных нужд, то согласия на импорт получать не надо [3]. Тут нельзя пройти мимо следующего факта.

Как указывалось выше в России установлен национальный принцип исчерпания исключительных прав на товарный знак [1, ст. 1487]. В ТС провозглашен региональный принцип исчерпания прав на товарный знак. [3]. Поэтому товар легально ввезенный в Беларусь, Казахстан, Киргизию, и т.д. по теории должен свободно обращаться на территории ТС, но при перевозке в Россию этот товар может автоматически по российскому законодательству стать контрафактным.

Необходимо провести грань между понятиями «незаконно ввезённый товар» в рамках параллельного импорта и «контрафактный товар». Определении контрафактной продукции содержится в ст. 1515 ГК РФ, в соответствии с которой под контрафактной продукцией понимается товара, на котором товарный знак размещен незаконно (без воли правообладателя) [1, ст. 1515].

Таким образом в настоящее время в России параллельный импорт запрещен. В целях таможенно-правового регулирования защиты прав на объекты интеллектуальной собственности и, в частности, противодействия параллельному импорту, в каждом государстве ТС был создан Таможенный реестр объектов интеллектуальной собственности. Для этих же целей в ТС был создан Единый таможенный реестр объектов интеллектуальной собственности государств - членов Таможенного союза [3, ст. 330]. Использование информации этих реестров позволяет таможенникам на границе со странами не членами ТС пресекать ввоз в Россию товаров, включающих объекты интеллектуальной собственности, неуполномоченными на это лицами. Правда, при этом таможенные органы не арестовывают товар, а приостанавливается его выпуск на 10 рабочих дней и сообщают правообладателю о нарушении его прав [3, ст. 331-333].

На сегодняшний день в Государственной Думе РФ находиться законопроект, которым вводятся поправки в ст. 1487 ГК РФ, после принятия которого фактически импортеры получают разрешение приобретать товары в любой стране и ввозить их на территорию РФ без каких-либо ограничений. Но как бы там ни было правительство решило поэтапно легализовать параллельный импорт в России не раньше 2018 - 2020 года [5] и только с учетом позиции инвесторов. Делая выводы из выше указанного, то мы наблюдаем расхождение внутригосударственного законодательства (национального принципа исчерпания прав) с законодательством Евразийским экономическим сообществом (регионального принципа исчерпания прав), хотя на практике используется международный принцип.

\section{Литература}

1.Гражданский кодекс Российской Федерации (часть четвертая) от 18.12.2006 № 230-Ф3 // СПС КонсультантПлюс [дата обращения: 20.04.2016].

2.«Договор о Евразийском экономическом союзе» (Подписан в г. Астане 29.05.2014) // СПС КонсультантПлюс [дата обращения: 20.04.2016].

3.«Таможенный кодекс Таможенного союза» (ред. от 08.05.2015) (приложение к Договору о Таможенном кодексе Таможенного союза, принятому Решением Межгосударственного Совета ЕврАзЭС на уровне глав государств от 27.11.2009 № 17) // СПС КонсультантПлюс [дата обращения: 20.04.2016].

4.Федеральный закон от 08.12.2003 № 164-Ф3 (ред. от 13.07.2015) «Об основах государственного регулирования внешнеторговой деятельности» // СПС КонсультантПлюс [дата обращения: 20.04.2016].

5. Режим доступа: http://www.tks.ru/news/nearby/2013/10/21/0007.

\section{Конституционное судопроизводство в РФ и Монголии}

(C) А. Н. Дамиилов магистрант 1 года обучения юридического факультета ФГБОУ ВО «Бурятский госуниверситет»

Россия, г. Улан-Удэ Dampilov.ayur@mail.ru

Каждая модель судебного производства обладает собственным обликом и собственными особенностями. Конституционный процесс РФ отличается от прочих форм правосудия не одними лишь внешними его появлениями, но и процедурными нормами, институтами и стадиями рассмотрения. Становление уставных или конституционных судов субъектов Федерации осуществляется спонтанно, а не системно, обычно по инициативе властных органов. Необходимо принимать во внимание, что такие суды представляют собой важный правовой инструмент по защите основ конституционного строя субъектов Федерации, свобод и прав гражданина и человека. 
Проблема эффективного надзора Конституции - одна из основных гарантий ее выполнения. Опыт создания специализированного суда, который разрешает споры, которые нарушают Конституцию, относится к новейшей истории.

По мнению ученых, если XX век являлся веком конституционного строя, то XXI век будет веком Конституционного суда [1]. В настоящее время конституционные суды, а также органы, которые эквивалентны им, сформированы в большей части стран мира. Они находят характеризующуюся эффективностью форму сотрудничества в целях совершенствования собственной деятельности, обмена опытом работы. К ним есть возможность отнести конференции судей Конституционных судов азиатских и европейских стран, Всемирный конгресс по конституционной юстиции, а также ежегодные встречи регионального уровня Конституционных судов $[2]$.

Конституционное судебное производство в сравнении с уголовным, гражданским, арбитражным и административным судебным производством обладает своим «лицом» и своей «архитектурой». Эта форма правосудия является сравнительно новой. Если в Европе конституционная юстиция утвердилась более семидесяти лет назад, то в РФ - лишь в начале 90-х годов двадцатого века.

По смыслу главы 7 российской Конституции, Конституционный Суд включен в судебную систему РФ. Полномочия Конституционного Суда достаточно детально описаны в статье 125 Конституции РФ, а также в Федеральном конституционном законе «О Конституционном Суде РФ», в соответствии с которыми Конституционным Судом разрешаются дела о соответствии Конституции РФ нормативных правовых актов, федеральных законов, договоров между субъектами и РФ, между самыми субъектами, не вступивших в силу международных договоров РФ и компетенции между органами госвласти на субъектном и федеральном уровнях. Помимо указанного Конституционный Суд имеет уникальное право давать толкование норм и принципов Конституции РФ; по запросу Совета Федерации дается заключение о соблюдении порядка выдвижения обвинения Президента РФ в госизмене или осуществлении другого тяжкого преступления. Законодателем на Конституционный Суд возлагаются функции, которые совершенно не свойственны прочим судам.

По содержанию полномочий Конституционным Судом осуществляется правосудие по обладающим чрезвычайной значимостью личностным и государственным вопросам.

Такой вариант правосудия предстает не только в качестве разновидности судебной власти, но и в качестве равного конституционного органа в одном ряду с федеральными звеньями исполнительной, законодательной и президентской властей.

Неординарность Конституционного Суда отражена в разнонаправленности и весомости полномочий, в объеме, масштабности юридической силы и фундаментальности правовых последствий его решений. Конституционные нормы и принципы, которые регулируют процессуальные, материальные и организационные отношения, отражаются в Федеральном конституционном законе «О Конституционном Суде РФ».

Если сопоставить требования, которые предъявляются, к примеру, к кандидатам в судьи Верховного Суда РФ и Конституционного Суда РФ, то нельзя не обратить внимание на более высокие стандарты требований к последнему.

В качестве судьи Конституционного Суда РФ можно назначать гражданина с безупречной репутацией, обладающего высокой признанной квалификацией в сфере права. Стаж работы по юридической профессии и возрастной ценз также выше на 5 лет.

Конституционное судебное производство в качестве особого способа осуществления судебной власти и самостоятельного вида судебного производства имеет отличие от прочих моделей судебного производства формой конституционного контроля, совмещением в нем нормотворческой, право интерпретационной, правоприменительной деятельности. Неповторимость конституционного правосудия может объясняться многократностью, общеобязательностью использования его итоговых решений, распространенностью его вердикта на всю систему права в государстве.

Особенность такого типа судоотправления может быть объяснена еще и тем, что решения Конституционного Суда не подлежат обжалованию, в этом формате судебного производства не предусматриваются надзорная, кассационная и апелляционная инстанции, в силу они вступают немедленно вслед за их провозглашением. Своеобразие такого варианта судебного производства определяется также составом суда, технологией доказывания, кругом субъектов, вопросами допустимости обращений, предметом рассмотрения спора, неповторимостью стадий. Если уголовное и гражданское судебные производства обслуживаются процессуальными нормами УПК и ГПК, то регулирование процедур конституционного судебного производства производится с помощью норм Федерального конституционного закона «О Конституционном Суде РФ» и Регламента. Юридическая природа Регламента заключена в том, что его применяет не законодатель, а сам суд. В Регламенте устанавливается порядок: определения персонального состава палат Конституционного Суда РФ; распределения дел; очередности рассмотрения, определенные правила этикета и процедуры; вопросы внутреннего распорядка и особенности делопроизводства [5].

Конституционным Судом принимается к рассмотрению только определенная часть обращений, которые поступают. Суд и его Секретариат в большей части случаев отказывают в принятии обращений к рассмотрению в качестве индивидуальных жалоб обычно на том основании, что не соблюдаются требования статей 66 - 67 Закона «О Конституционном Суде РФ».

Стоит обратить внимание, что в сравнении с другими видами судов конституционными судами рассматриваются дела лишь в коллегиальном порядке. Такая форма правосудия позитивным образом сказывается на ка- 
честве решений, которые выносятся, эта модель существенным образом уменьшает возможность совершения ошибок, поскольку вердикт, который выносится конституционным судом, превращается в процессуальный продукт интеллектуальных коллективных усилий. Специфика Конституционного суда РФ и уставных или конституционных судов заключается в том, что ими решаются исключительно вопросы права, и они воздерживаются от исследования и установления фактических обстоятельств в каждом случае, когда это входит в компетенцию прочих судов.

Одно из основных отличий Конституционного Суда от прочих видов судов - это наличие у него контрольной функции [3].

Невзирая на то, что конституционное судебное производство обладает общими чертами, которые присущи и прочим формам правосудия, но оно, очевидно, имеет свойственные лишь для этого типа судебного производства особенности. Кроме того, такие особые черты конституционной юстиции, выпукло обозначающие уникальность и самобытность такой модели правосудия в ряду прочих типов судебного производства нуждаются в наиболее подробном научном исследовании.

Создание Конституционного суда в Монголии превратилось в явление нового общества в стране. В 1990 году Великим народным Хуралом МНР был утвержден Закон «О дополнении к Конституции 1960 года», коренным образом изменивший систему госструктуры. Невзирая на то, что согласно новой Конституции в первый раз предусматривалось предусмотрено создание Конституционного Совета, Конституционное положение о создании Конституционного Совета не успело реализоваться, и в 1992 году была принята новая Конституция. Причина того, что Совет не был создан, крылась в том, что, в истории Монголии не было Конституционного суда или контрольного совета, по этой причине руководство высших госорганов тех времен, члены Великого Народного Хурала не обладали широким представлением о таком суде и существовала недооценка значимости такого госинститута.

В новой Конституции, которая стала основой для становления правового государства, и гарантией перехода государства на новый уровень демократии, по примеру прочих стран предусматривается создание самостоятельного Конституционного суда, который называется «Конституционный суд» (Цэц). В его компетенцию включена защита Конституции, а также установление высшего надзора над тем, как она исполняется. Это стало причиной появления в первый раз в монгольской политической структуре самостоятельного, действующего на постоянной основе суда, функция которого заключается лишь в установке высшего надзора над тем, как исполняется Конституция, в разрешении споров.

После того, как в силу вступила утвержденная Конституция, Малый Государственный Хурал, который является действующим на постоянной основе парламентом того времени 8 мая 1992 года утвердил «Закон о Конституционном суде» и 1 июня того же года им были назначены первые члены Конституционного суда. С того момента началась история суда - Цэц, в переводе на русский «Цэц» означает мудрый судья.

Неслучайное то обстоятельство, что завершающие две главы монгольской Конституции - о конституционном контроле, дают юридическую гарантию того, что Конституция и ее положения будут выполняться.

В пятой главе Конституции было особо указано о Конституционном суде в качестве специализированного суда. В соответствии с пунктом 1 статьи 64 Конституции, Конституционный Цэц (Суд) Монголии является полномочным органом, который осуществляет высший надзор за тем, как выполняется Конституция, выносит заключение о нарушении конституционных положений, рассматривает и разрешает споры; представляет собой гарантию того, что Конституция неукоснительно соблюдается. Видно, что Конституционный суд Монголии это специализированный суд, который имеет такие особенности:

1. Конституционным судом Монголии осуществляется высший надзор за тем, как выполняется Конституция. Этот суд разрешает споры о нарушении конституционных положений. Такой судебной властью не наделен ни один другой суд.

2. В пункте 1 статьи 65 говорится о регламенте назначения судей Конституционного суда, а также о сроке их полномочий и о том, что Конституционный суд включает девять членов. Из них трое назначает Великий Государственный Хурал по предложению Великого Государственного Хурала, трое назначаются по предложению Президента, трое назначаются по предложению Верховного суда на 6 лет. Это говорит о том, что Конституционный суд - это специализированный судом и члены его обладают своими особенностями. Отсюда можно увидеть источники принципа разделения властей. Можно сказать, что в создании Конституционного суда, а также в назначении его членов принимают участие Великий Государственный Хурал, который представляет законодательную ветвь власти, Президент Монголии, который представляет исполнительную ветвь власти, а также Верховный суд, который представляет судебную власть посредством внесения предложения кандидата на назначение членом суда. Однако это не является свидетельством того, что назначенные члены будут представлять те же органы.

3.Конституционным судом разрешаются лишь споры, которые предусмотрены Конституцией. Конституционным судом рассматривается и выносится решение о соответствии Конституции указов, законов и прочих решений Президента и Великого Государственного Хурала, а также решения Правительства, решения Центрального избирательного органа по всенародному референдуму по выборам Президента, Великого Государственного Хурала и его членов, международные договоры Монголии. А, кроме того, споры о нарушении Конституции Президентом, членами Великого Государственного Хурала и его Председателем, членами Правительства, Премьер-министром, Генеральным прокурором и Главным судьей Верховного суда по рассмотрению принадлежат Конституционному суду. Суд Конституционного надзора на основании закрепленных в пункте первом 
статьи 66 положений представляет заключения на рассмотрение в Великий Государственный Хурал. Если Великий Государственный Хурал не согласится с заключениями в соответствии с п. 2, в части 1 и 2 статьи 66 (о соответствии законов, указов и решений Центральных избирательных органов Конституции), то Конституционный суд повторно рассматривает это заключение и принимает окончательное решение.

Если действия, решения прочих государственных органов и должностных лиц не соответствуют Конституции, то их рассматривает Административный суд, в определенных случаях Уголовный или Гражданский суд [4].

4. Рассмотрение споров в Конституционном суде обладает некоторыми особенностями, которые представляют юридические, политические последствия в сравнении с обыкновенными судебными органами. Конституционный суд обладает большим значением в сбалансировании или уравновешивании госвласти. Важнейший принцип госустройства демократического общества - это создание правовой среды, а также порядка ее осуществления в целях проведения деятельности госорганов на базе обоюдной зависимости, обоюдного контроля и уравновешивания. Если акты, которые утверждены Правительством, Президентом, Парламентом, а также действия высокопоставленных должностных лиц государства не соответствуют Конституции, то Конституционным судом устанавливается наличие нарушения в целях отмены этих актов и устанавливается наличие оснований по отстранению их от должности. Это основной механизм разграничения полномочий высших госинститутов со стороны судебной власти, балансирования разделения властей. Судьи Конституционного суда должны обладать высокой квалификацией в сфере права. В Конституции сказано, что членами Конституционного суда назначают тех граждан Монголии, которые имеют высокую политическую и юридическую квалификацию, возраст которых не менее 40 лет. К этому естественно добавляются все критерии, требующиеся судьям обыкновенных судов, а также знания особенностей политической деятельности, высокая квалификация в политике. Если сопоставить возрастные требования, то Члены Конституционного суда должны быть старше на пять лет судьей Верховного суда, на пятнадцать лет старше членов Великого Государственного Хурала. Членом Конституционного суда должен быть человек с богатым опытом государственной службы, с высоким теоретическим знанием и занимающий определенное положение в обществе.

Можно сказать, что Конституционный суд считается судом, который имеет право дать официальное толкование Конституции. Положение четвертого пункта, статьи Шестьдесят шестой Конституции о том что «Если Конституционный суд принял решение о несоответствии Конституции закона, указа и других решении Великого Государственного Хурала и Президента, а также решения Правительства и международного договора Монголии, то соответствующий закон, указ, декрет и решение считаются недействительными”, и то что Великий государственный Хурал приняв заключение суда устраняет конституционное нарушение свидетельствуют и определяют вышесказанное.

Конституционный суд Монголии занимает своё достойное место в системе государственной структуры. Не случаен тот факт, что первый государственный конституционный орган, созданный согласно новой Конституции, был Конституционный суд (Цэц), которому с самого начало положено обязательство контролировать действия Великого Государственного Хурала, Правительства которого будут сформированы позже по новой Конституции, за действиями Президента, и чтобы законы, указы, решения и резолюции, принимаемые ими строго отвечали духу и букве Конституции.

\section{Литература}

1. Кокотов А. Н. Насущные вопросы регулирования деятельности Конституционного Суда Российской Федерации // Рос. юрид. журнал. 2012. № 2. С.20-27.

2. Князев С. Д. Конституционный Суд в правовой системе Российской Федерации // Журн. рос. права. 2013. № 12. C.5-13.

3. Несмеянова С. Э. Конституционный суд России: итоги работы и перспективы // Рос. юрид. журнал. 2012 . № 3. C.103-108.

4. Ондар С. Ю. Конституционный Суд Монголии: правовая природа и особенности. // История государства и права. 2010. № 24.

5. Шульженко Ю. Л., Чиркин В. Ю. Конституционный суд России между прошлым и будущим // Государство и право. 2011. № 12. С.24-30.

\section{Бюджетный федерализм в Российской Федерации}

(С) Л. Э. Дондупова магистрант 2 года обучения юридического факультета ФГБОУ ВО «Бурятский госуниверситет» Россия, г. Улан-Удэ liya.dondupova@mail.ru

Великое множество научных исследований как правоведов, так и экономистов, политологов посвящено рассмотрению вопроса о распределении ресурсов между разными уровнями власти, именно для этого используется понятие «бюджетный федерализм». Конституция Российской Федерации не закрепляет понятие «бюджетный федерализма», тем не менее оно наиболее детально исследуется в научной литературе. Бюджетный феде- 
рализм является одной из частей, составляющих федерализма и означает общность бюджетных отношений, возникающих между органами государственной власти РФ, органами государственной власти субъектов РФ и органами местного самоуправления по поводу формирования и реализации бюджетной политики государства, разграничения бюджетных полномочий в федеративном государстве, организацию и регулирование этих отношений в соответствии с принципами федерализма. [9, с. 45]

Разграничение предметов ведения и полномочий между федерацией и ее субъектами, является для государств с федеративной формой устройства очень важной проблемой и вызывает до сих пор много вопросов. По мнению, Р. Г. Абдулатипова, «от уровня решения данного вопроса во многом зависит характер всего комплекса федеративных отношений во всех сферах жизни общества и государства ... как разграничишь полномочия и ответственность, так и будешь жить». [1, с. 6]

Наука конституционного права выделяет несколько способов такого разграничения. Например, могут выделяться две сферы ведения: и федерации, и субъектов; также может иметь место исключительная компетенция федерации; также может быть указана еще и сфера совместного ведения, а может устанавливаться и перечень предметов ведения и полномочий федерации, и сфера совместного ведения федерации и ее субъектов, который собственно и применяется в Российской Федерации.

Бюджетный федерализм представляет собой, с одной стороны, основополагающий принцип построения бюджетной системы Российской Федерации, а с другой - одну из моделей бюджетного устройства. Также бюджетный федерализм может быть рассмотрен как форма организации межбюджетных отношений.

В научной литературе широко распространена типология межбюджетных отношений, предложенная профессором Национального исследовательского университета - Высшей школы экономики В.В. Ивановым. Он разграничил межбюджетные отношения на пять различных моделей: советскую, китайскую, американскую, канадскую и германскую. Рассмотрим наиболее интересные для нас.

Американская модель - это модель классического бюджетного федерализма. В данной модели налоги федерации, штатов и муниципалитетов не «пересекаются», а также федеральный центр не переводит бюджетам субъектов федерации средства от федеральных налогов. То есть каждый бюджет субъекта имеет в своем распоряжении те налоговые и неналоговые доходы, которые может собрать с территории своего штата, никаких перечислений из федерального бюджета. Участие центрального бюджета заключается в распределении целевых субвенций. Важно отметить, что для каждого штата приоритетными являются общенациональные цели. Экономическая эффективность в этой модели самая высокая.

В канадской модели есть налоги «непересекающиеся», но есть и общие. Но особенность налоговой системы в этой модели заключается в том, что при разделении налоговых поступлений используется метод «достраивания», то есть нижестоящие бюджеты могут увеличивать конечные ставки налогов путем добавления своих ставок к базовой федеральной ставке. В России же до 95\% бюджета формируется именно за счет налоговых поступлений. [3, с. 78]. Как известно, бюджетная система РФ как федеративного государства образуется из бюджетов трех уровней: федеральный бюджет, региональный и местный. Было бы логичным, если бы каждый из них находился в прямой зависимости от налоговых поступлений своего уровня. При поверхностном взгляде так оно и есть: федеральные налоги поступают в федеральный бюджет, региональные - в бюджет субъектов РФ, а местные налоги - в бюджеты муниципальных образований. Однако, на деле ситуация является принципиально иной: доля федеральных налогов значительно превышает долю остальных налогов, вследствие чего основная масса денежных средств (около 80\%) поступает именно в федеральный бюджет. В связи с централизацией налоговых поступлений в федеральный бюджет, таким образом, в первую очередь финансируются задачи федерации, что в итоге приводит к нехватке средств и невозможности региональных и местных уровней бюджетов, чтобы качественно и эффективно исполнять свои расходные обязательства. Так Р.И. Седельникова, считает наиболее критичным при исполнении региональных и местных бюджетов является то, что в их доходных частях ничтожно мала доля поступлений налогов, которые должны выполнять не только фискальную, но и регулирующую и стимулирующие функции. [10, с. 78]

Сложившаяся ситуация приводит к тому, что усилия субъектов РФ направлены на то, чтобы максимально получить финансовые средства из вышестоящего бюджета, что в итоге ведет к иждивенческим настроениям субъектов Федерации. В результате такая система снижает заинтересованность в увеличении своего бюджетного потенциала и росте собственных бюджетных доходов, работы по увеличению экономического, инвестиционного потенциала территории, и конечно же увеличению и эффективному использованию налогов. Конституция РФ прямо не закрепляет гарантию предоставления материальной базы, для реализации полномочий субъекта, но тем не менее из анализа статей, за субъектами Российской Федерации отведены определенные финансовые ресурсы такие как: использование природных ресурсов, налоги и сборы установленные федеральным законодательством и т.д. Самостоятельность бюджетов субъектов, заключается в том, что они обладают всей полнотой власти в пределах своей компетенции, собственно осуществление этих полномочий является способом реализации права субъекта Федерации на собственный бюджет. Бюджет следуют исполнять не на основании плановых расходов, а просчитав объемы необходимых затрат, узнав источники и соответствующие объемы доходов, при котором расходование бюджетных средств изначально обосновывается социально-экономическими результатами предоставления бюджетных услуг. По справедливому замечанию Ю.А. Крохиной, «одна из важнейших задач бюджетной деятельности федерации заключается в установлении баланса финансового соотношения между целым (РФ) и его частями (субъектами РФ)». [7, с. 4] 
В Российской Федерации региональные проблемы требуют глубоко исследования и анализа, так как являются основой федеративного устройства государства. На уровне субъекта Федерации и местного самоуправления, органы власти без дополнительного финансирования оказались обременены обязательствами. Таким образом, необходимы только обоснованные расходные потребности, соответствующие налоговым возможностям субъектов Российской Федерации.

В. В. Иванов рекомендует России реформировать свою систему межбюджетных отношений, взяв за основу канадскую модель. [5, с. 9]. На сегодняшний день каждое государство имеет широкий выбор между существующими моделями межбюджетных отношений. Главная проблема, стоящая перед государством, - выбрать такую, которая лучше всего подойдет к специфическим особенностям данной страны. Формирование российской модели межбюджетного федерализма сопряжено с выделением ряда принципиальных специфических условий. В силу этого, данный процесс изначально не может сводиться к механическому заимствованию швейцарского, германского, американского и т.д. вариантов. Тем не менее, важно выделение и ряда общих черт сближающих российскую модель с соответствующими аналогами. Здесь нужно учитывать, что налоговые системы развитых стран сильно дифференцированы. Дифференциация связана, главным образом, с преобладанием признаков федерализма либо унитаризма (США и Франция), либо с характером изначального процесса формирования федеративного государства - «снизу-вверх» (США), либо «сверху вниз» (Германия). Как унитаризм, так и процесс формирования федеративного государства «сверху вниз» определяют снижение самостоятельности региональных и местных бюджетов, усиление перераспределительных межбюджетных процессов.

В заключений еще раз хотелось бы отметить что, межбюджетные отношения постоянно эволюционируют и в различных странах постепенно приобретают свою специфику. В частности, формирование российской модели межбюджетных отношений связано с выделением принципиальных специфических условий. Поэтому реформирование федерализма в России не может основываться на механическом заимствовании зарубежного опыта, а скорее на адаптации некоторых элементов, функций или принципов функционирования межбюджетных отношений, тем более, что существуют модели, имеющие ряд общих черт с российской. Совершенствование межбюджетных отношений между уровнями власти способствует более успешной реализации бюджетной политики, что, в свою очередь, приводит к политическому, экономическому и социальному развитию всего государства.

\title{
Литература
}

1. Абдулатипов Р. Г. Федералогия. СПб.: Питер, 2014. С. 158.

2. Бюджетный кодекс Российской Федерации: Федеральный закон от 31 июля 1998 г. №145-Ф3 // С3 РФ. 1998. №31. Ст.3823.

3. Грачева Е. Ю., Толстопятенко Г. П. Финансовое право. М.: Проспект, 2014. С. 156.

4. Добрынин, Н.М. Российский федерализм: становление, современное состояние и перспективы. Новосибирск: Наука, 2013. $429 \mathrm{c}$.

5. Иванов В. В. Типология межбюджетных отношений и моделей бюджетного федерализма // Вестник МГТУ. 2010. №1. C. $9-13$

6. Конституция Российской Федерации. Принята всенародным голосованием 12 декабря 1993 г (принята всенародным голосованием 12.12.1993) // СПС КонсультантПлюс.

7. Крохина Ю. А. Бюджетная компетенция субъектов Федерации // Регионы: экономика и социология. 2001. № 2.

8.Налоговый кодекс Российской Федерации (часть первая): Федеральный закон от 31 июля 1998 г. №146-ФЗ // С3 РФ. 1998. №31. Ст.3824.

9. Рагулина Е. В, Конституционно-правовые проблемы бюджетного федерализма в Российской Федерации: автореф. дис. ...канд. юр. наук. М., 2006.

10. Сидельникова Р. И. Проблемы исполнения бюджетов субъектов в Российской Федерации: автореф. дис. ...канд. юр. наук. М., 2010.

11. Столповская Н. Б. Конституционно-правовое регулирование разграничения предметов ведения и полномочий органов государственной власти Российской Федерации и субъектов Федерации в сфере налоговых и бюджетных отношений: автореф. дис. ...канд. юр. наук. Белгород, 2008.

\section{Сравнительный анализ правового статуса Народного Банка Китая и Центрального Банка Российской Федерации}

\author{
() О. С. Жамбалова \\ студентка 4-го курса юридического факультета \\ ФГБОУ ВО «Бурятский госуниверситет» \\ Россия, г. Улан-Удэ \\ Olesenny@mail.ru
}

Банк - это финансово-кредитная организация, производящая разнообразные виды операций с деньгами и ценными бумагами, и, оказывающая финансовые услуги правительству, юридическим и физическим лицам. Банковская система - это совокупность различных видов национальных банков и кредитных учреждений, действующих в рамках общего денежно-кредитного механизма. Национальный банк проводит государственную эмиссионную и валютную политику, является ядром резервной системы. 
30 ноября 2015 г. Международным валютным фондом (МВФ) было принято решение о необходимости включить китайский юань в корзину резервных валют SDR (специальных прав заимствования) [1]. В соответствии с этим положением с 1 октября 2016 года юань становится 5-й валютой в корзине, что доказывает устойчивость и развитость экономики Китая. В связи с этим можно предположить, что для России было бы целесообразным опираться на опыт Китая при развитии своей банковской системы.

Народный банк КНР является центральным банком КНР, он проводит монетарную политику, а также осуществляет надзор и контроль над всей финансовой отраслью [2]. Приблизительно такую же позицию занимает Центральный банк РФ, который образует первый уровень банковской системы России. По этой причине является актуальным провести сравнительный анализ Народного Банка КНР и Центрального Банка РФ, с целью выявить положения, заимствование которых может помочь экономики России более активно развиваться.

К основными функциями Центрального Банка РФ относится: проведение единой государственной денежнокредитной политики; разработка и проведение политики развития и обеспечения стабильности функционирования финансового рынка РФ; монопольное осуществление эмиссии наличных денег; контроль и организация наличного денежного обращения; осуществление эффективного управления золотовалютными резервами Банка России; надзор за банковской деятельностью в стране; организация и осуществление валютного контроля; анализ и прогнозирование состояния экономики Российской Федерации, публикация статистических данных [3]. Центральный банк подотчетен Государственной Думе Российской Федерации, которая назначает его Председателя, по представлению Президента России, и независим от исполнительных и распорядительных органов государственной власти.

Функции и полномочия Центрального Банка России предусмотрены Конституцией РФ, а также множеством Федеральных законов: ФЗ "О клиринге, клиринговой деятельности и центральном контрагенте", ФЗ "О центральном депозитарии", Ф3 "Об ипотечных ценных бумагах", Ф3 "Об организованных торгах", ФЗ "О рынке ценных бумаг", Ф3 "Об инвестиционных фондах". Деятельности Центрального Банка России не зависит от других федеральных органов государственной власти, органов государственной власти субъектов Российской Федерации и органов местного самоуправления.

Россия, как и большинство стран мира, использует двухуровневую банковскую систему, второй уровень которой составляют кредитные организации. Кредитные организации в свою очередь подразделяются на банки, небанковские кредитные организации и филиалы и представительства иностранных банков.

В отличие от России, банковская система КНР состоит из трех уровней. Первый уровень составляется, как уже отмечалось, Народный банк КНР, который выполняет все функции центрального банка. Однако Народный банк КНР не является единственной составляющей, в Китае первый уровень банковской системы включает в себя также подконтрольные государству крупнейшие банки, такие как специализированные банки развития: Государственный банк развития, Экспортно-импортный банк, Банк развития сельского хозяйства Китая; и «большая четверка» коммерческих банков с государственным участием: Банк Китая, Торгово-промышленный банк Китая, Сельскохозяйственный банк Китая, Народный строительный банк Китая.

Торгово-промышленный банк Китая, Народный строительный банк Китая, Сельскохозяйственный банк Китая и Банк Китая соответственно занимают первые четыре места в рейтинге лучших банков мира по общей сумме активов на 2015 год. В совокупности общая сумма активов «большой четверки» превышает 11 триллионов долларов [4].

Второй уровень банковской системы КНР составляют крупные акционерные коммерческие банки; городские коммерческие и кооперативные банки (минимальный размер уставного капитала -100 млн юаней); сельские коммерческие и кооперативные банки; корпорации по управлению активами, трастовые и инвестиционные компании; финансовые и лизинговые компании.

Третий уровень системы представлен почтовыми отделениями связи и деятельностью многочисленных сельскохозяйственных и городских кредитных кооперативов.

Основными функциями Народного банка КНР являются: формирование и осуществление денежной политики в соответствии с законом и обеспечение стабильности стоимости юаня; выпуск юаня и контроль за его обращением; регулирование финансового сектора; осуществление надзора и контроля за финансовым рынком; хранение и осуществление управление государственными золотовалютными резервами, государственной казной; обеспечение нормальной деятельности системы платежей; осуществление надзора за статистикой банковской отрасли, произведение прогнозов; участие в международных финансовых мероприятиях в качестве центрального банка [5]. Для осуществления регулирования и надзора за финансовыми институтами, принимающими вклады, выдающими кредиты, проводящими расчеты по счетам и осуществляющими другую банковскую деятельность в КНР функционирует комиссия по регулированию банковской деятельности.

Структуру Центрального Банка РФ в первую очередь составляет Центральный аппарат, который складывается из департамента, обеспечивающего реализацию основных функций Центрального Банка России, департамента, сопровождающего деятельность самого Центрального Банка России, департамента международных финансово-экономических отношений, который работает по решению вопросов международного сотрудничества [6]. В рамках центрального аппарата действуют также Главное Управление безопасности и защиты информации, а наряду с ним Главное управление недвижимости. Так же частью структуры являются территориальные учреждения, расчетно-кассовые центры, вычислительные центры, полевые учреждения, учебные заведения и другие организации, в том числе подразделения безопасности и Российское объединение инкассации, которые необходимы для осуществления деятельности Центрального Банка РФ. 
Структура Народного банка КНР состоит из 18 функциональных департаментов [7]. Сопоставив основные функции и структуру Центрального Банка РФ и Народного банка КНР, можно сделать вывод об их схожести. Соответственно экономика России развивается не столь стремительно, как экономика Китая, вовсе не из-за недостатков в полномочиях основного органа страны, регулирующего денежно-кредитную политику, и даже не из-за его структуры его аппарата. Именно структура банковской системой Китая в целом, позволяет экономике Китая развиваться динамично и держать вторую позицию, по номинальному значению валового внутреннего продукта (ВВП), в списке стран составленному МВФ от 6 октября 2015 года [8] и Всемирным Банком от 17 февраля 2016 года [9].

Для России перенимание опыта Китая в развитии и управлении банковской системой является одним из путей ее совершенствования. При этом необходимо учитывать тот факт, что не все элементы из банковской системы КНР можно интегрировать в российскую систему, в связи с существенными различиями между рассматриваемыми государствами. Однако некоторые аспекты китайской банковской системы, при правильном подходе, можно успешно использовать в России. Сотрудничество российских и китайских банков также является немаловажным условием развития банковской системы Российской Федерации. Государству необходимо способствовать созданию благоприятных условий для межбанковского сотрудничества с КНР и для привлечения китайских инвестиций в банковскую систему России.

\title{
Литература
}

1.Ежедневное интернет-издание «ЭКД!» [Электронный ресурс]. http://ekd.me/2015/12/yuan-falling/

2.Федеральный закон РФ от 10 июля 2002 года № 86-Ф3 «О Центральном банке Российской Федерации (Банке России)».

3.Макарова А. Д. Сравнительный анализ банковских систем РФ и КНР // Молодой ученый. 2015. №24. С. 494-496.

4.Banks around the world [Электронный ресурс]. Режим доступа: http://www.relbanks.com/worlds-top-banks/assets

5.Официальный сайт НБК [Электронный ресурс]. Режим доступа: http://www.pbc.gov.cn/english/130712/index.html

6. Экмалян А. М. Банк России как мегарегулятор финансового рынка: цели деятельности, функции и полномочия. М.: Юрист, 2015. N 7.

7. Режим доступа: http://muzeydeneg.ru/money/institution/centralbanks/asia-papermoney-centralbanks/narodnyiy-bank-kitaya/

8. Gross domestic product, nominal (англ.). IMF (6.10.2015). — ВВП, номинал. Проверено 3 января 2015.

9. GDP at market prices (current US\$) (англ.). The World Bank (17.02.2016). — ВВП, номинал.

\section{Адаптация опыта США при привлечении к ответственности за налоговые преступления в России}

\author{
(C) B. E. Зуева \\ студентка 4-го курса юридического факультета \\ ФГБОУ ВО «Бурятский госуниверситет» \\ Россия, г. Улан-Удэ \\ zuewaviktoriya@yandex.ru
}

Ответственность за нарушение законодательства о налогах и сборах регулируется Налоговым кодексом, Уголовным кодексом и Кодексом об Административных правонарушениях. Несмотря на то что, данная сфера отношений регулируется достаточно широко, серьезным нарушением закона, а именно преступлением является уклонение от уплаты налогов. Такое уклонение может выражаться в виде непредставления налоговых деклараций или иных документов, сокрытие настоящих доходов посредством внесения в документы ложных или искаженных сведений, использование фальшивых документов.[1]

Данного рода преступления угрожают экономике нашей страны, а также наносят ущерб отдельным ее структурам и различным видам предпринимательской деятельности. Такой ущерб может носить как экономический, так и моральный характер. В количественном отношении наиболее точным учитывается экономический ущерб. Моральный характер ущерба от преступлений в сфере экономики выражается в том, что такая преступность разлагает общество, подрывает веру граждан в дееспособность государственных институтов и учреждений, в возможность честно получать прибыль и участвовать в конкуренции.

В Российской Федерации санкции за неуплату налогов не зависят от статуса и масштабов компании, какой именно вид наказания будет применяться в данном случае, будет зависеть только от размера неуплаченных налогов. Стоит обратить внимание на то, что регулирование налоговых преступлений в России имеет свои особенности. В законодательстве Российской Федерации действует принцип презумпции невиновности, согласно которому лицо не будет считаться виновным в совершении налогового правонарушения, пока его вина не будет доказана надлежащим образом. Также в нашем государстве существует грань между полицией и Федеральной налоговой службой при раскрытии преступлений в сфере налогообложения: налоги компетенция ФНС, борьба с преступностью - дело рук полиции. После инициативы бывшего президента России Дмитрия Медведева, в 2014 году были внесены изменения в Уголовно-процессуальный кодекс, предусматривающие запрет на оглашение мотивировочной части приговора, если уголовное дело связанно с экономической деятельностью.

Налоговые преступления в России регулируются статьями 198, 199, 199.1 и 199.2 Уголовного кодекса РФ и имеют некую схожесть с законами других стран. Важнейшими причинами в росте числа уклонений от уплаты налогов называют правовые причины, которые заключаются в несовершенстве и нестабильности налогового 
законодательства. [3, с. 15] Чтобы оградить бюджетную систему нашего государства от преступлений в сфере экономики, я считаю, следует обратиться к опыту других стран в решении такой проблемы. На сегодняшний день, многие россияне, которые разными способами избегают уплаты налогов, не верят в то, что они будут подвержены их уплате в принудительном порядке. Согласно данным статистике, в России раскрытие налоговых преступлений ведется не всегда результативно. Также такого рода преступления часто совершаются по предварительному сговору, а это в свою очередь значительно усложняет их расследование, так как преступники заранее тщательно планируют и организовывают свою преступную деятельность.[2]

Вследствие этого, я считаю, будет разумным обратиться к опыту зарубежных стран по предупреждению и раскрытию налоговых преступлений. Изучив законодательство некоторых стран, я пришла к выводу, что наиболее эффективно борются с налоговой преступностью в Соединенных Штатах Америки.

Отличительной чертой налогового законодательства в США является то, что ответственность за преступления в сфере налогообложения регулируется не уголовным кодексом, а нормативными правовыми актами, которые входят в систему законодательства о налогах. В Америке уголовная ответственность за уклонение от уплаты налогов закреплена в кодексе Свода законов США, в разделе под номером 26.

Данный кодекс основывается на законе 1954 года о внутренних доходах, который так и называется Кодекс внутренних доходов. Ответственность за налоговые преступления в штатах устанавливается законами соответствующих штатов.

Законодательство Америки устанавливает жесткие санкции за уклонение от уплаты налогов и вообее за нарушение налогового законодательства. В США за такие нарушения, устанавливаются наказания в виде тюремного заключения, а также в виде штрафов, которые наносят значительный материальный ущерб для нарушителя. Используемая в США практика заключения сделок о признании вины в ряде случаев приводит к тому, что налоговые санкции используются для наказания за неналоговые преступления. Любая деятельность, направленная на извлечение незаконных доходов (торговля оружием, наркобизнес и др.), влечет за собой сокрытие этих доходов от налогообложения. Собрать доказательственную базу в отношении неплательщиков налогов намного проще, чем в отношении лиц совершивших другие преступления, так как в первом случае доказательства строятся на основании документов, подтверждающих неисполнение обязанности по уплате, а во втором нередко основываются лишь на человеческих словах, которые в любое время могут оказаться ложью. [4]

Также к характерным чертам американского законодательства в части борьбы с налоговыми преступлениями можно отнести:

наличие института уголовной ответственности корпораций;

$\square$ подробная конкретизация налогового законодательства, а также более улучшенный и оптимальный процесс подачи налоговой отчетности плательщика;

жесткие наказания за нарушения налогового законодательства, способные повлечь за собой не только материальную, но и уголовную ответственность;

сформированный в американском обществе образ честного налогоплательщика;

боязнь не платить налоги и быть застигнутым в совершении данного преступления.

существование выработанного, конкретного и слаженного закона регулирующего налоговые правонарушения, не требующего внесения каких-либо дополнений.

В Российской Федерации правоохранительные органы все чаще стараются уйти от составов правонарушений связанных с налогообложением, посредством обвинения организаций в мошенничестве, фальсификации документов, хищении из государственного бюджета. Нередко, путем обвинения организаций в уклонении от уплаты налогов правоохранительные органы пытаются подвести их под санкцию статьи об отмывании денежных средств. Эти действия дают возможность привлечь компании к сотрудничеству на международном уровне, получать информацию об иностранных счетах организации, имуществе в оффшорах.[5]

Законодательство России не содержит уголовной ответственности корпораций, хотя Государственная Дума РФ не раз выступала с инициативой о ее введении.

Применить опыт США в данной сфере будет трудно, так как необходимо установить основания, в соответствии с которыми корпорации будут привлекаться к уголовной ответственности, в том числе и за налоговые преступления, наряду с физическими лицами.

Высокий удельный вес в России, в отличие от Америки составляют косвенные налоги, а не прямые. Хотя именно прямые налоги подтверждают прозрачность российской системы налогообложения, и способствуют более эффективному осуществлению пресечений и выявлений правонарушения.

Опыт, в частности США, привлечения к уголовной ответственности юридических лиц за налоговые преступления может быть очень полезен для российского налогового и уголовного законодательства, ведь уклонение от уплаты налогов осуществляется зачастую не только в личных интересах руководителя фирмы, но и в интересах предприятия, где присутствуют интересы всех учредителей.

С учетом вышеизложенного, я думаю, что нашей стране необходима адаптация опыта, характерного для системы сбора налогов Соединенных Штатах Америки, влияющего на их поступление в государственную казну. Такой опыт может быть учтен, при становлении эффективного налогового контроля и привлечении к ответственности за налоговые преступления в России. А именно целесообразно перенять опыт штатов по поводу:

1. совершенствования системы отчетности налогоплательщиков посредством упрощения заполнения налоговых деклараций, подачи таких отчетов в электронном виде, информировании предпринимателей и физических лиц о своевременном и правильном заполнении документов. 
2. повышения деловой и финансовой репутации бизнесменов в России. По этому поводу в нашем государстве ведется активная работа, получение льгот, кредитование, получение крупных тендеров и все это становится невозможным без хорошей налоговой истории или как минимум квитанций об уплате налогов.

3. систематизации работы налоговых и правоохранительных органов, обеспечения их необходимыми техническими средствами.

4. поднятия авторитета налоговых служб, формирования общественного мнения и пропаганды образа честного налогоплательщика.

5. ограничения виновных в совершении налоговых преступлениях в некоторых гражданских правах. В данном направлении, возможно, применить практику американских юристов, например в виде лишения права выезда за границу, лишения водительских прав, так как эти меры ответственности, безусловно, будут предупреждать налоговые преступления.

6. разработки и принятия законов регулирующих ответственность корпораций за совершение налоговых преступлений.

Таким образом, адаптация опыта Соединенных Штатов Америки заслуживает внимания в нашей стране, так как с помощью него, можно повысить эффективность работы налоговых служб в России. Ужесточение санкций за налоговые преступления не только позволят увеличить прибыль государственного бюджета, но и повысят правовой авторитет России на мировой арене. При использовании зарубежного опыта необходимо учитывать и объективные условия, в которых создается и развивается налоговая система, состояние экономики в каждой стране, а также принимать во внимание уровень культуры, благосостояние граждан, и даже психологические установки, традиции и менталитет населения.

\section{Литература}

1.Кодекс Российской Федерации об административных правонарушениях от 30.12.2001 N 195-Ф3 // Собрание законодательства РФ. 2016. 30 марта. глава 15.

2.Уголовный кодекс Российской Федерации от 13.06.1996 N 63-Ф3 // Собрание законодательства РФ. 2015.30 дек. ст.198, 199, 199.1, 199.2.

3.Александров И. В. Расследование налоговых преступлений: учеб. пособие. Москва: ЮРАЙТ, 2014. С. 15.

4.Соловьев И. Н. Налоговая амнистия: учеб. пособие. М.: Проспект, 2014. С. 52-53.

5.Селиванова М., Савкин А. Россия идет по пути ужесточения наказания за налоговые преступления [Электронный ресурс]. Режим доступа: http://www.klerk.ru/buh/articles/ 27960.

\section{Сравнительный анализ организации финансового контроля в России и Японии}

() М. С. Иринчеева

студентка 4-го курса юридического факультета ФГБОУ ВО «Бурятский госуниверситет»

Россия, г. Улан-Удэ

ponkinova@mail.ru

Контроль за финансами является одной из важнейших функций управления как на уровне экономического субъекта, так и на уровне государства, и от эффективности организации внутреннего и внешнего финансового контроля во многом зависит дальнейший экономический рост.

Как в России, так и в Японии, финансовому контролю отводится большое значение. «Механизм управления государством при помощи централизованной аккумуляции финансовых ресурсов и организации процесса их перераспределения создания четкой системы финансового контроля, способной обеспечить законность финансовой деятельности государства и оценить ее эффективность и целесообразность» [1].

Как полагает О.Н. Горбунова, «финансовый контроль представляет собой разновидность финансовой деятельности государства, которая осуществляется всей системой органов государственной власти и управления, специальными контрольными органами и состоит в проверке законности и целесообразности действий в области образования и расходования денежных средств, а также субъектов хозяйствования и управления с применением специфических форм и методов его организации и воздействия» [5, с. 108-109].

В современной России финансовый контроль рассматривается в двух аспектах - государственный финансовый контроль и независимый финансовый контроль - аудит.

Осуществлением государственного финансового контроля занимается сразу несколько государственных органов в той части, которая предусматривается законодательством. К примеру, финансовый контроль органов исполнительной власти реализуется через Правительство РФ; контроль законодательных (представительных) органов за деятельностью исполнительной власти в бюджетной сфере осуществляет Счетная палата и иные структуры.

Независимый контроль (аудит) осуществляется в соответствии с Ф3 «Об аудиторской деятельности», который предписывает, что аудиторский финансовый контроль является одним из видов независимого вневедомственного (внешнего) контроля, осуществляемого в качестве предпринимательской деятельности по проверке бухгалтерского учета и финансовой (бухгалтерской) отчетности организаций и индивидуальных предпринимателей. 
В Японии же предусмотрена другая система: во главе органов финансового контроля стоит Государственная ревизионная палата и подотчетные ей структурные органы.

ГРП является контролирующим органом, наделенным конституционным статусом независимости от законодательной, исполнительной и судебной ветвей власти государства. Она включает в себя:

- ревизионный совет;

- общее исполнительное управление.

В настоящее время ГРП возглавляет г-н Терухико Кавато. В общем исполнительном управлении работают 1293 сотрудника, в том числе 880 инспекторов, занимающихся контрольно-ревизионной деятельностью в рамках соответствующих отделов.

Право работать в контрольном управлении получают те лица, которые успешно сдали экзамены для поступления на службу в государственное учреждение. Экзамены принимает специально созданная правительственная национальная служба управленческого персонала. В дальнейшем серьезное внимание уделяется повышению квалификации кадров, для чего управление организует для своих сотрудников различные курсы с отрывом и без отрыва от работы.

Анализируя полномочия ГРП в финансово-экономической сфере, можно выделить два взаимосвязанных направления: контроль в сфере учета государственных финансов и ревизия отчетов об исполнении бюджета. ГРП контролирует ведение учета государственных финансов путем перманентного проведения ревизий бухгалтерской отчетности министерств, ведомств и организаций, получающих или использующих средства национального бюджета для обеспечения надлежащего ведения учета. Объекты ревизии разделяются на обязательные и выборочные, ревизия которых проводится по усмотрению ГРП.

Как в России, так и в Японии ревизии подразделяются на камеральные

и выездные. Только в 2005 г. камеральными проверками было охвачено 170 тыс. финансовых счетов и около 52460 тыс. подтверждающих документов.

Выездные проверки проводятся как внутри страны, так и за ее пределами -в странах исполнения проектов по линии официальной помощи, предоставляемой Кабинетом министров, посольствах и консульствах Японии.

Как показывает практика, на выездные проверки приходится наибольший процент выявленных нарушений. В 2006 г. такими проверками было охвачено 2785 объектов ревизии из 33089 проверенных объектов. В 2005 г. выявлено 473 факта нарушений, называемых японскими экспертами «замечаниями», стоимостное выражение которых составило 45297270 тыс. иен.

По всем нарушениям палатой осуществляется непрерывный последующий контроль вплоть до полного их устранения. При обнаружении нарушений действующего законодательства ГРП не только указывает на факты, но и расследует причины возникновения и активно участвует в исправлении недостатков организации и ведения учета, направляет предписания и представления как в отношении публично-правовых институтов и административных органов власти с требованием принятия мер по устранению нарушений, так и, в отдельных случаях, по совершенствованию законодательных актов страны.

Следует сделать вывод, что в Японии контролирующие органы имеют развитую централизованную систему с прекрасно организованным аппаратом, укомплектованным достаточным штатом высококомпетентных сотрудников.

В России же на сегодняшний день создаются определенные механизмы для повышения эффективности работы контролирующих органов, сформирована система казначейского исполнения бюджета, которая позволяет контролировать целевое использование бюджетных средств. Создана система «госзакупок», в основе которых легли принципы открытости, гласности и конкурентоспособности.

Несмотря на все эти изменения, в сфере финансового контроля России существуют пробелы и проблемы. К ним можно отнести такую актуальную проблему как законодательное обеспечение единства системы финансового контроля в России, вне зависимости от того, что были внесены поправки в Бюджетный кодекс. «В нынешних условиях существуют факторы, ограничивающие действенность государственного финансового контроля в Российской Федерации. К примеру, организационная система финансового контроля в Российской Федерации сегодня характеризуется как неэффективная система. Эта система состоит из органов внутреннего и внешнего финансового контроля, на которые возложены определенные контрольные функции, но действующие несогласованно и без должного взаимодействия друг с другом. Полагаем, что отсутствие четкого разграничения соответствующих органов власти, осуществлящих отдельные виды финансового контроля, повышает риск распространения коррупции в органах исполнительной власти, а также объективно снижает качество контроля за государственными и муниципальными финансами» [1].

Возможно, перенимая опыт у японских коллег, Россия может улучшить систему финансового контроля и тем самым решить другие взаимосвязанные проблемы, как теневая экономика, коррупция, нецелевое использование денежных средств и другие.

«На сегодня органы финансового контроля систематически выявляют факты финансовых нарушений: нецелевое использование и невозврат государственных средств, неэффективное использование денежных средств, неправомерные расходы денежных средств и иные финансово-хозяйственные нарушения. Несомненно, в государстве должен действовать принцип неотвратимости наказания. Однако остаются сферы, в которых этот принцип не действует или наказания за нарушения являются малозначительными. Например, факты оплаты за счет бюджетных средств товаров, которые фактически не были поставлены, или работ (услуг), которые по факту не были выполнены, порой исчисляются сотнями тысяч, миллионами. При этом обеспечить возврат в бюд- 
жет или обязать подрядчика выполнить неправомерно оплаченные работы бывает крайне затруднительно, как и наказать за эти нарушения виновных. Затруднительно привлечение нарушителей к уголовной ответственности, т.к. доказательственная база для этого формируется крайне сложно. При этом зачастую инициатива по выявлению случаев таких нарушений исходит от граждан как потребителей конечного результата закупки» [1].

Примером может служить практика, в частности, Муйского района Республики Бурятия, куда было выделено 17 миллионов рублей на закупку угля и оплаты перевозок. Однако власти района не смогли эффективно освоить деньги, отчего пострадало 500 жителей поселка Северомуйск.

«Вячеслав Наговицын поручил направить в прокуратуру Бурятии обращение, с просьбой дать оценку деятельности главы Северомуйска. Ему также, вероятнее всего, грозит отставка. Это дал понять глава Бурятии, прокомментировав ситуацию накануне журналистам» [9].

Сравнив системы организации финансового контроля России и Японии, можно предложить следующее решение проблем:

1) путем ужесточения ответственности государственных должностных лиц за нарушения требований закона при исполнении федерального бюджета и внебюджетных фондов, а также при распоряжении собственности государства;

2) создание четкой, слаженной системы органов финансового контроля;

3) создание системной и завершенной нормативно-правовой базы;

«На необходимость совершенствования правового регулирования финансового контроля обращают внимание ряд исследователей. Так, Т.В. Конюхова отмечает, что многочисленные акты о финансовом контроле на федеральном уровне, в субъектах Российской Федерации и на уровне местного самоуправления разнообразны не только по их наименованию, но и по содержанию. В Российской Федерации нет связующего базового акта о финансовом контроле» [3, с. 48].

«Стоит согласиться с мнением, что проблему отсутствия единой законодательной базы можно решить с помощью специального федерального закона о государственном (муниципальном) финансовом контроле, отвечающего потребностям современного государственного управления в сфере публичных финансов. Существует солидная аргументация в пользу его принятия. Поскольку основные контрольные функции в области финансового контроля возложены на структурные подразделения Министерства финансов, необходимо четкое законодательное закрепление компетенции каждого из них. Помимо разделения полномочий этих подразделений необходимо четко определить порядок их взаимодействия» [1].

Задача повышения эффективности финансового контроля является сложной, но решаемой. В целом инструментарий создан. Необходимо его использование с одновременным повышением ответственности руководителей и активизации общественного контроля в области расходования бюджетных средств и государственных инвестиций.

\title{
Литература
}

1. Бойко Н. Н. Проблемы организации финансового контроля в Российской Федерации // Финансовое право. 2014. N 3.

2. Клещенко Ю. Г., Савченко М. М. Финансовый контроль как один из факторов обеспечения финансовой безопасности // Финансовое право. 2009. N 5.

3. Конюхова Т. В. Проблемы совершенствования законодательства о финансовом контроле в Российской Федерации // Журнал российского права. 2008. N 2.

4. Саттарова Н. А. Финансовый контроль как фактор эффективной финансовой политики в условиях экономического кризиса: вопросы правового регулирования // Вестник Московского университета. Государственный аудит. 2010. N 1.

5. Финансовое право / под ред. О. Н. Горбуновой. М., 2000.

6. Финансовое право России: учебник. 4-е изд., перераб. и доп. М.: Норма: Инфра- М, 2011.

7. Финансовое право России: учеб. Пособие для бакалавров / отв. ред. М. В. Карасева. 4-е изд., перераб. и доп. М.: Юрайт, 2013.

8. Ялбулганов А. А. Некоторые проблемы развития законодательства о государственном финансовом контроле // Публично-правовые исследования. 2012. Т. 1.

9. Режим доступа: http://www.baikal-daily.ru/news/19/192669/?sphrase_id=6160948

10. Режим доступа: http://economic.social/osnovyi-finansov/sistema-gosudarstvennogo-finansovogo-kontrolya-41034.html

\section{Повышение правовой культуры молодежи: пути и способы решения (на материалах Республики Бурятия и Монголии)}

\author{
(С Д. П. Капустина \\ студентка 2-го курса \\ факультета экономики и управления \\ ФГБОУ ВО «Бурятский госуниверситет» \\ Россия, г. Улан-Удэ \\ dashenkaka-1996@mail.ru
}

Современное российское общество переживает глубокий духовный кризис, вызванный социально-экономическими переменами в стране. Кризис наблюдается и в правовом сознании граждан: правовой нигилизм, 
юридический «беспредел» и правовое бескультурье стали процветающими в обществе явлениями. В наши дни нельзя говорить не только о высоком, но даже и о среднем уровне правовой культуры молодого поколения.

Большинство молодёжи не знают, стоит ли принимать участие в голосовании или нет. Мы думаем, что на выборы молодёжь не ходит не потому, что хочет таким образом выразить свой протест, а потому что не интересно. Одним сложно сделать выбор среди многочисленных кандидатов и политических партий с их программами и обещаниями. Другие считают процедуру выборов формальной, а результат - заранее предрешённым. Этого мнения придерживается большинство. У некоторых нет времени прийти на выборы, есть и такие, кто считает, что его голос ничего не решит. Кто-то вообще не знает, где и когда можно проголосовать, и где расположен избирательный участок. Есть и такие, кто прислушивается к мнению друзей, а также те, которые сами не голосуют и другим не советуют.

Немаловажное значение для молодёжи играет мнение родителей. И если в семье нет такой традиции - ходить на выборы, скорее всего, молодые люди не пойдут и не воспользуются правом голоса. Право избирать и быть избранным в органы власти гарантируется Конституцией Российской Федерации, а заставлять идти голосовать никто не вправе. Несмотря на это, нужно решать эту проблему. В ближайшие годы именно молодёжь может составить основную массу избирателей на предстоящих выборах, таким образом, очень важно в данный момент повысить её электоральную активность. Что же такое правовая культура?

Правовая культура - это разновидность общественной культуры, отражающей определенный уровень правового сознания, законности, совершенства законодательства и юридической практики, и охватывает все ценности, которые созданы людьми в области права.

Кризис правосознания во многом определяется низким уровнем правовой культуры. Как же это исправить? Чтобы наиболее детально подойти этой проблеме, мы воспользовались такой методикой, как экспертный опрос - опрос экспертов с использованием методик индивидуального интервью и анкетного опроса. Метод экспертных оценок позволяет получить информацию, недоступную при помощи иных методов сбора данных, поскольку респондентами выступают лица, в силу занимаемых ими профессиональных или иных позиций, обладающие значительным объемом информации, значимым опытом в исследуемой сфере и/или влиянием на процесс принятия решений. В число экспертов вошли 12 респондентов, в пяти профессиональных и должностных группах, оказывающие значительное влияние на систему мероприятий по повышению правовой культуры молодежи, замещающие высокие позиции в профессиональной, общественно-политической и научной деятельности в сфере молодежной политики. Первую и вторую группы составили научные сотрудники и преподаватели в сфере политической науки и конституционного и муниципального права, занимающиеся изучением молодежной политики и принимающие активное участие в разработке и реализации различных программ и проектов исследуемой проблематики. В третью, четвертую и пятую группы вошли эксперты, в чьи должностные обязанности входит работа с молодыми избирателями. Это государственные и муниципальные служащие, руководители избирательных комиссий и руководители молодежных НКО.

Результаты показали, что уровень правовой культуры в Бурятии удовлетворительный, но есть необходимость проведения работ для её повышения. Работы по повышению правовой культуры молодёжи следует проводить с помощью организации правовых выборов, агитации в интернете, организации молодёжных конференций и фестивалей, а также проведение лекций и уроков, посвященные данной теме.

Что касается Монголии, то здесь ситуация обстоит не лучше, уровень правовой культуры молодых граждан соседнего государства низкий.

\section{Процент явки на парламентских выборах в Монголии}

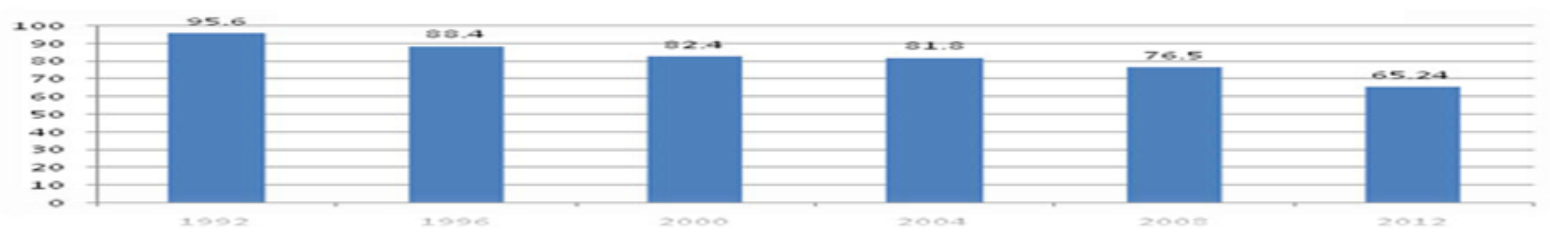

Почти 40\% населения Монголии - граждане в возрасте до 18 лет, 38,6\% активное население в возрасте 1835 лет, остальные 20\% - граждане среднего и пожилого возраста. Граждане, достигшие избирательного возраста, составляют 40\%. Явка на парламентских выборах 2012 года составила 65,24\%, это означает, что менее $20 \%$ молодежи приняли участие в голосовании. А остальные $80 \%$ мнения молодежи остались неучтенными [6].

Согласно исследованиям Генерального избирательного комитета Монголии по сравнению с другими возрастными группами, наименьшая явка на выборах составила всего 10\% среди молодежи в возрасте 18-25 лет. Это происходит из-за низкого уровня политизации и отдаленности от политической жизни молодежи. Данная проблема актуальна среди монгольского общества.

Согласно данным опроса, проведенного в Монголии, степень доверия респондентов к государственным структурам низкая. Результаты проведенного исследования показали, что люди начинают терять веру в законодательную и судебную власть, в политические партии, а также правительство, исполнительную власть и учреждения, которые призваны служить на благо гражданского общества, что неизменно приводит к снижению легитимности государственной власти в глазах молодежи [1]. 
Низкий уровень осведомленности и политическое участие в общественной жизни порождает среди молодежи мнение «Какая разница -участвовать или не участвовать в выборах, если и так наверху без нас все решено».

Таким образом, одной из важнейших задач монгольского государства должно стать преодоление абсентеизма. Для этого необходимо постепенно внедрять в сознание молодежи установки ответственности граждан за происходящие процессы в стране. Изменить отношение молодежи к политике возможно, если она почувствует себя реальным участником и субъектом политических процессов, происходящих в стране. Это станет возможно, если молодежная политика станет приоритетной в Монголии.

Исходя из полученных результатов экспертного опроса, предполагается следующее решение проблемы: написание и реализация социального проекта по повышению правовой культуры молодых избирателей под названием «Поколение И». В проекте будут осуществляться такие механизмы как: информирование о предстоящих избирательных кампаниях, проведение лекций и уроков в школах, вузах, ссузах, организация игровых выборов в учебных заведениях, телевизионная и интернет-агитация, организация тематических площадок по обсуждению политических событий, создание новых молодёжных органов, организация молодёжных конференций, фестивалей, форумов.

В результате работы данного проекта в течение года, в г. Улан-Удэ и в большинстве районов республики сформируется прослойка политически активной молодёжи, занимающейся развитием правовой и избирательной культуры в своих учебных заведениях. Закрепится информационная база, с помощью которой повышение избирательной культуры продолжится, несмотря на завершение проекта.

В заключении всего вышесказанного хочется отметить, что в формировании правосознания молодёжи должны участвовать разные социальные институты - семья, учебные заведения, органы государственной власти, правоохранительные органы, общественные организации, учреждения культуры. Их усилия должны быть объединёнными и системными, их действия и разработка должны регламентироваться законодательно. А также следует уделить внимание правовому воспитанию молодёжи, ведь от того, настолько будет образован и воспитан молодой человек, зависит будущее России!

\title{
Литература
}

1.Ромашов Р. А. Правовая культура молодежи и правовой нигилизм в молодежной среде // История государства и права. 2006. № 2. С.2-8.

2.Михайлова О. А., Ганичкина М. П. Участие молодежи в выборах по-молодежному // Журнал о выборах. 2002 . № 4. С.35-36.

3.Ивойлов И. В. Управление правовой социализацией молодежи // Право и образование. 2003. № 5. С.113-123.

4.Политическое участие молодежи в трансформирующихся обществах (на примере Монголии и Республики Бурятия РФ) // Теория и практика общественного развития. 2015. № 19. С. 2-7

5. Режим доступа: http://mobile.news.mn/mcontent/147768.shtml?s=news(Новости Монголии)

6. Режим доступа: http://manlailagch.mn/?p=1647политический обзор Монголии

\section{Сравнительный анализ некоторых аспектов федерализма Малайзии и России}

\author{
(C) А. В. Клементьев \\ студент 2-го курса юридического факультета \\ ФГБОУ ВО «Бурятский госуниверситет» \\ Россия, г. Улан-Удэ \\ andreymayakkv@gmail.com
}

Проблема федерализма является весьма актуальной для современного мира. Ведь последний не стоит на месте, он постоянно развивается. И что очень важно, это посмотреть в сравнительном русле на формирование моделей федерализма в разных странах.

В данном, относительно небольшом, исследовании хотелось бы остановиться на некоторых аспектах федерализма Малайзии и России.

Целью исследования является сравнение в поисках лучшего, более развитого в механизме реализации принципа федерализма.

Задача заключается в рассмотрении отдельных аспектов сравнения, среди которых стоит выделить:

1) основы административного деления Малайзии и России;

2) органы управления на федеральном и региональном уровнях;

В самом начале хотелось бы привести первые статьи Конституций соответственно Малайзии и Российской Федерации.

Конституция федерации Малайзии, принятая 27 августа 1957 года (в переводе):

«1. Федерация именуется на малайском и на английском языках - Малайзия.

2. Штатами Федерации являются Джохор, Кедах, Келантан, Малакка, Негри - Сембилан, Паханг, Пинанг, Перак, Перлис, Сабах, Саравак, Селангор и Тренгану.

3. С учетом пункта 4 территориями каждого из штатов, перечисленных в пункте 2 , являются территории, которые принадлежали данному штату непосредственно перед Днем независимости. 
4. Федеральная территория Куала-Лумпур, определенная согласно поправке № 2 к Конституции от 1973 года, не относится к территории штата Селангор, а федеральная территория Лабуан, определенная согласно поправке № 2 к Конституции от 1984 года, не относится к территории штата Сабах; обе упомянутые федеральные территории относятся к территориям Федерации» [4].

Конституция Российской Федерации, принятая 12 декабря 1993 года:

«1. Российская Федерация - Россия есть демократическое федеративное правовое государство с республиканской формой правления.

2. Наименования Российская Федерация и Россия равнозначны» [1].

Как видно, эти статьи различны по своей конструкции. В варианте Малайзии говорится в основном о территории, тогда как в первой статье российской Конституции уже начинает раскрываться сущность самого государства как такового.

Первая задача - это раскрыть основы административного деления Малайзии и России.

Малайзия состоит из 13 штатов и трёх федеральных территорий - столицы Куала-Лумпур, административного центра Путраджайи и острова Лабуан у побережья штата Сабах. В свою очередь эти 13 штатов можно разделить на две группы. В первых 9 штатах - Перлис, Кедах, Перак, Келантан, Тренггану, Паханг, Селангор, Негри-Сембилан и Джохор - правят наследственные монархи - так называемые, султаны. В остальных 4 штатах Малакка, Пинанг, Сабах и Саравак - управляют губернаторы, которые назначаются на срок четыре года. Стоит отметить, что у этих федеральных территорий не имеется самостоятельной административной системы, их руководство назначается центральным правительством [3].

Российская Федерация состоит из 85 субъектов, причём среди них можно выделить республики - их 22 , края - их 9, города федерального значения - их 3, области - их 46, автономные округа - их 4, а также одна автономная область. Но, несмотря на такое разнообразие, ч.1 ст. 5 Конституции РФ гласит, что все субъекты федерации равноправны. В статье 77 Конституции РФ сказано, что система органов государственной, в том числе исполнительной, власти субъектов устанавливается ими на своё усмотрение в соответствии с основами конституционного строя и общими принципами организации исполнительных органов государственной власти [1]. Все субъекты РФ имеют свои органы государственной власти. Управляет субъектом РФ высшее должностное лицо данного субъекта, избираемое гражданами Российской Федерации, которые проживают на территории данного субъекта Российской Федерации и обладают активным избирательным правом, на основе всеобщего равного и прямого избирательного права при тайном голосовании [2].

Представляется разница в том, кто управляет субъектами федераций. По большому счёту, более демократичной, а значит и свободной, является российская практика управления регионами. Да и принцип федерализма реализуется в России глубже, нежели в Малайзии. Однако это ни в коем разе не умаляет сложившийся там механизм воплощения идей федерализма, свойственный именно Малайзии.

Далее хотелось бы рассмотреть органы управления на федеральном и региональном уровнях. Начнём также с Малайзии.

Она представляет собой конституционную монархию. Принцип разделения властей нашёл своё отражение в государственном строе федерации. Главой государства выступает Верховный правитель (король), который избирается на пять лет из числа наследных правителей 9 штатов страны на основе ротации (обновления). Он управляет государством, при этом руководствуясь рекомендациями премьер-министра, кабинета министров, а также парламента. Король утверждает законы, принятые парламентом, кандидатуры на должности руководителей важнейших органов государственной власти, имеет также право помилования осуждённых и является главнокомандующим вооруженными силами в государстве. Нельзя не сказать о том, что из руководителей 13 штатов Малайзии формируется специальный орган - Совет правителей, главная цель которого заключается в избрании главы государства.

Что касается законодательного органа, то это Парламент, который состоит из двух палат. Верхняя палата это Сенат, состоящий из 70 членов (из них 44 сенатора назначаются Верховным правителем, а 26 избираются законодательными ассамблеями штатов - по два человека от каждого из 13 штатов). Срок полномочий сенатора составляет три года, при этом он может быть продлен только один раз. Нижней палатой является Палата представителей. Она, в свою очередь, состоит из 222 депутатов и формируется на пятилетний срок посредством всеобщих выборов. Руководитель Сената - Председатель, а Палаты представителей - спикер.

В каждом штате есть свой собственный законодательный орган - законодательная ассамблея, состоящая из одной палаты. Количество её членов определяется численностью населения штата.

Исполнительная власть в стране отводится кабинету министров, во главе которого стоит премьер-министр. Им становится лидер той партии, которая завоевала большинство мест в Палате представителей на всеобщих выборах. В кабинет министров входят 26 федеральных министерств и канцелярия премьер-министра (по факту являющаяся министерством, которое включает четырех министров). Кабинет министров состоит из премьерминистра, его заместителя, министров, их заместителей (всего 70 чел.) и назначается Верховным правителем страны. В соответствии с Конституцией, член кабинета министров должен быть членом одной из палат парламента.

Исполнительная власть штатов осуществляется местными правительствами или исполнительными советами штатов. Они возглавляются главными министрами, назначаемыми султанами/губернаторами по результатам местных выборов в законодательные ассамблеи. 
Судебная власть осуществляется судами различных инстанций, она централизованная и независимая. Высшим судебным органом в государстве является Федеральный суд. Председатель этого суда выступает главой всей судебной власти в стране. Далее иерархия судебной системы включает Апелляционный суд, Высшие суды территорий, сессионные суды, местные/районные суды (суды магистрата), суды несовершеннолетних. Для рассмотрения и разрешения дел, которые затрагивают непосредственно личные интересы Короля либо султанов штатов, созывается специальный суд. Но кроме светского правосудия действуют также и суды шариата. Система шариатских судов независима и не подчинена центру - в каждом штате такие суды подконтрольны местным исполнительным органам власти [3].

А теперь приведём соответствующие положения системы органов государственной власти РФ и её субъектов. Россия - это смешанная республика. Глава государства есть Президент, обладающий весьма широкими полномочиями. Также он является гарантом Конституции и основных прав и свобод человека и гражданина. Срок его полномочий составляет 6 лет, избирается гражданами РФ на основе всеобщего равного и прямого избирательного права при тайном голосовании. Президент РФ одновременно является Верховным Главнокомандующим Вооруженными Силами Российской Федерации. Он может издавать указы и распоряжения, то есть обладает нормотворчеством. Неприкосновенность - одна из привилегий Президента.

Парламентом России является двухпалатное Федеральное Собрание. Нижняя палата - Государственная дума - состоит из 450 депутатов, избираемых по смешанной избирательной системе на срок 5 лет. Верхняя палата - Совет Федерации - состоит из двух представителей от каждого субъекта РФ: по одному от представительного и исполнительного органов государственной власти. Эти представители именуются членами Совета Федерации.

На уровне субъектов создаются свои законодательные (представительные) органы государственной власти. Количество депутатов зависит от конкретного региона.

Исполнительную власть в Российской Федерации осуществляет Правительство РФ, в которое входят Председатель Правительства РФ (Премьер-министр), его заместители, а также федеральные министры. Председатель Правительства России назначается Президентом России с согласия Государственной Думы.

Высшее должностное лицо субъекта избирается гражданами или депутатами законодательного (представительного) органа на срок не более пяти лет. Высший исполнительный орган субъекта формирует и распускает глава субъекта. Судебная система разделена на 2 уровня: первый - федеральный уровень, а второй - региональный. В первый входят Конституционный суд Российской Федерации, Верховный Суд Российской Федерации; Верховные суды республик, краевые, областные суды, суды городов федерального значения, суд автономной области, суды автономных округов; окружные (флотские) суды; районные суды. Во второй входят Конституционные (Уставные) суды субъектов РФ и мировые судьи.

В заключение хочется сказать, что сравнение сводится не только к сопоставлению, но также и к поиску нового, лучшего, чего до этого ещё не существовало. Сравнительный анализ федерализма Малайзии и России даёт свой неповторимый результат, так как происходит исследование одних и тех же вопросов, но только с позиций таких, казалось бы, отличных друг от друга государств.

\title{
Литература
}

1.Конституция Российской Федерации: принята на всенародном референдуме 12 декабря 1993 года [Электронный реcypc]. URL: http://www.constitution.ru/10003000/10003000-3.htm (дата обращения: 10.04.2016).

2.Федеральный закон от 6 октября 1999 г. № 184 - Ф3 «Об общих принципах организации законодательных (представительных) и исполнительных органов государственной власти субъектов Российской Федерации» (в ред. от 9.03.2016). [Электронный ресурс]. URL: https://www.consultant.ru/document/cons_doc_LAW_14058/40abd0f7e6ff1af6397e3f1b926cf 24895a68a68/ (дата обращения: 10.04.2016).

3.CR. - O Малайзии / Посольство Российской Федерации в Малайзии. [Электронный pecypc]. URL: http://malaysia.mid.ru/o-malajzii/-

/asset_publisher/A0MEugzOD5wn/content/malajzia?inheritRedirect=false\&redirect=http\%3A\%2F\%2Fmalaysia.mid.ru\%2Fomalajzi i\%3Fp_p_id\%3D101_INSTANCE_A0MEugzOD5wn\%26p_p_lifecycle\%3D0\%26p_p_state\%3Dnormal\%26p_p_mode\%3Dview\% 26p_p_col_id\%3Dcolumn-1\%26p_p_col_pos\%3D1\%26p_p_col_count\%3D2 (дата обращения: 10.04.2016).

4.Malaysia's Constitution of 1957 with Amendments through 2007 (Конституция Малайзии: принята 27 августа 1957 года). [Электронный ресурc]. URL: https://www.constituteproject.org/constitution/Malaysia_2007.pdf?lang=en (дата обращения: 10.04.2016).

\section{Досудебное урегулирование налоговых споров в КНР}

\author{
(C) К. В. Красикова \\ магистрант 1 года обучения юридического факультета \\ ФГБОУ ВО «Бурятский госуниверситет» \\ Россия, г. Улан-Удэ \\ Karasik124@yandex.ru
}

Для достижения баланса между публичными и частными интересами во многих государствах осуществляет свою деятельность институт досудебного (административного) пересмотра налоговых споров. К таким государствам можно отнести и Китайскую Народную Республику. Еще с незапамятных времен на территории Китая начала действовать система надзора, но не судебного надзора, а именно со стороны административных органов. 
Досудебное урегулирование налоговых споров на территории Китайской Народной Республики регулируется следующими законодательными актами:

1. Закон КНР “Об административном пересмотре”;

2. Положение "О применении Закона КНР об административном пересмотре”;

3. Закон КНР “Об управлении сбором налогов”;

4. Регламент административного пересмотра налоговых споров” (2010 г.)

На основании “Регламента административного пересмотра налоговых споров” сфера применения досудебного пересмотра налоговых споров в КНР возможен досудебный пересмотр таких действий налоговых органов, как:

1) Сбор налогов, включая определение субъекта налогообложения, объекта налогообложения, сферу применения налога, уменьшения налога, освобождения от налога, налогового зачета и т.д.

2) Административное лицензирование и административное утверждение.

3) Регулирование счетов, включая, в том числе такие действия, как выдачу, конфискацию и выписку счетов.

4) Обеспечительные меры, а также меры по принудительному исполнению.

5) Административные наказания, такие как:

- Штрафы;

- Конфискация имущества, а также незаконно полученного дохода

- Приостановление прав на возврат налогов

6) Определение статуса налогоплательщика.

7) Любые административные действия по раскрытию правительственной информации.

В процессе досудебного урегулирования налоговых споров возможно проведение проверки на то или иное соответствие налоговому законодательству тех нормативно-правовых норм, на которые ссылались налоговые органы в процессе своей деятельности. Непосредственно само заявление о проведение проверки данных норм может быть подано совместно с подачей заявления о проведении досудебного урегулирования или же после того, как будет вынесено решение по результатам

Кроме того, в ходе административного пересмотра допускается проверка на соответствие законодательству тех правовых норм, на которых были основаны действия налоговых органов. Заявление о проверке правовых норм должно быть подано при подаче заявления об административном пересмотре или до вынесения решения по результатам административного пересмотра. Проверка законности допускается в отношении следующих актов: акты Главного государственного налогового управления КНР и других ведомств Государственного совета КНР; акты налоговых органов любой ступени; акты управлений местных народных правительств. Проверка на соответствие законодательству не распространяется на ведомственные нормативно-правовые акты. Административный пересмотр бездействия налоговых органов Как следует из названия главы 19 НК РФ, предметом административного пересмотра в России являются не только действия, но и бездействия работников налоговых органов. В КНР бездействие налоговых органов и их сотрудников не является предметом административного пересмотра. В случае бездействия налоговых органов допускается подача жалобы в соответствии с «Правилами подачи жалоб на предоставление налоговых услуг» (№ 11-2010) на следующие документы налоговых органов КНР:

1. Акты, которые были составлены и подписаны в ГГНУ КНР и подвластных ему иных ведомств Государственного совета КНР;

2. Акты, которые были составлены и подписаны в нижестоящих ведомствах Государственного совета КНР:

3. Акты, которые были составлены и подписаны в налоговых органах любой инстанции;

4. Акты, которые были составлены и подписаны в управлениях местных региональных народных правительствах.

Проведение проверки на соответствие нормам законодательства КНР не распространяется на все ведомственные НПА.

Для досудебного пересмотра всех бездействий налоговых органов, как указано в главе 19 налогового кодекса Российской Федерации, могут являться не только само бездействия налоговых органов, но так же и бездействие уже непосредственно самих работников налогового аппарата. Но вот в КНР такое бездействие как налоговых органов, так и их сотрудников, не входит в предмет досудебного урегулирования.

В КНР бездействие налоговых органов и их сотрудников не является предметом административного пересмотра. В случае бездействия налоговых органов допускается подача жалобы в соответствии с «Правилами подачи жалоб на предоставление налоговых услуг» (№ 11-2010). Орган административного пересмотра Административный пересмотр решения управления по центральным налогам производится в вышестоящем управлении по центральным налогам. Для административного пересмотра решения управления по местным налогам допускается подача заявления в вышестоящее управление по местным налогам или в местное народное правительство того же уровня, что и управление по местным налогам, действие которого является предметом административного пересмотра.

При этом местные законодательные органы (общие собрания народных представителей, постоянные комитеты собраний народных представителей) или народные правительства провинциального уровня могут принять отдельные положения о подведомственности налоговых споров, которые должны действовать в рамках отдельной провинции, автономного района или города центрального подчинения. Административный пересмотр решений ГГНУ КНР проводится ГГНУ КНР. В случае несогласия с решением по результатам административного 
пересмотра допускается обращение в народный суд или напрямую в Государственный совет КНР. В данном случае решение Государственного совета КНР является окончательным.

Органы административного пересмотра создают отдельные структуры, которые несут ответственность за выполнение работы по административному пересмотру налоговых споров. Данные структуры осуществляют прием заявлений, проводят рассмотрение дела и составляют проект решения по результатам административного пересмотра. Заявитель и ответчик Заявление об административном пересмотре может подать любое физическое или юридического лицо или иной субъект хозяйственной деятельности, чьи законные права и интересы были нарушены конкретными действиями налоговых органов. Другие заинтересованные лица могут подать заявление об участии в рассмотрении дела в качестве третьих лиц, а также могут быть приглашены органом административного пересмотра для участия в деле в том же качестве.

Если число заявителей превышает 5 человек, необходимо выбрать от 1 до 5 представителей для участия в административном пересмотре. Заявители и третьи лица также вправе уполномочить на участие в административном пересмотре одного или двух представителей. Основанием для участия в административном пересмотре в качестве представителя является выданная заявителями или третьими лицами доверенность, подтверждающая полномочия и содержащая предмет доверенности, пределы полномочий и срок действия. Ответчиком в административном пересмотре является налоговый орган, предпринявший действия, являющиеся предметом разбирательства. Налоговый орган может участвовать в административном пересмотре от своего лица или выдать доверенность одному из своих сотрудников на участие в разбирательстве.

В случае если действие, являющее предметом разбирательства, было осуществлено налоговым органом совместно с другим органом, наделенным соответствующими полномочиями законодательством и иными нормативно-правовыми актами, данные органы являются ответчиками совместно. Если же действие совершено совместно со структурой иного рода, то ответчиком является только налоговый орган. По действиям, осуществленным различного рода структурами, внутренними подразделениями или иными организациями, созданными налоговыми органами и не имеющими на то полномочий в соответствии с законодательством и иными нормативно-правовыми актами, ответчиком в ходе разбирательства является налоговый орган.

Сроки обращения с заявлением Заявление об административном пересмотре должно быть подано в течение 60 дней с того момента, как заявитель узнал о конкретном административном действии налогового органа, которое является предметом разбирательства. В случае препятствования налогового органа в получении информации о данном действии, возникновения обстоятельств непреодолимой силы, при расчете срока обращения с заявлением необходимо вычесть срок пропуска по данным причинам. Для расчета срока подачи заявления используются следующие правила:

1. при совершении налоговым органом действия непосредственно при заявителе, срок обращения с заявлением рассчитывается со дня совершения действия налоговым органом. при отправке правового документа, устанавливающего действие налогового органа,

2. непосредственно заявителю, срок обращения с заявлением рассчитывается со дня получения заявителем документа.

3. при отправке почтой правового документа, устанавливающего действие налогового органа, срок обращения с заявлением рассчитывается со дня заверения заявителем подписью квитанции о получении документа.

4. при уведомлении о действии налогового органа посредством публичного объявления, срок обращения с заявлением рассчитывается со дня окончания срока, установленного объявлением.

Если налоговый орган не уведомил заявителя при осуществлении действия, но впоследствии направил дополнительное уведомление, срок обращения с заявлением должен рассчитываться со дня получения заявителем дополнительного уведомления.

Если же налоговый орган направил соответствующий правовой документ, однако этот документ не был доставлен, следует считать, что заявитель не был поставлен в известность о действии налогового органа. Вместе с тем, если налоговый орган может подтвердить знание заявителем о данном действии, расчет срока обращения с заявлением проводится на основании подтверждающих документов, предоставленных налоговым органом. В случае если действия налогового органа имеют негативное влияние на права и обязанности заявителя, то налоговый орган должен уведомить о праве на подачу заявлению об административном пересмотре и сообщить информацию об органе, принимающем заявления, и сроках подачи заявления.

Подача заявления об административном пересмотре Заявление об административном пересмотре в письменном виде может быть подано лично, почтой или факсом. Если орган административного пересмотра имеет возможности для приема заявлений по электронной почте, то допускается подача заявлений и при помощи электронной почты. Заявление необходимо сопроводить документами, подтверждающими факт невыполнения налоговым органом должностных обязанностей или нанесение ущерба, если при подаче заявления исходит из предположения о невыполнении налоговым органом своих обязанностей или одновременно с подачей заявления обращается за административной компенсацией.

Получивший заявление орган административного пересмотра должен в течение 5 рабочих дней провести проверку содержащихся в нем сведений и принять решение о приеме заявления к рассмотрению или отказе в рассмотрении. Если в установленный срок проверка заявления не завершена или решение об отказе в рассмотрении не принято, заявление автоматически считается принятым к рассмотрению. В случае неполноты предоставленных материалов или неразборчивости изложения в материалах, заявитель может быть уведомлен о внесении дополнений в заявление. 
Уведомление должно быть направлено в течение 5 рабочих дней и содержать данные, которые необходимо внести, и разумно обоснованные сроки внесения дополнений. Срок внесения дополнений не включается в срок рассмотрения дела. Заявитель должен быть уведомлен об отказе в рассмотрении поданного им заявления. В течение 15 дней после получения отказа в рассмотрении заявления или окончания срока проведения административного пересмотра заявитель вправе обратиться в народный суд для проведения разбирательства в судебном порядке.

После принятия заявления к рассмотрению заявитель не может обратиться с иском в народный суд в течение установленного срока проведения административного пересмотра по тем же вопросам. Аналогичным образом, заявитель не имеет права обратиться с заявлением об административном пересмотре, если народный суд принял к рассмотрению заявление данного лица по тем же вопросам.

По статистическим данным, представленных налоговыми органами КНР на их официальных сайтах, в период с 1994г по 2005г. органами местного управления КНР различных уровней было принято на рассмотрение 4252 дела, касающиеся налоговых споров, из которых решение налоговых органов было оставлено в силе в половине случаев. ГГНУ КНР рассмотрело 88 дел, из которых управлением в силе было оставлено более $55 \%$. В этот же период времени было рассмотрено в судах первой и второй инстанции более 1399 дел о налоговых спорах различной сложности, из которых более $55 \%$ случаев решение налоговых органов было оставлено в силе.

Так же, с 2000 года было рассмотрено чуть более 40 дел об оспаривании положения НПА в досудебном порядке, 1/3 часть которых налоговыми органами были внесены в данные НПА соответствующие изменения.

\author{
Литература \\ 1.Judicial Review in New Democracies Conctitutional Courts in Asian Cases / by T. Ginsburg. Cambridge, 2003 \\ 2.Закон КНР "Об административном пересмотре". \\ 3.Положение "О применении Закона КНР об административном пересмотре”. \\ 4.Закон КНР “Об управлении сбором налогов”. \\ 5.Регламент административного пересмотра налоговых споров (2010 г.)
}

\title{
Эволюция правовой системы современного Китая
}

\author{
(С) А. А. Ласточкина, Т. А. Савельева \\ студентки 1-го курса юридического факультета \\ ФГБОУ ВО «Бурятский госуниверситет» \\ Россия, г. Улан-Удэ
}

Китайская цивилизация, будучи одной из крупнейших и древних на Востоке, на протяжении уже долгих лет не остается без внимания научных исследователей и видных правоведов. Прежде всего, это связано с темпами развития Китая, ведь, из отсталого и бедного, в сжатые исторические сроки Китай превратился в лидера международной арены. На сегодняшний день Китай - одна из мировых держав. У Китая и России сложились особые отношения, потому и изучение политики, проводимой китайским руководством, как внутренней, так и внешней, играет огромную роль для российского законодателя, да и вообще законодателей других стран. Именно это, на наш взгляд, свидетельствует об актуальности исследования эволюции правовой системы КНР, специфики и отличительных особенностей.

Прошло уже несколько тысячелетий, однако представления китайцев о власти и праве не изменились. Прежде всего, это связано с тем, что не изменилась, пожалуй, самая главная и содержательная, характеристика этого государства - жесткая государственность.

На самых ранних этапах развития государственности во многих странах мифология выступала главным регулятором общественных отношений. В Египте, например, считалось, что фараон - это Бог Солнца, в Вавилоне царь считался наместником бога на земле, был его служителем. В китайской мифологии высшим арбитром в земных делах выступает Небо. [1, с. 36]. Именно небо давало право осуществлять власть правителю на земле. Власть могла быть дарована лишь сильнейшим, как физически, так и духовно, кроме того, правители должны были обладать высшими нравственными и духовными качествами, важнейшим из которых была справедливость.

Согласно воззрениям китайцев, естественное право - установление Неба, его воля, в духе которой должны формулироваться отношения в семье, а их поддержание и воспитание являются обязанностью правителя и чиновников. Кроме того, санкционированное этнической нормой (Небом) естественное право превалирует над правом позитивным. Это подтверждается тем, что намерение, т.е. этническая позиция правонарушителя, важнее преступления как такового. Нарушение же этико-политических и социальных норм приравнивается к преступлению. [1, с. 36]

Что же касается национальной правовой системы Китая, то однозначного мнения здесь нет. Существует огромное количество дискуссий по этому поводу среди исследователей. Территориально данное государство относится к группе стран Дальнего Востока, поскольку расположено в Средней Азии.

В Современной компаративистике существует две концепции правовой системы Китая. Приверженцы первой (Д. Рене, К. Цвайгерт, Х. Кетц) относят Китай к дальневосточной правовой системе. 
Согласно второй концепции Китай - социалистическое государство и, значит, относится к социалистической правовой системе. (А. Х. Саидов, Кр. Осакве, М. Н. Марченко). [2, с. 286]

Народы стран Дальнего Востока предпочтение отдают методу убеждения - как способу урегулирования общественных отношений. По их мнению, право не способно быть социальным регулятор, даже в суды здесь обращаются лишь в тех случаях, когда разрешить конфликт или восстановить справедливость по-другому не удается. Образцом поведения в дальневосточном праве выступают нормы-морали, обычая и традиции. Человек сам определяет, какова же будет ситуация в обществе: хаос и беспорядок или же гармония, порядок и справедливость, все зависит от его поведения, потому как он - хозяин своих поступков. На переднем плане должны находиться воспитание и убеждение, а не власть и принуждение. Благодаря таким взглядам китайцы отрицательно относятся к западной идее права с его строгостью и абстрактностью. Они считают, что человек не должен настаивать на своих правах, поскольку долг каждого - стремиться к согласию и забывать о себе в интереcax всех. [2, с. 288] Компромисс - это то, к чему стремятся народы дальневосточной правовой семьи при разрешении какого-либо конфликта, чего юристы, по их мнению, не способны обеспечить. Так, например, они считают, что возмещение вреда нельзя класть непомерным грузом на плечи должника, ведь это может привести его семью к разорению. Они не считают, что законы в силах нормальным образом разрешить конфликт, идеальным для них будет, если законы перестанут издаваться, а судебные решения не будут выносить.

Такая концепция не отрицает права, но полагает при этом, что оно предназначено для ярых преступников, невежественных иностранцев, кому не знакомы китайские традиции, для тех, кто не заботится о морали. Китайский же народ прекрасно обходится и без права. Таким образом, согласно первой концепции, правовая система Китая относится к дальневосточной правовой семье.

Современная правовая система китайского государства включает в себя характерные черты права стран социалистической системы, нормы древнекитайского права, на ней, безусловно, сказалось влияние религиозных учений, таких, как конфуцианство и легизм, что, на наш взгляд, делает ее достаточно специфичной, не похожей на остальные. Главными в Конфуцианстве были вопросы этики, морали и управления государством. Путь к совершенству по Конфуцию лежит через почтительное уважение к родителям, почитание порядков, сложившихся в обществе, обычаев, уважение к государю. Человек, который понял суть порядка в мире, осознал, что нормы поведения - это главное, считается идеальным. Конфуций и его ученики верили, что человек по природе добр и с помощью воспитания его можно побудить к осознанию необходимости добродетельного поведения.

Однако победа конфуцианства, разумеется, не означала, что в Китае перестали издавать законы и социальная жизнь без помех осуществлялась на основе «ли».

Не меньшее значение для Китая сыграл и легизм, который был явной противоположностью конфуцианству. Легисты считали человека эгоистичным, думающим только о реализации своих интересов. Потому они говорили о необходимости создания государственного законодательства, чтобы дисциплинировать человека, независимо от социального статуса. Они разработали модель управления государством, которая была основана на жестких тоталитарных методах. Закон, по мнению легистов, это основной карательный элемент государства, закон должен быть настолько суровым, чтобы у потенциальных преступников и в мыслях не было его нарушать.

Китай - одна из немногих стран, не отвергнувших в настоящий момент социалистического пути развития, что, безусловно, отразилось на его законодательстве. Победившая в гражданской войне коммунистическая партия взяла всю полноту власти в свои руки. Государственная собственность ставится в приоритете над частной, которая отрицается и упраздняется. Ведомственное правотворчество конкурирует с законами. Кроме того, КНР как социалистическое государство характеризует и то, что законодательство недостаточно систематизировано, труднодоступно для граждан, населения в целом. Важно отметить, что статья 1 действующей Конституции КНР 1982 г. гласит: «Китайская Народная Республика ест социалистическое государство демократической диктатуры народа... Социалистический строй есть основной строй Китайской Народной Республики...»

Современная правовая система Китайской Народной Республики формируется в русле единой концепции построения в стране социализма с «китайской спецификой». Можно выделить основных три этапа. Первый этап ( с 1949 по 1957 г), характерен тем, что установленные в данный промежуток временные конституционные акты установили основные принципы страны. Но еще целостная правовая система не сформировалась ввиду низкой правовой культуры общества. Второй этап (1957-1976 гг.) - период так называемой «культурной революции». Он характеризуется углублением правового нигилизма, игнорированием закона в регулировании жизни общества. В этот период существенно снизилась роль, а затем и прекратилась деятельность представительных органов, произошел отказ от соблюдения законности, т. е., по существу, были разрушены складывающиеся правовые основы государства. Третий этап (с конца 1970-х гг. до настоящего времени) связан со значительным оживлением законодательной деятельности. Важным событием в этот период стало принятие в 1982 г. Конституции Китая. Уже после кончины Мао Цзэдуна были изданы «Избирательный закон», «Органический закон о судах», «Законы о совместных предприятиях», «О браке». Таким образом, мы видим, что на протяжении практически всей истории Китая существовали и боролись друг с другом две основные тенденции в политико-правовой мысли: конфуцианство и легизм, предлагавшие собственное видение права и государства.

Китайский законодатель не прекращает придерживаться политики принятия разрозненных локальных актов правотворчества в противовес трудноизменяемым и объемным кодифицированным документам. Правовое регулирование общественных отношений осуществляется в большей степени на уровне подзаконных нормативных правовых актов, значительную долю которых составляют акты Государственного совета КНР. Также 
Законодатель предпочитает идти по пути интенсивного принятия отдельных локальных актов правотворчества для более оперативного реагирования на происходящие в стране изменения Отсутствие в правовой системе КНР гражданского, административного и налогового кодексов ни сколько не обедняет ее.

Текстам китайских нормативных правовых актов, образующих правовую систему КНР, характерна нечеткость, расплывчатость, неконкретизированность формулировок, что было особенно характерно для актов правотворчества первых лет после образования КНР и после окончания «культурной революции». «На это обстоятельство особо обращали внимание отечественные исследователи китайского права». [3, с.14] Все это, без исключения, самым серьезным образом влияет на единообразное, правильное, точное толкование и применение содержащихся в правовом акте положений, ограничивает право сторон по делу на эффективную законную защиту своих интересов.

Особой спецификой обладает правосознание обычного китайского жителя. «В его понимании право, закон практически всегда ассоциируются с институтом наказания, институтом юридической ответственности.» [4, с.128] Китаец старается «стоять на почтительном расстоянии» от права, в своем поведении руководствуется не юридическими нормами, а стремлением «сохранить лицо», не подвергнуться осуждению со стороны родственников и знакомых, стремится соответствовать общепринятым нормам морали. Для китайского правосознания характерен приоритет морали над правом.

\title{
Литература
} C. $6-43$.

1. Черноков А. Э. Правовая система Китая // Вестник Санкт-Петербургской юридической академии. 2014 № 4 (25).

2. Пащкова Т. В. Проблема идентификации правовой системы Китая. Вестник Владимирского юридического института №2(7). C. 286-292.

3. Ахметшин Х. М. Уголовный кодекс КНР: лекция. М., 1981. С. 14.

4. Трощинский П. В. Юридическая ответственность в праве Китайской Народной Республики. М., 2011. С.128.

\section{Сравнительно-правовой анализ налогообложения Сингапура и России}

\author{
(ㄱ) И. А. Павлова \\ студент 4-го курса юридического факультета \\ ФГБОУ ВО «Бурятский госуниверситет» \\ Россия, г. Улан-Удэ \\ 000.0909@mail.ru
}

Сингапур город-государство, относящийся к первому поколению «азиатских тигров». Налоговая система Сингапура достаточно специфична, обусловленная в первую очередь политическими и социально-экономическими факторами. В прошлом Сингапур являлся в течение очень длительно времени колонией Великобритании, что, несомненно, сказалось на формировании налоговой системы страны.

Во второй половине XX века налоговая структура Сингапура терпит большие перемены, которые происходят благодаря воздействиям налоговых реформ и практики в передовых индустриальных государствах, а также стремительного развития глобализации хозяйственных связей в мире.

Основной законодательной базой налогообложения Сингапура выступают Закон о налоге на собственность, Закон о подоходном налоге, Закон о налогах на азартные игры и тотализаторы, Закон о стимулах для расширения экономической деятельности (освобождение от подоходного налога), Закон о налоге на товары и услуги, Закон о налоге на наследство, Закон о частных лотереях, Закон о гербовых сборах.

В Сингапуре налоги приобретают особенность в виде механизма мобилизации финансовых ресурсов для государственного бюджета: в 2004 г. на их долю в Сингапуре приходилось 61,8 \% всех поступлений в государственный бюджет.

Структура налоговой системы традиционна как в Сингапуре, так и в России, включающая в себя прямое налогообложение и косвенное налогообложение.

К прямым налогам в Сингапуре законодатель относит: индивидуальный подоходный налог, налог на прибыль компаний или корпоративный налог, поимущественный налог, а также налог у источника.

В России действует следующая система прямых налогов: прямые налоги, взимаемые с юридических лиц: налог на прибыль и налог на имущество предприятия; прямые налоги, которые удерживаются с физических лиц: налог на доходы и налог на имущество; смешанные налоги, которые уплачиваются как физическими, так и юридическими лицами, в частности - налог на добычу полезных ископаемых, водный налог, земельный налог, транспортный налог.

Начнем с подоходного налогообложения физических лиц (индивидуальный подоходный налог). Большое значение для подоходного налога имеет статус лица, физическое или юридическое лицо.

В Сингапуре для индивидуального подоходного налога имеет не меньшее значение территориальный принцип. В качестве налогоплательщика физическое лицо определяется исходя из принципа резиденства. Налогоплательщики делятся на следующие категории: налоговый нерезидент, налоговый резидент и так называемый необычный налоговый резидент (not ordinarily resident - NOR). 
Российский законодатель определяет НДФЛ как основной вид прямых налогов, который исчисляется в процентах от всего сложения доходов за вычетом документально подтвержденных расходов [4]. В России налогоплательщики подразделяются на две группы: лица, являющиеся налоговыми резидентами и лица не являющиеся таковыми.

Лицо постоянно проживающие в Сингапуре и иногда на непродолжительный срок, выезжающий из страны либо реально находящийся и работающий в Сингапуре не менее 183 дней в календарном году, который предшествует году налогообложения, то оно считается резидентом. Так же считается налоговым резидентом и лицо, которое живет и работает в течение трех лет подряд, причем, если в первый и третий год пребывания в Сингапуре не достигает 183 дней. Стоит отметить что, с 2004 года правительство Сингапура оставила принцип глобальной или мировой налоговой ответственности по налогам, при котором налог взимается со всех доходов, в том числе полученные за рубежом привезенный в Сингапур. В настоящее же время резидент налог уплачивает только исключительно с дохода, полученного в Сингапуре.

Если лицо проживает в Сингапуре не более 183 дней в календарном году, то оно считается налоговым нерезидентом и уплачивает налог только с дохода, который был извлечен в Сингапуре. Помимо всего вышеперечисленного, физическое лицо освобождается и от дохода, перечисленного в Сингапур из-за границы.

Похожие критерии складываются и в России, так резидентами считаются лица фактически находящиеся на территории России не менее 183 календарных дней в течение 12 следующих подряд месяцев.

Порядок уплаты НДФЛ в виде фиксированного авансового платежа распространен на иностранных граждан, прибывших в Российскую Федерацию в безвизовом режиме и работающих на основании патента не только у физических лиц (как было до 2015 года), но и в организациях, у индивидуальных предпринимателей или занимающихся частной практикой лиц.

В Республике Сингапур лица, часто выезжающие за рубеж, с 2002 года получают статус необычного резидента. К необычному резиденту предъявляются следующие требования:

- должен проживать и работать по найму в Сингапуре, но проводить в деловых поездках за рубежом более 90 дней;

- должен быть налоговым нерезидентом в течение трех лет, предшествующих году, когда оно впервые квалифицируется как необычный резидент;

- должен быть налоговым резидентом в том году налогообложения, в котором оно выказывает желание быть необычным резидентом.

Подоходный налог определяется пропорционально числу дней его пребывания в Сингапуре в календарном году и лишь с той части дохода, которая была заработана в Сингапуре. Необычный резидент пользуется льготным налоговым режимом в течение пяти лет и не платит налог на доход, который был получен до прибытия в Сингапур. Введение нового налогового статуса в будущем поспособствует прибытию в Сингапур креативных, талантливых людей и высококвалифицированных специалистов.

Сумма налога на доходы физических лиц - резидентов исчисляется путем уменьшения валового дохода за счет вычетов и персональных скидок. Законодательством Сингапура разрешены непроизводственные и производственные вычеты. Лица, которые занимаются предпринимательством и профессиональной деятельностью имеют право совершать производственные вычеты. Из валового дохода они вычитают все связанные с получением дохода расходы, в том числе затраты на износ капитальных активов. Непроизводственные вычеты включают проценты, которые выплачиваются по кредитам, взносы в профинституты или общества, членство в которых является непременным условием для трудоустройства, пожертвования в денежной или натуральной форме в законные местные учреждения благотворительности, взносы в Пенсионный фонд или в Центральный резервный фонд, а также платежи по страхованию жизни.

Налогоплательщик имеет право корректировать валовый доход путем вычета персональных налоговых скидок. Набор скидок, достаточно разнообразен и говорит о том, что налогообложение физических лиц имеет высокую социальную направленность. Например, скидка на заработанный доход предоставляется налогоплательщику в размере 1000 сингапурских долларов, данная сумма варьируется в зависимости от возраста или наличия физических недостатков. Имеется также и скидка на детей в трех формах: стандартная (до 4-х детей), скидка для детей с физическими недостатками, а также повышенная скидка на детей работающих матерей с высоким уровнем образования [6].

С начисленного после вычетов чистого налогооблагаемого дохода налоговые резиденты уплачивают подоходный налог по сложной прогрессивной многоступенчатой шкале ставок. В Республике Сингапур применяется эффективная налоговая ставка, т. е. средняя реальная ставка, по которой налог уплачивается, ниже номинальной с учетом необлагаемым минимум, а также ставка для отдельной взятой ступени. Так для 30 тысяч сингапурских долларов ставка составляет 1,2\% (номинальная 3,5\%).

Ставки налога с физических лиц на подоходный налог очень гибки и социально направлены. В последние 35 лет они менялись в двух направлениях - сокращение числа ступеней и снижение номинальных ставок. Количество ступеней уменьшилось с 14 до 7, а максимальная ставка с 40\% до 21\%. А.П. Муранова по данному поводу пишет что, «При такой динамике выигрыш получили и лица с низкими доходами, и лица с очень высокими доходами» [5].

Уменьшение номинальных ставок и введение необлагаемого минимума способствовали облегчению налоговой нагрузки на лиц с небольшими и средними доходами. 
В России Налоговым кодексом по налогу на доходы физических лиц предусмотрено пять налоговых ставок. Различные налоговые ставки установлены как в отношении видов доходов, так и в отношении категорий налогоплательщиков.

Налоговая ставка в 9\% производится в определенных случаях, установленные НК РФ. Если физическое лицо является налоговым резидентом РФ, большинство его доходов будет облагаться по налоговой ставке в размере $13 \%$. К таким доходам, например, относится заработная плата, вознаграждения по гражданско-правовым договорам, доходы от продажи имущества, а также некоторые иные доходы. По ставке $15 \%$ облагаются доходы, получаемые в виде дивидендов от долевого участия в деятельности российских организаций физическими лицами, которые не являются налоговыми резидентами РФ. Все прочие доходы физических лиц - нерезидентов облагаются по ставке $30 \%$. Ставка в $35 \%$ является максимальной и применяется к следующим доходам: например, к стоимости любых выигрышей и призов, получаемых в проводимых конкурсах, играх и других мероприятиях в целях рекламы товаров, работ и услуг, в части превышения установленных размеров и др. [4]

В Сингапуре нерезиденты налог уплачивают только с доходов, которые получены внутри государства. По ставке $15 \%$ валового дохода или по шкале ставок, которая применяется для резидентов. Таким же образом взимается налог с доходов лиг, проживающих в Республике Сингапур от 60 до 183 дней в календарном году и получающих доход из источников в Сингапуре. Интересно и то, что лица, которые прожили в Сингапуре не более 60 дней, подоходный налог не уплачивают.

Нагрузка на налоги у лиц с высокими доходами больше почти в 15 раз, чем у лиц с низкими доходами, тогда как в большинстве странах эта разница порой не превышает двух раз.

Корпоративный подоходный налог, т. е. налогообложение доходов юридических лиц. При данном налогообложении в Сингапуре также учитывается резидентство. Определяется данный статус, местом, где зарегистрировано юридическое лицо как компания, а также где происходит управление и контроль над ее деятельностью. Резидентами считаются местные компании и дочерние предприятия иностранных компаний, зарегистрированные по законам Сингапура. Нерезидентами являются филиалы иностранных компаний.

Налогооблагаемый доход понимается как валовая прибыль минус непроизводственные и производственные вычеты. В Сингапуре отсутствует специальный налог на прибыль от прироста капитала при его реализации, она облагается корпоративным налогом.

Корпоративный налог в Сингапуре является неким стимулятором расширения предпринимательской деятельности, нежели фискальное значение как в России. В последнее время ставки корпоративного налога регулярно понижаются, для создания благополучной инвестиционной деятельности и сохранение конкурентоспособности налоговой системы при привлечении инвестиций. С 2008 года ставка корпоративного налога и для нерезидентов, и для резидентов составляет $18 \%$.

В РФ Основным источником налоговых поступлений в бюджет государства являются налоги, которые уплачивают юридические лица и индивидуальные предприниматели. Как было сказано выше, юридические лица уплачивают налоги на прибыль и на имущество организации. Налоговые ставки по налогу на прибыль составляют: 0\% - при соблюдении установленных НК РФ условий: с дивидендов, полученных российскими организациями, при осуществлении образовательной или медицинской деятельности; 9\% - с дивидендов, полученных от российских и иностранных организаций российскими организациями, если ставка $0 \%$ не применяется; $10 \%$ - с доходов от использования, содержания или сдачи в аренду (фрахта) судов, самолетов и пр.; 15\% - дивидендов, полученных от российских организаций иностранными организациями; 20\% - в оставшихся случаях.

Плательщиками налога на имущество являются те организации, которые владеют движимым и недвижимым имуществом и ставка налога устанавливается законами субъектов РФ и не может превышать 2.2\%.

С 2003 года в Сингапуре была введена новая одноуровневая система налогообложения доходов корпоративного сектора - т. е. прибыль компании облагается на уровне корпорации, что является окончательным налогом, а дивиденды освобождаются от налога. Данная система упростила порядок взимания налога, а также уменьшила административные расходы компаний.

Корпоративный сектор получает налоговые льготы, тем самым Сингапур стремится развиваться как «финансовый супермаркет», т. е. основной финансовый центр, так же как и Япония с Гонконгом. Интересно и то, что вновь созданные компании претендуют на освобождение от корпоративного налога дохода до 100 тысяч сингапурских долларов, при условии соблюдения некоторых требований, например компания должна быть зарегистрирована в Сингапуре и быть резидентом.

Налоги у источника, являются следующим налогом, который взимается с достаточно большого круга доходов: вознаграждение за работу по найму, плата за различные услуги, роялти и доходы. В Сингапуре дивиденды не облагаются налогом ни при выплате резидентами и нерезидентами внутри страны, ни при переводе за границу.

Резиденты не платят налог ни с процентов, ни с роялти, а ставки для нерезидентов на иные виды доходов подразделены в зависимости от вида дохода. Ставки налога у источника постоянно снижаются, за последние 20 лет например, ставка на роялти и на процентный доход снизилась с 26 до 10\%.

Вышеизложенное показывает направление большей либеральности налоговых режимов в Республики Сингапур, снижение фискальной значимости одних налогов и придание большей роли другим. Данное направление обуславливается в первую очередь внешними факторами - глобализация мирового хозяйства, обостряющая конкуренцию в сфере налогообложения среди государств, которые стремятся привлечь инвестиции и профес- 
сионалов и предоставить для них льготный налоговый режим, а также политикой государства, которая позиционирует налоги одним из эффективных инструментов, при реализации основных экономических целей.

\title{
Литература
}

1.Погорлецкий А. Н. Международное налогообложение. СПб.: Изд-во Михайлова В. А., 2006. С. 271.

2.Налоговый кодекс Российской Федерации. URL: https://www.consultant.ru/document/cons_doc_LAW_19671/ (дата обращения: 11.04.2016 г.)

3.Singapore. Facts and pictures. 1987. Singapore. Ministry of communications and information, 1987. P. 60.

4.Официальный сайт Федеральной налоговой службы Российской Федерации. URL: https://www.nalog.ru/rn74/taxation/taxes/ndfl/

5.URL: http://www.orun.ru/upload/muranova.pdf

6.URL: http://sbf-group.com/articles/singapore/singapore_taxation/

7.URL: http://opisdela.ru/?p=2346

\section{Налогообложение предпринимательской деятельности в России и Китае}

\author{
(ㄱ) Т. А. Пькина \\ студентка 4-го курса юридического факультета \\ ФГБОУ ВО «Бурятский госуниверситет» \\ Россия, г. Улан-Удэ \\ heykitty16@mail.ru
}

Налог является важнейшим источником доходной части государственного бюджета, что в дальнейшем позволяет оказывать воздействие на социально-экономическое развитие страны. Занятие любой предпринимательской деятельностью, как в России, так и в Китае влечет за собой обязательство по уплате налогов. Каждая страна предусматривает свои виды налогов, размер, а также налоговые льготы и вычеты.

В России, как и в Китае предусмотрены меры поддержки для предпринимательства в виде уменьшения налоговой базы для субъектов малого и среднего предпринимательства, различные налоговые вычеты за занятия определенным видом деятельности.

На сегодня в Китае существует 17 видов налога. Из этих 17 видов налога любое предприятие, осуществляющее свою деятельность в КНР должен выплачивать следующие виды налогов: налог на доходы предприятий, НДС или налог на предпринимательскую деятельность, налог на городской ремонт и строительство и дополнительный сбор на образование, которые рассчитываются с суммы фактически уплаченного НДС, налога на предпринимательскую деятельность и потребительского налога, гербовый сбор, взимаемый при оформлении различного рода документов.

Однако помимо обязательных четырех указанных налогов предприятие может платить и другие виды налогов, например, транспортный в случае покупки автомобиля, если предприятию будет выделен земельный участок в городе или поселке, оно обязано уплачивать налог за использование городских земель. Также на предприятия КНР, как и России, возлагаются обязанности налоговых агентов, они должны удерживать сумму налогов из платежей в пользу другого лица, являющегося налогоплательщиком. Так предприятия обязаны удерживать НДФЛ из суммы заработной платы, выплачиваемой работнику и подавать соответствующую отчетность в налоговые органы. Кроме того, существуют различного рода местные сборы. Например, это утилизационный сбор с производителей электроники и электротехники, сбор за использование водных ресурсов, сбор за выброс загрязняющих веществ и др. Эти сборы не относятся к налоговым, но их тоже необходимо учитывать, особенно производственным предприятиям.

В течение предыдущего десятилетия в Китае был отменен ряд налогов: сельскохозяйственный налог, налог на забой скота, налог на банкеты, налог на пользование номерными знаками транспортных средств, регулирующий сбор на капиталовложения в основные средства [6].

С 2008 года новый налог на доходы предприятий заменил два ранее существовавших налога: налог на доходы предприятий, уплачиваемый китайскими предприятиями, и налог на доходы предприятий иностранного капитала и иностранных предприятий.

Ранее в Китае существовали различные льготы для иностранных инвесторов, однако сейчас такого не наблюдается, поскольку в Китае помимо значительных налоговых льгот существовало множество ограничений на иностранные инвестиции в наиболее привлекательных видах деятельности (банки, страхование, фондовый рынок). Поэтому при вступлении в ВТО перед Китаем было поставлено условие по предоставлению иностранным инвесторам национального режима - созданию одинаковых условий ведения бизнеса для китайских и иностранных предпринимателей. Выравнивание условий происходит поэтапно и включает как постепенное открытие для иностранных инвестиций китайского рынка, так и выравнивание налогообложения для китайских и иностранных предприятий.

На сегодняшний день в Китае существует множество налоговых льгот, однако в основном они поставлены в зависимость от вида деятельности предприятия. Например, такие налоговые льготы предоставляются предприятиям, использующим высокие технологии, занимающимся переработкой отходов, вновь созданным компаниям, предоставляющим социально-значимые услуги (услуги по трудоустройству населения), предприятиям, 
страдающим от стихийных бедствий; государственным благотворительным организациям, государственным сельскохозяйственным предприятиям. Для инвесторов существует налоговая льгота, не привязанная к деятельности предприятий - это сниженная ставка налога на доходы предприятий для малых малорентабельных предприятий.

Одной из основных проблем налогообложения в Китае выступает отсутствие единого кодифицированного акта, подобного Налоговому кодексу РФ. Для каждого налога в КНР существует отдельный закон или положение, а также правила применения. Данные нормативно-правовые акты содержат множество пробелов, в результате чего у налоговых органов имеются широкие полномочия по их толкованию и применению, что характерно не только для налогового законодательства Китая, но и других его отраслей. В результате этого создаются значительные трудности при ориентировании в Китайской законодательстве, в общем, и в налоговой законодательстве КНР, в частности.

Основные правила уплаты налога на доходы предприятий определены Законом КНР "О налоге на доходы предприятий" и Положением "О применении Закона КНР о налоге на доходы предприятий" (оба нормативноправовых акта вступили в силу с 1 января 2008 г.).

Предприятиями-резидентами являются: 1) предприятия, созданные в КНР в соответствии с китайским законодательством; 2) предприятия, созданные за рубежом в соответствии с иностранным законодательством, если место их фактического управления находится в пределах КНР.

Ставка налога на доходы предприятий составляет 25\%. 20\% - временная налоговая льгота, которую применяют к малорентабельным предприятиям мелкого бизнеса, 15 \% - ставка для стимулирования развития предприятий, которые ведут разработки и производство, вязанное с новыми прогрессивными технологиями. К новым и высоким технологиям относятся информационные технологии, биотехнологии, технологии в сфере авиации и космоса, производства новых материалов, высокотехнологичные услуги, технологии энергосбережения, охраны окружающей среды, рационального использования ресурсов и совершенствования технологических процессов в традиционных отраслях. Для получения данной льготы предприятие должно пройти процедуру предварительного присвоения статуса предприятия новых и высоких технологий.

Предприятие может уменьшить налоговую базу по налогу на доходы предприятий на 10\% в случае реализации проектов по использованию отходов, вторсырья, сопутствующих и побочных материалов и соответствия продукции предприятия государственным стандартам.

Сниженная ставка налога для малых малорентабельных предприятий составляет 20\%. Если годовой доход предприятия составляет менее 100000 юаней жэньминьби, в период с 1 января 2014 г. по 31 декабря 2016 г. ставка налога уменьшается до 10\% [3].

Правила уплаты налога на добавленную стоимость в КНР в основном регулируются Временным положением "О налоге на добавленную стоимость" и Подробными правилами применения Временного положения "О налоге на добавленную стоимость".

В КНР существуют два вида плательщиков НДС: обычные налогоплательщики и малые налогоплательщики. Малые налогоплательщики уплачивают НДС со всей суммы выручки и не вправе вычитать входной НДС из общей суммы налога к уплате. Ставка НДС для малых налогоплательщиков составляет 3\%. Если выручка предприятия достигает установленного порога, предприятие обязано обратиться в налоговый орган для присвоения статуса обычного налогоплательщика.

Обычными налогоплательщиками являются: 1) налогоплательщики, ежегодная выручка которых от реализации товаров, работ и услуг достигает установленного порога и получившие статус обычного налогоплательщика; 2) налогоплательщики с выручкой меньше установленного порога и вновь созданные организации, признанные налоговым органом обычным налогоплательщиком.

Стандартная ставка НДС для обычных налогоплательщиков - 17\%, льготная ставка при реализации сельскохозяйственной продукции первичной переработки, сельскохозяйственной техники, удобрений, кормов, печатных, электронных и аудиовизуальных материалов, пищевой соли, подаче топлива, газа, воды - $13 \%$.

Ставка НДС при оказании услуг по аренде материального движимого имущества - 17\%, оказании почтовых услуг, транспортных услуг, базовых телекоммуникационных услуг - 11\%, дополнительных телекоммуникационных услуг - 6\%, выполнении научно-исследовательских работ, оказании технических услуг и услуг в сфере информационных технологий, услуг в культурно-творческой сфере, услуг сертификации, консультационных услуг, дополнительных услуг в сфере логистики, услуг в сфере телерадиовещания, кинематографии и телевидения - $6 \%$.

Налог на предпринимательскую деятельность уплачивается организациями и физическими лицами: 1) реализующими на территории КНР некоторые виды услуг (кроме облагаемых НДС); 2) реализующими нематериальные активы или недвижимое имущество.

Правила уплаты налога на предпринимательскую деятельность определены Временным положением "О налоге на предпринимательскую деятельность" (в редакции от 10 ноября 2008 г.) и Подробными правилами применения Временного положения "О налоге на предпринимательскую деятельность" (в редакции от 15 декабря 2008 г.).

Ставки налога: 1) строительные работы - 3\%; 2) финансовые услуги - 5\%; 3) услуги в сфере культуры и спорта (организация культурно-спортивных мероприятий) - 3\%; 4) услуги в сфере развлечений - от $5 \%$ до $20 \%$ (конкретные ставки определяются провинциями самостоятельно); 5) остальные виды услуг - 5\%; 6) продажа нематериальных активов - 5\%; 7) продажа недвижимого имущества - 5\%. 
Налогом на предпринимательскую деятельность облагается реализация работ и услуг на территории КНР. В случае выполнения работ или оказания услуг иностранным предприятием, не имеющим постоянного представительства на территории КНР, на получателя услуг (китайское предприятие) возлагаются обязанности налогового агента. При оплате работ или услуг иностранного предприятия китайское предприятие обязано удержать из платежа сумму налога на предпринимательскую деятельность (ст. 11 Временного положения "О налоге на предпринимательскую деятельность").

В России налоговая базовая ставка налога на прибыль составляет $20 \%$, из них 2\% идет в федеральный бюджет, а 18\% в бюджеты субъектов РФ [1]. Однако в России так же существуют свои налоговые льготы. Так, например, налоговая ставка для организаций, осуществляющих образовательную или медицинскую деятельность, для организаций, осуществляющих социальное обслуживание граждан, организаций - участников свободной экономической зоны составляет $0 \%$.

Налог на реализацию товаров (работ, услуг), перечисленных в пп. пп. 1 - 14 п. 1 ст. 164 НК РФ составляет 0\%, реализация: отдельных продовольственных товаров; отдельных товаров для детей; периодических печатных изданий и книжной продукции, связанной с образованием, наукой и культурой (за исключением имеющей рекламный и эротический характер); отдельных медицинских товаров отечественного и зарубежного производства; отдельных видов племенного скота, а также их семенного материала и эмбрионов; услуг по внутренним воздушным перевозкам пассажиров и багажа (за исключением воздушных перевозок в/из Крыма или Севастополя); услуг по перевозкам пассажиров и багажа железнодорожным транспортом общего пользования в дальнем сообщении (за исключением услуг, указанных в пп. 4 п. 1 ст. 164 НК РФ) - 10\%. В случаях, не указанных выше $-18 \%$.

Стоит отметить, что как в России, так и в Китае государство поддерживает экспорт товаров, вследствие чего устанавливает налоговую ставку в $0 \%$.

Таким образом, мы можем сделать следующие выводы. Ставка на доходы в России меньше, чем в Китае. Но в тоже время Китай предоставляет более широкий спектр различных льгот для предпринимательской деятельности в стране. Еще одним положительным моментом налога на прибыль в Китае выступает поддержка технологического развития, охраны окружающей среды в виде льгот для предприятий, занимающихся переработкой отходов. Считается, что КНР больше вкладывает средств в социальную сферу, нежели экономическую. Говоря о налоге на добавленную стоимость и предпринимательскую деятельность, стоит отметить, что в Китае данные налоги ниже, чем НДС в России.

Китай, как и Россия, активно поддерживает малый бизнес, создавая им специальные налоговые льготы, однако Китай на сегодняшний день нуждается в систематизации налогового законодательства и принятии кодифицированного акта в целях устранения различных коллизий и устранения возможности для широкого толкования налоговых норм сотрудниками налоговых органов КНР. Таким образом, в Китае ввиду наличия широкого спектра налоговых льгот предпринимательская деятельность представляется более выгодной, в особенности, для малых предприятий.

\title{
Литература
}

1. "Налоговый кодекс Российской Федерации (часть вторая)" от 05.08.2000 N 117-ФЗ // Собрание законодательства РФ. 2000, N 32, ст. 3340.

2. Закон КНР «О налоге на прибыль предприятий» [Электронный ресурс]: Режим доступа: http://chinalawinfo.ru/economic_law/enterprise_tax_law (11.04.2015).

3. Бажанов П.В. Ведение бизнеса в Китае: правовые аспекты. Выпуск 1. Обзор правовой среды для бизнеса: кн. для юристов, сопровождающих бизнес. М.: Инфотропик Медиа, 2015. 212 с.

4. Аверин С.В. Источники международного частного права Китайской Народной Республики // Вестник международного коммерческого арбитража. 2012. N 2. С. 133-155.

5. Грибкова Н.Б. Опыт налогового регулирования в зарубежных странах // Налоговая политика и практика. 2005. №7. C. $16-18$.

6. Баженов Павел: Налогообложение в KHP сейчас находится в процессе реформы [Электронный pecypc]. URL: http://chinalogist.ru/book/articles/intervyu/pavel-bazhanov-nalogooblozhenie-v-knr-seychas-nahoditsya-v-processe-reformy (дата обращения: 11.04.2016).

\section{Формирование и развитие Азиатско-Тихоокеанского регионализма}

\author{
(С) Р.-Д. С. Санжнижапов \\ студент 4-го курса юридического факультета \\ ФГБОУ ВО «Бурятский госуниверситет» \\ Россия, г. Улан-Удэ \\ rinchin7@mail.ru
}

В последние десятилетия наблюдается усиление глобализации. Однако наряду с ней стала заметна другая тенденция, заключающаяся в интернационализации государственных и общественных связей на региональном уровне, и получившая название регионализация.

Актуальность темы обусловлена стремительным развитием стран Азиатско-тихоокеанского региона, увеличением их веса на международной арене, а также необходимостью понимания текущих процессов для осущест- 
вления более плодотворного сотрудничества со странами региона. Поэтому представляется необходимым рассмотреть историю становления и развития регионализма в Азиатско-тихоокеанском регионе, поскольку регионализм является одной из главных тенденций развития международных отношений, как в регионе, так и во всем мире.

В течение 40 лет после окончания холодной войны европейский регионализм рассматривался в качестве наиболее успешной модели интеграции [1]. В основе этой модели лежит подход, предполагающий постепенное продвижение через пять ступеней развития интеграции:

1. Формирование зоны свободной торговли

2. Таможенный союз

3. Общий рынок

4. Экономический и валютный союз

5. Полная экономическая и политическая интеграция

На протяжении длительного периода времен считалось, что только эта модель является единственно возможным вариантом интеграции, поскольку она предполагает постепенный закономерный переход к каждому последующему этапу,

Однако выяснилось, что такая модель не является единственно возможной. Более того, лишь только Европейскому Союзу присуща такая модель развития. Все остальные интеграционные группировки следуют другой модели. К числу последних относится и регионализм в Азиатско-Тихоокеанском регионе, одну из главных ролей в котором играет Азиатско-Тихоокеанское экономическое сотрудничество.

В настоящее время в АТЭС насчитывается 21 член. Среди них Тайвань, принятый с одобрения Китая. В результате в АТЭС принят термин участвующие экономики, а не страны-участники. В экономиках-участницах проживает примерно 40\% процентов населения мира, на них приходится 55\% мирового ВВП и 44\% мировой торговли, в последние десятилетия играет важную роль в развитии мировой экономики и международной торговли. Процесс региональной экономической интеграции, как представляется, будет и дальше способствовать экономическому развитию в регионе. Однако развитому региональному сотрудничеству предшествовал длительный инкубационный период.

Так, Хади Соесастро выделяет три этапа в формировании международных институтов в АТР [4, с.79]. Первый этап охватывает период с 1960 по 1967 и характеризуется преобладанием усилий Японии в развитии Тихоокеанского сотрудничества. Наиболее существенная идея, которая появилась в течение этого периода, была предложена японским экономистом, Киёши Кожима, который предложил создать Тихоокеанскую зону свободной торговли, которая включала бы пять развитых экономик: Австралию, Канаду, Японию, Новую Зеландию и США. В это время группа японских и австралийских бизнесменов занималась созданием Тихоокеанского экономического совета, который объединил представителей бизнеса стран с развитой экономикой.

Второй этап охватывает период с 1968 по 1977. На этапе происходит постепенное распространение идеи тихоокеанского сотрудничества в научных кругах. Начало этому положили Конференции по торговле и развитию в тихоокеанском регионе, объединявшие экономистов, представителей правительств государств и международных организаций. Однако идея тихоокеанского экономического сотрудничества не получала существенного внимания со сторон правительств вплоть до 1970-х.

Период с 1978 по 1989 образует третий этап институционального формирования в АТР, характеризующийся ростом интереса на правительственном уровне и включением официальных лиц в неформальную политическую дискуссию. 1978 год был отмечен как «начало новой эры в идеях о сотрудничестве». В 1978 году Комитет Сената США по международным отношениям поручил исследовать возможность создания Тихоокеанской экономической организации. В этом же году премьер-министр Японии Охира Масаёси поддержал идею сотрудничества государств тихоокеанского региона и учреждения Тихоокеанской исследовательской группы. Это примечательно тем, что эта группа развила концепцию «открытого регионализма», которая позднее стала центральным принципом АТЭС. Создание международной организации, тем не менее, не было реализовано ввиду сильного нежелания стран юго-восточной Азии вступать в более широкое сотрудничество. Однако встреча премьер-министра Японии Охира и премьер-министра Австралии Малкольма Фрейзера в 1979 проложила путь к созданию Тихоокеанского экономического совета в 1980, который объединил ученых, представителей бизнеса и официальных лиц.

Нет сомнений в том, что эта активность неправительственных групп сыграла существенную роль в формировании фундамента для последующего создания АТЭС посредством допущения развития концепций азиатскотихоокеанского сотрудничества и их распространения среди «элит» региона. Постепенный процесс институционального развития доказал эффективность объединения сопротивляющихся сторон за одним столом. Однако роль этих групп в создании АТЭС была косвенной. Тем не менее, существование регионалистских идей и деятельность неформальных групп не были существенным стимулирующим фактором для создания АТЭС [6, c.161].

Создание АТЭС в 1989 явилось водоразделом в истории институционального развития в регионе. Несмотря на постепенный процесс развития регионального сотрудничества в предшествующие три десятилетия, основной причиной учреждения организации явились внерегиональные препятствия, которые побудили правительства рассмотреть новую регионалистскую схему в качестве варианта развития собственной политики. Многие западно-тихоокеанские государства были обеспокоены тупиком в переговорах ГАТТ, возвышением США, унилатерализмом и ростом регионализма в Европе и Северной Америке [8, с.79-80] Эти обстоятельства при- 
вели к растущему чувству разочарования в перспективах руководимого ГАТТ режима либеральной торговли. На фоне этих обстоятельств в январе 1989 г. премьер-министр Австралии Роберт Хоук призвал к созданию азиатско-тихоокеанского регионального форума. Это предложение Хоука привело к первой встрече АТЭС в ноябре того года. Инициативе Хока предшествовало подобное заявление министерства международной торговли и промышленности Японии, которое было вызвано заявлением США о рассмотрении возможности заключения договора о свободной торговле межу США и Японией [3, с. 60] Внутренний доклад министерства призывал к сдвигу в экономических и торговых отношениях в регионе от «развития посредством зависимости от США» к «развитию посредством сотрудничества в регионе». Две черты предложения министерства особенно важны. Во-первых, в отличие от инициативы Хоука, предложение министерства включало США как члена организации. Во-вторых, одобрялась неформальная и свободная форма организации. Страны АСЕАН остались осторожными касательно участия в данной организации. Однако, как и в случае с Японией, импульс к рассмотрению участия в организации был обусловлен действиями США, которые страны АСЕАН восприняли как непосредственную угрозу их экономическим интересам [6, с.163].

Первая встреча АТЭС была проведения в Канберре в ноябре 1989 г. Страны АСЕАН продолжали настаивать на том, что АТЭС должно быть консультативным форумом по экономическим проблемам и не должен вести к принятию обязательных директив. Они также настаивали на том, чтобы организация была основана на принципах равенства, справедливости и взаимной выгоды. Она действительно переняла многие принципы и нормы, которые развил АСЕАН за свою долгую историю. Другой важной чертой АТЭС является то, что оно основано на концепции «открытого регионализма». На практике это означает, члены группировки снижают пошлины и прочие торговые ограничения как во взаимных отношениях, так и в отношении государств, не являющихся членами группировки. Хотя некоторые страны, в особенности США, настаивали на либерализации методов, принимаемых в АТЭС, большинство членов поддержали принцип открытого регионализма, поскольку они хотели избежать фрагментации мировой торговой системы. Другими словами, вместо еще одной закрытой группы, АТЭС был создан для дополнения более широкой системы мировой торговли, основанной на ГАТТ.

Таким образом, Азиатско-Тихоокеанское сотрудничество прошло долгий путь становления от неформальных встреч разного рода специалистов до активно функционирующего международного форума.

\title{
Литература
}

1. Афонцев С.А. Новый регионализм [электронный ресурс]. Режим доступа : http://postnauka.ru/longreads/26527 (дата обращения: 01.04.2016).

2. Севастьянов С.В. Глобализация и конкурирующие модели восточно-азиатского регионализма. 1995

3. Funabashi, Yoichi. Asia Pacific Fusion: Japan's Role in APEC. Washington, D.C.: Institute for International Economics,

4. Hadi Soesastro, "Pacific Economic Cooperation: The History of an Idea," in Ross Garnaut and Peter Drysdale, eds., Asia Pacific Regionalism: Readings in International Economic Relations (Pymble, Australia: Harper Educational, 1994). P. 77-88.

5. Hu Weixing. Building Asia-Pacific Regional Institution: the Role of APEC

6. Komori Yusamasa. Asia's Institutional Creation and Evolution. Asian Perspective 33,3 (2009). P.151-182.

7. Liu Chenyang. APEC's Role in Promoting Asia-Pacific Economic Integration

8. Ravenhill, John. APEC and the Construction of Pacific Rim Regionalism. Cambridge: Cambridge University Press, 2001.

\section{Системы регистрации прав на недвижимое имущество в странах Азиатско-Тихоокеанского региона: сравнительно-правовой анализ регистрации недвижимости в России и Японии}

\author{
(С) К. Д. Санжицыбиков \\ магистрант 2 года обучения юридического факультета \\ ФГБОУ ВО «Бурятский госуниверситет» \\ Россия, г. Улан-Удэ \\ sanzhitsybikov@gmail.com
}

Основным признаком, согласно которому отличаются системы регистрации прав на недвижимость, является то, какую роль играет государство в охране прав на недвижимость: берет ли оно на себя заботу об их охране или предоставляет эту роль владельцам этих прав [1, с. 32].

В настоящее время сохраняются две принципиально различные системы - «регистрация прав или титулов» и «регистрация сделок» с недвижимостью. Предмет регистрации является главным критерием для классификации, и поэтому выделяют титульные (или регистрации прав «title registration») и актовые системы регистрации (или регистрации сделок «deeds registration»). Также, большое значение имеют правовые последствия и факторы обязательности совершения регистрации.

В большинстве стран АТР, в том числе в Японии, Австралии, Канаде, действует система «регистрации прав» на недвижимость («Титульная система»), которая имеет многовековую историю. Главным центром распространения системы «регистрации сделок» с недвижимостью («Актовая система») являются практически все штаты США. 
При Титульной системе предметом регистрации является само право (обременения) на конкретный объект недвижимого имущества. Сведения о возникших правах или обременениях в публичном реестре свидетельствует об их существовании. Государство играет важную роль, являясь гарантом верности зарегистрированных прав. Доверие к системе создает высокий статус организации, часто приравненной к судебному, четкая регламентация деятельности регистраторов, привлечение нотариусов.

Классический вариант Титульной системы регистрации предполагает охрану государством прав лиц, чьи права оно признает, на недвижимое имущество, находящееся в пределах его юрисдикции. Механизм состоит в том, что определенные административные органы (управление юстиции) (Японии) или правительственные агентства (Австралии) регистрируют права на недвижимость в определенном регистре («Поземельная книга») $[1$, c. 36].

Необходимо иметь в виду, что на юридическом языке многих стран недвижимость нередко обозначается термином «земля». Существенным требованием данной системы является описание и идентификация объекта, как объекта регистрируемого права. Для целей регистрации прав системой описания объекта недвижимости служит «имущественный» - Земельный кадастр. В Титульной системе регистрации заложено конструктивное единство Поземельной книги и Кадастра недвижимости.

В противоположность этому в Актовой системе роль государства пассивна. Исполнительная власть лишь ведет в базе данных учет представленных договоров для регистрации, которая не является обязательной. Государство не дает никаких гарантий действительности и законности прав, предусмотренных сделками, и, естественно, не несет никаких обязательств, кроме обеспечения публичности и хранения зарегистрированных договоров. Для получения гарантии действительности прав, стороны сделки вынуждены обращаться к специальным компаниям, которые занимаются «страхованием титула». При возникновении проблем, связанных с нарушением в прошлом «чистоты титула», компании обязуются возместить ущерб лицу, застраховавшему свой титул.

Процедура страхования, по мнению специалистов, должна служить дополнительным инструментом защиты имущественных прав, а не заменять регистрацию прав [2, с. 59].

Сравнительный анализ практики стран показывает, что система «регистрации сделок» значительно более дорогая и неэффективная, чем система «регистрации прав» на недвижимость.

В АТР Россия является единственной страной, которая декларировала «совмещенную» систему регистрации прав и сделок, введенной в действие Федеральным законом от 17 июня 1997 г. № 122-Ф3 «О государственной регистрации прав на недвижимое имущество и сделок с ним» [3].

Российская «совмещенная» система, предусматривающая, помимо регистрации прав, ограничений, регистрацию сделок, нисколько не умаляет прав и интересов участников рынка недвижимого имущества, а скорее, предполагается законодателем в качестве дополнительной гарантии законности прав и обременений на конкретный объект.

Закон о государственной регистрации для объектов недвижимого имущества определил особый правовой режим и порядок совершения сделок, согласно которому, вещные права, их возникновение, ограничение и прекращение в обязательном порядке подлежат государственной регистрации в Едином государственной реестра прав на недвижимое имущество и сделок с ним специальными уполномоченными органами власти.

В настоящее время помимо Закона о государственной регистрации действует ряд законов, нормы которых, затрагивают вопросы регистрации прав. Вместе с тем, многие нормы российского законодательства зачастую противоречат интересам участников рынка и изменившимся в стране условиям.

При этом стремление к установлению стабильной экономики в России и совершенствованию законодательства вызывает необходимость совершенствования системы государственной регистрации прав. Очень ценным является обращение к опыту стран, успешно проводящих законодательное регулирование в исследуемой сфере.

Рассмотрим организационно-правовые аспекты и опыт регистрации недвижимости в Японии.

Система регистрации прав на недвижимое имущество в Японии была создана в девятнадцатом веке, когда впервые в 1886 г. был принят Закон о регистрации. Новый Закон о регистрации недвижимости от 1899 года упростил процедуру регистрации, которая допускает непредставление правоустанавливающих документов, а в случае их подачи возвращение сторонам после завершения регистрации [2, с. 63].

В Японии регистрацию прав на недвижимость осуществляют регистрационные палаты. Регистрационной палатой, которая осуществляет действия по регистрации недвижимости, считается управление юстиции или региональное бюро Министерства юстиции Японии, а также их филиалы или отделения.

Контроль над соблюдением нижестоящими органами нормативных правовых актов о регистрации прав на недвижимое имущество, в Японии, как и в России, осуществляет вышестоящий орган государственной власти Министерство.

В истории развития российской системы регистрации важным моментом стало принятие Закона о государственной регистрации в соответствии со ст. 131 Гражданского кодекса Российской Федерации [4].

Административная реформа в России существенно изменила систему управления в стране [5]. Так, результатом реформирования стало объединение обособленно организационных структур систем государственной регистрации прав и кадастрового учета и создание в 2008 г. уполномоченного органа по государственной регистрации прав - Федеральной службы государственной регистрации, кадастра и картографии, подведомственной Министерству экономического развития РФ.

В Японии, в ходе реформы система кадастрового учета из ведения налоговых управлений была переведена в управление юстиции, подконтрольное Министерству юстиции. В связи с чем, управления юстиции стали ор- 
ганами унифицированного управления системой регистрации недвижимости. Так, с 1960 г. в связи с объединением реестров недвижимости и земельных книг кадастровые сведения заносятся не в земельный кадастр, а в титульные разделы реестра [2, с. 63].

Помимо регистрации прав в японском законодательстве предусмотрена отдельная и относительно самостоятельная процедура регистрации описаний недвижимости (в России указанную функцию выполняет орган кадастрового учета - кадастровая палата).

С учетом международной практики развития систем регистрации и многолетнего опыта в российской системе произошли серьезные изменения. Так, принят новый Федеральный закон от 13 июля 2015 г. № 218 -Ф3 «О государственной регистрации недвижимости», предусматривающий создание Единого государственного реестра недвижимости (ЕГРН) и введение единой процедуры. Новый закон является законодательным закреплением объединения кадастрового учета и регистрации прав на недвижимость: от идеи создания объекта недвижимости до оформления прав на него. Его основные положения вступят в силу с 1 января 2017 года [6].

В Японии регистрация прав производится путем внесения соответствующих записей в реестр. Рассмотрим структуру реестра, состоящего из титульного подраздела, в котором регистрируется объект недвижимости, подраздела А, в котором регистрируются сведения о правообладателях, и подраздела В, в который вносятся записи о правах, ограничениях. При сравнении японской структуры со структурой ЕГРП, последняя, по мнению специалистов, явно проигрывает [2, с. 64].

На сегодняшний день в России нет единого реестра, содержащего актуальную информация об объектах недвижимости и правах на него, ЕГРП и ГКН - это разные информационные ресурсы. Создание в 2017 г. Единого государственного реестра недвижимости (ЕГРН) существенно упростит систему регистрации прав, прежде всего, за счет создания единой, достоверной базы данных [7, с. 34].

В Японии широко развит негосударственный сектор, связанный с оказанием услуг посредниками при подаче заявления о регистрации в управление юстиции. Это «юридические делопроизводители» и «кадастровые сюрвейеры», которые осуществляют профессиональную деятельность по обследованию и обмеру земли и строений, составлению документов.

В России отношение к посредникам неоднозначное. Новым законом предусмотрено совершенствование взаимодействия органа регистрации прав с профессиональным окружением - кадастровыми инженерами. Понятие «кадастровый инженер» в сферу земельно-имущественных отношений введен законом «О государственном кадастре недвижимости» с 2007 года [8]. Это физическое лицо, которое имеет действующий квалифицированный аттестат, что дает ему возможность готовить документы, необходимые для кадастрового учета объектов недвижимости [9, с. 50].

Японское правительство на первых этапах развития системы регистрации прав на недвижимость максимально стремилось упростить процедуру регистрации. В Японии, в отличие от законодательства других стран, необязательно привлечение нотариуса для получения нотариального удостоверения на сделках или подтверждения волеизъявления при подаче заявления на регистрацию. Для обеспечения надежности системы регистрации стремление гарантировать соответствие регистрируемых сведений истине заключается в требовании «явки заявителей в управление юстиции».

В России обязательное нотариальное удостоверение предусмотрено только в отношении определенных видов сделок, например, сделки по продаже недвижимого имущества, принадлежащего несовершеннолетнему гражданину или гражданину, признанному ограниченно дееспособным, подлежат нотариальному удостоверению (ст.ст. 24, 24.1, 30 Закона).

В российском законодательстве предусмотрена государственная регистрация прав на недвижимость независимо от формы собственности - частной, государственной или муниципальной.

Объектом регистрации в Японии выступают земельные участки в сухопутной части территории. Общественные водоемы (реки, моря, озера и пр.) не подлежат регистрации, поскольку являются общественными вещами (государственной собственностью) и не могут быть объектом частных прав. Гражданский кодекс Российской Федерации трактует строение и земельный участок, как отдельные виды объектов недвижимости, причем в качестве главной вещи рассматривает строение. В Японии, как и в России, здания это самостоятельные объекты недвижимого имущества, отдельные от земельных участков, на которых они размещены.

Законом о регистрации Японии зданием признается строение, прочно связанное с землей. Указанное требование является недостаточным, и в связи с этим, законодательно закреплены критерии признания зданий, которые отражают цели системы регистрации недвижимости и предотвращают возможные споры. К ним отнесены: неразрывная и прочная связь с землей (физическая связь и долговечность); наличие крыши и наружных стен (изолированность от внешнего воздуха и др.); состояние, позволяющее использовать его по назначению (применимость); способность быть предметом сделок.

Согласно Закону о регистрации России, здание это объект недвижимого имущества, перемещение которого без соразмерного ущерба его назначению невозможно (ст. 1). Если в российских нормативных правовых актах закрепить вышеуказанные подобные критерии, то возможно исключить разногласия, возникающие между заявителями и уполномоченным органом по регистрации прав по поводу определений объектов недвижимости.

В России государственная регистрация прав проводится с момента представления заявления и документов, необходимых для государственной регистрации (ст.16). До последнего времени поданные на государственную регистрацию документы подлежали постоянному хранению. С учетом новых правил с 1 января 2015 г. постоянному хранению на бумажных носителях подлежат только правоустанавливающие документы, заявления о 
государственной регистрации, а также документы, составленные заявителем и заверенные его личной подписью [10].

В Японии процедура регистрации описания недвижимости начинается с момента представления заявления собственником, либо доверенным лицом в управление юстиции. Законом о регистрации недвижимости ограничен срок хранения заявлений. Так, заявления, по которым регистрация была завершена, хранятся в течение пяти лет.

Срок (10 дней), процедура и порядок государственной регистрации в России четко регламентирован Законом о регистрации и Административным регламентом [11]. В Японии срок регистрации не установлен, на практике он составляет 4-5 дней в так называемых «простых» случаях и около месяца, например, когда требуется выезд на место.

Сравнение российской и японской систем регистрации прав на недвижимость показывает, что:

1. В России с 1 января 2017 г. вступает в силу новый закон «О государственной регистрации недвижимости», устанавливающий новые правила регистрации. Вводится единая процедура, при которой возможно одновременное осуществление кадастрового учета и государственной регистрации. В Японии действует унифицированная система: управления юстиции регистрируют, во-первых, описания недвижимого имущества (ведут учет объектов) и, во-вторых, права на него.

2. Процедуры подачи заявления и регистрации в Японии просты и не вызывают сложностей во взаимоотношениях правообладателей и регистраторов. Большинство опрошенных граждан России (65\%) считают систему регистрации - бюрократической структурой, создающей дополнительные сложности для населения. Сегодня в России создается единая система государственной регистрации прав и кадастрового учета недвижимости. Новый закон предусматривает введение единой учетно-регистрационной процедуры, создание ЕГРН, что повысит эффективность функционирования государственной регистрационной системы, а также снизит издержки пользователей и государства при государственной регистрации.

3. Гражданское законодательство России предусматривает простую письменную форму сделок, за исключением сделок, требующих нотариального удостоверения (гл.9 ГК РФ). В Японии стороны достаточно свободны в выборе формы сделки, поскольку возможность представления дубликата заявления вместо правоустанавливающего документа делает на практике возможным совершение сделки не только в простой письменной форме, но и в устной.

4. В Японии население активно пользуется услугами посредников - кадастровых сюрвейеров и юридических делопроизводителей. На сегодняшний день в России совершенствуется взаимодействие с кадастровыми инженерами, предусмотрено внедрение ресурса «Личный кабинет кадастрового инженера», обеспечивающего возможность самостоятельной проверки подготовленных им документов на соответствие установленным требованиям и содержащимся в реестре сведениям, что позволит снизить количество отрицательных решений органа регистрации прав.

Развитие и модернизация национальной учетно-регистрационной системы государственной регистрации прав на недвижимость в Российской Федерации высоко оценена Мировым банком и способствовала повышению в рейтинге Doing Business («Ведение бизнеса») на 38 позиций начиная с 2012 года [12, с. 50].

\section{Литература}

1. Никонов П. Н., Журавский Н. Н. Недвижимость. Кадастр и мировые системы регистрации прав на недвижимое имущество // Аналитический обзор. 2006.

2. Кирсанов А. Р. Сравнительно-правовой анализ регистрации прав на недвижимое имущество в России и за рубежом // Бюллетень Министерства юстиции РФ. 2002. № 3.

3. Федеральный закон от 17.06.1997 г. № 122-Ф3 «О государственной регистрации прав на недвижимое имущество и сделок с ним».

4. Гражданский кодекс Российской Федерации (часть первая) от 30.11.1994 г. № 51-Ф3 (ред. от 31.01.2016 г.).

5. О системе и структуре федеральных органов исполнительной власти, Указ Президента РФ от 09.03.2004 № 314 // Российская газета. 2004.

6. Федеральный закон от 13 июля 2015 г. № 218-ФЗ «О государственной регистрации недвижимости».

7. Елизарова Г. Ю. Законодательные изменения в сфере учета и регистрации недвижимости // Вестник Росреестра. 2015. № 1(23).

8. Федеральный закон от 24.07.2007 г. № 221-Ф3 «О государственном кадастре недвижимости».

9. Нусс А. В. Развитие института кадастровых отношений // Вестник Росреестра. 2014. № 4 (22).

10. Приказ Росреестра от 24.07.2014 г. П/349 «Об утверждении Правил ведения книг учета документов и дел правоустанавливающих документов при государственной регистрации прав на недвижимое имущество и сделок с ним».

11. Приказ Министерства экономического развития РФ от 09.12.2014 г. № 789 «Об утверждении Административного регламента Федеральной службы государственной регистрации, кадастра и картографии по предоставлению государственной услуги по государственной регистрации прав на недвижимое имущество и сделок с ним».

12. Радке В. А., Пшеничная А. А. Международный рейтинг Всемирного банка как индикатор качества оказания государственных услуг // Вестник Росреестра. 2015. № 4 (26). 


\section{Воздействие на экосистему озера Байкал при строительстве ГЭС «Шурен» на территории Монголии}

(C) С. П. Сверкунов

студент 3-го курса юридического факультета ФГБОУ ВО «Бурятский госуниверситет»

Россия, г. Улан-Удэ

sergei.sverkunov@mail.ru

Селенга является самой крупной артерией из притоков воды в оз. Байкал. Площадь накопления воды на реке Селенга достигает 525,245 км2 из них 282,154 км2 расположены на территории Монголии. Скорость течения реки Селенги через границу Монголии достигает в среднем 350 м/с. Для создания водохранилищ и выработки электроэнергии, Правительство Монголии на реке Селенга планирует строительство нескольких гидроэлектростанций. Однако экологические организации «Гринпис» и «Реки без границ» ставят вопрос о закрытии монгольского проекта, так они убеждены, что «с неизбежным уменьшением стока Селенги мы столкнемся во время заполнения водохранилища. Значит, уровень воды в Байкале упадет еще ниже. Конечно, потом средний многолетний сток возвратится в норму, но произойдет перераспределение стока между месяцами, что нанесет удар по экосистеме. Шуренская ГЭС призвана стать лишь первой из каскада гидроэлектростанций на реке Селенга. А значит, нужно просчитывать кумулятивный эффект, который окажет запуск каскада на озеро Байкал» [3].

Постройка платин негативно повлияет на всю экосистему озера Байкал, а также приведет к изменению экосистем рек Орхона и Селенги. По данной ситуации Всемирный фонд дикой природы считает, что строительство ГЭС «Шурен» на русле реки Селенга будет затруднять миграционный путь осетра, тайменя, омуля и др. рыб, вследствие чего будет значительна сокращена их популяция.

Защитники природы напоминают, что озеро уже пострадало от Ангаро-Енисейского каскада ГЭС, состоящие из шести станций. Только после сооружения первой - Иркутской ГЭС в 1956 году, уровень воды в озере поднялся на метр, берега озера сильно разрушились, пострадала популяция байкальского омуля и многих других рыб. Частично разрушились автомобильные и железные дороги, которые пришлось перенести.

Между тем, экологи прогнозируют новые изменения в уровне озера. В настоящее время на Ангаре строиться Богучанская ГЭС, однако экспертиза ее влияния на окружающую среду не проведена. Ниже по течению от нее планируется построить Мотыгинскую ГЭС [3].

Необходимо отметить, что с 1996 года Байкал входит перечь всемирного наследия ЮНЕСКО и проект строительства ГЭС в Монголии находится под его контролем.

Несмотря на нестабильное положение, правительство Монголии уверяет, что никакого проекта не будет, если строительство ГЭС будет негативно влиять на экосистему оз. Байкал.

Однако в случае строительства ГЭС на реке Селенга есть вероятность нарушения со стороны Монголии норм международного права, в частности:

1) Строительство ГЭС не соответствуют нормам Конвенции «Об охране всемирного культурного и природного наследия», которая вступила в силу 17 декабря 1975 года. Например, в ст. 6 указано, что «каждое государство - сторона настоящей Конвенции обязуется не принимать каких-либо преднамеренных действий, которые могли бы причинить прямо или косвенно ущерб культурному и природному наследию» [2].

2) Нормы Конвенции «О водно-болотных угодьях», цель которых «сохранение и разумное использование всех водно-болотных угодий путем осуществления местных, региональных и национальных действий и международного сотрудничества как вклад в достижение устойчивого развития во всем мире» [4]. В рамках данной Конвенции создан «Список водно-болотных угодий международного значения», в него также входит дельта реки Селенги, которая служит домом и приютом для 298 видов гнездящихся и мигрирующих птиц, из которых 70 - охраняемые виды, занесенные в Красную книгу. К числу наиболее редких видов птиц, обитающих в дельте, относятся: черный и даурский журавли, орлан-белохвост, сапсан, азиатский бекасовидный веретенник [6].

Необходимо отметить, что на реке Селенга также находиться государственный заказник «Кабанский» в Байкальском заповеднике, который входит в список водно-болотных угодий. В заповеднике встречаются пути миграции многих редких и ценных видов птиц и водоплавающих. Вследствие чего, при снижении уровня воды, возможно уменьшение количества видов животных, птиц и рыб. Однако одно из самых негативных последствий - это возможное исчезновение одного из самых крупнейших болот Российской Федерации.

3) Соглашение, заключенное между Правительством Российской Федерации и Правительством Монголии по охране и использованию трансграничных вод от 11.02 .1995 г. Согласно ст. 4 Соглашения, стороны обязуются принимать соответствующие меры по предотвращению, ограничению и сокращению негативных воздействий на трансграничные воды при проведении водохозяйственных и иных мероприятий на своей территории. В связи с обеим сторонам Соглашения необходимо дать анализ негативным последствиям, которые могут возникнуть при строительстве ГЭС.

Под негативным воздействием в данной конвенции пониматься - любые значительные вредные последствия для окружающей среды, человека и материальных объектов, возникающие в результате изменения состояния 
трансграничных вод, вызываемого деятельностью человека, физический источник которой расположен на территории другой Стороны [5].

В настоящее время Монголии не хватает электроэнергии. По данным СМИ Монголия тратит более 30 миллионов долларов в год. Вследствие чего Монголия стремиться стать независимой, и обеспечить с помощью строительства ГЭС увеличение подачи электроэнергии, получить полное водоснабжение в отдаленных участках своей территории, развивать национальную инфраструктуру тем самым повысить уровень экономики и воспользоваться производимой электроэнергией для нужд своего народа. Монголия имеет право использовать свои внутренние реки, опираясь на нормы международного права основным правом всех суверенных государств является право свободного распоряжения природными ресурсами, следовательно, и водой. Капустин А.Я. считает, что это право является неоспоримым, неотъемлемым и постоянным, поскольку вытекает из суверенитета государства над ресурсами, расположенных в пределах его государственной территории [1]. Однако в силу вступают основные принципы международного права водных ресурсов, которые регламентируют, разумное и справедливое использование вод, а также не нанесения ущерба другому государству. Международная экологическая коалиция «Реки без границ» считает, что риски проектов строительства плотин в бассейне Селенги несовместимы с задачами охраны природы и устойчивого развития региона, и тем более оз. Байкал, который является всемирным достоянием.

Комиссия по безопасности РФ установила, что строительство гидросооружений на реке Селенга и ее притоках в Монголии спровоцируют негативную экологическую ситуацию, в частности:

- ухудшиться экосистема реки Селенги и сократиться приток воды в оз. Байкал;

- уменьшится миграция редких видов рыб, а также численность редких видов животных;

- снизится качество воды и водоснабжения;

- исчезнут водно-болотные угодья.

Также возможно накопление токсичных тяжелых металлов (например, ртуть), появление оползней, эрозии почвы, наводнений, землетрясении и т.д.

Вследствие чего Россия подняла вопрос об отмене строительства плотин на реке Селенга, и начала разрабатывать различные варианты решения этой проблемы, которые могли бы служить альтернативной «Шуренской» ГЭС.

На сегодняшний день ученые-экологи, предлагают несколько проектов, которые способны бы были обеспечить Монголию электроэнергией, например, такие как:

1) строительство газопровода, который будет поставлять Монголии энергию и тепло и не затронет экосистему оз. Байкал;

2) строительство ветряных и солнечных электростанций «Гобитэк», позволит использовать огромные запасы солнца, ветра и подземной тепловой энергии и без каких-либо потерь получать и передавать электроэнергию не только по территории Монголии, но и соседним государствам. С помощью чего Монголия сможет обеспечить себя электроэнергией и предотвратить экологический кризис.

3) строительство Мокской ГЭС на реке Витим, с помощью которой можно подавать электроэнергию в Монголию. Ведь на данный момент у Мокской ГЭС отсутствуют потребители электроэнергии, которые оправдали бы ее строительство. Сейчас проект можно возобновить и всю электроэнергию подавать на территорию Монголии. Но пока что о сроках этого строительства говорить рано, поскольку данное строение требует вложение определённых денежных средств.

4) строительство новых линий электропередач от Ангарского каскада ГЭС на территорию Монголии. Реализация данного проекта поспособствует увеличению поставок электроэнергии в Монголию и снижению тарифов.

5) строительство нескольких ТЭЦ на территории Монголии, однако экологи настаивают, что данные проект не является альтернативой для обеспечения себя собственной электроэнергией.

Проанализировав данную проблему, можно сделать вывод что Монголии будет трудно решить данную проблему в одиночку, только совместными усилиями с Россией и принятии единогласных решений, мы способны найти безопасный путь, который полностью сможет обеспечить бесперебойную подачу электроэнергии на территорию Монголии, а также избежать экологических рисков и негативных последствий на озеро Байкал.

\section{Литература}

1. Капустин А. Я. Право на водные энергетические ресурсы в современном международном праве // Международная конференция по стихийным бедствиям, связанным с водой (Душанбе, 27-28 июня 2008 г.): сб. тез. Душанбе, 2008. С. 58-60.

2. Конвенция об охране всемирного культурного и природного наследия [Электронный pecypc]. URL: http://www.conventions.ru

3. Красноярское общественное объединение «Плотина, Нет!» // Монгольская ГЭС грозит Байкалу обмелением. [Электронный ресурc]. URL: http://www.plotina.net (27.01.2016 г.).

4. Руководство по Рамсарской конвенции: Справочник по осуществлению Конвенции о водно-болотных угодьях (Рамсар, Иран, 1971 г.), 4-е издание. Гланд, Швейцария: Секретариат Рамсарской конвенции, 2006 г. [Электронный ресурс]. URL: https://docviewer.yandex.ru

5. Соглашение между Правительством Российской Федерации и Правительством Монголии по охране и использованию трансграничных вод от 11 февраля 1995 г. [Электронный ресурc]. URL: http://voda.mnr.gov.ru

6. Магия Байкала // Река Селенга и дельта Селенги [Электронный ресурc]. URL: http://www.magicbaikal.ru. 


\title{
Краткая характеристика реализации свободы выражения мнения в Австралийском союзе
}

\author{
(C) А. Н. Тетерин \\ магистрант 1 года обучения юридического факультета \\ ФГБОУ ВО «Бурятский госуниверситет» \\ Россия, г. Улан-Удэ \\ teterin_aleksei@inbox.ru
}

В западных странах очень часто используется слово “диффамация”, что, как указывает Верховный суд РФ, тождественно равно понятию распространения не соответствующих действительности порочащих сведений, содержащемуся в статье 152 ГК РФ [12]. Дальше мы будем использовать исключительно это слово.

В Австралии отсутствует упоминание о свободе слова в конституции и законах, кроме защиты политической речи от уголовного преследования [6]. Такого рода защита является отсылкой к Биллю о правах, который был принят в Англии в 1689 г., одна из статей которого гласит: свобода слова и дебатов или производство по делу в Парламенте не должно быть причиной к импичменту или привлечения к ответственности в каком-либо суде или месте вне парламента [8]. Хотя Австралия является страной, которая не приняла Билль о правах. Органом по защите прав человека является Комиссия Австралии по правам человека, которая была создана в 1986 г., и является независимой организацией и отчитывается перед федеральным Парламентом через Генерального прокурора [1]. Австралийское правительство согласилось поддержать и уважать многие договорённости Всеобщей декларации прав человека, в том числе: Международный пакт о гражданских и политических правах [10]. В п. 2 статьи 19 этого пакта сказано, что каждый имеет право на свободу выражения мнения. Это право включает в себя свободу искать, получать и распространять информацию и идеи любого рода, независимо от границ, в устной, письменной или печатной форме, в форме произведения искусства или с помощью любых других медиа средств по своему выбору. В п.3 той же статьи сказано про особые обязанности и особую ответственность, то есть право может быть сопряжено с некоторыми ограничениями, но они должны быть предусмотрены законом и быть необходимыми. Такого рода необходимость нужна для: 1) уважения прав и репутации других лиц; 2) защиты национальной безопасности общественного порядка, или здоровья или нравственности населения [7]. Пункт 2 даёт очень широкое определение свободы выражения мнения, но п.3 дает возможность государству максимально ограничить такую свободу. Правовая система Австралии испытывала сильное влияние с момента образования английской колонии на территории страны [11], и поэтому можно считать, что Англия “создала" политическую систему Австралии. В Англии ещё в 17 в. закреплялась свободы слова (хотя и в Парламенте), но закон о диффамации 1996 г. является очень строгим [3]. В Австралии был принят не менее строгий закон о диффамации, который создаёт несколько проблем, о которых пойдёт речь в следующем абзаце.

Австралийский социолог Брайан Мартин пишет в 1995 г., что закон о диффамации должен защитить репутацию людей от несправедливого нападения, но на практике основным эффектом является ограничить свободу слова и защитить влиятельных людей от пристального внимания. Он разделяет диффамацию на 2 вида: 1) оральная диффамация (Oral defamation), которая называется "slander"; слово не имеет точного перевода на русский язык (или мы его не знаю), но означает что-либо сказанное, например история, рассказанная на встрече; 2) опубликованная диффамация (Published defamation), которая называется "libel”; слово переводится (или имеет близкое по смыслу значение) как клевета [5]. Такое разделение не заложено в статье 152 ГК РФ, то есть то, что некоторые сведения нельзя доказать, так как это является оценочное суждение. Требование доказать такие сведения является посягательством на свободу выражения мнения. На отсутствие такого разграничения указывает ЕСПЧ в постановление по делу “Гринберг против Российской Федерации” [13, с. 7]. Мартин указывает на ряд проблем, которые были созданы в правовой системы после принятия закона о диффамации, как например: высокая стоимость (десятки тысяч долларов), непредсказуемость (люди говорят и пишут дискредитирующие вещи всё время, но лишь некоторым из них угрожает судебное разбирательство), сложность (большинство авторов предпочитают быть в безопасности), медлительность (иногда дело заводят через много лет после опубликования диффамации) [5]. Именно непредсказуемость высказываний, то есть непреднамеренная диффамация во время реализации права на свободу слова, по нашему мнению, должна охраняется в демократическом государстве. Результатом всех этих проблем является то, что закон о диффамации не защищает многих людей, у которых, как, например, нет денег на долгие судебные разбирательства, но служит для подавления свободы слова. В 2005 году в Новом Южном Уэльсе, который является одним из шести штатов Австралийского Союза, был принят новый закон о диффамации, в котором различие между “slander” и “libel” отменялись [4]. То есть закон о диффамации стал частично походить на статью 152 ГК РФ, которая не раз критиковалась со стороны ЕСПЧ.

Если сравнить избирательную систему Англии и Австралии, то можно наблюдать, что Австралия имеет ряд существенных особенностей, такие как обязательное голосование, существуют политические партии, которые финансирует государство [2]. Мы считаем то, что обязательное голосование является допустимым в демократическом государстве. Карл Экштайн отмечает: “Принцип демократии гласит: формирование воли государства должно исходить от народа" [14, с. 209]. И поэтому если обязательное голосование способствует формированию демократического государства, то оно является допустимым, а в некоторых случая необходимым. Такого рода обязанность помогает развитию общественно-важных дискуссий, что в свою очередь повышает значимость свободы слова и информации. Таким образом, когда Австралийское правительство принудило граждан к 
обязательному голосованию, оно “выиграло” в долгосрочной перспективе развития общества, в котором будет понимание то, что их мнение и голос имеют значения. В тоже время, если государство финансирует политические партии, то у него может возникнуть соблазн в оценочных характеристиках относительно другого кандидата или партии, в предоставлении более выгодного эфирного времени им и т.д. Экштайн пишет, что свобода слова создает предпосылки для демократического процесса политического волеизъявления; в преддверии выборов и голосования различные точки зрения, мнений и предпочтений получают особое значение, так как демократический выбор большинства легитимен лишь в том случае, если он является результатом всеобъемлющего и справедливого формирования мнения [14, с. 208].

Свобода слова во время обсуждения общественно значимых вопросов, по нашему мнению, является фундаментальной составляющей демократического государства. ЕСПЧ в деле "Гринберг против Российской Федерации" отмечает то, что пресса играет важную роль в демократическом государстве, хотя оно и не должна преступать определённых границ, в частности, в отношении уважении репутации и прав других лиц [13, с. 15]. Похожая ситуация, когда пресса преступает границу диффамации, рассмотрена в деле “Ланге против Австралийской радиовещательной корпорации”, когда суд встал на защиту чести и достоинства человека, который занимал пост премьер-министра [9]. То есть, хоть Ланге и был политической личностью, которая находится под пристальным вниманием, это не дает право прессе заниматься клеветой.

Строгие законы о диффамации являются существенным ограничением свободы выражения мнения, потому что накладывают на ответчика большие материальные расходы и длятся судебные разбирательства иногда очень долго. Этот закон был создан для защиты чести и достоинства людей, но некоторые государства используют его для подавления свободы слова и для того, чтобы демократическое общество не развивалось, и граждане не понимали того, что их голос на выборах или их мнение может привести к смене власти. Когда на выборах неоднократно побеждает партия, которая поддерживается властью, то это формирует у граждан предчувствие, что на следующих выборах победит это же партия, и со временем они перестают ходить на выборы. Но что, если законодательно обязать их ходить на выборы? Это решает сразу две проблемы: 1) люди не ходят на выборы, потому что не верят в их прозрачность; 2) людям лень туда идти - вторая проблема является побочным эффектом первой. Вокруг обязанности ходить на выборы возникает больший интерес к общественным дискуссиям относительно этих выборов, что в свою очередь помогает развитию гражданского самосознания. Во время общественных дискуссий развивается свобода выражения мнения. Закон о диффамации нужен, чтобы свобода выражения мнения при обсуждении чего-либо не переходила в клевету. Если общество достаточно долго будет находиться в условиях строгих диффамационных законах и доступности дискуссий, которые могут изменить положение дел в стране, то это будет способствовать тому, чтобы вообще отменить или очень редко применять подобные законы, потому что у граждан уже выработается самосознание, при котором они не будут переходить на клевету относительно человека, который им не нравится. Таким образом, получается, что строгие диффамационные законы нужны для того, чтобы защитить честь и достоинство человека от различных посягательств, это в теории. Но на практике не существует государства (или мы его не знаем), которое бы не использовало такого рода законы в своих целях, как, например, оградить “своего” человека от пристального внимания прессы. Всё это ведёт к тому, что будет продолжаться ужесточение диффамационных законов, которые будут максимально ограничивать свободу выражения мнения.

\section{Литература}

1. About the Commission | Australian Human Rights Commission [Электронный ресурс]. Режим доступа: https://humanrights.gov.au/ about-commission-0 (21 марта 2016).

2. Comparing the Australian and UK electoral systems [Электронный ресурс]. Режим доступа: http://www.onlineopinion. com.au/view.asp?article=10791 (26 марта 2016).

3. Defamation Act 1996 [Электронный ресурс]. Режим доступа: http://www.legislation.gov.uk/ukpga/1996/31 (23 марта 2016).

4. DEFAMATION ACT 2005 - SECT 7 [Электронный ресурс]. Режим доступа: http://www.austlii.edu.au/au/legis/ nsw/consol_act/da200599/s7.html (26 марта 2016).

5. Defamation law and free speech [Электронный ресурс]. Режим доступа: https://www.uow.edu.au/ bmartin/ dissent/documents/defamation.html (23 марта 2016).

6. Freedom of speech by country [Электронный pecypc]. Режим доступа: https://en.wikipedia.org/wiki/Freedom_of_ speech_by_country (20 марта 2016).

7. International Covenant on Civil and Political Rights [Электронный pecypc]. Режим доступа: http://www.ohchr.org/EN/ ProfessionalInterest/Pages/CCPR.aspx (23 марта 2016).

8. Parliamentary Privilege First Report [Электронный ресурс]. Режим доступа: http://www.publications.parliament.uk/ pa/jt199899/jtselect/jtpriv/43/4306.htm (21 марта 2016).

9. Political discussion as a defence to defamation: Lange v Australian Broadcasting Commission [Электронный ресурс]. Режим доступа: http://epublications.bond.edu.au/cgi/viewcontent.cgi?article=1012\&context=hcourt (28 марта 2016).

10. What are human rights? A Australian Human Rights Commission [Электронный ресурс]. Режим доступа: https://humanrights.gov.au/about/what-are-human-rights (21 марта 2016).

11. Особенности правовой системы Австралии [Электронный ресурс]. Режим доступа: http://pravo.news/page/pvv/ist/ist16--idz-ax308--nf-224.html (23 марта 2016).

12. Постановление Пленума Верховного Суда РФ от 24.02.2005 N 3 "О судебной практике по делам о защите чести и достоинства граждан, а также деловой репутации граждан и юридических лиц" [Электронный ресурс]. Режим доступа: http://www.consultant.ru/document/cons_doc_LAW_52017/(23 марта 2016). 
13. Судебная практика европейского суда по правам человека по свободе выражения мнения и свободе информации : в 8 т. / сост. Г. Ю. Арапова, С. И. Кузеванова. Воронеж: Моби Дик, 2006. Т. 4. 208 с.

14. Экштайн К. Основные права и свободы. М.: NOTA BENE, 2004. 496 с.

\title{
Правовой статус государственного служащего в Российской Федерации и Монголии (сравнительное исследование)
}

\author{
(C) А. Г. Тышкенова \\ старший преподаватель кафедры \\ конституционного, административного \\ и муниципального права юридического факультета \\ ФГБОУ ВО «Бурятский госуниверситет» \\ Россия, г. Улан-Удэ \\ 79021612161@mail.ru
}

Современный институт государственной службы характеризуется тем, что требования к лицам, замещающим государственные должности самых разных категорий и групп, возрастают. Правовое положение (статус) государственных служащих постоянно претерпевает изменения. Так, в России с принятием Федерального закона «О системе государственной службы Российской Федерации» от 27.05.2003 г. № 58-Ф3 (далее по тексту Закон № 58-Ф3) [9] и Федерального закона «О государственной гражданской службе Российской Федерации» от 27.07.2004 г. № 79-Ф3 (далее по тексту - Закон № 79-Ф3) [8] понимание правового статуса государственных служащих расширилось. В развитие норм указанных законов были приняты и принимаются новые законодательные и подзаконные нормативно-правовые акты.

Правовой статус (правовое положение) государственных служащих - это содержание (сущность) государственно-служебных правоотношений [6, с. 318]. Высказывается мнение, что вопросу регламентации административно-правового статуса государственного гражданского служащего, а также классификации их прав и обязанностей в современный период уделено недостаточное внимание [3, с. 26].

Стремясь к совершенствованию правовой базы государственной службы, устанавливающей статус служащих, полезным представляется изучение опыта правового регулирования других стран, в том числе соседних. Благодаря сравнительным исследованиям мы имеем возможность сопоставить теоретические наработки и имеющуюся практику по самым разным вопросам.

Согласно ч. 1 ст. 2 Закона № 58-ФЗ система государственной службы включает в себя:

- государственную гражданскую службу;

- военную службу;

- государственную службу иных видов.

С учетом особенностей правового регулирования разных видов государственной службы, многочисленности актов, регламентирующих деятельность служащих в рамках настоящей статьи для сравнительного исследования статуса российских государственных служащих будет использоваться правовое положение гражданских служащих.

В российской юридической науке отмечается, что правовой статус государственного гражданского служащего, обладая общими с юридическими статусами иных субъектов права чертами, характеризуется рядом особенностей, которые придают ему качественную и количественную определенность [3, с. 29]. Считаем, что к числу особенностей можно отнести и новый подход к регулированию правового статуса государственных гражданских служащих.

Анализируя главу 3 Закона № 79-ФЗ, можно прийти к выводу, что в структуре правового положения (статуса) гражданского служащего выделяются следующие элементы: права; обязанности; ограничения, связанные с гражданской службой; запреты, связанные с гражданской службой; требования к служебному поведению гражданского служащего.

В действовавшем ранее Федеральном законе «Об основах государственной службы Российской Федерации» от 31.07.1995 г. № 119-Ф3 в правовом положении служащих выделялись: права, обязанности, ограничения и запреты [10]. Таким образом, можно утверждать, что требования к служебному поведению являются новым элементом правового статуса служащих.

В современной России впервые нормативно требования к служебному поведению государственных служащих были закреплены Указом Президента Российской Федерации от 12.08.2002 г. № 885 «Об утверждении общих принципов служебного поведения государственных служащих» [7]. Рассматривая требования, закрепленные в Законе № 79-Ф3, можно сделать вывод о том, что многие требования, установленные в Указе Президента РФ, были заимствованы разработчиками Закона № 79-ФЗ.

В Монголии базовым законодательным актом, устанавливающим правовой статус государственных служащих является Закон Монголии «О государственной службе» от 30.12.1994 г. [2]. Данный акт закрепляет права, обязанности и правоограничения лиц, замещающих должности государственной службы Монголии. Указанный закон в своих статьях не устанавливает виды государственной службы.

В монгольской юридической науке имеются исследования правового положения служащих. Профессор Б. Чимид при рассмотрении должности как организационной единицы государственных организаций говорит о 
правах и обязанностях [1, с. 249]. Тот же подход к элементам статуса служащих мы наблюдаем в трудах О. Амархуу [5, с. 51].

Нямцэрэн Дэмбэрэл отмечает, что хотя правовой статус государственных служащих Монголии имеет значительные особенности, все же монгольское законодательство исходит из того, что государственный служащий является трудящимся, как и все остальные работники, поэтому на него распространяется трудовое законодательство. Закон о государственной службе не устанавливает приоритета законодательства о государственной службе перед трудовым законодательством, а лишь упоминает об особенностях трудовых отношений в государственной службе [4, с. 80$]$.

Закон Монголии «О государственной службе» содержит разнообразные управомачивающие, обязывающие, запретительные нормы, которые действуют на служащих при прохождении службы. Группируя и анализируя их, мы получаем четыре элемента правового статуса служащих: права, обязанности, ограничения и запреты на государственной службе. Сравнивая структуры правового статуса служащих, закрепленные в законах России и Монголии, можно утверждать о том, что в российском акте используется более широкий подход. В российском законе в правовое положение включаются требования к служебному поведению гражданских служащих, которые не упоминаются в монгольском акте.

При рассмотрении внутреннего содержания элементов можно прийти к выводу о схожести норм российского и монгольского законов. Так, например, во многом ограничения и запреты имеют практически идентичный характер. Единую основу имеют такие ограничения как невозможность служащим осуществления своих служебных полномочий при наличии одного из следующих обстоятельств:

- признание недееспособным или ограниченно дееспособным решением суда, вступившим в законную силу;

- $\quad$ наличия подтвержденного заключением медицинской организации заболевания, препятствующего исполнению им должностных обязанностей;

- близкого родства или свойства с государственным служащим, если замещение должности связано с непосредственной подчиненностью или подконтрольностью одного из них другому;

- отказа от представления сведений о доходах и имуществе;

- и мн. др.

Запреты, связанные с государственной службой также имеют сходный характер. Так, государственному служащему и в России, и в Монголии запрещается использовать свое служебное положение в интересах политических партий или принимать награды, почетные и специальные звания иностранных государств, международных организаций без разрешения соответствующих должностных лиц и др.

Как было отмечено ранее, особенностью правового статуса гражданских служащих в России является законодательное закрепление требований к служебному поведению наряду с другими элементами, что отсутствует в монгольском законе. Опыт отечественного законодателя в этом вопросе может быть заимствован монгольскими коллегами при расширении структуры статуса государственных служащих.

\section{Литература}

1. Чимид Б. БНМАУ-ын захиргааны эрх зуй. Улан-Батор, 1973. 278 с.

2. Закон «О государственной службе Монголии» // Торийнмэдээлэл. 1995. № 11.

3. Костенников М. В., Куракин А. В., Марьян А. Ш. Административно-правовое регулирование противодействия коррупционным рискам в системе государственной службы: монография. Домодедово: ВИПК МВД России, 2011. 118 с. $196 \mathrm{c}$.

4. Нямцэрэн Дэмбэрэл. Правовое регулирование государственной службы в Монголии: дис. ... канд. юр. наук. М., 2004.

5. Амархуу О., Чимид Б. Ардын тор. Улан-Батор, 1981.

6. Старилов Ю. Н. Служебное право: учебник. М.: БЕК, 1996. 698 с.

7. Указ Президента Российской Федерации от 12.08.2002 г. № 885 «Об утверждении общих принципов служебного поведения государственных служащих» [Электронный ресурс] // СПС «Консультант Плюс» (дата обращения: 15.04.2016 г.).

8. Федеральный закон «О государственной гражданской службе Российской Федерации» от 27.07.2004 г. № 79-Ф3 [Электронный ресурс] // СПС «Консультант Плюс» (дата обращения: 15.04.2016 г.).

9. Федеральный закон «О системе государственной службы Российской Федерации» от 27.05.2003 г. №58-Ф3 [Электронный ресурс] // СПС «Консультант Плюс» (дата обращения: 15.04.2016 г.).

10. Федеральный закон «Об основах государственной службы Российской Федерации» от 31.07.1995 г. №119-Ф3 [Электронный ресурс] // СПС «Консультант Плюс» (дата обращения: 15.04.2016 г.).

\section{Конституционные основы организации денежного обращения в Российской Федерации и странах АТР}

(C) Б. Ч. Цыбикова

магистрант 1 года обучения юридического факультета ФГБОУ ВО «Бурятский госуниверситет»

Россия, г. Улан-Удэ

onatsybikova@mail.ru

Правильная организация денежного обращения является необходимым условием для успешного выполнения задач и достижения целей финансовой деятельности государства. В большинстве своем в юридической науке понимание денежного обращения такое же, как и в экономической науке. Так, В. П. Василец, руково- 
дствуясь тем, что с экономической точки зрения денежное обращение - это движение денег при выполнении ими своих функций в наличной и безналичной форме, в качестве правовой категории рассматривает его как установленный нормативными актами порядок и формы движения денежной массы на территории конкретного государства [9].

К аналогичному выводу приходит и Ф. Т. Диланян, который под денежным обращением, в широком смысле этого слова, понимает «денежную массу, хотя и не участвующую в конкретный момент времени в товарных сделках, но являющуюся законным платежным и покупательным средством». В связи с этим денежное обращение рассматривается им как система урегулированных нормами финансового права общественных отношений, возникающих между субъектами финансового права, которые непосредственно связаны с выпуском и обращением денег в Российской Федерации. Заметим, что такая позиция является доминирующей в науке финансового права. Нельзя не отметить и вывод Л. Л. Арзумановой, которая под денежным обращением понимает урегулированное финансово-правовыми нормами движение национальной и (или) иностранной валюты в наличной и безналичных формах, что является логичным развитием доминирующей позиции [9].

Иного мнения придерживается Е. Р. Денисов, который денежное обращение рассматривает как составную часть денежного оборота, представляющего собой постоянный переход наличных денежных знаков от одних юридических и (или) физических лиц к другим. А денежное обращение на территории РФ - это оборот наличных денежных знаков, т. е. банкнот и монет Банка России [9].

Таким образом, под денежным обращением в юридической науке, в основном, принято понимать движение денег в наличной и безналичной форме [9].

Правовое регулирование организации денежного обращения Российской Федерации осуществляется, прежде всего, Конституцией Российской Федерации.

Так, к основам экономических отношений следует отнести ст. 8 Конституции Российской Федерации, устанавливающую, что в Российской Федерации гарантируются единство экономического пространства, а также свобода экономической деятельности, признаются и защищаются равным образом частная, государственная, муниципальная и иные формы собственности. Деньги не упоминаются, но закладываются основные принципы их обращения. Содержащиеся в данной статье конституционные принципы формируют основы конституционного экономического строя. Эти принципы лежат в основе большой совокупности конституционных норм, связанных между собой логико-правовыми связями, и в силу этого представляющих собой определенное единство, подсистему конституционно-правовых норм [4, с. 249].

Принцип единства экономического пространства имеет особое значение в федеративных государствах, субъекты которых имеют свое законодательство (ст. 5 Конституции Российской Федерации). Он также связан с категорией «государственное единство», использованной в преамбуле Конституции Российской Федерации. Целый ряд конституционных положений в гл. 3 Конституции «Федеративное устройство» устанавливают гарантии экономической целостности федеративного государства [7].

Конституционное правовое регулирование организации денежного обращения Российской Федерации осуществляется, в основном, посредством регулирования его государственно-территориального устройства и организации системы государственных органов [9].

Территориальную организацию федеративного государства характеризует такой элемент устройства государства, как разграничение предметов ведения между федерацией и ее субъектами. Российская Федерация в целом является государством, которому принадлежит государственный суверенитет, в то время как субъекты федерации выступают в качестве государственно-территориальных образований. Наиболее важные направления деятельности относят к ведению федерации, а все остальные - к совместному ведению.

Проблема определения компетенции федеральных органов власти является главной и наиболее сложной в любом федеративном государстве. Федерация не может обладать неограниченными полномочиями по управлению страной, она обязана делиться этими полномочиями с субъектами Федерации, без чего государственная власть не может носить демократический характер [3].

Вопрос о мере соотношения возможностей центра и субъектов в федеративном государстве был, есть и останется злободневным. Однако мировой опыт, а также пример собственной истории говорит о том, что федеративное государство всегда настроено на сохранение, а то и увеличение своего влияния; ослабление федерации за счет изъятия у нее полномочий, собственности может привести к такому критическому пределу, за которым уже следует распад федерации [1].

Конкретизируя обязанность государства по созданию и защите единого экономического пространства, единого рынка, Конституция Российской Федерации относит к ведению Российской Федерации следующие вопросы, имеющие отношение к организации денежного обращения: денежная эмиссия, финансовое, валютное регулирование, федеральный бюджет, федеральные налоги и сборы, федеральные фонды регионального развития, федеральная государственная собственность и другие вопросы (ст. 71 Конституции Российской Федерации). В ведении субъекта Российской Федерации остается незначительное число вопросов, имеющих отношение к организации денежного обращения, как правило, в сфере публичных финансов (например, установление общих принципов налогообложения и сборов в Российской Федерации) (ст. 72 Конституции Российской Федерации).

Конституционные требования организации публичной власти в России предполагают неукоснительное соблюдение органами власти ст. 71 Конституции Российской Федерации, устанавливающей предметы исключительного ведения Российской Федерации. Эти предметы не могут быть переданы в ведение субъектов Россий- 
ской Федерации или в сферу их совместного с Российской Федерацией ведения иначе, чем через внесение изменений в Конституцию Российской Федерации. Следовательно, по предметам ведения Российской Федерации к полномочиям федеральных органов государственной власти должна относиться вся полнота прежде всего регулятивных и контрольных полномочий [5].

Здесь представляется уместным проанализировать, каким образом осуществляется разграничение предмета ведения по вопросу организации денежного обращения в конституциях зарубежных федеративных государств Азиатско-Тихоокеанского региона.

В современных федеративных государствах разграничение предмета ведения по вопросу организации денежного обращения на конституционном уровне решается по-разному. Условно их можно классифицировать на следующие группы.

Во-первых, это государства, в чьих конституциях прямо закреплено, что вопрос денежного обращения относится к ведению (исключительному ведению) федерации. В этой группе такие государства, как: Индия (ст. 246 Конституции Индии от 26 января 1950 г.), Малайзия (ст. 74 Конституции Малайзийской Федерации от 31 августа 1957 г.).

Во-вторых, это государства, в конституциях которых при определении вопросов ведения федерации упоминается не денежное обращение, а отдельные его элементы. Например, к ведению федерации относят установление монополии на выпуск денежных знаков единым банковским учреждением, контролируемым Федеральным Правительством (ст. 28 Конституции Мексиканских Соединенных Штатов от 5 февраля 1917 г.).

В ряде федеративных государств разграничение предмета ведения по вопросу организации денежного обращения осуществляется путем включения этого (или связанного с ним) вопроса в компетенцию федерального органа. В большинстве случаев таким органом является законодательный федеральный орган государственной власти. Полномочия Парламента Канады - денежное обращение и чеканка монеты (ст. 91 Конституционного акта Канады от 17 апреля 1982 г.); полномочия Конгресса Мексиканских Соединенных Штатов - учреждать монетные дворы, устанавливать курс и виды государственной валюты, определять курс иностранных валют (ст. 73 Конституции Мексиканских Соединенных Штатов от 5 февраля 1917 г.); полномочия Конгресса Соединенных Штатов Америки - чеканить монету (разд. 8 Конституции Соединенных Штатов Америки от 17 сентября 1787 г.) [9].

Как видно, в любом зарубежном федеративном государстве организация денежного обращения является вопросом ведения, который разграничивается в пользу федерации. При этом такое разграничение может быть прямым, когда вопрос именно денежного обращения относится к исключительному ведению федерации, либо опосредованным, когда при разграничении вопросов ведения в пользу федерации упомянуты лишь отдельные элементы организации денежного обращения. Разграничение предмета ведения по вопросу организации денежного обращения может также осуществляться путем закрепления соответствующей компетенции федерального органа государственной власти [9].

Система государственных органов Российской Федерации, организующих денежное обращение, устанавливается соответствующими главами Конституции Российской Федерации вместе с их компетенцией.

Так, Президент Российской Федерации, являясь главой государства и гарантом Конституции Российской Федерации, принимает указы и распоряжения, обязательные для исполнения на всей территории страны (ст. 80, 89 Конституции Российской Федерации). Кроме того, он назначает и освобождает от должности руководителей федеральных органов исполнительной власти, осуществляющих правоприменительную деятельность в сфере денежного обращения (ст. 83 Конституции Российской Федерации).

Федеральное Собрание, как представительный и законодательный орган Российской Федерации, принимает федеральные законы по вопросам организации денежного обращения (ст. 105 Конституции Российской Федерации). Обязательному рассмотрению в Совете Федерации подлежат принятые Государственной Думой федеральные законы по вопросам: федерального бюджета; федеральных налогов и сборов; финансового, валютного, кредитного, таможенного регулирования, денежной эмиссии (ст. 106 Конституции Российской Федерации). Также Государственная Дума назначает и освобождает от должности руководителей федеральных органов исполнительной власти, осуществляющих деятельность в сфере денежного обращения (ст. 103 Конституции Российской Федерации).

Правительство России, являясь высшим органом исполнительной власти, по вопросам организации денежного обращения осуществляет правотворческую деятельность, издавая постановления, а также правоприменительную деятельность, принимая соответствующие распоряжения (ст. 110, 115 Конституции Российской Федерации). Правительство обеспечивает проведение в Российской Федерации единой финансовой, кредитной и денежной политики (ч. 1 ст. 114 Конституции Российской Федерации).

Конституция Российской Федерации закрепляет, что денежная эмиссия осуществляется исключительно Банком России, а защита и обеспечение устойчивости рубля - его основная функция, осуществляемая независимо от других органов государственной власти (ч. 1, 2 ст. 75 Конституции Российской Федерации). Государство при помощи многочисленных правовых норм закрепляет за деньгами статус элемента образа жизни человека. Так в ст. 75 Конституции Российской Федерации устанавливается, что денежной единицей в Российской Федерации является рубль. А в ст. 140 ГК РФ закреплено, что рубль является законным платежным средством, обязательным к приему по нарицательной стоимости на всей территории РФ. И платежи на территории Российской Федерации осуществляются путем наличных и безналичных расчетов. В ст. 45 НК РФ устанавливается, 
что обязанность по уплате налога исполняется в валюте Российской Федерации. Таких примеров - множество [10].

И наконец, местное самоуправление обеспечивает владение, пользование и распоряжение муниципальной собственностью, а органы местного самоуправления самостоятельно управляют муниципальной собственностью, формируют, утверждают и исполняют местный бюджет, устанавливают местные налоги и сборы (ст. 130, 132 Конституции Российской Федерации).

Таким образом, конституционно-правовое регулирование организации денежного обращения Российской Федерации осуществляется, в основном, посредством регулирования его государственно-территориального устройства и организации системы государственных органов, а также законодательного определения национальной денежной единицы. При этом, как и для всех государств с государственно-территориальным устройством в форме федерации, организация денежного обращения в России является вопросом ведения самой федерации, а организация системы органов государственной власти выражается в установлении видов органов государственной власти, преимущественно федерального уровня, и закреплением за ними компетенции в сфере денежного обращения, как правило, правотворческого или правоприменительного характера.

\section{Литература}

1. Авакьян С. А. Конституционный лексикон: Государственно-правовой терминологический словарь. М.: Юстицинформ, 2015 // Справочно-правовая система «Гарант» [Электронный ресурс].

2. Арзуманова Л. Л. Право денежного обращения как подотрасль финансового права Российской Федерации // Справочно-правовая система «Гарант» [Электронный ресурс].

3. Бархатова Е. Ю. Комментарий к Конституции Российской Федерации. М.: Проспект, 2010 // Справочно-правовая система «Гарант» [Электронный ресурс].

4. Гаджиев Г. А. Экономическая Конституция // Конституционный вестник. 2008. № 1 (19). С. $249-263$.

5. Государственная власть в Российской Федерации: монография / А. Г. Пархоменко, 3. Ф. Софрина. М.: ЮРКОМПАНИ, 2014 // Справочно-правовая система «Гарант» [Электронный ресурс].

6. Диланян Ф. Т. Основы финансово-правового регулирования денежного обращения в Российской Федерации: дис. ...канд. юр. наук: 12.00.14. М., 2003. С. 213.

7. Комментарий к Конституции Российской Федерации / под ред. В. Д. Зорькина, Л. В. Лазарева. М.: Эксмо, 2010 // Справочно-правовая система «Гарант» [Электронный ресурс].

8. Кремянская Е. А. Проблемы и перспективы развития федерализма в Российской Федерации: дис. ...канд. юр. наук: 12.00.12. М., 2003. C. 225.

9. Крылов О. М. Правовое регулирование денежного обращения в Российской Федерации: монография / отв. ред. С. В. Запольский. М.: КОНТРАКТ, 2014 // Справочно-правовая система «Гарант» [Электронный ресурс].

10. Финансовый механизм и право: монография / отв. ред. С. В. Запольский. М.: КОНТРАКТ, 2014 // Справочноправовая система «Гарант» [Электронный ресурс].

\section{Транспарентность государственных органов в России и Канаде: сравнительно-правовой анализ}

(C) М. М. Шайдорова

магистрант 1 года обучения юридического факультета ФГБОУ ВО «Бурятский госуниверситет»

Россия, г. Улан-Удэ

mariya.shaidorova@mail.ru

В наше время информация и знания пронизывают все сферы человеческой деятельности. Право на доступ к информации является одним из фундаментальных прав в любом правовом государстве. Информация о деятельности публичной власти в свою очередь вызывает особый общественный интерес.

Транспорентность от англ. transparent - прозрачный, насквозь и pareo - быть очевидным: это отсутствие секретности, доступность информации, открытость, прозрачность. В конституционно-правовой сфере транспарентность представляет собой, закрепленные в конституции страны и конкретизированные в нормах конституционного права, общие принципы деятельности органов государственной власти, предполагающие информирование граждан об осуществлении органами власти их полномочий, обеспечение привлечения граждан к обсуждению и принятию властных решений, а так же осуществление общественного контроля над деятельностью государственных органов и органов местного самоуправления [1].

Вопрос транспарентности публичных институтов является одним из магистральных направлений развития национальных правовых систем в современном мире. Это обстоятельство обуславливает необходимость анализа нормативно - правовой регламентации.

Канада одна из первых в рамках государственной политики провозгласила курс на построение информационного общества и на проведение информационной политики. Транспарентность власти в Канаде отражается в Законе о доступе к информации, принятым парламентом в 1982 г. и вступивший в силу 1 июля 1983 г. [2]. При этом нельзя не отметить, что на конституционном уровне право на доступ к информации до сих пор не закреплено. Важной особенностью правовой системы Канады является отсутствие единого основного закона страны, 
конституцией в настоящее время признается Конституционный акт 1982 г., совокупность актов и распоряжений, а также устные традиции и конституционные соглашения, так называемая «неписаная конституция» [3].

Основополагающей частью Конституционного акта является Канадская хартия прав и свобод 1982 г., в статье 2 Хартии провозглашается свобода мысли, убеждений и их выражения [4]. На первый взгляд, подобная регламентация может показаться не имеющей отношения к свободе информации и соответствующего права на доступ. Тем не менее, в 2010 г. Верховный суд Канады в решении 2010SCC23 постановил, что свобода выражения мнений в соответствии со статьей 2(b) Хартии включает в себя право требовать предоставление доступа к правительственным документам [5].

Пол Томас, следуя толкованию канадских судебных решений, характеризует Закон Канады о доступе как «квазиконституционный», поскольку он обладает преимущественным юридическим действием по отношению к другим федеральным законам, за исключением тех, которые перечислены в приложении к нему [6]. Тем самым подтверждается не просто приоритет перед другими источниками права, но также подчеркивается значение открытости и транспарентности как фундаментального принципа политической и административной культуры государственного управления Канады.

Закон был принят в целях обеспечения права на доступ к информации, содержащейся в документах правительственных учреждений. В его основе лежат три принципа: правительственная информация должна быть доступна для общественности; необходимые исключения из права на доступ должны быть ограничены и точно определены; а решения о раскрытии правительственной информации должны приниматься автономно и проходить независимую экспертизу.

В Статье 3 Закона представлено определение, в соответствии с которым «правительственным учреждением» является любой департамент или министерство Канады, государственная (королевская) корпорация либо ее дочернее предприятие, находящееся в полной собственности (в понимании раздела 83 Закона о финансовом управлении). Многие исследователи отмечают, что данное определение должно быть расширено, с изменением указанной статьи с целью включения в понятие «правительственное учреждение» всех организаций, созданных в соответствии с законом и исполняющих публичные функции [7]. Правом на доступ обладает любой гражданин либо лицо, обладающее статусом постоянного жителя Канады. Отмечается, что все запросы на получение информации обрабатываются единообразно и без учета личности заявителя, его должности, профессии или целей для которых он обращается за информацией.

Закон подробно описывает процесс направления запроса в соответствующий государственный орган и порядок его рассмотрения. В частности, отмечается, что запрос в государственное учреждение на получение доступа подается в письменной форме. В Статье 7 устанавливается срок в 30 дней для рассмотрения обращения и принятия решения либо об отказе в предоставлении информации, либо о направлении запрашиваемого документа или его части заявителю. Даже в случае отказа лицу, запрашивающему информацию, направляется соответствующее письменное уведомление [2].

Действие Закона распространяется на около 251 госучреждение. В 2013 - 2014 году было проведено исследование по 27 выбранных учреждений, которые получили в общей сложности 56,171 запросов, около 93,5\% от всех запросов, полученных через правительство. 61\% запросов были завершены в течение 30 дней, наблюдается снижение по сравнению с 2012-2013 гг, который составил 64,8\% [8].

Было отмечено увеличение числа жалоб, на 30\% (новые жалобы по поводу административных вопросов, выросло на 54\%). Это увеличение отражает трудности, нескольких учреждений в выполнении ими своих обязательств в рамках Закона о доступе к информации.

В правительстве, приблизительно 61,0\% запросов были обработаны в течение 30 дней, и вся информация была раскрыта $26,8 \%$.

В 2013-2014 годах, данные учреждения получили 60,105 запросов и их нагрузка увеличилась на $9 \%$. Источники запросов: Общественный: 23723 (39\%), Бизнес: 23129 (38\%), Медиа: 8421 (14\%), Организации: 2898 (5\%), Научные: 1,934 (3\%) [8].

Как мы видим, представители общественности с 39\% от всех запросов, полученных в данный период, представляет собой основной источник запросов.

В дополнение к запросам доступа, учреждения получают запросы на консультацию от других государственных органов и других учреждений (например, провинциальных, территориальных или международных учреждений). Число консультаций значительно увеличивает нагрузку на учреждения, но в 2013-2014 этот показатель снизился на 18,1\% по сравнению с предыдущим годом.

В 1983 году в соответствии с Законом о доступе к информации было создано специализированное Управление Уполномоченного по вопросам информации для оказания помощи физическим лицам и организациям, которые считают, что правительственные учреждения нарушают их права, предоставленные в соответствии с Законом. При этом в обязанности Уполномоченного входит также обеспечение соблюдения прав государственных учреждений и других заинтересованных лиц.

В его компетенции находится право посещать любое правительственное учреждение, исследовать всю документацию и информацию кроме документов, защищенных грифом «тайны Кабинета». Он также может рекомендовать обнародовать информацию или дать обратный совет - не спешить и отказаться «открыть» документ. Федеральный суд - последняя инстанция, которая решает судьбу документа - обнародовать его или нет, если с таким решением Специального уполномоченного не согласен подавший запрос.

Являясь должностным лицом Парламента, Уполномоченный по вопросам информации назначается Кабинетом по рекомендации премьер-министра, и утверждается в должности совместной резолюцией Палаты общин и 
Сената на семилетний срок, который может быть возобновлен. С 30 июня 2010 г. по настоящее время функции Уполномоченного по вопросам информации исполняет Сюзанн Лего (Legault, Suzanne) ставшая шестым Уполномоченным занявшем эту должность. [9].

Работа Уполномоченного поддерживается сотрудниками Управления, в обязанности которых входит проведение расследований по поступившим жалобам и принятие мер по разрешению споров; представление Уполномоченного в судебных делах; оказание правовой помощи в расследованиях, а также проведение консультаций по вопросам законодательства. Управление рассматривает жалобы граждан, которые считают, что им было отказано в праве на доступ к информации или их право было каким-либо образом нарушено (изменение языка, излишние финансовые затраты, нарушение сроков т. д.). Граждане, которым было отказано в доступе вправе направить жалобу в Управление в течение 60 дней с момента отказа. Тем не менее, Уполномоченный по вопросам информации не обладает правом для вынесения решения, обязывающего раскрыть ту или иную информацию. Его решение является скорее рекомендацией для раскрытия, тем не менее, государственный орган не обязан его исполнять [10].

После проведенного расследования и отчета, полученного от Уполномоченного, заявители, которым было отказано в доступе, вправе обратиться в Федеральный суд Канады для пересмотра решения правительственного учреждения об отказе в предоставлении информации. Подобные обращения возможны только после окончания всех расследований Управления, и в этом случае Уполномоченный по вопросам информации оказывает поддержку заявителю в направлении жалобы в суд.

Ежегодно Уполномоченный представляет годовой отчет о доступе к информации граждан Канады. Данные отчетов находятся в свободном доступе в Интернет на официальном правительственном сайте. Это так же позволяет независимым исследователям, СМИ и другим общественным структурам проводить мониторинг деятельности уполномоченного и всех государственных структур, в которые поступают соответствующие запросы, и делать выводы относительно эффективности их работы и закона о доступе к информации в целом.

В 2015 году, в адрес Уполномоченного поступило 1738 жалоб, 1,605 из них были закрыты в течение года. В 2011 это число составило 2,061; 2012 - 1,495; 2013 - 1,621; 2014 - 1,789; 2015 - 1,605 соответственно [11].

В 2014-2015 годах, комиссар зарегистрировал 569 задержки (пропуска срока для ответа или о расширений времени, которые они принимают для обработки запросов), связанные с жалобами против 47 учреждений.

Созданная правовая система доступа к информации в Канаде представляется довольно перспективной, в отличие от многих стран, наблюдается серьезный подход к формированию системы доступа к информации и реализации законодательных положений на практике. Как отмечает А. Робертс, практика Канады во многих аспектах превосходит соответствующую практику применения Акта США о свободе информации [12, с. 117].

В целом, опыт Канады представляет интерес у исследователей для изучения и проведения сравнительного анализа с отечественной системой доступа к публичной информации. В российском законодательстве на сегодняшний день, создана необходимая база для реализации права граждан на доступ к информации. Правовую основу составляют соответствующие положения Конституции Российской Федерации п. 4 ст. 29 закрепляет право каждого гражданина свободно искать, получать, передавать, производить и распространять информацию любым законным способом [13], а также федеральных законов: «О средствах массовой информации» от 27 декабря 1991 г. № 2124-1, «Об информации, информационных технологиях и о защите информации» от 27.07.2006 № 149-Ф3 [14], «Об обеспечении доступа к информации о деятельности судов в Российской Федерации» от 9 февраля 2009 г. № 262-Ф3 [15], «Об обеспечении доступа к информации о деятельности государственных органов и органов местного самоуправления» от 22 декабря 2008 г. № 8 - Ф3 [16], и др.

Автор считает возможным объединение положений законодательных актов, описанных выше, в едином законе, посвященном доступу к информации. Таким образом, возможно достижение единообразия в регулировании процедур получения и осуществления доступа к информации, систематизации соответствующих норм и исключение дублирования. Нельзя забывать, что законы не должны носить «бумажный» характер и подрываться другими законами.

Опыт Канады так же может быть рассмотрен и применен на практике, с точки зрения перспективы создания в России такого важного института транспарентности, как Уполномоченного по вопросам информации, для защиты интересов граждан в сфере доступа к информации на досудебном этапе. При этом необходимо отметить что, выносимые решения Уполномоченного для госорганов, должны носить обязательный, а не рекомендательный характер.

Транспарентность органов власти, проходит красной нитью через формирование государственной политики, является необходимым элементов системы, не только для повышения уважения и доверия к власти, но и для обеспечения устойчивого функционирования, как системы государственного управления, так и политической системы в целом.

Транспарентность публичных институтов позволяет гражданам получать адекватное представление и формировать критические суждения о состоянии общества в целом и государственных учреждениях, укрепляет действенность и эффективность общественного контроля над их деятельностью. И не будем забывать, что «Солнечный свет является лучшим дезинфицирующим средством» - Луис Д. Брандейс судья Верховного суда США (1916 - 1939 г.). 


\title{
Литература
}

1. Транспарентность деятельности государственной власти и местного самоуправления в Российской Федерации и государствах Европы. [Электронный ресурс]. Режим доступа: http://justicemaker.ru/view-article.php?id=13\&art=3431 (дата обращения: 02.04.2016).

2. Закон о доступе к информации 1983 г. [Электронный ресурс]. Режим доступа: http://laws-lois.justice.gc.ca/eng/acts/A-1 (дата обращения: 05.04. 2016).

3. Конституционный акт 1982 г. [Электронный ресурс]. Режим доступа: http://laws- lois.justice.gc.ca/eng/const/page15.html (дата обращения: 05.04. 2016).

4. Хартия прав и свобод 1982 г. [Электронный ресурс]. Режим доступа: http://laws-lois.justice.gc.ca/eng/Const/page15.html (дата обращения: 06.04. 2016).

5. Ontario (Public Safety and Security) v. Criminal Lawyers' Association, 2010 SCC 23, [2010] 1 S.C.R. 815 [Электронный pecypc] - Режим доступа: http://scc-csc.lexum.com/scc-csc/scc-csc/en/item/7864/index.do (дата обращения: 06.04. 2016).

6. Paul G. Thomas. Advancing Access to Information Principles through Performance Management Mechanisms: The Case of Canada. World Bank Institute, Washington DC. 2010.

7. Мельничук Мария Александровна Опыт Канады в правовом регулировании доступа к информации // Пробелы в российском законодательстве. 2014. № 4. [Электронный ресурс]. Режим доступа: http://cyberleninka.ru/article/n/opyt-kanadyv-pravovom-regulirovanii-dostupa-k-informatsii (дата обращения: 10.04.2016).

8. Observations on the health of the access system 2013-2014 [Электронный ресурс]. Режим доступа: http://www.oicci.gc.ca/eng/observations-sur-la-sante-du-systeme-d-acces-2013-2014_observations-on-the-health-of-the-access-system-2013-

2014_1.aspx (дата обращения: 10.04.2016).

9. Information Commissioner [Электронный pecypc]. Режим доступа: http://www.oic-ci.gc.ca/eng/abu-ans_thecommissioner-le-commissaire.aspx (дата обращения: 10.04.2016).

10. Office of the Information Commissioner of Canada [Электронный pecypc]. Режим доступа: http://www.oicci.gc.ca/eng/abu-ans_what-we-do_ce-que-nous-faisons.aspx (дата обращения: 10.04.2016).

11. Официальный сайт комиссара по информации, Investigations [Электронный ресурс]. Режим доступа: http://www.oic-ci.gc.ca/eng/rapport-annuel-annual-report_2014-2015_3.aspx (дата обращения: 10.04.2016).

12. Alasdair Roberts. Two challenges in administration of the access to information act [Электронный ресурс]. Режим доступа: http://www.humanrightsinitiative.org/programs/ai/rti/interna tional/laws_papers/canada/al_roberts_ submission_to_go mery.pdf (дата обращения: 10.04.2016).

13. Конституция РФ (принята всенародным голосованием 12.12.1993) [Электронный ресурс]. Режим доступа: http://www.constitution.ru/10003000/10003000-4.htm (дата обращения: 11.04.2016).

14. Федеральный закон от 27.07.2006 N 149-Ф3 "Об информации, информационных технологиях и о защите информации" [Электронный ресурс]. Режим доступа: https://www.consultant.ru/document/ cons_doc_LAW_61798/ (дата обращения: 11.04.2016).

15. Федеральный закон от 22.12.2008 N 262-Ф3 "Об обеспечении доступа к информации о деятельности судов в Российской Федерации" [Электронный ресурс]. Режим доступа: https://www.consultant.ru/document/ cons_doc_LAW_82839/(дата обращения: 11.04.2016).

16. Федеральный закон от 09.02.2009 N 8-Ф3 "Об обеспечении доступа к информации о деятельности государственных органов и органов местного самоуправления" [Электронный ресурс]. Режим доступа: https://www.consultant.ru/document/cons_doc_LAW_84602/(дата обращения: 11.04.2016).

\section{The Perfection of Financial Transfer Payment System in the Perspective of The Equalization of Basic Public Service}

\author{
(C) Wang $\boldsymbol{R u}$ \\ Graduate student, School of Law, \\ Changchun University of Science and Technology \\ (C) Guan Fengrong \\ Professor, School of Law, \\ Changchun University of Science and Technology
}

China, Changchun

Fairness and justice is the eternal pursuit of human society. In the process of China's social and economic development, due to various factors, uneven economic development issues stands out, different levels of regional economic development highlight gaps between urban and rural areas, among regions and groups and the imbalance of the quality of basic public services. A citizen has the right to enjoy equal public services in his own country; especially in a socialist state like China, people's desire for equal access to public services is more prominent. To promote the equalization of basic public services, funding is the basis and the equalization of financial strength also becomes a must. The fiscal transfer payment system has become an important measure to gradually reduce regional differences in financial resources across the country .

\section{The Current Situation of Fiscal Transfer Payment System}

1. The Reality of Fiscal Transfer Payment System

The financial transfer payment system is an effective means to achieve the equalization of financial strength and enhance the financial capacity of the financially deficient areas. It has been set up since 1994. To date, this system has made great progress and its running are growing more and more standardized and perfect, further narrowing the gap of financial resources among different regions of China, meeting the different needs of the masses for basic public services and having received public recognition and support. At the present stage, China's fiscal transfer payment system includes three parts: institutional transfer pay- 
ments, financial transfer payments and special transfer payment. In recent years, the central government has increased financial support for local areas, and the proportion of local financial transfer payments among different regions is also gradually increasing, more and more narrowing the gap of financial resources between them, and the effect of financial transfers is increasingly apparent.

\section{The Inadequacy of China's Financial Transfer Payment System}

A. Legislation

We lack legislation on financial transfer payment system. Most of the existing legislative documents are normative, lower-level legislation lack of effectiveness, without clear rules on the specific rights and obligations of the related subject. Such legislation lags far behind actual needs, and can not provide a clear and comprehensive financial legal basis for the smooth operation of the fiscal transfer payment systems. China's current financial transfer payment system is legally based on "The Budget Law of the People's Republic of China " (hereinafter referred to as "Budget Law") and the "tax revenue sharing reform program" promulgated by the State Council in 2001.These two normative documents are not the specialized law on financial transfer payment, at best only the legal recognition of financial transfer payment. The amendment to the "Budget Law" passed on August 31, 2014 makes a more comprehensive revision and clearly defines the obligation of financial transfer payment and also implies obligations of financial transfer payment on basic medical service, but the specific operational methods should be stipulated by the State Council. Apparently, even the new "Budget Law" can not show the full view of the financial transfer payment.

B. The authority of office of the Local government does not match their financial authority

The 1994 reform of the system of tax distribution is in a way the readjustment of the intergovernmental powers of office and finance, but this adjustment has not been established in the Constitution and relevant laws. Thus, public affairs have not been clearly divided between the central and local governments, such phenomena as "dislocation", "offside" and "absence" coexist in government action at all levels. Financial transfer payment system is established to compensate for covering financial power so as to overcome vulnerabilities of the powers of office, and thus the existence of fiscal transfer payment and the determination of specific amount of funds are based on the degree of match between the powers of office and finance.

C. The lack of a relief mechanism for financial transfer payment

Under the background of the rule of law, the operation of a system should be in the track of the rule of law, and in order to truly guarantee the realization of rights we must provide perfect relief channels for various rights. In the operation process of financial transfer payment, when both the central government and local governments participate in it, there will be inevitably various conflicts and disputes. How to resolve these disputes will be a problem we have to face. It's clearly not enough to rely solely on tough administrative measures, therefore the drawbacks of a lack of right relief mechanism becomes apparent.

D. The lack of mechanisms of supervision and control

As financial transfer payment is closely related to the allocation and transfer of funds, there may be various kinds of corruption and other illegal activities involved, so supervision and control mechanisms are important and indispensable means to insure the smooth operation of the whole system and avoid black-box operation and the damage to national interests and the interests of the general public. But on the one hand, because of the lower legislative level, the requirements and restraints to the supervision subject are inadequate and supervision plays a limited role; on the other hand the single mechanism of supervision and the lack of external oversight powers to intervene, the effectiveness of supervision is impaired.

Reflection on the Perfection of Financial Transfer Payment Law System under the Perspective of the Equalization of Basic Public Services

\section{Improvement of Legislation}

First, the fiscal transfer payment system should be explicitly stipulated in the constitution--the fundamental law of a country. Some foreign countries have set good examples for us, which are worth our reference. Constitution articles can justify this system so that it can be enriched and improved in the framework of the Constitution. In addition, to raise the fiscal transfer payment legislation in the legal hierarchy, we need to formulate a comprehensive "financial transfer payment law"; thus, in the form of specific legislation we can make specific and clear requirements for the system, enhance its maneuverability, so that this system can be run in the track of the rule of law, and help achieve the objective of the equalization of basic public services.

\section{The Rational Division and Strict Implementation of Financial Powers and Powers of Office}

Affected by various factors, the current division of powers between the upper and lower levels of government expenditure BOUNDARY generous," many of the expenditure shall be borne by the central government fell on the shoulders of local governments, not central to its commitment financial ability to adapt to fiscal spending and transfer payments obligations. In the new rural cooperative for example, the proportion of rural population according to the 2009 National Midwest and subsidies of 80 yuan per person, the central financial burden of $62.5 \%$ of the required funds, calculate the required burden of 41.65 billion yuan the central government, local governments the burden of 24.99 billion yuan. "However, according to relevant statistics, in 2009 the central fiscal expenditure in NCMS safeguards only 19.8 billion yuan. Therefore, we must expand the central government payment obligations, the central and local powers and financial authority to substantially match.

\section{The Perfection of Relief System of Transfer Payment}

If there is conflict and controversy during the property transfer process, it is necessary to resolve the dispute by running relief mechanisms to ensure the realization of the legitimate rights and interests of all parties involved, make certain that financial transfer payment won't be shelved because of the emergence of any dispute, lest it ultimately affects the realization of the goal of the equalization of basic public services. Combined with China's reality, it can be 
permitted that a provincial government in our country realize right relief by dissenting declaration. If, in all aspects of financial transfer payment any dispute arises, the provincial government can conduct right relief by presenting a statement of objection to the Finance Payment Committee, so as to ensure the fairness of the financial transfer payment itself, which should be truly beneficial to the realization of the equalization of basic public services.

\section{The Perfection of the Supervision Mechanism of Financial Transfer Payment}

To further improve the supervision mechanism of financial transfer payment, we need to broaden the scope of the supervisors, and receive supervision from the legislative body and also the internal supervision of the executive authorities and the judicial organs, societal forces should also be included in the supervision work.

The 2012 Balanced Transfer Payments Approach from Central to local governments didn't give out any specific regulatory measures in the management and supervision of transfer payment funds, let alone refer to the supervision authority of People's Congress. Financial transfer payment being closely related to not only the rational use of financial resources, but also the realization of civil rights, is a major issue concerning people's livelihood and must be brought under the supervision of the legislative body. The supervision of the legislative body for financial transfer payment mainly embodied in the budget review beforehand, investigation and inquiry in the process, and the examination of the report afterwards and so on.

While we emphasize the supervision of the legislative body over the financial transfer payment of the administrative body, we must also lay emphasis on the internal check and supervision of the executive body. The internal supervision of the executive authorities are mainly reflected in the supervisory departments and audit departments monitoring allocation and usage of fund in the financial transfer payment, and ensuring the funds be put in place. In countries where the transfer payment system is relatively complete, a special organization is set up to guarantee the effective operation of transfer payments; similarly, in our country, we can also set up a specialized supervision bureau of financial transfer payment based on the actual situation. Attached to the National People's Congress, it can strengthen the supervision of the procedure of the use of funds in financial transfer payment at all levels.

Starting from the same purpose, various supervision subjects combined to execute the same functions of supervision, reduce the risk of fraudulent and illegal actions in the fiscal transfer payment system; in the meantime it is conducive to the formation of normative regulations and restraint to governments at all levels, making this system play a better role. It is necessary to set up a special department responsible for the management of funds to help realize a smooth and efficient operation of the fiscal transfer system.

\section{Literature}

1.Kou Tiejun,"Legal Arrangements about the Intergovernmental Division of Powers of Office and Finance. - Experiences of UK, USA, Japan and Germany and Their Implicationsto China. Legal Research,2006 (5).

2.Li Hongxia, Rational Thinking on China's Reform of Fiscal Transfer Payment System. Modern Finance,2008 (4).

3.Sun Kai, Situation Investigation on the status quo of special transfer payment and the optimization of its management style . Finance Research,2010 (8).

4.Feng Mei, China's Legal System of Financial Transfer Payment: Status Quo, Problems and Solutions. Finance \& Taxation Review,2011 (9).

5.Sun Jianfu, China's Legal System of Fiscal Transfer Payment: Practical Progress \& Theoretical Reflection. Theory,2012 (1). 


\title{
II. МЕЖДУНАРОДНОЕ ПРАВО И МЕЖДУНАРОДНЫЕ ОТНОШЕНИЯ
}

\author{
Военно-техническое сотрудничество России и Китая
}

(С) В. А. Алексеева

студентка 2-го курса юридического факультета ФГБОУ ВО «Бурятский госуниверситет»

Россия, г. Улан-Удэ

valentina09158@yandex.ru

\begin{abstract}
В период конца XX в. - начала XXI в. произошли серьезные перемены в мировом сообществе. Распад СССР и образование новых государств привели к возникновению новых отношений в Азиатско-тихоокеанском регионе, в первую очередь между Россией и Китаем. АТР является важнейшим регионом внешнеполитических и экономических интересов РФ, а военно-техническое сотрудничество с этими странами становится одним из средств достижения этих целей. Китай является одним из наиболее широких рынков вооружения в мире и для российского оборонно-промышленного комплекса расширение военно-технического сотрудничества с Китаем дает возможность развиваться, продолжая инвестировать в научно-исследовательские и опытно-конструктор-
\end{abstract} ские работы по созданию новых образцов вооружения и военной техники.

ВТС России и Китая имеет давнюю историю. Военные связи СССР и КНР были установлены еще в 1949 г., но в 1969 г., из-за ухудшения советско-китайских отношений, были приостановлены. За данный период Китаю было поставлено вооружения и военной техники на общую сумму около 4,1 миллиарда долларов, и было передано безвозмездно около 650 лицензий на производство военной техники и вооружения. Советские специалисты помогали китайским военным осваивать эту технику: в 1949-1969 гг. в КНР было командировано около пяти тысяч военных советников и специалистов, а в вузах Минобороны СССР подготовлено полторы тысячи китайских военнослужащих.

После многолетнего перерыва ВТС между Россией и Китаем возобновилось только в 1990 г. Одним из первых шагов по налаживания российско-китайского ВТС стало подписание 24 ноября 1992 г. Межправительственного Соглашения о ВТС. В соответствии с данным Соглашением была образована российско-китайская комиссия по ВТС, которая собирается один раз в год поочередно в Москве и Пекине [2].

11 ноября 1993 г. было подписано Соглашение о военном сотрудничестве между министерствами обороны России и Китая, направленное на развитие мира и безопасности в Азиатско-Тихоокеанском регионе и включавшее, как само ВТС, так и обмен опытом и информацией, торговлю вооружениями, сотрудничество в области связи, военно-медицинской сфере и т.д. 27 июня1997 г. был разработан механизм регулярных встреч глав правительств РФ и КНР, который был сформирован с целью координации действий со стороны Москвы и Пекина в торговой, военной, научно-технической, экономической и энергетической сферах [2]

Еще одним важным этапом в формирование нормативно-правовой базы российско-китайских связей стало подписание 16 июля 2001 г. в Москве президентом РФ и председателем КНР Договора о добрососедстве, дружбе и сотрудничестве, который охватывает все основные сферы и направления двустороннего сотрудничества и заключен на 20 лет с возможностью автоматического продления на следующие пятилетние периоды.

В соответствии с данным договором Россия и Китай обязались на долгосрочной основе развивать равноправное партнерство и стратегическое взаимодействие, в том числе и в военной сфере (статьи 7, 16 Договора). В случае возникновения угрозы миру или угрозы агрессии Москва и Пекин незамедлительно вступают в контакт и проводят консультации в целях устранения возникшей угрозы (статья 9 Договора). Договор также предусматривает совместные усилия сторон по поддержанию глобального стратегического баланса и координацию действий на международной арене в предотвращении и урегулировании конфликтов (статья 12) [1].

Необходимо отметить, что наиболее плодотворно ВТС с КНР развивалось в период с 1992 по 2004 г. За этот период Россией было поставлено Китаю большое количество боевой техники и вооружения. В их числе более ста боевых самолетов и вертолетов различных типов[6]. В 2009-2010 гг. Россия экспортировала в Китай 43 двигателя РД-93, а в 2014 г. заключила контракт на поставку до конца 2016 г. следующих 100 двигателей РД-93, их техническое обслуживание и ремонт. В 2010 г. Россия выполнила контракт на поставку Китаю 15 дивизионов зенитных ракетных систем [5]. В 2011 г. российская военно-промышленная компания направила в КНР 25 машинокомплектов бронеавтомобиля "Тигр" для сборки на территории этой страны, затем Китай получил еще 25 "Тигров" и заключил контракт на поставку еще 10 машин. В 2012 г. Пекин и Москва подписали крупный контракт на поставку 140 авиадвигателей АЛ-31Ф. По оценке "Рособоронэкспорта", в 2012 г. авиадвигатели составляли около 90\% российского экспорта в Китай. В марте 2013 года Россия и Китай подписали соглашение о поставке 24 самолетов и четырех подводных лодок. По оценкам китайской стороны, в будущем КНР и Россия 
могут расширить взаимодействие в области поставок вооружения, в частности, речь может идти о закупке Китаем российских зенитных установок, тяжелых двигателей, транспортного самолета Ил-76 и самолета-заправщика Ил-78. В сентябре 2014 г. был заключен контракт на приобретение шести дивизионов зенитных ракетных комплексов большой дальности С-400 "Триумф" на сумму более 3 млрд. долларов[5].

На заседании российско-китайской межправительственной комиссии, которая проходила 27-28 апреля 2015 г. в Ханчжоу, с участием компании «Вертолеты России» были проведены переговоры с китайской корпорацией AVIC о проекте по совместной разработки тяжелого гражданского вертолета.

19 ноября 2015 г. государственная корпорация "Ростех" объявила о заключении контракта на поставку в Китай 24-х истребителей Су-35. КНР стал первым иностранным покупателем этих самолетов.

В настоящее время и республика Бурятия экспортирует в Китай продукцию военно-технического назначения. Основными среди таких предприятий являются ОАО "Улан-Удэнский авиационный завод" - 31,7\% от всего объема экспорта (на 2013 год) и АО "ВИК" (Вертолетная инновационно-промышленная компания), в структуру которого входят ЗАО «Улан-Удэнский лопастной завод»; ОАО «Улан-Удэнский авиаремонтный завод»; ООО «Предприятие «Аэротех»; ООО «Электромашина», - 3,2\%. В основном, экспортируют летательные аппараты и запасные части к ним.

Следует подчеркнуть, что ВТС между Китаем и РФ развивается по многим направлениям, включая подготовку китайских военных специалистов: в российских вузах обучаются военнослужащие Китая, проходят обучение экипажи подводных лодок и надводных кораблей, а также летчики и расчеты противовоздушной обороны, также расширяется обмен военными делегациями, взаимными визитами боевых кораблей. Свидетельством укрепляющихся связей по военной линии являются проводимые на регулярной основе совместные учения, к примеру, в 2014 - антитеррористическое учение стран ШОС "Мирная миссия - 2014" на полигоне "Чжужихэ" в Китае, а в2015 г. прошло совместное российско-китайских военное учение "Морское взаимодействие 2015" в акватории Японского моря и Южном Приморье России (11-21 мая; 21-28 августа).

Таким образом, исходя из истории ВТС России и Китая, а также анализа текстов документов, можно выделить основные направления ВТС: проведение военно-технических консультаций; обучение и подготовка кадров; обмен опытом и совместное проведение военно-научных исследований; совместные НИОКР (Научно-исследовательские и опытно-конструкторские разработки); закупка ограниченных партий самых последних российских военных разработок; ремонт и модернизация ранее поставленных вооружений.

По мнению российских военных экспертов, наибольший интерес для Китая представляют российские авиационные двигатели, программное обеспечение для авиационных комплексов, композитные материалы для авиастроения, боевые комплексы и оборудование для авианосного флота, морская истребительная и бомбардировочная авиация. Со своей стороны Китай может предложить России газовые турбины для фрегатов, которые в связи с разрывом военного сотрудничества отказалась поставлять Украина, и Китай начал их выпуск по украинской лицензии.

Характеризуя военно-техническое сотрудничество России и Китая, можно выделить следующие сильные стороны:

Во-первых, взаимодействие государств в военной и в военно-технической сфере приводит к укреплению взаимного доверия друг к другу;

во-вторых, военно-техническое сотрудничество России и Китая является важным компонентом стратегического партнерства обоих государств; оно институционально оформлено, имеет под собой прочную договорноправовую базу, каналы взаимодействия и диалога;

в-третьих, военно-техническое партнерство приводит Россию и Китай к налаживанию взаимосвязей по вопросам глобальной и региональной безопасности;

в-четвертых, наблюдается заинтересованность России и Китая по экономическим (доходы по контракту, модернизация военно-промышленного комплекса) и политическим (укрепление взаимного доверия и стратегического партнерства) целям в военно-техническом сотрудничестве друг с другом;

и, наконец, в-пятых, российско-китайское ВТС кроме поставок и разработок вооружения, включает в себя налаживание взаимодействия в области связи, проведение совместных учений, сотрудничество в военно-медицинской области и т.д.

Каковы негативные последствия, с которыми сталкиваются Россия и Китай? Для России речь идет о перспективе сокращения объема китайских военных заказов, о несоблюдении Китаем условий при передаче российских лицензий, о конкуренции с китайским военно-промышленным комплексом на мировых рынках оружия. К негативным последствиям военного сотрудничества также следует отнести тот факт, что Китай стал заметным конкурентом России на рынках вооружений. Наращивание военного потенциала Китая в перспективе может составить угрозу безопасности России с учетом существующих противоречий и тенденций социальнополитического развития самой России в Сибири и на Дальнем Востоке. А негатив для Китая проявляется в том, что это в основном вопрос о поставке новейших технологий и новейших образцов оружия и слишком высокая зависимость от военного импорта, которые препятствуют достижению полной независимости Китая в данной сфере и реализации стратегических планов.

Одной из основных проблем можно выделить угрозу копирования российских образцов вооружения, производство китайского аналога и перепродажа его на мировом рынке вооружения, уменьшение доли российского экспорта вооружений в Китай, угроза смещения баланса сил с военно-технической точки зрения в сторону Китая [7]. Необходимо отметить, что с нарушением прав интеллектуальной собственности сталкиваются практи- 
чески все государства, имеющие какие-либо партнерские отношения с Китаем. Самым ярким примером является китайский истребитель J-11, который является копией российского истребителя Су-27. На этом фоне проходили различные дискуссии о целесообразности продажи Китаю новых российских истребителей поколения 4++ Су-35 [4]. Другим примером является 155-мм CAУ PLZ-05 (копия российской артиллерийской системы «Мста-С»). Однако это не является причиной, по которой стоило бы отказываться от огромного и перспективного китайского рынка.

Таким образом, военно-техническое сотрудничество России и Китая являются важной частью российскокитайских отношений, так как Китай является крупным покупателем российского оружия. ВТС России и КНР имеет под собой прочную, зафиксированную юридически обоими государствами, договорно-правовую базу. Оно является неотъемлемой составляющей военного и, таким образом, стратегического взаимодействия двух государств. История взаимоотношений в военно-технической сфере России и Китая берет своё начало в 1949 году, и не прекращается по сей день. Основными направлениями сотрудничества являются обучение и подготовка кадров, обмен опытом и информацией, совместные НИОКР.

Военно-техническое сотрудничество является перспективным как для России, так и для Китая, так как реализации заключаемых договоров приведут к дальнейшему развитию сотрудничества в данной сфере.

Наибольший интерес для Китая представляют российские авиационные двигатели, программное обеспечение для авиационных комплексов, композитные материалы для авиастроения, боевые комплексы и оборудование для авианосного флота, морская истребительная и бомбардировочная авиация.

У ВТС России и Китая имеются как положительные, так и отрицательные последствия, но, несмотря на это, военно-техническое сотрудничество помогает улучшать двусторонние отношения.

\section{Литература}

1. Договор о добрососедстве, дружбе и сотрудничестве между РФ и КНР.16июля 2001г. // URL:

http://chinalawinfo.ru/agreements/prc_rus_treaty_of_friendship (дата обращения 20.03.2016)

2. Распоряжение Правительства РФ от 11 октября 1993 г. № 1820-р о «Соглашении между Министерством обороны Российской Федерации и Министерством обороны Китая о военном сотрудничестве» // [Электронный ресурс]. Режим доступа: http://base.consultant.ru/cons/cgi/online.cgi?req=doc;base=EXP;n=226820

3. О заседании Российско-Китайской смешанной межправительственной комиссии по военно-техническому сотрудничеству // Пресс релиз официального сайта Федеральной службы по военно-техническому сотрудничеству России с иностранными государствами // [Электронный ресурс]. Режим доступа: http://www.fsvts.gov.ru/materials/2117AA634BB646F 343257DCD0029C366.html

4. Информация информационного агентства «РИА-Новости» от 02.04.2010

5. Информация информационного агентства «РИА-Новости» от 25.03.2013

6. Клименко А.Ф. Военно-стратегическое партнерство России и Китая. Проблемы безопасности в регионе СВА // Общественный политический журнал «СИАА» // [Электронный ресурс]. Режим доступа: http://www.siaa.ru/?pg=2\&id=152905\&type $=3 \&$ page $=0 \&$ hd $=$

7. Мухаметов Р. С. Проблемы российско-китайских отношений на современном этапе // Известия Уральского федерального университета. Общественные науки. 2012. № 3. С. 39-46.

\section{Сравнительная характеристика публичной дипломатии США и России}

(C) Ц. Б. Бальжинимаева студентка 4-го курса юридического факультета ФГБОУ ВО «Бурятский госуниверситет»

Россия, г. Улан-Удэ semisvetic95@gmail.com

Политические решения в процессе глобализации все больше учитывают не только реальные факты, но и субъективные представления и образы. Имидж государства и его восприятие на международной арене приобретает особую роль, а создание имиджа становится главным направлением государственной политики. При стремительном развитии технологий идет активный обмен информации и создает возможность активного и быстрого внедрения в массовое сознание стереотипов, ценностей и мифов с целью как дезориентации населения, так и формирования у него нужных восприятий.

Впервые в истории понятие "публичная дипломатия" был употреблен в докладе Комиссии Мэрфи по организации внешнеполитического аппарата в 1977г., а до этот термин упоминался в законодательном органе США как "культурная дипломатия". Некоторые исследователи трактуют понятие публичной дипломатии как «стратегическое политическое общение». Если рассматривать со стороны программ публичной дипломатии, то их определяют как «официальные государственные усилия, направленные на формирование информационной среды за рубежом, в которой проводится внешняя политика с целью уменьшения неправильного понимания сложных межгосударственных отношений». В США под публичной дипломатией понимают как «финансируемые правительством программы, направленные на информирование и влияние на граждан зарубежных стран через публикации и обменов в области культуры, кинопродукции, телевидения и радиовещания» [2, с.53]. Согласно официальной формулировке, «публичная дипломатия» - это «действия правительства США, которые способствуют культивации поддержки национальных интересов» [3]. 
В данной статье, под публичной дипломатией понимаются программы, реализуемые при государственной поддержке, направленные на позитивное формирование общественного мнения за рубежом и повышения имиджа страны, главными из которых являются информационные проекты в электронных и печатных средств массовых информаций в области науки, культуры и образования, повышения охраны окружающей среды и экономичекого развития.

Если говорить о структуре публичной дипломатии, то с июня 2015 г. в США была выпушена новая стратегия публичной дипломатии. В нем было обозначено распространение негативной информации «Исламского государства» (ИГИЛ) целевой аудитории, которая может оказаться под их информационным влиянием [1]. Новая стратегия перестала апеллировать с политикой распространения американских ценностей.

Со стороны России отсутствует стратегия публичной дипломатии, но существует Концепция внешней политики. Где появилось первое упоминание о публичной дипломатии только в 2008 г., и в 2010 году была дополнена Приложением 1, в котором были изложены главные направления гуманитарного и культурного международного сотрудничества. В этом документе говорилось, что неправительственные организации и бизнес должны заниматься развитием публичной дипломатии, но не описано каким способом.

Сейчас в России нет государственного органа, который мог бы управлять систематически публичной дипломатией. Существует только Министерство иностранных дел, Общественная палата, Министерство регионального развития, Россотрудничество, «РИА Новости», «Russia Today» и т. д., но нет механизма их регулирования. Так, управление общественной дипломатией в России происходит на уровне высшего руководства страны, и непосредственные распоряжения отдаются руководством пресс-службы первых лиц государства. Несмотря на некоторые достоинства у такой структуры имеются и очевидные недостатки: во-первых, в силу количества обязанностей занимающим эти должности на ежедневной основе сложно руководить публичной дипломатией систематически. Во-вторых, вся организация носит строго вертикальный характер, что осложняет проявление инициативы снизу и затрудняет горизонтальную кооперацию. Такая структура не отвечает требованиям координации системы публичной дипломатии на постоянной основе. Хотя некоторые элементы этой системы и имеют существенный опыт сотрудничества между собой (например, Министерство иностранных дел и Россотрудничество).

В отличии от России, у США хорошо разработана структура публичной дипломатии и четко распределены полномочия между ее участниками. Основными акторами является государственный департамент, роль которого прописана очень четко, наряду с программами и методами публичной дипломатии, которые предписано ему использовать. Президенту США отводится немаловажная роль в участии публичной дипломатии. Так же с государственными учреждениями, в публичной дипломатии США могут принимать участие и частные акторы, причем использование данного ресурса правительством одобряется законодательством. Среди методов публичной дипломатии, используемых в США, можно отметить культурные и образовательные обмены, которым уделяется важное место в законодательной базе США, что накладывает свой отпечаток на практическое применение публичной дипломатии институтами данного государства. Кроме того, необходимость использования информационных и аналитических методов публичной дипломатии прописана в законодательстве США. Таким образом, стратегия использования публичной дипломатии как инструмента внешней политики США проработана на высоком уровне и включает в себя использование всех известных методов и традиционных институтов.

Если рассматривать со стороны финансирования, то бюджеты, которыми распоряжается американский госдеп по направлению Public Diplomacy или Американское Агентство по международному развитию (USAID) по сравнению в Россией на развитие данного направления, ничтожно мала. Но в последнее время и Российское государство больше внимания начало уделять этому вопросу, увеличился бюджет Россотрудничества. Создали несколько фондов, которые выделяют гранты российским НКО на деятельность по направлению публичной дипломатии. Выделяются через систему крупных фондов-распределителей президентские гранты на подобные проекты некоммерческих структур.

Необходимо признать, что не все государства владеют столь сильным аппаратом публичной дипломатии как в США, сложно найти страну, которое бы не осознавало бы значимость и необходимость данного направления во внешнеполитической деятельности для достижения национальных интересов. На данный момент, в Российской Федерации предпринимаются определенные меры в сфере публичной дипломатии. И для эффективной реализации публичной дипломатии было бы целесообразно по примеру США назначить ведомство или должностное лицо, которое координировало бы ее на общегосударственном уровне. К примеру, можно было бы ввести должность заместителя министра иностранных дел по публичной дипломатии, либо же передать соответствующие полномочия Россотрудничеству.

\section{Литература}

1. A Strategy for Countering Terrorist Propaganda in the Digital Age // Department of State. URL: http://www.state.gov/r/cscc/releases/243877.htm (дата обращения: 13.04.2016)

2. Emmerson D.K. Americanizing Asia / D.K. Emmerson// Foreign Affairs.-May/June. 1998. № 77. P. 53.

3. Nye J.S. Jr., Owens W.A. America's Information Edge/ J.S. Nye Jr., W.A. Owens// Foreign Affairs. 1996. Mar/Apr. 


\title{
Институт права частной собственности в Риме в доклассический и классический периоды
}

\author{
(C) М. М. Варнакова \\ магистрант 2 года обучения юридического института \\ ФГБОУ ВО «Иркутский госуниверситет» \\ Россия, г. Иркутск \\ marmi07@mail.ru
}

На протяжении всей общественной истории практически не возможно найти другой системы частного права, которая достигла такой детализации и такого высокого уровня юридической формы и юридической техники, как римское частное право. Существовали два правовых института: институт индивидуальной частной собственности и институт договора [1, с. 38]. Они имели в Риме хорошо проработанную систему, которая имела очень важное значение для хозяйства. Право римской частной собственности можно отнести к числу самых интересных историко-правовых объектов. Научная характеристика этого права требует дальнейшего изучения. Вообще, в литературных источниках право римской частной собственности можно сравнить с позднейшим правом буржуазных государств Западной Европы. Этот образ не может быть точно идентифицирован с точки зрения метода. Высшее значение рабовладения в Древнем Риме привело к возникновению института собственности. Частная собственность стала основной, а объектом явились рабы. Гораздо позднее появилось право частной собственности на землю.

Для свободного населения римское частное право дает возможность самовыражения, большей свободы правового самоопределения. Частное право стоит на фундаменте единоличного субъекта собственности, который вправе отвечать за свои действия. В римском частном праве принят индивидуализм домохозяина, рабовладельца, который ведет свое хозяйство и взаимодействует на рынке с другими такими же хозяевами. Такое распределение сочеталось в Риме с формой выражения юридических норм. Ясность формулировок, аргументация, конкретность и практичность права, полное соответствие всех юридических форм интересам господствующего класса - все это отличает частное римское право. Поэтому многие римские юридические выражения и формулы стали афоризмами.

По способам фиксирования и выражения юридических норм, римское частное право в корне отличается от общепринятых систем частного (гражданского) права многих государств. Римское частное право очень схоже с англо-американским общим правом, главным образом, по набору решений конкретных казусов.

Становление классического понятия права собственности [2, с. 8]. Доклассический период.

В условиях господства общинного и племенного землевладения институт частной собственности на землю был в стадии зарождения. Поэтому первоначально вместо права собственности на что-либо применялось право владения, которое регулировало вопросы пользования. При этом на владельца накладывался ряд ограничений в части распоряжения владеемой им вещью. Так, например, владелец не мог передавать её другому лицу, устанавливались определенные правила пользования, нарушив которые владелец мог быть лишен права владения и т.д.

Классический период.

В этот период времени происходит постепенная абсолютизация владения вещью, заключающаяся в трех основных моментах:

1. Право владения было значительно расширено, ограничения сняты.

2. Появляется возможность получать с владения хозяйственную выгоду.

3. Возникает институт неограниченного владения вещью с признаками абсолютного господства над ней (частная собственность).

В это же время возникает право частной собственности на земельные владения, связанное с переходом части общинных и государственных земель в личное пользование.

Результатом поражения движения Гракхов было принятие закона Спурия Тория (111 г. до н. э.), которым переделы земли общинно-государственной земли прекращались. Отныне земельные наделы становились полной частной собственностью их владельцев. Укреплению частной земельной собственности способствовало и перераспределение земель в ходе гражданских войн, в особенной степени наделение землей ветеранов. Однако более общее значение для утверждения частной собственности имело развитие преторской. Преторская собственность возникла и утвердилась в деятельности претора в связи с необходимостью регулировать развитие товарно-денежные отношения [3, с. 17].

Утверждение наиболее абсолютного права индивидуальной частной собственности проявлялось также в постепенном разложении семейной собственности.

Таким образом, частная собственность утверждается как единое, наиболее неограниченное, исключительное для данного лица правовое господство над вещью, как право, дающее всестороннюю возможность владеть, пользоваться и распоряжаться ею.

Наряду с правом частной собственности развивается, обогащается содержанием институт владения. Оно четко отграничивается от собственности с точки зрения способов и средств защиты.

Право частной собственности и другие вещные права в Риме энергично защищались как с помощью норм уголовного права, так и средствами гражданского права. 
В. А. Савельевым в его работе указано: «Сложность понимания римской частной собственности в значительной мере вытекает из малочисленности сохранившихся юридических текстов» [7, с. 137]. Результатом экономических преобразований стало приведение в соответствие с экономическим базисом ее юридической надстройки. С учетом данных о классическом периоде в древнем Риме, имеется настоятельная потребность в изучении вышеуказанного явления.

Имеются определенные противоречия между отечественными научными трудами историков и юристов с каноническими текстами римского права.

Римской юриспруденцией не было разработано «единого» и «абсолютного» права собственности, общеизвестного в интерпретации буржуазной юриспруденции.

Более того, в римском праве не существовало общей формулировки собственности, для каждого конкретного случая применялись свои специфические атрибуты. Рассмотрим наиболее распространенные из них.

1. Доминий.

Область его применения по первоисточникам:

- Субъект собственности в общем случае.

- При цивильной, преторской, ius gentum системах римского права.

- Определение законности, правоприменения относительно собственности.

- Способ владения кем-либо чем-либо.

- Статус имущества как объекта права.

- Виндикация связана с доминием.

Доминий являлся основной формой владения на законных основаниях, полученной официальным путем цивильной, преторской и т. д.

Часто доминий смешивают с понятием проприетас. Савельев указывает на то, что такой подход недопустим: «Оно существенно деформирует понимание соответствующих текстов римских юридических источников и не отражает выработанной римскими классическими юристами плюралистической концепции частной собственности» $[6$, с. 15$]$.

Упоминаемый в Дигестах доминий, применение проприетас в целом четко зафиксировано в следующих источниках: «Об узуфрукте»(VII) и «О предоставлении в качестве легата (фидеикомисса) пользование, узуфрукта» (XXXIII). Для раскрытия понятия проприетас следует проследить его основные черты в книгах:

- Проприетас является специфическим термином, возникновение которого связано с антагонизмом узуфрукту.

- Проприетас допускает совместное владение собственностью (два и более лица).

- $\quad$ Тот, у кого есть проприетас, зачастую не в состоянии пользоваться вещью, а может лишь владеть ею, в отличие от узуфруктария.

- Проприетас не устанавливает и не может быть источником устранения сервитутов.

- В праве проприетас часто используется в переносном значении, не имеющем реальной силы.

- Весьма часто используемым для установления проприетас является отказ.

- Виндикация не может быть применена к проприетас.

Приобретение и прекращение права собственности в Древнем Риме.

Первоначально в Древнем Риме для фиксирования юридического факта собственности применялась так называемая «оккупация», т. е. «право наложения руки», заключающееся в свободном присвоении какой-либо вещи, для чего достаточно было объявить себя ее владельцем [4]. При этом существовал ряд ограничений: вещь должна была находиться без хозяина, права собственности на данную вещь не закреплены никем более. В случае перехода собственности от одного хозяина к другому существовал принцип «не имей больше прав, чем было до тебя».

Основной формой прекращения права собственности являлся простой отказ от владения в пользу кого-либо или чего-либо, судебное принуждение к отказу от собственности [5, с. 21].

Вывод. С течением времени происходит трансформация и дальнейшее совершенствование института собственности в виду изменяющихся общественно-экономических отношений.

\section{Литература}

1. Коренев Р. С. Римское право: практикум. М., 2003

2. Никитин А. М. Римское право в схемах и определениях: учеб. пособие для вузов. М.,2004.

3.Новицкий И. Б. Римское частное право: учеб. пособие для вузов. М.: ТЕИС, 2002. 245 с.

4. Покровский И. А. История римского права. Классика российской цивилистики [Электронный ресурс] / Консультант Плюс: комп. справ.правовая система [Электронный ресурс] / Компания "Консультант Плюс". URL: http://www.consultant.ru/popular/obob/ (дата обращения: 20.03.2016).

5.Римское право: учебник для вузов / под ред. С. М. Сафронова. М., 2003. 164 с.

6.Римское право: учебник для вузов / под ред. С. М. Мерецкова. М., 2003. 93 с.

7.Савельев В. А. Право собственности в римской классической юриспруденции: учеб. пособие для вузов. М., 2005.719 с. 


\title{
Азиатская и Европейская конвенции по правам человека: сравнительно-правовой анализ
}

\author{
() Г. С. Галецкая \\ студентка 4-го курса юридического факультета \\ ФГБОУ ВО «Бурятский госуниверситет» \\ Россия, г. Улан-Удэ \\ Galetskaya94@mail.ru
}

Права человека всегда являлись, и будут являться основополагающей и неотъемлемой прерогативой для людей всех наций и национальностей. В каждой стране существует ряд нормативно-правовых актов по защите прав и свобод своих граждан. На международном уровне существует множество конвенции по защите прав человека, а так же отдельные судебные органы, осуществляющие правосудие на основании одной из конвенций. В данном случае, государству, как «представителю» своего народа стоит лишь сделать выбор о том, какая именно конвенция по правам человека будет служить источником прав и свобод для своих граждан

С учетом современной политической обстановки в мире, Россия все чаще выбирает направление на восток не только в политэкономическом, но и в юридическом плане. Недавно, в публичном пространстве обсуждалась, актуальная тема создания Азиатского суда по правам человека, который действовал бы по аналогии с Европейским судом. Данная идея возникла, в связи с вынесенными решениями Европейского суда, которыми уже давно недовольны российские власти. Председатель Конституционного суда РФ Валерий Зорькин уже поддержал инициативу. "Россия не только европейская, но и евразийская страна", - пояснил он. [4, с.10] Однако, представители профессионального юридического сообщества, после долгих дискуссий, так и не пришли к единому мнению по данному вопросу. Оставление данного вопроса открытым позволит более детально понять деятельность данных судов, какую сферу они регулируют, а так же, на основе каких нормативно- правовых актов они действуют, то есть что для защиты прав человека в России является наиболее приоритетнее: Европейская конвенция о защите прав человека и основных свобод 1950 года или Декларация АСЕАН по правам человека 2012 года.

Европейская конвенция о защите прав человека и основных свобод (Европейская конвенция) была принята в Риме 4 ноября 1950 года. Государства, которые подписали данную Конвенцию, являлись членами Совета Европы. При создании Европейской конвенции была взята за основу Всеобщая декларация прав человека, принятая Генеральной Ассамблеей Организации Объединенных Наций 10 декабря 1948 года. Основной целью ЕКПЧ является обеспечение всеобщего и эффективного признания и осуществления провозглашенных в ней прав.

Декларация АCЕАН по правам человека (Азиатская конвенция) была принята в Пномпень, Камбоджа 18 ноября 2012 года. Главы правительств, ратифицировавшие данную декларацию, являются участниками Ассоциации государств Юго-Восточной Азии (АСЕАН). Для создания Азиатской конвенции за основу были взяты такие нормативно-правовые акты, как: Хартия АСЕАН, Всеобщая Декларация Прав Человека, Хартия ООН, Венская Декларация и Программы Действий и другие международные соглашения о правах человека, которые ратифицировали страны-участницы АСЕАН, создающие эту декларацию. Кроме того, для подтверждения значимости усилий АСЕАН в поддержании прав человека, была включена Декларация об улучшении положения женщин в регионе АCEAН и Декларация о прекращении насилия против женщин в регионе АCEAН. Основной целью АКПЧ является создание базы для сотрудничества в Азиатском регионе в сфере защиты прав человека, при этом увеличивая темп процесса построения сообщества АСЕАН.

По структуре Европейская конвенция состоит из преамбулы, 3 глав и 59 статей. В преамбуле говорится, когда и где была принята конвенция; кто является ее создателем; на основе чего она была создана, а так же указываются цели и задачи ее принятия.

Первый раздел посвящен «правам и свободам» человека. Он состоит из 18 статей, в которых закреплены такие права, как: право на жизнь; запрещение пыток; запрещение рабства и принудительного труда; право на свободу и личную неприкосновенность; право на справедливое судебное разбирательство; назначение наказания исключительно на основании закона; право на уважение частной и семейной жизни; свобода мысли, совести и религии; свобода выражения мнения; свобода собраний и объединений; право на вступление в брак; право на эффективное средство правовой защиты; запрещение дискриминации; право отступления от соблюдения обязательств в чрезвычайных ситуациях; запрет на ограничение на политическую деятельность иностранцев; запрещение злоупотреблений правами; пределы использования ограничений в отношении прав, касаемо данной конвенции.

Второй раздел посвящен «Европейскому суду по правам человека». Он состоит из 22 статей (с 19 по 51 ст.). В них говорится о составе, структуре и компетенции суда; о решениях, которые он выносит; о порядке обращения и подаче жалобы, а так же иных положениях, которые касаются процессуальной части по защите нарушенных прав и свобод граждан. Хотелось бы отметить, что Европейский Суд по правам человека специально был создан для полной реализации и действия Конвенции, позволяя гражданам в судебном порядке восстановить свои нарушенные права. Это является значительным преимуществом Конвенции, поскольку при ее ратификации, пропадает необходимость в создании контролирующего органа для ее соблюдения. 
Третий раздел посвящен «различным положениям». Состоит из 7 статей (с 52 по 59 ст.), в которых оговаривается порядок ратификации данной конвенции, сфера ее действия, а так же различные оговорки. Кроме того, к конвенции прилагается 14 Протоколов, которые вносят некоторые поправки в ЕКПЧ, а так же дают более точную формулировку того или иного права, раскрывая сферу его действия.

Конвенция АСЕАН по правам человека состоит из преамбулы, 6 разделов и 40 статей. В преамбуле говорится, когда и где была принята конвенция; кто является ее создателем; на основе чего она была создана, а так же указываются цели и задачи ее принятия, кроме того, в ней сказано, что все нормативно- правовые акты, касающиеся прав человека, которые ратифицировали страны- участницы АСЕАН (создатели данной декларации), подтверждаются АКПЧ и были взяты за основу ее создания.

Первый раздел Азиатской декларации посвящен «общим принципам» прав и свобод человека. Состоит из 9 статей, в которых говорится о: свободе и равенстве людей; у наличии у каждого прав и свобод; о равенстве перед законом; о том, что права женщин, детей, пожилых людей, инвалидов, рабочих мигрантов, уязвимых и отделенных групп являются неотъемлемой и неделимой частью прав и основных свобод человека;

о праве на эффективное и обязательное судебное возмещение; о том, что реализация прав и основных свобод человека должна балансироваться с выполнением соответствующих обязанностей; все права человека являются всеобщими, неделимыми, взаимозависимыми и взаимосвязанными; права и основные свободы каждого человека должны реализовываться с учетом прав и основных свобод других людей; о необходимости в

соблюдение принципов беспристрастности, объективности, недискриминации, неконфронтации и избегания двойных стандартов.

Во втором разделе говорится о «гражданских и политических правах». Состоит из 15 статей (с 10 по 25 ст.), в которых перечислены такие права как: право на жизнь; на личную свободу и безопасность; запрет рабства; свободу передвижения; право на получение политического убежища; право на частную собственность; право на гражданство; право на создание семьи; право на презумпцию невиновности; неприкосновенность частной и семейной жизни; право на свободу мысли, сознания и религии; право на свободное мнение; право на собрания и митинги; право на участие в политической жизни страны, в том числе, право на участие в выборах.

Третий раздел посвящен «экономическим, социальным и культурным правам». Он состоит из 9 статей (с 26 по 34 ст.). В данных статьях говорится о том, что страны-члены АСЕАН подтверждают все экономические, социальные и культурные права Всеобщей Декларации Прав Человека. В том числе:

право на труд; право на достойный уровень жизни для себя и своей семьи;

право на пользование наивысшими достижимыми стандартами физического, умственного и репродуктивного здоровья; право на социальную безопасность; право на образование;

право отдельно или совместно с другими свободно участвовать в культурной жизни. Данные права не распространяются в полной мере на граждан государств, не являющихся участниками АСЕАН. Для пользования некоторыми правами, перечисленными в третьем разделе необходимо дополнительное разрешение того государства, на территории которого вы находитесь.

Четвертый раздел состоит из трех статей, которые посвящены «праву на развитие». В них говорится, что право на развитие является неотъемлемым правом человека, в соответствии с которым каждый человек и народы АСЕАН имеют право на участие, содействие и получение равных выгод от экономического, социального, культурного и политического развития. [1, с.4] Кроме того, страны-участницы гарантируют принятие особых программ по развитию уровня жизни населения и поддержанию защиты прав и свобод граждан.

Пятый раздел посвящен «праву на мир», который укрепляется в рамках базы АСЕАН в сфере безопасности и стабильности, нейтралитета и свободы, при котором могут быть полностью реализованы права, закрепленные в данной декларации.

Заключительный шестой раздел посвящен «сотрудничеству в поддержании и защите прав человека». В данном разделе говорится о сплоченности и взаимопомощи стран-участниц данной декларации, для которых Хартия АСЕАН является основным и приоритетным источником, регулирующих их правоотношения.

Проанализировав Азиатскую и Европейскую конвенции по правам человека по порядку создания, нормативному содержанию и структурному составу. Можно сделать вывод о том, что: ЕКПЧ является полностью сформированным и целостным нормативно-правовым актом, действующим на протяжении многих десятилетий. Данная конвенция имеет логичный структурный состав и необходимые дополнения в качестве протоколов, помимо этого положительным моментом является ее общедоступность, а так же наличие собственного юрисдикционного органа, который осуществляет контроль ее соблюдения и исполнения. Отрицательный момент заключается в том, что перечень норм, закрепляющих права и свободы человека является ограниченным по своему содержанию, в то время, как научно-технический прогресс не стоит на месте, и требуется создание новых норм по охране и защите вновь возникших прав.

Что касаемо Декларации АСЕАН по правам человека, то данный международный акт появился сравнительно недавно. АКПЧ имеет хорошую нормативную базу, в которой подробно раскрываются права и свободы человека, а так же роль и участие государства в их защите. Структурный состав позволяет беспрепятственно найти необходимый перечень прав, а так же выявить недочеты в той или иной сфере жизнедеятельности человека, которую регулирует данная конвенция. Отсутствие своего судебного органа объясняется малыми сроками ее деятельности по регулированию и защите прав и свобод граждан. Думаем, в дальнейшем такой орган будет создан, что позволит беспрепятственно реализовывать свои права. Единственным минусом данной конвенции является её недоступность гражданам тех государств, которые не являются членами АСЕАН. Хотя, с 
другой стороны, каждое государство, желающее ратифицировать данную декларацию, вступит в Союз, и это увеличит значимость данной организации на политической арене, а так же сможет повысить уровень жизни населения тех стран.

\title{
Литература
}

1. Декларация АСЕАН о правах человека (Пномпень, Камбоджа, 18 ноября 2012 г.)

2. Конвенция о защите прав человека и основных свобод ETS N 005 (Рим, 4 ноября 1950 г.)

3. Лукьянцев Г.Е. Европейские стандарты в области прав человека: теория и практика функционирования Европейской Конвенции о защите прав человека и основных свобод.- Издательская программа общества "Мемориал". М.: Звенья. 20 с.

4. Электронный журнал Грани. Ру/ выпуск от 17.12.2014 (http://grani.ru/Politics/Russia/d.236053.html) (дата обращения: 04.04.2016).

\section{Орос монголын хоорондын харилцаа хx-хі-р зуунд: дипломат харилцааны гэрээ байгуулсанаас өнөөг хүртэл}

\author{
() Ганхуяг Алтандош \\ аспирант 1 года обучения \\ Института экономики и управления \\ ФГБОУ ВО «Бурятский госуниверситет» \\ Монголия, г. Улан-Батор \\ Altandosh1987@mail.ru
}

1921 онд Монгол Улс, Зөвлөлийн засагт Орос Улсын хооронд найрсаг түншлэлийн харилцаа тогтоох тухай хэлэлцээр байгуулж хоёр улс дипломат харилцаа тогтоосноос хойш 95 жилээ угтаж байгаа билээ.

Монгол орны газар зүйн онцлогыг авч үзэхэд, байршлын улмаас их хоёр гүрэний дунд манай улс оршин тогтнож байгаа улс төр юм - стратегийн ашиг сонирхлын өрсөлдөөн идэвХжсэн түүхэн ээдрээтэй нөхцөлд Монгол улсын Ардын засгийн газар өөрийн орны туурга тусгаар байдлыг бэхжүүлэх, улс төр, нийгмийн шинэ тогтолцооны үндсийг тавьж, ахиулахад чиглэсэн бодлого, идэвхтэй үйл ажиллагааг явуулж байсны нэг нь "үндэсний тусгаар тогтнолоо сэргээх зорилтыг хэрэгжүүлэхийн төлөө Зөвлөлт Орос Улстай нөхөрлөх нь чухал" гэсэн шийдвэр гаргажээ.

Энэ шийдвэрийн дагуу Монгол Улс 1921 оны 10 дугаар сард Зөвлөлт Орос Улсад өөрийн төлөөлөгчөө илгээн хэлэлцээ хийж 1921 оны 11 дүгээр сарын 5-ны өдөр "Монгол, Оросын хооронд найрамдалт харилцаа тогтоох гәрээ” -г байгуулсанаарМонгол улс, Орос улсад шинэ төр тогтоосоннос хойших үейийн хоёр орны харилцааны анхны үндсэн баримт бичиг байв.

Монгол Улсаас гадаад улстай эрх тэгш зарчимд тулгуурлан байгуулсан анхны энэхүү хэлэлцээр нь хоёр талын харилцаа, хамтын ажиллагааны хамгийн эгзэгтэй үеийн эрх зүйн чухал суурь баримт бичиг болсон бөгөөд түүгээр бүрэн эрхт дипломат болон консулын төлөөлөгчөө харилцан солилцохоор тохирч, дипломат харилцаа тогтоосон нь хоёр улс бие биеийнхээ бүрэн эрхт байдлыг хүлээн зөвшөөрсөн хэрэг гэж олонхи судлаачид үздэг нь эрх зүйн бүрэн үндэслэлтэй дүгнэлт юм.

Хэлэлцээрийн дагуу хоёр улс дипломат харилцаа тогтоож, 1922 онд Нийслэл хүрээнд болон Москва хотод Элчин сайдын яамаа харилцан нээсэн нь шинэ Монгол Улсыг гадаад улс хүлээн зөвшөөрсөн анхны үйл хэрэг байсан бөгөөд цаашид Монгол Улсын тусгаар тогтнолыг баталгаажуулах үндэс суурийг тавьснаараа түүхэн их ач холбогдолтой үйл явдал болжээ.

Мөн 1923 оны 12-р сард БНМАУ засгийн газар ЗСБНХОУ- ийн засгийн газартай анхны худалдааны гэрээг байгуулсан нь үндэсний худалдааг хөгжүүлэх, манай хоёр орны бараа гүйлгээг хөгжүүлэхэд чухал үүрэг гүйцэтгэсэн.

Монгол Улсын Зөвлөлт Холбоот Улстай тогтоосон цаашдын дипломат харилцаа, нягт хамтын ажиллагаа нь хэд хэдэн үе шаттай хэрэгжсэн байдаг үүнд, 1936 онд хоёр улсын хооронд байгуулсан хамтран ажиллах, харилцан туслах тухай гэрээ нь Монгол Улсад гаднын түрэмгийлэл бодитойгоор заналхийлсэн үед Монгол Улсын тусгаар тогтнол, нутаг дэвсгэрийн бүрэн бүтэн байдлыг хамгаалах хамтын ажиллагааны үндэс болсон юм. Дэлхийн II-p дайн дууссаны дараах 1946онд байгуулсан гэрээ нь Монгол Улсын бүрэн эрхийг олон улсын хэмжээнд баталгаажуулах, энхийн үйлсэд шилжиж улс орон сонгосон замаараа замнах идэвхтэй хөгжлийг дэмжсэн хэрэг байсан бөгөөд түүнийг зарим судлаачид 1921 оны хэлэлцээрээс дутуугүй ач холбогдолтой гэж дүгнэх тохиолдол ч байдаг. 1966 оны найрамдал, хамтын ажиллагааны тухай гэрээ нь дэлхий дахинд Монгол Улсын бүрэн эрхт байдал баталгаажсны дараа нийгэм эдийн засгийг нь хөгжүүлэхэд эрчимтэй хамтран ажиллах үндсийг бүрдүүлсэн. Улст орныг үйлдвэржүүлэн эдийн засгийг хүчин чадлыг эрс нэмэгдүүлэх бүтээн байгуулалт энэ үед өрнөсөн гэж хэлж болно.

СүҮлийн 20 гаруй жилийн дотор ОХУ, Монгол улсын хооронд хэд хэдэн чухал, олон улсын гадаад харилцааны гэрээ, хэлэлцээр, санамж бичиг байгуулсан. [2, с.67]

Хоёр улсад өрнөсөн ардчилсан өөрчлөлтийн дүнд тогтсон нийгмийн шинэ тогтолцооны эхэнд Монгол Улсын Ерөнхийлөгчийн 1993 онд ОХУ-д хийсэн албан ёсны айлчлалын үеэр байгуулсан "Монгол Улс, Оросын Холбооны Улсын найрсаг харилцаа, хамтын ажиллагааны тухай гэрээ” нь хоёр улсын орчин цагийн харилцааны эрх зүйн үндэс болж байна. 
1994 онд баталж, 2011 онд шинэчилсэн Монгол Улсын гадаад бодлогын үзэл баримтлал болсон “Гуравдагч хөрш” хэмээх гадаад харилцааны бодлого нь “ОХУ, БНХАУ, Өрнийн улс оронуудтай найрсаг харилцаатай байх нь Монгол Улсын гадаад харилцааны бодлогын нэн тэргүүний зорилт мөн бөгөөд тэдгээр улстай бүхэлдээ тэнцвэртэй харилцаж, сайн хөршийн ёсоор өргөн хүрээтэй хамтын ажиллагаа хөгжүүлнэ” гэж заасан байдаг. Энэхүү заалт үндсэндээ амжилттай хэрэгжиж ирсэн бөгөөд тэнцвэртэй харилцана гэдэг нь бүх асуудлаар адил байр суурьтай байхыг бус, итгэлцэл, ойлголцлыг бэхжүүлэх үндсэн дээр сайн хөршийн найрсаг харилцаа, харилцан ашигтай хамтын ажиллагааг бүх салбарт идэвхтэй хөгжүүлэхийг хэлж байгаа билээ. Эдүгээ Монгол, Оросын улс төрийн харилцаа идэвхтэй өрнөж, хамтын ажиллагааны бусад салбарын хөгжилд таатай нөхцлийг бүрдүүлж байна.

Монгол Улсын Ерөнхийлөгч Намбарын Энхбаряр 2006 онд ОХУ-д хийсэн төрийн айлчлалын үед хоёр улсын харилцааг стратегийн түншлэлийн хэмжээнд хөгжүүлэх тухай тохиролцоонд хүрч, “Москвагийн тунхаглал” байгуулсан бол ОХУ-ын Ерөнхийлөгч Дмитрий Медведевийн 2009 онд Монгол Улсад хийсэн төрийн айлчлалын дүнд “Стратегийн түншлэлийн харилцааг хөгжүүлэх тухай “Улаанбаатарын тунхаглал” гаргаснаар хоёр орны харилцаа цаашид урт хугацаанд тогтвортой урагшлан хөгжих хэтийн төлөвийг нээж өгсөн юм [4].

Хоёр улсын соёл, боловсрол, шинжлэх ухаан, онцгой байдал, цэрэг, хүмүүнлэгийн харилцаа амжилттай хөгжиж, соёл, хүмүүнлэгийн арга хэмжээнүүд амжилттай хэрэгжиж байна. Тухайлбал, ОХУ-д монголчуудын суралцах чиглэл, мэргэжлийн хүрээ жил бүр тэлж, суралцагчдын тоо, түүний дотор ОХУ-ын Засгийн газрын тэтгэлэгт хамрагдагсдын тоо жилээс жилд өсч байна. Онцгой байдал, хүчний байгууллагуудын харилцаа өргөжиж, цэргийн шугамаар нийлүүлж байгаа тусламжийн хэмжээ нэмэгдэж, хамтарсан цэргийн сургууль, дадлага хийж байна.

Монгол Улс, Оросын Холбооны Улсын найрсаг харилцаа, хамтын ажиллагааны тухай 1993 гэрээнд, Монгол Улс болон Орос Улсын хооронд найрамдалт харилцаа тогтоох тухай Монгол Улсын Ардын Засгийн газар, Зөвлөлт Орос Улсын Засгийн газар хоорондын хэлэлцээрийг дүгнэхдээ, “Монгол Улсын Ардын Засгийн газар, Зөвлөлт Социалист Бүгд Найрамдах Холбоот Орос Улсын Засгийн газар хооронд 1921 оны 11 дүгээр сарын 5нд байгуулсан хэлэлцээр нь хоёр орны хооронд сайн хөршийн харилцаа, хамтын ажиллагааг хөгжүүлэх хэрэгт ихээхэн үүрэг гүйцэтгэсэн” гэж цохон тэмдэглэсэн бөгөөд энэхүҮ гэрээний түүхэн ач холбогдол цаашид ч буурахгүй байна гэдэг эргэлзэлгүй билээ.

2014 оны 9-р сарын 9-нд ОХУ-ын ерөнхийлөгч В.Путин айлчлал хийсэн нь хоёр орны хувьд мэдээж онц чухал үйл ажиллагаа болов. Айлчлалын үеэр ОХУ-ын ерөнхийлөгч В.Путины хэлэхдээ "Халх голын байлдаанд Монгол Оросын цэргүүд хамтран ялалт байгуулсны 75 жилийн ойд зориулан Монгол Улсад ажлын айлчлал хийсэн билээ. Хамтын ажиллагааны хүрээнд шинээр үйлдвэрлэлийг бий болгох, худалдааг хөгжүүлэх, уламжлал харилцааг сэргээх талаар анхаарч ажиллахаар тохиролцсон. Орос, Монгол хоёр орны хувьд хамтын ажиллагааны арвин туршлага бий. Хоёр улсын хамтарсан компани болох "Эрдэнэт" үйлдвэр гэхэд Монголын ДНБ-ий 20 хүртлэх хувийг дангаараа хангаж байна. Агаарын тээврийн салбарт хамтарч ажиллана. Хоёр улсын хувьд харилцан визгүй зорчих талаар шийдвэрлэлээ. Түүний айлчлалаар эдийн засгийн хамтын ажиллагаанд чухал олон асуудлыг хэлэлцэж, хоёр улсын харилцаа, худалдаа, үйлдвэрлэл, боловсролын чиглэлээр 15 санамж бичиг болон гэрээ хэлэлцээрт гарын үсэг зурсан юм. Түүнчлэн Монгол, Орос хоёр улсын гадаад худалдааг 2020 он гэхэд 10 тэрбум ам.долларт хүргэх талаар В.Путин амалсан.Энэхүү айлчлалын томоохон үр дүн нь бол 2014 оны 11-р сарын 14-с ОХУ, Монгол улс хооронд харилцан визгүй зорчих хэлэлцээр нь хэрэгжиж эхэлсэн юм [3].

ОХУ, Монгол улсын хоорондох харилцааны ирээдүйд шинэ чиг хандлага, шинж чанар үүсэж байна. ОХУ, Монгол улсын харилцаанд нөлөөлж буй шалтгаанууд нь хоёр улсын дотоод асуудлууд юм. Эдийн засгийн хямралаас удаан гарч, түүнээс гадна ОХУ-ын өрсөлдөгч улс оронууд- Хятад улс, Япон, Өмнөд Солонгос улс, АНУзэрэг монголд нөлөө бүхий байр сууриа эзэлж байна.Энэ өрсөлдөөнд ОХУ-ын хожигдоа магадлал өндөр байгаа юм. Хятад улсын хөрөнгө оруулалт жилээс жилд нэмэгдэж, бага зэрэг алдагдалд орсон ч нефть шатахуун орулахад бэлэн байгаа юм. Өрнийн ба Дорно Азийн улс оронууд Монгол улсад өөрийн дэд бүтэцээ байгуулах төлөвлөгөө байгаа нь дэлхийн түүхээс авч харахад дараачийн зүйлүүд бүрдэнэ-байгалийн ашигт малтмалын хайгуул эхлүүлж эрчимтэй олборлож эхлэх жишээтэй [1, с.29-30]. Тиймээс ОХУ, Монгол улсын хоорондын харилцааг цаашид үр дүнтэй хөгжүүлэхэд гадаад харилцааны тодорхой чиг хандлага баримталсан гадаад харилцааны бодлого шаардлагдаж байгаа юм. Шинэчилсэн гадаад харилцааны бодлогонд ОХУ, Хойд Дорно Азийн эдийн засгийн орон зайд интеграци нэвтрүүлж, ОХУ-ын Сибирийн орон нутгууд Монгол улстай ойр дотны хамтын ажиллагааг эхлүүлэх нь чухал болж байгаа юм.

\section{Литература}

1. Джагаева О.А. Развитие монгольско-российских отношений: основные проблемы и перспективы (1921-2005 гг): автореф. дис. ...д-ра ист. наук. 2006. С. 29-30.

2. Современные российско-монгольские отношения: модели и сценарии / отв. ред. В. А. Родионов. Улан-Удэ: Изд-во Бурят. гос. ун-та, 2013. С. 67.

3. Сайт новостей Монголии. Политика. URL: http://politics.news.mn/content/192297.shtml

4. Сайт новостей Монголии. Mongolianeconomy. URL: http://mongolianeconomy.mn/mn/i/6578 


\section{Соотношение понятий «право» и «виная»}

(С) Ю. В. Лалетина

магистрант 1 года обучения юридического факультета ФГБОУ ВО «Бурятский госуниверситет»

Россия, г. Улан-Удэ laletina93@ya.ru

Актуальность темы исследования основывается на теоретической значимости вопросов, которые неразрывно связаны с формированием и эволюцией системы права. В этой статье дана характеристика соотношений понятия «право» и «виная».

Основной целью этой статьи я ставлю рассмотрение понятий «виная» и «право» на современном этапе развития, изучение и соотношение систем правовых норм с нормами буддийского монашеского закона.

Была использована англоязычная книга «Буддизм и право», статья Petra Kieffer-Pulz «Что такое виная». На основании своего перевода, я дала статье оценку, раскрыв понятие «виная», и постаралась соотнести с понятием «право», которое есть сейчас. Этот вопрос требует более глубокого изучения, однако собранный и проанализированный материал позволяет раскрыть поставленные передо мной задачи.

Закрепленному в конституции юридическому пониманию права противостоит легизм, отождествляющий право и закон и рассматривающий право как систему формально обязательных норм, охраняемых государственным аппаратом управления и принуждения. Право для выполнения регулятивных и охранительных функций опирается на авторитет и силу государства. Государство при принятии и применении законов действует не по субъективному усмотрению, а в соответствии с объективными требованиями права выполнять это действие в лице его органов законодательной, исполнительной и судебной власти. Основной закон страны в качестве одного из элементов правовой системы предусматривает именно юридическое понимание права. В теории и судебной практике возникающие в связи с этим вопросы воспринимаются неоднозначно. Рассматривая данный вопрос, я не могу обойти вниманием понимание сущности права. Результат, который складывался на протяжении длительного времени, на основании мнений и различных идей общества, которые были объективно закреплены и рассматриваются как сущность права. При рассмотрении сущности права важно учитывать два аспекта: формальный - то, что любое право есть, прежде всего, регулятор, и содержательный - то, чьи интересы обслуживает данный регулятор, и какие в первую очередь функции осуществляет данный регулятор в приоритетном порядке. Иначе говоря, сущность права многоаспектна. Для того чтобы продолжать анализ, необходимо четко понимать, что такое виная.

Виная - это руководство для повседневной жизни монахов буддийской общины (сангхи), является внутренним документом. В авторитетных буддийских писаниях этот свод правил называется «слово Будды». Он содержит правила и нормы, регламентирующие жизнь монаха, как отдельной личности и общества в целом.

На историческом этапе развития община буддистов разделилась на несколько ветвей, которые впоследствии разделились на несколько направлений школ, использовавших в своих учениях различные каноны. Виная не имеет систематизированного характера и не закреплена юридически. Правильнее, на мой взгляд, будет считать, что виная основана на прецедентном праве. Это один из старейших институтов автономных правовых систем, и Будда считается законодателем.

При рассмотрении данного понятия видим, что виная как раз-таки и основывается на религиозном подходе сущности права, так как оказывает опосредованное воздействие религиозных норм на формирование правовых норм через правосознание в результате восприятия правосознанием религиозных идей и представлений.

Передача знаний винаи происходила устно на протяжении веков, прежде чем их сформировали и прокомментировали. И это было сделано для исторического очерка, а не для закрепления их в формальном виде.

Происхождение винаи кроется в общих основополагающих правилах, зародившихся еще во времена Будды, запрещающих такие вещи, как убийство, воровство, ложь. Вопросы собственности имели также большое значение, поскольку те монахи, которые вступили в буддийскую общину, сангху, не должны были отказываться от своего имущества и принимать обет бедности. Что опять-таки свидетельствует о связи права и винаи. Оба понятия носят исторический характер, который складывается в процессе развития как общества в целом, так и отдельной религиозной группы. Право и закон - это также два неразрывных понятия. На сегодняшний день закон регулирует, так же как и виная, общественные отношения с нормами гражданского, уголовного и конституционного права, защищая тем самым права и свободы граждан.

Исторически сложившиеся понятия и понимания так называемых норм винаи подвергались и подвергаются изменениям, также в связи с ростом и распространением буддийской общины возникает ряд новых требований, предписаний и постановлений. Виная не была создана мгновенно, она создавалась из различных фрагментов, переведенных с разных языков. Причем есть фрагменты, которые на сегодняшний день относятся к оспоримым, и не может быть подтверждено, что они существовали в действительности.

Виная до сих пор в виде прецедента используется в Восточной Азии, в Тибете и Монголии, Таиланде и других странах. Виная - это список предписаний, который хранится у монахов буддийского сообщества. Количество предписаний в каждой школе различное, что еще раз свидетельствует о неточной систематизации предписаний виная, оно варьируется среди школ от 219 до 371. 
Виная монахов разделена, как правило, на восемь разделов, а для монахинь - на семь. Из них первые семь (шесть для монахинь) составляют предписания. Последний раздел содержит семь правовых процедур разрешения споров. В них принято начинать с самых тяжких нарушений и заканчивать легкими. Согласно российскому законодательству преступления делятся также по различным степеням тяжести, и существуют разные виды ответственности за различные виды преступлений, помимо всего на сегодняшний день понятие права знает еще отягчающие и смягчающие обстоятельства, которые в том или ином образе определяют различное наказание.

Согласно винае, за нарушения первой категории монахи и монахини изгоняются из сангхи, хотя могут остаться в общине, но с ограниченными правами. Грехи второго класса требуют собрания общины и последующего расследования. Все остальные правонарушения могут быть искуплены путем исповедания, некоторые дополнительно требуют возврата украденного.

Индивидуальные правила, закрепленные в винае, имеют особый характер. Так как нет точного предписания, они могут быть рассмотрены в каждом отдельном случае по-разному, потому что в зависимости от ситуаций могут быть дополнены новыми вводными данными, которые изменят полный ход событий. По вводным данным в дальнейшем и будет определена тяжесть нарушения по совершенному деянию. Например, юридические заключения в этом разделе отмечают разницу между «хорошими» деяниями, т. е. заменяется терминология, которая меняет цепочку событий-последствий по винае, например, «украсть объект» заменяется в связи с новыми обстоятельствами на «переместить объект».

Нормы винаи на протяжении всего периода своего существования изменялись, но не были закреплены документально, а лишь передавались из уст в уста. Поэтому мы вынуждены считаться с различными формулировками винаи из разных временных отрезков, что по нормам права не допустимо, т. к. нормы права имеют принцип действия во времени, что подразумевает, что закон недействителен после момента вступления в силу нового свода законов. В юридической литературе о принципе действия закона во времени размышляют по-разному, а именно, что новая норма распространяется только на отношения, возникшие после введения ее в действие или незамедлительного действия новой нормы, в связи с чем старая норма прекращает существовать. Данный принцип означает, что если отношение носит длящийся характер и возникло в период действия старой нормы, то с момента введения в действие новой нормы оно регулируется новой.

Винаю как источник права разделяют по срокам возникновения, как было выяснено ранее, а также по времени ее перевода: виная была переведена на китайский в первых десятилетиях V в. н. э., а на тибетский — в конце VIII - начале IX в. н. э.

Сохранились следы по крайней мере трех разных версий перевода: одна действовала до принятия канонической версии, другая более и менее соответствовала канонической версии, и третья представляла позднюю версию перевода. Мы не можем говорить о винае как о своде законов, так как она не была зафиксирована. Например, тот же закон Хаммурапи, который является одним из древнейших законодательных памятников, сохранился в виде клинописной надписи на черной диоритовой стеле, найденной французской археологической экспедицией Жака де Моргана в ходе раскопок в 1901-1902 гг. в Сузах. Что свидетельствует о его существовании не в устной форме, а зафиксированной, пусть и не документально. Нельзя забывать о том, что это было другое время, и тогда нормы права были зафиксированы иначе, чем сейчас.

Поскольку буддийские общины зависели от поддержки мирян и их существования, составителям монастырских кодексов пришлось приспосабливать монашеское право к правовым системам, регулирующим общество, в котором жили буддийские общины. В Индии, вероятно, около IV-V в. н. э. отредактированные сообществом и глубоко внедренные в крупнейшие в мире индийские знания, законы сформировались в правовую литературу, которая формально не имела юридической силы. Таким образом, монашеский закон не был отделен от светского права, как это можно было наблюдать в Индии. Из винаи мы узнаем, что, например, развод был возможен в некоторых регионах, а именно путем продажи одной жены.

В основе буддийского монашеского закона лежат общеправовые принципы, например, такие как: нет преступления без вины; невменяемость и психическое расстройство освобождает от наказания; четкое разграничение между умышленным деянием и неосторожным. Преступления согласно принципам винаи дифференцируются в зависимости от тяжести преступления, что очень напоминает уголовный закон России. Еще к принципам винаи можно отнести равенство всех, независимо от монашеской иерархии. Любое решение местной сангхи принималось единогласно на основе консенсуса. В случае расхождения мнений решение принималось большинством. Король, религиозные общины, гильдии, корпорации и другие группы, которые также имели свои собственные локальные правила или уставы, в целом были подчинены светским законам и оставались на высоком уровне юрисдикции. Отношения между светскими и монастырскими законами были подвержены изменениям и зависели от отношений соответствующего короля и сангхи. Короли определяли, какие права были предоставлены буддистам и в какой степени монахи были освобождены от светского права. Буддисты должны были уважать светское право при создании собственных локальных монашеских законов.

Нормы светского права и нормы винаи достаточно часто пересекаются, особенно в вопросах собственности, наследования, договоров и двух тяжких преступлений - кражи и убийства. К примеру, в вопросе наследования, согласно винае, только тот, кто присутствовал в погребальных обрядах, имел право претендовать на имущество умершего, но вместе с тем, если у наследодателя имелись долги, наследник обязан был их уплатить. Эти же положения мы можем наблюдать в российском праве. Например, в соответствии с нормами ГК РСФСР 1964 г. наследник, принявший часть наследства, признавался принявшим все наследство. Принятие части наследства 
не допускалось. В ч. 3 ГК РФ данное положение воспринято как основное: согласно абз. 1 п. 2 ст. 1152 ГК РФ принятие наследником части наследства означает принятие всего причитающегося ему наследства, в чем бы оно ни заключалось и где бы ни находилось наследственное имущество.

Для того чтобы узнать и понять буддийский монашеский закон, мы должны знать, что существует не одна версия понимания винаи, а несколько, и они исходят из разных школ, из разных временных периодов, из разных регионов. Чтобы иметь более четкое представление о буддийском монашеском праве, проводится множество филологических исследований в отношении юридической терминологии и текстовых определений. В качестве источников недопустимо использовать только формы винаи, переходящие из уст в уста. Мы должны основываться на археологических и эпиграфических фактах. Общие заявления на основе только винаи должны отойти в прошлое. В будущих исследованиях необходимо учитывать множество открытий и находок последних лет, которые показали все разнообразие буддийского монашеского закона.

В заключение можно сказать, что правовые нормы и буддийский монашеский закон имеют большое значение для общества и государства. Они имеют определенные сходства между собой и определенные различия. Буддийский монашеский закон - виная - это руководство для повседневной жизни монахов буддийской общины, которое определяет смысл их существования, а право рассматривает только отношения людей между собой. Буддийский монашеский закон играет более значимую роль для монахов, входящих в состав буддийской общины, чем право. Человек, который руководствуется только нормами закона, вполне может преступить какие-либо законы в своих интересах, будучи уверенным в том, что избежит наказания. Религиозный человек, к каковым мы относим монахов, считает, что, нарушая законы, заповеди, моральные принципы, он вредит своей душе, лишает себя благодати. То есть внутренне осознание дает строго дифференцируемую систему ценностей, меняет мироощущение человека. Право же не влияет на внутреннюю жизнь человека, лишь регулирует его внешние отношения. Таким образом, правовые нормы осуществляют внешнюю регулирующую функцию, а религиозные - внутреннюю. Взаимодействуя, они дополняют друг друга, направляя и совершенствуя человека. Одной из основных задач любых норм является установление порядка. Право непосредственно воздействует на условия и процесс производства, распределения и обмена, материальных благ, закрепляет своими нормами экономические отношения, выгодные тем или иным слоям общества. Я считаю, что буддийский монашеский закон имеет свой генезис, который зависит от различных внешних факторов, и что его можно назвать одной из основ сегодняшнего понимания права. Так как, генетически предшествуя праву, он оказывает существенное влияние на его возникновение и формирование. Правовое сознание первоначально тесно смыкается с религиозным. Понятия греховного и преступного во многом совпадают.

По характеру своих предписаний правовые нормы и нормы буддийского монашеского бывают очень близкими. В ряде случаев юридические нормы текстуально повторяют предшествующие им религиозные нормы. В результате такого взаимодействия социально необходимое поведение людей обеспечивается одновременно санкциями, как правовыми, так и закрепленными в виная.

Правовые нормы являются обязательными нормами в государстве. Религиозные обязательными не являются, но обеспечивают нравственность общества. Нравственность же влияет на поведение человека в обществе, что приводит к наиболее лучшему исполнению правовых норм.

Таким образом, в рассмотренном взаимодействии религиозных и правовых норм в государстве прослеживается четко выраженная тенденция к сближению их друг с другом и совместному решению общих задач, стоящих перед обществом.

\title{
Соотношение национальной доктрины Российской Федерации с международной доктриной
}

\author{
(ㄷ) E. O. Madaeb \\ стариий преподаватель кафедры \\ международного права и международных отношений \\ юридического факультета \\ ФГБОУ ВО «Бурятский госуниверситет», \\ канд. юр. наук, \\ Россия, г. Улан-Удэ \\ madaeo@mail.ru
}

В XIX и даже в начале XX в. международное право рассматривалось в значительной мере как «доктринальное» право, право ученых. Мнения авторитетных специалистов по международному праву различных стран являются одним из средств установления наличия или отсутствия тех или иных норм международного права, а также их толкования [7, с. 211].

Во всех странах признается, что нормы международных договоров (односторонних или многосторонних) вступают в действие после их надлежащего подписания и ратификации компетентными органами. Во многих странах такие нормы действуют непосредственно и имеют силу закона. Наряду с общепризнанными принципами и нормами международного права, в ч. 4 ст. 15 Конституции Российской Федерации международные договоры Российской Федерации объявляются в качестве составной части ее правовой системы и при этом уста- 
навливается, что «если международным договором Российской Федерации установлены иные правила, чем предусмотренные законом, то применяются правила международного договора». С учетом того, что соответствующие научные позиции нашли свое выражение в основном законе и в текущем законодательстве (законы о ратификации, законы, посредством которых осуществляется имплементация и т. д.), а также в практике международно-правовых отношений Российской Федерации и ее субъектов, можно констатировать, что отечественная доктрина о соотношении национального и международного права в целом сложилась. Однако с такой же уверенностью можно утверждать и то, что в деталях, причем в весьма существенных своих нюансах, она находится в стадии становления, доработки и совершенствования. Все ли виды международных договоров Российской Федерации являются составной частью ее правовой системы или только некоторые из них? Если некоторые, то какие именно? Какова их юридическая природа и чем определяется их правовой характер? Каковы механизмы их реального внедрения в национальную правовую систему России?

Этот проблемный ряд далеко не исчерпывающий. Международно-правовая практика ставит перед российской юриспруденцией все новые и новые вопросы в области международного права, разрешение которых требует консолидации усилий и консенсуса доктрин разных государств, в том числе имеющих принципиально разные национальные правовые системы. В частности, абсолютно новое звучание приобрела традиционная международно-правовая проблематика в последние годы в связи с принципиально новым качеством и интенсивностью криминальных вообще и террористических в частности экологических и иных транснациональных угpo3.

На фоне событий 2011-2016 гг., имевших место в ряде исламских государств Северной Африки и Азии, государства Южной Европы вынуждены пересматривать свою доктрину миграционной политики. Вероятно, России следует самым тщательным образом проанализировать этот опыт, внести соответствующие коррективы в собственную национальную правовую политику в области внешней миграции, а вместе с тем и в свои международные обязательства, дабы избежать угроз своей национальной безопасности.

Одним из самых болезненных и обсуждаемых вопросов доктринального характера последних лет является вопрос об обоснованности и обязательности решений международно-правовых институтов, в частности Европейского Суда по правам человека, для Российской Федерации. Отсутствие определенности в данных вопросах, с одной стороны, препятствует полноценной включенности норм международного права как конституционного закрепленного элемента правовой системы страны, а с другой - способно нанести ущерб, интересам государства, создавая условия для необоснованного и неполезного вмешательства во внутренние дела государства со стороны других государств и иных субъектов международно-правового общения. Для ответа на эти и многие другие вопросы, практики - субъекты международно-правовой деятельности - обращаются к доктринальным источникам. Доктрина вырабатывает формальные положения, к которым следует обращаться в случае возникновения противоречий. Она вырабатывает типовые решения для поиска выхода из спорных, коллизионных, конфликтных ситуаций. Официальная доктрина основана на признании приоритета и верховенства федеральной Конституции в правовой системе страны. Опираясь на данный постулат, можно сформулировать корректные позиции, позволяющие либо исключить складывающуюся конкуренцию между общепризнанными принципами и нормами международного права, международными договорами, Конституцией России и законами, либо квалифицированно разрешить возможные коллизии между ними. Вопрос о конституционном признании общепризнанных принципов и норм международного права в качестве составной части правовой системы России, а следовательно, и в качестве источников современного российского права является неотъемлемой составной частью более общего вопроса, а именно вопроса о характере взаимосвязи и взаимодействия международного и национального (внутригосударственного) права. В отечественной и зарубежной юридической литературе при анализе проблем, касающихся характера взаимосвязи и взаимодействия международного и внутригосударственного права исторически прослеживаются два различных подхода - дуалистический и монистический [5]. Каждый из них в разное время имел и имеет определенное распространение в юридической академической литературе и прикладной юриспруденции. В этих подходах отражаются сложившиеся в том или ином обществе и государстве официальные и неофициальные научные представления не только о своем национальном праве, но и о характере его взаимосвязи и взаимодействия с международным правом.

Конституция занимает высшее место в иерархии источников права любого государства. Именно конституции юридически определяют стратегию и тактику взаимоотношений конкретного государства с внешним миром, его участие в международных правоотношениях, закрепляют правовые способы и порядок выполнения им своих международных обязательств, как в межгосударственных отношениях, так и в отношениях внутри самого государства. Тем самым конституции выступают в качестве важнейшего правового элемента общемирового механизма поддержания и обеспечения международного правопорядка. Благоприятствует формированию международного конституционного права и принцип высшей юридической силы конституции, исповедуемый государствами. Участники международных отношений не могут, как правило, пойти на согласование таких норм, которые противоречили бы их конституциям и другим основополагающим актам [3, с. 159-162]. Одновременно они не могут отказаться от международного сотрудничества и поэтому стремятся сформировать благоприятную для себя внешнюю правовую среду, созвучную конституционным принципам, отстаивают их как неотъемлемую часть своей правовой позиции при создании правовых норм. Поскольку конституционные и общеправовые принципы очень близки, они достаточно быстро занимают свою нишу в международном праве, в дальнейшем заимствуются конституционными актами других стран. Таким образом, международное право выступает ретранслятором конституционных норм, обеспечивая их воспроизводство теми государствами, которые напря- 
мую вряд ли бы стали их заимствовать. Национальная доктрина в ряде случаев может оказывать прямое непосредственное воздействие на международную доктрину. Исторический опыт и международно-правовая практика показывают, что это могут быть нормы и теории, на которых эти нормы базируются, касающиеся дипломатических иммунитетов и привилегий, порядка заключения международных договоров и соглашений, иммунитета государства и его собственности, правового положения иностранцев и лиц без гражданства, дипломатических и консульских представительств в стране и др. [6, с. 31-32] первоначально возникающие в рамках деятельности одного или нескольких государств в пределах внутригосударственного права, а затем трансформирующиеся в нормы международного права. В систему международного права могут также трансформироваться принципы внешней политики того или иного государства, первоначально появившиеся в национальном праве и нередко закрепляющиеся в основных законах государства.

Вместе с тем не меньшее значение имеет изучение и обратного воздействия международной доктрины на национальную доктрину. Она оказывает как формальное, так и содержательное воздействие. Под формальным воздействием имеется в виду сам факт допущения доктрины в число источников права. Применение норм международного права национальными органами предполагает, что их содержание определяется согласно правилам и процедурам, существующим в межгосударственной системе. Обращение в этой связи к международной доктрине представляется обязательным и непременным элементом правоприменительной деятельности. Таким образом, обеспечивается признание за доктриной правообразующих начал.

Богатство содержательного воздействия международной доктрины на национальную доктрину страны определено множественностью точек соприкосновения международного и национального права.

Прямое воздействие международной доктрины на национальную доктрину выражается, например, через объявление в конституциях ряда государств и других законодательных актах общепризнанных принципов и норм международного права, а также международных договоров, заключенных государством, составной частью его национальной правовой системы. Прямое воздействие оказывается также путем трансформации норм, содержащихся в конкретных международных договорах и обычном международном праве, в нормы внутригосударственного национального права.

Косвенное воздействие проявляется в том, что, закрепляя в своей структуре и содержании те или иные прогрессивные принципы, нормы или положения, международная доктрина подает тем самым своего рода пример и побуждает государства, в правовых системах которых эти принципы, нормы или положения отсутствуют, к их принятию и практическому осуществлению.

В качестве примера можно сослаться на принцип уважения прав человека, который первоначально после Второй мировой войны был зафиксирован в самой общей форме в Уставе ООН и других международно-правовых документах (во Всеобщей декларации прав человека 1948 г., международных пактах о правах человека 1966 г., Заключительном акте Общеевропейского Совещания 1975 г. и др.), а затем, не в последнюю очередь под влиянием «извне», со стороны международного права, нашел свое адекватное отражение и закрепление в законодательстве большинства государств.

Влияние международной доктрины на доктрину практически любого государства несомненно. При этом активность, характер и направление воздействия во многом зависят от того, каким образом государство разрешает проблему соотношения и взаимодействия международного права и национального права в целом.

Единство правового пространства эпохи глобализма не ограничивается пределами территориальной юрисдикции государств. Назрела насущная потребность разрешения проблемы совместимости национальной и международной правовых систем, но не за счет их унификации, а посредством согласования.

Элементарная логика подсказывает, а современная международно-правовая практика подтверждает (например, расширение в Европе «зоны ответственности» НАТО, попытки подмены миротворческих функций $\mathrm{OOH,} \mathrm{«гуманитарные»} \mathrm{бомбардировки} \mathrm{Югославии,} \mathrm{вторжение} \mathrm{весной} \mathrm{в} 2011$ г. в Ливию, события в Сирии и т. д.), что в реальной жизни процесс формирования и реализации международного права - это не всегда процесс согласования действий и воль всех суверенных государств, к тому же равноправных партнеров. Специалисты в области международного права совершенно справедливо утверждают, что все существующие концепции соотношения международного и внутригосударственного права «возникли не случайно». Все они отражают не только личные позиции тех или иных авторов, но и вполне реальные внешнеполитические доктрины тех или иных государств. Можно даже обнаружить сложившуюся в рассматриваемой сфере общую тенденцию, суть которой заключается в том, что «сторонники примата международного права чаще всего представляли интересы сильных держав, которые в течение длительного времени оказывали значительное влияние на развитие международного права и в силу этого в определенном смысле являлись международными законодателями» [4, c. 128-129].

«Открытие» государства для международного права есть не что иное, как стремление выйти за рамки замкнутой системы, получить внешнюю энергетику, поддержку в реализации своих интересов и устремлений. Вместе с тем абсолютная открытость государства вредна, а по сути, невозможна, поскольку входит в противоречие с соображениями государственной безопасности и признаком суверенитета. Весьма опасно оценивать национальный суверенитет как слишком узкую базу для решения широких глобальных и региональных проблем [1, с. 96].

Умаление суверенитета ведет к потере государственности, а значит, к уничижению роли конституции как акта, определяющего пределы государственной власти. Главная составляющая национального интереса - это императив самосохранения государства [2, с. 263], который диктует соответствующую модель международноправового поведения. 
Именно конституционные нормы, основанные на доктринальных положениях и одновременно определяющие приоритеты внешнеполитической доктрины суверенного образования, устанавливают допустимый предел для проникновения норм международного права в национальную правовую систему, за которым следует утрата идентичности государства.

Активизация взаимодействия международного права и национальной правовой системы России неизбежно повлечет за собой рост влияния доктрины как источника права. Доктрина способна стать мощным фактором, повышающим потенциал конституционности российского законодательства, как в аспекте федеративного устройства России, так и в аспекте основ международных взаимодействий Федерации и ее субъектов, важным фактором единства правового пространства Российской Федерации.

Доктрина способна стать универсальным средством, связующим национальную и международную правовые сферы. Именно она обеспечивает примат права независимо от нормативно-правового уровня. Доктрина, последовательно отстаивающая высшую юридическую силу Конституции Российской Федерации, должна выработать критерии допустимости договорных норм в правовой массив Российской Федерации, правила применения общепризнанных принципов и норм международного права на территории России.

Таким образом, доктрина должна обеспечить индивидуализацию, самоидентификацию отечественной правовой системы с учетом происходящего процесса общецивилизационной унификации по ряду параметров национальных правовых систем различных государств, сближения правовой системы России и систем международного публичного и международного частного права.

\title{
Литература
}

1. Выступление премьер-министра Канады Брайана Малруни // Общеевропейские встречи в верхах, Париж, 19-21 ноября 1990 г.: документы и материалы. М., 1992. С. 96.

2. Гаджиев К. С. Геополитика. М., 1997. С. 263.

3. Иваненко В. С. Конституции государств - участников СНГ и международное право: некоторые проблемные вопросы их соотношения // Правоведение. 2002. № 1. С. 159, 162.

4. Международное право / под ред. Г. И. Тункина. М., 1986. С. 128-129.

5. Мюллерсон Р. А. Соотношение международного и национального права. М., 1992; Талалаев А. Н. Соотношение международного и внутригосударственного права и Конституция Российской Федерации // Московский журнал международного права. 1994. № 4; Зурабаева Е. Ю. Общепризнанные принципы и нормы международного права и международные договоры в правовой системе России. М., 2003; Барциц И. Н. Международное право и правовая система России // Журнал российского права. 2001. № 2; Бекяшев K. А. Российская Федерация и основные принципы международного права // Lex Russica. 2008. № 6; Гаврилов В. В. Взаимодействие международной и национальных правовых систем и правосознание // Журнал российского права. 2006. № 2; Лукашук И. И. Взаимодействие международного и внутригосударственного права в условиях глобализации // Журнал российского права. 2002. № 3.

6. Мюллерсон Р. А. Соотношение международного и национального права. С. 31-32.

7. Ст. 38 Статута Международного Суда ООН; Тункин Г. И. Теория международного права. М., 1970. С. 211.

\section{Проблема правового регулирования авторского права в России и Китае}

\author{
(C) Р. И. Максарова \\ студентка 4-го курса юридического факультета \\ ФГБОУ ВО «Бурятский госуниверситет» \\ Россия, г. Улан-Удэ \\ raksana.maksarova@mail.ru
}

В российском законодательстве под авторским правом понимается подотрасль гражданского права, регулирующий создание и использование научных, литературных и художественных произведений. Авторское право представляет собой сложный институт, который относится к интеллектуальной собственности.

Согласно Конституции РФ, каждому гарантируется свобода творчества и ее охрана [1, с. 8]. Подробно охрана авторских прав регламентирована частью четвертой Гражданского Кодекса РФ. В данном случае, гражданское право, выступающее регулятором личных неимущественных прав, включает в себя право на авторство, право на имя, исключительное право на произведение, право на неприкосновенность произведения и право на обнародование произведения [3].

Как правило, продолжительность авторского права охватывает жизнь автора плюс 50 - 100 лет (то есть, как правило, авторское право истекает от 50 до 100 лет после того, как автор умирает, в зависимости от юрисдикции). Как правило, авторское право регламентируется гражданским материальным правом, хотя в некоторых случаях применяются уголовные санкции.

Нет такого понятия, как «международное» авторское право, которое автоматически защищало бы произведение по всему миру. Тем не менее, наиболее широко известный договор авторского права, Бернская конвенция, говорит, что как только работа защищена в одной из стран-участниц Конвенции, она защищена авторским правом во всех из них [2]. Так как Россия и Китай являются участниками данной Конвенции, на них действует это правило. 
Под нарушением авторских прав понимается несанкционированное использование защищенного авторским правом продукта. Это может включать в себя коммерческое и некоммерческое использования. Нарушение авторских прав взлетели в результате распространения Интернета и наличия цифрового копирования программ. При использовании защищенного авторским правом материала, важно понимать все применимые законы и получить законное разрешение на их использование.

Наша страна - Россия занимает одно из ведущих мест по нарушению авторских прав в мире. В американских списках злостных нарушителей законов о защите авторских прав числится российская социальная сеть «ВКонтакте» - единственная социальная сеть в американском «черном списке».

Примеры нарушения авторских прав:

Плагиат видео: Распространение копий фильмов и телевизионных передач на дисках, путем копирования с помощью компьютерных сетей. Это может быть осуществлено также с целью получения прибыли (то есть продажа продукции в магазинах, на лотках), так и без (распространение копий фильмов в локальных сетях, в интернете, обмен фильмами с друзьями на дисках), были известны некоторые случаи появления на продажу незавершенной версии фильма, украденной из съемочной группы.

Плагиат аудио: Копирование и распространение копий музыкальных композиций. Включает в себя продажи музыкальных альбомов на аудиокассетах и компакт-дисках. К плагиату аудио также относится распространение музыкальных произведений в компьютерных сетях.

Литературные произведения: Были многие так называемые электронные библиотеки, которые бесплатно предоставляют доступ всем к текстам литературных произведений. И уже оттуда они копируют литературные произведения.

Главной причиной распространения нарушения авторских прав в странах является неплатежеспособность населения этих стран, ведь стоимость пиратских продуктов намного дешевле, чем оригиналы. Кроме того нарушения авторских прав обеспечивает доступ к информациям широкого слоя населения.[5, с.158]

Для регулирования вопроса об охране авторского права наша страна ввела ст. 146 УК РФ «Нарушение авторских и смежных прав»- пункт «Преступления против конституционных прав и свобод человека и гражданина», также ст. 158 УК РФ «Кража»- пункт «Преступления против собственности».

На мой взгляд, проблема регулирования авторского права очень актуальна и важна.Многие страны пытаются бороться с этой проблемой.

Например, Китай, как один из стран Азиатско-Тихоокеанского региона, так и граничащая страна с Россией. Китай разработал модель защиты прав интеллектуальной собственности, которая характеризуется параллельными административными и правовыми защитами.

Основным законом регулирования авторского права в Китае является, помимо Конституции КНР, Закон КНР «Об авторском праве».

Правительство КНР принимает ряд мер, которые направлены на повышение грамотности и информированности населения в сфере интеллектуальной собственности. Например, при издании нового нормативно правового акта, они публикуется в центральных средствах массовых информации для всенародного обсуждения. Помимо этого, Государственное ведомство интеллектуальной собственности в рамках «Недели популяризации интеллектуальной собственности» проводит различные конференции и симпозиумы в сфере регулирования авторского права, а также ведутся диалоги со студентами университетов.

Несмотря на активную работу китайских властей в области защиты интеллектуальной собственности, текущая ситуация и осуществление защиты прав интеллектуальной собственности в Китае не столь благоприятны, и защита интеллектуальной собственности является долгосрочной и трудной задачей для Китая.

Если сравнить законодательство РФ и КНР, то в Китае охраняетсяправо произведений народного творчества (фольклор) - ст. 6 Закона КНР «Об авторском праве», [4] в то время, как в России, данная ситуация носит дискуссионный характер. В соответствии с Гражданским Кодексом РФ, народ не является юридическим лицом, и в связи с этим не может участвовать в гражданском обороте.

Основной мерой для защиты интеллектуальной собственности может быть регистрация товарного знака.

Технологии борьбы с подделкой также стал более современным. В частности, производители улучшают целый арсенал специальных средств защиты. Теперь кроме голограмм, водяных знаков и специальных рельефов многие компании для защиты начали использовать технологию радиосвязи тегов, которые позволяют упростить отслеживание поставок и перемещение продуктов.

Против ужесточения авторских прав выступают политические движения, так называемые «Пиратские партии». С 1 января 2006 года в Швеции появилась первая партия пиратов. В Российской Федерации мы также имеем аналогичную партию - Пиратская партия России.

Данные Пиратские партии занимаются реформами авторских прав в соответствии с интересами авторов и общества, а не издателей [6]. Члены данной партии выступают за сокращение срока действия авторских прав, и за свободу обмена информацией. В связи с эти, они говорят о декриминализации ст. 146 УК РФ, ссылаясь на то, что нельзя ставить на один уровень людей, нарушивших авторские права, с убийцами и насильниками, называя их преступниками.

Несмотря на активную работу Китая и России в области авторского права проблемы все еще существуют. Для решения этих проблем, нам нужна хорошая правовая база и поддержка граждан России и Китая в борьбе с нарушениями авторских прав. 


\title{
Литература
}

1. Конституция РФ от 12.12.1993 г. М.: ЮРЛАЙТ, 2015.

2. Бернская конвенция по охране литературных и художественных произведений от 1886г.

3. Гражданский кодекс Российской Федерации: Часть 4 от 18.12.2006г.// [Электронный ресурс]. URL:http://www.consultant.ru/document/cons_doc_LAW_64629/5d2874854e8d6f002a2ab6ca07ef78313363ee73/

4. Закон КНР «Об авторском праве» от 07.09.1990 г.

5. Авторские и смежные с ними права: постатейные комментарии глав 70 и 71 Гражданского кодекса Российской Федерации / М. Я. Кириллова и др. М., 2010. 478 с.

6. Программа Пиратской партии России от 25.05.2014г. // [Электронный pecypc]. URL:https://libre.life/party/ pirat/program/ru.

\section{Практика предоставления дипломатического убежища в странах АТP}

\author{
(C) А. В. Цицденова \\ студентка 4-го курса юридического факультета \\ ФГБОУ ВО «Бурятский госуниверситет» \\ Россия, г. Улан-Удэ \\ alextsy2094@gmail.com
}

Современное развитие международного права неразрывно связано с расцветом международных отношений. Каждое государство стремится реализовать свой потенциал в полной силе и во всех сферах жизнедеятельности. Поэтому появилась необходимость в развитии национальных институтов, которые могли бы регулировать отношения между иностранными государствами, и в создании универсальной базы нормативно - правовых актов, регулирующих данную область отношений.

Сегодня мы рассмотрим один из таких институтов, главной функцией которого является предоставление убежища и защита иностранных лиц от посягательств со стороны другого государства. [4, ст. 33 ] Данный институт убежища исторически сложился еще в начале XV века, со временем трансформируясь и изменяясь. Исторически практику предоставления убежища делят на два вида: политическое и территориальное. Однако на сегодняшний день появилось новое понятие, такое как институт дипломатического убежища. Особенность этого института от других видов убежища является предоставление убежища в чрезвычайных ситуациях на территории дипломатических и консульских учреждениях, а также на военных кораблях, базах и лагерях [2, с. 12].

Данный институт давал и дает возможность государствам осуществлять защиту и покровительство иностранцев в экстренных ситуациях, требующих моментального решения. Сравнивая законодательство большинства стран мира, приходишь к выводу, что данный институт признан только в нескольких регионах мира.[8, с. ] Причина проблемы возникает в отсутствии четких рамок толкования термина «дипломатическое убежище», а также отсутствие законодательного закрепления на международном и национальном уровнях всех стран мира правового статуса института. При этом нельзя утверждать, что дипломатическая форма убежища отрицается всеми странами мира, что противоречило бы фактическому положению вещей.

Государства всего мира можно разделить на четыре группы:

1. Страны, не признающие, следовательно, и не практикующие этот вид убежища. К данной категории относится большинство стран мира.

2. Страны, не допускающие функционирования института на территории своего государства, но сами его предоставляющие. К числу таких стран следует отнести Францию, Великобританию, США.

3. Страны, предоставляющие и разрешающие институт дипломатического убежища. К группе отнесены латиноамериканские государства и несколько стран Европы.

4. Страны, сами не предоставляющие убежище, но разрешающие его предоставление на территории своего государства (например, Греция). [7, с. 56 ]

Деление стран по принятию правового статуса дипломатического убежища показывает, что большинство государств (в т.ч. и социалистические страны) не признают в целом институт дипломатического убежища, но допускают его существование и функционирования.

Рассматривая исторический аспект, можно увидеть прецеденты, где отдельные государства позволяют себе применение норм предоставления убежища, в виде исключения из правил. Однако норма о недопустимости предоставления убежища в дипломатических резиденциях адресована именно представительствам иностранных государств. Представительства, не могут нарушать запрет в предоставлении права на убежище иностранным лицам, если на это нет ясно выраженного согласия страны, в которой они аккредитованы. В ином случае речь идет о злоупотреблении дипломатическим иммунитетом, который можно будет рассматривать как вмешательство во внутренние дела данного государства. [6, с. 124 ]

На сегодняшний день практика предоставления дипломатического убежища возможна в основной массе странами Европы и Латинской Америки. [1, с. 78]. Однако есть случаи применения норм права дипломатического убежища и в других странах. Для более удобного быстрого рассмотрения применения норм института на практике, необходимо исследовать сразу группу стран одного какого либо региона. В данном случае буду рассматривать страны, входящие в Азиатско-Тихоокеанский регион. 
Причина выбора данного региона в том, что он включает в себя множество стран с разным политическим режимом и государственным строем, а также страны расположены на разных континентах.

Одно из демократических стран АТР является США, которое предоставляет право дипломатического убежища. США практикует такую деятельность на протяжении нескольких десятков лет. Не удивительно, что США вошла в десятку стран по количеству подаваемых запросов на предоставление убежища, в том числе и дипломатического. С увеличением числа запросов США ввело некоторые критерии, которые позволяют отсечь половину желающих. Но введение данной процедуры не отпугнуло большинство желающих получить убежище на территории Соединенных Штатов.[9, с.1]

Российская Федерация так же предоставляет убежище на своей территории. Россия, как и США ратифицировала большинство международных конвенций и соглашений, связанных с регулированием международных отношений, но в национальном законодательстве нет закрепления правового статуса дипломатического убежища. Как и нет точного толкования «дипломатического убежища», которое было бы закреплено в каком-нибудь нормативно правовом акте. Предоставление убежища дипломатическими, консульскими и военными учреждениями не предусмотрено право защиты иностранного лица, но также можно заметить, что данное право и не запрещает использовать данные учреждения в виде убежищ для иностранных лиц. Например, еще в конце XIX века русская дипломатическая миссия на территории Кореи предоставляют дипломатическое убежище для корейского короля Коджона. Это дипломатическое учреждение служило убежищем для короля более года, при этом государь не потерял свою власть.

В Китае до начала XX века сохранялись привилегии целому дипломатическому кварталу. Впоследствии данные привилегии были отменены, но правительство Китая позволяло иностранным представительствам использовать свои учреждениям в роли дипломатического убежища. Таким образом, множество северокорейских беженцев получили дипломатическое убежище на территории разных государств, в том числе и США.

В заключении могу добавить, что развитие института дипломатического убежища медленно, но развивается и модернизируется. Хотя до сих пор стоят вопросы в легитимации и его правового статуса не только на международном уровне, но и на национальном уровне любого государства. Однако, несмотря на различие в политических режимах Азиатско-Тихоокеанского региона, данный институт процветает. Об этом говорят многочисленные случаи предоставления дипломатического убежища этими странами. Перспектива в дальнейшем развитии института “дипломатического убежища” ждет большое будущее. Об этом можно судить по частичному принятию государствами права на предоставления дипломатического убежища, так как есть прецеденты, что страны, не практикующие данный институт, предоставляли убежище для иностранных лиц, на территории представительств своего государства, в виде исключения из правил.

Большой вопрос стоит о законности норм дипломатического убежища, его легитимности действий и правового статуса, что вызывает некоторое время споры в мировом научном сообществе. При этом, государства Латинской Америки, имея единственно существующие оформленные источники института - признают право дипломатического убежища, а остальные страны - по большей части, отрицают, но частично.

\section{Литература}

1. Всеобщая Декларация прав человека от 10 декабря 1948 г.

2. Венская конвенция о дипломатических сношениях от 18 апреля 1961 г. Режим доступа: http://www.un.org/ru/ documents/decl_conv/conventions/dip_rel.shtml

3. Венская конвенция о консульских сношениях от 24 апреля 1963 г.

4. Конвенция о статусе беженцев от 28 июля 1951 г.

5. Устав Организации Объединенных Наций от 26 июня 1945 г.

6. Блищенко И. П. Дипломатическое право. М., 2001.

7. Ривье А. Учебник международного права. М., 2001.

8. Сало Э. Международные соглашения стран Латинской Америки. М., 1994.

9. Режим доступа: http://www.koreana.ru/?id=1913\&page=675\&pg=2\&type $=10$

\section{Сравнительный анализ экологического законодательства РФ и КНР}

(С) В. Ж. Чимитдоржниева

студентка 4-го курса юридического факультета ФГБОУ ВО «Бурятский госуниверситет»

Россия, г. Улан-Удэ viktoriya231832@gmail.com

Все в природе взаимосвязано, мы живем на одной Земле, которая не знает разделения территорий на государства, поэтому сравнительный анализ экологического законодательства поможет нам в принятии наиболее эффективных и рациональных мер и методов по охране окружающей среды.

Основной целью принятия Повестки дня на XXI век, проходившей в Рио-де-Жанейро в 1992 году является сохранение экосистемы для будущих поколений. Но наши поставленные задачи, принципы не выполняются должным образом. Результатом нашей деятельности является загрязнение Земли, в Бурятии - это загрязнение 
воздуха, озера Байкал, достояния не только республики, но и всего мира, многочисленные вырубки деревьев, пожары и т.д. Около $60 \%$ побережья священного озера покрыто спирогирой-водорослью, ранее в Байкале почти не встречавшейся. Возникает вопрос, что мы оставляем нашему будущему поколению? В Пекине специально одевают маски для защиты от ядовитого смога. Врачебное сообщество говорит о таких последствиях загрязнения ОС как рак легких, одышка или инсульт. Даже недолговременное пребывание туристов может привести к раздражению слизистой оболочки глаз и дыхательных путей, а также головные боли. По данным ВОЗ, вдыхание такого воздуха приравнено к пассивному курению [9, с. 8].

Система нормативно- правовых актов экологического законодательства - это совокупность законов и иных нормативно- правовых актов, регулирующих отношения в сфере охраны окружающей среды и рационального использования природных ресурсов[10, с. 5].

Конституция РФ является фундаментальным, основным нормативно- правовым актом, обладающим высшей юридической силой. Согласно ст. 9 Конституции РФ земля и другие природные ресурсы могут находиться в частной, государственной, муниципальной и иных формах собственности [1, с. 2].

Решение вопроса об информировании населения об экологических опасностях немалый правовой смысл имеет норма ст. 41 Конституции РФ об ответственности соответствующих должностных лиц за сокрытие фактов и обстоятельств, создающих угрозу для жизни и здоровья людей (ч. 3 ).

Согласно ст.42, 40 Конституции Российской Федерации и Конституции Республики Бурятия: «Каждый имеет право на благоприятную окружающую среду, достоверную информацию о ее состоянии и на возмещение ущерба причиненного его здоровью или имуществу экологическим правонарушением» [1, с. 7].

В соответствии со ст. 57 Конституции Республики Бурятия: «Каждый обязан сохранять природу и окружающую среду, бережно относиться к озеру Байкал и другим природным богатствам» [1, с. 10].

В совместном ведении находятся вопросы природопользования, охраны ОС и обеспечения экологической безопасности, в т.ч. развитие земельного, водного, лесного законодательства, законодательства о недрах и охране ОС (ст. 72) [1, с. 15].

Нормотворческая деятельность субъектов РФ является неотъемлемой частью федеративного устройства РФ. Нормативно- правовые акты Республики Бурятия: закон РБ «Об охране окружающей среды», Закон Республики Бурятия от 9 марта 2010 г. N 1254-IV "Об отходах производства и потребления в Республике Бурятия», Закон Республики Бурятия от 5 мая 2011 г. N 1997-IV "Об охране зеленых насаждений в населенных пунктах Республики Бурятия", закон РБ от 29 декабря 2005 года N 1438-III «Об особо охраняемых природных территориях РБ», закон РБ «Об охране атмосферного воздуха», глава 4 закона РБ от 05.05 .11 «Об административных правонарушениях» и т.д.

ФЗ РФ «Об охране ОС» определяет объекты охраны ОС, ключевые категории (понятия), принципы охраны ОС, виды ответственности. К тому же установлены полномочия органов государственной власти, органов МСУ, права и обязанности граждан, общественных объединений и т.д. В законе перечисляются виды нормативов воздействия на окружающую среду, но ни один из них не устанавливается законом, что может привести к произволу устанавливающих нормативы органов [5].

Механизмы охраны ОС в КНР и РФ являются практически идентичными: нормирование и стандартизация, мониторинг, лицензирование, меры экономического стимулирования, экологическая экспертиза, сертификация, аудит, оценка воздействия планируемой деятельности на ОС, экологический контроль.

В систему нормативно- правовых актов РФ в сфере охраны ОС и рационального природопользования также входят: НПА Президента РФ; НПА Правительства РФ; НПА федеральных министерств и ведомств; конституции, законы и иные НПА субъектов РФ; НПА органов местного самоуправления; локальные нормативно-правовые акты;

Нормативно- правовая база КНР. У Китая долгая история охраны окружающей среды. На раннем периоде истории Китая были выработаны простые экологические законы. 4000 г. до н.э - 21 в. до н.э во время правления императоров Юя и династии Шан (Инь) были опубликованы законы «Ицзоушу - Дацзюй»: «Весной в период правления Юя запрещалась рубка деревьев в горных лесах для того, чтобы позволить растениям хорошо расти, а летом запрещалась ловля рыбы, чтобы обеспечить размножение рыб». Это высказывание на данный момент также рассматривается как норма права, имеющая скрытый запретительный характер. В наше время многие китайские ученые рассматривают эту фразу как 1 в мире норму права в области охраны ОС [6, с. 54].

Система источников экологического права КНР состоит из Конституции, закона КНР «Об охране окружающей среды», отдельных законов и других нормативных актов в сфере охраны окружающей среды, а также экологические стандарты.

Конституция КНР является также фундаментальным законом. В отличие от Конституции РФ Конституция КНР определяет, что собственность на природные ресурсы принадлежит государству и делится она на общенародную или коллективную.

Общенародная собственность включает в себя:

-собственность на полезные ископаемые и другие природные ресурсы. В ст. 9 устанавливается общенародная собственность на полезные ископаемые, леса, водные ресурсы, пустоши, горы, степи и другие природные ресурсы;

-собственность на городские земли. В ст. 10 Конституции КНР предусматривается, что земля в городах является государственной собственностью.

Коллективная собственность на природные ресурсы в соответствии с Конституцией Китая устанавливается на:

-не принадлежащие государству леса, пустоши и другие природные ресурсы, которые в этом случае согласно ст. 9 могут находиться в коллективной собственности в соответствии с законом; 
-на сельхозугодья и земельные участки в городах. В соответствии со ст. 10 сельхозугодья могут находиться в государственной и частной собственности;

-на землю под жилыми помещениями и приусадебные участки в соответствии со ст. 10 Конституции [2, с. 2].

Китайская конституция содержит принципы разработки и использования природных ресурсов. В соответствии со ст.9 Конституции КНР государство гарантирует разумное использование природных ресурсов, берет под охрану ценные виды животных и растений. Статья 10 запрещает любым организациям или физическим лицам присваивать в собственность, продавать, сдавать в аренду землю. Все организации и физические лица должны разумно использовать землю. В ст. 51 Конституции КНР устанавливается, что граждане не должны наносить ущерб государству, обществу, коллективу, окружающей среде [2, с. 8].

Закон КНР «Об охране окружающей среды» является также базовым законом в сфере охраны ОС, в котором определены права и обязанности правительств разных ступеней, общественных организаций, граждан, меры юридической ответственности и т.д.

Разработаны также специальные законы. В их числе: лесной кодекс

КНР, закон «О предотвращении и ликвидации загрязнения вод», белая книга КНР и т.д.

Центральные народные правительства разработали около 50 подзаконных актов и более чем тысячи местных нормативно-правовых актов.

Система экологического контроля состоит из правительств всех ступеней, которые отвечают за реализацию этих законов, ведомства (бюро) по охране ОС осуществляют единый административный контроль, а организации выполняют конкретную работу.

Основные изменения: Постоянным комитетом Всекитайского собрания народных представителей (ПК ВСНП) одобрены изменения в Закон КНР «Об охране окружающей среды», который вводит неограниченную материальную ответственность. Изменения вступили в силу с 1 января 2015 г.

В КНР вводится система длительных штрафов за загрязнение окружающей среды (ст. 59 Закона КНР «Об охране окружающей среды»).

За незаконные сбросы загрязняющих веществ предприятия и другие организации должны выплатить штраф и устранить нарушения. Если они не устраняются, то с нарушителей каждый день взимается штраф, исходя из первоначальной суммы. В российской правовой системе нет понятия длительных ежедневных штрафов [7, с. 1].

Местные власти также имеют право вводить ежедневные дополнительные штрафы за нарушения экологических норм и нормативов. Такие полномочия у органов местного самоуправления РФ отсутствуют.

В первое полугодие 2015 года общий размер штрафов составил 236359900 юаней, 1814 предприятий были ликвидированы, 1092 компании прекратили производство, в суд передано 740 дел.

Таким образом, конечным результатом быстрого темпа развития экономики Китая явилось тяжелое состояние окружающей среды Китая, что вызвало острую необходимость изменения основного закона. Правовая система Китая имеет много общего с российской правовой системой, аналогичные институты (Министерство охраны окружающей среды КНР- Министерство охраны окружающей среды РФ), принимаемые меры(меры экологического контроля), законы(Закон КНР «Об охране окружающей среды- Закон РФ «Об охране окружающей среды»). Эти сходства помогут компетентным государственным органам принять наиболее рациональные меры для предотвращения загрязнения окружающей среды. Охрана окружающей среды - это деятельность не только уполномоченных государственных органов, но и непосредственные осознанные действия каждого человека. Если мы сохраним нашу окружающую среду, наши природные богатства это будет являться огромным финансовым, политическим и духовным вложением в нашу жизнь, в наше будущее поколение. Например, дышать в Пекине- всё равно, что ежедневно выкуривать 40 сигарет. И поэтому канадский начинающий бизнесмен доставлял баллоны с чистым горным воздухом в Китай. Стоимость каждого баллона сто юаней - около пятнадцати долларов.

\section{Литература}

1. Конституция Российской Федерации [Электронный ресурс] // Сайт «Гарант». URL : http://base.garant.ru/10103000/.

2. Федеральный закон от 10 января 2002 г. №7- Ф3 «Об охране окружающей среды» // Российская газета. 2002. 12 янв.

3. Конституция Китайской Народной Республики [Электронный ресурс] // Сайт «Законодательство Китая». URL : http://chinalawinfo.ru/constitutional_law/constitution.

4. Закон КНР «Об охране окружающей среды» [Электронный ресурс] // Сайт «Бизнес в Китае». URL : http://www.asiabusiness.ru/law/law2/resources/environment/.

5. Изменения в законе КНР «Об охране окружающей среды » [Электронный ресурс] // Сайт «Блок о законодательстве KHP». URL : http://cnlegal.ru/uncategorized/china_environment_protection_law_amended/.

6. Борисов А. А. Экологическое право: конспект лекций. М., 2015. 488c._amended/.

7. Китай и Россия в международной системе обеспечения охраны окружающей среды Электронный ресурс] // Сайт «Молодой ученый». URL : http://www.moluch.ru/archive/91/20057/ .

8. Лю Хун Янь Развитие экологического права Китая и России: дис. ...канд. юр. наук. М., 2005. С. 89.

9. Последнее китайское предупреждение [Электронный ресурс] // Сайт «Газета.ru». URL: http://www.gazeta.ru/social/2015/12/18/7976093.shtml

10. Рыженков А. Я., Анисимов А. П. Модернизация российского экологического законодательства в контексте опыта Китайской народной республики // Вопросы российского и международного права. 2013. № 2. С. 123-136. 


\section{Монголия во время правления Богдо-Гэгэна (1911-1924 гг.)}

(ㄱ) С. Д. Шойбонова

студентка 4-го курса юридического факультета ФГБОУ ВО «Бурятский госуниверситет»

Россия, г. Улан-Удэ

yuzhikovazheniya@list.ru

Новый политический режим, сформированный в Монголии, с точки зрения формы являлась неограниченной теократической монархией, при которой глава государства - религиозный лидер - возглавлял и духовную, и светскую сферы жизни общества. Такой выбор, с одной стороны, был обусловлен старой традиционной концепцией власти, с другой, то, что Богдо-гэгэн сам имел чрезвычайно высокий авторитет «живого божества» среди верующих, составлявших подавляющее большинство в государстве.

Первым неограниченным монархом Монголии был Богдо-гэгэн Восьмой Джебдзундамба хутухта или Богдо-хан [2, с. 137]. Он родился в начале 1870 года в Тибете в семье бухгалтера министерства финансов и в 1911 году был избран следующим Богдо-гэгэном в столице Монголии Их Хурээ. Он активно поддержал инициативы, предложенные чинваном Ханддоржем и ламой Цэрэнчимэдом, и возглавил в 1911 году национально-освободительную революцию в Монголии. При провозглашении его лидером государства в качестве титула была избрана фраза «Хозяин Монголии, взявший на себя и светскую, и религиозную власть, светлейший владыка» [1, с.225]. После этого он стал возглавлять всевозможные руководящие посты во Внешней Монголии, в частности:

1. Лидер национальной революции 1911 года;

2.Духовный учитель всех верующих буддистов (в соответствии с положением духовного лидера страны);

3. Поскольку он являлся перерождением Святейшего Занабазара, потомка Чингисхана, то стал считаться и прямым потомком Чингисхана (наследником фамилии Борджигин - рода Чингисхана);

4. Благодаря своему положению в обществе и титулов стал самым богатым и почитаемым человеком во Внешней Монголии;

5. В целях того, чтобы вокруг него не возникло политической борьбы среди светских правителей, было решено отдать ему и светскую власть в государстве.

Правитель Джебдзун-Дамба хутухта единолично осуществлял неограниченную власть над государственными и духовными делами, впоследствии его указы автоматически стали основой нормативной правовой базы существования монгольского государства. В книге «Собрание законодательных актов Монголии, принятых указом Богдо-гэгэна» отмечается, что «любое постановление Джебдзундамбы, направленное духовенству, должно быть исполнено одновременно и всеми соответствующими светскими властями» [2, с. 28].

Постановлениями Верховного правителя определялись все вопросы, связанные с решением актуальных для страны вопросов, назначением и отставкой чиновников, награждением и повышением в должности отличившихся на службе, ратификацией соглашений с другими государствами, вручением верительных документов послам, направляемым за границу. Богдо-гэгэн должен был знакомиться со всеми официальными предложениями, поступавшими из министерств, проверять их и «постановлять опубликовать их своим одобрением».

Временное исполнительно-консультативное собрание по всем вопросам, расположенное в Хурээ, провозгласило независимость государства, определило Богдо-гэгэна неограниченным монархом, установило первичные основы функционирования государства, после чего передало свои полномочия соответствующим министерствам постоянного Правительства. Сразу же после своего прихода к власти, Верховный правитель своим постановлением утвердил создание пяти министерств (внутренних дел, иностранных дел, военных дел, финансовых дел, судебных дел), а также назначил их руководителей и их заместителей. При этом, министерство по внутренним делам было по статусу выше остальных, вследствие чего соответствующий министр стал исполняющим обязанности главы всего Правительства в целом.

Первым министром внутренних дел назначили ламу Г.Цэрэнчимэда, и официально его министерство занималось «разрешением всех дел, связанных с реализацией внутриполитической власти» [3, с.74]. В составе этого министерства были следующие отделы: Титульный отдел, отвечающий за правила наследования титулов, чинов, оформления и сохранения генеалогических древ старейших родов; Протокольный отдел, руководящий деятельностью по осуществлению государственных церемоний, и Главный отдел, отвечающий за создание законопроектов, регистрацию населения и административно-территориальные вопросы.

В феврале 1912 года после всеобщего провозглашения независимости государства, Богдо-гэгэн издал указ, согласно которому вторым по важности было названо Министерство по внешним делам. Первым его главой был М.Ханддорж. Южный отдел министерства отвечал за отношения с Китайской республикой, Северный отдел - за связи с Российской империей, Центральный отдел, по аналогии с другими министерствами, занимался общими вопросами выработки внешнеполитической стратегии, консультированием.

Третьим по важности Министерством - военным - руководил жунван Г. Гомбосурэн [4, с. 163]. В составе этого министерства были Отдел по военной политике, разрабатывавший нормы и правила несения военной службы, регистрировавший военнослужащих и решавший вопросы о ведении боевых действий; Отделом, занимавшимся подготовкой милиции, а также военнослужащих вооруженных сил, командующих войсками; Отделом рангового контроля, отвечавшим за присвоение воинских званий и наград. 
Министерство финансов возглавил жунван Г. Чагдаржав. В составе министерства был Отдел по внутренним процентным ставкам, отвечавший за финансовые доходы государства и торговые дела, Отдел иностранных процентных ставок, занимавшийся определением ставок за аренду имущества иностранным гражданам, а также Отдел таможенных сборов, отвечавший за решение таможенных вопросов.

Пятое министерство - Министерство суда - возглавил жунван М. Намсрай, имело правоохранительные и судебные функции. В его составе были отделы по регистрации дел, проведению следственных мероприятий, определению наказаний, исполнению наказаний и проведению амнистии.

Центральными органами политической власти теократической Монголии стали не пять, а шесть министерств - к вышеупомянутым в июне 1912 года добавилось и Министерство по таможенным делам. Его главой являлся бывший заместитель министра финансов бэйле Доржцэрэн. Представительства данного министерства были открыты в городах Кяхта, Улястай, Кобдо, а с началом сбора таможенных пошлин с граждан страны и иностранцев наблюдалось сильное укрепление бюджета Монголии, для которого этот источник финансирования стал серьёзным подспорьем.

Для укрепления контроля над исполнительной властью в середине 1912 года Богдо-гэгэн создал ещё одно министерство - Министерство всеобщего управления - руководителем, которого стал сайнноёнхан Намнансурэн, одновременно официально ставший первым Премьер-министром Монголии. Поскольку верховные ламы хотели, чтобы над премьер-министром, помимо самого Верховного правителя, был ещё и их представитель, было также создано Министерство помощников от духовенства светским министрам [3, с. 72]. Его возглавил лама Дашзэвэг, который по долгу службы стал контролировать деятельность Премьер-министра страны.

В форме и сущности работы центральных органов политической власти отражена особенность утверждения неограниченной теократической монархии в Монголии. В частности, каждому министерству был выделен один из буддийских святых, который должен был помогать их работе «свыше». Кроме того, порядок работы определялся с оглядкой на гороскопы (зурхай), а в начале каждого заседания совершались религиозные обряды. В своих речах Верховный правитель, помимо определения основных направлений политики и распределения обязанностей, обращался к верующим с проповедями.

Вышеупомянутые министерства, являясь частью системы центрального политического управления, сыграли важную роль в соответствующих процессах политического и социально-экономического реформирования государства.

Согласно монгольским архивам, с 1911 по 1919 гг. правительство издало около 200 законов, правил, постановлений и других актов, одобренных Богдо-гэгэном. Наиболее важными из которых были: правила заготовки сена и выделения плодородных земель под пастбища и пашни; о реорганизации войск четырех аймаков; правила для Шабинского ведомства, казначейства и министерств; о мобилизации и защиты южных границ; договоры с Россией, Тибетом и Китаем; нота правительству России о том, чтобы при переговорах с Китаем о Монголии вначале ставилось в известность монгольское правительство; правила из 32 пунктов о наказаниях для духовных лиц, которые находились в местах проживания большинства мирян и участвовавших в греховных действиях [5, с. 171].

В теократический период законодательство постепенно гуманизировалось. В 1913 г. под влиянием России были заменены жестокие цинские виды наказний - вытягивание жил и четвертование на расстрел. Девять главных видов пыток, применявшихся при судопроизводстве в цинскую эпоху, применялись все реже. Следствия, подразумевающие «Божий суд», стали применять чаще [ 5. с. 177].

\title{
Литература
}

1. Авирмэд Э. Монгол хууль: Уламжлал, шинэчлэл Монголын төр эрх зүйн түүхэн сэдэв / Э. Авирмэд, Д. Дашцэдэв, Г. Совд// Education Company. Улаанбаатар, 1997. 107 с

2. Батсайхан О. Монголын сүүчийн эзэн хаан VIII богд Жавзандамба (Последний император Монголии, Богдо-гэгэн VIII Жавзандамба) / О.Батсайхан. Улаанбаатар: ШУА-Олон улс судлалын хүрээлэн, 1997. 707 с.

3. Болдбадрал Ж., Лунээжанцан Д. Монгол улсын төр, эрх зүйн түүхэн уламжлал. Улаанбаатар, 2004. 450 с.

4. Дэндэв Л. Монголын товч түүх. Улаанбаатар, 1934. С. 2; Сандаг Ш. Монголын улс төрийн гадаад харилцаа (18501919). Улаанбаатар, 1971. 244 с.

5. Кузьмин С.Л. Монархическое Монгольское государство в 1911-1924 г. М.: Восточная литература, 1995.145 с.

\section{Конфликт интересов США и КНР в Азиатско-Тихоокеанском регионе}

\author{
(C) Е. А. Южикова \\ студентка 4-го курса юридического факультета \\ ФГБОУ ВО «Бурятский госуниверситет» \\ Россия, г. Улан-Удэ \\ yuzhikovazheniya@list.ru
}

\footnotetext{
Данная статья посвящена сложившейся ситуации в Азиатско-Тихоокеанском регионе, а именно конфликту интересов США и Китая, который был обусловлен «восхождением» Китая. Приводится историческая справка развития дипломатических отношений между этими странами после холодной войны, а также анализируются вопросы безопасности и экономической интеграции в контексте данного конфликта.
} 
За последние десятилетия роль стран Азиатско-Тихоокеанского региона в экономической, политической, военно-технической сферах значительно усилилась. В первую очередь это связано с динамичным развитием в области экономики. Во время экономического кризиса 2008г., страны АТР потерпели меньшие убытки, нежели другие страны. Доля совокупного ВВП стран АТР увеличилась с 29,6 в 2001г. до 67,5 млрд. долл.в 2014г., а удельный вес региона в глобальной экономике - с 57,6 до 62,6\% [2]. Согласно рейтинга стран и территорий мира по показателю ВВП за 2015г. Китай занимает второе место с ВВП 10354 832\$[3].

Превращение Китая в могущественную державу воспринимается в Вашингтоне как угроза мировому лидерству США. Действительно, еще в 1990-е годы Роберт Росс, научный сотрудник Центра восточноазиатских исследований Гарвардского Университета, прогнозировал биполярность системы международных отношений, в которой роль лидера в данном регионе будет поделена между США и Китаем.[4, с. 81-118].

В 2015 г. была принята новая Стратегия Национальной Безопасности США. Взаимоотношения с Китаем один из ключевых пунктов проведения внешней политики. Хотелось бы провести сравнение с предыдущей стратегией 2010г., которая приветствовала «восхождение» Китая. Предполагалось отслеживание программ модернизации Китая и принятие ответных действий для гарантии безопасности глобальным и региональным интересам США и его союзников. Таким образом, отношения США и КНР были направлены на конфронтацию. По сравнению с данной концепцией в 2015г. Вашингтон переосмыслил подходы к взаимодействию с КНР. Данный документ предполагает готовность США применить силу в отношении Китая, если последний не будет соблюдать нормы международного права по широкому спектру вопросов (включая морскую безопасность и торговлю, а также права человека), а также обвиняет китайское правительство в киберпреступлениях - воровстве технологий для получения коммерческой прибыли.

Первые попытки сближения двух могущественных держав были весьма удачно предприняты в 1969г. с началом вывода войск США из Вьетнама. В то же время взаимоотношения Китая и СССР переросли из дружественных во враждебные. Это в свою очередь связано с вводом войск СССР в Чехословакию. В июле 1972г. было подписано Шанхайское коммюнике, согласно которому страны обязались уважать внешнюю и внутреннюю политику государств, намеревались продолжить дальнейшую работу по укреплению взаимного доверия и рассмотреть перспективы экономического сотрудничества, США признавали всю целостность Китая, включая остров Тайвань. Однако, их взаимоотношения были резко ухудшены в 1982г., когда США без уведомления властей КНР начали поставлять оружие на Тайвань. В 1997 г. председатель КНР Цзянь Цзэминь в первые за долгое время посетил США и было принято решение сотрудничать в областях атомной энергетики, разработки эффективных методов решения споров в торговле.

Вопрос безопасности в контексте конфликта интересов США и Китая чрезвычайно актуален. Наиболее актуальными зонами столкновения считаются японо-китайские и китайско-филиппинские противоречия вокруг островов Южно-Китайского и Восточно-Китайского морей. В последнее время особое внимание уделяется архипелагу Спратли. Китай стремится снабдить данный архипелаг маяками в целях предоставления навигационных и спасательных услуг в случаях бедствий. Однако, на данную территорию помимо Китая заручившись поддержкой США претендуют Бруней, Вьетнам, Малайзия, Тайвань, Филиппины и Япония. Таким образом, хотелось бы отметить, что именно США является агрессором в данном регионе и обещают странам Юго-Восточной Азии оказать всяческую поддержку в случае обострения отношений с КНР.

Еще одной спорной территорией выступает архипелаг Дяоюйдао (яп. Название Сенкаку), обнаруженный в XIV в. китайским адмиралом Пин Шимином. C XIV по XIX века архипелаг принадлежал Китаю и лишь в результате Китайско-Японской войны территория перешла во владения Японии. С тех пор принадлежность островов постоянно оспаривается обеими сторонами. Японию поддерживает США, отмечая, что территория архипелага подпадает под юрисдикцию Договора о взаимном сотрудничестве и в случае вооруженного наступления готовы оказать всяческую поддержку. Китайские власти отвечают, что готовы любыми способами защищать свою территориальную целостность и национальный суверенитет. Таким образом, на сегодняшний день вопрос остается все так же нерешенным.

Так же ключевой проблемой конфликта интересов США и КНР является остров Тайвань. Вооруженные силы США, находящиеся на территории острова являются серьезной преградой для воссоединения Китая. Кроме того, США активно поддерживают глобальную борьбу за независимость Тибета, выстраивают независимые отношения с Тайванем, продают оружие, выстраивают систему противоракетной обороны.

Наиболее успешным проектом региональной интеграции является АСЕАН. Интересы Китая и АСЕАН в отношении США совпадают: оба акторане желают усиления роли США в АТР, и проводят с ним равноудаленную и сбалансированную политику. Все участники данного объединения подчеркивают территориальную целостность Китая, признавая Тайвань частью территории. АСЕАН и КНР имеют взаимодополняемую экспортноориентированную экономику. Подписан ряд двусторонних соглашений: «О торговли товарами» 2004г. и «О торговле услугами» 2007г. Однако, другие участники организации считают необходимым участие в данном сотрудничестве США как гаранта стабильности и безопасности в регионе.

Ведутся переговоры о создании Транстихоокеанского партнерства, официальной целью которого является создание экономического блока, которому будет принадлежать 40\% мировой экономики. На деле же это представляется как неограниченный доступ к рынкам и экономикам стран АТР. В переговорном процессе участвуют около 12 государств-«союзников» США.

Конфликт интересов США и КНР обусловлен укреплением Китая на международной арене как одного из наиболее могущественных акторов международных отношений и нежеланием США потерять господствующие 
позиции на мировой арене. Необходимость сотрудничества КНР с другими странами, в особенности с Россией смогло бы предотвратить усиливающуюся роль манипулятора США в регионе и разработать общую стратегию противодействия гегемонистским амбициям США.

Хотелось бы отметить, что сталкивание интересов Китая и США вряд ли когда-нибудь вызовет вооруженный военный конфликт, а будет продолжать выражаться в экономическом соперничестве, территориальных противоречиях и деятельностью в рамках международных организаций.

\section{Литература}

1. Белобров Ю. Геополитические амбиции и интриги США в АТР. Международная жизнь. 2015. №9. Режим доступа: https://interaffairs.ru/jauthor/num/2015/9

2. Обзор экономической ситуации в Азиатско-Тихоокеанском регионе (май 2015г.) / Российский Центр исследования АТЭС (РЦИ АТЭС) при РАНХ и ГС

3. Рейтинг стран мира по уровню валового внутреннего продукта. Гуманитарная энциклопедия [Электронный ресурс] // Центр гуманитарных технологий. - 10.10.2009 (последняя редакция: 16.02.2016). URL: http://gtmarket.ru/ratings/rating-countries-gdp/rating-countries-gdp-info

4. Robert R. Ross. The Geography of the Peace: East Asia in the Twenty-first Century // International Security, Vol. 23, No 4 (1999). C. 81-118.

5. US National Security Strategy, May $2010 / /$ www.whitehouse.gov

6. US National Security Strategy, February 2015 // www.whitehouse.gov 


\title{
ІІІ. ГРАЖДАНСКО-ПРАВОВЫЕ ПРОБЛЕМЫ СРАВНИТЕЛЬНОГО ПРАВОВЕДЕНИЯ В СТРАНАХ АТР
}

\author{
Перспективы введения в России института частных судебных приставов \\ на примере стран АТР
}

() C. A. Баиров

студент 4-го курса юридического факультета ФГБОУ ВО «Бурятский госуниверситет»

Россия, г. Улан-Удэ Sergeo.94@mail.ru

Принудительное исполнение судебных актов, актов других органов и должностных лиц возлагается на Федеральную службу судебных приставов и ее территориальные органы (ст. 5 ФЗ от 02. 10. 2007 г. «Об исполнительном производстве» № 229-Ф3). Данное исполнение осуществляется в целях защиты нарушенных прав, свобод и законных интересов граждан и организаций, а также в целях обеспечения исполнения обязательств по международным договорам Российской Федерации.

В последнее время все чаще говорится о том, что существующая система исполнения судебных решений не способна в достаточной степени защитить интересы взыскателей, дает возможность должникам безнаказанно уклоняться от исполнения судебный решений, а это, в свою очередь, дискредитирует идею правосудия, превращая институт судебной власти в формальный бесполезный орган. Низкая эффективность исполнения судебных актов приводит к возникновению проблем не только в правовой сфере, но и в общесоциальном аспекте, так как это способствует формированию и укоренению в обществе правового нигилизма, неуважительного отношения к закону и суду, поощрению противоправного и асоциального типа поведения. В качестве причин такого положения вещей А. Г. Рубцов называет ограничение полномочий судебных исполнителей, их загруженность, вопросы оплаты труда, отсутствие заинтересованности исполнителей в надлежащем исполнении актов и другие $[4$, c.19]. Также данный автор отмечает, что судебные приставы обременены множеством существующих в законодательной базе проблем и несоответствий.

В последние годы необходимость модернизации системы исполнительного производства была воспринята законодателем, что повлекло подготовку законопроекта о внесении изменений в законы «Об исполнительном производстве» и «О судебных приставах», выполненную рабочей группой при Минюсте РФ под руководством Владимира Зубрина. Данный законопроект в целях повышения эффективности правосудия предусматривает введение института частных судебных приставов-исполнителей параллельно с государственной системой исполнения судебных решений.

Разработчики законопроекта предлагают предоставить взыскателям (физическим и юридическим лицам) право выбора варианта исполнения судебного решения. Решение может быть исполнено как через государственных, так и через частных приставов. При этом объем полномочий у государственных и частных приставов будет одинаковым. В законопроекте указано, что частный судебный пристав сможет «принять все исполнительные документы, за исключением исполнительных документов о взыскании с государства и в пользу государства».

Нынешнее исполнительное производство признается неэффективным. Так, по данным на 2012 год, доля оконченных фактическим исполнением производств в системе Федеральной службы судебных приставов (ФССП) составляет менее половины (45,4\%), а по суммам отношение взысканной задолженности к подлежащей взысканию составляет 18,5\%. Остаток невзысканных сумм достигает 2 трлн рублей. При этом, как указано в документе, максимально эффективно исполняются документы, связанные со взысканием налоговых платежей и штрафов, а взыскание в интересах граждан и организаций осуществляется менее успешно [1].

Предложенная система исполнения судебных актов, по мнению разработчиков законопроекта, позволит не только повысить эффективность исполнения судебных актов (увеличит процент исполнения судебных актов) для частных взыскателей, но также позволит разгрузить ФССП, тем самым значительно снизятся расходы государства на содержание данного института.

Отметим, что в мировой практике существуют частная, государственная (публично-правовая) и смешанная системы судебных исполнителей. К примеру, в США исполнением судебных решений занимаются государственные служащие службы маршалов. Это одна из старейших федеральных государственных должностей, представители которой имеют большие полномочия. 
Другой моделью организации принудительного исполнения является частноправовая. Ей присуще то, что выполняют коллекторские агентства, тем самым освобождая государственные органы для работы над более серьезными делами. Это позволяет государственным органам, отвечающим за исполнение судебных решений, отдавать предпочтение более трудным или потенциально спорным делам, где государственные органы наиболее необходимы и эффективны. Методы работы частных коллекторских агентств различаются в различных местах, как и уровень регулирования в штатах, где они работают. Кроме этого, многие частные взыскания долгов осуществляются агентами, которым кредитор продает судебное решение, и эта продажа была должным образом зарегистрирована в суде, в котором было принято это решение. В этой связи коллекторскому агенту передаются все права кредитора, и кредитор получает согласованный авансовый платеж от коллекторского агента. Такое соглашение также включает в себя использование коллекторскими агентами, при необходимости, ресурса государственных ведомств.

Процедура исполнительного производства в США регулируется законодательными актами штатов и правилами гражданского судопроизводства конкретного штата

В современных системах права распространена и публично-правовая модель принудительного исполнения с элементами частно-правовой модели (смешанная модель). Эта модель характеризуется тем, что в системе принудительного исполнения судебных актов действуют как государственные, так и частные судебные исполнители. Такая модель действует в Канаде и других странах АТР. Принудительное исполнение в Канаде осуществляются шерифами (sheriff), состоящими на государственной службе, а также частными судебными исполнителями (bailiff) или специализированными фирмами, предоставляющими на коммерческой основе услуги в области правоприменения по гражданским делам, которые получают лицензию на данную деятельность от государства и осуществляют ее самостоятельно.

Типология судебных приставов (в канадской правовой терминологии - bailiff или sheriff) различается в зависимости от их подведомственности и вытекающего отсюда соответствующего правового статуса, а также функциональных обязанностей.В последние годы в Канаде наблюдается тенденция передачи полномочий в сфере гражданского исполнительного производства от государственных ведомств частным агентствам.

В качестве примера можно привести правовую реформу в провинции Альберта, которую многие эксперты в Канаде называют весьма успешным проектом реформирования системы исполнительного производства, опыт которого можно распространить на всю страну. В 2006 г. в провинции Альберта вступил в силу закон о гражданском исполнительном производстве, в котором были даны определения частного бейлифа и специализированного агентства по исполнительному производству, подробно прописан их статус, права и обязанности, порядок взаимодействия с государственными органами, а также механизм организации исполнительного производства. Надзорные функции над деятельностью частных бейлифов и агентств были возложены на министерство юстиции провинции Альберта, а точнее на специальный отдел судебного департамента ведомства - офис шерифа по вопросам исполнительного производства. Данное подразделение занимается лицензированием частных бейлифов и агентств, а также имеет полномочия проводить расследования фактов несоблюдения деловой этики с их стороны в отношении как кредиторов, так и должников. Целью реформы было минимизировать роль суда, оставив ему преимущественно надзорные полномочия, а также свести исполнительное производство по гражданским делам к административной процедуре, осуществляемой в основном через специализированное агентство, действующее на основе инструкций кредитора, повысив тем самым роль последнего в общей системе мер исполнительного производства. Важным нововведением стала отмена прежнего законодательного требования к кредитору получать судебный приказ на наложение ареста на имущество. Согласно закону о гражданском исполнительном производстве, только специализированные агентства могут осуществлять данную меру исполнительного производства. Проблемы, связанные с выбором моделей принудительного исполнения решений, исследуются в современной юридической литературе такими учеными, как В. В. Ярков, М. 3. Шварц, Г. Д. Улетова и другими. Согласно их точке зрения, наиболее приспособленной к потребностям функционирования современного общества и государства при реализации гарантий своевременного исполнения актов органов гражданской юрисдикции обязанными лицами и обеспечения их прав является частноправовая модель принудительного исполнения. Такого мнения придерживаются многие исследователи. Например, В.В. Ярков полагает, что «приватизация» правоприменительной деятельности является одним из наиболее перспективных направлений развития системы гражданской юрисдикции. По мнению данного автора, система исполнения может быть организована в дальнейшем по системе нотариат [5, с. 51].Также с предложением допустить в исполнительный процесс частных приставов, исполняющих юрисдикционные акты по договору, выступает О. В. Исаенкова [2, с. 53].Удобство указанной системы для государства выражено в том, что оно никоим образом не финансирует деятельность судебных исполнителей, а наоборот, возлагает на самих судебных исполнителей бремя расходов по самофинансированию и полной имущественной ответственности перед клиентами. Еще одно важное преимущество частных приставов перед государственными обозначает В. В. Ярков, который отмечает, что «поскольку оплата судебного исполнителя при частноправовой организации профессии зависит от результатов его работы, то судебный исполнитель заинтересован в максимальной результативности своей деятельности» [6, c. 24]. Отметим также, что за последние годы существенно возросло количество коллекторских агентств, при этом их правовой статус так и не определен законодательно. Согласимся с В. Куликовым, что гораздо правильнее урегулировать эту сферу, снабдить коллекторов правовыми механизмами, которые сделают работу частников прозрачной, законной и контролируемой государством. Как предлагает данный автор, «негосударственные образования могут участвовать, например, в сборе доказательств, подтверждающих, что должник фиктивно 
переписал свое имущество на посторонних. Тогда суды смогут признавать эти сделки притворными, а имущество будет арестовываться государственными службами» [3].

Подводя итог, выделим следующие преимущества частной системы принудительного исполнения.

1. При данной системе обеспечивается мотивация судебного исполнителя на эффективную работу, поскольку его вознаграждение при этой системе увязано с результатами исполнения.

2. Появляется имущественная ответственность судебного исполнителя за свои ошибки, тогда как за ошибки должностных лиц государства потери несет государственный бюджет, а не сам исполнитель.

3. Данная система позволит государству не финансировать систему органов принудительного исполнения, приведет к переводу ее работы в режим самофинансирования за счет средств, полученных от взыскателя и должника.

4. Увеличивается самостоятельность судебных исполнителей. Частный судебный пристав самостоятельно организует работу своей конторы, нанимает сотрудников, приобретает необходимое оборудование и технические средства.

5. Органы юстиции осуществляют контроль за профессиональной деятельностью как непосредственно, так и через органы управления, которые создают сами частные исполнители - палаты национального и регионального уровня.

6. Государство получает доход от деятельности небюджетных исполнителей через уплачиваемые ими налоги.

Однако в небюджетной (частной) системе принудительного исполнения есть и некоторые недостатки, среди которых отметим следующие.

1. Возникнет вопрос о реализации мер принуждения частными судебными приставами, поскольку принуждение - функция, традиционно присущая и реализуемая должностными лицами государства.

2. Трудноразрешимым станет вопрос о финансировании взысканий в доход государства, поскольку публично-правовые взыскания, о чем свидетельствует и мировая практика, обычно осуществляются через государственную систему принудительного исполнения.

3. Возникнет необходимость стимулирования частных судебных приставов на работу с взысканиями на небольшие суммы, поскольку возникает конфликт интересов между стремлением к большему доходу и низкой доходностью многих социально значимых взысканий (таких, например, как алименты). В результате взыскания на небольшие суммы так и будут оставаться неисполненными, так как никто не захочет ими заниматься.

4. Частная система судебного исполнения повлечет более сложное взаимодействие небюджетного судебного исполнителя с другими юридическими органами, необходимое для сбора информации об имуществе, денежных средствах, самом месте нахождения должника и т.д. Неизвестно, насколько эффективным и отлаженным будет процесс предоставления государственными структурами ответов на запросы частных судебных приставов, а также процесс предоставления различных документов и сведений, зачастую необходимых в их работе.

Таким образом, введение института частных судебных приставов потребует разрешения многих проблем на законодательном уровне. Допуская возможность создания смешанной системы судебного исполнения, обозначим свой взгляд на пути решения некоторых из них. Частный пристав будет получать полномочия от имени государства, поэтому необходимо установить определенные правила доступа к профессии: наличие высшего юридического образования, прохождение стажировки, сдача квалификационного экзамена, прохождение конкурса, получение лицензии.

На законодательном уровне должен быть установлен равный правовой статус государственных и частных судебных исполнителей, оформленные ими документы должны иметь равную юридическую силу. Однако определенную категорию дел, связанных с интересами государства, возможно оставить в компетенции только государственных исполнителей.

Государство должно иметь возможность контролировать деятельность частных судебных исполнителей, вплоть до приостановления их деятельности, в связи с чем возникает необходимость создания контролирующих органов в виде палат судебных исполнителей, которые будут представлять профессию в органах суда и управления, а также обеспечивать соблюдение дисциплины и профессиональной этики. Частные судебные исполнители не получают заработную плату от государства, поэтому возникает вопрос о регулировании тарифов за осуществление их полномочий. Учитывая, что полномочия частным судебным приставам делегируются государством, тарифы также должны устанавливаться государством и оплачиваться за счет должника. При расчете сумм тарифов необходимо будет обеспечить заинтересованность судебного исполнителя в исполнении взысканий на небольшие суммы, поскольку здесь исполнение может быть трудоемким, но невыгодным.

Осуществляя свои профессиональные обязанности от имени государства, частный судебный исполнитель несет личную имущественную и иную ответственность за юридические последствия своих действий. Практически имущественная ответственность частного судебного исполнителя должна гарантироваться созданием специальных фондов, коллективным и индивидуальным страхованием профессиональной ответственности, за пределами которых судебный исполнитель отвечает лично принадлежащим ему имуществом.

На сегодняшний день требуется создание условий для качественного улучшения ситуации в сфере исполнения судебных актов, актов других органов и должностных лиц. Поэтому для успешной реализации задач, стоящих перед судебными приставами, а также в целях повышения эффективности и качества отправления правосудия представляется целесообразным введение института частных судебных приставов наряду с государственной системой взыскания и законодательное урегулирование их полномочий и деятельности. 


\title{
Литература
}

1. Законопроект о частных судебных приставах внесут весной [Электронный ресурс]. URL: http://izvestia.ru/news/564091

2. Исаенкова О. В. К разработке Исполнительного кодекса РФ // Законодательство. 2002. №1. С. 72.

3. Куликов В. Отдам долг в хорошие руки. Минюст одобрил идею о узаконить частных судебных приставов // Российская газета. 2009. № 4855 .

4. Рубцов А. Г. О возможности введения института частных судебных приставов в Российской Федерации // Исполнительное право. 2012. № 1. С. 19.

5. Ярков В. В. Будущее системы гражданской юрисдикции: попытка прогноза // Система гражданской юрисдикции в канун XXI века: современное состояние и перспективы развития: межвуз. сб. науч. тр. / под ред. В. В. Яркова, М. А. Викут, Г. А. Жилина и др. Екатеринбург, 2000. С. 51.

6. Ярков В.В. Небюджетная (частная) организация принудительного исполнения: "за" и "против" // Вестник Высшего Арбитражного суда Российской Федерации. 2007. N 9. С. 24-43.

\section{Банкротство физических лиц в России и США}

\author{
(C) Ю. А. Баннова \\ студентка 4-го курса юридического факультета \\ ФГБОУ ВО «Бурятский госуниверситет» \\ Россия, г. Улан-Удэ \\ BJA.5@yandex.ru
}

1 октября 2015 года в России вступили в силу долгожданные поправки к Федеральному закону от 26 октября 2002 г. N 127-Ф3 "О несостоятельности (банкротстве)", касающиеся банкротства физических лиц. Правоприменительная практика по данному закону еще не устоялась, поэтому в ходе его применения выявляются недостатки и пробелы законодательства.

Фактически законодательное закрепление институт банкротства граждан получил еще в Федеральном законе от 8 января 1998 г. N 6-Ф3 "О несостоятельности (банкротстве)". Но в соответствии с п. 2 ст. 185 этого акта нормы о банкротстве граждан (ст. 152-163) должны были вступить в силу с момента внесения соответствующих изменений в Гражданский кодекс РФ [4]. Однако изменения внесены не были, и нормы о банкротстве физических лиц так и не начали работать.

В Федеральном законе от 26 октября 2002 г. N 127-Ф3 "О несостоятельности (банкротстве)" также с самого начала содержались нормы о банкротстве физических лиц, не являющихся предпринимателями (ст. 202-213), но в силу п. 2 ст. 231 они не применялись [5].

Таким образом, в современной России сложилась интересная ситуация: институт банкротства граждан формально существует уже 18 лет, но по разным причинам до 2015 г. в действие введен не был. Поэтому на практике данный институт является для российского правоприменителя новым, а потому необходимо обратить внимание на зарубежную практику в этих вопросах, в частности, на опыт Соединенных Штатов Америки.

В США, в отличие от России, специальные положения, которые регулируют банкротство физических лиц, действуют достаточно давно. Предыдущий закон о банкротстве 1898 г. в 1978 г. был заменен новым. Американские граждане давно воспринимают банкротство как вполне обыденную вещь, как, собственно, и потребительские кредиты, из-за невозможности исполнения обязательств, по которым они и прибегают к данной процедуре.

В США положения о несостоятельности (банкротстве) содержатся в едином кодифицированном акте - Кодексе о банкротстве. Закон предъявляет идентичные требования по банкротству как физическим, так и юридическим лицам. Все это позволяет упростить толкование и применение закона судами.

В РФ основным источником, регулирующим банкротство, как уже говорилось выше, является Федеральный закон от 26 октября 2002г. №127-Ф3 [5], по своему содержанию и структуре он наиболее приближен к результату такой формы систематизации, как кодификация.

В США регулирование банкротства на законодательном уровне является достаточно продуманным. Для рассмотрения банкротных дел существуют специализированные суды, которые есть в каждом федеральном округе.

В РФ таких судов нет, хотя их необходимость уже практически не вызывает сомнения. Так, например, в Арбитражном суде Республики Бурятия «банкротная группа» состоит всего из трех судей, и они просто физически не могут выдержать ту лавину, которая на них обрушилась после принятия закона, поскольку на них лежит обязанность по рассмотрению не только дел по банкротству граждан, но и остальных категорий должников.

В США заявление о признании себя банкротом имеет право подать гражданин, который имеет необеспеченные долги на сумму более ста тысяч долларов или обеспеченные - свыше трехсот пятидесяти тысяч долларов. В заявлении должник обязан указать всю кредиторскую и дебиторскую задолженность, приложить опись имущества.

Заявление о признании гражданина банкротом в России принимается арбитражным судом тогда, когда требования к гражданину составляют не менее пятьсот тысяч рублей и не исполняются в течение трех месяцев с даты, когда они должны были быть исполнены. Также гражданин имеет право подачи данного заявления в си- 
туации предвидения банкротства, когда имеются обстоятельства, очевидно свидетельствующие о том, что он не имеет возможности исполнить денежные обязательства и (или) обязанности по уплате обязательных платежей в установленные сроки, и при этом отвечает признакам неплатежеспособности и (или) недостаточности имущества.

Подача заявления о признании банкротом превращается в обязанность, когда при удовлетворении требований одного или нескольких кредиторов у гражданина возникает невозможность исполнить денежные обязательства и (или) обязанности по уплате обязательных платежей в полном объеме перед другими кредиторами, а размер таких обязательств и обязанностей в совокупности составляет не менее чем пятьсот тысяч рублей. Гражданин обязан подать заявление не позднее тридцати рабочих дней со дня, когда он узнал или должен был узнать об этом [5].

В заявлении должник обязан указать всю имеющуюся у него кредиторскую и дебиторскую задолженность, приложить опись имущества.

В США за полгода до подачи заявления о банкротстве должник обязан обратиться к кредитному консультанту по своему юридическому округу для проведения беседы, затем должен пройти платные курсы по личному финансовому менеджменту, являющиеся обязательными. Для этого создано специальное Агентство по кредитным консультациям, в функции которых входит обучение должников и предупреждение их об уголовной ответственности за сокрытие информации своих доходах и имуществе.

В России такого института пока не предусмотрено, всю информацию в результате должники могут узнать, лишь обратившись за юридической консультацией к специалисту либо уже непосредственно в суде.

В США банкротство физических лиц находится под контролем федерального управляющего, который имеет право вести дело о банкротстве сам либо назначить доверительного управляющего.

В России также есть подобное лицо, которое носит название финансового управляющего. Его обязанности в рамках процедуры банкротства строго регламентированы законом. В их число входит: выявление имущества должника и обеспечение его сохранности, проведение финансового анализа состояния гражданина-должника, выявление признаков преднамеренного и фиктивного банкротства. А также, ведение реестра кредиторов и уведомление кредиторов о проведении собрания кредиторов, рассмотрение отчетов гражданина об исполнении им утвержденного плана реструктуризации и составление заключения о доходах его исполнения, опубликование сведений о банкротстве гражданина в Едином федеральном реестре сведений о банкротстве [5].

В США банкротство физических лиц чаще всего подпадает под регулирование глав 7 и 13 Кодекса о банкротстве. Глава 7 регулирует процедуру, согласно которой активы должника, не освобожденные от реализации, распродаются управляющим, а вырученные средства направляются в счет погашения требований кредиторов в соответствии с установленной законом очередностью, в главе 13 говорится о реструктуризации для долгов физических лиц, имеющих стабильный доход и желающих сохранить часть активов. Реже применяется глава 11 , предполагающая реорганизацию. Данная процедура, преимущественно используется компаниями, согласно ей должник продолжает владеть своим имуществом и вести хозяйственную деятельность, однако должен представить на рассмотрение кредиторам план реорганизации, который утверждается судом [2].

В России при банкротстве могут применяться такие процедуры, как реструктуризация долга, реализация имущества, мировое соглашение.

В США после сбора всех активов должника управляющий на аукционе в частном порядке (с помощью прямых договоров купли-продажи) либо в иной форме, которая позволяет выручить максимальную денежную сумму, распродает их. Полученные средства в порядке очередности распределяются между кредиторами [3, с. 442].

В отношении всех лиц, подавших заявление о добровольном банкротстве, обязательной процедурой является прохождение квалификационного теста, позволяющего установить, имеется ли у должника возможность отчислять $25 \%$ от постоянного дохода на оплату необеспеченных долгов. В отдельных случаях суд может принять решение об уменьшении такого размера до $20 \%$.

Должник в течение семи дней до первой встречи с кредиторами должен представить доверительному управляющему информацию об уплаченных налогах и налоговых льготах, иначе ему будет отказано в возможности подать в суд заявление о банкротстве по главам 7 и 13.

В США существует Служба внутренних доходов США, в компетенцию которой входит определение того, какие расходы банкротящегося должника являются разумными и необходимыми для поддержания среднего по стране уровня жизни. К таким расходам закон относит расходы на содержание семьи, средства на содержание больных и нетрудоспособных членов семьи, коммунальные расходы.

Законодательство США более строгое по некоторым аспектам, одновременно определяет справедливые и полезные моменты. Так законодательство позволяет исключить по ходатайству должника из конкурсной массы имущество, необходимое ему для «нового старта», которое будет неприкосновенно для кредиторов [1]. И это еще при том, что Кодекс о банкротстве базируется на презумпции недобросовестности несостоятельных должников. По статистике 90\% «полных банкротств» по Главе 7, происходит вообще без реализации имущества с полным списанием долгов.

В России все имущество гражданина, которое имеется у него на момент принятия арбитражным судом решения о признании его банкротом и введении реализации принадлежащего ему имущества составляет конкурсную массу, за исключением имущества, на которое не может быть обращено взыскание в соответствии с гражданским процессуальным законодательством. В конкурсную массу включается и активы должника, выявленные либо приобретенные после даты принятия указанного решения. 
По мотивированному ходатайству гражданина и иных лиц, которые участвуют в деле о его банкротстве, арбитражный суд имеет право исключить из конкурсной массы имущество данного гражданина, на которое может быть обращено взыскание и доход, от реализации которого не окажет существенного влияние на удовлетворение требований кредиторов. Общая стоимость исключенного имущества не должна превышать десяти тысяч рублей [5].

Имущество гражданина, часть этого имущества реализуется на торгах в порядке, установленном законом о банкротстве. Иной порядок может быть предусмотрен решением собрания кредиторов или определением арбитражного суда. Драгоценности и другие предметы роскоши, принадлежащие гражданину, в случае если их стоимость превышает сто тысяч рублей, а также недвижимость, вне зависимости от ее стоимости, подлежат реализации на открытых торгах [5].

Для того чтобы пройти в США процедуру полного банкротства и реструктуризации задолженности, физическое лицо обязано уплатить госпошлину в размере 306 и 281 долларов соответственно. Суд может принять решение о рассрочке либо об освобождении от уплаты госпошлины. Госпошлина включает оплату услуг федерального управляющего. В случае обращения к адвокату его помощь оплачивается отдельно. Таким образом, стоимость банкротства в США в среднем может обойтись гражданину от 0 до 1500 долларов [6].

В России госпошлина составляет 6000 рублей. Оплата же услуг финансового управляющего осуществляется отдельно в размере фиксированной суммы, составляющей 10000 рублей. Также в случае введения процедуры реструктуризации долгов гражданина, ему уплачивается $2 \%$ от размера удовлетворенных требований кредиторов, а при введении реализации имущества - 2 \% от размера выручки от распроданного имущества и денежных средств, которые поступили в результате взыскания дебиторской задолженности, а также применения последствий недействительности сделок. Кроме того, необходимы расходы на другие судебные издержки. Еще недавно, суд при принятии искового заявления к производству требовал, подтверждение у должника наличия имущества достаточного для погашения расходов по делу о банкротстве на сумму не менее 70000 рублей либо внесения данной суммы на депозит суда. В эту сумму не входили расходы на арбитражного управляющего и уплату госпошлины. Сейчас ситуация намного улучшилась, поскольку суд требует наличие имущества на сумму не менее 25000 рублей или, соответственно, внесения данной суммы на депозит суда, что значительно улучшает доступность судопроизводства, хотя для многих процедура банкротства по прежнему является не по карману. Также потребуются дополнительные расходы, если гражданин решится обратиться за юридической помощью.

В США при признании гражданина банкротом к нему применяются ограничения как личного, так и имущественного характера. Ему запрещается покидать место конкурсного производства без разрешения суда, ограничивается тайна переписки. Возможно оспаривание сделок, в первую очередь, заключенных гражданином с родственниками и знакомыми, в течение года до процедуры банкротства. Срок всех обязательств считается наступившим.

В России к последствиям признания гражданина банкротом относится то, что в течение пяти лет данный гражданин не имеет право без указания на факт своего банкротства принимать на себя обязательства по кредитным договорам и (или) договорам займа. В течение названного периода дело о банкротстве данного гражданина не может быть возбуждено повторно по его заявлению. В случае вторичного признания гражданина банкротом в период указанного срока по заявлению конкурсного кредитора или уполномоченного органа в ходе вновь возбужденного дела о банкротстве гражданина, правило об освобождении гражданина от обязательств после завершения расчетов с кредиторами от дальнейшего исполнения требований кредиторов не применяется.

Кроме этого, в трехлетний период с момента признания гражданина банкротом он не вправе занимать должности в органах управления юридического лица или иным образом участвовать в управлении юридическим лицом. Проанализировав банкротство физических лиц в России и США, мы пришли к выводу о том, что в США, в силу давности существования и активного применения, данный институт является более развитым и продуманным, чем в России. В России же пока существуют некоторые недостатки законодательства, однако, выявив недочеты на практике, а также изучив опыт зарубежных стран, законодатели и правоприменители в скором времени смогут устранить их. Из опыта США нам требуется обратить внимание на создание специализированных судов или хотя бы расширить «банкротные группы» в арбитражных судах. Необходимо также предусмотреть освобождение от расходов отдельных категорий граждан, ввести какие-либо льготы для лиц, попавших в трудные жизненные ситуации и не способных нести расходы по процедуре банкротства.

\section{Литература}

1. Банкротство физических лиц по законам США [Электронный ресурс]. Режим доступа: http:// http://cyberleninka.ru/article/n/bankrotstvo-fizicheskih-lits-po-zakonam-ssha

2. Будылин С. Л. Все мы делим пополам. Банкротство граждан и семейное имущество в России и за рубежом [Электронный ресурс]. Режим доступа : http://base.consultant.ru/cons/cgi/online.cgi?req=doc;base=CJI;n=89004

3. Ефремов А. В. Банкротство физических лиц: сравнительно-правовой анализ законодательства России и США // XXXI Студенческая международная научно-практическая конференция «Научное сообщество студентов XXI столетия» ГУМАНИТАРНЫЕ НАУКИ. Новосибирск, 2015. № 4(31). С. 438-444.

4. О несостоятельности (банкротстве) [Электронный ресурс] : [Федеральный закон от 8 января 1998 г. N 6-Ф3 (утратил силу)]. Режим доступа : http://base.garant.ru/12107720/

5. О несостоятельности (банкротстве) [Электронный ресурс] : [Федеральный закон от 26.10.2002 N 127-Ф3 (ред. от 29.12.2015)]. Режим доступа : http://www.consultant.ru/document/cons_doc_LAW_39331/

6. Что необходимо знать о банкротстве физических лиц [Электронный ресурс]. Режим доступа: http://ttov.org/blog/bankrotstvo-fiz-lic 


\title{
Правовое регулирование трудового договора в законодательстве Российской Федерации и Китайской Народной Республики
}

\author{
(C) C. C. Баmуевa \\ магистрант 1 года обучения юридического факультета \\ ФГБОУ ВО «Бурятский госуниверситет» \\ Россия, г. Улан-Удэ \\ Selmeg_92@mail.ru
}

В настоящее время проблема оформления надлежащим образом трудовых отношений приобрела особо актуальное значение, поскольку многие работодатели в России, стараясь уйти от исполнения установленных трудовым законодательством льгот и гарантий для работников, достаточно часто оформляют с ними гражданскоправовые договоры о труде. В силу действующего трудового законодательства Российской Федерации главным основанием возникновения трудовых отношений является трудовой договор. Именно посредством его заключения лицо может осуществлять свое конституционное право на труд [1].

Институт трудового договора, безусловно, сложен и многогранен, что неоднократно отмечалось учеными. Актуальность данного исследования заключается в том, что трудовой договор имеет исключительно важное практическое значение. Большое значение при изучении данного института имеет зарубежный опыт регулирования трудовых отношений, в том числе трудового договора, в частности в Китайской Народной Республике.

Предметом исследования в рамках данной статьи является Трудовой Кодекс Российской Федерации, а также трудовое законодательство Китайской Народной Республики.

В современной российской юридической литературе вопросу понятия, регулирования, совершенствования трудового договора посвящено достаточно большое количество исследований. Такие известные юристы как М.Ю.Тихомиров, Е.А.Новиков, Л.Н. Анисимов неоднократно рассматривали данную тему.

Определение трудового договора приведено в статье 56 Трудового кодекса РФ. Согласно этому определению, трудовой договор представляет собой соглашение между работодателем и работником, в соответствии с которым работодатель обязуется предоставить работнику работу по обусловленной трудовой функции, обеспечить условия труда, предусмотренные трудовым законодательством и иными нормативными правовыми актами, содержащими нормы трудового права, коллективным договором, соглашениями, локальными нормативными актами и данным соглашением, своевременно и в полном размере выплачивать работнику заработную плату, а работник обязуется выполнять определенную этим соглашением трудовую функцию, соблюдать правила внутреннего трудового распорядка, действующего у данного работодателя. [1]

Из содержания приведенного законодательного определения видны такие характерные черты трудового договора, как стороны трудового договора, их права и обязанности.

Основным актом, регулирующим трудовой договор в Китайской Народной Республике, является «Закон о трудовом договоре» (далее по тексту - Закон о трудовом договоре), который вступил в силу с 1 января 2008г. В статье первой этого Закона указано на то, что он разработан с целью совершенствования системы трудового договора, установления прав и обязанностей сторон трудового договора, защиты законных прав и интересов работников, становления и развития гармоничных и стабильных трудовых отношений [2]. Однако в отличие от Трудового Кодекса РФ в данном законе Китайской Народной Республики отсутствует определение трудового договора. В статье 2 этого Закона КНР указано на то, что он применяется к возникновению трудовых отношений между работниками и предприятиями, индивидуальными экономическими организациями, организациями без образования юридического лица, находящимися на территории КНР (далее - работодатель), и заключению, выполнению, изменению, расторжению и прекращению трудовых договоров [2].

Совпадает с требованиями Трудового кодекса РФ и положения статьи 7 названного Закона КНР, закрепляющие принцип возникновения трудовых отношений с момента начала работы работника: «трудовые отношения между работодателем и работником возникают с момента, в который работодатель приступил к использованию труда работника». Однако в отличие от российского трудового законодательства Закон КНР о трудовом договоре в этой же статье устанавливает обязанность работодателя создать реестр работников для регистрации и проверки.

Также как и в российском законодательстве, названный Закон КНР о трудовом договоре в статье 10 закрепляет обязанность работодателя заключать с работником письменный трудовой договор. Вместе с тем, статья 67 Трудового кодекса РФ подробно прописывает форму и порядок заключения трудового договора: «трудовой договор заключается в письменной форме; составляется в двух экземплярах, каждый из которых подписывается сторонами; один экземпляр трудового договора передается работнику, другой хранится у работодателя», тогда как Закон КНР о трудовом договоре таких подробностей не содержит.

Кроме того, в статье 10 Закона КНР о трудовом договоре закреплено, что в случае, если после установления трудовых отношений трудовой договор в письменном виде не был заключен, то работодатель обязан заключить трудовой договор в письменном виде в течение одного месяца со дня возникновения трудовых отношений.

Здесь также имеются отличия от российского трудового законодательства, поскольку статья 67 Трудового кодекса РФ устанавливает, что при фактическом допущении работника к работе работодатель обязан оформить с ним трудовой договор в письменной форме не позднее трех дней со дня фактического допуска работника к работе. 
Так же, как и в Российской Федерации, в Китае трудовой договор подразделяется на два вида в зависимости от срока его действия, т.е. он может быть заключен бессрочно или на определенный фиксированный срок [2]. Оба эти вида трудового договора, закрепленные в китайском законодательстве, можно сравнить с видами трудового договора, закрепленными в Трудовом кодексе РФ. Согласно положениям статьи 58 Трудового кодекса РФ трудовые договоры могут заключаться на неопределенный срок и на определенный срок не более пяти лет (срочный трудовой договор). При этом законодатель уточнил, что срочный трудовой договор может быть заключен только тогда, когда трудовые отношения не могут быть установлены на неопределенный срок с учетом характера предстоящей работы или условий ее выполнения.

Подход к характеристике бессрочного трудового договора и в российском трудовом законодательстве, и в китайском трудовом законодательстве одинаков: бессрочным трудовым договором является трудовой договор, в котором отсутствует дата окончания действия этого договора.

При этом заслуживают внимания положения Закона КНР о трудовом договоре, касающиеся обязанностей работодателя заключить бессрочный трудовой договор и отличающиеся по своему содержанию от норм российского трудового законодательства.

Так, согласно статье 14 Закона о трудовом договоре работодатель обязан заключить с работником бессрочный трудовой договор, если непрерывный стаж работника у работодателя составляет не менее 10 лет; в случаях, когда работодатель впервые заключает трудовой договор с работником, либо государственное предприятие перезаключает трудовой договор после реорганизации, при этом непрерывный стаж работника у работодателя составляет не менее 10 лет, и до достижения установленного законом пенсионного возраста работнику остается менее 10 лет [2].

Трудовой договор РФ не содержит положений о недействительности трудового договора, тогда как в Законе КНР о трудовом договоре этому положению посвящены статьи 26 и 27. В частности статья 26 Закона о трудовом договоре закрепляет, что трудовой договор считается полностью недействительным либо отдельные положения трудового договора считаются недействительными, в случаях, если: 1) трудовой договор был заключен или изменен заключенный с применением обмана, угроз, принуждения, или использования затруднительного положения в котором оказался работник, в результате чего, договор был заключен вопреки доброй воле одной из сторон.

2) исключения работодателем из трудового договора положений об ответственности работодателя и правах работника, установленных законом;

3) в иных случаях нарушения императивных норм законодательства и подзаконных актов.

Положения статьи 26 Закона КНР о трудовом договоре дополняются положениями статьи 27, предусматривающей, что недействительность отдельных положений трудового договора не оказывает влияния на действительность остальных его положений; остальные положения договора сохраняют правовую силу [2].

Необходимо отметить и имеющиеся в китайском трудовом законодательстве значительные отличия от российского трудового законодательства в регулировании вопросов изменения и расторжения трудового договора, которым может быть посвящена отдельная статья.

\section{Литература}

1. Трудовой кодекс Российской Федерации №197-Ф3 от 30.12.2001г (ред. от 30.12.2015) // Собрание законодательства РФ. 07.01.2002. N 1 (ч. 1). ст. 3.

2. Закон КНР «О трудовом договоре» [Электронный ресурс]. Режим доступа: http://chinalawinfo.ru/xianfa

3. Гейхман Л. В., Дмитриева И. К. Трудовое право. М.: Юрайт, 2012.

4. Лапердин В. В. Совершенствование регулирования трудовых отношений в КНР // Труд за рубежом. 2009. №1. С.185-194.

5. Петров А. Я. Трудовой договор для магистров. М.: Инфра, 2013.

\section{Правовое регулирование труда несовершеннолетних работников: сравнительный анализ РФ и Китая}

(C) В. С. Домшоева

студентка 4-го курса юридического факультета ФГБОУ ВО «Бурятский госуниверситет»

Россия, г. Улан-Удэ dvs.1994@yandex.ru, riversong888@mail.ru

Вопрос о защите прав несовершеннолетних до сих пор является одним из основных направлений развития трудового законодательства и в Российской Федерации, и за рубежом. Масштабы детского труда практически невозможно измерить. Недаром в Европейскую социальную хартию 1961 года включена статья 7 «Право детей на защиту», предусматривающая особое положение детей и несовершеннолетних в области трудовых отношений. Рассмотрению вопросов, касающихся прав несовершеннолетних, уделяют огромное внимание практически все государства мира, Организация Объединенных Наций (ООН) и множество специализированных учреждений системы ООН.

Актуальность вовлечения несовершеннолетних в трудовой процесс, связанность его с правовым регулированием в современном обществе бесспорна. В данном случае немаловажное значение имеет следующий правовой аспект: правильное использование детского труда даст возможность использовать трудовой потенциал де- 
тей без наступления негативных последствий для их здоровья. Другими словами, наделение трудовыми правами несовершеннолетних должно иметь под собой некие юридические гарантии те льготы, те законодательные запреты, которые позволили бы обезопасить данную категорию работников от многих проблем: давления со стороны работодателя, уменьшения личного времени и эксплуатации на тяжелых работах [6].

Одна из основных проблем как в Российской Федерации, так и в КНР является проблема законодательного регулирования детского труда, то есть обеспечение приемлемых условий на рынке труда.

В России одновременно с активизацией рынка труда, произошло еще большее расслоение общества, участились случаи нарушений трудовых прав граждан, в особенности несовершеннолетних. Распространенным явлением является нарушение условий охраны труда несовершеннолетних. Также надо сказать, что труд несовершеннолетних используется недостаточно активно. Это происходит, в том числе, по причине сложности законодательного регулирования процедуры найма на работу несовершеннолетних, большого количества ограничений при их трудоустройстве, коррупционной составляющей контролирующих государственных органов и пр. Все это потребовало новых подходов к нормативно-правовому регулированию трудовых отношений [4].

Основы правового статуса личности в целом и ребенка, в частности, в Российской Федерации закреплены в главе 2 Конституции РФ 1993 г. и других законодательных актах Российской Федерации и ее субъектов. Надо сказать, что с принятием нового Трудового кодекса Российской Федерации произошло упорядочение правового регулирования труда несовершеннолетних работников, однако не решило всех проблем [8].

Как известно, сегодня на рынке труда даже квалифицированные специалисты не могут реализовать право на труд в соответствии со своей квалификацией и знаниями. Поэтому трудоустройство молодых людей, особенно не достигших 18 лет, является весьма острой проблемой в Российской Федерации. Так как, регулирование трудоустройства несовершеннолетних работников усложнено множеством правовых документов и процедурой найма на работу. Для работодателя процедура найма устройства несовершеннолетнего работника является неудобным, а в какой-то степени и рискованным. Например, работодатель несет материальные расходы в связи с официальным приемом на работу несовершеннолетнего, а также бремя за медицинский осмотр несовершеннолетнего тоже возложено на работодателя. Также одной из существенных проблем является коррупция и репрессивный характер российских контролирующих органов, т.е. при нарушении законодательства в области охраны труда несовершеннолетних, контролирующие органы в первую очередь стремятся наказать работодателя.

Все это представляет угрозу для работодателя в связи с трудоустройством несовершеннолетнего и вызывает у него нежелание взять его на работу.

Как и в России, Китай ратифицировал основные международные документы в области защиты прав детей, внутреннее законодательство Китая также обеспечивает защиту широкого спектра прав детей. Реальность, однако, является спорной. На практике исполнение договорных обязательств и законодательных деклараций остается огромной проблемой.

Основные международные документы, касающиеся прав детей КНР подписало и ратифицировало следующие нормативно-правовые акты:

- Конвенция о правах ребенка 1989 года (КПР) (Вступление в силу для Китая: 1 апреля, 1992);

- Факультативный протокол к Конвенции о правах ребенка, касающийся торговли детьми, детской проституции и детской порнографии 2000 (Вступление в силу для Китая: 3 января 2003 г.);

- Международный пакт об экономических, социальных и культурных правах 1966 года (вступление в силу для Китая: 27 июня 2001);

- Конвенция о ликвидации всех форм дискриминации в отношении женщин 1979 года (вступление в силу для Китая: 3 декабря 1981 г.);

- О наихудших формах детского труда Конвенции 1999 года (вступление в силу для Китая: 8 августа 2003 г.);

- Гаагская конвенция о защите детей и сотрудничестве в области межгосударственного усыновления 1993 (получение документа: 16 сентября)

Кроме того, Китай подписал, но не ратифицировал Международный пакт о гражданских и политических правах 1966 года по 5 октября 1998 г. Минимальный возраст для вступления в трудовые отношения несовершеннолетнего наступает с возраста шестнадцати лет [3].

Правительство Китая открыло свои двери для мировой экономики в конце 1970-х годов, постепенно, но неуклонно растет торговля и производство. Идет развитие количество фабрик и производственных мощностей. Это быстрый экономический рост усугубляется нарушением трудовых прав, в первую очередь в связи с увеличением потребностей производства на китайских фабриках. Для того, чтобы быть более конкурентоспособными, Китай требует сильной рабочей силы. Скорость роста и развития экономики в Китае ускоряется благодаря принятие законов о труде и человека в области трудовых прав. Предполагается, что из 250 миллионов детей в возрасте 5-14 лет, которые незаконно заняты во всем мире, 61 процентов находятся в Азии. Поскольку Китай имеет один из крупнейших азиатских экономик и быстро трансформировали свою экономику в последние годы, проблема детского труда является весьма актуальной. Дети нелегально работают на опасных условиях, в таких отраслях, как изготовление и продажа фейерверка или на работают на заводах, где изготавливают трудоемкие кирпичные печи для обжига. Данные, касающиеся использования детского труда крайне трудно обнаружить в Китае. Китайское правительство запрещает сбор таких статистических данных. Даже крупные организации, как ЮНИСЕФ не знает точные цифры об использовании детского труда в Китае. 
Основной причиной использование детского труда является отсутствие образования. В Китае образовательные сборы очень высоки. В сельской местности, семьи не могут позволить себе расходы на образование для своих детей или предоставить поездки до ближайших школ, а также, во многих семьях, родители оставляют в приоритете отдавать в школы своих сыновей. Дети в таких районах часто вынуждены работать, чтобы помочь семье с финансовыми проблемами.

Предпосылками проблемы образования детей является отсутствие государственной поддержки и обеспечения надлежащими гарантиями, а также культурные и противоречивые социальные нормы, которые не позволяют детям посещать школу. Все эти причины вызывают увеличение спроса труда несовершеннолетних.

Несмотря на требования законодательства, практика детского труда считается нерешенной проблемой Китая [5]. Хотя АМИК соглашается с тем, что общий объем детского труда в Китае остается неясным из-за правительственной категоризации данных по этому вопросу, так как эти данные остается засекреченными. Ребенок трудится как правило, в секторах услуг с низким уровнем квалификации, а также небольших мастерских и предприятий, в том числе текстильной, игрушки, и производство обуви предприятий [7]. Проанализировав действующее трудовое законодательство Российской Федерации, мы пришли к выводу о том, что российским трудовым законодательством не предусматриваются специфические особенности порядка прекращения трудового договора с несовершеннолетним лицом по сравнению со взрослым при проявлении инициативы работника или по соглашению между ним и работодателем. Думается, что из-за такого упущения создаются условия для нарушения их трудовых прав. Исходя из вышесказанного, можно сделать вывод о том, что, несмотря на свою немногочисленность, конвенции МОТ в целом служат охране детского труда, устанавливая основные права и гарантии несовершеннолетних в области труда. Но неоспоримым является тот факт, что многие положения нуждаются в доработке либо требуют дополнительной регламентации.

Многообразие источников трудового права, взаимное существование норм, принятых десятилетие назад и вступивших в силу в последние годы, наличие множества ведомственных инструкций, положений, правил, нередко усложненных и противоречивых, неразработанность механизмов реализации принятых правовых актов все это затрудняет осуществление механизма защиты трудовых прав несовершеннолетних как в России, так и в Китае. Наверное, необходимо разработать программы и новые законопроекты для усовершенствования и восполнение пробелов в законодательстве, предусматривающую все проблемы труда несовершеннолетних с установлением жесточайшего контроля за соблюдением всех нормативных актов, касающихся этой проблемы.

\section{Литература}

1. Трудовой кодекс Российской Федерации от 30 декабря 2001 г. №197 ФЗ: в ред. от 28 июня 2014 г. Доступ из справ.правовой системы «КонсультантПлюс».

2. О дополнительных гарантиях по социальной поддержке детей-сирот и детей, оставшихся без попечения родителей: федер. закон Рос. Федерации от 21 дек. 1996 г. № 159-ФЗ. Доступ из справ.-правовой системы «КонсультантПлюс».

3. Закон КНР «О защите несовершеннолетних», 2007 Ведомости Постоянного комитета Всекитайского собрания народных представителей 5 (P.R.C) (официальный источник).

4. Алистархов В. Труд несовершеннолетних в Российской Федерации // Трудовое право. 2013. № 11.

5. Конгресс- Исполнительная Комиссия по Китаю 2007 Годовой отчет, сноска 33, на 70 лет.

6. Корнилова А. В. Некоторые аспекты представительства и защиты прав несовершеннолетних работников в РФ // Гуманитарные научные исследования. 2013. № 2 [Электронный ресурс]. URL: http://human.snauka.ru/2013/02/2347 (дата обращения: 31.07.2014)

7. Лао Донг Фа [Трудовое право] (принят Постоянным комитетом ВСНП, эффективным 1 января 1995), ст. 15.1994 Fagui Huibian 91, 94 (официальный источник).

8. Рузаева Е. М. Российское трудовое законодательство в области правового регулирования труда лиц до восемнадцати лет // Вопросы российского и международного права. 2011. № 3.

9. Чернышева Л. Детский труд. Международное и российское законодательство о правовом регулировании труда несовершеннолетних // Кадровик. Трудовое право для кадровика. 2007. № 7. URL: http://hr-portal.ru/article/detskiytrudmezhdunarodnoe-i-rossiyskoe-zakonodatelstvo-opravovom-regulirovanii-truda?page=0 (дата обращения: 16.10.2014).

\section{Порядок раздела общего имущества супругов в России и странах Азиатско-Тихоокеанского региона}

() О. С. Жамбалова студентка 4-го курса юридического факультета ФГБОУ ВО «Бурятский госуниверситет»

Россия, г. Улан-Удэ Olesenny@mail.ru

Общим имуществом супругов законом Российской Федерации признается совместная собственность супругов - каждый из супругов имеет право собственности не на определенную долю, а на все имущество. И пока существует совместная собственность, доли супругов не выделяются. Каждый супруг имеет равное право на общее имущество в независимости от того, какой у него был доход и доля в приобретенном имуществе [3]. Права супругов признаются равными даже в случае, когда один из супругов вовсе не работает, но при этом за- 
нят ведением домашнего хозяйства, уходом за детьми или по другим уважительным причинам не имеет самостоятельного дохода (например, является инвалидом) (ст. 34 СК РФ).

Значительные отличия порядка раздела общего имущества супругов в России и других странах АзиатскоТихоокеанского региона основаны именно на том, что на территории каждого государства действует свой законный режим имущества супругов. Так, например, в Китае, как и в России действует принцип общности супружеского имущества. Согласно ст. 17 Закон КНР о браке, к совместному имуществу супругов относится все имущество, приобретенное мужем и женой в период существования брака. Также к совместной собственности супругов относится заработная плата, премии, доходы от производственной и хозяйственной деятельности, от прав интеллектуальной собственности, имущество, приобретенное по договору дарения или в порядке наследования (если оба супруга установлены в качестве получателя имущества), и иное имущество, которое должно быть отнесено к совместной собственности супругов [5].

А в Японии не существует системы совместной собственности супругов. Всё имущество, которое было у супругов до брака является их раздельной собственностью, соответственно, на чье имя оно записано, у того имущество и остается. Также, все приобретенное за время брака имущество, и даже долги, нажитые в браке, являются раздельной собственностью. Это принцип действует во всех сферах жизни супругов: заработная плата каждого супруга считается его собственностью, а второй супруг не может иметь на неё прав [4].

В Индии же, уделяется большое внимание регулированию семейно-правовых отношений. Так как в Индии в каждом штате есть свой Семейный кодекс, который регулируют отношения супружеской собственности, рассмотрим данный вопрос на примере Гражданского кодекса штата Гоа. Согласно традиционному индусскому праву, брак - это неразрывный семейный союз супругов и имущество у супругов общее. Но имущество, принадлежащее супруге до брака, не может быть объектом для взыскания при расторжении брака. Также супруг не может распоряжаться этим имуществом. Соответственно имущество, принадлежащее супруге до брака - это её личное имущество, что закреплено в положениях Гражданского кодекса штата Гоа [7].

В США выделяются разные режимы собственности супругов. В восьми штатах США, таких как Калифорния, Техас, Луизиана, Вашингтон, Айдахо, Нью-Мексико, Невада и Аризона законным режимом является общность собственности [11]. Порядок управления общим имуществом строится на принципе равенства прав супругов при наличии определенных различий в отдельных штатах. Управление раздельным имуществом осуществляется каждым из супругов самостоятельно, что не исключает его использования в общих семейных целях. В некоторых штатах супруг вправе свободно распоряжаться любым общим имуществом от имени обоих супругов, без каких-либо ограничений. Однако, в большинстве штатов, без ограничений супруги вправе распоряжаться только движимым имуществом, а для распоряжения недвижимым общим имуществом необходимо получение письменного согласия, как это делается и в России. В остальных штатах, за исключением этих восьми, действует режим раздельного имущество каждого из супругов, который не ограничивает право каждого из супругов в распоряжении своим имуществом.

Раздел имущества производится в случае, когда брак прекращает свое существование. Однако раздел имущества возможен и в момент существования брака. Раздел имущества может проводиться по субъективным причинам, например, при желании одного из супругов подарить часть своего имущества в общем имуществе супругов детям либо другим лицам. В некоторых случаях раздел имущества в период брака обязателен, например, в случае необходимости произвести взыскание за долги одного из супругов из его доли в общем имуществе, что закреплено в статье 45 СК РФ [9].

При отсутствии спора между супругами, они самостоятельно могут разделить их общее имущества. И в данном случае супруги могут заключить между собой соглашение о разделе в любой форме. К нотариальной форме соглашения при добровольном разделе, обращаются только, когда объектом раздела является имущество, право собственности, на которое должно быть зафиксировано в правовом документе.

В случае, когда супруги не достигли согласия, раздел их общего имущества производится судом РФ. В большинстве случаев такой раздел производится по требованию супругов или одного из них в бракоразводном процессе. В статье 24 СК РФ закреплено, что допускается соединение исковых требований о разделе общего имущества супругов совместно с иском о расторжении брака. Эта же статья обязывает суд по требованию супругов или одного из них при вынесении решения о расторжении брака разделить их имущество, находящееся в их совместной собственности.

Главным вопросом, возникающим при рассмотрении дел о разделе имущества, относящегося к совместной собственности супругов, является определение конкретного имущества, которое должно включаться в раздел, его стоимость и в каком порядке оно должно быть поделено [8].

При рассмотрении спора супругов о разделе общего имущества суд в первую очередь должен определить состав имущества, которое подлежит разделу. Для начала устанавливаются и выделяются объекты, которые не подлежат будущему разделу. В российском праве к таким объектам относятся личные вещи каждого из супругов, а также вещи, приобретенные для удовлетворения потребностей несовершеннолетних детей, а также вклады, открытые на имя детей. К имуществу, не подлежащему разделу, суд может отнести и другие вещи, которые были приобретен супругом в период их раздельного проживания при фактическом прекращении семейных отношений (ст. 38 СК РФ). Также для раздела совместного имущества в суде необходимо также определение объема и стоимости имущества, подлежащего разделу.

После установления состава имущества, подлежащего разделу, суд определяет доли, причитающиеся каждому из супругов. Доля каждого супруга должна быть определена в идеальном выражении, например, каждому 
по $1 / 2$, или жене, с которой остались дети, $-2 / 3$, а мужу - 1/3. И уже в соответствии с долями производится раздел имущества в натуре. В своем решении суд указывается, конкретно какая вещь передается кому из супругов. Например, жене: дом, холодильник, спальный гарнитур, мужу - автомобиль, гараж, телевизор.

В случае, когда у одного из супругов, находится по стоимости больше вещей, чем его идеальная доля, суд на него возлагает обязанность выплатить второму супругу денежную компенсацию, соответствующую стоимости превышающую его идеальную долю.

Кроме вещей, разделу подлежат также права требования, принадлежащие супругам, и их общие долги. Под общими долгами понимают - обязательства, возникшие из сделок, заключенных в порядке владения, пользования и распоряжения совместной собственностью супругов, и долги по обязательствам одного из супругов, если они были приобретены в интересах семьи. Сложность представляется в подтверждении того, что долги возникали именно из семейных нужд. Общие долги супругов распределяются соответственно присужденным им долям (ст. 39 СК РФ).

Для требований о разделе общего имущества разведенных супругов установлен трехлетний срок исковой давности (ст. 38 СК РФ). Начало этого срока исчисляется не с момента расторжения брака, а с момента, когда бывший супруг узнал или должен был узнать о нарушении своего права (ст. 200 ГК РФ) [2]. Например, это может быть момент, когда его лишили возможности пользоваться или владеть имуществом или когда другой супруг распорядился имуществом без его согласия.

Также в бракоразводном процессе не допускается участия третьих лиц. При возникновении в рамках этого процесса вопроса о разделе общего имущества супругов, которое затрагивает интересы третьих лиц согласно п. 3 ст. 24 СК РФ суд вправе выделить требование о разделе имущества в отдельное производство. При появлении третьих лиц в деле о разделе имущества супругов, которое рассматривается отдельно от дела о расторжении брака, все имущественные требования супругов и иск третьего лица, претендующего на предмет спора, разрешаются в рамках одного судебного процесса.

В Китае, при расторжении брака, совместное имущество супругов распределяется по соглашению сторон. А при отсутствии согласия - решением народного суда в соответствии с конкретными обстоятельствами дела и принципом защиты прав и интересов детей и женщины. Если супруги в письменном виде заключили соглашение о раздельной собственности имущества, приобретенного в период существования брака, однако один из супругов внес больший вклад в воспитание детей, заботу о пожилых, содействие другому из супругов в работе, при расторжении брака, данный супруг вправе потребовать от другого компенсации, которая должна быть выплачена ему другим супругом (ст. 40 Закон КНР о браке).

При решении вопроса раздела совместных обязательств, долги, нажитые супругами в период совместной жизни, вместе и возвращаются. В случае недостатка совместного имущества для погашения долга или раздельной собственности в отношении имущества, погашение долга осушествляется по соглашению сторон или по решению народного суда при отсутствии согласия.

В Японии, согласно статье 767 Гражданского Кодекса Японии раздел имущества производится по соглашению супругов, а в случае если согласие не было достигнуто, имущество делится между супругами по решению суда.

В Индии для различных религий существуют разные законы о разводе. Также в каждом штате имеется свое семейное законодательство, которое часто отличается друг от друга.

Например, в соответствии с Гражданским кодексом штата Гоа основным требованием для развода является наличие согласия обоих супругов. Есть два аспекта, которого должны достичь супруги при разводе по обоюдному согласию - это размер алиментов или пособий и вопрос по воспитанию детей. Развод по взаимному согласию длится от одного до шести месяцев, иногда это происходит в более длинные сроки. В законодательстве Индии ни чего не сказано о необходимости согласия на раздел имущества супругов, соответственно имущество, принадлежащее каждому из супругов, является его собственностью и после расторжения брака.

В США, решение о разделе имущества может осуществиться как по письменному соглашению сторон, так и по устному. Также можно заявить о разделе имущества в процессе расторжения брака в открытом судебном заседании. Суд, при рассмотрении вопроса о разделе имущества, обязан разделить все имущество, нажитое в браке, на одинаковые доли для каждого супруга [6].

Однако законодательство штата, имеет свои отличительные особенности, к которым можно отнести особое регулирование судьбы недвижимого имущества. В случае, если есть решение суда или гражданский иск о возмещении ущерба за акт бытового насилия, совершаемый одним из супругов против другого супруга, суд вправе, передать долю собственности пострадавшему супругу, при разбирательстве дела о расторжении брака или раздельном проживании сторон, если проживание сторон вместе невозможно, а решение еще не вынесено.

В вопросе раздела совместных долговых обязательств, суд исследует, для каких целей были взяты в долг денежные средства, и на что они были потрачены. Только в случае если они были необходимы для удовлетворения общих потребностей жизни супругов или потребностей жизни детей они являются общими. Это должен подтвердить каждый из супругов.

Рассмотрев порядок раздела общего имущества супругов в России и странах Азиатско-Тихоокеанского региона, было бы верным сделать вывод о том, что является общим для всех государств.

Несмотря на значительную разницу правовых систем и особенности национальной культуры каждой страны, решение вопроса раздела общего имущества супругов изначально решается в добровольном порядке по соглашению супругов. Государство осознает, что в данном случае брачно-семейные отношения - это общест- 
венные отношения, возникающие из брака между двумя людьми [10], в соответствии с этим, вопросы, касающиеся только правоотношений возникающих между супругами и не затрагивающих интересы других лиц, могут быть разрешены самостоятельно. А в случае недостижения согласия, все спорные вопросы, возникающие в ходе раздела общего имущества супругов, разрешает суд, основывая свое решение на принципах законности и справедливости [1].

\section{Литература}

1. Конституция Российской Федерации от 12 декабря 1993 г. (с изм. от 30.12. 2008 г.) // Российская газета. 1993. 25 дек.; СЗ РФ. 2009. № 1. СТ. 1.

2. Гражданский кодекс Российской Федерации. Части первая, вторая, третья и четвертая: с изм. и доп. (ред. от 31.01.2016) // СЗ РФ. 1994. № 32. Ст. 3301.

3. Семейный кодекс Российской Федерации от 29 декабря 1995 г. № 223-Ф3 (в ред. от 30.12.2015 г.) // С3 РФ. 1996. № 1. СT. 16.

4. Гражданское право (девять) Последняя редакция: Март два-пять лет, два месяца и один день закон статья девяносто Мэйдзи двадцать девять лет в апреле двадцать седьмой день Закона нет. восемьдесят четыре) [Электронный ресурс]. Режим доступа: http://law.e-gov.go.jp/htmldata/M29/M29HO089.html

5. Закон КНР о браке [Электронный ресурc]. Режим доступа: http://chinalawinfo.ru/civil_law/law_marriage/ law_marriage_ch4

6. Калифорнийский Семейный Кодекс [Электронный ресурс]. Режим доступа: http://www.leginfo.ca.gov/cgibin/calawquery?codesection=fam $\&$ codebody $=\&$ hits $=20$

7. Право Индии [Электронный ресурс]. Режим доступа: http://india4ever.0pk.ru/viewtopic.php?id=511

8. Добровольная (бесспорная) юрисдикция в России и за рубежом (Восточная и Западная Европа, Латинская Америка, Китай) / под ред. В. В. Аргунова. М.: Статут, 2014.

9. Международное частное право: учебник: в 2 т. / отв. ред. С. Н. Лебедев, Е. В. Кабатова. М.: Статут, 2015.

10. Бошно С. В. Правоведение. М.: Право и закон, 2002. 416 с.

11. Имущество супругов за рубежом [Электронный ресурс]. Режим доступа: http://городскойсуд.pф/razdel/imushestva_razvod/zarubezhom

\section{Предоставление земельных участков из государственных и муниципальных земель в России и Монголии: сравнительный анализ}

(C) М. С. Иринчеева

студентка 4-го курса юридического факультета ФГБОУ ВО «Бурятский госуниверситет»

Россия, г. Улан-Удэ ponkinova@mail.ru

Рациональное использование земель и ее охрана являются одними из немаловажных функций государства. Земля является невосполнимым и бесценным природным ресурсом, от которого зависит жизнь и состояние человечества. Но земля рассматривается не только как природный ресурс, но и как объект имущественных прав. Использование природных ресурсов всегда сопряжено с интересами государства и населения. Путем сравнения законодательства двух стран можно выявить определенные достоинства и недостатки, связанные с правовым регулированием предоставления земельных участков. К тому же, земельное законодательство претерпело большие изменения, и в связи с этим вопросы, которые рассматриваются в данной статье, являются актуальными и могут служить основой для дальнейшего изучения.

В интересах населения государство на протяжении нескольких лет разрабатывало нововведения, применение которых привело к значительным преобразованиям в земельных правоотношениях. Итогом данных преобразований является Федеральный закон от 23.06.2014 г. № 171- Ф3 «О внесении изменений в Земельный Кодекс РФ и отдельные законодательные акты РФ». «По оценкам научного сообщества, данные изменения являются крупнейшими за последнее десятилетие, и обещают наладить систему использования земельных ресурсов» [2].

Земельные участки в соответствии со ст. 39 действующего Земельного кодекса Российской Федерации предоставляются на следующих видах прав:

1) В собственность. Земельное законодательство предусматривает предоставление земельных участков в собственность, как за плату, так и бесплатно. Продажа земельных участков, находящихся в публичной собственности, осуществляется исключительно на аукционе. Без проведения аукциона в специальном порядке осуществляется продажа земельных участков для комплексного освоения территории, для индивидуального жилищного строительства, для ведения садоводства, огородничества, дачного, фермерского хозяйства, для собственников зданий, сооружений либо помещений в них.

Предоставление земельного участка гражданину или организации в собственность бесплатно осуществляется на основании решения уполномоченного органа. «В том числе в следующих случаях: лицу, с которым заключен договор развития территории; религиозной организации, имеющей в собственности здания или сооружения религиозного или благотворительного назначения; муниципальным служащим» [1]. 
Законодательство РФ и субъектов РФ предусматривает предоставление земельных участков в собственность бесплатно определенным категориям граждан: инвалидам I и II групп, гражданам, имеющим трех и более детей; гражданам, являющимся приемными родителями, имеющим трех и более детей, и другие категории.

2) В аренду. Согласно ЗК РФ земельные участки, находящиеся в государственной или муниципальной собственности, предоставляются в аренду на торгах и без проведения торгов. В новой редакции ЗК РФ законодатель определил срок сдачи в аренду публичного земельного участка-49 лет, чего не было предусмотрено в редакции кодекса до Ф3 «О внесении изменений в Земельный Кодекс РФ и отдельные законодательные акты РФ».

3) В безвозмездное пользование. Ранее земельные участки на данном виде права предоставлялись только юридическим лицам и только в качестве служебного надела для граждан. Сейчас Земельный кодекс расширил перечень случаев, кто может претендовать на земельный участок на праве безвозмездного пользования: религиозные организации для размещения зданий, сооружений религиозного или благотворительного назначения, лица, с кем заключены гражданско-правовые договоры на строительство или реконструкцию объектов недвижимости, в целях ведения личного подсобного хозяйства или осуществления крестьянским (фермерским) хозяйством, для индивидуального жилищного строительства или ведения личного подсобного хозяйства; гражданин, если на земельном участке находится служебное жилое помещение в виде жилого дома, предоставленное этому гражданину, на срок права пользования таким жилым помещением; граждане в целях осуществления сельскохозяйственной деятельности (в том числе пчеловодства) для собственных нужд на лесных участках; некоммерческие организации, созданные гражданами, для ведения огородничества или садоводства; некоммерческие организации, созданные гражданами, в целях жилищного строительства в случаях и на срок, которые предусмотрены федеральными законами; лица, относящиеся к коренным малочисленным народам Севера, Сибири и Дальнего Востока Российской Федерации, и их общинам в местах традиционного проживания и традиционной хозяйственной деятельности; некоммерческие организации, предусмотренные законом субъекта Российской Федерации и созданные субъектом Российской Федерации в целях жилищного строительства для обеспечения жилыми помещениями отдельных категорий граждан; лица, право безвозмездного пользования которых на земельный участок, находящийся в государственной или муниципальной собственности, прекращено в связи с изъятием земельного участка для государственных или муниципальных нужд, взамен изъятого земельного участка.

4) В постоянное (бессрочное) пользование. Земельные участки, которые находятся в публичной собственности, предоставляются в постоянное (бессрочное) пользование исключительно органам государственной власти и органам МСУ, государственным и муниципальным учреждениям, казенным предприятиям, центрам исторического наследия президентов Российской Федерации, прекративших исполнение своих полномочий. Данный перечень является исчерпывающим.

Проанализировав изменения земельного законодательства РФ, можно сделать вывод, что законодатель постепенно отходит от иных вещных прав. На данный момент из Земельного Кодекса уже исключено право пожизненного наследуемого владения, которое еще закреплено в ГК РФ.

В Монголии государственные и муниципальные земли предоставляются в собственность и в аренду:

Рассмотрим некоторые аспекты предоставления земельного участка в собственность бесплатно и посредством аукциона.

Гражданин Монголии может получить бесплатно в собственность от своего государства земельный участок один раз для семейного использования- земледелия, для выращивания овощей, фруктов и других пищевых продуктов.

В Монголии процесс урбанизации и связанной с ней оседлости неизбежно затронул вопрос о приватизации земли, которая играет важнейшую роль при приобретении прав на публичные земли. Конституция Монголии 1992 года закрепила данное право с некоторыми исключениями.

При предоставлении земельного участка в собственность бесплатно важно учесть то, что земельный участок должен быть включен в список земель, предназначенный для приватизации гражданами и должен быть свободен от прав других лиц. Тогда монгольский гражданин может получить участок в первую очередь.

В соответствии с нормами, установленными Гражданским кодексом Монголии, Законом "О земле", гражданин, не имеющий права владения на землю, но желающий приобрести ее, может сделать это посредством покупки ее с аукциона.

Для того чтобы приобрести право собственности на земельный участок, в Монголии предусмотрена особая процедура. Это выражается в том, что изначально подается заявление префекту, в котором проживает заявитель, о желании приобрести право собственности на землю. Префект, обладающий соответствующей компетенцией на основании заявления гражданина, после определения, вправе ли данное лицо приобрести в собственность землю, выносит решение о приватизации данной земли соответствующим гражданином. На основании решения орган государственной регистрации выдает гражданину свидетельство о том, что указанный гражданин является собственником данной земли. Свидетельство является основанием возникновения у гражданина права собственности на землю и его гарантом. При проведении данной процедуры возникает множество проблем и споров: к примеру, до конца не ясны критерии, по которым выбирают граждан, имеющие право на предоставление земельного участка.

Кроме того, как мы писали выше, гражданин Монголии имеет право взять в аренду земельный участок из государственных и муниципальных земель. При этом гражданин должен обратиться в соответствующие органы с пакетом документов. 
Отечественное понятие «аренда» в рамках монгольского права соприкасается с понятием «право владения». Согласно земельному закону монгольские граждане и организации могут получать в аренду государственную землю сроком от 15 до 60 лет с последующим продлением аренды еще на 40 лет. Однако первоначальный срок аренды обрабатываемых земель не может превышать 25 лет. Арендное право передается по наследству. В РФ срок договора аренды определяется исходя из положений договора. Для некоторых категорий земель срок ограничен, например, для земель сельскохозяйственного назначения находящегося в государственной и муниципальной собственности договор заключается на срок от трех до сорока девяти лет.

Таким образом, в отличие от отечественного законодательства, в законодательстве Монголии не предусмотрены такие права как:

- право пожизненного наследуемого владения земельным участком;

- право постоянного (бессрочного) пользования земельным участком;

- безвозмездное пользование земельным участком.

Данный подход, по мнению научного сообщества Монголии, упрощает имущественные правоотношения и благоприятно влияет на гражданский оборот.

\title{
Литература
}

1. «Земельный кодекс Российской Федерации» от 25.10.2001 N 136-Ф3 (ред. от 30.12.2015) (с изм. и доп., вступ. в силу с 01.01.2016). Документ предоставлен системой КонсультантПлюс.

2. Железнов Д. С. Новеллы правового регулирования предоставления земельных участков для строительства в свете ключевых положений Федерального закона от 23 июня 2014 г. №171- Ф3. // «Аграрное и земельное право». 2014. N 11.

\section{Институт усыновления по русскому праву и обычному праву монголов: сравнительный анализ}

\author{
(C) А. А. Ковалёва \\ магистрант 1 года обучения юридического факультета \\ ФГБОУ ВО «Бурятский госуниверситет» \\ Россия, г. Улан-Удэ \\ baldanova_aa@mail.ru
}

«Дети - наше будущее. Дети - цветы нашей жизни». Эти фразы неизвестного автора для современного человека, возможно, звучат банально и просто. В сегодняшнем ритме жизни мы и не задумываемся над глубоким смыслом этих слов. В век высоких технологий, кажется, что нет ничего недоступного. Медицина предлагает разные методы решения проблем, связанных с бесплодием и бездетностью. Но ведь так было не всегда. И не всегда на призрении у государства находилось такое огромное число детей-сирот и детей, оставшихся без попечения родителей. Для современного общества это является значительной проблемой. Согласно ст. 20 Конвенции ООН о правах ребенка 1989 года «ребенок, который временно или постоянно лишен своего семейного окружения или который в его собственных наилучших интересах не может оставаться в таком окружении, имеет право на особую защиту и помощь, предоставляемые государством»[1]. Государства-участники в свою очередь разрабатывают различные формы и меры поддержки этой категории несовершеннолетних. При этом приоритетной формой устройства детей-сирот и детей, оставшихся без попечения родителей, признается усыновление.

Институт усыновления, известный с древнейших времен, существует во всех правовых системах. Упоминания об усыновлении встречаются в Законах Хаммурапи и Законах Ману. В качестве института права усыновление оформилось в Древнем Риме, где оно выступало «способом установления отцовской власти (patria potestas) над чужими детьми»[12, с. 64]. Именно усыновление долгое время решало проблему бездетных семей и проблему сиротства.

В современной науке под усыновлением (удочерением) понимается «юридический акт, в результате которого между усыновителем (усыновителями) и его родственниками, с одной стороны, и усыновленным ребенком - с другой стороны, возникают такие же права и обязанности, как между родителями и детьми, а также их родственниками по происхождению» [9, с. 512]. Таким образом, правовая сущность усыновления заключается в полном приравнивании усыновленного ребенка в личных и имущественных правах и обязанностях к родным детям усыновителя. Усыновители не только по существу, но и по форме заменяют родителей, и здесь нет того временного характера воспитания детей, который присущ иным формам. В этом заключается особенность усыновления, обуславливающая приоритетность данной формы устройства детей.

У всех народов и государств институт усыновления проходил свой исторический путь развития, который зависел от экономического, политического и социального состояния общества.

В Древней Руси усыновление именовалось «искусственным сыновством», приемом «стороннего» в состав семьи. И было известно еще во времена язычества. В качестве первого примера усыновления на Руси одни исследователи приводят передачу на смертном одре Рюриком своего сына Игоря Олегу, другие считают Святополка усыновленным сыном Владимира. Изначально усыновление вызывалось потребностью сохранить численность и прочность общины, сохранить имущество рода. Уже позже проявляется другая цель усыновления - 
необходимость иметь наследника, которая объяснялась, прежде всего, тем, что принесение жертв и поминание душ усопших составляло обязанность их детей. Русское обычное право предусматривало разные процедуры усыновления. В их числе [8, с.263]:

- обряд фиктивного рождения. В некоторых местностях на мнимую роженицу для большей достоверности надевали рубашку, испачканную кровью;

- женитьба на вдове брата;

- фактический прием усыновляемого в дом;

- особый договорный акт между усыновителем и усыновляемым.

С принятием христианства на Руси стало применяться Византийское право, и усыновление, как и все семейные отношения, перешло в ведение церкви. Оно освящалось особым церковным обрядом «сынотворенья», а также утверждалось епархиальным архиереем.

Достаточно долгое время порядок усыновления не подвергался существенным изменениям. Усыновление существовало фактически, но долгое время специальных законов, посвященных усыновлению, издано не было. Причина этого заключается в крепкой сельской общине, которая существовала продолжительное время. Она регулировала все сферы жизни общинников, поэтому у государства не возникало необходимости в правовой регламентации усыновления. Лишь в XIX в. начали издаваться указы, регулировавшие институт усыновления. А. И. Загоровский отмечает: «...подведомственность дел о незаконных детях переходит из рук церкви в руки светских властей. Скудность законодательства и господствовавшая тогда привычки обращаться к Высочайшей власти способствовали развитию пестроты и случайности в постановлениях о внебрачных детях» [4, с.334-335]. Церковь резко отрицательно относилась к внебрачным связям, поэтому усыновление чужих детей было предпочтительнее. Однако российский законодатель долгое время не предоставлял возможности официального узаконения и усыновления, а согласившись придать этим институтам юридическую форму, наложил существенные ограничения на применение данных институтов, особенно строго - в отношении дворян [6, с.169]. Так фамилия потомственного дворянина передавалась усыновленному при условии, если он не пользовался большими правами состояния, и только по Высочайшему соизволению. Наследовал усыновленный исключительно благоприобретенное имущество, даже если усыновитель не имел родных сыновей, а имел лишь дочерей. Тогда имение делится между «сими последними поровну» [11, с.204]. Вместе с тем усыновленный сохранял право наследования по закону после своих родителей и их родственников [12, с. 132].

Таким образом, хоть усыновляемый ребенок и вступал по отношению к усыновителю во все права и обязанности кровных детей, ввиду всех существовавших ограничений мы не можем говорить о полном правовом тождестве усыновленного с родным ребенком усыновителя. Развивающееся законодательство по-прежнему охраняло принцип сословности. Все ограничения относительно имущества и фамилии потомственных дворян не касались усыновления купцами и лицами податного состояния. Для каждого сословия устанавливались свои правила и порядок усыновления.

Целью усыновления, прежде всего, выступала охрана имущественных интересов усыновителя-наследодателя. В сельской же местности усыновление давало возможность усыновителю приобрести дополнительные рабочие руки в домашнем сельском хозяйстве. И, что не менее важно, с помощью усыновления хозяйскому сыну можно было избежать воинской службы, так как усыновленный мог его заменить в случае призыва. Однако не только материальные корыстные цели преследовали усыновители. Не редки были и случаи усыновления, исходившие из гуманистических настроений. Когда хотелось отдать частичку тепла и заботы осиротевшему ребенку.

Совсем в ином виде предстает перед нами институт усыновления по обычному праву монголов. Именно в сфере семейных отношений обычное право преобладало над писаным, традиции были очень крепки.

Дети у монголов считались главным богатством человека. Чем больше было детей, тем счастливей были родители. Остаться без потомства означало не продолжить свой род, а это было большим несчастием для любого человека. Бездетные семьи, стремясь обзавестись желанным потомством, прибегали к помощи лам в молитвах, к помощи шаманов, проводили различные обряды и магические приемы.

Также желание иметь детей породило институт усыновления. Традиция усыновлять - урчлэх ес — была издавна известна монголам и была очень распространена. В «Сокровенном сказании монголов» упоминается об историческом акте усыновления между Ван-ханом кереитским и Чингис-ханом: «...Ван-хан сошелся с Чингисханом в Тульском Темном Бору, и они дали друг другу обеты отцовства и сыновства. Наподобие того, какие слова произносились некогда при обряде братания Ван-хана с отцом Есугай-ханом, так же и теперь обряд усыновления состоял...» $[10, \S 164]$. В монгольских преданиях часто рассказывают о приемных детях, которые становились приемными братьями членов различных родов. Обычно усыновляли детей, подобранных в неприятельских улусах, во время войн и набегов. Приемные дети не всегда входили в род своих приемных родителей, а продолжали считаться принадлежащими к тому роду, из которого были взяты. Тем не менее, они пользовались имущественными правами наравне с родными детьми своих приемных родителей; хотя чаще всего получали меньшую долю. Главное, они получали убежище и защиту рода, их принявшего [3, с. 61$]$.

Усыновляли в основном бездетные семьи, ведь тогда семейная пара уже не считалась бездетной. К тому же считалось, что усыновленный ребенок может привести к рождению в семье собственных детей — «дагуулах», «татах» - «притянуть». Усыновленный мальчик становился продолжателем рода, а девочка - помощницей для матери в хозяйстве. Ребенок мог быть взят по сговору у родственников или же совсем у чужих людей [7, с. 141]. Бывало, что супруги, не имеющие потомства, покупали детей у бедняков, платя за них большие деньги (до 
1000 р. за ребенка) [5, с. 54]. Нередки были и случаи кражи детей в городах: их увозили в степь бездетные и обычно состоятельные родители и воспитывали там, как своих наследников. Внебрачное рождение ребенка у монголов не составляло позора ни для матери, ни для самого ребенка [2, с. 24].Усыновление детей, рожденных до брака, по монгольскому обычному права не производится.

В зависимости от целей усыновление у монголов следует различать двух видов:

- С целью собственно воспитания, тогда приемный ребенок приравнивался и в личных, и в имущественных правах с родными детьми;

- В основе второго вида усыновления лежало соглашение о взаимовыгодных интересах: усыновитель получает хозяйственную выгоду в виде дополнительных рабочих рук, а усыновленный необходимое материальное обеспечение. В этом случае усыновленный не получал равных прав с родными детьми. Данный вид усыновления начал зарождаться в период складывания феодальных отношений. И в дальнейшем приобрел форму эксплуатации детского труда, бедняков. Закреплен он был в "Монгол цааз бичиг" - нормативно-правовом акте Монголии эпохи маньчжурского господства.

Правом усыновления пользуется каждое совершеннолетнее лицо, самый акт усыновления у рядовых монголов совершается с санкции хошунного управления, у князей - с разрешения чулган-дарги, причем о таком усыновлении должно быть поставлено в известность центральное правительство. Для усыновления требуется согласие родителей ребенка, но согласие усыновляемого не предусмотрено. Усыновленный ребенок формально пользуется всеми правами родного, но на практике, при разделе имущества или при наследовании власти (у князей), обычно возникает много споров и недоразумений [5, с.293].

Таким образом, проведя данный анализ института усыновления у русских и монголов, можно сделать следующие выводы. На его развитие большое влияние оказывало политическое, экономическое и социальное состояние общества. Монголы, у которых существовал культ детей, с удовольствием усыновляли детей, с целью их воспитания, передачи им родительской любви, а также в последующем - наследством. Однако развитие феодальных отношений придало данному институту не свойственные от природы черты: усыновление с целью получения дополнительных рабочих рук в хозяйстве принимало форму эксплуатации бедняков. В русском же праве усыновление долгое время существовало фактически, но никак не регламентировалось законодательно. Большое влияние на это оказало существовавшая сельская община. И даже когда начали издаваться нормативно-правовые акты, касаемые усыновления, их главной целью была охрана имущества усыновителя-наследодателя. И носило это законодательство ярко выраженный сословный принцип: усыновление дворянами предполагало множество запретов и ограничений.

\section{Литература}

1. Конвенция ООН о правах ребенка 1989 г. [Электронный ресурс]. Режим доступа: http://www.un.org/ru/documents/ decl_conv/conventions/childcon (дата обращения: 05.04.2016).

2. Банчиков Г. Г. Брак и семья у монголов. Улан-Удэ: Бурят. кн. изд-во, 1964. 60 с.

3. Владимирцов Б. Я. Общественный строй монголов. Монгольский кочевой феодализм. Л.: Изд-во АН СССР, 1934. 224 с.

4. Загоровский А. И. Курс семейного права / под ред. и с предисл. В. А. Томсинова. М.: Зерцало, 2003. 448 с.

5. Майский И. М. Современная Монголия. Иркутск: Знание сила, 1921. 332 с.

6. Минникес И. В., Бимбаева О. Л. Принятие детей в семью: историко-компаративистское исследование [Электронный pecypc]. Режим доступа: http://vestnik-msal.ru/articles/2015/01/01/article_101905.html (дата обращения: 05.04.2016).

7. Монголоведные исследования: сб. науч. ст. Улан-Удэ: Изд-во БНЦ СО РАН, 2000. Вып. 3. 180 с.

8. Нечаева А. М. Семейное право: учебник. 3-е изд., перераб. и доп. М.: Юристь, 2008. С. 263.

9. Пчелинцева Л. М. Семейное право России: учебник. 5-е изд., перераб. М.: Норма, 2008. С. 512.

10. «Сокровенное сказание монголов», § 164 [Электронный ресурс]. Режим доступа: http://booksonline.com.ua/view.php?book=170435\& page $=22$

11. Татаринцева Е. А. Правовые усыновления в семейной политике Российского государства: от исторического прошлого к реалиям современности // Исторические, философские, политические и юридические науки, культурология и искусствоведение. Вопросы теории и практики. 2011. № 3-2. С. 204

12. Фабричная Т. Б. Эволюция института усыновления в Российском праве XVIII-XX вв. (историко-правовое исследование): дис. ...канд. юр. наук. Владимир, 2010. 192 с.

\section{Недействительность сделок в гражданском праве России и Японии}

(С) Д. А. Ласточкина

магистрант 1 года обучения юридического факультета ФГБОУ ВО «Бурятский госуниверситет»

Россия, г. Улан-Удэ darlast@mail.ru

В данной статье ставится задача провести сравнительный анализ института признания сделки недействительной в соответствии с основами гражданского законодательства Российской Федерации и Японии. В статье рассматривается понятие сделки и основания признания ее недействительной в законодательстве этих двух стран. В статье отражена статистика дел судов общей юрисдикции по всей территории Российской Федерации, а также ее отдельных регионов, которая показывает большое объем рассматриваемых дел по данной теме, что 
подтверждает ее актуальность. Проведенный анализ темы позволил сделать вывод о том, что изучение института признания сделки недействительной имеет большое практическое значение.

В условиях глобализации современные государства ориентируются на интеграцию политических, экономических, культурных и правовых аспектов. Знание законодательства других государств может сделать более доступным перспективное направление экономической интеграции, обусловив правовую предсказуемость взаимодействия с потенциальными партнерами. Россия стремится занять ведущее место в интеграции стран АТР. Для осуществления этой цели необходим анализ особенностей законодательства стран АТР, в частности столь перспективного партнера, как Япония. Взаимная заинтересованность России и Японии проявляется в совместной реализации крупных проектов (например, в области культуры и спорта). Развитие русско-японских отношений в экономической сфере станет более продуктивным при условии взаимного изучения законодательства. В частности это касается такого основания возникновения, изменения и прекращения правоотношений как сделка.

Понятию сделки, ее формам, видам, а также вопросам недействительности сделок посвящена 9 глава 1 части ГК РФ - статьи со 153 по 181.[1] Согласно данному кодексу, сделками являются «действия граждан и юридических лиц, направленные на установление, изменение или прекращение гражданских прав и обязанностей.[1]

Сходным образом характеризуются сделки и в японском гражданском законодательстве: «правомерное действие, направленное на установление, прекращение или изменение гражданских прав и обязанностей».[2] Таким образом, сделку можно рассматривать как действие, направленное на получение некоего конкретного результата. Говоря о сделке, нельзя не упомянуть о ее структуре. Чтобы сделка состоялась, необходимо наличие таких составляющих, как: соблюдение формы сделки, законность содержания сделки, соответствие воли и волеизъявления участников, а также способность участников совершать данное действие. Таким образом, сделка рассматривается как акт волеизъявления сторон.

Существенные особенности имеет механизм возникновения гражданских прав и обязанностей из сделок, совершенных под условием. Возможность существования сделок, совершенных под условием, традиционно признается российским гражданским законодательством. В соответствии со ст. 157 ГК РФ, условной называется сделка, стороны которой ставят возникновение или прекращение прав и обязанностей в зависимость от какого-то обстоятельства, которое может наступить или не наступить в будущем. В качестве условия могут выступать как события, так и действия граждан и юридических лиц. При этом в качестве условия могут рассматриваться как действия третьих лиц, так и действия самих участников сделки (например, женитьба покупателя имущества, договорившегося с продавцом о том, что право собственности на проданное имущество перейдет к покупателю только с момента его женитьбы). Действия участников сделки могут являться условиями, так как действующее российское законодательство не содержит прямого запрета на это. Вместе с тем в некоторых законодательных системах имеют место запреты подобного рода. Так, например и в Японии, в соответствии со ст. 134 ГК Японии не может считаться условием действие, всецело зависящее от воли должника.[2] События и действия, относимые к условиям, должны обладать определенными признаками. События и действия в качестве условия должны характеризоваться тем, что в момент совершения сделки ее участникам не должно быть известно, наступит или не наступит в будущем обстоятельство, включенное в сделку в качестве условия. Именно неопределенность относительно того, наступит или не наступит то или иное обстоятельство, позволяет субъектам придать мотиву сделки значение условия. Например, гражданин обязуется предоставить в аренду свою дачу, если он приобретет или построит новую.[3]

В Российском законодательстве достаточно четко прописаны требования, предъявляемые к участникам сделки. Таковыми могут выступать юридические лица, а также дееспособные граждане. Сходные требования к участникам сделки предъявляет и японский гражданский кодекс. Однако, существует нюанс: полная дееспособность наступает в России в 18 лет, в Японии - в 20 лет. ГК РФ допускает возможность совершения сделок несовершеннолетними гражданами в специально оговоренных законом случаях (ст. 26, 28).

Недействительность сделки характеризует ситуацию, при которой правовые последствия, на которые была направлена сделка, не наступают.

В тексте ГК РФ содержится парадокс: в ст. 166 недействительными сделки признаются по основаниям, указанным в кодексе, а следующей ст. 167 указано, что «недействительная сделка не влечет юридических последствий, за исключением тех, которые связаны с ее недействительностью, и недействительна с момента ее совершения».[1] Такое неоднозначное прочтение недействительности сделки связано с тем, что сделка может быть рассмотрена как правоотношение или как юридический факт.

Недействительными в российском законодательстве признаются ничтожные и оспоримые сделки. Ничтожные сделки недействительны независимо от признания их судом (например, сделки с недееспособными лицами). А оспоримые сделки признаются недействительными судом. Их также принято называть абсолютно недействительными и относительно недействительными.[4]

В Японском законодательстве различают такие понятия как недействительность сделки и ее аннулирование.[2] Недействительные сделки, согласно ГК Японии, не требуют оспаривания и являются полностью недействительными (то есть сделка признаются недействительной для всех лиц с момента совершения). Аннулирование сделок происходит постфактум и требует оспаривания со стороны определенного законом круга лиц. До признания сделки аннулированной она считается действительной.

Основаниям для признания сделки недействительной служат пункты, указанные в статьях ГК РФ со 168 по 179.[1] Недействительными признаются сделки, нарушающие законы и иные правовые акты, противоречащие 
нравственности и правопорядку, мнимые и притворные сделки, сделки, совершенные недееспособными гражданами и (за некоторым исключением) несовершеннолетними и малолетними, а также сделки, совершенные под влиянием заблуждения, обмана или угрозы. Таким образом, сделка считается недействительной в тех случаях, когда правовым требованиям не соответствует какой-либо из ее компонентов.

В законодательстве Японии сделка, не соответствующая закону, относительно недействительна, то есть она может быть действительной при следующих условиях: если ни одна из сторон не проявила недобросовестность и не совершила в рамках сделки виновных деяний.[6]

В целом недействительные сделки в Японии аналогичны российским ничтожным сделкам. Однако в российском законодательстве сделка с недееспособным гражданином признается ничтожной, тогда как, согласно японским правовым нормам, недееспособный гражданин обладает правом аннулирования сделки (как и его представитель). То есть до того, как это право будет реализовано, сделка считается действительной. Безусловно недействительными признаются в Японии сделки, направленные против государства (ст. 90 ГК Японии).[7]

Аннулирование сделки в японском ГК всегда связано с волеизъявлением лиц, обладающим правом аннулирования. Если это право не было реализовано, то сделка считается действительной. К таким лицам гражданский кодекс Японии относит недееспособных граждан, лиц, подвергшихся обману или принуждению, их представителей и преемников. Последствием аннулирования сделки является признание ее недействительной с момента заключения. Признание сделок, подлежащих аннулированию, приравнивается к отказу от права аннулирования. Правом признания обладают те же лица, что имеют право аннулирования. Существует только одно ограничение: если на момент признания сделки лицо, обладающее правом аннулирования, остается недееспособным или продолжает подвергаться обману или принуждению, признание сделки не имеет правовых последствий. Право аннулирования может быть утрачено со временем: 20 лет с момента совершения сделки или по истечении 5 лет с того момента, как стало возможно осуществление признания.

С практической стороны изучения данной темы необходимо выяснить реальную статистику судебных дел, рассматриваемых судами в Российской Федерации и Японии. К сожалению, архив и статистические данные по судебным делам, рассматриваемых в Японии, не находится в открытой информации на русскоязычных источниках, что лишь свидетельствует о крайне малой степени изученности правового поля Японии в целом.

Таким образом, приведем статистику судебных дел, рассматриваемых судами общей юрисдикции по всей территории Российской Федерации, а также ее отдельных регионов.

Для начала представим статистику дел всех судов общей юрисдикции по всей территории Российской Федерации.[8]

За 2013 год судами общей юрисдикции в Российской Федерации было рассмотрено 135105 дел о признании сделки недействительной.

За 2014 год судами общей юрисдикции в Российской Федерации было рассмотрено 150205 дел о признании сделки недействительной.

За 2015 год судами общей юрисдикции в Российской Федерации было рассмотрено 176021 дел о признании сделки недействительной.

За начало 2016 года судами общей юрисдикции в Российской Федерации было рассмотрено уже 31874 дела о признании сделки недействительной.

Ссужая обзор судебной практики переходим к статистике дел, рассмотренных судами общей юрисдикции по Сибирскому федеральному округу. [9]

За 2013 год судами общей юрисдикции по Сибирскому федеральному округу было рассмотрено 22572 дела о признании сделки недействительной.

За 2014 год судами общей юрисдикции по Сибирскому федеральному округу было рассмотрено 26501 дел о признании сделки недействительной.

За 2015 год судами общей юрисдикции по Сибирскому федеральному округу было рассмотрено 38273 дел о признании сделки недействительной.

За начало 2016 года судами общей юрисдикции по Сибирскому федеральному округу было рассмотрено уже 7979 дел о признании сделки недействительной.

Заканчивая обзор судебных дел о признании сделки недействительной нельзя не представить статистику дел по районным судам г. Улан-Удэ. [10]

Так, за 2013 год в районных судах города Улан-Удэ, а именно в Железнодорожном, Советском, Октябрьском районных судах, было рассмотрено около 400 дел о признании сделки недействительной.

За 2014 год в районных судах города Улан-Удэ было рассмотрено свыше 2000 дел о признании сделки недействительной. [11]

За 2015 год в районных судах города Улан-Удэ было рассмотрено чуть более 1600 дел о признании сделки недействительной.

За начало 2016 года в районных судах города Улан-Удэ было рассмотрено уже около 570 дел о признании сделки недействительной. [12]

Из представленной статистики судебных дел по делам о признании сделки недействительной отражается постепенное увеличение, рассматриваемых судами дел по такого рода случаям. Особенно это видно на примере приведенной статистики дел по судам общей юрисдикции на всей территории Российской Федерации и по Сибирскому федеральному округу. Исходя из статистики дел по районным судам г. Улан-Удэ наблюдается резкое повышение на 2014 год и постепенное снижение к последующим годам. 
Причину, по которой это происходит достаточно сложно точно определить. Остается только анализировать различные правовые, а также социально-экономические предпосылки для этого. Но несколько выводов можно сделать совершенно точно:

1) Институт признания сделки недействительной широко применяется участниками гражданских правоотношений как в Российской Федерации, так и в Японии;

2) Тема является одной из наиболее острых и актуальных сфер для изучения в правовом поле различных стран, особенно в аспекте сравнительного анализа таких разных стран как Российская Федерации и Япония;

3) Существует необходимость дальнейшего изучения и совершенствования законодательства обеих стран с целью более эффективного правового, экономического и социального взаимодействия.

Таким образом, можно констатировать, что при наличии общего категориального ряда в рамках гражданского законодательства двух стран, существует немало отличий, без учета которых невозможно правильное понимание и адекватное взаимодействие правовых, политических, социальных институтов, организаций, а также физических лиц. Изучение специфики гражданского права в сфере сделок поможет выявить особенности условий и правовых последствий недействительности сделок и сформировать единое экономико-правовое поле.

\title{
Литература
}

1. Гражданский кодекс Российский Федерации. М.: Проспект, 2011. Ст. 153-181. C. 100.

2. Гражданское право Японии: 1 кн. / Сакаэ Вагацума, Тору Аридзуми; пер. с яп. В. В. Батуренко. М.: Прогресс, 1983.

3. Брагинский М. И. Сделки: понятия, виды и формы (комментарий к новому ГК РФ). М., 2005. С. 50.

4. Гражданское право: в 2 т. / отв. ред. Е. А. Суханов. М.: БЕК, 1998. Т. 1.

5. Гражданское право Японии: 1 кн. / Сакаэ Вагацума, Тору Аридзуми; пер. с яп. В. В. Батуренко. М.: Прогресс, 1983. C. $134-136$

6. Недействительность сделок в предпринимательской деятельности // Отчет 1-го семинара по сравнительному изучению законодательства стран Средней Азии и Японии. - 10-19 декабря 2008 г. [Электронный ресурс]. Режим доступа: http://www.docme.ru/doc/651461/nedejstvitel._nost._-sdelok-v-predprinimatel._skoj-deyatel._nosti (дата обращения: 20.12.2015).

7. Civil Code of Japan [электронный ресурс]. Режим доступа: http://www.moj.go.jp/content/000056024.pdf (дата обращения: 21.12.2015).

8. Статистика судебных дел [Электронный ресурс]. Режим доступа: https://rospravosudie.com.

9. Статистические данные справочно-правовой системы "Консультант Плюс".

10. Статистическая справка Советского районного суда г. Улан-Удэ [Электронный ресурс]. Режим доступа: http://sovetsky.bur.sudrf.ru.

11. Статистическая справка Железнодорожного районного суда г. Улан-Удэ [Электронный ресурс]. Режим доступа: http://zheleznodorozhniy.bur.sudrf.ru/.

12. Статистическая справка Октябрьского районного суда г. Улан-Удэ [Электронный ресурс]. Режим доступа: http://oktiabrsky.bur.sudrf.ru.

\section{Понятие «разумный срок» в гражданском праве КНР}

\author{
(С) Ли Яо \\ магистрант 1 года обучения \\ Китайско-российского института \\ Хэйлунизянского университета \\ Китай, г. Харбин \\ 245259947@qq.com
}

В действующем гражданском законодательстве Китая очень часто употребляется понятие «разумный срок», например, в законе КНР «О договорах» (принят 2-й сессией ВСНП девятого созыва 15 марта 1999 г.) устанавливает: «Статья 23. Акцепт должен быть получен оферентом в пределах срока, установленного в оферте. Если срок в оферте не установлен, акцепт должен поступить в соответствии со следующими правилами:1) в случае, когда оферта сделана в ходе переговоров, акцепт должен быть заявлен немедленно; 2) в случае, когда оферта сделана не в ходе переговоров, акцепт должен быть получен в течение разумного срока. Статья 69. В случае если сторона в соответствии с положениями статьи 68 настоящего Закона приостановила исполнение, она обязана своевременно уведомить другую сторону. Если другая сторона предоставит надлежащие гарантии исполнения, исполнение надлежит продолжить. Если после приостановления исполнения другая сторона в разумный срок окажется не в состоянии продолжить исполнение, а также не предоставит надлежащих гарантий, сторона, приостановившая исполнение, вправе расторгнуть договор. Статья 118. Если одна из сторон не может исполнить договор из-за непреодолимой силы, она обязана своевременно уведомить другую сторону с целью уменьшения у нее возможных убытков, а также должна в разумный срок предоставить доказательства[1]». Хотя его легальное определение в законе отсутствует, «разумный срок-это оценочная категория, для которой характерно отсутствие достаточного количества общих признаков [4]».

Понятие «разумный срок» уже традиционно существует в праве отдельных государств, а в современной науке китайского гражданского права только разрабатывается, вследствие чего проблему понимания этой категории нельзя признать решенной на теоретическом уровне. 
В настоящее время выработано два основных подхода к изучению данной категории. Первый подход при оценке такого срока считает необходимым учитывать предмет обязательства, взаимоотношения сторон, условия исполнения, влияющие на действие субъектов конкретных правоотношения. Второй подход предлагает использовать понятие «средний (разумный или простой человек» [2, с.101]: «разумный срок-это время, необходимое разумному человеку для осуществления действия в конкретном случае» [3, с. 528]. Разумными являются действия, которые совершило бы в данной ситуации большинство людей. А эти действия в основной массе стремятся к средней величине. При этом, однако, надо учитывать, что уровень интеллекта, знаний и опыта абстрактного среднего человека не является одинаковым для всех случаев. Для элементарных действий он ниже, чем для сложных, требующих образования и специальных навыков. Причем под разумным человеком понимается абстрактная личность, обладающая нормальным средним уровнем интеллекта, знаний и жизненного опыта. В англо-американском праве понятие «разумный человек» (reasonable man) используется очень широко и определяется как «обычный гражданин, иногда называемый человеком из автобуса» [5, с. 383] . Слово "разумность", которое в обычном смысле обозначает интеллектуальную деятельность человека, как юридическое понятие характеризует объективную сторону его действий. Дело в том, что, оценивая разумность действий, мы не рассматриваем интеллектуальный или волевой элемент реальных действий конкретного субъекта. В этом случае проверяется возможность совершения определенных действий не конкретным лицом, а средним человеком. Мы говорим, что нормальный человек, желая совершить определенное действие (осуществить право или исполнить обязанность), был способен сделать это в конкретных условиях. При этом не имеет значения, знал ли конкретный субъект о последствиях своих действий, желал или не желал их наступления. Существенным является лишь то, что нормальный (средний) человек мог совершить в данной ситуации определенные действия. Таким образом, разумность характеризует интеллектуальные и нравственные качества лица опосредованно, через сравнение его поведения с возможным поведением среднего человека.

В этих подходах имеются следующие недочеты: в первом случае авторы указывают лишь на общие понятия, которые характеризуют обязательство в целом, а признаков разумного срока нет; во втором случае одну оценочную категорию определяют через другую оценочную же категорию.

Китайская судебная практика такой срок определяет как разумный исходя из конкретных обстоятельств. Поэтому продолжительность разумного срока зависит от конкретных обстоятельств дела.

Можно предложить следующее решение вопроса об определении критериев, которым должен соответствовать разумный срок- закрепить в законодательстве указанные критерии оценки разумного срока применительно к любой сложившейся ситуации.

\title{
Литература
}

1. Законодательство Китая [Электронный ресурс]. Режим доступа: http://chinalawinfo.ru

2. Брагинский М.И. Осуществление и защита гражданских прав. Сделки. Представительство. Доверенность. Исковая давность // Вестник ВАС РФ. 1995. N 7. С. 101

3. Договорное право / под ред. Цуй Джаньюань. Пекин: Юридическое издательство, 2010. 528 с.

4. Комментарий к закону КНР «О договорах» от 15.12.1999 // «Собрание законодательства КНР». 05.12.2008. № 69. Ст. 786.

5. Elizabeth A. Martin. Oxford Dictionary of Law. Oxford, 1997. P. 383.

\section{Значение применения семейного обычного права в Китае}

\author{
(С) Жэнь Линлин \\ стариий преподаватель Маньчжурского института \\ университета Внутренней Монголии \\ Китай, г. Маньчжурия \\ rll1015@yandex.ru
}

Как известно, обычное право, как существование источника права в современном мире стало распространенным фактом. М.Вебер считает, что в традиционном китайском обществе, законы в значительной степени являются всего лишь этическими нормами, китайский традиционный закон по существу является этическим законом. Тем не менее, по мере изменения общества, постепенного распада традиционной семьи, семейное обычное право постепенно утратила его фундамент существования. Так, в текущем социальном контексте, может ли закон полностью отказаться от традиционной семейного обычного права, имеет ли традиционное обычное право семьи какое-нибудь значение для действующего закона о браке и семье в Китае? В этой статье автор намерен обсудить этот вопрос, не слишком углубляясь в детали.

1. Семейное обычное право дополняет недостаток действующего закона.

Законодательство становится всё более совершенными и в качестве основного источника права выступает нормативно-правовой акт в Китае, в этом случае, национальный обычай или обычное право перестает быть основным источником китайского закона. Эффективный диапазон или роль обычного права постепенно сокращаются, но единая правовая система не исключает специфику этнических районов, так, в некоторых этнических группах и сельских районах, которые более меньше подвергаются воздействию внешней окружающей среды, первоначальное обычное право всё же активно существует и играет важную роль. Обычное право семьи призвано компенсировать недостаток действующего закона, восполнять его пробелы. 
С одной стороны, брачно-семейное правоотношение, как область частного права, иногда придерживается народных обычаев, тем самым в большей степени способствуя семейной гармонии и стабильности в обществе. С другой стороны, в брачно-семейных отношениях часто существует много эмоциональных факторов и которые трудно загнать в жёсткие рамки закона. Кроме того, Китай как многонациональная страна, основывается на своеобразии национальных регионов, соблюдает их национальные обычаи. Это всё создаёт благоприятные условия для разрешения конфликтов. Статья 35 закона Китайской Народной Республики «О наследовании» гласит, что Собрание народных представителей национальных автономий вправе на основе принципов базового закона о наследовании, а также с учётом объективно сложившейся среди местной народности ситуации с наследованием имущества разработать адаптивные либо дополнительные нормативные акты. В законе КНР «О браке» есть аналогичное положение. Эти положения оставляют место для применения обычая. Согласно этим законам, в брачно-семейных делах могут применяться обычаи, привычки, быт и нравы народов национальных автономий. В соответствии со статьей 35 закона «О наследовании», Аба-Тибетско-Цянский автономный округ в провинции Сычуань применяет адаптивные нормативные акты, которая гласит: «Дело по наследовании, рассматривается согласно закону о наследовании, если же в деле имеется завещание, то оно рассматривается по завещанию; когда имеется соглашение завещание-содержания, тогда наследование производится по соглашениям; когда не имеются ни завещания, ни соглашения, после того, как наследники согласились, можно наследовать по национальному обычаю». На самом деле, эта статья условно приняла местный обычай.

Статья 14 закона Китайской Народной Республики «О защите прав и интересов пожилых людей» гласит, что алиментант обязан содержать пожилых людей, в том числе удовлетворение в экономических, жизненных и моральных сторонах, обязан удовлетворить особые потребности пожилых людей и заботиться о них. Статья 18 гласит, что члены семьи должны заботиться о моральных потребностях пожилых людей, нельзя игнорировать их, отстраняться от них. Члены семьи, проживающие отдельно, должны часто навещать и приветствовать их. В судебной практике содержания вышеизложенных статьей не обладает пригодностью, цель которых заключается в руководстве поведением людей. Какое поведение считается в соответствии с положениями предыдущей статьей? Обычное право семьи по-прежнему должно иметь единую силу.

2. Применения в судебной практике.

Согласно статистическим данным суда, в гражданском процессе, особенно, в семейном праве обычай применяется намного чаще, чем в других отраслях. Народный суд средней ступени в некоторых городах провинции Гуандун с 2004 по 2007гг проводил анализ 192 дел его города, в которых применяется обычай. Получилось, что среди них 124 брачных споров, 8 алиментных споров, 9 споров наследования, 51 других споров. Во всех сферах жизнедеятельности людей, количество обычаев в области брака и семьи является самым частным, Например, Разъяснение Верховного народного суда о проблемах обработки возвращения калыма по браку. «Разъяснение Верховного народного суда О некоторых вопросах применения Закона КНР о браке (№2)» статьей 10 предусматривает, что заявление возврата выплаченного в соответствии с традициями выкупа за невесту (калыма), если определен относиться к следующим обстоятельствам, народный суд должен поддерживать: (1)Обе стороны не зарегистрировались в ЗАГСе; (2) Обе стороны зарегистрировались в ЗАГСе, но никогда не жили вместе; (3) Перед тем как обе стороны сочетались браком плательщик выплатил калым, который привёл к трудностям его жизни. Согласно содержанию вышеизложенного разъяснения, заявление стороны возврата выплаченного в соответствии с традициями выкупа за невесту (калыма), если обе стороны не зарегистрируются в загсе, народный суд должен поддерживать. Тем не менее, согласно обычаям некоторых районов, если девушка инициировала прекращение отношений, калым должен быть возвращен, и когда мужчина - прекратил отношение, как правило, не возвращают калым. Таким образом, в судебной практике, всегда с учётом содержания обычаев, если девушка решила прекратить отношения, то суд решит возвращать калым, а когда мужчина прекращает отношение, то суд может решить частично возвращать калым. В вышеперечисленных случаях разъясняются три ситуации возврата калыма. Это является примером принятия и уважения обычаев.

В процессе регулирования семейных отношений, обычай играет огромную роль, как в процессе регулирования брачных отношений, так и в регулировании споров имущественных наследований, а также в регулировании споров по поводу содержания пожилых людей, детей и инвалидов, в регулировании споров распределения семейного имущества и т.д. По сравнению с нормативным правовым актом, обычай выполняет более активную социальную функцию. Причина в том, что обычай является накоплением традиционной культуры, но и люди глубоко признают его и относятся к нему как к своей духовной опоре.

3. В районах проживания малых народностей обычное право практикуется особенно часто.

Некоторые учёные считают, что Обычное право в районах национальных меньшинств оказывает значительное влияние на правотворчество, особенно в сфере экологической защиты, брака, собственности, наследования. Обычное право играет существенную роль в поддержании общественного порядка. По глубине и эффективности регулирования социальных отношений Обычное право сильнее государственного закона. [2] В уголовно и административно процессуальных делах обычное право в большинстве случаев практикуется в сельских районах и районах проживания малых народностей. В районах малых наций, этнические обычаи, на самом деле, наравне с законом, могут эффективно регулировать и поддерживать общественный порядок.

В настоящее время, обычаи малых народностей в этнических районах всё ещё имеют широкое влияние и играют важную роль, это есть объективный факт. Тем не менее, многие обычаи малых наций соответствуют духу закона. Брак малых наций в некоторых районах способствует поддержанию стабильности брачно-семейных отношений, их брак будет характеризоваться меньшим влиянием эмоциональных факторов, сокращением 
споров в семейных отношениях. Почти отсутствуют факторы влияющие на их брак, что сокращает брачно-семейные споры. Например, предки народности наси (одной из национальных меньшинств КНР, пров. Юньнань, Сычуань) считали, что брачный союз не только является общей жизнью двух людей, но и долговременным соединением души. После бракосочетания супруги не могут быть разделены. Такой обычай способствует поддержанию стабильности брачно-семейных отношений. Кроме того, среди дел с окончательным решением судов в районах малых наций, доля примирительных исходов очень велика. Это связанно с применением местных обычаев судьями в ходе судебного разбирательства.

В Китае, несмотря на то, что традиционные идеи семьи постепенно утрачивают свою силу, тем не менее, она не полностью исчезла. В современном обществе Обычное право всё ещё оказывает огромное влияние на все аспекты жизни. Сейчас, оправданные обычаи используют в судебной практике или внедряют в законодательство, что очень полезно.

\section{Литература}

1. Редактор Чжэн Э. Исследование проблемы горячей точки юстиции Наньюе (Гуандун). Гуанчжоу: Гуандунское нар. изд-во, 2008. С. 448.

2. Ли Сюелань. Научный доклад исследований китайского народного закона (2002-2005 гг.) // Вестник Шаньдунского университета. 2006. № 1. С.30.

\section{Особенности несостоятельности (банкротства) физических лиц в России и Южной Корее}

(ㄷ) Ю. К. Лосева

магистрант 1 года обучения юридического факультета ФГБОУ ВО «Бурятский госуниверситет»

Россия, г. Улан-Удэ

ulenka94.11.02@mail.ru

В связи с тем, что в российском законодательстве возник институт банкротства физических лиц, опыт иностранных государств в данном вопросе имеет важнейшее значение. На наш взгляд, Республика Корея представляет значительный интерес в вопросе банкротства физических лиц, так как практикует данный институт банкротства более пятнадцати лет. Поэтому в настоящей статье мы проанализировали нормативно-правовую базу, регламентирующую институт банкротства Республики Корея, которая охватывает широкое регулирование данного института.

Из-за финансового кризиса 1997-1998 гг. многие компании, а также физические лица оказались неплатежеспособными. В законодательстве Южной Кореи появились пробелы ввиду отсутствия механизма обеспечения восстановления платежеспособности. В связи с этим, были приняты нормативно-правовые акты, регулирующие отношения банкротства физических лиц. С 1 апреля 2006 г. вступил в силу Закон Республики Корея «О восстановлении и банкротстве должника» [2].

Законодательство Республики Корея предусматривает возможность урегулирования вопроса о неплатежеспособности физического лица во внесудебном порядке. Такой механизм называется финансовой реструктуризацией задолженности физического лица. Однако данный метод применяется только в отношении физических лиц перед финансовыми организациями.

Финансовой реструктуризацией задолженности занимается Служба по финансовому восстановлению, образованная в 2002 году при поддержке Правительства Республики Корея.

Данная служба содействует в трудоустройстве должников (в случае, если у должника нет постоянного источника дохода), проводит для них консультации, выдает займы на условиях обязательного страхования и проводит процедуру реструктуризации долгов физических лиц перед финансовыми организациями.

Следует отметить, что важным условием во внесудебной процедуре погашения долгов является размер ее суммы. Для граждан, не осуществляющих предпринимательскую деятельность, задолженность не должна превышать 1,5 млрд. вон (около 60 млн. рублей), для индивидуальных предпринимателей - 3 млрд. вон (около 120 млн. рублей). Необходимо учесть, что просрочка задолженности не может превышать трех месяцев. Для участия во внесудебной процедуре погашения долга возможно, если должник имеет постоянный доход, который обеспечивает проживание его самого и членов его семьи, при этом остается денежная сумма, которая может быть обращена на погашение долга. Если у должника на момент обращения нет постоянного источника дохода, ему могут предоставить отсрочку, но не более, чем на два года.

Во внесудебной процедуре реструктуризации долга Служба подготавливает план погашения задолженности, который предполагает сокращение долга на определенный размер, сокращение процентов, предоставление отсрочки по выплатам. Срок утверждения плана составляет 2,5 месяца. При этом чтобы принять данный план, необходимо собрать согласие не менее половины кредиторов. Так как долг погашается только перед финансовыми организациями, а не перед любыми кредиторами, погашение задолженности будет нести оправданный и преодолимый характер, в особенности в части погашения перед единственным банком.

Реструктуризация долга осуществления на основании соглашения между должником и финансовой организацией кредитором. Предельный срок этой процедуры составляет десять лет, а по ипотечным кредитам - двадцать. 
Внесудебная процедура погашения задолженности имеет положительный характер и ряд преимуществ перед судебной процедурой. Во-первых, длительный срок погашения задолженности, во-вторых, возможность дополнительного выделения денежных средств (займ), в-третьих, возможность управлять задолженностью на основании соглашения с финансовой организацией. Однако существует и ряд недостатков. К их числу относятся ограниченный объем сокращения долга и погашение последнего только у финансовых организаций, а не у любых кредиторов.

Появление внесудебного порядка погашения задолженности по обязательствам в российском законодательстве помогло бы решить проблему с массовой неплатежеспособностью населения. На наш взгляд, российским законодателям можно было бы взять опыт корейской республики по поводу создания органа, в функции которого относилось содействие в финансовом восстановлении неплатежеспособных граждан.

Перейдем к судебной процедуре банкротства.

Законодательство Кореи содержит в себе две судебные процедуры несостоятельности (банкротства) для физических лиц: восстановление платежеспособности и банкротство. Данные процедуры направлены на освобождение гражданина от имеющихся долгов. Необходимо отметить, что отличительной чертой от законодательства Российской Федерации является тот факт, что законодательство Республики Кореи не содержит процедуру мирового соглашения. В соответствии с п.1 ст. 150 Федерального Закона от 26.10.2002 № 127 -Ф3 «О несостоятельности (банкротстве)» на любой стадии рассмотрения арбитражным судом дела о банкротстве должник, его конкурсные кредиторы и уполномоченные органы вправе заключить мировое соглашение [1].

Процедура восстановления платежеспособности физического лица предполагает урегулирование задолженности перед любыми кредиторами. Для того чтобы применить условия процедуры восстановления должны быть соблюдены определенные условия.

Во-первых, сумма долга не должна превышать 500 млн. вон.

Во-вторых, должник должен иметь источник постоянного дохода.

В-третьих, должник должен осуществлять выплаты в размере оставшегося дохода на протяжении пяти лет в пользу кредиторов.

Таким образом, для того, чтобы установить процедуру восстановления нужно, чтобы физическое лицо имело постоянный заработок. При удовлетворительном выполнении условия в течение пяти лет гражданин по окончании процедуры освобождается от оставшейся части задолженности. Процедура восстановления признается предпочтительной перед процедурой банкротства, если будет установлено, что сумма выплат за пять лет превышает сумму, которую возможно получить от продажи имущества физического лица[4].

При подаче заявления должник обязан представить план погашения долга. Данный план рассматривается кредиторами, но, если суд придет к выводу, что денежные средства должника отвечают всем требованиям, план принимается без собрания кредиторов. После утверждения плана должник погашает долг в определенные этим планом сроки.

По российскому законодательству процедура восстановления платежеспособности намного жестче. Вопервых, нормы российского законодательства требуют погашения полностью всей задолженности перед кредиторами, только лишь с согласия отдельного конкурсного кредитора и (или) уполномоченного органа план реструктуризации долгов гражданина может содержать положение о погашении не в полном размере требований. Во-вторых, по российскому законодательству удерживаются проценты на сумму долга. В-третьих, срок выполнения плана составляет всего три года.

Таким образом, когда в корейском законодательстве должник может быть признан полностью освобожденным от долговых обязательств на стадии восстановления при соблюдении всех условий, российское законодательство предусматривает освобождение от долгов только на стадии процедуры банкротства и реализации имущества.

В законодательстве Республики Корея следует отметить, что в процедуре восстановления, право управления имуществом должника осуществляется самим должником и не передается управляющему (п. 2 ст. 580 Закона). Таким образом, должник независимо от кредиторов самостоятельно распоряжается своим имуществом, однако при условии, что будет придерживаться графика выплат. В российском законодательстве положение должника ограничено. Самостоятельно должник не может распоряжаться своим имуществом в период проведения реструктуризации (ст. 213.11 Закона о банкротстве), при этом участие арбитражного управляющего в процедуре является обязательным условием.

При надлежащем выполнении должником плана восстановления суд может освободить должника от оставшейся суммы долга, но только той, которая указана в плане. Так как не указанные в плане восстановления обязательства сохраняют силу.

В законодательстве корейской республики существует вероятность освобождения от долгов в определенных ситуациях. Например, когда должник теряет работу, постоянный источник дохода в результате ухудшения здоровья или в результате несчастного случая. В этом случае по решению суда освобождение должника от оставшейся части долга возможно, если с момента начала процедуры уже была погашена ее большая часть (п. 2 ст. 624 Закона).

В процедуре банкротства гражданина имущество должника реализуется с момента признания должника банкротом. В результате данной процедуры происходит освобождение должника от оставшейся непогашенной задолженности. 
Согласно корейскому законодательству процедура восстановления и процедура банкротства не являются взаимозависимыми. Суд может при не успешности процедуры восстановления ввести процедуру банкротства, минуя процедуру восстановления. Таким образом, банкротство может быть первой и единственной применяемой процедурой.

В российском законодательстве реструктуризация задолженности и реализация имущества должника применяются только в строгой последовательности. Арбитражный суд выносит решение о признании должника банкротом только после процедуры реструктуризации. В случае если физическое лицо, конкурсный кредитор, уполномоченное лицо не представило план реструктуризации, суд признает должника банкротом и принимает решение о введении реализации имущества гражданина (ст. 213.24 Закона). Таким образом, Арбитражный суд обязательно предоставляет должнику шанс ввести процедуру реструктуризации.

В отличие от российского законодательства, корейское законодательство не предусматривает признаки банкротства. Отсутствует характер задолженности, не установлены суммы долга, при которых допускается обращение в суд с заявлением.

Подать заявление о банкротстве может и должник, и кредитор. После рассмотрения всех необходимых документов и перечисления должником предварительной оплаты, суд объявляет о банкротстве должника и назначает управляющего в процедуре банкротства. Именно в процедуре банкротства Закон предусматривает обязательное участие арбитражного управляющего. К нему переходит право управления и распоряжения всем имуществом должника, составляющим фонд банкротства (ст. 382 Закона). Управляющим осуществляется продажа выявленного имущества с перечислением всех полученных сумм в фонд банкротства, за исключением имущества небольшой стоимости в пределах до 30 млн. вон, необходимой для проживания должника [3]. Как и в российском законодательстве о банкротстве физических лиц, конкурсная процедура не предусматривает исполнение требований отдельных кредиторов, все требования можно предъявить только в процедуре банкротства. Необходимо отметить, что в российском законодательстве предусмотрены последствия банкротства, таких как, запрет на занимание должности в органах управления юридического лица, в течение пяти лет не вправе заключать договоры без указания на факт своего банкротства, когда по корейскому законодательству ограничения отсутствуют.

По итогам реализации имущества и осуществления расчетов с кредиторами судом принимается решение о завершении процедуры банкротства. Если у должника не выявлено имущество, которым можно погасить долг перед кредиторами, суд выносит решение об отмене банкротства. Однако, как в случае завершения, так и в случае отмены банкротства должник освобождается от оставшейся части долга, если нет оснований для отказа в освобождении (ст. ст. 564, 566 Закона). Неисполненные требования кредиторов в таком случае автоматически погашаются.

Как и в российском, так и корейском законодательстве к основаниям для отказа в освобождении от долговых обязательств относятся действия, которые нарушают интересы кредиторов. К их числу относятся: сокрытие документов, преднамеренное или фиктивное банкротство, предоставление недостоверных сведений, скрытие и умышленное уничтожение имущества, мошенничество.

Следует отметить, что согласно корейскому Закону должник освобождается от задолженности не более одного раза за семь лет. То есть в течение семи лет с даты прекращения производства по делу о банкротстве, дело не может быть возбуждено по заявлению этого гражданина. Аналогичная норма установлена и в российском законодательстве, только в течение пяти лет.

Таким образом, в соответствии с проведенным сравнительным анализом можно прийти к выводу о том, что российскому законодателю необходимо смягчить систему процедуры банкротства физического лица на примере корейского законодательства. Это должно проявиться в создании службы по восстановлению платежеспособности должника, увеличения срока погашения задолженности, смягчении применения негативных последствий для должника. На наш взгляд, применение внесудебного порядка погашения задолженности перед кредиторами (финансовыми организациями) в Российской Федерации положительно повлияло бы на граждан-должников. Проблемы несостоятельности физических лиц, таким образом, могут быть преодолены без судебных разбирательств.

\section{Литература}

1. О несостоятельности (банкротстве) [Электронный ресурс] : [Федеральный закон от 26.10.2002 N 127-Ф3 (ред. от 29.12.2015)]. Режим доступа :http://www.consultant.ru/document/cons_doc_LAW_39331

2. Закон Республики Корея "О восстановлении и банкротстве должника".

3. Литвинов А. В., Юрченко Е. В. Современный мировой опыт банкротства и антикризисного управления. М.: МАРТИТ, 2011. С. 61-64.

4. Пирогова Е. С., Жукова Ю. Д. Особенности несостоятельности (банкротства) физических лиц по законодательству Республики Корея // Право и бизнес. 2011. № 4. С. 17-20. 


\title{
Сравнительно-правовой анализ договора аренды земельного участка в России и Китае
}

\author{
(C) C. M. Мантатова \\ магистрант 1 года обучения юридического факультета \\ ФГБОУ ВО «Бурятский госуниверситет» \\ Россия, г. Улан-Удэ \\ smantatova@gmail.com
}

Договор аренды земельного участка это один из наиболее востребованных гражданско-правовых договоров не только в практической деятельности предпринимателей, но и широко за ее пределами. Лицо, которое занимается на постоянной основе производством товаров, выполняет работы или оказывает услуги, не всегда имеет финансовую возможность приобрести землю в собственность для осуществления на ней предпринимательской деятельности. Но даже при наличии такой возможности, целесообразна и экономически выгодна именно аренда земельного участка, а не приобретение его в собственность.

Право аренды возникает на основании договора, заключенного в отношении земельного участка, который может находиться как в частной, так и в государственной или муниципальной собственности. Поэтому применение Гражданского кодекса РФ к арендным отношениям очевидно. Однако в правовой литературе справедливо отмечается, что границы свободы договора, объектом которого является земельный участок, должны определяться на основе публично-правового регулирования (земельного законодательства) [3].

Федеральным законом от 23.06.2014 №171-Ф3 «О внесении изменений в Земельный кодекс Российской Федерации и отдельные законодательные акты Российской Федерации» [2], вступившим в законную силу с 1 марта 2015 года, были внесены изменения в Земельный Кодекс РФ. Статьи 22, 39.6 - 39.8 и другие статьи ЗК РФ предусматривают специальные правила об аренде земельного участка. Статья 22 ЗК РФ не подверглась существенным изменениям и предусматривает общие положения об аренде земельного участка. Стоит отметить, что законодатель перенес из ст. 65 ЗК РФ в ст. 22 ЗК РФ положение о том, что существенным условием договора аренды земельного участка является размер арендной платы. Положения ст. 22 ЗК РФ должны применяться во всех случаях заключения договоров аренды земельного участка и являются специальными по отношению к нормам гражданского законодательства об аренде недвижимого имущества.

Особый интерес представляют нормы ст. 39.6 - 39.8 ЗК, которые регулируют предоставление в аренду земельных участков, находящихся в собственности государства или муниципалитета. П. 1 ст. 39.6 ЗК РФ устанавливает единое для всех субъектов гражданских правоотношений правило - договор аренды земельного участка, находящегося в государственной или муниципальной собственности, заключается на торгах, проводимых в форме аукциона. Исключение из данной нормы составляют три группы случаев, которые перечислены в п. 2 ст. 39.6 ЗК РФ: 1) при первичном заключении договора аренды; 2) при заключении нового договора гражданами и юридическими лицами - арендаторами находящихся в государственной или муниципальной собственности земельных участков; 3) при заключении договора аренды с собственником объекта незавершенного строительства. В приведенных выше случаях договор аренды заключается без проведения торгов.

Из ст. 39.8 ЗК РФ следует, что при заключении договора аренды земельного участка, находящегося в государственной или муниципальной собственности, его условия определяются Гражданским кодексом РФ, Земельным кодексом РФ и иными федеральными законами. Таким образом, законодатель отнес данный вопрос к полномочиям РФ, и иные нормативные акты, принимаемые на федеральном, региональном или местном уровне не смогут регулировать эти правоотношения, что позволит упорядочить правоприменительную практику.

П. 8 ст. 39.8 ЗК РФ содержит нормы, предусматривающие срок, на который может быть заключен договор аренды. Для одних случаев установлены предельные минимальные и максимальные сроки договора (например, для комплексного освоения территории юридическому лицу аренда земельного участка может составлять 3 - 5 лет), для других установлен только предельный максимальный срок (например, для строительства линейных объектов - до20 лет). В-третьих, срок договора аренды обусловлен ранее возникшими отношениями (в случае предоставления в аренду земельного участка, образованного из исходного земельного участка, за исключением случаев, если земельный участок предоставлен юридическому лицу для комплексного освоения территории или ведения дачного хозяйства, договор аренды заключается на срок, не превышающий срока действия договора аренды земельного участка, являющегося исходным). В четвертых случаях устанавливается конкретный срок договора аренды земельного участка - например, 20 лет в случае предоставления гражданину земельного участка для индивидуального жилищного строительства или земельного участка в границах населенного пункта для ведения личного подсобного хозяйства.

Согласно п. 15 ст. 39.8 ЗК РФ арендатор земельного участка, находящегося в государственной или муниципальной собственности, не имеет преимущественного права на заключение на новый срок договора аренды такого земельного участка без проведения торгов. Считаем, что арендатор, зная это обстоятельство, не заинтересован в использовании земли, в обеспечении проведения кадастровых работ, что может негативно сказаться на рациональном и эффективном использовании земель в муниципальном образовании. Данная норма не дает устойчивости использования земли, ощущения «своего» земельного участка и даже заинтересованности в его получении (поскольку гражданин, неся расходы по подготовке земельного участка к торгам, может его не получить). 
Земельный кодекс РФ насыщен отсылочными к гражданскому законодательству и процессуальным нормам, что затрудняет восприятие правовых норм о правах на земельные участки, их толкование и применение.

В Китае, как известно, крайне мало земель сельскохозяйственного назначения, так как большая площадь страны занята горами и, следовательно, непригодна для ведения на ней сельского хозяйства. Конституция КНР предусматривает две формы собственности: государственная и коллективная. Согласно частям первой - четвертой ст. 10 Конституции земля в городах является государственной собственностью, а в деревнях и пригородах (за исключением участков, принадлежащих по закону государству), а также земля под жилыми постройками, приусадебные земельные и горные участки принадлежат коллективам. Всем субъектам гражданского права запрещены присвоение, купля-продажа, аренда или незаконная передача земли в другой форме. Государство же может в соответствии с законом реквизировать земли на общественные нужды. Передача права пользования земельным участком возможна в соответствии с законодательством.

Земельные участки в Китае предоставляются в аренду на конкурсной основе. Все средства, получаемые от субъектов землепользования, поступают в госбюджет для социального обустройства проживающих в деревне, а также для содержания аппарата управления по земельным ресурсам.

Договор аренды в Китайской Народной Республике регулируется Законом КНР от 15 марта 1999 г. «О договорах». Глава 13 данного закона предусматривает общие положения об аренде, сроке и арендной плате. Существенными условиями договора аренды являются условия о наименовании предмета аренды, способе и сроке использования арендованного имущества, способе и сроках оплаты, а также обязанности сторон по содержанию предмета аренды. Согласно ст. 214 Закона КНР «О договорах» срок аренды, который должен быть определен сторонами в договоре, не может превышать 20 лет.

Конституция КНР устанавливает, что сельские коллективные экономические организации (иначе - коллективные хозяйства) осуществляют двухуровневую систему хозяйствования, основой которой (первым уровнем) является "семейный подряд". Под семейным подрядом понимаются первичные правоотношения по поводу земли, которые возникают непосредственно между физическими лицами, занимающиеся обрабатыванием земельных участков, и коллективными хозяйствами на договорной основе. Коллективное хозяйство деревни, комитет или группа сельских жителей имеют право предоставить свои земли, принадлежащие им на праве коллективной собственности, в пользование лицам, ведущим домашнее крестьянское хозяйство в настоящей деревне. Коллективное хозяйство деревни, комитет или группа сельских жителей выступают по договору в качестве стороны, представляющей договор, а лицо, ведущее домашнее крестьянское хозяйство, в качестве, так называемого, подрядчика. Право, на котором подрядчик получает земельный участок согласно договору, называется "право договорного управления землей". После заключения договора подрядчику выдается сертификат, который подтверждает его право на земельный участок. Такие договоры являются долгосрочными. Возможные сроки определены в ст. 20 Закона об управлении землей и различаются в зависимости от вида предоставляемой по договору земли.

Сторона, представляющая договор, в течение срока договора не имеет права расторгнуть его и вернуть обратно себе землю. Однако подрядчик наделен таким правом и может им воспользоваться в любое время действия договора.

Ст. 47 Закона о договорах на землю предусматривает преимущественное право членов коллективного хозяйства перед остальными частными лицами или объединениями на заключение договора землепользования с данным коллективом. Право договорного управления землей положено в основу китайской системы договорного управления в отношении земель, расположенных в сельской местности.

Второй уровень системы управления, осуществляемой коллективными хозяйствами, представлен кооперативами. Отношения, связанные с организацией и деятельностью кооперативов в сельской местности,

регулируются Законом о специальных фермерских кооперативах от 01 июля 2007 г. Эти организации в основном обслуживают своих участников, но не касаются вопросов управления или использования земельных участков.

Право частной собственности на землю в Китае не предусмотрено. Взамен права частной собственности закон предусматривает несколько основных вещных прав, включенных в гражданский оборот вместо земельных участков, на которые эти права распространяются. Однако при этом не устанавливается и исключительная государственная собственность на все земли, расположенные в границах государства. Существует специфический институт коллективной собственности на земельные участки, которая юридически отграничивается от государственной собственности и предоставляет определенную свободу действий местному населению в регионах. Видно, что законодатель довольно гибко определяет границу между государственной и коллективной собственностью, что, в свою очередь, связано с другой проблемой, явно отраженной в законе.

Эта проблема касается баланса между защитой земель, активно задействованных в сельском хозяйстве, и желанием сделать процедуру предоставления земель под строительство как можно более простой

и удобной вне зависимости, что это за земли, и где они расположены. Несмотря на обширную территорию Китай обладает небольшим количеством пригодных для ведения сельского хозяйства земель, отсюда такое количество мер, направленных на их сохранение. Очевидно, что основной целью китайского государства является поощрение быстрого и эффективного развития сельского хозяйства и городского строительства на местах.

Таким образом, аренда земельных участков предусмотрена как в Российском законодательстве, так и в Китайском. Причем арендовать землю можно из государственной собственности. Порядок предоставления земель регулируется федеральным уровнем, что значительно упорядочивает оборот земельных участков. 


\title{
Литература
}

1. Федеральный закон от 23.06.2014 N 171-Ф3 (ред. от 29.12.2015) "О внесении изменений в Земельный кодекс Российской Федерации и отдельные законодательные акты Российской Федерации" // Российская газета. 2014. N 142. 27 июля.

2. "Земельный кодекс Российской Федерации" от 25.10.2001 N 136-ФЗ(ред. от 30.12.2015) // Российская газета. 2001. N 211-212. 30 сент.

3. Аграрная реформа в Российской Федерации: правовые проблемы и решения / под ред. 3. С. Беляевой, О. А. Самончик. М.: ИГиП РАН, 2009. 226 с.

4. Лисина Н. Л. Иные, кроме собственности, виды прав на земельные участки // Вестник Кемеровского государственного университета. Вып. 2-2 (62). 2015.

\section{Особенности гражданско-правового регулирования недействительных сделок}

\author{
(C) А. В. Молчанова \\ студентка 2-го курса юридического факультета \\ ФГБОУ ВО «Бурятский госуниверситет» \\ Россия, г. Улан-Удэ \\ tasesya18@mail.ru
}

Сделки являются неотъемлемой частью жизни современного человека, которые он совершает ежедневно. О том, какое значение имеют сделки, можно судить уже по тому, что абсолютно все участники гражданского оборота ведут правовую жизнь главным образом путем заключения различного рода таких соглашений. К примеру, как физические, так и юридические лица изо дня в день заключают сделки, на основании которых им оказываются услуги, продаются товары или выполняются какие-либо работы. И происходят эти действия постоянно.

Также значительное место занимают сделки в предпринимательской деятельности независимо от того, идет ли речь о торговле, торговом посредничестве, банковских и биржевых операциях, которые в иной, чем сделки, форме, не могут существовать. Совершая сделки, организации согласовывают свою деятельность по производству продукции, снабжению друг друга необходимыми материалами, сырьем, оборудованием по капитальному строительству и выполнению научно-исследовательских, проектных и конструкторских работ. При помощи сделок юридические лица организовывают перевозки продукции разными видами транспорта. Широко используются сделки и в области внешней торговли. Большое значение имеют они и в сфере культуры, например, договоры между издательствами и авторами, объявление конкурсов на создание произведений науки и искусства.

Ст.153 ГК РФ определяет понятие сделки как действия граждан и юридических лиц, направленные на установление, изменение или прекращение гражданских прав и обязанностей [1].

В силу того, что сделка - это правомерное юридическое действие, в разных источниках литературы по гражданскому праву уже несколько лет ведется дискуссия о том, может ли вообще считаться сделкой недействительная сделка. По мнению некоторых ученых, в случае, когда действие направлено на установление, изменение или прекращение гражданских правоотношений, но не может порождать такой результат, правильнее говорить не о недействительности сделки, а о недействительности волеизъявления. В то же время, с точки зрения других авторов, термин «недействительная сделка» имеет право на существование.

Согласно ст. 166 Гражданского Кодекса Российской Федерации недействительные сделки подразделяются на оспоримые и ничтожные. В законе названы формальные критерии их разграничения: оспоримая сделка недействительна в силу признания ее таковой судом, а ничтожная - независимо от судебного признания. Кроме того, различие между оспоримыми и ничтожными сделками проявляется в неодинаковых правовых последствиях их недействительности, разном определении круга лиц, имеющих право требовать признания их недействительными, а также в различных сроках исковой давности [2, с. 1].

Отечественная цивилистика в целом придерживается классической доктрины, что находит яркое выражение в вышеуказанной статье Гражданского Кодекса Российской Федерации, где закреплено правило о недействительности ничтожной сделки независимо от признания ее таковой судом. Таким образом, реализуется правило о недействительности ничтожных сделок в силу закона, независимо от иска сторон или третьих лиц, т.е. недействительности, которая существует объективно и никак не связана с актом судебного признания. При этом предоставляется возможность предъявления исков о констатации ничтожности данных сделок [4, с. 227].

Поскольку недействительная сделка является неправомерным действием, она не приводит к тем результатам, на которые она была направлена. Однако необходимо отметить, что она не является юридически безразличным фактом, так как она все-таки порождает определенные последствия, связанные с ее недействительностью. Их можно классифицировать в зависимости от вида недействительной сделки, а также от того, приступили стороны к ее исполнению или нет.

Недействительная сделка считается таковой с момента ее совершения, даже если недействительность сделки была констатирована позднее. Данное правило знает исключение, которое предусмотрено п. 3 ст. 167 ГК РФ. В ряде случаев, исходя из характера сделки, она может быть прекращена лишь на будущее время. То есть, если предметом сделки было оказание услуг или предоставление имущества во временное пользование, возвращение сторон в первоначальное положение при частичном исполнении сделки оказывается невозможным, поскольку соответствующая услуга уже потреблена, а из имущества в процессе его использования извлечены полезные свойства. В этом случае суд, признавая сделку недействительной, прекращает ее действие на будущее время. 
Это означает, что к отношениям сторон, имевшим место до вступления в силу решения суда, применяются условия той сделки, которая признана судом недействительной [5, с. 75].

Что касается зарубежных стран, то здесь необходимо отметить, что подходы к признанию сделок недействительными у каждого государства индивидуальны. Из анализа нормативных правовых актов США можно сделать вывод, что все категории сделок, вне зависимости от типа или вида сделки, обозначаются слияниями, то есть законодатель и правоприменитель основываются на экономическом содержании сделок, а не на их типологии [2, с. 32]. Так, например, законодательство Соединенных Штатов Америки предусматривает критерии признания сделок недействительными. Они могут быть разделены в широком смысле на объективные и субъективные критерии.

1) Объективные критерии. Один подход подчеркивает зависимость от общих объективных критериев для определения недействительности сделок. Необходимо выяснить, была ли сделка совершена в пределах периода для проверки подозрений, соответствует ли сделка ряду общих характеристик, установленных в законе (например, была ли уплачена соответствующая стоимость за переданные активы или взятое обязательство); наступил ли срок уплаты долга или взятого обязательства; находятся ли стороны, участвующие в сделке, в особых отношениях. Так, например, могут быть признаны недействительными законные и полезные сделки, если они имели место в течение определенного периода, в то время как мошеннические или преференциальные сделки, совершенные вне определенного периода, могут оказаться защищенными законом.

2) Субъективные критерии. Другой подход ориентирован на определенные случаи и такие субъективные критерии как: есть ли доказательство намерения скрыть активы от кредиторов; был ли должник неплатежеспособен при совершении сделки или стал неплатежеспособным в результате сделки; была ли сделка несправедливой в отношении определенных кредиторов, и знал ли контрагент, что должник был несостоятелен на время совершения сделки или что станет несостоятельным в результате сделки. Этот индивидуализированный подход может потребовать детального рассмотрения намерения сторон в отношении сделки, а также других факторов, таких как финансовые обстоятельства должника во время совершения сделки, финансовые последствия сделки на активы должника, а также что могло бы составить нормальный ход деловых отношений между должником и определенными кредиторами [3, с. 20].

Согласно действующему законодательству в США, признание определенной сделки недействительной обычно требует подачу заявления в суд для признания ее ничтожной, и законы о несостоятельности принимают разнообразные подходы к сторонам, которые могут инициировать производство. Признавая центральную роль, которую играет специалист по несостоятельности в смысле управления конкурсной массой, многие законы о несостоятельности предусматривают, что производство по делу о признании определенной сделки недействительной должно инициироваться специалистом по несостоятельности, хотя некоторые законы требуют, чтобы специалист по несостоятельности получил согласие кредиторов или большинства кредиторов до возбуждения любого производства.

В данной стране имеются также законы, которые разрешают возбуждение производства о признании сделок недействительными кредиторам (и в некоторых случаях комитету кредиторов). В то же время, некоторые законы ограничивают право на возбуждение, предоставляя его тем кредиторам, долг которых предшествует оспариваемой сделке по времени. Иные законы, разрешающие кредиторам инициировать такое производство, требуют получение согласия специалиста по несостоятельности. Если считается желательным разрешать кредиторам подавать такие иски, то требование о согласии специалиста по несостоятельности обеспечивает то, что он проинформирован о предложении кредиторов, и это дает специалисту по несостоятельности возможность отказать кредиторам в согласии, что поможет избежать какое-либо отрицательное воздействие такого производства о признании сделок недействительными на управление конкурсной массой.

В тех случаях, когда специалист по несостоятельности имеет эксклюзивные полномочия на возбуждение производства о признании сделок недействительными, и он на основе баланса рассмотренных выше соображений (т.е. по причинам иным, чем халатность, недобросовестность или упущение) решает не возбуждать производство в отношении определенных сделок, законы о несостоятельности принимают различные подходы к проведению и финансированию такого производства.

Таким образом, рассмотрев некоторые вопросы гражданско-правового регулирования недействительности сделок в странах Азиатско-Тихоокеанского региона, можно сделать некоторые выводы. Что касается ограничения, которое имеет решающее значение в большинстве стран Азиатско-Тихоокеанского региона, необходимо отметить, что оно непосредственным образом влияет на эффективность положений о признании сделок недействительными и состоит, прежде всего, в недостаточности средств для оспаривания сделок, которые могут быть признаны недействительными.

Также имеются различные подходы к вопросу финансирования этих процедур. В некоторых странах специалисту по несостоятельности выделяют государственные средства для возбуждения производства о признании сделок недействительными, в то время как в других странах требуются, чтобы это производство финансировалось за счет конкурсной массы. Однако важно помнить, что последний подход может быть приемлемым только в тех случаях, когда имеется достаточное количество средств, но в некоторых обстоятельствах возврат активов, изъятых из конкурсной массы, преднамеренно делается невозможным путем оставления в конкурсной массе слишком малого объема активов для финансирования их возврата через возбуждение производства о признании сделок недействительными. 
Кроме того, некоторые законы о несостоятельности разрешают специалисту по несостоятельности наделять третье лицо правом возбуждения производства или привлекать кредитные средства для возбуждения производства о признании сделок недействительными. Имеются явные и существенные различия между странами относительно возможности использования государственных средств для финансирования производства о признании сделок недействительными, обосновывающие использование некоторых из этих альтернативных механизмов.

\section{Литература}

1. Гражданский кодекс Российской Федерации (часть четвертая) от 18.12.2006 N 230-Ф3 // Собрание законодательства РФ. 25.12.2006, N 52 (1 ч.), ст. 5496; Боброва М. В., Абрамова М. В. Место сделок с пороками воли и субъектного состава в системе недействительных сделок // Вестник НГУ. 2011. № 2. С. 1.

2. Борзило Е. Ю. Отдельные вопросы правового регулирования сделок экономической концентрации в ЕС и США // Вопросы российского и международного права. 2015. № 10. С. 32.

3. Проект Тасис «Эффективность процедур банкротства» TacisProject «EfficiencyofInsolvency Proceedings (InsolvencyPhase II)» / Сравнительный анализ регулирования вопросов признания сделок недействительными в законах о банкротстве нескольких стран ЕС, включая Францию, Соединенное Королевство, Германию и Нидерланды. М., 2015. С. 20.

4. Тюльпарова А. Р. Недействительные сделки по законодательству РФ: сравнительно-правовое исследование // Вестник Северо-Осетинского государственного университета им. К. Л. Хетагурова. 2012. № 1. С. 227.

5. Шевчук Д. А. Недействительные сделки: виды и последствия // Аудиторские ведомости. 2009. № 4. С. 75-76.

\section{Правовое регулирование страхования ответственности туристических агентств в КНР}

(С) С. Ц. Мункуева

магистрант 1 года обучения юридического факультета ФГБОУ ВО «Бурятский госуниверситет»

Россия, г. Улан-Удэ mseseg@mail.ru

Современный мир предлагает людям безграничное количество возможностей, однако, при этом, он таит в себе столько же опасностей. Нестабильное экономическое развитие, невозможность предугадать развитие событий, несовершенное медицинское обслуживание и многие другие причины заставляют нас заблаговременно позаботиться о своем здоровье и имуществе, то есть застраховаться от событий, которые могут оказать негативное влияние на качество нашей жизни. Страхование прочно вошло в жизнь многих людей во всем мире, в том числе и в Китайской Народной Республике.

В развитых странах Европы и Америки рынок страхования давно сформирован, а правовой механизм его регулирования отшлифован до мелочей. В развивающихся же странах сейчас происходит большой рост данного рынка. Многие крупные инвесторы вкладывают средства в страхование в Китае, Бразилии, Индии, Мексике и в России [3]. Среди перечисленных стран КНР обладает наибольшим потенциалом в сфере развития страховой системы благодаря большому количеству населения и динамично развивающейся экономике.

Следует отметить, что рынок страхования в Китае имеет долгую историю возникновения и развития. В начале 20-х годов XX века появились первые страховые компании. С приходом коммунистического режима все страховые фирмы были объединены в одну - Китайскую Народную Страховую Компанию. Она осуществляла все страховые выплаты в стране. Данное решение затормозило развитие рынка страхования из-за монополизации. В результате реформ, которые длились с 1984 по 1995 годы, КНСК была разделена на несколько автономных страховых компаний. Кроме того государство отказалось от монополии на страховании. Однако государственной страховой организации все еще принадлежит около 70\% рынка [3]. Основным нормативно - правовым актом является Закон КНР «О страховании», вступивший в силу 10 января 1995 года, принятый на 14-ой сессии Постоянного Комитета ВСНП 8-ого созыва. Поправки в закон были внесены в соответствии с решением о внесении изменений на 30-ой сессии Постоянного Комитета ВСНП 9-ого созыва [1].

Международный туризм является одной из высокоразвитых отраслей экономики Китайской Народной Республики. Туристическая сфера в этой стране быстро и динамично развивается. Китай достиг в области туризма значительных достижений всего за двадцать пять лет. Из страны, в которую въезд туристов почти отсутствовал (до 1978 г.) Китай превратился в одного из мировых туристских лидеров. По численности туристов, посещающих страну, и по уровню прибыли от международного туризма Китай занимает 4-е место в мире. В 2013 году Китай посетило 55,7 миллионов зарубежных туристов [4]. В 2014 году доход страны от международного туризма составил 58,9 миллиардов долларов США [2]. По прогнозам Всемирной Организации Туризма КНР станет крупнейшей туристической державой к 2020 году.

Китай уделяет большое значение страхованию в сфере туризма для сохранения своих позиций в сфере международных путешествий. В целях защиты законных прав и интересов туристов Национальное управление по туризму КНР и Комиссия по регулированию страхового дела КНР совместно в 2010 году приняли «Меры по управлению страхования ответственности туристических агентств» или «Measures for Administration of Travel Agency Liability Insurance». Они вступили в силу с 1 февраля 2011 года. Согласно данному правовому акту, туристические агентства обязаны покупать «страховку ответственности». Турагентство несет материальную ответственность за свою небрежность, за травмы туристов и гидов, гибель имущества, также компенсирует вред, 
возникший вследствие аварии. Меры предписывают, что при покупке страховки ответственности туристическое агентство должно заключить Страховой договор в письменной форме. После заключения договора страхования, турагентство должно выплачивать страховые премии согласно условиям контракта. Если туристическое агентство желает расторгнуть данный договор, оно должно уведомить административный отдел по туризму на уровне уезда в письменной форме и подписать новый договор, за исключением случаев расторжения контракта по причине аннулирования или отзыва лицензии.

В случае возникновения аварии при организации туристической деятельности, за которую турагентство несет ответственность, страховая компания производит возмещение в соответствии с условиями договора и лимита ответственности страховой компании. Предел ответственности за травмы не может быть ниже 200000 юаней на каждого человека. При наступлении страхового случая турагентство информирует страховую организацию. Пострадавшие вправе сделать запрос в страховую фирму самостоятельно. Страховая компания выплачивает компенсацию непосредственно пострадавшим лицам. Если иное не предусмотрено договором, страховая компания должна сделать проверку на соответствие события страховому случаю после получения запроса о выплате страховой премии в течение 30 дней. Вынесенное решение доводится до сведения турагентства и пострадавших лиц. Если страховой случай имел место быть, то страховая организация выплачивает страховую сумму в течение десяти дней.

Безусловно, и рынок страхования, и рынок туризма будут продолжать расти и развиваться в Китайской Народной Республике.

Литература

1. Законы КНР, законодательство и право Китая [Электронный ресурс]. URL: https://law.uglc.ru/insure.html.

2. В 2014 году доходы Китая от туризма увеличились на 14.7\% [Электронный pecypc]. URL: https://tourprom.ru/news/27987

3. Рынок страхования в Китае [Электронный ресурc]. URL: https://vchaye.com/rynok-strahovaniya-v-kitaye-2

4. Список стран по туристическим посещениям [Электронный pecypc]. URL: https://ru.wikipedia.org/wiki/ Cписок_стран_по_туристическим_посещениям.

\title{
Сравнительный анализ суррогатного материнства в Российской Федерации и Китайской Народной Республики
}

\author{
(C) Э. С. Очирова \\ магистрант 1 года обучения юридического факультета \\ ФГБОУ ВО «Бурятский госуниверситет» \\ Россия, г. Улан-Удэ \\ erzhenaochirova@bk.ru
}

Одной из ключевых целей формирования семьи считается деторождение. К сожалению, растет число лиц, не способных к рождению детей в результате ухудшения экологической обстановки окружающей среды и нездорового образа жизни [7]. В этой сложной ситуации положительным фактом можно назвать, что современные методы искусственной репродукции человека позволяют иметь детей супругам, которые по состоянию здоровья, биологической несовместимости, ряде наследственных заболеваний и противопоказанности беременности не могут самостоятельно выносить ребенка. На сегодняшний день с помощью вспомогательных репродуктивных технологий в мире родилось уже более 3 миллионов детей [8]. Особый интерес вызывает развитие суррогатного материнства в России и Китае.

Основные вопросы, касающиеся правового регулирования суррогатного материнства, правового положения лиц, которые согласились на использование метода суррогатного материнства, закреплены в Семейном Кодексе РФ [1], Федеральном законе от 21 ноября 2011 г. №323-Ф3 «Об основах охраны здоровья граждан в Российской Федерации»[3], Федеральном законе от 15 ноября 1997 № 143-Ф3 «Об актах гражданского состояния» [2], а также в Приказе от 30 августа 2012 г. №107н «О порядке использования вспомогательных репродуктивных технологий, противопоказаниях и ограничениях к их применению» [4]. Данный приказ является ключевым документом, в применении методов искусственной репродукции человека.

Благодаря быстрому прогрессу в медицинской науке и научным достижениям в лечебной практике многим бесплодным семьям удалось почувствовать радость отцовства и материнства. Это стало возможно с помощью успешного применения такого метода вспомогательных репродуктивных технологий, как метод суррогатного материнства.

Суррогатное материнство представляет собой вынашивание и рождение ребенка (в том числе рождение недоношенного ребенка) в соответствии с договором, который заключается между суррогатной матерью (женщиной, вынашивающей плод после переноса донорского эмбриона) и будущими родителями, чьи половые клетки использовались для оплодотворения, либо одинокой женщиной, для которых вынашивание и рождение ребенка невозможно по медицинским показаниям (п. 10 ст. 55 Закона об основах охраны граждан).

В соответствии с п. 3 ст. 55 Федерального закона «Об основах охраны здоровья граждан в Российской Федерации» субъектами, которым могут быть применены вспомогательные репродуктивные технологии это: женщина и мужчина, независимо от того супруги они или нет, имеют право на использование методов вспомо- 
гательных репродуктивных технологий при наличии согласия, которое должно быть добровольным, информированным и обоюдным, на медицинское вмешательство; также и одинокая женщина имеет право на использование методов вспомогательных репродуктивных технологий с добровольного и информированного согласия на медицинское вмешательство.

Таким образом, в российском законодательстве предусмотрена возможность одиноким женщинам применять метод суррогатного материнства, в отличие от многих стран где «супружество или устойчивые партнерские отношения с лицом противоположного пола» рассматриваются в качестве обязательного условия для осуществления репродуктивной программы [6]. Россия является одной из немногих стран, где закон защищает право каждой женщины на материнство независимо от ее семейного положения, физических характеристик, необходимости в донорских гаметах, а также наличия или отсутствия партнера.

В отличие от России, растущий в Китае спрос на применение метода суррогатного материнства и появление огромного количества агентств по предоставлению услуг суррогатных матерей, привлекло к этой проблеме внимание законодателя. И в 2001 г. Министерство здравоохранения КНР своим постановлением запретило суррогатное материнство, т.е. запретило медицинским организациям оказывать услуги экстракорпорального оплодотворения, а также услуги суррогатной матери одиноким женщинам. Представители Министерства здравоохранения Китая утверждают, что данное постановление решает многие проблемы, например, устанавливает ответственность за осложнение в период беременности и различные возможные патологии ребенка, а также возможность отказа суррогатной матери передать ребенка генетическим родителям [5].

Однако, несмотря на запрет Министерства здравоохранения КНР, спрос на услуги суррогатных матерей в этой стране продолжает расти. Практически любое агентство по предоставлению услуг суррогатных матерей ежемесячно заключают договоры с более тридцати бесплодных семей, основными клиентами подобных агентств являются обеспеченные семьи и иностранные граждане. Клиентами не могут быть лица, не имеющие документов, не состоящие в браке, а также супруги, если один из них против применения метода суррогатного материнства.

«Нелегальное» суррогатное материнство в Китае с новой силой начало процветать в 2006 году, после принятия постановления о запрете на коммерческую деятельность в сфере репродукции человека. Данное постановление запрещает вынашивание детей суррогатной матерью в коммерческих целях и незаконную продажу биологического материала для репродукции (яйцеклетки и сперма), ограничивает использование спермы одного донора для экстракорпорального оплодотворения пятью женщинами, и восемью - в случае обычного. А также запрещает клиникам, не имеющим лицензии использовать донорскую сперму и яйцеклетки, и ограничивает число женщин, которые имеют право воспользоваться методом искусственного оплодотворения на законных основаниях [12].

После запрета на первом этапе всего 64 медицинских учреждения получили право на оказание услуг с применением экстракорпорального оплодотворения, и всего лишь 7 получили право иметь банки спермы. Медицинские учреждения, оказывающие такого рода услуги, должны были приостановить свою деятельность до получения государственного разрешения, весь персонал клиники обязан пройти специальное обучение и получить лицензии [9].

В августе 2012 года Министерство здравоохранения КНР совместно с Государственным комитетом по делам здравоохранения и планового деторождения приняли постановление, которое запрещает врачам и медицинским клиникам предоставлять услуги суррогатного материнства. В случае обнаружения фактов такой деятельности, на агентство может быть наложен штраф в размере 30 тысяч юаней. Ясно, что этот штраф не сравним с получаемой агентствами прибылью от незаконной деятельности. Именно поэтому Государственный комитет по делам здравоохранения и планового деторождения решил разработать новый закон, который полностью запрещает суррогатное материнство, а также ужесточение наказания за подобную деятельность [11].

16 декабря 2013 года у китайских граждан появилась надежда на возможность иметь своего ребенка. В этот день Министерство здравоохранения Тайвань представил законопроект, по которому планируется на его территории легализация суррогатного материнства. Следует отметить, что Тайвань имеет в Китае несколько двусмысленный статус. Как столица Китайской Республики, основанной на острове противниками коммунистического строя после второй мировой войны, в провинции Тайвань развитая экономика, собственная валюта и достаточно сильная армия. Тем не менее, в настоящее время идет процесс юридического и фактического ограничения его суверенитета и присоединения к КНР. Из этого следует, что если суррогатное материнство будет признано на законодательном уровне, граждане Китайской Народной Республики получат возможность приезжать на Тайвань ради этой программы [10].

В заключение хотелось бы отметить, что, несмотря на развитие законодательства, регулирующего порядок применения метода суррогатного материнства, быстрое развитие медицины значительно опережает темпы принятия соответствующих правовых норм, законодательство отстает от современных технологий, что часто приводит к нарушению прав и свобод человека и гражданина. Необходимо принятие специального Закона в РФ, регулирующего процесс реализации прав граждан на использование метода суррогатного материнства. И хотелось бы надеяться, что законодательство Китайской Народной Республики уделит должное внимание этой сложной проблеме, и с учетом опыта других стран и их собственной специфики предпримут усилия по подготовке закона, регулирующего сферу репродукции с применением новейших технологий, в котором будет четко сформулирован запрет (или разрешение) как коммерческого (вынашивание женщиной генетически чуждого ей 
ребенка на заказ) суррогатного материнства, так и деятельности агентств, которые предоставляют услуги суррогатных матерей.

\section{Литература}

1. Семейный кодекс Российской Федерации: от 29 декабря 1995 г. № 223-Ф3 (ред. Федерального закона от 30.12 .2015 г. № 457-Ф3) // Рос. газ. 1996. 27 янв.; 2015. 30 дек.

2. Об актах гражданского состояния: Федеральный закон от 15 ноября 1997 г. № 143-ФЗ (в ред. Федерального закона от 28.11.2015 № 358-Ф3) // Рос. газ. 1997. 20 нояб.; 2015. 28 нояб.

3. Об основах охраны здоровья граждан в Российской Федерации: Федеральный закон от 21 ноября 2011 №323-Ф3 (в ред. Федерального закона от 8 марта 2015 № 33-Ф3) // Рос. газ. 2011. 21 нояб.; 2015. 3 марта.

4. О порядке использования вспомогательных репродуктивных технологий, противопоказаниях и ограничениях к их применению: приказ Министерства здравоохранения РФ от 30 августа 2012 г. № 107н // Рос. газ. 2013. 11 апр.

5. Погачина. О. Суррогатное материнство в Китае // Проблемы Дальнего Востока / Институт Дальнего Востока (РАM). M., 2009. № 3. C. 150.

6. Свитнев К. Н. ВРТ и право на материнство // Семейное и жилищное право. 2010. № 3. С. 5.

7. Сергеев Ю.Д., Павлова Ю. В. Проблемы правового регулирования применения методов вспомогательных репродуктивных технологий // Медицинское право. 2006. № 3. С. 3.

8. Беременность и роды у суррогатных матерей / Е. А. Чернуха, Л. Н. Кузьмичев, Л. Б. Киндаров, О. Н. Васильченко // Акушерство и гинекология. 2006. № 4. С. 23.

9. Surrogate pregnancy [Электронный ресурс]. Режим доступа : http : // chinadaily.com.cn/ china/ 2006 - 05/ 22/ content_597045.htm (12 апреля 2016 г.)

10. Китай планирует легализовать суррогатное материнство [Электронный ресурс]. Режим доступа: http : // www.probirka.org/ surrogatnieprogrammy/6219/htm (13 апреля 2016 г.).

11. Китай ужесточает борьбу с суррогатным материнством [Электронный ресурс]. Режим доступа: // http : // ru.gbtimes.com/.../kitay-uzhestochaet-borbu-ssurrogatnym-materinstvo... (12 апреля 2016 г.)

12. «COMPARATIVE JURISPRUDENCE IN THE COUNTRIES OF ASIAN-PACIFIC REGION - VI Materials of the international scientific conference young scientists, postgraduate, masters and students ...»[Электронный ресурс]. Режим доступа : http : // www.konf.x-pdf.ru/19yuridicheskie/217151-12-comparative-jurisprudence-the-countries-asian-pacific-region-materials-theinternational-scientific-conference-youn.php ( 14 апреля 2016 г.).

\section{Актуальные проблемы осуществления личных неимущественных прав супругов на примере России и США}

(С) И. А. Павлова

студентка 4-го курса юридического факультета ФГБОУ ВО «Бурятский госуниверситет»

Россия, г. Улан-Удэ 000.0909@mail.ru

Личные неимущественные отношения в Российской семье традиционно регулировались нормами нравственности и морали. Считалось, что законом могут устанавливаться лишь внешние границы личных отношений между членами семьи, в частности между супругами. Данное обстоятельство не могло отразиться на кодифицированном акте. В нашем случае Семейный кодекс РФ содержит всего лишь две статьи, которые посвящены личным правам и обязанностям супругов что, безусловно, является большим недостатком в их регулировании, а также в их защите.

В Соединенных Штатах Америки как такового семейного законодательства не существует, есть только нормы, которые регулируют семейные правоотношения. Статутные и подзаконные нормы, и конечно нормы судебных прецедентов, которые принимаются на уровне штатов, тут они и преобразуются в как таковое семейное право. Но это не маловажное обстоятельство никоим образом не отразилось в регулировании личных неимущественных прав, так как, нормы которые осуществляют данную сферу семейных правоотношений, являются достаточно гибкими и на них не давит многовековой уклад семьи со своеобразным менталитетом.

Дискуссионным моментом в регулировании личных неимущественных прав супругов, является, то что, в настоящее время действующий СК РФ запрещает регулировать брачным договором данные отношения и устанавливать имущественную ответственность за нарушение личных неимущественных прав. Права и обязанности являются содержанием любых правоотношений, к тому же права не могут подвергаться ограничениям, но Е.А. Душкина отмечает что: « ... что касается семейного права, то здесь права супруга ограничиваются аналогичными правами второго супруга, что предполагает их реализацию на основе взаимного согласия супругов» [4]. Ни одна семья не избегает каких-либо разногласий, в том числе связанных с лично неимущественными правами, поэтому стоило бы предоставить супругам самостоятельность в определении объема неимущественных прав, а также обязанностей, посредством брачного договора.

Стоит отметить пункт 2 ст. 42 СК РФ, который позволяет супругам ставить права и обязанности, предусмотренные брачным договором, в зависимость от наступления или ненаступления определенных условий, в частности и неимущественного характера [1]. Л.Б. Максимович по данному поводу пишет: «Несмотря на то, что брачный договор не может регулировать личные неимущественные отношения супругов, нарушение любого личного права может повлечь для супруга - нарушителя ряд неблагоприятных имущественных последст- 
вий предусмотренных брачным договором» [3, с. 127]. Можно привести пример, где супруга предусмотрела положение в договоре, которое не позволяет супругу злоупотреблять спиртными напитками, то есть одна сторона данного соглашения ставит возникновение, изменение и прекращение прав и обязанностей в зависимость от наступления или ненаступления определенного события от воли одной из сторон. Сделаем вывод, предусмотрев в договоре наступление неблагоприятных последствий имущественного характера, при нарушении запрета супругом в употреблении алкоголя - вполне уместно и логично. Следовательно, посредством условий брачного договора, регулируются лично неимущественные отношения между сторонами, так как супруг сто раз подумает, прежде чем нарушать условия, ведь для него последует «наказание». Данный способ регулирования может оказаться эффективнее прямых запретов, принудить супруга ограничить себя в алкоголе. Вышесказанное доказывает, что на практике имущественные отношения не существуют без личных неимущественных и наоборот.

Семейное законодательство США не запрещает регулирование личных неимущественных отношений между супругами посредством брачного соглашения. В особенности данное соглашение полюбилось звездам Голливуда, например, певица Барбара Стрейзанд и актер Джеймс Бролин подписали брачный контракт, который гласит: после развода последний получает содержание размером 32 тысячи долларов в год, а также 1 миллион в качестве отступного, плюс после 10 лет совместной жизни отступные увеличатся на аналогичное количество миллионов. Еще один нашумевший контракт миллиардера Билла Гейтса и Мелинды Френч, который предусматривал, что Билл Гейтс один выходной в год может проводить время со своей бывшей любовницей. Сосипатрова Н.Е. также приводит пример контракта Ж. Кеннеди и А. Онассиса, которые предусматривал компенсацию в размере 10 миллионов долларов в пользу супруги, если супруг ее оставит, и в 18.7 миллионов, если уйдет уже Жаклин с условием продолжения брака не менее 5 лет [8, с. 78]. Таким образом, личные неимущественные отношения и имущественные отношения супругов тесно взаимосвязаны, первые своеобразным способом переходят во вторые. Благодаря таким соглашениям супруги не провоцируют развод, ведь на кону стоит имущество каждого из супругов. «Заранее заключенный брачный договор, регулирующий личные отношения между ними доверительных отношений, раскрывает характер и личные черты, присущие каждому из супругов, как личности» [4].

Брачным договором в США возможно урегулировать и исполнение супружеской обязанности, и уборку по дому, что в российском семейном законодательстве считается абсурдным. Регулируется и брачным соглашением вопросы, связанные с рождением ребенка, в частности осуществление аборта. Российским законодательством предусмотрено правило, в котором устанавливается что, «Каждая женщина имеет право самостоятельно решать вопрос о материнстве» [2]. Данная операция осуществляется по желанию только женщины, не учитывая мнение отца, хотя последний имеет те же самые права, что и женщина. То есть вопрос о рождении ребенка становиться семейным, поэтому стоит предусмотреть мнение супруга о совершении аборта, так как решается судьба об его отцовстве.

В Америке аборты также разрешены, но отдельные штаты предусматривают ограничения в доступе по операционному прерыванию беременности. Осуществляются такие ограничения с помощью лицензий как, например, в штате Джорджия, либо определенные медицинским показаниям, от которых зависит жизнь пациентки.

В регулировании личных неимущественных прав проблемным вопросом является также смена пола одним супругом или обоими. Российским законодательством не урегулирован данный вопрос, а это значит что, состояв в браке один из супругов может без какого - либо согласия другого сменить биологический пол. Однако затронут интерес семьи, поэтому ее дальнейшее традиционное существование не возможно. Брак, заключенный в прошлом логически становиться недействительным, поэтому целесообразно запретить смену пола одним или обоим супругам, которые состоят в браке. Если операция все же состоялась, то следовало бы в ст. 61 Основ законодательства об охране здоровья граждан включить обязанность врача, который оперировал пациента, информировать о произведенной операции и ее последствиях семью, в частности супругу или супруге. Данная ситуация может возникнуть если один из супругов находиться в долговременной командировке или проходит обучение в другом городе. В 2014 году в России был впервые заключен так называемый ЛГБТ - брак, то есть между женщиной и трансгендером, которой с правовой точки зрения все еще является мужчиной, но намеревается осуществить операцию по коррекции пола. Если в дальнейшем супруг все же поменяет пол, то брак следует признать недействительным или прекратить его, но есть одно «но», Семейный кодекс РФ не предусматривает основанием для недействительности или расторжения брака, факт изменения пола одним из супругов, потому что однополые браки российским законодательством запрещены. Дискуссии по данному вопросу многочисленны, но большинство исследователей приходят к выводу, что законность брака может определяться только судом.

Как уже говорилось выше, США относит семейное право к юрисдикции штатов, поэтому вопрос ЛГБТ браков решается каждым штатом отдельно. В 1996 году в Америке был принят Закон о защите брака (Defense of Marriage Act), который дает понятие брака как союз мужчины и женщины, разрешая штатам не признавать однополые браки, которые заключены в других штатах. 26 июня 2013 года Верховный суд США принял решение о неконституционности третьей части данного закона, что позволило предоставить ЛГБТ - супругам федеральные пособия и льготы, как и традиционным семьям, всего насчиталось 1138 прав и привилегий. Недавнем и самым нашумевшим примером можно назвать трансгендерный переход Кейтлин Дженер в прошлом олимпийского чемпиона Уильяма Брюса Дженнер, который будучи женатым три раза и имеющий в общей сложности 
шестеро детей страдал от гендерной дисфории, а также практиковал кроссдрессинг. В 2015 году он официально поменял имя и стал использовать местоимение «оно» что, безусловно, затронуло интерес семьи, хотя официально он все еще остается мужчиной. Конечно, брак был расторгнут, так как затронуты интересы супруги и с точки зрения нравственности семья не могла существовать дальше. Данный пример подтверждает негативное отражение смены пола одним из супругов, который будучи состоит в браке.

Конечно, данные правоотношения не могут не существовать и им стоит оставить место для существования широкого разнообразия семейных отношений в обществе, ведь семья в наше время становиться понятием непостоянным. Семья может восприниматься по-разному для разных социальных групп, но и моральные устои ни кто еще не отменял.

Подводя итог вышесказанному, следует отметить, что законодательство Российской Федерации не регламентирует все разнообразие личных неимущественных отношений между супругами, что вызывает их незащищенность. В российском семейном праве неоправданно ограничено действие брачного договора, который регулирует лишь имущественные отношения супругов. Также является актуальным вопрос прав и свобод граждан, относящихся к ЛГБТ. При смене пола одним из супругов или обоими, меняется судьба брака и семьи в целом.

\section{Литература}

1. Семейный кодекс РФ от 29 декабря 1995 г. № 223-ФЗ (в ред. от 30. 12. 2015 №-Ф3) // Собрание законодательства РФ. 1996. № 1. Ст. 16; Собрание законодательства РФ. 2012. № 47. Ст. 6394.

2. Федеральный закон от 22. 08. 1993 г. №5487-1 (ред. 27. 12. 1993 г.) «Основы законодательства Российской Федерации об охране здоровья граждан» // Ведомости Советов народных депутатов и Верховного Совета РФ. 1993. №33. ст. 1318

3. Брачный договор в российском праве / Л. Б. Максимович. М.: Ось-89, 2003. 144 с.

4. Душкина Е. А. Проблемы защиты семейных прав по семейному законодательству РФ : дис. ... канд. юp. наук. URL: http://www.dissercat.com/content/problemy-zashchity-semeinykh-prav-po-semeinomu-zakonodatelstvu-rf (дата обращения: 02.03.2016 г.)

5. Малеина M. Н. Изменение биологического и социального пола: перспективы развития законодательства. URL: http://www. spbpravo. ru/comm. php? id=4721 (дата обращения: 02.03.2016 г.).

6. Никитин Д.Н. Зарубежный опыт договорного регулирования личных неимущественных отношений субъектов семейного права // Молодой ученый. 2013. № 3.

7. Палькина Т. Н. Проблемы реализации права на изменение пола // Компьютерная справочно-правовая система «Консультант Плюс». Режим доступа: http://www.consultant.ru

8. Сосипатрова Н. Е. Брачный договор: правовая природа, содержание, прекращение // Государство и право. 1999. N 3.

9. Цабиева С. Э. Личные неимущественные отношения в брачном договоре // Общество и право. 2010. N 1.

10. URL: http://abcnews.go.com/Entertainment/bruce-jenner-im-woman/story?id=30570350 (дата обращения: 04.03.2016 г.).

\section{Юридическая процедура покупки «жилой» недвижимости нерезидентами в Российской Федерации и Социалистической Республике Вьетнам: сравнительно-правовой анализ}

() E. Ю. Петрова студентка 3-го курса юридического факультета ФГБОУ ВО «Бурятский госуниверситет»

Россия, г. Улан-Удэ Pedros_946@mail.ru

Ни для кого не секрет, что политикой Российской Федерации взят курс на взаимоотношение со странами Азиатско-Тихоокеанского региона, что приводит к более тесным взаимоотношениям граждан рассматриваемого региона. В связи с этим одним из наиболее актуальных вопросов настоящего времени становится вопрос приобретения недвижимости нерезидентами иностранных государств.

С 1 июля 2015 года вступил новый Жилищный закон Социалистической Республики Вьетнам (далее - СРВ) [3]. Согласно данному закону граждане СРВ имеют право приватизировать свою недвижимость, а иностранные граждане, имеющие действующую визу, международные фонды, банки, а также филиалы крупнейших иностранных компаний, которые осуществляют свою деятельность на территории Социалистической Республики Вьетнам, вправе приобретать недвижимость, в частности, таунхаусы, частные дома, вилы, квартиры, а также офисные помещения. Стоит отметить, что право собственности ограничивается 50 годами. В указанный срок можно продать недвижимость жителю СРВ или же продлить право пользования при необходимости.

Кроме того, новый закон закрепляет за нерезидентами право покупки до $30 \%$ апартаментов в одном доме и до 250 объектов в одном районе жилого фонда государства.

Что касается самой процедуры приобретения недвижимости в Социалистической Республики Вьетнам, то, она, как правило, начинается с внесения задатка за будущий объект собственности, согласно которому стороны должны придерживаться условий сделки. Чаще всего, в пользу продавца перечисляется депозит в размере 4500 долларов, который становится гарантией намерений покупателя, а в случае отказа от сделки размер задатка останется у продавца как компенсация. На следующем этапе рассматриваемой процедуры, необходимо представить документы нотариусу, который оформит договор купли-продажи объекта. В перечень документов входят: документ, удостоверяющий личность, свидетельство о браке/разводе или документ, подтверждающий факт того, что продавец/покупатель не состоит в браке, свидетельство о собственности на жилой объект недвижимо- 
сти, сертификат, подтверждающий право пользования землей. Затем необходимо в течение десяти дней подать заявление о внесении изменений о праве пользования земельным участком в одном экземпляре, а также налоговую декларацию для последующей уплаты налогов в агентство природных ресурсов и окружающей среды. В противном случае при нарушении сроков внесения документов необходимо уплатить штраф в соответствии с действующим законодательством.

И, наконец, заключительным шагом в рассматриваемой процедуре является государственная регистрация перехода прав собственности. Данная процедура осуществляется после перечисления денежных средств в пользу продавца. Однако для получения свидетельства о праве собственности, а также праве пользования землей необходимо представить следующие документы: заявление о выдаче свидетельства на вьетнамском и английском языках согласно установленному образцу, документы, подтверждающие право собственности продавца на объект недвижимости, разрешение на строительство местных властей, если осуществляется покупка квартиры в доме со статусом «жилого коммерческого проекта», договор аренды земли или постановление о передаче земли, если осуществляется покупка виллы, план-схема квартиры, акт передачи квартиры, соответствующие документы согласно предписанию в случае дарения или передачи квартиры по наследству, оригинал договора купли-продажи или дарения или завещания, заверенная копия загранпаспорта, квитанция об уплате налога и государственной пошлины в соответствии с законом.

Согласно ч. Зст. 62 Конституции Российской Федерации, иностранные граждане и лица без гражданства пользуются в Российской Федерации правами и исполняют обязанности наравне с гражданами Российской Федерации, кроме случаев, установленных федеральным законом или международным договором Российской Федерации. Законодательством РФ не предусмотрено ограничений по приобретению иностранными гражданами, а также лицами без гражданства жилой недвижимости [1]. Отметим, что существуют ограничения на приобретения земель, однако данные ограничения не распространяются, если земельный участок приобретается иностранным гражданином под индивидуальное жилищное строительство, например, для строительства жилого дома. Важным моментом является легальное нахождение иностранного гражданина на территории РФ: либо не более, чем на срок действия визы, либо не более 90 дней, если иностранный гражданин прибыл в РФ в порядке, не требующем получения визы. Необходимо обратить внимание и на срок действия паспорта иностранного гражданина.

С 1 марта 2013 года в РФ вступили изменения законодательства, которые упрощают процедуру покупки недвижимости. Во-первых, была отменена двойная регистрация, но, тем не менее, осталось право регистрации договора у нотариуса, если стороны изъявят данное желание, а также это может выступать в качестве гаранте при совершении сделки. Во - вторых, оплата госпошлины производится только при регистрации перехода права собственности. В-третьих, сокращен срок регистрации до 10 дней, вместо 30. И, наконец, в - четвертых, согласие супруга не требуется.

Одним из условий для нерезидента РФ при подаче документов для регистрации права собственности - это перевод паспорта на русский язык, причем необходимо, чтобы был заверен нотариально на территории РФ, а также документы, подтверждающие законность пребывания в РФ: визы, миграционная карта, вид на жительство или разрешение на временное проживание.

Федеральным законом «О государственной регистрации прав на недвижимое имущество и сделок с ним», а также Федеральной службой регистрации, кадастра и картографии установлен перечень документов, которые необходимы для регистрации, в том числе и "жилой" недвижимости [2]. В указанный перечень входят следующие документы: правоустанавливающие документы на недвижимое имущество, Кадастровый паспорт на квартиру или дом из территориального органа БТИ, заявление о регистрации перевода права, квитанция об уплате государственной пошлине за регистрацию перехода права на недвижимое имущество.

Проанализировав ситуации в РФ И СРВ, можно сделать вывод о том, что во Вьетнаме, благодаря нововведениям в Жилищный закон, ситуация на рынке недвижимости изменилась в положительную сторону, а именно продажи жилой недвижимости увеличились на 11 \% в 2015 году, по сравнению с 2014 годом, прибыль составила практически 22,9 млрд. долл., однако цены начинают расти. Наибольшая активность в покупке недвижимости проявляют японские, южнокорейские, сингапурские и малазийские фирмы и граждане. В РФ наблюдается также активная купля-продажа жилой недвижимости, но систематического увеличения цен не наблюдается.

Изменения, произошедшие в рассматриваемых государствах, объединяет одно - стремление государства упростить процедуру приобретения недвижимости, в частности для нерезидентов государств.

\section{Литература}

1. Конституция Российской Федерации от 12 декабря 1993 [ Электронный ресурс ] / Консультант Плюс. Режим доступа: http://base.consultant.ru/cons/cgi/online.cgin177236 (дата обращения: 08 апреля 2016).

2. Федеральный закон от 21.07.1997 №122-Ф3 "О государственной регистрации прав на недвижимое имущество и сделок с ним" [Электронный ресурс] / Консультант Плюс. Режим доступа: https://www.consultant.ru/document/ cons_doc_LAW_15287/ (дата обращения: 10 апреля 2016).

3. Жилищный закон Вьетнама 2015. [Электронный ресурс]. Режим доступа : http://vietnamlawmagazine.vn/the-housinglaw-4041.html (дата обращения: 08 апреля 2016). 


\section{Российско-китайский опыт приватизации государственного имущества}

() В. А. Пинигин

студент 3-го курса юридического факультета ФГБОУ ВО «Бурятский госуниверситет»

Россия, г. Улан-Удэ

pinigin.victor@mail.ru

Сегодня процесс приватизации выступает неотъемлемой частью институциональных изменений, сопровождающих демократические реформы. Являясь способом увеличения доли частных владельцев в экономике, приватизация проходила везде по-разному. У всех государств, избравших приватизацию как средство на пути к реформированию экономики, имеется собственный опыт в деле отчуждения государственного имущества. Данный опыт различен в силу того, что на момент начала приватизации отсутствовали единые подходы и принципы приватизации государственного имущества. Немалую роль сыграли формы экономики, господствовавшие в странах с различным государственным устройством.

Определенный опыт в отчуждении государственного имущества накоплен нашим государством. Толчком к приватизации послужил переход от административно-командной к рыночной форме экономики, а также необходимость создания мощного класса собственников. Существует множество мнений по поводу успешности проведения приватизационных реформ в стране, как положительных (взгляды А.Б. Чубайса, Е.Т. Гайдара, др.), так и осторожных и даже негативных (напр. А. Л. Кузенков, Е. В. Бодрова и др.). Согласиться можно и с теми, и с другими. С первыми - потому, что другого опыта приватизации страна не имела, однако с поставленной задачей - перехода государственной собственности в частные руки - она справилась (однако, не без проблем). Со вторыми - потому, что от отчужденного имущества казна получила намного меньше средств, чем могла бы, и потому, что конечными собственниками государственного имущества стали не россияне, а иностранные граждане.

Приватизационный опыт России: взгляд в прошлое, оценка настоящего. Об основных направлениях экономических реформ было сказано в речи Президента России Б.Н. Ельцина, которая прозвучала 28 октября 1991 года на Пятом Съезде народных депутатов РСФРС. В ней Президент указал на одну из важных задач создания в России здоровой смешанной экономики с мощным частным сектором [11, с. 548].

Приватизационные процессы начались ранее. Еще в 1988 году после принятия ряда законов СССР, в частности Закона СССР «О государственном предприятии (объединении)», у «красных директоров» появился доступ к финансовым потокам и имуществу государственных предприятий.

Приватизация в России имела характер крайне идеологизированный $[7$, с. 191]. Она осуществлялась в рамках реформ, где основой служило мнение о том, что неограниченная «свобода рынка» и «свобода предпринимательства» являются наилучшим способом устройства экономики.

Как результат не учитывался многогранный и объемный опыт зарубежных стран (прежде всего, Китая), который показывал, что ускорение перехода следующему этапу формационного развития должно базироваться на активизации роли государства в экономике.

Приватизация 90-х годов XX века имела несколько направлений. Одним из них стала минимизация роли государства в экономике, «преодоление традиций этатизма» и устранение государства как «субъекта экономических отношений в стране» [3, с. 98].

По мнению Е. В. Бодровой, опыт осуществления приватизации государственной собственности в постсоветской России позволяет констатировать, что ни полная, ни тем более частичная смена формы собственности еще не означает автоматического возникновения «эффективной» частной собственности, так как вне конкурентного рынка, гражданского общества и развитого правового государства тот позитивный заряд, который несет в себе частная собственность реализован быть не может [1, с. 5].

21 декабря 2001 года в России был принят Федеральный закон №178-Ф3 «О приватизации государственного и муниципального имущества» [9]. В нем были сформулированы понятие и принципы приватизации, сфера действия указанного федерального закона, компетенция государственных органов по отчуждения имущества, а также закреплялись стадии процесса приватизации.

На сегодняшний день государственное имущество приватизируется в соответствии с законодательством и прогнозным планом (программой) приватизации. Действует Распоряжение Правительства РФ от 1 июля 2013 года «Об утверждении прогнозного плана (программы) приватизации федерального имущества и основных направлений приватизации федерального имущества на 2014-2016 годы» [8]. По заявлению главы Министерства финансов РФ А. Г. Силуанова правительство за два года (на которые утверждена программа - авт.) планирует заработать на приватизации госкомпаний 1 трлн. рублей [2].

Причин и условий для продолжения приватизации государственного имущества сложилось множество. Одними из них являются снижение стоимости энергоресурсов, резкое и значительное изменение соотношения стоимости иностранной валюты к отечественной, а также введенные против России санкции. Имеющееся законодательство и подзаконные акты в совокупности с опытом и уроками приватизации государственного имуще- 
ства 90-х годов XX века должны позволить правительству провести достаточно грамотное отчуждение госимущества на наиболее выгодных условиях и, самое главное, с пользой для экономики.

Однако из зарубежных инвесторов можно рассчитывать, по мнению А.М. Ходорковского, только на инвесторов с Востока - можно говорить уверенно об Индии и Китае [2]. Приватизация в условиях, когда экономика находится в состоянии спада, очень сложна. Непросто будет получить высокую цену за имущество, которое предполагается приватизировать, а также, найти самих желающих купить это имущество.

Приватизация государственного имущества в Китае: опыт прошлого и современное положение. В Китае не слишком любят применять термин «приватизация» для описания изменений, произошедших в форме собственности предприятий, именно развитие частной собственности стало главным катализатором очень быстрого по историческим меркам перехода от изначально государственной экономики к диверсифицированной [10, с. 2]. Однако проведенные реформы по своему характеру и форме являются приватизацией, но со свойственными Китаю особенностями проведения.

Одним из главных отличий приватизации, проводимой в Китае, от других стран стало отчуждение малых предприятий, в то время как крупные оставались в руках государства. Одно из многих преобразований - реформа малых предприятий, центром которой являлась реформа собственности (приватизация), привела к успеху: за достаточно короткий срок на малых госпредприятиях постепенно была создана соответствующая рыночной экономике система [4, с. 157]. Итоги по осовремениванию госпредприятий на 10-й пятилетке (20012005) Китай признал как «этапный» успех, однако дальнейшее проведение реформы госпредприятий требует многолетнего упорного труда.

Китайский опыт приватизации госпредприятий значительно отличается от массовой приватизации, проведенной в большинстве стран соцлагеря, в т.ч. и России. Во-первых, приватизация в Китае затронула только малые предприятия, в то время как деятельность госпредприятий переводилась на коммерческую основу. Во-вторых, макрореформы проводились до макроприватизации, в отличие от стран, где они проводились совместно.

С 2005 года Китай взял курс на точечную приватизацию отдельных крупных предприятий посредством IPO (продажи акций на зарубежных биржах) [4, с. 29]. Однако государство оставляет за собой крупные предприятия энергетики, транспорта, добычи и переработки сырья, оборонной промышленности. В 2006 году приняты «Правила поглощения компаний» в целях ускорения процесса укрупнения предприятий и приватизации крупных предприятий.

В 2016 году Китай запускает масштабные реформы на госпредприятиях [5]. Госсовет КНР по контролю и управлению госсобственностью планирует провести реформы в некоторых сферах, среди которых - полномочия советов директоров, слияния и поглощения, инвестиционная деятельность. Преобразования намечены в целях превращения принадлежащих государству корпораций в «полноценные субъекты рыночной экономики» уже к 2020 году. За счет нововведений планируется расширить присутствие частного капитала в госсекторе. Возможен также отказ от контрольных пакетов акций в большинстве госкорпораций [5]. При этом будут оставлены так называемые «золотые акции», которые наделяют правом вето на принятие таких важнейших решений, как перераспределение пакетов акций, слияния и поглощения, пересмотр базовой политики компании.

Уроки на будущее. Таким образом, приватизация, как передача госсобственности в частные руки имела и имеет место быть как в России, так и в Китае. Начав приватизацию примерно в одно и то же время, оба государства избрали разный путь ее реализации. Поскольку не было четкого понятия и механизма реализации данных реформ, не обошлось и без ошибок. Стоит сказать, что наиболее удачным опытом (по сравнению с Россией) приватизации обладает именно Китай. Китайская реформа отличается от стихийной либерализации направляющей рукой прагматичного государства [4, с. 392]. Было верным решение оставить за государством крупные промышленные предприятия и не отдавать до конца в частные руки мелкие.

России в этом плане необходимо извлекать определенные уроки и стремиться перенять положительный опыт приватизации госимущества. В целом, опыт реформ, проводимых в нашем государстве в 90 -е годы XX века, можно оценить как негативный. Возможно, это было результатом того, что избранные модели приватизации не соответствовали заявленным целям. Государство недополучило от таких реформ больше, чем приобрело. Сегодня, когда Россия все больше идет на сближение с Китаем, как в экономических, так и политических отношениях, нужно изучать и применять опыт приватизационных процессов нашего соседа. Тем более, что проведенные и проводимые Китаем реформы имеют целью укрепление экономики страны и повышение уровня жизни, а также сохранение идеологии с одновременным повышением уровня частного капитала в промышленном секторе. Китаю удалось найти определенный баланс между интересами государства и интересами частных лиц. По мнению министра торговли Китая Гао Хучена, «вне зависимости от того, (как идут дела - авт.) в области политики, экономики, ресурсов и сотрудничества на местном уровне, а также инвестиций и торговли, Россия и Китай располагают большим количеством механизмов кооперации» [6]. Сейчас Россия проводит приватизацию, что является одним из направлений сотрудничества наших стран.

\section{Литература}

1. Бодрова Е. В. Российская приватизация : «время разбрасывать камни» // Власть. 2014. № 2. С. 5-9.

2. Веденеева А. Можно рассчитывать только на инвесторов с Востока [Электронный pecypc]. URL: http://www.kommersant.ru/doc/2905970 (дата обращения: 25 марта 2016 г.).

3. Гайдар Е. Т. Государство и эволюция. М.: Альпина Паблишер, 2015. 152 с. 
4. Дин Жуджунь, Ковалев М. М., Новик В. В. Феномен экономического развития Китая. Минск: Изд. центр БГУ, 2008. $446 \mathrm{c}$.

5. Китай начнет реформу госпредприятий в 2016 году [Электронный pecypc]. URL.: http://russian.cri.cn/841/2015/12/12/1s568612.htm (дата обращения: 19 марта 2016 г.).

6. Китай подтвердил интерес к приватизации в России [Электронный pecypc]. URL:: http://www.vestifinance.ru/articles/69047 (дата обращения: 24 марта 2016 г.).

7. Маляров О. В. Приватизация как фактор эволюции экономической системы : опыт России и Индии // Управление развитием крупномасштабных систем (MLSD’11) : труды V междунар. конф. 2011. C. 191-199.

8. Распоряжение Правительства РФ от 01.07.2013 № 1111-р (ред. от 15.03.2016 г.) «Об утверждении прогнозного плана (программы) приватизации федерального имущества и основных направлений приватизации федерального имущества на 2014 - 2016 годы» [Электронный ресурс]. URL:: http://docs.cntd.ru/document/499030503 (дата обращения: 21 марта 2016 г.).

9. О приватизации государственного и муниципального имущества : Федеральный закон от 21 декабря 2001 года №178-Ф3 // Российская газета. 2002. 26 янв. С. 14.

10. Фэн Шаолей. Приватизация «по-китайски» // Свободная мысль. 2011. № 1. С. 66-80.

11. Яник А. А. История современной России : истоки уроки последней российской модернизации (1985-1999). М.: Изд-во Моск. ун-та, 2012. 760 с.

\title{
Сравнительно-правовой анализ посреднических договоров по законодательству Российской Федерации и Китайской Народной Республики
}

\author{
(ㄱ Д. М. Побежимов \\ стариий преподаватель кафедры \\ гражданского права и гражданского процесса \\ юридического факультета \\ ФГБОУ ВО «Забайкальский госуниверситет» \\ Россия, г. Чита \\ pobejimovd@mail.ru
}

Посредническая деятельность имеет приоритетное значение для установления и развития торгово-хозяйственных связей между странами. Она состоит в оказании производителям и потребителям юридических и фактических услуг, связанных с отечественной и международной торговлей. Кроме того, посредники часто выполняют дополнительные услуги, такие как маркетинговые, рекламные, услуги по сопровождению товара. Посредническая деятельность образует самостоятельный вид предпринимательской деятельности, поскольку требует определенных профессиональных качеств, умений, знания тарифов, цен, правил оформления различного рода сделок. Традиционно в континентальном праве регулируются два вида таких договоров - поручение и комиссия, в англо-американском праве - договор агентирования. В нашу торговую практику они были внесены иностранными организациями (фирмами), т.е. для улучшения качества жизни населения наше государство начиная с 90-х годов привлекает внешние инвестиции. Благодаря этому, в последнее время набирают обороты международные торговые отношения, в которых посреднические договоры выполняют одну из ключевых ролей [3, с. 85].

Особый интерес вызывает рассмотрение и сопоставление посреднических договоров по законодательству России и Китая. На современном этапе российско-китайское взаимодействие характеризуется широким спектром областей сотрудничества, не только в оборонной сфере, но и в торгово-экономической, где широко применяются посреднические договоры, используемых в КНР и РФ.

Договорное посредничество в праве Китая и в праве России имеет несколько существенных нормативных отличий, которые необходимо учитывать не только для приобретения иностранного товара, но и использовать для организации экспорта отечественных товаров в Китай.

Основной нормативно-правовой акт, регулирующий отношения посредничества в Российской Федерации это Гражданский кодекс Российской Федерации. В Китае отношения посредничества регулируются «Общими положениями гражданского права КНР» от 12. 04. 1986 года и Законом КНР «О договоре» от 15. 03. 1999 года [2].

В России посредничество регламентируется тремя договорами: поручение, комиссия и договор агентирования, причем все они юридически равны (главы 49, 51, 52 ГК РФ) [1]. В Китае действуют три вида посреднических договоров, таких как: договор поручения, договор комиссии и договор посредничества. Эти виды договоров могут применяться нашими российскими предпринимателями и производителями для расширения рынка сбыта своих товаров, в частности на рынок Китая.

Начнем с договора поручения. Главное отличие договорных отношений поручения в праве Китая и в праве России состоит в том, что страны по-разному дают (толкуют) понятие представительства. Право России рассматривает представительство только в его узком (прямом) смысле, т.е. поверенный вправе совершать юридические действия по исполнению поручения только от имени доверителя (ст. 971 ГК РФ). Право Китая квалифицирует понятие представительства более широко, включая в него основное представительство, т.е. поверенному позволяется действовать от своего имени в интересах доверителя и приобретать права и обязанности или для доверителя, или для себя (факультативное представительство) ст. 403 Закона КНР «О договоре». Эти признаки определяют остальные отличия отношений поручения между законодательством России и законодательством Китая. Например, в силу этого, нормы о договоре поручения КНР применяются и к отношениям комиссии, т. е. могут их регулировать (Ст. 423 Закона КНР «О договоре»). 
Другим существенным отличием в отношениях поручения по праву КНР является применение солидарной ответственности при нарушении обязательств из отношений основного представительства. В отношениях факультативного представительства по праву Китая и во всех отношениях поручения по праву России применяется долевая ответственность.

Что касается договора комиссии, то законодательство России понимает отношения комиссии шире, чем право Китая. По китайскому законодательству комиссионер совершает от своего имени только коммерческие сделки, то есть только те, которые совершаются возмездно в целях торговли, это купля-продажа, мена, перепродажа товара (Ст. 414 Закона КНР «О договоре»). По российскому законодательству допускается совершение комиссионером всех видов сделок, в том числе и торговых. По общему правилу возмездность этих сделок предполагается, но в российском законодательстве не говорится об исключительной торговой направленности этих сделок (ст. 990 ГК РФ). Однако в отношениях комиссии по российскому праву имеется достаточно много вопросов, которые не урегулированы законодательством, поэтому возникает много проблем при урегулировании не только внешних торговых отношений, но и внутренних.

Например, в российском законодательстве конкретно не определены ответственное лицо и размер компенсации в случаях причинения убытков комитенту, если имущество продано комиссионером по цене, ниже согласованной, или если имущество куплено по цене, выше установленной (ст. 995 ГК РФ). В этой коллизии право Китая регулирует отношения комиссии более последовательно и четко, т.е. в нормах существует конкретная определенность (Ст. 418 Закона КНР «О договоре»).

Далее проанализируем агентский договор. В отличие от российского законодательства эта сделка (ст. 1005 ГК РФ) в законодательстве Китая не предусмотрена. Однако в международной торговой практике Китая агентские договорные отношения встречаются довольно часто. В России и в Китае, при заключении сторонами договора агентирования в международной торговле за основу берутся Рекомендации Международной Торговой Палаты. Которая создает унифицированные правила, стандарты и обобщает международную практику ведения торговых операций, а также активно участвует в процессе изменения национальных законодательств в интересах развития бизнеса, торговли и инвестиций [5]. В российско-китайских торговых отношениях нормы договора агентирования применяются по модели договора комиссии или поручения КНР.

В законодательстве Китая предусмотрен ещё один вид посредничества, это договор посредничества (ст. 424 Закона КНР «О договоре»). Абсолютно точное определение этому договору дала Нырова Наталья Николаевна, которая называет его простым («чистым») посредничеством или договором маклерства. Для права России этот договор не является новым, но в Гражданском кодексе РФ этот вид отношений не закреплён. Однако схожие виды правоотношений закреплены в других российских нормативно-правовых актах, например, в Кодексе торгового мореплавания РФ, а также федеральных законах РФ, регулирующих деятельность брокеров и других посредников на рынке ценных бумаг и иных фондовых рынках, осуществляющих специализированные виды деятельности на основе специальных разрешений (лицензий). Данная сделка способствует заключению других договоров, способствующих проникновению товара на китайский рынок (например, договоры комиссии или агентирования; бартерные сделки; создание совместного предприятия и т. п.) [4, с. 85].

Таким образом, знание особенностей договоров посредничества, установленных законодательством КНР, обеспечивает российского экспортера такими умениями и навыками, которые позволят ему строить справедливые торговые отношения с китайскими предпринимателями и позволят беспрепятственно, и финансовых потерь преодолевать барьеры, тем самым расширяя рынок сбыта российских товаров.

\section{Литература}

1. Гражданский кодекс Российской Федерации (часть вторая) от 26 января 1996 г. № 14-ФЗ (ред. от 29.06.2015) // Собр.законодательства Российской Федерации. 1996. № 5. Ст. 410.

2. Закон КНР «О договоре» от 15. 03. 1999 г. [Электронный ресурс]. Режим доступа: http://chinalawinfo.ru/civil_law/law_contract (дата обращения: 06.02.2016).

3. Беляева О.А. Коммерческое право России: курс лекций. 3-е изд., пер. и доп. М.: Юстицинформ, 2009. С.85.

4. Нырова Н. Н. Договоры посредничества в законодательстве КНР и их использование для организации экспорта российских товаров [Электронный ресурс]. Режим доступа: http://www.cfin.ru/press/practical/2002-12/04.shtml (дата обращения: 04.02.2016).

5. Россия - экспорт - импорт. Международная Торговая палата. [Электронный ресурс]. Режим доступа: http://www.rusimpex.ru/Content/Links/Interorg/.../iccwbo.htm (дата обращения: 16.02.2016).

\section{Правовое регулирование товарного знака в России и Китае}

Роль товарного знака как средства индивидуализации товаров постоянно возрастает в условиях формирования свободного рынка товаров, работ и услуг. Все мы ежедневно выступаем потребителями какого-либо продукта, идентифицируя необходимую нам продукцию, отличая одних производителей от других с помощью то- 
варного знака. Товарный знак - это зарегистрированное в установленном порядке обозначение для отличия товаров одних организаций и физических лиц от однородных товаров других организаций и физических лиц.

Очень часто мы видим товары с обозначением общеизвестных товарных знаков, таких как «Chanel, Guccu, Prada, Versace, Louis Vuitton и др.) по весьма низким ценам, и которые продаются не в официальных магазинах брендов. Рассматриваемая продукция является контрафактной, т.е. выпускаемая предприятием с нарушением исключительных прав правообладателей, дизайнеров товарных знаков, авторских прав. В последнее время весьма актуальной стала обувь Парижской обувной компании Cristian Louboutin. Отличительной особенностью продукции этой фирмы выступает красная подошва туфель. В 2008-м Louboutin зарегистрировал красную подошву как товарный знак. В 2011 г. апелляционный суд Нью-Йорка вынес решение о признании красной подошвы в качестве товарного знака в споре с Yves Saint Laurent[5]. Теперь ни одна фирма в мире не имеет права выпускать туфли с красной подошвой за исключением монохромной обуви (когда обувь окрашена в один цвет). Однако рынок переполнен обувью с красной подошвой от других производителей, и на ценниках к данной обуви указана страна-производитель Китай [6].

Китай выступает основным производителем и экспортером контрафактной продукции в мире [7]. В том случае, если правообладатель не реализует свою продукцию в Китае, он может понести ощутимый ущерб от экспорта контрафакта на рынки других стран.

Как известно, в Китае отсутствует кодифицированный акт гражданского законодательства в отличие от России. В РФ нормативно-правовым актом, регулирующим право на результаты интеллектуальной деятельности выступает ч. 4 ГК РФ, в КНР же это Закон КНР «О товарных знаках», Закон КНР «О патентах», Закон КНР «Об авторских правах»), а также ряд административных правовых актов.

С учетом развития рыночных отношений, развития международной экономики, активного импорта и экспорта товаров, большого количества недобросовестных предпринимателей, желающих ввести в заблуждение потребителей - граждан и организаций, правовое регулирование данного института права является весьма актуальным, а сравнительный анализ норм различных стран поможет выявить сильные и слабые места различных правовых систем, сделать выводы о вопросах возможного правопреемства.

Закон КНР «О товарных знаках» был принят в 1982 г., он определяет условия охраны товарного знака, порядок его регистрации (в Управлении по товарным знакам Главного государственного управления торговопромышленной администрации КНР), подачу возражений против регистрации товарного знака, порядок разрешения споров по поводу товарных знаков в административном порядке.

В августе 2013 г. в данный закон были внесены изменения, позволяющие регистрировать звуковые знаки, разрешена подача одной заявки при регистрации в разных классах Международной классификации товаров и услуг (МКТУ), усовершенствованы правила подачи и рассмотрения возражений против регистрации товарных знаков, изменена система наложения штрафов за нарушение исключительных прав на товарный знак.

Исключительные права на товарный знак возникают лишь после его регистрации в уполномоченном государственном органе.

В качестве товарного знака, как в России, так и в Китае могут быть зарегистрированы любые обозначения, позволяющие различить товары и услуги. Обозначения должны обладать различительной способностью - способностью указывать на конкретного производителя товара или лицо, оказывающее услуги

Не могут быть зарегистрированы в качестве товарных знаков: общепринятые обозначения (стол, стул); описательные обозначения - являющиеся прямым указанием на качество, основные материалы; другие обозначения, не обладающие различительной способностью: буквы и цифры, не имеющие характерного графического исполнения; сочетания букв, не являющиеся словами; линии, простые геометрические фигуры.

Кроме того, в качестве товарного знака в КНР не могут быть зарегистрированы следующие обозначения: тождественные или сходные до степени смешения с официальным наименованием, государственным флагом, государственным гербом, государственным гимном, флагом вооруженных сил, гербом вооруженных сил, гимном (маршем) вооруженных сил, наградами КНР и иностранных государств, международных межправительственных организаций, центральных государственных органов КНР и др. (ст. 10 Закона КНР "О товарных знаках").

Заявка на регистрацию товарного знака подается в Управление по товарным знакам ГГУТПА КНР. Иностранные граждане, не проживающие на территории КНР, и иностранные организации, не имеющие места ведения деятельности в пределах КНР (включая филиалы и представительства), могут подать заявку только через специализированную агентскую организацию (организацию поверенных по товарным знакам). Для регистрации необходимо заполнить заявку на регистрацию и представить изображение товарного знака.

После приема заявки и проверки содержания и наличия необходимых документов Управление по товарным знакам проводит экспертизу заявки на регистрацию товарного знака в срок до 9 месяцев. После экспертизы заявка на регистрацию товарного знака публикуется в бюллетене Управления по товарным знакам. В течение 3 месяцев со дня публикации заинтересованные лица вправе обратиться в управление с возражениями против регистрации данного товарного знака. При отсутствии возражений Управление по товарным знакам осуществляет регистрацию и выдает свидетельство о регистрации товарного знака. Срок рассмотрения возражений составляет 12 месяцев и может быть продлен еще на 6 месяцев с разрешения руководителя ГГУТПА КНР. По результатам рассмотрения возражений Управление по товарным знакам принимает решение о регистрации или отказе в регистрации товарного знака, которое может быть обжаловано в Апелляционную комиссию. 
В России орган, регистрирующий товарные знаки - Федеральная служба по интеллектуальной собственности, патентам и товарным знакам (Роспатент). Федеральный орган исполнительной власти по интеллектуальной собственности публикует в официальном бюллетене сведения о поданных заявках на товарные знаки. После публикации сведений о заявке до принятия решения о государственной регистрации товарного знака любое лицо вправе представить в федеральный орган исполнительной власти по интеллектуальной собственности обращение в письменной форме, содержащее доводы о несоответствии заявленного обозначения требованиям статей 1477 и 1483 настоящего ГК РФ. Приоритет товарного знака устанавливается по дате подачи заявки на товарный знак в федеральный орган исполнительной власти по интеллектуальной собственности (данное правило действует и в Китае).

Экспертиза заявки включает формальную экспертизу (в течение месяца) и экспертизу обозначения, заявленного в качестве товарного знака (заявленного обозначения). Товарные знаки регистрируются, а заявителю выдается свидетельство на товарный знак, если поданные на регистрацию обозначения соответствуют требованиям Гражданского кодекса РФ

Право на товарный знак может передаваться как полностью - по договору отчуждения, так и частично - по лицензионному договору. Такие договоры подлежат обязательной регистрации в Федеральной службе по интеллектуальной собственности.

Срок действия свидетельства о регистрации товарного знака составляет 10 лет со дня регистрации товарного знака. Продление срока регистрации возможно в течение последнего года, а также в 6-месячный период после окончания срока действия. Те же правила предусмотрены и в России.

Международная регистрация товарного знака со страной происхождения КНР возможна только для организаций и физических лиц, которые имеют действительное и фактическое место ведения деятельности на территории КНР, место жительства в КНР или гражданство КНР.

На органы торгово-промышленной администрации возложена обязанность по проведению проверок по фактам нарушения прав на товарные знаки, а также по применению административных наказаний за совершение правонарушений. Обратиться с жалобой на нарушение может любое заинтересованное лицо.

Разбирательство проводится на основании ст. 60 Закона КНР "О товарных знаках", по которой в случае нарушения исключительных прав правообладатель может: 1) самостоятельно договориться с правонарушителем; 2) обратиться с иском в народный суд или 3) обратиться с заявлением о проведении разбирательства в орган торгово-промышленной администрации.

Разбирательство проводится органом торгово-промышленной администрации уездной ступени по месту совершения правонарушения в течение 7 рабочих дней; разрешено продление данного срока до 15 дней. Если факт правонарушения подтверждается достаточными доказательствами, орган торгово-промышленной администрации обязан вынести предписание о незамедлительном прекращении нарушения, конфискации и уничтожении контрафактных товаров, а также подделанных обозначений товарного знака и средств для изготовления контрафакта. Кроме того, орган торгово-промышленной администрации обязан наложить штраф в размере до $500 \%$ от незаконно полученного дохода или до 250000 юаней жэньминьби (если незаконно полученный доход составляет менее 50000 юаней жэньминьби, а также если доход отсутствует или его сумму невозможно определить).

Основным недостатком разбирательства по фактам правонарушений в органах торгово-промышленной администрации является то, что данные органы не вправе присудить правообладателю возмещение убытков (вся сумма административного штрафа поступает в государственную казну. Поэтому законодательство КНР допускает возможность обращения в народный суд с иском о возмещении убытков.

На сегодняшний день большую проблему представляет действие товарного знака, зарегистрированного в одной стране, в рамках реализации товаров с данным знаком в другой стране. Так, например, если товарный знак был зарегистрирован на территории в России, а через какое-то время производитель решил импортировать товар в Китай, но в Китае уже существует такой же товарный знак, зарегистрированный в установленном порядке, то таможенные органы воспрепятствуют экспорту данного товара из России, а если товар все же перейдет границу, то в дальнейшем его изымут как «контрафактный» и наложат запрет на его реализацию. Что бы такого не случилось, юристы советуют зарегистрировать в Китае свой товарный знак до начала любых взаимоотношений с китайскими контрагентами[8].

Для пресечения экспорта контрафактной продукции из Китая правообладатель может зарегистрировать в таможенном реестре принадлежащие ему права на зарегистрированный товарный знак в двух случаях: 1) если товарный знак был зарегистрирован непосредственно в КНР; 2) если товарный знак был зарегистрирован за рубежом, но в дальнейшем была подана международная заявка на регистрацию с распространением правовой охраны на территорию КНР. Если товарный знак зарегистрирован только в России, данный товарный знак не может быть включен в таможенный реестр ГТУ КНР.

Однако здесь опять же видится проблема - пока гражданин РФ будет два года регистрировать товарный знак в Китае, контрафактная продукция будет на протяжении этого времени продаваться на рынке России. Поэтому считаем, что в случае экспорта товара из Китая, таможенные органы должны запрашивать у экспортера справку из международного реестра о том, что на их товарный знак отсутствует другой правообладатель.

Еще одной проблемой здесь выступает в случае обнаружения таможенными органами контрафактной продукции требования от правообладателя обеспечения, которое может достигать 100000 юаней, также данный 
способ защиты прав интеллектуальной собственности не решает проблему распространения контрафакта в пределах КНР [4].

Другим проблемным вопросом регулирования товарного знака как в России, так и в Китае выступает длительный срок его регистрации: в КНР - до года, а в России от года до полутора лет. В России подобная проблема связана с отсутствием регламентации сроков рассмотрения заявки в ФИПС, также на увеличение сроков влияет работа почты, переписка с ФИПС. В указанных ранее изменениях в Законе КНР о товарных знаках срок предварительной экспертизы заявок на товарный знак уже составляет 9 месяцев.

Представляется целесообразным регламентация срока регистрации товарного знака в рамках 10 месяцев одного года. В дальнейшем, когда система уже будет отработанной, можно будет поставить вопрос о сокращении и данного срока.

Таким образом, мы сегодня видим, что цели, указанные в статье 1 Ф3 о товарных знаках, такие как усиление контроля за использованием товарных знаков; содействие обеспечению качества товаров со стороны производителей и поддержанию репутации товарных знаков; защита интересов потребителей; содействие развитию социалистической товарной экономики не выполняются.

На сегодняшний день существует много неурегулированных проблем, которые требуют как можно скорейшего разрешения. Большие проблемы возникают также при пересечении права на товарный знак и авторских прав. Поэтому считаем целесообразным, во-первых, уменьшить срок регистрации товарного знака, во-вторых ужесточить контроль в таможенных органах с предоставлением справки о наличии у экспортеров разрешения на использование товарного знака или отсутствия других правообладателей, в-третьих, ужесточить штрафы, учитывая, что в России, исходя из судебной практики штрафы весьма не высокие, производителям легче заплатить штраф и продолжить заниматься незаконной деятельностью, и, в-четвертых, административным органам, как России, так и Китая, необходимо проводить более регулярные проверки производителей с целью выявления соответствующих правонарушений.

\section{Литература}

1. Гражданский кодекс Российской Федерации (часть четвертая) от 18.12.2006 N 230-Ф3 // Собрание законодательства РФ. 25.12.2006. N 52 (1 ч.). Ст. 5496.

2. Джермакян В. Ю. 500 вопросов по товарным знакам: разъяснения правоприменительной практики // СПС КонсультантПлюс. 2015.

3. Аверин С. В. Источники международного частного права Китайской Народной Республики // Вестник международного коммерческого арбитража. 2012. N 2. С. 133-155.

5. Кристиан Лабутен добился правовой охраны красной подошвы в России [Электронный pecypc]. URL: http://www.vedomosti.ru/business/articles/2012/12/03/christian_louboutin_dobilsya_v_rossii_pravovoj_ohrany_svoego (дата обращения: 8.04.2016).

6. На основании личных исследований.

7. Баженов П. Защита прав на товарный знак в Китае. URL: http://cnlegal.ru/china_intellectual_property/ trademark_protection/ 16.07.2013

8. Бажанов П. В. Ведение бизнеса в Китае: правовые аспекты. Вып. 1. Обзор правовой среды для бизнеса: кн. для юристов, сопровождающих бизнес. М.: Инфотропик Медиа, 2015. 212 с.

\section{Особенности режима труда работников, воспитывающих ребенка-инвалида по трудовому законодательству России, Узбекистана, Туркменистана и Таджикистана}

(C) В. О. Самсонова

Судья Рославльского городского суда

Смоленской области,

Россия, г.Рославль

vogorchakova@yandex.ru

В рамках данной работы интерес представляет исследование особенностей закрепленных в трудовых кодексах России, Таджикистана, Туркменистана и Узбекистана в отношении труда работников, воспитывающих ребенка-инвалида и их оценка с позиции защиты означенной категории работников.

В соответствии со ст.93 Трудового кодексе Российской Федерации (далее - ТК РФ)[1] на работодателя во3ложена обязанность установления неполного рабочего дня (смены) или неполной рабочей недели по просьбе одного из родителей (опекуна, попечителя), имеющего ребенка-инвалида до восемнадцати лет.

При работе на условиях неполного рабочего времени оплата труда работника производится пропорционально отработанному им времени или в зависимости от выполненного им объема работ.

В свою очередь, в ст.168 Трудового кодекса Республики Таджикистан (далее - ТК Республики Таджикистан) [2] определяется, что по просьбе женщины, имеющей ребенка-инвалида в возрасте до восемнадцати лет, в том числе находящегося на ее попечении, работодатель обязан установить им неполный рабочий день или неполную рабочую неделю (ст.64 ТК Республики Таджикистан).

При этом, как оговорено в ст.64 ТК Республики Таджикистан [2], при введении режима неполного рабочего времени продолжительность рабочего времени не может быть менее половины месячной нормы рабочего времени, а оплата труда - ниже установленного законодательством Республики Таджикистан минимального размера. 
Согласно ст.229 Трудового кодекса Республики Узбекистан (далее - ТК Республики Узбекистан) [3] по просьбе женщины, имеющей ребенка-инвалида до шестнадцати лет, в том числе находящегося на ее попечении, работодатель обязан устанавливать им неполный рабочий день или неполную рабочую неделю (ст.119 ТК Республики Узбекистан).

Согласно требованиям ст.119 ТК Республики Узбекистан [3], работа на условиях неполного рабочего времени оплачивается пропорционально отработанному времени или в зависимости от выработки. В статье 63 Трудового кодекса Республики Туркменистан (далее - ТК Республики Туркменистан) [4] определяется, что по просьбе одного из родителей (опекуна, попечителя), имеющего ребенка-инвалида до шестнадцати лет, работодатель обязан устанавливать им неполный рабочий день или неполную рабочую неделю.

Согласно ст.130 ТК Республики Туркменистан [4], оплата труда при неполном рабочем дне или при неполной рабочей неделе производится пропорционально отработанному времени или в зависимости от выполнения норм выработки. Во всех анализируемых кодексах предусмотрено, что нормальная продолжительность рабочего времени не может превышать 40 часов в неделю. Таким образом, для обеспечения работнику, воспитывающему ребенка-инвалида, права на работу в условиях неполного рабочего времени, он должен обратиться к работодателю с соответствующей просьбой. Ни один из изучаемых нами кодексов не содержит указания на форму такой просьбы, но, безусловным является то, что она должна быть выражена письменно.

Положительной особенностью всех изучаемых нами трудовых кодексов является закрепление положения о том, что работа на условиях неполного рабочего времени не влечёт для работника каких-либо ограничений продолжительности отпуска, исчисления трудового стажа и других трудовых прав.

Следует обратить внимание на то, что в России и Туркменистане гарантия работы на условиях неполного рабочего дня (смены) или неполной рабочей недели распространяется на родителей, опекунов и попечителей ребенка-инвалида.

В тоже время, статьей 249 ТК Республики Туркменистан [4] предусмотрено, что гарантии и льготы, предоставляемые женщине в связи с материнством (ограничение труда на ночных и сверхурочных работах, ограничение привлечения к работам в выходные, нерабочие праздничные и памятные дни и направления в командировки, предоставление отпуска без сохранения заработной платы, установление льготных режимов труда и другие гарантии и льготы, установленные законодательством Туркменистана), распространяются на отцов, воспитывающих детей без матери (в случае её смерти, лишения родительских прав, длительного пребывания в лечебном учреждении и в других случаях отсутствия материнского попечения о детях), а также на опекунов (попечителей) несовершеннолетних.

В Узбекистане и Таджикистане право работы на условиях неполного рабочего дня (смены) или неполной рабочей недели допускается для женщин, воспитывающих ребенка-инвалида.

Термин «женщина» свидетельствует о том, что указанные нормы могут распространяться не только на женщин-матерей, но и на усыновительниц, опекунш и попечительниц.

Между тем, в силу положений ст.238 ТК Республики Узбекистан [3] гарантии и льготы, предоставляемые женщинам в связи с материнством (ограничение ночного труда и сверхурочных работ, привлечения к работам в выходные дни и направления в командировки, а также предоставление дополнительных отпусков, установление льготных режимов труда и другие гарантии и льготы, установленные законодательными и иными нормативными актами о труде), распространяются на отцов, воспитывающих детей без матери (в случае ее смерти, лишения родительских прав, длительного пребывания в лечебном учреждении и в других случаях отсутствия материнской заботы о детях), а также на опекунов (попечителей) несовершеннолетних.

Кроме того, указанные гарантии и льготы предоставляются также бабушке, деду или другим родственникам, фактически воспитывающим детей, лишенных родительского попечения.

Согласно ст.173 ТК Республики Таджикистан [2] гарантии и льготы, предоставляемые женщине в связи с материнством (ограничение ночного труда и сверхурочных работ, непривлечение к работам в выходные дни и направления в командировки, предоставление дополнительных отпусков, установление льготных режимов труда и другие гарантии и льготы, установленные законодательством Республики Таджикистан о труде), распространяются на отцов, воспитывающих детей без матери (в случае ее смерти, лишения родительских прав, длительного пребывания в лечебном учреждении и в других случаях отсутствия материнского попечения о детях), а также на опекунов (попечителей) несовершеннолетних.

Другой важной трудовой гарантией для работников, воспитывающих ребенка-инвалида, является закрепление необходимости получения письменного согласия работника на привлечение к сверхурочной работе, работе в ночное время, работе в выходные и нерабочие праздничные дни, направления в служебные командировки.

В Российской Федерации работодатель обязан получить письменное согласие на привлечение работника, воспитывающего ребенка-инвалида, к сверхурочным работам (ст.259 ТК РФ) [1] и выполнять такую работу последний может только в случае, если она не запрещена ему по состоянию здоровья в соответствии с медицинским заключением. Кроме того, работник работодателем должен быть в письменной форме ознакомлен со своим правом отказаться от сверхурочной работы.

Аналогичная позиция (ст.259 ТК РФ) закреплена в отношении работников, воспитывающих ребенка-инвалида, при направлении в служебные командировки, привлечении к работе в выходные и нерабочие праздничные дни, ночное время.

Порядок выдачи медицинского заключения установлен приказом Министерства здравоохранения и социального развития РФ от 02.05.2012 № 441н [5]. 
В Трудовом кодексе Республики Туркменистан (ст.243) [4] предусмотрено, что женщины, имеющие ребенка-инвалида до шестнадцати лет, не могут привлекаться к работам в ночное время, к сверхурочным работам, работам в выходные дни, нерабочие праздничные и памятные дни, а также направляться в служебные командировки без их письменного согласия.

В статье 228 ТК Республики Узбекистан [3] закреплено, что не допускается привлечение к работам в ночное время, к сверхурочным работам, работам в выходные дни и направление в командировку женщин, имеющих детей-инвалидов до шестнадцати лет, без их согласия.

Согласно ст.162 ТК Республики Таджикистан [2] от женщин, имеющих детей и лиц, осуществляющих уход за ребенком в связи с семейными обязанностями, требуется согласие на привлечение к сверхурочным работам и направление в служебные командировки.

Таким образом, в России и Туркменистане от работников требуется получение письменного согласия на работу в ночное время, в выходные и нерабочие праздничные дни, привлечение к сверхурочным работам и направление в служебные командировки.

В Узбекистане и Таджикистане законодатель, предусматривая обязанность получить от работника согласие, не оговаривает его форму.

В тоже время, в ТК РФ и ТК Республики Туркменистан предусмотрено требование о разъяснении в письменном виде работодателем работнику (в России - любому работнику, в Туркменистане - только работницеженщине) его право отказаться от сверхурочной работы, работы в ночное время, в выходные и нерабочие праздничные дни и направления в служебные командировки.

Также только в ТК РФ оговорено, что выполнять работник такую работу (сверхурочную, в ночное время, в выходные и нерабочие праздничные дни, служебные командировки) может только в случае, если она не запрещена ему по состоянию здоровья в соответствии с медицинским заключением.

В тоже время в ст.284 ТК Республики Таджикистан [2] закреплено, что к вахтовому методу работы не могут привлекаться женщины, имеющие ребенка-инвалида до шестнадцати лет.

В ТК России такого ограничения не закреплено.

В ТК Республики Туркменистан также такого права в отношении работников, воспитывающих детей-инвалидов не предусмотрено. Зато в этом законе закреплен запрет работодателю на привлечение к работе вахтовым методом, работников, осуществлющих уход за больными членами семьи, если на основании медицинского заключения они нуждаются в осуществлении ухода (ст.243).

Статья 161 ТК Республики Таджикистан [2] определяет, что при организации смежных работ женщинам, имеющим детей-инвалидов до восемнадцати лет, с учетом возможности производства оказывается предпочтение в использовании на работе в дневное время.

Анализ положений трудовых кодексов России, Туркменистана, Таджикистана и Узбекистана позволяет сделать несколько выводов.

Во всех изучаемых трудовых законах закреплены положения, регулирующие гарантии для работников, воспитывающих детей-инвалидов.

При этом можно констатировать, что все трудовые кодексы определили родителей детей-инвалидов как особую категорию работников, для которой установлены специальные правила регулирования труда.

Закрепление в трудовых кодексах дополнительных гарантий и льгот для работников, воспитывающих детей-инвалидов, явилось существенным законодательным изменением, направленным на совершенствование правового механизма труда данной категории работников и на систематизацию всего законодательства, обеспечивающего режим труда данных работников.

Важным шагом по выделению необходимости специального трудового статуса работника, воспитывающего ребенка-инвалида, стало закрепление во всех трудовых кодексах гарантии предоставления им неполного рабочего дня или неполной рабочей недели.

Особенностью обеспечения трудовых гарантий для работников, воспитывающих детей-инвалидов, является то, что они находятся в прямой зависимости от наличия у ребенка категории «ребенок-инвалид» и достижения им определенного в законе возраста.

В России и Таджикистане работникам разрешено получение льгот до достижения ребенком-инвалидом возраста восемнадцати лет, в Туркменистане и Узбекистане допустимо получение работниками льгот до достижения ребенком-инвалидом возраста шестнадцати лет.

Таким образом, в России и Таджикистане для работников, воспитывающих детей-инвалидов, предусмотрено более продолжительное предоставление трудовых льгот.

Проводя параллели с российским трудовым законодательством, приходится констатировать, что трудовые кодексы Таджикистана, Узбекистана и Туркменистана в части регулирования труда работников, воспитывающих детей-инвалидов, на наш взгляд, нуждается в дополнениях, приведенных в работе.

Таким образом, трудовое законодательство Российской Федерации аккумулировало в себе все лучшее.

Как представляется, Россия может воспользоваться опытом Республики Таджикистан, не разрешающим работу вахтовым методом женщинам, имеющим ребенка-инвалида.

Усилия законодателей всех изучаемых стран должны быть направлены на использование эффективных правовых средств и наиболее удачных юридических способов обеспечения гарантированности реализации права работников на труд в здоровых и безопасных условиях. 
Несомненно, это будет активно стимулировать законодателей этих стран продолжать совершенствовать нормативные конструкции кодексов в вопросах труда работников, воспитывающих детей-инвалидов.

Литература

1. Трудовой кодекс Российской Федерации от 30.12.2001 № 197-Ф3 (ред. от 30.12.2015) // С3 РФ. 07 января 2002 года. № 1 (ч. 1). Ст. 3. № 9.

2. Трудовой кодекс Республики Таджикистан от 15.05.1997 // Ахбори Маджлиси Оли Республики Таджикистан, 1997 г.

3. Трудовой кодекс Республики Узбекистан от 21.12.1995 // Народное слово. 30 января 1996 года

4. Трудовой кодекс Республики Туркменистан от 18.04.2009 №30-IV // Ведомости Меджлиса Туркменистана №2(996) часть 4 , ст.30.

5. Приказ Министерства здравоохранения и социального развития РФ от 02.05.2012 г. № 441н «Об утверждении Порядка выдачи медицинскими организациями справок и медицинских заключений» // Российская газета. 6 июня 2012. № 127.

\section{Ответственность за нарушение договора: сравнительный анализ законодательства Китая и России}

(C) Сунь Ци

магистрант 1 года обучения юридического факультета ФГБОУ ВО «Новосибирский национальный исследовательский государственный университет»

Россия, г. Новосибирск sunqidabao@163.com

Актуальность данной работы обусловлена существенным изменением норм Гражданского кодекса Российской Федерации об обязательстве (далее - ГК РФ), в том числе об ответственности за нарушение договора, которые вступили в силу с 1 июня 2015 года [1], а также изменением правового регулирования ответственности за нарушение договора в Законе КНР «О договоре» (далее - Закон о договоре) [2]. Существует необходимость анализа данных изменений; выявления общих и отличительных признаков, присущих договорной ответственности Китая и России.

Юридическая ответственность является одной из фундаментальных категорий юриспруденции. Так, Покровский И.А. отмечал, что гражданское право имеет своей задачей установить вредные последствия, причиненные правонарушением, и для него важно только одно [3] - определить, имеет ли место то, что называется правонарушением и что дает основание возложить ответственность на его виновника

Касаемо ответственности за нарушение договора, хотим обратить внимание на то, что обязательства должны строго соблюдаться, и в случае их неисполнения или ненадлежащего исполнения (далее - неисполнение) гражданское право возлагает на должника ответственность перед кредитором. Ответственность в гражданском праве - это неблагоприятные для должника имущественные последствия несоблюдения им обязательств, дополнительная его обязанность.

Ответственность в гражданском праве носит имущественный характер и ее основной формой является возложение на неисправного должника обязанности возместить причиненные другой стороне имущественные потери - убытки. Согласно ст. 15 Гражданского кодекса РФ лицо, право которого нарушено, может требовать полного возмещения причиненных ему убытков; это же правило повторено в ст. 393 Гражданского кодекса РФ.

Другой формой имущественной ответственности, широко используемой законодательством и при заключении договоров, является обязанность неисправной стороны уплатить кредитору неустойку (штраф, пени).

Ответственность должника за нарушение обязательств наступает не при любом его несоблюдении, а только при наличии обстоятельств, признаваемых правом необходимыми для возложения ответственности. Ими являются:

1) противоправность действий должника;

2) вина должника. (Отсутствие вины доказывается лицом, нарушившим обязательство. В частности, это касается обязательств при осуществлении предпринимательской деятельности.)

3) наличие убытков у кредитора;

4 ) наличие причинной связи между действиями должника и возникшими у кредитора убытками.

В Китае и России гражданское законодательство предусматривает и некоторые другие формы имущественного воздействия на неисправного должника: право кредитора отказаться от принятия исполнения по обязательству, если оно является ненадлежащим, право удерживать имущество должника при невыполнении им его денежных обязательств, потеря выданного должником задатка и др.

Различают долевую, солидарную и субсидиарную ответственность, которым присущи значительные особенности.

В Китае Содержание договора устанавливается сторонами и по общему правилу должно включать следующие условия: 1) наименования (имена) и местонахождение сторон; 2) предмет договора; 3) количество; 4) качество; 5) цена или оплата; 6) срок, место, способ исполнения; 7) ответственность за нарушение договора; 8 ) спо- 
соб разрешения споров. Стороны могут заключить договор в соответствии с моделью той или иной разновидности договора, содержащейся в настоящем Законе.

Статья 42 Закона КНР «О договорах» устанавливает, что если одна из сторон в процессе заключения договора причиняет убытки другой стороне, она обязана нести ответственность по их возмещению при одном из следующих условий:

1) если переговоры о заключении договора займа ведутся с недобросовестными намерениями;

2) если умышленно скрываются важные факты, связанные с заключением договора, либо предоставляется ложная информация;

3) если имеют место иные действия, нарушающие принцип добросовестности и доверия.

В Китае существуют следующие нарушения договора: 1) неисполнение договорных обязательств одной из сторон или исполнение их не в соответствии с условиями договора; 2) если одна из сторон ясно заявляет о том, что не исполнит договорное обязательство, либо если это становится очевидным из ее действий, другая сторона может до истечения срока исполнения потребовать ее ответственности за нарушение договора.; 3 ) если одна из сторон не уплачивает цену или отказывается от оплаты, другая сторона может потребовать от нее уплаты цены или оплаты.; 4) если качество не соответствует условиям договора, надлежит нести ответственность за нарушение договора согласно договоренности сторон; 5) если одна из сторон не исполняет договорное обязательство либо исполняет его не в соответствии с условиями договора, то после исполнения обязательства или принятия мер для исправления положения она обязана нести ответственность по возмещению убытков в случае, когда у другой стороны возникли и иные убытки.

В соответствии со ст. 48 Закона КНР «О договорах» мерами ответственности за нарушение договора являются возмещение убытков, причиненных неисполнением или ненадлежащим исполнением обязательств по договору, а также уплата неустойки.

Хочу обратить внимание на то, если заключен договор между КНР и РФ, что касается международного договора, то стороны договора, имеющего отношение к загранице, могут избрать применимое право для разрешения спора, вытекающего из договора, если иное не установлено прочими правовыми нормами. Если стороны не сделали выбора, применяется право государства, наиболее тесно связанного с договором. К исполняемым на территории Китайской Народной Республики договорам о совместных предприятиях, о кооперационных предприятиях с китайским и иностранным участием, о китайско-иностранном сотрудничестве в освоении природных ресурсов применяется право Китайской Народной Республики.

В Китае в законодательстве об ответственности за нарушение договора появилось немало вопросов. Например, стандарт определения неустойки и исполнение принуждения. При этим, как решать такие вопросы появится основная задача для развития законодательства об ответственности за нарушение договора. По нашему мнению, обязательно в содержании договора необходимо прописывать конкретные неустойки в письменной форме, и размер законной неустойки может быть увеличен соглашением сторон.

При определении и регулировании ответственности за нарушение договора, должно на рыночную систему учитывать основное содержание договора и основные обязанности, которые две стороны должны соблюдать.

Гражданско-правовая ответственность за нарушение договора по законодательству Китая и России исследована не достаточно. Большинство китайско-российских фирм при исполнении договорных обязательств руководствуются только заключенным договором, а не законодательством обеих стран об ответственности. Поэтому так важно изучение темы диссертации для развития китайско-российского партнерства. В соответствии со ст. 107 Закона о договорах КНР, в случае неисполнения договорных обязательств одной из сторон или исполнения их не в соответствии с условиями договора эта сторона обязана продолжить исполнение; на нее также возлагается ответственность за нарушение договора в форме восстановления положения, возмещения убытков и т. д.

\section{Литература}

1. Ф3 от 8 марта 2015 г. № 42-Ф3 «О внесении изменений в часть первую Гражданского кодекса Российской Федерации» // Правовая информационная система КонсультантПлюс. Дата сохранения: 15 мая 2015 г.

2. ЗАКОН О ДОГОВОРАХ от 1 июня 2014 г. «О ДОГОВОРАХ» // Правовая информационная система китайские права. Дата сохранения: 1 июня 2014г.

3. Покровский И. А. Основные проблемы гражданского права. М.: Статут, 2004. 786 с.

\section{Сравнительно-правовое исследование права собственности на недвижимость в зарубежных странах на примере Монголии и Южной Кореи}

(C) Е. П. Трофимова

магистрант 1 года обучения Института экономики и права ФГБОУ ВО «Восточно-Сибирский государственный университет технологий и управления»

Россия, г. Улан-Удэ

President_an@mail.ru

Право собственности - важный аспект в регулировании отношений субъектов права. В рамках данного вопроса, особое значение всегда уделялось и уделяется правам собственности на недвижимое имущество. Это не 
случайно, поскольку к данному виду относятся наиболее ценные и значимые для граждан и юридических лиц объекты. Согласно одному из общепризнанных определений, право собственности - это совокупность юридических норм, закрепляющих и охраняющих принадлежность объектов определенным лицам, которая предоставляет права на имущество.

Данная работа касается особенностей оформления прав собственности на недвижимое имущество в странах Азии, а именно в Монголии и Южной Корее.

В Монголии, в силу особенностей географического положения и экономического уклада, всегда придавалось большое значение земельному праву. Эта отрасль занимает одно из важнейших мест в правовой системе государства и в настоящее время. В основном законе государства - Конституции Монголии, земле и правам на нее посвящена отдельная статья.

Земельное право в этой стране уходит своими корнями к древним обычаям. В Законе Чингисхана Великая Яса (первый письменный источник права Монголии) было указано, что земли, предназначенные для скотоводства, охраняются законом, и предусматривалось суровое наказание за осквернение пастбищных земель. Долгое время не было понятия частной собственности на землю, не шло речи и о ее приватизации [6, с.42]. В соответствии с законом Халх Журам (1709 г.) первый, кто привел свой скот на определенную землю, имел право пользоваться данной землей [3, с.23].

Конституция Монголии, принятая 13.01.1992 г., ввела и разграничила понятия частной и государственной собственности на землю, ее недра, леса, воды и другие богатства природы. А также акцентировала внимание на одной особенности, а именно определила, что земля, за исключением пастбищ, земельных наделов общественного и специального государственного пользования, может быть передана в частную собственность только гражданам Монголии. Передача земли во временное пользование другим лицам без разрешения соответствующих органов государственной власти запрещена. Государство вправе накладывать на собственников земли определенные обязательства, исходя из особых интересов государства, обменять землю собственника или изъять ее вновь в собственность государства с соответствующей компенсацией $[1, \mathrm{c.14}]$.

В то же время каждый гражданин Монголии имеет право честно приобретать, владеть, распоряжаться и передавать по наследству движимое и недвижимое имущество [1, с.18]. Статья 6 Конституции запрещает незаконную конфискацию и отчуждение частной собственности. Если государство, его правомочные органы, исходя из насущных потребностей общества, произвели отчуждение имущества, то собственнику выплачивается ее стоимость и компенсация.

Согласно норм земельного законодательства, граждане Монголии имеют право приобрести в собственность землю несколькими способами:

- в соответствии с Законом "О земле" приобрести в собственность участок земли можно бесплатно один раз для семейного предназначения или же купить ее с аукциона $[9$, с.6][8, с.20];

- в соответствии с нормами Закона "О государственной и местной собственности" собственники построенных за счет собственных средств и приватизированных зданий, владеющие землей на праве аренды, могут по договору купли-продажи приобрести земельный участок.

В последние годы, в результате внесения изменений в действующее законодательство, в Монголии право частной собственности становится доступным для домовладельцев и инвесторов. Важным моментом в этом является то, что право на приобретение объектов теперь имеют не только граждане Монголии, но и иностранцы $[7$, c.45]. Это право коснулось также и долгосрочной аренды. Правовые основы рыночной экономики заложил принятый в 2002 году Гражданский кодекс, которым регламентированы: свобода договора; равноправие всех участников на рынке; неприкосновенность частной собственности; свобода предпринимательства; ответственность государственных органов и органов самоуправления за причинение вреда частным интересам. Все эти изменения привели к тому, что к началу XXI века Монголия преодолела системный кризис и вступила в фазу модернизации своего народного хозяйства, и, несмотря на малочисленное население (2,8 млн. чел.), сегодня Монголия представляет большой интерес для иностранных инвесторов как страна, обладающая большой территорией и высокой концентрацией различных полезных ископаемых.

В Монголии существует недостаток качественной недвижимости, особенно жилой, что может сделать её непривлекательной для некоторых категорий иностранных инвесторов, но учитывая богатые запасы полезных ископаемых (золото, уголь, медь) интерес у иностранных компаний существует. Налоги на недвижимость в Монголии низкие, качество её обслуживания тоже. Учитывая изложенное довольно просто прийти к выводу, что законодательная система Монголии находится на начальной стадии развития. Еще одним минусом является то, что плюсом к этому, переход прав собственности на недвижимое имущество особенно не урегулирован и имеет массу пробелов, подтверждением того является, что даже основной документ государства - Конституция, содержит нормы, говорящие лишь о правах на землю.

Остановимся подробнее на процедуре оформления прав. Гражданин, желающий приобрести право собственности на землю, обязан: подать заявление об этом префекту территории, на которой расположен земельный участок; предъявить кадастровый план на объект, который желает приобрести и план, обозначающий границы соответствующей земли; получить документ государственного контрольного органа о состоянии земли, ее качестве. Префект, обладающий соответствующей компетенцией на основании заявления гражданина, желающего приобрести право собственности на землю, после определения, вправе ли данное лицо приобрести в собственность землю, выносит решение о приватизации данной земли соответствующим гражданином. На основании решения орган государственной регистрации выдает гражданину свидетельство о том, что указанный гра- 
жданин является собственником данной земли. Свидетельство является основанием возникновения у гражданина права собственности на землю и его гарантом. Право иметь в своем распоряжении землю в соответствии с предназначением, условиями, указанными в договоре, называется правом владения на землю. Оформление покупки недвижимости независимо на первичном или вторичном рынке оформляется договором, который составляется нотариусом и подписывается в регистрационном офисе [2, с.85]. Это относительно простой процесс, который завершает передачу прав собственности.

В сравнении с вышеизложенным, рассмотрим процедуру оформления прав собственности на недвижимое имущество в Южной Корее. Одним из фундаментальных законов, наряду с Гражданским кодексом Республики и Уголовным правом в этой стране является Конституция Южной Кореи, пересмотренная 29 октября 1987 г. Данный закон, в отличие от Конституции Монголии, не уделяет пристального внимания правам на недвижимое имущество, его нормы больше направлены на устройство государства и власти. В плане определения и оформления прав на недвижимое имущество больше интересует Гражданский кодекс Республики Корея (Южная Корея), который был принят в 1958 как Закон № 471 и вступил в силу с 1 января 1960 г. [5, с.44]. Часть 2 этого нормативного акта посвящена праву собственности. Стоит отметить, что в перечень вещных прав включены: собственность, владение, сервитут, преимущественное право покупки, залог, ипотека.

Право Южной Кореи в отличие от Монголии не столь консервативно в отношении недвижимого имущества, в нем урегулировано право собственности (собственническое право), его ограничение, приобретение, совладение, залог, передача в аренду [4, с.51]. Учитывая тот факт, что положение экономики Южной Кореи отличается своей стабильностью и надежностью, уровень жизни людей высокий, отличная экология, которая привлекает туристов - вложение средств в недвижимость является перспективным, в связи с чем цены на недвижимость в Южной Корее постоянно растут. Большое влияние на развитие рынка недвижимости оказывает периодическое снижение налогов на передачу права собственности и покупку недвижимости, корректировка действующего законодательства с целью оживить рынок недвижимого имущества страны, привлечь иностранные инвестиции.

Процедура покупки недвижимости на территории Южной Кореи также достаточно проста, как и в Монголии. Для покупки недвижимости необходимо открыть счет в корейском банке. После предъявления продавцом или агентством недвижимости документов, подтверждающих право собственности на квартиру подписать договор, при подписании договора заплатить продавцу аванс, подтверждающий серьезность намерений покупки, который не возвращается. Последним этапом является окончательный расчёт и оформление в собственность. Переоформление и регистрация квартиры на имя покупателя производится в Земельном Департаменте Республики Корея. Покупатель получает Свидетельство о праве собственности и паспорт владения («домовая книга»).

Изложенный материал позволяет сделать вывод о том, что в Монголии в ближайшие годы будет активно происходить процесс приватизации земли, в связи с чем перед законодательными и исполнительными органами страны встанет непростая задача, связанная с созданием системной правовой базы, регулирующей правоотношения в сфере недвижимости. Южная Корея избежит этого процесса, поскольку юридических преград для оформления перехода права собственности, в том числе и иностранным гражданам там не существует. Следует отметить, что система регистрации сделок в обоих странах имеет недостатки, по крайней мере один из них прослеживается четко. Государственная система регистрации документов не гарантирует законность права на недвижимость лицу, к которому оно переходит. Это минус, поскольку документ, подтверждающий переход права собственности не подтверждает наличия у субъекта сделки права на такую передачу. Нормативной базы, обязывающей регистрирующие органы проводить расследование законности сделки нет. Это говорит о том, что система регистрации документов обеспечивает только приоритет зарегистрированных документов перед незарегистрированными. Объектом регистрации в рассматриваемом случае являются права. При неоднократном заключении сделки с недвижимым имуществом, а также при наличии нескольких участников с каждой стороны определить законность права на объект становится все сложнее. Но это не является недостатком систем только двух рассматриваемых стран, такая проблема возникает у всех титульных систем, которые также приняты в Германии, Австрии, Швейцарии, России, Украине и многих других странах.

Согласно Мирового Атласа Данных индекс соблюдения прав собственности в Южной Корее при наибольшей оценке в 6 баллов по состоянию на 2015 год составил 5,9 балла, если говорить об этом показателе для Монголии, то данные о нем не предоставлены, но есть все основания полагать что он значительно ниже, в виду малой развитости законодательной базы в этом направлении.

Вывод: Таким образом, по результатам проведенного анализа процедур государственной регистрации прав на недвижимое имущество в Монголии и Южной Корее можно установить следующие общие признаки: каждый человек в стране, согласно законодательству, может реализовать свое право на землю, система государственной регистрации базируется на руководящих принципах (обязательность, достоверность, публичность), главный принцип системы - без регистрации нет права. Отличиями являются: в Южной Кореи создана системная правовая база, в Монголии правовая база, регулирующая правоотношения в сфере недвижимости, находится в стадии становления и регулирует в основном отношения, касающихся прав собственности на земельные участки.

\section{Литература}

1. Конституция Монголии, принята 13.01.1992 г., ст. 5, 6.

2. Гражданский кодекс Монголии 1994 г. С. 432.

3. Акимушкин Р. В. Безопасность бизнеса. 2006. N 2.

4. Конституция Южной Кореи (Республика Корея), провозглашена 17 июля 1948, пересмотрена 29 октября 1987. 
5. Гражданский кодекс Республики Корея (Южная Корея), принят в 1958 как Закон № 471 глава 2.

6. Нарангэрэл С. Правовая система Монголии. Улан-Батор; М., 2004. С. 105.

7. Акимушкин Р. Особенности гражданского права Монголии. М., 2005.

8. Закон о Земле Монголии. 2002.

9. Закон о приватизации земли монгольскими гражданами. 2004.

\section{Сравнительно-правовой анализ между Россией и Китаем: примерные условия в договоре купли-продажи}

(C) Фань Цзинчжао

магистрант 1 курса юридической школь Дальневосточного федерального Университета

России, г. Владивосток

В соответствии с гражданским законодательством РФ в договоре может быть предусмотрено, что его отдельные условия определяются примерными условиями (approximate terms of contract), разработанными для договоров соответствующего вида и опубликованными в печати (ст. 427 ГК РФ). В случаях, когда в договоре не содержится отсылка к примерным условиям договора, такие условия применяются к отношениям сторон в качестве обычаев делового оборота, если они отвечают требованиям, установленным ст. 5 и п. 5 ст. 421 ГК РФ. Примерные условия договора могут быть изложены в форме примерного договора или иного документа, содержащего эти условия [1, с. 111;2] .

Применение примерных условий договоров имеет несколько недостатков:

1. С точки зрения формата такое применение ставит стороны в неравное положение. Создание подобных условий ставит одних людей в доминирующее положение, наделяет их монопольными правами. В табачной, газовой и нефтяной промышленности это явление становится особенно очевидным.

2. У сторон отсутствуют консультации. Стороны консультируются, чтобы увидеть договор и только выбрать решение. При этом, обе стороны не адекватно проводят консультации при заключении договора.

3. Договор между сторонами не является полностью добровольным, все дело в различном статусе двух сторон. Даже если обе стороны официально подписали контракт добровольно, при этом на самом деле это не является добровольным.

4. Ущемляются интересы потерпевшей стороны. Примерные условия, как правило, включают в себя: снятие с себя ответственности, например, за продажу онлайн, после согласия продавца продать товар, последний не может быть возвращен полностью; отказ показать партии.

Статьея 427 ГК РФ:

1. Примерные условия облегчают заключение и исполнение договоров и получают в рыночной экономике широкое распространение. Обычно они разрабатываются предпринимательскими объединениями и могут согласовываться с основными потребителями и их ассоциациями. Особое распространение примерные условия получили в сфере внешней торговли.

2. Примерные условия, как это следует из п.3 статьи, могут иметь разную форму (общие условия договора, текст договора, руководство к заключению договора и т.д.) и различное наименование (примерный или типовой договор, проформа договора и т.д.). Практикуется также разработка отдельных примерных условий, например, о скользящей цене, арбитражном разбирательстве споров.

3. Согласно п.1 примерные условия не являются для сторон обязательными; они становятся таковыми при наличии отсылки к ним в договоре. Утверждаемые Правительством РФ и федеральными органами типовые и примерные договоры (на поставку газа, аренду отдельных видов имуществ и др.) являются нормативными актами и под действие правил ст.427 не подпадают [3].

4. Примерные договоры отражают положительный опыт предпринимательской деятельности и могут быть признаны обычаем делового оборота, если они отвечают признакам, названным в ст. 5 ГК. Сам по себе факт публикации текста примерного договора в печати (такие публикации в Российской Федерации распространены) не дает основание считать такой опубликованный примерный договор обычаем. Его качество обычая должно быть заинтересованной в том стороной доказано.

В Китае «договорное право» регламентируется статьей 39, положениями об обязательствах, которая гласит, что при заключении договора с использованием примерных условий сторона, предлагающая примерные условия, обязана определять права и обязанности сторон, следуя принципу справедливости, а также обязана разумным образом попросить другую сторону обратить внимание на условия, которые исключают или ограничивают ответственность предлагающей стороны; по требованию другой стороны должны быть даны разъяснения относительно этих условий.

Примерными условиями признаются условия, которые заранее разрабатываются для неоднократного применения и которые не обсуждаются с другой стороной при заключении договора [4, с. 35].

Условия формата «палка о двух концах», примерные долгосрочные преимущества, есть и недостатки. Статья 40. Недействительны примерные условия, подпадающие под действие норм статей 52 и 53 настоящего Закона либо предлагаемые с целью исключения ответственности одной стороны, увеличения ответственности другой стороны, лишения ее важных прав. Для того, чтобы поддерживать «принцип добросовестности» и 
«справедливости» гражданского права, при разработке примерных условий должны выполняться следующие обязательства:

1. справедливость прав и обязанностей обеих сторон. Разработка примерных положений партии, как правило, имеет более высокое положение, они используют свои собственные преимущества контракта. На практике другим общепринятым правилам не сопротивлялся. Это состояние противоречит основным принципам гражданского права. По закону другая сторона может быть основана на «договорном праве», подаче в народный суд или арбитражный орган договора для рассмотрения.

2. Напоминание обязательств друг к другу. Статья 4. В гражданской деятельности необходимо следовать принципам добровольности, справедливости, эквивалентной компенсации, искреннего доверия. Примерные условия, термины обычно развиваются в пользу своих собственных условий. Многие отказываются от ответственности в контракте. Отказ от ответственности в форме контракта является распространенным явлением. Таким образом, при разработке контракта сторона обязана предупредить другую информацию об изменения. Они должны быть четкими и разумным, чтобы напомнить о ней другой стороне. Если контракт на разработку партии не выполнили это обязательство, то другая сторона имеет право подать в суд.

3. Объяснение обязательств. Как правило, разработкой примерных условий занимается одна крупная организация, у которой для этого есть профессиональный персонал. Примерные условия часто сложны, хай-тек и высокое качество очень трудно для понимания обычных людей. Таким образом, при разработке примерных условий необходимо объяснить условия. Если сторона не понимает договора и подписывать контракты, эффективность данного контракта является спорной.

4. Принцип не приносит никакой пользы. Если возникает спор, суды при толковании договора не способствуют использованию пояснений производители. Человек должен разработать примерные условия про выгодное положение, правовую защиту прав обычных граждан.

В Китае статья 41. При возникновении спора, связанного с толкованием примерных условий, их надлежит толковать в соответствии с обычным пониманием. В случае наличия двух или более пониманий примерных условий надлежит принимать во внимание понимание той стороны, которая не была заинтересована в предложении примерных условий. Если примерные и непримерные условия не совпадают, применению подлежат непримерные условия [5]. Толкование примерных условий происходит в соответствии со следующими принципами:

1. Примерные условия должны быть интерпретированы в соответствии с обычным способом мышления. Когда смысл с точки зрения формата является очень сложным, интерпретация происходит в соответствии с пониманием общественности.

2. Примерные условия толкуются в пользу другой стороны. Техническое обслуживание «справедливости» гражданского права, защита законных прав граждан.

3. примерные условия и непримерные условия, когда возникает конфликт, в соответствии с непримерными условиями для объяснения. В договоре есть примерные условия и непримерные условия, непримерные условия очень важны, поскольку при возникновении конфликтов используются непримерные условия.

Относительно высокая частота использования формы договора с универсальной ценностью легко может привести к спорам и злоупотреблению служебным положением и законом. Только в ходе договора, заключенного в соответствии с законом, справедливое и разумное использование стандартных условий может быть достигнуто по формату договора с целью, чтобы защитить интересы контракта, с целью повышения эффективности контракта, в целях обеспечения безопасности сделок, успешной реализации экономических интересов обеих сторон.

\title{
Литература
}

1. Волгин, В. В. Продавец запасных частей [Электронный ресурс] : учебник. 4-е изд. М.: Дашков и К을. 2013. С. 111.

2. Шешко Г. Ф. Договоры жилищного найма: обязанности нанимателя, ответственность // Жилищное право. 2009 . № 8.

3. Рожкова М. А. Юридические факты в гражданском праве // Хозяйство и право. 2006. № 7.

4. Джан Цзянзун. Правовое регулирование примерного договора, Пекин, Китайский Политико-правовой университет, 2014, С. 35.

5. Ван Циян. Правовое регулирование примерного положении // Цзилинь университета, 2007.

\section{Правовое регулирование труда несовершеннолетних по законодательству КНР}

\author{
(С) А. Г. Хабеева \\ студентка 4-го курса юридического факультета \\ ФГБОУ ВО «Бурятский госуниверситет» \\ Россия, г. Улан-Удэ \\ Anna_Habeeva@mail.ru
}

Дети, не достигшие совершеннолетнего возраста, как правило, испытывают сложности, работая в обычных для взрослых условиях труда, им зачастую не обеспечиваются обязательные социальные гарантии, они работают сверх нормативного времени, низкая заработная плата, плохие санитарно-эпидемиологические условия труда, что оказывает большое влияние на жизнь и развитие детей. Несовершеннолетние граждане до сих пор являются социально не защищенной группой, нуждающейся в особом внимании и помощи. Наша страна для защиты детского труда должна контролировать все звенья от предприятий работодателей, центров занятости, 
служб опеки и попечительства, несовершеннолетних работников, вплоть до надзорных органов, все они становятся ответственными лицами по искоренению детского труда.

Некоторые законодательные акты КНР запрещают использование детского труда. Конституцией КНР закреплено право детей на образование, Закон КНР «Об обязательном образовании»[1] гласит, что все дети соответствующего возраста должны получить обязательное образование. Закон КНР «О защите прав несовершеннолетних граждан»[2] четко устанавливает право на образование, право на жизнь и развитие, право на защиту и участие в делах государства и другие права. Государство уделяет особое внимание духовному и физическому развитию и, прежде всего, защищает и гарантирует законные права несовершеннолетних граждан.

Законодательство КНР в вопросе использования детского труда устанавливает следующие запретные нормы: глава 2 статья 15 Закона КНР «О труде»[3] гласит, что работодателям запрещено использовать труд несовершеннолетних, не достигших 16 лет. Глава 4 статья 38 Закона КНР «О защите несовершеннолетних» устанавливает запрет организациям или частным лицам использовать труд граждан, не достигших 16 лет, кроме случаев, регламентированных государством. Указанный нормативно-правовой акт запрещает использование труда несовершеннолетних на работах, связанных с чрезмерными физическими нагрузками и напряженным ритмом трудовой деятельности. В общем, использование детского труда связано с некоторыми обстоятельствами, а именно: с использованием труда несовершеннолетних, не достигших 16 летнего возраста, в различных формах трудовой деятельности на производственных предприятиях, с начислениями и оплатой, а также с изменениями в начислении и оплате трудового вознаграждения; с вопросами трудоустройства на производственных предприятиях, ограниченных в средствах на учебу несовершеннолетних, не достигших 16 лет, с вопросами связанными с практикой, педагогической практикой, профессиональной квалификацией не достигших 16 летнего возраста, а так же с вопросами, связанными с влиянием трудовой деятельности несовершеннолетних на их физическое и психологическое здоровье и безопасность из-за избыточных нагрузок в учебной деятельности.

Исключением является использование труда несовершеннолетних, не достигших 16 лет, с разрешения их родителей или опекунов в культурных, спортивных учреждениях для участия в соответствующих возрасту мероприятиях, не влияющих на их физическую и психологическую безопасность и здоровье. Несовершеннолетние могут в меру своих сил и возможностей заниматься вспомогательным трудом, не угрожающим их физической и психологической безопасности, школы, учреждения профессионального обучения и другие учреждения образования на основании установленных государством правил организуют обучение и практику несовершеннолетних. Соответствующие ведомства утверждают специалистов, обладающих определенным социальным статусом набирать несовершеннолетних обучению наукам и искусству. В данном случае учреждения, организации и частные лица должны гарантировать право несовершеннолетних граждан на обязательное образование.

Правовая защита труда несовершеннолетних.

Касательно несовершеннолетних, обучающихся в школе и не достигших 18 летнего возраста, не включая несовершеннолетних, не достигших 16 лет, в статье 309 Закона КНР о «Точка зрения Министерства труда КНР о проблемах последовательного исполнения трудового закона КНР»[10] установило не рассматривать как занятость работу учащихся в свободное от учебы время, а так же полагает, что подобный подход не соответствует правовым нормам трудового законодательства и ущемляет законные права и интересы тех, кто совмещает учебу с трудовой деятельностью, и считает необходимым использование других норм. Например, в случае получения травмы на рабочем месте учащийся не может воспользоваться «страхованием от производственного травматизма», однако может обратиться в Верховный Суд с требованием возмещения причиненного ущерба.

Общие положения правовой защиты труда несовершеннолетних.

Отличительные особенности частного (особого) и общего законодательства об охране труда. Общее законодательство об охране труда применяется в отношении совершеннолетних граждан, действующий в настоящее время Закон по регулированию трудовых отношений и праве на трудовую деятельность был принят ВСНП в 1995 году, в 2008 году принят Закон о трудовых договорах (отношениях) [4]. Эти два закона затрагивают вопросы рабочего времени и времени отдыха, страховой выгоды, безопасности и гигиены труда, профессиональной подготовки, заключения и исполнения трудового договора, оплаты труда, а также материальной компенсации после прекращения трудовых отношений. В случае возникновения вопросов и споров несовершеннолетнего с нанимателем, последний может обратиться с ходатайством в арбитражный (третейский) суд.

Частные положения правовой защиты труда несовершеннолетних.

Эти положения предусматривают нормативные акты, применяемые в особых случаях. Необходимо уделить особое внимание охране труда несовершеннолетних граждан в направлении охраны безопасности здоровья, помимо улучшения условий труда, необходимо обеспечить особую охрану рабочего времени и рабочего места несовершеннолетнего работника, несомненно, что охрана труда несовершеннолетнего является охраной производительных сил страны. Например, глава 7 статья 58 Закона КНР «О труде» «Об особой охране труда работниц женщин и несовершеннолетних граждан».

Глава 7 статья 64 Закона КНР «О труде» гласит: «запрещается использовать труд несовершеннолетних граждан на рудниках, в шахтах, на производствах, связанных с вредными и токсичными веществами, на производствах, определенных государством как труд 4 категории сложности и других запрещенных производствах». В главе 7 статья 65 Закона КНР «О труде» говорится, что «наниматель обязан регулярно проводить обследование здоровья несовершеннолетних работников» и т.д. Вместе с этим в 1995 году министерство труда реализовало «Особые нормы охраны труда несовершеннолетних граждан»[5] и ограничило сферы деятельности, в которых 
разрешено использование труда несовершеннолетних. Конкретно определило трудоемкость работы и время медицинского осмотра работников.

Наказания, предусмотренные в случае нарушения закона об охране труда.

Законодательством КНР четко определены меры надзора за исполнением соответствующими административными органами трудового и социального обеспечения закона об охране труда несовершеннолетних и запрете на использование труда детей. Работодатели, нарушившие запрет на использование труда детей, подвергаются штрафу. Работодатели, не санкционировано использующие труд детей, подвергаются административному наказанию, штрафу, а также могут подвергаться уголовному наказанию, основанием для которого является Закон КНР «О запрете использования труда детей»[6]. Работодатель, использующий труд детей, облагается департаментом охраны труда ежемесячным штрафом в размере 5000 юаней за каждого ребенка. Работодатели, использующие труд детей на производствах с использованием вредных и токсичных веществ, облагаются штрафам в размере, предусмотренном Законом КНР «Об охране труда на производствах с использованием вредных и токсичных веществ», либо штрафом в размере 5000 юаней за каждого ребенка или более строгим наказанием. Вместе с тем, административные органы по охране труда вменяют в обязанность работодателям возвращать детей домой родителям или опекунам в сроки, установленные данными органами, возмещение транспортных расходов также ложиться на работодателя. В случае, если работодатель является государственным, бюджетным учреждением, то в соответствии с законом непосредственный руководитель данного учреждения или предприятия, или другие ответственные лица подвергаются наказаниям в виде снятия с должности, понижения в должности либо дисциплинарному взысканию. Помимо административных штрафов работодателю необходимо в будущем также подвергать штрафу в размере 5000 юаней за каждого несовершеннолетнего, не достигшего возраста 16 лет, посреднические организации и частные лица, оказывающие посреднические услуги при найме на работу. В случае, если подобные посреднические организации устроили на работу несовершеннолетнего, не достигшего 16 лет, то департамент охраны труда имеет право аннулировать их лицензии на деятельность. В случае, если несовершеннолетний заболел или получил травму, работодатель оплачивает все расходы, связанные с лечением и госпитализацией несовершеннолетнего. В случае, если несовершеннолетний получил производственную травму или умер, работодатель обязан выплатить единоразовую компенсацию потерпевшему или родственникам умершего. Размер компенсации вычисляется соответственно государственному страхованию от производственного травматизма.

Уголовной ответственности подвергаются работодатели в случае если использовали труд несовершеннолетнего на высотных, подземных работах, радиоактивных, вредных и токсичных производствах, с легковоспламеняющимися веществами, а также на производствах 4 категории интенсивности при использовании труда несовершеннолетних, не достигших 14 лет. Уголовную ответственность несет работодатель в случае, если он допустил смерть или тяжелое ранение несовершеннолетнего, похитил и принудил к труду.

Наказания, предусмотренные за нарушение закона об охране труда несовершеннолетних.

Наказание, налагаемое за несанкционированное использование труда детей, основывается на Законе КНР «О запрете использования труда детей». Для сравнения, подобные наказания не столь обобщены и встречаются в различных нормативных актах закона о труде, в основном имеют следующее содержание. Закон КНР «О труде» гласит: «В случае неправомерного использования труда несовершеннолетнего, не достигшего 16 летнего возраста, административные органы налагают на работодателя взыскание и обязуются исправить положение, налагают штрафные санкции, при наличии отягчающих обстоятельств, органы промышленно-торговой администрации аннулируют лицензию». Кроме того, Закон КНР «О труде» также устанавливает в обязательном порядке компенсацию за вред и ущерб нанесенный несовершеннолетнему со стороны работодателя.

В Законе КНР «О защите труда несовершеннолетних»[7] говорится, в случае несанкционированного использования труда несовершеннолетних, не достигших 16 лет, либо уже достигших 16 лет на производствах с чрезмерными нагрузками, с вредными и ядовитыми веществами, на производствах наносящих, физический и психический вред либо опасных, связанных с риском производствах, органы охраны труда поручают работодателю исправить положение, налагают штрафные санкции, при отягчающих обстоятельствах аннулируется лицензия на деятельность.

Статья 423 Указа Госсовета КНР «Правила надзора за охраной труда» [8] определяет налагаемые на работодателя департаментом труда штрафные санкции в размере от 1000 до 5000 юаней в зависимости от тяжести причиненного ущерба в случае использования труда несовершеннолетних на рудниках, шахтах, вредных и токсичных производствах и других производствах 4 категории интенсивности. Административно-штрафные санкции, налагаемые в случае нарушения Закона КНР «О труде», в статье за номером 532 [9] говорится, что работодатель выплачивает штраф в размере 3000 юаней и ниже каждому несовершеннолетнему, труд которого был использован на рудниках и шахтах, на вредных и токсичных производствах, на производствах 4 категории интенсивности. В случае, если работодатель не провел медицинское обследование работника в установленные сроки, он обязан в указанный срок исправить положение. Если же он не уложился в указанный срок, то обязан выплатить компенсацию в размере 1000 юаней и ниже.

Совершенствование системы охраны труда несовершеннолетних.

Следует признать, что КНР создала достаточно совершенную систему охраны труда несовершеннолетних граждан, правительство также задействует все меры по борьбе с явлениями несанкционированным использованием труда детей и несовершеннолетних граждан страны. Однако, по-прежнему, остаются проблемы, требующие внимания и решения. 
Последовательное ужесточение административного контроля.

По мере непрерывного развития рыночной экономики появилось большое количество частных предприятий, владельцы которых в погоне за прибылью пытаются снизить производственные затраты путем найма несовершеннолетних, помимо этого некоторые предприятия допускают халатное отношение к найму персонала, контролю за соблюдением порядка, что создает условия, благоприятствующие появлению нарушений законодательства. Часто возникает ситуация, когда сотрудники административных органов не могут своевременно обнаружить и пресечь возникающие нарушения, а начинают действовать только после того, как возникают трудовые споры либо поступают жалобы от работников. Подобная ситуация в большей степени попустительствует нарушениям закона, поэтому с одной стороны возникает насущная необходимость более тщательного отбора сотрудников на всех уровнях, во всех отделах министерства труда и социального обеспечения, с другой стороны министерство труда и социального развития должно организовать более скоординированное взаимодействие со всеми органами правительства и организациями в деле охраны труда несовершеннолетних и запрете на использование труда детей. Кроме этого административные органы на местах обязаны усилить контроль, проводить постоянные проверки и инспекции для искоренения нарушений работодателями своих должностных полномочий.

Создание соответствующей судебной системы охраны труда несовершеннолетних.

Прежде всего, необходимо создать отвечающую требования процессуальную систему. В отличие от совершеннолетних граждан, несовершеннолетние ограничены в судебной защите своих права и интересов. В судебных тяжбах с участием несовершеннолетних существует определенный порядок защиты прав несовершеннолетних, например, система внесудебного разбирательства спорных вопросов, система присяжных заседателей и т.д. Вместе с тем, в гражданском процессе с участием несовершеннолетних в основном применяются судебные положения, используемые в делах совершеннолетних граждан страны, поэтому особенно важным является создание специальной судебной системы для несовершеннолетних граждан. К примеру, достаточно слабая доказательственная база, ограниченные финансовые возможности при найме адвоката, отсутствие у некоторых несовершеннолетних опекуна или представителя на судебном заседании и другие вопросы, требующие своего решения.

Усиление пропаганды законности и порядка.

Следует распространять и пропагандировать законы «О защите труда несовершеннолетних», «О запрете использования труда детей» и другие законодательные акты. Объектом пропаганды должны становиться не только работодатели и несовершеннолетние граждане, но также учителя, родители и опекуны несовершеннолетних. Необходимо позволить им до конца уяснить всю пагубность найма и использования труда несовершеннолетних, призывать придерживаться законодательных и нормативных актов, стать силой, способной противостоять незаконным действиям и содействовать административным органом надзора и контроля.

\section{Литература}

1. Закон КНР «Об обязательном образовании» от 1 июля 1986 г.

2. Закон КНР «О защите несовершеннолетних» от 4 сентября 1991 г.

3. Закон КНР «О труде» от 5 июля 1994 г.

4. Приказ Президента КНР № 65 о вступлении в законную силу Закона о трудовом договоре КНР. Принят 29 июня 2007 г. На 28-й сессии ПК ВСНП 10-ого созыва с 1 января 2008 г.

5. Закон КНР «Особые нормы охраны труда несовершеннолетних граждан» от 1 января 1995 г.

6. Закон КНР «О запрете использования труда детей» от 1 декабря 2002 г

7. Закон КНР «О защите труда несовершеннолетних» от 1 января 1992 г.

8. Указ Госсовета КНР статья 423 «Правила надзора за охраной труда» от 1 декабря 2004 г.

9. Закон КНР статья 532 «Административно-штрафные санкции, налагаемые в случае нарушения Закона КНР «О труде» от 1 января 1995 г.

10. Закон КНР «Точка зрения Министерства труда КНР о проблемах последовательного исполнения трудового закона КНР» от 4 августа 1995 г.

11. Цао Ян Фэй. Юридический анализ о защите интересов труда несовершеннолетних // Вестник Чунцинского научнотехнического института. 2009. №9.

12. Ян ДунСя. Об особой охране труда несовершеннолетних // Вестник Института трудовых отношений КНР. 2007. № 4.

13. Ху ЧжиСин, Чэн Ли Лин. Анализ вопросов о защите прав труда несовершеннолетних // Вестник Юлинского педагогического института. 2004. № 6.

14. Режим доступа: www.xinhuanet.com

15. Режим доступа: www.people.com.cn

16. Режим доступа: www.gov.cn

\section{Имущество должника в рамках исполнительного производства России, США, Китая и Японии}

() В. С. Цыденова

студентка 4-го курса юридического факультета ФГБОУ ВО «Бурятский госуниверситет»

Россия, г. Улан-Удэ

«Каждому гарантируется судебная защита его прав и свобод», - объявляет статья 46 Конституции России, которая провозглашает возможность обращения в суд и предоставляет определенные гарантии эффективного 
восстановления нарушенных прав посредством правосудия, которое считается свершенным только тогда, когда вынесенный судебный акт исполнен. Соответственно из права на судебную защиту вытекает право на исполнение судебного решения. Нарушенное право считается не восстановленным, если не исполняется судебное решение, поэтому целью исполнительного производства является реальное восстановление взыскателя в правах.

Одной из основных мер принудительного исполнения является обращение взыскания на имущество должника путем поиска, наложения ареста на имущество и его реализации. В этой связи российская практика встречается с различными проблемами, ликвидация которых требует всесторонних путей решения, дальнейшего развития принудительных и стимулирующих мер, направленных на добровольное исполнение судебных решений, учитывая положительный опыт зарубежных стран.

Анализ законодательства зарубежных стран свидетельствует о проблеме поиска эффективных средств исполнения судебных решений, касающихся взыскания имущества с должника и зарубежный опыт в этой сфере крайне интересен.

В российской юридической литературе предлагается ввести институт декларирования должником своего имущественного положения, наделив судебного пристава-исполнителя полномочиями по получению от должника исполнительной декларации либо с обращением в суд. Данный институт с большим успехом пользуется в исполнительном производстве зарубежных стран, в частности США [3, с. 15].

Однако институт исполнительной декларации эффективен лишь при установлении уголовной ответственности за непредставление такой декларации или включение в нее заведомо ложных сведений. Подобное правовое регулирование будет носить характер общей превенции и сможет решить актуальную проблему сокрытия должником своего имущества, а также существенно сократить время, затраченное на поиск имущества, исключения объявления его в розыск и в целом на сокращение сроков исполнительного производства, но и стимулировало бы должника к добровольному исполнению возложенных на него обязанностей судом.

В США органом по принудительному исполнению судебных актов является Федеральная служба маршалов. Также этим занимается Федеральная сводная бригада по исполнению судебных решений, которая проводит расследования для обнаружения имущества должника, после чего сведения передаются прокурору США. Если же должник намерено скрывал свое имущество или предоставлял ложные сведения своего имущественного положения, против него может быть начато уголовное преследование и к делу подключается ФБР [2, с. 44]. После вступления в силу решения суда у должника есть 30 дней для добровольного исполнения. Если этого не происходит, взыскатель вправе обратиться в частное детективное агентство или в суд [5, с. 69].

В ряде штатов используются такие меры принуждения как: блокирование кредитной карты должника; лишения лицензии на осуществление определенных видов деятельности (приостановление лицензии); гражданский арест. Последняя является крайней мерой и может быть применена при уклонении должника от явки в суд либо отказе раскрыть информацию о местонахождении имущества. Конкретный срок законодательством не установлен, должник может быть освобожден, когда раскроет необходимую информацию. Конечно же, такая мера может быть применена, когда имеется точная информация, что должник скрывает свое имущество либо денежные средства [2, с. 45].

Уголовный кодекс Японии 1907г предусматривает ответственность лиц, которые скрыли, разрушили или же с помощью мнимой сделки продали свое имущество, для того чтобы уклониться от принудительного взыскания. За совершения этого деяния должник лишается свободы с принудительным физическим трудом на срок до двух лет или денежным штрафом на сумму до пятисот тысяч иен [6, с. 619].

Уголовное законодательство Китая также предусматривает статью, состоящую из десяти частей, которые устанавливают различные сроки с непременной конфискацией имущества [6, с. 547].

Помимо этого в США Агентство по кредитным сведениям собирает информацию о ненадлежащих заемщиках и составляет их рейтинг. Взыскатель, предупредив должника, может обратиться в данное агентство, и должник будет занесен в список неблагонадежных заемщиков, с последующим затруднением при получении кредита, так как база является открытой и общедоступной [7, с. 8].

Анализ принудительных мер стран АТР заслуживает пристального внимания, а некоторые, например, лишения лицензии на осуществление определенных видов деятельности, может применяться в России.

После того как проведены необходимые мероприятия по розыску имущества должника с наложением ареста и установлением цены, арестованное имущество должно быть реализовано судебным приставом. Российское законодательство предусматривает два способа реализации имущества должника: комиссионная продажа и публичные торги. С помощью комиссионной продажи реализуется имущество стоимостью не менее 500000 рублей. Общий срок для реализации данного имущества составляет 30 дней. Довольно часто данная реализация имущества остается безуспешной в силу отсутствия эффективного механизма доведения информации о продаже до широкого круга лиц.

Как вид реализации имущества должника публичные торги содержат более сложную схему. Публичные торги проводятся в форме аукциона, где устанавливается начальная цена имущества должника. На аукционе реализуется имущества должника: имущество обремененное залогом, недвижимое имущество, ценные бумаги, вещи, которые имеют художественную или историческую ценность, а также имущественные права. Срок по реализации имущества должника в форме аукциона не должен превышать 60 дней [1, с. 22].

Реализацией имущества должника в США занимается Служба маршалов в форме открытого аукциона в течение 90 дней. Для этого Служба маршалов, суд и организации, содействовавшие в проведении аукциона, размещают всю необходимую информацию у себя странице в интернете и в местных СМИ. При этом срок 90 дней 
начинает длиться с момента возбуждения исполнительного производства и включает в себя розыск имущества. Российское законодательство устанавливает 2 месяца для реализации имущества и еще 2 месяца для розыска и наложения ареста на имущество должника. Соответственно общий срок мероприятий по реализации имущества должника в РФ составляет четыре месяца, при этом этот срок может быть увеличен, а по законодательству США этот срок составляет 90 дней и его нельзя нарушить[2, с. 46]. Предлагаем существенно сократить сроки по реализации имущества должника в нашей стране.

Законодательство Японии предусматривает аналогичный способ реализации имущества должника и устанавливает обязанность для судебного пристава опубликовывать информацию об аукционе в местных СМИ и на интернет сайтах, для большего привлечения покупателей. А также судебный пристав- исполнитель может сам делать предложения с помощью электронной почты либо телефонной связи и это вызывает наибольший интерес. Также пристав может до начала аукциона по реализации имущества провести запрос предложений о размере покупной стоимости имущества. Если же предложения о стоимости имущества поступают, то они обязательно учитываются на торгах [3, с. 17.].

Российская наука предлагает проводить аукцион по реализации имущества на электронной основе [1, с. 24]. Помимо этого можно было бы наделить судебного пристава правом обращаться к риелторам или иным продавцам, которые могут оперативно привлечь покупателей. При реализации имущества использовать публичные интернет - ресурсы, направлять предложения в компании занимающиеся перепродажей определенных видов товаров, например, автотранспортных средств. Все это поможет оперативно реализовать имущество должника.

Стоит отметить, что зарубежная практика стран АТР в сфере обращения взыскания на имущество должника не столь идеальна и имеет свои проблемы. Например, по исполнительному производству США широкий круг субъектов, осуществляющих функции по взысканию долгов. Их могут взыскивать как государственные органы, так и негосударственные (коллекторские службы), поэтому возникает проблема недобросовестного взыскания долгов [2, с. 47].

В Китае отсутствует специальный закон, регулирующие данные правоотношения, пока разработан проект Обязательного закона об исполнительном производстве, также отсутствует специализированная государственная служба по исполнению решений суда. Аналогичная проблема встречается в Японии, там тоже отсутствует специальный закон об исполнительном производстве [6, с. 608]. Как нам кажется, Китай и Япония могли бы восполнить данный пробел, опираясь на опыт иных стран, в том числе и Россию.

Анализ принудительной меры, как обращения взыскания на имущество должника в разных странах, позволяет сделать вывод, что российское законодательство нуждается в изменениях, в частности, сокращения сроков реализации имущества должника и изменения порядка проведения аукциона. Придать Федеральной службе судебных приставов России статуса правоохранительного органа, на примере Федеральной службы маршалов США. И наделить судебного пристава правом прослушивать телефонные переговоры должника, отслеживать контакты по сотовой связи, оперативному осмотру и контролю почтовых и иных сообщений для взыскания крупной суммы долгов и некоторых категорий дел, например, взыскание алиментов. Ввести институт исполнительной декларации имущества должника, расширить список мер принудительного исполнения, в частности, лишения лицензии на осуществление определенных видов деятельности.

Данные изменения помогут судебным приставам более эффективно вести работу по взысканию долгов всех категорий, что положительно скажется на исполнении судебных решений в целом для достижения окончательной цели правосудия[4, с. 44$]$.

\section{Литература}

1. Белянов Ю. В. Проблемы реализации арестованного имущества должника и пути их решения // Современное право. 2015. № 10. С. 21-24.

2. Медведев В. В. Сравнительный анализ систем принудительного исполнения России и Соединенных Штатов Америки // Практика исполнительного производства. 2013. № 4. С. 44-47.

3. Мирошниченко, А. А. Средства принуждения должника к исполнению судебных актов (сравнительно-правовой об3ор) // Арбитражный и гражданский процесс. 2013. № 2. С. 15-18.

4. Морозова, Л. А. Исполнение судебных решений или уважение к суду // Lex russica. 2015. N 11. C. 42-44.

5. Парфенчикова, А. А. Концепция применения мер косвенного принуждения в исполнительном производстве // Арбитражный и гражданский процесс. 2015. № 11. С. 68-71.

6. Сравнительное правоведение: национальные правовые системы. Правовые системы Азии / под ред. В. И. Лафитского. М.: ИЗиСП, КОНТРАКТ, 2013. Т. 3.704 с.

7. Чобанян, А. Г Некоторые вопросы розыска должников и их имущества в развитых зарубежных странах // Российский следователь. 2011. № 9. С. 7-9.

\section{Частная собственность на землю в России и Монголии: сравнительный анализ}

() О. Ч. Циденова магистрант 1 года обучения юридического факультета ФГБОУ ВО «Бурятский госуниверситет» Россия, г. Улан-Удэ

Земельное право в России и Монголии - одна из ключевых отраслей права, регулирующая земельные правоотношения с целью обеспечения рационального и эффективного использования земель государством и насе- 
лением. Близкое географическое положение России и Монголии, а также возможность взаимовыгодного сотрудничества между странами, обуславливает актуальность данной темы.

На ранних этапах формирования правовых систем формального различия между формами собственности не проводилось, и собственность соотносилась с непосредственным обладанием (владением) вещью - закономерно, именно римское понятие «владение» (лат. dominium) означало собственность вообще, то есть как государственную, так и частную; данные понятия, очевидно, в римском праве вообще не различались. Фактически термин «частный» (private - англ., privee - фр., privat - нем.) сформировался в середине XVI в. как характеристика экономической (хозяйственной) деятельности индивида, в отличие от деятельности публичных структур.

Первые официальные закрепления земельной собственности за физическими лицами относятся к периоду Московского княжества (XIV-XV вв.). До этого времени собственность существовала, но она ни за кем официально не закреплялась.

В период Московского государства кроме собственности вотчинника-князя, первые частные землевладения принадлежали монастырям и княжеским служилым людям - знатным боярам. В допетровской России землевладения подразделялись на несколько видов: вотчинное, дворцовое и крестьянское.

В следующие два столетия княжеские вотчины на землях были национализированы. Частная земельная собственность исчезла.

Частная собственность на землю возникает лишь во второй половине XVIII века. Значимым событием XVIII в. стал Манифест Екатерины II «О свободе промыслов», который закрепил права частной собственности не только на поверхность, но и на недра земли.

Сама же законодательная дефиниция права собственности на землю впервые была дана в ст. 262 ч. 1 т. X Свода законов Российской империи, введенного в действие с 1835 г. Право собственности на землю определялось как право «на все произведения на поверхности ее, на все, что заключается в недрах ее, на воды, в пределах ее находящиеся, и, словом, на все ее принадлежности» [7, с. 184].

В советский период развития нашего общества экономическая система СССР базировалась на принципе отрицания частной собственности. Преобладание государственной собственности фиксировали основы гражданского законодательства 1961 г., гражданские кодексы республик 1963-1964 гг. и Конституция СССР 1977 г.

Принятый 24 декабря 1990 года закон «О собственности в РСФСР» [4], вступивший в действие 1 января 1991 года, внес коренные изменения в институт права собственности. Данный закон восстанавливал частную собственность в Российской Федерации. Субъектами частной собственности являлись физические лица и юридические лица. Впервые в отдельных статьях содержалось право собственности на землю и земельные ресурсы. Таким образом, закон внес серьезные изменения в регулирование отношений собственности и создал условия перехода к рыночной экономике.

Основы гражданского законодательства СССР и союзных республик [5], принятые 31 мая 1991 г. стали первой систематизацией гражданского законодательства. Однако принятие в 1993 г. Конституции России и изменения в государственном устройстве после распада СССР, обусловили то, что законодательство РФ к середине 90-х гг. состояло из противоречивших друг другу советских и российских нормативных актов. Гражданский кодекс РФ, принятый 21 октября 1994 года [3], стал единым для всей федерации российским систематизированным гражданско-правовым нормативным актом. По сравнению с законодательством предшествующих периодов институт права собственности в данном кодексе получил наибольшее развитие.

В Монголии частная собственность на землю появляется во времена распада Монгольской империи (XIV XV вв.). До этого времени земля находилась в собственности государства в лице великого Чингисхана.

С 1691 года, когда Монголия была под экспансией Маньчжурской империи вопросы, касающиеся земельных отношений, регулирует Маньчжурское государство посредством министерства государственного регулирования внешней Монголии. В эти времена землепользование определялось общим, однако хозяин хошуна (административно-территориальной единицы) был вправе арендовать, дарить и наследовать землю.

В 1924 г. право на земельную собственность запрещается Конституцией [6]. Впредь земля распределялась исходя из принципа уравнительного землепользования.

В ходе принятия Конституции 1992 года в целях развития гражданского демократического общества и экономической перестройки, земля признается собственностью народа. Принятая конституция узаконила все формы собственности, в том числе и частную. Частная собственность на землю разрешалась только для лиц, занимающихся земледелием, и владельцев дач. Пастбища и земли общего пользования, которые составляли свыше 90 \% всех сельскохозяйственных угодий, остались государственной собственностью.

После Конституции, в 1994 г. утверждается «Закон о земле», который осуществил основные направления новой Конституции.

В России и Монголии законодатели одинаково подходят к понятию права собственности с позиции римского права. То есть у собственника земли есть право владения, пользования и распоряжения принадлежащей ему земельного участка по своему усмотрению, но в пределах, установленных законом.

В России право собственности на землю закреплено в Конституции РФ от 12 декабря 1993 г., Гражданском кодексе РФ от 30.11.1994 г. № 51-Ф3 (далее - ГК РФ), Земельном кодексе РФ от 25.10.2001 г. № 136-Ф3 (далее - ЗК РФ) и Федеральном законе «Об обороте земель сельскохозяйственного назначения» от 24.07.2002 № 101-Ф3.

В соответствии с Конституцией РФ [1]:

- земля и другие природные ресурсы могут находиться в частной, государственной, муниципальной и иных формах собственности; 
- право частной собственности охраняется законом;

- каждый вправе иметь имущество в собственности, владеть, пользоваться и распоряжаться им как единолично, так и совместно с другими лицами;

- граждане и их объединения вправе иметь в частной собственности землю. Владение, пользование и распоряжение землей и другими природными ресурсами осуществляются их собственниками свободно, если это не наносит ущерба окружающей среде и не нарушает прав и законных интересов иных лиц;

- условия и порядок пользования землей определяются на основе федерального закона;

- вопросы владения, пользования и распоряжения землей, недрами, водными и другими природными ресурсами находятся в совместном ведении Российской Федерации и субъектов Российской Федерации.

В Монголии право собственности на землю закреплено в Конституции Монголии, Гражданском кодексе Монголии, Законе о земле и Законе о приватизации земель.

Согласно Конституции Монголии [8]:

- земля, ее недра, леса, воды, животные, растительные и другие богатства природы Монголии принадлежат только народу и находятся под защитой государства;

- вся земля, не переданная в частную собственность граждан Монголии, недра земли, их богатства, леса, воды, животный и растительный мир являются государственной собственностью;

- земля, за исключением пастбищ, земельных наделов общественного и специального государственного пользования, может быть передана в частную собственность только гражданам Монголии. Это не относится к недрам земли. Гражданам Монголии продажа, обмен, дарение, закладывание под залог земель, находящихся в их частной собственности, иностранцам и лицам без гражданства запрещается. Запрещается также передача земли во временное пользование другим лицам без разрешения соответствующих органов государственной власти;

- государство может накладывать на собственников земли определенные обязательства, исходя из особых интересов государства, обменять землю собственника или изъять ее вновь в собственность государства с соответствующей компенсацией. В случаях использования земли во вред здоровью людей, окружающей природы, интересам национальной безопасности, государство может эту землю конфисковать;

- передача земли в аренду иностранным гражданам, юридическим лицам и лицам без гражданства может быть осуществлена в соответствии с условиями и порядком, установленными в законодательстве.

Таким образом, различия выявляются в следующем:

- согласно Конституции Монголии только граждане Монголии имеют право собственности на землю в Монголии. В России же такое право наряду с гражданами имеют юридические лица, государственные и муниципальные образования;

- в России иностранные граждане, лица без гражданства и иностранные юридические лица могут обладать на праве собственности земельными участками, кроме земель сельскохозяйственного назначения, земель, находящихся на приграничных территориях и на иных установленных особо территориях Российской Федерации. В Монголии же такие категории могут только арендовать землю;

- в Конституции Монголии определено, что права собственника могут быть ограничены только на основании, указанном в законе. Конституция России содержит более общую норму, прямого указания не включает. В соответствии с п. 3 ст. 55 Конституции РФ права и свободы человека и гражданина могут быть ограничены федеральным законом только в той мере, в какой это необходимо в целях защиты основ конституционного строя, нравственности, здоровья, прав и законных интересов других лиц, обеспечения обороны страны и безопасности государства [1];

- Конституция России, в отличие от Конституции Монголии не содержит запрета на передачу земли в собственность иностранных граждан и лиц без гражданства, так как на основании п. 3 ст. 62 Конституции РФ иностранные граждане и лица без гражданства пользуются в Российской Федерации правами и несут обязанности наравне с гражданами Российской Федерации, кроме случаев, установленных федеральным законом или международным договором Российской Федерации [1]. Подобные запреты включены в состав специального законодательства, который регулирует определенную сферу правоотношений.

Случаи прекращения права собственности на земельный участок:

- в России, согласно ст. 44 ЗК РФ [2], право собственности на земельный участок прекращается при отчуждении собственником своего земельного участка другим лицам, отказе собственника от права собственности на земельный участок, по иным основаниям, предусмотренным гражданским и земельным законодательством;

- в Монголии основаниями прекращения права собственности являются: 1) передача права собственности на землю другим лицам; 2) отказ от права собственности на землю; 3) потеря монгольского гражданства собственником земли; 4) наступление случаев, указанных в законе.

В результате исследования частной собственности на землю можно прийти к тому, что урегулирование земельных вопросов в РФ и Монголии заметно отличаются. Существенную роль в этом играет, то, что земля по законодательству Монголии может находиться только в собственности граждан, когда в России определяется помимо собственности граждан и другие формы собственности. Также различие состоит в том, что в России предоставлен широкий круг прав пользования землей, как российским гражданам, так и иностранным гражданам и лицам без гражданства, когда, как в Монголии имеются сравнительно строгие ограничения по использованию землями. Кроме этих различий имеются другие, имеющие национальные, исторические основы. По 
большому счету, в урегулировании земель в РФ и Монголии имеется своя нормативная база, также специальные законы.

Важной задачей, стоящей перед государствами РФ и Монголии представляется дальнейшее совершенствование механизма реализации прав собственников и законодательной техники, вплоть до неприкосновенности частной собственности.

\title{
Литература
}

1. Конституция Российской Федерации от 12 декабря 1993 г. // СЗ РФ. 2014. № 31. Ст. 4398.

2. Земельный кодекс Российской Федерации от 25.10.2001 № 136-Ф3 // Российская газета. 2001. № 211-212.

3. Гражданский кодекс Российской Федерации (часть первая) от 30.11.1994 № 51-ФЗ // СЗ РФ. 1994. № 32. Ст. 3301.

4. Ведомости Верховного Совета СССР. 1990. № 30.

5. Ведомости Верховного Совета СССР. 1991. № 26.

6. Балжинням Т., Мягмаржав И. Об истории земельных отношений в Монголии. МГСХИ, Улан-Батор, 2007.

7. Титов Ю. П. История государства и права России. М., 1999. С. 184.

8. Режим доступа: http://www.bsu.ru/university/departments/faculties/uf/13244/13252/13364

\section{Международное регулирование охраны труда: сравнительные аспекты}

\author{
(C) C. В. Чагдурова \\ студентка 4-го курса юридического факультета \\ (С) Я. Б. Дамбиева \\ студентка 2-го курса Института экономики и управления \\ ФГБОУ ВО «Бурятский госуниверситет» \\ Россия, г. Улан-Удэ \\ chgdrv@gmail.com
}

Каждый день 6300 человек умирают в результате несчастных случаев или заболеваний, связанных с работой. Ежегодно во всем мире от профессиональных травм и заболеваний умирают более 2,3 млн работающих женщин и мужчин, свыше 350 тыс. человек погибают по причине несчастных случаев и почти 2 млн человек по причинам, связанным с профессиональными заболеваниями. Кроме этого, более 313 млн работников оказываются пострадавшими от несчастных случаев без смертельного исхода, приводящим к серьезным травмам и невыходам на работу. Международная организация труда (далее - МОТ) подсчитала также, что ежегодное число случаев профессиональных заболеваний без смертельного исхода составляет 160 млн.

Вышеперечисленная статистика ужасает и наглядно показывает всю важность и ценность охраны труда во всем мире.

В современных условиях глобализации и международной экономической интеграции мировое сообщество на данный момент столкнулось с серьезной проблемой в лице повсеместного нарушения прав человека в сфере охраны труда. Для большинства стран мира обеспечение охраны труда работников является одним из основных источников проблем и вопросов, которые необходимо решать незамедлительно, более того, на данный момент этот вопрос занимает важное место в дискуссиях как на национальном, так и на международном уровнях. Международная охрана труда, несомненно, должна обсуждаться на мировом уровне, т.к. затрагивает интересы не только самих государств, но и всего мирового сообщества.

Глобальный экономический кризис и его последствия означают, что мир сталкивается с перспективой затяжного роста безработицы, усиления бедности и неравенства. Уровень занятости обычно восстанавливается лишь несколько лет спустя после восстановления экономики. В некоторых странах простого восстановления прежних уровней занятости будет недостаточного для того, чтобы эффективно содействовать созданию мощных экономических систем и достижению целей достойного труда для женщин и мужчин.

Фундаментом успешной реализации политики достойной охраны труда, прежде всего, является международная нормативно-правовая база, касающаяся данного вопроса, и ее необходимо проанализировать.

Во-первых, стоит отметить «Всеобщую декларацию прав человека», 23 статья которой имеет следующее содержание: «Каждый человек имеет право на труд, на свободный выбор работы, на справедливые и благоприятные условия труда и на защиту от безработицы» [1].

Следующим базовым документом является «Декларация МОТ об основополагающих принципах и правах в сфере труда и механизм ее реализации», которая служит цели поощрить предпринимаемые государствами-членами Организации усилия по содействию соблюдению основополагающих принципов и прав [2].

Далее согласно статье 2 «Декларации о праве и обязанности отдельных лиц, групп и органов общества поощрять и защищать общепризнанные права человека и основные свободы»: «Каждое государство несет основную ответственность и обязанность защищать, поощрять и осуществлять все права человека и основные свободы, в частности путем принятия таких мер, какие могут потребоваться для создания всех необходимых условий в социальной, экономической и политической, а также в других областях и правовых гарантий, необходимых для обеспечения того, чтобы все лица под его юрисдикцией, индивидуально и совместно с другими, могли пользоваться всеми этими правами и свободами на практике». 
В преамбуле Устава МОТ (1919 г.) [3] защита трудящихся от болезней, профессиональных заболеваний и несчастных случаев на производстве названа одним из приоритетных направлений деятельности, которое сохраняет свою актуальность и сегодня. Этот основополагающий принцип был подтвержден в Филадельфийской декларации 1944 года и позднее - в Сеульской декларации 2008 года, где было отмечено, что право на безопасную и здоровую производственную среду следует признать не только в качестве трудового права, но и в качестве основополагающего права человека.

Фундаментальные принципы МОТ в отношении охраны труда сформулированы в Конвенции 1981 года о безопасности и гигиене труда (№ 155), в Конвенции 1985 года о службах гигиены труда (№ 161) и в Конвенции 2006 года об основах, содействующих безопасности и гигиене труда (№ 187). Эти важные документы могут использоваться правительствами, работодателями и работниками для установления разумной практики в области охраны труда. Кроме того, МОТ приняла более 40 международных трудовых норм, имеющих прямое или косвенное отношение к охране труда, а также разработала по данному вопросу ряд сводов практических правил.

Для достижения мира и социальной справедливости крайне необходимо сотрудничество между правительствами и социальными партнерами (организациями работодателей и работников), способствующее социальноэкономическому прогрессу. В контексте широких усилий по содействию эффективному государственному управлению основная ответственность за признание правительством социальных партнеров в качестве ключевых социально-экономических структур в сфере труда возлагается на министерства труда. Министерства труда играют важнейшую роль в решении вопросов управления охраной труда как на национальном уровне, так и на уровне отдельных предприятий. Социальный диалог между правительствами и социальными партнерами способствует достижению согласия и демократическому участию сторон, имеющих жизненно важные интересы в сфере труда.

Во многих странах сложность и размах проблем в области охраны труда в сочетании с наличием множества источников производственных опасностей и рисков нередко приводит к тому, что ответственность за обеспечение охраны труда разделяют разные учреждения. Но основную роль чаще всего играют министерства труда, министерства здравоохранения и системы социального обеспечения. Социальный диалог по вопросам охраны труда зачастую проводится в рамках соответствующих национальных трехсторонних советов или аналогичных структур, в которых представители работодателей, работников и соответствующих государственных учреждений встречаются и принимают решения относительно национального законодательства, стратегий, программ и первоочередных мер в области охраны труда. Необходимо помнить, что обязанности правительств, обязательства работодателей, права и обязанности работников следует считать взаимодополняющими и взаимоусиливающими, поскольку все они способствуют достижению общей цели - продвижению охраны труда с учетом национальных условий и практики.

Важную роль по совершенствованию регулирования в области охраны труда играют страны Азиатского региона, т.к. многие из них сейчас претерпевают сильные изменения во всех сферах жизни общества. Многим странам следует выделять больше ресурсов на исследования в области охраны труда, на управление знаниями и распространение информации, а также на последовательное обеспечение соблюдения законодательства, направленные на борьбу с последствиями непрерывного приспособления рабочих мест к потребностям быстро меняющейся сферы труда.

Политика Российской Федерации сейчас направлена на улучшение связей со странами Востока и развитие экономических отношений с последними, что, несомненно, делает важным рассмотрение института охраны труда стран Азиатского региона.

Для начала рассмотрим ситуацию в Монголии. Новая Конституция была принята в 1992 году. Как указано в статье 16 главы второй - «Права и свободы человека», граждане Монголии имеют право на свободный выбор профессии, на обеспечение хороших условий труда, на получение заработной платы, на отдых, на ведение собственной хозяйственной деятельности. Никто не может быть подвергнут принудительному труду. Статья 16 является ядром государственной политики в области охраны труда, социальной защиты, здравоохранения и других, связанных с ними услуг [4].

Национальная концепция развития, провозглашенная в 1995 году, одной из задач определяла создание среды с безопасными условиями труда для всего населения и гарантией для развития народа. В 2001 году национальная политика в области здравоохранения определила следующее направление в области охраны труда: снизить уровень временной потери трудоспособности, профессиональных заболеваний, а также несчастных случаев на производстве за счет обеспечения применения стандартов по охране труда на рабочих местах. В 2004 государственная политика в области развития населения была определена как задача по улучшению качества жизни людей путем предоставления населению возможности работать и жить в здоровой окружающей среде, улучшить свое благосостояние, получить образование, активно участвовать в общественной жизни». В 2001 году Правительство Монголии приняло Национальную программу по охране труда и улучшению состояния здоровья населения.

Важными документами Монголии, связанными с рассматриваемым институтом, являются:

- Закон о труде Монголии;

- Закон о социальном страховании;

- Закон о льготах, предоставляемых Фондом социального страхования от несчастных случаев и профессиональных заболеваний;

- Закон о пенсиях и пособиях для военнослужащих; 
- Закон Монголии о государственной аудиторской деятельности;

- Закон об административном надзоре;

- 2003 Общий Устав SPIA утвержден постановлением Правительства № 37;

- Другие законы и нормативные акты.

Далее рассмотрим законодательство в области охраны труда Китая, одного из самых важных стратегических партнеров Российской Федерации. Конституция Китайской Народной Республики, принятая на пятой сессии пятого Национального Народного Конгресса 4 декабря 1982 года, включает в себя следующие основные положения, касающиеся безопасности труда: государство создает условия для труда, повышает безопасность в данной области, повышает вознаграждение за труд и социальные пособия [5].

Закон Китайской Народной Республики по безопасности труда вступил в силу 1 ноября 2002. Его основное содержание включает: общие положения; обеспечение безопасности труда в производстве; права и обязанности работников; надзор и контроль за безопасным ведением работ; правовая ответственность и дополнительные положения.

Закон Китайской Народной Республики по профилактике и контролю профессиональных заболеваний, вступивший в силу с 1 мая 2002 года, был принят с целью предотвращения, контроля и устранения опасности профессиональных заболеваний, защиты прав и здоровья работников, а также содействия развитию экономики.

Следующим важным документом служит Закон КНР «О труде» 1995 года, который был принят для защиты законных прав и интересов работников, регулирования трудовых отношений, установления и сохранения системы труда подходит для рыночной экономики, а также содействия экономическому развитию и социальному прогрессу.

В целом ситуация в области охраны труда в обеих странах еще не достаточно урегулирована законодательством указанных стран, однако стоит отметить развитие данного направления и усиление контроля по данному вопросу со стороны государств.

\title{
Литература
}

1. Всеобщая декларация прав человека (принята на третьей сессии Генеральной Ассамблеи ООН резолюцией 217 А (III) от 10 декабря 1948 г.) // Российская газета. 1998.

2. Декларация МОТ «Об основополагающих принципах и правах в сфере труда» // Международная организация труда и права человека. Женева: МВТ, 1998.

3. Устав МОТ. Женева: МВТ, 1998.

4. Конституция Монголия. [Электронный ресурс]. URL: http://worldconstitutions.ru/archives/33

5. Конституция Китайской Народной Республики 1982 г. с поправками 1988, 1993, 1999, 2004 гг. // www.russian.people.com.cn.

\section{Краткий анализ настоящего положения о защите персональных данных граждан в КНР}

\author{
Чжжао Лэ \\ магистрант Политико-юридического \\ университета Китая \\ Китай, г. Пекин
}

В последние годы умножается незаконный сбор персональных данных граждан. Этому способствует распространение интернета во всех сферах жизнедеятельности жителей КНР. Интернет стал неотъемлемой частью современной жизни, это приносит удобства в нашу жизни, но одновременно и создает опасность разглашения персональных данных граждан.

1. Неправомерный доступ к персональным данным граждан - это новый вид преступления.

По содержанию злоупотребление персональных данных граждан делится на следующие виды:

Во-первых, незаконный сбор персональных данных граждан. Некоторые органы и организации получают связанные с их деятельностью персональные данные граждан при выполнении своих обязанностей или оказании услуг. Например, во время регистрации накопительной карты некоторые торговцы требуют от покупателей предоставить некоторые персональные данные, такие как номер удостоверения личности, указать место работы, образование, состояние семьи, контакты и так далее.

Во-вторых, разглашение персональных данных граждан. Некоторые организации без разрешения покупателей разглашают их персональные данные. Например, некоторые банки публикуют имена вкладчиков, их номера удостоверения личности, контакты, домашние адреса или другие персональные данные должников на своем сайте.

В-третьих, незаконная продажа персональных данных граждан. Без разрешения субъектов некоторые организации даже продают персональные данные граждан.

2. Особенности неправомерного доступа к персональным данным граждан.

Анализ преступлений данного рода показа, что они имеют следующие особенности: во-первых, в большинстве случаев данное преступление совершают молодые люди, которые умело работают на компьютере. Во-вторых, немалое число виновных в совершении этого преступления - служащие государственных органов или со- 
трудники финансовых организаций, организаций связи, транспорта, образования или здравоохранения, которые получают при выполнении своих обязанностей персональные данные граждан и тайком незаконно продают их в корыстных целях. В-третьих, содержание и количество персональных данных граждан становится многообразнее. Информация, которая продается на «черном рынке», включает имя, телефонные номера, адреса, записи телефонных переговоров, прописки, номера автомобилей, записи расходов и так далее.

Защита персональных данных граждан в КНР.

Результаты анкетного исследования показывают: 99,3\% жителей требуют усовершенствования законодательства в сферах защиты персональных данных граждан, многие надеются на то, чтобы правительство строго боролось с неправомерным доступом к персональным данным граждан и их незаконной продажей.

Девятая поправка к Уголовному кодексу УНР более защищает безопасность персональных данных граждан. Во-первых, расширение круга субъектов преступления. Раньше за данное преступление могли быть наказаны только сотрудники государственных органов или сотрудники экономических организаций, организаций связи, транспорта, образования и здравоохранения. В соответствии с Поправкой 9 к УК КНР за данное преступление могут быть привлечены к уголовной ответственности любые лица, получившие доступ к персональным данным граждан при выполнении служебных обязанностей.

Во-вторых, более строгое наказание за неправомерный доступ к персональным данным граждан. Поправка 9 к УК КНР предусматривает привлечение к уголовной ответственности поставщиков интернет-услуг, которые не выполняют возложенные на них обязанности по обеспечению безопасности и неприкосновенности персональных данных граждан. Данное преступление наказывается лишением свободы на срок до 3 лет, арестом, надзором и штрафом, можно привлекать к уголовной ответственности организации.

3. Пути усиления правовой защиты персональных данных граждан.

Во-первых, совершенствование системы правовой защиты персональных данных граждан. В международном сообществе многие страны и регионы уже усиливают работу по усовершенствованию законодательства о защите персональных данных граждан. Но в КНР до сих пор не существует специального правового акта о защите персональных данных граждан. Поэтому перед нами стоит срочная и важная задача - принятие закона о защите персональных данных.

Во-вторых, повышение правового сознания жителей о неприкосновенности персональных данных и личной жизни других.

В-третьих, строгое ограничение права операторов, у которых есть возможность доступа к такой информации. Когда они разглашают персональные данные граждан, к ним применяется меры наказания по УК КНР.

\title{
Раздел недвижимости супругов при разводе по закону КНР
}

\author{
(C) Чэнь Си \\ магистрант Китайского \\ политико-юридического университета, \\ Китай, г. Пекин
}

Данные показывают, что в Китае в 2008 году количество рассмотренных дел о семейных спорах по первой инстанции насчитывало 1286437, в 2009 году 1341029, в 2010 году 1374136, что указывает на тенденцию роста. Наряду с этим, в 2010 году количество рассмотренных бракоразводных дел по первой инстанции было 1164521 , рассмотренных семейных дел об имущественных спорах 24676. В этом контексте, 9 августа 2011 года Верховный народный суд принял разъяснение «О некоторых вопросах применения Закона КНР о браке (№3)», которое вступило в силу 13 августа 2011 года. Разъяснение состоит из 19 правовых положений, в том числе 12 положений, касающихся режима имущества супругов. Отсюда очевидно, что режим имущества супругов уже стал наиважнейшим приоритетом «Закона о браке».

Действующий режим имущества супругов в Китае.

В новой редакции «Закона КНР о браке» 2001 года были внесены существенные поправки в отношении законодательства режима имущества супругов: добавлен режим личного имущества супругов и сужены рамки законного совместного имущества. В «Законе о браке» отменено положение «добрачное имущество через определенное время преобразуется в совместное имущество супругов» и четко предусмотрено, что добрачное имущество относится к собственности каждого из супругов, тем самым налагая ограничение на сферу совместного имущества супругов. Этот закон не только недвусмысленно определяет структуру режима имущества супругов, перечисляет типы доходов и имущества, но и уточняет границы между имуществом, совместно нажитым супругами в браке, и личным имуществом каждого из супругов.

«Закон о браке» 2001 года предусматривает два вида режима имущества супругов: законный и договорный. Законный режим имущества супругов действует, если брачным договором не установлено иное. Ст. 17 «Закона КНР о браке» предусматривает, что «муж и жена имеют равные права по распоряжению имуществом, находящимся в совместной собственности супругов». Помимо общей собственности, для защиты личных имущественных прав, в ст. 19 Разъяснения Верховного народного суда «О некоторых вопросах применения Закона КНР о браке (№1)» указывается, что собственность одного из супругов переходит в общую совместную собственность супругов после заключения брака, если стороны не договорились об ином. По статье 19 «Закона КНР о 
браке», «супруги могут заключить соглашение о том, что имущество, приобретенное в период существования брака, а также имущество, находившееся в собственности одного из супругов до заключения брака, находится в совместной собственности, раздельной собственности, либо частично совместной, частично раздельной собственности. Соглашение должно быть заключено в письменном виде. Соглашение супругов об имуществе, приобретенном в период существования брака, а также имуществе, находившемся в собственности одного из супругов до заключения брака, имеет обязательную силу для обоих супругов».

Особые правила о разделе недвижимости при разводе.

По мере развития китайской экономики и урбанизации, значительная часть населения переселилась в город, это объективно привело к дефицитности земли города и непрерывному увеличению цены на жилье, поэтому раздел общей недвижимости супругов при разводе является повсеместно распространенной проблемой в бракоразводном процессе.

На данном этапе в основном существует два типа спорной недвижимости при разводе: добрачная ипотечная недвижимость и недвижимость, приобретенная за счёт средств родителей. В отличие от полностью оплаченной недвижимости, время владения правом собственности ипотечной недвижимости не ясно. В бракоразводном процессе, если не оговорено иное, послебрачная ипотечная недвижимость обычно считается совместной собственностью супругов, раздел которой происходит относительно легко. Но что касается добрачной ипотечной недвижимости, то есть случаи, когда один из супругов до брака купил квартиру или выплатил первый взнос за счёт собственных средств, после брака супруги вместе возвращали ипотечную ссуду, но документ о праве собственности на недвижимость выдается на имя добрачного покупателя; до брака супруги совместно купили квартиру ипотекой от имени одного из супругов, после брака тоже вместе возвращали ипотечную ссуду и т.д. Все эти вопросы делают «раздел добрачной ипотечной недвижимости» трудностью при разводе.

С устойчивым ростом цен на жилье в последние годы для молодых супругов становится всё труднее в короткий срок купить квартиру после брака на свои доходы. Так возникают ситуации, когда родители детям покупают квартиру полной оплатой или выплачивают первый взнос. Из-за этого между родителями и детьми, родителями и родителями имеются более сложные юридические отношения, при разводе вопрос «как определить право собственности родителей» весьма спорный.

Разъяснение Верховного народного суда КНР «О некоторых вопросах применения Закона КНР о браке» содержит правила, которые регулируют споры о жилом помещении, взятом в ипотеку одним из супругов до заключения брака; споры о распоряжении недвижимым имуществом в совместной собственности без согласия другого супруга; споры о разделе жилых помещений, купленных для родителей одного из супругов.

Кроме того, в первом, втором и третьем судебных разъяснениях Верховного народного суда КНР «О некоторых вопросах применения Закона КНР о браке» предусмотрены конкретные нормы о разделе недвижимости; в общем, всего два способа: раздел недвижимости по брачному договору или соглашению супругов. Если супруги не могут договориться о мирном разделе имущества, раздел недвижимости супругов осуществляется в суде в следующих ситуациях: 1) оба супруга выступают за право собственности на жилье и могут добиться этого путём ценовой конкуренции, 2) один из супругов выступает за право собственности на жилье, нужно выплатить компенсацию другой стороне, в) никто из супругов не претендует на право собственности на жилье, нужно продавать с аукциона по заявлению сторон и разделять полученные деньги.

С развитием общества закон о браке должен продвигаться вперед в ногу со временем, особенно положения о разделе недвижимости в бракоразводных процессах. Хотя закон о браке уточняет совместное имущество супругов во время существования брака, но с развитием рыночной экономики, видов совместного имущества супругов появляется всё больше и больше, как ипотечная недвижимость, сносная и переездная недвижимость. Соответственно, появляются новые вопросы, которые требуют решения путем регулирования государством. Но действующий закон о браке не чётко определяет раздел недвижимости при разводе. Согласно статье 39 «Закона о браке», «при расторжении брака совместное имущество супругов распределяется по соглашению сторон; при отсутствии согласия - решением народного суда в соответствии с конкретными обстоятельствами дела и принципом защиты прав и интересов детей и женщины. Права и интересы мужа или жены в осуществлении семейного хозяйственного подряда должны быть защищены согласно закону». Это проводит к тому, что судья не может найти юридическое основание, только по опыту и личному пониманию, когда рассматривает дело по разделу недвижимости при разводе. В «Законе о браке» пока нет единого стандарта, это в значительной степени препятствует развитию законодательства нашего государства. С другой стороны, при применении существуют коллизии между положениями «Закона о собственности» и «Закона о браке», касающиеся недвижимости. Это требует от законодательных органов исследования и изучения конфликтов правовых норм и решения проблем.

Действующий «Закон о браке» Китая обращает большое внимание на режим имущества супругов, но данный режим в настоящий момент ещё находится на пути совершенствования с учетом современных реалий и специфики, присущей Китаю. 


\title{
Ипотечное кредитование в России и Индонезии: сравнительно-правовой анализ
}

\author{
(C) T. Н. Шагдаров \\ студент 3-го курса юридического факультета \\ ФГБОУ ВО «Бурятский госуниверситет» \\ Россия, г. Улан-Удэ
}

Сегодня вложения в объекты недвижимости - это достаточно прибыльное мероприятие. Данный факт заставляет инвесторов подыскивать рынки, позволяющие заработать. Кого-то привлекает недвижимость Европы, а кто-то обращает свой взор к Азии.

К сожалению, не все страны Азии могут предложить хорошие условия зарубежным инвесторам. В этом плане Индонезия - самый выгодный вариант.

В данной статье хотелось бы кратко осветить исторические аспекты рынка недвижимости Индонезии, как один из факторов, влияющих на ипотечное кредитование.

Индонезия, как и многие другие развивающиеся страны, почти полностью погрязла в строительные работы. Страна находится в активной фазе строительства, что центральные районы столицы Джакарты, что и самые отдаленные уголки - кондоминиумы, офисы, дома разных строений переживают больше перемены. Естественным фактором является то, что недвижимость существенным образом преобладает над общим рынком. Связано это, прежде всего с ростом в экономике, а также снижением процентных ставок [6].

Рассмотрим непосредственно цены на жилье. Так, за один год к концу первого квартала 2013 года индекс вырос на 7,4 \%. Активными темпами растет спрос на недвижимое имущество. Четвертый квартал 2012 года выдал неожиданный взлет продажи жилья на целых 26,7\% [5]. Предыдущие четыре года экономического прироста послужили, причиной такого сильного спроса со стороны граждан, как местных, так и иностранных. Но все же цены за последние пять лет в Индонезии повышены сильно не были. Закономерными причинами стали высокие процентные ставки, ряд ограничений по продаже недвижимости иностранным гражданам, а также повышенная стоимость материалов для строительства, и высокие налоги на недвижимость.

В 2013 году произошли изменения. Индонезийский банк был вынужден приступить к «охлаждению» рынка жилья при помощи ряда ограничений по ипотечным займам. Этому обстоятельству способствовали растущие цены на жилье. Новые положения вводит центральный банк по размеру первоначального взноса на приобретение второй недвижимости. Согласно новым положениям минимальный аванс по кредиту должен составлять $40 \%$ для второй недвижимости, и 50 \% за каждый следующий дополнительный объект жилья. Теперь при подаче заявок на новые займы покупателям необходимо будет в обязательном порядке прописывать в декларации, имеющиеся у них ипотечные кредиты. Важно отметить, ранее требования банка были иными, первоначальный платеж был 30\%. Руководящие звенья предполагали, что это поспособствует охлаждению рынка недвижимости. А на деле этих мер оказалось мало. В Индонезии стремительным образом повышались цены на жилье, поэтому власти предприняли путь к охлаждению рынка недвижимости.

2015 год порадовал хорошей новостью. Теперь местные жители, как и прежде, смогут оформлять кредиты на покупку недвижимости без каких либо на это ограничений. Агус Мартовардоджо - директор индонезийского банка сообщил населению, о том, что Центральный банк попытается минимизировать соотношение размера кредита к стоимости недвижимого и движимого имущества, что приведет к доступности банковских услуг для покупателей со скромными доходами. Директор возразил более детально охарактеризовать эту ситуацию, также отметил, что Центральный банк поддерживает здоровый баланс потребительских кредитов и пытается предотвратить создание «пузыря» на рынке недвижимости, поскольку это скажется отрицательно на всей экономической ситуации.

Весьма интересным является закон, вступивший в силу 28 декабря 2015 года. Теперь зарубежным инвесторам с видом на жительство по этому закону, дается возможность оформлять право собственности на объекты недвижимого имущества на 30 лет с возможностью продления на 20 лет, а затем снова на 30 лет. Иностранцы обладают правом передать объекты по наследству. Что касается наследника, то он должен будет иметь вид на жительство в стране или быть самим индонезийцем, состоящим в браке с представителем иностранного государства. В тех случаях если наследник покидает Индонезию, то он будет обязан передать недвижимость другой стороне с условиями закона. Если же все-таки дом не будет передан другому лицу, проводится принудительный государственный аукцион.

Иностранцам благоприятен тот факт, что национальная валюта не стабильна, таким образом, недвижимость более доступна и реальна для них. Цены на жилье снизились в долларовом эквиваленте. Жилье для отпусков на Бали всегда пользуется большим спросом. На протяжении прошлого года, цены на него не были высокими, спрос был еще больше, а рынок прогрессирует в различных сделках. Весьма актуальным является спрос со стороны граждан Китая. Обеспеченные граждане поднебесной вынуждены выводить деньги за рубеж из-за ослабевающего юаня. Сами же власти Индонезии открывают разные возможности для иностранных граждан. Перспективы рынка недвижимости Бали и самой Индонезии становятся безграничными [2].

Несколько слов по ипотечному кредитованию в России. Сбербанк России и ВТБ 24 по итогам 2013-2015 гг. в общем, выдали самые большие объемы ипотечных кредитов [4]. Эти банки остаются лидерами по показате- 
лям ипотеки. Но высокие показатели ни как не влияют на разрешение проблем связанных в этой сфере услуг [1, c. 151].

«Проблемы, возникающие при ипотечном кредитовании в России»:

- поданная заявка от заемщика рассматривается, как правило, с затягиванием сроков;

- заемщик при подаче заявки, может потерять определенные денежные средства, поскольку организация выдававшая кредит, может указать цену отличную первоначальной;

- ограниченная платежеспособность граждан;

- некоторые регионы обычно не богаты объектами новостроек, вследствие чего цены на них бывают высокими;

- социальные проблемы [3, с. 121].

Таким образом, проанализировав вопрос ипотечного кредитования в России и Индонезии, можно сделать вывод о том, что рынок ипотечного кредитования и в России, и в Индонезии не стабилен. Процентные ставки цикличны. Количество ипотечных займов также зависит от роста цен на недвижимость. Но, тем не менее, для малоимущих граждан ипотека - это возможность приобрести недвижимость в собственность. А здесь возникает другой риторический вопрос: помогает ли ипотека осуществить мечту о собственном жилье или приводит к долговым обязательствам граждан?

\title{
Литература
}

1. Мурычев А. В. Проблемы и перспективы развития ипотеки в России // Банковское дело. 2012. 221с.

2. Перспективы рынка недвижимости Индонезии [Электронный ресурc]. URL: http://prian.ru (дата обращения: 31 марта 2016 г.).

3. Симионова Ю. Ф. Ипотека для всех. Ростов н/Д.: Феникс, 2012. 330 с.

4. Статистика ипотечного кредитования в России [Электронный ресурс]. URL: http://rusipoteka.ru (дата обращения: 2 апреля 2016 г.).

5. Статистика цен на жилье в Индонезии [Электронный ресурc]. URL: http://www.globalpropertyguide.com (дата обращения: 22 марта 2016 г.).

6. Строительный бум в Индонезии [Электронный ресурc]. URL: http://www.globfin.ru/ (дата обращения: 29 марта 2016 г.).

\section{Сравнительно-правовой анализ оценки недвижимости в странах АТР}

\author{
(С) О. К. Шакирова \\ студентка 4-го курса юридического факультета \\ ФГБОУ ВО «Бурятский госуниверситет» \\ Россия, г. Улан-Удэ \\ shok-1994@mail.ru
}

Именно недвижимость формирует центральное звено всей системы рыночных отношений. Объекты недвижимости не только важнейший товар, удовлетворяющий разнообразные личные потребности людей, но одновременно и капитал в вещной форме, приносящий доход. Вложения в них обычно представляют собой инвестирование с целью получения прибыли. Недвижимость - основа национального богатства страны, имеющая по числу собственников массовый, всенародный характер

История показывает, что Россия прошла долгий и тяжелый путь в установлении порядка в институте оценки. Начало было положено в 18 веке после заимствования подходов оценки широко применяемых во Франции, затем отмечались постоянные попытки ввести единую систему, путем масштабной оценки, но до настоящего дня эти старания не заканчивались успехом. В России, как и в зарубежных странах в результате оценки недвижимости определяется либо рыночная, либо кадастровая стоимость. Актуальным остается вопрос о разнице между ними, и повышение суммы налога в связи с введением изменений в Налоговый Кодекс Российской Федерации. В связи, с чем особый интерес вызывает порядок и методы оценки недвижимости.

Оценка стоимости недвижимости - сложный и трудоемкий процесс, состоящий из нескольких этапов:

1) определение проблемы;

2) предварительный осмотр объекта и заключение договора на оценку;

3) сбор и анализ данных;

4) оценка земельного участка;

5) применение трех подходов к оценке стоимости объекта недвижимости;

6) согласование результатов, полученных при различных подходах;

7) подготовка отчета и заключения об оценке;

8) доклад об оценке.

Известно несколько десятков методов оценки объектов недвижимости, используемых для различных видов объектов: зданий, сооружений, земельных участков, квартир и т.д. Выбор того или иного метода оценки зависит от ряда факторов, в том числе от характера объекта, цели и функции оценки, от имеющейся в распоряжении эксперта информации. Если объект недвижимости приносит стабильный доход, наиболее приемлем метод капитализации; если оценивается квартира и имеется достаточно рыночных данных о фактических продажах ана- 
логичных квартир на жилищном рынке, то для оценки целесообразнее использовать метод прямого анализа продаж; если объект недвижимости функционирует на "пассивном" секторе рынка недвижимости, оптимальным считается один из методов затратного подхода. Выбор метода зависит от функции оценки. Если результаты оценки необходимы для страхования объекта, целесообразнее использовать один из методов затратного подхода. Если результаты оценки необходимы для того, чтобы инвестировать определенные средства в развитие объекта недвижимости, лучше использовать один из методов доходного подхода.

Сравнительный метод предполагает сравнительный анализ рыночных продаж, т.е. сопоставление рыночных аналогов. Этот метод основан на принципе замещения, смысл которого в том, что информированный покупатель не заплатит за недвижимость больше, чем стоит аналогичный объект недвижимости на рынке. Стоимость объекта оценки определяется на основе цен реальных недавних продаж. Данный метод используется в качестве основного при оценке жилья для целей андеррайтинга ипотечных жилищных кредитов.

Основными этапами оценки недвижимости с помощью сравнительного метода являются:

- исследование рынка и сбор информации о совершенных сделках;

- отбор информации с целью повышения ее достоверности; подтверждения того, что сделки были совершены в свободных рыночных условиях;

•подбор сравнимых объектов для анализа;

- проведение сравнительного анализа.

Затратный метод предполагает оценку стоимости полного воспроизводства или стоимости полного замещения оцениваемой собственности, за вычетом из нее суммы оцененного износа зданий и сооружений. Этот метод применяется при технико-экономическом обосновании нового строительства, определении варианта наилучшего и наиболее эффективного использования земли, при страховании.

Основные этапы процедуры оценки затратным методом:

- расчет стоимости возведения нового аналогичного здания, получение восстановительной стоимости;

- определение величины физического и морального износа зданий;

- уменьшение восстановительной стоимости на сумму износа для получения реальной стоимости здания;

- добавление к рассчитанной реальной стоимости здания стоимости земли.

Доходный метод означает оценку текущей стоимости собственности с точки зрения планируемого дохода от использования и возможной дальнейшей продажи собственности. Он применяется при оценке инвестиций и коммерческой недвижимости.

При проведении оценки оценщик должен использовать затратный, сравнительный и доходный подходы к оценке, причем конкретные методы оценки он может определять самостоятельно. На основе анализа Российских и зарубежных источников можно сделать вывод, что цель любого метода оценки состоит в том, чтобы определить ожидаемую цену, по которой недвижимость могла бы продаваться на свободном рынке. Поэтому модель должна отражать то, как покупатели и владельцы недвижимости будут оценивать на этом рынке рыночную стоимость этой собственности.

В России оценку недвижимости осуществляют саморегулируемые организации, которые зарегистрированы в едином государственном реестре саморегулируемых организаций оценщиков. Что касается деятельности оценщиков, то несомненно она регулируется Законом «Об оценочной деятельности Российской Федерации» [1]. Где доходчиво определяются права и обязанности оценщиков, якобы требования. Но на деле, если зрить в корень проблемы к которой мы пришли сегодня, сетуя на пробелы и отсутствие хорошей единой законодательной базы. Нельзя отметить и роль в этой деятельности непосредственно субъектов осуществляющих оценку, их не сколько желание, а обязанность предписанную МСО оказывать содействие государству в оценке недвижимости. На мой взгляд, ситуацию с ролью оценщиков в оценочном процессе наиболее точно определяет профессор Коростелев. Который сделал прогноз результатам масштабной оценки, и еще с 2011 года говорил о том, что если государство будет продолжать выравнивать цены, то мы придем к катастрофе [2]. Институт независимых оценщиков исчезнет. Что подтверждается и сегодня, ведь по факту независимые оценщики выполняют роль «подносчиков снарядов», а их деятельность подходит под описание «таскать каштаны из огня».

Граждане Российской Федерации столкнулись с проблемой несоответствии кадастровой стоимости( то есть стоимости по которой государство фактически начисляет налог) и рыночной стоимости.

2016 год предвещает большие перемены в истории оценки недвижимости. Есть большая вероятность того, что государство проведет наконец то масштабную оценку и появится единая база. Об этом сообщил В.В. Путин 30 марта на совещании министров, однако ясно и дал понять что возможность оспорить кадастровую стоимость станет затруднительно.

В Австралии регулирование оценочной деятельности осуществляется саморегулируемой организацией профессиональных оценщиков - Австралийским институтом оценщиков(Australian Property Institute - API) [3]. Основная роль данной организации - создание и поддержание высоких стандартов профессиональной практики, образования, этики и дисциплины. Австралийский институт оценщиков предлагает несколько категорий членства для специалистов в области оценки. В зависимости от стажа работы и квалификации члену ассоциации присваивается степень от студента до заслуженного члена саморегулируемой организации. Услуги по оценке не лицензируются. В ряде штатов для осуществления деятельности оценщика требуется членство в Австралийском институте оценки [4].

На территории Канады действует смешанная система регулирования оценочной деятельности: только в двух провинциях действует государственное регулирование лицензирования оценщиков, во всех остальных 
провинциях ситуацию контролирует Канадский Институт Оценки(причем лицензирование не является обязательным) [5]. Необходимо отметить, что даже в тех регионах, где действует государственное регулирование лицензирования, обязанности по данному регулированию переданы местным аффилированным ассоциациям Канадского Института Оценки. Оценочная деятельность в Канаде регулируется профессиональной организацией оценщиков недвижимости - Канадским Институтом Оценки и на сегодняшний день насчитывает 4800 членов по всему миру. Обязательное требование к оценщику - членство в аффилированных ассоциациях Института. Таким образом, местные ассоциации уполномочены региональным законодательством регулировать оценочную деятельность в данных провинциях, при этом региональные власти сами не вмешиваются в их деятельность. Канадские Единые Стандарты Профессиональной Оценочной Практики (CUSPAP) не являются нормативным актом. Законодательное регулирование оценочной деятельности в Канаде отсутствует. Для получения кандидатского членства оценщик должен иметь высшее образование (минимум 3 года),. Члены Института осуществляют свою деятельность на основании Правил этики, Профессиональных правил оценки и Единых Стандартов Оценочной Практики. Институтом введено обязательное повышение квалификации и проведение повторной сертификации. Обязательное лицензирование или сертификация оценочной деятельности на большей территории Канады отсутствует (кроме двух провинций - New Brunswick и Nova Scotia). За исключением двух провинций можно заниматься оценочной деятельностью даже без наличия членства в Канадском Институте Оценки. При этом обязательное страхование на наличие ошибок в оценке членов Канадского Института оценок, не распространяется на оценку объектов, отличных от недвижимого имущества. CUSPAP позволяет использовать оценщикам в своем отчете «Специальные допущения» (Extraordinary Assumption), которые, если окажутся ложными, могут изменить мнение оценщика о стоимости.

Отчет об оценке может быть в письменной или устной форме. Основной принцип предоставления отчета заключается в том, что клиент оценщика должен иметь полную информацию о процессе составления мнения оценщика о стоимости объекта [6] .

Оценщик-рецензент должен разработать и предоставить клиенту квалифицированное мнение относительно качества работы другого оценщика и четко раскрыть объем работ, которые необходимо выполнить для написания рецензии. Стандарт CUSPAP устанавливает порядок разработки и передачи экспертизы оценки объекта, и включает в себя минимальное содержание необходимых для получения квалифицированного отчета, который не вводит в заблуждение клиента.

В США регулирование оценочной деятельности представляет собой многоуровневую систему. Подкомитет по оценке (Appraisal Subcommittee) является государственным органом, осуществляющим надзор за исполнением оценочного законодательства и контроль за деятельностью Фонда оценки (The Appraisal Foundation). Фонд оценки - частная некоммерческая организация, созданная для достижения единообразия и профессионализма в оценке [7]. Фонд оценки контролирует и финансирует Совет по стандартам оценки (ССО), Совет по квалификации оценщиков (СКО) и Совет по оценочной практике (СОП). Совет по стандартам оценки (ССО) разрабатывает Единые стандарты профессиональной оценочной практики (Uniform Standards of Professional Appraisal Practice (USPAP)) [8], которые являются обязательными для применения оценщиками в своей практической деятельности на территории США. Совет по классификации оценщиков (СКО) устанавливает минимальный уровень образования, опыта и экзаменационных требований для оценщиков недвижимости. Согласно закону «О реформе финансовых институтов» принятому Конгрессом США в 1989 году, полномочия по регулированию оценочной деятельности на федеральном уровне переданы Фонду оценки. Одновременно с ним в структуре правительства США действует орган по надзору за исполнением оценочного законодательства - Подкомитет по оценке (Appraisal Subcommittee). На уровне штатов регулирование осуществляется на основании местных законодательных актов Комиссиями по регулированию оценочной деятельности, на которые возложены требования по лицензированию и сертификации оценщиков недвижимости [9]. На сегодняшний день требования по лицензированию и сертификации в отдельных штатах отличаются друг от друга, и для работы в конкретном штате необходимо получить там соответствующую лицензию, сдав квалификационный экзамен.

Оценщик может специализироваться в различных сферах оценочной

деятельности:

- Оценка недвижимости. Оценщик может выбрать специализацию в различных видах недвижимости (жилая, коммерческая, сельскохозяйственная и т.п.).

- Оценка личного имущества. Данный вид оценки охватывает все виды личной собственности: предметы изобразительного и декоративного искусства, драгоценные камни и ювелирные изделия, автомобили и оборудование.

- Оценка бизнеса.

- Массовая оценка. Данный вид оценки включает в себя методы, которые используются при оценке различных видов недвижимого имущества или личного имущества с использованием общепризнанных формул. Оценщики недвижимости должны иметь определенное количество часов обучения и опыта работы. Помимо этого для получения сертификации, оценщик обязан сдать профессиональный экзамен.

Единые стандарты профессиональной оценочной практики (ЕСПОП), являющиеся обязательными для применения в США, разрабатываются и утверждаются Советом по стандартам оценки Фонда оценки. Стандарты 7 и 8 устанавливают нормы для развития и обобщения оценок личного имущества. Стандарты 9 и 10 устанавливают нормы для развития и обобщения оценок бизнеса [10]. 
Оценщик должен вести письменные записи при подготовке и ревизии отчетов по оценке или оказанию консультативных услуг и хранить подобные записи в течение, по крайней мере, пяти лет с момента завершения работ и, по крайней мере, двух лет после завершения любого судебного разбирательства, в котором давалось свидетельство, независимо от срока длительности судебного разбирательства. Оценщик должен быть готов продемонстрировать, что объем проделанной работы был достаточным для получения достоверных результатов. Не существует строгого перечня работ, который должен выполнить оценщик. Поэтому необходимый объем работ определяется исходя из того, была ли проведена оценка корректно и соответствовала ли она единым стандартам.

Отчет (письменный или устный), предоставляемый по результатам оценки, должен содержать достаточный объем информации, который позволит пользователям понять весь объем выполненных работ. Экспертизу отчетов об оценке проводят различные сообщества профессиональных оценщиков, в частности американское сообщество оценщиков (American Societyof Appraisers). Согласно Кодексу федерального регулирования США (49 CFR 24.104) при приобретении имущества государственными агентствами, а также при

осуществлении проектов с государственными софинансирование, отчеты об оценке

должны проходить обязательную экспертизу квалифицированными оценщиками. На данный момент система регулирования оценочной деятельности в США действует довольно эффективно. Смешанная система регулирования (наличие государственного органа надзора и негосударственного органа регулирования) позволяет, с одной стороны Фонду оценки устанавливать довольно гибкие стандарты проведения оценочной деятельности, с другой стороны Подкомитету по оценке контролировать деятельность саморегулируемых сообществ, что ведет к унификации стандартов. По этой причине сама система регулирования вряд ли будет меняться в ближайшем будущем [11].

При этом очевидно, что будут меняться стандарты оценки в целях дальнейшей их

унификации на уровне штатов, а также ужесточение требований к уровню квалификации оценщиков. В настоящее время в США рыночная информация передается через модемы. В результате она обновляется ежедневно, что важно для оценщика.

Японские национальные стандарты по оценке недвижимости приведены к МСО и практически не отличаются от МСО по базовым концепциям и методам оценки. Японские стандарты оценки регулируют только оценку недвижимости (отсутствуют стандарты по оценке движимого имущества, нематериальных активов и финансовых активов). Министерством земли, инфраструктуры, транспорта и туризма (MLIT)присваивает квалификацию оценщикам недвижимости. Японская Ассоциация оценщиков недвижимости (Japan Association of Rea lEstate Appraisers, JAREA) выдвигает следующие требования к членам Ассоциации: прохождение экзамена по оценке недвижимости, проводимым Министерством земли, инфраструктуры, транспорта и туризма (MLIT) Наряду с JAREA существует также Ассоциация оценщиков недвижимости, представленная в каждом административном округе. Членами ассоциации могут быть как физические, так и юридические лица.

Китайским Обществом Оценщиков (China Appraisal Society, CAS), которое является саморегулируемой организацией [12]. Функции CAS включают в себя:

- разработку стандартов и правило осуществления оценки, а также кодекса этики оценщиков;

- организацию национальных экзаменов название Сертифицированного Общественного Оценщика (СеrtifiedPublicValuer, CPV);

- регистрацию членов Общества и CPV.

В качестве членов Общества могут быть зарегистрированы как физические лица, так и юридические лица, как лица занимающиеся осуществлением оценочной деятельности, так и лица, не ведущие этой деятельности, как имеющие звание Сертифицированного Общественного Оценщика, так и лица, не имеющие такого звания. Главным условием является поддержка членом Общества тех стандартов и правил, которые разрабатываются обществом. Китайское Общество Оценщиков контролируется со стороны Министерства Финансов Китая [13]. Министерство Финансов и Китайское Общество Оценщиков совместными усилиями разрабатывают и принимают систему Стандартов Оценки.

Деятельность лицензируется. Выдаются лицензии на осуществление оценочной деятельности различных видов активов, которые действуют независимо. Оценщики в Китае делятся на шесть категорий - оценщики недвижимости, земли, прав на добычу полезных ископаемых, подержанных автомобилей, страховые оценщики и оценщики всех прочих активов [14]. Деятельность каждой из категорий оценщиков регулируется отдельно, необходимо иметь отдельную лицензию для осуществления оценки каждого из видов активов.

В отчете об оценке должно быть приведено описание объекта оценки, указан пользователь и назначение оценки, указана степень детализации отчета об оценке, перечислен существенные ограничения, применимые к проведенной оценке, а также указано влияние ограничений на результаты оценки. Отчет об оценке должен быть подписан двумя или более сертифицированными оценщиками (CPV), а также подписан уполномоченным представителем или партнером организации, занимающейся проведением оценки, и заверен печатью организации. В случае, если осуществляется оценка государственного имущества, которое затем будет передано частному лицу, то отчет об оценке должен пройти согласование в Министерстве Финансов Китая [15].

Таким образом, на основании изложенного можно сделать вывод, что:

1. В большинстве проанализированных стран национальные стандарты близки или полностью соответствуют Международным стандартам оценки (МСО). Кроме того, прослеживается тенденция к сближению систем национальных стандартов оценки с международными стандартами оценки. 
2. Оценочная деятельность в значительной части проанализированных стран регулируется исключительно профессиональными саморегулируемыми ассоциациями (без участия государственных органов).

3. Существует ряд стран, в которых практически отсутствует система как государственного, так и профессионального регулирования оценочной деятельности.

4. Экспертиза отчетов в значительной части стран требуется только при судебных разбирательствах (в таких странах экспертов обычно выбирает и назначает суд). Также существуют страны, в практике которых требование обязательной экспертизы при оценках государств

5. В значительной части проанализированных стран детальному регулированию подлежит только оценка недвижимости и земли (кадастровая оценка), в то время как другие сферы оценочной деятельности регулированы в существенно меньшей степени.

\title{
Литература
}

1. Федеральный закон 29.07.1998 N 135-Ф3 (ред. от 13.07.2015) РФ «Об оценочной деятельности в Российской Федерации».

2. Коростелев С. П. Кадастровая оценка недвижимости: учеб. пособие. М.: Маросейка, 2010. 380 с.

3. Официальный сайт Австралийского института оценки. URL: http://www.api.org.au

4. Australian Valuation Industry Review -Only QLD, NSW \& WA State Gov's License Valuers - February 1, 2011. URL: http://www.australian-realestate.net.au/investing/2011/02/01/australian-valuation-industry-review-only-qldnsw-wa-license-valuersand-no-nationalregulation

5. Сайт Канадского Института Оценки (Appraisal Institute of Canada - AIC). [Электронный доступ]. URL: http://www.aicanada.ca

6. Верхозина А. В., Федотова М. А. Сравнительный анализ международного и российского законодательства в области оценочной деятельности.

7. Сайт Фонда оценки США (Appraisal foundation). [Электронный доступ]. URL: http://www.appraisalfoundation.org

8. Сайт Подкомитета по оценке (Appraisal Subcommittee) [Электронный доступ]. URL: https://www.asc.gov/Home.aspx

9. Сайт Американского сообщества оценщиков (American Society of Appraisers) [Электронный доступ]. URL: http://www.appraisers.org/ASAHome.aspx

10. Портал «Appraiser.Ru. Вестник оценщика» [Электронный доступ]. URL: http://www.appraiser.ru

11. Портал: «Корпоративный менеджмент - финансовый анализ инвестиции, бизнес-планы, консалтинг» [Электронный доступ]. URL: http://www.cfin.ru

12. .Официальный сайт Китайского Общества Оценщиков CAS. URL: http://www.cas.org.cn/ENGLISH/TheCon stitution of CAS/40023.htm , http://www.cas.org.cn/ENGLISH/Introducti on of CAS/Major Functions and Responsibilities/40011.htm )

13. Данные СМИ. URL: http://www.china.org.cn/business/2012-02/28/content_24748019.htm

http://www.chinabriefing.com/news/2012/11/20/chinareleases-development-plan-for-assetappraisal-industry.html, http://www.mofo.com/news/xpqNewsDet ail.aspx?xpST=NewsDetail\&news=1618

14. База данных законодательных актов Китая (демонстрационная версия) (http://hk.lexiscn.com/law/standards-forassetappraisal--appraisal-reports.html )

15. Сайт World Association of Valuation Organisations ttp://www.webboe.com/wavo/page.asp? value1=45 )

\section{Сравнительно-правовой анализ правового регулирования в области ограничения недобросовестной конкуренции в России и Китае}

\author{
(C) Юй Xaй \\ магистрант 1 года обучения \\ Института экономики и управления \\ (С) М. Э. Лумбунова \\ студентка 3-го курса юридического факультета \\ ФГБОУ ВО «Бурятский госуниверситет» \\ Россия, г. Улан-Удэ \\ rita.lumbunova@mail.ru
}

1.Понятие и законодательное регулирование конкуренции

Что такое конкуренция? Элберт Хаббард сказал, «Конкуренция - жизнь торговли и смерть торговцев». И ведь верно, конкуренция это громадный рычаг, который запускает экономику, с помощью конкуренции появляются новые технологии, улучшается качество товаров. Пока есть конкуренция, есть и рыночная экономика. Пока есть конкуренция, есть и выигравшие и проигравшие. Лучшие производители, которые смогли удовлетворить потребности покупателей, будь то в качестве или в количестве, в зависимости от спроса, выходят на рынок продаж и занимают не самую последнюю нишу в экономике, а те которые не могут противостоять им - уходят. Таким образом, в конкуренции заключается одновременно и жизнь, и смерть.

Здоровая конкуренция поддерживается эффективной рыночной экономикой - экономикой, которая функционирует на принципах рыночных отношений, свободного предпринимательства, когда каждый покупатель свободен в выборе товаров, а каждый предприниматель свободен в выборе сферы приложения своей продукции или услуги, а также стремится удовлетворить потребности каждого. В России, основы в области защиты конкуренции закрепляется в ч.2 ст.34 Конституции РФ [1] - запрет на недобросовестную конкуренцию, провоз- 
глашая экономическую и правовую свободу участников рыночных отношений, а подробные организационные и правовые основы здоровой конкуренции и экономической свободы определяет Федеральный закон от 26.07.2006 № 135-Ф3 «О защите конкуренции» [2].

Первым законом КНР, защищающим свободный рынок, стал Закон «О защите от недобросовестной конкуренции», принятый 2 сентября 1993 г. на заседании постоянного совета ВСНП 8 созыва (1993年9月2日，中华人民共和国反不正当竞争法 [6]). Закон разработан в целях защиты здорового развития социалистической рыночной экономики путем поощрения и защиты добросовестной конкуренции и предотвращения фактов недобросовестной конкуренции для защиты законных прав и интересов производителей и потребителей [10]. Организационные и правовые основы защиты конкуренции, предотвращение злоупотребления доминирующим положением на рынке [13], определяет Закон «О противодействии монополиям» принятый 30 августа 2007г. на 29-м заседании Постоянного комитета Всекитайского собрания народных представителей 10-го созыва, опубликован и $\quad$ применяется $\quad$ с $\quad 1 \quad$ августа (中华人民共和国反垄断法2007年 8 月 30 日第十届全国人民代表大会常务委员会第二十九次会议通过 [7]).

В экономическом плане Китай является главным партнёром и союзником России. И к тому же в июле 2016г. исполнится ровно пятнадцать лет с момента подписания Договора о добрососедстве, дружбе и сотрудничестве между Россией и Китаем 16 июля 2001г. (中俄睦邻友好合作条约), подписанный на 20 лет с правом продления на 5 лет. Взаимная помощь в пресечении недобросовестной конкуренции является одним из пунктов данного соглашения. Отношения России и Китая имеют ключевое значение в российской внешней политике. Поэтому мы заинтересовались данной темой и решили сравнить паровое регулирование ограничения недобросовестной конкуренции этих стран.

На заре становления рыночных отношений в России и Китае, встала необходимость в правовой защите конкуренции от монополий, сговора хозяйствующих субъектов, завышения цен, а равно необходимость в обеспечении качественной продукции и увеличения объемов производства. Все эти вопросы послужили причиной для создания первых законов для создания свободной арены рыночных отношений.

2.Ограничение недобросовестной конкуренции

В соответствии со ст. 4 Федерального закона РФ от 26.07.2006 №135-Ф3 «О защите конкуренции», недобросовестная конкуренция - это любые действия хозяйствующих субъектов (группы лиц), которые направлены на получение преимуществ при осуществлении предпринимательской деятельности, противоречат законодательству Российской Федерации, обычаям делового оборота, требованиям добропорядочности, разумности и справедливости и причинили или могут причинить убытки другим хозяйствующим субъектам - конкурентам либо нанесли или могут нанести вред их деловой репутации [2].

В КНР, в соответствии с Законом «О защите от недобросовестной конкуренции», недобросовестной конкуренцией признаются действия коммерческих организаций по установлению цены ниже средней цены или себестоимости товара, используют неправомерным образом прибыль производимой продукции или услуги, которые наносят ущерб правам и законным интересам других коммерческих предприятий, одновременно нарушая социально-экономический порядок страны.

Россия и ее взгляды на формы недобросовестной конкуренции:

1. распространение ложных, неточных или искаженных сведений, способных причинить убытки другому хозяйствующему субъекту либо нанести ущерб его деловой репутации;

2. введение потребителей в заблуждение относительно характера, способа и места изготовления, потребительских свойств, качества товара;

3. некорректное сравнение хозяйствующим субъектом производимых или реализуемых им товаров с товарами других хозяйствующих субъектов;

4. продажа товаров с незаконным использованием результатов интеллектуальной деятельности и приравненных к ним средств индивидуализации продукции, выполнения работ, услуг;

5. получение, использование, разглашение научно-технической, производственной или товарной информации, в том числе коммерческой тайны, без согласия ее владельца.

В России ряд ограничений недобросовестной конкуренции также устанавливает Федеральный закон от 13.03.2006 N 38-Ф3 (ред. от 08.03.2015) «О рекламе» [4]. Ст. 3 предусматривает, что ненадлежащая реклама это реклама, не соответствующая требованиям законодательства Российской Федерации.

Законодательство о рекламе выделяет следующие формы ненадлежащей рекламы:

- недобросовестная реклама;

- неэтичная реклама;

- заведомо ложная реклама;

- скрытая реклама [14].

Китай и ее взгляды на формы недобросовестной конкуренции:

1) фальсифицировать зарегистрированные торговые марки других предпринимателей;

2) использовать без получения предварительного разрешения названия, упаковку, отделку одинаковую или аналогичную другим известным маркам, что вводит покупателя в заблуждение и заставляет его принимать данный товар за товар известных марок;

3) использовать без получения предварительного разрешения названия других предприятий или имена, что ведет к тому, что покупатель принимает данный товар за товар других марок; 
4) подделывать или нарушать идентификационные обозначения, маркировку товаров высшего качества и другую маркировку качества продукции, фальсифицировать место производства товара или использовать другие фальшивые обозначения, которые вводят покупателя в заблуждение в отношении качества товара [12].

К недобросовестным конкурентным действиям в Китае относится ложная или обманная реклама. Не допускается распространение недостоверных сведений (недобросовестной рекламы), вводящих в заблуждение потребителей относительно свойств товара, с целью получения конкурентных преимуществ [8].

Таким образом, в целом законодательство обеих стран повторяют вдруг друга, однако есть и незначительные отличия, которые, безусловно, исходят из характера экономики каждой страны. Целями экономики РФ являются обеспечение единства экономического пространства, свободного перемещения товаров, свободы экономической деятельности, защита конкуренции и создание условий для эффективного функционирования товарных рынков, а сферой применения - отношения, которые связаны с защитой конкуренции, в том числе с предупреждением и пресечением монополистической деятельности и недобросовестной конкуренции [5]. Целями экономики КНР являются повышение эффективности управления рыночной экономикой, улучшение технологий, исследований и развитие новой продукции, улучшение качества продукции, снижение ее себестоимости, укрепление конкурентоспособности малых и средних хозяйствующих субъектов, защита законных интересов в сфере внешнеэкономического сотрудничества и внешней торговли [9]. Китайское законодательство старается не только обеспечить свободное перемещение товаров на территории одного государства, но также сохранить окружающую среду, и не допустить экономической депрессии. Из-за большого количества населения даже политика на сдерживание недобросовестной конкуренции направлена на сбережение энергии за счет улучшения характеристик продукции и ее стандартов. Это положительные стороны, которым стоило уделить внимание законодательству РФ. Во всяком случае, для того чтобы обеспечить эффективную экономику и защитить ее от недобросовестной конкуренции, необходимо взаимное заимствование опыта в регулировании основных вопросов данной области.

\section{Литература}

1. Конституция Российской Федерации (принята всенародным голосованием 12.12.1993) [Электронный ресурс] // СПС «Консультант-плюс». Режим доступа: http://base.consultant.ru/cons/cgi/online.cgi?req=doc;base=LAW;n=2875

2. Федеральный закон от 26.07.2006 N 135-ФЗ (ред. от 05.10.2015) «О защите конкуренции» (с изм. и доп., вступ. в силу c 10.01.2016) [Электронный ресурс] // СПС «Консультант-плюс». Режим доступа: https://www.consultant.ru/document/cons_doc_LAW_61763/

3. Федеральный закон от 26.07.2006 N 135-Ф3 (ред. от 05.10.2015) «О защите конкуренции» [Электронный ресурс] // СПС «Консультант-плюс». Режим доступа: http://base.consultant.ru/cons/cgi/online.cgi?req=doc;base=LAW;n=183145

4. Федеральный закон от 13.03.2006 N 38-Ф3 (ред. от 08.03.2015) «О рекламе» (с изм. и доп., вступ. в силу с 01.10.2015) [Электронный ресурс] // СПС «Консультант-плюс». Режим доступа: https://www.consultant.ru/document/ cons_doc_LAW_58968/

5. Постановление от 2 сентября 2014 г. по делу № А51-17482/2013 по вопросу о защите конкуренции. Председатель судебного состава Федерального арбитражного суда Дальневосточного округа Л. К. Кургузова [Электронный ресурс]. Режим доступа: http://sudact.ru/arbitral/doc/lvk3Ve7GnwgV/
6. Закон
KHP
$« \mathrm{O}$
защите
от недобросовестной
конкуренции» (中华人民共和国反不正当竞争法（１９９３年９月２日第八届全国人民代表大会常务委员会第三次会议通过）中华人民共 和国主席令) [Электронный ресурс] // Режим доступа: http://www.law-lib.com/law/law_view.asp?id=245

7. Закон КНР 《O 中华人民共和国反垄断法(2007年8月30日第十届全国人民代表大会常务委员会第二十九次会议通过) [Электронный ресурс] // Режим доступа: http://wenku.baidu.com/link?url=cBkWJ4f8xU-B6RUQC-BSeH8iDxTGVB5QcVrb6FAtshnVQ710FgWHBQz7ZltO0eyXZRhfYW3fwGi1J55NWRfKHpNaSFkGljGW4I-UgQh1Q3

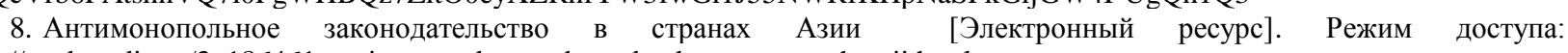
http://studopedia.ru/3_186461_antimonopolnoe-zakonodatelstvo-v-stranah-azii.html

9. Еременко В. И. Антимонопольное законодательство зарубежных стран. М.: ВНИИПИ, 1997. С. 36-68.

10. Еременко В. И. Охрана промышленной собственности в Китайской Народной Республике. 2-е изд. М.: ИНИЦ Роспатента, 2004. С. 77-92.

11. Определение от 13 января 2016 г. по делу № А51-14975/2015 Арбитражный суд Дальневосточного округа в составе председательствующего судьи Е.П. Филимоновой [Электронный ресурс]. Режим доступа: http://sudact.ru/arbitral/doc/od5Rhsrt9ulW/

12. Перевод Закона КНР «О недобросовестной конкуренции» [Электронный ресурс]. Режим доступа: http://www.asiabusiness.ru/law/law2/marketing/competition

13. Перевод Закона КНР «О противодействиям монополиям» Павла Бажанова [Электронный ресурс]. Режим доступа: http://pavel.bazhanov.pro/translations/chinaeconomiclaw/china_antimonopoly_law/

14. Правовые формы ограничения недобросовестной конкуренции [Электронный ресурс]. Режим доступа: http://bibliotekar.ru/kodex-7/31.htm 


\title{
IV. УГОЛОВНО-ПРАВОВЫЕ И КРИМИНОЛОГИЧЕСКИЕ ПРОБЛЕМЫ СРАВНИТЕЛЬНОГО ПРАВОВЕДЕНИЯ В СТРАНАХ АТР
}

\author{
Профилактика коррупции в образовании: опыт Китая
}

\author{
(C) А. С. Байкалов \\ магистрант 1 года обучения юридического факультета \\ ФГБОУ ВО «Бурятский госуниверситет» \\ Россия, г. Улан-Удэ \\ juristbaikalov@gmail.com
}

\begin{abstract}
Данная статья написана с целью привлечения внимания к китайскому языку и изучению права Китая. По мнению автора, нехватка переведенных источников сильно сказывается на восприятии правовой системы КНР. Знания россиян о Китае становятся стереотипными и несоответствующими действительности. Выражая свое мнение о необходимости чего-либо, мы фактически формируем спрос. Китай - именно та азиатская страна, с помощью которой можно формировать собственное право. Россия должна брать пример с Китая.

Самой коррумпированной страной после России считается Китай, занимая 28 и 27 места в рейтинге Transparency International по состоянию на 2011 год [4]. Те источники, которые свидетельствуют об обратном, всего-навсего предоставляют сведения выгодные для китайского правительства, не соответствующие современным реалиям. Автору не хотелось бы затрагивать вопрос, почему искажаются некоторые факты, выгодные КНР. Тем боле, что дальше пойдет не критика, а подчеркивание положительной зарубежной практики в противодействии коррупции, конкретно в сфере образования.
\end{abstract}

Если делать выводы по официальным изданиям, то Китай стремительно врывается, хоть не в лидеры, но даже просто в число стран, которые формируют международный уровень образования [3]. Также можно подчеркнуть, что считавшееся недосягаемым для большинства населения обучение в старшей школе (только около $30 \%$ учащихся получали образование выше средней школы) на сегодняшний день стало доступным большинству.

Ярким примером образовательных успехов служит «56 международная математическая олимпиада» среди школьников, проходившая 15 июля 2015 года в Таиланде. По результатам общего зачета китайская сборная заняла 2 место. К таким успехам Китай пришел благодаря реформе образования, начавшейся со второй половины 80-х годов прошлого века. Проследить динамику и этапы развития можно с помощью хронологии нормативных правовых актов в законодательстве страны. Таковыми являются: 1) Постановление ЦК КПК относительно реформы системы образования (05.1985 г.); 2) Закон об обязательном образовании КНР (04.1986 г.); 3) Программа реформ и развития образования Китая (02.1993 г.); 4) Закон об учителе КНР (03.1995 г.); 6) План действий для активизации образования навстречу 21 -му веку (12.1998 г.); 7) Постановление ЦК КПК и Госсовета КНР относительно углубления реформы образования, направленного на повышение качественных характеристик учащихся (07.1999 г.); 8) Учебная программа для предметов в повседневной высшей средней школе (ЭКСПЕРИМЕНТ) (01.2001 г.); 9) Программа реформы предметов в сфере базового образования (ЭКСПЕРИМЕНТ) (07.2001 г.); 10) Сообщение Министерства образования КНР относительно активного продвижения системы оценок и экзаменов в школах $(12.2002$ г.); 11) План реформы предметов в сфере повседневной высшей школы (ЭКСПЕРИМЕНТ) (03.2003 г.); 12) Закон об обязательном образовании КНР (06.2006 г.).

Из приведенного выше перечня законов можно сказать, что Китаем была проведена за 20 лет по объемам меньшая реформа, чем в Российской Федерации. Для России потребовалось всего 8 лет, чтобы перекроить всю систему образования (начиная с присоединения с 2003 года к Балонскому процессу до введения 2-хуровней системы высшего образования в 2011 году). Не удивительно, что Китай достигает высоких успехов в образовании на международном уровне, благодаря понятным для населения и преподавателям мерам по реформированию. Еще одной положительной тенденцией является то, что образование в Китае в целом нацелено на практическую ориентированность [2, с. 10]. Это не значит, что при получении образования кому-то обеспечена работа. Вся особенность в том, что устраиваются на работу при минимально необходимом образовании (имеется в виду без высшего). Однако для получения высшего образования и для продвижения по карьерной лестнице не требуется больших усилий и времени. В Китае возможно получить необходимый сертификат за 2 года.

Образование в старшей школе и в ВУЗах является полностью платным, поэтому общая коррумпированность страны практически не влияет на образовательные процессы. Тем более, что экзамены как в школах, так и в ВУЗах являются едиными [1, с. 105]. В России только ЕГЭ выполняет подобные функции. Как стало известно, 
именно единые экзамены эффективно борются со внутренней коррупцией. Россия пока отказывается от идеи введения единых экзаменов в ВУЗах, ссылаясь на их стоимость для самих учебных заведений.

Анализ законодательного реформирования системы образования Китая показывает, что все нововведения соответствуют потребностям населения. Со стороны Правительства не было действий, которые были не востребованы, это подтверждается увеличением числа студентов и учеников старшей школы от $20 \%$ до $60 \%$. Не удивительно, что в литературе практически не встретишь отрицательных отзывов реформы (это касается и западных источников).

Подводя итог, необходимо сделать вывод относительно нашей страны. Россия имеет уже положительный опыт проведения единого экзамена в школах. Необходимо также эту тенденцию перевести и на ВУЗы. Однако учитывая, как опыт Китая, так и наш опыт, нужно поэтапно вводить изменения. Кардинальным отличием реформирования между нашими странами стал тот факт, что изменения в Китае подробно разъясняются как населению, так и преподавателям, и только после этого вводятся.

\section{Литература}

1. Кананыкина. Педагогические модели развития образования стран романо-германской правовой семьи // Философия и культура. 2010. № 2. С. 104-107.

2. Чжан Лили. Состояние китайского высшего образования // Высшее образование в России. 2002. № 5. С. 10. 2009.

3. The 2008 Green Paper on Education in China (Зеленая книга: Образование в Китае 2008). Пекин. Образование и наука.

4. Сайт: transparency.org.ru / Индекс взяткодателей -2011: Позор на экспорт.

\section{Анализ опыта легализации оружия в США и право на ношение оружия в России: сравнительно-правовая характеристика}

(C) А. С. Балаганская

студентка 2-го курса юридического факультета ФГБОУ ВО «Бурятский госуниверситет»

Россия, г. Улан-Удэ

nirvanapasani@mail.ru

Самозащита - это одно из ключевых составных российского права. Без нее все остальные права рискуют остаться пустым местом в правовой сфере. Именно это право отражает цель написания моей статьи. Многие говорят, что оружие нам нужно для самообороны, между тем, они не знают, как пользоваться оружием. Это большая ответственность. Необходимо более детально разобрать проблему легализации оружия, установить его необходимость на современном этапе развития российского общества.

Во времена античности правом на ношение оружия обладали только свободные граждане, это было их обязанностью, и в этом заключалось их отличие от раба. В Средние века право владеть оружием принадлежало господствующему классу. Городское население активно боролось за это право. Меч или шпага служили отличаем дворянина от простолюдина, смерда. В Новое время оружие служило гарантом демократического порядка в обществе. Оружие понимается как право на защиту от посягательств на жизнь, честь и имущество гражданина. Вторая поправка Конституции США несет в себе именно этот смысл. Начиная с 15 века, в Российском государстве начинает формироваться правовой режим оборота оружия. Со времен правления Петра Великого оружие становится символом чести и достоинства. В Российской Империи до революции 1917 года правом на оружие в качестве самообороны обладал почти каждый поданный. Помимо самозащиты они могли приобретать оружие для занятий спортом или в целях охоты. Большевики до революции распространяли лозунги всеобщего вооружения, но уже после прихода к власти и Первой мировой войны они приступили к разоружению, так как им не хотелось создавать себе препятствий при проведении красного террора и продразверстки. После окончания НЭПа запрет на приобретение и ношение оружия для простых граждан стал абсолютным. Во времена правления Хрущева охотничье оружие можно было купить, лишь предъявив паспорт. В брежневские времена право на огнестрельное оружие принадлежало только охотоведам, профессиональным охотникам из Севера и Сибири.

После падения коммунистического режима огнестрельное оружие самообороны было восстановлено в правах. В 1992 г. выходит первый единый российский законодательный акт - Закон РФ «Об оружии», который закрепил в себе систему государственного контроля за оборотом оружия и определил место оружия среди органов внутренних дел. 13 декабря 1996 Государственная дума принимает Федеральный закон № 150 - Ф3 «Об оружии», который действует в нашей стране и сейчас.

В Российской Федерации ношение, а также хранение огнестрельного оружия категорически запрещено. Действующий президент В.В. Путин не раз говорил, что он против инициативы Правительства легализовать оружие, он обосновывает, это тем, что это пагубно скажется на безопасности населения.

В России первый закон относительно легализации оружия был принят в 1993 году, согласно которому гражданин имеет право на приобретение газового, травматического или другого небоевого вида оружия. В 1996 году ввели еще один закон, который разрешил населению приобретать длинноствольные виды оружия и короткоствольные газовые. Однако в 2001 году шум в отношении оружия и необходимости разрешения населению 
владения им возобновился. В 2003 году законодатели пытались легализовать пистолеты и револьверы, но проект закона не был принят. В 2004 году газовые пистолеты получили лицензию, можно было использовать резиновые пули, а также травматические пистолеты с резиновыми пулями.

Если рассматривать вопрос в корне, то он исходит не из простого решения власти «разрешить или запретить». Легализация оружия затрагивает базовые проблемы отношений человека и власти. Следует спросить у населения, а нужно ли нам вообще оружие? Какую помощь оно нам принесет?

Так сложилось, что в России практика свободного ношения и продажи оружия не знакома нашим стереотипам социального поведения, традициям и культуре. Население Америки всю свою историю имело дома оружие, свободно пользовалось им, где только захотят. Это для них обычный образ жизни. Но это не правильно. Само население Российской Федерации сугубо отрицательно относится к легализации оружия. Согласно статистике на 2015 год, против такой инициативы выступило более 75\% жителей. Согласно Конституции Российской Федерации, права человека - это наивысшая ценность, стоящая на одной ступени со свободой, тогда кому, как ни нам, решать, нужно нам оружие или нет.

Вопрос о легализации оружия - это вопрос о самосознании общества в целом и индивидуума в отдельности.

К примеру, вспомним митинги на Болотной, как народ безжалостно кидал камни в сотрудников правоохранительных органов, а теперь представим, что в Российской Федерации легализовали оружие, и вместо камней применяли оружие, тогда сотрудники правоохранительных органов пришли бы не с дубинками, а с автоматами.

Многие активисты, поддерживающие легализацию оружия в РФ, приводят нам статистики опыта других стран. Например, опыт США, Финляндии, Швейцарии.

Конституция США законодательно закрепила право на ношение оружия. Американцы считают это право священным и неотъемлемым. В разных штатах оно реализуется по-разному. По данным 2007 года в США проживало 5\% от общего числа населения всего земного шара, но эти люди владели половиной всего существующего на свете огнестрельного оружия. Именно в руках граждан находится две трети огнестрельного оружия страны, армия и полиция используют всего треть официально зарегистрированного оружия.

Так, согласно данным, уровень преступности в США гораздо ниже, чем в России, благодаря свободному ношению и хранению оружия, как утверждают активисты.

За период с 1973-1992 гг. количество убийств сократилось на 10\%, а количество оружия возросло на $73 \%$ это 222 миллиона оружия. Количество людей, владеющих оружием, составляет 78 миллионов человек.

Согласно данным ФБР, начиная с 90-ых годов количество случаев применения оружия снижается. Согласно статистике полиции США, те, кто имеют оружие, намного реже становятся жертвами преступлений.

Хотелось бы добавить, что статистика в странах со свободной продажей оружия составляется как это выгодней, прежде всего им.

Когда приводят в пример Америку или Швейцарию, забывают о том, что оружие легкодоступно населению, прежде всего потому что армия этих стран на начальном этапе развития государства задумывалась, как народное ополчение. На самом деле знаменитая вторая поправка к американской конституции гласит: «Хорошо организованное ополчение необходимо для безопасности свободного государства, для этой цели право народа хранить и носить оружие не должно нарушаться». Даже после того, как американцы после войны 1812 года осознали свою ошибку и создали регулярную армию, вторая поправка осталась, как дань всеми любимому популизму.

Стоит вспомнить несколько примеров из опыта США, чтобы сделать вывод о том, как оружие влияет на общественную безопасность.

20 июля 2012 года в городе Аврора штата Колорадо в кинотеатре на показе фильма про Бэтмена произошло массовое убийство. Человек в противогазе врывается в зал, кидает гранату и открывает огонь. Жертвами убийства стали 12 человек, 58 - ранены. Убийцу арестовывают. Джеймс Холмс - обычный студент, который любил комиксы.

14 декабря 2012 года в штате Коннектикут произошла бойня в школе Сэнди-Хук. В итоге 27 погибших, из них 20 - дети, ученики начальных классов. Убийца - Адам Ланца, 20 лет, студент. Жил с матерью, известно, что в доме было, как минимум, 12 стволов. Для Америки - вовсе не редкость. Мать Ланца, научившая его стрелять, и стала первой его жертвой. Он застрелил её, а потом отправился в Сэнди Хук. Во всех этих случаях преступники имели свободный доступ к пользованию оружием. Мать Ланца работала воспитателем в детском саду. Как законодатели позволяют приобретать оружие человеку, работающему с детьми?

Например, в Техасе оружие можно купить, предъявив водительские права. Патроны можно свободно купить в супермаркете, как хлеб. Оружие можно носить везде, кроме государственных и общественных учреждений. Носить с собой пистолеты можно в 32 штатах из 52.

Среди молодежи США до 20 лет, убийства с применением огнестрельного оружия стоят на втором месте, на первом месте - убийства афроамериканской молодежи. Каждый день из-за применения оружия в США погибает в среднем 13 детей. Поэтому, многие считают, что нужно ужесточить легализацию оружия, а некоторые говорят, что вторая поправка к Конституции устарела и не соответствует современному американскому праву.

Если обратиться к истории Америки, то можно увидеть, как запреты на продажу товаров приводят к образованию черного рынка запрещенных товаров, например, времена «сухого закона». На сегодня под запретом стоят наркотики, но, несмотря на их запрет, наркотический бизнес приносит самые большие доходы. В настоящее время в США активно процветает черный рынок оружия. Поэтому, даже если произойдет ужесточение 
правил на приобретение оружия, потребителей черного рынка оружия эти правила не коснутся. Следовательно, отобрать оружие у преступников практически невозможно.

В США оружие занимает особый статус, имеет неприкасаемое место среди разного рода средств уничтожения людей. Не было никакой информации о том, что хотя бы один оружейник заплатил суду за то, что из его оружия кого-то убили, тогда, как табачные корпорации ежедневно подвергаются судебным преследованиям. Люди специально придумали термин «пассивный курильщик» для тех, кто не курит, но страдает от того, что курят другие. Но все молчат о «пассивных стрелках», которые становятся жертвами огнестрельного оружия.

Ношение оружия само по себе не несет какой-либо ценности, это ни на что не влияет, кроме негативных последствий - развития культуры оружия, повышения уровня насилия среди населения.

Многие скажут, оружие дано нам для защиты, что наша полиция не в силах всех нас защитить. Мы хотим, чтобы государство обеспечивало нашу безопасность, чтобы оно методично уменьшало количество нелегальных стволов, а не раздавало со словами «вдруг сумеете защититься». В истории России было всего два периода, когда государство не могло защитить население, а у гражданских лиц было значительное число огнестрельного оружия - это Гражданская война и бандитские девяностые.

Стоит отметить вопрос о необходимой обороне с использованием огнестрельного оружия на примере США. В 9 из 10 случаев использование оружия при обороне не является необходимым, никто не станет нападать на вооруженную жертву. В Российском уголовном праве будет трудно доказать, что была необходимая оборона, и лишь в $20 \%$ случаев вы избежите наказания. Но вспомним английскую пословицу - «Лучше стоять перед двенадцатью (перед присяжными), чем лежать на руках у шестерых (в гробу)».

Чтобы суметь защититься, нужно научиться владеть оружием. Необходима инфраструктура и высокие доходы у населения для приобретения оружия и оплаты обучения навыкам владения оружием.

Высокий уровень коррупции в России дает отличные возможности для получения легального приобретения оружия с помощью подкупа.

Проблему нелегального приобретения оружия мы не решим, закон вовсе не потребуется преступникам, которые собираются вооружиться. В России, согласно оценкам криминологов, порядка нескольких миллионов стволов огнестрельного оружия находятся в незаконном обороте, они были получены с помощью контрабанды оружия или были украдены со складов. Каждый год правоохранительная структура занимается изъятием нелегального оружия.

К каким последствиям может привести легализация оружия? К хорошим точно не приведет. Произойдет резкое повышение уровня агрессии во взаимоотношениях граждан, произойдет скачок роста преступлений, связанных с применением оружия, особенно это касается бытовых преступлений. Стоит напомнить, что на данный момент самым распространенным орудием убийства является нож, огнестрельное оружие заменит его.

Произойдет снижение уровня безопасности, возрастет уровень случайной гибели невинных людей.

Подводя итог, стоит отметить, что убивает не само оружие, а тот, кто им владеет, человек. Распространение оружия приведет к тому, что первой спонтанной реакцией на любой раздражитель станет выстрел.

\section{Литература}

1. Конституция Российской Федерации (принята на всенародном голосовании 12 декабря 1993 г.) // Российская газета. 1993. 25 дек.

2. Об оружии: [федер. закон № 150-ФЗ от 13 дек. 1996 г.] // Рос. газ. 1996. 18 дек.

3. История США / под ред. Г. Н. Севостьянова. М., 1983. Т. 1.

\section{Актуальные проблемы противодействия коррупционной деятельности в Российской Федерации и Китайской Народной Республике}

() Б. Б. Батоев

магистрант 2 года обучения Института экономики и права ФГБОУ ВО «Восточно-Сибирский государственный университет технологий и управления»

Россия, г. Улан-Удэ batoev87@mail.ru

Коррупция позволяет нарушителям уходить от юридической ответственности за совершенные противоправные деяния - это порождает безнаказанность и способствует падению престижа правоохранительных и судебных органов, а также в целом государственной власти в глазах населения, что в итоге порождает опаснейшее явление - правовой нигилизм.

Разрастанию коррупции и, в частности, ее наиболее общественно опасной формы проявления взяточничеству способствуют самые разнообразные факторы, как субъективного, так и объективного характера.

В настоящее время в мире нет ни одного государства, в котором бы совершенно отсутствовала коррупция. Однако во многих индустриально развитых зарубежных государствах создана действенная система пресечения коррупции, сформирована атмосфера нетерпимости общества в целом к этому опасному социальному явлению. 
По данным исследований, проведенных в нашей стране, коррупция, как массовое социальное явление в системе государственной власти и управления, а также в системе государственной и муниципальной службы, еще не получила должного общественного осуждения.

Бизнесмены, предприниматели, т.е. представители бизнес-сообщества, а зачастую и граждане, не имеющие отношения к бизнесу, вполне терпимо относятся к фактам коррупции среди служащих органов власти и управления, более того, большинство считают, что с помощью коррупции можно добиться решения многих возникающих проблем. А отдельные служащие органов власти и управления рассматривают взятку, как почти «легальную» дополнительную форму оплаты своего труда.

Сложившаяся, таким образом, противоправная обстановка, угрожающая национальной безопасности и экономическому развитию нашей страны, не может длиться бесконечно.

Коррупция - в самом широком понимании явления - это использование служащим органа власти и управления своих властных полномочий в личных интересах, а также в интересах третьих лиц или групп. В современной научной литературе, и в практике противодействия коррупции выделяют несколько ее видов. Преимущественно акцентируется внимание на политической, экономической, административной, бытовой и элитной коррупции; кроме того, выделяют национальную и международную коррупцию. Все перечисленные виды коррупции носят социально опасный характер, и они, безусловно, между собой взаимосвязаны. Последствия коррупции непременно сказываются на уровне развития социальной и экономической инфраструктуры государства. Наибольшую опасность несет в себе политическая и административная коррупция, а также коррупция, которая имеет место в судебных и правоохранительных органах. Как уже отмечалось, коррупция в государственных институтах подрывает доверие населения к органам государственной власти, снижает престиж страны на международной арене.

Административная же коррупция, которая имеет место в органах исполнительной власти и управления, способствует формированию рынка бюрократических услуг; кроме того, этот вид коррупции способствует развитию чиновничьего предпринимательства, а также организации заведомо привилегированного бизнеса.

Все это самым негативным образом сказывается на развитии предпринимательской деятельности, добросовестной конкуренции, защите прав потребителей.

Особенностью современной коррупции является и то, что она последовательно расширяет зоны своего влияния за счет новых, ранее защищенных от нее сфер воздействия, что делает ее особенно опасной.

Будучи обеспокоенной серьезностью порождаемых коррупцией проблем и угроз для стабильности и безопасности международного общества, подрывающих демократические институты и ценности, этические ценности и справедливость, Генеральная Ассамблея Организации Объединенных Наций 21 ноября 2003 г. на 58-й сессии приняла Конвенцию Организаций Объединенных Наций против коррупции, в которой отразила основные положения, меры по предупреждению коррупции и механизмы борьбы с ней[1].

В России также принимаются беспрецедентные меры по борьбе с этим явлением. Фундаментальным антикоррупционным законом стал Федеральный закон от 25 декабря 2008 г. № 273-Ф3 «О противодействии коррупции», содержащий в себе определение коррупции и регламентирующий основные направления по борьбе с коррупционными проявлениями в Российской Федерации[2]. Наряду с указанными положениями в данном законе также определены сферы деятельности, наиболее подверженные коррупции, и субъекты коррупционных правонарушений.

В соответствии со Стратегией национальной безопасности Российской Федерации до 2020 года коррупция признана одной из основных угроз для общества и государства[3]. В этой связи Указом Президента Российской Федерации от 13 апреля 2010 г. № 460 была утверждена Национальная стратегия противодействия коррупции, определившая ключевые направления организации работы по системному противодействию коррупции и предупреждению ее проявлений[4].

В целях консолидации усилий, направленных на противодействие коррупции, начиная с 2010 года Президентом Российской Федерации последовательно утверждались Национальные планы противодействия коррупции[5]. В настоящее время действует Национальный план противодействия коррупции на 2014-2016 годы[6].

Следует отметить, что в пункте 1 приказа Генерального прокурора Российской Федерации от 29 августа 2014 г. № 454 «Об организации прокурорского надзора за исполнением законодательства о противодействии коррупции» предписано рассматривать коррупцию как одну из системных угроз безопасности Российской Федерации, принимать меры к усилению борьбы с ней и активизации работы по выявлению и пресечению злоупотреблений служебными полномочиями. Важнейшей же задачей надзорной деятельности считается своевременное предупреждение коррупционных правонарушений, выявление и устранение их причин и условий, минимизация и (или) ликвидация последствий коррупционных правонарушений[7].

Таким образом борьба с коррупцией является приоритетным направлением правоохранительной деятельности в Российской Федерации.

Противодействие этому явлению включает в себя три этапа:

1) предупреждение (профилактика) коррупции, в том числе выявление и устранение причин коррупции;

2) выявление, предупреждение, пресечение, раскрытие и расследование коррупционных правонарушений (названный законодателем борьбой с коррупцией);

3) минимизация и ликвидация последствий коррупционных правонарушений[8].

В этой связи, а также в целях обеспечения единого подхода и полноты отражения в формах государственного статистического наблюдения сведений о состоянии преступности Генеральной прокуратурой Российской 
Федерации совместно с МВД России были разработаны и введены в действие перечни статей Уголовного кодекса Российской Федерации, используемые при формировании статистической отчетности, в числе которых закреплен перечень преступлений коррупционной направленности[9].

Учитывая изложенное, следует отметить, что в России предпринимаются активные действия по борьбе с коррупцией, к числу которых относится получение и анализ общих статистических данных о состоянии преступности, однако приходится констатировать отсутствие единого для всех органов, занимающихся антикоррупционной деятельностью, нормативно-правового акта, позволяющего систематизировать преступления коррупционной направленности и на его основе вести статистический учет. В стране не налажен единый подход к ведению государственного статистического наблюдения сведений о состоянии коррупционной преступности, проблема единой классификации преступлений коррупционной направленности в российском законодательстве не решена.

Борьба с коррупцией в Китае ведется по разным направлениям: издаются различные постановления, директивы и резолюции, а также совершенствуется антикоррупционное законодательство. В процессе пересмотра уголовного законодательства КНР один из 17 рассмотренных вариантов "Закона по борьбе с коррупцией и взяточничеством" вошел в Уголовный кодекс, который был принят 14 марта 1997 год (вступил в силу 1 октября 1997 года).

Согласно действующим нормам, оговариваемым в УК, в отношении пойманных на коррупции чиновников и партийных функционеров практически любого уровня приговоры жесткие - либо огромные тюремные сроки или же смертная казнь. Со временем изменилась технология самой казни - вместо расстрелов ввелись более "гуманные" смертные инъекции. Двухлетняя отсрочка исполнения приговора означает возможность замены смертной казни на пожизненное заключение - с учетом примерного поведения и искреннего раскаяния осужденного. И всегда это сопровождается конфискацией имущества.

Начало одного из эффективных этапов антикоррупционной кампании в КНР датируется осенью 2002 года, когда на XVI съезде компартии бывший в то время генеральным секретарем ЦК КПК Цзян Цзэминь сформулировал основные принципы создания новой системы борьбы с мздоимством. Он призвал, опираясь на сочетание профилактических и радикальных мероприятий, сформировать принципиально новую систему противостояния пагубному явлению.

27 октября 2005 года Китай ратифицировал принятую в конце октября 2003 года Конвенцию ООН против коррупции (вступила в силу 14 декабря 2005 года).

Наряду с уже существовавшими централизованными структурами по борьбе с проявлениями продажности чиновников, таких как Центральная комиссия КПК по проверке дисциплины (учреждена в 1978 году) и министерство контроля, в декабре 2007 года было создано Национальное бюро по предупреждению коррупции при Верховной народной прокуратуре КНР. К функциям учрежденного ведомства относятся и выявления коррупционеров, и разработка комплексов антикоррупционных мер, и даже ведение собственных расследований. При местных прокуратурах также созданы подобные департаменты.

Одним из существенных достижений в процессе формирования законодательной базы по пресечению коррупции стало принятие в апреле 2005 года "Закона о государственных служащих", согласно которому все сотрудники государственно- управленческих структур КНР подлежат наказанию в случае уличения их во взяточничестве или нарушении дисциплины. В настоящее время среди китайских госслужащих, как утверждают руководители страны, практически не осталось "неприкосновенных" должностей.

В рамках антикоррупционной кампании 31 октября 2006 года Постоянный комитет Всекитайского собрания народных представителей (ВСНП) одобрил Закон "О борьбе с отмыванием денег", что позволило добиться определенных успехов и в этой сфере. Еще одним из видов борьбы с разложением власть имущих в Китае является ротация кадров во всех органах власти, которая способствует тому, что у расхитителей госсобственности чиновников нет возможности использовать уже сложившиеся служебные, родственные, дружеские и другие связи, способствующие незаконным действиям.

За 35 лет экономических реформ к уголовной ответственности за коррупционные действия привлечено около миллиона сотрудников партийно-государственного аппарата. Однако даже несмотря на публичные казни, что, конечно, сдерживает многих потенциальных правонарушителей, все же полностью искоренить случаи сговора представителей бизнеса и чиновничества не удается. По мнению аналитиков, благоприятной почвой для коррупции является отставание политических реформ от экономических, что позволяет чиновникам скрывать от общественного контроля управление госимуществом и природными ресурсами. Это помогает им превращать народное богатство в личную собственность.

В 2007 году Центральная комиссия КПК по проверке дисциплины выпустила указ, который предусматривал "снисходительность" в отношении тех нарушителей, которые добровольно сознаются в преступных деяниях. В октябре 2012 года агентство Синьхуа сообщило, что с октября 2007 года по июнь 2012 года надзирающие органы приняли более 6,606 млн жалоб на коррупцию лиц, по которым после разбирательств было наказано более 668 тыс. человек, захотевших обогатиться за счет государства.

За пять лет, с 2007 по 2012 годы в Китае было проведено около 640 тыс. расследований коррупционных дел. Более 660 тыс функционеров были наказаны.

По оценкам зарубежных экспертов, экономические потери от коррупции в КНР ежегодно составляют 13 $17 \%$ ВВП, около $20 \%$ государственного финансирования оседает в карманах недобросовестных чиновников, 
при содействии коррупционеров преступниками отмывается около 25 млрд. долл. Общий объем нецелевого использования бюджетных средств ежегодно превышает 8,5 млрд долларов.

По итогам 2010 года, как сообщала юридическая газета "Фачжи жибао", в Китае к высшей мере наказания и пожизненному заключению были приговорены 11 высших чиновников. Среди этих коррупционеров четверо были приговорены к пожизненному заключению, семеро - к смертной казни.

В июне 2011 года Центральный банк КНР в своем отчете сообщил, что с середины 1990-х годов из Китая уехали за границу или же исчезли в неизвестном направлении почти 16 тысяч партийных функционеров, а также чиновников органов безопасности, юстиции, государственных предприятий и китайских ведомств, расположенных за границей. В отчете также говорилось, что беглецы прихватили с собой в общей сложности около 800 млрд юаней (127 млрд долларов). Средства массовой информации в последние годы обращают внимание на то, с какой интенсивностью чиновники стараются вывезти из страны свои семьи. В этой связи в июле 2010 года были опубликованы антикоррупционные правила, согласно которым чиновники должны своевременно предоставлять начальству отчеты об изменениях своего семейного положения, местонахождении супруг и детей в случае их выезда за рубеж, личных доходах, находящемся в собственности жилье и семейных инвестициях.

С января нынешнего года в Китае усилилась борьба с преступлениями в сферах приобретения земельной собственности, образования, защиты окружающей среды, трудоустройства, здравоохранения, социальной защиты, а также с нарушениями закона в области безопасности пищевых продуктов и фармацевтики.

Расширяя кампанию, направленную на искоренение мздоимства на всех уровнях, сотрудники китайской прокуратуры за первые шесть месяцев 2013 года проверили деятельность свыше 13,8 тысячи чиновников и выявили более 9,7 тысячи случаев коррупции и хищений со стороны госслужащих. В опубликованном 22 июля докладе говорится, что за этот период был нанесен ущерб казне на сумму 1,77 млрд юаней (287 млн долларов).

Как сообщают пекинские СМИ, программа борьбы с коррупцией на 2013-2017 годы будет вынесена на рассмотрение 3-го пленума ЦК КПК, который состоится в ноябре текущего года. Решение о созыве пленума было принято на прошедшем 20 августа заседании Политбюро ЦК КПК. На нем было отмечено, что "наказание за коррупционную деятельность и ее предотвращение является важной политической задачей всей партии и общей ответственностью всего китайского общества".

В Китае, конечно, ответственность за взяточничество более жесткая, чем в России. Китай является мировым лидером по числу выносимых и приводимых в исполнение смертных приговоров. Так, по данным правозащитных организаций, в 2009 г. в Китае планировалось казнить около 5 тыс. человек. По различным данным, ежегодно в КНР приводят в исполнение от 2 до 7 тыс. смертных приговоров. Это подтверждается, к примеру, фактом того, что 60-летний Ли Пейинг был признан виновным во взяточничестве, растрате и присвоении чужого имущества. По данным следствия, он получил взяток на 26,6 млн. юаней (\$3,9 млн.) и присвоил более 82 млн. юаней (\$12 млн.) государственных средств. Ли был осужден в феврале, его казнь состоялась после того, как Верховный суд Китая отклонил апелляцию осужденного 15 июля 2009 г.

Также в 2009 г. бывший глава китайской нефтяной группы China Petroleum and Chemical Group, болеe известной как Sinopec, Чэнь Тунхай приговорен к смертной казни за взяточничество. Об этом сообщается без указания деталей.

\section{Литература}

1. Конвенция Организации Объединенных Наций против коррупции № 58/4 от 21.11.2003 // СПС КонсультантПлюс [Электронный pecypc]. URL: http://www.consultant.ru/edu/highschool/links/ (дата обращения: 27.03.2015).

2. О противодействии коррупции: федеральный закон от 25.12.2008 № 273-Ф3 (в ред. федерального закона от 28.12.2013 № 396-Ф3) // СПС КонсультантПлюс [Электронный pecypc]. URL: http://www.consultant.ru/edu/ highschool/links/ (дата обращения: 27.05.2015).

3. О Стратегии национальной безопасности Российской Федерации до 2020 года: Указ Президента Российской Федерации от 12.05.2009 № 537 (в ред. Указа Президента Российской Федерации от 01.07.2014 № 483) // СПС КонсультантПлюс [Электронный ресурc]. URL:http://www.consultant.ru/edu/highschool/links/ (дата обращения: 27.08.2015).

4. Национальная стратегия противодействия коррупции: Указ Президента Российской Федерации от 13.04.2010 № 460 // СПС КонсультантПлюс [Электронный ресурс]. URL: http://www.consultant.ru/edu/highschool/links/ (дата обращения: 27.08.2015).

5. О Национальной стратегии противодействия коррупции и Национальном плане противодействия коррупции на 20102011 годы: Указ Президента Российской Федерации от 13.04.2010 № 460 // СПС КонсультантПлюс [Электронный ресурс]. URL: http://www.consultant.ru/edu/highschool/links/ (дата обращения: 27.08.2014); О Национальном плане противодействия коррупции на 2012-2013 годы и внесении изменений в некоторые акты Президента Российской Федерации по вопросам противодействия коррупции: Указ Президента Российской Федерации от 13.03.2012 № 297 // СПС КонсультантПлюс [Электронный ресурc]. URL: http://www.consultant.ru/edu/highschool/Iinks/ (дата обращения: 27.05.2015).

6. О национальном плане противодействия коррупции на 2014-2015 годы: Указ Президента Российской Федерации от 11.04.2014 № 226 // СПС КонсультантПлюс [Электронный ресурс]. URL: http://www.consultant.ru/edu/highschool/ links/ (дата обращения: 27.06.2015).

7. Об организации прокурорского надзора за исполнением законодательства о противодействии коррупции: приказ Генерального прокурора Российской Федерации от 29.08.2014 № 454 // СПC КонсультантПлюс [Электронный ресурс]. URL: http://www.consultant.ru/edu/liighschool/links/ (дата обращения: 27.09.2015). 
8. О противодействии коррупции: федеральный закон от 25.12.2008 № 273-Ф3 (в ред. федерального закона от 28.12.2013 № 396-Ф3) // СПС КонсультантПлюс [Электронный ресурс]. URL: http://www.consultant.ru/edu/ highschool/links/ (дата обращения: 27.08.2015).

9. О введении в действие перечней статей Уголовного кодекса Российской Федерации, используемых при формировании статистической отчетности: указание Генеральной прокуратуры Российской Федерации и МВД России от 31.12 .2014 № 744/11/3 // СПС КонсультантПлюс [Электронный ресурс]. URL: http://www.consultant.ru/edu/ highschool/links/ (дата обращения: 30.10 .2015$)$.

10. О некоторых вопросах организации деятельности президиума Совета при Президенте Российской Федерации по противодействию коррупции (вместе с "Положением о порядке рассмотрения президиумом Совета при Президенте Российской Федерации по противодействию коррупции вопросов, касающихся соблюдения требований к служебному (должностному) поведению лиц, замещающих государственные должности Российской Федерации и отдельные должности федеральной государственной службы, и урегулирования конфликта интересов, а также некоторых обращений граждан"): Указ Президента РФ от 25.02.2011 N 233 // Собр. законодательства Рос. Федерации. 2011. N 9. Ст. 1223.

11. Россинская Е.Р. Антикоррупционная экспертиза нормативно-правовых актов и их проектов / М. С. Азаров, В. В. Астанин, И. С. Барзилова. М.: Проспект, 2010. С. 4.

12. Власов И. С, Колесник А. А., Кошаева Т. О. Правовые акты: антикоррупционный анализ: науч.-практ. пособие. М.: Волтерс Клувер, 2010. С. 27.

13. Смирнов Д. А. Укрепление стабильности и борьба с коррупцией в связи с усиление социальной направленности политики государства КНР // Материалы ежегодной конференции Центра совместной истории и политики Китая ИДВ РАН. 2010. С. 59-60.

14. Подолько Е. Борьба с коррупцией - гарантия процветания Китая // Политический журнал. 2008. N 9(186).

15. Афитский В. И. Принцип независимости судебной власти: общие проблемы реализации // Журнал российского права. 2008. N 4.

16. Ануфриева Е.А. Особенности методики предварительного расследования и судебного разбирательства по делам о коррупционных преступлениях, совершаемых сотрудниками ОВД: автореф. дисс. ... канд. юрид. наук. Томск, 2012. 25 с.

\title{
Некоторые вопросы противодействия терроризму и экстремизму на современном этапе
}

\author{
(С) О. Ц.-Д. Будаева \\ студентка 4-го курса юридического факультета \\ ФГБОУ ВО «Бурятский госуниверситет» \\ Россия, г. Улан-Удэ \\ bud_ayna@mail.ru
}

В настоящее время одним из основных источников угрозы международной безопасности признается террористическая и экстремистская деятельность организаций, группировок и отдельных лиц. Столь высокая степень общественной опасности данной угрозы обуславливает актуальность проблемы данной статьи - выработки эффективного международного механизма борьбы против терроризма и экстремизма. Опасность экстремистской деятельности для международной безопасности вызвана наблюдаемыми тенденциями повышения уровня ее организованности, создания крупных экстремистских формирований с развитой инфраструктурой, усиления взаимосвязи организованной преступности, в том числе транснациональной [6, с. 2].

Интенсивность экстремистской деятельности напрямую зависит от уровня ее финансирования и материально-технической оснащенности. В связи с последними политическими событиями, повлиявшими на взаимоотношения стран Запада и Российской Федерации, следует обратить внимание на сотрудничество со странами, которые входят в Азиатско-Тихоокеанский регион.

Несмотря на невысокий уровень угроз террористической направленности, имеющихся в странах Юго-Восточной Азии, законодательно все же эти государства рассмотрели наиболее острые вопросы противодействия этому опасному явлению [7, с. 129]. Авторы считают необходимым легально закрепить категорию «экстремизм» и «терроризм», так как данный специальный международный правовой акт позволит выделить ряд критериев квалификации той или иной деятельности как международный терроризм, создание единого списка организаций, деятельность которых является террористической или экстремисткой, замораживание активов и перекрытие каналов их финансирования.

Как считает О. Молдалиев, «необходимо создать международный механизм, способный в мировой монетарной системе надежно отслеживать и перекрывать все каналы финансирования политического и религиозного экстремизма. Нельзя ограничиваться лишь публикациями списков таких организаций и наиболее опасных преступников, необходимы соответствующие санкции против стран-спонсоров и укрывателей террористов» [3, с. 44].

Между тем, ни в законодательстве (в том числе, международном), ни среди ученых нет единого определения данной категории. Как верно отметил В. Выжутович, «...нужно, наконец, договориться, что такое экстремизм. В четком определении этого понятия равно заинтересованы и государство, и политические партии, и отдельные граждане, и общество в целом» [1]. Шанхайская конвенция о борьбе с терроризмом, сепаратизмом и экстремизмом от 15 июня 2001 г. определяет экстремизм как какое-либо деяние, направленное на насильственный захват власти или насильственное удержание власти, а также на насильственное изменение конституционного строя государства, а равно насильственное посягательство на общественную безопасность, в том числе организация в вышеуказанных целях незаконных вооруженных формирований или участие в них, и преследуемые в уголовном порядке в соответствии с национальным законодательством Сторон [8]. 
При этом некорректно применение данного правового акта, в связи с тем, что участниками данной конвенции являются лишь только две страны которые входят в АТР. В связи с этим определяется необходимость легального закрепления понятий «экстремизм», «терроризм» странами-участниками АТР, принятие единого документа, содержащего рекомендательные нормы, для совместного противодействия террористической, экстремисткой деятельности.

Получение упреждающей информации об источниках и каналах финансирования экстремистской деятельности является следующим условием повышения результативности борьбы с данным видом преступной деятельности.

В качестве примера ответственности за финансирование экстремистской деятельности, в том числе правовых норм, направленных на противодействие данному преступному явлению, приведем США. Так, в центре правовой и политической дискуссии, развернувшейся во многих европейских странах после террористических актов в США 11 сентября 2001 г., особое место занимают вопросы контроля над денежными потоками и доступа к имущественным ценностям, полученным противоправным или сомнительным путем. Разработанные за последние десять-пятнадцать лет основы для борьбы с организованной преступностью, центральное внимание в которых уделяется законодательству по борьбе с отмыванием денег, используются также для борьбы с экстремизмом, который до недавних пор понимался как самостоятельный феномен, не сравнимый и не связанный с организованной преступностью [5, с. 147]. Смещению акцентов способствовало установление того факта, что финансовые трансакции, которые осуществлялись предположительно сетью Аль-Каиды в преддверии сентябрьских актов терроризма в США, по большей части были легальными (во всяком случае, опровержений этому в научной литературе не приводится). Поэтому в тот момент речь еще не шла о грязных деньгах экстремистских и террористических организаций [2, с. 60].

Лишь после 11 сентября 2001 г. среди криминологов стало доминировать мнение о том, что если бы в США был надлежащий контроль над отмыванием денег и имущества, добытых преступным путем, то эти террористические акты, а также другие экстремистские акции можно было бы предотвратить. Полагаем, что это заблуждение. Такие суждения европейских ученых можно считать следствием того, что именно события 11 сентября поставили перед мировым сообществом проблему тотального контроля над движением капитала. Через две недели после террористических нападений, совершенных в Соединенных Штатах, Совет Безопасности ООН принял Резолюцию №1373 (2001), которая налагает на все государства обязательства не допускать оказания террористическим и экстремистским группам какой-либо финансовой поддержки (п. п. 1(a), (b), (c) и (d)); отказывать террористам и экстремистам в предоставлении убежища, средств к существованию или какой-либо поддержки (п. п. 2(a), (c), (d), (g) и 3(f) и (g)); включить в национальные законодательства положения, предусматривающие уголовную ответственность за активное и пассивное оказание содействия терроризму и экстремизму, и привлекать тех, кто нарушает эти положения закона, к судебной ответственности (п. 2(e)).

Финансирование, несомненно, является наиболее существенной мерой поддержки экстремистской, в том числе, террористической деятельности. В Российской Федерации законодатель ввел в уголовное и административное законодательство новые нормы об ответственности именно за действия по финансированию.

С 11 июля 2014 г. в УК РФ появился новый состав преступления - финансирование экстремистской деятельности. Статья 282.3 УК РФ предусматривает ответственность за предоставление или сбор средств либо оказание финансовых услуг, заведомо предназначенных для финансирования организации, подготовки и совершения хотя бы одного из преступлений экстремистской направленности либо для обеспечения деятельности экстремистского сообщества или экстремистской организации. Квалифицированный состав предполагает совершение тех же деяний, совершенных лицом с использованием своего служебного положения (ч. 2 той же статьи) [4, с. 9].

К сожалению, борьба с терроризмом и экстремизмом и его финансированием останется ключевой проблемой на длительную перспективу. Лишь совместными усилиями, при тесном сотрудничестве, правового взаимопонимания стран АТР станет возможным противостоять террористической и экстремисткой деятельности, ведь данная проблема в настоящее время настолько глобальна и не носит национальных пределов.

\section{Литература}

1. Выжутович В. Экстремизм - понятие не растяжимое // Российская газета. 2014. №5511 (135)

2. Кожушко Е. П. Современный терроризм: анализ основных направлений / под общ. ред. А. Е. Тарасова. Минск: Харвест, 2000. С. 60.

3. Молдалиев О. А. Указ. соч. Приоритетные проблемы нетрадиционных угроз безопасности Центральной Азии в условиях глобализации. С. 44.

4. Смушкин А. Б. Комментарий к Федеральному закону от 25 июля 2002 г. №114-Ф3 «О противодействии экстремистской деятельности». М., 2015. С. 9.

5. Сочнев Д. В., Абасов М. М. Общая характеристика законодательства стран Западной Европы в области противодействия финансированию терроризма // Административное и муниципальное право. 2013. №2. С. 147-153.

6. Ульянова В. В. Противодействие финансированию терроризма: автореф. дис. ...канд. юр. наук. Екатеринбург, 2010. C. 2 .

7. Хармаев Ю.В. Особенности обеспечения безопасности в исправительных учреждениях России и Монголии // Eurazia: Statum et Legem. Улан-Удэ: Изд-во Бурят. гос. ун-та, 2014. - 2 - 3/2014: Государство и правовые системы стран АзиатскоТихоокеанского региона. С.129-133.

8. Шанхайская конвенция о борьбе с терроризмом, сепаратизмом и экстремизмом (Заключена в г. Шанхае 15.06.2001) // Собрание законодательства РФ. 2003. №41. Ст. 3947. 


\section{Кража скота на приграничных территориях \\ (Россия и Монголия)}

(ㄱ) Ю.А. Бюрбю

магистрант 1 года обучения юридического факультета ФГБОУ ВО «Бурятский госуниверситет»

Россия, г. Улан-Удэ

byurbyuyunona@yandex.ru

Актуальность темы определяется тем, что реалии нынешнего торгово-экономического состояния Российской Федерации нуждаются в научном осмыслении, когда наша страна пытается уравновесить западное и восточное направления. Это особо касается международного сотрудничества и преступлений, совершаемых в приграничных территориях.

В современное время, как пишет О.С. Дамдын: «приграничное сотрудничество является наиболее результативной формой реализации двусторонних отношений» [1, с. 233].

Одной из перспективных стран для экономического сотрудничества России является Монголия. Россия и Монголия связаны многовековыми историческими, экономическими и культурными отношениями. Международные отношения России и Монголии начали укрепляться с конца 80-Х - начала 90-х гг. XX века.

Нормативно-правовыми актами, регулирующими приграничные отношения между Россией и Монголией являются: «Договор о дружественных отношениях и сотрудничестве» (1993), «Соглашение о пограничных пунктах пропуска и упрощенном сообщении через российско-монгольскую государственную границу» (1994) и «Соглашение о сотрудничестве приграничных аймаков Монголии и республик, областей, краев Российской Федерации» (2000). Последнюю называют Улан-Баторской Декларацией. Он устанавливает принципы сотрудничества местных администраций Монголии и органов исполнительной власти субъектов Российской Федерации.

Также в интересы Российской Федерации входит политическая и экономическая стабильность и предсказуемость стран, с которыми она сотрудничает. Данный фактор отражен в Концепции национальной безопасности Российской Федерации, Московской декларации и Программе по развитию российско-монгольского сотрудничества на 2006-2010 годы, подписанные в декабре 2006 г. Президентом РФ В.В. Путиным и Президентом Монголии Намбарын Энхбаяром [5].

Протяженность границы Российской Федерации с Монголией составляет 3485 км, где 1305 км приходится на территории Республики Тыва.

На местном уровне между правительством Республики Тыва и Монголией подписаны Соглашения о торгово-экономическом, научно-техническом и культурном приграничном сотрудничестве с Убсу-Нурским (2002), Завханским (2002), Баян-Уйгильским (2003) и Хубсугульским аймаками (2004). Данные Соглашения рассматривают развитие и расширение следующих межнациональных направлений: торговля, рациональное использование природных ресурсов, сельское хозяйство и пищевая промышленность, развитие транспортных путей, средств коммуникации, научные исследования и опытно-конструкторские проекты, образование (обмен студентами) и т.д. Но несмотря на подписанные Соглашения, которые предусматривают создание комиссии, которая не только координирует проблемы сотрудничества, но и разрабатывает рекомендации усовершенствования торгово-экономического приграничного сотрудничества, где участвуют правоохранительные органы и общественность, которая содействует профилактике нарушений перехода госграницы и кражи скота, все равно количество преступлений кражи скота не уменьшается.

В приграничную территорию вошли территории шести муниципальных образований республики - это Монгун-Тайгинский, Овурский, Тес-Хемский, Эрзинский, Кызылский, Каа-Хеский районы.

Жители сел приграничной зоны исторически связаны с Монголией. Пастбища жителей приграничных сел Эрзинского, Тес-Хемского, Овурского, Монгун-Тайгинского районов с давнишних времен входят в территорию Монголии. И в настоящее временя местные жители беспрепятственно осуществляют свою хозяйственную деятельность - пасут скот, заготавливают корма, собирают растения. Все это говорит о том, что несмотря на свою протяженность, тувинский участок госграницы является самым не обустроенным. В свою очередь, правительство Монголии принимает серьезные меры для укрепления своей границы, что доказывается возросшей за десять лет плотностью войсковой охраны. А в тувинской стороне более 400 километров тувинского участка горно-таежной части госграницы почти не охраняется. В связи с этим, с каждым годом увеличивается факт кражи скота через государственную границу.

Например, в 2014 году правоохранительными органами Республики Тыва зарегистрировано 11 фактов скотокрадства, совершенного через госграницу. Больше нарушений со стороны России - семь случаев. Монгольские граждане четыре раза проникали на территории нашей страны и угнали 44 животных. Гражданами обоих государств было украдено 205 животных [4]. 
Сравнение социально-экономических показателей приграничных районов Монголии и Республики Тыва (на 01.01 .2016$)$ [2, с. 58].

\begin{tabular}{|l|l|l|l|l|l|}
\hline & $\begin{array}{l}\text { Территория } \\
\text { тыс. кв. км. }\end{array}$ & $\begin{array}{l}\text { Население } \\
\text { тыс. чел. }\end{array}$ & $\begin{array}{l}\text { ВВП на } \\
\text { душу } \\
\text { насел., тыс. } \\
\text { руб. }\end{array}$ & $\begin{array}{l}\text { Уровень } \\
\text { безработицы } \\
\%\end{array}$ & $\begin{array}{l}\text { Зарегистр. } \\
\text { преступлений на } \\
100 \text { тыс. } \\
\text { населения }\end{array}$ \\
\hline Республика Тыва & 168,0 & 317,1 & 63,7 & 22 & 2515 \\
\hline $\begin{array}{l}\text { Ббб Баян- } \\
\text { Ульгий }\end{array}$ & 45,8 & 101,9 & 16,7 & 8,4 & 580 \\
\hline Завхан & 82,6 & 79,3 & 27,2 & 4 & 670 \\
\hline Ховд & 76,1 & 88,5 & 23,5 & 9,6 & 750 \\
\hline Убсу-Нур & 69,6 & 78,8 & 23,7 & 7,8 & 910 \\
\hline Итого & & 348,5 & 22,7 & 7,4 & 727,5 \\
\hline
\end{tabular}

Причин данного вида преступлений несколько. Во-первых, причина в низком социальном уровне жизни населения и отсутствие работы в сельских поселениях. Во-вторых, отсутствие четко разработанной нормативноправовой по регулированию кражи скота в приграничных территориях.

В Республике Тыва по борьбе со скотокрадством юристами и правительством разрабатываются и принимаются нормативно-правовые акты.

Попытку регулирования проблемы угона скота на законодательном уровне в начале 2000 года предпринял юрист В. Даржа. Он разработал кодекс животновода. На местном правительственном уровне его активно обсуждали и направили в Государственную думу РФ, где его отклонили из-за противоречий федеральному законодательству.

В 2007 г. региональными законодателями был разработан законопроект «О профилактике скотокрадства и правонарушений, связанных с оборотом скота и мясопродуктов в Республике Тыва». Данный законопроект предлагал введение в республике поголовного клеймения.

Кроме всего прочего, правоохранительными органами проводятся специальные профилактические операции, такие как «Скотокрад», цель которого - повышение эффективности работы по пресечению, выявлению и раскрытию краж скота. Благодаря этой операции, 2014 году «в ходе операции оперуполномоченные отдела по борьбе со скотокрадством проверили более 30 торговых точек, занимающихся продажей мясопродуктов и порядка 20 предпринимателей, скупающих мясо, на наличие документов для реализации мясной продукции. В ходе рейда грубых нарушений не выявлено. Также в рамках мероприятия было досмотрено 420 единиц автотранспорта, провоз краденого скота и мяса не зарегистрирован. Особое внимание уделили проверке ранее судимых граждан и лиц, склонных к скотокрадству. Задержано 4 преступника, находящихся в розыске. Задержано 16 подозреваемых в скотокрадстве, трое из них помещены в изоляторы временного содержания, остальные отпущены под подписку о невыезде» [6].

Также в 2011 году в Верховный Хурал (Парламент) Республики Тыва был направлен проект Закона «О мерах по организации содержания, сохранности и учету сельскохозяйственных животных (скота), профилактике скотокрадства и правонарушений, связанных с оборотом мяса и мясопродуктов на территории Республики Тыва».

Его разработал правовой отдел МВД по Республике Тыва с учетом предложений правового управления УФСБ России по Республике Тыва, Департамента ветеринарной службы Республики Тыва. Данный законопроект до сих пор рассматривается парламентом республики, направлен всем субъектам законодательной инициативы.

Другой проблемой, которая требует законодательной разработки является самостоятельная работа комиссий по противодействию и профилактике скотокрадства, которые создаются согласно «Соглашению между Правительством Российской Федерации и Правительством Монголии о совместных комиссиях по розыску и возвращению угнанного и перепасшегося через государственную границу скота», в составе которого должностные лица муниципалитета, полицейские, потерпевшие, переводчики и другие. Данные комиссии создаются в каждом муниципальном образовании, в администрациях района и практически носят формальный характер. Например, после совершении кражи скота через государственную границу, на поиски скота едут только сотрудники полиции и потерпевшие. Как видно из примера, отсутствие четко разработанной законодательной основы выступает еще одним фактором кражи скота через государственную границу.

Таким образом, можно сделать вывод о том, что проблема кражи скота через государственную границу России и Монголии является до сих пор не разрешенной. Причина тому, по нашему мнению, слабо разработанная законодательная база. Меры, которые принимаются на местном уровне, хоть и работают, но являются малоэффективными. На федеральном уровне нужно совершенствовать и принимать законы по борьбе с преступлениями по краже скота через государственную границу.

\section{Литература}

1. Дамдын О. С., Дабиев Д. Ф., Лебедев В. И. Основные направления и перспективы приграничного сотрудничества России и Монголии на макро и мезоуровне // Проблемы современной экономики. 2011. № 3. С. 233.

2. Социально-экономическое положение Республики Тыва (за январь - декабрь 2015 года): стат. сб. Кызыл, 2015.58 с.

3. Статистический ежегодник Республики Тыва: стат. сб. / Тывастат. Кызыл, 2016. С. 5, 10, 14. 
4. Дарбаа, Ю. Рассмотрели вопросы трансграничного скотокрадства [Электронный ресурс] // Официальный сайт газеты «Тувинская правда». Режим доступа: http://tuvapravda.ru/?q=content/rassmotreli-voprosy-transgranichnogo-skotokradstva

5. Московская декларация. Принята Президентом России Владимиром Путиным и Президентом Монголии Намбарын Энхбаяром 8 декабря 2006 года в Москве. [Электронный ресурс] // Официальный сайт Президента России. Режим доступа http://www.krcmlin.ru

6. Право на клеймо. В Туве перекрывают пути скотокрадам». [Электронный ресурс] // Режим доступа: http://www.agronews.ru/press_review/detail/7270/.

\section{Наказание за злоупотребления при проведении экзаменов по Уголовному кодексу Китая}

(C) Ван Цзиюй

докторант Политико-юридического университета Китая,

Китай, г. Пекин

В июне 2015 г. в г. Наньчан провинции Цзянси Китая в первый же день вступительных экзаменов в вузы (ниже - гаокао) были выявлены нарушения в организации экзаменационного процесса. Прямо во время экзамена по китайскому языку был задержан мужчина, после того как в социальных СМИ появилась информация о том, что он сдает экзамены за другого человека. Была выявлена организованная группа, занимавшаяся подделкой документов, удостоверяющих личность сдающих экзаменов. В прошлом году в уезде Цисянь провинции Хэнань Китая административные взыскания за нарушения правил проведения гаокао были вынесены в отношении 100 с лишним сотрудников местных органов образования, преподавателей, учащихся и их родителей.

Подобные факты стали достаточно распространенными. И это происходит, по мнению автора статьи, главным образом из-за того, что участники сделки несут очень небольшие риски. Так, например, в конечном итоге вышеупомянутого дела, раскрытого в провинции Хэнань, должностные лица госоргана получили лишь партийные и дисциплинарные взыскания. Результаты тестов студентов, которые попали в вуз за счет подставных лиц, сдававших экзамен, аннулированы, а сдававшие экзамен студенты - отчислены.

Относительно таких правонарушений в августе 2015 г. было внесено девятое изменение в китайский УК Постоянным комитетом ВСНП КНР. В «Поправке № 9» добавлена в УК статья 284-1, согласно которой уголовную ответственность понесут за злоупотребления при проведении государственных экзаменов (организация злоупотреблений, предоставление средств другим лицам, незаконная продажа или предоставление другим лицам тем и ответов на вопросы - лишение свободы на срок до 3 лет, краткосрочный арест и (или) штраф, при наличии отягчающих обстоятельств - лишение свободы на срок от 3 до 7 лет; участие в экзаменах вместо других лиц - краткосрочный арест, надзор и (или) штраф).

И это, на взгляд автора настоящей статьи, сделано весьма справедливо и имеет важное значение для предотвращения мошенничества на экзаменах. И теоретически, и практически существует актуальная необходимость признать злоупотребления при проведении экзаменов как преступные деяния.

Рассматриваемые правонарушения нужно признать как общественно опасные. Государственные экзамены это экзамены, принимаемые государственной комиссией с целью допущения экзаменуемого к выполнению какой-либо профессиональной деятельности или занятию какой-либо должности. Для некоторых специальностей, в частности медицинских, юридических, государственные экзамены служат единственным способом государственной аттестации выпускников. Перед другими формами контроля государственные экзамены имеют ряд достоинств, таких как объективность, надежность, достоверность и т. д. И именно достоверность и объективность снижают злоупотребления при проведении экзаменов и приводят к потере доверия к результатам госэкзаменов. К тому же злоупотребления при проведении экзаменов могут угрожать соблюдениям основных принципов этики, создают условия для нарушения принципов добросовестной конкуренции и честности.

Наказания за рассматриваемые деяния бывают и в судебной практике зарубежных стран и регионов. Так, например, в 2012 г. Сянганский суд приговорил трех студентов к лишению свободы на срок 10 месяцев за то, что они сдавали международный экзамен по английскому языку как иностранному TOEFL за других людей. В 2008 г. за инсценировку сдачи языкового экзамена Харьюский уездный суд Эстонии наказал правонарушителей крупными денежными штрафами.

Отсюда следует, что криминализация злоупотреблений при проведении экзаменов в законодательстве обоснована и уместна.

Объектом, которому причиняют вред подобные деяния, являются порядок проведения государственных экзаменов и законные права других сдающих экзамены. С объективной стороны злоупотребления при проведении госэкзаменов выражаются в организации, предоставлении средств, продаже или предоставлении другим лицам ответов на вопросы и сдаче экзаменов за других лиц. Субъективная сторона любой формы злоупотреблений характеризуется виной в виде прямого умысла. Виновный осознает общественную опасность своих действий, предвидит неизбежность причинения в результате этого вреда другим лицам и желает наступления этих последствий. Субъект преступления - физическое, вменяемое лицо, достигшее 16 лет.

По мнению автора, дальнейшее усовершенствование ст. 284-1 заключается в том, что необходимо четко определить понятие «государственные экзамены, установленные законом». Несомненно, гаокао (всекитайские 
государственные вступительные в вузы экзамены), ежегодные государственные экзамены на должность госслужащих и т.п. есть государственные экзамены. Но какие экзамены еще могут быть? Ответ на вопрос может быть в форме судебных разъяснений, опубликованных Постоянным комитетом народных представителей по вопросам применения уголовного закона либо совместного судебного разъяснения со стороны Верховного народного суда и Верховной народной прокуратуры КНР. Кроме того, тех на экзаменационном процессе, кто передает соответствующие материалы и средства «двойникам», тоже нужно признать как соучастников преступления. Это должно быть выражено в упомянутых выше судебных разъяснениях, чтобы все, кто имеют отношение к злоупотреблениям при проведении экзаменов, стали объектами преступления. И, в конце концов, необходимо принять такие меры как создание по всей стране и усовершенствование системы личной кредитной информации гражданина, чтобы устранить причины и условия подобного преступного деяния либо его нейтрализировать, и тем самым способствовать сокращению всех форм мошенничества на экзаменах.

\title{
Сравнение зарубежного опыта антикоррупционной политики: Китай и Сингапур
}

\author{
(C) A. A. Верхотуров \\ аспирант 1 года обучения \\ ФГБОУ ВО «Дальневосточный федеральный университет» \\ Россия, г. Владивосток \\ andrey_verhoturov@mail.ru
}

Как отмечалось высшими чинами стран Азиатско-Тихоокеанского региона [7], юридический опыт одних стран АТР может найти применение во внутренней практике других из них, что придаёт ему ценность в качестве источника для последующего внутреннего правового регулирования.

Ознакомление и усвоение передового зарубежного антикоррупционного опыта видится полезным, прежде всего, в связи с тем, что исследование проблемы противодействия коррупции в сфере уголовно-правовой охраны должно происходить в неотрывной связи с процессами глобализации в Азиатско-Тихоокеанском регионе, так как часто современные коррупционные преступления выходят за рамки юрисдикции национальных государств и приобретают международный характер. Также, после такого исследования мы предположительно сможем улучшить применение нашего собственного права, поскольку специфические черты антикоррупционной политики, в том числе: место коррупционных преступления в системе преступлений против государственной власти, а также интересов государственной службы и службы в органах местного самоуправления отчётливо выявляется в сопоставлении с иными правовыми доктринами.

Выбор стран для анализа в данном случае должен быть обусловлен как особенностями правовой системы, так и географическими и социально-экономическими аспектами. Идеальным в данном случае представляется рассмотрение Китая и Сингапура: Китай не только похож на Россию управленческими и культурными традициями [9, с. 114], но и является также крупной развивающейся страной, испытывая влияние схожих стимулирующих коррупцию факторов. Думается, что из его опыта будет наиболее полезен именно подход к общегосударственному регулированию антикоррупционной политики и распределения взаимной ответственности проверяющих органов. Нельзя также не отметить важность того, что теснота экономических и политических связей между Китаем и Россией по неизбежности влияет и на незаконную деятельность, так что рассмотрение механизма противодействия коррупции в этой стране имеет и значение в качестве своего рода подготовки к борьбе с возможным взаимным влиянием коррупционной преступности двух стран.

Сингапур же, в свою очередь, представляет собой своеобразный иной полюс антикоррупционной политики: являясь маленькой и развитой страной, он досконально показывает модель противодействия коррупции, которая могла бы найти применение в других странах как образец для проведения антикоррупционной политики на региональном уровне.

Сингапур является одним из основателей Ассоциации государств Юго-Восточной Азии (далее - АСЕАН), что естественно, учитывая его географическую, политическую и экономическую специфики. Секретариат АТЭС (главный орган организации) также находится именно в Сингапуре. Таким образом, роль Сингапура в антикоррупционной политике в странах Юго-Восточной Азии представляется довольно очевидной. Более того, следует отметить, что согласно исследованию индекса восприятия коррупции, приводящимся международной организацией по противодействию коррупции «Трансперенси Интернешнл» (Transparensy International), Сингапур входит в число наименее коррумпированных государств Азии, что обуславливает необходимость обстоятельного изучения его опыта антикоррупционной политики и её реализации в сфере уголовно-правовой охраны государственного устройства и общественного порядка. Представляет интерес и то, что в уголовно-правовой сфере Сингапура присутствует дуализм англо-американского и обычного права. Это обусловлено исторической юрисдикцией общего права, весьма характерной для стран, ранее являвшихся колониями Британской империи.

Следует признать, что базой для антикоррупционной политики Сингапура является сочетание двух явлений: эффективной профилактики коррупционных преступлений и высококачественного надзора за государственным аппаратом.

Профилактические меры противодействия коррупции в Сингапуре ведутся преимущественно по двум направлениям предупреждения возникновения факторов, способных привести либо стимулировать к совершению 
коррупционных преступлений. Первым направлением является перманентная забота о состоянии кадрового состава профессионального чиновничества, прежде всего: рассмотрение вопросов кадровой ротации, соблюдения надлежащей формы отчётности, а также вопросов материального положения и оплаты труда чиновников, а равно и всех государственных служащих, а также, в особенности, непосредственно вовлечённых в борьбу с коррупцией. Вторым главным направлением профилактики совершения коррупционных преступлений в Сингапуре представляется стимулирование бескомпромиссного общественного порицания коррупции во всех её видах и проявлениях. Она осуществляется достаточно разнообразными мерами - социальной рекламой, наказаниями «из принципа», политикой «открытых дверей» для жалоб населения. Граждане Сингапура несут ответственность и за коррупционные деяния, совершённые вне границ этой страны [2, с. 22]. Отдельно отмечается существенная роль большого количества кодексов и стандартов профессионального поведения, которые используются с целью превентивного воздействия на поведение потенциальных нарушителей [8, с. 219].

Система мер по борьбе с коррупцией в Китае имеет достаточно большое сходство с применяемой в Сингапуре: велика роль жалоб населения - они могут осуществляться как по особой телефонной линии, так и анонимно в электронной форме, а также роль профилактики - с детского возраста. Китай поддерживает и политику прозрачности государственных структур (см. Правила Китайской Народной Республики по открытой информации Правительства). Следует отметить, что в отличие от Сингапура, в Китае норма об ответственности за коррупционные преступления, совершённые вне Китая, касается только государственных чиновников, а не всех граждан.

Подобный подход - упор на антикоррупционную пропаганду - в весьма малой степени применяется в России. У нас система антикоррупционной пропаганды по большому счёту не развита: в некоторых регионах она не ведётся, несмотря на указания федерального законодательства, в других отнесена к компетенции очень узкого круга государственных органов или вовсе вменяется негосударственным, в отдельных случаях даже подменяется понятием правовой пропаганды [3, с. 881-882]. Реализация закона на местах также часто не ведётся [1]. В результате отмечается лишь усиление терпимости к коррупции [6, с. 62].

Главным направлением антикоррупционной политики Сингапура является поддержание и совершенствование системы антикоррупционного контроля, в основе которого стоит специальный орган - Бюро по расследованию фактов коррупции. Это небольшой государственный орган, подчиняющийся лично премьер-министру Сингапура и наделённый исключительными полномочиями, такими как: право ареста без повестки любого человека, подозреваемого в совершении коррупционных преступлений, если информация об этом получена из достоверных источников. Также значимой является чёткая регламентация прав и обязанностей любого чиновника в случаях, создающих возможность для совершения коррупционных преступлений [4].

Система антикоррупционного контроля в Китае отличается достаточно сильно. Прежде всего, следует отметить, существование систем особого контроля: за наиболее важными государственными чиновниками и за отдельными отраслями экономики (например, Временные правила по запрещению коммерческого взяточничества). В отношении руководящих органов по борьбе с коррупцией Китай придерживается политики множественности. Специализированную работу по борьбе с коррупцией осуществляют, прежде всего: Национальное Бюро по предупреждению коррупции в Китае, Центральная Комиссия дисциплинарной инспекции Коммунистической партии Китая, Министерство надзора [5, с. 19]. Они как направляют усилия по борьбе с коррупцией полиции и прокуратуры, так и самостоятельно осуществляют расследование фактов коррупции, например, в отношении партийного чиновничества.

В России специализированным органом по борьбе с коррупцией является Управление Президента Российской Федерации по вопросам противодействия коррупции. Также, координационную роль осуществляет Совет при Президенте Российской Федерации по противодействию коррупции, непосредственное противодействие коррупции осуществляется федеральными органами исполнительной власти, органами исполнительной власти субъектов и органами местного самоуправления. На региональном уровне координационную роль осуществляют соответствующие комиссии субъекта.

Таким образом, можно говорить о двух главных сходствах антикоррупционной политики данных стран:

1. Отсутствие защищённых от преследования должностей, чинов и рангов;

2. Неприятие незаконного обогащения в любых формах, включая конфискацию и иные меры уголовной ответственности.

Это определяет и общее сходство реализации антикоррупционной политики, осуществляющейся, по большому счёту, в виде неких «клещей», где с одной стороны выступает сильная профилактическая работа, а с другой - наказание за совершение коррупционных преступлений даже в том случае, когда реальный вред от коррупционных деяний наносился иным государствам.

Но между ними есть и существенные различия. Прежде всего, это касается структурного различия в формировании органов по борьбе с коррупцией. Сингапур в этом смысле жёстко стоит на позиции единоначалия, а вот для Китая характерен некоторый дуализм (Министерством надзора и Национальным Бюро по предупреждению коррупции в Китае руководит один и тот же человек, министр Ма Вэнь) между собственно государственной и партийной системами. Нельзя сказать, что одна система превосходит другую, поскольку обе ориентированы явно на работу в совершенно разных масштабах, думается, что обе являются ничем иным, как проявлением специфики обоих государств. 


\title{
Литература
}

1. Антикоррупционная пропаганда - важное условие противодействие коррупции. Официальный сайт прокуратуры Республики Башкортостан [Электронный ресурс]. Режим доступа: http://bashprok.ru/the_prosecutor_explained/9328.php.

2. Иванова Л. А., Данилов А. Г. Опыт борьбы с коррупцией в азиатских странах //Следователь. 2014. № 10. С. 21 -23.

3. Кабанов П. А. Понятие и содержание антикоррупционной пропаганды как правовой категории в российском региональном антикоррупционном законодательстве //Административное и муниципальное право. 2013. № 9. С. 878-884.

4. Лечение заразной жадности: Борьба с коррупцией в Сингапуре / Арсений Сиротин. 09.03.2010, Антикоррупционная информационная база сайта «Суда нет» [Электронный ресурс]. Режим доступа: http://center.sudanet.ru/?tag=cингапур.

5. Макаров А. В. Коррупция: опыт успешной борьбы Китая и реальность современной России // Государственная власть и местное самоуправление. М.: Юрист, 2012. № 3. С. 13-21.

6. Номоконов В. А. Коррупция в России: социальные последствия и особенности причин // Актуальные проблемы экономики и права. 2013. № 4 (28). С. 61-67.

7. Саммит АТЭС. Выступление Медведева [Электронный ресурс]. Режим доступа: http://www.vestifinance.ru/videos/24730.

8. Филиппов В. В. Антикоррупционная политика Сингапура. Хабаровск: ДВИУ-филиал РАНХиГС, 2016. 251с.

9. Шишкарёв С. Н. Противодействие коррупции: теория и практика. М.: КДУ, 2009. 168c.

\section{Особенности уголовной ответственности за мошенничество по законодательству России и Китая}

\author{
(C) A. C. Вторушина \\ магистрант 2 года обучения юридического факультета \\ ФГБОУ ВО «Бурятский госуниверситет» \\ Россия, г. Улан-Удэ \\ Al.vtorushina@gmail.com
}

Азиатско-Тихоокеанский регион (АТР) на сегодняшний день объединяет 58 абсолютно разных стран, каждая из которых представлена своей уникальной экономик ой и политическими взглядами. И, пожалуй, именно динамично развивающийся Китай сегодня является страной, за развитием которой следит все мировое сообщество. Одной из глобальных современных проблем поступательного развития экономики и сотрудничества между странами является преступность. Анализ закономерностей развития мошенничества, разнообразие его способов совершения свидетельствует о высокой степени актуальности, рассматриваемой проблемы. В целях эффективного противостояния мошенничеству необходимо исследовать данный негативный феномен, поэтому в этой статье нам бы хотелось провести сравнительный уголовно-правовой анализ мошенничества России и Китая.

В российском законодательстве в статье 159 УК РФ дано определение мошенничества. Мошенничество это хищение чужого имущества или приобретение права на чужое имущество путем обмана или злоупотребления доверием. Квалифицированными составами мошенничества являются мошенничество совершенное группой лиц или с причинением значительного ущерба, совершенное лицом с использованием своего служебного положения или в крупном размере, совершенное организованной группой либо в особо крупном размере или повлекшее лишение права гражданина на жилое помещение [1].

В свою очередь хищение - это совещенное с корыстной целью противоправное безвозмездное изъятие и/или обращение чужого имущества в пользу виновного или других лиц, причинившее ущерб собственнику или иному владельцу этого имущества [1]. Предметом мошенничества является не только чужое имущество как таковое, обладающее экономической ценностью, но и право на это имущество как юридическая категория. То есть виновному достаточно приобрести незаконные права на чужое имущество, то есть у мошенника должна появиться закрепленная юридически возможность распорядиться чужим имуществом [2].

Ключевым признаком объективной стороны мошенничества, отличающим его от других форм хищения, которые предусмотрены главой 21 УК РФ является то, что виновный путем обмана или злоупотреблением доверия воздействует на потерпевшего, последний в свою очередь передает имущество или же право на него виновному.

Мошенничество на сегодняшний день является общемировой проблемой. Мошенники не перестают изобретать все новые и новые способы добиться своего, поживиться за чужой счет. Ведь нужно быть изобретательным человеком, чтобы обманом заставить потерпевшего добровольно передать свое имущество. Но законодательство тоже не стоит на месте. ФЗ от 29 ноября 2012 г. № 207-Ф3 «О внесении изменений в УК РФ и отдельные законодательные акты РФ» Уголовный кодекс РФ был дополнен новеллами, предусматривающими ответственность за мошеннические деяния, совершаемые в различных сферах деятельности, а именно [3]:

-Мошенничество в сфере кредитования (статья 159.1)

•Мошенничество при получении выплат (статья 159.2)

•Мошенничество с использованием платежных карт (статья 159.3)

-Мошенничество в сфере предпринимательской деятельности (статья 159.4)

-Мошенничество в сфере страхования (статья 159.5)

•Мошенничество в сфере компьютерной информации (статья 159.6) 
Данная поправка позволила в первую очередь дифференцировать мошеннические действия и ответственность за них.

Теперь рассмотрим мошенничество в уголовном праве Китая. В настоящем УК КНР, который был принят в 1997 году, мошенничество было отделено от грабежа и кражи, в отличие от кодекса 1979 года. Согласно статье 266 УК КНР завладение путем мошенничества государственным или частным имуществом в сравнительно крупном наказывается лишением свободы на срок до 3 лет, арестом или надзором, а также одновременно или в качестве самостоятельного наказания - штрафом. Квалифицированными признаками мошенничества согласно статье 266 в Китае указаны мошенничество в крупном размере или при иных отягчающих обстоятельствах, которое наказывается лишением свободы на срок от 3 до 10 лет и штрафом; мошенничество, совершенное в особо крупном размере или при иных отягчающих обстоятельствах, которое наказывается лишением свободы на срок свыше 10 лет или бессрочным лишением свободы, а также штрафом или конфискацией имущества [4]. Статья 266 УК КНР является основной статьей по мошенничеству, однако мошенничество, предусмотренное другими статьями УК КНР, подлежит классификации по этим статьям.

В Главе 3 УК КНР «Преступления против социалистического рыночного экономического порядка» есть 5 параграф под названием «Финансовое мошенничество», куда входит 9 статей, которые криминализируют такие деяния как накопление капитала противозаконным способом; получение кредита мошенническим путем; мошенничество с векселями, аккредитивами и кредитными картами; осуществление мошеннических действий с использованием фальсифицированных, подделанных гос. облигаций или иных выпущенных государством ценных бумаг; мошенничество в области страхования и все это в сравнительно крупном размере. УК КНР также содержит отдельные статьи, которые предусматривают квалифицированные составы мошенничества, такие как [4]:

•завладение имуществом, путем мошенничества в целях сокрытия награбленного, сопротивления аресту или уничтожения доказательств преступления, соединенное с применением насилия или угрозы применения насилия (статья 269);

•использование компьютера для завладения деньгами путем мошенничества для взяточничества и нецелевого использования общественных средств (статья 287);

•осуществление мошеннических действий, получение обманным путем паспортов, виз и других выездных документов под видом экспорта рабочей силы (статья 319).

Если рассмотреть статью 269 УК КНР с точки зрения российского уголовного права, то можно заметить что согласно УК РФ данная статься выходит за рамки отечественного понимая мошенничества. Так как в статье 269 УК КНР мошенничество обязательно должно быть соединено с применением насилия или угрозы применения насилия, согласно УК РФ такие действия уже следует классифицировать не как мошенничество, а как разбой согласно статье 162.

В отличие от УК РФ, где в примечаниях к статьям есть точное определение какую сумму законодатель подразумевает под значительным ущербом, какую под крупным, а какую под особо крупным, в УК КНР таких пояснений нет - законодатель не разъясняет в Уголовном кодексе, что является сравнительно крупным ущербом, как отличить крупный от особо крупного, нет и пояснений, что понимается под отягчающими и особо отягчающими обстоятельствами.

Это связано с тем, что в каждой провинции, городе центрального значения и автономном районе Китая установлен свой порог категории ущерба в зависимости от экономического развития данного региона. Соответственно мошенничество, совершенное на одну и ту же сумму в разных провинциях Китая, может быть классифицировано по-разному. Такой гибкий подход на наш взгляд является более справедливой и адекватной оценкой преступного деяния и отнесения его к более подходящей категории преступления в зависимости от того, в каком регионе мошенничество было совершено. Данный подход в Росси позволил бы более точно оценивать степень общественной опасности преступления, ведь нельзя сказать, что мошенничество, совершенное на сумму 250000 рублей в городах федерального значения, таких как Москва или Санкт-Петербург по своей общественной опасности равно мошенничеству на эту же сумму, совершенному в поселке на территории республики Бурятия - данные территории кардинально отличаются и по экономическому развитию, по уровню жизни.

Объединяет Россию и Китай в данном уголовно-правовом вопросе - это проблема классификации мошенничества и отграничение мошенничества от других составов преступления. В российской практике нередко возникают вопросы отграничения мошенничества от других смежных составов преступления, которые также совершаются с помощью обмана или злоупотребления доверием. В УК РФ в первую очередь нужно отграничивать мошенничество от статьи 165 «Причинение имущественного ущерба путем обмана или злоупотреблением доверием». В последнем случае отсутствуют признаки хищения, то есть отсутствует противоправное, совершенное с корыстной целью безвозмездное изъятие и/или обращение чужого имущества в пользу виновного. Если же обман или злоупотребление доверием облегчили виновному доступ к чужому имуществу, которое виновный затем тайно изымает, то такие действия следует классифицировать как кражу [5, с.186].

В уголовном праве Китая же не совсем понятна позиция законодателя на счет классификации некоторых «полученных обманным путем» ценностей. Например, такие действия как обратное получение обманным путем налогоплательщиком возвращаемого налога на экспорт (статья 204) и получение обманным способом имущества противной стороны при подписании и исполнении контракта (статья 224) законодатель предлагает рассматривать как мошенничество. Но уже действия согласно статье 382: «получение мошенническим путем или 
незаконное завладение иным способом общественным имуществом гос. служащим с использованием своего служебного положения» расцениваются как коррупционные.

Мошенничество имеет длительную историю и продолжает развиваться по сей день. Преступники изобретают все новые, до этого неизвестные способы мошенничества. Этот вид преступления можно назвать интеллектуальным. Порой, чтобы осуществить свой замысел злоумышленники тратят немало сил, времени и даже денег на свои задумки, которые в итоге могут окупиться в десятки раз. Поэтому мошенничество является опасным преступлением, так как это не спонтанное решение совершить преступление здесь и сейчас, а четко продуманный план, который зачастую осуществляется профессиональными преступниками или даже организованными группами. Конечно, от мошенничества совершенного путем злоупотребления доверием уберечься сложнее, чем от обмана. Поэтому нам бы хотелось, чтобы каждый гражданин был бдительным и не попадался на обманные действия преступников, тем самым позволяя мошенничеству развиваться и дальше.

\title{
Литература
}

1. Уголовный кодекс Российской Федерации" от 13.06.1996 N 63-Ф3 (ред. от 30.12.2015) [Электронный ресурс] // Справочная система «КонсультантПлюс».

2. Постановление Пленума Верховного Суда Российской Федерации от 27 декабря 2007 г. N 51 г. Москва "О судебной практике по делам о мошенничестве, присвоении и растрате" // Российская газета. 2008. № 4561

3. Федеральный закон Российской Федерации от 29 ноября 2012 г. N 207-Ф3 "О внесении изменений в Уголовный кодекс Российской Федерации и отдельные законодательные акты Российской Федерации" // Российская газета. 2012 . №5951.

4. Уголовный кодекс КНР 2001г.

5. Шишков И.В. Уголовное право. Особенная часть. М., 2012. С.186.

\section{К вопросу профессионального запрета в Уголовном кодексе КНР}

\author{
(C) Гао Япэн \\ магистрант Политико-юридического \\ университета Китая, \\ Китай, г. Пекин
}

Поправки в Уголовный кодекс Китайской Народной Республики (далее - УК КНР) (№ 9) были приняты Постоянным комитетом Всекитайского собрания народных представителей (далее - ПК ВСНП) 29 августа 2015 года и вступили в силу 1 ноября 2015 года. В соответствии с Поправками № 9 в УК КНР добавлены 15 новых статей и внесены изменения в 33 статьи, в том числе и в ст. 37 УК КНР - «запрет на определённую профессию». До внесения поправок № 9 было регламентировано: «Лица, совершившие малозначительные преступления, за которые нет необходимости применять наказания, могут быть освобождены от уголовного наказания; с учетом конкретных обстоятельств дела таким лицам может быть вынесено общественное порицание или их можно обязать раскаяться письменно, принести извинения, возместить ущерб либо компетентным административным органом на них может быть наложено административное взыскание или наказание». Согласно Поправкам № 9 УК КНР дополнен статьей, 37-1:

- Запрет заниматься определённой профессией может быть наложен на лиц, совершивших преступление с использованием профессионального положения или в нарушение определённых обязанностей, соблюдение которых требует данная профессия. В зависимости от обстоятельств совершения преступлений и с учётом предупреждения совершения преступлений народные суды вправе лишить виновного в совершении преступления права заниматься работой по определённой профессии на срок от 3 до 5 лет после отбытия наказания или со дня применения условно-досрочного освобождения.

- В случае нарушения осуждённым запрета заниматься определённой профессией, решения народного суда, вынесенного в соответствие с данной частью, на основании закона органами общественного порядка может быть наложен на него штраф; в случае наличия тяжких обстоятельств, на основании статьи 313 настоящего кодекса, налагается наказание в соответствии с квалификацией преступления.

- Предусмотренные другими законами, административным законодательством запреты и ограничения в отношении (этого) лица, подвергнутого запрету заниматься определённой профессией, применяются в соответствии с этими законами.

В соответствии с поправками к УК КНР № 9 «Запрет заниматься определённой профессией» является частью установленных статьей 37 УК КНР «Мер, не относящихся к уголовному наказанию». Отсюда видно, что «Запрет заниматься определённой профессией» не является каким-то новым уголовным наказанием и не принадлежит к их перечню, но является не носящим уголовного характера правовым последствием, является важнейшей целью предотвращения осуждённого вновь совершить преступление, используя свою профессию и должностные преимущества.

Запрет заниматься определённой профессией по УК КНР не относится к основному наказанию или дополнительному наказанию. В ст. 33 УК КНР сказано: «Основные наказания делятся на следующие виды: 1) надзор; 2) арест; 3) срочное лишение свободы; 4) пожизненное лишение свободы; 5) смертная казнь». Исходя из ст. 34 УК КНР, дополнительные наказания делятся на следующие виды: 1) денежный штраф; 2) лишение политических прав; 3) конфискация имущества. Как сказано выше, запрет заниматься определённой профессией явля- 
ется лишь одной из иных уголовно-правовых мер, которые, как предусматривает ст. 37 УК КНР, применяются к лицам, совершившим преступления небольшой опасности.

По сути, запрет заниматься определённой профессией по УК КНР является одной из мер безопасности. Например, в УК ФРГ определено, что мерами исправления и безопасности являются помещение в психиатрическую больницу, помещение в учреждение изоляции для алкоголиков или наркоманов, лишение разрешения управлять автотранспортным средством и запрет на профессию (ст. 61). Меры безопасности - это меры принудительного ограничения поведения физических лиц и деятельности юридических лиц, применяемые при наличии указанных в законе оснований и имеющие целью предотвращения вредоносного воздействия определенного источника опасности либо ограждения объекта защиты от вредного влияния источников опасности [1, с. 89]. Меры безопасности не преследуют целей воздаяния или устрашения, а призваны устранить «опасное состояние» лица.

В соответствии с Поправками № 9, условия применения решения о запрете заниматься определённой профессией УК КНР народным судом заключаются в следующем: во-первых, обвиняемым должно быть лицо, совершившее преступление. Преступление должно быть совершено, то есть совершенное преступление служит предпосылкой наложения запрета заниматься определённой профессией на исполнителя преступления.

Во-вторых, лицом, к которому применяется запрет на профессию, должно быть лицо, совершившее преступление с использованием профессионального положения или в нарушение определённых обязанностей, соблюдения которых требует данная профессия. Профессия - род трудовой деятельности, занятий, требующий определенной подготовки и являющийся обычно источником существования [2, с. 149]. С одной стороны, понятие «профессия» в ст. 37.1 УК КНР не имеет точного определения и пояснения. Лицо, занимающееся любой трудовой деятельностью, совершившее преступление с использованием профессионального положения или в нарушение определённых обязанностей, соблюдения которых требует данная профессия, становится объектом запрета заниматься определённой профессией УК КНР. С другой стороны, понятие профессии включает в себя должность, поэтому запрет заниматься определённой профессией может быть наложен на лиц, совершивших преступление с использованием служебного положения.

В-третьих, здесь наказанием за данное деяние, по меньшей мере, является тюремное заключение на определенный срок, задержание с исправительными работами и надзор. Следует отметить, что имеются в виду только основные наказания. Лица, приговоренные к таким наказаниям, могут быть освобождены после отбытия наказания или со дня применения условно-досрочного освобождения. В этих случаях, если суд считает необходимым решение о применении профессионального запрета после отбытия наказания, то он может объявить запрет заниматься определённой профессией.

В-четвертых, когда народный суд принимает решения о наложении запрета заниматься определённой профессией, суд должен рассматривать ситуацию использования профессионального положения осуждённым и учесть нарушение определенных обязанностей, соблюдения которых требует данная профессия. Наложение запрета на профессию может быть принято только при условии, что после отбытия наказания или со дня применения условно-досрочного освобождения у обвиняемого имеется возможность и опасность совершения преступления с использованием профессионального положения. Цель решения о наложения запрета на профессию состоит в предупреждении повторного преступления и защите социального порядка и общественной безопасности.

В соответствии с вышесказанными условиями народный суд может объявить запрет заниматься определённой профессией в отношении обвиняемого. Иными словами, профессиональный запрет лишает лицо права заниматься определённой профессией в течение определённого времени. Таким образом, судья должен внимательно относиться к решению о наложения профессионального запрета. Запрет заниматься определённой профессией осуществляется лишь при условии, что совершенное преступление напрямую зависит от профессиональной деятельности обвиняемого.

Из вышесказанного видно, что профессиональный запрет в УК КНР относится к одной из мер безопасности. В последние годы в уголовном законодательстве КНР обращается большое внимание на меры безопасности. Установление профессионального запрета в Поправках № 9 будет дополнять уголовное законодательство нашей страны. Это значит, что новая система осуществления правовых последствий преступления в нашей стране уже сформировалась.

Правовыми последствиями уголовно-противоправного деяния в зависимости от наличия или отсутствия вины по настоящему уголовному законодательству нашей страны являются наказания при наличии вины, а при отсутствии вины - меры безопасности. Конечно, по ныне действующему УК КНР положение о профессиональном запрете не идеально, но оно может постоянно совершенствоваться по мере развития государственного уголовного законодательства.

Литература

1. Райзберг Б. А., Лозовский Л. Ш., Стародубцева Е. Б. Современный экономический словарь. 5-е изд. М.: ИНФРА-М, 2007. C. 495.

2. Ус А. В., Примирение вместо наказания (как течение в правоприменительной практике) // Правоведение. 1990. № 6. C. 89 . 


\section{Генезис уголовной ответственности за похищение человека по законодательству России и Азербайджанской Республики}

(C) Э. М. Гасанова

магистрант 1 года обучения юридического факультета ФГБОУ ВО «Бурятский госуниверситет»

Россия, г. Улан-Удэ

mira_gasanova@icloud.com

В современном мире права на свободу, достоинство личности и личную неприкосновенность являются одними из основных социальных благ, объектами уголовно-правовой охраны и находятся под защитой государств.

За последнее время широкое распространение получило похищение человека. Это объясняет актуальность данной проблемы.

В разные времена похищение человека воспринималось по-разному. Но в состав преступления по статье 126 Уголовного Кодекса Российской Федерации входит совсем иной смысл [1, с.142]. Это деяние является насилием над свободой, волей человека, носит противозаконный характер. С правовой точки зрения проблема похищения людей оказывается связанной с нарушением всех фундаментальных прав и свобод: права на жизнь, свободу и безопасность личности, права не подвергаться пыткам и другим жестоким и бесчеловечным или уничтожающим достоинство видам обращения и наказания. Это преступление является одним из самых опасных, так как может за собой повлечь смерть человека и другие тяжкие последствия. Именно поэтому рассмотрение данной проблемы можно считать актуальной.

История наполнена случаями о похищении, о нем рассказывают еще античные мифы Древней Греции. Еще римское право относило похищение людей к тяжким преступлениям, понимая под ним обращение человека свободного в состояние не свободное. Свод законов Российской Империи, повелением государя Императора Николая Павловича, устанавливал ответственность за похищение людей свободных для содержания их в неволе. Статья 429 гласила, что тот, кто человека свободного состояния похитит и продаст, тот подлежит лишению всех прав состояния, наказанию кнутом и ссылке на каторжную работу. О тяжести данного наказания свидетельствует тот факт, что лишение всех прав состояния заключалось для дворян - в лишении дворянства, потомственного или личного и сопряженных с ним прав. Для духовенства - в низвержении или духовного сана. Лишение всех прав состояния сопровождалось лишением чинов, чести, доброго имени и знаков отличия. Однако, за похищение инородцев (татар, калмыков) положено было взыскивать штраф, тех, кто не мог его заплатить подвергали телесным наказаниям. И только впоследствии был принят Указ, который уже не проводил различий между кражей людей у инородцев или обывателей.

В Уложении о наказаниях уголовных и исправительных 1845 года, одна из глав которого - «О противозаконном задержании и заключении» - была посвящена по сути дела защите лишь физической свободы, т. е. свободе выбора местонахождения и передвижения. Объявляя самовольное, насильственное лишение свободы преступлением, законодатель устанавливал тяжесть санкции в зависимости от длительности незаконного заключения или задержания, различая в этой связи три срока: до одной недели, от одной недели до трех месяцев, свыше трех месяцев.

При правлении Николая II в 1903 году было принято Уголовное уложение, которое содержало гл. 26 «О преступных деяниях против личной свободы», которая состояла из 15 статей (498-512). При этом в эту главу были включены посягательства не только против личной свободы (как называлась сама глава), но и связанные: с похищением людей; с похищением и задержанием людей в больнице умалишенных (п. 1 ст. 500); с похищением и задержанием в притоне разврата лиц женского пола (п. 2 ст. 500); с продажей и передачей в рабство или в неволю (ст. 501); с принуждением рабочих к отказу участвовать в стачках (ст. 509); с умышленным вторжением в чужое здание или иное помещение (ст. 512).если такое вторжение имело место ночью, то оно рассматривалось как квалифицирующий признак, что усиливало наказание. Система преступлений против личной свободы по Уложению 1903 г. включала не только те составы, которые непосредственно посягают на свободу, но и другие, имеющие весьма отдаленное отношение к этому объекту посягательства. Уложение (ст. 498) устанавливало основной состав по посягательству на личную свободу, без указания каких-либо признаков его, например, по способу совершения, личности потерпевшего, месту задержания, его продолжительности, возраста потерпевшего. Все указанные признаки, а также и другие законодатель устанавливал в других составах преступлений данной главы и в зависимости от этого дифференцированно определял вид и размер наказания. Как правило, наличие каких-либо признаков отягчало ответственность. К числу таких квалифицирующих признаков уложение 1903 г. относило:

- лишение личной свободы, продолжавшееся свыше одной недели (ч. 2 ст. 498; ч. 2 ст. 499; ч. 2 ст. 500);

- лишение свободы матери, законного отца, иного родственника по восходящей линии (п. 1 ст. 499), должностного лица при исполнении им служебных обязанностей или по поводу этого (п. 2 ст. 499).

Посягательства, связанные с похищением людей, Уложение дифференцировало в зависимости от возраста потерпевшего: например, ст. 502 предусматривала похищение, сокрытие или подмен ребенка, не достигшего 14 лет; ст. 505 (п. 1 и 2) - похищение несовершеннолетней женского пола от 14 до 16 лет с ее согласия или без та- 
кового. Часть 2 этой статьи устанавливала ответственность за похищение лица женского пола от 14 до 21 года [5, c.201].

После прихода к власти большевиков в 1917 году, ими был разработан свой Уголовный кодекс который вступил в действие в 1922 г. Данный кодекс конкретизировал систему посягательств против личной свободы, посвятив этому четыре состава преступлений. Это - «Насильственное незаконное лишение кого-либо свободы, совершенное путем задержания или помещения его в каком-либо месте» (ст. 159); «Лишение свободы способом, опасным для жизни или здоровья лишенного свободы или сопровождавшееся для него мучениями» (ст. 160); «Помещение в больницу для душевнобольных заведомо здорового лица из корыстных или иных личных видов» (ст. 161); «Похищение, сокрытие или подмен чужого ребенка с корыстной целью, из мести или иных личных видов» (ст. 162).

В связи с изменением ситуации в стране в 1926 году был принят новый уголовный кодекс. Но в нем преступления против личной свободы сохранились (ст. 147, 148, 149), с той лишь разницей, что лишение свободы способом, опасным для жизни или здоровья потерпевшего или сопровождавшимся причинением ему физических страданий, было не самостоятельным преступлением, как в Кодексе 1922 г., а квалифицированным признаком основного состава насильственного незаконного лишения свободы (ч. 2 ст. 147).

После смерти Сталина и изменением политического курса стал разрабатываться новый Уголовный кодекс, который был принят 1960 г. В первоначальной редакции кодекс устанавливал более узкий перечень преступлений, посягающих на личную свободу. К ним было отнесено всего два состава: незаконное лишение свободы, в том числе совершенное способом, опасным для жизни и здоровья потерпевшего (ч. 1 и ч. 2 ст. 126), и подмен ребенка из корыстных или иных низменных побуждений (ст. 125 УК). В течение всего времени действия УК 1960 г. в него вносились определенные изменения, обусловленные разными причинами, в том числе и социальной обусловленностью каких-либо деяний. Такие изменения были внесены в группу преступлений против личной свободы в разное время.

В 1988 г. в Кодекс была введена ст. 126.2, устанавливающая ответственность за незаконное помещение в психиатрическую больницу заведомо психически здорового лица. Появление этой статьи связано с протестами международных организаций против нарушений прав человека в России в отношении диссидентов и иных инакомыслящих лиц, к которым применялись методы психиатрии в репрессивных целях. Следует заметить, что ответственность за подобные действия предусматривалась в Уголовном уложении 1903 г. и в Уголовных кодекcax 1922 и 1926 гг. Лишь с 1960 и до 1988 г. такой ответственности законодательство России не содержало.

В 1987 г. в Уголовный кодекс 1960 г. был введен состав захвата заложников (ст. 126.1), а в 1993 г. установлена ответственность за похищение человека (ст. 125.1). В процессе подготовки УК 1996 г. (в частности, в одном из последних проектов) состав захвата заложников включили в раздел «Преступления против общественной безопасности и общественного порядка», что, с точки зрения более высокой степени общественной опасности этого деяния, является правильным, поскольку при захвате заложника ущерб причиняется не отдельной личности (как в преступлениях против свободы), а неопределенно широкому кругу общественных отношений: безопасности личности, сохранности имущества, нормальной деятельности государственных и общественных организаций и др.

В действующем УК РФ, в частности, также как и в УК РСФСР 1960г., определение похищения человека не сформулировано. В ст. 127 УК РФ незаконное лишение свободы определяется через отсутствие в деянии признака похищения (т.е. через неопределенный признак), а соотношение захвата заложника с этими преступлениями вообще никак не обозначено. Поэтому в теории и на практике отграничение рассматриваемого преступления от смежных составов представляется затруднительным. Квалификация фактически сходных действий по разным статьям Уголовного кодекса (ст. ст. 126, 127, 206 УК РФ) влечет применение к виновным не только различных сроков и размеров, но и видов наказания, что, несомненно, противоречит принципам справедливости наказания и равенства граждан перед законом.

Сравнительно-правовой анализ данной проблемы свидетельствует о том, что начиная с середины 80-х годов прошлого века, уголовные законодательства бывших союзных республик были дополнены новыми статьями, устанавливающими ответственность за эти деяния. Однако ответственность за похищение человека в полном объеме и ответственность за захват заложника в соответствии с нормами международного права были предусмотрены лишь при принятии нового УК Азербайджанской Республики в 1999 г. Уголовно-правовые аспекты ответственности за похищение человека и захват заложника еще не были предметом отдельного научного исследования в Азербайджанской Республике, данная тема освещена лишь в рамках учебной литературы и в комментариях к УК Азербайджанской Республики 1999 г. Установление ответственности за похищение человека является новеллой УК Азербайджанской Республики 1999 г. Это преступление не выделялось в качестве самостоятельного преступления в предыдущих уголовных законодательствах 1922, 1927 и 1960 гг. УК Азербайджанской ССР 1922 г. также не предусматривал ответственности за похищение человека в полном объеме. Только в ст. 162 УК 1922 г. предусматривалась ответственность "за похищение, сокрытие или подмен чужого ребенка с корыстной целью, из мести или из иных личных видов", что каралось лишением свободы на срок до четырех лет со строгой изоляцией. УК Азербайджанской ССР 1927 г. также не устанавливал ответственности за похищение человека в полном объеме, но в ст. 187 предусматривал ответственность за похищение, сокрытие или подмен чужого ребенка с корыстной целью, из мести или иных личных видов (санкция предусматривала наказание в виде лишения свободы на срок до пяти лет), а в ст. 189 - за похищение женщины с целью вступления с нею в брак или половую связь без ее на то согласия (санкция предусматривала наказание в виде лишения 
свободы на срок до пяти лет). УК Азербайджанской ССР 1960 г. также придерживался вышеупомянутых традиций и содержал ответственность только за два вида похищения, а именно: 1) похищение или подмен чужого ребенка с корыстной целью, из мести или иных личных побуждений (ст. 126); 2) похищение женщины с целью вступления в брак (ст. 129). Наказывались оба деяния одинаково - до трех лет лишения свободы и были размещены в группе преступлений против личности (глава 3). Статьи 126 и 129 УК 1960 г. в первоначальной редакции не содержали квалифицирующих и особо квалифицирующих признаков, законодательно дифференцирующих ответственность за эти деяния.

Таким образом, все три предыдущих уголовных законодательства (1922, 1927 и 1960 гг.) предусматривали ответственность за похищение человека только в отношении узкого круга потерпевших: ребенка или женщины. Обязательным признаком состава преступления при этом являлось наличие специальной цели преступления. Итак, новый УК 1999 г. значительно расширил круг потерпевших, установив в ст. 144 ответственность за похищение не только ребенка или женщины, а в целом "человека". В то же время УК 1999 г., сохранив отдельно ответственность за подмену ребенка, исключил из диспозиции ст. 172 (подмена чужого ребенка) упоминание о его похищении, а также предусмотрел в ст. 172 факультативный признак объективной стороны (место совершения преступления - медицинское учреждение) и специальные признаки субъекта (лицо, на которое возложена обязанность охраны ребенка или заботы о нем) в качестве необходимых признаков состава преступления, чем значительно сузил круг лиц, подпадающих под ответственность за подмену чужого ребенка. В отличие от предыдущих УК, законодатель в новом УК 1999 г. отказался также от установления самостоятельной нормы об ответственности за похищение женщины с целью вступления с нею в брак помимо ее воли. Вместо этого в УК 1999 г. была введена новелла - ст. 144, предусматривающая ответственность за похищение человека, что, конечно, является более широким понятием и включает в себя, в том числе, и похищение чужого ребенка, и похищение женщины с целью вступления в брак, т. е. впервые в истории отечественного уголовного законодательства была установлена ответственность за похищение человека в полном объеме. Интересно, что некоторые государства СНГ ввели подобную норму намного раньше. Так, Российская Федерация в 1993 г., еще до принятия своего нового УК, ввела ответственность за похищение человека в связи с ростом числа подобных деяний. Анализируемая норма (ст. 144) сложилась, прежде всего, под влиянием международных документов о правах и свободах человека. К их числу в первую очередь относятся: Всеобщая декларация прав человека 1948 г.; Международный пакт о гражданских и политических правах 1966 г.; Конвенция о защите прав человека и основных свобод 1950 г., положения которых были закреплены и получили дальнейшее развитие в Конституции Азербайджанской Республики 1995 г. Так, Конституция устанавливает право каждого гражданина на личную свободу (ст. 28). Это право предполагает возможность каждого свободно передвигаться, избирать место жительства и выезжать за пределы государства[3, с.6].

Как видно из истории ответственность за преступления против свободы в России была введена в 19 веке. К началу 20 века перечень преступлений был расширен. Но с приходом к власти большевиков свободам человека стало уделяться меньшее значение, чем при царской России и в начале второй половины 20 века количество статей уголовного кодекса, которые предусматривали ответственность за преступления против свободы сократилось до минимума. И только началом распада СССР в уголовный кодекс стали добавлять статьи предусматривающие ответственность за данные преступления.

Масштабы распространения преступности, появление се новых форм вызывают необходимость дальнейшего развития и совершенствования уголовного законодательства, проведения программ в рамках международного сотрудничества в области обеспечения прав и свобод граждан, их защиты от противоправных посягательств.

\title{
Литература
}

1. Уголовный кодекс Российской Федерации. М.: Эксмо, 2015.

2. Уголовный кодекс Азербайджанской Республики. Баку: Юридический центр, 2015.

3. Гаджиев Т.Е. Уголовно-правовая характеристика похищения человека по Уголовному кодексу Азербайджанской республики // Международное уголовное право и международная юстиция. 2009. № 3.

\section{Особенности уголовной ответственности за мошенничество в сфере кредитования по законодательству России и США}

\author{
(C) С. В. Григорьева \\ магистрант 2 года обучения юридического факультета \\ ФГБОУ ВО «Бурятский госуниверситет» \\ Россия, г. Улан-Удэ \\ Sesegma.grigoreva@mail.ru
}

Мошенничество в сфере кредитования представляет собой хищение денежных средств заемщиком путем представления банку или иному кредитору заведомо ложных и (или) недостоверных сведений. Преступность в кредитно-банковской сфере тормозит экономическое развитие любого государства, подстегивает инфляцию, а 
также обостряет все существующие экономические проблемы. В статье дана сравнительная характеристика состава преступления по российскому законодательству и законодательству США.

Согласно статье 8 Конституции в Российской Федерации гарантируются единство экономического пространства, свободное перемещение товаров, услуг и финансовых средств, поддержка конкуренции, свобода экономической деятельности; признаются и защищаются равным образом частная, государственная, муниципальная и иные формы собственности [1].

В настоящее время при господстве в экономике рыночных отношений эффективность любых преобразований в различных сферах жизнедеятельности общества во многом зависит от стабильности и надежности ее финансово-кредитной системы. Нестабильность финансово-кредитной системы сопровождается конкуренцией на финансовом рынке и криминализацией экономики, и данные негативные процессы выявляют несовершенство действующего законодательства. Для современного общества кредит является основным способом удовлетворения возникающих потребностей. Благоприятные условия для предоставления кредитов создаются государством, прежде всего, для удовлетворения интересов своих граждан, однако в некоторых случаях, государство терпит больше убытков.

Федеральным законом от 29.11.2012 года №207-Ф3 «О внесении изменений в Уголовный кодекс Российской Федерации и отдельные законодательные акты Российской Федерации» законодатель дифференцировал уголовную ответственность за совершение мошеннических действий, что обусловило включение в УК РФ специальных составов мошенничества. По мнению законодателя данная новелла призвана «снизить число ошибок и злоупотреблений во время возбуждения уголовных дел о мошенничестве, способствует повышению качества работ по выявлению и расследованию таких преступлений» [3].

Мировые экономические кризисы 2008 и 2013 гг., согласно данным финансовой аналитики, были спровоцированы именно нестабильностью кредитной системы. Свои корни данное явление взяло именно в США. Выдача кредитов под низкие процентные ставки сподвигла гражданское население к искажению данных своей кредитной истории. Кроме того, для американской банковской системы 2008 года было не обязательно предоставление обеспечения под получение кредита. Таким образом, кредит на выгодных условиях мог получить фактически любой желающий. Безусловно, когда возникла необходимость выплачивать заемные средства, появились проблемы, и многие граждане попали в долговую яму.

После ипотечного кризиса банки и государственные организации США ужесточили стандарты кредитования и начали тщательно проверять заемщиков. Примерно такова ситуация и на российском кредитном рынке: требования к заемщикам и профилактика мошенничества не стоят на месте, введение в УК РФ самостоятельного состава преступления - явное тому подтверждение.

Таблица 1

Основные мошенничества на рынке США в 2008 году [6, с. 45]

\begin{tabular}{|l|c|c|}
\hline Виды мошенничества & Количество отчетов & Проценты от выборки отчетов \\
\hline $\begin{array}{l}\text { Искажение сведений о доходах, долгах и } \\
\text { активах }\end{array}$ & 761 & 28,04 \\
\hline Подделка документов & 496 & 14,41 \\
\hline Занятость заемщика & 255 & 13,11 \\
\hline Оценка имущества & 232 & 10,18 \\
\hline Подделка удостоверений & 180 & 5,65 \\
\hline Подставные покупатели & 100 & 3,45 \\
\hline Кража удостоверений личности & 61 & 2,71 \\
\hline Раздувание цены (флиппинг) & 48 & \\
\hline
\end{tabular}

В США отсутствует единая уголовно-правовая система, что обусловлено особенностями американского федерализма. На территории каждого штата действует собственное законодательство, в частности и уголовное. Таким образом, в практическом правоприменении возможна ситуация, когда одно и то же мошенническое деяние на территории двух разных штатов будет иметь разную уголовно-правовую характеристику. Следует отметить, что это негативным образом складывается на формировании нормативной базы и статистике привлечения к уголовной ответственности. На территории США с 1962 года действует Примерный уголовный кодекс, который содержит фундаментальные положения уголовного права, в нем закреплены принципы, определения основных понятий.

На федеральном уровне в американской правовой системе мошенничество - это «разветвленная система самых утонченных и сложных по своей форме деяний в виде схем, приемов, методов, способов, соглашений и 
поступков, которые имеют обманный (вымышленный, воображаемый, фиктивный, не обязательственный) характер, посягают на различные объекты уголовно-правовой охраны» [4, с. 7].

Примерный уголовный кодекс США содержит описание разнообразных мошеннических действий в разделах «Хищение и родственные ему посягательства» и «Подлог документа и обманные приемы». Так, ст. 223.3 Примерного УК США предусматривает хищение путем обмана, при котором виновный посредством умышленных действий получает чужое имущество. Под имуществом понимается все, что имеет ценность - недвижимое имущество, материальное и нематериальное личное имущество, права, вытекающие из договоров, имущество в требованиях и иные интересы или притязания по имуществу, входные или перевозочные билеты, пойманные домашние животные, пища и питье, электрическая или иная энергия [5].

Довольно скудная правовая регламентация мошенничества в сфере кредитования для страны, на которой лежит ответственность за произошедшие мировые финансовые кризисы, недопустимо. Поэтому требуется более полная правовая регламентация данного состава преступления именно на уровне федерации, поскольку категория преступления имеет обширный характер и охватывает собой фактически каждый из пятидесяти штатов.

Таким образом, законодательство США и России в сфере кредитования отличается, в первую очередь, нормативно-правовой базой. Несмотря на то, что оба государства являются федеративными, в США отсутствует единство уголовного законодательства на всей территории, в разных штатах применяются различные составы. Назначение наказания также дифференцировано. Так, преступники могут избегать наказания в сфере кредитного мошенничества перемещаясь из штата в штат. Следует также отметить различие в самом понятии мошенничества в российском и американском законодательстве. Злоупотребление доверием в законодательстве США в понятие мошенничества не включается. Выделение в США кредитного мошенничества в особый, квалифицированный состав преступления не произошло, как это сделано в нашей стране. В этом видится весомый плюс российской уголовно-правовой системы. Ужесточение наказания по сравнению с обычным составом мошенничества играет прежде всего превентивную роль, положительным образом сказываясь на статистике привлечения к ответственности.

Тем не менее, в силу развития технологического прогресса, именно в США возникают новые схемы кредитного мошенничества, способы борьбы с которыми можно использовать в правоприменительной практике российских правоохранительных органов. В целом обращение к законодательному и правоприменительному опыту зарубежных стран, таких развитых как США, является одним из способов совершенствования национальной правовой системы, унификации уголовного законодательства, поскольку такое явление как мошенничество распространено по всему миру, а кредитные операции могут быть проведены на территории различных государств, в том числе и с использованием международных средств платежа.

\section{Литература}

1. Конституция Российской Федерации (с учетом поправок, внесенных Законами РФ о поправках к Конституции РФ от 30.12.2008 № 6-ФКЗ, от 30.12.2008 №7-ФКЗ, от 05.02.2014 №2-ФК3, от 21.07.2014 №11-ФКЗ) // Российская газета. 25.12.1993. № 238 .

2. Уголовный кодекс Российской Федерации от 13.06.1996 №63-Ф3 (ред. от 30.12.2015) // Собрание законодательства РФ. 17.06.1996. №25. ст. 2954.

3. Пояснительная записка к проекту Федерального закона от 29.11.2012 года №207-Ф3 «О внесении изменений в Уголовный кодекс Российской Федерации и отдельные законодательные акты Российской Федерации» // СПС «КонсультантПлюс».

4. Оськина И., Лупу А. Мошенничество: термин один, а понятие разное // ЭЖ-Юрист. 2013. № 29.

5. Примерный Уголовный кодекс США [Эл.pecypc]: http://constitutions.ru/?p=5849\&page=6 (дата обращения: 29.04.2016).

6. Саблин М. Т. Как выбраться из долговой ямы (на примере ипотечного кредита). М.: Библиотечка «Российской газеты», 2013. Вып. 18. 144 с.

\section{Уголовная ответственность за совершение дорожно-транспортных происшествий (сравнительно-правовой анализ законодательства России и Китая)}

(ㄷ) Б. Б. Даиинимаев

магистрант 1 года обучения юридического факультета ФГБОУ ВО «Бурятский госуниверситет»

Россия, г. Улан-Удэ gamer405@mail.ru

В последнее время отмечается ужесточение уголовного наказания к лицам, совершившим дорожно-транспортные происшествия. Данное обстоятельство связано с тем, что отмечается тенденция роста числа пострадавших в ДТП. Указанная проблема характерна не только для Российской Федерации, но также и для соседней Китайской Народной Республики.

Данное обстоятельство обусловило актуальность сравнительно-правового анализа современного уголовного законодательства двух государств. 
В исследовании дается сравнительный уголовно-правовой анализ норм, предусматривающих ответственность за преступления против безопасности движения и эксплуатации транспорта по законодательству России и Китая.

В Уголовном кодексе Российской Федерации преступления в сфере транспортной безопасности объединены в главу «Преступления против безопасности движения и эксплуатации транспорта». Наиболее полно реализация уголовных норм в области обеспечения транспортной безопасности проявляется в сфере регулирования безопасности движения на автомобильном транспорте. Ответственность участников дорожного движения в большей степени конкретизирована в Правилах дорожного движения.

Отличие же уголовного законодательства КНР заключается в том, что нормы, предусматривающие уголовную ответственность за совершение дорожно-транспортных происшествий, сформулированы простыми диспозициями и содержат минимум квалифицирующих признаков.

В Уголовном кодексе КНР установлена уголовная ответственность за преступления против безопасности дорожного движения и эксплуатации транспортных средств по трем статьям, которые содержатся в главе «Преступления против общественной безопасности».

Еще одним отличием законодательства КНР является отсутствие мер наказания в виде лишения права занимать определенную должность или заниматься определенной деятельностью, а также лишения права управлять транспортным средством на определенный срок.

Статья 264 Уголовного кодекса РФ предусматривает лишение права занимать определенные должности или заниматься определенной деятельностью.

К примеру, статьей 133 Уголовного кодекса КНР устанавливается, что нарушение законоположений об управлении движением транспортных средств, приведшее к серьезному инциденту, если это повлекло тяжкое телесное повреждение, смерть человека или нанесло крупный ущерб общественной, частной собственности, наказывается лишением свободы на срок до трех лет либо арестом; в случае бегства после дорожно-транспортного происшествия или при других особо злостных обстоятельствах наказывается лишением свободы на срок от трех до семи лет; если бегство повлекло смерть человека, наказывается лишением свободы на срок семь и более лет [6, с. 71$]$.

Уголовный кодекс РФ устанавливает нижние пределы наказания в виде лишения свободы сроками от двух и четырех лет.

Уголовный кодекс Российской Федерации дополнен статьей 264.1, предусматривающей уголовную ответственность за управление транспортным средством в состоянии опьянения лицом, ранее подвергнутым административному наказанию за управление транспортным средством в состоянии опьянения либо имеющим судимость за совершение в состоянии опьянения преступления, предусмотренного ст. 264 Уголовного кодекса РФ. Санкция ст. 264.1 Уголовного кодекса РФ предусматривает наказание в виде штрафа от 200 до 300 тысяч рублей или в размере заработной платы осужденного за период от 1 года до 2 лет, обязательных работ на срок до 480 часов, принудительных работ и лишения свободы на срок до 2 лет. В качестве дополнительного наказания предусмотрено лишение права занимать определенные должности или заниматься определенной деятельностью до 3 лет.

Верховный народный суд КНР, Верховная народная прокуратура КНР и Министерство общественной безопасности КНР при расследовании ДТП, совершенных в состоянии алкогольного опьянения, руководствуются Совместными рекомендациями по применению законодательства при производстве по уголовным делам, связанным с вождением в состоянии алкогольного опьянения от 28 декабря 2013 года.

Согласно практике расследования дорожно-транспортных происшествий в Китае вождением в пьяном состоянии признается вождение автомобиля при концентрации алкоголя свыше 80 мг на 100 мл. В этом случае виновный подлежит привлечению к уголовной ответственности за опасное вождение в соответствии со статьей 1331 Уголовного кодекса КНР. Опасное вождение в соответствии со статьей 1331 Уголовного кодекса КНР наказывается краткосрочным арестом (арестом на срок от 1 до 6 месяцев) и штрафом.

Сумма штрафа должна определяться в зависимости от степени опьянения виновного лица, фактически нанесенного им ущерба, степени раскаяния. Кроме того, сумма штрафа должна быть сопоставима с основным наказанием.

Обстоятельствами, отягчающими ответственность за вождение в пьяном состоянии, могут быть:

- дорожно-транспортное происшествие, за которое виновное лицо несет полную или основную ответственность, или сокрытие с места совершения дорожно-транспортного происшествия (если данные деяния не образуют состава другого преступления);

- вождение автомобиля при концентрации алкоголя в крови свыше 200 мг на 100 мл;

- вождение автомобиля по скоростным автодорогам или скоростным внутригородским дорогам;

- управление автомобилем для коммерческих перевозок с пассажирами;

- существенное превышение количества пассажиров, веса груза, максимально допустимой скорости, управление автомобилем без водительского удостоверения, использование поддельных или модифицированных автомобильных номеров или другое существенное нарушение законодательства о безопасности дорожного движения;

- уклонение от проверки сотрудниками дорожной полиции, отказ или препятствование сотрудникам дорожной полиции в проведении проверки (если данные деяния не образуют состава другого преступления); 
- рецидив (управление автомобилем в пьяном состоянии после того, как данное лицо привлекалось к административной или уголовной ответственности за вождение в пьяном состоянии);

- другие обстоятельства, при котором ответственность виновного лица должна быть ужесточена [4, с. 19].

Если пьяный путем применения насилия или угроз применения насилия препятствует сотрудникам дорожной полиции в проведении проверки, то при наличии состава преступления, предусмотренного статьей 177 Уголовного кодекса КНР (препятствование должностным лицам в выполнении обязанностей), виновный должен наказываться по совокупности преступлений (ст. 177 + ст. 1331 Уголовного кодекса КНР). По статье 177 Уголовного кодекса КНР за препятствование должностным лицам в выполнении обязанностей предусмотрено наказание в виде лишения свободы на срок до 3 лет, краткосрочного ареста на срок от 1 до 6 месяцев, надзора на срок до 1 года или штрафа.

При выявлении лица, которое может находиться в состоянии алкогольного опьянения, сотрудники проводят проверку при помощи трубки для дыхания, образца крови; при наличии условий - ведут фотосъемку, видеосъемку или аудиозапись; при наличии свидетелей - опрашивают свидетелей.

Если трубка для дыхания показывает высокую концентрацию алкоголя в крови, при этом лицо, которое может находиться в состоянии алкогольного опьянения, уклоняется от сдачи крови на анализы, результаты, показанные трубкой, могут быть подтверждением того, что лицо находилось в состоянии алкогольного опьянения.

После задержания подозреваемого он может быть оставлен под стражей или выпущен под залог. Подозреваемый, который соответствует условиям освобождения под залог, но не может предоставить необходимую сумму средств для залога или поручителя, может быть освобожден из-под стражи и помещен под домашний арест. В случае нарушения условий освобождения под залог или условий нахождения под домашним арестом подозреваемый может быть снова помещен под стражу [5, с. 1064].

Анализ теоретических источников позволил нам сделать следующие выводы.

Так, в современной юридической литературе отсутствует комплексное изучение проблемы криминалистического противодействия нарушениям правил дорожного движения или эксплуатации транспортных средств.

В Уголовном кодексе КНР, в отличие от Уголовного кодекса РФ, отсутствует самостоятельная глава, посвященная транспортной безопасности и ответственности за нарушения правил движения и эксплуатации транспортных средств. Глава «Преступления против общественной безопасности» Уголовного кодекса КНР содержит три статьи, посвященные данным преступлениям с минимальным указанием квалифицирующих признаков.

На основании изложенного можно считать, что российское законодательство имеет более совершенное правовое установление ответственности лиц, виновных в совершении дорожно-транспортных происшествий.

Кроме того, отечественное уголовное законодательство, в отличие от китайского, постоянно корректируется в виду часто меняющихся жизненных условий, что очень важно для правового регулирования.

\title{
Литература
}

1. Уголовный кодекс Российской Федерации от 13.06.1996 № 63-Ф3 (ред. от 30.12.2015) // С3 РФ, 17.06.1996, № 25, ст. 2954.

2. Постановление Правительства РФ от 23.10.1993 № 1090 (ред. от 21.01.2016) «О Правилах дорожного движения» // Российские вести. № 227. 23.11.1993.

3. Литвяк Л. Г., Зайцев А. И., Бирюков И. И. Ответственность за нарушение правил дорожного движения и эксплуатации транспортных средств (ст. 264 УК РФ): проблемные вопросы // Ученый XXI века. 2015. № 1-2 (2-3). С. 51-55.

4. Петров С.А. Уголовная ответственность за нарушения правил, обеспечивающих безопасную работу транспорта по уголовному законодательству России и Китая // Актуальные вопросы борьбы с преступлениями. 2014. № 1. С. 17-21.

5. Трощинский П.В. Нормативно-правовое регулирование борьбы с «пьяным вождением»: опыт Китая // Журнал зарубежного законодательства и сравнительного правоведения. 2015. № 6 (55). С. 1062-1070.

6. Уголовный кодекс Китайской Народной Республики / под ред. А. И. Коробеева; пер. с кит. Д. В. Вичикова. СПб.: Юридический центр Пресс, 2001. 301 с.

7. Финк Д.А. Дорожно-транспортные происшествия: причины, предупреждение, защита прав пострадавших // Право и государство. 2015. № 2 (67). С. 68-72.

\section{Конфуцианство в уголовном праве Республики Корея}

\author{
(ㄱ. Д. А. Добряков \\ аспирант 1 года обучения \\ ФГАОУ ВО «Российский университет дружбы народов» \\ Россия, г. Москва \\ den-dobryakov@yandex.ru
}

Очевидным кажется то, что большим значением для жизни общества обладает идеология, то есть система часто разных по сути, но при этом тесно взаимосвязанных друг с другом идей и взглядов, выражающих отношение членов общества к окружающей действительности [8, с. 475]. Фактически являясь основой для всей совокупности общественных отношений (достаточно вспомнить, например, марксистскую идеологию в странах коммунистической ориентации, которая играла ведущую роль при решении всех вопросов на всех уровнях, начиная с брачно-семейных отношений и заканчивая государственной внешней политикой), такая система обу- 
славливает, в том числе, и многие основополагающие начала национального законодательства конкретного государства, а равно и особенности его уголовно-правовой отрасли.

Одной из таких идеологий является конфуцианство, представляющее собой этико-философское учение, названное по имени древнекитайского философа Конфуция (Кун-цзы; $551-479$ гг. до н. э.) и вот уже более двух тысяч лет оказывающее сильнейшее влияние на жизнь общества в странах Юго-Восточной Азии. Это влияние можно сравнить с влиянием религий - недаром конфуцианство иногда к ним приравнивается [7, с. 95-100]. Однако в отличие от традиционных религий, конфуцианство не пытается объяснить природу всего сущего, а является в достаточной мере светским, рационалистическим учением, нашедшим широкое признание в мире и сохраняющим свой авторитет до настоящего времени. Показательно, что это учение благополучно пережило даже времена господства достаточно жёсткой коммунистической идеологии в Китае XX века, фактически не столкнувшись с гонениями со стороны государства, хотя иногда и подвергаясь критике. Китайские авторы писали, например, так: «Если осмотрительно и вдумчиво использовать некоторые конфуцианские изречения и формулы, вкладывая в них новое классовое содержание, то они могут широко применяться и сейчас. ...Важно, что учение оставило народу Китая ценное культурное наследие, и этим наследием китайский народ должен дорожить» [9, с. 174].

При рассмотрении места конфуцианства в уголовном праве Республики Корея представляется уместным кратко остановиться на основных положениях этой идеологии, излагая их во взаимосвязи с соответствующими особенностями действующего права, а также обратить внимание на вопрос о том, какое отношение китайское философское учение имеет к корейскому государству и обществу. Думается, что начать следует со второго.

Страны Юго-Восточной Азии, а точнее их правовые системы, объединяются в семью общинного права, одной из отличительных черт которой является особое понимание права и отношение к нему как к средству регулирования жизни общества, не сопряжённому с принуждением. Во многом это обусловлено ключевым положением в регионе Китая [1, с. 70], где учение Конфуция и его интерпретации имели официальный статус государственной идеологии со II века до н. э. по начало XX века н. э. [8, с. 624]. Распространяясь вслед за влиянием китайского государства, конфуцианство веками внедрялось в культуру как отдельных народностей внутри Китая, способствуя их объединению в одном государстве, так и народов окружающих Китай стран. Не обошёл стороной этот процесс и Корею, чьё расположение в непосредственной близости к Китаю естественным образом повлекло тесное (и далеко не всегда мирное) взаимодействие с этой страной и её культурой.

Китай не был единственным внешним фактором, оказывающим влияние на формирование современной Республики Корея, бывшей некогда лишь южной частью единого корейского государства. Среди других таких факторов наибольшее значение имели, пожалуй, Япония, в связи с которой стоит упомянуть хотя бы факт аннексии всего корейского государства Японской империей в 1910 году, за чем последовала принудительная «японизация» общественной жизни в стране, производимая самыми суровыми средствами [3, с. 224-244], и США, чьё влияние достигло апогея после окончания Корейской войны 1950-1953 гг., когда созданное на южной части Корейского полуострова государство Республика Корея стало американским протекторатом. Очевидно, что тесное «партнёрство» между странами совершенно разного политического веса не могло не привести к изменениям в жизни корейского общества и государства (достаточно взглянуть на современную корейскую массовую культуру, то же отчасти касается и области права).

Тем не менее, несмотря на то, что влияние Японии и США было более поздним хронологически и часто характеризовалось откровенной агрессивностью, невзирая на последовавшую за этим культурную трансформацию (вестернизацию) и современные общемировые процессы глобализации, позиции конфуцианства в Корее до настоящего времени предельно сильны: хотя конфуцианство более не имеет официального статуса государственной идеологии (как и в Китае, о чём было сказано выше), оно и сейчас является основой корейской культуры [4, с. 268, 304]. Корни конфуцианства в Корее восходят к Х веку, когда в 992 году был основан первый национальный университет, где стали изучать китайскую модель общественных отношений (традиции, обряды и пр.) и учение Конфуция как таковое [13, с. 228], что способствовало последующему многовековому процессу формирования устоев общественной жизни.

Теперь можно перейти к самому учению Конфуция и его корреляции с нормами уголовного права Республики Корея. Вместо того, чтобы выделять обобщённую «эссенцию» учения Конфуция и его последователей (или, говоря словами Мао Цзэ-дуна - получать «экстракт» [5, с. 270]; хотя Мао, предлагая «разделить на отбросы, которые устраняются, и экстракт, который усваивается», писал не о конфуцианстве, а об иностранной культуре, этот подход иногда применялся по аналогии), уместно обратиться к конфуцианским книгам и содержащимся в них высказываниям. Помимо общечеловеческих норм морали (например, принцип «чего сам не желаешь, того не делай другим» [6, с. 177]), правил поведения и рекомендаций доброму правителю, в этих книгах много говорится о почитании старшего, уважении его и подчинении ему, что полагается неоспоримым благом. В Лунь-Юй («Рассуждения и разговоры») есть такие строки: «Редко бывает, чтобы человек, который отличался бы сыновьей почтительностью и братской любовью, любил бы восставать против старших, и никогда не бывает, чтобы тот, кто не любит восставать против высших, захотел произвести возмущение» [6, с. 97]. В книге Чжун-Ю («О неизменных законах духовной жизни, или учение о неизменяемости в состоянии середины»), говорится, в частности: «Высший человек будет соблюдать четыре вещи: служить своему отцу так же, как я хотел бы, чтобы мой сын служил мне; служить моему государю, как я желал бы, чтобы мне служил мой слуга; служить своему старшему брату, как я хотел бы, чтобы мне служили мои младшие братья; поступать по отношению к своему другу так, как я хотел бы, чтобы он поступал по отношению ко мне...» [6, с. 27$].$ 
Итак, конфуцианское учение придаёт большое значение почитанию старшего, почитанию патриарха - будь то отец, дед или предок вообще, старший брат, муж (отдельно внимание уделяется семейным - муж должен заботиться, а жена подчиняться), правитель, чиновник и так далее. При этом показательно, что отец, брат и правитель ставятся в один ряд, хотя отец и брат всегда останутся отцом и братом, а правитель - категория, а вовсе не какая-то конкретная личность. Из этого можно сделать вывод о том, что правитель, а равно и всякий вышестоящий субъект власти (существующий и властвующий в данный момент), должен уважаться почти так же, как родной отец, уже из-за одного того, что он правит или хотя бы просто находится выше по социальной лестнице. Поэтому, если говорить ещё более обобщённо, одним из базовых элементов конфуцианства (конфуцианской этики) можно назвать культ авторитета (или старшинства, статуса). Здесь необходимо, однако, упомянуть, что обязанности подчиняться соответствует обязанность быть добрым по отношению к подчинённому, при этом обеим этим обязанностям уделяется примерно равное внимание.

Представляется, что влияние той или иной идеологии на правовую систему государства, а равно и на конкретную отрасль права можно определить (или просто обнаружить) через отражение этой идеологии в деятельности законодателя (т.е. косвенно) и через упоминание её в актах правоприменения (и прочих родственных им актах; т.е. прямо), а также в доктрине, которую, пожалуй, стоит выделить отдельно.

Первый способ предполагает сосредоточение внимания на законах, как на вполне конкретных результатах деятельности законодателя. Здесь следует обращать внимание на символизм уголовного законодательства, на выражение в его структуре и конкретных нормах принятой государством системы ценностей. Нужно оговориться отдельно по поводу системы ценностей, о которой здесь идёт речь - структура уголовного закона того или иного государства обусловлена не одной лишь законодательной техникой, но и является проявлением государственной политики и результатом воплощения в тексте закона официальных воззрений на приоритеты государственной защиты. Это можно показать на примере сопоставления Советского Союза и современной России. Советский законодатель декларировал примат интересов государства и общества над интересами личности, примат общественного над частным, из чего следовала и структура Особенной части уголовного закона, где сначала приводились нормы об ответственности за преступления против государства (государственной власти, государственной собственности), затем - против общества и лишь после всего этого - против отдельно взятой личности. Российский же законодатель, развивая положения Конституции Российской Федерации, на первое место поместил преступления против личности в целом и жизни человека в частности, а далее следовал логике, намеченной Основным законом [2, с. 246-247].

Структуру Особенной части Уголовного закона Республики Корея (형법, имеющего кодифицированную форму, однако не являющегося единственным актом, содержащим нормы уголовного права) нельзя назвать уникальной, однако она имеет некоторые особенности, отличающие её от национального уголовного законодательства других государств, прежде всего, от стран Запада, например, от Российской Федерации, но при этом являющиеся обычными для стран семьи общинного права (и не только для них), где имеет авторитет конфуцианская идеология [15]. Так, корейским законодателем вперёд выносятся преступления, связанные с вооружёнными выступлениями против действующей государственной власти (восстание и т.д.; ст. 87 и далее), связанные с внешней агрессией (и поддержкой такой агрессии; ст. 92 и далее), преступления против общественного порядка (ст. 114 и далее), деятельности должностных лиц и органов власти (ст. 136 и далее) и так далее. Даже такие деяния, как супружеская измена (ст. 241) и вовлечение в занятие проституцией (ст. 242), то есть преступления против морали и нравственности (в числе прочих) выносятся перед преступлениями против жизни и здоровья (ст. 250 и далее). Можно сказать, что уголовное законодательство Республики Корея является, в некоторой степени, воплощением закреплённого в конфуцианском учении принципа «уважения» старшинства, ведь установленный в государстве порядок, олицетворяющие государство высшие должностные лица, государственные служащие и общие интересы формально признаются более приоритетными объектами уголовно-правовой защиты, чем отдельная «простая» личность. При этом важно подчеркнуть именно формальный характер этого распределения приоритетов, который носит, прежде всего, символический характер, выражая близкое конфуцианству (но, если обратиться к иным правовым системам, не только к нему - стоит вспомнить упомянутый выше далёкий от конфуцианства УК РСФСР) мировоззрение.

Второй способ подразумевает обращение к актам правоприменения, содержащим официальное толкование положений законодательства. В частности, в актах Конституционного суда Республики Корея можно встретить такой оборот: «Со времён династии Чосон (1392 - 1897 (1910) гг. - прим. авт.) и до настоящих дней отцеубийство карается суровее (как деяние, совершённое с отягчающими обстоятельствами), как того требуют Конфуцианские ценности и традиционные идеи, которые подчёркивают сыновий долг» [10]. Здесь имеется прямая отсылка к учению Конфуция и даже раскрывается конкретное его положение - сыновий долг, т.е. уважение к родителям. Здесь Конституционный суд поясняет статью 250 Уголовного закона Республики Корея, часть 2 которой содержит санкцию за убийство родителя или любого родственника по восходящей линии (своего собственного, а равно и супруга/супруги), являющуюся более суровой, чем санкция за обычное убийство (часть 1 этой же статьи). Обосновывая обособление диспозиции части 2 в отдельную норму положениями конфуцианского учения, суд даёт понять, что, хотя законодатель и не упомянул это учение в законе прямо, он подразумевал его в качестве основы для данного закона.

Далее следует остановиться на доктрине уголовного права. В научной литературе отмечается [14, с. 71-72], что конфуцианское учение (а точнее - конфуцианская правовая традиция), выражающееся в «гармоничных отношениях между человеком и обществом, а равно и в гармоничных отношениях между человеком и природой» вступает в конфликт с западной правовой системой в связи с оценкой нарушений закона и последующей на них 
реакцией. Если западная модель правового регулирования и судопроизводства во многом нашла отражение в действующем официальном законодательстве и государственной политике Республики Корея, то конфуцианские ценности и воззрения по-прежнему широко распространены среди граждан и выражаются в том, что население полагает разрешение последствий преступлений своим делом. Следовательно, это разрешение должно достигаться за счёт соглашения между группами людей (общинами, семьями), хотя и под патронажем государства, но никак не при помощи вовлечения в процесс государственных репрессивных институтов [11, с. 429]. «Если руководить народом посредством законов и поддерживать порядок посредством наказаний, то народ будет стараться избегать их, но у него не будет чувства стыда. Если же руководить им посредством добродетели и поддерживать в нём порядок при помощи церемоний, то у народа выработается чувство стыда, и он будет исправляться» [6, с. 107].

Этот своеобразный конфликт является одной из ключевых особенностей уголовного права и уголовной политики Республики Корея в начале XXI века. Интересно, что конфликт здесь понимается ни как нечто негативное и деструктивное, а напротив - как повод для синтеза новой правовой системы, по-конфуциански гармонично сочетающей древние традиции и современные юридические механизмы. В этой связи в научных кругах идёт дискуссия по поводу возможности широкого внедрения практики восстановительного (почти что третейского) правосудия в сфере уголовного права, где конфуцианские традиции договоров между отдельными лицами и общинами без привлечения к выяснению отношений государства могли бы послужить идеальной основой.

Таким образом, можно заключить, что философское учение Конфуция находит определённое выражение в современном уголовном праве Республики Корея, хотя и в гораздо меньшей степени, чем в общественном сознании и в корейской культуре. При этом древнее учение не только не устарело, но даже называется современными учёными подходящей почвой для реформирования (иначе говоря, развития, обновления) законодательства вообще и его уголовно-правовой отрасли в частности, реформирования, которое должно привести корейскую правовую систему в гармонию, т.е. в соответствие с классическими принципами конфуцианства.

\title{
Литература
}

1. Есаков Г. А., Крылова Н. Е., Серебренникова А. В. Уголовное право зарубежных стран: учеб. пособие. М.: Проспект, 2014.

2. Игнатов А. Н. Избранные труды. М.: Изд-во РУДН, 2013.

3. Корея глазами россиян (1895-1945). Тула: Гриф и К, 2008.

4. Корея и Россия: социокультурная динамика / под ред. Р. К. Тангалычевой, Д. В. Иванова, В. И. Ильина, Е. А. Островской. СПб.: Алетейя, 2015.

5. Мао Цзэ-дун. Избранные произведения. Т. 3. М., 1953.

6. Мудрость Конфуция: афоризмы и поучения / под ред. В. П. Бутормеева, В. В. Бутормеева. М.: ОЛМА Медиа Групп, 2010.

7. Основы религиоведения / Ю. Ф. Борунков, И. Н. Яблоков и др.; род ред. И. Н. Яблокова. М.: Высш. шк., 1994.

8. Советский энциклопедический словарь / гл. ред. А. М. Прохоров. 3-е изд. М.: Сов. Энциклопедия, 1985.

9. Фань Вэнь-Лань. Древняя история Китая от первобытно-общинного строя до образования централизованного феодального государства: монография. М.: Изд-во Академии наук СССР, 1958.

10. Aggravated Punishment on Parricide (25-2(A) KCCR 82, 2011Hun-Ba267, July 25, 2013).

11. An, Sung Hoon. The Korean Conventional Alternative Dispute Resolution (ADR) System in Criminal Justice // Selected Essays of the KIC Research Projects (2012-2013). Korean Institute of Criminology. Seoul, 2014.

12. Constitutional Court of Korea [Электронный ресурс] (Режим доступа): URL: http://english.ccourt.go.kr (дата обращения: 20.02.2016).

13. Kim Ch. S. Kimchi and IT. Tradition and Transformation in Korea. Ilchokak, 2007.

14. Steels, B., Goulding, D. \& Abbot, K. Restorative justice in Asia: from the margins and corners to commonplace // Contemporary Trends in Asian Criminal Justice: Paving the Way for the Future. Korean Institute of Criminology. Seoul, 2014.

15. 형법 (시행 2013.4.5.; 법률 제11731호, 2013.4.5., 일부개정).

\section{Сравнительно-правовой анализ уголовного законодательства о преступлениях против половой неприкосновенности несовершеннолетних России и США}

\author{
(ㄷ) А. Л. Дондокова \\ студентка 4-го курса юридического факультета \\ ФГБОУ ВО «Бурятский госуниверситет» \\ Россия, г. Улан-Удэ \\ dondokova_94@mail.ru
}

Половые преступления против несовершеннолетних посягают на один из самых охраняемых объектов уголовно-правовой охраны - половую неприкосновенность детей, их нормальное физическое и психическое развитие. Отечественный законодатель, конечно же, защищает эти интересы, но преимущественно уголовно-правовыми способами. Это проявляется, в основном, в изменении санкций преступлений, посягающих на половую неприкосновенность несовершеннолетних, внесении поправок в диспозиции указанных статей, что предполагает недостаточную урегулированность законодательного описания данных противоправных деяний, что мы и отметим далее. 
Как отмечает Ю.Е. Пудовочкин, в рамках уголовно-правовой политики государства в качестве ее подсистемы функционирует ювенальная уголовно-правовая политика, или, по-другому, уголовно-правовая политика в отношении несовершеннолетних. Наиболее зримо она выражается в деятельности государства по созданию и реализации группы взаимосвязанных специфических нормативных предписаний в ситуации противодействия преступности лиц молодого возраста и посягательствам на процесс развития несовершеннолетних. Особенности содержания этих норм, содержащих зачастую изъятия из общих правил, специфика объекта государственного воздействия, его цели, принципы, субъекты и средства свидетельствуют о том, что уголовно-правовая политика в отношении несовершеннолетних обладает не только относительно самостоятельным, но и приоритетным статусом[9].

Статья 134 УК РФ «Половое сношение и иные действия сексуального характера с лицом, не достигшим шестнадцатилетнего возраста».

Ст. 134 УК РФ устанавливает ответственность за половое сношение и иные действия сексуального характера с лицом, не достигшим шестнадцатилетнего возраста. Однако диспозиция рассматриваемой статьи УК РФ устанавливает ответственность за половое сношение (ч. 1 ст. 134) и мужеложство и лесбиянство (ч. 2 ст. 134). Наука уголовного права и правоприменительная практика [6] под половым сношением понимают совершение полового акта между мужчиной и женщиной. Поскольку в отечественном законодательстве предусмотрена ответственность за отдельный состав преступления, связанный с насильственными действиями сексуального характера, то, по мнению А.В. Дыдо, «половое сношение представляет собой только введение полового органа мужчины в половой орган женщины». Половое сношение как нормальный, т.е. физиологический, акт может иметь место только между лицами разного пола - между мужчиной и женщиной. Все остальные действия, направленные на удовлетворение половой потребности в иной форме, не являются половым сношением»[7]. Развивая указанную трактовку, А.Н. Игнатов, А.П. Дъяченко, писали: «с научных позиций определяющим признаком полового сношения является соединение (контакт) мужских и женских половых органов... Различные способы имитации полового акта существенно отличаются Постановление Пленума Верховного Суда РФ «О судебной практике по делам о преступлениях, предусмотренных статьями 131 и 132 Уголовного кодекса Российской Федерации» от полового сношения, поскольку не могут порождать беременность женщины... (а также дефлорацию)». Практически все авторы научной и учебной литературы поддерживают указанное мнение.

Проблемы применения законодательства об ответственности за ненасильственные сексуальные посягательства на несовершеннолетних. В.Г. Романов уверяет, что в целях правильного разграничения насильственных и ненасильственных действий сексуального характера в отношении несовершеннолетних, УК РФ необходимо дополнить статьей 132-1 «Насильственные действия сексуального характера в отношении несовершеннолетних»[9]. Указанный пробел попытался исправить Верховный суд РФ, который в п. 16 Постановления Пленума Верховного Суда Российской Федерации «О судебной практике по делам о преступлениях против половой неприкосновенности и половой свободы личности» от 4 декабря 2014 г. № 6 указал, что «уголовная ответственность за половое сношение и иные действия сексуального характера с лицом, достигшим двенадцатилетнего возраста, но не достигшим шестнадцатилетнего возраста, а равно за совершение в отношении указанных лиц развратных действий (статьи 134 и 135 УК РФ) наступает в случаях, когда половое сношение, мужеложство, лесбиянство или развратные действия были совершены без применения насилия или угрозы его применения и без использования беспомощного состояния потерпевшего лица». Однако мы полагаем, внесение законодателем слова «ненасильственное» в диспозицию статьи 134 УК РФ исключит ошибки при квалификации и разграничении насильственных и ненасильственных преступлений против половой неприкосновенности несовершеннолетних. Примечание к ст. 131 УК РФ. Федеральным законом от 29 февраля 2012 г. № 14-Ф3 ст. 131 УК РФ дополнена примечанием следующего содержания: «К преступлениям, предусмотренным пунктом «б» части четвертой настоящей статьи, а также пунктом «б» части четвертой статьи 132 настоящего Кодекса относятся также деяния, подпадающие под признаки преступлений, предусмотренных частями третьей-пятой статьи 134 и частями второй-четвертой статьи 135 настоящего Кодекса, совершенные в отношении лица, не достигшего двенадцатилетнего возраста, поскольку такое лицо в силу возраста находится в беспомощном состоянии, то есть не может понимать характер и значение совершаемых с ним действий». Закрепляя указанную норму, законодатель, по-видимому, руководствовался положениями Рекомендации № R Комитета министров Совета Европы «О защите женщин от насилия», в которых предусмотрено, что возраст, с которого согласие на осуществление сексуальных актов признается законом, не всегда совпадает с возрастом, с которого возможно привлечение к уголовной ответственности. Здесь имеется в виду возраст, с которого возможно привлечение к уголовной ответственности, а за государствами остается право определить возраст, с которого данное согласие считается законным. Если этот возраст не был достигнут, речь идёт о неоспоримой презумпции отсутствия согласия. Согласие, данное лицом, не достигшим установленного законом возраста, недействительно.

Не лишено противоречий и примечание к ст. 134 УК РФ, согласно которому, лицо, впервые совершившее преступление, предусмотренное частью первой настоящей статьи. Постановления Пленума Верховного Суда РФ «О судебной практике по делам о преступлениях против половой неприкосновенности и половой свободы личности» - освобождается судом от наказания, если будет установлено, что это лицо и совершённое им преступление перестали быть общественно опасными в связи со вступлением в брак с потерпевшей (потерпевшим). Вступление в брак с потерпевшим лицом означает добровольную государственную регистрацию брака в установленном законом порядке в органах записи актов гражданского состояния (ЗАГС). Ю.Е. Пудовочкин совершенно справедливо отмечая нелогичность ситуации, связанной с действием указанного примечания, пишет: 
«если виновный совершал лишь развратные действия с потерпевшей и вступил с ней в брак, он не может быть освобождён от наказания; а вот если он совершал с ней половое сношение - то может». На это же обстоятельство указывает в своих исследованиях и А.Д. Оберемченко. Кроме того, буквальное толкование данного примечания приводит проф. А.И. Чучаева к выводу о том, что «освобождение от наказания распространяется только на преступления, выразившиеся во вступлении в половое сношение, поскольку брак с потерпевшим лицом при мужеложстве и лесбиянстве по законодательству РФ не допускается». Такое ограничение действия представляется ему труднообъяснимым, поскольку это законодательное положение нарушает принцип равенства граждан перед законом.

В целом следует отметить, что отечественный законодатель, несмотря на не совсем последовательную уголовноправовую политику в области охраны половой неприкосновенности несовершеннолетних, твердо придерживается определенных принципов этой охраны: установление двух возрастных границ для потерпевших («возраст согласия») - лица, не достигшие 16-летнего и 14-летнего возраста; установление возраста субъекта преступления - 18 лет. Как мы уже отмечали, отечественный законодатель, конечно же, защищает эти интересы, но преимущественно уголовноправовыми способами. В этой связи считаем целесообразным изучить и по возможности использовать опыт накопленный законодателем и правоприменительной практикой зарубежных государств.

Далее мы исследуем способы уголовно-правовой охраны половой неприкосновенности несовершеннолетних, взятые на вооружение в США. Вначале необходимо напомнить, что в Соединенных штатах нет единой уголовно- правовой системы. Там действуют 53 самостоятельные системы - федеральная, 50 штатов, столичного округа Колумбия и свободно присоединившегося государства Пуэрто-Рико. Основу этих систем в большинстве штатов составляют собственные уголовные кодексы. На федеральном уровне основная масса уголовно-правовых норм собрана в разделе (титуле) 18 «Преступления» Свода законов США.

Статья 21.11 УК Техаса устанавливает ответственность за непристойное поведение, связанное с ребенком. В соответствии с п. «а» исследуемой статьи, лицо совершает посягательство, если с ребенком моложе 17 лет, не являющимся супругом такого лица, независимо от пола такого ребенка, это лицо: 1) вступает в половой контакт с таким ребенком или делает так, что такой ребенок вступает в половой контакт; 2) с намерением вызвать возбуждение или удовлетворить сексуальное желание какого-либо лица демонстрирует свое анальное отверстие или любую часть своих гениталий, осознавая присутствие такого ребенка, либо делает так, что такой ребенок демонстрирует свое анальное отверстие или любую часть своих гениталий. В п. «б» рассматриваемой статьи разъясняется, что утверждаемой защитой против преследования является то, что деятель был старше потерпевшего не более чем на три года и был лицом противоположного пола; не применял принуждение, насилие или угрозы в отношении потерпевшего во время совершения посягательства, а также: А) не требовалась пожизненная регистрация в качестве правонарушителя в сфере половых отношений и свобод личности в соответствии с положениями главы 62 УПК штата Техас (основания, порядок и процедура регистрации и контроля над лицами, совершившими половые преступления в США, будут нами рассмотрены отдельно); В) не был ранее осужден в соответствии с положениями главы 62 УПК штата Техас и не подвергался осуждению за совершение посягательства, предусмотренного настоящей статьей. Согласно п. «с» ст. 21.11. УК Техаса, в настоящей статье термин «половой контакт» означает любое касание лицом, включая касание через одежду, анального отверстия, груди или любой части гениталий ребенка, а также любое касание какой-либо части тела ребенка, включая касание через одежду, анальным отверстием, грудью или любой частью гениталий лица, если эти действия совершаются с намерением вызвать возбуждение или удовлетворить сексуальное желание любого человека. П. «d» анализируемой статьи сообщает нам о том, что посягательство, предусмотренное ч. (а) п. 1, является фелонией второй степени, а п. 2 ч. (а) - фелонией третьей степени. В соответствии со ст. 12.32. УК штата Техас, индивидуум, признанный виновным в совершении фелонии второй степени карается наказанием в виде лишения свободы на срок от 2 до 20 лет, с отбыванием в федеральном учреждении. В качестве дополнительного наказания индивидууму, признанному виновным в совершении фелонии второй степени, может быть назначено наказание в виде штрафа в размере, не превышающем 10000 долларов. В соответствии со ст. 12.34., индивидуум, признанный виновным в совершении фелонии третьей степени, карается наказанием в виде лишения свободы на срок от 2 до 10 лет, с отбыванием в федеральном учреждении. В качестве дополнительного наказания индивидууму, признанному виновным в совершении фелонии второй степени, может быть назначено наказание в виде штрафа в размере, не превышающем 10000 долларов[5].

Незаконное половое сношение в соответствии с Уголовным кодексом штата Калифорния - это половой акт, совершаемый виновным с несовершеннолетним, не являющимся супругом данного лица. Для целей настоящего раздела «несовершеннолетний - лицо, не достигшее 18 лет и «взрослый» - лицо, достигшее возраста 18 лет и старше (Раздел 9 «О преступлениях против личности, связанных с сексуальными нападением и преступлениях против общественной нравственности и морали», Глава 1: «Изнасилование, похищение, оскорбительные сексуальные действия в отношении детей и совращение», ч. «а» ст. 261.5.). возраста, либо те же деяния в отношении лица, достигшего 15-летнего возраста, но неспособного понимать юридические последствия совершаемого с ним деяния. Если преступление при указанных обстоятельствах совершается виновным с помощью применения силы, обмана или угроз, назначаемое наказание увеличивается наполовину (ч.4. ст. 103); б) сексуальные злоупотребления с детьми, достигшими 15-летнего возраста с помощью силы, обмана или угроз. В случае, если рассматриваемое преступление совершено родственниками- предшественниками (antecedents), родственниками второй и третьей степени кровного родства, отчимом, опекуном, педагогом, тренером, медицинским работником, либо любым лицом, оказывающим медицинские услуги, или ответственным за защиту или наблюдение за 
ребенком, а также злоупотреблением влиянием, основанным на государственной должности, назначенное наказание увеличивается на половину (ч.4 ст. 103). Любое лицо, совершившее незаконное половое сношение с несовершеннолетним, который не более чем на три года старше или на три года младше деятеля, является виновным в мисдиминоре (ч. «b» ст. 261.5.). Любое лицо, совершившее незаконное половое сношение с несовершеннолетним, который на три года младше деятеля, является виновным как в мисдиминоре, так и в фелонии (ч. «с» ст. 261.5). Также, любое лицо, достигшее 21-летнего возраста и старше, совершившее незаконное половое сношение с несовершеннолетним, не достигшим 16-летнего возраста, является виновным как в мисдиминоре, так и в фелонии и наказывается лишением свободы на срок до 1 года с отбыванием наказания в окружном учреждении, либо на срок 2, 3, или 4 года лишения свободы в соответствии с ч. (h) ст. 1770 настоящего Кодекса (ч. «d» ст. 261.5., ст. 1770 УК штата Калифорния - «Постановление приговора»). По нашему мнению, интересные особенности содержатся

Уголовное законодательство штата Джорджия карает виновного, который совершил растление малолетнего (child molestation). Согласно § 16-6-4, растление - любой аморальный или непристойный акт, совершенный с любым ребенком, не достигшим 16-летнего возраста, либо в его присутствии, с намерением вызвать возбуждение или удовлетворить сексуальное желание виновного либо ребенка (п.1 ч. «а»), либо передача с помощью электронных устройств изображений лица, непосредственно совершающего, подстрекающего, либо иным образом участвующего в аморальных или непристойных актах, ребенку, не достигшему 16-летнего возраста, с намерением вызвать возбуждение или удовлетворить сексуальное желание виновного либо ребенка (п.2 ч. «а»). Лицу, осужденному впервые за растление малолетнего, назначается наказание в виде лишения свободы на срок от 5 до 20 лет лишения свободы. Департамент исполнения наказаний обязан предоставлять консультативную помощь осужденному на весь срок его пребывания в заключении. При повторном и последующих осуждениях, виновный наказывается лишением свободы на срок от 10 до 30 лет лишения свободы, либо пожизненным лишением свободы, при условии, что до начала судебного процесса подсудимый в письменной форме уведомляется о том, что Штат намерен добиваться пожизненного лишения свободы.

Сравнительно-правовой анализ уголовного законодательства отдельных штатов США о преступлениях против половой неприкосновенности несовершеннолетних позволяет отметить, что в большинстве изученных уголовноправовых актов наличествует состав преступления под общим названием «Инцест», либо подобный квалифицирующий признак в иных составах преступлений о половой неприкосновенности несовершеннолетних. Подводя итог сравнительно-правовому анализу уголовного законодательства о преступлениях против половой неприкосновенности несовершеннолетних, необходимо отметить, что законодательный подход к уголовно-правовой охране половой неприкосновенности несовершеннолетних примерно одинаков как в России, так и в США. Различен только подход к закреплению возраста субъекта указанных преступлений. В разных штатах возраст субъекта определяется по-разному: начиная с 17 лет до 21 года, но чаще всего - лицо, достигшее 18-летнего возраста - так же, как и в отечественном уголовном законодательстве. Отечественный и американский законодатель по-разному подходят к определению потерпевших от рассматриваемых деяний. Уголовный закон Российской Федерации выделяет две группы потерпевших - несовершеннолетние и малолетние, а применительно к преступлениям против половой неприкосновенности также и лица, не достигшие 16 и 12 лет. В США возраст согласия закреплен отдельными штатами самостоятельно и по-разному: 10, 12, 13, 14,16,17,18 лет, причем в Уголовном законодательстве даже одного и того же штата этот возраст может быть различным применительно к разным составам преступлений против половой неприкосновенности несовершеннолетних.

\section{Литература}

1. О согласии на вступление в брак, брачном возрасте и регистрации браков [Электронный pecypc]. URL: http://www.un.org/ru/documents/decl_conv/conventions/conmarr.shtml. - С. 667-669.

2. О защите детей от сексуальной эксплуатации и сексуального насилия (CETS № 201) [Электронный pecypc]. URL: http://www.refworld.org.ru/docid/5357602a4.html.

3. Уголовный кодекс Российской Федерации [Электронный pecypc]. URL: https://www.consultant.ru/document/ cons_doc_law_10699. 224 c.

4. Уголовный кодекс штата Техас / науч. ред. и предисл. И. Д. Козочкина; пер. с англ. Д. Г. Осипова, И. Д. Козочкина. СПб.: Юридический центр Пресс, 2006. 576 с.

5. Авдеев М. И.Судебно-медицинская экспертиза живых лиц. Режим доступа: http://www.forensmed.ru/book.php?id=3 (дата обращения: 9.03.2014.).

6. Романов В. Г. Уголовная ответственность за половое сношение и иные действия сексуального характера с лицом, не достигшим шестнадцатилетнего возраста: автореф. дис. ... канд. юр. наук. М., 2013. С. 12.

7. Педофилия: основные криминальные черты: монография / под ред. Ю. М. Антоняна. М.: Проспект, 2013. 304 с.

8. Пудовочкин Ю. Е. Ненасильственные половые посягательства на лиц, не достигших 14 лет // Законность. 2002 . № 4. C. $46-47$.

9. Пудовочкин Ю. Е. Некоторые проблемы уголовно-правовой политики несовершеннолетних // Дружественное к ребенку правосудие и проблемы ювенальной уголовной политики. 2013. №4. С.191-194. 


\title{
Особенности уголовной ответственности и наказания несовершеннолетних в уголовном праве России и Китая
}

\author{
(C) Д. В. Дондокова \\ магистрант 1 года обучения юридического факультета \\ ФГБОУ ВО «Бурятский госуниверситет» \\ Россия, г. Улан-Удэ \\ dondokova84@mail.ru
}

Проблема борьбы с преступностью несовершеннолетних - это проблема не только наших дней, ее пытаются разрешить законодатели и практики с давних времен. Так, в царской России действовали специальные суды для несовершеннолетних. Первых из них появился в 1910 году в городе Санкт-Петербурге, а затем такие суды действовали во многих крупных городах. Опыт их деятельности повсеместно рассматривался как положительный, и специалисты отмечали изменение криминогенной ситуации в лучшую сторону.

Э.Л. Раднаевой обосновывается необходимость имплементации норм международного права, в частности, Руководства $\mathrm{OOH}$ по оценке показателей в области правосудия в отношении несовершеннолетних, а также разработки научно обоснованной целостной концепции ювенальной уголовной политики, которая включает в себя уголовно-правовое, уголовно-процессуальное, уголовно-исполнительное и криминологическое направления [9].

На наш взгляд, Российский законодатель сделал довольно успешный шаг в повышении эффективности охраны несовершеннолетних, закрепив в статье 150 УК РФ ответственность за «вовлечение несовершеннолетнего в совершение преступления». Аналогичного состава преступления в УК КНР не предусмотрено, однако имеется нормы статьи 29 УК КНР устанавливающая, что «подстрекающий к преступления лиц моложе 18 лет должен нести более строгое наказание». Так же действует статья 295 УК КНР, которая содержит состав преступления «обучение к способам преступной деятельности», наказание за которое однако не зависит от возраста обучаемого лица. Представляется, что общественная опасность вовлечения или подстрекательства к совершению преступления несовершеннолетних выше, нежели аналогичное действия в отношении взрослых, в связи с чем, положение к УК РФ в регулировании данных отношения выглядят более основательно. Относительно этого вопроса имеется позиция, высказанная в пункте 42 Постановления Пленума Верховного Суда РФ от 01.01.2011: «действия взрослого лица по подстрекательству несовершеннолетнего к совершению преступления при наличии признаков состава указанного преступления должны квалифицироваться по «статье 150» УК РФ, а также по закону, предусматривающему ответственность за соучастие (в виде подстрекательна) в совершении конкретного преступления», которую можно трактовать как указание на тяжесть таких действий для общества.

Уголовный кодекс Китая в статье 262 предусматривает ответственность за «принуждение путем хитрости и обмана несовершеннолетнего, не достигшего 14 лет, к оставлению своей семьи или опекуна». Диспозиция части 1 статьи 151 УК РФ в отличии от указанного состава статьи 262 УК КНР предусматривает «вовлечение» несовершеннолетних в совершении антиобщественных действий, в том числе и бродяжничество. В соответствии с пунктом 42 Постановления Пленума ВС РФ, «вовлечение» означает «действие взрослого лица, направленные на возбуждение желания совершить преступление или антиобщественные действия», действия же взрослого лица могут выражаться в формах: обещание, обмана, угроз, предложение совершить преступление, разжигание чувства зависти, мести и иных действий. Состав преступления статьи 151 УК РФ как правовая конструкция представляется более предпочтительной, поскольку включает в себя большее количество действий по вовлечению несовершеннолетних в бродяжничество и, следовательно, обеспечивает более эффективную правовую защиту, как отмечают в научных кругах, в то время как законодатель КНР отмечает лишь принуждение [8, с.70].

Необходимо заметить, что и в УК РФ и УК КНР составы преступлений, в которых потерпевшими являются несовершеннолетние, расположены не только в указанных главах уголовных законов. И такое положение вполне обусловлено тем, что и китайский и российский законодатель очевидно относит к более тяжким нарушениям незаконный оборот наркотиков в сравнении с охраной семьи. Так статья 347 УК КНР содержит такое положение: «использование подстрекательно несовершеннолетних к контрабанде, продаже, транспортировке и изготовлению наркотиков или продаже наркотиков несовершеннолетним - наказываются максимально суровым наказанием из предусмотренных настоящей статьей», данное деяние охватывается составами уже указанной статьей 150 и пунктом «в», части 4 статьи 2281 УК РФ.

Наказание за многие преступления в УК КНР и УК РФ так же отличаются. Следует отметить, что минимальное наказание за такое преступление статьи 347 по УК КНР - 15 лет лишения свободы, максимальное смертная казнь, в то время как санкция части 4 статьи 150 УК РФ предусматривающей ответственность за вовлечение несовершеннолетних «в совершение тяжкого или особо тяжкого преступления», предусматривает наказание в виде лишения свободы сроком от 5 до 8 лет с ограничением свободы на срок до 2 лет, либо без такового. Представляется, что подобное наказание не вполне соответствует общественной опасности подобного преступления.

Таким же образом обстоит дело и со склонением несовершеннолетних к употреблению наркотиков в КНР. Согласно статье 353 УК КНР «вовлечение, обучение, привлечение обманным путем или принуждение несовершеннолетних к употреблению наркотиков перорально или путем инъекций - наказывается максимально суровым наказанием из предусмотренных настоящей статьей», то есть 10 годами лишения свободы и штрафом. 
Согласно пункту «а» части 2 статьи 230 УК РФ «склонение к потреблению наркотических средств, психотропных веществ или их аналогов», наказывается лишением свободы от 10 до 15 лет.

«Ребёнок, ввиду его физической и умственной незрелости, нуждается в специальной охране и заботе, включая надлежащую правовую защиту, как до так и после рождения», - говорит преамбула Декларации о правах ребенка. Надлежащая защита ребенка не должна вступать в противоречие с надлежащей правовой защиты семьи в целом, но соответствовать требованиям защиты несовершеннолетних лишенных семьи.

Уголовный закон КНР устанавливает ответственность за ряд преступлений, которые не запрещены уголовным законом России. Так, статья 261 УК КНР содержит следующий состав преступления: «лица, обязаны осуществлять уход за стариками, младенцами, больными, не способные самостоятельно обслуживать себя, и отказавшиеся от выполнения своих обязанностей при отягчающих обстоятельствах. В то время как статья 156 УК РФ устанавливает ответственность лишь за «неисполнение обязанностей по воспитанию несовершеннолетнего». Воспользоваться опытом Китая в данном вопросе представляется в полнее целесообразным и для законодателя России, поскольку в статье 38 Конституции РФ на равнее с тем, что закреплено: «забота о детях их воспитание - равное право и обязанность родителей», так же провозглашается, что: «трудоспособные дети, достигшие 18 лет, должны заботятся о не трудоспособных родителях». В связи с чем отсутствие уголовной ответственности за преступление подобное указанному в УК КНР представляется не справедливым упущением российского законодателя [8, с.71].

Некоторые исследователи утверждают, что расположение главы «преступления против семьи и несовершеннолетних» в УК РФ не соответствует степени общественной опасности указанных в ней деяний, об этом свидетельствует санкции статей главы 20 УК РФ [10, с.83]. Отсутствует же в УК КНР подобной главы пагубно, сказывается на систематизации уголовного закона и реализации Конституции КНР, где защита указанна как обязанность государства.

Санкции УК КНР во многом более жестоки по сравнению с санкциями УК РФ. Представляется, что Россия не должна идти по пути ожесточения санкций, ровно как и неоправданного смягчения или декриминализации. Целью здесь должно ставится, изыскание новых действенных способов достижение цели наказания, в частности - исправление преступника, которая в охране семьи имеет особое значение.

\section{Литература}

1. Всеобщая декларация прав человека (принята Генеральной Ассамблеей ООН 10.12.1948) [Электронный ресурс]. URL: http://base.consultant.ru/cons/cgi/cgi/onlin.cgi?red=doc;base=LAW;n=120805.

2. Конвенция о правах ребенка (одобрена Генеральной Ассамблеей OOH 20.11.1989) [Электронный pecypc]. URL: http://base.consultant.ru/cons/cgi/cgi/onlin.cgi?red=doc;base=LAW;n=9959.

3. Конституция Китайской Народной Республики (принята на пятой сессии Всекитайского собрания народных представителей пятого созыва 04.12.1982) [Электронный ресурс]. URL: chinalawinfo.ru/constitutional_law/constitution.

4. Конституция Российской Федерации (принята всенародным голосованием 12.12.1993).URL: http://base.consultant.ru/cons/cgi/cgi/onlin.cgi?red=doc;base=LAW;n=2875.

5. Уголовный Кодекс Российской Федерации от 13.06.1996 N63-Ф3 (ред. 30.12.2015) [Электронный pecypc]. URL: http://base.consultant.ru/cons/cgi/cgi/onlin.cgi?red=doc;base=LAW;n=176257.

6. Уголовный кодекс Китайской Народной Республики от 01.10.1997 [Электронный pecypc]. URL: http://law.edu.ru/norm/norm.asp?normID=1247252\&subID=100110722,100110730,100110747\#text.

7. Постановление Пленума Верховного Суда РФ от 01.02.2011 N1 (ред. от 02.04.2013) «О Судебной практике применения законодательства регламентирующего особенности уголовной ответственности и наказания несовершеннолетних».

8. Белов В.Ф. Преступления против семьи и несовершеннолетних в аспектах de lege lata и de lege ferenda. М.: Русаки, 2002. C.80.

9. Попова Е.И. О недопустимости применения в отношении несовершеннолетних норм об особом порядке принятия судебного решения (гл. 40 и 40.1 УПК РФ) // Судья. 2015. №7. С. 32-35.

10. Раднаева Э. Л. Ювенальная уголовная политика и ее особенности в Монголии [Электронный pecypc]. URL: http://cyberleninka.ru/article/n/yuvenalnaya-ugolovnaya-politika-i-ee-osobennosti-v-mongolii.

\section{Международный терроризм и способы борьбы с ним в крупнейших странах АТР (на примере Китая, США и России)}

(С) Ж. Б. Дондупова

студентка 2-го курса юридического факультета ФГБОУ ВО «Бурятский госуниверситет»

Россия, г. Улан-Удэ

dondupova97@mail.ru

На сегодняшний день международный терроризм является одной из самых важнейших и острейших глобальных проблем современности. Ужасает тот факт, что данная проблема остается неразрешенной и даже находит свое развитие благодаря информационным технологиям. Только за последние 10 лет в мире погибло около 140 тысяч человек в результате террористических атак. 
По данным международной группы экспертов под эгидой Института экономики и мира Сиднейского университета, ежегодно публикующей глобальный индекс терроризма, в 2015 г. Китай занял 22 место в рейтинге, Россия 23 место и США 35. Терроризм определяется исследователями как «угроза или реальное применение силы незаконными организациями, добивающимися своих политических, социальных и религиозных целей путем насилия и устрашения» [1].

В целях осуществления противодействия терроризму появляется необходимость обращения к положительному опыту зарубежных стран и тесному взаимному сотрудничеству, где к террористам присутствует нетерпимое отношение со стороны государства и общества. Повышенное внимание привлекают к себе такие ведущие державы мира, как Китайская Народная Республика и Соединенные Штаты Америки.

Так КНР является сторонником предотвращения терактов без активных боевых действий. Китайская политика невмешательства, конечно, не подразумевает отсутствия китайских войск за рубежом, которые принимают участие в борьбе с такими террористическими группировками, как Исламское государство, однако возможна лишь при условии, если принимающая страна обратиться к Китаю с данной просьбой [7].

КНР активно взаимодействует с такими организациями как ООН, ШОС, РАТС, АТЭС, а также со многими странами на двухсторонней основе. Шанхайская пятерка является главным механизмом противодействия как региональному, так и международному терроризму. В августе 1999 года прошел четвертый саммит «Шанхайской пятерки», который способствовал объединению спецслужб России и Китая, действия которых принесли более высокие и качественные результаты. Ими были проведены антитеррористические учения, оперативно-розыскные действия по задержанию и обезвреживанию террористов, создание международных списков террористических организаций, создание системы мониторинга действий террористов на территориях РФ и КНР, а также близлежащих стран.

Правительство КНР обязалось применять все принятые в международной практике формы и методы сотрудничества, включая обмен информацией, согласование и сближение нормативно-правовой базы, координацию взаимодействия и проведение совместных операций, что привело к положительным последствиям. Стоит упомянуть о ряде соглашений, которые обеспечивают защиту секретной информации, о сотрудничестве в области выявления и перекрытия каналов проникновения на территории государств-членов ШОС лиц, причастных к террористической, сепаратистской и экстремистской деятельности.

23 декабря 2002г. было подписано китайско-казахское соглашение о сотрудничестве в борьбе с терроризмом, сепаратизмом и экстремизмом.

За предотвращение терактов в КНР отвечает Министерство общественной безопасности, осуществляющее свои действия на основе Закона о государственной безопасности КНР, Криминальном законе КНР, Законе о сохранении тайны и иных законодательных документах КНР.

После теракта, произошедшего перед Олимпиадой 2008 г., было принято решение привлечь к антитеррористической деятельности также Народно-освободительную Армию Китая.

После терактов 11 сентября 2001 г. Китай ужесточил уголовные наказания за преступления террористической направленности. Существует ряд программ, благодаря которым Госсовет КНР ужесточил паспортно-визовый режим и даже ограничил въезд на территорию страны гражданам Ближнего и Среднего Востока, также были усилены режимные мероприятия на всех видах транспорта - воздушном, железнодорожном, автомобильном. Была заблокирована граница с Афганистаном и Пакистаном, а также усилены воинские группировки в приграничных с Афганистаном Синьцзянском и Ланьчжоуском военных округах.

КНР поддержала резолюцию Совета безопасности ООН №1373 относительно борьбы с терроризмом, ратифицировала международное соглашение о борьбе с терроризмом.

В декабре 2015 года был принят первый в истории страны закон о борьбе с терроризмом, который позволит военнослужащим осуществлять и вмешиваться в антитеррористические операции за границами страны [2].

Что касается США, то особенно усиленная борьба с терроризмом началась после терактов 11 сентября 2001 г. Страна пережила мощнейший шок, после чего Администрация Д. Буша-младшего приняла ужесточение мер борьбы с терроризмом, чем нашла отклик американского населения.

В стране широкое распространение получили гражданские движения, а выразилось это в создании добровольных пожарных команд, активизации деятельности соседских общин, выдвижении проектов улучшения безопасности страны.

Указом президента было образовано Министерство внутренней безопасности, а администрацией Вашингтона при поддержке Конгресса были разработаны международные и национальные программы США по борьбе с терроризмом на собственной территории и даже в различных регионах мира. Конгрессом было принято решение создать объединенный антитеррористический комитет по разведке, разрешить предоставлять вознаграждения за предоставление информации о деятельности террористических организаций, ввести смертную казнь за убийство заложников, признать убийство граждан США вне страны федеральным преступлением. Стратегия борьбы с терроризмом в США направлена на соблюдение закона, эффективную деятельность разведывательных служб и военный компонент. Был создан Объединенный центр по предотвращению террористической угрозы (Terrorist Threat Integration Center), который призван вырабатывать план действий на основе собранной информации.

Министерство национальной безопасности сотрудничает с Контртеррористическим Советом безопасности ООН, который был учрежден после атаки на Нью-Йорк. В последние годы США тесно сотрудничает со многими государствами мира 
По инициативе Дж. Буша-младшего были разработаны совместные программы США и Европейского союза, а также с Японией и Южной Кореей. В 1976 г. был создан оперативный отряд специальных сил американский армии, занимающийся освобождением американских заложников вне страны. Также существует Отряд чрезвычайной службы нью-йоркской полиции (ESU), Отряд полиции Лос-Анджелеса (SWAT) 1956 г., Bоенноморская Специальная Группа 1980 г., действующая на воде.

Важнейшим инструментом антитеррористической политики стала осведомленность, а конкретнее готовность к действиям в чрезвычайной ситуации. Администрация США пресекает разглашение информации о терроризме во избежание страха и паники, сохранения спокойствия среди граждан. Принят даже законопроект, относящий к государственной тайне сведения (приемы, тактики и состав участников) в области противодействия терроризму, чему также последовала и РФ.

В американском Национальном антитеррористическом центре работают не только с информацией о предстоящих терактах, но и с дезинформацией, с ложными сигналами. Сотрудники ведут борьбу с запрещенной литературой в интернете, из которой террористы узнают о новых технологиях изготовления взрывчатых веществ, инструкции, используемые в терактах и т.д. При антитеррористических центрах сформированы группы информаторов, которые за вознаграждение сообщают о терактах или готовящихся диверсиях. Следует отметить, что в США не существует федерального закона, который бы непосредственно касался терроризма внутри страны.

Правительство США ежегодно выделяет десятки миллиардов долларов для борьбы с терроризмом, что привело к значительному снижению уровня терроризма.

К сожалению, Россия также не защищена от международного террора. Так, 31 октября 2015 г. российский лайнер авиакомпании «КогалымАвиа», направлявшийся из Египта в Санкт-Петербург, потерпел крушение в результате теракта. Ответственность за теракт взяло на себя Исламское Государство (запрещенное в России).

Деятельность РФ по противодействию терроризму на сегодняшний день осуществляется на основе закона «О противодействии терроризму», который регламентирует основные положения и регулирует участие Вооруженных сил, а также координирует действия органов исполнительной власти и Указу Президента РФ от 15.02.2006 N 116 (ред. от 26.12.2015) «О мерах по противодействию терроризму».

За 2008-2012 годах был сделан значительный шаг в совершенствовании антитеррористической правовой базы. Так, были внесены изменения в федеральные законы, регулирующие вопросы транспортной безопасности, устанавливающие уровни террористической опасности, утверждена Федеральная целевая программа «Антитеррор (2009 - 2012 годы)».

Президент РФ 2 ноября 2013 года подписал Федеральный закон № 302-Ф3 «О внесении изменений в отдельные законодательные акты РФ», который был направлен на формирование комплексной системы противодействия террористической деятельности. Данный документ внес изменения в семь нормативно-правовых актов, в том числе в ГК РФ, УК РФ, УПК РФ, Федеральные законы от 12.08.1995 № 144-ФЗ «Об оперативно-розыскной деятельности», от 07.08.2001 № 115-Ф3 «О противодействии легализации (отмыванию) доходов, полученных преступным путем, и финансированию терроризма», от 06.03.2006 № 35-Ф3 «О противодействии терроризму» и от 07.05.2002 № 50-ФЗ «О внесении изменений в статьи 188 и 189 Уголовного кодекса РФ». Уголовный кодекс был дополнен новыми статьями: статья 205.3. «Прохождение обучения в целях осуществления террористической деятельности», статья 205.4. «Организация террористического сообщества и участие в нем», статья 205.5. «Организация деятельности террористической организации и участие в деятельности такой организации».

Следует отметить, что президент играет значительную роль в данной деятельности. Он определяет главные направления антитеррористической деятельности, устанавливает компетенции федеральных органов исполнительной власти, а также принимает решение об использовании воинских и специальных подразделений за рубежом для борьбы с террористическими проявлениями против Российской Федерации и ее граждан.

В России отсутствует специализированный орган по борьбе с терроризмом, в связи с чем основные полномочия возложены на Федеральную службу безопасности. Также противодействие терроризму обеспечивает Национальный антитеррористический комитет, Федеральный оперативный штаб, антитеррористические комиссии и оперативные штабы в субъектах Российской федерации.

5 апреля 2016 года Указом Президентом России была создана новая структура - Федеральная служба войск национальной гвардии Российской Федерации, одной из основных задач которых должна стать борьба с терроризмом и организованной преступностью.

Таким образом, в ходе проведенного сравнительного анализа данных стран, следует сделать вывод, что наиболее высоким уровнем борьбы с терроризмом обладает США. Китай же значительно продвинулся вперед за последние несколько лет, все более ужесточая меры по борьбе с международным терроризмом, но остается узкоспециализированным. Россия на законодательном уровне нисколько не отстает от других стран, тогда как сами меры профилактики терроризма слабы: усилия направлены на защиту важных государственных объектов, в то время как гражданское общество остается незащищенным. Эффективность и успешность политики борьбы с международным терроризмом последует только при тесном сотрудничестве различных стран и в первую очередь таких влиятельных мировых держав как США, КНР и Россия.

\section{Литература}

1. Алексеев О. Н. Международный терроризм и борьба с ним крупнейших государств Тихоокеанского региона: дис. ...канд. юр. наук. Владивосток, 2013. С.134. 
2. Глобальный индекс терроризма за 2015 г. University of Maryland, Institute for Economics and Реace [Электронный реcypc]. URL: http://gtmarket.ru/ (дата обращения: 14.04.2016 г.)

3. Указ Президента РФ от 15.02.2006 г. №116 (ред. от 26.12.2015) «О мерах по противодействию терроризму» (вместе с «Положением о Национальном антитеррористическом комитете»).

4. Федеральный закон от 06.03.2006 г. N 35-Ф3 (ред. от 31.12.2014) «О противодействии терроризму» // СПС «КонсультантПлюс».

5. Противодействие терроризму в США: опыт и проблемы [Электронный pecypc]. URL: http://cyberleninka.ru/article/n/protivodeystvie-terrorizmu-v-ssha-opyt-i-problemy/

6. Китай разрешил армии проводить антитеррористические операции за рубежом [Электронный pecypc]. URL: http://www.rbc.ru/politics/27/12/2015/567fbed89a79472b029fde5/

7. The Diplomat: как Китай планирует бороться с международным терроризмом? [Электронный pecypc]. URL: http://south-insight.com/teror?language=ru/

\title{
Незаконный оборот наркотических средств и психотропных вешеств и противодействие ему в Российской Федерации и Китайской Народной Республике
}

\author{
(C) А. Г. Доржиева \\ магистрант 1 года обучения юридического факультета \\ ФГБОУ ВО «Бурятский госуниверситет» \\ Россия, г. Улан-Удэ \\ ayuna-94@yandex.ru
}

Наркомания и незаконный оборот наркотиков не имеют границ. Оказывая все более разрушительное воздействие на развитие мирового сообщества, стимулируя рост преступности, насилия и коррупции, они поражают людей независимо от социального положения, пола, расы или религии.

Человечество продолжает искать эффективные пути решения одной из мировых проблем - борьбы с незаконным оборотом наркотиков. Исчисляемая тысячелетиями в настоящее время данная проблема обрела глобальный характер и остро стоит практически перед всеми государствами. По оценкам Интерпола по всему мира свыше 200 млн. человек курят марихуану - самый распространенный наркотик. Кокаин употребляют 13 млн. человек, героин - 8 млн., 30 млн. злоупотребляют стимуляторами амфитаминового ряда [5, с. 52].

Международный масштаб незаконного оборота наркотиков и вовлечения все большего количества государств в мировую сеть маршрутов, их нелегальной транспортировки уже не позволяют в настоящее время четко разграничить страны на производителей наркотических средств или их потребителей. Сознавая всевозрастающую масштабность и опасность распространения наркотиков в мире, Россия прилагает определенные усилия по имплементации международных правовых актов в целях противодействия незаконному обороту наркотических средств и психотропных веществ.

Первым шагом в создании международных органов по предотвращению наркомании явился созыв так называемой Шанхайской опиумной комиссии, заседание которой происходило в Шанхае в 1909 году с участием представителей 13 государств, в том числе России, которая положила начало международному контролю над распространением наркотических средств и предопределила направление международно-правовой помощи в этой сфере.

Первая в истории Конвенция о наркотиках была выработана на международной конференции по опиуму, проходившей в ГААГЕ в 1911 - 1912 годах. В ней участвовали 12 государств: Германия, США, Франция, Япония, Китай, Россия и другие. Конвенцию ратифицировали 58 государств. В числе участников Конвенции значилась Россия, которая ее подписала, но не ратифицировал [1].

В России незаконный оборот наркотических средств и психотропных веществ должен быть искоренен. По данным статистики в январе-марте 2016 года выявлено 59,7 тыс. преступлений, связанных с незаконным оборотом наркотиков, что на 10,2\% меньше, чем за аналогичный период прошлого года. При этом сотрудниками органов наркоконтроля выявлено 20,8 тыс. преступлений (-7,0\%), сотрудниками органов внутренних дел - 37,5 тыс. преступлений (-11,6\%). По сравнению с январем - мартом 2015 года на 9,0\% сократилось число выявленных преступлений, совершенных с целью сбыта наркотических средств, психотропных веществ или их аналогов, а их удельный вес в числе преступлений, связанных с незаконным оборотом наркотиков, вырос с 49,7\% в январе - марте 2015 года до 50,4\% [10].

Эффективной мерой борьбы с распространением и применением наркотиков является предоставление и увеличение бесплатных клиник по лечению наркозависимых, так как масштаб употребления наркотиков возрастает с каждым годом. В то же время, на всю Россию существует только три крупных реабилитационных центра. У нас также есть 27 маленьких стационаров. В Китае таких центров около 600 [9].

Справедливы высказывания отдельных ученых, призывающих разобраться с содержанием стратегии борьбы с наркотизмом. Так, И.И. Зуй справедливо замечает, что «воздействие уголовного закона в основном обращено на потребителей наркотиков, которых в стране насчитывается около 6 млн. Возникает вопрос, не допускаем ли мы ошибку, воздействуя на ситуацию подобным образом, не является ли установление уголовной ответственности за названные деяния проявлением избыточности уголовно-правового запрета? Наркомания сложное психическое расстройство, которое не поддается излечению, и лицо не может избавиться от него в 
результате осуждения. Тем более что места лишения свободы абсолютно не приспособлены для лечения и реабилитации такой категории людей» [2, с. 6].

Обязательства перед населением своей страны, являются частью нашей правовой системы. Позиция правоприменителя, игнорирующего их, неправомерна. Из содержания ст. 1 УК РФ вовсе не следует, что международные нормы не должны применяться, пока не найдут соответствующего отражения в УК. Напротив, в силу норм Конституции РФ и положений самого УК они в случаях коллизий и пробельности последнего (в особенности это касается положений Общей части) могут применяться непосредственно. Приоритетом по отношению к уголовному закону обладают не только общепризнанные принципы и нормы международного права, но и международные договоры Российской Федерации. И если уголовно-правовая норма не соответствует по своему содержанию международным стандартам уголовной репрессии (в рамках которых, например, исключается уголовная ответственность и наказуемость определенного деяния), то прямое применение норм международного права следует рассматривать как насущную необходимость, вытекающую из принципа соблюдения прав человека и выполнения Россией своих международных обязательств в данной сфере [3, с. 21].

Китайская Народная Республика в борьбе с незаконным оборотом наркотических средств и психотропных веществ в рамках Организации Объединенных Наций и ратификации Конвенций, регулирующих деятельность по противодействию наркотиков, активно применяет свои ужесточенные наказания по УК КНР за контрабанду и распространение наркотиков и психотропных веществ.

На 31-м заседании ПК ВСНП десятого созыва 29 декабря 2007 г. принят Закон КНР «О запрещении наркотиков». Согласно его положениям борьба с наркотиками признается «совместной ответственностью всего общества». «Государственные органы, общественные коллективы, производственные единицы, а также иные организации и граждане обязаны в соответствии с положениями настоящего Закона и иных законов осуществлять функции и обязанности по запрету наркотиков» (ст. 3).

Китайским законодательством предусматривается льготная налоговая политика в отношении тех, кто участвует в борьбе с наркотиками (ст. 7); поощряются заявления граждан о совершаемых наркопреступлениях и при этом обеспечивается их безопасность и материальное стимулирование (ст. 9); поощряется общегосударственная программа пропаганды вреда наркотиков (глава 2), в том числе особые требования предъявляются к родителям несовершеннолетних в рамках исполнения их обязанностей по недопущению употребления их детьми наркотических средств (ст. 18); государство осуществляет особую систему контроля над оборотом наркотических и психотропных веществ (ст. 21); делается особый упор на контроль со стороны органов общественной безопасности за увеселительными местами отдыха граждан (ст. 27); осуществляется система принудительного лечения наркозависимых граждан (ст. 31).

Наркозависимые лица вправе самостоятельно обращаться для лечения в соответствующие учреждения, которые не могут ставить целью своей деятельности извлечение прибыли, а применяемые ими лекарственные препараты, лечебная аппаратура и методы не подлежат рекламированию. При взимании платы за лечение необходимо руководствоваться утвержденными стандартами (ст. 36). Наркозависимые лица подлежат принудительной изоляции в случае их отказа от лечения, если в период лечения они употребляли наркотики, допускали серьезные нарушения заключенного о лечении соглашения, после курса лечения снова употребляли наркотики (ст. 38). Принудительная изоляция не применяется к беременным и женщинам, кормящим грудью младенца возрастом до недели, а также по решению компетентных органов к несовершеннолетним лицам, не достигшим 16 лет (ст. 9). Рядом российских ученых в своих работах отмечается важность данного закона для правоохранительной системы КНР [6, с. 94].

Кроме приведенных выше УК КНР и Закона КНР «О запрещении наркотиков» в правовой системе страны приняты и успешно действуют некоторые другие локальные акты правотворчества, регулирующие исследуемую проблематику. К основным из них следует отнести:

1. Принятые Государственным советом КНР 22 июня 2011 г. «Правила лечения от наркомании», состоящие из 7 глав (46 статей). Данный подзаконный документ своими положениями дополняет Закон КНР «О запрещении наркотиков» и регламентирует добровольный и принудительный порядок лечения наркозависимых лиц в специальных лицензированных медицинских учреждениях Китая.

2. Принятые Государственным советом 17 августа 2005 г. «Правила управления химическими препаратами, из которых легко изготавливаются наркотики», включающие 8 глав (45 статей). Положения этого нормативного документа посвящены регулированию оборота химических препаратов, из которых возможно в обычных условиях изготовить наркотическое средство, а также порядок лицензирования организаций, хозяйствующих в данной сфере.

3. Принятое совместно несколькими министерствами 18 января 2013 г. «Мнение об усилении работы в районах лечения от наркомании и в районах восстановления здоровья», состоящее из 5 разделов (16 пунктов). Этот локальный нормативный акт затрагивает вопросы усиления государственной работы в созданных для лечения наркозависимых лиц местах и районах, конкретизируются сроки, задачи такой работы.

4. Принятое Государственным комитетом по запрещению наркотиков 12 ноября 2013 г. «Мнение о дальнейшем усилении и нормализации работы по принудительной изоляции для лечения от наркомании», состоящее из 6 разделов (17 пунктов). Данный ведомственный акт посвящен конкретным вопросам практической реализации закрепленного в действующем китайском законодательстве института принудительного лечения от наркомании.

5. Принятый в июне 2012 г. совместный нормативный документ Верховного народного суда, Верховной народной прокуратуры и Министерства общественной безопасности «О некоторых вопросах применения законо- 
дательства при производстве по уголовным делам о контрабанде и незаконном обороте комбинированных препаратов с содержанием эфедриновых веществ».

6. Обнародованное в июле 2014 г. Центральным комитетом Коммунистической партии Китая и Государственным советом КНР «Мнение об усилении работы по борьбе с наркотиками».

7. Принятое в августе 2014 г. Верховным народным судом, Верховной народной прокуратурой и Министерством общественной безопасности совместное Извещение «Мнение по некоторым вопросам стандартизации толкования наименований наркотических средств».

Тем не менее нормативно-правовая база китайского государства, регламентирующая борьбу с наркотиками, все еще находится на стадии своего становления. Несмотря на действующий Уголовный кодекс, предусматривающий суровые меры ответственности за преступления в сфере незаконного оборота наркотиков (вплоть до смертной казни), детали борьбы с этим злом законодательно отрегулированы слабо. С одной стороны, правоохранитель не связан «по рукам и ногам» жестким материальным и процедурным правом при проведении практической работы по противодействию наркобизнесу. С другой - присутствует недостаточная профилактическая работа, информационное сопровождение угрозы наркомании для безопасности государства, чему должны быть посвящены положения отдельных актов правотворчества.

В то же время российской правоохранительной системе, отечественной науке и законодателю есть чему поучиться у наших китайских коллег. Так, например, в Китае широко применяется институт уголовной ответственности юридических лиц, как это имеет место и во многих других странах, от чего в свое время отказался отечественный законодатель [4, с. 136].

Многие российские ученые не только неоднократно подтверждали необходимость в ее существовании для правовой системы России, но и делают прогнозы о неизбежности введения в перспективе такой ответственности [7, с. 429]. Решимость китайских властей в борьбе с незаконным оборотом наркотиков и злоупотреблением ими несомненно приведет к положительным результатам. Будущее страны также не в последнюю очередь зависит и от успешности работы правоохранительной системы КНР в сфере борьбы с наркотиками. В этом важном деле Россия и Китай должны объединить совместные усилия и осуществлять более тесное сотрудничество на благо народов двух государств и всего мира.

\title{
Литература
}

1. Ажакина Т. А., Моднов И. С., Сергеев А. Н. Международно-правовое регулирование отношений в сфере противодействия незаконному обороту наркотиков. Русский народный сервер против наркотиков.

2. Зуй И. И. Социальная обусловленность и перспективные направления криминализации деяний, связанных с незаконным оборотом наркотиков // Вестник Северокавказского государственного технического университета. 2009. С. 6.

3. Кауфман М. А. Пробелы в уголовном праве и способы их преодоления: автореф. дис. ...д-ра юр. наук. М., 2009 . С.21.

4. Колесников К. А. Консолидация антинаркотического законодательства: опыт Китайской Народной Республики // Наркоконтроль. 2012. № 1. С. 38-39; Диченко А. А. Борьба с незаконным оборотом наркотиков в КНР: история, современность, международный аспект // Проблемы Дальнего Востока. 2012. № 2. С. 136-143.

5. Сергеев А. Н. Противодействие незаконному обороту наркотических средств и психотропных веществ: учеб. пособие. М.: Изд-во Моск. ун-та МВО России, 2003. С. 52.

6. Трощинский П. В. Влияние традиции на право современного Китая // Журнал российского права. 2014. № 8. С.94-106; Его же. Юридическая ответственность в праве Китайской Народной Республики. М., 2011.

7. Федоров А. В. Введение уголовной ответственности юридических лиц — прогнозная тенденция развития российской уголовно-правовой политики // Журнал зарубежного законодательства и сравнительного правоведения. 2014 . № 3. С. $429-433$.

8. Федоров А. В. Об уголовной ответственности юридических лиц за контрабанду наркотиков по законодательству Китая // Таможенные чтения 2014. Актуальные проблемы теории и практики таможенного дела (к 20-летию СанктПетербургского им. В. Б. Бобкова филиала Российской таможенной академии): материалы Всерос. науч.-практ. конф. с междунар. участием / под общ. ред А. Н. Мячина. СПб.: Санкт-Петербургский им. В. Б. Бобкова филиал РТА, 2014. С.339-345; Федоров А. В. Об уголовной ответственности юридических лиц за наркопреступления по законодательству Китая // Расследование преступлений: проблемы и пути их решения: сб. науч.-практ. тр. / Следственный комитет Российской Федерации; под ред. А. И. Бастрыкина. 2014. Вып. 6. С. 6-16.

9. Тихоненко И. CRIME.VL.RU. Владивостокский центр исследования организованной преступности http://www.crime.vl.ru/mdeks.php?p=33558spriiit=1\&more= 1 (дата обращения: 15.03.2016).

10. Режим доступа: https://mvd.ru/folder/101762/item/7572658/.

\section{Профилактика преступности в России и других странах Азиатско-Тихоокеанского региона}

\author{
(С Д. С. Доржниева \\ студентка 2-го курса юридического факультета \\ ФГБОУ ВО «Бурятский госуниверситет» \\ Россия, г. Улан-Удэ \\ Darishka93@inbox.ru
}

Выбор темы профилактики преступности был связан с тем, что, на наш взгляд, это одна из основных составляющих в борьбе с преступностью, которая может предотвратить совершение преступлений, понизить уровень преступности и сделать общество безопаснее, повлиять на уважение населения к государственным и 
муниципальным органам, а также сэкономить много времени, людских и материальных ресурсов, не запуская масштабно-карательный механизм уголовно судопроизводства. Поэтому, проблема развития института профилактики остается актуальной на данный момент и имеет огромное значение для развития общества и страны в целом.

Из всех определений самое точное, на мой взгляд, дал В.В. Лунеев, который считает, что под предупреждением преступности понимается совокупность мер, направленных на предотвращение преступлений во всех сферах общества и минимизацию причин, порождающих преступность [4].

На данный момент, российская модель профилактики преступности получила международное признание. Ряд ее организационных форм и методологических положений получили поддержку в документах ООН, ее специализированных органов и были успешно адаптированы в практике ряда зарубежных стран.

Однако в самой Российской Федерации, в силу ряда объективных и субъективных причин, отечественная система профилактики в годы реформ оказалась разрушенной. В.Е. Эминов объясняет это тем, что существовавшая в УПК СССР строгая обязанность правоохранительных органов выявлять причины и условия преступности и принимать необходимые меры реагирования в ныне действующем УПК РФ заменилась в ст.73 частью второй: «подлежат выявлению также обстоятельства, способствовавшие совершению преступлений», практически никого конкретно ни к чему не обязывающей [6].

В настоящее время в субъектах РФ действуют региональные системы профилактики правонарушений на основе базовой модели, разработанной МВД России. Их деятельность урегулирована более чем 130 законами субъектов Российской Федерации в области профилактики правонарушений [2].

Такой закон принят и в нашей республике, который называется Закон Республики Бурятия от 13 октября 2010 г. N 1570-IV "О системе профилактики правонарушений в Республике Бурятия". В соответствии с этим законом профилактическую деятельность могут осуществлять органы государственной власти и местного самоуправления Республики Бурятия, иные государственные органы, полиция, комиссии и иные коллегиальные органы, организации и граждане [3].

Меры общей профилактики правонарушений заключаются в сборе и анализе сведений о правонарушениях, создании условий, препятствующих совершению правонарушений, проведении правовой и антикоррупционной экспертизы нормативных правовых актов и их проектов, осуществлении правового воспитания населения, формировании общественного мнения, направленного на недопустимость совершения правонарушений и др. [3].

Закон четко прописал полномочия субъектов профилактической деятельности, формы и меры профилактики, но, к сожалению, результатов по реализации данного закона мы пока не наблюдаем. Так, например, в прошлом 2015 году в Бурятии почти во всех районах зафиксирован рост числа преступлений на 13\% - с 24,5 тысяч до 27,7 тысяч, при том, что уровень преступности в Бурятии один из самых высоких в Сибирском федеральном округе.

В субъектах Российской Федерации, где приняты законы, регулирующие профилактическую деятельность, нет единообразия и системности правового закрепления основ этой деятельности. В других же субъектах, где подобные законы еще не приняты, ссылаются на отсутствие федерального закона об основах системы профилактики правонарушений [2]. И с учетом того, что сейчас в РФ наблюдается серьезный экономический кризис, то соответственно уровень преступности будет расти по геометрической прогрессии.

Все эти обстоятельства ведут нас к выводу о необходимости и безотлагательном ускорении принятия законопроекта "Об основах системы профилактики правонарушений в Российской Федерации".

Хоть российскую модель предупреждения преступности признало международное сообщество и успешно реализует ее своих странах, однако в нашей же стране она функционирует не так эффективно, как хотелось бы. Поэтому стоит принять во внимание зарубежный опыт, и в частности, опыт стран Азиатско-Тихоокеанского региона, таких как Китай, Япония, Малайзия, Сингапур и другие, где уровень преступности по мировым стандартам многие годы был значительно ниже, чем например, в европейских странах. В 1987 году было зафиксировано всего 570 тысяч преступлений (540 на 100 тыс. населения), однако в ходе бурного развития рыночных отношений, резкий рост показала и преступность [8]. Китайские правоохранители оказались не готовы к такому взрыву преступности, как общеуголовной, так и преступности белых воротничков. Уже в 1990 году число преступлений составило 2 миллиона 216 тысяч - коэффициент преступности с 1987 года вырос вчетверо. А уровень молодежной преступности в Китае стал одним из самых высоких в мире, 75\% преступлений совершались лицами, не достигшими 25 лет [8]. Эти события повлекли изменения в стратегии борьбы с преступностью в сторону повышения удельного веса жестких мер воздействия на правонарушителей.

Китай, не отказываясь от многовековой практики воспитания всех слоев населения, использует средства убеждения и воспитания уважения к закону. Как пишет Г.В. Дашков, важнейшими стратегическими установками, применительно к борьбе с преступностью в Китае, являются: формирование у граждан страны преданности своему народу, уважительное отношение к партийному и государственному руководству, воспитание скромности, всегда и везде соизмерять свои потребности с законными возможностями [8].

Эти гуманистические установки не просто висят в воздухе, они действительно подкрепляются сложным, постоянно корректируемым механизмом регулирования противоречий в обществе, включая уголовное право. При этом, отмечает Г.В. Дашков, что элементы жесткого подхода к преступникам четко просматриваются как уголовно-правовых нормах, так и в правоприменительной практике. Например, численность тюремного населения в настоящий момент достигает приблизительно 1,5 миллиона человек [8]. До последнего времени за 55 преступлений, таких как убийство, торговля наркотиками, терроризм, преступная халатность, повлекшая за 
собой пожар, наводнение и т.п., контрабанда редких видов животных, махинации векселями, выдача мнимых чеков НДС, грабеж, разграбление древних захоронений, флоры, фауны и другие по УК КНР может последовать наказание в виде смертной казни.

На первый взгляд, можно задуматься о чересчур жестоком уголовно-правовом законодательстве. Однако, в Китае наблюдаются конкретные положительные сдвиги в борьбе с преступностью, которые засчитываются в пользу поэтапно реализуемой здесь государственной политики, где репрессия удачно сочетается с мерами убеждения.

Например, борьба с коррупционными преступлениями предупреждается определенными формами частого напоминания о необходимости жить честно и строго соблюдать законы страны. Такими формами выступают: широко известный моральный кодекс Ху Цзиньтао; обучение на специальных партийных курсах для госслужащих, включающих в себя психотерапию, медитация, восточные единоборства; специальные компьютерные игры типа «Неподкупный борец», где пользователь учится уничтожать коррупционных чиновников; привлечение к ответственности чиновников всех уровней от низших до высших, например, приговор к смертной казни бывшего вице-мэра города Пекин Лю Чжихуа.

Также большое значение в этой профилактике придается семье. На высочайшем уровне управления страной был провозглашен лозунг: «Честная китайская женщина без колебаний разоблачит мужа-коррупционера» [8].

Жена чиновника должна интересоваться появлением лишних денег, помимо зарплаты, дорогих вещей, должна по собственной инициативе возвращать подарки, полученные от разных фирм и организаций, незамедлительно информировать уполномоченные государственные структуры о финансовых злоупотреблениях своего мужа, во избежание стать соучастницей коррупционного преступления.

Также существуют в Китае так называемая практика милосердия и снисхождения в качестве средства предупреждения преступлений в Китае. В стране действует решении Центральной Комиссии КПК, предусматривающее фактическое освобождение от уголовной ответственности чиновников, которые по собственной инициативе, добровольно признались в получении взятки и вернули государству незаконно полученные деньги. Ежегодно этой возможностью пользуются более 30 тысяч должностных лиц, взявших взятку.

Также есть новационный метод профилактики в Пекине с использованием электронных средств массовой информации и социальных сетей. Например, полиция Пекина с августа 2012 года ведет микроблог, который читают уже 6 миллионов пользователей. В микроблоге содержаться не только пресс-релизы и статистика преступлений, но и советы по виктимологической профилактике - как избежать опасности, а также методы самообороны [10].

Еще один «наш сосед», к которому мы могли бы обратиться для заимствования опыта по профилактике преступлений - это Япония, где главным направлением уголовной политики является предупреждение преступности.

Уголовная политика Японии основывается на таких принципах: доминирование мер социального контроля над государственным, экономия уголовной репрессии, бессмысленность сверхкриминализации деяний и ужесточения уголовных санкций, эффективности системы профилактики, вовлечение широких слоев населения в воспитательно-принудительную работу.

Большое значение руководство полиции придает взаимодействию с общественностью и все более широкому привлечению граждан к профилактике правонарушений. При этом основной акцент в этой работе делается на расширении активности жителей префектур. Именно с этой целью еще с 2007 г. в Японии вступила в действие разработанная полицией система поощрения (в т.ч. денежного вознаграждения) граждан, информирующих о серьезных правонарушениях [7].

В рамках профилактики общего назначения ведется широкая пропаганда законопослушания, проводимая силами полиции, школы, общественных организаций, чему способствует издание самой разнообразной юридической литературы большими тиражами (включая четко прокомментированные законы) [9].

Полицейские, государственные и муниципальные органы Японии для привлечения населения к деятельности по профилактике преступности проводят широкомасштабную пропагандистскую работу. К примеру, по стране ежегодно проводятся месячные кампании, направленные на повышение правовой грамотности населения и усиление общественной поддержки государственной политики в области борьбы с преступностью [9].

Еще одной давней и традиционной формой участия общественности в профилактике преступности является институт добровольных сотрудников службы пробации, осуществляющих постпенитенциарный «защитный надзор» (Hogo Kansatsu), которые, по сути дела, и ведут всю работу по контролю за поведением условно осужденных и условно досрочно освобожденных. Их деятельность регламентирована законодательным актом -Тhе Volunteer Probation Officer Act, № 204,. принятом еще в 1950 г.

Россия и Япония - страны, у которых на самом деле много общего. Например, в обеих странах общества традиционно коллективистского типа, подвергающееся влиянию «вестернизации». Глобальные скачки преступности вызваны переходом стран от плановой экономики к конкурентному рынку (Япония в 1950-х, Россия в 1990-х гг.). Для России крайне актуален и приемлем опыт мер социального контроля Японии, сохранения и использования коллективистских традиций противодействию антиобщественному поведению.

В заключение, хотелось бы отметить, что у России, большие возможности и перспективы, но ее реформирование тормозят многие факторы, такие как коррупция, экономический кризис, низкий уровень правосознания граждан и другие, которые следовало бы нейтрализовать или минимизировать. 
Отсутствие на федеральном уровне отдельного законодательного акта, надлежащим образом регулирующего вопросы организации системы профилактики правонарушений, жесткого контроля над нею со стороны государства, утрата опоры на население, недооценка роли общественных сил в профилактике преступлений обуславливают серьезные недостатки федерального законодательства и недостаточный уровень профилактики правонарушений.

Зарубежный опыт полезен, уникален, а самое главное применим в Российской Федерации. С учетом национальных особенностей и криминальной ситуации, мы могли бы разработать системные меры по профилактике преступности. Нашему законодательству, относительно новому, еще предстоят долгие годы совершенствования и преобразований.

Выбор курса на профилактику, а не на карательное возмездие - единственно верное решение, если целью действительно является благо народа.

\section{Литература}

1. Проект Федерального закона "Об основах системы профилактики правонарушений в Российской Федерации". Режим доступа : http://rg.ru/2011/08/16/profilaktika-site-dok.html

2. Пояснительная записка к проекту федерального закона «Об основах системы профилактики правонарушений в Российской Федерации»

3. О системе профилактики правонарушений в Республике Бурятия : закон Республики Бурятия от 13 октября 2010 г. N1570-IV. Режим доступа : http://base.garant.ru/29537126/

4. Лунеев В. В. Курс мировой и российской криминологии : учебник. Т. 1. М., 2011. 720 с.

5. Криминология: учеб. пособие для бакалавров / Г. И. Богуш, О. Н. Ведерникова, М. Н. Голоднюк [и др.]; науч. ред. Н.Ф. Кузнецова. 2-е изд., перераб. и доп. М.: Проспект, 2013. 496 с.

6. Криминология: учебник / отв. ред. В. Е. Эминов. М.: Проспект, 2015. 368 с.

7. Морозов Н. А. Преступность в современной Японии: проблемы криминологической и уголовно-правовой политики : дис. ...д-ра юр. наук. М., 2016.

8. Дашков Г. В. Особенности борьбы с преступностью в Китайской народной республике // Экономика и право. XXI век. 2012. № 4. С. 115-121.

9. Еремин В. Н. Как Япония справляется с преступностью // Знакомьтесь - Япония. М., 1998. Вып. 21. С. 5-6.

10. Туристический интернет-проект о Китае [Электронный ресурс]. Режим доступа: http://visitchina.ru/news/society/18351

\section{Применение условного осуждения по уголовному законодательству России и Японии: сравнительно-правовой анализ}

(C) Х. Ю. Доржиева

магистрант 2 года обучения юридического факультета ФГБОУ ВО «Бурятский госуниверситет»

Россия, г. Улан-Удэ

lady.handa@yandex.ru

Под условным осуждением в современном уголовном праве понимается отсрочка судом исполнения или назначения наказания с установлением для осужденного определенных обязанностей и правил поведения в целях его реабилитации и предупреждения совершения им нового преступления в будущем. В случае соблюдения этих условий правовыми последствиями условного осуждения является полное освобождение по истечении испытательного срока от какого бы то ни было наказания за совершенное преступление и отсутствие судимости как определенных правоограничений, являющихся следствием осуждения за преступление.

Каким же образом Японии удается при всех трудностях и сбоях получать впечатляющие результаты в борьбе с преступностью? За тысячелетия человеческой истории выкристаллизовались следующие глобальные методы воздействия на преступность: воспитание, обеспечение удовлетворенности населения, социальный контроль, изоляция лиц, представляющих общественную опасность, самозащита.

Очевидно, что в данной системе приводятся два общеизвестных начала: общесоциальное, реализуемое государством и обществом в целом, и специально ориентированное на борьбу с преступностью, также находящееся в компетенции государственных и общественных, но уже специализированных формирований. Если придерживаться предложенной С.Иншаковым схемы, то основные контуры уголовной политики в Японии можно очертить следующим образом.

В сфере развития и снабжения удовлетворенности населения государство и общество развили (основываясь на национальные традиции и используя национально-психологические черты) и продолжают развивать законопослушных, дисциплинированных граждан, склонных ставить свой труд и свое хорошее состояние в сильную зависимость друг от друга, а также продолжают предоставлять членам общества удовлетворяющие их материальные и духовные блага. Специализированные органы и организации участвуют в воспитательной работе, осуществляя ее в порученной им узкой части спектра, и удовлетворяют одну из важнейших потребностей населения - потребность в безопасности.

В области социального контроля и изоляции общественно опасных лиц локальное общество, окружение по месту работы или учебы, иная контактирующая среда находят способы для того, чтобы показать лицам, внушающим опасение, свое негативное отношение к перспективе их перехода от возможности криминального поведения к реаль- 
ному поведению такого рода, делая им таким образом предупреждение вплоть до демонстрации отчуждения (подобие неформальной превентивной изоляции) и продолжая этим давние национальные традиции в адаптированном к современности виде. Что касается специфических мер контроля и изоляции, в соответствии с законами, применяемых правоохранительными органами при участии специализированных общественных организаций, то они являются особой частью соответствующей всеобщей системы.

В сфере самообороны еще сближаются общее и специальное начала. К примеру, правоохранительные органы предметно инструктируют граждан о способах самозащиты от преступных посягательств, а государство и общество, взятые в целом, воспитывают людей в духе самоуважения и готовности постоять за свои материальные и духовные ценности.

В данной статье считается главным образом та часть глубокого воздействия на преступность, которая осуществляется государственными органами (полицией, прокуратурой, судами, службой защитного надзора, пенитенциарными учреждениями), а также участие общественности в непосредственной работе по борьбе с преступностью (профессиональные приемы раскрытия японскими службами тех или иных конкретных преступлений, конечно, останутся за кадром). Имелось в виду лишь в некоторых случаях затронуть общесоциальные меры, так или иначе снижающие уровень преступности.

Борьба с преступностью в Японии основана на ряде принципов, среди которых могут быть названы: приоритет гуманистического начала; обеспечение прав подозреваемого, обвиняемого и вообще человека, оказавшегося в сфере специфических интересов правоохранительных органов; упор на профилактику преступности оставление граждан, оказавшихся в «уголовном конвейере» (т.е. либо в стенах правоохранительных органов, либо в пенитенциарных учреждениях, либо в иных условиях жесткого ограничения личной свободы), в качестве подозреваемых, подсудимых или осужденных лишь тогда, когда это совершенно необходимо; развитый и эффективный контроль за лицами, выводимыми из «конвейера»; выдвижение на передний план задачи сохранения молодежи и подростков в рамках законопослушного поведения; максимальная опора уголовной политики на поддержку ее обществом.

Нельзя не сказать, что та высокоэффективная система борьбы с преступностью, которой с полным правом могла бы гордиться современная Япония, прошла далеко не простой путь эволюции, освобождаясь от довоенных элементов грубого насилия и проникаясь гуманистическим содержанием, которое и предопределяет успехи системы. Как справедливо отметил С. Оока, «простой пересмотр законов еще не может разрешить всех проблем. Необходимо время и еще раз время, чтобы новые правовые институты прочно вошли в сознание людей. Только тогда правосудие будет вершиться в полном соответствии с теми идеальными моделями, которые предусматриваются правом» $[2$, с. 86$]$.

Те, кто формируют уголовную политику Японии, и те, кто претворяют ее в жизнь, исходят из того, что суровость и массовость наказаний не могут сдержать преступность. «Японская система воздействия на преступность наиболее интересна тем, что в ней почти идеально удалось совместить относительную мягкость с высокой эффективностью» [3, с. 35]. В Японии даже лишение свободы (не говоря уж о смертной казни) применяют только тогда, когда тяжесть преступления и личность преступника делают этот вид наказания неизбежным. Таким образом, суровость не исключается, но обращение к ней резко сужается до пределов, в которых она максимально обоснованна.

Отмеченные отличительные черты воздействия на преступность в Японии сочетаются с главными факторами эффективности контроля над преступностью - интенсивной воспитательной работой и высокими результатами оперативно-розыскной и следственной деятельности.

Что касается прав подозреваемого, обвиняемого и вообее человека, оказавшегося в сфере специфических интересов правоохранительных органов, то эти проблемы также находятся в Японии в центре внимания государства и общества. Для их решения создана развитая законодательная база. Зорким и самоотверженным стражем соблюдения этих прав зарекомендовала себя японская адвокатура.

В деле контроля за лицами, выводимыми из «уголовного конвейера», важнейшую роль играет система защитного надзора. По законодательству под этот надзор могут или должны быть поставлены следующие пять категорий лиц: несовершеннолетние по соответствующему решению семейного суда; несовершеннолетние, условно освобожденные от содержания в исправительно-воспитательном учреждении; условно-досрочно освобожденные из тюрем; осужденные условно с постановкой под защитный надзор; женщины, условно освобожденные от содержания в воспитательном учреждении (проститутки и т.п.). Защитный надзор состоит в том, что преступника следующим образом подвергают реабилитации под психологическим принуждением: ему на некоторое время дается отсрочка от помещения в пенитенциарное учреждение, он оставляется в обычном обществе и берется под контроль, а если нарушит поставленные ему условия, то будет помещен в пенитенциарное учреждение. Защитный надзор также применяется как руководство и контроль при обращении в обществе с лицами, условно-досрочно освобожденными из тюрем» [4, с.62].

В практической работе по сохранению молодежи и подростков в рамках законопослушного поведения правоохранительные органы Японии используют комплексное понятие «делинквентные несовершеннолетние». В соответствии с японским законодательством к категории таких лиц относятся: несовершеннолетние преступники, то есть находящиеся в возрасте 14-20 лет (по законам уголовная ответственность наступает с 14 лет, а совершеннолетие - с 20); несовершеннолетние до 14 лет, совершившие деяния, предусмотренные уголовным законом; несовершеннолетние со склонностью к правонарушениям, для которых характерно неподчинение руководству со стороны опекающих их лиц, контакт с преступными или аморальными элементами и иной образ действий, который сам по себе не подпа- 
дает под уголовный закон, но несет опасность перехода отделяющей от этого грани. Цель обращения с «делинквентными несовершеннолетними» состоит в том, чтобы как можно больше применять к ним воспитательные меры в обществе, в необходимых случаях помещать их в воспитательные учреждения и лишь в исключительных обстоятельствах прибегать к содержанию в тюрьмах.

Взаимодействие японского государства с обществом в области борьбы с преступностью носит весьма разнообразный характер. Формы и методы этого сотрудничества постоянно обновляются. Обращены к гражданам и предназначены для пробуждения их активности размещенные в людных местах табло с информацией о количестве дорожно-транспортных происшествий и их жертв; щиты-оповещения, оперативно выставляемые в местах недавних происшествий такого рода; водруженные для всеобщего обозрения крупно исполненные схемы жилых домов с указанием возможных путей проникновения преступников и т.д. Появляется немало изданий, предназначенных для стимулирования самозащиты граждан и обучения их способам самозащиты. Так, выпущено в свет подготовленное полицией пособие для изучения и использования гражданами Закона о борьбе с организованной преступностью. В этой публикации начальник уголовного департамента Главного полицейского управления выразил надежду, что «читатели уяснят закон о мерах против борёкудан и станут использовать его активно и в полной мере, благодаря чему смогут избежать неправомерного ущерба, наносимого действиями членов организованных преступных групп, и будут вести спокойную и безопасную гражданскую жизнь и предпринимательскую деятельность» [5, с.125].

Участие японской общественности, прежде всего разнообразных и многочисленных специализированных общественных организаций, в борьбе с преступностью выражается в систематическом посещении членами общественных организаций заключенных в тюрьмах и ненавязчивой заботе об освобожденных из тюрем по отбытии наказания. Особенно активно участвует население в предупреждении отклоняющегося от нормы поведения несовершеннолетних.

\title{
Литература
}

1. Малолеткина Н. С. Некоторые проблемы применения условного осуждения // Вестник Владимирского юридического института. 2010. № 1. С. 94-97.

2. Медведев Е. В. Понятие и сущность условного осуждения как инструмента уголовно-правового воздействия // Общество и право. 2010. № 2. С. 107-112.

3. Миньков М. М., Разогреева А. М. Условное осуждение и ограничение свободы: контроль и (или) ресоализация // Уголовное право. 2010. № 4. С. 47-51.

4. Минязева Т. Ф. Условное осуждение - иная мера уголовно-правового характера // Правовое государство: Теория и практика. 2009. № 18. С. 27-32.

5. Михайлов К. В. Индивидуализация уголовной ответственности и наказания при условном осуждении // Человек: преступление и наказание. 2008. № 2. С. 35-39.

6. О принципах и практике статистики преступности в Японии см.: О.Белявская. Преступность в Японии. Статистический анализ. М., 2012.

7. Преступность и правовая культура России и Японии // Преступность и культура общества. М.: Криминологическая Ассоциация, 2008. С. 37-38.

\section{Виктимологическая профилактика насилия в России и Японии: сравнительно-правовая характеристика}

\author{
(С) Л. В. Дружинина \\ магистрант 1 года обучения юридического факультета \\ ФГБОУ ВО «Бурятский госуниверситет» \\ Россия, г. Улан-Удэ \\ date1608@mail.ru
}

Актуальность темы исследования. Неблагоприятные социальные, экономические, психологические и иные процессы, связанные с распадом СССР, становлением независимых государств, переходом к рыночной экономике и общим обострением социально экономической ситуации, обусловили резкое обострение криминогенной ситуации. В условиях всеобщего стресса, моральной дезориентации, огромных материальных трудностей и общего ужесточения нравов, насилие приобрело характер обыденного явления [1, с. 45].

Между тем количественные и особенно качественные параметры насильственной преступности, общий рост ее интенсивности и тяжести последствий, возрастание ее отдельных видов темпами, заметно опережающими рост ненасильственных преступлений - все это приобрело характер серьезной угрозы безопасности общества и потому требует самого пристального внимания.

Как показывает практика, правоохранительные органы почти не использует меры профилактического характера, направленные на снижение насильственной виктимизации, на все более реальную угрозу для многих граждан стать жертвами насильственных посягательств. Не случайно многочисленные социологические и криминологические исследования показывают, что все большее число граждан опасается стать жертвой преступлений, что уровень виктимизации остается недопустимо высоким и уровень страха в обществе не снижается.

Изучение общественного мнения граждан по этой проблеме показывает, что огромное число граждан не обращаются в органы внутренних дел в связи с фактами преступных посягательств, причем удельный вес таких 
лиц постоянно растет. Это свидетельствует не только о растущей латентности такого рода посягательств, но и о продолжающемся отчуждении граждан от правосудия [6, с. 76].

Целью нашего исследования является изучение широкого спектра личностных и поведенческих особенностей потерпевших от насильственных преступлений и разработка предложений, направленных на повышение эффективности профилактической деятельности правоохранительных органов в борьбе с указанными посягательствами против личности. Исходя из этого, основными задачами исследования являются:

- анализ современного состояния виктимологической теории, ее

исходных положений и основных операционных понятий;

- анализ криминальных ситуаций в насильственных преступлениях,

изучение взаимоотношений и взаимодействия жертвы и преступника в

механизме насильственного преступления.

Объектом исследования выступают общественные отношения в сфере защиты граждан от насильственных преступлений против личности.

Прежде всего, необходимо отметить, что если российские криминологи обращают внимание главным образом на проблемы уголовного права и уголовно-правовой политики, предметом которой является борьба с преступностью уголовно-правовыми средствами, то японские, напротив, останавливаются на более широких проблемах социальной политики борьбы с преступностью, что предполагает использование всех средств, имеющихся в распоряжении государства и общества.

В японской юридической науке термин, аналогичный российскому понятию «уголовная политика», появился в начале 19 в. В настоящее время общепринято понимание уголовной политики как системы мероприятий по контролю над преступностью, причем ведется оживленная полемика вокруг вопроса о содержании этого понятия, прежде всего - о его объеме. Обсуждается круг субъектов уголовной политики, виды включаемой в нее деятельности и т.п.

В настоящее время в японской специальной литературе высказывается мнение о необходимости включения в понятие уголовной политики также и мероприятий по предупреждению преступлений, не связанных с применением принудительных мер, т.е. необходимость отнести к объектам уголовной политики граждан и общественные формирования, действующие в области контроля над преступностью на локальном уровне. Это обусловлено традиционной спецификой организации контроля над преступностью в Японии с широким привлечением к этой деятельности населения и возрастающей потребностью активизации усилий, направленных на привлечение населения, в условиях модернизации японского общества.

Уголовная политика в Японии в широком значении рассматривается как общесоциальная политика, включающая политику в области занятости, образования, жилищного строительства. Более того, в самом широком смысле уголовной политикой называют государственную политику в целом, которая вообе не ставит задачи предупреждения преступности, однако объективно оказывает влияние на ее динамику и тенденции. Соответственно такому пониманию уголовной политики задачи науки уголовной политики не ограничиваются исследованием эффективности отдельных мероприятий по предупреждению преступности, а обязательно включают в себя социологическое изучение направленности практической уголовной политики в историческом и международном планах, а также анализ взаимосвязи государственного строя и уголовной политики [3, с. 89].

В настоящее время в Японии существуют такие учреждения, как Комплексный юридический НИИ министерства юстиции и НИИ полиции при Главном полицейском управлении, которые занимаются исследованием проблем предупреждения преступности в Японии.

В каждой стране проблема предупреждения преступности важна, независимо от системы и мер предупреждения, от различий в законодательстве конкретных стран. Без принятия конкретных мер к предупреждению преступности борьба с ней становится невозможной, более того - неэффективной.

В настоящее время отнюдь не общепризнанным, имеющим не только сторонников, но и противников, стало, казалось бы, бесспорное, «выстраданное» на протяжении веков всей мировой цивилизацией концептуальное положение о приоритетности предупреждения в ряду основных направлений борьбы с преступностью. Не только в научных и публицистических дискуссиях, но, например, и в ходе законопроектных работ, сводится на нет воспитательно-предупредительный потенциал судебной власти, уголовного судопроизводства, принижается роль превентивных компонентов правоохраны в целом [2, с. 31].

Криминологическое предупреждение преступлений представляет собой наиболее действенный способ борьбы с преступностью, поскольку оно:

- обеспечивает выявление и устранение ее корней, истоков, упреждает возможность совершать преступления;

- воздействует на криминогенные факторы, когда они еще не набрали силы и легче поддаются устранению;

- позволяет, используя разнообразные средства, прерывать замышляемую преступную деятельность;

- препятствует наступлению вредных последствий.

\section{Литература}

1. Ананич В. А., Серебрякова И. М. Предупреждение преступности: зарубежный опыт, международное сотрудничество. M., 2010. $432 \mathrm{c}$.

2. Воронин Ю. А. Система борьбы с преступностью в США. М.,2009.

3. Жалинский А. Э. Условия эффективности профилактики преступления. М.,2010. 176 с.

4. Криминология: учебник для вузов / под ред. А. И. Долговой. М., 2009. 345 с. 
5. Криминология: учебник / под ред. В.Д. Малкова. М.,2010. 234 с.

6. Морозов Н. А. Сравнительно-правовой анализ преступности в современной Японии. М., 2009. 332 с.

7. Михеев Р. И., Морозов Н. А., Коидзуми Е. Международное сотрудничество России и стран АТР в сфере уголовной политики, борьбы с преступностью и её предупреждения: материалы междунар. науч.-практ. конф. 2009. 243 с.

8. Уэда К. Преступность и криминология в современной Японии. М.,2010. 198 с.

\section{Преступность в России и США: сравнительный анализ}

(C) П. П. Зуев

студент 3-го курса юридического факультета ФГБОУ ВО «Бурятский госуниверситет»

Россия, г. Улан-Удэ

Zuev-p@inbox.ru

Исследование преступности в разных странах предполагает обращение к криминологической статистике. В самом деле, получения информации другими возможностями, соответствующей требованиям сравнительного исследования, крайне ограничены. Данные требования имеют отношение к сопоставимости данных, получению их из одних и тех же источников, верности анализируемой информации в плане того, насколько верны исследуемые показатели, в какой мере им можно доверять. Разумеется, что удовлетворить этим запросам нельзя, если использовать в качестве главного метода получения информации не статистику, а, например, опрос. Так же, именно материалы статистической отчётности препровождает официальное «лицо» той или иной страны: они проходят установленную, порой довольно жесткую процедуру регистрации и верификации, которой нет аналогов при обращении к иным приёмам получения и обобщения эмпирических данных.

Для юридической общественности данные мировой криминологической статистики, к сожалению, труднодоступны. Например, на сайте Интерпола (www.interpol.ru) подобной информации нет, хотя международная организация уголовной полиции собирает и ежегодно обобщает сведения о преступности в государствах-членах организации. Потому приходится использовать те базы данных, доступ к которым не ограничен. Информация о преступности в США представлена на сайте ФБР Министерства юстиции США (www.fbi.gov), сведенья о преступности в России - на сайте генеральной прокуратуры Российской Федерации (www.crimestat.ru).

При сравнительном анализе преступности в США и России появляется необходимость преодоления методологических проблем. Они имеют отношение к особенностям преступлений уголовно-правовых систем сравниваемых стран. Если с позиций компаративистики нет значительной разницы в понимании изнасилования и убийства, то они имеются в характеристике иных преступлений. Например, в уголовном праве Соединённых Штатов (и соответственно в статистике) выделяется «berglary», которое означает взлом и проникновение в обитаемое помещение с намерением совершить там фелонию (преступление, караемое свыше одного года тюремного заключения). В качестве российского аналога «ближе» всего к этому преступлению будет находиться грабеж, кража, разбой с незаконным проникновением в жилище или в иное хранилище, хотя совершенного совпадения здесь, конечно, нет. Берглэри чаще всего представляет собой кражу или ограбление со взломом, однако область преступлений в данном случае не исчерпывается тайным хищением имущества и может содержать в себя насильственные преступления. Также существует такое преступление как «robbery», понимаемое как ограбление, по уголовному праву России означает совокупность разбоя и грабежа.

Насильственное преступление, как «aggravated assault» включает в себя случаи нападений с использованием оружия, которое может причинить потерпевшему смерть. Таким оружием является, кроме огнестрельного, ножи (с лезвием длиной не менее трёх дюймов), бейсбольные биты, метательные ножи, нунчаки, дубинки, сюрикены и др. В российской уголовной праве ему наиболее близко соответствует умышленное причинение тяжкого вреда здоровью. Установление таких аналогий, как неминуемое результат различия правовых систем приводит к выводу об условности соответствующих сравнений: целиком требование сопоставимости основных показателей здесь не выполнено.

Сравнивая данные о преступности, надлежит учитывать, что в итоговой криминальной отчётности США преступления разделяются на две части: первую и вторую. В первую часть содержатся корыстные и насильственные преступления, причисленные к списку А (индексу преступности): изнасилования, убийства, роббери, нападения с оружием, берглери, кражи, кражи автомобилей. Вторая часть криминальной отчётности содержит сведения о простом насилии, мошенничестве, нарушениях общественного порядка, преступлениях, связанных с наркотиками, вандализме, кражах вещей, оставленных без присмотра, проституции, публичном потреблении спиртных напитков на улицах, вождении автомобиля в состоянии опьянения и др., часть которых по российскому праву рассматривается в качестве административных правонарушений.

Сведения об индексной преступности в США за 2010-2015 гг. приведены в таблице 1. 
Коэффициенты преступности в США за 2010-2015 гг. по видам, в расчёте на 100 тыс. населения[3]

\begin{tabular}{|l|c|c|c|c|c|c|c|}
\hline Годы & Убийство & Изнасилование & $\begin{array}{c}\text { Нападения с } \\
\text { оружием }\end{array}$ & Роббери & Кража & Берглэри & $\begin{array}{c}\text { Кража } \\
\text { автомобилей }\end{array}$ \\
\hline 2010 & 5,6 & 31,8 & 290,8 & 140,8 & 2287,8 & 726,9 & 416,8 \\
\hline 2011 & 5,8 & 31,7 & 292,0 & 150,6 & 2213,2 & 735,2 & 401,1 \\
\hline 2012 & 5,7 & 30,5 & 287,2 & 148,4 & 2285,4 & 726,0 & 364,6 \\
\hline 2013 & 5,4 & 29,7 & 277,5 & 145,7 & 2166,1 & 732,1 & 315,0 \\
\hline 2014 & 5,0 & 28,7 & 264,7 & 133,0 & 2064,5 & 716,3 & 258,8 \\
\hline 2015 & 4,8 & 27,5 & 252,3 & 119,1 & 2003,5 & 699,6 & 238,8 \\
\hline
\end{tabular}

Из анализа таблицы видно, что регистрируемая общеуголовная преступность в США имеет устойчивую тенденцию к снижению. Данная тенденция может значить одно из двух: либо общеуголовная преступность в США в самом деле снижается, либо статистикой манипулируют, демонстрируя оптимистическую картину развития общества.

Уменьшение общеуголовной преступности «само по себе» совершается вслед за старением населения. Чем больше в составе населения лиц в возрасте свыше 39 лет, тем меньше происходит общеуголовных преступлений. В частности, лица в возрасте 13-39 лет совершают в США 76,9 \% общеуголовных преступлений, в том числе 82,6 \% убийств, 76,6 \% изнасилований, 85,4 \% ограблений, 86,4 \% берглери, 79,7 \% краж, 86,1 \% краж автомобилей. Средний возраст населения США сдвигается к 39 годам [2], и это в некоторой степени объясняет уменьшение криминальной активности населения.

Другое соображение в пользу первой гипотезы (реального снижения преступности в США) заключается в улучшении работы американской полиции. В некоторых регионах, например, в Чикаго, образованы особые отряды для борьбы с картелями наркобизнеса и уличными гангстерами, что принесло свои результаты. Количество убийств в Чикаго снизилось на 11 \%. Данное обстоятельство внушает уверенность на продолжительность благоприятного процесса. Стратегия действий спецотрядов и постоянное патрулирование ими самых опасных, с точки зрения преступной активности, городских районов будет с каждым годом набирать обороты.

Объясняя уменьшение преступности, американские эксперты указывают также на понижение интенсивности миграционных процессов и употребления наркотиков.

Профессор Розенфельд говорит, что рост безработицы содействует как раз уменьшению преступности: безработные проводят дома намного больше времени и в следствие этого реже страдают от квартирных краж, потому что домушники выбирают пустые жилища [1]. К. Маркс наверняка бы огорчился, узнав это, ведь он считал безработицу основной причиной преступности.

Данные объяснения верны только частично, в основном они показывают изощрённость человеческого ума, который должен разъяснять парадоксы. Они не объясняют стабильное уменьшение преступности в США.

В полицейских государствах значимость неформальных социальных норм в деле контроля над преступностью делается очевидной, когда формальный контроль слабеет.

Сказанное свидетельствует о повышение уровня социального контроля в США, значение которого из поколения в поколение усиливается главным образом благодаря контактам граждан с правоохранительными органами. Они являются вынужденными и представляют собой ответ на угрозу подавляющей анонимности. Это, в свою очередь, свидетельствует о качественном видоизменении контроля в государстве, которое делается всё более полицейским. Развитие США в сторону полицейского государства - вот главное причина понижения преступности в этой стране. Также нужно подчеркнуть, что уменьшается регистрируемая, а не реальная преступность. Во-первых, в США огромна доля нераскрытых преступлений. По данным ФБР, в 2014 г. раскрываемость составила берглэри - 12,6 \%, изнасилований - 41,3\%, краж - 21,6 \%, ограблений - 28,3 \%, убийств 66,7 $\%$, краж автомобилей - 12,5\%. Основная масса зарегистрированных преступлений в США остаётся нераскрытой. В данных условиях говорить об улучшении криминологической обстановки в США не приходится. Такое чувство что в США из года в год стали меньше регистрировать преступления, которые всё равно не раскрываются. Такая тенденция присуще для любой бюрократической системы, которая не располагает устойчивыми обратными связями. Сведения о преступлениях общеуголовной направленности в России за последние пять полных лет представлены в таблице 2 .

Таблица 2

Коэффициенты преступности в России за 2010-2015 гг. по видам, в расчете на 100 тыс. населения [4]

\begin{tabular}{|l|c|c|c|c|c|c|c|}
\hline Годы & Убийство & Изнасилование & $\begin{array}{c}\text { Причинение } \\
\text { тяжкого вре- } \\
\text { да здоровью }\end{array}$ & $\begin{array}{c}\text { Грабеж, } \\
\text { разбой }\end{array}$ & Кража & $\begin{array}{c}\text { Кража, гра- } \\
\text { беж, разбой в } \\
\text { жилище }\end{array}$ & $\begin{array}{c}\text { Кража авто- } \\
\text { мобилей }\end{array}$ \\
\hline 2010 & 21,4 & 6,4 & 40,3 & 284,4 & 1096,1 & 487,4 & 47,1 \\
\hline 2011 & 19,2 & 6,2 & 36,0 & 291,9 & 1174,3 & 451,6 & 45,2 \\
\hline 2012 & 15,6 & 4,9 & 33,3 & 239,4 & 1101,9 & 384,4 & 41,1 \\
\hline 2013 & 14,2 & 4,4 & 31,9 & 196,7 & 934,0 & 297,7 & 36,8 \\
\hline 2014 & 12,4 & 3,8 & 30,4 & 165,9 & 837,6 & 276,6 & 34,7 \\
\hline 2015 & 10,9 & 3,4 & 27,8 & 132,3 & 775,6 & 255,8 & 33,3 \\
\hline
\end{tabular}


При рассмотрении её материалов также концентрируют на себя внимание твердые тенденции к уменьшению регистрируемых показателей. В пользу таблицы, казалось бы, свидетельствуют и данные о раскрываемости общеуголовной преступности в Российской Федерации. В 2014 г. раскрываемость убийств составила 86,6 \%, изнасилований - 91,3\%, разбоев - 66,3 \%, грабежей - 49,4 \%, краж - 36,6 \%, краж транспортных средств $19,3 \%$

Сравнивая материалы двух таблиц, надлежит отметить более высокий уровень убийств в России. В то же время в Соединённых Штатах более высок (в 10 раз) коэффициент изнасилований.

В принципе, эти показатели показывают уровень агрессивности в социуме, их суммирование не в пользу США. Если судить по статистике, агрессивность в США сублимирована по Фрейду в сексуальном насилии, а в России она проявляется в посягательствах на жизнь знакомых и родных, обычно во время совместного потребления спиртных напитков.

Уровень изнасилований в России неизменно уменьшается и скоро, видимо, изнасилования исчезнут совсем. Верное объяснение здесь только одно - материалы статистики не соответствуют настоящей криминологической ситуации. В реальности уровень агрессии в России значительно выше, чем в США. В этом может убедиться любой, побывав в США. Как только он возвращается в Россию, он уже на пороге паспортного контроля чувствует агрессивность социальной среды капиталистической России, где каждый думает только о себе. Эта агрессия видна на автомобильных дорогах, она усматривается из сопоставления данных таблиц об величине ограблений в двух государствах.

В то же время в США более высока интенсивность совершения корыстных преступлений. Отличия в уровне краж разного вида свидетельствуют на то, что увеличение благосостояния на одном полюсе сопутствует ухудшением его на другом полюсе. Сбросить напряжение между полюсами можно лишь за счёт результативной социальной политики. Решить эту проблему путём статистических манипуляции невозможно, поскольку преследует другую цель - сохранить собственное благополучие ценой больших социальных издержек. Данная стратегия гибельная.

\title{
Литература
}

1. В США резко снизился уровень преступности. URL: http://mail.yandex.ru/neo/message?

2. Население США - 300 миллионов. URL: www.languages-study.com/demography/ USA.html

3. Официальный сайт Федерального бюро расследований США. https://www.fbi.gov

4. Официальный сайт генеральная прокуратуры Российской Федерации. http://www.crimestat.ru

\section{Реформы в системе уголовного наказания Монголии}

\author{
(C) Ижсийт Баатар Баясгалан \\ Заведуюший кафедрой охрань и безопасности \\ Института исполнения судебных решений \\ Университета правоохранительной службы Монголии, \\ полковник \\ Монголия, г. Улан-Батор \\ bayasgalan.b@leu.gov.mn,bayasgalan.0700@yahoo.com
}

Со времени принятия Первой Конституции Монголии от 1924 года и до правовых документов от 1926, 1929, 1934 гг. “Правил судебного разбирательства” и в 1942, 1961, 1986, 2002 гг. "Уголовного кодекса Монголии”, которые с присущей преемственностью отражали политические, социальные черты своего времени и носили исторические обязательства своего времени.

Уголовный Кодекс Монголии от 2002 года, утвержденный в соответствии с концепцией Конституции Монголии от 1992 года, был изменен более 10 раз, учитывая временные обстоятельства и изменения в общественных отношениях. Эти изменения и дополнения были внесены для установления размеров ущерба, или для более подробного установления обстоятельств преступления, или для правового регулирования состава преступления, соблюдения прав и обязательств, принятых Монголией в соответствии с международными договорами, а также в связи с принятием новых законов и законодательных актов.

В Программе работы Парламента на 2012-2016 гг., утвержденный постановлением Великого Государственного хурала № 37 от 2012 года говорится, что “принятие и соблюдение уголовного законодательства соответствующей социальным ценностям и принципам демократии, государственным нуждам развития, с возможностью учета обязательств и с эффективной, результативной и многовыборочной политикой системы наказания".

Чтобы защитить ценности, утвержденные Конституцией Монголии материальным законом нужно утвердить Уголовный кодекс, отвечающий требованиям нынешней общественности, гарантирующий права и свободы человека.

Также в концепции Уголовного кодекса утверждено, что “установление новых видов преступлении и их состава; пытки человека, незаконное проникновение в личное помещение, незаконный обыск, незаконное изъятие и конфискация имущества, расследование человека не имея на то законных прав, незаконный арест, дискриминация и бытовое насилие считать преступлением, установить положения, отвечающие требованиям и нужда государственной и социальной политики". 
Для реальной защиты законных интересов граждан от преступных посягательств, которая является ценностью охраняемая Конституцией Монголии, в новом Уголовном Кодексе Монголии, утвержденная 3-го декабря 2015 года Великим Государственным Хуралом и которая приступить в действие с 1-го сентября 2016 года внесли дополнения, регулирующие ответственности и уголовная субъективность не только физических лиц, но юридических лиц, и тем самым дало возможность соблюдать нормы, возложенные международными договорами.

Рассмотрим в следующем контексте обновления в системе наказания в данном новом законе:

1. Улучшения целей уголовного наказания:

В пункте 45.3 статьи 45 Уголовного кодекса Монголии от 2002 года оговорено следующее: “Целью уголовного наказания является защита гражданина и общественности от преступных посягательств, восстановление прав, нарушенных в результате преступления, уголовная наказуемость лиц, совершивших преступление и их перевоспитание, предупреждение преступлений.” А в пункте 5.1. статьи 5-ой Уголовного Кодекса Монголии от 2015 года оговорено, что “Целью наказания является наказуемость физических и юридических лиц, совершивших преступление, восстановления прав, нарушенных в результате преступления, компенсация причиненного ущерба, предупреждение от преступлении, реабилитация и социализация лиц, совершивших преступление”.

Реабилитация и социализация лиц, совершивших преступление, имеет цели социализации осужденных лиц, их перевоспитание, тем самым избавления от вредных привычек и совершения преступления в дальнейшем.

2. Обновления видов наказаний:

В статье 46 Уголовного Кодекса Монголии от 2002 года, регулируется следующим образом:

•штраф;

•лишение права занимать определенные должности или заниматься определенной деятельностью;

•конфискация имущества;

•обязательные работы;

-арест;

•лишение свободы;

•смертная казнь.

При этом штраф, обязательные работы, арест, лишение свободы и смертная казнь применяются только в качестве основных видов наказаний, а лишение права занимать определенные должности или заниматься определенной деятельностью применяются в качестве основных и дополнительных видов наказании, а конфискация имущества применяются только в качестве дополнительного вида наказания.

В новом Уголовного Кодексе Монголии, регулируется следующим образом:

А. Физическим лицам, совершившим преступления применяются следующие виды наказании:

-штраф;

•обязательные работы, на благо общественности;

•ограничение прав передвижения;

•лишение свободы;

•лишение прав.

При этом штраф, ограничение прав передвижения и лишение свободы применяются в качестве основных, обязательные работы, на благо общественности применяются в качестве основных или дополнительных, а лишение прав применяются в качестве дополнительных.

Б. Несовершеннолетним лицам, совершившим преступления применяются следующие виды наказании:

•обязательные работы, на благо общественности;

•ограничение прав передвижения;

•лишение сводобы в дисциплинарных специализированных местах;

В. Юридическим лицам, совершившим преступления применяются следующие виды наказании:

•штраф;

•лишение прав;

•ликвидация.

Самой явной реформой в новой системы наказания является отказ от смертной казни. В статье 16 Конституции Монголии говорится, следующие права человека: “Право на жизнь. Строго запрещается лишение жизни любого человека, за исключением лиц, приговоренных судом к высшей мере наказания за особо тяжкие преступления, указанные в Уголовном Кодексе Монголии”. В соответствии с этим положением только за особо тяжкие преступления, установленные в Уголовном кодексе можно приговорить к смертной казни, а в остальных случаях нельзя такое допускать. В Уголовном кодексе от 2002 года установлены семь видов особо тяжких преступлении, предусматривающих наказание в виде смертной казни, таких как, посягательство на жизнь государственного и общественного деятеля, саботаж, преднамеренное убийство, изнасилование, терроризм, бандитизм, геноцид.

Суд устанавливал наказание лицам, совершившим данные виды преступлении. Принятие закона является прерогативой Правительства и поэтому несмотря на положения Конституции Монголии, Правительство имеет право устранить смертную казнь из уголовного законодательства, как меру наказания.

Правительство Монголии поддержало инициативу Президента Монголии об устранении смертной казни, как меры наказания, а также издало закон 5-го декабря 2012 года о ратификации Факультативного Протоколо II к Международному Пакту о гражданских и политических правах, направленного на устранение смертной казни, тем самым возложив на себя обязанность на международном уровне. 
3. Наказание в виде лишения свободы, его улучшения:

Лишение свободы заключается в изоляции лица, признанного судом виновным от общества, путем направления его в тюрьму на срок и условие, оговоренное в судебном решении и является мерой государственного принуждения, регулируемая действующим законодательством для защиты населения от преступных посягательств. Данный вид государственного принуждения на данный момент регулируется Уголовным кодексом Монголии, Законом Монголии об исполнении судебных актов, а также более 40 постановлениями и порядками, утвержденными в соответствии с ними Парламентом Монголии, Министром внутренних дел, Председателем Генерального управления Монголии службы исполнения судебных решений.

В рамках наказания в виде лишения свободы есть целый круг вопросов, которые нужны разрешить, такие как, улучшение методов эффективности отбывание лишения свободы, обеспечение прав осужденных лиц, улучшение их условии отбывания, социализация осужденных лиц, улучшения трудового менеджмента с целью обеспечения осужденным лицам трудового места после отбывания наказания, активизация работы по устранению компенсации причиненного ущерба, результат отбывания наказания должен полностью соответствовать целям наказания.

В стратегии развития Управления службы исполнения судебных решений, в приоритетных целях и стратегических направлениях Управления службы исполнения судебных решений главной целью является соответствие международным стандартам наказания в виде лишения свободы.

Соответствие международным стандартам наказания в виде лишения свободы предполагает не только улучшение стандартов жилищных условий и помещения, где отбывает наказание осужденные лица, но и присоединение к международным конвенциям и договорам ООН, регулирующим данные вопросы и внесение этих основных принципов и понятии в внутреннее законодательство страны. Реформы улучшения и результативности наказания в виде лишения свободы предполагают также правильное соотношение целей наказания с режимом, методом, способом отбывания наказания, правами и свободами осужденных лиц, обеспечение этого соотношения на законодательном уровне, улучшение профессиональности работников этих сфер.

Глобализация и уровень развития на современном этапе во многих странах мира подталкивает к реформам и обновлениям в политике наказания. В современных концепциях все больше отталкиваются от наказания в виде лишения свободы и дают приоритет другим видам наказания, что приводит к снижению численности осужденных лиц в местах лишения свободы. Также приоритетным является социализация и адаптация лиц, пребывающих наказание в местах лишения свободы, полное обеспечение им трудового места, обеспечение полной компенсации причиненного ущерба, обеспечение интересов потерпевших лиц, предоставление возможностей осужденным лицам предотвращающие от вторичного преступления.

Наказание в виде лишения свободы направлено на обеспечение политики и целей уголовного наказания, при этом уголовная политика является направлением государства, имеющим цели борьбы с преступностью, обеспечения общественного порядка, защиты прав, свобод и законных интересов гражданина в рамках общества, экономики, политики, законодательства на уровне развития данного государства. При этом государство обеспечивает данную политику уголовного наказания путем принятия таких мер, как создание подходящих видов уголовной ответственности, усовершенствование деятельности назначения наказания, посредством которых осуществляется предупреждение от преступлении и борьба с преступностью.

Основным методом улучшения эффективности уголовного наказания в виде лишения свободы является правовое регулирование, предусматривающее более подходящую систему режима отбывания наказания. Что касается правового регулирования в Монголии, то действующее регулирование не достаточно направлено на конечные цели наказания и не предусматривает более широкий круг режимов.

Каждый согласен с тем, что уголовное наказание в виде лишения свободы это особая мера государственного принуждения с целью наказания преступника и его перевоспитания, которая является основным способом защиты общества и человека от преступного посягательства. В последнее время 60-70 процентов от всех наказании имеет место вышесказанный вид наказания и на сегодняшний день при Управлении службы исполнения судебных решений действует 25 тюрем /из них 1 тюрем, 1 колонии особого режима, 11 колонии строгого режима, 11 колонии общего режима/ реализующих судебное решения о лишении свободы.

С даты принятия в 2002 году Закона Монголии об исполнении судебных актов и по 2012 год были приняты конкретные меры для устранения и компенсации ущерба, причиненного гражданам и обществу, и реализованы наказания в виде лишения свободы более 66228 осужденным лицам по совпадающим числам, в соответствии с правилами, процедурами, временем и режимом установленным законом.

В соответствии с новым Уголовным кодексом Монголии лишение свободы это изоляция лица, совершившего преступление в открытых или закрытых колониях на определенный срок или пожизненно. При этом режим открытой или закрытой колонии определяется законом. А также срок отбывания наказания числится от 7 дней до 20 лет в открытых, или в закрытых колониях на определенный срок.

В законе также установлено, что в случае пожизненного лишения свободы в закрытых колониях, после отбывания 25-летнего срока осужденным лицом, судебные органы повторно рассматривают это дело, с целью решения об освобождении на основании условии совершения преступления, размера и характера причинённого ущерба, личных обстоятельств осужденного лица.

Исходя из вышесказанного можно сказать, что новое регулирование в уголовном законодательстве Монголии предусматривает уголовную политику направленную на частое применения других видов наказания при- 
оритетным над наказанием в виде лишения свободы и устранение ущерба и последствия, причиненного в результате преступного деяния.

Предложения

•Другие виды наказании, чем наказание в виде лишения свободы, такие как ограничение прав передвижения, обязательные работы на благо общества нужно реализовать с помощью технического наблюдения, также нужно внедрять более финансово доступные методы реализации данного вида наказании, практикующие в других странах и создать систему исполнения наказании, которая подходит для наказания юридических лиц.

•Внести изменения и дополнения в законодательство с целью улучшения эффективности работ по социализации осужденных лиц в исправительных учреждениях.

-Создать правовое регулирование более точно определяющее различие между закрытым и открытым исправительным учреждением, его условии и положении.

•В новом законодательном проекте “Закона об исполнений судебных решений Монголии” внести предложения по созданию правового регулирования соответствующей мировым тенденциям и международноправовым договорам и иным документам, которая будет предусматривать основание, условие и правила реализации наказания.

\title{
Сравнительный анализ наказаний за преступления, носящие террористический характер в РФ, Китае и Таиланде
}

\author{
(ㄱ) А. В. Кобылкин \\ магистрант 1 года обучения юридического факультета \\ ФГБОУ ВО «Бурятский госуниверситет» \\ Россия, г. Улан-Удэ \\ a20794@yandex.ru
}

Так как не существует единого для всех стран понятия «терроризм», каждое законодательство всех стран дает определение терроризму по-своему. У каждой страны есть свое уголовно-правовое законодательство, уголовный кодекс, в котором содержатся преступления с террористическим оттенком. За каждое преступление, предусмотрено свое наказание.

В Уголовном кодексе Российской Федерации ст.205 регламентирует наказание за совершение террористического акта.

Наказание содержится в санкции статьи, которая предусматривает собой лишение свободы:

- по ч.1 на срок от восьми то пятнадцати лет;

- по ч.2 на срок от десяти до двадцати лет с ограничением свободы на срок от одного года до двух лет;

- по ч.3 на срок от пятнадцати до двадцати лет с ограничением свободы на срок от одного года до двух лет или пожизненным лишением свободы.

За содействие террористической деятельности (ст.205.1 УК РФ) предусматривается наказание лишение свободы:

- по ч.1 на срок от пяти до десяти лет со штрафом в размере до пятисот тысяч рублей либо в размере заработной платы или иного дохода осужденного за период до трех лет либо без такового;

- по ч.2 на срок от восьми до пятнадцати лет со штрафом в размере от пятисот тысяч до одного миллиона рублей либо в размере заработной платы или иного дохода осужденного за период от трех до пяти лет либо без такового;

- по ч.3 на срок от десяти до двадцати лет; по ч.4 на срок от пятнадцати до двадцати лет с ограничением свободы на срок от одного года до двух лет или пожизненным лишением свободы.

За публичные призывы к осуществлению террористической деятельности или публичное оправдание терроризма (ст.205.2 УК РФ) предусматривается наказание:

- по ч.1 штраф в размере до пятисот тысяч рублей либо в размере заработной платы или иного дохода осужденного за период до трех лет, либо принудительными работами на срок до четырех лет, либо лишением свободы на срок от двух до пяти лет;

- по ч.2 штраф в размере от трехсот тысяч до одного миллиона рублей либо в размере заработной платы или иного дохода осужденного за период от трех до пяти лет, либо принудительными работами на срок до пяти лет с лишением права занимать определенные должности или заниматься определенной деятельностью на срок до пяти лет или без такового, либо лишением свободы на срок до семи лет с лишением права занимать определенные должности или заниматься определенной деятельностью на срок до пяти лет.

За прохождение обучения в целях осуществления террористической деятельности (ст.205.3 УК РФ) предусматривается наказание:

- лишение свободы на срок от пятнадцати до двадцати лет с ограничением свободы на срок от одного года до двух лет или пожизненным лишением свободы.

За организацию террористического сообщества и участия в нем (ст.205.4 УК РФ) предусматривается наказание: 
- по ч.1 лишение свободы на срок от пятнадцати до двадцати лет со штрафом в размере до одного миллиона рублей или в размере заработной платы или иного дохода осужденного за период до пяти лет либо без такового и с ограничением свободы на срок от одного года до двух лет или пожизненным лишением свободы;

- по ч.2 лишение свободы на срок от пяти до десяти лет со штрафом в размере до пятисот тысяч рублей либо в размере заработной платы или иного дохода осужденного за период до трех лет либо без такового.

За организацию деятельности террористической организации и участие в деятельности такой организации (ст.205.5 УК РФ) предусматривается наказание:

- по ч.1 лишение свободы на срок от пятнадцати до двадцати лет со штрафом в размере до одного миллиона рублей или в размере заработной платы или иного дохода осужденного за период до пяти лет либо без такового и с ограничением свободы на срок от одного года до двух лет или пожизненным лишением свободы;

- по ч.2 лишение свободы на срок от пяти до десяти лет со штрафом в размере до пятисот тысяч рублей либо в размере заработной платы или иного дохода осужденного за период до трех лет либо без такового.

Квалифицирующие признаки терроризма аналогичны, как правило, признакам других насильственных преступлений: по предварительному сговору группой лиц, неоднократно, с применением огнестрельного оружия.

В п. 2 ст. 35 УК РФ дается определение преступления, совершенного группой лиц по предварительному сговору, из которого можно сделать вывод, что этому квалифицирующему признаку свойственны три обязательные условия: наличие двух и более субъектов преступления (вменяемых и достигших 14летнего возраста), которые заранее, т.е. на стадии приготовления, вступили в сговор о совершении акта терроризма и которые полностью или хотя бы частично выполнили действия, входящие в объективную сторону терроризма (взрывали, поджигали, блокировали и т.д.).

Неоднократность, согласно ст. 16 УК РФ, означает совершение двух или более актов терроризма. Для признания терроризма неоднократным не имеет значения, был ли террорист уже осужден за предыдущий теракт или привлечен впервые к ответственности за два и более террористических действия. Несомненно, неоднократность отсутствует, если снята судимость за террористический акт, совершенный в прошлом.

Если один из неоднократных актов терроризма представляет оконченное преступление, а другой - покушение на терроризм, то такие действия должны квалифицироваться по правилам совокупности преступлений, согласно ст. 17 УК РФ.

Применение огнестрельного оружия при совершении террористического акта повышает его общественную опасность.

Применение огнестрельного оружия означает использование его поражающих свойств для причинения вреда здоровью или уничтожения людей, как с реальными последствиями, так и при покушении на жизнь и здоровье людей, а также использование огнестрельного оружия в целях психического воздействия, когда оно только демонстрировалось, но при этом возникала опасность причинения вреда людям.

Организованная группа определена в п. 3 ст. 35 УК РФ как устойчивая группа лиц, заранее объединившихся для совершения одного или нескольких преступлений.

Устойчивость преступной группировки означает ее существование в течение более или менее значительного промежутка времени в целях подготовки преступления.

Об устойчивости говорит относительно стабильный численный состав преступной группы. Устойчивость может проявляться и в неоднократности однородных преступных действий. В таких группах существуют внутренние связи между их членами, наличествует распределение ролей между преступниками не только в момент террористических актов, но и в период между ними, когда группа существует как структура.

Согласно п. 5 ст. 35 УК РФ организатор или руководитель преступной группировки несет ответственность за все преступления, совершенные террористической группой, если они охватывались его умыслом.

Участники группировки несут ответственность за те террористические акты, в которых они участвовали, или принимали участие в их подготовке. Если выполнялись действия по подготовке террористического акта, но сам теракт еще не был совершен, то его приготовление квалифицируется как преступление, предусмотренное ст. 205 УК РФ.

Наступление смерти пострадавших от терроризма людей или наступление иных тяжких последствий, причиненных по неосторожности, по тяжести составляет, по мнению законодателя, равноценный квалифицированный вид терроризма, как и совершение, его организованной группой.

В действующем Уголовном кодексе Таиланда и других нормативно-правовых актах Таиланда отсутствует понятие терроризма и террористического преступления. Вместе с тем раздел VI «Преступления, относящиеся к общественной безопасности» дает перечень из двадцати двух составов, которые можно отнести к способам терроризма. Так, статья 218 Уголовного кодекса Таиланда регламентирует: любой, кто поджигает:

1) Здание, лодку или плавучий дом, где проживают люди;

2) Здание, лодку или плавучий дом, используемый для хранения или производства товаров;

3) Место для развлечений или собраний;

4) Здание, которое является собственностью государства, общественным местом или местом для отправления религиозных обрядов;

5) Железнодорожную станцию, аэропорт, общественную парковку или лодочный причал;

6) Пароход или моторную лодку водоизмещением пять тонн или больше, самолет или поезд, используемый для общественных перевозок, 
- должен быть приговорен к смертной казни, пожизненному тюремному заключению или тюремному заключению на срок от пяти до двадцати лет.

Статья 221 Уголовного кодекса Таиланда регламентирует: любой, кто становится виновником взрыва, который может нанести вред другому человеку или собственности, принадлежащей другому человеку, должен быть приговорен к тюремному заключению на срок не более семи лет и к штрафу в размере не более четырнадцати тысяч бат.

Статья 222 Уголовного кодекса Таиланда говорит: любой, кто становится виновником взрыва, чтобы нанести вред одному из объектов, указанных в статье 218, должен быть наказан по этим статьям.

В Статье 224 Уголовного кодекса Таиланда сказано: если совершение преступлений, предусмотренных статьями, 218, 220, 221 или 222, влечет за собой смерть человека, виновный должен быть приговорен к смертной казни или к пожизненному тюремному заключению. Если совершение указанных в параграфе 1 настоящей статьи преступлений причиняет значительный физический вред другому человеку, виновный должен быть приговорен к смертной казни, пожизненному тюремному заключению или тюремному заключению от десяти до двадцати лет.

Статья 232 Уголовного кодекса Таиланда регламентирует: любой, кто каким бы то ни было образом приводит одно из нижеперечисленных транспортных средств в такое состояние, при котором они могут представлять опасность для человека:

1) Морское транспортное средство, самолет, поезд или трамвай;

2) Автомобиль, используемый для общественных перевозок;

3) Пароход или моторную лодку водоизмещением пять тонн и более, используемую для общественных перевозок

- должен быть приговорен к тюремному заключению на срок от шести месяцев до семи лет и к штрафу в размере от одной тысячи до четырнадцати тысяч бат.

В Статье 237 Уголовного кодекса Таиланда сказано: любой, кто добавляет отравляющее вещество или любое другое вещество, которое может нанести вред здоровью, в пишу, воду в любом колодце, пруду или резервуаре, и эти пища или вода становятся доступными для общественного потребления, должен быть приговорен к тюремному заключению на срок от шести месяцев до десяти лет и к штрафу в размере от одной тысячи до двадцати тысяч бат.

Следует отметить, что в уголовном законодательстве КНР пока отсутствует определение терроризма.

В Китае, как и в России, основные террористические проявления связаны с сепаратизмом. В Китае острие государственной политики в борьбе с этим явлением направлено против уйгурских сепаратистов, выступающих за создание независимого государства «Восточный Туркестан» на территории Синьцзян - Уйгурского автономного района КНР. Сепаратисты создали лагеря боевиков, склады боеприпасов и оружия; с 1990 года ими совершено более двухсот терактов, где пострадали свыше шестисот человек.

В связи с этой угрозой, в Уголовном кодексе Китая в главе «Преступления против государственной безопасности» предусмотрен ряд статей направленных на противодействие причинам террористической деятельности:

- Причинение вреда территориальной целостности и безопасности КНР (ст. 102 УК КНР);

- Организация, планирование и совершение практических действий направленных на раскол государства, нарушение государственного единства, осуществленные зачинщиками или лицами, совершившими тяжкие преступления (ст. 103 УК КНР);

Статья 1136 УК КНР допускает, за совершения преступлений, указанных в главе «Преступления против государственной безопасности», в случае «причинения особо серьезного вреда государству и народу, и при особо отягчающих обстоятельствах», применение смертной казни.

Итак, главным сходством является что ни в РФ, ни в КНР, ни в Таиланде нет единого определения терроризма. Наиболее суровые наказания за преступления, носящие террористический характер, наблюдаются в Китае и Таиланде, вплоть до применения смертной казни. В России всё более гуманно: самым суровым наказанием является лишь пожизненное лишение свободы. И тут встает вопрос, а нужен ли нам такой гуманизм, когда из года в год погибают тысячи людей? Не перенять ли нам опыт некоторых стран АТР?

\section{Литература}

1. Даниленко Н. О. О проблеме терроризма в Российской Федерации. М.: Междунар. отношения, 2012. С. 75-76.

2. Картавый А. А. Совершенствование уголовного законодательства России о борьбе с терроризмом // Терроризм в России и проблемы системного реагирования / под ред. А. И. Долговой. М.: Российская криминологическая ассоциация, 2010. $132 \mathrm{c}$.

3. Ромашев Ю. С. Борьба с преступлениями международного характера, совершаемыми на море (терроризм, пиратство, незаконный оборот наркотиков и другие преступления). М.: РосКонсульт, 2011. С. 111-112.

4. Алексенко Д. М. Актуальность новых подходов в борьбе с терроризмом. М.: Междунар. отношения, 2012.54 с.

5. Уголовный кодекс Российской Федерации от 13.06.1996 № 63-Ф3 (ред. от 03.02.2015) // Собрание законодательства РФ. 1996. № 25. 


\title{
Особенности уголовной ответственности за дорожно-транспортные преступления: сравнительно-правовой анализ
}

\author{
() K. C. Латыпова \\ преподаватель кафедры \\ уголовного процесса и криминалистики \\ юридического факультета \\ ФГБОУ ВО «Бурятский госуниверситет» \\ Россия, г. Улан-Удэ \\ krista.100@mail.ru
}

В условиях роста мировой автомобилизации и повышения интенсивности дорожного движения, увеличилось количество дорожно-транспортных происшествий, что привело к значительному росту смертности на дорогах.

Аварийность на автомобильном транспорте - одна из острейших социально-экономических проблем современности. Структура смертности от неестественных причин показывает, что наиболее социально и экономически значимой становится смертность от транспортного травматизма, на долю которого, по данным ВОЗ, приходится 30-40 \% и более всей смертности от несчастных случаев. Автотранспорт - наиболее потенциально опасное средство передвижения: на него приходится подавляющая часть транспортных происшествий - 98,8$99,2 \%$ от общего количества, при этом в дорожно-транспортных происшествиях (далее, ДТП) на планете ежегодно гибнет 1,2 млн. человек и более 15 млн. получают ранения [3, с. 25].

Наряду с положительным влиянием на экономику и социальное развитие государства, ускоренные темпы автомобилизации влекут отрицательные последствия. За последние 10 лет в нашей стране в ДТП погибло свыше 300 тысяч человек, а более 2 миллионов - получили увечья. Количество ежегодно пострадавших на дорогах России соизмеримо с населением крупного областного центра. При этом, в большинстве случаев основной причиной ДТП является пренебрежительное отношение к требованиям Правил дорожного движения (далее, ПДД)[1].

Тяжесть последствий ДТП в России в несколько раз выше аналогичных показателей других стран. Каждые сутки на дорогах Российской Федерации погибают более 20 и получают ранения около 500 человек [15, с. 5]. По данным ГИБДД, за январь - март 2014 года в России произошло 35120 тяжких ДТП, что на 3,9 \% превышает показатель за аналогичный период прошлого года. Число погибших в этих авариях составило 4632 человека, еще 44795 серьезно пострадали. Оба показателя заметно подросли в сравнении с прошлым годом: на 6,3 \% увеличилось число погибших, на 2,4 \% - количество пострадавших в ДТП [6] .

Тем не менее, проблема в полной мере характерна как для России, так и для стран Азиатско-Тихоокеанского региона $[4$, с. 5]. Рассмотрим эту проблему в сравнительном анализе уголовной ответственности за ДТП в России и Монголии.

Криминогенная обстановка на дорогах мира в целом, так же как в Монголии и России в частности представляет собой реальную опасность для государственного управления и национальной безопасности государства [7]. Опасность преступлений, совершаемых на дорогах, заключена, прежде всего, в том, что они всеми своими формами активно воздействуют на сознание большой массы людей, которые могут и не относиться к участникам дорожного движения. Тем самым преступления в сфере дорожного движения нарушают общественное спокойствие, вызывая у населения чувство неуверенности и страха за свою безопасность и обостряя общую социальную напряженность.

Сравнительно-статистический анализ показывает, что данные дорожных происшествий в Монголии по некоторым показателям не уступают, а в некоторых случаях, например по транспортному риску, даже превосходят показатели органов дорожной безопасности Российской Федерации. Безусловно, основное влияние на число ДТП оказывает количество автомобилей на дорогах. Чем их больше, тем выше аварийность. За последние 20 лет численность автопарка Монголии возросла почти в четыре раза, и в 2010 г. составила свыше 181 тыс. транспортных единиц [6, с. 7]. Как следствие с каждым годом происходит увлечение уровня нарушений в сфере безопасности дорожного движения. Так в 2010 г. в Монголии было совершено 879,8 тыс. нарушений в сфере безопасности дорожного движения, что почти вдвое превышает число нарушений подобного рода, зарегистрированных в 2000 г. 470,4 тыс.

Основными видами нарушений правил дорожного движения в 2010 г. являлись - управление транспортным средством в состоянии опьянения - 16125; отсутствие права на управление ТС -53671 ; техническая неисправность ТС - 197089; не предоставление ТС на государственный технический осмотр - 38486; превышение установленной скорости - 108223; нарушения правил обгона - 91879; выезд на полосу встречного движения 58950 ; прочие нарушения водителей - 315441 [7, с. 55].

В то время как в Российской Федерации основными видами нарушений ПдД являются - управление ТС в состоянии опьянения - $13,1 \%$; отсутствие права на управление - $15,3 \%$; несоответствие скорости конкретным условиям $-29,8 \%$; нарушение правил обгона $-1,8 \%$; выезд на полосу встречного движения $-12,7 \%$; несоблюдение очередности проезда перекрестков - $11,2 \%$; превышение установленного скорости $-5,1 \%$; прочие нарушения водителей $-11,0 \%[10$, с. 12$]$. 
Сравнительно-статистический анализ данных органов безопасности дорожного движения Монголии и РФ показывает, что структура основных видов нарушений ПдД по некоторым показателям таким, как управление ТС в состоянии опьянения, превышение скорости, нарушения правил обгона и т.п. кардинально различаются. Это связано, на наш взгляд, с тем, что уровень дисциплинированности водителей в Монголии ниже, чем уровень такого показателя в России.

Именно, недисциплинированность водителей является основной причиной дорожно-транспортных происшествий в Монголии, уровень совершения которых с каждым годом увеличивается.

Таким образом, сохраняются и даже расширяются предпосылки к росту дорожно-транспортных преступлений в Монголии. Основными правовым средством борьбы с дорожно-транспортными преступлениями является уголовное законодательство Монголии. Составы преступлений, связанных с преступным нарушением правил дорожного движения и эксплуатации транспортных средств, предусмотрены ст.ст. 215 - 225, содержащимися в главе 24 УК Монголии [11] «Преступления против правил безопасности движения и эксплуатации транспортных средств». В России же за те же действия предусмотрена уголовная ответственность в ст. 264 УК РФ [11], которая в отличие от ст. 215 УК Монголии, состоит не из 3, а из 6 частей. Это «нарушения правил дорожного движения и эксплуатации транспортного средства», которая относиться к 9 разделу Уголовного кодекса РФ «Преступления против общественной безопасности и общественного порядка»

Анализ норм показывает, что уголовное законодательство Монголии в сфере безопасности дорожного движения характеризуется полнотой и структурой норм. Однако, судебная практика по делам, связанным с нарушениями правил дорожного движения и эксплуатации транспортных средств и сравнительный анализ с аналогичными нормами российского уголовного законодательства, свидетельствуют о том, что вышеуказанные нормы уголовного законодательства Монголии отличаются чрезмерной строгостью, можно даже сказать репрессивностью. Хотя в рамках правовой реформы большое число деяний Монголии было выведено из уголовной ответственности.

Так, ч. 1 ст. 215 УК Монголии гласит, что «Нарушение водителем правил дорожного движения или эксплуатации транспортных средств, повлекшее причине менее тяжкого вреда здоровью человека либо причинение менее тяжкого вреда здоровью человека либо причинение значительного ущерба, - наказывается лишением права занимать определенные должности или заниматься определенной деятельностью на срок до двух лет или без такового, штрафом в размере от пяти до пятидесятикратной минимальной заработной платы, либо арестом на срок от одного до трех месяцев». По российскому законодательству указанное деяние не является уголовно наказуемым, оно подпадает под административную ответственность [9].

Ч. 2 ст. 215 УК Монголии предусматривает «То же деяние, совершенное в состоянии алкогольного опьянения и повлекшее причинение тяжкого вреда здоровью человека либо причинение ущерба в крупном размере. Данная норма предусматривает наказание в виде лишения права занимать определенные должности или заниматься определенной деятельностью на срок до трех лет или штрафа в размере от пятидесяти одного до двух сот пятидесятикратного размера минимальной заработной платы, либо ареста на срок до трех лет или штрафа в размере от пятидесяти одного до двух сот пятидесятикратного размера минимальной заработной платы, либо ареста на срок от трех до шести месяцев или лишения свободы от двух до пяти лет». В то время, в ч. 1 и ч. 2 ст. 264 УК РФ за данное деяние предусматривает санкцию в виде - ограничения свободы на срок от 2 до 3 лет лишения свободы. Существенным различием этих двух норм является отсутствие в диспозиции ст. 264 УК РФ положения «о причинении крупного ущерба», в отличие от УК Монголии, который предусматривает за его причинения уголовную ответственность.

По ч. 3 ст. 215 УК Монголии определяется «То же деяние, повлекшее смерть человека либо причинение ущерба в особо крупном размере, - наказывается штрафом в размере от двух сот пятидесяти одного до пяти сот кратной минимальной заработной платы с лишением права управлять транспортным средством до четырех лет, либо лишением свободы от пяти до десяти лет». В то время, по ст. 264 УК РФ за данное деяние предусмотрено наказание до 9 лет лишения свободы.

Помимо вышерассмотренного состава, УК Монголии определяет еще ряд норм, которые предусматривают уголовную ответственность за ДТП, одной из которых является ст. 216 УК Монголии - оставление места дорожно-транспортного происшествия.

В Уголовном кодексе РФ данная норма отсутствует. До 2003 года, это была статья 265 УК РФ «Оставление места дорожно-транспортного происшествия», водитель мог в дополнении к сроку получить по ней еще три года лишения свободы, а сейчас такой статьи вообще нет.

Современный Уголовный кодекс позволяет привлекать к ответственности водителя, оставившего места дорожно-транспортного происшествия, участником которого он является по ст. 264 УК РФ «Нарушения правил дорожного движения и эксплуатации транспортного средства» и ст. 125 УК РФ «Оставление в опасности». Однако правоохранительные органы указанной возможностью не пользуются. Вызвано это тем, что доказать состав преступления по этим статьям практически невозможно.

Уголовное законодательство европейских государств, таких, как Германия (ст. 142 УК ФРГ) [13], Испания (ч.2 ст. 382 УК) [14] и др., предусматривает уголовную ответственность за оставления места дорожно-транспортного происшествия. Аналогичные требования содержит Европейская конвенция о наказаниях за дорожнотранспортные преступления [2].

Проанализировав нормы, регулирующие уголовное законодательство за ДТП в России и Монголии, мы пришли к выводу о том, что законодатель Монголии не подчеркивает форму вины субъекта совершившего до- 
рожное преступление, не учитывая, что данные преступления носят малую степень общественной опасности и совершаются с неосторожной формой вины. В отличие от нашего законодательства, где в диспозиции ст. 264 УК РФ после слова «повлекшее» следует слова «по неосторожности».

Законодательство Монголии в области регулирования безопасности на дорогах в значительной мере более совершенно, чем в России. Что обуславливает необходимость изменить ситуацию на дорогах нашей страны в лучшую сторону, путем заимствования уголовно и административно правовых мер борьбы с ДТП в Монголии. В первую очередь, необходимо уделить внимание ужесточению отечественного законодательства в данной области.

Необходимость России в международном сотрудничестве в противостоянии дорожным преступлениям, т.е. выработки общей стратегии и совместных мер борьбы. Это соответствующие действия и мероприятия органов одного государства по соответствующему запросу другого государства, регламентируемые международными документами в данной сфере с ориентацией на положения Европейской конвенции о наказаниях за дорожнотранспортные преступления.

Подводя итог вышесказанному, необходимо отметить, что в России и Монголии с каждым годом уровень ДТП продолжает, в связи со сложившейся неудовлетворительной социально-экономической обстановкой в стране, низкой эффективностью профилактических работ в области безопасности дорожного движения среди водителей, а также отсутствием должного внимания в области повышения уровня правосознания и культуры вождения на дорогах нашей страны. Поэтому рассматриваемая проблема уголовной ответственности за ДТП вызывает большой научный и практический интерес и требует дальнейшего углубленного исследования.

\section{Литература}

1. Абрамочкин В. В. Расследование дорожно-транспортных преступлений: учеб. пособие. М.: Щит-М, 2010. 240 с.

2. Европейская конвенция о назначении наказания за дорожно-транспортные преступления, Страсбург, 30 ноября 1964 г. [Электронный pecypc]. URL: htth://www.asmap.ru/home.php?id=2402 (дата обращения: 15.03.2012).

3. Евтюков С. А., Васильев Я. В. Дорожно-транспортные происшествия: расследование, реконструкция, экспертиза. СПб.: ДНК, 2008. 392 с.

4.Ищенко Е. П. Энциклопедия дорожной безопасности, или как попасть в дорожно-транспортное происшествие: учеб.практ. пособие. М.: Юрлитинформ, 2010. 400с.

5. Кодекс об административных правонарушениях Российской Федерации от 30 декабря 2001 года № 195-Ф3 // Собрание законодательства Российской Федерации. 2002. № 1 (ч. 1). Ст. 1.

6. Официальные данные ГИБДД по РФ Официальный сайт ГИБДД [Электронный ресурс] - официальные данные о количестве ДТП по РФ. URL: http://www. 03.gibdd.ru/stat (дата обращения: 1.09.2014).

7. Официальные данные Управления дорожной полиции Монголии. Улан-Батор, 2010. С. 6-15

8. По данным ООН смертность при ДТП стоит на 3-м месте после сердечно-сосудистых и раковых заболеваний.

9. Постановление правительства Российской Федерации от 29.06.1993 №1090 «О Правилах дорожного движения». Собрание актов президента и правительства РФ. 22.11.1993. № 47.

10.Проблема национального масштаба. Материалы всероссийских конференций по безопасности дорожного движения. M., 2011.

11.Уголовный кодекс Монголии, 2002 г. [Электронный pecypc]. URL: htth://www.law.vlu/comments/ show_articl.php\&art_id (дата обращения: 15.06.2012).

12. Уголовный кодекс Российской Федерации: текст изм. и доп. на 10 марта 2013 г. М.: Эксмо, 2013. 160 с.

13. Уголовный кодекс Германии / науч. ред. и предисл. Д. А. Шестакова; пер. с нем. Н. С. Рачковой. СПб.: Юридический центр Пресс, 2002. 650 с.

14. Уголовный кодекс Испании / под ред. Н. Ф. Кузнецовой и Ф. М. Решетникова. М.: Зерцало, 1998. 214 с.

15. Чичерина М.П. Виктимологический анализ и профилактика дорожно-транспортных происшествий, совершаемых водителями частных автомобилей: автореф. дис. ... канд. юр. наук. М., 2000. 165 с.

\section{Сравнение преступных группировок России и Китая}

(С) И. Д. Левин

магистрант 1 года обучения юридического факультета ФГБОУ ВО «Бурятский госуниверситет»

Россия, г. Улан-Удэ master95740@mail.ru

Большая степень опасности организованных преступных групп, малоизученность данной темы, а также внедрение такого явления в жизнь обычных граждан показывает актуальность изучения и сравнения ОПГ в разных странах, в данной статье - это сравнение России и Китая. Изучение данной проблемы является весьма интересным как с научной, так и с практической точки зрения, так как для этого требуется разработка и введение новых подходов для борьбы с организованными преступными группами, а также объединение усилий разных государств в решении данного вопроса.

Основная цель исследования заключается в определении на основе анализа сходств и различий «русской мафии» «китайской триады». Для начала стоит рассказать немного о каждой из рассматриваемых преступных группировок. 
Начнем с российской преступной группировки. Она значительно отличается от преступных группировок мира. Можно сказать, что она гораздо раньше остальных приобрела большие масштабы, и, конечно же, еще один немаловажный факт - образовалась гораздо раньше. По сравнению с ОПГ других стран отличается быстротой и гибкостью. Она не упускала представляющейся для нее возможности, преодолевала любые преграды несмотря ни на что, а также была внутри огромного денежного круговорота, что давало большие силы и перспективы. Международное распространение российской преступной группы произошло еще до развала Советского Союза, этот факт способствовал дальнейшему распространению ее преступных действий по миру при помощи уже полученных за это время «связей».

«Русская мафия» насчитывает в себе уже более 500 тысяч человек. Ее главы контролируют большую часть российской экономики, а также удерживают свои позиции в других странах: к примеру, контроль оборота наркотических средств в Узбекистане и Таджикистане, отмывание огромного количества денег на Кипре, в Израиле, Англии и Бельгии, проституция в Макао и Китае, автомобильные кражи, торговля оружием. Все это, скажем, «внешняя политика» преступных группировок России.

После падения «железного занавеса» независимость российской преступности перестала контролироваться, как это происходило до распада СССР. Так называемая первая волна, первый переброс преступности произошел в начале 70-х годов, когда разрешили выезд из Израиля советским евреям. Вторая же волна приходится на распад СССР и падение «железного занавеса». Криминальные сообщества России выражали свои специфические интересы в разных частях мира. Как раз в этот момент мир оценил масштабы русской преступности и впоследствии назвал ее «русской мафией».

ОПГ России основано на корыстных и корыстно-насильственных преступлениях, ведут как теневую, так и легальную экономику, а также имеют «связи» в органах власти.

На западе под «русской мафией» подразумевают вообе любые преступные группировки - как российские, так и других государств, которые были в составе СССР до распада, а также эмигрантов из дальнего зарубежья.

Очень непростая ситуация была в 90-е года. Как раз то время расцветали преступные (криминальные) группировки, бандитские разборки, вандализм и терроризм, рекет, направленный на честных предпринимателей и продавцов. Появляются рыночные экономические отношения, множество преступных элементов. Лидеры ОПГ принимаются «крышевать» эту структуру, за счет чего получают новый способ получения денег, причем не плохих, постепенно продвигаются дальше, добиваясь власти в сфере политики, а, следовательно, и возможности влиять на нее в государстве. Это повлияло на то, что криминальный мир, который на данный момент имеет широкую распространённость, вошел в жизнь обычных граждан.

При этом преступное сообщество несет в себе не приобщение к гражданской жизни, как некое составляющее, а наоборот внедряется как полноправный член в общественную жизнь. Но при этом преступность опирается на свою уже сохранившуюся идеологию, и тем самым вливается в жизнь обычных граждан не только своими «представителями», но и криминальной культурой.

А. И. Долгова представляет причины и условия, создавшие возможность для криминализации общества и быстрого роста организованной преступности в современной России:

1. Рыночные преобразования, которые проводились в экстренном и форсированном порядке, были основаны на принятом некритично положении о самодостаточности рынка как регулятора общественных отношений. В результате этого становление механизмов свободной конкуренции не сопровождалось введением системы экономических и социальных сдержек и противовесов, обеспечивающих нормальное функционирование рыночной экономики в современных развитых странах.

2. Игнорирование социальной составляющей преобразований в обществе, приведшее к распаду традиционных нравственных ценностей и отсутствию насаждаемых легалистским обществом новых ценностных установок, в результате чего значительное влияние на процессы формирования подрастающего поколения стала оказывать преступная среда.

3. Отношение власти к народу как к объекту, а не субъекту воздействия, в результате чего не были предсказаны и вовремя скорректированы тенденции преступного реагирования на изменения привычного образа жизни.

4. Недооценка способностей преступности воздействовать на общественные отношения, изменять структуру общества, обусловившая непродуманность и недостаточную эффективность мер борьбы с ней.

5. Сознательное непринятие мер к недопущению формирования преступных капиталов, обеспечение им финансовой неприкосновенности, что дало возможность преступным формированиям выйти на политическую и международную арены.

Замечу, что на становление организованной преступности оказала влияние слабость правоохранительной системы государства, недостаточность паровой силы, а также материальной базы.

Гай Данн выделил следующие группы участников преступных формирований по выполняемой ими роли:

- Лидеры, руководящие организациями и обеспечивающие её успешную деятельность путём использования личных связей в бизнесе и органах власти.

- Заместители лидеров по разным направлениям, которые обеспечивают планирование операций, финансовое планирование, «смотрящие» по различным направлениям деятельности организации.

- Главари отдельных групп и подразделений преступной организации.

- Солдаты —исполнители преступных и иных деяний. 
Общей мотивацией всех этих участников групп является стремление к наживе, «большим деньгам», для них характерны такие качества, как цинизм и жестокость, алчность и честолюбие (для лидеров), скрытность, двуличие, приспособленчество и равнодушие (для рядовых участников).

Рассказав немного о преступных группировках в России, перейдем к выяснению, что же представляют из себя «китайские триады», их история и сущность.

О том, что быстро развивающийся Китай стремительно становится лидером, давно говорят во всем мире. Но есть и негативные стороны этого процесса. За счет укрепления лидирующих позиций КНР в глобальной экономике китайская преступность будет расти и пускать все больше свои корни в транснациональные криминальные отношения.

В докладе Европола (июнь 2006-го) отмечено, что китайские мафиозные группировки названы лидерами в торговле людьми в странах Европейского союза. «Китайская триада» вытеснила в Японии «якудзу»: на долю китайцев приходится около половины всех преступлений, совершаемых иностранцами.

Всем триадам были свойственны общие убеждения и ритуалы, как, например, вера в мистическое значение цифры 3, откуда и пошло их название. В мирное время большинство подобных обществ действовало как братства взаимопомощи, но вместе с тем многие из них были связаны с преступной деятельностью.

Затронем деятельность триад в России. Китайские мафиозные группировки отличаются скрытностью, информации об их структуре и деятельности у наших правоохранительных органов очень мало. Чаще всего преступления происходят в среде их же соотечественников, в результате чего рэкет, угрозы и даже убийства не попадают в российскую криминалистическую статистику. Ситуация ухудшается закрытостью китайской общины и отсутствием в органах полиции людей, знающих язык, чтобы в полной степени войти в курс дела. По имеющимся данным, основными триадами являются пекинская, шанхайская и харбинская. По оперативным данным, рядовых членов триады отличают показная внешняя скромность - строгая иерархия, слепое повиновение главарям, беспощадность, круговая порука и обет молчания. Триада, за редким исключением, не оставляет практически никаких материальных следов. Основная сфера их деятельности на Дальнем Востоке России - вывоз леса и контрабанда.

Привыкшие к скрытному образу жизни члены триад до сих пор используют свой сленг, тайные рукопожатия, жесты и знаки, а также числовые коды для обозначения званий и должностей в иерархии группировки. Иерархия триад довольно проста, но беспощадно запутана. «489» означает «мастер горы», «голова дракона» или «владыка воскурения» (то есть лидер клана). Это число состоит из иероглифов, означающих «21» (4+8+9), что в свою очередь представляет собой производное двух чисел: «3» (создание) умноженное на «7» (смерть) равно «21» (возрождение). «438» означает «управитель» (заместитель лидера, или оперативный командир, или церемониймейстер). Сумма составляющих этих цифр равна 15, а число «15» у каждого суеверного китайца вызывает благоговейное почтение, потому что встреча с ним, включая различные комбинации, сулит большую удачу. «432» - «соломенные сандалии» (то есть связной между различными подразделениями клана), «426» «красный шест» (то есть командир боевиков или исполнитель силовых решений), «415» - «веер из белой бумаги» (то есть финансовый советник или администратор), «49» - рядовой член. Это число также имеет своё значение. Оно раскладывается на «4» и «9». Их производное «36» означает число клятв, произносимых при вступлении в триаду. Не случайно и то, что все коды начинаются с цифры «4», ведь по древнему китайскому поверью мир окружен четырьмя морями. Числом «25» члены триад обозначают полицейского агента, внедренного в группировку, предателя или шпиона другой банды.

В других источниках, «желтый дракон» (лидер) ведает общим руководством и стратегией триады, «белый бумажный веер» отвечает за воспитание и контрразведку, а также за общие вопросы и финансы, «соломенные сандалии» (он же «сандаловая палочка») - за контакты с другими тайными обществами, «красный шест» (он же «красный жезл» или «красный посох») - за защиту и силовые операции, в том числе разборки с конкурентами и ликвидацию предателей, а прозвищем «монах» обозначают рядовых членов.

В структуре каждой триады имеются направления защиты, информации, связи, вербовки и воспитания, каждый из которых возглавляет заместитель главаря или очень авторитетный гангстер. Например, информационный отдел занимается разведкой в среде конкурентов и полиции; отдел вербовки работает в школах и вузах, а также ищет информаторов среди рикш, таксистов, официантов, уличных торговцев и проституток. Члены триад связаны между собой сложной системой ритуалов, клятв, паролей и даже церемониальным смешением крови. Они безошибочно узнают друг друга по многим признакам, невидимым для посторонних: порядку расставленной на столе посуды, особой манере держать палочки и чайные чашки во время еды или по вопросам-загадкам. Например, на вопрос «Сколько будет трижды восемь?» член триады ответит: «Двадцать один», так как знает, что иероглиф «хань» (китайское название триады) состоит из трёх частей, обозначенных цифрами «3», «8» и $\ll 21 »$.

Некоторые триады Гонконга до сих пор придерживаются традиции торжественного посвящения новичков в своё братство. Вот как описана эта церемония в книге Всеволода Калинина «Золотая орхидея» (отрывки из книги):

Для вступления в «братство» нужно быть рекомендованным одним из членов триады со стажем, пройти подготовительный период, во время которого новичок должен проходить суровые и опасные испытания, включая его в проводимые гангстерами операции. Кроме того, «новобранцы» изучают историю и обряды тайного общества, секретные сигналы жестами и пальцами, словесные пароли. К моменту вступления необходимо наизусть выучить 21 правило дисциплинарного кодекса и 10 пунктов наказаний за нарушение его, а также 36 
клятв. В ходе мистического ритуала предстоит дать правильные ответы на вопросы в форме иносказаний или загадок. В церемонии принимают участие Шан Цю (Владыка воскурения) и Хань Цю (Управитель). Проход Горы ножей - так называется начальная стадия ритуала. Управитель записывает имена, адреса, возраст вступающих. Они платят небольшие взносы. Владыка воскурения зажигает пахучие палочки перед кумирней и объявляет: «Братство Хань будет жить миллионы лет». Затем он читает длинную поэму о подвигах предков, о сердечном союзе братьев, о процветании триады, после чего растолковывает 24-ю клятву из тех 36 , которые будут произнесены позже. В пункте 24 говорится о том, что новый член общества может подняться на иерархическую ступеньку не раньше, чем через три года. Далее новичкам предстоит пройти через трое ворот, у каждых из которых стоит по двое высокопоставленных членов общества. Стражи плашмя ударяют их по спинам мечами и вопрошают каждого: «Что твёрже: меч или твоя шея?» «Моя шея», - следует ответ, означающий, что даже под угрозой смерти тайны общества не будут раскрыты. Далее новички произносят все 36 клятв, и с последними словами каждый из них втыкает тлеющий конец палочки в пол, показывая этим, что также исчезнет огонек его жизни в случае, если он нарушит клятвы. Потом идет проверка знания тайных сигналов, их паролей. После говорит третий по рангу руководитель - Красный посох — он отвечает за порядок и дисциплину, исполнение приговоров. Новички остаются на коленях, протягивают левые руки ладонями вверх. Красный посох прокалывает иглой с толстой красной ниткой средние пальцы, из которых сочится кровь. Её добавляют к смеси в кубке, разливают по чашечкам и каждому дают выпить. С этого момента новички считаются принятыми в скрепленное клятвой на крови братство, от уз которого может избавить только смерть. Все предметы, участвовавшие в церемонии предают огню, чтобы все произошедшее было тайной. Затем члены триады отмечают вступление в их группировку новобранцев и за данный «праздник» платят новички.

В триадах весьма почитаемо патриотическое отношение к родной земле и государству. При этом члены триады далеки от занимания высоких должностей на тех же государственных службах. И, к примеру, обычный мелкий чиновник может занимать ведущую роль в группировке и получать доход в разы больше, чем получает на «легальной» работе.

Также история китайской триады рассказывает о наличии женщины на высокой “должности”, которая заняла место своего отца.

Как и в других криминальных сообществах, в триадах важное место занимают татуировки (могут изображаться в виде рисунков и обозначающего их иероглифа). К примеру, дракон означает процветание, благородство и власть, змея - мудрость, прозорливость и волю, черепаха - долголетие, ель - терпение и избранность, сосна- долголетие, мужество, верность и стойкость, слива - долголетие, чистоту, силу, стойкость и отшельничество, вишня - мужество и надежду, олива - покой, стойкость и щедрость, апельсин - бессмертие и удачу, клевер - триаду, орхидея - совершенство, гармонию и изысканность, лотос - богатство, благородство и верность, пион - мужское начало, славу, удачу и богатство, бархатцы - долголетие, магнолия - самоуважение, подорожник - самообразование.

В настоящее время для борьбы с триадами используется методика внедрения в их среду полицейских агентов, вербовка среди гангстеров информаторов, которым обещаны судебные послабления и программа защиты свидетелей.

Узнав в кратком содержании сущность двух преступных группировок разных стран - «русской мафии» и «триады», можно заметить, что схожесть их очень велика. В каждой есть свои традиции, идеология, пути следования. Учитывая то, что история и цели у них разные, мы видим, что действуют они практически идентично. Тут и распределение по кастам, вербование более молодых новобранцев, разведка среди власти для введения ОПГ в курс дела, методы общения - свой язык, который знает только та или иная группировка.

Можно сделать вывод о том, что даже если преступность и развивается в разных странах, но действовать по-разному она не будет, они похожи по своей сути.

Различия в проведении воспитательных мер. В русской мафии есть и жестокие меры, связанные с причинением физических страданий, а также убийством, но наравне с этим есть и гуманные «наставления» в качестве становления на правильный путь. В триадах же, наоборот, исключены гуманные решения вопросов, наказание «неверных» идет путем убийства, причем жестокого, практикуется лишение каких-либо частей тела или шрамирование.

Не только рассматриваемые, но и вообе международные группировки очень хорошо освоились, что противодействие им становится очень сложной, а иногда практически невыполнимой задачей.

Как обновляется мир, так и обновляется преступная общность, в связи с этим местным правоохранительным органам разных стран, все сложнее понять, отследить и выловить преступников.

Нужно серьезное модернизирование и активность сотрудников правопорядка, дабы улучшить состояние в стране и освободить его от гнета ОПГ. Хотя никто и не говорит об этом, все знают, что это есть.

Сейчас люди пропускают это мимо ушей просто из-за боязни или считая, что это их никогда не коснется. Но думают, что лучше было бы без «бандитов»? Так ли это на самом деле? Ведь они настолько влились в жизнь государств, что даже если искоренить такое составляющее как преступные группы, то и государство потихоньку будет меняться в лучшую, а может и в худшую сторону. Но это уже философский вопрос.

Хочется отметить, что сейчас очевидна необходимость изменений в духовно-нравственной сфере общества, так как в ней накопилось множество негатива, что порождает резкий рост преступности. По факту это демонстрирует нравственную деградацию общества и общее духовное обеднение нашей страны. 
Замечу, что основное направление противодействию распространения криминальной субкультуры в российском обществе проявляется в целомудренном возрождении общества, культуры российской цивилизации, её оригинальности. Как правило, систему ценностей невозможно оспорить, но возможно вывести из моды. Сделать так, чтобы нынешние ориентиры стали смотреться старомодными. Нужна пропаганда патриотизма, труда, чести, долга, иными словами, возвращение норм общечеловеческой морали и ценностей, исконно присущих российской цивилизации.

\title{
Литература
}

1. Антонян Ю. М., Бабаев М. М., Гуров А. И. Криминогенная ситуация в России на рубеже XXI века. М., 2010.

2. Долгова А. И. Изучение личности преступника // Советское государство и право. 2000. № 4.

3. Долгова А.И. Преступность, её организованность и криминальное общество. М., 2003.

4. Дубягина О.П. Криминологическая характеристика норм, обычаев и средств коммуникации криминальной среды: дис. ...канд. юр. наук. М., 2008.

5. Костяева А. С. Тайные общества Китая в первой четверти XX века / РАН, Ин-т востоковедения. М: Восточная литература, 1995. $240 \mathrm{c}$.

6. Маслов А. А. Тайные общества в политической культуре Китая XX века: дис. ...канд. ист. наук. 209 с.

7. Новиков Б. М. Социальные утопии тайных обществ «Белый лотос» и «Триада» // Философия и история стран зарубежной Азии и Африки. Л., 1967.

8. Ожегов С., Шведова Я. Ю., Антонян Ю. М., Самовигев Ю. Г. Отражение в приговоре мотивов насильственного преступления // Советская юстиция. 1982. № 20.

9. Пирожков В. Ф. Законы преступного мира молодежи (криминальная субкультура). 1994.

10. Пирожков В. Ф. Криминальная психология. М., 2008.

\section{Сравнительно-правовая характеристика противодействия коррупции в Казахстане и Российской Федерации}

\author{
(C) С. А. Линник \\ студент 4-го курса юридического факультета \\ ФГБОУ ВО «Бурятский госуниверситет» \\ Россия, г. Улан-Удэ \\ Sergeylinnik.1994@gmail.com
}

Коррупция на современном этапе развития общества выступает неким тормозящим эффектом, современному адекватному человеку намного сложнее развиваться, поскольку уровень коррупции во многих развитых странах настолько высок, что Совету Безопасности Организации Объеденных Наций (далее по тексту - ООН) давно необходимо бить тревогу. Безусловно, каждая страна пытается найти выход из сложившийся ситуации.

К сожалению, проблема коррупции продолжает быть актуальной в России. Правоохранительные органы очень заинтересованы в формировании антикоррупционного общества, направлением деятельности которого является борьба с коррупцией.

Данной теме посвящено не мало научных трудов, озвучено много концепций и исследований как на международной арене, так и внутри России [8]. Коррупция - это социальное явление общества, то, что сопутствует развитию государства и может стать реальной угрозой его безопасности. Это явление настолько многопланово, что подлежит изучению не только науками антикриминального цикла, но и геополитики, социологии, психологии, этики и т.д.

Определенностью юридической мысли по вопросам борьбы с коррупцией является Конвенция ООН против коррупции, которая была принята резолюцией 58/4 Генеральной Ассамблеи от 31 октября 2003 года [1]. Основополагающий принцип этого документа рассматривает коррупцию как «злоупотребление государственной властью для получения выгоды в личных целях».

Российская Федерация подписала Конвенцию ООН против коррупции 9 декабря 2003 года, а ратифицировала 8 марта 2006 года (N 40-Ф3) [2]. Федеральный закон о ратификации содержит заявления по отдельным статьям и пунктам, по которым Россия обладает юрисдикцией и обязательностью для исполнения. В этот список не вошли, например: ст. 20 «Незаконное обогащение», ст. 26 «Ответственность юридических лиц», ст. 54 «Механизмы изъятия имущества посредством международного сотрудничества в деле конфискации», ст. 57 «Возвращение активов и распоряжение ими».

Парламент Казахстана ратифицировал данную Конвенцию только лишь в 2008 году [3], однако ввел ограничение только на применение п. 2 ст. 66 Конвенции. Статья 62: «Другие меры: осуществление настоящей Конвенции посредством экономического развития и технической помощи. 2. Государства-участники, насколько это возможно и в координации друг с другом, а также с международными и региональными организациями, предпринимают конкретные усилия для: а) активизации своего сотрудничества на различных уровнях с развивающимися странами в целях укрепления возможностей этих стран в области предупреждения коррупции и борьбы с ней; b) расширения финансовой и материальной помощи в целях поддержки усилий развивающихся стран по эффективному предупреждению коррупции и борьбе с ней и оказания им помощи для успешного осу- 
ществления настоящей Конвенции; с) оказания технической помощи развивающимся странам и странам с переходной экономикой в целях содействия удовлетворению их потребностей в связи с осуществлением настоящей Конвенции. Для этого Государства-участники стремятся вносить на регулярной основе достаточные добровольные взносы на счет, конкретно предназначенный для этой цели в механизме финансирования, созданном Организацией Объединенных Наций. Государства-участники могут также особо рассмотреть, в соответствии со своим внутренним законодательством и положениями настоящей Конвенции, возможность перечисления на вышеупомянутый счет определенной доли денежных средств или соответствующей стоимости доходов от преступлений или имущества, конфискованных в соответствии с положениями настоящей Конвенции; d) поощрения и убеждения других государств и финансовых учреждений, в надлежащих случаях, присоединиться к ним в усилиях, предпринимаемых в соответствии с настоящей статьей, в том числе путем обеспечения для развивающихся стран большего объема программ подготовки кадров и современного оборудования, с тем чтобы помочь им в достижении целей настоящей Конвенции».

В России существует Федеральный закон от 25.12.2008 N 273-Ф3 (ред. от 15.02.2016) «О противодействии коррупции» [4], где установлены следующие понятия: - коррупция: а) злоупотребление служебным положением, дача взятки, получение взятки, злоупотребление полномочиями, коммерческий подкуп либо иное незаконное использование физическим лицом своего должностного положения вопреки законным интересам общества и государства в целях получения выгоды в виде денег, ценностей, иного имущества или услуг имущественного характера, иных имущественных прав для себя или для третьих лиц либо незаконное предоставление такой выгоды указанному лицу другими физическими лицами; 2) противодействие коррупции - деятельность федеральных органов государственной власти, органов государственной власти субъектов Российской Федерации, органов местного самоуправления, институтов гражданского общества, организаций и физических лиц в пределах их полномочий: 4) функции государственного, муниципального (административного) управления организацией - полномочия государственного или муниципального служащего принимать обязательные для исполнения решения по кадровым, организационно-техническим, финансовым, материально-техническим или иным вопросам в отношении данной организации, в том числе решения, связанные с выдачей разрешений (лицензий) на осуществление определенного вида деятельности и (или) отдельных действий данной организацией, либо готовить проекты таких решений.

В Республики Казахстан основой для противодействия коррупции является Закон Республики Казахстан «О борьбе с коррупцией» от 02 июля 1998 года № 267. Помимо этого, Закон Республики Казахстан от 18.11.2015 № 410 - V ЗРК «О противодействии коррупции» [5]. В данном законе существуют следующие понятия: 1) лицо, занимающее ответственную государственную должность - лицо, занимающее должность, которая установлена Конституцией Республики Казахстан, конституционными и иными законами Республики Казахстан для непосредственного исполнения функций государства и полномочий государственных органов, в том числе депутат Парламента Республики Казахстан, судья, а равно лицо, занимающее согласно законодательству Республики Казахстан о государственной службе политическую государственную должность либо административную государственную должность корпуса «А»; 2) должностное лицо - лицо, постоянно, временно или по специальному полномочию осуществляющее функции представителя власти либо выполняющее организационно-распорядительные или административно-хозяйственные функции в государственных органах, субъектах квазигосударственного сектора, органах местного самоуправления, а также в Вооруженных Силах, других войсках и воинских формированиях Республики Казахстан; 3) лицо, уполномоченное на выполнение государственных функций,государственный служащий в соответствии с законами Республики Казахстан о государственной службе, депутат маслихата, а также лицо, временно исполняющее обязанности, предусмотренные государственной должностью, до назначения его на государственную службу; 4) лицо, приравненное к лицам, уполномоченным на выполнение государственных функций, - лицо, избранное в органы местного самоуправления; гражданин, зарегистрированный в установленном законом Республики Казахстан порядке в качестве кандидата в Президенты Республики Казахстан, депутаты Парламента Республики Казахстан или маслихатов, акимы городов районного значения, поселков, сел, сельских округов, а также в члены выборного органа местного самоуправления; служащий, постоянно или временно работающий в органе местного самоуправления, оплата труда которого производится из средств государственного бюджета Республики Казахстан; лицо, исполняющее управленческие функции в государственной организации или субъекте квазигосударственного сектора, служащие Национального Банка Республики Казахстан и его ведомств; 5) конфликт интересов - противоречие между личными интересами лиц, занимающих ответственную государственную должность, лиц, уполномоченных на выполнение государственных функций, лиц, приравненных к ним, должностных лиц и их должностными полномочиями, при котором личные интересы указанных лиц могут привести к ненадлежащему исполнению ими своих должностных полномочий; 6) коррупция - незаконное использование лицами, занимающими ответственную государственную должность, лицами, уполномоченными на выполнение государственных функций, лицами, приравненными к лицам, уполномоченным на выполнение государственных функций, должностными лицами своих должностных (служебных) полномочий и связанных с ними возможностей в целях получения или извлечения лично или через посредников имущественных (неимущественных) благ и преимуществ для себя либо третьих лиц, а равно подкуп данных лиц путем предоставления благ и преимуществ; 7) антикоррупционная политика - правовые, административные и организационные меры, направленные на снижение коррупционных рисков, повышение доверия общества к деятельности государственных органов, и иные меры в соответствии с настоящим Законом; 8) антикоррупционные ограничения - ограничения, установленные настоящим Законом и 
направленные на предупреждение коррупционных правонарушений; 9) противодействие коррупции - деятельность субъектов противодействия коррупции в пределах своих полномочий по предупреждению коррупции, в том числе по формированию антикоррупционной культуры в обществе, выявлению и устранению причин и условий, способствующих совершению коррупционных правонарушений, а также по выявлению, пресечению, раскрытию и расследованию коррупционных правонарушений и устранению их последствий; 10) уполномоченный орган по противодействию коррупции - государственный орган, непосредственно подчиненный и подотчетный Президенту Республики Казахстан, и его территориальные подразделения, осуществляющие в пределах своих полномочий функции по реализации антикоррупционной политики Республики Казахстан и координацию в сфере противодействия коррупции; 11) коррупционное правонарушение - имеющее признаки коррупции противоправное виновное деяние (действие или бездействие), за которое законом установлена административная или уголовная ответственность; 12) коррупционный риск - возможность возникновения причин и условий, способствующих совершению коррупционных правонарушений; 13) предупреждение коррупции - деятельность субъектов противодействия коррупции по изучению, выявлению, ограничению и устранению причин и условий, способствующих совершению коррупционных правонарушений, путем разработки и внедрения системы превентивных мер.

Проанализировав данные Федеральные законы, мы приходим к выводу о том, что Республика Казахстан более глубже рассмотрела данную проблему, что говорит о том, что руководство Республики Казахстан очень сильно обеспокоено сложившейся ситуацией. Вероятно, что федеральный закон о коррупции в России требует доработки по ряду вопросов, особенно в части таких разделов как общие определения и понятия того или иного коррупционного явления.

По индексу восприятия коррупции, рассчитываемом Transparency International [6], Казахстан находится на 123 месте, а Россия занимает 119 строчку данного рейтинга, данный индекс показывает нам, что Республика Казахстан, как и РФ находиться в очень сложном положении коррумпированности.

Безусловно, в России и Казахстане правоохранительные органы борются с результатами коррупционной деятельности в рамках наделенных полномочий. В результате такой деятельности могут быть выявлены преступные схемы растраты бюджетных средств. Наиболее показательными являются коррупционные процессы, связанные со строительством объектов «Экспо 2017», который пройдет в Казахстане в 2017 году, что свидетельствует о системном характере этого явления. Что же касается России, то громкие коррупционные дела с многомилионными коррупционными схемами связаны со строительством таких объектов, как космодром «Восточный», олимпийские объекты в г. Сочи, инфраструктуры для саммита АТЭС в 2012 году, который проходил во Владивостоке.

Казахстанская модель борьбы с коррупцией имеет разработанную нормативную базу. В целом осуществляется: сокращение штата госслужащих, проведение проверок, курсов переподготовки, сдачи экзаменов; упрощение бюрократических процедур через систему Центров обслуживания населения; несмотря на общую декриминализацию законодательства, коррупционные правонарушения её не подверглись.

За последний годы по ИВК Казахстан поднялся на 16 пунктов, следовательно, принимаемые меры имеют положительный результат. Сохраняя такие темпы борьбы с коррупцией, необходимо также повышать уровень правосознания граждан, что даст больший положительный эффект. Развитие института гражданского общества - сложный и длительный процесс, но только гражданское общество может стать основой правового государства.

В современной России в последние годы заметно активизируется борьба с коррупцией: появляются новации в законодательстве, разрабатываются более эффективные политические механизмы на основе Стратегии и Национальных планов, участились аресты публичных лиц. В Послании Президента Российской Федерации Федеральному Собранию РФ, в Национальном плане борьбы с коррупцией на 2016-2017 гг. [7] основными задачами выделено следующие: 1) совершенствование правовых основ и организационных механизмов предотвращения и выявления конфликта интересов в отношении лиц, замещающих должности, по которым установлена обязанность принимать меры по предотвращению и урегулированию конфликта интересов; 2) совершенствование механизмов контроля за расходами и обращения в доход государства имущества, в отношении которого не представлено сведений, подтверждающих его приобретение на законные доходы, предусмотренных Федеральным законом от 3 декабря 2012 г. N 230-Ф3 «О контроле за соответствием расходов лиц, замещающих государственные должности, и иных лиц их доходам»; 3) повышение эффективности противодействия коррупции в федеральных органах исполнительной власти и государственных органах субъектов Российской Федерации, активизация деятельности подразделений федеральных государственных органов и органов субъектов Российской Федерации по профилактике коррупционных и иных правонарушений, а также комиссий по координации работы по противодействию коррупции в субъектах Российской Федерации; 4) повышение эффективности противодействия коррупции при осуществлении закупок товаров, работ, услуг для обеспечения государственных и муниципальных нужд; 5) усиление влияния этических и нравственных норм на соблюдение лицами, замещающими государственные должности Российской Федерации, государственные должности субъектов Российской Федерации, муниципальные должности, должности государственной и муниципальной службы, запретов, ограничений и требований, установленных в целях противодействия коррупции; 6) расширение использования механизмов международного сотрудничества для выявления, ареста и возвращения из иностранных юрисдикций активов, полученных в результате совершения преступлений коррупционной направленности; 7) повышение эффективности информационно-пропагандистских и просветительских мер, направленных на создание в обществе атмосферы нетерпимости к коррупционным прояв- 
лениям. В завершение нам хотелось бы сказать следующее: мы полностью понимаем проблему коррупции в современном мире, считаем, что необходимо в РФ ввести отдельных правоохранительный орган, который смог бы заниматься выявлением, профилактикой и расследования уголовных дел коррупционной направленности. Например, в Казахстане существует национальное бюро по противодействию коррупции. Мы согласны с тем, что, к огромному сожалению, в России совершить «Сингапурское чудо» не получится, однако собрать все самое лучшее в плане борьбы с коррупцией со всех сторон России вполне под силу.

\section{Литература}

1. Конвенция Организации Объединённых Наций против коррупции, принята резолюцией 58/4 Генеральной Ассамблеи от 31 октября 2003 года // [Электронный ресурс]. Режим доступа: http://www.un.org/ru/documents/decl_ conv/conventions/corruption.shtml.

2. Федеральный закон от 08 марта 2006 г. № 40-Ф3 «О ратификации Конвенции Организации Объединённых Наций против коррупции» [Электронный ресурс] // ИПС Гарант. Режим доступа: http://base.garant.ru/12145648/.

3. О ратификации Конвенции Организации Объединённых Наций против коррупции, Закон Республики Казахстан от 04 мая 2008 года № 34-4 // [Электронный ресурс]. Режим доступа: https://tengrinews.kz/zakon/parlament_respubliki_kazahstan/ mejdunapodnyie_otnosheniya_respubliki_kazahstan/id-Z080000031_/.

4. Федеральный закон от 25 декабря 2008 г. N 273-ФЗ ( от 15.02.2016 N 24-Ф3) "О противодействии коррупции" [Электронный ресурс] // СПС «Консультант Плюс». Режим доступа: http://base.consultant.ru/cons/cgi/online.cgi?req=doc\&base= LAW\&n=194066\&fld=134\&from=82959-0\&rnd=214990.9682953700938839\&.

5. Закон Республики Казахстан от 18.11.2015 года № 410-V ЗРК «О противодействии коррупции» [Электронный ресурс]. Режим доступа: http://alm.kgd.gov.kz/ru/content/zakon-respubliki-kazahstan-ot-18112015-goda-no-410-v-zrk-o-protivodeystvii-korrupcii-6.

6. Transparency International [Электронный ресурc]. Режим доступа: http://www.transparency.org.

7. Указ Президента РФ от 01.04.2016 № 147 «О Национальном плане противодействия коррупции на 2016-2017 годы» [Электронный ресурс] // СПС «Консультант Плюс». Режим доступа: http://www.consultant.ru/document/cons_doc_LAW_196138/.

\section{Сравнительно-правовой анализ квалификации дачи, получения взятки в России и Китае}

(C) С. Б. Манзыев

магистрант 1 года обучения Института экономики и права ФГБОУ ВО «Восточно-Сибирский государственньй университет технологий и управления»

Россия, г. Улан-Удэ

aleks.vagner.91@mail.ru

Уголовный закон практически любого современного государства предусматривает уголовную ответственность за совершение коррупционных преступлений. Такие преступления, как известно, опасны тем, что подрывают нормальную деятельность органов публичной власти, тем самым создавая у значительного числа людей представление о возможности получить желаемый результат достаточно простым способом - путем передачи денег, ценных бумаг, иного имущества, услуг лицу, которое в силу возложенных на него должностных обязанностей может способствовать получению такого результата [5, с.129-132].

По-моему, интересным будет сравнительно-правовой анализ норм уголовного закона России и Китая как минимум в связи с тем, что Китай демонстрирует хорошие результаты в направлении борьбы с коррупционными преступлениями; Россия и Китай в последние годы активно взаимодействуют в различного рода направлениях, являясь при этом геополитическими партнерами.

УК РФ содержит главу 30 «Преступления против государственной власти, интересов государственной службы и службы в органах местного самоуправления», которая, кроме всего прочего, включает в себя нормы об ответственности за взяточничество [2, с.186]. В УК КНР ответственность за взяточничество предусмотрена отдельной главой «Коррупция и взяточничество». Самостоятельная глава о коррупции и взяточничестве и её строение имеют большое значение в борьбе с данными видами опасных и распространенных преступлений [1, c. 134].

Рассмотрим состав получения взятки по российскому законодательству. Предмет - обязательный признак получения взятки. Согласно ст. 290 УК РФ взятка может передаваться в виде: 1) денег, 2) ценных бумаг, 3) иного имущества (автомобили, земельные участки и т.д.), 4) выгод имущественного характера (оказываемых должностному лицу безвозмездно, но в других случаях подлежащих оплате услуг имущественного характера - предоставление туристических путевок, ремонт квартиры и т.д.). Позиция китайского законодателя сходна с российским. Предметом взятки по УК КНР (ст. 385) может выступать: 1) имущество третьих лиц, 2) выгоды, причитающиеся третьим лицам, 3) именное комиссионное или агентское вознаграждение.

Объективная сторона преступления по получению взятки согласно ст. 290 УК РФ состоит в получении взятки лично или через посредника. При этом должностное лицо обязано совершить определенные действия в пользу взяткодателя: 1) действия (бездействие), если такие действия (бездействие) входят в служебные полномочия должностного лица; 2) действия (бездействие), если лицо в силу должностного положения может способствовать таким действиям (бездействию); 3) общее покровительство взяткодателю со стороны должностного лица; 4) попустительство взяткодателю по службе со стороны должностного лица. На самом деле эти действия не требуют фактического совершения для получения квалификации взяткополучателя. Состав этого преступле- 
ния носит формальный характер, то есть для его завершения должностное лицо должно принять хотя бы часть заранее оговоренной взятки [8, с. 191].

Объективная сторона аналогичного преступления согласно ч. 1 ст. 385 и ч. 1 ст. 387 УК КНР состоит в требовании и получении взятки государственными служащими или юридическими лицами от других лиц или в незаконном получении выгоды, причитающейся третьим лицам, с использованием своего служебного положения (для юридических лиц без такового) [1, с. 142]. Согласно ч. 2 ст. 385 и ч. 2 ст. 387 УК КНР взятка - незаконное получение именного комиссионного или агентского вознаграждения государственными служащими и юридическими лицами в процессе осуществления хозяйственно-экономической деятельности, что характеризует более широкое понимание объективной стороны данного состава китайским законодателем, чем российским [7, с. 78].

Ещё одна норма, посвященная получению взятки - ст. 388 УК КНР. Она закрепляет самостоятельный вид данного преступления, особенность которой состоит в том, что государственный служащий может не только использовать свои служебные полномочия, но и использовать полномочия других служащих для получения взятки. Данный состав наиболее сходен с составом, предусмотренным ч.1 ст. 290 УК РФ. Все вышеуказанные составы получения взятки по законодательству обоих стран являются формальными [9, с. 163].

Рассмотрим субъект взятки. В соответствии со ст. 285 УК РФ должностное лицо - лицо, постоянно, временно или по специальному полномочию осуществляющее функции представителя власти либо выполняющее организационно-распорядительные, административно-хозяйственные функции в государственных органах, органах местного самоуправления, государственных и муниципальных учреждениях, государственных корпорациях, а также в Вооруженных Силах Российской Федерации, других войсках и воинских формированиях Российской Федерации.

В УК КНР специальным субъектом получения взятки является государственный служащий. Законодательное определение государственного служащего содержится в ст. 93 УК КНР - лицо, выполняющее служебные обязанности в государственных органах. Согласно ч. 2 ст. 93 УК КНР к ним также относятся служащие, посвятившие себя государственной службе в государственных компаниях, организациях, предприятиях, народных коллективах, служащие государственных учреждений, компаний, организации, общественные объединения, а равно и прочие служащие, посвятившие себя государственной службе. Китайское законодательное определение специального субъекта должностного преступления - государственный служащий, принципиально отличающийся от российского законодательного определения субъекта состава получения взятки - должностного лица. При этом уголовный закон Китая не дает определения государственной службы. Представляется, что такое определение позволяет относить к субъектам получения взятки довольно широкий круг лиц [5, с. 32].

Следует отметить, что УК КНР в качестве субъектов получения взятки называет и юридических лиц, к которым согласно ст. 387 УК КНР относятся государственные органы, компании, предприятия, непроизводственные единицы, народные организации.

Субъективная сторона получения взятки по законодательству как России, так и Китая представлена прямым умыслом и корыстным мотивом, который вытекает из существа данного преступления.

УК РФ в зависимости от наличия/отсутствия квалифицирующих признаков предусматривает возможность назначения наказания в виде штрафа с лишением права занимать определенные должности или заниматься определенной деятельностью, исправительных работ с лишением права занимать определенные должности или заниматься определенной деятельностью, принудительных работ с лишением права занимать определенные должности или заниматься определенной деятельностью, лишения свободы на определенный срок со штрафом. Размер штрафа определяется в зависимости от тяжести содеянного, но не более стократной суммы взятки (ч. 6 ст. 290 УК РФ).

По уголовному законодательству Китая наказание дифференцировано в зависимости от суммы полученной взятки и наличия смягчающих и отягчающих обстоятельств. К преступникам (государственным служащим) может применяться административное взыскание, краткосрочный арест, лишение свободы на срок от 2 до 10 лет и более, пожизненное лишение свободы и конфискация имущества как дополнительное наказание, а также смертная казнь (ст. 383 УК КНР). Виновные юридические лица согласно ст. 387 УК КНР наказываются штрафом, а их руководящие или ответственные лица - лишением свободы на срок до 5 лет или арестом.

Положительными моментами назначения наказания по УК КНР по сравнению с УК РФ является, на мой взгляд:

1. Возможность привлечения юридических лиц к уголовной ответственности. В российском законодательстве, а именно в ст. 2.1 КоАП РФ эта проблема лишь по некоторым деяниям решается посредством привлечения должностного лица к уголовной ответственности, а юридического лица - к административной за одно и то же преступление;

2. Конфискация имущества, которая предусмотрена в качестве наказания в общей части УК РФ, в том числе и за получение взятки, не предусмотрена соответствующей статьей особенной части, что говорит о неопределенности в возможности ее применения.

Но вместе с тем УК КНР не определяет минимальный и максимальный размеры штрафа, срок ареста, что является его отрицательной чертой. Перейдем к сравнительной характеристике такого преступления как дача взятки. Признаки этого преступления обозначены в статье 291 УК РФ. Объективная сторона заключается в действиях по передаче должностному лицу взятки лично или через посредника. Так как состав дачи взятки сконст- 
руирован как формальный, то его следует считать оконченным с момента вручения должностному лицу хотя бы части заранее оговоренной взятки.

Объективная сторона дачи взятки по ст. 389 УК КНР включает в себя следующие деяния: а) передача имущества государственному служащему в целях получения незаконной выгоды; б) передача имущества государственному служащему в сравнительно крупном размере либо выдача государственному служащему именного комиссионного или агентского вознаграждения в процессе осуществления экономической деятельности в нарушение государственных установлений. Причем передача имущества государственному служащему под принуждением, не носящая характер получения незаконной выгоды не является дачей взятки (ст. 389 УК КНР) [3, c. 89]. Состав данного преступления формальный, как и по УК РФ.

Субъектом дачи взятки по уголовному законодательству как России, так и Китая может выступать физическое вменяемое лицо, достигшее возраста 16 лет. Но в Китае можно привлечь к ответственности за совершение данного преступления и юридических лиц: государственные органы, компании, народные организации. Субъективная сторона данного преступления по УК РФ и по УК КНР характеризуются прямым умыслом.

Дача взятки должностному лицу по ст. 291 УК РФ может наказываться штрафом, исправительными работами с лишением права занимать определенные должности или заниматься определенной деятельностью, принудительными работами, лишением свободы на определенный срок со штрафом в размере до семидесятикратной суммы взятки.

Наказание же по ст. 391 УК КНР за аналогичное преступление отличается большей суровостью: арест либо лишение свободы на срок до 5 лет, при отягчающих обстоятельствах - лишение свободы на срок до 10 лет, при особо отягчающих обстоятельствах возможно назначение пожизненного заключения с конфискацией имущества в качестве дополнительного наказания. Юридическое лицо наказывается штрафом, другие непосредственные исполнители наказываются лишением свободы до 3 лет либо краткосрочным арестом (ст. 391 УК КНР).

Подводя итог можно сказать, что и Российская Федерация, и Китайская Народная Республика имеют довольно развитое уголовное законодательство в сфере противодействия коррупции. Однако каждой стране есть, что заимствовать друг от друга. На мой взгляд, российскому законодателю следует установить уголовную ответственность юридических лиц за взяточничество, ужесточить наказание за данные преступления, в том числе установить в качестве санкции применение конфискации имущества, сделать его более дифференцированным, что увеличит эффективность борьбы со взяточничеством. Китайскому законодателю, возможно, следовало бы сделать более определенным понятие специального субъекта преступлений, установить минимальные и максимальные размеры штрафа, сроки ареста, что будет способствовать более объективному применению законодательства.

\title{
Литература
}

1. Уголовный кодекс Китайской Народной Республики от 14 марта 1997 г.; Вступил в силу с 1 октября 1997 г.

2. Уголовный кодекс Российской Федерации от 13.06.1996 N 63-Ф3 (ред. от 30.12.2015).

3. Уголовный кодекс Китайской Народной Республики / под ред. А. И. Коробеева, пер. с кит. Д. В. Вичикова. СПб.: Юридический центр Пресс, 2001.

4. Гармаев Ю. П., Степаненко Р. А. Обстоятельства, подлежащие установлению и доказыванию по делам о преступлениях, связанных с посредничеством во взяточничестве // Российский следователь. 2013. № 11. С. 34-37.

5. Пан Дунмэй. Теория уголовной ответственности юридических лиц в КНР // Уголовное право. 2009. № 2.

6. Попова Е.И. Бальхаева В.В., Гулина А.В. Уголовная ответственность за посредничество во взяточничестве в некоторых зарубежных странах Азиатско-Тихоокеанского региона // Сравнительное правоведение в странах Азиатско-Тихоокеанского региона-VI: материалы междунар. науч.-практ. конф. молодых ученых, аспирантов, соискателей, магистрантов и студентов (Улан-Удэ, 17 апреля 2015 г.) / отв. ред. Ю. П. Гармаев. Улан-Удэ: Изд-во Бурят. гос. ун-та, 2015. С. 129-132.

7. Трощинский П.В. Юридическая ответственность в праве Китайской Народной Республики. М.: ИДВ РАН, 2011.

8. Фёдоров А.В. Введение уголовной ответственности юридических лиц - прогнозная тенденция развития российской уголовно-правовой политики // Журнал зарубежного законодательства и сравнительного правоведения. 2014. № 3.

9. Юридическая жизнь в Китае: пер. с кит. М., 1990.

\section{Проблема соблюдения прав женщин, содержащихся в исправительных колониях: опыт некоторых стран АТР}

\author{
(C) E. A. Moxocoera \\ магистрант 1 года обучения юридического факультета \\ ФГБОУ ВО «Бурятский госуниверситет» \\ Россия, г. Улан-Удэ \\ kakerimova@gmail.com
}

Женщины составляют более 8 процентов всего тюремного населения (если точнее, то по данным ФСИН России на 1 марта 2016 г. в учреждениях УИС содержалось 650,6 тыс. человек, из которых 52,9 тыс. женщин, то есть 8,1\%), а в Монголии женщины составляют 5 процентов. В России при женских колониях имеется 13 домов ребенка, в которых проживает 637 детей. Проблема дефицита мест наиболее актуальна для женских исправительных учреждений и СИЗО. В женских колониях содержится на 26 \% больше заключённых, чем предусмот- 
рено. В целом по России в настоящее время действует 46 женских колоний, рассчитанных на 38,5 тыс. человек, в то время как заключённых женщин в них содержится более 60,0 тыс. человек

В уголовном законодательстве РФ не так много документов, регулирующих положение женщин в системе уголовного правосудия, которые бы учитывали гендерную специфику проблемы. Таким образом, можно с уверенностью заявить, что главным объектом регулирования в системе уголовного правосудия является мужчина, а женщины и дети представляют некие условные меньшинства, вынужденные с большими, а иногда и необратимыми, потерями приноравливаться к жизни «старшего брата». При этом необходимо учитывать, что разнообразные социальные проблемы и массовые нарушения фундаментальных прав человека, характерные для ситуации в России и в прежние годы, и сегодня в особенности усугубляются в местах лишения свободы.

Женщины, находящиеся в исправительных колониях, создают особые проблемы для администрации исправительных учреждений, несмотря на то, или, возможно, из-за того, что они составляют лишь небольшую часть от общего числа заключенных. Характер прежней деятельности, а также причины, по которым женщины оказываются в исправительных колониях, отличаются от причин, по которым отбывают наказания мужчины. Психологические и социальные требования женщин, оказавшихся в исправительных колониях, к охране собственного здоровья также будут другими. Следовательно, сами исправительные колонии, а также программы и услуги, осуществляемые в них, должны учитывать потребности женщин-заключенных. Все существующие на сегодняшний день учреждения, программы и услуги для женщин первоначально разрабатывались для мужчин, которые всегда составляли большую часть заключенных.[2, с. 28]

Большинство женщин, содержащихся в исправительных колониях, относятся к социально-маргинализованным группам, многие из них были вовлечены в практику употребления наркотиков и предоставления сексуальных услуг. Значительная часть женщин-заключенных - это жертвы физического и сексуального насилия или те, кто имели опыт рискованного сексуального поведения. Все эти факторы существенно повышают уязвимость женщин, содержащихся в исправительных колониях. Злоупотребление наркотиками, насилие, стигма и дискриминация, плохое питание, ранние и нежелательные беременности, требуют других психологических, социальных и медицинских подходов по сравнению с теми, которые применяются в отношении мужчин.

В переполненных пенитенциарных учреждениях с нехваткой обслуживающего персонала женщины в лучшем случае имеют ограниченный доступ к базовым удобствам и услугам. Существующие программы трудовой занятости и адаптации, применяемые в отношении женщин в исправительных колониях, чаще примитивны и неэффективны, и даже там, где имеются благоприятные условия, женщины, могут не иметь возможности пользоваться этими преимуществами. Часто не удовлетворяются даже основные потребности женщин, - такие как наличие гигиенических средств, необходимых во время менструального цикла. Поскольку количество исправительных колоний для содержания женщин ограничено, женщины обычно отбывают наказание вдали от дома; расстояние, отделяющее их от детей, семей и друзей, усугубляет чувство одиночества, которое может стать источником дополнительных проблем (финансовые трудности, тревожность) как для женщин, так и для семей. После освобождения женщины острее ощущают бремя стигматизации, чем мужчины.

В конце 2010-го года генеральная прокуратура Российской Федерации проверила исполнение требований законодательства об обеспечении права осужденных и лиц, заключенных под стражу, на получение квалифицированной медицинской помощи, и нашла множество нарушений. Проверки прошли в исправительных учреждениях и следственных изоляторах 80 регионов страны. Проведенные проверки показали, что свыше $90 \%$ заключенных под стражу и осужденных имеют различные, часто - социально-значимые заболевания (туберкулез, гепатит, ВИЧ-инфекция). В 2009 в учреждениях уголовно-исполнительной системы зарегистрировано более 1,2 млн. заболеваний, включая почти 400 тыс. с впервые установленным диагнозом. Условия, в которых размещаются медицинские части, неудовлетворительны и не позволяют организовать надлежащим образом лечебный процесс; оснащение медицинским оборудованием не соответствует существующим стандартам. «Из-за несовершенства нормативно-правового регулирования распространены случаи отказов администрациями учреждений государственной и муниципальной систем здравоохранения в диагностике и оказании медицинской помощи осужденным и лицам, заключенным под стражу», - отмечает Генпрокуратура в официальном сайте. [6]

Согласно ч.1 ст.98 УИК РФ «Обязательное государственное социальное страхование и пенсионное обеспечение осужденных к лишению свободы»:

- Осужденные к лишению свободы, привлеченные к труду, подлежат обязательному государственному социальному страхованию, а осужденные женщины также обеспечиваются пособиями по беременности и родам в порядке, установленном Правительством Российской Федерации. Пособия по беременности и родам выплачиваются осужденным женщинам независимо от исполнения ими трудовых обязанностей и иных обстоятельств.

Размеры единовременных и ежемесячных дополнительных пособий осужденным женщинам определены в Федеральный законе «О государственных пособиях гражданам, имеющим детей» от 19 мая 1995 г. №81-Ф3.[3, c.3] Пособия назначаются и выплачивается администрацией по месту работы либо отбывания осужденных. Выплата осуществляется путем зачисления денежных средств на лицевые счета осужденных

Де-факто же эти законы не работают в отношении женщин, подпадающих под их критерии. Беременных женщин, оказавшихся в СИЗО, либо в исправительных колониях, всеми возможными способами, вплоть до угроз, мотивируют на прерывание беременности, не предоставляют необходимой профильной медицинской помощи, не улучшают условия содержания. Несмотря на то, что создание Домов ребёнка при ИУ регламентируется законодательством, дети, родившиеся в исправительных колониях, при отсутствии опекунов из числа родственников, в большинстве случаев не могут содержаться вместе с матерью. Дома ребёнка существуют лишь в 
13 из 46 женских колоний, а этапирование женщин из одного региона в другой (где в ИУ есть Дом ребёнка) достаточно дорогостоящее и на практике почти никогда не применяется. Женщин, рожающих в условиях учреждений уголовно-исправительной системы, во многих случаях сразу же лишают права на опеку над детьми, особенно если в ИУ нет Дома ребёнка. Если этого не происходит, ребенок может оставаться с матерью до трех лет, после чего его отправляют в детский дом. С выплатой родовых денег и детских пособий дела тоже обстоят плохо - администрация учреждений не хочет заниматься оформлением документов, т.к. по их мнению, это не входит в круг их профессиональных обязанностей. После освобождения женщины часто оказываются не в состоянии выполнить требования для сохранения опеки над детьми и не могут вернуть себе этого права, если оно перешло к другим членам семьи. Они испытывают огромные трудности с устройством на работу - в большинстве случаев бывшим заключенным предлагают работу, связанную с тяжелой физической нагрузкой, которая противопоказана женщинам. Отсутствие заработка усугубляет ситуацию с восстановлением права опеки над детьми.

Ущемляются права ВИЧ-инфицированных матерей, что является дискриминацией по заболеванию и противоречит Конституции РФ.

Детям, рождённым от вич-позитивных матерей требуется заменитель грудного молока (ЗГМ) так как существует риск передачи вируса от матери к ребёнку при кормлении грудью. Поэтому администрации учреждений не слишком заинтересованы, чтобы в их учреждениях находились женщины с грудными детьми - это влечёт за собой множество дополнительных проблем.

У заключённых женщин, имеющих диагноз «ВИЧ-инфекция», на фоне ослабленного иммунитета и плохих условий содержания часто развиваются онкологические заболевания. Необходимое медицинское обследование им не предоставляется, рак выявляется уже на поздних стадиях, но даже и в этих случаях женщин очень редко освобождают от дальнейшего отбывания наказания. В большинстве своём они оказываются на свободе либо став недееспособными инвалидами, либо перед смертью.[1, с.91]

Для решения вышеперечисленных проблем предлагаются следующие пути их решения:

1. Обеспечить наличие всех необходимых медицинских специалистов, препаратов для лечения заболеваний, специальных тестов и оборудования, включая лечение и диагностику онкологических заболеваний.

2. Улучшить уход заключённым женщинам во время беременности и роды в соответствующей обстановке. Обеспечить всех новорожденных, рождённых от вич-позитивных матерей качественными заменителями грудного молока в соответствии с рекомендациями ВОЗ и протоколами лечения.

3. Увеличить количество Домов ребёнка, чтобы обеспечить возможность содержания заключённых женщин вместе с детьми во всех регионах РФ.

4. Вовремя и в полном размере выплачивать женщинам все гарантированные государством пособия по материнству в соответствии с Федеральном законе от 19 мая 1995 №81-Ф3 «О государственных пособиях гражданам, имеющим детей».

5. Развивать и поддерживать сервисы социальной адаптации для заключённых женщин, с целью их последующей социализации на свободе.

Существующие программы трудовой занятости и адаптации, применяемые в отношении женщин в исправительных колониях, чаще примитивны и неэффективны, и даже там, где имеются благоприятные условия, женщины, могут не иметь возможности пользоваться этими преимуществами. При освобождении из заключения женщины сталкиваются с особыми проблемами. Например, трудности при получении разрешения властей на возвращение детей.

Администрация исправительного учреждения должна тесно взаимодействовать с органами государственной власти и местного самоуправления, а также с неправительственными организациями, чтобы помочь женщинам в благополучном обустройстве по месту жительства. Поскольку женщины после освобождения острее ощущают неприятие обществом. [5]

Например, в Монголии отдел труда префектуры Чингэлтэй принимают меры, чтобы помочь людям, освобожденным из тюрем найти рабочие места. Для этого они выплачивают работодателям, трудоустроивших бывших заключенных на 12 месяцев 6 млн. тугриков.

Внешний вид женских колоний оставляют желать лучшего. Как и во всех учреждениях такого рода, превалируют тяжелые темно-серые тона, постройки однообразны и удручающе некрасивы, осужденные одеты в одинаковую форму. Многие из этих исправительных учреждений давно пора закрывать, останавливают только жалобы на вечный недостаток мест и недостаток финансирования. В комнатах (около 40 кв. м каждая) размещаются до семидесяти женщин. Такие комнаты называются секциями, в каждой из них расположен один отряд. Обычно в колониях до 20 отрядов.

В Монголии женщины составляют 4,5 процентов всего тюремного населения [4, с. 75.]. При этом большинство исправительных учреждений там построены в соответствии с международными стандартами. Строительство новых исправительных учреждений производятся на средства ООН и других международных организаций.

В некоторых монгольских исправительных колониях обстановка, как внутренняя, так и внешняя значительно отличается от российских, причем в лучшую сторону. Женщины проживают в общежитии, примерно по 3-4 человека и одеты в гражданскую одежду. Обстановка в этих комнатах приближена к домашнему уюту, также есть музыкальная и другая техника.

В уголовном законодательстве РФ не так много документов, регулирующих положение женщин в системе уголовного правосудия, которые бы учитывали гендерную специфику проблемы. Таким образом, можно с уве- 
ренностью заявить, что главным объектом регулирования в системе уголовного правосудия является мужчина, а женщины и дети представляют некие условные меньшинства. В переполненных пенитенциарных учреждениях с нехваткой обслуживающего персонала женщины в лучшем случае имеют ограниченный доступ к базовым удобствам и услугам. Существующие программы трудовой занятости и адаптации, применяемые в отношении женщин в исправительных колониях, чаще примитивны и неэффективны, и даже там, где имеются благоприятные условия, женщины, могут не иметь возможности пользоваться этими преимуществами.

\title{
Литература
}

1. Альперн Л. И. Тюрьма не женское дело. М.: Юристъ, 2010. 91 с.

2. Волкова Т. И. Проблемы отбывания наказания и ресоциализации женщин, осужденных к лишению свободы. М.: Норма, 2010. 28c.

3. О государственных пособиях гражданам, имеющим детей: Федеральный закон от 19 мая 1995 г. № 81-Ф3 (в ред. от 01.01.2014 г.) // Российская газета. 2004. 19 мая. № 21.

4. Хармаев Ю. В. Некоторые вопросы пенитенциарной политики государства в ходе ее реформирования (на примере России и Монголии) // Law enforcement / "Cooperation between law enforcement organization" special issue dedicated to international scientific conference. 2015. № 2 (06). С. 75-80.

5. Права женщин в местах лишения свободы [Электронный ресурс]. Режим доступа: http://pytki.prpc.ru/leaflet.shtml

6. Генпрокуратура внесла представление главе ФСИН [Электронный ресурс]. Режим доступа: http://www.gazeta.ru/ news/lastnews/2010/08/11/n_1532507.shtml

\section{Нелегальный оборот наркотических средств, психотропных веществ в странах ATP: основные направления борьбы и их результаты (на примере КНР)}

\author{
(C) О. А. Мурзинова \\ магистрант 2 года обучения Института экономики и права \\ ФГБОУ ВО «Восточно-Сибирский государственный \\ университет технологий и управления» \\ Россия, г. Улан-Удэ \\ o.spiridonova88.88@mail.ru
}

В настоящий момент немедицинское потребление наркотиков является серьезной угрозой национальной безопасности государства, так как приводит к ухудшению криминогенной обстановки, распространению опасных заболеваний, убыли населения, кроме того в большинстве своем трудоспособного возраста, и, как следствие, ухудшению экономической ситуации и социальной дестабилизации. По мнению экспертов Управления ООН по наркотикам и преступности, в настоящее время в КНР, а также на Тайване ежегодное потребление героина составляет $65 \%$ - 70\% от общего потребления в странах Восточной Азии [11]. По данным Национального бюро по контролю за оборотом наркотиков Министерства Общественной Безопасности (МОБ) КНР по состоянию на 2013 год в Китае было зарегистрировано 2,4 млн. наркозависимых, тогда как в 2011 г. - 1,55 млн. наркозависимых, при этом 1/3 от этого числа - граждане в возрасте младше 25 лет. Однако по мнению независимых экспертов, данные цифры в реальности больше в 6-7 раз. В одном только г. Яньцзи в Яньбянь-корейском национальном автономном районе провинции Цзилинь в 2010 г. было зафиксировано 2090 наркозависимых, употребляющих синтетические наркотики, тогда как в 1999 г. их насчитывалось всего 44 человека (увеличение в 47 раз). В общем по стране 70\% наркозависимых употребляют героин, вместе с тем в северо-восточном Китае 90\% - синтетические наркотики. В период с 2008 по 2010 гг. в КНР было изъято 408 тонн синтетических наркотиков, а за 2011-2012 гг. уже 528 тонн. В провинции Юньнань в 2010 г. было конфисковано 4 тонны синтетических нароктиков, а в 2013 г. - 14 тонн. Следует отметить, что нормативно-правовая база для борьбы с наркотической угрозой в КНР создавалась постепенно. Так, в июле 1979 г. решением Всекитайского Собрания Народных Представителей (ВСНП) были внесены статьи в УК КНР (с 347 по 357), в которых определена ответственность за контрабанду, продажу, транспортировку, изготовление, хранение и распространение наркотиков. В сентябре 1984 г. был принят «Закон о медикаментах и химических реагентах», в 1987-1988 гг. были разработаны и приняты «Правила контроля за оборотом наркотиков и психотропных веществ». «Закон КНР о борьбе с наркотиками», который решением ВСНП вступил в силу 1 июня 2008 г., направлен на усиление борьбы с производством и распространением наркотиков через организацию пропагандистской работы, международного сотрудничества, а также принудительного лечения наркозависимых.

Первое подразделение по борьбе с наркотиками в КНР было организовано в 1982 г. в провинции Юньнань, которая граничит со странами «Золотого треугольника» (Мьянма, Лаос, Таиланд) - основными производителями героина. В настоящее время в Китае создана система органов: Национальная комиссия по контролю за оборотом наркотиков (НККН) МОБ КНР, которая организует работу 25 различных министерств и ведомств как на территории страны, так и за ее пределами; 22-е управление МОБ КНР, которое является аналогом российской Федеральной службы по контролю за оборотом наркотиков (ФСКН), на которое возложена основная нагрузка по борьбе с нелегальным оборотом наркотических средств [6].

Программа по борьбе с наркотиками разрабатывалась сотрудниками НККН МОБ КНР в период с 1991 по 1998 гг. и включала 4 «стратегических шага»: 
- информирование населения об опасности потребления наркотиков;

- перекрытие каналов поставки наркотиков в КНР;

- оказание помощи наркозависимым;

- осуществление контроля за оборотом медикаментов, содержащих наркотические средства.

В стратегическом проекте по борьбе с наркотиками, разработанном в 1999 г. сотрудниками НККН МОБ КНР под названием «Четыре запрета», были определены следующие задачи:

- максимально сократить доставку наркотиков в КНР;

- улучшить реабилитационную работу с наркозависимыми;

- активно проводить антинаркотическую пропаганду среди населения;

-деятельно сотрудничать со странами-соседями и международными организациями [4].

Следует выделить два основных маршрута наркотрафика в КНР:

- Мьянма, Лаос, Таиланд - провинция Юньнань - Гуаньси-Чжуанский

автономный район - провинция Гуандун;

- Мьянма, Лаос, Таиланд - Камбоджа - Вьетнам - КНР.

Именно из Мьянмы, Лаоса, Вьетнама, Таиланда наблюдается значительный рост импорта в Китай наркотических средств и их прекурсоров в последние годы. В 2012 г. урожай мака только на территории Мьянмы составил 690 тонн, что, по сравнению с общим производством всех стран «Золотого треугольника» в 2011 г. в 730 тонн, представляет угрожающие объемы. Одной из причин резкого увеличения урожая мака является рост производительности плантаций опийного мака и повышение качества переработки опиума. Эксперты Управления $\mathrm{OOH}$ по наркотикам и преступности отмечают, что благодаря привлечению рабского труда, применению современной фармацевтической техники и технологий, на которые ОПГ тратят серьезные суммы, уже в 2013 г. производство синтетического наркотика - метамфетамина в странах «Золотого треугольника» достигло 1,4 миллиарда таблеток. В большинстве случаев транспортировка наркотиков осуществляется мелкими партиями, в качестве перевозчиков привлекаются неграмотные и нищие сельские жители, в том числе дети и женщины. В странах «Золотого треугольника», а также на территории прилегающих к ним провинций КНР действуют ОПГ, состоящие из иммигрантов из Тибета, Синьцзян-Уйгурского автономного района, провинций Юньнань, Сычуань, Гуйчжоу, так как социально-экономическая обстановка в этих регионах оставляет желать лучшего. При этом ОПГ, занимающиеся контрабандой наркотиков из Мьянмы в КНР, вооружены автоматическим оружием и нередко оказывают сопротивление силовикам. Конкуренцию им составляют группы наркокурьеров из Восточной Африки, которые постоянно набирают новых рекрутов в своих странах и в странах «Золотого полумесяца» (Афганистан, Иран, Пакистан) [6]. Для координации борьбы с наркотической угрозой и распространением ВИЧ руководство КНР в 1993 г. подписало многостороннее соглашение о взаимопонимании с Лаосом, Мьянмой и Королевством Таиланд, а в период с 1999 по 2001 гг. - отдельные двусторонние меморандумы о контроле за оборотом наркотиков, реабилитационных программах, а также техническом взаимодействии и обмене информации между КНР и Социалистической Республикой Вьетнам, Камбоджей, Лаосом, Мьянмой, Королевством Таиланд [4]. Пример эффективного взаимодействия - операция «Безопасная река», которая проводилась с 20 апреля по 20 июня 2013 г. совместно специальными службами КНР, Лаоса, Мьянмы и Королевства Таиланд. В результате двухмесячной операции было конфисковано 260 тонн прекурсоров, 9,78 тонны готовых синтетических наркотиков, 36 единиц огнестрельного оружия, также арестовано 2534 человека по подозрению в причастности к наркосиндикатам. Руководство КНР организует курсы по обучению и повышению квалификации специалистов по борьбе с наркотиками в структурах правопорядка стран «Золотого треугольника», также выделяет финансовые средства для приобретения специальной техники.

Кроме взаимодействия специальных служб, организовано взаимодействие на уровне провинций. Так, правительство провинции Юньнань в рамках 12-ой пятилетки (2011-2015 гг.) выделило на программы социального и экономического развития Северной части Мьянмы и Лаоса 250 млн. юаней для уничтожения местными властями маковых полей и на выращивание риса, сахарного тростника, каучука и т.д. В период с 2005 по 2010 гг. 180 государственных и частных китайских компаний вложили около 1 млрд. юаней на борьбу с производством наркотиков [1].

Серьезную угрозу социальной и экономической стабильности КНР представляет собой деятельность производителей и перевозчиков наркотической продукции, которые располагаются на территории КНДР. Известно, что вплоть до 1998 г. по решению правительства КНДР было организовано производство героина, объемы которого в конце XX в. составляли около 40 тонн в год, вся территория страны была поделена на шесть зон выращивания опийного мака. Заводы по переработке опиума находятся в провинции Хамён-Пукто, кроме этого, известно о заводе в г. Янган и в г. Пукчён. Для организации процесса выращивания опийного мака, производства опиума и переработки его в героин в системе органов Рабочей партии КНДР создано Бюро № 39, а в составе Корейской Народной Армии (КНА) - Бюро № 25.

В настоящее время северокорейские производители наркотиков перешли на производство синтетических наркотиков, кристаллического метамфетамина («льда»), которое отличается высоким качеством. Производство организовано на фармацевтическом предприятии «Ронан» в г. Чхончжин и «Сунчхон» в г. Пинань и на фармацевтическом заводе «Mannyun» в г. Пхеньян. Реализуют продукцию последнего из указанных заводов под видом продукции традиционной восточной медицины северокорейские фирмы «Sujong Joint Venture Co., Ltd» и «Rhoksan». Для легализации доходов от реализации наркотиков было создано 15 компаний с правом ведения внешнеэкономической деятельности, которые подконтрольны Трудовой партии Кореи, КНА, различным мини- 
стерствам и ведомствам. По мнению китайских и западных специалистов, производство синтетических наркотиков в КНДР приносит ежегодно около 100 млн. долл. США прибыли, а производство героина - 500 млн.долл. США в год [10].

Доставка наркотиков из КНДР в КНР осуществляется торговыми судами под флагами КНДР, Камбоджи, Таиланда. Транспортным коридором для наркотрафика из КНДР в провинции Ляонин, Хэйлунцзян, Шаньдун, г. Пекин и г. Тяньцзинь является провинция Цзилинь, на территории которой только в период с 2009 по 2011 г. было изъято 9,4 кг метамфетамина, 29506 таблеток «льда», 1200 таблеток петидина, 430,61 граммов МДМА, 150,89 грамма героина, 513,58 граммов марихуаны, 102488 таблеток трамадола, 7150 таблеток алпразолама. В указанный период было возбуждено 303 уголовных дела, осуждено на пожизненный срок 991 человек [5]. В зимний период доставка наркотиков из КНДР в КНР осуществляется наземным транспортом в направлении г. Даньдун, уездов Чанбай, Шаньтунь, Лунцзин. Водный маршрут доставки наркотиков проходит через порты Далянь и Шанхай. Аэропорт «Чжоушуйцзы» г. Далянь достаточно часто упоминается в сводках 22-ого управления МОБ КНР.

Как показало исследование факультета пограничной охраны Института Народной Вооруженной Милиции, северокорейские ОПГ действуют по схеме 3-3-3, то есть три гражданина КНДР организуют перевозку наркотиков через границу, затем три гражданина КНР корейской национальности осуществляют транспортировку по территории Китая, которые впоследствии сбывают их трем гражданам Республики Кореи, проживающим постоянно в КНР и регулярно совершающим полеты к себе на родину либо в Японию [3].

Представители иностранных спецслужб также отмечают в докладах, что за последние годы резко увеличился поток синтетических наркотиков из КНР. В основном их производство осуществляется в провинциях Сычуань, Гуандун, Юньнань, Аньхой, Хубэй и Хэбэй, известно о лабораториях, производящих наркотические вещества в городах Луфэн, Тунлун, Жуйли, Хуйчжоу, Шаньвэй, Чэнду.

Китай также является лидером по производству псевдоэфедрина, который является компонентом метамфитамина («льда»). Китайские ОПГ организовали производство метамфитамина в Австрии, Бельгии, Великобритании, Голландии, Испании, Италии, Индонезии, Канаде, Литве, Мексике, Швеции. Основные пункты экспорта наркотических средств из КНР - порты Гуанчжоу, Шэньчжэнь, Чжухай, Сямэнь, Фучжоу [3]. Трафик синтетических наркотиков из КНР осуществляется в следующих направлениях:

- через Украину в страны Европы;

- через Коста-Рику и Мексику в США и Канаду [2]

В некоторых случаях доставка синтетических наркотиков в США производилась через почтовую службу американского государства [7].

Усиление угрозы наркотизации населения обусловлено развитием информационных технологий. В настоящее время китайскими ОПГ организована реализация наркотиков через сеть Интернет, а именно, зарегистрированный на Кипре сайт drsynthetic.com предлагает синтетические наркотики в объеме от 1 кг и более. На сайте китайской компании «Hubei Prosperity Galaxy Chemical» размещена информация о возможности отправки 5000 кг JWH-019 в течение месяца, что достаточно для изготовления 50 миллионов доз «синтетической марихуаны» [8]. Еще одна компания «KaiKai Technology Co., Ltd» на вполне законных основаниях продает химические компоненты для изготовления «синтетической марихуаны» по цене 2500 долл. США за 909 грамм [9].

Правоохранительными органами США составлен список наркотических средств, изготовляемых в КНР на основе химических соединений: метилендиоксипировалерон (МДПВ), метилендиоксиметамфетамин (МДМА), которые продаются под видом «солей для ванн». Такие «соли» содержат опасные для психического здоровья и жизни людей соединения аминоалкилов (нафтоилиндолов), запрещены к открытой продаже и предназначены для создания новых лекарственных препаратов, в том числе для обезболивания, борьбы с болезнью Альцгеймера, психическими расстройствами. Для совместной борьбы с наркотической угрозой НККН МОБ КНР и Агентство по борьбе с наркотиками США еще в феврале 2005 г. подписали Меморандум о намерениях, согласно которому создана совместная группа по обмену оперативной информацией [7].

Китайские правоохранительные органы ведут активную борьбу с производством наркотических веществ, результаты обнадеживают и пугают одновременно. Согласно данным из открытых источников в КНР в 2013 г.:

- осуждено более 1300 человек;

- находятся под следствием более 10000 человек;

- закрыто около 140 сайтов, предлагающих наркотики и прекурсоры;

- уничтожено, по разным данным, от 326 до 378 лабораторий по производству синтетических наркотиков (в 2004 г. - 244 лаборатории). Только за 4 месяца 2013 г. при взаимодействии правоохранительных органов КНР и Королевства Таиланд было арестовано 2534 человека и изъято 10 тонн героина.

В рамках операции «Гром», проведенной Шанхайским управлением по борьбе с наркотиками в апреле-мае 2014 г. в провинции Гуандун города Луфэн уезда Бошэ, арестованы 182 человека из 18 бандгрупп, ликвидированы 77 точек реализации наркотиков, изъяты три тонны метамфетамина, 260 кг. кетамина, 23 тонны сырья для производства наркотиков [1].

Безусловно, в активной деятельности спецслужб КНР по борьбе с ОПГ в рассмотренной сфере заинтересованы многие соседние государства, в том числе и Россия. Разработаны и реализуются программы по контролю за оборотом наркотиков между КНР, Ираном, Пакистаном, Туркменистаном, Узбекистаном и РФ. 
В России в октябре 2014 года жертвами, так называемых курительных смесей, солей для ванн стали более 700 человек, причем 25 - с летальным исходом. Чаще всего "соли" и "спайсы" привозят к нам из Китая под видом косметических средств или бытовой химии.

12 июня 2015 банда торговцев курительными смесями из Китая и Таиланда попала под суд в Вологде.

Примером эффективного взаимодействия РФ и КНР в борьбе с наркотиками является совместная операция под названием «Троянский конь», которая проводилась с апреля 2012 г. по ноябрь 2013 г. В ходе данной операции сотрудники ФСКН изъяли около 267 кг. синтетических наркотиков и их компонентов, а также арестовали 17 человек.

Подводя итоги, можно сделать вывод о том, что КНР находится в эпицентре деятельности наркосиндикатов, которые не только сбывают свою продукцию гражданам Китая, но и используют порты, аэропорты суверенного государства в качестве пунктов транзита смертельного груза, что определяет необходимость применения комплексной системы мер (как репрессивных, так и социального характера), а также расширение взаимодействия с правоохранительными органами соседних государств.

\section{Литература}

1. China's drug takers are chasing newer highs. The Conversation Trust. URL: http://theconversation.com/chinas-drug-takersare-chasing-newer-highs-21815 (дата обращения: 02.03.2014).

2. Chinese synthetic drugs supplied to international drug trafficking ring. China News. URL: http://chinanews.bannedbook.org/201309/chinese-synthetic-drugs-supplied-tointernational- drug-trafficking-ring.html

3. Cindy Hurst. A Government-Sponsored Drug Trafficking Network. Joint reserve intelligence centre. Kansas. 2006.37 p.

4. Golden Triangle Main Source of Drugs in China. Easy Branches // URL: http://phuketnews.easybranches.com/phuketnews/429962.html

5. Police bust drug trafficking ring in SW // URL: http://www.china.org.cn/china/2012- 03/14/content_24898767.htm (дата обращения: 01.02.2014).

6. Su Xiaobo. China's anti-drug policies in the Golden Triangle. East-West Centre. URL: http://www.eastwestcenter.org/publications/chinas-antidrug-policies-in-southeastasia\%E2\%80\%99s-golden-triangle

7. Synthetic Cathinones (Bath Salts): An Emerging Domestic Threat. U.S. Department of Justice National Drug Intelligence Center. Johnstown. 2011. 16 p.

8. Synthetic marijuana - a Billion dollar unregulatedand unsafe industry. K2 Incense information. URL: http://www.k2info.org/2011/11/30/synthetic-marijuana-a-billion-dollarunregulated- and-unsafe-industry

9. Synthetic marijuana, other designer drugs enter United States - legally. The Meredith Corporation. URL: http://www.kmov.com/news/national/Synthetic-marijuana-otherdesigner- drugs-enter-United-States----legally-234592781.html

10. The Business of Ice: North Korea's Crystal Meth Trade. Pulitzer Center on crisis reporting. URL: http://pulitzercenter.org/slideshows/china-meth-north-korea-addictionexport

11. World Drug Report UNODC // URL: http://chinadigitaltimes.net/2013/09/chinademand-heroin-outpacing-golden-trianglesupply/ (дата обращения: 02.02.2014).

\section{Международный правовой опыт назначения наказания с учетом гендерных признаков по законодательству стран АТР}

(C) E. В. Найданова

магистрант 2 года обучения юридического факультета ФГБОУ ВО «Бурятский госуниверситет»

Россия, г. Улан-Удэ

Elena_nadanova@mail.ru

В отношении гендерного подхода в анализе российского законодательства и юридической литературы можно сказать, что наиболее распространенным в них является указание на особенности правового статуса женщины (а не мужчины), при этом выделяются дополнительные, так называемые, био-социальные статусы: например, беременная женщина, роженица, женщина-мать. Таким образом, в некоторых случаях законодатель указывает только лишь на половую принадлежность (возможно, подразумевая и иные дополнительные свойства, в первую очередь, социальные, которые ему сопутствуют), а в других - уточняет специальный, дополнительный статус женщины.

К примеру, согласно польскому законодательству субъект изнасилования считается общий (законодатель в статье понятно прописал то, что лицо таким образом - «кто совершил изнасилование...», см. Глава XXV «Преступления против сексуальной свободы и нравственности»). По сути, только лишь сведения, отмеченные в статьях, содержат указание и конкретизирование гендерных отличительных черт субъекта.

В УК Швейцарии наиболее многообразнее отображается наиболее всевозможная позиция к субъекту правонарушения согласно гендерных отличительных черт. Кроме регламентирования ответственности за прерывание беременности (ст. 118), в ст. 190 содержится указание на половую принадлежность потерпевшей от данного преступления: «Кто принуждает лицо женского пола к сожительству, при котором он угрожает ей применить насилие, применяет в отношении ее психическое насилие или делает ее неспособной к сопротивлению...». Неповторима законная мера, предусматривающая в УК Швейцарии криминальную обязанность за многобрачие равно как представители сильного пола, таким образом и представительницы слабого пола (субъект не опреде- 
лен конкретно). В частности, ст. 215 данного Закона следующим образом указывает на признаки субъекта данного преступления: «Кто заключает брак, состоя в браке, кто заключает брак с лицом, состоящим в браке...» [2, c. 215].

Данное законодательное состояние является совершенно объективным: невзирая в традиционность многоженства равно как учреждения союза одного мужчины с некоторыми представительницами слабого пола, ответственность за такое действие представительницы слабого пола обязана являться равной, по-другому утрачивают значение принципы законности, равенства абсолютно всех пред законодательством, справедливости.

УК Латвии фактически упоминает гендерную особенность (в частности, половой признак) в очень редких случаях, но именно в данном уголовном законе устанавливается преступность «нарушения национального и расового равноправия, ограничения прав человека», причем дается толкование данных действий как умышленного прямого или косвенного ограничения экономических, политических или социальных прав человека или создание прямых или косвенных преимуществ лицу в зависимости от данных признаков. Непосредственно непрямым образом чаще в целом нарушаются права и свободы представительниц слабого пола (в особенности мам, беременных), по этой причине нужно выделить очевидную сознательность этого объяснения, сделанного законодателем.

Так же, как и в ранее рассмотренных законах, в данном Уголовном кодексе установлена специальная ответственность за убийство матерью новорожденного ребенка (привилегированный состав), незаконное производство аборта, а также принуждение к производству аборта (ст. ст. 119, 135, 136). Что касается последнего состава, то было бы целесообразно предусмотреть аналогичное преступление и установить ответственность за него и в российском уголовном законодательстве, - данная мера только способствовала бы более эффективной охране прав и свобод женщин, предупреждению насилия (не только физического, но и психологического) в семье, а в конечном итоге - улучшению демографической ситуации.

Таким образом, в УК Польши отыскали весьма небольшое число норм, в каковых акцентируется женщина равно как субъект преступления или правоотношения (потерпевшая). Фактически, указание на половую принадлежность существует только в ст. 152 (§ 2), ст. 153, регламентирующих прерывание беременности, нарушающее предписания закона, ст. 154 (смерть беременной в результате аборта), ст. 157 (§ 3), где указано об освобождении от ответственности беременной за неосторожное причинение плоду телесного повреждения [4, c.114].

Невозможно никак не выделить кроме того следующую направленность: при использовании гендерного подхода в иностранном (и российском) законодательстве и практике реализации уголовной ответственности все нередко изучается женщина не только как субъект правонарушения, но и равно как потерпевшая. При этом большая часть научных работников фиксируют то, что с начала 90-х гг. прослеживается очевидное осложнение положения представительниц слабого пола, испытывающих страдания с бытового насилия. Равно как продемонстрировало данного рода сопоставление, и в международно-правовых документах, и в уголовном законодательстве различных государств прослеживаются очевидные противоречия в подходе к оценке значимости и значения представительницы слабого пола как субъекта преступления. С одной стороны, это одна из самых «чувствительных» категорий жителей (наряду с детьми), с другой (к примеру, в международных Минимальных правилах обращения с заключенными) роль привилегированного признака содержит только лишь социальноролевой статус представительниц слабого пола беременных и с маленькими детьми. Но все без исключения действительно в любом из пересмотренных нами уголовных законов такая группа как беременные женщины выделена (однако никак не постоянно наравне с ней акцентируется группа представительниц слабого пола мам маленьких детей, равно как, к примеру, в УК штата Нью-Йорк).

Хаотичность обозначается и в определенных сводах уголовного законодательства различных государств. Государства по - всякому относятся к вопросу определения в уголовном законе гендерных отличий. В отдельных законодательствах (например, УК Польши), они вообе переведены к минимальному количеству и это никак не отображает настоящую картину осуществлении уголовной репрессии с учетом гендерных отличительных черт субъектов преступлений. В уголовном законодательстве иных государств представитель сильного пола и женщина по сути признаются равносильными субъектами, несущими полную ответственность и наказание за свершенные действия (в том числе, и сексуальные посягательства) - равно как в Швейцарии [3, с. 96].

Вместе с тем российское законодательство вполне могло бы заимствовать отдельные выделенные нами положения уголовных законов стран зарубежья.

\section{Литература}

1. Уголовный кодекс Польши. СПб.: Юридический Центр- Пресс, 2002.

2. Уголовный кодекс Швейцарии. СПб.: Юридический центр- Пресс, 2002.

3. Уголовный кодекс штата Нью-Йорк // Уголовное законодательство зарубежных стран. Сборник законодательных материалов. М.: Зерцало, 2001.

4. Доклад о деятельности Уполномоченного по правам человека в 1999 году // Становление и развитие Уполномоченного по правам человека в Российской Федерации и ее субъектах. М.: Юридическая литература, 2000. 


\title{
Опыт борьбы с коррупцией в странах АТР
}

\author{
(С) Л. Т. Оболов \\ магистрант 1 года обучения юридического факультета \\ ФГБОУ ВО «Бурятский госуниверситет» \\ Россия, г. Улан-Удэ \\ obolovlev@mail.ru
}

Сегодня существуют страны, которые максимально ограничили масштабы коррупции. Известны примеры, когда мероприятия, направленные на понижение уровня коррупции, привели к положительным результатам (Сингапур, Гонконг, США, Япония). Это свидетельствуют, что методы эффективной борьбы с коррупцией существуют.

Помимо расформирования органов государственной власти или местного самоуправления, существуют другие подходы к уменьшению коррупции. К таким подходам можно отнести ужесточение законов и их исполнения, при этом соответственно увеличив риск наказания, создание экономических механизмов, позволяющих должностным лицам увеличить свои доходы, не нарушая законодательства, и усиление роли рынков и конкуренции, что позволяет уменьшить размер потенциальной прибыли от коррупции.

Многие меры, давшие положительные результаты, относятся к внутренним или внешним механизмам надзора, в совокупности с детальной регламентацией деятельности должностных лиц, публичностью всех управленческих процедур, развитыми институтами общественного контроля и гражданского общества. Данный опыт как с организационной, так и специальной уголовно-правовой точки зрения нуждается в тщательном изучении.

Рассматривая мировой опыт противодействия коррупции, обычно пишут о сингапурском пути ее организации. Существенные усилия по предупреждению и пресечению коррупции в органах государственной власти предпринимают США, Япония и некоторые другие страны.

Заслуживает внимания антикоррупционная политика Сингапура. Сингапурская стратегия предупреждения коррупции строится на строгости и последовательности, полагаясь на логику в контроле над коррупцией.

Во время обретения независимости в 1965 г. Сингапур являлся высококоррумпированной страной. Для ее минимизации были осуществлены ряд мер: произведена регламентация действий чиновников, упрощены бюрократические процедуры, строгий надзор за соблюдением этических стандартов. Основная часть работы была направлена на нейтрализацию причин и условий коррупционного поведения.

Бюро по расследованию случаев коррупции, обладающее политической самостоятельностью, стало центральным органом в данном механизме. В данный орган граждане могут писать жалобы на действия государственных служащих и требовать компенсации убытков. В следствие чего были приняты меры по ужесточению законодательства, повышению независимости судебной системы, а также повышена заработная плата судьям. Кроме того, были введены санкции за дачу взятки или отказ от участия в антикоррупционных расследованиях, а также произведены показательные жесткие акции по увольнению сотрудников государственного аппарата. Эти меры предпринимались совместно с регулированием экономики, ростом заработной платы политиков и государственных служащих и подготовкой компетентных кадров.

Суть политики направленной на предупреждение коррупции в Сингапуре состоит в том, что в этом государстве стремятся исключить обстоятельства, которые создают стимул и возможность совершения коррумпированных действий. Этого можно добиться антикоррупционными мерами:

- оплата труда государственных служащих согласно формуле, привязанной к средней заработной плате успешно работающих в частном секторе лиц;

- контролируемая ежегодная отчетность государственных должностных лиц об их имуществе, активах и долгах, при этом прокурор вправе проверять любые банковские, акционерные и расчетные счета лиц, подозреваемых в нарушении Акта о предотвращении коррупции;

- большая строгость в делах о коррупции в отношении высокопоставленных чиновников для поддержания морального авторитета неподкупных политических лидеров;

- ликвидация излишних административных барьеров для развития экономики.

Серьезных успехов в антикоррупционной деятельности достигли США. Соединенные Штаты Америки являются государством с богатой коррупционной историей. Если изучить историю США ХIX в.- нач. XX в., можно увидеть, насколько высоким был уровень коррупции. Конечно, в Америке не сразу была построена эффективная антикоррупционная структура.

Антикоррупционная структура состоит из четырех основных элементов:

- законодательство, направленное на то, чтобы закрыть пробелы и коллизии, не дать возможности совершить коррупционные правонарушения;

- этические стандарты государственной и муниципальной службы;

- правоохранительные, судебные органы;

- гражданское общество, многочисленные неправительственные организации, средства массовой информации.

Первый элемент - законодательство на уровне государства, которым является Конституция США, программа защиты свидетелей, законы о регулировании лоббизма и др. В разных штатах антикоррупционное зако- 
нодательство и антикоррупционные структуры различны. Кстати, это касается не только вопросов противодействия коррупции. Так, в штате Миссисипи имеется, которая решает вопросы судебной эффективности, а в штате Луизиана такая комиссия отсутствует. В некоторых штатах имеется должность аудитора штата, в одних штатах эта должность выборная, а в других - назначаемая. Аудитор штата подчиняется только закону, и если он подозревает о наличие коррупционных фактов, аудитор должен предпринять необходимые меры.

Что касается второго элемента, которым являются этические стандарты, то в 1970-х гг. были приняты законы, которыми были введены более жестки меры, внесены существенные изменения в правила, определяющие правила поведения должностных лиц, и распространили их на все ветви федеральной власти. В дальнейшем основанием для принятия норм для должностных лиц послужил уотергейтский скандал, в результате которого произошла отставка Президента США Р. Никсона в 1974 г., когда высшие эшелоны власти потеряли в глазах американского общества компетентность.

В октябре 1990 г. помимо Закона «О реформе этических норм» был издан приказ Президента США «Принципы этики поведения должностных лиц и служащих государственного аппарата». Эти правила стали распространяться не только на всех государственных служащих. Последние:

- не должны участвовать в финансовых операциях, при проведении которых предполагается использование закрытой правительственной информации или использование такого рода информации в личных целях;

- не могут в какой бы то ни было форме поощрять подношения или принимать подарки от любых лиц или группы лиц, добивающихся от них совершения каких-либо официальных действий, имеющих вместе с ними какие-либо общие дела или осуществляющих деятельность, регулируемую органом, в котором работают эти служащие;

- не должны принимать подарки от лиц, интересы которых зависят от выполнения или невыполнения этими служащими своих должностных обязанностей;

- обязаны докладывать в соответствующие инстанции обо всех замеченных случаях разрушения собственности, обмана, злоупотребления и коррупции.

Третьим элементом являются правоохранительные, судебные органы. Основным органом, деятельность которого направлена на предупреждение коррупции является Министерство юстиции во главе с генеральным прокурором, имеющее несколько подразделений, наиболее известным из которых является Федеральное Бюро Расследований. В США разделяются ведомственные полномочия, к примеру ФБР принимает меры в случае совершаются коррупционные действия федеральными должностными лицами при использовании средств федерального бюджета, если коррупционное преступление охватывает территорию двух и более штатов, а также если при совершении коррупционного акта использовались федеральная почта, телеграф. Все остальное находится в компетенции органов штатов. В США существуют городские комитеты по этике. Это муниципальная структура наподобие департамента, подотчетная городскому совету. Ее назначение в том, чтобы помогать чиновникам не оказаться в ситуации конфликта интересов. Полномочия комитета по этике широкие: просвещение, выпуск литературы, справочников, оказание консультаций, проведение обучающих семинаров, тренингов, а также рассмотрение жалоб, вынесение порицания или ходатайства о применение мер наказания.

Четвертый элемент антикоррупционной системы - гражданское общество, многочисленные неправительственные организации, средства массовой информации. В США очень развито гражданское общество. В стране действует более 1,4 млн. общественных организаций. Конечно, только некоторые из них принимают меры по профилактике коррупции, но многие (а некоторые специально для этого создаются) осуществляют общественный контроль, призванный обеспечить прозрачность власти.

Политики в США больше всего боятся огласки в СМИ. Политическая карьера может закончиться, если СМИ выявит факт недостойного поведения в общественность. Показательным примером служит скандал вокруг губернатора штата Нью-Йорк Э. Спитцера. Он был избран на должность губернатора штата с должности генерального прокурора штата и был известен американцам как непримиримый борец с коррупцией, поборник чистоты нравов. По иронии судьбы попался ровно на этом - пользовался услугами элитных проституток. Спитцер был вынужден объявить о своей отставке, принес извинения избирателям штата и семье за свое поведение. Этот вопрос у них решается однозначно.

Антикоррупционная политика Японии интересна тем, что применен широкий комплекс мер предупреждения коррупции.

В Японии отсутствует единый комплексный акт, направленный на борьбу с коррупцией. Нормы такого характера содержатся в законах «О выборах общественных должностных лиц» 1950 г., «О Парламенте» 1950 г., «О регулировании политических фондов» 1948 г., «О государственных служащих» 1948 г., «О местном самоуправлении» 1947 г.

Большое внимание в законодательстве уделено запретам в отношении политиков, государственных и муниципальных служащих. Они в большинстве своем создают многочисленные меры, политически нейтрализующие должностное лицо в отношении коммерческой деятельности во время службы и после ухода с должности.

Одним из приоритетных направлений предупреждения коррупции является кадровая стратегия. Кадровая политика построена на принципе меритократии (принцип управления, согласно которому руководящие посты должны занимать наиболее способные люди независимо от их социального или экономического положения, происхождения) и ориентировано на службу. 
В Японии и в США развита система социально и правового контроля над поведением чиновников. В стране производится регулируемая законом регистрация должностных лиц, в отношении которых выдвинуто обвинение в причастности к коррупции.

Данная регистрации доводится до общественности через СМИ и является фактом для установления контроля над поведением конкретного лица, источниками его доходов и может повлечь за собой применение к нему ряда ограничений, препятствующих совершению правонарушений, растраты и легализации средств, получивших преступным путем, в том числе в виде взяток.

В стране ведется реестр лиц, против которых выдвинуты обвинения в коррупции или причастности к организованной преступности. Этот факт доводится до сведения общественности через средства массовой информации, может повлечь за собой установление контроля над поведением конкретного лица, применение к нему ряда правоограничений.

Гражданский протест есть комплекс мер, который дает сдерживающий эффект, направленный на предупреждение коррупции среди политиков.

Положительный опыт зарубежных стран в предупреждении коррупции в органах государственной власти и местного самоуправления доказывает тот факт, что предупреждение коррупции - не какая-то разовая операция, а система мер, реализуемая в течение длительного времени.

Условия, способствующие коррупции в органах государственной власти и местного самоуправления, можно разделить на следующие три группы:

- условия организационно-управленческого характера - отсутствие общественного контроля за работой органов государственной власти и местного самоуправления и их должностных лиц, бюрократизм в их работе, недостатки в кадровой работе;

- условия нормативно-правового характера - пробелы и коллизии в законодательстве, множественность подзаконных актов органов государственной власти и местного самоуправления, порождающих негативные тенденции и способствующих коррупции, недостатки в организации деятельности территориальных органов МВД России на районном уровне и других правоохранительных органов;

- условия, связанные с недостатками социально-воспитательного характера, - формирование у отдельных служащих органов государственной власти и местного самоуправления возможности использовать свое служебное положение в корыстных целях, идеология стяжательства (корыстолюбие, стремление к наживе) и др.

\title{
Литература
}

1. Стефанишин С. С. Предупреждение коррупционных преступлений в зарубежных странах: автореф. дис. ...канд. юр. наук. Казань, 2005.

2. Куракин А. В. Административно-правовые средства предупреждения и пресечения коррупции в системе государственной службы зарубежных государств: монография. Домодедово, 2007. С. 124.

3. Максимов С. В. Национальный план противодействия коррупции и проблемы имплементации международных антикоррупционных стандартов в российское уголовное законодательство // Закон. 2012. № 11. С. 75-80.

4. Ли Куан Ю. Сингапурская история: из третьего мира в первый. М., 2005. С. 24.

5. Бочарников И. В. Зарубежный опыт противодействия коррупции // Государственная власть и местное самоуправление. 2008. № 9. С. 12-16.

6. Руденкин В. А. Борьба с коррупцией: американский вариант. URL: http://netsten. livejournal.com/5421.html (дата обращения: 25.04.2015)

7. Иванов А. М. Корруптология - правовая наука и учебная дисциплина: путь совершенствования уголовной политики и законодательства о воздействии на организованную преступность и коррупцию. Владивосток, 2002. С.15.

8. Сенаторов А. Как избавиться от коррупции? // Япония сегодня. 2001. № 7. С. 3-5.

9. Бочарников И. В. Указ. соч. С. 57

10. Номоконов В. А. Коррупция в мире и международная стратегия борьбы с ней: монография. Владивосток: Изд-во ДВГУ, 2004. С. 12.

11. Гармаев Ю. П. Криминалистические средства предупреждения коррупции // Гуманитарные науки и образование в Сибири. 2014. № 6 (18). С. 238-241.

\section{Законодательная конструкция грабежа в уголовном законодательстве Китая, Кыргызстана и России}

\author{
(С Д. С. Сапарбаев \\ адъюнкт 2 года обучения \\ ФГКОУ ВО ««Нижегородская академия \\ Министерства внутренних дел \\ Российской Федерации» \\ Россия, г. Нижний Новгород \\ kzkg@inbox.ru
}

Поражение абсолютных прав по владению, распоряжению имущества перманентное деструктивное явление в обществе, взывающая необходимость фактической и символической охраны собственности[1, с. 802]. Противоправные посягательства на собственность, остаются, пожалуй, самым массовой и серьезной проблемой для 
общества, требующая конструктивных шагов по защите прав и свобод личности. Совершенствование в частности, затрагивает соотношения уголовно-правовых и организационных мер противодействия хищениям чужого имущества, повышению эффективности норм уголовного законодательства.

Совершенствование национального права как процесс, неразрывно связан к обращению зарубежного и исторического правотворческого, правоприменительного и право корректирующего опыта. Сопоставление правовых позиций на одни и те же вопросы позволяет, обнаружит новые грани, нуждающегося во внедрении или прийти к выводу об оправданности шага национального законодателя.

Особое внимание следует уделить такого виду преступления как грабеж. Деление на тайный и отрытый способ завладения чужого имущества сохраняется во многих уголовных законодательствах стран мира, в уголовных кодекса отдельных странах он поглощается разбоем, а в странах мусульманской правовой семьи кража признается более общественно опасным посягательством на имущество, чем грабеж [2, с.338].

В ст.161 УК Российской Федерации и ст.167 УК Кыргызской Республики грабеж трактуется, как отрытое хищение чужое имущества [3, с. 74]. Законодательская конструкция грабежа в УК КР совпадают с УК РФ [4, c.83]. Грабеж от кражи отличается тем, что неправомерное открытое завладение лицом чужого имущества происходит при возможном присутствии, как потерпевшего лица, так и в присутствии третьих лиц. Для грабежа характерно наличие субъективных или объективных признаков совершения такого рода хищения [5, с.247]. Грабеж по своим признакам более дерзкая форма хищения, что повышает ее общественную опасность. Грабеж является двух объектовым преступлением, в отличие иных форм хищения как кража или мошенничество, так как присутствует потенциальная угроза причинения насилия или выражение угрозы насилия, неопасного для жизни и здоровья[6, с.30].

Законодатели Кыргызской Республики и Российской Федерации единодушны, что в уголовно-правовой доктрине придерживается теория завладения. Моментом окончания грабежа признается с момента реализации пользования или распоряжения чужим имуществом по усмотрению виновного лица и вследствие этого причинение вреда[7, с.18].

УК, Китай, в основе которого лежат теоретические исследования советской уголовно-правовой школы, но, тем не менее, наблюдается отличная концепция, связанной с юридической техникой, квалификации и пенализации грабежа.

Преступления против собственности в Уголовном Кодексе Китая рассматриваются в уголовном кодексе в главе 5 «преступления против имущества», начинается состава преступления - грабежа. Отличием, в юридикотехническом подходе: законодатель не дает название статьям, кроме их нумерации[8, с.177].

Исходя из диспозиции ст. 263 УК КНР грабежом признается хищение частного или частного имущества, сопряженного с применением насилия, угроз или «иных методов». Простой грабеж предусматривает наказание в виде лишения свободы на срок от 3 до 10 лет или штраф. Наличие отягчающих обстоятельств совершение грабежа предусматривает более строгую ответственность, выраженную в лишении свободы на срок более 10 лет, бессрочного лишения свободы и применения смертной казни, а также штрафа, а равно наложение конфискации имущества виновного лица. Отягчающими обстоятельствами грабежа признается в случае вторжения в жилище, в средствах общественного транспорта, банка или иных финансовых учреждений, его неоднократности или грабежа крупной суммы; с причинением увечья или смерти; под видом представителя правоохранительных службы, вооруженного грабежа: а также в отношении имущества, принадлежащего армии и экстренным службам.

Квалифицированные составы грабежа указывается в ст. 267 и ст.268 УК КНР. В случае завладения имущества в сравнительно или особо крупном ущербе. В ст.268 УК КНР указывается о более суровом наказании в отношении организаторов и активных участников группового грабежа.

Уголовно-правовыми источниками помимо Уголовного Кодекса и Конституции КНР, также являются разъяснения Верховного народного суда и Верховной народной прокуратуры КНР[9].

Следует обратить внимание, что в Главе 5 на наличия терминов «грабеж», «хищение», в структуре УК отсутствует соответствующие к ним определения. В руководящих разъяснениях, обладающей юридическую силу, дается особенности квалификации, определение к оценочным признакам составов преступлений.

В совместном разъяснении Верховного народного суда КНР и Верховной народной прокуратуры КНР «О некоторых вопросах применения законодательства при производстве по уголовным делам о грабеже» №25-2013 от 18 ноября 2013 года правило установления Сум сравнительно крупного, крупного и особо крупного размера ущерба. При этом, разъяснения расстанавливают лишь диапазон: для сравнительно крупного ущерба - от 100 до 300 юаней женьминби (далее юань), крупного ущерба - от 30000 до 80000 юаней, для особо крупного ущерба признается сумма от 200000 до 400000 юаней.

Дело в том, что конкретные критерии зависят от уровня экономического благосостояния и показателей уровня преступности того региона и устанавливаются органами суда и прокуратуры административной единицы (провинции, автономных районов и городов общего значения) по согласованию с Верховным судом народным судом и Верховной народной прокуратуры Китая.

Любопытным является позиция китайского законодателя по обеспечении. строгости уголовной ответственности при наличии отягчающих обстоятельств. Разъяснения ВНС и ВНП КНР за №25-2013 к ним относит совершение грабежа в случае наличия у виновного лица рецидива или факта привлечения административной ответственности в течение одного года за аналогичное правонарушение; грабежа с использованием транспортных средств или вовлечением несовершенных лиц; в отношении пожилых инвалидов, беременных женщин или 
несовершенных лиц; на территории больницы в отношении больных лиц и их близких; имущества необходимого для ликвидации последствий чрезвычайных ситуаций, предназначенного для помощи нуждающимся или пострадавших лиц, равно в время бедствия иных чрезвычайных происшествий; в причинении легкого вреда здоровья или психического расстройства. В указанных обстоятельствах предусматривается двух кратное снижение сравнительно крупного размера.

Также Разъяснение ВНС и ВНП предусматривает обстоятельства смягчающие уголовное наказание за совершение простого грабежа лицом впервые, наличия деятельного раскаяния, возмещения ущерба [8].

Также грабеж может быть признан малозначительным и допускать лишь применение к лицу ответственности по административному законодательству, если был прощен потерпевшим лицом или виновное лицо при совершении группового грабежа получило незначительную часть похищенного и не являлось активным участником или организатором преступления.

Китай сохраняет свою уголовно-правовую политику «суверенной»; наличием незначительного влияния зарубежных инициатив. Учитывая населения и территорию государства, можно признать рациональным решение законодателя, по применению такой практики, как дополнения органов правосудия и прокуратуры национального Уголовного Кодекса, что позволяет сохранять абстрактность и лаконичность норм. Содержание разъяснений, которые изменяются исходя из криминологической и экономической картины социума, учет судебноследственной практики позволяют избежать чрезмерного внесения изменений и дополнений в уголовный закон, включение или утрату юридической силы статей, осуществляется после их апробирования в актах дополнения, коим являются разъяснения к уголовному кодексу.

Исходя из сравнительного подхода изучения уловного законодательства Китая, Кыргызстана и России, можно сделать следующие выводы. Для постсоветских стран СНГ характерно во многом схожая позиция: наличия обще конструктивного для схожих составов преступления против собственности понятия как хищение; определение, которого указывается в примечании к статье «кража». Кроме того, степень причиненного ущерба также дается в примечании, в отличие законодателя Китая, который рассматривает данный вопрос в иных уголовно-правовых законах. Критически можно принять, то, что в УК КНР дается не столь четкое разграничение грабежа от разбоя, состав преступления можно признать как формально-материальный.

Тем не менее, не китайским дается многовариантность квалифицирующих признаков грабежа, с учетом затруднительного положения потерпевшей, по сравнению уголовных законодательств, основанных на рекомендательном Модельном Уголовном Кодексе для стран СНГ, принятого в 1996 году. Интересен китайский опыт включение квалифицирующего признака совершение грабежа в условиях чрезвычайных ситуаций, а также имущества, предназначенного для ликвидации и устранению их последствий. Более детального исследования требует модель снижения при отягчающих обстоятельствах сравнительно крупного ущерба, дифференциации суммы ущерба, в зависимости от криминогенной и экономической ситуации того или иного региона.

\section{Литература}

1. Бачинин В. А. Энциклопедия философии и социологии права. СПб., 2006.

2. Колмаков Д. А. Грабежи и разбои в уголовном законодательстве зарубежных стран // Вестник ТГУ. 2011. № 12. С.338.

3. Уголовный Кодекс Российской Федерации. М., 2014.

4. Уголовный Кодекс Кыргызской Республики. Бишкек, 2014.

5. Токторов Э. С., Жолдошев Т. Т. Кыргыз Республикасынын кылмыш-жаза Кодексине тушундурмо. Окуу. китеби. [Комментарий к Уголовному Кодексу Кыргызской Республики: учеб. пособие. Бишкек, 2015.

6. Арцыбашев П. Я., Бодобаев К. А. Преступления против собственности: учеб.-метод. пособие. Бишкек, 1999.

7. Малкова И. Ю. Грабеж: вопросы квалификации, дифференциации ответственности и индивидуализации наказания: автореф. дис. ...канд. юр. наук. Саратов, 2009.

8. Уголовный кодекс Китайской Народной Республики / под ред. А. И. Коробеева, пер. с кит. Д. В. Вичикова. СПб., 2001

9. CNLegal.ru: Блог о законодательстве Китая [Электронный pecypc]. cnlegal.ru

\section{Развитие системы наказаний в уголовном праве некоторых стран АТP}

() В. А. Сахинов

магистрант 2 года обучения юридического факультета ФГБОУ ВО «Бурятский госуниверситет» Россия, г. Улан-Удэ sakhinov.vova@yandex.ru

В данной статье проведен анализ развития и изменения наказаний в уголовном праве (от древних времен и до наших дней), отображены различные аспекты наказаний, использовавшиеся в разное время в разных государствах.

Наказание является одним из возможных способов реализации задач, возложенных на правосудие. В научной литературе довольно часто можно встретить такое понятие, как «справедливое правосудие». Необходимо выяснить, что представляет собой именно справедливое правосудие, какие у него имеются особенности, для того чтобы начать говорить о наказании. 
Однозначно можно сказать только то, что справедливое правосудие представляет собой справедливое наказание за совершенное деяние. Нельзя не согласиться с мнением, что правосудие представляет собой концепцию моральной правоты, основывающейся на этике, рациональности, праве, естественном праве, религии, справедливости и объективности, а также предусматривающую наказание за нарушение соответствующих социальных норм.

Многие современные правоведы придерживаются позиции ужесточения наказания, например, высказывают мнение о том, что «убийца заслуживает смертной казни даже в том случае, если его можно исправить, ибо смертная казнь в этом случае удовлетворяет чувство гнева, с которым население воспринимает совершение этого тяжкого преступления». Исследователь Ч. Лиан на примере КНР показал, что действующее уголовное законодательство некоторых стран имеет множество возможностей реального применения смертной казни.

Начнем исследование истории развития наказаний с древних времен. Уголовное наказание, как правило, вводили в действие органы правопорядка. В Древней Греции органы правопорядка противодействовали преступности с помощью законов Драконта (621 г. до н. э.), которые считались необычайно суровыми. Например, кража овощей приравнивалась к убийству, а наказанием была смертная казнь. На вопрос, почему почти за все преступления архонт приговаривал своих подданных к смертной казни, Драконт ответил, что незначительные проступки заслуживают этого наказания, а для серьезных не мог придумать большего. Кроме этого смертной казнью наказывались такие преступления как святотатство и поджог. Интересен тот факт, что по приказу законодателя наказанию подвергались даже неодушевленные предметы, если они являлись причиной смерти человека.

Другим государством, которое в силу своего демократизма внесло большой вклад в развитие уголовных наказаний, является Римская империя. Стоит обратиться к Законам XII таблиц, которые являются первыми писаными источниками, регулирующими практически все отрасли права в Древнем Риме. В законах присутствует отраслевое деление: VIII-IX таблицы содержат нормы уголовного права. Система наказаний не была конкретизирована, практически все зависело от решения судьи. Система наказаний была построена на причинении физических страданий человеку. Наказания можно было условно разделить на 2 вида: тяжкие и прочие. К тяжким можно отнести смертную казнь (отсечение головы, закалывание, повешение, сжигание заживо, отдача диким зверям на растерзание и т. д.), ссылку, изгнание, к прочим - штрафы (например, «если рукой или палкой переломит кость свободному человеку, пусть заплатит штраф в 300 ассов, если рабу - 150 ассов») или физическое насилие (например, в тех случаях, когда вор был пойман на месте совершения преступления, он подвергался телесному наказанию). Однако наказанием за совершенное деяние могло быть и незамедлительное убийство вора в случаях вооруженной или ночной кражи. Если же человек совершил кровное убийство, то его зашивали в мешок с собакой, петухом или змеей, а затем топили в реке или в море. Девушек же, нарушивших обет целомудрия, заживо закапывали в землю. Несмотря на «недостатки» таких законов, авторитет их был непререкаем.

Нельзя не обратиться к истории еще одного государства - Индии, которая для своего времени отличалась высоким уровнем развития. Уголовное право Древней Индии можно рассмотреть в рамках законов Ману (II в. до н. э.). Несмотря на то, что в Индии существовало множество различных источников права, именно эти законы получили наибольшую известность. Законы Ману особенны в стиле написания - они имеют форму двустиший для лучшего запоминания. Основной целью наказаний по Законам Ману являлось устрашение - «наказанием весь мир держится в порядке». При обвинении человека учитывалась его классовая принадлежность: чем выше статус у обвиняемого в обществе, тем лояльнее наказание («вследствие своей исключительности, превосходства происхождения, соблюдения ограничительных правил и особенности посвящения брахман владыка варн»). Наказания были суровыми, часто применялась смертная казнь (отрубание головы, сажание на кол, утопление, сожжение, разрезание тела на части бритвами, помещение в кипящий котел, топтание слоном). Если же обвиняемый оказывался брахманом, наказание заменялось бритьем головы. Также были широко применяемы такие наказания как кастрация, ослепление, отрезание пальцев, рук, ног, языка. Частым явлением в Древней Индии было клеймение (в зависимости от тяжести совершенного деяния), но данному виду наказания подвергались только низшие слои населения. Обобщая, можно сказать, что в названый период, в Индии большое значение при выборе наказания имела сословно-кастовая принадлежность преступника.

Как обстояло дело с наказаниями в Европе? Самое страшное время для Европы - V век. Этот период характеризуется переходом от Античности к Средневековью. Наиболее яркое представление об этом времени дают «варварские правды» - своды правовых обычаев, Салическая правда (составителем которой был король франков - Хлодвиг), Рипуарская правда. Вместе они являются сборниками правовых норм, затрагивающими все отрасли жизни раннеклассового государства. Именно преступлениям и наказаниям посвящена большая часть статей варварских правд. Преступлением являлись обида, вред и нарушение королевского мира. Тяжесть наказания во многом зависела от социального статуса преступника и потерпевшего. Виды наказаний в средневековой Европе были самыми разнообразными - бичевание, ослепление, карнаушание (обрезание ушей), вырывание зубов, ампутация различных частей тела, распятие, четвертование, колесование, избиение камнями и т. д. На смену ссылкам пришли тюрьмы. Тюрьма представляла собой яму или каменный мешок. Выбор наказаний и в это время так же зависел от решения судьи.

Для получения наиболее широкого представления об изменении во времени уголовных наказаний, стоит обратиться к истории Древнерусского государства, где в тот период только начинает складываться государственность. Наиболее известным древнерусским памятником, содержащим достаточно подробное описание уголовных норм, является «Русская правда». В статьях «Русской правды» говорится о смертной казни как о нака- 
зании, хотя документ отрицает какое-либо физическое воздействие на человека. Смертная казнь упоминается только в 996 г. в «Повести временных лет» - «...Володимир же отверг виры, нача казнити разбойников...». «Двинская грамота» 1397 г. отмечает, что смертная казнь предполагалась за кражу, совершенную человеком в третий раз. А спустя 100 лет в Московском княжестве после принятия судебника, преступник приговаривался к смертной казни за 10 видов преступлений: разбой, убийство, кражу, клевету, измену, святотатство, кражу холопов, поджог, государственные и религиозные преступления. Таким образом, наказания стали иметь более суровый характер для устрашения населения. В период правления Петра I, уголовное наказание обеспечивалось Воинским артикулом 1715 г., Воинским Уставом 1717 г., Морским артикулом 1722 г. Эти документы включали в себя военно-уголовное законодательство, но в них помимо воинских преступлений были включены и наказания за другие виды преступлений. Например, кража в первый раз наказывалась прогоном через строй 6 раз, во второй - 12 раз, в третий - урезанием ушей или ссылкой, в четвертый - смертной казнью.

Многовековой опыт показывает, что ужесточение наказаний не приводит к снижению уровня преступности. Исходя из сказанного, можно прийти к выводу, что большое значение в системе уголовных наказаний имеет не столько суровость, сколько политическое и нравственное состояние государства. В тех странах, где ее уровень достигает минимума, преступлений совершается больше, чем в странах с развитой культурой. Наказания имеют тысячелетнюю историю. Безусловно, что их содержание изменялось в зависимости от той или иной исторической эпохи, типа и формы государства, от господствующей правовой доктрины и от уровня правовой культуры. Одна из целей наказания, а именно пресечение совершения новых преступлений, достигалась ранее и достигается сегодня. Ужесточение наказания не следует воспринимать как отсутствие гуманизма в законодательстве. Необходимо учесть то, что приоритетным фактором общего предупреждения преступлений всегда была и будет не суровость наказания, а неотвратимость наступления ответственности. Очень интересным представляется исследование, проведенное американскими криминологами Д. Арчер и Р. Гартнер. Они изучили 14 стран, в которых была отменена смертная казнь, сравнили динамику убийств до и после отмены этого вида наказания. Вывод, к которому пришли ученые: уровень убийств остался неизменным. Таким образом, наличие или отсутствие в законе смертной казни за убийство не влияет на реальный уровень этих преступлений. Согласно статистике, за последние 10 лет в странах Юго-Восточной Азии было казнено намного больше людей, чем во всем остальном мире.

Изучив историю развития уголовных наказаний в разных странах, а также современную судебную практику, можно сделать вывод, что российскому законодательству необходимо усиление и развитие принципа неотвратимости наказания. Реакция правоприменителя на преступления реальной практикой применения принципа неотвратимости наступления ответственности, по моему мнению, будет способствовать уменьшению количества преступлений. Преступление не должно быть без наказания. Неотвратимость наступления наказаний за преступления сегодня - это защита общества и предотвращение угрожающих обществу преступлений в будущем. На основании предоставленных выводов предлагаю законодательно закрепить в Уголовно-процессуальном кодексе Российской Федерации и практически реализовывать «принцип неотвратимости наказания».

\section{Литература}

1. Верещагин С. Г. Правовые формы легализации политики налогов в Древней Греции и Древнем Риме // Право и политика. 2007. № 5. С. 100-110.

2. Законы Ману: Манавадхармашастра / пер. С. Д. Эль- мановича. М.: ЭКСМО-Пресс, 2002. 496 с.

3. Исаев М. А. История Российского государства и права: учебник. М.: Статут, 2012. 840 с.

4. История Древнего Востока / под ред. В. И. Кузищина. М., 1988. 416 с.

5. История Древней Греции / под общ. ред. Э. Д. Фролова. СПб.: Полигон, 2002. 864 с.

6. История Средних веков / под ред. С.Д. Сказкина. М.: Высшая школа. 1977. 471 с. $560 \mathrm{c}$.

7. Римское частное право: учебник / В. А. Краснокутский, И. Б. Новицкий, И. С. Перетерскийидр. М.: Юристъ, 2004.

8. Савва В. Московские цари и византийские василевсы. Харьков, 1901. $411 \mathrm{c.}$

9. Степанова В. Е., Шевеленко А. Я. История Средних веков: хрестоматия. М.: Просвещение, 1969. $351 \mathrm{c.}$

10. Тихомиров М. Н. Пособие по изучению «Русской Правды». М., 1953. 192 с. $328 \mathrm{c}$.

11. Хрестоматия по истории Древнего Востока: учеб. пособие / под ред. М.А. Коростовцева. М.: Высшая школа, 1980.

12. Х Хрестоматия по истории Древнего Рима / под ред. С. Л. Утченко. М., 1962. 675 с.

13. Черниловский 3. М. Хрестоматия по общей истории государства и права. М.: Юристь, 1996. 413 с.

14. Мурсалов А. В. Варварские (германские) правды и краткая редакция «Русской правды»: сравнительный анализ положений и норм уголовного права // Военно-юридический журнал. 2007. № 11. URL: http://base.consultant.ru/cons/cgi/online.cgi?req=doc;base=CJI;n=25923

15. Arcer D., Gartner R. Violence and Crime in CrossNational Perspektive. New Haven-London, 1984. 315 p.

16. Berns W. For Capital Punishment: Crime and the Morality of the Death Penalty. New York: Basic Books, 1979. 450 p.

17. Hood R. The Death Penalty. A Worldwide Perspective. Oxford: Clarendon Press, 2002. 214 p.

18. Konow J. Which is the Fairest One of All? A Positive Analysis of Justice Theories // Journal of Economic Literature. 2003. Vol. 41. No. 4. Pp. 1188-1239.

19. Liang Ch. X. The Death Penalty // The United Nations Standards and China's Legal System of Criminal Justice. 1998. Pp.536-541. 


\title{
Мошенничество в Китае: уголовно-правовая характеристика
}

\author{
(C) В. А. Суранов \\ магистрант 1 года обучения юридического факультета \\ ФГБОУ ВО «Бурятский госуниверситет» \\ Россия, г. Улан-Удэ \\ vasiliy193q@ya.ru
}

Мошенничество имеет длительную историю. В криминальной среде накоплен и продолжает накапливаться опыт совершения данного преступления. С мошенничеством связана деятельность профессионалов преступного мира, т.е. профессиональная преступность, а также многие проявления организованной преступности, что следует из анализа использования фальшивых банковских и финансовых документов, деятельности специально созданных для совершения мошеннических операций различных фондов, предприятий и компаний. Это объясняется прибылью указанного криминального промысла. Одна стремительно и умело проведенная операция приносит доход, который покрывает не только все затраты на ее подготовку, но и является неизмеримо большим по сравнению с доходами полученными, например, от кражи. Мошенничество и менее рискованно, чем другие преступления против собственности. В Российском законодательстве мошенничество - есть хищение чужого имущества или приобретение права на чужое имущество путем обмана или злоупотребления доверием. Таким образом, в диспозиции ч. 1 ст. 159 УК РФ речь идет о двух видах мошенничества. Если предметом первого вида мошенничества (хищения) является имущество как вещь (имущество в узком смысле), то предметом второго его вида выступает право на имущество (имущество в широком смысле).

Рассматриваемые виды мошенничества отличаются также по объективной стороне. В одном случае формой общественно опасного действия является хищение, в другом - приобретение. Оба вида мошенничества совершаются с помощью обмана или злоупотребления доверием, выступающих самостоятельными способами преступления.

На практике под обманом понимают умышленное искажение или сокрытие истины с целью ввести в заблуждение лицо, в ведении которого находится имущество, и таким образом добиться от него добровольной передачи имущества, а также сообщение с той же целью заведомо ложных сведений. Иными словами, как отмечает А.Н. Щеглов обман - это, прежде всего, сознательная дезинформация контрагента либо иного лица.

Обман - понятие широкое, оно включает в себя не только предоставление ложных сведений, но и факт умолчания об истине либо замалчивание иных сведений. Поэтому сам факт искажения истинных действий (бездействия) должен носить исключительно предумышленный характер (прямой либо косвенный умысел). Нет умысла - нет и состава мошенничества. Следовательно, наличие умысла как субъективной стороны преступления обязательно для того, чтобы признать совершенное таким способом хищение мошенническим действием.

В уголовном кодексе КНР мошенничество отнесено, в большинстве своем, к преступлениям против порядка управления в сфере финансов и только потом к преступлениям против собственности.

«Финансовое мошенничество» (ст. 192-200) отражает «новейшие тенденции» в китайском преступном миpe. Составители Уголовного кодекса 1979 г., очевидно, даже не догадывались о возможности таких преступлений в КНР. Поэтому нет ничего удивительного в том, что о мошенничестве в самом общем виде говорится лишь в двух его статьях (ст. 151-152) в увязке с кражами и грабежами. В 80-е гг. такой проблемы не существовало. Только в 90-е гг. законодатель был вынужден к ней обратиться, реагируя на процессы, происходившие в обществе.

Целый ряд положений Постановления о наказании за преступления против финансового порядка 1995 г., в том числе статьи 8, 10, 14 и др., были направлены на борьбу с неизвестным ранее злом. Работа была продолжена при подготовке нынешнего кодекса, но события, произошедшие после его принятия, не вызывали сомнений относительно целесообразности дальнейшего совершенствования законодательной базы в этом направлении.

По статье 192 УК КНР 1997 г., сбор средств с помощью мошеннических способов с целью незаконного присвоения на значительную сумму наказывается лишением свободы на срок до пяти лет либо арестом, в качестве дополнительного наказания применяется штраф в размере от 20 тысяч до 200 тысяч юаней; при крупном размере суммы - от пяти до десяти лет и штрафом от 50 тысяч до 500 тысяч юаней; при особо крупном размере суммы или других отягчающих обстоятельствах - десять и более лет либо пожизненным заключением, в качестве дополнительного наказания - штраф от 50 тысяч до 500 тысяч юаней либо конфискация имущества. При этом не следует забывать, что согласно статье 199, преступления, предусмотренные статьями 192,194 и 195 данной главы, при особо крупном размере суммы и нанесении особо крупного ущерба интересам государства и народа караются пожизненным лишением свободы либо смертной казнью, а также конфискацией имущества.

Мошенническая деятельность с финансовыми векселями в зависимости от конкретных сумм проделанных операций наказывается лишением свободы на срок до пяти лет либо арестом, от пяти до десяти и более лет, либо пожизненным заключением; в качестве дополнительного наказания применяется штраф соответственно от 20 тысяч до 500 тысяч юаней либо конфискация имущества (ст. 194). По сообщению агентства Синьхуа от 12 марта 1999 г., предпринимательница Цао Ши со своим подельником в провинции Шаньдун, используя «липо- 
вые» векселя, присвоила 10 млн. юаней (более 1 млн. долларов). Позднее аналогичным образом она разбогатела еще на 15 млн. юаней (около 2 млн. долларов). С учетом размера суммы и величины ущерба интересам государства (ст. 194 и 199) суд средней ступени города Вэйфан приговорил мошенницу к смертной казни, а суд второй инстанции отклонил ее кассационную жалобу. Сообщник был осужден к пожизненному лишению свободы. Председатель суда второй инстанции, вынося окончательный вердикт, подчеркнул, что «своими действиями Цао Ши нанесла большой ущерб государству и заслуживает самого сурового наказания».

Санкции статей настоящей главы на редкость однообразны (ст. 192-197). Некоторое исключение составляет статья 198 - мошенническая деятельность в сфере страхования. В ней при идентичных сроках лишения свободы размеры штрафа колеблются от 10 тысяч до 200 тысяч юаней (в других от 20 тысяч до 500 тысяч). В данной статье достаточно подробно перечислены варианты такого мошенничества, что свидетельствует о хорошем знании конкретной ситуации и поэтому, естественно, представляет интерес: 1) умышленное заявление ложных страховых сведений страхователем для получения страхового вознаграждения обманным путем; 2) предоставление ложных сведений о причинах произошедшего страхового инцидента либо преувеличение размера потерь по нему страхователем, застрахованным лицом или выгодоприобретателем для получения страхового вознаграждения обманным путем; 3) фабрикация не произошедшего страхового инцидента страхователем, застрахованным лицом или выгодоприобретателем для получения страхового вознаграждения обманным путем; 4) умышленное создание страхового инцидента с утратой собственности страхователем, застрахованным лицом для получения страхового вознаграждения обманным путем; 5) умышленное причинение застрахованному лицу смерти, увечья или заболевания страхователем, выгодоприобретателем для получения страхового вознаграждения обманным путем.

Деяния, предусмотренные пунктами 4,5 и в то же время образующие состав другого преступления, наказываются в соответствии с положениями о наказании за совершение нескольких преступлений. Умышленное предоставление ложных свидетельств по страховому инциденту экспертами, свидетелями, лицами, оценивающими собственность, что создало условия другим лицам для проведения мошеннических операций, рассматривается как соучастие в мошенничестве в области страхования.

В разделе преступления против собственности, наказание за мошенничество предусмотрено лишь за завладение имуществом в сравнительно крупном размере. Кража, завладение имуществом путем мошенничества или грабежа, в целях сокрытия награбленного, сопротивления аресту или уничтожения доказательств преступления, соединенные с применением насилия или угрозы применения насилия наказывается лишением свободы на срок от 3 до 10 лет и штрафом.

Ровно в два раза по количеству статей, в сравнении с УК КНР 1979 г., увеличилась глава 5 (ст. 263-276). В кодексе под общественной собственностью понимаются: государственная собственность; коллективная собственность трудящихся масс; социальные пожертвования или специальные фонды, нацеленные на помощь бедным и другие общие блага. В государственных органах, компаниях, на предприятиях, коллективных предприятиях и в народных организациях контролируемая, используемая или перевозимая частная собственность рассматривается как общественная. Частная собственность граждан включает: законные доходы, сбережения, жилье и другие средства существования граждан; средства производства, в соответствии с законом принадлежащие одному лицу, семье; законная собственность индивидуального хозяйства и частного предприятия; паи, акции, облигации и другая собственность, в соответствии с законом принадлежащая отдельному лицу (ст. 91-92).

Как и в 1979 г. законодатель, формулируя понятие «собственность» (общественная и частная), применяя его в названии указанной главы, тем не менее, включает в соответствующие статьи слово «ценности», подчеркивая их финансово-материальный характер. Именно в этом значении термин «ценности» употребляется по тексту всего УК КНР.

По статье 263 квалифицируются и наказываются грабеж с использованием орудия убийства (ч. 2, ст. 267) и кража, мошенничество, грабеж с применением насилия или угрозой применения насилия для сокрытия краденого, оказания сопротивления задержанию или уничтожения улик (ст. 269).

Мошенничество (ст. 266) и грабеж (ст. 267) ,в отличие от кодекса 1979 г., где они были объединены вместе с кражей в статьях 151 и 152, предусмотрены в отдельных статьях. Причем в статье 266 сделана оговорка, согласно которой мошенничество, предусмотренное другими статьями кодекса, подлежит квалификации по другим статьям УК. Еще ряд статей УК 1997 г. содержит нормы о мошенничестве, в том числе: статья 192 - сбор средств с помощью мошенничества, 193 - получение кредита мошенническим способом, 194-197 - мошенничество соответственно с финансовыми векселями, аккредитивами, кредитными картами, государственными ценными бумагами, 198 - мошенничество в сфере страхования (все они включены в главу 5 «Финансовое мошенничество» главы 3 «Преступления против социалистического рыночного экономического порядка» Особенной части). В отличие от кражи в санкциях ни одной из перечисленных статей не предусмотрена смертная казнь.

Не совсем четкая позиция у некоторых китайских специалистов, выборочно квалифицирующих «получение обманным путем» тех или иных ценностей как «мошенничество». Так, статью 204 - получение обманным путем возвращаемого государством налога на экспорт и статью 224 - получение обманным путем ценностей другой стороны в ходе подписания, исполнения контракта предлагается рассматривать как «мошенничество», что, вероятно, оправданно, но игнорируется, например, статья 382 - получение обманным путем общественных ценностей государственными работниками с использованием служебного положения $(13,343)$. 
Также УК КНР предусматривает использование компьютера для завладения деньгами путем мошенничества или их хищения, для взяточничества и нецелевого использования общественных средств, для завладения путем хищения государственной тайной и совершения иных преступлений.

Мошенничество в Китае отнесено и к преступлениям против режима государственной границы. Статья 319. Осуществление мошеннических действий, получение обманным путем паспортов, виз и других выездных документов под видом экспорта рабочей силы или осуществления торгово-экономического обмена, в отношении организаторов нелегального пересечения государственной границы (границы приграничного района) третьими лицами.

Распространенные виды мошенничества в Китае.

Когда Вы стоите в очереди, к Вам может подойти человек, который предложит купить бахилы или заранее пройти проверку паспорта для входа в мавзолей. Но имеется несколько моментов при посещении мавзолея Мао Цзэдуна:

- Для того, чтобы посетить мавзолей, не нужно ничего платить, посещение совершенно бесплатно;

- Не нужно покупать никакую сменную обувь;

- Здесь нет никакой идентификационной проверки паспорта;

- Никто не сможет провести вас за деньги вне очереди.

Очень часто многие туристы, которые не знают этих моментов, становятся легкой добычей для мошенников. Вам говорят, что для входа в мавзолей необходимо надеть бахилы, которые они как раз могут продать. Так же многим предлагают пройти быстрый паспортный контроль за небольшую сумму, хотя никакого контроля на самом деле нет. Единственное, за что Вам придется заплатить - камеры хранения, в которых оставляются сумки, шапки, а также фото и видео аппаратура.

KTV - это китайские бары, где можно выпить, спеть караоке и просто расслабиться. Как правило, схема мошенничества такова: Вас приглашают спеть караоке, Вы входите в комнату, начинаете петь, и тут неожиданно появляются девушки и требуют выпить. Через пару минут в комнату приносят большой поднос со всевозможной выпивкой и закуской, которую Вы, якобы, заказали девушкам. После нескольких песен практически все бутылки оказываются открытыми, а закуска съеденной. В итоге Вам предъявляют длинный счет, который Вы должны оплатить, ведь девушки здесь работают и за услуги бара не платят. Вывод: держитесь от КTV баров подальше или будьте максимально бдительны при их посещении.

В наиболее популярных туристических зонах, таких как Tiananmen Square или Wangfujing, к Вам может подойти одна или несколько привлекательных женщин или мужчин, которые будут предлагать Вам свои услуги гида. Они в подробностях опишут увлекательную экскурсию по дворам Hutong и другим популярным туристическим маршрутам. Будут увлекательно рассказывать об уникальной культуре Китая, его древних традициях, и даже международных отношениях с другими странами. Далее Вас приглашают в традиционное китайское кафе, чтобы поучаствовать в чайной церемонии. В заведении Вам предложат выбрать несколько наиболее приглянувшихся видов чая. После чаепития с новыми «друзьями» Вам выставят счет, в котором все цены будут завышены минимум вдвое. Подвох в том, что Ваши новоиспеченные знакомые специально заманивают туристов в кафе, чтобы они выложили там как можно больше денег. Дабы не рассекречивать себя, они могут предложить Вам разделить всю сумму пополам, что, конечно же, никак не повлияет на их бюджет, так как они состоят в сговоре с кафе. Такие махинации чаще всего происходят в центральной части Пекина: площадь Тяньаньмэнь (Tiananmen) и Запретный город (Forbidden city).

Посольство России в Пекине. Адрес: Russian Embassy, No. 4 Dongzhimen Beizhongjie, Beijing, 100600 China. Телефон: +80610 6532 1381, +8610 6532 2051; факс: +8610 6532 4851; e-mail: embassy@ russia.org.cn.

\title{
Литература
}

1. Уголовный кодекс Китайской Народной Республики / под ред. А. И. Коробеева, пер. с кит. Д. В. Вичикова. СПб.: Юридический центр Пресс, 2001. 303 с.

2. Новые тенденции развития уголовного законодательства в Китае (интерпретация «Поправок к Уголовному кодексу Китайской Народной Республики (№ 8) // Пан Дунмэй. 2011. № 2. С. 61-67.

\section{Обстоятельства, смягчающие наказание, в уголовном праве России и странах АТP}

\author{
(C) A. Б. Тармаханова \\ магистрант 2 года обучения юридического факультета \\ ФГБОУ ВО «Бурятский госуниверситет» \\ Россия, г. Улан-Удэ \\ Adisatarm93@mail.ru
}

Развитие общества объективно предполагает прогресс во взглядах на государство, на право, а также на политику государства по обеспечению правопорядка: в частности, борьбы с преступностью, обеспечения безопасности личности, общества и государства. 
Рассмотрение особенностей уголовной политики, а именно смягчающие обстоятельства в России и странах АТР представляется интересным и актуальным, и самое главное, необходимым на современном этапе развития России, могущим помочь в выработке наиболее эффективной уголовной политики Российского государства [4, 114].

Уголовная политика является одним из направлений внутренней политики России. Она нуждается в серьезном анализе современного периода развития государства с учетом всех изменений, происшедших в политическом режиме, социально-экономических отношениях и законодательстве [1, 74]. Для полного анализа уголовной политики России и стран АТР, необходимы теоретические исследования, разрешающие методологические проблемы уголовной политики, куда входит определение ее понятия, содержания, принципов, форм реализации, и формирующие основные положения.

Россия и АТР должны как воспитательно-профилактический, так и характер уголовной политики, что усилит на преступности и обеспечение [7, 24]. Ведь политика - это мер правового, и характера, на разработку программ и с преступностью, ресоциализации преступников, особое в системе власти России, осуществлять и составлять и прогнозы преступности.

В с законодательством наказание является формой уголовной и из наиболее средств с преступностью. При наказания в числе обстоятельств, учету ч. 2 ст. 54 УК Монголии, суду предписано обстоятельства, и наказание. Вместе с тем, суда по норм во зависит от формы законодательного соответствующих положений, и их регулирования, толкования обстоятельств в и практике.

Обстоятельства, наказание, достаточно значимое в общих назначения и выполняют существенную роль в индивидуализации лицу, признанному виновным в преступления. Без на них суда лишается необходимой конкретности.

Однако в время в смягчающих обстоятельств существует ряд вопросов. Так, в уголовно-правовой науке, успешно развивающейся в и в России, нет мнений по сущности правовой обстоятельств, и наказание; не выработано и не на уровне обоснованное определение обстоятельств [11].

В от уголовного закона, кодекс КНР не содержит перечня обстоятельств, и наказание. Хотя в УК КНР установлено, что при наказания обстоятельства должны учитываться. В УК КНР в ст. 232 предусматривается, что умышленное наказывается казнью, лишением свободы или свободы на срок 10 лет; при обстоятельствах - наказывается свободы на срок от 3 до 10 лет. действия, приведшие к человека, лишением на срок от 3 до 7 лет; при обстоятельствах - лишением на срок до 3 лет [9].

Не во всех в законодательстве в виде присутствует смягчающих обстоятельств. Так, в Японии лишь в виде называются обстоятельства, должны судом при наказания (возраст, и цели, поведение и т. д.), в результате чего может на внутреннего решить, какие обстоятельства дела смягчающими [10]. Уголовная Японии, с самым среди стран преступности, естественный научный и интерес $[2,46]$.

Уголовный России содержит лишь примерный перечень смягчающих обстоятельств, поскольку при наказания суд признать ответственность и обстоятельства, не в законе:

1. Совершение впервые преступления или средней тяжести случайного обстоятельств.

2. Несовершеннолетие виновного.

3. Беременность.

4. Наличие у виновного.

5. Совершение в силу тяжелых обстоятельств либо по сострадания.

6. Совершение в результате или принуждения либо в силу материальной, служебной или иной зависимости.

7. преступления при условии правомерности необходимой обороны, лица, совершившего преступление, необходимости, риска, исполнения или распоряжения.

8. противоправность или аморальность поведения потерпевшего, явившегося поводом для преступления.

9. Явка с повинной, способствование и расследованию преступления, изобличению соучастников и имущества, в результате преступления.

10. Оказание и иной потерпевшему после преступления; добровольное имущественного и вреда, в результате преступления, иные действия, на вреда, причиненного потерпевшему.

Таким образом, лицо, преступление, к ответственности и наказание, суд в каждом конкретном учитывать обстоятельства, не степень общественной совершенного преступления, но и особенности, характеризующие виновного. Эти принимаются за основу при вопроса об или назначаемого субъекту наказания в закона в виде и уголовную ответственность обстоятельств.

Все факторы, составить обстоятельство, смягчающее ответственность, быть взаимосвязанными, т. е. быть в в один момент и одно из другого. в не считается обстоятельством, смягчающим вину.

Таким образом, назначение смягчающих обстоятельств заключается в том, предоставить суду оценить не только характер и общественной совершенного преступления, но и решить об лица, [6, 15] преступление, от уголовной и наказании. При этом, суду принимать во внимание содержание обстоятельства, а то, в какой мере его зависело от воли и в мере оно на его поведение, то есть его.

\section{Литература}

1. Александров А. И. Политика и процесс в российской государственности. СПб., 2005. С.74.

2. Бабаев М. М. Об уголовной и политики // Проблемы социологии права. М.: Наука, 2000. С. 46.

3. Беляев Н. А. Уголовно-правовая и пути ее // Избранные труды. СПб., 2005. С. 17.

4. Газетдинов Н. И. Уголовная и отечественная о уголовного // Журнал российского права. 2007. № 7. С.114. 
5.Коржихина Т. П. О российской государственности. М., 1995. С.33.

6. Уголовное право / отв. ред. И. Я. Козаченко, 3. А. Незнамова. 3-е изд., изм. и доп. М., 2001. С. 15.

7. Юридическая / отв. ред. Б. Н. Топорнин. М., 2001. С. 1112; Энциклопедический словарь. М., 1984. С.24.

8. Уголовный кодекс Федерации от 13.06 .1996 г. № 63 - Ф3 (от ред. от 05.05.2014) (с изм. и доп. вступ. в силу с 25.05.2014) (принят ГД ФС РФ 24.05.1996) // Рос. газета. 1996. 18 июня; 1996. 19 июня; 1996. 20 июня; 1996. 25 июня.

9. Большая онлайн e-Reading [Электронный pecypc]. Режим доступа: http://www.e-reading.club chapter.php/ 1022102/19/Mirovye_religii_o_prestuplenii_i_nakazanii.html (дата обращения: 01.04.2016 г.).

10. Википедия [Электронный ресурс]. Режим доступа: https://ru.wikipedia.org/wiki (дата обращения: 02.04.2016 г.).

11. Библиотека наук Law Theses [Электронный pecypc]. Режим доступа: http://lawtheses.com/obstoyatelstvasmyagchayuschie-i-otyagchayuschie-nakazanie-po-ugolovnomu-zakonodatelstvu-mongolii (дата обращения: 03.04.2016 г.).

\section{Сравнение института ограниченной вменяемости в уголовном законодательстве РФ и ряде других стран}

(ㄷ) В. В. Телятников

студент 3-го курса юридического факультета ФГБОУ ВО «Новосибирский государственный технический университет»

Россия, г. Новосибирск

Для того чтобы дать полную характеристику субъекту состава преступления следует установить, что перед нами физическое вменяемое лицо, достигшее возраста уголовной ответственности. Каждый из перечисленных критериев в своем индивидуальном рассмотрении представляет собой непростой вопрос, который изучался на протяжении всей истории уголовного права. В данном случае стоит выделить отдельно такой критерий характеристики субъекта состава преступления как вменяемость. Вменяемости или же невменяемости посвящены некоторые статьи УК РФ. В ст. 21 Уголовного кодекса дается достаточно подробное определение понятию «невменяемость», принятом в уголовном праве с точки зрения законодателя.

«Не подлежит уголовной ответственности лицо, которое во время совершения общественно опасного деяния находилось в состоянии невменяемости, т.е. не могло осознавать фактический характер и общественную опасность своих действий (бездействия) либо руководить ими вследствие хронического психического расстройства, временного психического расстройства, слабоумия либо иного болезненного состояния» [4].

УК РФ не дает разъяснений по поводу противоположного понятия - «вменяемость». Эту позицию законодателя можно объяснить тем, что вменяемость лиц, совершивших общественно опасное деяние, выступает в роли презумпции. Тем самым человек считается вменяемым до тех пор, пока у соответствующих должностных лиц не возникнет оснований усомниться в психическом здоровье этого лица. В этом случае назначается судебно-психиатрическая экспертиза, которая и представит соответствующее медицинское заключение о состоянии психического здоровья данного лица.

Выяснение того, осознавало ли лицо значение своих действий и могло ли отдавать себе отчет, руководить ими во время совершения общественно опасного деяния, имеет большое значение. В случае если будет установлена невменяемость лица, то оно не будет являться субъектом состава преступления, и к такому лицу могут быть применены принудительные меры медицинского характера. Вот они два важных критерия: вменяемость и невменяемость. Но согласно ст. 22 УК РФ существует и третий критерий, занимающий среднее, промежуточное положение, характеризующий состояние лица в момент совершения противоправного деяния.

Данный институт получил название ограниченной либо же уменьшенной, частичной вменяемости, по поводу которой уже многие годы ведутся споры между учеными различных стран, эпох и взглядов. Одно из первых ярких проявлений этого института пришлось на сороковые годы XIX века, когда некоторые кодексы германских стран закрепили в себе положения об уменьшенной наказуемости слабоумных, недоразвитых и нравственно оскуделых субъектов.

В России по этому вопросу ученые так же разделились в своих мнениях. Такие знаменитые специалисты уголовного права как В. Д. Спасович, Л. Е. Владимиров и другие вполне признавали теорию уменьшенной (ограниченной) вменяемости. Другая группа ученых, в которую входили: Н. С. Таганцев, А. Ф. Кистяковский, С. Будзинский, С. В. Познышев, категорически отрицала существование какого-либо среднего понятия, между вменяемостью и невменяемостью.

Не остались в стороне и известные психиатры, В. Х. Кандинский, В. П. Сербский, И. Г. Оршанский, которые возражали против такого института, указывая на то, что не существует никакой промежуточной мерки, то есть не может быть измененной вменяемости. Ученые-теоретики могут в своих доктринальных трудах выражать различные точки зрения видения данного вопроса, но игнорировать мнения именитых психиатров, которые разбираются в психических состояниях человека куда лучше правоведов, было бы неразумно.

В нынешнее же время судебная психиатрия разрабатывает судебно-психиатрические критерии так называемых пограничных состояний между вменяемостью и невменяемостью. В этом аспекте можно выделить следующие основные группы: не резко выраженные хронические психические заболевания (эпилепсия, шизофренические дефекты, хронический алкоголизм), временные психические расстройства (психозы и посттравмати- 
ческие стрессовые расстройства), психические аномалии (умственная отсталость, расстройства личности), неврозы и иные болезненные состояния. Любое из перечисленных заболеваний или отклонений психики в отдельности может оказаться достаточным для признания наличия медицинского критерия ограниченной вменяемости.

Законодательство других стран имеет свои особенности при регулировании данного правового института. Например, УК Республики Казахстан гласит, что психическое расстройство, не исключающее вменяемости, учитывается судом при назначении наказания как смягчающее обстоятельство [2]. Хоть и перечень обстоятельств, смягчающих наказание, закрепленный в ст. 61 УК РФ не является исчерпывающим, и суд при назначении наказания вправе учитывать иные обстоятельства как смягчающие, остается сожалеть, что этот перечень не содержит указания на ограниченную вменяемость. Это в свою очередь, могло бы хоть как-то прояснить сущность рассматриваемого института, который до конца не изучен, и о целесообразности которого ведутся споры.

Законодатели КНР при составлении норм УК избрали несколько иной путь при определении ответственности лиц, страдающих психическими заболеваниями и совершившими общественно опасные деяния. Лица, страдающие психическими заболеваниями и совершившие общественно опасные деяния не несут уголовной ответственности, однако государство возлагает на членов семьи этого лица или его опекунов функции по контролю за его поведением, а также по принятию мер по обеспечению лечения этого лица. Данное правило нашло свое отражение в ст. 18 УК КНР [1]. Также важно учесть психическое состояние лица именно в момент совершения общественно опасного деяния, так если лицо хоть и страдает психическими заболеваниями, но во время совершения общественно опасного деяния отдавал отчет своим действиям и их последствиям, то оно подлежит уголовной ответственности как вменяемое лицо.

Еще одной особенностью УК КНР является то, что в качестве обстоятельства, смягчающего уголовное наказание является условие, что лицо, совершившее общественно опасное деяние, является глухонемым или слепым. Это хоть и не относится к психическим заболеваниям, но ввиду ограничения физических возможностей лица, мешают этому лицо отдавать себе отчет в последствиях совершенного деяния. К примеру, слепой человек не может в полной мере оценить окружающую его реальность с ее предметами и явлениями, особенно, если человек слепой с рождения и не имеет вообще визуального представления об устройстве мира.

Уголовное законодательство Турции предусматривает конкретные изменения уголовного наказания при совершении преступления лицом, находящемся в момент совершения общественно опасного деяния в состоянии психического расстройства, которое повлияло на свободу действий данного лица и на возможность осознания вредных последствий. Ст. 47 УК Турции предусматривает следующие сокращения уголовного наказания:

1) смертная казнь заменяется тяжким заключением на срок не менее 15 лет;

2) пожизненное тяжкое заключение заменяется тяжким заключением на срок от 10 до 15 лет;

3) пожизненный запрет на публичную службу заменяется временным запретом на публичную службу.

Иные наказания сокращаются от одной трети до половины [5].

УК Японии имеет отличную от привычной нам модель построения уголовного кодекса. Так основу составляет романо-германское право, но также присутствуют отдельные правовые нормы, сформулированные под влиянием англо-саксонской правовой семьи. Что касается института вменяемости, то ст. 39 УК Японии гласит: «Действие, совершенное психически ненормальным, ненаказуемо. Наказание за действие, совершенное слабоумным, подлежит смягчению» [6]. Тем самым присутствуют элементы ограниченной вменяемости, которые способствуют смягчению наказания. В этой роли выступает слабоумие лица, совершившего общественно опасное деяние. В отличие от УК РФ в данной статье есть конкретное указание на основание смягчения ответственности - слабоумие, что, с одной стороны, в каком-то роде является более совершенным шагом законодателя. Однако можно заметить, что, например, в законодательстве УК РФ слабоумие будет являться основанием признания лица невменяемым. И это вполне обоснованно, так как слабоумие является известным науке психиатрическим синдромом, который может быть в форме врожденной умственной отсталости либо же приобретенной деменции психики. Но, безусловно, при решении вопроса относительно вменяемости необходимы исследования врачей-психиатров для определения уровня психического здоровья лица.

Также за смягчение уголовного наказания в отношении лиц, совершивших общественно опасное деяние в состоянии психического расстройства, не исключающего вменяемость, выступает УК Республики Корея, отобразив это в ст.10 УК [3]. Помимо этого, в ст.11 УК Республики Корея в отдельную категорию вынесены глухонемые, в отношении которых закон предусматривает смягчение уголовного наказания.

Следует признать тот факт, что такое нечеткое определение сущности ограниченной вменяемости в уголовном законодательстве влечет за собой множество проблем как в понимании и толковании, так и непосредственно в правоприменительной практике. Законодателю следует наиболее детально раскрыть правовую природу института ограниченной вменяемости для стабилизации мнений ученых, а также приведения судебной практики к единообразному принципу решения проблемы.

\section{Литература}

1. Уголовный кодекс Китайской Народной Республики от 01.10.1997 г. (8-е издание от 25.02.2011г.).

2. Уголовный кодекс Республики Казахстан от 3 июля 2014 года № 226-V (с изменениями и дополнениями по состоянию на 16.11.2015 г.).

3. Уголовный кодекс Республики Корея от 18.09.1953 г. (в ред. Законов от 13.12.1997 г.).

4. Уголовный кодекс Российской Федерации от 13.06.1996 N 63-Ф3 (ред. от 28.11.2015).

5. Уголовный кодекс Турецкой республики от 01.03.1926 г. (в ред. от 30.04.2008 г.). 
6. Уголовный кодекс Японии (Закон № 45 от 24.04.1907 г. в ред. Закона № 91 от 12.05.1995 г.).

7. Долгова С. В. Особенности медицинского критерия ограниченной вменяемости // Вестник Балтийского федерального университета им. И. Канта. 2012. № 9.

8. Исмагулова А. Т. Коллизионные вопросы уголовной ответственности лиц, страдающих психическими расстройствами, не исключающими вменяемости, по законодательству РФ, республики Казахстан и ряда зарубежных стран // Вестник Челябинского государственного университета. 2009. № 7. 145 с.

9. Уголовное право. Общая часть: учебник. Изд. 2-е, перераб. и доп. / под ред. Л. В. Иногамовой-Хегай, А. И. Рарога, А. И. Чучаева. М.: КОНТРАКТ; ИНФРА-М, 2008. 560 с.

10. Шамгунов А. Н. Проблемы применения нормы уголовной ответственности лиц, с психическими расстройствами, не исключающими вменяемости, в судебной и судебно-психиатрической практике // Вестник Челябинского государственного университета. 2003. Вып. 2, т. 9.

\title{
Использование зарубежного опыта в повышении эффективности предупреждения правонарушений среди несовершеннолетних (на примере Монголии и Японии)
}

\author{
(ㄱ) Э. Ю. Хармаева \\ юрист ООО «Юралинк» \\ Россия, г. Москва \\ Erzhena.Kh@mail.ru
}

Эффективность системы предупреждения подростковой преступности в России может быть повышена посредством заимствования положительного опыта зарубежных стран, в частности государств азиатско-тихоокеанского региона.

В отличие от европейской, в частности российской криминологических школ, где основной формой реализации уголовной политики является нормативно-правовой акт, в азиатских государствах (Япония, Монголия и др.) не преувеличивают роль последнего как основного средства сдерживания преступности, и предпочтение отдается социальным и общественным аспектам противодействия противоправного поведения несовершеннолетних.

В начале XXI века интеграционные и глобализационные процессы в условиях стирания национальных различий между приграничными регионами России и Монголии заметно возросли. В настоящее время Монголия стремится развивать добрососедские отношения и сотрудничать не только с Россией, но и с ее субъектами на новой взаимовыгодной основе, используя многолетние, традиционные связи [4, с. 49].

Тем интереснее наблюдать за правоприменительной деятельностью субъектов профилактики правонарушений среди несовершеннолетних в соседнем для нас государстве [1 с. 64]. Закон Монголии «О профилактике преступлений» от 5 декабря 1997 года [8] является одним из основных нормативно-правовых актов регламентирующих данное направление. Можно смело отметить, что основные положения Закона находятся в строгом соответствии с международными стандартами в данной области: особая роль отводится участию общественности в профилактической работе п.V (5.1.4); роли средствам массовой информации и телевидению п. XI; в п. VI (6.1.3) на органы возложены обязанности выявления и устранения причин условий совершения преступлений несовершеннолетними.

Вышеперечисленный нормативно-правовой источник, как сама судебно-следственная практика правоохранительных органов Монголии определяет следующие важные стратегические аспекты в противодействии подростковой преступности [5, с. 140]:

- личное поручительство: два совершеннолетних лица, берущих на себя ответственность за подозреваемого или осужденного, письменно обязуются в прибытии в срок своего подопечного по повестке. Эти поручители должны иметь регистрацию по месту жительства, постоянную работу (ст.ст. 65, 77 УПК Монголии);

- залог имущества: в этом случае подозреваемый сам за себя поручается либо иные лица, учреждения переправляют на специальный счет деньги или ценные вещи. Размер залога определяется в зависимости от степени тяжести преступления или личного имущественного положения подозреваемого или осужденного. Если осужденный не прибудет по вызову в назначенное время, по решению судьи имущество, взятое в залог, становится государственной собственностью (ст. 67 УПК);

- передача под контроль родителей, родственников: Родители или иные заинтересованные лица дают письменное обязательство за положительное поведение подростка. В случае невыполнения своих обязательств родители или иные лица компенсируют все материальные затраты на поиски беглеца;

- наконец, задержание и арест несовершеннолетнего: данное решение судом принимается в исключительном случае, за совершение особо тяжкого преступления.

В случае задержания и обнаружения безнадзорных и беспризорных несовершеннолетних, их могут доставить с Центр установления места жительства, где могут находиться до двух недель (14 дней). Центр располагается в г. Улан-Батор, где доставленных детей фотографируют, дактилоскопируют, заводят личные дела безнадзорных детей. Подростков, имеющих родителей, отправляют по домам, а остальных определяют в Попечительские Центры или передают в местную сомонную администрацию. 
Интересным, на наш взгляд, видятся различные формы контроля за поведением несовершеннолетних, на которые обратили внимание правоохранительные и иные социальные органы в Монголии [11, с. 148].

Родительский контроль. Как показывает практика, и опыт самым распространенным способом освобождения от заключения является контроль несовершеннолетних подростков со стороны родителей, которые обязуются о примерном поведении своих детей и гарантируют прибытие подростков по первому вызову в полицейское управление.

Контролирующие центры. Такие Центры создаются в районных и сомонных образованиях, с целью интенсивного контроля несовершеннолетних, не находящихся под контролем родителей, подверженными к повторному совершению преступления. Главной задачей этих Центров является эффективное и результативное проведение свободного времени, досуга несовершеннолетних, отвлечение их от негативного воздействия со стороны.

Общественный или попечительский контроль. Как правило, данный вид контроля возлагается на представителей общественных, самодеятельных организаций, чаще всего студенческих (по педагогическому профилю). Студенты педагогических или юридических учебных заведений в тесном контакте с представителями полиции занимаются профилактической, организационной функцией, в качестве добровольного воспитателя.

Интенсивный домашний контроль с участием преподавательского коллектива общеобразовательных школ. Следующим распространенным методом контроля за детьми, подверженных девиантному поведению, является интенсивный домашний контроль. Подростков в обязательном порядке отдают на обучение в общеобразовательные школы, оказывают им поддержку и помощь, подключают их к остальным программам, дают возможность трудиться. Педагогический коллектив определяет конкретных учителей обязанных оказывать помощь несовершеннолетнему по месту его жительства.

Воспитание в Попечительских Центрах. В Попечительских центрах воспитываются беспризорные и брошенные дети, а также не имеющие родственников. Эти Центры, находящиеся в попечении сомонных администраций, как правило, расположены внутри жилого сектора, спального района (обыкновенные квартиры, жилые дома, двери которых всегда открыты для детей).

Воспитательно-попечительские семьи. В ряде странах есть опыт передачи несовершеннолетнего правонарушителя под контроль и надзор новым представителям общественности, чаще всего родственникам подростка. Государство привлекает такую категорию людей посредством небольшой ежемесячной оплаты, связанной с расходами в данной деятельности. Как показывает практика, вышеуказанный метод более приемлем для детей, оставшихся без попечения родителей, несовершеннолетним, подвергшихся семейному насилию. Следует отметить, что такая форма контроля и воспитания в Монголии распространена гораздо меньше.

Заслуживающим внимание считаем опыт реагирования на противоправное поведение несовершеннолетних, который имеется в Японии.

Следует отметить, что Япония - это одна из немногих развитых зарубежных стран, которая устояла в конце XX и начале XXI веков (годы кризисного положения с преступностью несовершеннолетних) и не перешла, как многие европейские страны, Канада, США к усилению уголовной политики в отношении девиантных подростков.

В Японии система субъектов профилактики правонарушений среди несовершеннолетних отделена от системы юстиции для взрослых и представляет собой необычную структуру [2, с. 123]. Уголовная политика в Японии осуществляется, как и в Монголии, основными группами субъектов - правоохранительные органы и представители общественности.

Несмотря на высокий уровень правонарушений несовершеннолетних, можем выделить такую особенность, как небольшой процент вынесенных приговоров в отношении подростков не связанных с лишением свободы. Какие же субъекты в Японии непосредственно заняты проблемами девиантных подростков? Так как основной целью всей государственной правоохранительной машины провозглашено предупреждение и профилактика преступлений несовершеннолетних, в государстве имеется ряд ведомств, как государственных, так и общественных занятых в данной сфере деятельности.

В судебной системе Японии можем заметить такую интересную структуру, как семейные суды, которые заняты производством дел в отношении несовершеннолетних, включая право предварительного рассмотрения вопроса о возбуждении уголовного преследования [3, с. 125] и, тем самым, приравнены по их правовому статусу к судам общей юрисдикции.

Еще одна особенность, характерная для юстиции Японии, это возможность семейных судов назначать так называемые «обследования» условий жизни и пребывания девиантного подростка. «Обследования» могут проводить специалисты, которые структурно входят в судебную систему Японии в качестве экспертов. В отдельных случаях несовершеннолетних правонарушителей могут отправить на стационарное обследование, которое располагается в специальных центрах по месту жительства. Как отмечают сами представители практических органов институт обследователей - одна из самых эффективных форм и моделей японского семейного суда.

Кроме этого, существует и полицейская «ранняя профилактика» в задачу, которой входят превентивные действия правоохранительных органов на более раннем этапе.

В соответствии с практикой и статистическим данными в Японии уголовное наказание для несовершеннолетних - исключительная мера. По данным Н. А. Морозова [6, с. 157] семейные суды основной упор направляют на воспитательный и предупредительный аспект, в отличии от чрезвычайных, жестких и строгих мер уголовно-процессуального принуждения.

До 80 \% несовершеннолетних по всем обвинительным приговорам осуждаются условно, в этом можно найти определенные сходства с российской современной статистикой судебных приговоров в отношении несо- 
вершеннолетних. Деятельность семейных судов имеет приоритетный характер в отношениях с прокуратурой по уголовным делам, совершенными подростками. Если первый посчитает карательную реакцию излишней, могут быть назначены наказания, не связанные с изоляцией от общества, в крайнем случае, исправительная школа закрытого типа.

Как и в Монголии, можем заметить особую роль и значение муниципальных органов по предупреждению подростковой преступности. Эту деятельность координируют префектуральные и местные советы по проблемам молодежи и комплексные Центры по руководству несовершеннолетними, цель которых - положительное воздействие на подрастающее поколение. Центры включают в себя представителей образовательных заведений, членов добровольных ассоциаций, опорные пункты, куда могут входить и полицейские.

Среди различных самодеятельных общественных организаций в Японии выделяется особенный субъект профилактики - это население, т.е. обычные граждане, не связанные с деятельностью по контролю над преступностью, общественные формирования (ассоциации граждан), работающие на добровольных началах в этой области [7, с. 155].

Ассоциации «Big Brothers and Sisters Movement» («старших братьев и сестер»- разновидность молодежного движения, появившегося впервые в начале XX в. в США. Кроме молодежных добровольных организаций, в данном направлении можем видеть и женские общества реабилитационной помощи, которые также заняты адаптацией несовершеннолетних правонарушителей [9, с. 163].

Очень знакомое для современной школьной общественности в России [12], объединение «Рarents and Teachers Association» - ассоциация родителей и учителей, в задачу которой входят: решение возникших проблем с родителями и учителями; проведения совместных мероприятий по оздоровлению среды, окружающей детей и др.

Особая роль в Японии отводится комитетам самоуправления (квартальные комитеты), которые расположены во всех префектурах. Функции этих комитетов определяются в основном в решении местных вопросов, касающейся защиты населения от стихийных бедствий, сил природы, пожаров, в том числе и предупреждения преступности.

Таким образом, изучение уголовной политики азиатских государств , в частности Японии, Монголии показывает универсальность целого ряда выводов, относимых и к российской действительности, в том числе о нежелательности чрезмерного применения жестких мер в отношении несовершеннолетних за их противоправное поведение, а использовать в большей мере возможности общественных структур в ресоциализации отклоняющегося поведения несовершеннолетних [10, с. 111]. Для современного российского законодателя может быть полезен принцип «экономии уголовной репрессии», отчасти последние изменения в отечественном законодательстве в отношении несовершеннолетних являются тому примером.

\section{Литература}

1.Амгаланбаяр Ц. Предупреждение преступности несовершеннолетних в Монгольской Республике // Вопросы ювенальной юстиции. М., 2002. С.64.

2. Белявская О. А. Ответственность несовершеннолетних по японскому законодательству и практика его применения // Несовершеннолетние: их возрастные особенности и проблемы правовой ответственности. М., 1992. С. 120-128.

3. Белявская О. А. Уголовная политика Японии. М: ИНИОН АН СССР, 1991. С. 25-28.

4. Дугаров В. Д. Опыт интеграционных процессов Республики Бурятия и регионов Сибирского федерального округа с приграничными территориями Монголии // Монголия и Россия: новые парадигмы отношений: материалы междунар. науч.практ. конф. (21 апреля 2011 г.). Улан-Батор, 2011. С. 49.

5. Монгол улсын Эруугийн байцаан шийтгэх хууль. Улаанбаатар хот, 2002. Н. 140-141, 152-153.

6. Морозов Н. А. Преступность и борьба с ней в Японии. СПб.: Юридический центр Пресс, 2003. С. 157.

7. Морозов Н. А. Преступность и борьба с ней в Японии. СПб.: Юридический центр Пресс, 2003. С. 155

8. О профилактике преступлений: Закон Монгольской Республики // Сб. законов Монгольской Республики. Улан-Батор, 2002.

9. Уэда Канн. Преступность и криминология в современной Японии / пер. с яп.; под ред. Н. Ф. Кузнецовой и В. Н. Еремина. М.: Прогресс, 1989. С. 163.

10. Хармаев Ю. В. Особенности уголовной политики в отношении несовершеннолетних в Монголии // Судебная реформа 1864 года, ее значение и влияние на развитие общества и государства: материалы всерос. науч.-практ. конф. ОреховоЗуево: Изд-во МГОГИ, 2015. С. 111-117.

11. Хармаева Э. Ю. Особенности профилактики правонарушений и преступлений среди несовершеннолетних (по законодательству России и Монголии) // Сравнительное правоведение в странах Азиатско-тихоокеанского региона-V: материалы междунар. науч.-практ. конф. (12 апреля 2013 г.). Улан-Удэ: Изд-во БГУ, 2013. С. 148.

12. По аналогии с российскими общественными объединениями при общеобразовательных учебных заведений, такими как «Родительские комитеты», «Советы отцов» и др.

\section{Обзор «Закона о борьбе с терроризмом» Китая}

(С) Цзан Цземэй

докторант Политико-юридического университета Китая (г. Пекин)

«Закон о борьбе с терроризмом» принят путем голосования на 18-той сессии Постоянного Комитета ВСНП 12-го созыва. Данный закон состоит из 10 глав и 97 статей, и введен в силу первого января 2016 года. Реализа- 
ция «Закона о борьбе с терроризмом» дает законное основание Китаю для подавления террористических событий и террористов.

I. Опубликование «Закона о борьбе с терроризмом»

1 января 2016 года «Закон о борьбе с терроризмом» был официально введен в действие. Он состоит из 10 глав и 97 статьей и предусматривает соответствующие установление в области признания, предосторожности безопасности, разведывательной информации, расследования, ответной обработки, международного сотрудничества, мер по обеспечению гарантий, судебной ответственности и т.д. для организации лиц с террористической деятельностью.

В статье 3 дано четкое определение терроризма - «притязание и поведение к созданию общественной паники, нарушению общественной безопасности и посягательства на человеческую жизнь и имущество путем таких средств как насилие, разрушение, запугивание и т.д., или принуждение государственных органов и международных организаций к достижению своих политических целей, идеологии и т.д.».

Во-первых, необходимо четко определить руководящие органы и системы по борьбе с терроризмом.

В законодательстве Китая четко определены существующие и руководящие органы системы в отношении борьбы с терроризмом. Отрегулирована нынешняя ситуация борьбы с терроризмом под руководством нескольких органов, таким образом, в будущем борьба с терроризмом станет более эффективной и удобной. С самого начала «Закон о борьбе с терроризмом» определенно указывает на то, что в борьбе с терроризмом неизбежно предстоят многочисленные вопросы в координации, при отсутствии единого и высокоэффективного рабочего механизма у руководства по борьбе с терроризмом даже появится состояние задержки или снятия с себя ответственности.

В соответствии с существующей рабочей системой для руководства по борьбе с терроризмом Китая, государственная руководящая группа по борьбе с терроризмом является высшим органом системы.

Во-вторых, профилактические меры: предупреждение, профилактика, предотвращение.

Безопасность охватывает целый ряд аспектов. В основном они разделены на три категории, первая - профилактика, вторая - оборона населения, третья - физическая оборона. Необходимы гласность и образование, участие населения в борьбе с терроризмом как в рамках оборонного характера, чтобы общество знало, что помимо профессиональных Департаментов по борьбе с терроризмом практически каждый человек может принять участие в борьбе с терроризмом.

Также необходимы технологии, в первую очередь, террористической деятельности, технической подготовленности, в том числе увеличение камер в общественных местах. Важна физическая оборона нефтепродуктов, опасных веществ и т.д., чтобы принимать меры предосторожности с опасными грузами.

В-третьих, установка национального центра информации о борьбе с терроризмом.

Установлен национальный центр информации о борьбе с терроризмом, который является центром для единого планирования, исследования, определения, сбора и координации. Другие различные функциональные отделы должны укрепить силу сбора информации о борьбе с терроризмом вокруг национального центра информации о борьбе с терроризмом и представить информацию этой платформе. Межотраслевое обращение информации касается динамического сбора информации и совместного использования данных, оно занимает важное положение в «Законе по борьбе с терроризмом», а также является одной из самых ключевых содержимых о борьбе с терроризмом, т.е. подавление террористической деятельности в начальной стадии, раннее выявление, раннее вмешательство и раннее поражение.

В-четвертых, определение преждевременного права на командование командиром.

Вышеуказанные три пункта относятся к предварительным работам по борьбе с терроризмом. Данный пункт касается обработки внезапного террористического события и соответствующих работ по ликвидации. После появления террористической деятельности, обработка события касается несколько отделов, таким образом, появится вопрос командования на месте, доклад, запрос и координация в определенной степени задержки и времени для обработки. После опубликования «Закона о борьбе с терроризмом» командующий на месте должен полностью отвечать за события в целях уменьшения вреда людям.

В-пятых, наличие правового основания для международного сотрудничества в борьбе с терроризмом. В отношении террористической угрозы, предстоящей Китаю, проблема о «скрытой злой силе» за рубежом является очень очевидной, даже весьма серьезной, в том числе зарубежной Восточно-Туркестанской злой силы и Восточно-Туркестанского исламского движения. Районы деятельности этой «скрытой злой силы» не находится на территории Китая, поэтому надо коренным образом изменить, т.е. не только подавить террористов перед нами, совершающих террористическую деятельность, но и наказать по всей строгости закона скрытую злую силу. Когда связь между террористической организацией за рубежом и террористами на территории Китая еще более тесна, кооперация по информации и юстиции в международной борьбе с терроризмом является необходимой. Закон о борьбе с терроризмом предоставит нам правовое основание для укрепления сотрудничества по борьбе с терроризмом с соседними странами.

II. Уголовная ответственность за преступления террористической деятельности в Законе о борьбе с терроризмом

Статья 79 в «Законе о борьбе с терроризмом» предусматривает, что лицо, организовавшее, планировавшее, готовившее к совершению, совершившее террористическую деятельность, распространявшее терроризм, подстрекавшее к совершению террористической деятельности, незаконно обладавшее предметами для распространения терроризма, принудительно позволившее другим носить украшения и знаки для распространения терро- 
ризма в общественных местах, организовавшее, руководившее и участвовавшее в организации террористической деятельности, и оказавшее помощь организации террористической деятельности, персоналу террористической деятельности, совершению террористической деятельности или подготовке террористической деятельности, будут привлечены к уголовной ответственности в соответствии с законом.

В «Поправке к уголовному кодексу (VIIII)», введенной в силу 1 ноября 2015 года, дополнительно предусматривают некоторые новые преступления террористической деятельности, таким образом, уголовные нормы и правила преступлений террористической деятельности становятся еще более крепкими. Кроме того, террористическая деятельность, предусмотренная в ст. 79 «Закона о борьбе с терроризмом» соответствует п. 2 «Подготовка преступления и планировка террористической деятельности» и п. 3 ст. 120 «Распространение терроризма, экстремизма и подстрекательства к совершению террористической деятельности», п. 6 ст. 120 «Пропаганда террористических и экстремистских предметов: книг, аудио или видео материалов», п. 5 ст. 120 «Ношение костюмов пропагандирующие терроризм, экстремизм, является преступлением», ст. 120 «реступление по организации, руководству и участию в террористических организациях» и п. 1 «Финансирование террористической деятельности». В ст. 120 Уголовного Кодекса в отношении действия совершения, тем самым, реализуя соответствие и примыкание между «Законом о борьбе с терроризмом» и Уголовным кодексом в отношении положения по уголовной ответственности преступления террористической деятельности.

III. заключение

Уголовный Кодекс определяет действие и результаты террористической деятельности, и угрожает террористам путем наказания их преступления, из-за чего устрашающая сила для террористов является недостаточной. Целью террористов является успешное совершение террористической деятельности, а сущностью борьбы с терроризмом является заблаговременное предотвращение. Опубликование «Закона о борьбе с терроризмом» эффективно достигло цели заблаговременного предотвращения. Но мы не можем быть слепо оптимистичными, точность антитеррористической правовой системы должна быть проверена на практике борьбы с терроризмом, много вопросов может возникнуть в практике борьбы с терроризмом, в связи с этим мы должны осторожно выявить их и тщательно обобщить в будущей практике, тем самым делая антитеррористическую правовую систему более зрелой и точной.

\title{
Литература
}

1. Чжан Минкай. К «Поправке к Уголовному Кодексу (VIIII)» о преступности терроризма // Современное право. 2016. № 1.

2. Чжоу Хунбо. Понимание и применение в Поправке к Уголовному Кодексу (VIIII)» нового террористического преступления // Китайский прокурор. 2015.№ 10.

3. Ли Хун. Уголовное законодательство в «Поправке к Уголовному Кодексу (VIIII)», связанное с терроризмом, экстремизмом преступностью // Журнал Цучжоуского университета. 2015. № 6.

\section{Неисполнение обязанностей по воспитанию несовершеннолетнего по уголовному законодательству Российской Федерации и Китайской Народной Республики: сравнительно-правовой анализ}

\author{
(С) А. В. Цицикков \\ магистрант 2 года обучения юридического факультета \\ ФГБОУ ВО «Бурятский госуниверситет» \\ Россия, г. Улан-Удэ \\ tsytsykov.ayur@mail.ru
}

С переходом России на рыночную экономику негативным образом отразились в первую очередь на сферу семейных отношений, в части падения доходов семьи, рост безработицы, задержки и невыплаты заработных плат, в следствии чего злоупотребление родителями алкоголем, наркотиками, что не могло не отразиться на положение наших детей, многие из которых нередко подвергались физическому и психическому насилию в семье, в школе, на улице, с целью получения источника дохода дети могли подрабатывать на заправочных станциях, вокзалах, на стихийных рынках и др. местах вынужденные зарабатывать на жизнь различными способами.

В Уголовном кодексе преступления такого вида включено такая норма как неисполнение обязанностей по воспитанию несовершеннолетнего [2]. Анализ нововведений данной статьи говорит нам, что были внесены изменения в сторону применения законодательством мер, способствующих ужесточению санкции по преступлениям связанных с неисполнением по воспитанию несовершеннолетнего. Нововведением статьи 156 УК РФ стало отнесение данного состава преступления к категории преступлений средней тяжести.

Ужесточив меры ответственности за преступление, предусмотренное ст. 156 УК РФ, законодательство вовсе исключило из санкции данной статьи такую ответственность, как ограничение свободы гражданина, совершившего данный вид преступления.

Неисполнение родителями или иными законными представителями несовершеннолетних обязанностей по содержанию и воспитанию несовершеннолетних влечет не только моральную сторону вопроса, но и административную ответственность [2]. 
Согласно судебной практике, угрозу жизни и здоровью ребенка представляют действия (бездействие) родителей и иных лиц, воспитывающих детей, в результате которых ребенку причинены телесные повреждения либо его здоровье значительно ухудшилось.

В настоящее время в теории остается спорным понимание таких вопросов, как обязательность систематического характера неисполнения обязанностей по воспитанию несовершеннолетнего; понимание жестокого обращения с несовершеннолетним как такового, соотношение жестокого обращения и насилия при неисполнении обязанностей по воспитанию. На наш взгляд, необязательно устанавливать систематический характер неисполнения обязанностей по воспитанию несовершеннолетнего, так как в законе текстуально отсутствует такое требование, то есть криминальным может быть и однократное исполнение указанного деяния. Понятие "жестокое обращение" слабо разработано в уголовно-правовой науке [3].

Данные преступления в отношении несовершеннолетних происходит в большинстве случаев в семье или же закрытых учреждениях социальной защиты, что в свою очередь осложняют процесс расследования. Так как на протяжении определённого периода времени родители или уполномоченные лица не исполняют обязанности по воспитанию детей одновременно допуская жестокое обращение с несовершеннолетними.

В целях профилактики данных преступлений необходимо в качестве мер воздействия за неисполнение возложенных обязанностей по воспитанию детей увеличить сроки исправительных работ и вместо ограничения свободы установить санкцию в уголовном законодательстве в виде лишения свободы.

Неисполнение или ненадлежащее исполнение лицом обязанностей по воспитанию несовершеннолетнего возникает только в тех, случаях, когда на лицо возложена обязанность, т.е. он должен был и мог выполнить данную обязанность. Обязанность по воспитанию несовершеннолетнего вытекает из Конституции Российской Федерации из которого следует, что лица в силу закона обязано принимать участие в воспитании несовершеннолетнего ребёнка.

Таким, образом можно сказать, что неисполнение лицом обязанностей по воспитанию несовершеннолетнего ребёнка происходит тогда, когда родитель или иное лицо согласно закона, родительского долга и иных документов было обязано осуществлять воспитание ребенка и имелось реальная возможность данную обязанность исполнить, но проявило бездействие, безучастие в жизни ребёнка.

В связи с чем, судам необходимо в каждом случае устанавливать наличие правовой обязанности на выполнение воспитательного процесса, факт зависимости потерпевшего от виновного, и реальной возможности выполнения данной обязанности у конкретного лица.

В Уголовном кодексе Китайской Народной Республики в ст. 239 предусматривает наказание в виде лишения свободы на срок 10 и более лет, либо пожизненное лишение свободы, а в качестве дополнительного наказания - штраф либо конфискация имущества за похищение младенца, малыша с целью вымогательства ценностей, а в случае причинения захваченному лицу смерти или его убийства виновный подлежит смертной казни. В ст. 240 УК КНР предусмотрена ответственность за «похищение, обман с целью продажи женщины, ребёнка» которые наказываются лишением свободы на срок от 5 до 10 лет и дополнительно штрафом.

Под похищением, обманом с целью продажи женщины, ребёнка нужно понимать одно из следующих деяний: похищение обманным путём, захват, приобретение продажа, приём, отправка. Установление такого наказания китайским законодателем обусловлено сложившейся в КНР сложной ситуации. В ст. 262 той же главы УК Китая устанавливается ответственность за похищение обманным путём ребёнка, не достигшего 14 лет, с целью разлучения с семьёй или опекуном. Наказание за данное преступление менее строгое (до 5 лет лишения свободы), чем за схожее деяние, но совершённое с иной целью.

УК КНР в ст. 261 установил наказание в виде лишения свободы на срок до 5 лет, ареста либо надзора за «отказ от содержания пожилых, малолетних, больных или других лиц, не имеющих способности к самостоятельной жизни, со стороны тех, на ком лежит обязанность по содержанию, при злостных обстоятельствах».

В ст.260 УК КНР предусмотрена наказание в виде лишения свободы на срок до 2 лет, арестом или надзором за «жестокое обращение с членами семьи при злостных обстоятельствах». Если данное преступление повлекло «тяжкое телесное повреждение» или смерть потерпевшего, то виновный наказывается лишением свободы на срок от 2 до 7 лет.

В КНР в 1991 г. был принят Закон о защите несовершеннолетних, в котором четко предусмотрена система семейной, школьной, социальной и судебной защиты для несовершеннолетних. Кроме того, в 1999 г. был принят Закон о профилактике преступности несовершеннолетних, руководящей идеей которого является "сочетание защиты прав несовершеннолетних с профилактикой". Оба вышеуказанных Закона регламентируют следующие принципы привлечения несовершеннолетних к уголовной ответственности: применение установки на "воспитание, исправление и спасение"; осуществление руководящей идеи "приоритет воспитательных мер над применением наказания".

Для того чтобы соответствовать идеям гуманизма и защиты несовершеннолетних преступников, содержащимся в двух вышеуказанных специальных законах о несовершеннолетних, в 2011 г. были внесены изменения и поправки в Уголовный кодекс КНР.

Таким образом, нам представляется, что не конца оцениваются последствия неисполнения обязанностей по воспитанию несовершеннолетнего. Необходимо, чтоб к субъектам данного преступления должны применялись более серьезные меры уголовной, административной и иной ответственности. И исходя из этого, следует разграничить ответственность родителей за неисполнение обязанностей по воспитанию несовершеннолетнего от 
ответственности должностных лиц, которые в силу своих наделённых полномочий взялись за воспитание несовершеннолетнего.

Основной задачей уголовного законодательства Российской Федерации и законодательства Китайской Народной Республики в отношении несовершеннолетних является предупреждение правонарушений и меры воспитательного воздействия на несовершеннолетнего с целью возврата юного правонарушителя в общество. Нам необходимо оградить от влияния нерадивых родителей и условий, влияющих на них негативно в семье пока наш несовершеннолетний правонарушитель не встал на путь «профессионального преступника».

\title{
Литература
}

1. Красиков А. Н. Преступления против личности. Саратов, 1999. С. 177.

2. Кодекс Российской Федерации об административных правонарушениях от 30.12.2001 N 195-Ф3 (ред. от 12.02.2015) (с изм. и доп., вступ. в силу с 01.03.2015).

3. Уголовный кодекс Российской Федерации от 13.06.1996 N 63-Ф3 (ред. от 30.03.2016);

4. Николаева Ю. В. Охрана интересов семьи уголовно-правовыми средствами: дис. ...канд. юр. наук. М., 1995. С. 59.

\section{Сравнительно-правовой анализ организованной преступности в РФ и КНР}

\author{
(C) E. В. Чагдуров \\ магистрант 2 года обучения юридического факультета \\ ФГБОУ ВО «Бурятский госуниверситет» \\ Россия, г. Улан-Удэ \\ mikelanjelo922@mail.ru
}

В настоящее время наиболее опасной и разрушительной и для России и для КНР, несомненно, является организованная преступность. Она оказывает вполне негативное воздействие не только на экономические, но и на социальные, морально-психологические, социокультурные и иные процессы в обществе. Ежегодные доходы от организованной преступности в конце XX в. составили около 400 млрд. долл.

Формирование организованной преступности в Китайской Народной Республике хотя и имеет свои исторические корни, вместе с тем в определенной мере повторило путь многих государств. В ее формировании не малую роль сыграли такие общемировые процессы, как несоблюдения устойчивости в экономике и социальной сфере государства, разложение бюрократических структур государства, несоблюдение принципов социальной справедливости, обесценивание моральных ценностей, накопление больших ценностей в теневой экономике и интенсивный выход ее из тени и др. Специфические же национальные корни организованной преступности в КНР связаны с давней историей существования в этой стране таких сообществ, как «триады», послужившие базой для создания организованных преступно-мафиозных организаций.

Интенсивное формирование организованной преступности в КНР возникло с этапа реформирования Китайской экономики с середины 70-х гг. ХХ в. В настоящее время организованная преступность представляет для КНР такую же опасность, как и во многих странах мира. Непосредственно организованная преступность стала одним из важных условий, социально-экономической нестабильности, ухудшения криминальной ситуации в стране. По этой причине борьба с организованной преступностью в КНР стала одной из важных задач правоохранительных органов страны. В КНР на законодательном уровне к основному инструменту борьбы с анализируемым явлением относится указ об организованной преступности и особо тяжких преступлениях, который позволяет выносить жесткие приговоры, осуществлять конфискацию контрабандных товаров и денежных средств. В 1997 г. впервые ряд положений, касающихся понятия «преступное сообщество», ответственность главного преступника за организацию и руководство преступным сообществом, были включены в УК КНР.

Не только зарубежные, но и китайские исследователи отмечают рост оргпреступности в различных сферах КНР, в частности в организации наркотрафика, торговли оружием, нелегальной миграции, похищения людей, вымогательств, убийств, ограблений, краж и т.п. Промежуток с начала до конца 1990-х гг. характеризовался как лавинообразным увеличением числа преступных групп, так и расширением сферы их действия. Банды появлялись не только в городах, но и в сельской местности, на основных автомагистралях и т. д. В то же время происходили качественные изменения преступных сообществ, имеющих свойства ОПГ. Увеличивался уровень их организованности, расширялась территория деятельности, выражалось желание к установлению контактов с иностранными ОПГ, увеличивался диапазон совершаемых преступлений, совершенствовались техническое оснащение и вооружение, формировался и легализовался капитал, подконтрольный ОПГ.

Катализирующим условием в формировании организованной преступности в континентальном Китае стало активное проникновение на его территорию иностранных криминальных структур: корейских, японских, английских (Чжунго Лун) и американских (Фучжоу фэйлун бан), а кроме того ОПГ, функционирующих на территории Гонконга и Тайваня. Помимо этого, важным условием стремительного формирования китайских ОПГ представилось формирование «китайского канала» наркотрафика, протекающего с местности «золотого треугольника» (района на стыке границ Лаоса и Таиланда, где изготавливалась существенная доля мирового объема производства героина) через провинцию Юньнань, приморские города Китая и далее транзитом через Тайвань и Гонконг в районы окончательной реализации. 
С начала XXI века организованная преступность КНР вышла на наиболее высокий уровень развития. Территориально областью деятельности преступных сообществ чаще всего становятся несколько уездов и городов; число действующих участников ОПГ доходит до нескольких сотен человек. Обширное продвижение приобретают ОПГ с четкой иерархической структурой. Все больше преступных сообществ КНР применяют способы управления, используемые на современных предприятиях. Происходит усовершенствование технологического оборудования ОПГ. Оформляются особенности слияния бизнеса и криминала (завершение формирования теневого капитала). Наблюдается и тревожный фактор сращивания криминала и власти. С одной стороны, наибольшее количество китайских госслужащих оказывается причастными к деятельности ОПГ, с другой - лидеры китайских ОПГ достигают наиболее высоких постов во властных структурах.

В России официальное признание факта существования организованной преступности произошло в 1989 г. с принятием Верховным Советом СССР Постановления от 4 августа 1989 г. «О решительном усилении борьбы с преступностью», в котором отмечалось, что «в стране резко возросла преступность, в том числе организованная». Последующее нормотворческое развитие способствовало включению в новый Уголовный кодекс ряда положений, регламентирующих вопросы борьбы с организованной преступностью. Так, в ч. 3 ст. 35 Общей части УК РФ 1996 г. указывается, что преступление признается совершенным организованной преступной группой, если оно совершено устойчивой группой лиц, заранее объединившихся для совершения одного или нескольких преступлений. При этом свыше 70 составов преступлений Особенной части (п. «ж» ч. 2 ст. 105; п. «г» ч. 2 ст. 112; п. «е» ч. 2 ст. 117 и др.) содержат в качестве квалифицирующего признака - совершение преступления организованной преступной группой.

В количественном отношении, согласно официальной статистике МВД РФ, за период январь-декабрь 2015 года организованными группами или преступными сообществами совершено 13,3 тыс. тяжких и особо тяжких преступлений $(1,7 \%)$, их удельный вес в общем числе расследованных преступлений этих категорий остался на уровне января - декабря 2014 года - 5,1\%.. Вместе с тем, как отмечают многие российские исследователи, для нее характерен высокий уровень латентности (вследствие высокого криминального профессионализма, конспиративности действий, возможности прикрытия своей деятельности со стороны коррумпированных чиновников и пр.). Помимо этого для противоправных действий преступных организаций характерны использование взрывов, других общеопасных способов совершения преступлений.

Криминальный бизнес крепко связал организованную преступность региона с многочисленными государствами АТР. Вместе с тем, следует отметить, что существенная доля совершенных преступлений носит высоколатентный характер. Еще более латентна деятельность организованной преступности, для которой характерны сплоченность, собранность, жесткая конспирация. При этом коррумпированные должностные лица оказывают содействие каждому третьему противозаконному формированию. Это также связано с несовершенством самих криминалистических учетов информационных центров органов внутренних дел и неопределенностью критериев, согласно которым необходимо относить преступления к деятельности организованной преступности, с зависимостью показателей от возможностей процессуального доказывания преступной деятельности и т.п.

Сравнительный анализ показывает, что в общих чертах криминалистических свойств организованной преступности в Китайской Народной Республике и Российской Федерации есть много общего, а именно, в направленности её преступных интересов, стремлении к монополизации преступного бизнеса, наличии большой материальной базы, характере и развитости коррупциональных связей и др.

Одновременно с этим имеются, и характерные черты, сопряженные со своеобразием видов организованной преступности в КНР, в особенности таких ее видах, как Триады.

Имеется общее и специфика в отдельных элементах их криминалистических характеристик.

Наличие единых качеств в их криминалистических свойствах дает возможность применять в практике расследования данных преступлений в КНР отдельные методические рекомендации, разработанные криминалистами РФ.

Немало общего есть в общеметодических подходах к расследованию данных преступлений в КНР и РФ. А именно, общее прослеживается в: способах получения розыскной информации; основаниях и тактике возбуждении таких уголовных дел; методах установления основных направлений расследования; способах установления основной криминальной направленности действия организованных групп и т. д.

Это кроме того дает возможность применять китайскими криминалистами отдельные методические рекомендации криминалистов России.

Транснациональная организованная преступность - одна из острых и сложных проблем, вставших перед нашим обществом на рубеже тысячелетий. Она оказывает мощное воздействие на все сферы общественной жизни, не только нарушает нормальное функционирование социальных и экономических институтов страны, является реальной силой, подрывающей безопасность государства и общества, но и представляет собой новую серьезную угрозу существованию всего мирового сообщества. Правоохранительным органам весьма сложно пробраться в хорошо организованные и оснащенные транснациональные криминальные труппировки, использующие насилие и подкуп, действующие в пространстве, охватываемом юрисдикцией различных стран. Стремление к сверхнаживе с использованием любых средств привело к расширению таких взаимосвязанных видов транснациональной преступности, как нелегальная миграция, наркобизнес, незаконный оборот оружия, терроризм, незаконная вырубка леса, незаконная добыча и реализация нефрита за границу.

Таким образом, для более эффективной борьбы с организованной преступностью следует усилить международное и китайско-российское сотрудничество. Наиболее перспективны будут следующие направления: уси- 
ление сотрудничества правоохранительных органов в пограничных регионах; повышение квалификации персонала правоохранительных органов обоих государств; формирование финансовых инструментов поддержки сотрудничества между КНР и РФ; совершенствование сотрудничества в борьбе с легализацией (отмыванием) доходов от преступной деятельности, также усиление карательно-репрессивных мероприятий в отношении организованных преступных группировок.

\section{Литература}

1. Уголовный кодекс Российской Федерации от 13.06.1996 N 63-Ф3 (ред. от 30.03.2016).

2. Уголовный кодекс Китайской Народной Республики / под ред. А. И. Коробеева, пер. с кит. Д. В. Вичикова. СПб.: Юридический центр Пресс, 2001.

3. Лунеев В. В. Преступность ХХ в.: мировые, региональные и российские тенденции. М., 2003.

4. Баранник И. Н. Транснациональная организованная преступность и сотрудничество правоохранительных органов российского Дальнего Востока и стран АТР в борьбе с ней (криминологические аспекты): дис. ...канд. юр. наук. Владивосток, 2006. 222 с.

5. Иванов А. Я., Корчагин А. Г. Сравнительное уголовное право: учебник. Владивосток, 2002. 129 с.

\section{Кибертерроризм}

(ㄱ) И. А. Чернышев

магистрант 1 года обучения юридического факультета ФГБОУ ВО «Бурятский госуниверситет»

Россия, г. Улан-Удэ

chigal1994@gmail.com

Актуальность данной статьи обусловлена серьезной угрозой человечеству со стороны кибертерроризма. Имеющийся на данный момент у мирового сообщества опыт недостаточен для полноценного противодействия данной угрозе и говорит о наличии гарантированной уязвимости любого государства. Это напрямую связано с тем, что кибертерроризм является транснациональным явлением, а его участники имеют возможность угрожать информационным системам из любой точки мира. Ведь используя глобальную сеть Интернета террористам можно собрать подробную информацию об объектах атак, их местонахождении. Так же осуществление сбора денег для поддержки террористических движений.

Кибертерроризм - это технический вид терроризма. По мнению А. Кассиса [1](американский политолог), существует более сотни определений данного понятия. Предпосылкой возникновения такого феномена, как терроризм, в какой-то степени является проявление информационного терроризма в псевдонаучной среде. Т.е. понятие кибертерроризм эволюционировало от информационного терроризма.

Постоянно растет число пользователей сети Интернет. В США их уже 158 миллионов, в Европе - девяносто пять, в Азии - 90, в Латинской Америке - четырнадцать, а в Африке - три. В России, по разным оценкам, количество пользователей Интернет составляет от 3,5 до 8 миллионов человек. [4]

Сегодня можно говорить, что Интернет охватывает все страны мира, так как с применением новых технологий (использование мобильных спутниковых устройств связи) возможно подключение к сети Интернет с любой точки земного шара. Если же говорить о развернутой инфраструктуре, то в таком контексте Интернет охватывает сегодня более 150 стран мира.

В настоящее время более 100 стран, в том числе 60\% членов Интерпола, не имеют законов, предназначенных для борьбы с киберпреступлениями».[2; стр 2]

Удачным примером профилактики информационных преступлений можно назвать Южную Корею. Ввиду развития информационных технологий, Южная Корея входит в число лидеров-стран, в которых были приняты законы об электронном обучении, индустрии электронного обучения и об индустрии знаний. Примером такой системы является «E-Learning». Существует определение, которое дали специалисты ЮHЕCКО: «е-Learning обучение с помощью Интернет и мультимедиа».[5] Новые технологии дают возможность получать знания жителям самых удаленных регионов страны, в том числе детям-инвалидам. Об этом и многом другом рассказал профессор южнокорейского Университета Сунгьюнкван Дэ Джун Хван. В стране поддерживают e-learning на государственном уровне. E-learning трансформировался в многообещающий бизнес, объемы которого ежегодно растут на $8,2 \%$. Сегодня в Корее на основе закона о высшем образовании и закона о непрерывном образовании работают 18 виртуальных университетов.

Министерство обороны Японии в свою очередь создаст комитет для защиты компьютерных сетей от растущего числа кибератак. Напомним, что в июле 2009г. правительственные сайты в Южной Корее и США были атакованы целой волной данных от зараженных вирусами компьютеров из нескольких десятков стран. Зараженная вирусами электронная почта была послана также в Министерство обороны и Силы самообороны Японии.

Помимо этого списка существует еще множество мер, которые принимаются правительствами данных стран. Проблема приобретает все больший масштаб и отрицать ее актуальность и необходимость решения становится просто бессмысленным. 
Китай также, как и другие страны Восточной Азии, подвержен кибератакам. Но при этом мы можем говорить о том, что киберпреступления в основном процветают именно в этой стране. Как уже было сказано выше правительство КНР «закрывает глаза» на действия преступников. Или даже молчаливо «поощряют» их действия, ведь пиратство в Китае помогает в развитии информационных технологий.

Явным признаком такого «поощрения» является то, что Китай не принял участие в подписании как Европейской Конвенции по киберпреступлениям, так и Окинавской Хартии глобального информационного общества.

Предполагается, что мерами уголовно-правового противодействия кибертерроризму можно добиться существенного улучшения состояния защищённости критически важных объектов информационной инфраструктуры России.

Мнения исследователей по данному поводу разделились на два основных направления. Так, одна группа исследователей проблемы кибертерроризма полагает, что кибертерроризм подпадает по действие ст. 205 УК РФ и не требует включения в уголовный закон ещё одной нормы. Так, Д.Б. Фролов считает, что в ст. 205 УК РФ [3] налицо все признаки терроризма: и политическая окраска, и совершение деяний с целью создания атмосферы страха, напряженности, паники, и принцип публичности (четко выделяющий эту категорию преступлений из остальных разновидностей киберпреступности), и направленность не на конкретных лиц (в отличие от других видов преступлений), а на неопределенный круг граждан, становящихся жертвой кибертеррора. Только указанные деяния кибертеррориста носят характер не взрыва, поджога, а «иных действий». Данные поправки вступили в законную силу только 27 июля 2006 года, с чего можно сделать вывод, что доктринальное закрепление многих важных положений в нашей стране сильно отстает от авторов данных идей, которые были предложены еще в 2005 году. На сегодняшний день УК РФ к кибертерроризму относятся преступность террористической направленности - «Террористический акт» (ст. 205 УК РФ), «Содействие террористической деятельности» (ст. 205-1), «Публичные призывы к осуществлению террористической деятельности или публичное оправдание терроризма» (ст. 205-2), «Заведомо ложное сообщение об акте терроризма» (ст. 207).

Решения проблемы, кибертерроризма не просты и не однозначны. Кибертеррористы и их действия должны быть «привязаны» к закону. Это должно быть сделано в контексте как национальной, так и международной политики противодействия кибертерроризму.[6] Серьезность террористической угрозы не может игнорироваться ни Россией, ни другими странами. Решимость принять необходимые меры может быть реализована в рамках новых эффективных международных законов и с новым воззрением на их действенность и применимость. Таким образом, решение проблемы борьбы с

этими опасными явлениями на сегодняшний день это задача, которая требует объединения усилий, интеллектуального потенциала и доброй политической воли всего мирового сообщества.

Комплексная реализация соответствующих мер в России будет способствовать обеспечению международной безопасности от кибертеррористических угроз, а также защите интересов государства, общества, личности.

В нынешнее время складывающаяся обстановка требует неотложного совершенствования и развития действующей системы борьбы с терроризмом как целостной, интегрированной структуры, объединяющей противодействие терроризму на всех направлениях, включая и новое его проявление. Одним из инструментов противодействия кибертерроризму является уголовно-правовой институт как в рамках национального законодательства, так и на уровне международном. В условиях борьбы с терроризмом особую значимость приобретает предупредительная функция уголовно-правовой системы.

\section{Литература}

1. Уголовный кодекс Российской Федерации от 13.06.1996 № 63 - Ф3 // Собрание законодательства РФ. 17.06.1996. №25 (ред. от 30.12.2015).

2. Правовые аспекты борьбы с кибернетическими преступлениями в ЕС // Борьба с преступностью за рубежом. М., 2003. $48 \mathrm{c}$.

3. Фролов Д. Б. Пути совершенствования законодательной системы в борьбе с кибертерроризмом в России и за рубежом // Законодательство и экономика. 2005. № 5.

4. Голубев В. Кибертерроризм как новая форма терроризма. URL: http://www.crime-research.org/library/Gol_tem3.htm

5. Понятие E-Learning. 2009 г. URL: http://elms.eoi.ru

6. Россия не торопится в электронное общество? 2009 г. URL: http://old.poisknews.ru/articles/5835-otstavit-otstavanie.html

\section{О преступлении против порядка судебного заседания}

(С) Чжнан Синь, магистрант Политико-юридчческого университета Китая, Китай, г. Пекин

Уголовный кодекс КНР был принят в 1978 г. В настоящее время в КНР действует редакция уголовного кодекса от 1 октября 1997 года. Именно в этом УК впервые установлено преступление против порядка судебного заседания. В предыдущих восьми поправках к УК КНР не предусматривалось вышесказанное преступление. Положение о преступлении против порядка судебного заседания было установлено девятой поправкой к УК КНР. В данной статье анализируется ряд вопросов об изменении данного преступления, включая в себя процесс 
и мотив изменения, расширения круга данного преступления и его влияние после принятия «Поправки к УК КНР (№ 9)».

В процессе изменения преступления против порядка судебного заседания было много препятствий. Законодатели расширили круг деяний, определенных как преступление против порядка судебного заседания. Раньше за преступление данного типа могли быть наказаны только два обстоятельства - «массовые беспорядки, нападение на суд» и «избиение сотрудников органов юстиции». На 11-ом совещании 27-ого октября 2014 г. 12-ого созыва Постоянного комитета Всекитайского собрания народных представителей (ВСНП) обсуждали «Проект поправки к УК КНР (№ 9)» (далее в сокращении черновик первого обсуждения). 3 ноября 2014 г. он был опубликован. В статье 35 добавилось несколько деяний, в том числе «избиение участников судебного иска», «оскорбление, диффамация, угроза сотрудникам органов юстиции или участникам судебного иска, несмотря на пресечение суда» и «другие действия, серьезно нарушающие судебный порядок». На 15-ом совещании 24-ого июня 2015 г. 12-ого созыва Постоянного комитета ВСНП обсуждали «Второй проект поправки к УК КНР (№ 9)» (далее в сокращении черновик второго обсуждения), в котором статья 36 почти полностью сохранила содержание черновика первого обсуждения, только с изменением слов и выражений. В этот период изменение данного преступления вызвало ожесточённый спор, как в кругу теоретиков, так и в кругу практиков. Учитывая бурное возражение, 24-ого августа 2015-ого года на 16-ом совещании 12-ого созыва Постоянного комитета ВСНП обсуждали «Третий проект поправки к УК КНР (№ 9)» (далее в сокращении черновик третьего обсуждения). В статье 37 конкретизировались «другие действия, серьезно нарушающие судебный порядок, при отягчающих обстоятельствах». Девятая поправка к уголовному кодексу КНР принята на 16-й сессии ВСНП двенадцатого созыва 29 августа 2015 года и вступила в силу с 1-ого ноября 2015 года. В ней статья 37 полностью совпадает со статьей 37 черновика третьего обсуждения. На этом поставили точку всякому спору.

Общепринятым мотивом изменения вышеупомянутого преступления является усиление справедливости юстиции, повышение общественного доверия к правосудию и смягчение острых конфликтов между судебным разбирательством и защитой. Сейчас в Китае существуют следующие проблемы. Некоторые дела разобранны некачественно, несправедливо и без эффективности. Отсутствие совершенного механизма исправления ошибок делает исправления неправосудных приговоров особенно трудными. Коррупция юстиции наносит огромный вред общественному доверию к правосудию. И из-за недоверия к органам юстиции некоторые на судебном заседании совершают действия, серьезно нарушающие судебный порядок.

Чтобы обеспечить благополучное проведение уголовного процесса, в статье 7 Уголовно-процессуального кодекса КНР 1996-ого года установлен принцип разделения обязанностей между народным судом, народной прокуратурой и органом общественной безопасности, то есть «взаимодействие и взаимная обусловленность». Но на самом деле во многих делах суд держится не нейтрально. На протяжении длительного времени суд находится под влиянием общественного положения участников уголовного дела. Кроме вышесказанного суд, прокуратура и орган общественной безопасности совместно берут на себя ответственность за охрану общественного порядка, что превратило «взаимодействие и взаимную обусловленность» во «взаимодействие». В общем, судьи выносят приговор на основе документов, предоставленных прокуратурой. Иногда на заседании некоторые судьи даже более настоятельно обвиняют ответчиков, чем прокуроры. До 2010-ого года не было четкого положения об исключении незаконных доказательств, что ещё больше приводило к чрезвычайно слабому положению защитников в судебной структуре. Поэтому, узнав своё положение, большинство адвокатов не боролись за свободу обвиняемых и только делали вид, что защищали. И, конечно, на судебном заседании очень редко встречались действия, серьезно нарушающие судебный порядок.

Но потом конфликты между судами и защитниками стали происходить гораздо чаще и острее. В 2012-ом году приняли новый Уголовно-процессуальный кодекс, который предоставил больше гарантий прав адвоката. Приведем пример: адвокат в период рассмотрения и обвинения мог читать материалы обвинения и просить суд и прокуратуру собрать и затребовать благоприятные доказательства для ответчика. Как только адвокаты вмешаются в дело, они имеют больше возможностей получить благоприятные доказательства для подзащитного. В ряде общеизвестных дел некоторые адвокаты на судебном заседании ходатайствуют об отводе, подают отвод юрисдикции, уходят из суда коллективом, пытая оспорить каждый мелкий вопрос по судебной процедуре с судьей. Судьи естественно считают, что такие адвокаты презирают их авторитет. Поэтому они и прерывают, и не обращают внимание на просьбу, даже делают предупреждение, выговор и изгоняют «непослушных» из суда. Поэтому действия, серьезно нарушающие судебный порядок, возникают всё чаще и чаще.

Как оценивать расширение круга преступлений против порядка судебного заседания? У адвокатов существует общая позиция, что поправка данного преступления специально направлена на них. Это дискриминационное изменение, нарушившее принцип равноправия, и оно не рационально. Но с этим можно поспорить. По изложению статьи 37 «Поправки к УК КНР (№ 9)», круг субъектов довольно широк: в том числе судьи, защитники, обвинители, судебные поверенные, стороны в делах, вольнослушатели.

Существует мнение о том, что слишком жестоко, если осудят их за острую искусную речь. Когда защитники очень взволнованы, неизбежно совершают неловкости, иногда даже произносят ругательства. С моей точки зрения, речевое насилие при отягчающих обстоятельствах имеет не меньше вредности по сравнению с насилием телом. Конечно же, некоторое речевое насилие может подорвать порядок судебного заседания и авторитет юстиции. Например, на судебном заседании прямо называют судей «подлецами, зелеными новичками, мерзкими» и так далее. Это является не только сильным оскорблением личности судей, но и произвольным нарушением судебного порядка. Судья является представителем закона, поэтому неуважение к судьям является 
неуважением к закону. По сравнению с преступлениями, связанными с неуважением суда, в западных странах (например: за действия, как бросание в судей яйцами, помидорами или оскорбление речью, будут наказаны), наши законодатели больше сдержаны, потому что внесено речевое насилие как преступление с двумя элементами ограничения, то есть «несмотря на пресечение суда» и «при отягчающих обстоятельствах».

Законодательство представляет собой искусство норм. По поводу 4-ого пункта статьи 36 черновика второго обсуждения многие заявили протест из-за того, что в нём нет ограничения видов действий. А круг преступлений против порядка судебного заседания очень широк, что похож на мешок, может включать в себя слишком много действий. Чтобы предупредить злоупотребление и неразумное расширение круга преступлений, орган законодательства конкретизировал «другие» действия, то есть указаны «уничтожение оборудований суда, грабеж, уничтожение судебных документов или доказательств и другие действия, серьезно нарушающие судебный порядок при отягчающих обстоятельствах». Это уже гораздо конкретнее и чётче, чем черновик второго обсуждения. В основном эта поправка данного преступления руководствовалась принципом равноправия, принципом самосдерживания и принципом точности.

Как должны реагировать защитники и органы юстиции на преступления против порядка судебного заседания после принятия девятой поправки? С учётом того, что острые слова и унизительная речь могут принести себя в тюрьму, защитники обязательно на практике и на судебном заседании сдержат себя в руках, и будут осторожны в речах и осмотрительны в поступках. Одновременно нельзя игнорировать отрицательное влияние на защитников. В последние годы некоторые защитники действительно не уважали сотрудников органов юстиции. Некоторых из них судьи уже приняли инакомыслящими и изготовителями неприятностей. В этом случае вряд ли судьи могут быть нейтральными, когда встретят своих «старых непослушных враждебных приятелей»? Чтобы предупредить злоупотребление данной статьи, привлекающей защитников к уголовной ответственности, на практике органов юстиции надо строго ограничить применение преступления против порядка судебного заседания и снизить отрицательное воздействие в наименьшей степени.

Во-первых, необходимо строго объяснить компоненты и элементы преступления против порядка судебного заседания. Например, объяснение «оскорбления» должно быть по стандарту статьи 246 Уголовного кодекса. Иными словами, на судебном заседании оскорбительные действия могут быть осуждены только тогда, когда эти действия одновременно являются публичным оскорблением другого человека с применением насилия или иных способов либо фальсификация фактов в целях очернения другого человека при отягчающих обстоятельствах, ещё и действиями, серьёзно нарушающими судебный порядок. Во-вторых, должно строго нормализовать судопроизводство преступления против порядка судебного заседания. Прежде всего, разбирательство такого дела необходимо строго по процедуре возбуждения уголовного дела публичного обвинения. Например, если преступление случилось на судебном заседании одного суда, то рассматриваться данное дело должно другим судом. В-третьих, надо необходимо соблюдать принцип самосдержания. Наказание является последней мерой, то есть только тогда, когда действия при отягчающих обстоятельствах и имеют огромную общественную вредность.

В конце придем к выводу, что через 3 раза обсуждения в основном изменение преступления против порядка судебного заседания совпадает с требованием уголовного законодательства по технике законодательства. Судебное заседание представляет собой место, где решают споры цивилизованно и мирно. Действия, нарушающие судебный порядок, отрицательно влияют на судебные разбирательства и унижают авторитет юстиции. Чтобы повысить общественное доверие, усилить справедливость и улучшить порядок правосудия, судьям на практике необходимо со строгим объяснением и ограничением принимать статьи, предусматривающие преступления против порядка судебного заседания.

\title{
Сравнительно-правовой анализ судебного толкования уголовно-правовых норм в Российской Федерации и Соединенных Штатах Америки
}

\author{
(C) Г. Т. Чимитдоржнева \\ студентка 2-го курса юридического факультета \\ ФГБОУ ВО «Бурятский госуниверситет» \\ Россия, г. Улан-Удэ \\ Gerelma.chimitdorjieva@yandex.ru
}

Толкование норм права является важным для точного и единообразного понимания и применения закона. В отличие от толкования других отраслей права, толкование уголовного закона влечёт за собой серьёзные последствия, так как предусматривает уголовную ответственность и уголовное наказание, а возможно и освобождение виновных от уголовной ответственности или назначение несправедливого наказания. Именно толкование права объективно восстанавливает пробелы, «дефекты», которые не были учтены законодателем в силу быстрого развития общественных отношений.

В настоящее время всё чаще на практике особую значимость приобретает судебное толкование. Трактовка уголовного закона судами становится важнейшим, а иногда и единственным средством адаптации к быстро развивающимся общественным отношениям, которые должны быть урегулированы государством. 
Так в Российской Федерации набирает свои обороты расширительное толкование норм, даваемое Конституционным судом, Пленумом Верховного суда РФ. Это также обусловлено тем, что Уголовный закон РФ характеризуется высокой степенью абстрактности правовых норм, а также существованием бланкетных и отсылочных норм, правовых предписаний, которые требуют конкретное разъяснение норм. Они же в свою очередь предлагают несколько вариантов поведения в силу специфики терминов и понятий, в связи с чем в правоприменительной деятельности при регулировании уголовно-правовых отношений существенную роль начинает играть судебное толкование. Однако эти разъяснения относятся делегированному виду толкования, так как они не являются правотворческими органами. Отсюда следует, что проблема толкования в РФ состоит в том, что изложение закона судом не является обязательным и единственным разрешением дела, не является источником права. В данном случае следует упомянуть работу Ругины О.А., которая видит разрешение данной проблемы в признании постановлений Конституционного суда РФ и Пленума Верховного суда по конкретным делам дополнительными источниками права. Также на эту проблему обращала внимание Савельева О. А. в своей научной работе « Роль судебного толкования в применении уголовного закона». Автор указывал на важность «законодательно закрепить акты судебного толкования в качестве дополнительного источника уголовного права, предусмотрев в Федеральном конституционном законе «О судебной системе РФ» норму следующего содержания: «Решения Конституционного Суда РФ, Верховного Суда РФ и Высшего Арбитражного Суда РФ по вопросам толкования нормативного правового акта являются дополнительным источником права и обязательным для применения всеми судами Российской Федерации».

По поводу решения Конституционного суда РФ можно сказать, что они играют особую роль в системе регулирования общественных отношений, поскольку они являются обязательными для исполнения всеми судами РФ и должностными лицами. Ругина О.А. также считает, что решения Конституционного суда обладают всеми признаками для признания его источником права, а именно нормативность и общеобязательный характер. Конституционный суд проверяет на соответствие нормы уголовного права с основным законом государства, что может повлечь за собой утраты юридической силы, в том числе выявление несоответствий путём толкования смысла закона, а это в свою очередь определяет содержание нормы и порядок применения уголовного закона.

В юридической науке России существует нормативное и казуальное судебное толкование.

Нормативное толкование - это разъяснение, которое является обязательным для должностных лиц и органов, используемых норму или нормы права. Например, Постановление Верховного суда РФ об убийстве, разбое, изнасиловании и т.д. В зависимости от субъекта толкования казуальное толкование трактует нормы лишь в конкретном деле. Так к этой категории можно отнести толкование районных судов.

Отсюда следует, что Постановления Пленума Верховного Суда является одним из видов судебных решений. Данное судебное решение складывается за счёт казуальных решений. Так, например, в связи с принятием УК РФ 1996 г. на практике возникли трудности, связанные с назначением уголовного наказания. Пленум Верховного Суда РФ, обобщив и проанализировав судебную практику по конкретным делам, принял постановление от 11 июня 1999 г. №40 «О практике назначения судами уголовного наказания».

До сих пор ведутся споры в отношении судебного толкования к числу официального источника права. Так одни считают, что нарушается принцип разделения властей, что суды не создают новые нормы, а лишь разъясняют смысл. Однако следует отметить, что как раз-таки расширительное толкование текста, которое наделяется функциями «компенсации технических неясностей, неточностей и восполнения пробелов правовых норм», «правокорректирующей» и «правосозидательной» функциями, признается вполне допустимым и объективно обусловленным так называемое коррекционное (исправляющее) толкование правовых норм, которое позволяет изменять содержание правовой нормы без изменения текста закона.

Одним из таких сторонников, подтверждающим нашу точку зрения является А.В. Наумов, который указывал, что "...опубликованные судебные решения Верховного Суда чаще всего и являются прецедентами толкования уголовно-правовых норм и фактически... выполняют роль подлинного судебного прецедента".В частности, А.И. Рарог отмечает, что общеобязательный для судов характер разъяснений Пленума Верховного Суда РФ не вытекает ни из ст. 126 Конституции РФ, ни из Федерального конституционного закона «О судебной системе Российской Федерации» от 31 декабря 1996 г., в соответствии с которым «суды осуществляют судебную власть самостоятельно, независимо от чьей бы то ни было воли, подчиняясь только Конституции Российской Федерации и закону (п.1 ст.5), а Верховный Суд РФ вправе давать лишь разъяснения по вопросам судебной практики, но никак не указания относительно того, как нужно понимать и применять уголовный закон.

В этом плане США, наоборот, признаёт прецедент судебных органов в качестве источника права и соответственно с этим упрощает действие самого толкования в целом, а также применения этого толкования в последующем, что способствует единообразному применению закона. Целью же создания прецедента является раскрытие смысла, «духа» нормы. Также можно отметить утверждение С.Л. Зивса, что в англо-американской системе судебный прецедент не создает правовой нормы на голом месте, а именно представляет собой по существу прецедент толкования нормы права. В США правом толкования норм обладают и Верховный Суд США, и верховные суды штатов. Фактически закон мертв без прецедентов, которые истолковывают, разъясняют и уточняют смысл правовых предписаний. В связи с чем, на наш взгляд, среди них нельзя выделить главный или второстепенный источник уголовного права. Они стоят на одной ступеньке, в одном ряду, гармонично дополняя друг друга. 
Решение судьи США создаёт прецедент и помогает другим судьям разрешать те или иные сложности квалификации преступления, назначения наказания, даёт указание, чем руководствовался и какие обстоятельства следует учитывать при разрешении дела, тем самым вырабатывается практика единообразного применения.

На наш взгляд, следует задуматься о том, чтобы внедрить в России дополнительный инструмент в арсенал тех орудий и средств, являющимся формально закрепленным источником права.

Таким образом, применения толкования уголовных норм является одним из важных и значимых аспектов для реализации уголовных норм в действительность. На наш взгляд, это поможет избежать серьезных ошибок, которые, в конце концов, могут быть необратимыми. Насколько точно будет уяснён и применён уголовный закон, настолько и будет эффективнее, справедливее правосудие. Следует признать, что судебное толкование уголовных норм является дополнительным источником права, так как именно его разъяснения способствуют разрешения конкретных дел, учитывая все обстоятельства в совокупности. Опыт применения этих толкований можно позаимствовать у исторически применяемых странах, таких как США.

\title{
Литература
}

1. Александрова А. Н. Толкование юридических норм и его влияние на судебную практику.

2. Зивс С. Л. Источники права. М.: Наука, 1981. С. 179-180.

3. Наумов А. В. Судебный прецедент как источник уголовного права // Российская юстиция. 1994. № 1. С. 11.

4. Нерсесянц В. С. У российских судов нет правотворческих полномочий // Судебная практика как источник права. М., 2000. С. 107-112; Петрушев В. А. Юридическая природа актов судебного толкования права // Академический юридический журнал. 2000. № 1. С. 54.

5. Рарог А. И. Правовое значение разъяснений Пленума Верховного Суда РФ // Государство и право. 2001. № 2.

6. Ругина О. А. Судебное толкование уголовного закона и его роль в законотворческой и правоприменительной деятельности: дис. ...канд. юр. наук.

7. Савельева О. А. Роль судебного толкования в применении уголовного закона: дис. ... канд. юр. наук.

\section{Преступность граждан стран АТР в Забайкальском крае}

\author{
(С) Ж. Ц. Чимитов \\ студент 4-го курса юридического факультета \\ ФГБОУ ВО «Бурятский госуниверситет» \\ Россия, г. Улан-Удэ \\ chimitov_95@mail.ru
}

Современная ситуация состояния миграционных процессов как в России в целом, так и в регионах в частности свидетельствует о том, что сегодня миграция приобретает характер трансграничной в масштабах, которых еще не знала наша страна. Во многом такие трансграничные миграции определяют траекторию экономического, этнического, политического и культурного развития нашей страны. Они неизбежны, потому что жизненно необходимы для России в условиях демографического спада, уменьшения численности населения, его неминуемого старения, особенно в восточных, слабозаселенных регионах. Повышающийся спрос на рабочую силу может быть удовлетворен сегодня только за счет граждан зарубежных стран. Однако, столь активное развитие неминуемых миграционных процессов связано с недостаточной готовностью государства принять такое количество мигрантов, дав им необходимые социальные гарантии, и соответственно это порождает ряд негативных процессов, среди которых самыми распространенными являются нелегальная миграция, рабское положение мигрантов вследствие нелегального использования их рабочей силы, расширение криминального рынка труда и других его сегментов и ряд взаимосвязанных с этим моментов. Бесспорно, самым крайним проявлением криминализации миграционных процессов является преступность мигрантов, и насколько сильно преступность мигрантов влияет на состояние преступности в регионе и в чем действительно проявляется криминализация трансграничных миграционных процессов [1].

В ежегодном послании Президента РФ Владимира Путина Федеральному Собранию Российской Федерации, прозвучавшем в день 20 -летия Конституции Российской Федерации, развитие Сибири и Дальнего Востока объявлено национальным приоритетом XXI века. Перед Правительством Российской Федерации поставлена задача в данных регионах, создать сеть территорий опережающего развития. Президент Российской Федерации подчеркнул, что ресурсы государства и частного бизнеса должны быть направлены на развитие, на достижение стратегических целей, таких как развитие Сибири и Дальнего Востока. Это наши основные задачи на весь XXI век [2].

В связи с этим актуализируется задача формирования в этих регионах такого миграционного режима, который бы наилучшим способом выполнял

свою макроэкономическую функцию - обеспечение максимальной экономической эффективности в системе рыночной конкуренции, что вероятно при эффективном противодействии современным криминальным угрозам, как со стороны мигрантов, так и в отношении них.

Научно доказан тот факт, что состояние преступности напрямую зависит от уровня развития экономики в стране. Миграция населения как социальный процесс естественно повлекла за собой разнообразные по своему 
характеру последствия: экономические, демографические и социальные. Отрицательные последствия миграции часто порождают антиобщественное поведение, способствующие правонарушениям, затрудняя борьбу с ними, либо осложняя работу по предупреждению преступлений и иных нарушений закона. В связи с этим некоторые ученые-криминологи рассматривают миграцию как один из факторов, влияющих на состояние преступности в обществе, как одну из причин, детерминирующих преступность.

Миграционная ситуация характеризуется интенсивностью потоков мигрантов, что обусловлено «прозрачностью» российско-китайской и российско-монгольской границы, недостаточно эффективной защитой государственной границы с Китаем и Монголией [3].

Принимая во внимание локализованный характер современной миграции, возрастает востребованность анализа региональных особенностей миграционной обстановки и миграционной взаимозависимости определенных стран, как одной из ключевых закономерностей современной международной миграции населения.

На пути миграционного потока находится Забайкальский край, который в силу своего геополитического положения выступает одновременно элементами двух крупнейших миграционных систем - Азиатско-Тихоокеанской и Евразийской [4].

Анализ структуры и динамики преступности на территории края, а также преступлений, совершенных иностранными гражданами и лицами без гражданства, указывает о наметившейся в 2015 году тенденции понижения числа преступлений, совершенных иностранными гражданами. Всего в 2015 году было совершено 138 преступлений иностранными гражданами и лицами без гражданства, что на 24\% меньше, чем в 2014 году (182). В целом эта категория лиц не оказывает значительного влияния на уровень преступности и криминогенную обстановку в крае [5]. Удельный вес совершенных ими преступлений составляет 0,8\% от числа оконченных расследованием преступлений (в 2014 году он составлял - 1,1\%). Криминальная активность мигрантов, чаще всего связана с такими преступлениями, как незаконного пересечения государственной границы РФ 46 или 33\% (в 2014 году - 80 или 42\%), а также преступления, связанные с фальсификацией документов, предоставляющих право их пребывания на территории России - 18 или 14,2\% (в 2014 году - 51 или 27\%); контрабанда (7,3\%); перевозка и сбыт наркотических веществ $(28,4 \%) ;$ кража чужого имущества $(33,4 \%) ;$ грабежи $(12,5 \%)$; посягательство на личность и хулиганство $(9,1 \%)$;

Также в крае снизилось число иностранных граждан, поставленных на миграционный учёт по месту пребывания, в том числе приехавших для работы. В 2015 году на учёт встали 24,4 тысячи иностранных граждан, что на 20,2\% меньше чем в 2014 году. 33 тысячи иностранных граждан прибывают в регион для работы, 125 иностранцев проходят обучение в вузах. Также выявлено 5,5 тысяч административных нарушений миграционного законодательства, за которые были наложены административные штрафы на общую сумму 34,1 миллиона рублей и за нарушения законодательства 825 иностранных граждан выдворены из края за пределы России[6].

Кроме того, также самостоятельного рассмотрения требует анализ ситуации, когда иностранный гражданин выступает не только в качестве преступника, но и в качестве жертвы преступления, что сказывается на ограничении притока профессиональных работников в отдельные регионы Российской Федерации, нуждающиеся в интенсификации экономического развития. Характерно, что большинство потерпевших иностранцев в Забайкальском Крае (в разные годы от $36,8 \%$ до 65,6\%) составляли граждане КНР и Монголии. В отношении них совершаются кражи (68\%), грабежи (до 76\%), разбойные нападения (до 71\%)20.

Однако, существущие пробелы в уголовном законодательстве Российской Федерации, Китая и Монголии, отсутствие в ряде регионов специализированных подразделений по борьбе с преступностью, связанной с мигрантами, пробелы в теории практике предупреждения преступности, недостаточная криминологическая изученность миграционных преступлений, слабое понимание иностранными гражданами законодательства Российской Федерации ввиду его сложной, многоплановой, достаточно быстро развивающейся юридической конструкции затрудняют эффективность совершенствования мер борьбы с преступлениями мигрантов и против них.

Следовательно, к наиболее значимым, мерам предупреждения преступлений гражданами Монголии и других приграничных государств, можно отнести совершенствование экономических мер по предупреждению нелегальной миграции; проведению постоянной целенаправленной работы по приему и обустройству трудовых мигрантов из иностранных государств; создание в городах (регионах) страны центров по оказанию правовой, психологической и социальной помощи иностранным гражданам и лицам без гражданства, при которых должны быть «телефоны доверия», курсы обучения русскому языку и т.д. Также в процессе проведения оперативнорозыскных и следственных мероприятий по уголовным делам, возбужденным по фактам совершения преступлений монголами и гражданами других зарубежных стран, возникает проблема языкового барьера, что значительно затрудняет раскрываемость данных дел. В связи с чем считаем, что необходимы специальные программы в плане подготовки специалистов не только с хорошим знанием иностранных языков, но и с глубокими знаниями зарубежного законодательства, с их последующим трудоустройством в соответствующие правоохранительные структуры [7].

Концентрация информации в едином информационном массиве на федеральном и окружном уровне, очевидно, расширит возможности ее практического использования во всех аспектах деятельности правоохранительных органов [8].

С учетом вышеизложенного можно сделать следующие выводы:

1. Причинный комплекс преступности иностранцев, состоит из двух блоков. Один из них связан с нищетой на родине, побуждающей к эмиграции в поисках заработка, с формированием социально-психологических ка- 
честв мигрантов в странах выезда, определяющих их возможности по адаптации в российских условиях и влияющих на их криминальное поведение. Особую роль в этом имеет значение национальный состав миграционных потоков, что отражается в показателе гражданства мигрантов. Другой блок сформирован негативными условиями труда и быта мигрантов в России, социальной незащищенностью и их эксплуатацией. К этому же блоку причинного комплекса преступности иностранцев относится неудовлетворительное состояние противодействия незаконной миграции.

2. Доля совершенных иностранцами преступлений невелика и составляет 2-3 \%, от общего числа раскрытых преступлений в стране. Но за этой невзрачной цифрой скрыт очаговый характер преступности иностранцев. Их преступность сосредоточивается в наиболее экономически развитых регионах. Особую тревогу вызывает то, что: во-первых, преступность иностранцев в России почти целиком, на 95\% является преступностью граждан государств-участников СНГ; во-вторых, опять же почти целиком, на 90 \% преступность иностранцев представляет собой преступность незаконных мигрантов, ранее бывших трудовыми мигрантами или являющихся таковыми на момент совершения преступления.

\title{
Литература
}

1. Репецкая А. Л. Миграция и региональная преступность: характеристика и проблемы борьбы // Сибирский криминологический журнал. 2007. № 1. С. 15-20.

2. Ежегодное послание В. Путина Федеральному Собранию Российской Федерации // Российская газета. 2013. 12 дек.

3.Пан Дунмэй. Противодействие преступлениям, совершаемым гражданами КНР на территории Российского Дальнего Востока. Владивосток, 2008. С. 273.

4. Козыкина Н. В. Китайская миграция в Забайкальском крае: состояние и тенденции развития. 2011. С. 2.

5. http://www.mvd.ru/presscenter/statistics/

6.Справочный материал УФМС по Забайкальскому краю. URL: http://www.fms.ru

7. Раднаева Э. Л., Гармаева А. Э. Криминологическая характеристика преступности граждан Монголии на территории Сибирского Федерального округа // Вестник Бурятского госуниверситета. 2014. Вып. 2. С. 254; Евланова О. А. Взаимосвязь миграционных процессов и организованная преступность.

8. Организованная преступность, миграция, политика. М.: Российская криминологическая ассоциация, 2002. С. 30-44.

\section{Уголовная ответственность военнослужащих в России и США: сравнительно-правовой анализ}

\author{
() 3. Ж. Шаргакшанова \\ студентка 4-го курса юридического факультета \\ ФГБОУ ВО «Бурятский госуниверситет» \\ Россия, г. Улан-Удэ \\ sh_z_zh@mail.ru
}

Неотъемлемой частью военно-уголовного законодательства каждого государства являются нормы, устанавливающие ответственность военнослужащих за уклонение от военной службы. Борьба с этими преступлениями велась во все времена и у всех народов с тех пор, как появились вооруженные группы людей, выполняющие функцию обеспечения военной безопасности государства.

Особенно актуальна борьба с этими преступлениями в странах, где существует воинская обязанность.

Военнослужащие, совершая рассматриваемые преступления, либо нарушают режим прохождения военной службы, самовольно оставляя расположение воинской части, либо полностью уклоняются от обязанности проходить военную службу (например, в случае дезертирства). Это вносит элементы дезорганизованности в войска, ослабляет их боеспособность, приводит к срыву выполнения поставленных перед ними задач.

Эффективность борьбы с различными уклонениями от военной службы зависит от многих факторов - от положения армии в обществе, включая ее обеспечение всем необходимым, от способов ее комплектования, в особенности офицерскими кадрами, от состояния дисциплины и правопорядка в войсках и т.д.

Важное место в системе мер противодействия уклонениям от военной службы принадлежит военно-уголовному законодательству. Современные государства накопили богатый опыт уголовно-правового регулирования порядка прохождения военной службы. Изучение этого опыта, сопоставление различных вариантов правового решения рассматриваемого вопроса в целях совершенствования национального военно-уголовного законодательства, относится к числу приоритетных задач военно-правовой науки.

Современные системы военно-уголовного законодательства США и России устанавливают уголовную ответственность за следующие преступления, связанные с уклонением военнослужащих от военной службы:

1) дезертирство

2) самовольное оставление части

3) членовредительство -

4) уклонение от военной службы путем обмана, в том числе симуляция болезни, подлог документов (Россия)[1].

Наиболее опасной формой уклонения от военной службы является дезертирство. Устанавливая строгую ответственность за это преступление, законодатели различных государств по-разному сформулировали признаки 
этого преступления, расширяя либо сужая тем самым сферу уголовной репрессии против лиц, уклоняющихся от прохождения военной службы.

Наиболее распространенным видом уклонения от военной службы является самовольное оставление части или места службы (самовольная отлучка). В Российской Федерации это преступление именуется самовольным оставлением части или места службы, в США - самовольной отлучкой, С объективной стороны преступление состоит в самовольном оставлении части (подразделения) или места службы, а равно в неявке без уважительных причин на службу. Критерием разграничения преступления и дисциплинарного проступка является срок самовольного отсутствия военнослужащего в части (подразделении) или на месте службы. Рассматриваемое преступление представляет собой временное уклонение от несения обязанностей военной службы. Субъективная сторона этого преступления включает в себя намерение субъекта лишь временно находиться вне части или места службы и желание его вернуться в часть и продолжать прохождение военной службы. Отсутствие у виновного цели вовсе уклониться от несения обязанностей военной службы отличает рассматриваемое преступление от дезертирства.

В соответствии с законодательством США наказанию подлежит военнослужащий, который умышленно или по небрежности самовольно оставит свое подразделение или служебные обязанности на срок более трех суток[2].

В России подлежат уголовной ответственности за самовольное оставление части или места службы по ст. 337 УК военнослужащие, проходящие военную службу, как по призыву, так и по контракту.

В военно-уголовном законодательстве ряда стран уголовная ответственность дифференцируется в зависимости от сроков пребывания военнослужащего вне части. В России, например, установлено три таких срока: а) от 2 до 10 суток; б) от 10 суток до одного месяца; в) свыше одного месяца. В США до 3 суток, от 3 до 30 суток, свыше 30 суток.

Чтобы представить себе строгость наказуемости данного преступления в названных странах, рассмотрим уголовно-правовые последствия нахождения военнослужащего вне места службы в течение, например, шести суток. В США он может быть осужден на 3 года лишения свободы. В России, если военнослужащий проходит военную службу по призыву, за аналогичное деяние он может быть подвергнут наказанию на один год содержания в дисциплинарной воинский части (у контрактника это деяние вообще рассматривается как дисциплинарный проступок)[3].

УК РФ предусматривает возможность освобождения от уголовной ответственности за уклонение от военной службы, совершенное путем самовольного оставления части или места службы. В примечании к ст. 337 говорится: "Военнослужащий, впервые совершивший деяния, предусмотренные настоящей статьей, может быть освобожден от уголовной ответственности, если самовольное оставление части явилось следствием стечения тяжелых обстоятельств".

Таким образом, в России самовольное оставление части на небольшой срок влечет существенно менее строгое наказание по сравнению с законодательством США . Однако незаконное пребывание военнослужащего вне части свыше 30 суток в США не влияет на размер максимального наказания, тогда как в России он увеличивается до пяти лет лишения свободы. Иными словами, самовольное оставление части на значительный срок влечет в России более строгое наказание. В США для всех категорий военнослужащих установлены одни сроки преступной самовольной отлучки.

Преступление признается оконченным с момента, когда военнослужащий, причинивший себе какое-либо повреждение, фактически в связи с этим прекратил исполнение обязанностей военной службы. При этом не имеет значения, оформлено ли соответствующим приказом командира освобождение виновного от тех или иных обязанностей[4].

Вред здоровью при членовредительстве могут причинить либо сам военнослужащий, либо по его просьбе другие лица, как военнослужащие, так и не военнослужащие. Причем, военнослужащий, причинивший вред здоровью другому военнослужащему с целью оказать ему содействие в уклонении от исполнения обязанностей военной службы, является соисполнителем этого преступления.

В Российской Федерации во всех случаях исполнителем преступления, предусмотренного ст. 339 УК, является военнослужащий, которому причинен вред. Другие лица, умышленно причинившие вред здоровью виновного, признаются соучастниками, а не исполнителями (соисполнителями) этого преступления. Кроме того, они подлежат ответственности за причинение вреда здоровью по соответствующим статьям главы XVI УК.

Симуляция болезни признается формой уклонения от военной службы и в законодательстве Российской Федерации (ст. 339 УК), под которой понимается имитация заболевания, придание огласке таких физических или психических недостатков, которыми лицо в действительности не страдает. Симуляцией также является преувеличение симптомов имеющегося заболевания (аггравация). В отличие от членовредительства при симуляции болезни в действительности отсутствуют те недостатки, ссылаясь на которые, лицо добивается освобождения от исполнения обязанностей военной службы. Для оконченного состава преступления, как и при членовредительстве, необходимо, чтобы лицо в результате симуляции болезни постоянно или временно уклонилось от исполнения всех или некоторых обязанностей военной службы [5].

Преступления против порядка подчиненности и соблюдения воинской чести в структуре современного военно-уголовного законодательства занимают особое место. В любом государстве основное предназначение вооруженных сил - отражение агрессии, вооруженная защита целостности и неприкосновенности его территории. Успешное выполнение этой задачи связано с качественным выполнением военнослужащими своих обя- 
занностей, беспрекословным повиновением подчиненных начальникам. В свою очередь должностные лица армии наделены всей полнотой распорядительной власти по отношению к подчиненным и несут персональную ответственность перед государством за все стороны жизни и деятельности войск. Неисполнение военнослужащими отданных им по службе приказов, сопротивление командирам (начальникам) или принуждение их к нарушению служебных обязанностей, а также физическое или психическое насилие над ними во всех армиях мира и во все времена влекло за собой суровые меры воздействия, в том числе меры уголовно-правового характера.

В США преступлениями против порядка подчинённости признаются: неподчинение; отказ военнослужащего от выполнения приказа; легкомысленное несоблюдение закон а, приказа; ошибка в обязанности исполнения приказа; угроза начальнику; принуждение начальника; насильственные действия в отношении начальника; мятеж (бунт); сговор к непослушанию; преступление против военнослужащего старшего по званию (служебному положению).

В России к преступлениям против порядка подчиненности и воинских уставных взаимоотношений (ст. 332 - 336 УК) относятся: неисполнение приказа; сопротивление начальнику или принуждение его к нарушению обязанностей военной службы; насильственные действия в отношении начальника; нарушение уставных правил взаимоотношений между военнослужащими при отсутствии между ними отношений подчиненности; оскорбление военнослужащего.

Другим не менее опасным преступлением против порядка подчиненности является неисполнение приказа. В ст. 332 УК РФ оно определяется как "неисполнение подчиненным приказа начальника, отданного в установленном порядке, причинившее существенный вред интересам службы".

В США ответственность за отказ от "подчинения" и отказ от исполнения приказа установлена без указания на какие-либо последствия. Ответственность усиливается, если это деяние было совершено: в военное время, или на территории, где действовало чрезвычайное положение, или на борту военного корабля во время пожара, угрожавшего безопасности корабля, или на борту военного самолёта.

Воинские должностные преступления в зарубежном военно-уголовном законодательстве и по количеству составов преступлений, и по строгости мер воздействия на правонарушителей занимают одно из основных мест.

В США наказуемость неисполнения приказа или распоряжения также не увязывается с последствиями совершения этого преступления. Ответственности подлежит лицо, которое: 1) нарушает или не исполняет любой законный общий приказ или предписание /требование/ или 2) зная о любом другом законном приказе, изданном лицом из состава вооружённых сил, которому по роду своей службы он должен подчиняться, не исполняет его или 3) уклоняется от исполнения своего долга (ст. 92 ЕКВЮ).

К должностным преступлениям можно также отнести следующие деяния: не выполнение обязанностей специального поручения (ст. 45); незаконное освобождение заключённого, разглашение личной тайны, получение взятки, принуждение к даче показаний, служебный подлог, разглашение государственной тайны (ст. 48) [6].

В системе преступлений против военной службы в УК РФ в отличие от законодательства иностранных государств отсутствует также состав такого опасного преступления, как хищение оружия, боеприпасов и предметов военной техники, несмотря на то, что в России широкое распространение получили такие хищения, в том числе совершаемые военнослужащими.

Хищение оружия, боеприпасов и предметов военной техники, совершаемое военнослужащими создает не только реальную угрозу общественной безопасности, но и причиняет вред собственности, и, прежде всего, вред военной безопасности государства - снижается уровень боевой готовности и боеспособности частей и учреждений военной организации государства.

В зарубежных странах состав хищения военного имущества, в том числе вооружения и военной техники, как правило, входит в систему военно-уголовного законодательства.

В зарубежных странах, в отличие от России, в систему военно-уголовного законодательства входит, как правило, состав хищения военного имущества, в том числе вооружения и военной техники. Между тем, когда хищение оружия, боеприпасов и предметов военной техники совершают военнослужащие, создается не только реальная угроза общественной безопасности и причиняется вред собственности, но, прежде всего, причиняется вред военной безопасности государства. Именно поэтому хищение военнослужащими принадлежащих военной организации огнестрельного оружия, боевых припасов или предметов военной техники подлежит включению в систему преступлений против военной службы.

\section{Литература}

1. Уголовный кодекс Российской Федерации от 13 июня 1996 г.

1. Вихров А. А. Военно-уголовное право США - орудие реакции и войны. Л.: Военная академия тыла и транспорта, 1989. $221 \mathrm{c}$.

2. Вихров А. А. Военно-уголовное законодательство США, его реакционная сущность: автореф. дис. ...канд. юр. наук. М.: Военно-политическая академия, 1973. 19 с.

3. Вихров А. А. Общая характеристика военно-уголовного законодательства современных империалистических государств // Советское уголовное право. Воинские преступления: учебник. М.: Изд-во Военного ин-та, 1978. С. 417-419.

4. Воинские преступления: учебник. М.: Изд-во Военно-юридической академии, 1956. 413 с.

5. Давид Р., Жоффре-Спинози К. Основные правовые системы современности. М.: Международные отношения, 1998. 399 c. 
6. Карпов Н. Н. Преступность в войсках и правовая политика государства // Преступность и законодательство. М.: Криминологическая ассоциация, 1996. С. 316-331.

7. Кучер Г. И. Ответственность за воинские преступления по уголовному законодательству США: автореф. дис. ....канд. юр. наук. М.: Всесоюзный юридический заочный институт, 1975. 23 с.

\title{
Незаконное проведение искусственного прерывания беременности: сравнительно-правовой анализ субъекта состава преступления по УК РФ и УК Японии
}

\author{
() О. Д. Яковлев \\ студент 3-го курса юридического факультета \\ ФГБОУ ВО «Новосибирский государственный \\ технический университет» \\ Россия, г. Новосибирск
}

В теории уголовного права распространенным является следующее определение субъекта состава преступления: «Субъект преступления - лицо, совершившие запрещенное уголовным законом общественно-опасное деяние и способное нести за него уголовную ответственность» [3].

В ст. 19 УК РФ указаны признаки общего субъекта состава преступления: вменяемое физическое лицо, достигшее возраста, установленного настоящим Кодексом (с 16 лет по общему правилу, в отдельных случаях - с 14 лет).

Специальный субъект состава преступления - лицо, которое наряду с признаками общего субъекта имеет хотя бы один специальный признак, необходимый для правильной квалификации общественно-опасного деяния.

Признаки, характеризующие специальный субъект состава преступления (возраст, пол, должность, гражданство и др.), указываются в диспозициях уголовно-правовых норм Особенной части УК РФ.

Во всех уголовно-правовых нормах УК РФ, где указаны признаки специального субъекта, он выступает в качестве «виновного» лица. Но из этого правила есть исключение, и это статья 123 УК РФ, посвященная незаконному проведению искусственного прерывания беременности.

Со ст. 123 УК РФ тесно связана ст. 56 ФЗ № 323 от 21.11.2011 «Об основах охраны здоровья граждан в РФ» [4]. В этой статье Ф3 определены требования, соблюдение которых является обязательным для проведения искусственного прерывания беременности. Следовательно, нарушение положений, закрепленных в статье 56 Ф3 № 323, может повлечь уголовную ответственность.

Как следует из диспозиции ч. 1 ст. 123 УК РФ, законодатель признает преступлением лишь проведение искусственного прерывания беременности лицом, не имеющим высшего медицинского образования соответствующего профиля [1]. Из уголовного закона следует, что виновными в этом преступлении могут быть любые лица, не имеющие высшего медицинского образования и сертификата акушера-гинеколога: врачи иных специальностей, фельдшеры, медсестры и другие медицинские работники, а также лица, которые вообще не имеют отношения к медицине.

Таким образом, в соответствии с ч. 1 ст. 123 УК РФ врачи, имеющие высшее медицинское образование соответствующего профиля, за незаконное прерывание беременности по этой статье привлечены быть не могут. При наличии необходимых признаков состава преступления их действия могут быть квалифицированы по другим статьям.

Возникает вопрос - как квалифицировать деяния лиц, которые имеют высшее медицинское образование по соответствующему профилю и все же незаконно осуществляют прерывание беременности?

Решением этого вопроса может стать внесение изменений в диспозицию ч.1 ст. 123 УК РФ, а, именно, дополнение ее словами «... а также проведение искусственного прерывания беременности вне специализированного стационара лицом, имеющим высшее медицинское образование соответствующего профиля...». Данное изменение диспозитивной части уголовно-правовой нормы необходимо в целях борьбы с проведением незаконных абортов.

Статья 123 УК РФ состоит из 3-х частей, две из которых действуют на сегодняшний день (2 часть утратила силу в 2003 году):

- ч. 1 ст. 123 УК РФ: проведение искусственного прерывания беременности лицом, не имеющим высшего медицинского образования соответствующего профиля, -

предусматривает максимальное наказание в виде исправительных работ на срок до 2 лет (преступление относится к категории небольшой тяжести).

- ч. 3 ст. 123 УК РФ: то же деяние, если оно повлекло по неосторожности смерть потерпевшей либо причинение тяжкого вреда ее здоровью, -

предусматривает максимальное наказание в виде лишения свободы до 5 лет с лишением права занимать определенные должности или заниматься определенной деятельностью на срок до 3 лет или без такового (преступление относится к категории средней тяжести). 


\begin{tabular}{|c|c|c|c|c|c|}
\hline \multirow{2}{*}{$\begin{array}{l}\text { Уголовно-правовая норма } \\
\text { (УПН) }\end{array}$} & \multicolumn{3}{|l|}{ Санкции } & \multirow{2}{*}{$\begin{array}{l}\text { Вид карательной } \\
\text { части УПН }\end{array}$} & \multirow{2}{*}{$\begin{array}{l}\text { Категория } \\
\text { преступления }\end{array}$} \\
\hline & Штраф & $\begin{array}{l}\text { Обязат. } \\
\text { работы }\end{array}$ & $\begin{array}{l}\text { Исправит. } \\
\text { работы }\end{array}$ & & \\
\hline \multirow[t]{3}{*}{$\begin{array}{l}\text { ч. } 1 \\
\text { ст. } 123 \\
\end{array}$} & $\begin{array}{l}\text { До } \\
80000 \text { руб. }\end{array}$ & $\begin{array}{l}\text { до } \\
480 \text { час. }\end{array}$ & до 2 лет & альтернативная & $\begin{array}{l}\text { небольшой } \\
\text { тяжести }\end{array}$ \\
\hline & \multicolumn{3}{|l|}{ Санкции } & & \\
\hline & $\begin{array}{l}\text { Принудит. } \\
\text { работы }\end{array}$ & $\begin{array}{l}\text { Лишение } \\
\text { свободы }\end{array}$ & $\begin{array}{lr}\text { Личение } & \text { права } \\
\text { занимать... } & \text { или } \\
\text { заниматься... } & \end{array}$ & & \\
\hline $\begin{array}{l}\text { ч. } 3 \\
\text { ст. } 123\end{array}$ & до 5 лет & до 5 лет & до 3 лет & альтернативная & $\begin{array}{l}\text { средней } \\
\text { тяжести }\end{array}$ \\
\hline
\end{tabular}

УК Японии

\begin{tabular}{|c|c|c|c|}
\hline \multirow{2}{*}{$\begin{array}{l}\text { Уголовно-правовая норма } \\
\text { (УПН) }\end{array}$} & Санкции & \multirow{2}{*}{$\begin{array}{l}\text { Вид карательной } \\
\text { части УПН }\end{array}$} & \multirow{2}{*}{$\begin{array}{l}\text { Категория } \\
\text { преступления }\end{array}$} \\
\hline & Личение свободы & & \\
\hline ст. 212 & до 1 года & простая & $\begin{array}{l}\text { небольшой } \\
\text { тяжести }\end{array}$ \\
\hline ст. 213 & до 2 лет & простая & $\begin{array}{l}\text { небольшой } \\
\text { тяжести }\end{array}$ \\
\hline $\begin{array}{l}\text { + дополнит. } \\
\text { последствия }\end{array}$ & $\begin{array}{l}\text { от } 3 \text { мес. } \\
\text { до } 5 \text { лет }\end{array}$ & простая & $\begin{array}{l}\text { средней } \\
\text { тяжести }\end{array}$ \\
\hline ст. 214 & $\begin{array}{l}\text { от } 3 \text { мес. } \\
\text { до } 5 \text { лет }\end{array}$ & простая & $\begin{array}{l}\text { средней } \\
\text { тяжести }\end{array}$ \\
\hline $\begin{array}{l}+ \text { дополнит. } \\
\text { последствия } \\
\end{array}$ & $\begin{array}{l}\text { от } 6 \text { мес. } \\
\text { до } 7 \text { лет }\end{array}$ & простая & $\begin{array}{l}\text { тяжкое } \\
\text { преступление } \\
\end{array}$ \\
\hline ст. 215 & $\begin{array}{l}\text { от } 6 \text { мес. } \\
\text { до } 7 \text { лет }\end{array}$ & простая & $\begin{array}{l}\text { тяжкое } \\
\text { преступление }\end{array}$ \\
\hline ст. 216 & до 10 лет & простая & $\begin{array}{l}\text { тяжкое } \\
\text { преступление }\end{array}$ \\
\hline
\end{tabular}

Глава 29 Уголовного кодекса Японии включает в себя пять статей, предусматривающих ответственность за искусственное прерывание беременности.

Ст. 212 УК Японии «Производство себе аборта самой беременной»:

- беременная, прервавшая свою беременность путем применения медикаментов или другим способом, наказывается лишением свободы с принудительным физическим трудом на срок до 1 года.

Ст. 213 УК Японии «Производство аборта с согласия беременной и причинение в результате этого смерти или телесных повреждений»:

- тот, кто производил аборт по желанию или с согласия женщины, -

наказывается лишением свободы с принудительным физическим трудом на срок до 2 лет;

- если результатом этого было причинение смерти или телесного повреждения женщине, -

наказывается лишением свободы с принудительным физическим трудом на срок от 3 месяцев до 5 лет.

Ст. 214 УК Японии «Производство аборта лицом, занимающимся специальным видом деятельности и причинение в результате этого смерти или телесных повреждений»:

- врач, акушерка, фармацевт или торговец медикаментами, которые произвели аборт по желанию или с согласия беременной женщины, -

наказываются лишением свободы с принудительным физическим трудом на срок от 3 месяцев до 5 лет;

- если в результате этого наступила смерть беременной женщины или ей было причинено тяжелое повреждение, -

наказывается лишением свободы с принудительным физическим трудом на срок от 6 месяцев до 7 лет.

Ст. 215 УК Японии «Производство аборта без согласия беременной и покушение на совершение этого деяния»:

- кто производил аборт женщине не по ее желанию и без ее согласия, -

наказывается лишением свободы с принудительным физическим трудом на срок от 6 месяцев до 7 лет;

- покушение на совершение деяния, предусмотренного предыдущей частью, наказуемо.

Ст. 216 УК Японии «Причинение смерти или телесного повреждения в результате производства аборта без согласия беременной»:

- если совершение указанного в предыдущей статье преступного деяния повлекло причинение смерти или телесного повреждения женщине, -

должно быть назначено наказание, установленное за телесное повреждение, если это наказание является более строгим (ст. 204 «Нанесение телесных повреждений» предусматривает наказание в виде лишения свободы до 10 лет или штраф до 300 тыс. иен) [2]. 
Необходимо отметить, что в ст. 123 УК РФ субъект состава всех рассматриваемых преступлений является общим, а в уголовно-правовых нормах главы 29 УК Японии предусмотрен как общий субъект (ст. 213, 215, 216), так и специальный субъект (ст. 212 и 214).

Интерес вызывает сравнение мер уголовно-правового характера, предусмотренных законами России и Японии, которые могут быть применены к субъектам составов этих преступлений.

Из анализа санкций карательных частей рассматриваемых уголовно-правовых норм обеих стран видна их существенная разница, как по видам, так и по содержанию.

Так, карательные части уголовно-правовых норм, предусматривающих ответственность за незаконное проведение искусственного прерывания беременности, в УК РФ являются альтернативными[6], включающими в себя относительно-определенные санкции, содержащие виды наказаний, совершенно разные по своему удельному весу, что, на наш взгляд, совершенно недопустимо.

Касаемо уголовного законодательства Японии, несмотря на большее количество уголовно-правовых норм, стоящих на страже здоровья беременных женщин, их карательные части все без исключения являются простыми, то есть состоящими из одной относительно-определенной санкции. Это свидетельствует о наиболее логичном конструктивном исполнении карательных частей уголовно-правовых норм, предусматривающих ответственность за подобные преступления.

Говоря о границах относительно-определенных санкций, можно отметить, что как в УК Японии, так и в УК РФ их пределы необоснованно широки (от 8 до 118 месяцев). Например, в соответствии с санкцией ст. 216 УК Японии может быть назначено наказание в виде лишения свободы до 10 лет (117 месяцев), а в соответствии с санкцией ч. 3 ст. 123 УК РФ может быть назначено наказание в виде лишения свободы от 2 месяцев до 5 лет (58 месяцев). На наш взгляд, относительные размеры границ санкций за более тяжкие преступления должны стремиться к абсолютной определенности (абсолютно-определенным санкциям).

Существует мнение, что абсолютно-определенные санкции сводят судейское усмотрение к нулю при решении вопроса о наказании. Позволим себе не согласиться с данным утверждением. Абсолютно-определенные санкции оставляют значительный простор для деятельности профессиональных юристов по анализу доказательств, их оценке, квалификации деяния и так далее, о чем не следует забывать противникам ограничения судейского усмотрения. Применением в карательной части уголовно-правовых норм абсолютно-определенных санкций ограничивается не судейское усмотрение, а судейский произвол при определении вида и размера наказания виновному, что далеко не одно и то же [7].

\section{Литература}

1. Уголовный кодекс Российской Федерации от 13.06.1996 г. № 63-Ф3 (ред. от 30.12.2015 г.) // СПС Консультант плюс.

2. Уголовный Кодекс Японии от 24.04.1907 г. № 45 (ред. от 12.05.1995 г.) [Электронный ресурс]. Режим доступа: http://law.edu.ru

3. Уголовное право РФ. Общая часть: учебник / под ред. Б. В. Здравомыслова. М.: Юристъ, 1996. С. 203.

4. Федеральный закон Российской Федерации от 21.11.2011 г. № 323-Ф3 (ред. От 29.12.2015 г.) «Об основах охраны здоровья граждан в РФ» // СПС Консультант плюс.

5. Поляков С. А. Уголовно-правовые санкции при унификации уголовного законодательства // Вестник Межпарламентской Ассамблеи государств - участников СНГ. СПб., 1995. № 4.

6. Поляков С. А. К вопросу об альтернативных и кумулятивных санкциях // Сборник научных трудов Омской академии МВД России. Омск: Изд-во ОмА МВД РФ, 2007.

7. Поляков С. А. К вопросу об абсолютно-определённых санкциях // Проблемы высшего технического образования. межвуз. сб. науч. тр. Новосибирск: Изд-во НГТУ, 2007. С. 24.

8. Поляков С. А. К вопросу о месте уголовно-правовой нормы в системе правовых норм // Вестник Санкт-Петербургского университета МВД России. 2008. № 4. С. 69-76.

9. Поляков С. А. Карательная часть в структуре уголовно-правовой нормы // Актуальные проблемы подготовки конкурентоспособных кадров: опыт, современное состояние и перспективы развития: материалы научно-практической конференции, город Семей. Казахский гуманитарно-юридический инновационный университет, 2009. - 346 с.

10. Поляков С. А. К вопросу об альтернативных карательных частях специальных уголовно-правовых норм // Актуальные проблемы борьбы с преступлениями и иными правонарушениями: материалы восьмой междунар. науч.-практ. конф.: в 2 ч. Барнаул: Изд-во Барнаульского ЮИ МВД России, 2010. Ч. 2.

11. Поляков С. А. Проблемы конструирования карательных частей уголовно-правовых норм в контексте исторического опыта // Современные проблемы юридической науки: сб. науч. ст. / под ред. Л. П. Чумаковой. Новосибирск: АльфаПорте, 2011. Вып. 9. 256 с.

\section{Criminal law interpretation of «firearms» in firearms-related crimes in China on behavior regulation of firearms-related crimes}

Firearms-related crimes in Chinese criminal law mainly include crime of illegally manufacturing, trading, transporting, mailing and storing firearms and ammunitions, crime of illegally manufacturing and selling firearms, crime of stealing and robbing firearms and ammunitions, crime of robbing firearms and ammunitions, crime of illegally holding and hiding firearms and ammunitions, crime of illegally leasing and lending firearms, crime of losing firearms without 
reporting, and crime of endangering public security by illegally carrying firearms and ammunitions specified in Articles 125-130, Chapter II Crime of Endangering Public Security, Criminal Law, as well as crime of smuggling weapons and ammunitions specified in Article 151 of Criminal Law, etc. The accurate definition of "firearms" in firearms-related crimes in China is related to realizing nulla poena sine lege and safeguarding judicial justice. Therefore, it shall be further interpreted and clarified.

I. Standards Followed in Firearm Interpretation

With the social change, the seemed definite meaning of "firearm" remains a controversy in judicial application. Non-systematical firearms not approved by competent department or not conforming to national standard do not necessarily have the same functions as systematical firearms. A concrete analysis is needed to determine whether they shall be included in the range of "firearms" in the criminal law. As indicated in The Supreme People's Court's Explanation to Several Problems on Applicable Laws in Trying Robbery Cases, the concept and the range of "firearms" in "gun robbery" apply to provisions of Law of Gun Control. Article 46 of 1996 Law of Gun Control specifies as follows: Guns in this Law refer to various firearms powered by gunpowder or compressed gas, etc. and launching metal bullets or other substances utilizing tubular appliance, which are enough to cause human death or loss of consciousness. This concept can be divided into two levels: Provisions on power and launching appliance belong to the appearance and structure conditions, i.e., formal elements of firearms, while "lethality" is the substantial element for firearm judgment. To clarify the lethality element specified by Law of Gun Control, public security organs give more concrete standards for judgment.

\section{Experiment of shooting}

Regulation on Public Security Organs' Performance Testing for Case-related Firearms and Ammunitions (G.T.Zi [2001] No.68) uses the energy of bullets launched by firearms as the standard for firearm identification. When a firearm shoots at a dry deal board with the thickness of $25.4 \mathrm{~mm}$ from a distance above $1 \mathrm{~m}$, the firearm is deemed as sufficient to cause death to a person if the warhead penetrates through the board, or the firearm is deemed as sufficient to cause damage to a person if the warhead or shrapnel gets stuck in the board. It can be identified as firearm if one of the above conditions is met.

2. Specific kinetic energy at muzzle

Standard for Imitation Gun Identification (G.T.Zi.[2008]No.8) specifies as follows: It can be identified as an imitation gun if it conforms to the key components of firearms specified in Law of Gun Control, and the specific kinetic energy at muzzle of metal bullets or other substances launched by it is less than $1.8 \mathrm{~J} / \mathrm{cm} 2$ (not including $1.8 \mathrm{~J} / \mathrm{cm} 2$ ) and more than $0.16 \mathrm{~J} / \mathrm{cm} 2$ (not including 0.16 J/cm2). 2010 Regulation on Public Security Organs' Performance Testing for Case-Related Firearms and Ammunitions holds that all non-systematical firearms shall be identified as firearms when the specific kinetic energy at muzzle of launched bullet is equal or greater than $1.8 \mathrm{~J} / \mathrm{cm} 2$. Meanwhile, this regulation abolished the experiment of shooting.

In the general international theory of firearm lethality computation, the section specific kinetic energy is frequently used as the energy index to measure bullet lethality. The expression of section specific kinetic energy is: Where, Es is the section specific kinetic energy; $\mathrm{E}$ is the kinetic energy; $\mathrm{S}$ is the cross sectional area of warhead; $\mathrm{d}$ is the maximum diameter of bullet. This expression fully reflects the lethal effect of bullet launched by firearms [2, c.3]. It is reasonable to identify "lethality" through kinetic energy from this angle. However, opinions are divided on the determination and source of the specific value--1.8J in practice. Some experts point out that in addition to kinetic energy, factors such as body parts damaged by firearms shall also be considered upon formulating a scientific standard on "firearm lethality" [3, c.3]. In firearms-related cases, it is not scientific to use specific kinetic energy at muzzle exceeding $1.8 \mathrm{j} / \mathrm{cm} 2 \mathrm{as} \mathrm{cri}-$ teria for the lethality of non-systematical firearms that cannot launch standard bullets [4, c.3]. Others hold that overemphasizing the identification of firearm lethality is not consistent with the actual situation of firearm crime. The lethality of firearm depends on the firearm, ammunition or other articles \& devices used by the firearm and the status of firearm, etc $[5$, c.3].

II. Subject and Jurisdiction of Interpretation

In accordance with Resolution on Strengthening Legal Interpretation, articles of laws and decrees in need of further clarification or supplement shall be interpreted or specified by the Standing Committee of the National People's Congress through decrees; the specific application of laws and decrees in the trial of the court and in the investigation \& prosecution of the procuratorate shall be interpreted by the Supreme People's Court and the Supreme Peoples' Procuratorate, respectively. Specific application of laws and decrees in areas other than trial, investigation $\&$ prosecution shall be interpreted by the State Council and competent departments. However, combining with provisions of criminal law, the boundary is not so clear in practice as to laws in need of definition, specific application in judicial domain or specific application in domains other than judicial domain. For instance, the Standing Committee of the National People's Congress had made a concrete interpretation on "credit card", "other invoices of export rebates and deduction tax", and the subject of crime of dereliction of duty specified in the criminal law. The Supreme People's Court had interpreted the accurate understanding and application of "national regulation", etc. in the criminal law. The Supreme Peoples' Procuratorate had interpreted whether units such as Geological Engineering Survey Institute and individuals can be the subject of crime specified in Article 229 of criminal law. However, with respect to the definition of "firearm" and whether non-systematical firearms such as imitation guns belong to the scope of firearms, etc., only the administrative interpretation of public security organs can be used as important evidences for court judgment in the level of legal interpretation presently, lacking of relevant legislative interpretation and judicial interpretation. 
The public security organ of China both has the right of security administration and the right of criminal detection. Therefore, although normative documents have a particular emphasis sometimes, the definition of terminology is not distinguished clearly in the administration field and the criminal field sometimes. Regulation on Public Security Organs' Performance Testing for Case-related Firearms and Ammunitions (G.T.Zi [2001] No.68) is mainly used for the identification of the performance of firearms and ammunitions by public security organs in handling firearm-related criminal cases. Standard for Imitation Gun Identification (G.T.Zi.[2008]No.8) aims at "effectively strengthening the management for imitation guns". 2010 Regulation on Public Security Organs' Performance Testing for Case-related Firearms and Ammunitions adopted the standard specified in the latter and abolished the former. Notice on Effectively Strengthening the Banning of Imitation Guns issued by the Ministry of Public Security in 2008 is also applicable to criminal department and security administration department: The criminal technique department shall be responsible for the identification of substantial elements of imitation guns, i.e., the identification of specific kinetic energy at muzzle. The security administration department of public security organ above the county level shall be responsible for the identification of formal elements, such as appearance and functional similarity.

III. Balance of Legal Interest and Application of Criminal Policy

(I) Extensive interpretation and analogical interpretation

Do non-systematical firearms and imitation guns belong to "firearms" in the criminal law? The inclusion of them into the scope of firearms does not exceed the maximum implication of language from the level of semantic interpretation. However, the difference of extensive interpretation and analogical interpretation in the structure lies in that the conclusion drawn from the former conforms to the prediction possibility of common citizens, while the conclusion drawn from the latter can be comprehended by common citizens only after rational thinking [6, c.5]. China has strict management and inspection systems for systematical firearms. Generally, firearms made as per systematical firearms obviously belong to firearms whose personally holding, selling and borrowing, etc. are banned by the criminal law. Common citizens mostly associate firearms with systematical firearms. From the angle of a normal person, non-systematical firearms that cannot launch standard bullets do not belong to firearms of normal meaning. Some believe that imitation guns and genuine guns have essential differences. With the development of society, the appearance and content structure of firearms keep updating. Although some firearms possess relevant elements of legal provision, they look quite different from conventional firearms with naked eyes. Even if "imitation guns" have equal harm as genuine guns, laws shall be amended at first [7, c.5]. Some defendants try to defend themselves with the following excuses: "The involved are toy guns not firearms in a real sense", [8, c.5] "They are just two imitation guns not genuine guns. It's not a big deal" [9, c.5]. Out of hobbies and interests of collecting or displaying, etc., the defendants hold that the case-related firearms belong to non-systematical firearms. Common citizens do not understand firearms, let alone a clear understanding that non-systematical firearms belong to the scope of "firearms" banned by national criminal law. Therefore, the inclusion of imitation guns into firearms in the criminal law seems exceeding the range of extensive interpretation.

\section{(II) Teleological interpretation}

The Supreme Court of the United States holds that dumping hydrochloric acid to the face of the victim by the actor is a behavior resulting in bodily injury "with the help of weapons". This interpretation also combines with the purpose of law that harsh punishment shall be given to extremely dangerous damage method [10, c.6]. As for the legislation of firearms-related crimes, from the making of 1979 criminal law to the amendment of 1997 criminal law, the legislators may not foresee the growing of imitation gun market. The definition of firearms is mainly limited to systematical firearms. However, the original intention of legislators is not the main reason of interpretation, the legislative purpose (normative purpose of articles of law, i.e., purpose of legal interest protection) is the decisive reason [11, c.6]. Kriele holds that no matter the decision is made by the legislator or the judge, if it preferentially protects the "obviously more important interest" among various relevant interests, it can be legitimized [12, c.6]. However, is public security a preferential legal interest compared to the personal freedom of citizens using or selling imitation guns? If the public security is used as the standard, does collecting imitation guns by citizens form a real danger threatening the public security? There are lots of disputes on how to divide the boundary of imitation guns and genuine guns from the protected legal interest in firearms-related crimes.

(III) Modest and restrained principle of criminal law

Is the intervention of criminal law necessary in the imitation gun-related crime? Public laws emphasize the principle of proportionality, i.e., adopting the means with the minimum damage to protect the legal interest to be protected. Under the modest and restrained principle, criminal law is regarded as the "last law". Under the premise that other laws cannot play a role, criminal law can regularize the behavior of people. Some existing judicial interpretations of China also reflect the modest and restrained principle. As indicated in The Supreme People's Court's Explanation to Several Problems on Applicable Laws in Trying Criminal Cases of Illegally Manufacturing, Trading and Transporting Firearms, Ammunitions and Explosives, etc., those illegally manufacturing, trading, transporting, mailing and storing explosives with quantity reaching the standard specified in Article 1 can be given a lesser punishment, if they did them out of normal production and living needs such as paving road, building house, digging well, renovating homestead or land, etc., or out of legal production and operating activities, did not bring about severe social harm, and showed repentance. They can be exempted from punishment if the circumstance is minor. In the minority area, some common laws still play the role of excluding crime. Some minorities have the habit of holding firearms. In some minority areas, holding firearms by minorities based on customs is not identified as a crime [13, c.7]. Among firearms-related cases tried by Chongqing No.3 Intermediate People's Court, 116 defendants were sentenced to non-custodial penalty or exempted from criminal 
punishment, accounting for $95.08 \%$ of people involved. In these cases, some firearms are handed down by elder generations; some are simple self-made powder shotguns. Main purpose of firearms is to hunt and protect crops, without specific social harms [14, c.7].

The firearm-related crime is not an intent crime. The criminal suspect is not required to have the intention of illegal use, etc. Therefore, the purposes of collection and hobby, etc. cannot be used as evidences of decriminalization. In firearms-related crimes, the actor's ambiguous understanding of the nature of "firearm" crime is not a reason for decriminalization. Under the modest and restrained principle of criminal law, the chance of decriminalization can be given to the criminal suspects who do not have strong consciousness and determination of violating laws, lack a clear understanding for the illegality of behavior, and accidentally enter the procedure of criminal prosecution due to negligence, so as to fully reflect the modest and restrained spirit of criminal law in the law enforcement and case-handling process. Even if some imitation gun-related behaviors shall be regulated by the criminal law, conviction and sentencing shall also be different from ordinary systematical firearms, to realize the balance between crime and punishment. Secondly, the connotation of "firearms" in criminal law shall be further interpreted reasonably. A more stringent standard of firearm identification shall be formulated. Since public security organs, procuratorial organs and people's courts handle firearm-related criminal cases at different stages, and the identification of the nature of firearms is the key of firearmsrelated cases, these three organs shall uniformly formulate an identification standard and a procedure norm for firearmrelated cases combining with their functions, so as to realize the consistency of legal interpretation and realize the unification of judicial standard and law enforcement standard. Meanwhile, all links of imitation guns from production, circulation to consumption shall be regulated from the level of social administration. Administrative measures and methods shall be strengthened.

\section{Literature}

1. Yu Aoyang, Bai Tiegang, Li Hua: The experimental research on the lethality standard of non-systematical guns, Journal of Fujian Police Academy. No.2. 2008.

2. Ji Jun: Discussion on the identification of lethality of guns, Journal of Criminal Police College of China. No.2. 2009.

3. (2010)S.Z.F.X.Y.Z.Zi No. 330.

4. Zhang Lizhao, Yao Yu, Deng Qiang: Exploration to problem and countermeasure in handling gun-related crimes, People's Procuratorial Semimonthly, p63. No.9. 2010.

5. Feng Jun: Boundary and way of criminal law interpretation - Concentrating on extensive interpretation and application by analogy, The Jurist, p70. No.1. 2012.

6. Chen Aihe, Wang Yonggang: Robbery with imitation guns not equal to "gun robbery": The Procuratorate Daily, page 006, May 6. 2009

7. Criminal ruling of second instance on illegally trading and transporting firearms by Chen Fengliang (2014) L.X.Y.Z.Zi No. 64

8. The "gun fun" physics teacher is prosecuted due to purchasing imitation gun from Internet, December 29, 2014 Source: Xiaoshan website - Xiaoshan Daily http://www.xsnet.cn/news/shms/2014_12/2235948.shtml

9. Refer to Claus Roxin: Overview of German Criminal Jurisprudence: Base Configuration of Crime Principle, translated by Wang Shizhou, Law Press, 2005.

10. Zhang Mingkai: Criminal Jurisprudence, Law Press, 2013 edition, p39.

11. Germany Karl Larenz: Methodology of Jurisprudence, translated by Chen Ai'e, Commercial Press, 2003 edition, p28-29.

12. Zhang Mingkai: Chinese Practice of Nulla Poena Sine Lege, from Dialogue of Chinese and German Criminal Scholars -Nulla Poena Sine Lege and Criminal Law Interpretation, Editor-in-Chief Liang Genlin [Germany] Eric Hilgendorf, Peking University Press, 2013 edition, p91.

13. Lan Xiaorong, Li Jian: Why is light sentence imposed on the majority of firearms-related cases? http://www.flzx.com/wenji/216985.html

\section{On the death penalty with reprieve}

(c) Guo Donglei

China, Beijing

I. Definition of the Death Penalty with Reprieve

Death sentence with reprieve, shortened from death sentence with a two-year reprieve and forced labour, is a penalty enforcement measure with Chinese characteristics. It means that if the immediate execution of a criminal punishable by death is not deemed necessary, a two-year suspension of execution may be pronounced simultaneously with the imposition of the death sentence, and compulsory labor is forced to determine whether the criminals mend their deeds. Scholars from home and abroad have had a heated discussion on the reprieve system of death penalty. Opinions vary from person to person. For those who are in favour of this punishment, the reprieve system of death penalty is an unique punishment. Created by China, revealing the humanitarian spirit of punishing cautiously of criminal law, the respect and expect for life and the return of humanity. For those who doubt the death penalty with reprieve, the progressive meanings of this system are denied for the vogue relationship between death sentence with reprieve and death sentence and the muddy distinctions between death sentence and death sentence with reprieve. Through deep research into the death sentence system and the reprieve system of death penalty, the author holds the positive attitude towards this system. Therefore, the author believes that the reprieve system of death penalty is a creative system growing up in the soil of 
Chinese traditional culture with positive values. However, some problems on logic and practice of this system indeed exist in some provisions of Chinese criminal Code.

II. Conditions and Legal Results of the Death Penalty with Reprieve

This punishment is the unique innovative Chinese criminal law practice and is concerned and studied by the law professionals from all over the world. But this punishment is not first innovated in the contemporary era. This practice can be derived from the "practice of suspended hanging"and "decapitation execution"in ancient China's Ming and Qing dynasties and was established and improved in the Criminal Law [1]. Therefore, the legislative spirit of this punishment in China has a long historical roots and fertile cultural soil of rule of virtue.In China's Criminal Law, this punishment refers to the immediate execution of a criminal punishable by death is not deemed necessary, a two-year suspension of execution may be pronounced simultaneously with the imposition of the death sentence.Thus reduce the scope of practical application of this practice and achieve the legislative thought of discreet penalty and discreet death penalty. This punishment certainly is a rigorous system where two preconditions must be duly met before this punishment becomes applicable referring to the Paragraph 1 of Article 48 of the Criminal Law :

Firstly, the criminal shall be sentenced to a death penalty, that is, according to the provisions of Criminal Law, the criminal who committed extremely serious crimes deserves a death penalty. Criminals have already been sentenced to death penalty and this punishment is the execution method of death penalty. This practice is a totally different kind of punishment with a direct aim to the life of criminals comparing to the life imprisonment and fixed-term imprisonment.

Secondly, an immediate execution is not deemed necessary. That is to say, for the criminal who deserves a death penalty, an immediate execution shall be deemed unnecessary under the following circumstances:

1)after a crime has been committed, the criminal surrenders himself to justice, or performs meritorious services;

2)the ringleaders and the ones who committed major crimes has been sentenced to immediate execution of death penalty and the other principal offenders has not committed the most serious offense;

3)the victim is obviously blamable and the crime has been committed by the doer in a state of passion; tion [2] .

4)The criminal committed the crime out of righteous indignation or has other situations worthy of a reconsidera-

Thirdly, the legal results of the death penalty with probation. The law has explicit provisions on the test period, namely, 2 years of the death penalty with probation. Meanwhile, according to the different performances of criminals during the period of this punishment, the Article 50 in Criminal Law has stipulated three different legal results:

1) anyone who is sentenced to death with a suspension of execution commits no intentional crime during the period of suspension, his punishment shall be commuted to life imprisonment upon the expiration of the two-year period;

2) if he has truly performed major meritorious service, his punishment shall be commuted to fixed-term imprisonment of not less than 15 years but not more than 20 years upon the expiration of the two-year period;

3 ) if it is verified that he has committed an intentional crime, the death penalty shall be executed upon verification and approval of the Supreme People's Court.

III. Certain Problems of the Death Penalty with Reprieve

Any practice has to go through the process from establishment to improvement, so has this punishment. This practice is getting improved with the amendment of Criminal Law in 1997 and the Amendment VIII to the Criminal Law in 2011. However, it is undeniable that the there still exists several problems needed to be solved by lawmakers and judiciaries.

Firstly, two preconditions must be duly met before this punishment becomes applicable, one is the crime committed deserves a death penalty. The immediate execution of death penalty and the death penalty with probation belong to the executive mode of the death penalty punishment.However, the law neither made explicit provisions on nor the according judicial interpretations of the wording " committed extremely serious crimes". Under this circumstances, it to some extent simply depends on the subjective judgment of judges. In terms of legal effect, although the death penalty with probation is a kind of method of the execution of death penalty, there exists the immeasurably vast difference of life and death between this punishment and the death penalty. The wide gap between the immediate execution of the death penalty and the death penalty with probation results from the the fact that everyone only lives once, which even transcend the difference among the kinds of punishment.Here comes the question about how to determine the nature of this punishment. If the scale line cannot be decided correctly, this punishment tend to become the transitional criminal penalty from the life imprisonment and the death penalty in judicial practice. Thus the aim of the lawmakers can be violated and the practical effect can be reduced.

Secondly, "whether an immediate execution is deemed necessary or not". When the criminal who committed serious crimes deserves a death penalty, the criminal may be sentenced to death penalty with probation if the immediate execution is not deemed necessary. While there is no explicit stipulation on the wording " an immediate execution is not deemed necessary". Thus the another problem of the boundaries between the wording " an immediate execution is not deemed necessary"and "an immediate execution is deserved". As mentioned above, despite that the immediate execution of the death penalty and the death penalty with probation belong to the death penalty, the legal results of life and death are totally different. Based on this, there always exists an insuperable borderline between life and death in the mind of humans. Once crossing this borderline, the life comes to an end. People have awestruck attitudes toward this world and the other world. Crossing the borderline between life and death never exists in any fluke mind of humans [3]. The judgment of judges are allowed in such a wide scale, which obviously conflict with the principle of rule of law and the objectivity of criminal law. 
Thirdly, the problem of intentional crimes. For criminals who are sentenced to death penalty with probation, the Article 50 has stipulated that " if a person sentenced to death with a suspension of execution does not commit an intentional crime during the period of suspension, his punishment shall be commuted to life imprisonment upon the expiration of that two-year period; if he performs great meritorious service, his punishment shall be commuted to fixed-term imprisonment of not less than 15 years and not more than 20 years upon the expiration of that two-year period; if it is verified that he has committed an intentional crime, the death penalty shall be executed upon the approval of the Supreme People's Court." this is the kernel article of law stipulated by Criminal Law on the death penalty with probation.

From the meaning of this article, the important content of this punishment consists of the following two aspects: firstly, for the criminal who is sentenced to death penalty with probation, his punishment shall be commuted to life imprisonment or fixed-term imprisonment upon the expiration of the two-year period; secondly, for the criminal who is sentenced to death penalty with probation has committed criminal negligence during a two-year suspension of execution, the death penalty shall not be executed; thirdly, for the criminal who is sentenced to death penalty with probation has committed an intentional crime during a two-year suspension of execution, the death penalty shall be executed upon the approval of the Supreme People's Court. It is obvious to see that the Criminal Law specifies that for the criminal who is sentenced to death penalty with probation has committed an intentional crime during the two-year period, the death penalty shall be executed. It doesn't make sense at all. For example, both A and B are sentenced to death penalty with probation. During the two-year period, A commits crime of insult under provocation, while B leads to the death of others out of negligence during the period of compulsory labour. According to the provisions of Criminal Law, the death penalty shall be executed because A commits intentional crimes, while the execution of death penalty is avoided because the crime $\mathrm{B}$ has committed belongs to negligence in spite of the casualties. The different results highlights the irrationality of Criminal Law.

\section{IIII. Conclusion}

In spite of plenty of defects and even problems demanding prompt solution, this punishment is positive and valuable. A sound institution has never been born flawlessly. On the contrary, some original defects come along with the establishment of a new institution. Through the academic research and practical development, the institution will advance with the times and be perfected and enriched continually. This punishment in ancient China possessed a tradition of rule of virtue, rule of criminal law ran parallel with rule of rites and music filled the legal theory with humanism. Under the background of this culture and rule of law, this punishment came into being. Therefore, this punishment should be integrated with the times constantly. Only in this way can this punishment make better effects on the theory of criminal law and practice.

\section{Literature}

1. Qian Daqun believes that "the practice of sentencing the jailed in autumn prevailing in Ming and Qing dynasties is the embryonic form of China's reprieve system of death penalty ". See Qian Daqun: China's Legal History and Examination. Nanjing Normal University Press, 2001 edition, pp.190-198. Quoted from: Gao Mingxuan, and Xu Hong: Three Dimensional Inspection of China's Reprieve System of Death Penalty, Political Science and Law, 2010, Issue 2.

2. Cheng Xinsheng: Discussion on Factors Affecting the Application of the Death Penalty, Jurists Review, 2001, Issue 2.

3. Guo Donglei: "Further Discussion on the Death Penalty--from Beccaria to Garofalo", Journal of Southwest University For Nationalities(the Theory of Social Sciences Version), 2013, Issue 10.

\section{China's criminal injunction system}

In 2011, the criminal injunction system was established in the Amendment VIII of China's Criminal Law, which stipulates, "Where a criminal is sentenced to pubic surveillance, he/she may also be prohibited, during the term of public surveillance, from engaging in certain activities, entering certain regions or premises, or meeting with certain persons, depending upon the circumstance of crimes committed." Furthermore, China's judicial authorities jointly issued the Provisions on the Relevant Issues concerning the Application of Injunctions to Convicts Sentenced to Public Surveillance or Probation that further clarified the application, content, period, implementing authority, and legal ramifications of violating the injunction.

I. Introduction

A. Concept of Criminal Injunction

The criminal injunction is essentially a kind of order that prohibits convicts from engaging certain activities, entering certain regions or premises, or meeting with certain persons. Specific prohibitions are announced in tandem with public surveillance or probation.

B. Nature of Criminal Injunction

In view of existing criminal punishment system, the injunction is not an independent punishment as those explicitly enumerated in the criminal law. Some scholar argues the injunction is a non-criminal punishment with the nature of security measure [1]. Though there are some similarities between the injunction and security measure, to equate the two needs further discussions [2]. In the mainstream opinion, the injunction is not a new criminal punishment, rather a su- 
pervising measure imposed on the convicts sentenced to public surveillance and probation [3]. This interpretation corresponds with original legislative purpose and the modern trend of socialized criminal theories.

C. Features of Criminal Injunction

Its main features include:

First, the injunction is auxiliary and thus could only be applied with principle or supplementary punishments. In addition, only those who have been sentenced to public surveillance and probation could be imposed of injunction. This is a precondition of its application.

Second, the injunction is designed to ensure victim's safety and prevent new crimes, so as to supervise and educate the convicts. As one French scholar's point, we do not want to use the injunction to doubly punish the convicts; instead, we are more concerned about public safety [4]. We can expect the injunction, as an auxiliary measure, to achieve the goal of specific prevention and reduce potential crimes in the near future.

Third, the injunction is a prohibitive order per se, which imposes special obligations on certain convicts. The legislature explains that, "The injunction, embodied within the judgment, is of mandatory legal effects that regulate certain convicts during certain periods" [5]. The convicts will be punished in case of violation, viz., when violating public surveillance requirements, the convicts have to assume administrative burdens; when violating probation requirements, the probation will be withdrew and original punishment will be implemented.

D. Significance in Practice

As an important component of social management and criminal punishment, the injunction is of vital significance. First, consist with the policy of "Severity with Lenience" and the principle of individualized punishment, the injunction is applied not to all the convicts, but depending upon various circumstances in individual case. Second, as an effort to help rehabilitate the convict and return the society, it reflects the socialized development of criminal punishment. Third, it reduces some drawbacks of implementing the public surveillance and probation, and therefore conducive to prevent cross-infection of implementing non-imprison punishments.

II. Application of Criminal Injunction

A. Conditions

Two conditions should be met before imposing the injunction. The first looks like a precondition, i.e., the court could apply the injunction only when the convict has been sentenced to public surveillance and probation. The second requires authorizes the court considering whether it is necessary to use the injunction. The court shall, according to the cause and nature of the crime committed, the criminal means, the convict's repentance, the usual performance of the convict and other factors, fully consider the extent of relevance of such factors to the convict's guilt, and then make a pertinent decision on imposing one or more parts of the injunction [6].

B. Principles

The injunction is imposed to those who the court deem it is necessary to applied, not including all the convicts who have been sentenced to public surveillance and probation. If applied, not all the three prohibitions (of activities, regions, and meeting persons) will be simultaneously imposed. We can infer some principles from this general requirement.

(1) Necessity

As a preventive measure, the injunction is applied only when the court deems it is necessary to. In other words, the court shall impose the injunctions after comprehensively evaluating the convict's dangerousness and the possibility of rehabilitation. If the convict's usual performance is good and the crime is induced by passionate impulse, or the circumstances of alleged conduct are obviously minor and will not threaten certain person or public safety, it is not necessary to announce an injunction.

(2) Pertinence

In order to achieve the goal of specific prevention, according to the cause and nature of crime committed, the court shall impose the injunction of different contents and periods. The activities prohibited by the injunction must be those count against rehabilitation or might induce new crimes, rather than irrelevant activities. For example, juveniles who previously stole or robbed in the Internet cafes may be prohibited from reentering similar public entertainment places; convicts who committed credit card frauds may be prohibited from applying for or using credit cards again.

(3) Proportionality

In view of its potential restrictions on personal liberty and other basic rights, the injunction must be appropriately imposed so as not to affect convict's normal life. Prohibitions within the injunction shall be proportionately balanced between rehabilitation, specific prevention and public safety. Those goals should not disproportionately restrict convict's other legal rights.

\section{Contents}

China's injunction includes three kinds, i.e., prohibitions from engaging in a certain activity, entering a certain area or place, or contacting a certain person.

First, the court may prohibit a convict from engaging in one or more of the following kinds of activities during the period of public surveillance or probation. E.g., (A) an individual who established a company for the purpose of committing illegal or criminal activities or committed crimes as the main activities of a company shall be prohibited from establishing any company; (B) whoever committed any securities crime, loan crime, bill crime, credit card crime or other financial crime shall be prohibited from engaging in securities transactions, applications for loans, use of bills, applications for and use of credit cards or other financial activities.

Second, with respect to certain place or area, the court may prohibit a convict from entering one or more of the following kinds of areas or places, e.g., (A) Prohibition from entering nightclubs, bars, discotheques, Internet cafes and 
other entertainment places; (B) prohibition from entering any place where any large-scale mass activity is held without the approval of the enforcement organ; (C) prohibition from entering primary and middle schools, kindergartens and their surrounding areas.

Third, with respect to certain person, the court may prohibit a convict from contacting one or more of the following kinds of persons during the period of public surveillance or probation, e.g., (A) prohibition from contacting a victim or the legal representative or close relatives thereof without the consent of such a party; (B) prohibition from contacting a witness or the legal representative or close relatives thereof without the consent of such a party; (C) prohibition from contacting an accuser, criticizer or informant or the legal representative or close relatives thereof without the consent of such a party.

D. Procedures

(1) Decision-making of the Injunction

The court has the authority to announce the injunction, while the procuratorate and public security organ can make suggestions. The procuratorate may suggest the announcement of an injunction on a defendant who may be sentenced to public surveillance or probation. The parties concerned, defenders and representatives may give opinions and reasons on whether an injunction on the defendant shall be announced. The court shall announce in a separate item of the main part of the written sentence any injunction on a defendant sentenced to public surveillance or probation.

(2) Period

The period of an injunction may be the same as or shorter than the period of public surveillance or probation, but shall not be less than three months if a convict is sentenced to public surveillance and shall not be less than two months if a convict is sentenced to probation.

Where a convict sentenced to public surveillance has already been taken in custody before the execution of a sentence, so that the period of public surveillance is less than three months, the period of an injunction shall not be restricted by the shortest period as prescribed in the preceding paragraph.

E. Legal Ramifications of Violations

The ramifications vary in different injunctions. Where a convict sentenced to public surveillance violates an injunction, or a convict sentenced to probation violates an injunction but the circumstances are not serious, the public security organ at the place where the community correction organ responsible for executing the injunction is located shall punish the convict according to the Article 60 of China's Public Security Administrative Punishments Law.

Where a convict sentenced to probation violates an injunction and the circumstances are serious, the probation shall be revoked and the original punishment shall be executed. The ruling of the court on revoking probation shall take effect immediately after being made.

III. The Future of China's Injunction System

It has been only five years since its establishment. Though as an innovation within broad legal reforms, there are many problems in practice, such as lack of systematic support, lack of effective supervision, and inefficient implementation. However, we shall believe, with the improvement of supporting systems and accumulation of judicial experience, China's criminal injunction is developing and will become mature in the near future.

\section{Literature}

1. Zhang Mingkai, The Criminal Law, Beijing: China Legal Press, 2010, at 559.

2. For example, some points out that the security measure and criminal injunction are different with respects to the conditions and subjects of application. See An Qi, On China's Criminal Injunction System, Master Degree Thesis of Shandong University, 2014.

3. See editorial, Accurately Apply the Criminal Injunction, Ensure the Effect of Implementation People's Arbitration, No. 6, 2011 , at 9-10.

4. Gaston Stefani, General Introductions of French Criminal Law, Chinese edition, Beijing: China University of Political Science and Law Press, 1998, at 430.

5. National People's Congress Legal Committee, ed., Explanations, Legislation Reasons and Related Laws of Amendments VIII of China's Criminal Law, Beijing: Peking University Press, 2011, at 40.

6. See editorial, supra note 3 , at 10. 


\title{
V. УГОЛОВНО-ПРОЦЕССУАЛЬНЫЕ И КРИМИНАЛИСТИЧЕСКИЕ ПРОБЛЕМЫ СРАВНИТЕЛЬНОГО ПРАВОВЕДЕНИЯ. ПРАВООХРАНИТЕЛЬНЫЕ ОРГАНЫ В СТРАНАХ АTP
}

\section{Особенности процессуального положения свидетеля в процессе РФ и США}

\author{
(ㄷ) С. И. Аносова \\ студентка 3-го курса юридического факультета \\ ФГБОУ ВО «Бурятский госуниверситет» \\ Россия, г. Улан-Удэ \\ svetanikolay@gmail.com
}

\begin{abstract}
Известно, что англосаксонская правовая система, которая действует на территории Соединенных Штатов Америки, имеет ряд отличительных черт от романо-германской правовой системы, характерной для Российской Федерации. Правовая система государства оказывает непосредственное влияние на содержание и применение нормативно-правовых актов, в частности и на уголовное судопроизводство, на процессуальное положение лиц, участвующих в деле. Уголовно-процессуальное право, в целом, и институт защиты прав и законных интересов участников уголовного процесса, в частности, отличается значительным разнообразием, что в полной мере объяснимо экономическими, историческими, этническими, религиозными и иными условиями каждого государства.

Свидетель в российском и американском уголовном судопроизводстве имеет определенные процессуальные права и обязанности. Явка свидетеля в Соединенных Штатах, как и в Российской Федерации, обеспечивается извещением о вызове в суд, повесткой или приказом.

В Российской Федерации, согласно ч. 1 ст. 56 Уголовно-процессуального кодекса свидетелем является лицо, которому могут быть известны какие-либо обстоятельства, имеющие значение для расследования и разрешения уголовного дела, и которое вызвано для дачи показаний[1]. Данное лицо относится к иным участникам уголовного процесса. Показания свидетеля чаще всего служат основным источником информации о преступном деянии.

В уголовном процессе США, свидетелем является любое лицо, которое дает показания. Здесь, к свидетелю можно отнести обвиняемого (подсудимого), потерпевшего (жертва преступления), свидетеля (в узком смысле слова), эксперта, иных лиц, дающих показания (например, полицейский).

В американском уголовном процессе лицо, дающее свидетельские показания должно дать присягу или торжественное обещание, которые, в свою очередь, накладывают на него уголовную ответственность за заведомо ложные показания[3]. В нашем государстве мы наблюдаем более упрощенную процедуру, которая выражается в оглашении судьей прав и обязанностей свидетеля.

В США, по общему правилу, всякое лицо признается компетентным давать показания в роли свидетеля, если оно достоверно воспринимает факты, дает адекватные показания, а также способно осознавать значимость этих показаний и необходимость дачи правдивых показаний. Препятствием этому могут служить либо малый возраст свидетеля, либо его психические или физические недостатки.

Также наряду с компетентными лицами выделяются те лица, которые имеют право отказываться от дачи показаний. Основаниями освобождения являются привилегии, которые предоставляются в целях защиты и охраны основных прав и свобод, определенных общественных отношений, которые отражают доверительный характер, в интересах государства.

Например, в России супруг имеет право не свидетельствовать против своего супруга, здесь нет разделения на компетентного и некомпетентного свидетеля, как в США, где супруг обвиняемого не является компетентным свидетелем стороны обвинения, но при этом является компетентным свидетелем стороны защиты. Иначе сказать, супруг всегда может быть свидетелем защиты, но не может быть свидетелем обвинения[3].

В рассматриваемых государствах свидетель дает показания в суде устно, в открытом заседании[2]. Это общее правило имеет исключения, предусмотренные из соображений целесообразности, когда показания даются до суда. В Америке, физически нездоровые свидетели, или находящиеся за границей государства, могут быть допрошены соответствующим должностным лицом, иностранным судом, и их показания в представляются в суд в виде аффидевита. Аффидевит - письменное показание свидетеля, данное также под присягой или торжественным обещанием.
\end{abstract}


Свидетель, в США, обязан сообщать лишь о тех фактах, которые были восприняты им лично. Данное требование - есть гарантия получения более надежной и достоверной информации судом. Первая гарантией является присяга или торжественное обещание, которые служат также подтверждением знания об ответственности за донесение ложных сведений. Вторым обоснованием недопустимости показаний не своих слов является возможность ошибки, даже двойной ошибки, при переходе информации заявителя лицу, сообщающему ее в суде, а также самим этим лицом при передаче этого заявления в суде. Третье обоснование - это то, что присяжные заседатели не имеют возможности видеть поведение и мимику лица "автора чужих слов". Четвертое, и самое важное, обоснование - показания с чужих слов не дают возможности противоборствующей процессуальной стороне вести перекрестный допрос, который является проверкой надежности. Именно во время такого допроса возникает возможность выявить скрытые ошибки, допущенные допросе на прямую.

В американском судопроизводстве обвиняемый вправе не давать показания или отвечать на любой вопрос со стороны обвинения. Это касается не только обвиняемого, но а также и любого свидетеля. Если свидетель сочтет, что его показания могут инкриминировать его в совершении преступного деяния, он имеет право на отказ от ответа на любой вопрос [3].

В России эксперт, также как и свидетель, является иным участником уголовного процесса, но он не считается свидетелем, как в Америке. Здесь данное лицо признается таким же свидетелем, как любые иные лица, но он приглашается в суд для дачи показаний в специальной, определенной сфере, где он обладает достаточными и специальными знаниями.

В США из-за необходимости получения свидетельских показаний был создан институт "иммунитет свидетеля" - предоставляемая судом гарантия, что факты и показания, которые возникают из слов свидетеля, не будут использоваться в качестве обвинительных доказательств в его сторону в уголовном судопроизводстве.

К элементам данного иммунитета относится право лица не предоставлять некоторые виды документов. Документы как доказательства вводятся в судебный процесс посредством свидетельских показаний. То есть документы в отдельных случаях можно считать частью свидетельских показаний.

Данные положения обеспечивают права на личную тайну и неприкосновенность частной жизни, а также являются частью "привилегии против самообвинения"[2].

Привилегия супругов заключается в том, что они имеют право отказаться давать показания относительно фактов, которые стали им известны друг от друга во время состояния в браке. Супружеская привилегия предоставляется лицам, находящимся в законном браке и перестает действовать после прекращения брака.

Одна из самых давних привилегий - конфиденциальность отношений между адвокатом и клиентом. Ее суть в том, что свидетель имеет право не давать ответы на вопросы, которые касаются его общения с адвокатом.

Как и в России, за дачу ложных показаний американский свидетель несет уголовную ответственность. За отказ от дачи показаний или отказ от предоставления затребованных доказательств, свидетель несет уголовную ответственность за неуважение к суду. Наказание может выражаться в виде штрафа или тюремного заключения.

Таким образом, тип уголовного судопроизводства в странах с различными правовыми системами обусловливает особенности защиты прав и законных интересов участников уголовного процесса. Состязательность в странах англосаксонской правовой системы, к которым относится США, понимание уголовного процесса и судебного разбирательства как спора между сторонами защиты и обвинения определяют особенности правового и процессуального положения лиц, участвующих в деле. Отличительная черта данной правовой системы права в том, что весь процесс судебного разбирательства подвластен принципам допустимости доказательств. Не обязательно установление истины для суда, который, при вынесении вердикта, исходит из того, что преступление совершено с большой вероятностью этим обвиняемым. В Америке судебный процесс не имеет деления на этапы или стадии, что является отличительной чертой от российского судопроизводства. На практике - это последовательное изложение сторонами обвинения и защиты своей позиции в речах, которые сочетаются с доказательствами. В данной правовой системе свидетелем может являться любой человек, дающий показания суду.

Для того, чтобы права и свободы участников уголовного процесса могли качественно обеспечиваться государством, страны за рубежом на протяжении многих лет создавали механизмы гарантий. В Российской Федерации такие механизмы находятся на стадии формирования, и это есть единичное средство предотвращения и сдерживания злоупотреблений. Эффективность действий юридических гарантий, в том числе и уголовно-процессуальных, влияет на степень реализации прав и свобод граждан, их обязанностей, правоприменительную практику и в целом на подчиненность государства действующему праву.

\section{Литература}

1. Уголовно-процессуальный кодекс Российской Федерации: федер. закон Рос. Федерации от 18 дек. 2001 г. № 174-Ф3; ред. от 23 июля 2013 г. № 245-Ф3 // СЗ РФ. 2001. № 52. Ч. 1. Ст. 4921; 2013.№ 30. Ч. 1. Ст. 4078.

2. Епихин А. Ю. Законодательство зарубежных стран, обеспечивающее безопасность участников уголовного судопроизводства. М.: Юридический центр Пресс, 2004. 331 с.

3. Лоскутова Т. А. Особенности процессуального положения свидетеля в уголовном процессе Англии и США // Адвокатская практика. 2005. № 5. С. 39-42. 


\title{
Право подозреваемого на защиту в уголовном судопроизводстве Китайской Народной Республики и Российской Федерации
}

\author{
(C) А. В. Бродникова \\ студентка 3-го курса юридического факультета \\ ФГБОУ ВО «Бурятский госуниверситет» \\ Россия, г. Улан-Удэ \\ aleksandrula@mail.ru
}

Важнейшими направлениями совершенствования уголовно-процессуального законодательства являются преобразование организации государственных органов, ведущих уголовный процесс; внесение существенных изменений в принципы, порядок и практику судопроизводства, в том числе на стадии предварительного расследования. Процессуальными гарантиями прав личности служат средства, обеспечивающие фактическую реализацию этих прав, прежде всего, право каждого гражданина на получение квалифицированной юридической помощи.

Уголовное судопроизводство - это та сфера государственной деятельности, где права подозреваемого затрагиваются наиболее существенно, где возможно применение различных мер уголовно-процессуального принуждения, где решается вопрос о судьбе привлекаемого к уголовной ответственности лица, его свободе и даже жизни. Адвокатская помощь становится важнейшим средством обеспечения права на защиту подозреваемого. Уголовное судопроизводство в КНР и РФ обладает многими общими характеристиками, однако в России право подозреваемого на адвокатскую помощь обеспечивается в значительно большем объеме, чем в Китайской Народной Республики.

С учетом изложенного, представляется, что сравнительное исследование обозначенной научной проблемы, равно как и формулирование предложений по совершенствованию законодательства Китайской Народной Республики в части, касающейся оказания квалифицированной юридической помощи подозреваемому объективно вызывают исследовательский интерес и имеют большое практическое значение.

В обеих странах требуется высшее образование. Однако, в Китае лицу требуется иметь только высшее - не обязательно высшее юридическое образование, а в России необходимо иметь не просто высшее, а высшее юридическое образование.

В обеих странах требуется стаж работы по юридической специальности. Такое требование, безусловно, необходимо, поскольку адвокатская деятельность требует не только специальных знаний, но и обширного профессионального опыта. Стаж работы по юридической специальности позволяет лицу набирать необходимый опыт. В Китае требуется получить стаж работы обязательно в адвокатуре, а в России необходимо иметь стаж по юридической специальности либо пройти стажировку в адвокатском образовании, не обязательно в адвокатуре.

Есть различия и в сроках: в Китае стаж работы требуется не менее одного года, в России - не менее двух лет.

Проблема обеспечения права на защиту решается в зависимости от правового положения личности, характера и степени развития демократии в государстве. Чем больше процессуальных гарантий от незаконных задержаний, арестов и обысков получает человек, тем выше уровень свободы личности. Уголовный процесс, в свою очередь, во многом характеризует политический режим государства, уровень свободы личности. Закон выступает в качестве гарантии демократии, выполняя роль организующего фактора по отношению к самому государству. Требование законности обращено к государству, ко всем его органам, включая высшие органы государственной власти.

Участие адвоката в допросе подозреваемого имеет важное значение для реализации процессуальных прав. В Китае данное право не обеспечено ни в законодательстве, ни на практике. Важную роль в реальной жизни играют взаимоотношения между знакомыми. Суть проблемы в том, что решение вопросов зависит от обладания властью, а не от положений закона.

Ученые теоретики предполагают внести изменения в положение о допросе подозреваемого, предусмотренное ст. 93 УПК КНР, а именно, изложить ее в следующем виде: «С момента допуска к участию в уголовном деле защитник вправе участвовать в допросе подозреваемого, обвиняемого, а также в иных следственных действиях, производимых с участием подозреваемого, обвиняемого либо по его ходатайству или ходатайству самого защитника»[7].

Согласно ст. 5, 6, 7, 8 «Закона об адвокатской деятельности и адвокатуре в Китайской Народной Республики», статус адвоката вправе приобрести лицо, которое имеет высшее образование, сдало единый общегосударственный экзамен на право осуществлять адвокатскую деятельность. Указанное лицо также должно иметь стаж работы в адвокатуре не менее одного года. На основе положений «Закона об адвокатской деятельности и адвокатуре в КНР» китайские ученые дали свои определения понятия «адвокат»[4].

Лю Инцюань писал, что китайский адвокат - это лицо, сдавшее единый общегосударственный экзамен, по закону получившее сертификат на право осуществлять адвокатскую деятельность и оказывать юридические услуги обществу[7, с. 33].

В ст. 9 «Закона об адвокатской деятельности и адвокатуре в Российской Федерации» предусмотрено, что статус адвоката в Российской Федерации вправе приобрести лицо, которое имеет высшее юридическое образо- 
вание, полученное в имеющем государственную аккредитацию образовательном учреждении высшего профессионального образования, либо ученую степень по юридической специальности. Указанное лицо также должно иметь стаж работы по юридической специальности не менее двух лет либо пройти стажировку в адвокатском образовании в сроки, установленные настоящим Федеральным законом[3].

Для осуществления помощи подозреваемому уголовно-процессуальный закон должен обеспечить адвокату широкий круг прав, в первую очередь, это право на свидание с подозреваемым. В Китае момент свидания подозреваемого с адвокатом определяется днем, когда подозреваемый впервые был допрошен следственными органами. Это значит, - их свидание может быть организовано только после первого допроса подозреваемого, который имеет большое значение как для подозреваемого, так и для следственных органов.

Российский УПК от УПК КНР отличается тем, что в п. 3 ч. 4 ст. 46 УПК РФ установлено, что подозреваемый имеет свидания с защитником с момента возбуждения уголовного дела в отношении его либо с момента фактического задержания до первого допроса подозреваемого; одновременно в п. 1 ч. 1 ст. 53 УПК РФ указано, что с момента допуска к участию в уголовном деле защитник вправе иметь свидания с подозреваемым. В соответствии со ст. 92 УПК РФ, в протоколе задержания, который должен быть составлен в срок, не превышающий трех часов после физического задержания, должна быть отметка о том, что подозреваемому разъяснены его права, в том числе право на свидание с избранным им защитником. В той же ст. 92 УПК РФ, также, предусмотрено, что в протоколе задержания должна быть отметка о том, что подозреваемому разъяснены его права, предусмотренные ст. 46 УПК РФ. В числе этих прав есть право знать, в чем он подозревается, право давать объяснения и показания или, что очень важно, отказаться от дачи показаний[3].

Соблюдение этих требований закона имеет практическое значение, поскольку показания, полученные на допросах подозреваемого, которому не были разъяснено его право иметь свидание с защитником, или право не давать показания, не могут быть использованы в дальнейшем судом в качестве доказательств. В соответствии со ст. 50 Конституции РФ, «при осуществлении правосудия не допускается использование доказательств, полученных с нарушением федерального закона»[1].

Ознакомление с материалами дела; является способом получения информации о содержании следственных материалов - участии субъектов процесса в производстве следственных действий в ходе досудебного процесса. Под ознакомлением адвоката с материалами дела досудебного производства понимается совокупность прав адвоката, а также его действий, реализуемых в форме правоотношений, которые обеспечивают адвокату получение информации о ходе и результатах расследования из документов и предметов материального мира, собранных в процессе отдельных следственных и иных процессуальных действий.

В УПК КНР возможность для стороны защиты ознакомиться с материалами дела до окончания предварительного расследования отсутствует, то есть на стадии предварительного следствия адвокат не имеет права знакомиться с материалами дела, а в ходе рассмотрения дела прокуратурой для предъявления обвинения права адвоката по ознакомлению с материалами дела ограничены.

Проблема обеспечения права на защиту, как в России так и в КНР, решается в зависимости от правового положения личности, характера и степени развития демократии в государстве. Чем больше процессуальных гарантий от незаконных задержаний, арестов и обысков получает человек, тем выше уровень свободы личности.

\section{Литература}

1. Конституция Российской Федерации : принята всенародным голосованием 12.12.1993 (с учетом поправок, внесенных Законами РФ о поправках к Конституции РФ от 30.12.2008 № 6-ФКЗ, от 30.12.2008 № 7-ФКЗ, от 05.02.2014 № 2-ФКЗ, от 21.07.2014 № 11-ФКЗ) // Российская газета. 1993. 25 дек. № 237.

2. Уголовный кодекс Китайской Народной Республики (принят Постоянным комитетом ВСНП 02.08.2014) [Электронный ресурс]. URL : http://ru.china-embassy.org/rus/zfhz/zgflyd/t1330730.htm (дата обращения: 29.03.2016).

3. Уголовно-процессуальный кодекс Российской Федерации: федер. закон Рос. Федерации от 18 дек. 2001 г. № 174-Ф3; ред. от 23 июля 2013 г. № 245-ФЗ // СЗ РФ. 2001. № 52. Ч. 1. Ст. 4921; 2013. № 30. Ч. 1. Ст. 4078.

4. Закон Китайской Народной Республики «Об адвокатах и юридическом представительстве» (Обнародован на 19-м съезде Постоянного Комитета Всекитайского Собрания Народных Представителей 8-го созыва 15 мая 1996 года, вступил в силу 7 января 1997 года) [Электронный ресурс]. URL : http://online.zakon.kz/Document/?doc_id=30188188 (дата обращения: 29.03.2016).

5. Об адвокатской деятельности и адвокатуре в Российской Федерации: Федеральный закон от 31 мая 2002 года № 63 Ф3, с изменениями от 13.07.2015 года // Собрание законодательства Российской Федерации. 2002. № 23. Ст. 2102.

6. Гармаев Ю.П., Попова Е.И. Памятка подозреваемому, обвиняемому об особенностях рассмотрения уголовного дела судом в особом порядке, предусмотренном главой 40 УПК РФ и советы по ее практическому применению // Российский следователь. 2013. №24. С.10-13.

7. Чжан Ин. Сравнительное исследование права подозреваемого на адвокатскую помощь в уголовном судопроизводстве КНР и РФ : дис. ...канд. юр. наук. Владивосток, 2010. 186 с.: ил. РГБ ОД, 61 10-12/93. 


\title{
Сравнительно-правовой анализ американской сделки о признании вины и особого порядка судебного разбирательства российского уголовного судопроизводства
}

\author{
(С) К. О. Будникова \\ студентка 3-го курса юридического факультета \\ ФГБОУ ВО «Бурятский госуниверситет» \\ Россия, г. Улан-Удэ \\ 684920@mail.ru
}

На протяжении почти всей истории развития уголовно-процессуального законодательства, красной нитью конкурируют два основных положения на оценку эффективности уголовного судопроизводства: необходимо ли в ходе производства по уголовному делу, в обязательном порядке, устанавливать истину, подтверждая обстоятельства дела доказательствами, в том числе в ходе судебного разбирательства, вне зависимости от затрат организационного, технического, материального, временного характера либо важнее провести процесс быстро, при минимуме затрат, умиротворить стороны и при соблюдении определенных юридических условий постановить итоговое решение по уголовному делу?

На современном этапе, при совершенствовании уголовного судопроизводства, остается потребность в оптимизации действующей уголовно-процессуальной формы, которая эффективно бы обеспечивала реализацию прав человека и способствовала экономному и рациональному использованию ресурсов, выделяемых для осуществления правосудия, сокращение сроков рассмотрения уголовных дел и уменьшению нагрузки на судейский корпус. В настоящее время, обозначилось стремление общества избегать продолжительной, педантичной и ненужной «научности уголовного судопроизводства». Одним из таких процессуальных инструментов ускорения уголовного судопроизводства является институты «сделки о признании вины», эффективность которого подтверждается практикой применения его в США и «особый порядок» судебного разбирательства российского уголовного судопроизводства [5, с.145].

Уголовно-процессуальный кодекс Российской Федерации содержит главу, регламентирующую «Особый порядок принятия судебного решения при согласии обвиняемого с предъявленным ему обвинением» (глава 40 УПК РФ). В научной юридической литературе эту форму принято называть упрощенной. Процедура оформления «сделок о признании вины» регламентируется Федеральными правилами уголовного судопроизводства.

В уголовно-процессуальной литературе исследуется вопрос о юридической природе «особого порядка» судебного разбирательства в России. Вызывает интерес то, что некоторые авторы определяют «особый порядок» как российский вариант той самой «сделки о признании вины»[4,c.130]. Для этого рассмотрим историю возникновения «сделки о признании вины».

Исторические корни института «сделок о признании» необходимо искать в англосаксонском праве. Формирование подобной упрощенной формы судебного разбирательства произошло в начале 19 в. в США на базе института присяжных заседателей в качестве правоприменительной меры. Апелляционный суд Нью-Йорка в одном из своих решений датировал возникновение указанной упрощенной формы отправления правосудия 1804 г. Как альтернатива громоздкому судебному следствию с участием присяжных, «сделки о признании» достаточно быстро получили распространение на территории США. К 1900 г. около 90\% всех уголовных дел решалось путем заключения таких сделок. В 1970 г. Верховный Суд США признал конституционность практики «сделок о признании», окончательно ее легализовав. Природа состязательного уголовного процесса в англосаксонском праве создает предпосылки для упрощения процедуры без ущерба основам судопроизводства. Суд изначально не решает задачи установления истины, т.е. всех фактических обстоятельств дела, его основная функция сводится к беспристрастному разрешению уголовно-правового спора между сторонами на базе предоставленных ими доказательств. Состязательность стадии судебного разбирательства сводится к оценке судом тех материалов, которые представляют стороны обвинения и защиты, чья задача убедить суд в правильности своей позиции. Указанная процессуальная процедура является благодатной почвой для возникновения договорных отношений между участниками процесса, что привело к возникновению рассматриваемого института. Суть сделки о признании в теории англо-американского уголовного процесса сводится к следующему: «Если обвиняемый признает свою вину в совершении преступления, его первоначальное обвинение будет уменьшено (изменено), и с этого момента он получит только часть наказания - часть срока в тюрьме или пробацию, но не полномерное наказание, которое было бы ему назначено, если бы первоначальное обвинение было доказано в суде». [3,с.175]

Проведем сравнительный анализ этих институтов. В странах общего права, где прокурор свободно распоряжается обвинением, принцип состязательности может быть реализован путем заключения сделки о признании обвиняемым своей вины, когда прокурор договаривается (иногда при участии судьи) с адвокатом о том, что подсудимый признает полностью либо часть предъявленных ему обвинений в обмен на отказ прокурора от поддержания части обвинений или смягчение наказания. Такая договоренность влечет отказ подсудимого от рассмотрения его дела судом, при вынесение судьей приговора по обвинениям, признанным подсудимым. Следует согласиться с мнением ученых о том, что отечественный особый порядок разрешения уголовного дела, предусмотренный гл. 40 УПК РФ, аналогичен американской модели сделки о признании вины. Однако в силу различий типологии уголовного процесса стран континентального и общего права рассматриваемые процедуры предполагают отличную друг от друга процессуальную реализацию. Институт особого порядка судебного раз- 
бирательства, предусмотренный гл. 40 УПК РФ, применим по определенным категориям преступлений, закрытый перечень которых дан в УПК РФ. Тогда как «основания и виды преступлений, по которым применяется сделка о признании вины, нормативно не закреплены ни в одном из действующих на территории США уголовных кодексов». Согласно ст. 314 УПК РФ суд не вправе рассматривать ходатайство обвиняемого о постановлении приговора без проведения судебного разбирательства по делам о преступлениях, отнесенных законом к особо тяжким, тогда как в США сделка по таким видам преступлений может быть заключена. Несколько разнятся указанные институты и по участию потерпевшего в данной процедуре. Для постановления приговора без проведения судебного разбирательства в особом порядке, согласно ст. 316 УПК РФ, недостаточно ходатайства самого обвиняемого, требуется еще согласие потерпевшего и государственного обвинителя [1]. В США при заключении сделки о признании вины интересы потерпевшего представляет прокурор в процессе обсуждения со стороной защиты условий самой сделки. Позиция потерпевшего судом не учитывается ни при заключении сделки, ни при постановлении приговора. [2]

Согласно требованиям главы 40 УПК РФ уступки обвиняемому допускаются только в пределах, границы которых четко закреплены в ч. 7 ст. 316 УПК РФ. В США основания, объем, виды и пределы уступок виновному при заключении с ним сделки о признании вины законодательно не определены, этот вопрос целиком зависит от усмотрения прокурора и суда. Наиболее ярким отличием американской сделки от российского особого порядка принятия судебного решения, предусмотренного гл. 40 УПК РФ, является то, что последний не допускает снижения предъявленного обвинения, его переквалификации с более тяжкого на менее тяжкое, из предъявленного обвинения не исключаются отдельные пункты обвинения. Тогда как сделка о признании вины допускает широкие пределы усмотрения прокурора, который может произвольно изменить как квалификацию преступления, так и объем предъявленного обвинения. В США участники уголовного судопроизводства при заключении сделки руководствуются принципом целесообразности, а должностные лица, ведущие процесс, пользуются широкими дискреционными полномочиями, что обусловлено частнопоисковым характером американского уголовного судопроизводства [6, с.31].

Отечественный институт согласия обвиняемого с предъявленным ему обвинением основывается на свойственных российскому уголовному процессу в целом принципах публичности и законности и связанном с ними ограниченном характере дискреционности. Кроме указанных отличий, рассматриваемые нами уголовно-процессуальные институты имеют ряд схожих положений. Так, при заключении сделки и производстве особого порядка судебного разбирательства, предусмотренного гл. 40 УПК РФ, обязательным условием является признание обвиняемым своей вины; возмещение потерпевшему причинного ущерба; состав участников, заключающих сделку (соглашение).

Согласно ст. 316 УПК РФ постановление приговора без проведения судебного разбирательства в особом порядке возможно только по тем уголовным делам, по которым вина обвиняемого в совершенном преступлении полностью установлена на основе доказательств, собранных в точном соответствии с требованиями и процедурами, предусмотренными УПК РФ [7, с. 43-47]. Сходное положение содержится в уголовно-процессуальном законе США. При заключении сделки о признании вины одной из функций американского судьи является процессуальное закрепление доказательств, обличающих виновного, поскольку сделка не может быть заключена только на основании признательных показаний обвиняемого. Так пункт «f» Федеральных правил уголовного процесса в окружных судах США гласит: суд не должен выносить судебного решения без проведения исследования, которое должно удостоверить его с точки зрения наличия фактических оснований для такого заявления. Сделка о признании вины не может быть признанной заключенной пока судом не будет установлено, что именно этот обвиняемый совершил данное преступление. В российском уголовном судопроизводстве, ходатайство обвиняемого о постановлении приговора без проведения судебного разбирательства может быть заявлено им как в ходе предварительного расследования, так и непосредственно в суде (на предварительном слушании). В США сделка о признании вины так же заключается на стадии предварительного слушания дела в суде. Ее заключение на досудебной стадии невозможно, поскольку в США уголовно-процессуальные отношения начинаются только в суде. Для американской сделки характерно выполнение процедуры ознакомления обвиняемого с обвинительным документом (актом или информацией), в ходе которой судья разъясняет обвиняемому, в каких правах он будет ограничен, в случае заключения сделки (в частности, отказ от права рассмотрения дела судом присяжных заседателей, права ходатайствовать о невиновности), а также устанавливает наличие полного понимания выдвинутых против него обвинений и последствий поданных заявлений.

Статья 316 УПК РФ регламентирует аналогичный порядок рассмотрения ходатайства подсудимого. И в США и в России признание вины ведет к немедленному окончанию судебного разбирательства и вынесению обвинительного приговора. Схожи положения относительно порядка обжалования и пересмотра приговора.

Таким образом, американская сделка и российский особый порядок принятия судебного решения при согласии обвиняемого с предъявленным ему обвинением являются схожими лишь по своему назначению, которое заключается в упрощении судебной процедуры рассмотрения дела, экономии судейского времени и средств, отпускаемых на содержание судов (второе более характерно для Запада).

\section{Литература}

1. Уголовно-процессуальный кодекс Российской Федерации от 18.12.2001 N 174-Ф3 (ред. от 30.03.2016) // Российская газета. 2001. N 249. 22 дек. 
2. Federal Criminal Code and Rules. Federal Rules of Criminal Procedure (amendment received to January 6, 1997) // West Group. St. Paul. Minn. 1997. P. 42.

3. Бирюков П. Н., Жданов И. Н. Назначение наказания при заключении сделки о признании вины в США // Вестник Воронежского государственного университета. Сер. Право. 2015. № 2. С. 164-175.

4. Гаврицкий А. В., Водяная В. Ю. Особый порядок судебного разбирательства в российском уголовном процессе: общее и различия в правовой регламентации // Наука и образование: хозяйство и экономика; предпринимательство; право и управление. 2012. № 7(26). С. 130-135

5.Дудоров Т. Д. Институт «сделки о признании»: зарубежный опыт и российская модель ускоренного судебного разбирательства в порядке, предусмотренной главой 40 УПК РФ // Общество и право. 2009. № 2(24). С. 175

6. Новак Р. В. Институт сделок о признании вины в зарубежных странах: сравнительно-правовой аспект // Человек: преступление и наказание. 2013. № 4(83). С. 145.

7. Попова Е.И. Некоторые типичные ошибки, допускаемые при постановлении приговора в особом порядке судебного разбирательства при согласии обвиняемого с предъявленным ему обвинением // Российский судья. 2016. 4. 43-47.

8. Попова Е.И. Взаимодействие следователя и работников прокуратуры по уголовным делам с перспективой рассмотрения судом в особом порядке (гл. 40 УПК РФ) // Российский следователь. 2015. №19. 25-29.

9. Топчиева Т. В. Соотношение сделки о признании вины (на примере США) и порядка разрешения уголовного дела, предусмотренного главой 40 УПК РФ // Алтайский юридический вестник. 2013. № 1(1). С. 31-33.

\title{
Институт обеспечения судьи в России и Китае: сравнительно-правовой анализ
}

\author{
Ван Хайцзюнь \\ преподаватель Восточно-китайского \\ университета политики и права, \\ доктор юридических наук, \\ Китай, г. Шанхай \\ nivi2006@163.com
}

Судебная справедливость является центральным назначением осуществления судебной власти. Законодательство многих стран мира предусматривает, что судебная власть принадлежит только судам - в лице судей и представителей народа, привлекаемых в установленных законом случаях к осуществлению правосудия. Судебная власть самостоятельна и действует независимо от законодательной и исполнительной властей. При этом следует отметить, что судьи - носители судебной власти, в соответствии с законом осуществляют правосудие и исполняют свои обязанности на профессиональной основе. В связи с этим, мы считаем, что обеспечение прав судей является важным вопросом судебной справедливости и является актуальным в настоящее время.

Во-первых, самое важное обеспечение - осуществление правосудия судьей. По законодательству РФ, в своей деятельности по осуществлению правосудия, судьи никому не подотчетны[1]. Процедура осуществления правосудия, предусмотренная законом - одна из важнейших гарантий прав судьи. В нормах процессуального законодательства и федеральных законодательных актах детально излагаются правила проведения судопроизводства по уголовным, гражданским, арбитражным делам, а также порядок осуществления конституционного контроля. В современных странах мира, включая КНР, государственное законодательство предусматривает вышесказанное. Обеспечение осуществления правосудия судей, установленное Законом «О судьях КНР» в соответствии с Конституцией КНР (ст. 126): судьи осуществляют свои полномочия независимо, в соответствии с законом. Ни один административный орган, общественная организация или частное лицо не может вмешиваться в их деятельность [2]. Следование этим нормам объективно обеспечивает устранение из процедуры правосудия посторонних влияний, а всякое вмешательство в процессуальную деятельность судьи преследуется по закону.

Во-вторых, обеспечение несменяемости судьи. В России полномочия судьи федерального суда не ограничены определенным сроком, за исключением судей конституционных судов. Предельный возраст пребывания в должности судьи - 70 лет, если иное не установлено соответствующим федеральным конституционным законом. Русский судья не подлежит переводу на другую должность или в другой суд без его согласия, и его полномочия могут быть прекращены или приостановлены не иначе, как по основаниям и в порядке, установленном федеральным законодательством. В Китае, полномочия судьи ограничены определенным сроком - его полномочия могут быть прекращены или приостановлены по основаниям и в порядке, установленном Конституцией КНР и Законом. Судья подлежит переводу на другую должность или в другой суд, в зависимости от решения руководителя своего суда и соответственного Собрания народных представителей, а не от его согласия. Причина заключается в том, что в Китае судья в значительной степени, прежде всего, является государственным служащим, а потом уже судебным персоналом. При этом, - значение первого выше, чем последнего.

В-третьих, обеспечение неприкосновенности судьи. Неприкосновенность судьи включает в себя неприкосновенность личности, неприкосновенность занимаемых им жилых и служебных помещений, используемых им личных и служебных транспортных средств, принадлежащих ему документов, багажа и иного имущества, тайну переписки и иной корреспонденции (телефонных переговоров, почтовых, телеграфных, других электронных и иных принимаемых и отправляемых судьей сообщений). Обеспечение безопасности судей - один из главных вопросов, установленных Законом Российской Федерации от 26 июня 1992 г. № 3132-I «О статусе судей в Рос- 
сийской Федерации» (ст. 9) в соответствии с Конституцией Российской Федерации (ст. 120) и Федеральным конституционным законом от 31 декабря 1996 г. № 1-ФКЗ «О судебной системе Российской Федерации» (ст. 5). Обеспечение безопасности судьи, членов его семьи, сохранности принадлежащего им имущества в порядке, определённом Федеральным законом от 20 апреля 1995 г. № 45-Ф3 «О государственной защите судей, должностных лиц правоохранительных и контролирующих органов». В Китае есть закон обеспечения личной и имущественной безопасности судей, и домицилий, однако только простое содержание, в последние годы в Китае было много несчастных случаев с судьями - словесные оскорбления, угрозы, травмы, даже убийства судей.

В-четвёртых, обеспечение права на судейский иммунитет судей. В России судья, в том числе после прекращения своих полномочий, не может быть привлечен к какой-либо ответственности за выраженное им при осуществлении правосудия мнение и принятое судом решение, если только вступившим в законную силу приговором суда не будет установлена виновность судьи в преступном злоупотреблении, либо вынесении заведомо неправосудных приговоров, решений или иных судебных актов. Закон «О судьях КНР» только предусматривает - судьи исполняют свои обязанности в соответствии с законом, охраняются законом. Это положение, которое является слишком абстрактным, не может пользоваться правовой основой обеспечения права на судейский иммунитет судей [3, с. 44].

В-пятых, материальное и социальное обеспечение судей. В соответствии с Законом «О статусе судей в Российской Федерации» заработная плата судьи состоит из должностного оклада. Размеры доплат за квалификационные классы и выслугу лет судей устанавливаются федеральным законом; судья, достигший возраста 60 лет (женщины - 55 лет), при стаже работы по юридической профессии не менее 25 лет, в том числе не менее 10 лет работы судьей, вправе, уйдя в отставку, получать ежемесячное пожизненное содержание в полном размере; судьям предоставляются ежегодные оплачиваемые отпуска продолжительностью 30 рабочих дней; жилое помещение передается в собственность судьи бесплатно; судья имеет право по служебному удостоверению бесплатно пользоваться на территории Российской Федерации всеми видами общественного транспорта городского, пригородного и местного сообщения (кроме такси). Кроме того, в России судья и члены его семьи имеют право на медицинское обслуживание, включая обеспечение лекарственными средствами, которое оплачивается за счет средств федерального бюджета. При этом следует отметить, что в настоящее время материальное обеспечение российских судей внушительно [4, с. 123].

Меры социальной защиты судьи и членов его семьи включают, что жизнь, здоровье и имущество судьи подлежат обязательному государственному страхованию за счет средств федерального бюджета. При этом жизнь и здоровье судьи подлежат страхованию в размере его 180 ежемесячных денежных вознаграждений. Органы государственного страхования выплачивают страховые суммы в случаях, предусмотренных законом.

В Китае заработная плата судьи регулярно увеличивается. В соответствии с законом, работа судей должна регулярно оцениваться. Если результат оценки является отличным, или соответствующим занимаемой должности, то возможно увеличение его заработной платы в соответствии с законом. Если судья внес особый вклад в своей деятельности, то возможно досрочное увеличение его заработной платы. Судьи пользуются судебными пособиями, региональными и другие пособиями, а также страхованием и другим благосостоянием, как это предписано государством. Другие меры обеспечения судей законодательством прямо не предусмотрены.

Исходя из анализа вышесказанных вопросов, следует отметить, что в рамках института обеспечения судей между Россией и Китаем существует большая разница. В современном Китае продолжается новый раунд судебной реформы, улучшение института обеспечения судей является его важной частью. Таким образам, Китай должен не только основываться на своих собственных национальных условиях и реалиях, но и заимствовать правила институтов обеспечения судей из других странах, в том числе России.

Литература

1. Закон «О статусе судей в Российской Федерации», [Электронный ресурс]. URL: http://www.consultant.ru/document/ cons_doc_LAW_648/.

2. Закон «О судьях КНР» [Электронный ресурc]. URL: http://www.china.com.cn/zhuanti2005/txt/200107/01/content_5042140.htm.

3. Цэнь Яли, Чжан Гэвэнь. Сравнительное исследование института обеспечения судей в Китае и западных странах // Вестник Гуанчжоуского университета. 2010. № 1.

4. Клеандров М. И. Статус судьи: правовой и смежные компоненты. М., 2011.

\title{
Особенности производства допроса подданных Японии
}

\author{
(С) Б. И. Васильев \\ студент 4-го курса юридического факультета \\ ФГБОУ ВО «Бурятский госуниверситет» \\ Россия, г. Улан-Удэ \\ ugadaiktougadai@yandex.ru
}

В деятельности правоохранительных органов может сложиться ситуация, когда нужно допросить иностранного гражданина, в том числе подданных Японии. Для этого потребуется учесть некоторые особенности 
этой страны. В частности их следует учитывать при ведении допроса в целом, налаживании психологического контакта, а также при осуществлении некоторых тактических приемов.

Учитывая, что в чужой стране иностранцы в целом чувствуют себя подавленно и незащищено, особенно в силу различных стереотипов или негативного отношения к нашему государству, допрашивать рекомендуется в учреждении дипломатического или консульского представительства. Вызывать на допрос иностранных граждан в криминалистической литературе советуют, если они прибыли в составе делегаций, групп через их руководителей, если это учащиеся учебных заведений - через их администрацию.

При допросе иностранного гражданина рекомендуется объяснить различия в правовых системах. Но если деяния допрашиваемого являются преступными, можно воспользоваться его неведением. Возможно и так, что ошибочное представление своих действий как преступных послужит мотивом дачи ложных показаний.

Может возникнуть ситуация, когда допрашиваемый иностранец попытается политизировать деятельность следствия и интересующие следствие события. Необходимо пресекать такие попытки, ссылаясь на их логическую несостоятельность. К примеру: «Мы же взрослые люди, нам не до политики»; «Пускай политические дискуссии останутся мужчинам (если допрашиваемый женщина) / женщинам-домохозяйкам (если допрашиваемый мужчина) / под- росткам в Интернете (если в поведении допрашиваемого наблюдаются сексуальные аберрации)»; «у вас вид человека, переросшего политический экстремизм масс» и др. [2, с. 157]. В частности, по поводу территориального спора о Курильских островах, можно отметить, что независимо от спора, юрисдикция РФ над этими островами признается Японией. Нужно объяснить, что следствие интересуют обстоятельства преступления, а не политические предпочтения участников. Если допрашиваемый японец негативно воспринимает следствие, и Российское государство в целом, достичь психологического контакта будет затруднительно. Психологический контакт следует настраивать с малознакомым с культурой и образом жизни, положительно или нейтрально настроенным к нашей стране японцем. Для его установления, основанного на позитивном отношении к собеседнику, следует учитывать некоторые особенности их культуры, менталитета, японского языка. Также, углубленное знание языковых особенностей может вызвать интерес к личности следователя, может насторожить допрашиваемого или подтвердить профессионализм переводчика.

При подготовке к допросу целесообразно заранее потренироваться в произношениях имен допрашиваемого и других участвующих лиц, предполагаемых названиях населенных пунктов, географических объектов и т.д.

В японском языке слова состоят из слогов, и после каждой согласной идет гласная за исключением заднеязычного назализованного звука «н» и дифтонгов, а некоторые звуки, используемые в русском языке, отсутствуют. Поэтому самими японцами также очень трудно воспринимаются и различаются между собой используемые в России фамилии, имена, отчества. При первом коммуникативном контакте рекомендуется представить себя без отчества и предоставить обращение на бумаге или визитную карточку. При этом следует учесть, что на японском языке произношение будет звучать по-другому (Например, Бальжинимаев будет звучать как [барудзинимаэфу]), а слова неяпонского происхождения пишутся специальной азбукой - катаканой. Допрашиваемый, возможно сам попытается проговорить непривычные звуки, однако им не всегда это удается или бывает слишком затруднительно, поэтому искаженные слова следует воспринимать нормально, как обычное имя, не пытаясь поправить. Это касается и имен других участников. Принимать же от собеседника визитную карточку в ответ лучше как принято в Японии - двумя руками.

Вполне возможно, соблюдение этикета, принятого в его стране окажет благоприятное воздействие на установление психологического контакта.

При приветствии в Японии принято кланяться. Достаточно немного наклониться корпусом и головой в ответ, и задержатся на пару секунд. При этом руки располагаются по бокам или на коленях. Смотреть прямо в глаза не следует. Прислушиваться, что говорят во время поклона не обязательно, они могут сказать что угодно.

Рекомендуемое в российской литературе упрощение разговора до обращения на «ты» не допускается, при обращении обязательно употребление фамилии, то есть фамилии или фамилии и имени (в Японии не используются отчества), с добавлением именного суффикса - сан (рус. вариант «господин...»). Использование одного имени или отсутствие именных суффиксов будет крайне неуважительно, однако всегда можно уточнить заранее, как следует обращаться к собеседнику. Кроме того, несмотря на составление протокола допроса от первого лица, личность допрашиваемого при переводе следует выражать в третьем лице. Например: «Что делал господин ... в ...?».

Если допрашиваемый не хочет давать показания, не желая в последующем быть вызванным на производство следственных действий или в суд, его можно заверить, что если он возвращается к себе в страну, в соответствии с ч. 7 ст. 13 договора между Россией и Японией о взаимной правовой помощи по уголовным делам, при неявке он не может быть подвергнут принудительному приводу или какому-либо наказанию, а в случае добровольной явки, расходы оплачиваются запрашивающей стороной.

Во время заполнения анкетных сведений, вносить в протокол допроса биографические данные лучше после их написания на чистом листе бумаге самим допрашиваемым, чтобы не допустить ошибок. На этой стадии, в рамках тактического приема «беседа на отвлеченную тему», можно поговорить о достижениях страны в области экономики, спорта, похвалить, отметив строгое сохранение национальной культуры при их тесном сближении с западом. При заполнении места рождения можно поинтересоваться этой местностью, упомянуть красоту японских городов. Можно проявить интерес к национальным особенностям допрашиваемого, попросив рассказать его об отдельных сторонах общественной жизни - о традициях, обычаях, языке, культуре и др. Следует учесть, что в Японии вне работы не говорят о ней, иногда в трудовых договорах даже указывается об этом. 
В компаниях среди сотрудников строго определены все обязанности, им очень сложно принять решение, не присущее их статусу, даже касающееся только формальностей. Поэтому узнать сведения о работе может быть затруднительно, даже если допрашиваемому в этом нечего скрывать.

По различным диалектам японского языка можно определить из какой местности прибыл собеседник или какой деятельностью он занимается (может относиться к профессиональному «языку»). Между собой они преимущественно различаются ударениями, морфологией глаголов, использованием частиц, некоторые - составом согласных и гласных звуков. Диалекты делятся на восточные и западные, помимо этого выделяется лексика островов Рюкю и Косю. Речь восточных жителей отличается акцентированием согласных, а в западных акцентируются гласные. Всего диалектов свыше десятка. В Киото сохранились местные диалекты видов деятельности, связанных с традиционной культурой. Например, диалект ткачей и красильщиков шёлка Нисидзина, диалект ремесленников, изготовителей традиционных вещей, красильщиков шёлка и изготовителей традиционной керамики; наречие гейш и прочих лиц, имеющих отношение к их культуре, сопровождаемый особой жестикуляцией «мибуриго», речь квартала публичных домов. На сегодняшний день общенациональным языком страны принято считать стандартный литературный, сложившийся на основе языка Токио. Хотя в наши дни, современное поколение в основном употребляет смешанный язык, который включает в себя стандартный язык и местные особенности [3].

При допросе следует учитывать, что среди отличительных черт менталитета у жителей Японии выделяют такую как сдержанность, они не проявляют эмоций, всегда стараются говорить спокойно не громко, не меняют интонацию, если это не требуется в речи, не кричат, не меняют темп. Японцы говорят много об одном и том же, у них это считается проявлением уважения к собеседнику. Также они стараются не смотреть друг другу в глаза. В целом, несмотря на свою выразительность и приветливость, сложно понять, что они думают на самом деле [6].

При такой внешней скромности, вместо мимики и эмоций в речи могут употребляться частицы, которые имеют различное значение, в том числе способны выражать и интонации. Например, частица «уо» служит для эмоционального усиления («Вот ведь печально!»); позволяет отметить сказанное, когда предполагают, что собеседник не знает об этом («Слышали, сегодня произошло такое»). Мужская частица «па» делает легкий акцент, также используются при размышлении («Вот как, из-за болезни он не должен прийти сегодня...») или при грубом запрете что-либо делать. Легкий акцент позволяет сделать и женская частица «ша», но смягчая при этом речь («Немного не так», вместо «Все не так!»). С помощью частицы «sа» можно выразить раздражение («Ну если уж вам так не нравится, может стоит прекратить?»), также она используется, чтобы показать свою крутость («И что с этого?!»). Используемая в женской речи «kashira» показывает неуверенность, сомнение [7].

Чрезмерная мимика и жестикуляции не привычна для японцев. Чем сдержаннее человек, тем больше он внушает уважение. Неприлично также и указывать пальцем, похлопывать по плечу, хвататься за руку. Если японец кивает головой, это не означает, что он согласен, он показывает, что внимательно вас слушает. Проведение ладонью по горлу, значит не только смерть, но и увольнение. Размахивание раскрытой ладонью перед лицом - отрицание. Указывать пальцем можно только на себя, на все остальное нужно вытягивать руку с раскрытой ладонью. Сгибание указательного пальца наподобие крючка означает кражу или подозрительную ситуацию. Подзывают двумя-тремя махами ладонью вниз вытянутой рукой. Легкий поклон, но со сложенными руками (как при молитве) означают просьбу, или извинения, или благодарность. Однако некоторые жесты не используются самими жителями Японии при серьезном разговоре, а некоторые вообще могут являться неприличными, самим лучше избегать излишней жестикуляции [5].

В Японии используются разнообразные формы вежливости, выбор той или иной формы зависит от различных ситуаций и собеседников. С помощью разных форм вежливости можно судить о взаимоотношениях с кемлибо, об отношении к чему-либо, из чего можно сделать определенные выводы.

В японском языке выделяются несколько типов взаимоотношений:

- отношения благодеяния: человек должен оказывать почтение тому, кто ему в чём-то помог;

- отношения между сэмпаями, и кохаями (старшими и младшими товарищами по изучению или осуществлению какой-либо деятельности, предполагается, что старшинство определяется опытом): распространяются на учебные заведения, компании, клубы и организации;

- отношения заинтересованности: партнёрские отношения в бизнесе. Отличаются высокой степенью вежливости;

- отношения между вышестоящими и нижестоящими: в японских фирмах речевой этикет построен вокруг понятий подчинённости;

- отношения между близкими и неблизкими: «простые» отношения с друзьями, вежливые формы почти не используются. «Отдалённые» отношения - с соседями по дому: обычно все контакты ограничиваются взаимными приветствиями [1].

Их следует принять во внимание в частности и при очной ставке, если они успевают обменяться между собой словами (достаточно приветствия) и при сторонней беседе нескольких лиц. Вежливое обращение между собой позволит предположить положительное или нейтральное отношение между ними, формальный язык будет свидетельствовать о близких, грубая речь соответственно о негативных. Например, «аnata» - самый вежливый способ обратиться к собеседнику после использования имени, также используется женщинами при обращении к мужу, «anta», грубое обращение «ты» часто употребляется для выражения гнева, кроме этого может обозначать признак необразованности, и «koitsu» - «этот парень», грубое местоимение третьего лица, исполь- 
зуемое мужчинами и указывающее на находящегося рядом, их употребление может свидетельствовать о негативном отношении друг к другу. Употребление особой формы вежливости к другому допрашиваему зависит от отношений к профессии, роду деятельности, подчинению.

Возможны случаи, когда отрицание указанных при допросе сведений, при сопоставлении с известными следствию фактами подвергаются сомнению наличием устной или письменной речи в соответствующей им форме вежливости. Например, утверждение об отсутствии совместного бизнеса и имеющееся у следствия сообщение с употреблением речи, характерной для партнеров по бизнесу.

Однако выявить проявление какой-либо особой формы вежливости при просьбе пересказать дословно не получится, поскольку при пересказе речи для постороннего, то есть допрашивающего, японцы употребляют обычную форму вежливости. Не следует идеализировать современное состояние культуры речи, многое может не соблюдаться самими японцами, они могут позволить себе некоторые ошибки, поэтому выводы должны исходить не от отсутствия должных слов и фраз, которое может быть ошибочным, но допустимым, а от их наличия в речи.

В японской речи слова-звукоподражания не выделяются среди обычных слов. Их могут использовать, чтобы задействовать ассоциативные связи, напомнив об интересующих обстоятельствах, при которых могли быть слышны какие-либо звуки, переносились эмоциональные состояния, выделялись различные состояния объектов, их признаки.

Выделяются гионго - звуки, издаваемые неживыми объектами («рин-рин» - звук велосипедного звонка, « саку-саку» хрустящий звук, - например, снега), гисэйго - «слова, имитирующие голоса», которые передают голоса людей и животных («гохон» - звук кашля, «вай-вай» - говорить громко, кричать). Некоторые из них относятся к «детскому языку», их нельзя употреблять, поскольку они уместны в разговоре только со своим ребенком, и как указано выше, дословный пересказ воспроизводится в обычной форме. Другой разновидностью являются гитайго («слова, имитирующие состояния»). Они могут передавать характер движения («гуру-гуру»вращаться, «юккури» - медленно, не спеша), действий («коссори»- скрытное действие), состояния, характер предметов (фува-фува - мягкий, воздушный), физические ощущения («кута-кута» - измотанный, «мука-мука»тошнит), эмоции («ира-ира» - раздражённый, «куё-куё» - обеспокоенный) [4].

При предъявлении доказательств в определенной последовательности на бумаге (например, по нарастающей или убывающей силе), а также при ознакомлении с протоколом допроса или его переводом, необходимо учитывать, что в Японии страницы перелистываются как слева направо, так и в обратном направлении, это относится и к рядам фотографий, которые могут ассоциироваться с «мангой» (японскими комиксами), где изображения располагаются справа налево. Поэтому, лучше всего будет заранее предупредить, откуда начинать ознакомление или предъявить доказательства поочерёдно.

Активизируя нравственные качества личности, можно обратиться к национальной гордости японцев. Например, использовать убеждение об исключительности японской нации, их коллективизм. Обращаясь к их положительным качествам напомнить, что в данный момент они представляют свою нацию в чужой стране или наоборот, упрекнуть тем, что они «находятся не у себя дома».

\section{Литература}

1. Аниме. [Электронный ресурс]. URL: http://anime.com.ru/modules.php?name=Encyclopedia\&op=content\&tid =466 (дата обращения: 01.04.2016 г.).

2. Ахмедшин Р. Л. Тактика допроса иностранных граждан // Вестник Томского государственного университета. 2015. № 391. C. $155-159$.

3. Диалекты в японском языке [Электронный ресурс]. URL: http://www.uchiyaziki.ru/index.php/stati-pro-yaponskijyazyk/2322-dialekti-v-yaponskom-yazike (дата обращения: 19.03.2016 г.).

4. Звуки, образы и чувства в японских «звукоподражательных» словах [Электронный pecypc]. URL: http://www.nippon.com/ru/nipponblog/m00092/ (дата обращения: 04.04.2016 г.).

5. Какие есть особенности японской жестикуляции? [Электронный pecypc]. URL: http://www.genon.ru/GetAnswer.aspx?qid=7731b944-c931-4b0f-8ce0-1669618ec7f0 (дата обращения: 26.03.2016 г.).

6. На другой планете [Электронный ресурс]. URL: http:/guide.travel.ru/japan/4566.html (дата обращения: 21.03.2016 г.).

7. Частицы в японском языке. Сделаем свою речь более живой [Электронный ресурc]. URL: http://nihon-go.ru/yaponskiechastitsyi/ (дата обращения: 22.03.2016 г.).

8. Ануфриева Е.А. Особенности тактики допроса подозреваемого (обвиняемого) по делам о коррупционных преступлениях, совершаемых сотрудниками ОВД // Актуальные проблемы борьбы с преступлениями и иными правонарушениями. 2015. № 13-1. c. 79-81. 


\title{
Достоверность как основное условие использования результатов оперативно-розыскной деятельности в доказывании
}

\author{
(음.В. Викулов \\ аспирант 4 года обучения юридического факультета \\ ФГБОУ ВО «Бурятский госуниверситет» \\ адвокат, \\ Россия, г.Улан-Удэ \\ Vikulov-advokat@yandex.ru
}

Оперативно-розыскная деятельность (далее - ОРД) крайне важный, а зачастую и незаменимый инструмент борьбы с преступностью. Он позволяет эффективно противодействовать этому явлению тогда, когда уголовнопроцессуальные средства для такой борьбы непригодны. Однако результаты ОРД постоянно находятся под прицелом критики правоприменителей. На наш взгляд в большей степени это вызвано недостаточностью гарантий достоверности информации, добытой в результате оперативно-розыскной деятельности.

Закон, регламентирующий оперативно-розыскную деятельность является ярким примером так называемого «квалифицированного молчания законодателя», поскольку многие аспекты ОРД умышленно не урегулированы. Достаточно сказать, что Федеральный закон от 12.08.1995 года №144-Ф3 «Об оперативно-розыскной деятельности» (далее - Закон «Об ОРД»)[1] не раскрывает содержание оперативно-разыскных мероприятий (далее OPM) и в самых общих чертах устанавливает порядок их проведения. Но вряд ли это является его безусловным недостатком.

Ценность ОРД в том, что она основана на использовании нестандартных подходов для решения поставленных перед ней задач. Для её осуществления требуются тактическая хитрость и быстрота принятия решений. Излишняя регламентация ОРД подрывает заложенные в ней возможности.

Вместе с тем, оперативно-розыскной закон должен содержать гарантии, которые бы исключали возможность фальсификации результатов ОРД, в том числе и посредством оказания давления на подозреваемых. В то же время, закон «Об ОРД» плохо защищает от злоупотреблений оперативных сотрудников.

Правоприменительная практика идет по пути «процессуализации» ОРД. Это хорошо видно из оперативнорозыскных материалов, представляемых органу дознания, следователю или в суд для использования в доказывании. В особенности это касается таких оперативно-розыскных мероприятий (далее - ОРМ), как оперативный эксперимент и проверочная закупка. Вошло в обыкновение составление протоколов или актов с целью фиксации хода и результата выполнения таких действий в отношении лиц, содействующих органам, осуществляющим ОРД как их досмотр (до и после ОРМ), выдача денег (для передачи взяткополучателю) и специальной техники, изъятие документов, веществ, специальной техники (по окончании ОРМ) и т.п. Все же, действенным барьером от фальсификации результатов ОРД такие меры не являются.

Нередко, при выполнении упомянутых действий, в качестве «понятых» («представителей общественности») привлекаются лица, в беспристрастности и добросовестности которых имеются сомнения. Речь идет, в частности, о стажерах, практикантах органов внутренних дел, знакомых и друзьях оперативных сотрудников. Автор не раз в своей практики сталкивался с фактами фальсификации оперативных протоколов и актов при наличии на этих документах подписей «понятых».

Также не повышает степень достоверности результатов ОРД процедура их трансформации в доказательства, когда добытая оперативными сотрудниками информация легализуется путем допроса лиц, участвовавших в проведении ОРМ, выемки и осмотра и приобщения к уголовному делу в качестве доказательств изъятых в ходе ОРМ предметов, документов, веществ и т.п. Выполняемые, как правило, формально, такие действия, не устраняют сомнения в достоверности результатов ОРД.

На наш взгляд, закон об оперативно-розыскной деятельности нуждается в существенных изменениях. Необходимо, чтобы в нем были предусмотрены эффективные средства защиты граждан от злоупотреблений оперативных сотрудников при проведении ОРМ. В числе таковых, в первую очередь видим введение механизма вневедомственного санкционирования ОРМ.

В соответствии со статьей 8 Закона «Об ОРД» проверочная закупка, контролируемая поставка, оперативный эксперимент и оперативное внедрение проводятся на основании постановления, утвержденного руководителем органа, осуществляющего оперативно-розыскную деятельность.

Такой порядок санкционирования ОРМ не раз подвергался критике со стороны Европейского суда по правам человека. В соответствии с его позицией, высказанной в постановлении по делу «Веселов и другие против России» он указал: «Должностные лица, уполномоченные давать разрешения, не должны санкционировать собственную деятельность. Кроме того, должностные лица, уполномоченные давать разрешения, должны быть независимыми от расследования, насколько это возможно». Разрешая это дело, Суд провёл сравнительный анализ законодательства двадцати двух Европейских государств в части порядка проведения проверочных закупок и сходных негласных операций. Результатом этого анализа стал вывод о том, что в большинстве государств «предусмотрена исключительная или частичная ответственность судебных органов за процедуру получения санкции, хотя в некоторых странах решение принимается прокурором, административными органами или руководителями полицейских служб»[2]. 
Также вневедомственный порядок санкционирования ОРМ предусмотрен и в США. Анализируя законодательство США, М.П. Смирнов отмечает, что любая секретная операция, предполагающая склонение лица к участию в незаконной деятельности, должна быть в письменном виде санкционирована директором ФБР, после того как Комитет по контролю над секретными операциями определит, что:

- существуют различные основания (базирующиеся на информации, сообщенной осведомителями или полученной иными оперативными методами) предполагать, что объект операции занимается, занимался или, по всей вероятности, будет заниматься противозаконной деятельностью, сходной с той, к которой его предполагается склонить;

- оперативные мероприятия по созданию возможностей для противозаконной деятельности спланированы на основании уверенности в том, что лица, которым предполагается предложить эти возможности, сами по себе уже склонны к участию в такого рода противозаконной деятельности.

Санкционирования требует не только прослушивание телефонных переговоров, но и так называемый «контроль без согласия», который заключается в записи разговоров объекта расследования по телефону, в помещении, в автомашине и так далее, но без получения согласия от участников разговора.

Решение о внедрении секретного оперативного сотрудника, проблемы процессуального или материальноправового характера, возникающие при использовании этих сотрудников, должны обязательно согласовываться с прокуратурой [3].

Ничего подобного в России нет.

Также способствовало бы повышению доверия к результатам ОРД законодательно возложенная на оперативных сотрудников обязанность применять технические средства фиксации хода и результатов ОРМ, вместо привлечения «понятых». 4 марта 2013 года в ряд статей УПК РФ внесены изменения, в результате которых следователь был наделен правом выбора привлекать к производству некоторых следственных действий понятых или применять технические средства. Полагаем, что давно назрела необходимость внесения подобных изменений и в Закон «Об ОРД».

Необходимо, чтобы в Законе «Об ОРД» была закреплена обязанность оперативного сотрудника разъяснять заподозренному его права не только перед началом гласного ОРМ, но и на завершающем этапе негласных ОРМ в момент захвата заподозренного.

Частью 4 статьи 5 Федерального закона от 07.02.2011 года N 3-Ф3 «О полиции»[4] установлено, что в случае применения к гражданину мер, ограничивающих его права и свободы, сотрудник полиции обязан разъяснить ему причину и основания применения таких мер, а также возникающие в связи с этим права и обязанности гражданина. Однако при осуществлении ОРД данная норма не применяется, поскольку, как справедливо отметил А.И. Бочаров, правовые последствия несоблюдение данного требования в законе отсутствуют. Нельзя не согласиться и с предложением А.И. Бочарова о введении универсальной формы - печатного уведомления о правах, которая действовала бы на всей территории РФ [5, с.12]. Такая форма давно используется в полиции США.

«Прежде чем начать первую официальную встречу с субъектом расследования, сотрудник полиции должен представиться, назвав свои анкетные данные и место работы, предъявив при этом свое служебное удостоверение. Затем он заявляет, а точнее, зачитывает права гражданина, которые указаны у него в удостоверении. Текст зачитывается с целью недопущения искажения его пунктов или их пропуска, так как впоследствии адвокат обязательно поинтересуется у подзащитного о процедуре сообщения прав и их полноте. Если выяснится какое-нибудь упущение полицейского, то гражданин должен быть освобожден из-под стражи» - пишет М.П. Смирнов[6].

А.С. Александров и Д.С. Кучерук верно заметили, что в настоящее время формируется доктрина «относительной допустимости доказательств», которая подразумевает применение судами доказательств, получаемых обеими сторонами в любой не запрещенной законом форме, оценивая их не только с точки зрения допустимости, но и с учетом общепризнанного в мировой юридической практике стандарта справедливости. Можно сказать, что это аналог зародившейся в США доктрины «серебряного блюда» допускающей возможность использования незаконно полученных доказательств, если в суд они переданы из рук «неопороченного субъекта»[7].

Полагаем возможным применение стандарта справедливости и при использовании в доказывании результатов ОРД, но только при условии реального обеспечения «процессуального паритета сторон» [8, с.196]. Равные права сторон процесса по проверке оперативно-разыскной информации, безусловно, содействовали бы эффективной проверке её достоверности.

\section{Литература}

1. Федеральный закон от 12.08.1995 N 144-Ф3 (ред. от 29.06.2015) «Об оперативно-розыскной деятельности» // Собрание законодательства РФ от 14.08.1995 г. N 33. Ст. 3349.

2. Постановление Европейского Суда по правам человека от 2 октября 2012 г. Дело «Веселов и другие (Veselov and others) против Российской Федерации» (Жалобы № 23200/10, 24009/07 и 556/10) (Первая Секция) // СПС «КонсультантПлюс» [Электронный ресурс] / Компания «Консультант плюс».

3. Смирнов М. П. Комментарии законодательного регулирования оперативно-розыскной деятельности в Российской Федерации и за рубежом: учеб. пособие (постатейный). 5-е изд., расширенное и перераб. // СПС «КонсультантПлюс» [Электронный ресурс]/ Компания «Консультант плюс».

4. Закон Российской Федерации от 7 февраля 2011 года N 3-Ф3 «О полиции». Официальный текст с комментариями полковника полиции А. И. Бочарова. М.: Книжный мир, 2011. 72 с. 
5. Доля Е. А. Формирование доказательств на основе результатов оперативно-розыскной деятельности // СПС «КонсультантПлюс» [Электронный ресурс]/ Компания «Консультант плюс».

6. Смирнов М. П. Зарубежная налоговая и криминальная полиция и их оперативно-розыскная деятельность. М.: Изд-во МГУ, 2000. $569 \mathrm{c.}$

7. Александров А. С., Кучерук Д. С. К вопросу о допустимости доказательств, полученных стороной обвинения в ходе досудебного производства // Конституционно-правовые проблемы оперативно-розыскной деятельности: материалы Всерос. круглого стола (3 ноября 2011 г.) / сост. К. Б. Калиновский // СПС «КонсультантПлюс» [Электронный ресурс] / Компания «Консультант плюс».

8. Закотянский А. С. Проблемы использования непроцессуальной информации в доказывании по уголовным делам: дис. ... канд. юр. наук. Самара: Изд-во Самарского гос. ун-та, 2015. 241 с.

9. Гармаев Ю. П. Устранение сомнений в допустимости доказательств // Законность. 2011. N 5.

10. Боруленко Ю. П. Юридическое познание в процессуальной, оперативно-розыскной и частной детективной деятельности. Владимир: Изд-во ВГГУ, 2009. 365 с.

\title{
Сравнительный анализ доказывания в уголовном судопроизводстве на стадии предварительного расследования в Российской Федерации и Таджикистане
}

\author{
(C) А. М. Гатилова \\ студентка 4-го курса юридического факультета \\ ФГБОУ ВО «Бурятский госуниверситет» \\ Россия, г. Улан-Удэ \\ Nastyshka-14m@mail.ru
}

Основной целью в деятельности следователя в уголовном судопроизводстве является доказывание, поскольку только доказывание позволяет установить истину, а затем разрешить другие задачи уголовного судопроизводства. Процесс доказывания - это единый и неразрывный процесс познания, в структурном отношении традиционно включающий в себя следующие элементы: собирание, проверку и оценку доказательств.

Вместе с тем уголовно-процессуальное познание имеет существенные особенности:

1. Оно осуществляется в соответствии с уголовно-процессуальным законом, который указывает все стороны познания. Уголовный закон определяется в границах познания, который устанавливает все способы и средства познания, ограничивает круг субъектов, осуществляет познание уголовного дела. Знания, который были полученные именно с нарушением УПК, признаются ничтожными, а также не имеющими силы принятия решения в уголовном деле.

2. Уголовные дела носят прерывный характер. Расследование этих дел ограничивается поставленными сроками. Также ограничиваются их предметы и пределы доказывания - то, что не входит в предмет доказывания, обязательного познания в уголовном деле не требуется.

3. Познание в уголовном деле носит опосредованный характер. Познаются все обстоятельства, имеющие значение в прошедшем времени. Именно в познании выражается сложность в расследовании преступлений. Большую объективность придает характер познания. В настоящем законе указывается, что запрещено производить расследование уголовного дела лицу, который был непосредственным свидетелем совершения преступления [3].

В УПК Республики Таджикистан устанавливается, что собирание и проверка доказательств по уголовным делам имеет огромную роль в принятие нового УПК от 5 декабря 2008 г. Кроме того, Республика Таджикистан кодифицировала все нормы международного сотрудничества в сфере уголовного процесса.

Если сравнивать новый УПК Республики Таджикистан с УПК Таджикской ССР от 6 августа 1964 г., то в новый УПК были внесены большие изменения, например, в систему уголовного-процесса, а также было изменено само понятие «доказательство», «собирание и проверка» доказательств.

Понятие «доказательство» дано в ч.1 и ч.2 ст.72 УПК Республики Таджикистан. В содержании статьи указано, что могут выделяться признаки относительно доказательства: конкретные сведения, на основе которых суд, прокурор, следователь, дознаватель имеют дело к обстоятельствам дела, а также имели какое-либо значение к уголовному делу, порядок рассматривается в УПК Республики Таджикистан, который был известен из соответствующих источников [5].

Теория уголовного процесса выделила несколько мнений ученых, в которых указывается, что тождества терминов определяют понятие доказательство. В дореволюционной России наиболее распространенным было понимание доказательства именно как «фактических данных». В соответствии с ч. 1 ст. 74 УПК Российской Федерации в советское и современное время под доказательствами понимаются сведения о фактах, доказательственные факты, единство фактов и сведений о фактах и другие любые сведения. В уголовно-процессуальном законодательстве Таджикистана под доказательствами понимаются любые сведения. Также термин «доказательство» является «единым» и учитывается его процессуальный статус. Так, в ч.1 ст. 72 УПК Республики Таджикистан указывается одна из сторон, которая характеризует именно фактические сведения, а уже в ч.2 говорится непосредственно о перечнях видов процессов, которые в большинстве случаев содержат фактические сведения о них. Также как и раньше основными источниками доказательств будут являться: показания подозреваемого, обвиняемого, потерпевшего и свидетелей; заключение эксперта; вещественные доказательства; протоколы следственных и судебных действий; иные документы. Структура также традиционно включается в 
себя: собирание, проверку, а также и оценку доказательств. Эта структура указывается в ст. 86-88 УПК Республики Таджикистан и ст.85 УПК Российской Федерации [4].

В УПК Республики Таджикистан в ст.86 «Собирание доказательств» состоит из четырех частей:

1. Дознание производит собирание доказательств в уголовном процессе дознания, предварительном расследовании и разбирательстве в суде, предусмотренном настоящим Кодексом.

2. Следователь, дознаватель, прокурор, а также суд, судья по ходатайству сторон вправе: по делу, которое находится у него в производстве, вызывать в порядке, установленном настоящим Кодексом, допрашиваться может любое лицо, если было дано заключение в качестве эксперта; производился осмотр места происшествия, обыски и другие, предусмотренные настоящим Кодексом, следственные действия; требовать от предприятий, учреждений, должностных лиц и граждан, а также органов, осуществляющих оперативно-розыскную деятельность, представления документов и предметов, которые имели значение для уголовного дела; требование произвести ревизии и проверки уполномоченными органами и должностными лицами.

3. Защитник, который был допущен в установленном настоящим Кодексом порядке, допускается для участия в деле и вправе: предоставлять доказательства; собирать сведения, которые были необходимые ему для оказания юридической помощи; запрашивать справки, характеристики и иные документы из различных учреждений, предприятий, которые будут обязаны в установленном порядке выдавать все документы и их копии; заслушивать мнение специалистов для разъяснения возникших в связи с оказанием юридической помощи вопросов, требующих специальных познаний.

4. Полученные сведения, которые были в устной и в письменной форме, в виде аудио- и видеозаписи, а также любые предметы и имеющиеся документы, которые являются доказательствами в уголовном деле, также могут предоставлять подозреваемый, обвиняемый, защитник, обвинитель, подсудимый, потерпевший, гражданский истец, гражданский ответчик и их представители, граждане, должностные лица предприятий, организации и учреждений [2].

УПК Российской Федерации ст. 86 «Собирание доказательств» устанавливает:

1. Собирание доказательств может осуществляется в ходе уголовной деятельности дознавателем, следователем, прокурором и судом путем производства следственных и иных процессуальных действий, предусмотренных настоящим Кодексом.

2. Подозреваемый, обвиняемый, а также потерпевший, гражданский истец, гражданский ответчик и их представители могут собирать все имеющие значение для уголовного дела доказательства и представлять также письменные документы и предметы для приобщения их к уголовному делу в качестве доказательства.

3. Также защитник вправе собирать доказательства путем:

1) получения каких-либо предметов, документов и иных сведений;

2) производства опросов лиц с их согласия;

3) требования справок, характеристик, иных документов от органов государственной власти, органов местного самоуправления, общественных объединений и организаций, соответствующие органы должны предоставлять документы или копии на запросы [1].

Собирание доказательств является основным элементом в деятельности следователя и дознавателя. Также в УПК Республики Таджикистан в ст.87 указывается, что именно собранные доказательства подлежат всесторонней и объективной проверке. Проверку можно разделить на несколько этапов: анализа полученных доказательств, их сопоставления с другими доказательствами, собранных новых доказательств, проверки источников получения доказательств. А в УПК Российской Федерации в ст. 87 понимается, что проверка доказательств производится дознавателем, следователем, прокурором, судом путем сопоставления их с другими доказательствами, имеющимся в уголовном деле, а также установления их источников, получения иных доказательств, подтверждающих или опровергающие проверяемое доказательство. Каждое доказательство подлежит оценке с точки зрения относимости, допустимости, достоверности, а все собранные доказательства - в их совокупности, достаточности для разрешения дела определяет ч. 1 ст.88 «Оценка доказательств» УПК Республики Таджикистан, а также ч.1 ст.88 «Правила оценки доказательств».

В завершении исследования нам бы хотелось отметить следующее: во-первых, уровень развития уголовнопроцессуального законодательства в России и Таджикистане примерно одинаковый, вероятнее всего это свидетельствует о том, что Республика Таджикистан держится на высоком уровне по раскрываемости преступлений, точно такая же ситуация на сегодняшний день в РФ. Во-вторых, УПК Республики Таджикистан, принятый через восемь лет после УПК Российской Федерации, сохранил традиционное для постсоветских стран определение понятия доказательств (ст. 72). При этом, в данной статье, кроме видов доказательств, указанных в ч. 2 ст. 74 УПК Российской Федерации, предусмотрены: «скрытые записи; прослушанные и зафиксированные телефонные разговоры; электронные, видео- и аудиозаписи наблюдения». Это свидетельствует о том, что УПК РТ сильно не отстал по развитию от УПК Российской Федерации, что может характеризовать уголовное законодательство соседнего государства с положительной стороны.

\section{Литература}

1.Уголовно-процессуальный кодекс Российской Федерации.

2.Уголовно-процессуальный кодекс Республики Таджикистан.

3. Якимович Ю. К. Доказательства и доказывание в уголовном процессе России: учеб. пособие. Томск: Изд-во Томского ун-та, 2015. С. 80. 
4. Шейфер С. А. Доказательства и доказывание по уголовным делам. М.: Норма, 2012. С. 212.

5. Абдуллоев П. С. Международно-правовая помощь при собирании и проверке доказательств по уголовным делам: автореф. дис. ...канд. юр. наук. М., 2014.

\section{Особенности расследования убийства матерью новорожденного ребенка в некоторых странах АТP}

(C) М. В. Дармаева

магистрант 2 года обучения юридического факультета ФГБОУ ВО «Бурятский госуниверситет»

Россия, г. Улан-Удэ

marina_darmaeva@mail.ru

История развития уголовного законодательства показывает, что жизнь и здоровье человека всегда занимали особое место в системе уголовно-правовой охраны всех стран. Преступления против жизни и здоровья - это особая группа преступлений.

Следует отметить, что жизнь человека охраняется уголовным законом независимо от возраста, морального и физического облика и состояния. В связи с этим представляет определенный интерес уголовно-правовая норма, предусматривающая ответственность за убийство матерью новорожденного ребенка.

В современных условиях приоритетные направления государственной политики, как России, так и в странах АТР в области народонаселения - улучшение состояния здоровья населения, в том числе и репродуктивного, стабилизация рождаемости и укрепление семьи. Уровень рождаемости, сложившийся под влиянием социально-экономических факторов, отражает изменение репродуктивного поведения населения, что выражается в сокращении числа женщин и семей, желающих иметь детей.

Актуален вопрос детоубийств и сегодня, в условиях строительства правового государства, наличия современных требований морали, а также на фоне снижения рождаемости. Число этих преступлений в России - показатель постоянный и относительно высокий. Ежегодно количество зарегистрированных убийств матерями новорожденных детей превышает цифру 250, и это при высокой латентности преступлений указанной категории.

Расследование детоубийств часто представляет сложность, так как виновные применяют множество способов сокрытия преступления, противодействия расследованию. Ужасает и тот факт, что проблема детоубийства приобрела общемировой масштаб. Так встречаются на практике увеличение данных преступлений в странах АТР (Корея, Китай, Япония).

Во-первых, в названных странах разнится перечень преступлений против жизни. Во-вторых, при построении диспозиций уголовно-правовых норм, устанавливающих ответственность за убийство, законодатели используют разную терминологию. В-третьих, в данных странах по-разному сконструированы санкции за умышленное и неумышленное причинение смерти.

На сегодняшний день ситуация изменилась, но не кардинально. В современном Китае и сегодня девочкам предпочитают мальчиков. Причем смягчающие или отягчающие вину обстоятельства в законе отражения не нашли. Поэтому оценку тому, имеются ли в действиях виновного смягчающие вину обстоятельства или нет, суд дает, ориентируясь на чисто субъективные признаки конкретного преступления, что практически бывает трудно установить.

Конечно, эта проблема не нова и существовала в России всегда. «За последние годы продолжается рост числа убийств рассматриваемой категории. Это свидетельствует о недостаточности принимаемых по их предупреждению мер и необходимости более глубокого исследования проблем борьбы с данными преступлениями»[4].

По утверждению И. И. Карпеца, «истоки повышенной жестокости преступности женщин следует искать в общей ситуации озлобления, в которой пребывает наше общество, в разрушении и падении нравственных ценностей, разочаровании жизнью и социальным строем. Однако надо искать и внутренние причины формирования женской психологии в современных условиях»[5].

На сегодняшний день реализуются программы по работе с семьями из группы риска; проводятся улучшение материальной базы, путем введения целевых программы в пользу поддержки семьи (год молодежи, семьи). Также необходимо провести работы с целью принятия более эффективных мер по защите интересов семьи, матерей-одиночек, оставшихся без кормильца, несовершеннолетних матерей и инвалидов.

\section{Литература}

1. Уголовный кодекс Японии / пер. с япон. В. Н. Еремина; науч. ред. и предисл. А. И. Коробеева. СПб., 2002.

2. Уголовное право зарубежных государств. Особенная часть: учеб. пособие / под ред. и с предисл. И. Д. Козочкина. М., 2004. C. 458.

3. Уголовный кодекс Китайской Народной Республики / пер. с кит. Д. В. Вичикова; под ред. А. И. Коробеева. Владивосток, 1999.

4. Сердюк Л. В. Детоубийство: вопросы правовой оценки // Российская юстиция. 2003. № 11. 80 с.

5. Карпец И. И. Преступность: иллюзии и реальность. М., 1992. 431 с. 


\title{
Предмет и основание гражданского иска в уголовном процессе России и Китая
}

\author{
(C) А. В. Дашиев \\ магистрант 2 года обучения юридического факультета \\ ФГБОУ ВО «Бурятский госуниверситет» \\ Россия, г. Улан-Удэ \\ dashiev90@list.ru
}

Главной целью существования уголовного процесса (согласно ст. 6 УПК РФ) всегда была и будет поддержание прав и интересов физических и юридических лиц, которые являются потерпевшей стороной от совершенных преступлений.

Одним из путей её достижения является возможность возмещения имущественного вреда и компенсации морального вреда, в качестве одного из средств восстановления справедливости. Популярным методом компенсации причиненного преступлением вреда, является гражданской иск.

Институт гражданского иска в уголовном деле был заимствован Россией из уголовного процесса Франции, но само учение об иске берет свое начало еще в римском праве. Общее понятие иска приводилось в Дигестах (Digesta или Pandectae - Свод судебных постановлений римских юристов, составленный в 533 году по указанию Юстиниана): иск есть не что иное, как право лица осуществлять судебным порядком принадлежащее ему требование[3, с.23].

В данной статье проведен сравнительный анализ института гражданского иска в рамках уголовного процесса по законодательству России и Китая. Для реализации этой задачи были проанализированы два ключевых нормативно-правовых акта: Уголовно-Процессуальный Кодекс РФ и Уголовно-процессуальный Кодекс Китайской Народной Республики.

В действующем УПК РФ законодатель не дает определения термина «гражданский иск», эта информация отсутствует и в 5 статье Кодекса, где рассматривается основная терминология уголовно-процессуального законодательства и в других нормативно-правовых актах. Однако, многие авторы пытались определить термин «гражданский иск в уголовном процессе», среди них следует отметить Д.Б. Разумовского, который определил гражданский иск как "требование лица о возмещении имущественного вреда, причиненного ему преступлением, заявленное после возбуждения уголовного дела в целях решения вопроса о его удовлетворении при рассмотрении судом уголовного дела". Т.М. Махова указывает на важное свойство гражданского иска - это требование к виновному лицу о возмещении ущерба, непосредственно причиненного гражданину, предприятию, учреждению, организации [7, с.199].

В УПК КНР также отсутствует определение гражданского иска в уголовном процессе, в главе 7 описаны нормы о дополнительном гражданском иске. Однако смысл существования гражданского иска в УПК КНР [2] аналогичен российскому, это также требование о возмещении причиненного ущерба.

Предполагаем, что можно предложить следующую формулировку, гражданский иск - это требование, совершенное в письменной форме, в котором содержатся основные запросы истца о возмещении вреда как имущественного, так и компенсации морально-нравственного, которое обращено к ответчику, имеющему статус гражданского по уголовному делу, в связи с доказанным фактом нанесения вреда совершенным преступлением. Причем это требование должно быть заявлено после возбуждения самого уголовного дела, но до момента, когда судебное следствие по такому делу уже закончится (согласно ч.2 ст.44 УПК РФ). Важно отметить, что гражданский иск в уголовном процессе всегда рассматривается в особом процессуальном порядке, в данном случае некоторые нормы права задействуются из гражданско-процессуального законодательства.

Гражданский иск - это требование физического или юридического лица о возмещении имущественного ущерба и компенсации морального вреда, причиненного преступлением, к обвиняемому или лицам, несущим материальную ответственность за действия обвиняемого, заявленное при производстве по уголовному делу.

Что касается предмета гражданского иска, то в УПК РФ указано, что преступлением наносится вред здоровью, жизни, личности и имуществу, в рамках гражданского иска может быть взыскан не только материальный вред, но и моральный. Что касается законодательства КНР, то в нем определено право требовать, возмещения только материального вреда (ст.77 УПК КНР).

Предметом гражданского иска в уголовном процессе является материально-правовое требование истца к обвиняемому (гражданскому ответчику) или к лицу несущему материальную ответственность за действия обвиняемого (в случае если последний - несовершеннолетний) в возмещении имущественного вреда, имущественной компенсации морального вреда.

Говоря об основаниях предъявления гражданского иска в рамках уголовного судопроизводства РФ, можно выделить следующие:

- подсудность дела (в силу ч. 10 ст. 31 УПК РФ подсудность гражданского иска, вытекающего из уголовного дела, определяется подсудностью уголовного дела, в котором он предъявлен) [1, с.26];

- субъект, который является гражданским истцом, должен обладать правоспособностью и дееспособностью. Также ч.3 ст.44 УПК РФ предполагает, что если иск предъявляется в пользу недееспособного либо несовершеннолетнего лица, он предъявляется его представителем или прокурором, а в случае если нарушены права государства, только прокурором; 
- юридическая заинтересованность в предъявлении гражданского иска (личная либо государственно-правовая). Следует отметить, что в УПК КНР также указано, что истцом по дополнительному гражданскому иску может выступать народная прокуратура (ст.77 УПК КНР [2]), но только в том случае если материальный ущерб от преступления причинен государственной либо коллективной собственности;

- в производстве суда должен отсутствовать такой же иск (по такому же делу, с аналогичными сторонами), который либо рассматривается, либо находится на стадии подготовки постановления по результатам его рассмотрения.

К условиям предъявления гражданского иска по российскому законодательству можно отнести следующие:

- лицо, которое предъявляет гражданский иск, должно быть признано гражданским истцом по уголовному делу (в УПК КНР не описана процедура признания стороны уголовного процесса истцом по дополнительному гражданскому иску);

- должно быть доказано, что ущерб был причинен именно совершенным обвиняемым преступлением;

- гражданский иск может быть предъявлен после возбуждения уголовного дела и до окончания судебного следствия при разбирательстве данного уголовного дела в суде первой инстанции (ч. 2 ст. 44 УПК РФ );

- в содержании гражданского иска может быть указано заявление о возмещении вреда имуществу и компенсации морально-нравственных страданиях, которые должны быть возмещены, по УПК КНР в дополнительном гражданском иске может быть отражено требование возмещения только имущественного вреда.

Согласно ч. 1 статье 44 УПКРФ, гражданским истцом является физическое или юридическое лицо, предъявившее требование о возмещении имущественного вреда, при наличии оснований полагать, что данный вред причинен ему непосредственно преступлением. Решение о признании гражданским истцом оформляется определением суда или постановлением судьи, следователя, дознавателя. Гражданский истец может предъявить гражданский иск и для имущественной компенсации морального вреда.

В ч. 2 ст. 44 УПК РФ указано, что гражданский иск может быть предъявлен после возбуждения уголовного дела и до окончания судебного следствия при разбирательстве данного уголовного дела в суде первой инстанции. При предъявлении гражданского иска гражданский истец освобождается от уплаты государственной пошлины.

Обращаясь к законодательству КНР, следует отметить, что вопрос периода рассмотрения гражданского иска в рамках уголовного процесса, описан в статье 78 УПК КНР, где указано, что дополнительный гражданский иск должен быть рассмотрен в одно время с уголовным делом, в исключительных случаях, с целью предупреждения слишком затянутого процесса судопроизводства, рассмотрение гражданского иска может проводиться судом этого же уровня, но после завершения рассмотрения уголовного дела.

Статья 115 УПК РФ описывает процедуру проведения ареста имущества на имущество ответчика с целью исполнения требований приговора суда по гражданскому иску.

Наложение ареста на имущество состоит в запрете, адресованном собственнику или владельцу имущества, распоряжаться и в необходимых случаях пользоваться им, а также в изъятии имущества и передаче его на хранение [9, с.29].

В ч. 4 ст. 115 УПК РФ и ст. 446 ГПК РФ определено имущество, на которое не может быть обращено взыскание.

В УПК КНР в статье 77 предусмотрена аналогичная российской норма права, которая гласит, что в случае необходимости народный суд может опечатать либо наложить арест на имущество обвиняемого.

Таким образом, проведя сравнительный анализ законодательства России и Китая о предмете и основаниях предъявления гражданского иска в уголовном процессе, можно сделать следующие выводы:

1. Сходство законодательства двух стран состоит в том, что:

-основной задачей существования гражданского иска в уголовном процессе является удовлетворение требования о возмещении причиненного преступлением вреда;

-истцом по гражданскому иску в уголовном процессе в законодательстве обеих стран может быть как гражданин, так и государство, в случае если ущерб причинен государственной (или коллективной по законодательству КНР) собственности;

-время рассмотрения гражданского иска в уголовном процессе также одинаково, он рассматривается как одновременно, так и после уголовного процесса.

2. Отличия уголовно-процессуального законодательства России и КНР заключаются в том, что:

-в УПК РФ существует процедура признания стороны уголовного процесса гражданским ответчиком, в отличие от УПК КНР;

-в рамках дополнительного гражданского иска по законодательству КНР можно требовать возмещения только материального ущерба, тогда как в УПК РФ может быть возмещении моральный вред.

Таким образом, законодательство КНР по гражданскому иску в уголовном процессе нуждается в совершенствовании и в более тщательной проработке существующих норм. Налицо отсутствие регламентации важных вопросов предъявления гражданского иска, например, требований по его оформлению, необходимым реквизитам, процессуальным возможностям, таким как приостановление дела, и др.

По уголовно-процессуальному праву Российской Федерации, следует отметить, современные правовые реалии таковы, что институт гражданского иска для досудебных стадий уголовного процесса регламентирован явно недостаточно, в целом указанный институт нуждается в усовершенствовании с целью сохранения его для 
реализации задач и принципов уголовного процесса, а также конституционно гарантированного права на судебную защиту.

\section{Литература}

1. Конституция Российской Федерации : принята всенародным голосованием 12.12.1993 (с учетом поправок, внесенных Законами РФ о поправках к Конституции РФ от 30.12.2008 № 6-ФКЗ, от 30.12.2008 № 7-ФКЗ, от 05.02.2014 № 2-ФКЗ, от 21.07.2014 № 11-ФКЗ)// Собрание законодательства РФ, 04.08.2014, № 31, ст. 4398.

2. Уголовно-процессуальный кодекс Российской Федерации от 18.12.2001 № 174-Ф3 (ред. от 30.12.2015) // Российская газета. 2016. № 1.11 янв.

3. Уголовно-процессуальный Кодекс КНР Принят на 2-й сессии Всекитайского собрания народных представителей пятого созыва 1 июля 1979 года, с поправками, внесенными Постановлением, принятым на 4-й сессии Всекитайского собрания народных представителей восьмого созыва 17 марта 1996 года «О внесении изменений в «Уголовно-процессуальный кодекс КНР Китайской Народной Республики».

4. Афанасин Е. В. Римское право. Практикум. Новосибирск, 1999. С. 23.

5. Бубчикова М. В. Гражданский иск в уголовном процессе // Российский судья. 2015. № 9. С. 44-47.

6. Уголовно-процессуальное право Российской Федерации: учебник / под общ. ред. П. А. Лупинской. М., 2014. С. 199.

7. Оськина И. Ю., Лупу А. А. Гражданский иск в уголовном процессе // ЭЖ-Юрист. 2014. № 11. С. 4-5.

8. Сычева О. А. Гражданский иск в уголовном судопроизводстве // Мировой судья. 2015. № 5. С. 28-33.

9. Сычев П. Г. Взаимодействие гражданской и уголовной юстиции: проблематика гражданского иска в уголовном деле // Закон. 2014. № 10. С. 95-101.

10. Международная научно-практическая конференция "Сравнительное правоведение в странах АТР" [Электронный pecypc]. URL www.bsu.ru/university/departments/faculties/uf/13244.

\section{Правовой статус жертвы преступления (потерпевшего) в уголовном процессе России и Казахстана}

(ㄷ Д. А. Доржиева

студентка 2-го курса юридического факультета ФГБОУ ВО «Бурятский госуниверситет»

Россия, г. Улан-Удэ

dorzhieva97@list.ru

Согласно Уголовно-процессуальному кодексу Российской Федерации, российское уголовное судопроизводство направлено на защиту прав и законных интересов лиц и организаций, потерпевших от преступлений (п. 1 ч. 1 ст. 6). Законодатель, при реализации данного принципа, производит реформирование уголовно-процессуального закона с учетом положительного мирового опыта. Так, в изначальной редакции УПК РФ отсутствовал механизм обеспечения права потерпевшего на оказание бесплатной юридической помощи при производстве по уголовному делу. Помимо этого, доступ потерпевшему к правосудию был ограничен запретом на пересмотр в порядке надзора обвинительного приговора и других судебных решений по основаниям, влекущим ухудшение положения осужденного.

Вносимые изменения в определенной степени решили существовавшие недочеты. К примеру, в юридической науке несколько лет назад было много дискуссий относительно неопределенности момента признания лица потерпевшим [8, с.37]. Федеральный закон от 28 декабря 2013 г. № 432-Ф3 "О внесении изменений в отдельные законодательные акты Российской Федерации в целях совершенствования прав потерпевших в уголовном судопроизводстве" было внесено положение, которое установило в ч. 1 ст. 42, что «решение о признании лица потерпевшим принимается незамедлительно с момента возбуждения уголовного дела» соответствующим постановлением. Но диспозиция данной статьи на сегодняшний момент все еще остается несовершенной $[9$, с. 52].

Для дальнейшего развития в России механизма защиты прав и законных интересов потерпевших в уголовном судопроизводстве имеет интерес правовое регулирование в странах СНГ, как ближайших соседей, одной из которых является Республика Казахстан.

В статье 42 УПК РФ потерпевшим признается физическое лицо, которому преступлением причинен физический, имущественный, моральный вред, а также юридическое лицо в случае причинения преступлением вреда его имуществу и деловой репутации [3]. Анализ данного положения, позволяет выделить следующие основные условия (признаки), при наличии которых юридическое лицо может выступать в уголовном процессе в качестве потерпевшего:

1) наличие физического, имущественного, морального вреда, применительно к физическому лицу, либо вреда имуществу и деловой репутации, если от преступления пострадало юридическое лицо;

2) причинение одного из указанных видов вреда непосредственно преступлением.

Возникает вопрос, почему приобретение статуса потерпевшего ставится в зависимость от удостоверения уполномоченными органами фактических обстоятельств причинения вреда? В связи с чем, следует согласиться с мнением ученых о введении нового определения потерпевшего, допускающего возможность признания по- 
терпевшим лица, если имеются достаточные основания полагать, что против его охраняемого законом блага совершено преступное посягательство, причинившее ему предусмотренный законом вред [6, с. 80].

Стоит заметить, что подобное положение закреплено в Уголовно-процессуальном Кодексе Республики Казахстан. Так, по ч. 1 ст. 71 потерпевшим в уголовном процессе признается лицо, в отношении которого есть основание полагать, что ему непосредственно уголовным правонарушением причинен моральный, физический или имущественный вред.

Как было сказано выше, в процессе реформ значительно расширились права потерпевшего. Наряду с правами у данного участника есть и обязанности. Так, например, потерпевший не вправе уклоняться от явки по вызову дознавателя, следователя и в суд. При неявке потерпевшего по вызову без уважительных причин он может быть подвергнут приводу. Применить эту меру суд вправе только тогда, когда установлено, что вызываемое лицо не является в суд без уважительной причины. Суд обязан откладывать судебное разбирательство и повторно направлять потерпевшим повестки, что занимает много времени с учетом загруженности судов. Закон запрещает применение привода в отношении несовершеннолетних в возрасте до четырнадцати лет, беременных женщин, больных лиц, которые по состоянию здоровья согласно удостоверению врача, не могут, или не должны оставлять место своего пребывания. Таким образом, и эти лица не могут быть допрошены в суде.

Наряду с вышеназванными обстоятельствами следует отметить, что вызов в судебное заседание и допрос малолетних и несовершеннолетних потерпевших являются психологически неблагоприятными для них

Нередко, в судебном заседании, потерпевшие (свидетели), допрошенные в ходе предварительного следствия, свои показания не подтверждают. Это объясняется различными причинами, в том числе и тем, что на них действуют угрозы заинтересованных в исходе дела лиц. Потерпевшие (свидетели) боятся давать показания, и это отрицательно сказывается на уголовном судопроизводстве.

В Республике Казахстан в 2014 году в уголовно-процессуальном законе предусмотрен институт депонирования[4]. Институт депонирования показаний заключается в закреплении показаний потерпевшего и свидетеля следственным судьей в том случае, если имеются основания полагать, что более поздний их допрос, в ходе досудебного расследования либо судебного следствия, может оказаться невозможным в силу объективных причин.

Так, если лицо находится за пределами страны, где ведется уголовное судопроизводство, может применяться депонирование. Оно также проводится, если существует необходимость обеспечения личной безопасности от заинтересованных в исходе дела лиц со стороны защиты (подозреваемого, обвиняемого). Немаловажным обстоятельством выбора рассматриваемой процедуры в отношение малолетнего является цель избегания психотравмирующей ситуации для последнего, так как в стадии досудебного расследования исключается последующий допрос таких депонентов следователем, дознавателем.

При допросе следственным судьей на судебном заседании ведется протокол, к уголовному делу приобщаются аудио- и видеозапись хода депонирования. При этом присутствуют прокурор, подозреваемый (при его наличии), его адвокат, а в случаях необходимости и другие участники процесса. В случае если присутствие подозреваемого на допросе угрожает безопасности потерпевшего, свидетеля, то подозреваемый не вызывается на допрос. Депонированные показания непосредственно проверяются и оцениваются при рассмотрении уголовного дела судом в качестве источника доказательства [5, с.174]. При сомнениях суда и сторон в достоверности депонированных на следствии показаний или их ключевой роли в системе доказательств потерпевший и свидетель могут быть допрошены в главном судебном разбирательстве в режиме онлайн с применением дистанционных технических средств[7].

Таким образом полностью обеспечиваются гарантии прав сторон защиты и обвинения, соблюдения принципа равноправия сторон и состязательности. Немаловажен факт, что казахстанский институт депонирования показаний свидетеля и потерпевшего полностью соответствует требованиям Международного пакта о гражданских и политических правах [2] и Европейской конвенции о защите прав человека и основных свобод [1], поскольку именно данные международно-правовые акты послужили правовой основой создания данного института в уголовном процессе.

На основании вышеизложенного можно сделать вывод, что российское уголовно-процессуальное законодательство в области защиты прав и законных интересов потерпевшего нуждается в дальнейшем совершенствовании. В данной области представляет пользу изучение опыта в Казахстане, в результате которого можно предложить следующие:

1) введение нового определения потерпевшего, допускающее возможность признания потерпевшим лица, если имеются достаточные основания полагать, что против его охраняемого законом блага совершено преступное посягательство, причинившее ему предусмотренный законом вред;

2) создание института депонирования на стадии предварительного расследования, который служит целям защиты прав потерпевших от давления со стороны обвиняемого, избежание последующей психотравмирующей ситуации во время судебного разбирательства, исключению уголовной репрессии и уголовно-процессуального принуждения при обеспечении их явки.

\section{Литература}

1. Конвенция о защите прав человека и основных свобод ETS N 005 (Рим, 4 ноября 1950 г.) [Электронный ресурс]. Режим доступа: http://docs.cntd.ru/document/1000003045 (дата обращения: 29 марта 2016). 
2. Международный пакт о гражданских и политических правах: Принят резолюцией 2200 А (XXI) Генеральной Ассамблеи от 16 декабря 1966 года [Электронный ресурс]. Режим доступа: http://www.un.org/ru/documents/ decl_conv/conventions/pactpol (дата обращения: 29 марта 2016).

3. Уголовно-процессуальный кодекс Российской Федерации от 18 декабря 2001 г. № 174-ФЗ (в ред. от 1.10.2015) // Собрание законодательства РФ. 2001. № 52, ч. 1, ст. 42.

4. Уголовно-процессуальный кодекс Республики Казахстан от 4 июля 2014 года № 231-V [Электронный ресурс]. Режим доступа: http://kodeksy-kz.com/ka/ugolovno-protsessualnyj_kodeks.htm (дата обращения: 31 марта 2016).

5. Ахпанов А. Н. Депонирование показаний потерпевшего и свидетеля в уголовном процессе Казахстана // Вестник Омской юридической академии. Сер. Право. 2015. № 4 (45). С. 173-179.

6. Божьев В. К вопросу об обеспечении потерпевшему доступа к правосудию // Уголовное право. 2003. № 3. С. 80.

7. Депонирование показаний [Электронный ресурс]. Режим доступа: http://ibirzha.kz/deponirovanie-pokazanij (дата обращения: 29 марта 2016).

8. Леви А., Давыдова Е. Положение потерпевшего в уголовном процессе: нужна конкретизация // Законность. 2009. № 2. C. 37-40.

9. Марфицин П. Г. Момент возбуждения уголовного дела // Вестник Омской юридической академии. 2014. № 3 (24). C. 50-52.

10. Попова Е.И. Памятка потерпевшему об особенностях рассмотрения уголовного дела судом в особом порядке, предусмотренном главой 40 УПК РФ // Администратор суда. 2014. №2. С.3-7.

\section{Сравнительно-правовой анализ использования видеоконферецсвязи в уголовном процессе РФ и США}

(С) В. В. Дымибрылова

студентка 3-го курса юридического факультета ФГБОУ ВО «Бурятский госуниверситет»

Россия, г. Улан-Удэ

Valeria20101@yandex.ru

На сегодняшний день различные технологии призваны автоматизировать и упростить нашу жизнь, повысить её качество. Инновации присутствуют во всех сферах деятельности, исключения не составляет и уголовное судопроизводство. В этой связи особую актуальность приобретает использование судами систем видеоконференцсвязи и ведение видео протокола судебного заседания.

Федеральная целевая программа «Развитие судебной системы России на 2013-2020 годы» предусматривает для повышения качества работы судов, а также открытости, доступности и прозрачности их деятельности на основе информационно-коммуникационных технологий, применение системы видео- и аудио протоколирования хода судебных заседаний, программно-технические средства оцифровки документов и видеоконференцсвязи.

Представляется важным отметить, что использование информационных и коммуникационных технологий в уголовном судопроизводстве в целях оптимизации, при условии строгого соблюдения конституционных прав и свобод граждан, требует формирования правовых аспектов.

В конце XX в. Конституционный Суд Российской Федерации определил правомерность применения информационных технологий для рассмотрения кассационных и надзорных жалоб в режиме видеоконференцсвязи при удаленном участии осужденного. [4]

В рамках проведения судебной реформы, повышения эффективности деятельности судебной власти в Российской Федерации, оптимального организационно-правового и материально-технического обеспечения судебной системы по поручению Президента Российской Федерации была разработана, а затем утверждена Постановлением Правительства Российской Федерации от 20 ноября 2001 г. N 805 Федеральная целевая программа "Развитие судебной системы России" на 2002 - 2006 гг., где основной задачей являлось информационное обеспечение судебной системы, а 4 августа 2006 г. Распоряжением Правительства Российской Федерации N 1082-p утверждена Концепция Федеральной целевой программы "Развитие судебной системы России" на 2007 - 2011 гг.

В соответствии с Окинавской хартией глобального информационного общества, принятой лидерами стран "Большой восьмерки" 22 июля 2000 г., и другими международно-правовыми актами судебная власть Российской Федерации полностью выполняет международные требования, касающиеся осужденных.

Также, международные правовые аспекты применения технологий были представлены в Декларации принципов и Плане действий "Построение информационного общества - глобальная задача в новом тысячелетии" на Всемирной встрече на высшем уровне по вопросам информационного общества, проходившей под эгидой ООН и Международного союза электросвязи, первый этап которой состоялся в Женеве в декабре 2003 г., а второй - в ноябре 2005 г. в Тунисе.

В результате сформировалось правовое поле для широкого использования видео технологий в системе судебного производства, которое, в свою очередь, обеспечило формирование федеральной системы видеоконференцсвязи в рамках системы судебного производства.

Традиционно принято считать, что впервые видеоконференцсвязь в ходе уголовного судопроизводства применена американскими процессуалистами. Сегодня в США видеоконференцсвязь применяется на всех стадиях уголовного процесса, в отличие от Российской Федерации. 
Американскими законодателями разработан проект «Судебный процесс XXI века», целью которого стало совершенствование международных систем уголовной юстиции путем внедрения современных информационных технологий в уголовный процесс. В рамках этого проекта осуществляется разработка современных технологий для использования в судебной системе, а также создание и демонстрация возможностей оборудованного современными технологиями зала судебных заседаний XXI века. Новшества, закреплённые в данном проекте, в первый раз использованы в апреле 2002 года в Окружном суде штата Массачусетс. Тогда, в ходе хотя и показательного процесса, но была установлена видеоконференцсвязь с тремя судами, которые были расположены на различных континентах. Участники процесса посредством использования специального оборудования (очков трехмерного видения, экранов, аудиосистем, технологии голографии) находились в виртуальном точно воссозданном пространстве места совершения преступления [5].

Возвращаясь к практике применения видеоконференцсвязи в России, следует отметить, что в отечественном законодательстве уже более 10 лет нормативно закреплено положение о применении видеоконференцсвязи в уголовном судопроизводстве. В соответствии со статьями Уголовно-процессуального кодекса Российской Федерации (УПК РФ) правом участвовать в судебном заседании путем использования систем видеоконференцсвязи обладают следующие лица: обвиняемый; подсудимый, содержащийся под стражей, или осужденный, отбывающий наказание в виде лишения свободы; потерпевший, его законный представитель, представитель; свидетели. А также при помощи данной связи согласно п.8 ст. 389.13. УПК суд апелляционной инстанции может исследовать доказательства [1].

Впервые судебное заседание с использованием видеоконференцсвязи было проведено 18 ноября 1999 года в Челябинском областном суде. Осуждённый М. Муртазин обжаловал решение районного суда в кассационной инстанции и стал первым, кто участвовал в процедуре рассмотрения своей жалобы, находясь в СИЗО, в то время, как члены судебной коллегии - в зале областного суда. Они имели возможность видеть друг друга на телеэкранах. Посредством видеоконференцсвязи осужденному было обеспечено право принимать участие в судебном разбирательстве и отстаивать свою позицию, наравне с государственным обвинителем. Причиной рассмотрения дела, с использованием техники, послужили ограниченный штат и финансовая база конвойной службы, которые не могли доставить М. Муртазина в суд, а также определённую роль сыграло Постановление Конституционного Суда Российской Федерации от 10.12.1998 г. № 27-П по делу о проверке конституционности ч. 2 ст. ст. 335 УПК РСФСР, согласно которому вопрос об участии осужденного в заседании суда, рассматривающего дело в кассационном порядке, разрешается этим судом, данная норма закона признана не соответствующей Конституции Российской Федерации [6].

На данный момент, в нашем государстве использование видеоконференций в судах I, апелляционной, кассационной и надзорной инстанции достаточно распространено. В частности, во многих субъектах РФ (Красноярский край, Иркутская область, Ленинградская область и другие) с использованием видеоконференцсвязи довольно часто проводятся заседания по рассмотрению кассационных жалоб. Например, несколько лет назад в Иркутском областном суде проведено судебное заседание в режиме видеоконференции с СИЗО-6 г. Ангарска, в котором находился осуждённый, подавший кассационную жалобу на постановление, вынесенное районным судом. [3] Однако её применение допускается только при наличии уважительных причин, по которым лицо, подлежащее допросу не может явиться к месту судебного производства. Помимо этого, трансляция должна быть организована так, чтобы было видно все помещение, в котором находится лицо, участвующее в судопроизводстве, а также иные лица, находящиеся с ним. Видеоконференция должна быть построена таким образом из-за возможного воздействия за кадром.

Итак, нужно отметить, что с принятием УПК РФ были внесены существенные изменения, предоставляющие возможность с использованием данной системы осуществлять допрос свидетеля, потерпевшего и обвиняемого. То есть, можно сделать вывод, что использование видеоконференцсвязи в РФ имеет своей целью повышение результативности и качества производства по уголовным делам, соблюдение процессуальных сроков, применение новых методов сбора и закрепления доказательств по делу, обеспечение безопасности участников уголовного процесса при неукоснительном соблюдении их конституционных прав и свобод. [5] Хотя изначально причиной его применения была необходимостью соблюдения прав осужденных, находящихся под стражей, при рассмотрении уголовных дел судами кассационной и надзорной инстанций.

Возвращаясь к практике США, следует отметить, что здесь отсутствуют какие-либо федеральные правила или законодательные акты, прямо устанавливающие процессуальную форму и основания получения показаний с использованием видеоконференцсвязи. Обычно такие вопросы решаются по мере их возникновения окружным судьей, председательствующим при рассмотрении дела на основании судебных прецедентов. Однако применяемые в таких случаях федеральные правила получения показаний свидетелей, находящихся на территории другого государства, для их использования в уголовном процессе требуют доказательства того, что «в связи с исключительными обстоятельствами дела, в интересах правосудия, необходимо получить и сохранить показания будущего свидетеля...». Факторы, при помощи которых можно определить обстоятельства как исключительные, включают в себя содержание показаний и недоступность свидетеля для дачи показаний в ходе судебного заседания. Суды в своей практике придерживаются того мнения, что под «недоступностью» свидетеля для дачи показаний понимается нежелание свидетеля прибыть в суд и добровольно дать показания, если на него не распространяется обязанность являться по повестке, направленной судом. В соответствии с этим положением лица, не являющиеся гражданами США и находящиеся на территории иностранного государства, обычно считаются недоступными [2]. 
Также нужно сказать, что в США закреплена непосредственно сама процедура использования видеоконференцсвязи в суде. А именно для применения видеоконференции, в первую очередь, необходимо разрешение председательствующего судьи. Во-вторых, суд использует лишь корпоративную видеоконференцсвязь, напримep, Polycom, Cisco и LifeSize, и не поддерживает связь потребительского уровня, такую как Skype или Face Time. Также за один месяц до проведения судебного заседания обязательно происходит тестирование необходимой техники. Во время самого судебного заседания нужно, чтобы как в суде, так и в месте, с которым связываются, находился технический персонал. Связь должна быть установлена за 15 минут до начала судебного разбирательства [7].

При соблюдении установленных законом стандартов соответствующие правила позволяют получить и записать показания свидетеля заранее, до начала судебного процесса, а потом, в ходе судебного заседания, представить их в качестве доказательств. Федеральное законодательство США также позволяет, в соответствующих случаях, получать показания, как до начала судебных слушаний, так и в ходе них с использованием видеоконференцсвязи.

Из всего вышесказанного следует, что видеоконференцсвязь имеет большое распространение и в России, и в США. Однако в США использование видеотрансляций возможно не только в судебном, но и в досудебном производстве при проведении следственных действий. То есть наша страна хоть и применяет видеоконференции, но пока ещё не в полной мере, в какой это возможно. На наш взгляд, Россиия должна перенять у США использование видеоконференцсвязи в досудебном производстве для более быстрого разрешения дела, для экономии денежных средств, связанных с участием в уголовном судопроизводстве лиц, проживающих в населенных пунктах, отдаленных от места производства по уголовному делу.

Таким образом, изучение опыта зарубежных стран, в том числе и США, в данной сфере может помочь совершенствованию использования видеоконференцсвязи в РФ, а также наглядно продемонстрировать ее потенциал при производстве процессуальных действий.

\section{Литература}

1. Уголовно-процессуальный кодекс Российской Федерации от 18 декабря 2001 № 174-Ф3 (ред. от 30.03.2016) [Электронный ресурc]. URL : https://www.consultant.ru/document/cons_doc_LAW_34481/ (дата обращения: 29 марта 2016).

2. Волеводз А.Г. Правовые основы взаимной правовой помощи по уголовным делам с использованием видеоконференцсвязи // Военно-юридический вестник Приволжского региона: сб. науч. тр. / ВП ПУрВО, Приволжский окружной военный суд и Самарская гуманитарная академия. Самара: Изд-во Самарской гуманитарной академии, 2003. Вып. 1. С. 70-96.

3. Иркутский областной суд: Видеоконференцсвязь с СИЗО-6 г. Ангарска [Электронный pecypc]. URL : http://oblsud.irk.sudrf.ru/modules.php?did=149\&name=press_dep\&op=1.

4. Краснопевцев С.А. Использование систем видеоконференцсвязи в уголовном процессе [Электронный pecypc]. URL : http://www.justicemaker.ru/view-article.php?id=22\&art=3192.

5. Родивилина В. А. Некоторые вопросы применения видеоконференцсвязи в досудебном производстве // Вестник Иркутского государственного технического университета. 2015. № 2. С. 278-280.

6. Смолина М. Осуждённый на связи // Вечерний Челябинск. 1999. № 218 [Электронный pecypc]. URL : http://old.stel.ru/videoconference/tech_vc/using/chelyabinsk-newspaper.php.

7. United States Court of Federal Claims: Guidance on Use of Videoconferencing in the Court [Электронный pecypc]. URL : http://www.uscfc.uscourts.gov/video-conferencing-guidance.

\section{Законодательство РФ и Китая, регламентирующее институт защиты в уголовном процессе: сравнительный анализ}

(ㄱ Д. Я. Каминский

курсант 3 курса

ФГКОУ ВО «Крымский филиал Краснодарского университета Министерства внутренних дел Российской Федерации» Россия, г. Симферополь

В современных демократических государствах особое место занимает адвокатура, призванная содействовать успешному отправлению правосудия. Содействует адвокат отправлению правосудия, защищая своего клиента всеми законными способами. Неопровержимым является тот факт, что адвокат должен оказать квалифицированную помощь своему подзащитному, используя все имеющиеся в его арсенале механизмы.

Подзащитный должен полностью доверять своему защитнику, быть уверенным в том, что все подробности и неприятные мелочи его жизни, связанные с производством по делу, не будут доступны всем желающим. Однако на практике иногда происходит по-другому. Адвокат может "поделиться" доверенной ему информацией, например, в средствах массовой информации, из побуждений прорекламировать себя, с правоохранительными органами, ведь для полноценной защиты адвокат должен знать практически все по делу, в котором обвиняют его клиента, либо в узком кругу друзей ради бахвальства.

Считаем, что такие ситуации нарушают права подзащитного и обнаруживают имеющуюся важную проблем, связанную с понятием «адвокатская тайна». 
Изучив законодательство РФ и Китая, касающееся данного вопроса, считаем необходимым обратить внимание на следующие положения.

Закон КНР «Об адвокатах и юридическом представительстве», уголовный кодекс КНР и уголовно-процессуальный кодекс КНР, мы пришли к выводу, что понятия «адвокатская тайна» в законодательстве КНР не предусмотрено. Закон прямо указывает на обязанность адвоката хранить государственную тайну и коммерческие секреты участника тяжбы, ставшие известными во время ведения дела, и не раскрывать тайн сторон, участвующих в тяжбе (ст.33 Закон КНР «Об адвокатах и юридическом представительстве») [1].

Таким образом, можно сделать вывод, что законодательство Китая хотя и не содержит четкого определения адвокатской тайны, но закрепляет круг сведений, составляющих адвокатскую тайну, и включает в себя: коммерческие секреты, тайна частной жизни.

Конечно же, возникает вопрос об ответственности за разглашение сведений, ставших известными адвокату от своего доверителя.

Так ч. 6 статьи 44 Закона «Об адвокатах и юридическом представительстве» содержит право юридического отдела органов власти провинции, автономной области, муниципалитета или города, имеющего районы, наложить дисциплинарное взыскание на адвоката, раскрывшего коммерческую тайну или тайну личной жизни доверителя. Необходимо заметить, что перечень оснований для наложения дисциплинарного взыскания, являясь открытым, включает помимо вышеуказанного следующие виды: одновременная деятельность в более чем двух адвокатских конторах; работа в качестве представителя обеих сторон в тяжбе; попытка обеспечить себе работу, прибегая к таким нечестным методам конкуренции, как клевета на других адвокатов или выплата комиссионных за привлечение клиентов; отказ без веских на то причин от защиты или представления интересов клиента после принятия предложения клиента на ведение дела; не появление в назначенное время в суде для участия в судебном процессе или арбитраже; принятие частным образом предложения клиента по ведению дела, или принятие частным образом платы с клиента, поручившего адвокату дело, или принятие денег и личного имущества клиента, или попытка присвоить права и интересы, оспариваемые двумя сторонами, участвующими в тяжбе, используя, таким образом, преимущество, предоставляемое возможностью оказания юридических услуг, или принятие денег или личного имущества от противоположной стороны, участвующей в процессе; встреча с судьей, государственным прокурором или третейским судьей в нарушение действующих положений или приглашение судьи или государственного прокурора, или третейского судьи, или другого ответственного лица на обед либо вручение им подарков или дача взяток; препятствование законному сбору улик со стороны противной стороны, участвующей в процессе; нарушения порядка в суде или арбитражном суде или препятствование нормальному ведению суда или арбитража; совершение других наказуемых действий. Совершение вышеуказанных действий влечет возможность отстранения от адвокатской деятельности на срок от трех месяцев до одного года и обращения в доход государства полученных незаконных доходов.

При этом, статья 45 рассматриваемого Закона «Об адвокатах и юридическом представительстве» предусматривает и возможность наступления уголовной ответственности в случаях, если: адвокат раскрыл государственную тайну; предлагал взятку судье, государственному прокурору или третейскому судье или другим ответственным лицам либо подстрекал своих доверителей к даче взятки; представил фальшивые улики, скрыл важные факты, принуждал либо уговаривал других, обещая при этом получение выгоды.

Как мы видим, в Китае, за определенные действия адвоката предусмотрена уголовная ответственность, однако про ответственность за нарушение адвокатской тайны нет ни слова, а значит, за данное деяние уголовная ответственность в Китае не предусмотрена.

Что же касается РФ, то согласно Федеральному закону от 31.05.2002 N 63-Ф3 «Об адвокатской деятельности и адвокатуре в Российской Федерации», адвокатской тайной являются любые сведения, связанные с оказанием адвокатом юридической помощи своему доверителю [2].

Следует отметить, что Закон «Об адвокатской деятельности и адвокатуре в Российской Федерации», не установил границ информации, которая может быть отнесена к категории адвокатской тайны. Однако, частично круг сведений, составляющих адвокатскую тайну, вытекает из ч. 5 ст. 6 Кодекса профессиональной этики адвоката [3], а именно: факт обращения к адвокату, включая имена и названия доверителей; все доказательства и документы, собранные адвокатом в ходе подготовки к делу; сведения, полученные адвокатом от доверителей; информация о доверителе, ставшая известной адвокату в процессе оказания юридической помощи; содержание правовых советов, данных непосредственно доверителю или ему предназначенных; все адвокатское производство по делу; условия соглашения об оказании юридической помощи, включая денежные расчеты между адвокатом и доверителем; любые другие сведения, связанные с оказанием адвокатом юридической помощи. Данный перечень, конечно, является открытым, а это значит, что он может включать также и иные сведения, связанные с оказанием адвокатом юридической помощи.

В отличие от Китая, в РФ все-таки имеется понятие адвокатской тайны, и даже конкретизируется та информация, которую можно отнести к адвокатской тайне, однако ответственность за разглашение данной информации, согласно действующему законодательству ни уголовная, ни административная не предусмотрена. Привлечен за такое нарушение адвокат будет лишь к дисциплинарной ответственности, а именно мерой дисциплинарной ответственности адвоката за совершенный проступок может быть замечание, предупреждение, прекращение статуса адвоката, иные меры, установленные собранием (конференцией) соответствующей адвокатской палаты. Также за разглашение указанных сведений адвокат может быть привлечен к гражданско-правовой ответственности. По решению суда на адвоката может быть возложена обязанность возместить ущерб, причинен- 
ный лицу в результате разглашения сведений, составляющих адвокатскую тайну, компенсировать моральный вред, совершить иные действия, связанные с прекращением нарушения прав доверителя или другого лица.

Исходя из вышеизложенных норм законодательства РФ, можно сделать вывод о недостаточном воздействии на адвоката в результате разглашения им адвокатской тайны. Соответственно, если адвокату будет выгоднее предоставить информацию о своем подзащитном третьим лицам (СМИ, правоохранительные органы и т.д.), он вполне может воспользоваться этой возможностью, ведь наказание по большей части не серьезное. Нормы же законодательства Китая предусматривают наступление административной и уголовной ответственности совсем за другие деяния, законодательство Китая не наделяет адвоката-защитника свидетельским иммунитетом, что, на наш взгляд, неминуемо искажает смысл защиты и может повлечь существенное ухудшение положения подзащитного, ведь одним из главных проявлений свободы в правозащитной деятельности является хранение адвокатом тайны доверителя, а предательство доверителя считается самым тяжким грехом не только в этической традиции адвокатуры, но и в культурной традиции вообще, начиная с ее религиозных основ.

Подытоживая, следует подчеркнуть, что в РФ больше ценят адвокатскую тайну, однако следует применять более суровые меры воздействия к тем адвокатам, которые не могут держать в тайне доверенную им информацию, т.е. действует в явном противоречии с принципами и природой адвокатуры как института, совершая грубый профессиональный проступок и ставят себя вне рядов корпорации.

\title{
Литература
}

1. Международная научно-практическая конференция "Сравнительное правоведение в странах АТР" [Электронный реcypc]. URL: http://www.bsu.ru/university/departments/faculties/uf/13244 (дата обращения 26.03.2016).

2. Об адвокатской деятельности и адвокатуре в Российской Федерации»: Федеральный закон от 31 мая 2002 № 63 -Ф3 (в ред. от 13.07.2015) [Электронный ресурс]. URL: http://www.consultant.ru/document/Cons_doc_LAW_36945 (дата обращения 26.03.2016).

3. Кодекс профессиональной этики адвоката (принят Первым Всероссийским съездом адвокатов 31.01.2003) (ред. от 22.04.2015) [Электронный pecypc]. URL: http://www.consultant.ru/document/cons_doc_LAW_44841 (дата обращения 26.03.2016).

\section{Особенности методики расследования вымогательства в России, Казахстане и Китае}

\author{
(C) Н. К. Коровин \\ стариий преподаватель кафедрь \\ уголовного права и проиесса юридического факультета \\ (C) К. И. Крахмалёва \\ студентка 3-го курса юридического факультета \\ ФГБОУ ВО «Новосибирский государственный \\ технический университет» \\ Россия, г. Новосибирск \\ knk3746@mail.ru
}

С появлением новых информационных и телекоммуникационных технологий, в виде социальных сетей, электронной почты, сотовых телефонов и иных технических средств изменяется форма совершения вымогательства, предопределяющая создание новых частных криминалистических методик расследования вымогательства. Кроме того на современном этапе в России продолжается рост объемов кредитования населения. Одновременно увеличилась и доля просроченной задолженности в общем объеме кредитов, предоставленных физическим лицам. В связи с этим банки и кредитные организации обращаются к коллекторским агентствам, которые осуществляют работу посредника между кредитной организацией и заемщиком, на предмет взыскания задолженности зачастую противоправной и нелегальной деятельностью, такой как: оскорбление должника; применение физической силы; истребование долга под угрозой либо психологическим давлением; произвольное увеличение суммы долга; изъятие денежных средств и материальных ценностей без согласия должника в отсутствие законных оснований; повреждение имущества должника; ограничение права передвижения должника и другие действия, многие из которых квалифицирующиеся как вымогательство. Также одним из распространенным способом вымогательства является использование сети Интернет с требованием передачи денег за распространение позорящих или порочащих данных о лице, его фотографий, личной переписки, размещения видеозаписи на канале Youtube и т.д.

Вымогательство, согласно статье 163 УК РФ - это требование о передаче чужого имущества, или права на имущество, или совершение других действий имущественного характера под угрозой применения насилия либо уничтожение или повреждение чужого имущества, равно под угрозой распространения сведений, позорящих потерпевшего или его близких, либо иных сведений, которые могут причинить существенный вред правам или законным интересам потерпевшего или его близких [3, ст. 163].

УК Республики Казахстан практически дублирует ст.163 УК РФ, а также в ч.2 ст. 181 УК Республики Казахстан даются такие квалифицирующие признаки, как: а) с применением насилия; б) группой лиц по предварительному сговору; в) неоднократно, а в ч.3: а) организованной группой; б) с причинением тяжкого вреда здо- 
ровью потерпевшего; в) с целью получения имущества в крупном размере; г) лицом, ранее два или более раз судимым за хищения либо вымогательство [2, ст. 181].

В ст. 274 УК КНР указываются, что вымогательство путем шантажа государственного или частного имущества в сравнительно крупном размере наказывается лишением свободы на срок до 3 лет, краткосрочным арестом или надзором; то же деяние, совершенное в крупном размере или при иных отягчающих обстоятельствах наказывается лишением свободы на срок от 3 до 10 лет [1, ст. 274].

Таким образом, в соответствии с УК РФ, РК, КНР вымогательство является уголовно-наказуемым преступлением. Для того чтобы правильно организовать расследование необходимо, во первых отталкиваться от конкретной сложившейся следственной ситуации, во вторых выдвинуть в соответствии с данной сложившейся ситуацией все возможные версии и вести их проверку параллельно, в третьих в соответствии с выдвинутыми версиями определить задачи расследования. В целях решения этих задач предлагается осуществлять следователем планирование совместно с оперативными сотрудниками, а также экспертами, психологами и специалистами в различных отраслях знаний; составлять план каждого этапа расследования в отдельности, а также каждого следственного действия; продолжать разработку типовых программ расследования.

Для обеспечения эффективного расследования уголовных дел о вымогательстве следует сфокусировать необходимые усилия по обнаружению и фиксации следов при производстве неотложных следственных действий. Проблема заключается в том, что почти не остается каких-либо следов совершения вымогательства либо преобладают косвенные доказательства, требующие многоступенчатой процедуры доказывания с использованием самых различных связей между расследуемым событием и явлениями действительности. Данная проблема определяет характерную поисковую направленность следственных действий и оперативно-розыскных мероприятий, проводимых на первоначальном этапе расследования.

В связи с этим на первоначальном этапе расследования предлагается осуществлять следующий комплекс оперативно-розыскных и следственных действий: допрос потерпевшего, освидетельствование, наблюдение, осмотр места происшествия, осмотр документов, если предметом вымогательства являлось требование перехода права собственности, либо об оказании различного рода услуг материального характера, либо с документами, при помощи которых производились сделки, наведение справок, контроль и запись переговоров, осмотр предмета вымогательства, контроль и запись переговоров, выемка электронной почты с почтового ящика и социальных сетей, при этом следует использовать специальные знания привлекаемого специалиста, с соответствующей вербальной и наглядно-образной формой фиксации доказательственной информации, как в протоколе следственного действия, так и на фотоаппарат и видеокамеру.

Учитывая, что в настоящее время используется цифровая фотосъемка и видеозапись, при этом следует наиболее полно описать название и тип записывающего устройства и носителя информации, название и объем файла, формат видеозаписи, произвести упаковку носителя информации с сопровождением пояснительной надписью, удостоверенной подписями понятых, следователя, специалиста и скрепленной печатью.

Большое значение при расследовании вымогательства имеет тактическая операция, при производстве которой следует учитывать такие тактические приемы, как подготовка, выбор состава группы, метка специальными средствами предметов вымогательства. Формирование следственно-оперативных групп должно происходить из числа наиболее квалифицированных следователей, специалистов и техников-криминалистов, с учетом знания профессиональных возможностей друг друга, психологически совместимых между собой; личный состав следственно-оперативной группы необходимо распределить по соответствующим подгруппам, в зависимости от выполняемых функций.

На последующем этапе, основной целью которого является процесс доказывания, характерен комплекс следственных действий, включающий в себя: подробный допрос подозреваемого с целью получения конкретизированных показаний, облегчающих впоследствии разоблачение во лжи; обыски по месту жительства вымогателя, его родственников с целью обнаружения вещественных доказательств таких как записки, письма, предметы, которые могут быть использованы в качестве предмета запугивания; предъявление для опознания потерпевшему, свидетелям холодного оружия, применявшегося для подавления воли жертвы; назначение экспертиз: фоноскопической, лингвистической, криминалистической экспертизы веществ, материалов и изделий, баллистической, трасологической, почерковедческой, технико-криминалистической экспертизы документов и других; производство очных ставок с потерпевшим, свидетелями, соучастниками, признающими факт наличия отягчающих обстоятельств; повторный допрос подозреваемого с целью разоблачения во лжи путем предъявления полученных доказательств.

Таким образом, в целях эффективного расследования вымогательства следует в первую очередь определить способ совершения преступления, служащего источником сведений, необходимых для разработки средств, приемов и методов раскрытия, расследования и предупреждения преступлений в соответствии с предлагаемой частной криминалистической методикой расследования вымогательства.

\section{Литература}

1.Уголовный кодекс Китайской Народной Республики [Электронный ресурс]. Режим доступа: http://ukknr.ucoz.ru/index/0-8 (дата обращения: 30.03.2016).

2. Уголовный кодекс Республики Казахстан [Электронный ресурс]. Режим доступа: http://kodeksykz.com/ka/ugolovnyj_kodeks/181.htm (дата обращения: 30.03.2016).

3. Уголовный кодекс Российской Федерации [Электронный ресурс]. Режим доступа: http://base.garant.ru/10108000/22/. (дата обращения: 30.03.2016). 


\title{
Криминалистистические особенности боевого веера как холодного оружия
}

\author{
(C) Н. В. Линникова \\ студентка 4-го курса \\ Иркутского юридического института (филиала) \\ ФГКОУ ВО «Академия Генеральной прокуратуры \\ Российской Федераичии» \\ Россия, г. Иркутск \\ Evriala.aka.natsuo@mail.ru
}

Современная криминалистика не последнюю роль отводит изучению холодного оружия. Однако, на сегодняшний день больший акцент как в науке, так и при применении криминалистических знаний на практике, делается на распространённых видах оружия, которые повсеместно применяются при совершении преступлений, например, различные виды ножей. В то же время, преступление может быть совершено и с использованием предмета, который всё ещё не был освещён в науке в качестве холодного оружия. Таким образом, существенно затруднится возможность квалификации по некоторым статьям Уголовного кодекса Российской Федерации (например, ст. 222 УК РФ, 223 УК РФ, 224 УК РФ, 225 УК РФ), а также признания наличия квалифицирующих признаков в иных составах преступлений.

Одним из таких малоисследованных видов холодного оружия является боевой веер. В силу культурных традиций, он получил своё распространение в Японии, Китае и Корее. Сегодня, искусством боевого веера попрежнему занимаются мастера в Японии, так что древний тессен наряду с другим специализированным оружием феодальной эры, появляется время от времени в тренировочных методиках современных дисциплин координации, таких как каратэ, айкидо и кендо, наряду с сумо, кю-до и ябусамэ (стрельбы из лука с лошади по бегущей собаке).

В криминалистической практике существует понятие замаскированного холодного оружия, боевая часть которого скрыта, и которое имеет внешний вид предмета, не являющегося оружием. На наш взгляд, боевой веер можно отнести именно к такому виду оружия. Его боевая часть не скрыта, однако само оружие выполняется очень похожим внешне на обыкновенный веер, чем вводит окружающих в заблуждение относительно его свойств. Это позволяет иметь при себе данное оружие даже тогда, когда имеется официальный запрет государства на свободное хранение и ношение оружия. В силу своих конструктивных особенностей боевой веер не относится к клинковому оружию, так как удар наносится всей поверхностью сложенного веера, а раскрытый веер выступает исключительно в качестве щита.

Для того, чтобы выяснить, является ли боевой веер холодным оружием, необходимо проверить наличие определённых признаков. Существует три вида боевых вееров: гунбаи, гунсен и тессен. Веер гунбаи был нескладным, выполнялся из цельной пластины металла и предназначался не для атаки, а для подачи сигнала, и в бою использовался только как щит. Гунсен изначально создавался как обычный веер, предназначенный для охлаждения воинов, спицы которого укреплены металлом снаружи и внутри. Внутренние пластины выполнялись из бронзы, меди; внешние пластины часто выполнялись из железа. В качестве оружия он применялся достаточно редко, так как его прочность была гораздо ниже, чем у тессен. Так как, согласно Федеральному закону "Об оружии", к оружию не относятся изделия, сертифицированные в качестве изделий хозяйственно-бытового и производственного назначения, спортивные снаряды, конструктивно сходные с оружием[1], то гунсен является именно изделием, конструктивно схожим с оружием, но не самим оружием. Тессен (鉄扇) - складной веер с наружными спицами из толстых листов железа, который был разработан, чтобы выглядеть как обычный веер. Самурай мог носить его в местах, где мечи или другое оружие не было разрешено, и некоторые школы фехтования включали обучение в использовании такого веера в качестве оружия. В сложенном состоянии тессен использовался как дубинка. Данный вид веера также использовался для парирования стрел и дротиков, и даже как помощь в плавании [5]. На наш взгляд, именно веер тессен следует рассматривать в качестве классического примера боевого веера, так как из всех представленных видов данного объекта именно он, на первый взгляд, обладает признаками холодного оружия.

В российском законодательстве под холодным оружием понимается оружие, предназначенное для поражения цели при помощи мускульной силы человека при непосредственном контакте с объектом поражения[3]. Холодное оружие обладает обязательными признаками, и только наличие их совокупности может говорить о том, что исследуемый объект является им.

Цель изготовления - поражение цели. На сегодняшний день в законодательстве не даётся чёткого определения понятию "поражение". Профессор Воробьёв Ю.Л. утверждает, что механическое поражение - это результат воздействия на объекты или живые организмы кинетической энергии, приводящий к потере ими способности к заданному функционированию (выполнению поставленных задач), нарушению трудоспособности (боеспособности)[2]. Умение использовать веер в качестве оружия приобрело популярность и у представителей общественных классов, которым было запрещено носить меч в силу «низкого происхождения», а также среди самураев, которые в определённых местах не имели права обнажать клинки. В литературе, посвящённой боевым искусствам, нередко описываются случаи побед, одержанных при помощи только одного лишь веера [4]. Благодаря своей конструкции тесен успешно использовался и как оборонительное, и как наступательное ору- 
жие. Отсюда можно сделать вывод о том, что целью изготовления боевого веера действительно являлось именно поражение цели.

Многократность использования. Данный признак подразумевает под собой достаточную прочность оружия, то есть соответствие прочностных характеристик как конструкции в целом, так и отдельных деталей исследуемого объекта (в том числе и материалов, из которых они изготовлены) требованиям ГОСТов или другим нормативно установленным характеристикам, а также прочностным характеристикам аналогов-образцов данного типа холодного оружия [1]. В Российской Федерации, разумеется, нет ГОСТа, в котором бы прописывались требования к боевому вееру, как к холодному оружию. Однако, вести речь о достаточной прочности тессена можно даже на основании того, что те из самых первых боевых вееров, что сохранились до наших дней, несмотря на их участие в реальных боях всё же не потеряли ни формы, ни потенциальной опасности. Так, самый известный тессен - черный складной командный веер в форме gunsen-gata c 10-ю металлическими пластинами и с изображением самурайского родового герба (мона) клана Ичидзэн на обеих сторонах веера. Он сохранился до наших дней, пройдя множество боёв, что позволяет сделать вывод о вероятности его многоразового использования, хотя окончательный вывод, разумеется, возможен только после проведения экспертизы прочности каждого конкретного веера. При этом следует учитывать и тот факт, что современный уровень техники и технологии позволяет создавать боевые веера ещё более прочные, чем в древности.

Использование мускульной силы человека для нанесения удара. Конструкция боевого веера позволяет использовать его только тогда, когда он непосредственно находится в руках использующего его человека. Кроме того, веер может быть использован и для применения с его помощью метательных снарядов. В литературе описаны следующие варианты такого применения. Маленькие ножи размещали между перьями, окаймляющими веер. Когда эти перья скользили по лицу врага, он ощущал укус острых лезвий, которые ослепляли его. Также, эти маленькие лезвия специальным методом складывались и хранились в складках веера и при резком его открытии ножи выстреливали, как метательные снаряды, поражая лицо и тело противника. Помимо этого, между перьями прятали мешочки с ядом, которые при раскрытии веера прорывались и яд поражал противника вызывая слепоту или даже смерть [6]. Но в любом из приведённых выше случаев для применения боевого веера используется именно мускульная сила человека, держащего оружие в руках в данный момент.

Способ применения - применение оружия при непосредственном контакте с объектом поражения. Так как, в большинстве случаев, веер используется именно в качестве ударно-раздробляющего оружия, то данный признак невозможно поставить под сомнение, так как такой тип оружия предполагает нанесение удара непосредственно ударной поверхностью.

Между тем, не клинковое оружие обладает дополнительными обязательными признаками, такими как наличие выраженной рукояти и наличие ударной поверхности, а также определённая масса каждого ударного элемента (более 100 грамм). Если признак массы невозможно поставить под сомнение (ведь каждый лепесток тенсен весит от 200 до 500 грамм), то рукоять и ударная поверхность веера настолько плавно переходят друг в друга, что отсутствует их яркая выраженность. Однако, фактически, держать веер можно только с одной стороны, и та часть, которая обычно находится в руке, никогда не затачивается, а также зачастую выделяется рисунком либо окраской. В сложенном состоянии эта часть тессен значительно уже боевой части, а следовательно, можно говорить о том, что именно она является рукоятью, так как находится непосредственно в руке, а также ею никогда не наносится удар. На наш взгляд, слабая выраженность перехода между ударной поверхностью и рукоятью не может свидетельствовать об отсутствии данных признаков вообще. К примеру, у кастета эти части так же не являются ярко выраженными, однако он, несомненно, относится к холодному оружию.

Факультативными признаками не клинкового оружия выступают: наличие дополнительных конструктивных элементов рукояти и наличие дополнительных конструктивных элементов ударной поверхности. Дополнительные конструктивные элементы рукояти обычно не играли роли при ведении боя, однако во времена распространённости такого вида оружия, они помогали маскировать тессен под обыкновенный веер. Это были всевозможные рисунки, кисточки, бантики и ленты. На сегодняшний день, они, в большинстве случаев, присутствуют при создании современных боевых вееров. Большее же внимание, по нашему мнению, следует уделить дополнительным конструктивным элементам ударной поверхности. Часто (но не всегда) тессен был снабжен острыми лезвиями, которые размещались в складках и на концах веера, придавая ему ещё более серьёзные режущие и ударные свойства. Можно ли считать веер с заточенными краями пластин клинковым оружием? На наш взгляд - нет, хотя бы потому, что даже при наличии острия (которое было далеко не во всех случаях) не соблюдаются требования ни длины, ни толщины предполагаемого клинка. Прочностной критерий нам пришлось опустить, так как в мире ещё не было проведено ни одного исследования прочности ни одного боевого веера. Однако, оружие не может считаться клинковым без наличия всех признаков одновременно. Более того, применить боевой веер в качестве режущего оружия не представляется возможным, так как критически сложно при попытке такого удара удержать тессен в раскрытом состоянии, ведь при подобном ударе повреждения (кисти руки) получит в первую очередь тот человек, который наносит удар.

Таким образом, можно сделать вывод о том, что боевой веер имеет все признаки холодного оружия: целью его изготовления является поражение цели, он применим к многократному применению, при его использовании ведущую роль играет мускульная сила человека, при непосредственном контакте с объектом поражения. Боевой веер является не клинковым холодным оружием ударно-раздробляющего действия наряду с кастетом, кистенем, булавой, необходимо учитывать при квалификации по соответствующим статьям. 


\title{
Литература
}

1. Астапов А. Н., Герасимов А. М. Методика испытаний гражданского холодного, метательного оружия и изделий, конструктивно сходных с таким оружием, на соответствие криминалистическим требованиям, утвержденная МВД и Госстандартом России 21.07.1997 г., ЭКЦ МВД России [Электронный ресурс]. URL: http://napoleonic.ru/gallery/albums/userpics/ 10138/metodika_prinadlezhnosti_holodnomu_oruzhiju.pdf (дата обращения: 25.03.2016)

2. Гражданская защита. Энциклопедический словарь / Ю. Л. Воробьёв [и др.]; под общ. ред. С. К. Шойгу / МЧС России, 2005.

3. Об оружии: Федеральный закон от 13 декабря 1996 г. № 150-Ф3 [Электронный pecypc]. URL: http://www.consultant.ru/document/cons_doc_LAW_12679 (дата обращения 25.03.2016).

4. Jōchi Daigaku, JSTOR (Organization), Monumenta Nipponica, Volume 16, p.71-p.73

5. Oscar Ratti, Adele Westbrook, Secrets of the Samurai: A Survey of the Martial Arts of Feudal Japan, p.296-304

6. William E. Deal, Handbook to Life in Medieval and Early Modern Japan, p.167

\section{Сравнительно-правовой анализ регулирования в сфере недопустимых доказательств}

\author{
(C) М. Э. Лумбунова \\ студентка 3-го курса юридического факультета \\ ФГБОУ ВО «Бурятский госуниверситет» \\ Россия, г. Улан-Удэ \\ rita.lumbunova@mail.ru
}

Любой факт в нашем деле требует подтверждения факта своего существования, - будь то научное утверждение или простая жизненная ситуация. В уголовном процессе доказательства играют далеко не последнюю роль и от того, насколько эти доказательства являются достоверными, может зависеть не только исход дела, но и судьба человека. В случае, если доказательства будут собраны незаконным путем, - велик риск вероятности нарушения одного из главных принципов уголовного судопроизводства - принцип справедливости. В современно мире все больше развиваются идеи правового государства, возрастает внимание к обеспечению и охране основных прав и законных интересов человека. Поэтому, при поиске и получении доказательств, необходимо строго принимать во внимание конституционные права человека в этой области. Отступление от этого принципа может привести к недопустимости доказательства, то есть лишению его юридической силы и невозможности использования в процессе доказывания [2]. К тому же, согласно, ч.1 ст.88 Уголовно-процессуального кодекса Российской Федерации, каждое доказательство подлежит оценке с точки зрения относимости, допустимости и достоверности, а собранные доказательства проверяют на достаточность для разрешения уголовного дела.

Итак, для соблюдения всех процессуальных мероприятий нужно более ясно для себя определить недопустимые доказательства, чтобы впоследствии не совершать подобных действий. Недопустимые доказательства урегулированы нормой уголовного закона - ч.1 ст.75 УПК РФ. Так, недопустимыми являются такие доказательства, которые получены с нарушением требований уголовного законодательства. Такие доказательства не имеют юридической силы и, следовательно, не могут быть положены ни в основу обвинения или защиты, ни для доказывания любого из обстоятельств дела. В свою очередь, ч. 2 ст. 50 Конституции гласит, что правосудие не может осуществляться с использованием доказательств, полученных с нарушением законодательства. Пленум Верховного Суда (ПВС) РФ разъяснил, что нарушение законодательства при сборке доказательств будет являться нарушение гарантированных Конституцией права человека и гражданина или установленный уголовно-процессуальным законодательством порядок их собирания и закрепления, в случае собирания доказательств осуществлено ненадлежащим лицом либо в результате действий, не предусмотренных уголовно-процессуальными нормами [3].

К недопустимым доказательствам уголовный закон РФ относит:

1) показания подозреваемого, обвиняемого в отсутствие защитника, равно случаи отказа от защитника.

Главной функцией данного пункта является защита подозреваемого или обвиняемого от самооговора. Также напоминает систему сдержек и противовесов, когда защитник предупреждает признание вины под воздействием психического или физического воздействия. Особенно запрещается воспроизводить показания подозреваемого, обвиняемого, данные в ходе досудебного производства по уголовному делу в отсутствие защитника, путем допроса в качестве свидетеля, дознавателя или следователя, производившего дознание или предварительное следствие [4].

Зачастую, ч.2 ст.75 УПК РФ распространяют на случаи когда участие педагога или психолога, согласно ст. 425 УПК РФ, было обязательным, то есть признания полученные в отсутствие таковых не допускается [6].

2) нарушены права личности.

Участникам, не разъяснены их процессуальные права, не обеспечены права тех лиц, которые не владеют государственным языком, правом на переводчика.

3) Случаи, когда установленный уголовно-процессуальным законом порядок собирания доказательств, нарушен.

Осмотр места происшествия или при производстве иных следственных действий отсутствовали понятые или отсутствовало их необходимое количество. Также в случае, если отсутствует постановление о производстве 
следственного действия, согласно ч. 1 ст. 164 УПК РФ оно должно быть, либо постановление о признании предмета вещественным доказательством, а в протоколе следственного действия дата и время его проведения неверно указаны или не указаны вообще.

4) показания «по слуху», когда показания даются без ссылки на первоисточник.

5) собирание и закрепление доказательств осуществлено ненадлежащим лицом.

Например, следователь не вынес постановление о присвоении уголовного дела, равно как доказательство получено следователем, который не включен в следственную группу, производящую расследование по данному уголовному делу.

6) собирание и закрепление доказательств осуществлено в результате действий, не предусмотренных уголовно-процессуальными нормами.

Например, признание подозреваемого, обвиняемого получено путем составления «чистосердечного признания», тогда как нужно составлять протокол допроса, как и обыск, оформляемый неким «протоколом добровольной выдачи». В любом случае такие «доказательства» в РФ не будут иметь никакой юридической силы и не смогут представляться в качестве таковых.

Итак, перейдем к уголовному законодательству Китая. К недопустимым доказательствам уголовный закон КНР относит [7]:

1) Доказательства, добытые с подсудимого путем пыток и уговоров.

Итак, ст.63 УПК КНР гласит, что доказательства полученный путем таковых средств являются недопустимыми. Комментарий Верховного народного суда о вопросах применения УПК КНР предусматривает, что показания подозреваемого, полученные под пыткой, путем обмана, с использованием угроз и запугивания, не могут быть положены в основу для принятия решения судом. Однако по мнению кандидата юридических наук Китая Юань И, это не является преградой для получения доказательств, так как законодательством это строго не предусмотрено. В целом судебное разбирательство полностью утрачивает контроль над следствием в этой сфере. При этом стоит отметить, что содержание подозреваемого под стражей в течение длительного срока является обычной мерой пресечения при расследовании уголовных дел, что также можно приравнять как к «особому» средству получения доказательств [9].

2) Доказательства свидетелей, потерпевшего. собранные путем угроз и запугивания.

Согласно законодательству, доказательства собранные путем запугивания свидетелей, потерпевшего не могут являться допустимыми, в силу того, что таким образом нарушаются основные права и свободы человека.

3) Собирание вещественных, письменных доказательств путем, не соответствующих законодательству.

Ст.42 УПК КНР предусматривает 7 видов доказательства и акцентирует на том, что доказательствами являются любые фактические данные, свидетельствующие об истинных обстоятельствах дела [5]:

1) показания и объяснения подозреваемого и обвиняемого в совершении преступления;

2) заявления потерпевших;

3) показания свидетелей;

4) вещественные и письменные доказательства;

5) заключение экспертизы;

6) протоколы осмотра и освидетельствования;

7) видео- и аудиоматериалы.

УПК уточняет, что только после тщательной проверки их достоверности они могут выступать в качестве допустимых доказательств.

В ст.110 УПК КНР говорится, что любое юридическое или физическое лицо обязаны по требованию народной прокуратуры и органов полиции предоставить видео- и аудиоматериалы, которые могут свидетельствовать о виновности либо невиновности подозреваемого в совершении преступления [7].

4) Доказательства, происхождение которых невозможно разумно объяснить.

Ст.150 УПК КНР допускает использовать в уголовном судопроизводстве копии либо фотографии важнейших доказательств, однако при наличии сомнительных доказательств согласно статьям 158 и 119 соответственно проводятся по ним следственная проверка, и назначается экспертиза.

5) Доказательства признаются недопустимыми по ходатайству сторон.

Итак, уголовное законодательство обеих стран практически не отличается, однако в практическом плане, по моему мнению и по мнению китайских ученых [9], Китаю нужно стремиться к улучшению позиции личности в уголовном судопроизводстве, тогда как сейчас при всех внесенных изменениях и поправках, УПК КНР сохранил свою сущность и на первом месте стоят интересы государства, а не личности [8].

Также отличие очевидно в институте защиты подозреваемого и обвиняемого. В России, согласно ст.16 УПК РФ, обеспечивается право на защиту, а также, согласно ст.46, 47 УПК РФ, гарантируется право на конфиденциальные встречи с защитником без ограничения их количества и продолжительности. А в Китае, при свидании адвоката с находящимся под стражей подозреваемым, следственные органы, исходя из обстоятельств дела и необходимости, могут послать своего работника для присутствия на таком свидании. При допросе подозреваемого следователями присутствие адвоката не предусмотрено. Подозреваемый не имеет права на молчание, наоборот, он обязан правдиво отвечать на задаваемые следователем вопросы, а так называемые правдивые ответы, естественно, становятся на практике признанием подозреваемым своей вины. Здесь, по моему мнению ставится под сомнение право на защиту вообще, а также возможность получить достоверные и правдивые показания от подозреваемого или обвиняемого. 
Законодательство Китая более чрезвычайно относиться к человеку, как личности, в процессе, когда как в России права человека находятся под зашитой государства. Все это, по моему мнению, происходить по некоторым причинам, таким как большая численность населения и влияние общественного строя. Однако влияние такого более критичного подхода уголовному законодательству дает свои положительные плоды в отношении статистики совершаемых преступлений. Поэтому, считаю, что следует законодательствам обеих стран обратить друг на друга, поинтересоваться опытом и сделать свое законодательство более гуманным и эффективным.

\section{Литература}

1. Конституция Российской Федерации (принята всенародным голосованием 12.12.1993) [Электронный ресурс] // СПС «Консультант-плюс». Режим доступа: http://base.consultant.ru/cons/cgi/online.cgi?req=doc;base=LAW;n=2875

2. Комментарий к 75 УПК РФ [Электронный ресурс]. Режим доступа: http://upkod.ru/chast-1/razdel-3/glava-10/st-75-upk$\mathrm{rf} /$ kommentarii

3. О некоторых вопросах применения судами Конституции Российской Федерации при осуществлении правосудия : постановление Пленума Верховного Суда Рос. Федерации от 31 окт. 1995 г. № 8. П. 16.

4. Определение КС РФ от 06.02.2004 N 44-О по жалобе гр. Демьяненко В. Н. на нарушение его конституционных прав положениями статей [Электронный ресурс] // 56, 246, 278 и 355 УПК РФ // РГ. 07.04.2004. N 71.

5. Особенности использования криминалистической видеозаписи в уголовном процессе Китая, Казахстана и России Коровин Н. К. Россия, г. Новосибирск [Электронный ресурс]. Режим доступа: http://www.uzluga.ru

6. Постановления Пленума ВС РФ от 01.02.2011 N 1 "О судебной практике применения законодательства, регламентирующего особенности уголовной ответственности и наказания несовершеннолетних" // Бюллетень Верховного Суда РФ. 2011. N 4 .

7. Уголовно-процессуальный кодекс КНР, принят на 2-й сессии Всекитайского собрания народных представителей пятого созыва 1 июля 1979 года, с поправками, внесенными Постановлением, принятым на 4-й сессии Всекитайского собрания народных представителей восьмого созыва 17 марта 1996 года «О внесении изменений в «Уголовно-процессуальный кодекс КНР Китайской Народной Республики» (中华人民共和国刑事诉讼法) [Электронный ресурс]. Режим доступа: http://www.lawtime.cn/ faguizt/43.html

8. Чжан Ин. Сравнительное исследование права подозреваемого на адвокатскую помощь в уголовном судопроизводстве КНР и РФ : автореф. дис. ...канд. юр. наук. Владивосток, 2010. 26 с.

9. Юань И. ПРОБЛЕМЫ ИСТИНЫ В УГОЛОВНОМ ПРОЦЕССЕ КНР [Электронный ресурс]. Режим доступа: http://cj.isea.ru/pdf.asp?id=10622 criminology journal ounuel

\section{Сравнительный анализ уголовно-процессуального законодательства Российской Федерации и стран СНГ на предмет обеспечения прав и законных интересов участников уголовного судопроизводства, имеющих физические недостатки}

(C) P. О. Мамаева

аспирант 2 года обучения

ФГБОУ ВО «Удмуртский госуниверситет»

Россия, г. Ижевск

regi-mam@mail.ru

Вопросы защиты прав и законных интересов участников уголовного судопроизводства, имеющих физические недостатки, в каждой стране регулируются по-своему.

В целях отыскания оптимального подхода к решению указанного вопроса, мы рассмотрим уголовно-процессуальное законодательство Российской Федерации и уголовно-процессуальные законодательства Украины, Белоруссии, Республики Молдова, Азербайджанской Республики, Республики Казахстан, Республики Узбекистан, Кыргызской Республики и Туркменистана.

Каждое из рассмотренных законодательств имеет свою точку зрения на вопрос защиты прав и законных интересов лиц - участников уголовного судопроизводства, имеющих физические недостатки. Это подтверждается следующим:

1. Обязательное участие защитника в уголовном процессе должно быть

обеспечено:

а) при невозможности самостоятельного осуществления подозреваемым или обвиняемым своего права на защиту в силу немоты, слепоты, глухоты, иных серьезных нарушений функций речи, слуха, зрения, тяжелой продолжительной болезни [1];

б) по делам немых, глухих, слепых и других лиц, которые в силу своих физических недостатков испытывают затруднения в осуществлении права на защиту[2];

в) подозреваемому, обвиняемому, подсудимому, которому трудно самостоятельно реализовывать свое право на защиту вследствие немоты, глухоты, слепоты, иного существенного нарушения функций речи, слуха, зрения, а также других физических недостатков[3];

г) подозреваемому, обвиняемому или подсудимому, которому трудно самостоятельно осуществлять принадлежащее ему право на защиту вследствие существенного нарушения функций речи, слуха, зрения, продолжительной тяжелой болезни, а также других физических недостатков[4]; 
д) по делам немых, глухих, слепых и других лиц, которые в силу своих физических недостатков не могут самостоятельно осуществлять свое право на защиту[5];

е) по делам о преступлениях лиц, которые вследствие своих физических или психических недостатков (немые, глухие, слепые и т.п.) не могут сами реализовать свое право на защиту, — с момента задержания лица или предъявления ему обвинения либо с момента установления этих недостатков (ч.2 ст. 45 УПК Украины);

ж) подозреваемый или обвиняемый в силу физических или психических недостатков не могут самостоятельно осуществлять свое право на защиту (п. 4 ст. 45 УПК Белоруссии).

В российском же законодательстве факт обязательного назначения защитника также присутствует, но в общей формулировке Именно участие защитника обязательно в уголовно-процессуальном производстве, если подозреваемый, обвиняемый в силу физических недостатков не может самостоятельно осуществлять свое право на защиту[6]. По нашему мнению российская формулировка обязательного участия защитника является самой несовершенной по сравнению с рассмотренными выше уголовно-процессуальными законодательствами.

2. В качестве свидетелей не могут быть вызваны лица, которые в силу физических недостатков не могут правильно воспринимать и излагать подлежащие расследованию обстоятельства[7].

В российском же уголовно-процессуальном законодательстве о состоянии здоровья лиц, участвующих в уголовном процессе в качестве свидетелей вообще ничего не сказано[8], что является отрицательным моментом в вопросе защиты прав и законных интересов участников уголовного судопроизводства, имеющих физические недостатки.

3. Под переводчиком понимается:

а) лицо, понимающее знаки общения немых и глухих и способное общаться с ними с помощью таких знаков[9];

б) лицо, свободно владеющее языками, знание которых необходимо для перевода, или необходимыми навыками для интерпретации знаков глухонемых, а также юридической терминологией, не заинтересованное в уголовном деле и давшее согласие на участие в судопроизводстве в этом качестве[10];

в) лицо, не заинтересованное в уголовном деле, владеющее языком, а также понимающее знаки глухого или немого, знание которых необходимо для перевода, и привлеченное для участия в следственных и судебных действиях в случаях, когда подозреваемый, обвиняемый, подсудимый, их защитники либо потерпевший, гражданский истец, гражданский ответчик или их представители, а также свидетели и иные участники процесса не владеют языком, на котором ведется производство по делу, а равно для перевода письменных документов[11];

г) переводчиком является не заинтересованное в исходе уголовного дела лицо, владеющее языками, знание которых необходимо для перевода, и участвующее в следственных и других процессуальных действиях в случаях, когда подозреваемый, обвиняемый, их защитники либо потерпевший, гражданский истец, гражданский ответчик или их представители, а также свидетели и иные участники уголовного процесса не владеют языком, на котором ведется производство по уголовному делу, а равно для перевода письменных документов. Переводчиком в соответствии с настоящим Кодексом считается также лицо, понимающее знаки глухого или немого и способное изъясняться с ними знаками (ч.1 ст. 63 УПК Белоруссии).

В УПК РФ под переводчиком понимается лицо, привлекаемое к участию в уголовном судопроизводстве свободно владеющее языком, знание которого необходимо для перевода. Данное определение по сравнению с рассмотренными выше уголовно-процессуальными законодательствами является совершенно не доработанным с точки зрения вопроса защиты прав и законных интересов участников уголовного судопроизводства, имеющих физические недостатки.

4) Следователь или прокурор, осуществляющий процессуальное руководство предварительным расследованием может прекратить применение избранной меры пресечения в виде ареста только при наличии медицинского заключения о невозможности содержания обвиняемого под стражей в связи с тяжелой болезнью[12].

В УПК РФ имеется статья 108 «Заключение по стражу», в которой о прекращении применения меры пресечения в виде заключения под стражу (ареста) ничего не сказано. При изучении обстоятельств, учитываемых при избрании меры пресечения[13] мы видим, что состояние здоровья присутствует в общем списке данных обстоятельств, но как именно оно влияет на избрание меры пресечения не ясно. Либо применение меры пресечения смягчается, либо вообще прекращается. Это в российском уголовно-процессуальном законодательстве по нашему мнению не продумано.

5) Домашний арест не применяется к лицам, старше 60 лет, инвалидам 1 группы[14]. Однако, в ст. 107 УПК РФ «Домашний арест» состояние здоровья подозреваемого, обвиняемого не учитывается.

6) Допрос немого, глухого или слепого свидетеля производится с участием лица, понимающего его знаки или разговаривающего с ним посредством знаков. Участие такого лица в допросе отмечается в протоколе допроса. Допрос свидетеля, страдающего тяжким заболеванием, производится по разрешению и с участием врача. При допросе немого, глухого, слепого или страдающего иной тяжкой болезнью свидетеля может присутствовать его законный представитель или представитель[15].

Подобная статья в российском уголовно-процессуальном законодательстве вообще отсутствует, что в очередной раз позволяет выделить УПК Азербайджанской Республики с положительной стороны, а УПК РФ в изучении данного вопроса оставить несовершенным.

Глухонемые свидетели допрашиваются при участии переводчика, который знает их знаки и умеет посредством их общаться. Участие такого переводчика отмечается в протоколе. В случае если свидетель страдает другим тяжелым заболеванием, его допрос осуществляется с согласия врача и в его присутствии[16]. 
Допрос немого или глухого свидетеля, потерпевшего, подозреваемого, обвиняемого осуществляется с участием лица, которое понимает его знаки и умеет изъясняться с ним знаками. Участие этого лица в допросе отражается в протоколе. При наличии у допрашиваемого иного тяжкого заболевания его допрос осуществляется с разрешения врача и в его присутствии [17].

В УПК РФ медицинские показания влияют лишь на продолжительность допроса[18].

7) Председательствующий в судебном заседании устанавливает личность подсудимого, а именно сведения об инвалидности в том числе[19].

В УПК РФ председательствующий устанавливает личность подсудимого, выясняя его фамилию, имя, отчество, месяц, дата и место рождения, выясняет, владеет ли он языком, на котором ведется уголовное судопроизводство, место жительства подсудимого, место работы, род занятий, образование, семейное положение и другие данные, касающиеся его личности[20]. Стоит лишь самим догадываться входит ли в «другие данные» состояние здоровья подсудимого.

8) освобождение от отбывания наказания в силу болезни[21].

В российском уголовно-процессуальном законодательстве подобной статьи вообще не имеется. В таком случае можно сделать вывод, что в местах лишения свободы России находились, находятся и будут находиться лица, страдающие физическими недостатками, тяжелой болезнью, инвалиды на тех же правах, что и лица, не имеющие физических недостатков, что является крайне несправедливым к первым участникам уголовного судопроизводства.

Несмотря на все вышеизложенное, все же хотелось бы отметить и положительные сторону российского уголовно-процессуального законодательства, не имеющей места в других законодательствах - п. 2 ч. 2 ст. 281 УПК РФ: при неявке в судебное заседание потерпевшего или свидетеля суд вправе по ходатайству стороны или по собственной инициативе принять решение об оглашении ранее данных ими показаний в случае болезни, препятствующей явке в суд.

Хотелось бы также отметить несовершенство всех рассмотренных выше законодательств, в том числе и российского в изучении вопроса предъявления для опознания лиц и предметов, поскольку ни в одном из законодательств не расписана процедура предъявления для опознания лицам, страдающим таким физическим недостатком, как слепота.

Многим известно, что лица, имеющие данный физический недостаток воспринимают окружающий мир тактильным способом, то есть «видят при помощи рук», также известно, что при отсутствии одного из органов чувств обостряются остальные чувства, предназначенные для восприятия окружающей среды. Так почему же не создать процедуру опознания лица слепым человеком?!

В таком случае необходимо будет документально установить лицо, которое будет гарантировать качество опознания слепым лицом (например, врач специализированной клиники, имеющий достаточный опыт работы со слепыми людьми). До официального предъявления для опознания необходимо провести несколько экспериментов, позволяющих убедиться в достоверности и качестве опознания слепым лицом. Тоже касается и предъявления для опознания предмета.

Таким образом, если бы в нашем законодательстве имелась статья подобного рода, то раскрываемость преступлений, совершаемых в отношении лиц, имеющих физические недостатки значительно бы возросла.

На основании вышеизложенного, мы можем сделать вывод, что российское уголовно-процессуальное законодательство по сравнению с уголовно-процессуальными законодательствами рассмотренных нами выше стран является самым несовершенным в изучении вопроса защиты прав и законных интересов лиц - участников уголовного судопроизводства, имеющих физические недостатки.

\section{Литература}

1. п.2 ч. 3 ст. 92 Уголовно-процессуального кодекса Азербайджанской Республики.

2. ч. 2 ст. 51 Уголовно-процессуального кодекса Республики Узбекистан.

3. ч. 2 ст. 69 Уголовно-процессуального кодекса Республики Молдова.

4. ч. 2 ст. 46 Уголовно-процессуального кодекса Кыргызской Республики.

5. п. 3 ч. 1 ст. 82 Уголовно-процессуального кодекса Туркменистана.

6. п.3 ч.1 ст. 51 Уголовно-процессуального кодекса Российской Федерации.

7. п. 1 ч. 2 ст. 95 Уголовно-процессуального кодекса Азербайджанской Республики, п.4 ч. 2 ст. 82 Уголовно-процессуального кодекса Республики Казахстан, п. 2 ч. 2 ст. 60 Уголовно-процессуального кодекса Белоруссии.

8. ст. 56 Уголовно-процессуального кодекса Российской Федерации.

9. ч.3 ст.99 Уголовно-процессуального кодекса Азербайджанской Республики.

10. ч.1 ст. 85 Уголовно-процессуального кодекса Республики Молдова.

11. ч. 1 ст. 66 Уголовно-процессуального кодекса Кыргызской Республики.

12. п. 1 ч. 8 ст. 157 Уголовно-процессуального кодекса Азербайджанской Республики.

13. ст. 99 Уголовно-процессуального кодекса Российской Федерации.

14. ст. 188 Уголовно-процессуального кодекса Республики Молдова.

15. ст. 229 Уголовно-процессуального кодекса Азербайджанской Республики.

16. ч. 4,5 Уголовно-процессуального кодекса Республики Молдова, ч. 7,8 ст. 213 Уголовно-процессуального кодекса Республики Казахстан.

17. ч.7,9 Уголовно-процессуального кодекса Туркменистана.

18. ч. 4 ст. 187 Уголовно-процессуального кодекса Российской Федерации.

19. ст. 358 Уголовно-процессуального кодекса Республики Молдова. 
20. ст. 265 Уголовно-процессуального кодекса Российской Федерации.

21. ст. 511 Уголовно-процессуального кодекса Азербайджанской Республики, ст. 534 Уголовно-процессуального кодекса Республики Узбекистан.

\title{
Некоторые правовые вопросы по обеспечению психологической помощи в уголовно-исправительной системе Монголии
}

\author{
(C) Хойд Баатар Мунхбаатар \\ преподаватель кафедры сочиальной работь \\ Института исполнения судебных решений \\ Университета правоохранительной службы Монголии, \\ Монголия, г. Улан-Батор \\ munkhbaatar.b@leu.gov.mn; baatarmunkhbaatar@gmail.com
}

Исправление лиц, совершивших преступления, неотъемлемая часть существования любого современного правового государства. Перед исправительными учреждениями стран стоят чрезвычайно сложные задачи по перевоспитанию лиц, совершивших преступления, приобщению их к трудовой деятельности и адаптации к дальнейшей нормальной жизни в обществе. Важно понимать, что исправление человека, переступившего грань дозволенного законом и пошедшего на преступление, очень трудоемкий и длительный процесс с трудно прогнозируемым исходом. Для его успешной реализации необходим целый спектр внешних и внутренних факторов и условии, которые, соединившись, воздействуют на заключенных, помогая сформировать у него установки на правопослушный тип поведения в социальной среде. При этом самым важным фактором является наличие заинтересованности у государства и общества, в первую очередь именно в исправлении лиц, совершивших преступление, а не только в их строгой изоляции от общества.

Современная уголовно-исполнительная политика в Монголии направлена на смягчение кары и усиление воспитательных мер воздействия на осужденных, создание гуманной среды отбывания наказания.

Социально-психологическая служба [1], как и другие подразделения, функционирует в четких рамках правового поля, и деятельность пенитенциарного психолога связана с правами человека, его интересами и конфиденциальности информации. Введение должности специалистов-психологов[2] рекомендовано Минимальными стандартными правилами обращения с заключенными, принятыми на первом Конгрессе ООН по предупреждению преступности и обращению с правонарушителями.

Миссия или предназначение пенитенциарного психолога в Уголовно исполнительной системе (далее УИС) Монголии состоит в повышении эффективности исправительного воздействия на осужденных, в оказании им психологической [3] помощи и оптимизации отношений между персоналом и осужденными, цель службы - обеспечить максимально полное использование достижений психологической науки и практики для повышения эффективности процесса исполнения уголовных наказаний. Главная задача и деятельность пенитенциарных психологов данной службы - это исследования психологичесих особенностей, оказать психологическую помощь нуждающимся, осуществлять психологическую коррекцию, развитие личности и повышение эффективности исправительного воздействия на осужденных[4].

Хотя по статистическим данным последних 10 лет около 51-54\% из освобождаемых из мест лишения свободы вновь совершают преступления. Около 85\% от общего числа заключённых в колониях строгого и высшего режима содержания это лица, ранее 1-8 раз отбывавшие наказание в тюрьмах и колониях[5].

Основываясь на статистических данных и результатах научных работ, можно сказать, что в нашей стране не снижаются преступления, правонарушения не только по количеству, но и возрастает уровень их общественной опасности, нанесённый ими вред и ущерб. То есть, почти каждое второе преступление совершается лицом, имеющим криминальный опыт и стойкую установку на противоправное поведение[6]. Это свидетельствует о том, что пенитенциарная система не справляется со своими основными задачами, в частности воспитательной[7] (то есть исправление осужденных) и профилактической (недопущение повторных преступлений).

Хотя в совместном приказе министра юстиции и внутренных дел и министра социальной защиты и труда “Об установлении примерных стандартов” от 20 августа 2008 года №205/94 установлено дифференцированное количество психологов в зависимости от вида и режима учреждений[8], на практике из-за многих факторов не всегда соблюдаются установленные правила, и соответствующие лица работают с большой нагрузкой.

На результаты психокоррекционных работ в учреждениях негативное влияние оказывают такие факторы, как неконструктивность организационной структуры учреждений, неэффективное распределение функциональных обязанностей между сотрудниками, неправильное определение показателей оценки результатов работы[9] и правовые пробелы противоречащиеся с друг другом.

Кроме того, необходимы также современная инфраструктура пенитенциарных учреждений, высоко квалифицированный персонал[10] и еще ряд условий, выполнение которых позволит вернуть человека в гражданское общество, избавив его от криминогенности. Однако, необходимо осознать тот факт, что преступник - это, как правило, личность с уже устоявшимися делинквентными поведенческими паттернами, и подход к нему необходим особый. 
Поэтому, основываясь на вышесказанных и других данных, хотелось бы сделать частичный вывод о том, что можно попытаться рассмотреть возможные пути развития уголовно-исполнительной системы, а также реальность внедрения тех или иных инноваций, заимствованных у более успешных в решении данных задач стран как Россия, Германия, США, Великобритания и т.д. Кроме того, имеет практическое значение изучение опыта работы с заключенными в зарубежных странах, поскольку западными пенитенциарными психологами разрабатываются и активно используются современные методы психодиагностики и психокоррекции для заключенных.

Для Монголии зарубежный опыт социальной и психологической работы с заключенными чрезвычайно интересен и актуален. Хотя правовая среда и практика в нашей стране формируется в увязкой с тенденциями международного развития, но для повышения ее эффективности необходимо улучшить тесную взаимосвязь исследовательской, законодательной и правореализирующей деятельностей, а также подготовку и переподготовку специалистов-психологов.

\title{
Литература
}

1. Приказ министра юстиции внутренных дел Монголии от 20 февраля 2013 года № Б/224.

2. Приказ начальника ГУИСР Монголии “Об утверждении инструкции работы психолога учреждения” от 10 ноября 2010 года №A/106.

3. Психологические аспекты уголовно-исполнительной системы изучаются в рамках пенитенциарной психологии. Пенитенциарная психология является одним из разделов юридической психологии, который исследует проблемы эффективности наказания, динамику личности осужденного в процессе исполнения наказания, формирование ее поведенческих особенностей в различных условиях режима, особенности ценностных ориентации и стереотипов поведения малой группы в условиях социальной изоляции, соответствие текущего исправительного законодательства задачам исправления и перевоспитания осужденных.

4. Приказ начальника ГУИСР Монголии “Об утверждении инструкции работы психолога учреждения” от 10 ноября 2010 года №A/106.

5. Отчёт Главного управления исполнения судебных решений Монголии 2014 года // Материалы совещания руководящих работников ГУИСР от 05 по 06 марта 2015 года.

6. ч.7, ст.52 Уголовгого кодекса Монголии.

7. Уголовном Кодексе Монголии, утвержденный 3-го декабря 2015 года Великим Государственным Хуралом (вступит в силу с 1-го сентября 2016 года).

8. Так, в централизованных учрежденияхна одного психолога 100-150осужденных. В тюрьме должны работать по одному психологу и на одного педагога приходится 50-75 осужденных. В центральном следственном изоляторе один психолог должен работать с 100-150 подозреваемым.

9. Социальные работники, психологи подчиняются заместителю начальника учреждения по оперативной работе и охране, поэтому они часто привлекаются к работе, не входщей в их функцианольной обянанности.

10. Около $70 \%$ психологов имеют другие профессии (педогог, социальный работник, юрист и.т.д)и среди них происходит большое кадровое перемещение.

\section{Полномочия прокурора в досудебном производстве по уголовно-процессуальному законодательству России и Вьетнама}

\author{
(C) Е. Н. Петрова \\ студентка 3-го курса юридического факультета \\ ФГБОУ ВО «Бурятский госуниверситет» \\ Россия, г. Улан-Удэ \\ Pedros_946@mail.ru
}

Во всех государствах современности в качестве основной государственной задачи выступает защита граждан, общества и государства от такого негативного социального явления как преступность. На современном этапе в Российской Федерации (далее - РФ) и Социалистической Республике Вьетнам (далее - СРВ) охрана общественного порядка и безопасности, а также защита личности от преступных посягательств осуществляется не только органами предварительного расследования, но и органами прокуратуры, а также и другими правоохранительными органами.

Вся ценность деятельности прокуратуры признается и на международном уровне. Вместе с тем, в Рекомендации Парламентской ассамблеи Совета Европы № 1604 (2003) от 27 мая 2003 г. «О роли прокуратуры в демократическом правовом обществе» высоко оценивается «роль прокуратуры в обеспечении безопасности и свободы в европейских обществах: путем обеспечения верховенства права, защиты от преступных посягательств прав и свобод, обеспечения уважения к правам и свободам подозреваемых и обвиняемых в совершении уголовных преступлений, а также путем наблюдения за надлежащим функционированием органов, отвечающих за расследование и преследование преступлений»[7].

Для наиболее эффективного осуществления своих полномочий по охране прав и свобод граждан, органам прокуратуры должны быть предоставлены соответствующие полномочия, благодаря которым смогли бы своевременно и качественно, что не мало важно, осуществлять меры реагирования на нарушения норм законодательства. 
В уголовно-процессуальное законодательство России и Вьетнама определен статус участников уголовного судопроизводства, в том числе и статус прокурора, который уполномочен осуществлять надзор за законностью и обоснованностью деятельности органов на стадиях досудебного разбирательства в целях эффективной защиты конституционных прав и законных интересов лиц, потерпевших от преступлений, а также ради недопущения привлечения к ответственности невиновных лиц.

В Конституции РФ ст. 129 [1], посвященная прокуратуре Российской Федерации, которая появилась относительно недавно, однако там не закреплено какими именно полномочиями обладают должностные лица рассматриваемой структуры. Полномочия прокуратуры закреплены в Федеральном законе от 17. 01. 1992 № 2202-1 "О прокуратуре РФ"[3], а также в Уголовно-процессуальном кодекс РФ [2].

Согласно ч. 1 ст. 37 УПК РФ, прокурор - должностное лицо, уполномоченное в пределах компетенции, предусмотренной УПК РФ, осуществлять от имени государства уголовное преследование в ходе уголовного судопроизводства, а также надзор за процессуальной деятельностью органов дознания и органов предварительного следствия [2].

Итак, прокурор, являясь участником уголовного судопроизводства со стороны обвинения, осуществляет надзор за ходом предварительного расследования, но одновременно не имеет права при нарушении уголовного и уголовно-процессуального законодательства возбуждать уголовное дело, в том числе и прекращать его производство.

Отметим, что уголовное преследование в соответствии с п. 55 ст. 5 осуществляет сторона обвинения, однако стороной обвинения согласно гл. 6 УПК РФ, в первую очередь, является прокурор. Ст. 37 УПК РФ, регламентирующая права и обязанности прокурора, дает ему право в полном объеме осуществлять уголовное преследование, однако другими нормами УПК отмечается, что он, наоборот, не имеет права осуществлять уголовное преследование за рамками надзорной функции. В итоге, прокурор решает судьбу обвинения, утверждая обвинительное заключение или обвинительный акт, а также при направлении уголовного дела в суд [2].

Правомочия прокурора в ходе предварительного следствия были ограничены в связи с предоставлением возможности реализовать процессуальную самостоятельность следователя. Отметим, что подобного рода ограничение не дало должного результата поскольку, постольку все полномочия, которые осуществлял прокурор, стал осуществлять руководитель следственного органа.

Таким образом, рассматриваемую проблему изучают многие ученые - процессуалисты. Например, Кругликов А. П. указывает на необходимость возврата процессуальных полномочий прокурору в части осуществления уголовного преследования[5, с. 15].

Отметим, что в уголовно-процессуальном законе Российской Федерации содержатся и другие противоречия, которые фактически дают полномочия следователю и руководителю следственного органа осуществлять практически надзорные полномочия за процессуальной деятельностью прокурора, а также за законностью и обоснованностью решений, которые он, в свою очередь, принимает, позволяющие следователю и руководителю следственного органа играть по сути основную роль в уголовном преследовании.

Согласно, например, ч. 6 ст. 37 УПК, которая предусматривает положение, которое заключается в том, что прокурор, в случае получения отказа руководителя следственного органа либо следователя по поводу требования об устранении нарушения федерального законодательства, имеет право обращения к руководителю вышестоящего следственного органа с требованием устранения нарушений. Одновременно, если руководитель вышестоящего следственного органа не согласен с требованиями прокурора, последний вправе обратиться к председателю Следственного комитета РФ или руководителю следственного органа исполнительной власти (при федеральном органе исполнительной власти). И только после этого прокурор имеет право обратиться к Генеральному прокурору РФ, решение которого является окончательным. Таким образом, законность и обоснованность требований прокурора об устранении нарушений федерального законодательства «проверяют», как бы это не противоречило, соответствующие руководители следственных органов, и даже следователь.

Согласно уголовно-процессуальному законодательству Социалистической Республики Вьетнам прокурор, также как и в Российской Федерации, в досудебных стадиях осуществляет уголовное преследование, а также надзор за соблюдением законодательства следственными органами, при этом обеспечивая полноту, и мало того объективность предварительного расследования. В обязанности прокурора входит своевременность выявления нарушений нормативно-правовых актов в ходе следствия и принимать меры для их устранения, обеспечивать своевременность возбуждения уголовного дела, а также расследования преступления в отношении тех лиц, которые их совершили, верно применять уголовный закон, не допуская необоснованного привлечения к уголовной ответственности невиновных лиц.

Согласно УПК Социалистической Республики Вьетнам, прокурор осуществляет надзор за возбуждением и расследованием уголовных дел в целях пресечения возможных нарушений закона и необоснованного привлечения к уголовной ответственности, а также обеспечения своевременное расследование и разрешение уголовных дел [4].

Д.Т. Нгуен считает, что в уголовном процессе Вьетнама нечетко определена форма, в которой осуществляется предварительное расследование, органы предварительного расследования и органы дознания действуют в соответствии с принципом единоначатия. Одновременно, по его мнению, существенным недостатком выступает также и отсутствие четко-определенной грани между оперативно-розыскными и процессуальными действиями[6, с. 40]. 
В связи с этим, возрастает значение прокурорского надзора за оперативно-розыскной деятельностью, которая обеспечивает эффективность предварительного расследования и решение следующих задач: раскрытие преступлений, а также изобличение виновных в их совершении.

Помимо всего прочего, прокурор ограничен в праве заниматься расследованием, а лишь только имеет право давать письменное указания по данному случаю, но законом не предусмотрены меры ответственности следователя в случае невыполнения этих указаний. Иногда это приводит к тому, что следователи не выполняют указаний прокурора в полном объёме, а уголовное дело, в свою очередь, несколько раз возвращается для производства дополнительного расследования, тем самым затягиваются сроки расследования. Считаем, что прокурор должен иметь полномочия не только в сфере дачи указаний письменных следователю о направлении расследования, производстве процессуальных действий, но также непосредственно иметь право возбуждать уголовное дело, а также осуществлять расследование, благодаря чему и возрастет эффективность надзора, путем своевременного устранения нарушений законодательства следователем и другими участниками уголовного судопроизводства. Вместе с тем, прокурор может иметь право возбуждения уголовного дела, в случаях невыполнения органами предварительного расследования его указания.

Согласно Уголовно-процессуальному кодексу СРВ прокурор ограничен правом отстранения следователя от производства уголовного дела, даже если последний нарушил требования закона. В связи с эти некоторые ученые предлагают дополнить ст. 36 уголовно-процессуального закона Вьетнама нормой, которая бы наделила прокурора полномочиями по отстранению работника следственного органа от дальнейшего разбирательства по уголовному делу, при условии, что следователь допустил за собой нарушение законодательства [4].

Проанализировав уголовно-процессуальное законодательство Российской Федерации и Социалистической Республики Вьетнам, можно сделать вывод о том, что законодательство рассматриваемых государств, в части полномочий прокурора требует реформирования. Отметим, что в рассматриваемых государствах отсутствие полномочия прокурора возбуждать уголовное дело ограничивает его право на осуществление, его полномочия, которое дано федеральным законодательством.

\title{
Литература
}

1. Конституция Российской Федерации от 12 декабря 1993 [Электронный ресурс] / Консультант Плюс. Режим доступа : http://base.consultant.ru/cons/cgi/online.cgin177236 (дата обращения: 08 апреля 2016).

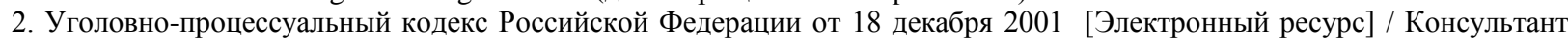
Плюс. Режим доступа : http://base.consultant.ru/cons/cgi/online.cgin177263 (дата обращения: 08 апреля 2016).

3. Федеральный закон от 17 января 1992 №2202-1-Ф3 "О прокуратуре РФ" [Электронный ресурс] / Консультант Плюс. Режим доступа : https://www.consultant.ru/document/cons_doc_LAW_262/ (дата обращения: 08 апреля 2016).

4. Уголовно-процессуальный кодекс Социалистической Республики Вьетнам 2003 [Электронный ресурс]. Режим доступа: http://vietnamnews.ru/economy_2 (дата обращения: 08 апреля 2016).

5. Кругликов А.П. Полномочия прокурора по возбуждению уголовного дела и осуществлению уголовного преследования // Законность. 2012. № 1.

6. Нгуен Д. Т. О необходимости изменений в организации деятельности следственных органов Вьетнаме // Государство и право. Ханой. 1999. № 2. С. 40.

7. Рекомендации Парламентской ассамблеи Совета Европы № 1604 (2003) от 27 мая 2003 г. «О роли прокуратуры в демократическом правовом обществе» [Электронный pecypc]. URL: http://www.coe.int/T/r/Parliamentary_Assembly/ 5BRussian_documents5D/5B20035D/Rec1604.asp (дата обращения: 10 апреля 2016).

\section{Сравнительный анализ правового статуса показаний подсудимого в уголовно-процессуальном законодательстве США и РФ}

\author{
(C) A. B. Помmanoвa \\ студентка 2-го курса юридического факультета \\ ФГБОУ ВО «Бурятский госуниверситет» \\ Россия, г. Улан-Удэ \\ alinapot@yandex.ru
}

Конституция Соединенных Штатов не регламентирует структуру судебной власти, а только содержит нормы, определяющие создание Верховного суда. При условии одобрения сената, президент назначает судей, которые занимают свои посты пожизненно, если демонстрируют «безупречную службу». Остальные суды учреждаются Конгрессом[6].

Основой американского гражданского общества является свобода, что обуславливает важную роль органов суда во всех областях взаимоотношений граждан, а также отношений государства и гражданина. На протяжении всей истории США, компетенция судов была практически неограниченной. Это позволяло судам принимать иски и разрешать споры в самых различных сферах общественной жизни - гражданской, экономической и других. Соединенные Штаты часто именуют «государством судей», поскольку в стране действует самое большое количество судей и судебных адвокатов. А очень сложная судебная система хорошо развита и имеет высокий уровень демократических процессуальных гарантий.

Принятые судебные решения безоговорочно исполняются государственными органами и гражданами, что объясняет высокий авторитет судов. Неукоснительное исполнение судебных решений проводится также и по 
вопросам признания Верховным судом отдельных административных актов и законов не соответствующими нормам Конституции, в результате чего они подлежат немедленному исключению из действующего права. Любое решение Верховного суда, вступившее в законную силу, имеет общеобязательный характер, хотя необходимо отметить, что повышается значимость статутного права, то есть норм, непосредственно определенных законодательством, по сравнению с действующими судебными прецедентами. Отметим, что суды, в то же время, не уполномочены вмешиваться в сферу компетенции исполнительной и законодательной власти.

Особенность судебной власти определяется набором методов (процедур) своего осуществления, что и обуславливает ее справедливость. Перед окончательным вынесением приговора производится доскональный разбор требований и прав каждой из сторон процесса. То есть, судебная власть стоится на принципах независимости, гласности, коллегиальности и состязательности.

И в России, и в США вопрос о правовой силе признательных показаний обвиняемого, (подозреваемого), актуальности не утратил даже сегодня. С одной стороны, в связи с постановлением Верховного суда США, (далее по тексту ВС США), «добровольная дача показаний и признание вины считается наилучшим доказательством». Однако с иной стороны, судебные органы США осознали достаточно давно недостоверность указанных показаний. К примеру, в решении Апелляционного суда второго федерального округа США прямо указывается, что «показания о признании вины по многим причинам часто оказываются недостоверными, к примеру, как невроз, принуждение, самореклама, заблуждение либо защита иного лица». ВС США, в решении по делу Эскобедо, отмечает: «Примеры из новейшей и древней истории показывают, что система принудительного исполнения закона, которая основывается на признательных показаниях, становится со временем все менее надежной, а также более подвергается злоупотреблениям, чем система, которая основывается на независимых, полученных при расследовании, доказательствах».

Эти противоречия между потенциальной недостоверностью признательных показаний и доказательной силой, ставят задачу перед системой правосудия любого государства по выработке набора правил, которые обеспечат нужную юридическую силу подлинным показаниям, которые получены без определенного злоупотребления, либо принуждения со стороны органов правоохраны. Сравнительный анализ путей решения указанной проблемы в России и в США помогает выявить слабые и сильные стороны правовых систем 2 стран, а также реализует возможность подготовить рекомендации по дальнейшему развитию указанных правовых систем.

Вместе с тем, правило об исключении доказательств показаний, которые даны обвиняемым либо подозреваемым на этапе досудебного расследования, в России и США применяется по-разному.

Российское уголовно-процессуальное законодательство смогло избежать данных проблем, прямо запретив использовать в суде в качестве допустимых доказательств показания обвиняемого, (подозреваемого), которые даны в отсутствие защитника в ходе предварительного следствия. В связи с п. 1 ч. 2 ст. 75 УПК РФ, к недопустимым доказательствам относятся «показания обвиняемого, подозреваемого, которые даны в ходе досудебного производства по уголовному делу в отсутствии защитника, вместе со случаями отказа от защитника, и не подтвержденные в суде обвиняемым, подозреваемым» [1]. Если учесть, что допустимо принятие признательных показаний исключительно в присутствии защитника, УПК РФ устанавливает правило, которое позволяет сэкономить средства, расходуемые судами США с целью установить, действительно ли признательные показания и/или отказ от услуг адвоката были «осознанными, информированными и добровольными». Еще более важным является факт, что УПК РФ имеет в своем распоряжении более эффективный механизм сдерживания принуждения как способа получения признательных показаний. Норма американского права, оставляя открытой возможность признания допустимости признательных показаний, которые получены в отсутствие защитника, поощряет следователей добиваться признания вины именно данным способом, тогда как российская правовая норма не дает указанной возможности, и, следовательно, не создает этого стимула. Органам правосудия в США было бы полезно ввести аналогичное правило в свою практику.

Также, стоит отметить, что в уголовно-процессуальном законодательстве США и России существует очевидное различие в трактовке влияния на судебный процесс осуществленного подсудимым права хранить молчание.

Ради защиты прав человека, закон США четко устанавливает, что не может считаться доказательством вины отказ подсудимого от дачи показаний, связанный с тем, что подсудимый имеет право не свидетельствовать против себя.

В уголовно-процессуальном законодательстве Российской Федерации и Соединенных Штатов прослеживается аналогия в предусмотренных методах защиты от принуждения к показаниям, однако следует отметить некоторые различия в части установленной процедуры допроса.

Во-первых, различаются обстоятельства, когда суд разрешает оглашать показания подсудимого, данные в ходе судебного расследования.

Нормы части 1 статьи 276 УПК РФ регламентируют условия оглашения показаний подсудимого, данных в ходе предварительного расследования. Если соблюдены все иные критерии допустимости доказательств, то они могут быть оглашены в суде в следующий случаях:

- при наличии существенных противоречий между показаниями, данными подсудимым в ходе предварительного расследования, и данными затем в суде;

- при рассмотрении уголовного дела в отсутствие подсудимого, или же, при отказе подсудимым от дачи показаний [2]. 
Следовательно, если показания подсудимого в ходе судебного разбирательства в значительной степени повторяют данные им показания при проведении предварительного расследования, то государственный обвинитель не в праве ходатайствовать перед судом об оглашении в суде протокола допроса подсудимого.

В США же подобных ограничений нет- если ранее данные подсудимым показания удовлетворяют критериям допустимости, то государственный обвинитель имеет право огласить их в суде, даже если данные показания абсолютно идентичны показаниям, данным в суде.

Ст. 307 Уголовного кодекса РФ указывает наказание за заведомо ложные показания иных участников уголовного процесса (свидетеля, специалиста, эксперта и потерпевшего), и ответственность за неправильный перевод переводчика. Нет определенных оснований для исключения из правила по отношению к заведомо ложным показаниям подсудимого. Значит, в свете наказания, которое предусмотрено уголовным законом для всех других участников процесса, отсутствие конкретного наказания за дачу ложных показаний для подсудимого противоречит состязательности судебного процесса и принципам равноправия сторон, а также несправедливо дает преимущества подсудимому перед иными участниками [3].

В качестве допустимого доказательства не могут рассматриваться никакие показания обвиняемого, полученные без присутствия защитника (даже если обвиняемый сам отказался от его услуг), если обвиняемый отказывается их подтвердить. Многими судебными работниками подобный закон был встречен с большим неодобрением.

Вместе с тем, механизмы защиты, позволяющие подозреваемому, (подсудимому), не свидетельствовать против себя, никоим образом не препятствуют введению уголовной ответственности подсудимого за дачу ложных показаний. К примеру, ВС США отмечал неоднократно, что введение уголовной ответственности подсудимого за дачу ложных показаний поставит указанного перед «жесткой трилеммой» - хранить молчание, признать свою вину либо отрицать с помощью ложных.

При проведении сравнительного анализа, безусловно, стоит отметить, что судебная система таких великих держав, как Российская Федерация и Соединенные Штаты Америки, не могут не содержать общих черт, ведь зачастую исторические события сталкивали их пути- как в позитивных, так и в негативных ситуациях. Судебный процесс обеих держав, несомненно, стремиться к честности и установлению истины, прибегая иной раз к схожим методам. Однако, и различий в судебном процессе США И РФ немало. Наглядно представлены различия судебного процесса в таблице 1.

Российская Федерация Соединенные Штаты Америки

Конституционный Суд - 19 судей: споры о компетенции между государственными органами, соответствие законов Конституции.

Верховный Суд - уголовные, гражданские, административные дела, подсудные судам общей юрисдикции.

Высший Арбитражный Суд - экономические споры Верховный суд, суды штатов

Верховный суд имеет прямую юрисдикцию в процессах, где какой-то из сторон выступает штат в целом, либо высшее должностное лицо. В остальных ситуациях прямую юрисдикцию осуществляют суды другого уровня, Верховный суд рассматривает апелляции.

Решения выносит жюри присяжных.

\section{Литература}

1. Уголовно-процессуальный кодекс Российской Федерации от 18.12.2001 № 174-Ф3 (ред. от 02.03.2016) Ст. 75. Недопустимые доказательства [Электронный ресурс]. URL: http://base.consultant.ru/cons/cgi/online.cgin177263 (дата обращения: 29 марта 2016).

2. Уголовно-процессуальный кодекс Российской Федерации от 18.12.2001 № 174-Ф3 (ред. от 02.03.2016) Ст. 276 (п.1). Оглашение показаний подсудимого [Электронный ресурс]. URL: http://base.consultant.ru/cons/cgi/online.cgin177263 (дата обращения: 29 марта 2016).

3. Уголовный кодекс Российской Федерации от 13.06.1996 № 63-Ф3 (ред. от 30.12.2015) Ст. 307. Заведомо ложные показание, заключение эксперта, специалиста или неправильный перевод // Собрание законодательства Российской Федерации. 1996. 17 июня. Ст. 2954.

4. Уголовно-процессуальный кодекс Российской Федерации от 18.12.2001 № 174-Ф3 (ред. от 02.03.2016) Ст. 273. Начало судебного следствия [Электронный ресурс]. URL: http://base.consultant.ru/cons/cgi/online.cgin177263 (дата обращения: 29 марта 2016).

5. Уголовно-процессуальный кодекс Российской Федерации от 18.12.2001 № 174-Ф3 (ред. от 02.03.2016) Статья 77. Показания обвиняемого [Электронный ресурс]. URL: http://base.consultant.ru/cons/cgi/online.cgin177263 (дата обращения: 29 марта 2016).

6. Конституционное право зарубежных стран: учебник для вузов / под общ. ред. М. В. Баглая, Ю. И. Лейбо, Л. М. Энтина. 2-е изд., перераб. М.: НОРМА, 2005. 1056 с.

7. Баглай М. В. Конституционное право РФ. 6-е изд., изм. и доп. М.: НОРМА, 2007. 784 с. 


\title{
Процессуальные особенности производства по уголовным делам о преступлениях несовершеннолетних в РФ и КНР: сравнительно-правовой анализ
}

\author{
(C) А. В. Раздрогин \\ аспирант 2 года обучения \\ ФГБОУ ВО «Удмуртский госуниверситет» \\ Россия, г. Ижевск \\ industrialsledstvie@mail.ru
}

Психофизиологические особенности развития и формирования лиц, не достигших совершеннолетия, обусловливают особенности их правового положения, диктуют необходимость регламентировать особые правила и процедуры обращения с несовершеннолетними правонарушителями во всех стадиях уголовного процесса [4, c.1].

Производство по делам в отношении несовершеннолетних в Российской Федерации характеризуется усложнением процессуальной формы, имеющей целью предоставление несовершеннолетним подозреваемым (обвиняемым) и их законным представителям дополнительных гарантий их прав и законных интересов. При подобном подходе наиболее полно учитываются специфические качества несовершеннолетнего, принятие во внимание которых позволяет не только соблюсти его права и законные интересы, но и свести к минимуму психотравмирующие воздействие уголовно-процессуальных процедур, получить наибольшее количество сведений о личности несовершеннолетнего, а также более продуктивно проводить следственные действия с участием несовершеннолетнего.

Особенности производства по данной категории уголовных дел можно условно разделить на три группы: общие принципы производства, особенности производства на досудебной и судебной стадии:

К общим принципам относятся:

- обязательность рассмотрения вопроса о выделении уголовного дела в отношении несовершеннолетнего (п. 2 ч. 1 ст. 154, ст. 422 УПК РФ);

- большее количество обстоятельств предмета доказывания по сравнению с общим предметом доказывания, предусмотренным ч. 1 ст. 73 УПК РФ (ч. 1-3 ст. 421 УПК РФ);

- участие законного представителя несовершеннолетнего подозреваемого (обвиняемого) (ст. 426 УПК РФ);

- наличие специальной меры пресечения - присмотра, а также необходимость наличия особых условий для применения меры пресечения в виде заключения под стражу в отношении несовершеннолетнего - преступление должно быть тяжким или особо тяжким. В случае, если преступление относится к категории средней тяжести, то применение данной меры возможно только в исключительных случаях (ст. 105, ч. 2 ст. 108 УПК РФ);

- вызов несовершеннолетнего подозреваемого (обвиняемого), не находящегося под стражей, к следователю производится через его законных представителей, а если несовершеннолетний содержится в специализированном учреждении для несовершеннолетних - через администрацию этого учреждения (ст. 424 УПК РФ).

На досудебной стадии исследуемое производство имеет следующие особенности:

- общая продолжительность следственного действия - допроса несовершеннолетнего подозреваемого (обвиняемого) не может продолжаться без перерыва более 2 часов, а в общей сложности более 4 часов в день (ч. 1 ст. 425 УПК РФ);

- наличие дополнительных участников следственного действия. В допросе несовершеннолетнего подозреваемого, обвиняемого, не достигшего возраста шестнадцати лет либо достигшего этого возраста, но страдающего психическим расстройством или отстающего в психическом развитии, участие педагога или психолога обязательно (ч. 3 ст. 425 УПК РФ). Кроме того в производстве допроса, а с согласия следователя в иных следственных действиях вправе участвовать законный представитель несовершеннолетнего (п. 3 ч. 2 ст. 426 УПК РФ);

- смешанная предметно-персональная подследственность. Уголовные дела о тяжких и особо тяжких преступлениях, совершенных несовершеннолетними подслественны следователям Следственного Комитета Российской Федерации. По остальным уголовным делам предварительное расследование проводится следователями, дознавателями, к подследственности которых относится совершенное преступление (п. «Г» п. 1 ч. 2 ст. 151 УПК РФ);

- возможности не предъявления несовершеннолетнему обвиняемому части материалов дела при ознакомлении с ним. Следователь, дознаватель вправе по окончании предварительного расследования вынести постановление о не предъявлении несовершеннолетнему обвиняемому для ознакомления тех материалов уголовного дела, которые могут оказать на него отрицательное воздействие (ч. 3 ст. 426 УПК РФ);

- возможности прекращения уголовного преследования несовершеннолетнего с применением принудительной меры воспитательного воздействия (ч. 1 ст. 427 УПК РФ).

Для судебного производства для данной категории дел характерно:

- закрытое судебное разбирательство по делам о преступлениях несовершеннолетних, не достигших 16 лет (п. 2 ч. 2 ст. 241 УПК РФ);

- участие в судебном заседании законного представителя (ч. 1 ст. 428 УПК РФ);

- удаление несовершеннолетнего подсудимого из зала судебного заседания возможно на время исследования обстоятельств, которые могут оказать на него отрицательное воздействие (ч. 1 ст. 429 УПК РФ); 
- обязательность решения судом вопроса о возможности освобождения несовершеннолетнего подсудимого от наказания в случаях, предусмотренных статьей 92 УК РФ, либо условного осуждения, либо назначения ему наказания, не связанного с лишением свободы (ч. 1 ст. 430 УПК РФ).

Таким образом, в Российской Федерации на сегодня имеется полноценный институт производства по уголовным делам данной категории, характеризующийся наличием усложненной процессуальной формы.

Производство же по делам несовершеннолетних в КНР как самостоятельный правовой институт же только начинает зарождаться. В УПК КНР само упоминание о несовершеннолетних подозреваемых (обвиняемых) встречается всего 4 раза.

Так ч. 2 ст. 14 УПК КНР допускает возможность вызова на допросы и судебные разбирательства законных представителей несовершеннолетних подозреваемых (обвиняемых) [7].

Несовершеннолетнему наряду со слепыми, глухими и немыми народный суд должен назначить для его защиты адвоката, в обязанности которого входит оказание юридической помощи (ч. 2 ст. 34 УПК КНР).

Все дела о преступлениях, совершенных несовершеннолетними в возрасте до 18 лет рассматриваются в закрытом судебном заседании. Ранее до принятия Закона КНР «О профилактике преступлений среди несовершеннолетних» от 26 октября 2012 года дела несовершеннолетних в возрасте от четырнадцати до шестнадцати лет, рассматривались в закрытом заседании[5,с. 393]. Дела о преступлениях, совершенных несовершеннолетними в возрасте от шестнадцати до восемнадцати лет, обычно также рассматривались в закрытом заседании (ч. 2 ст. 152 УПК КНР).

Изменениями, внесенными в УПК КНР Законом КНР «О защите несовершеннолетних» от 26 октября 2012 года до проведения допроса или производства по уголовному делу, в котором подозреваемый или обвиняемый является несовершеннолетний, необходимо уведомить законного представителя несовершеннолетнего или иных лиц для присутствия при производстве процессуальных действий (ч. 2 ст. 14 УПК КНР) [1, с. 102-103].

Указанные фрагментарные особенности производства по данной категории дел не создают полноценного института, практически не учитывают специфики несовершеннолетнего подозреваемого (обвиняемого), что отмечалось в исследованиях рядом китайских ученых правоведов [2, с.55].

Столь большую разницу в подходах следует искать в источниках УПК РФ и КНР. Большое влияние на содержание УПК РФ оказал ранее действующий УПК РСФСР 1960 года, содержавший детально проработанный институт производства по данной категории уголовных дел.

В отличие от отечественного права, «право Китая было подвержено совершенно иным историческим влияниям как, например, буддизм, а также такому политико-философскому учению как конфуцианство и даосизм» [3, c. 121].

В традициях конфуцианства, например, в противоположность западной идее развития индивидуальности в ребенке, а соответственно и повышенного внимания к нему, главным является воспитание у ребенка одного из пяти сяо (добродетели) - сыновней почтительности к родителям, подразумевающей беспрекословное повиновение детей родителям, выполнение их воли.

Естественно, что господствующие в обществе взгляды воплощаются в соответствующих правовых установлениях. Вместе с тем малое внимание китайского законодателя к производству в отношении несовершеннолетних не характеризует китайское право, как ущербное - оно лишь свидетельствует о самостоятельном направлении его развития, опирающемся на традиции многовековой истории.

В то же время стоит отметить, что, несмотря на нынешнюю неразвитость процессуальной формы по исследуемой категории дел в КНР, китайский законодатель уделяет ей все больше и больше внимания, о чем свидетельствуют изменения в УПК КНР от 26 октября 2012 года, а так же проект изменений от 01 января 2013 года, согласно которым в УПК КНР должна была появиться новая глава, регламентирующая порядок производства по исследуемой категории дел.

\section{Литература}

1. Ван Чжицзе, Лю Сяохуа. Исследование о профилактике и исправлении преступности несовершеннолетних на примере города Чунцин // Вестник Китайской молодежной политической академии, 2008. № 6. С. 102-103.

2. Ван Чжуншэн. Эмпирическое исследование преступности несовершеннолетних в контексте культурного строительства - по уголовным делам, возбужденным в отношении несовершеннолетних в 2007-2011 гг. в провинции Хайнань // Исследование о предупреждении преступности несовершеннолетних. 2012. № 8. С. 55.

3. Давид Р., Жоффре-Спинози К. Основные правовые системы современности / пер. с фр. В. А. Туманова. М.: Междунар. отношения, 1996. С. 121.

4. Дмитриенко С. А. Обеспечение прав несовершеннолетнего обвиняемого на предварительном следствии: уголовнопроцессуальное и криминалистическое исследование: автореф. дис. ... канд. юр. наук. Волгоград, 2005. С. 1.

5. Пан Дунмэй. Проблемы преступности несовершеннолетних и борьба с ней в KHP/ "Lex russica (русский закон). 2013. № 4. С. 393.

6. Чжан Юань Хуан. Обследование состояния преступности несовершеннолетних // Прокуратура в борьбе с преступностью. 2011. № 11. С. 13; Чжан Юань Хуан, Яо Бин. Всестороннее применение уголовной политики «сочетание строгости наказания со снисходительностью» на основе новых особенностей преступности несовершеннолетних // Правовой журнал. 2009. № 11. С. 20; Цунь Мэй. Исследование о повторной преступности несовершеннолетних // Вестник Хэнаньской полицейской академии. 2011. № 5. С. 24, 26.

7. Уголовно-процессуальный кодекс КНР, принят на 2-й сессии Всекитайского собрания народных представителей пятого созыва 1 июля 1979 года (ред. 26.10.2012 г.). Режим доступа: http://chinalawinfo.ru/procedural_law/law_ criminal_procedure (дата обращения: 16.12.2015 г.). 


\section{Особенности примирения с потерпевшим в уголовном законодательстве России и Казахстана}

() Н. Н. Редикальцева

магистрант 2 года обучения юридического факультета ФГБОУ ВО «Бурятский госуниверситет»

Россия, г. Улан-Удэ

Natali_RN@mail.ru

Согласно уголовно-процессуальному законодательству Российской Федерации, уголовное судопроизводство имеет своим назначением: защиту прав и законных интересов лиц и организаций, потерпевших от преступлений; защиту личности от незаконного и необоснованного обвинения, осуждения, ограничения ее прав и свобод [2]. Кроме того, одной из задач является восстановление социальной справедливости. Лицо, совершившее преступление, должно понести предусмотренное уголовным законом наказание, а потерпевшему должен быть возмещен причиненный ему ущерб - материальный и моральный.

Задачами уголовного закона Российской Федерации являются: охрана прав и свобод человека и гражданина, собственности, общественного порядка, и общественной безопасности, окружающей среды, конституционного строя Российской Федерации от преступных посягательств, обеспечение мира и безопасности человечества, а также предупреждение преступлений [4]. Наказание за преступление применяется в целях восстановления социальной справедливости, а также в целях исправления осужденного и предупреждения совершения новых преступлений. Безусловно, лицо, совершившее преступление, должно понести законное наказание за преступное деяние. Вместе с тем, уголовно-процессуальным законодательством, как Российской Федерации, так и Республики Казахстан, предусмотрена возможность примирения обвиняемого, подсудимого с потерпевшим, то есть освобождение лица, привлекаемого к уголовной ответственности, от данной ответственности и освобождения его от наказания.

Согласно словарю Даля В.И. слово «примирять» означает прекратить ссору или тяжбу, согласить обе стороны, подружить; мириться взаимно, заключать мир [19].

Нормативной базой для создания такого института, как примирение с потерпевшим в уголовном законодательстве, явилось создание Модельного уголовного кодекса.

17 февраля 1996 г. Межпарламентская Ассамблея государств - участников Содружества Независимых Государств, приняла Модельный Уголовный кодекс, который является рекомендательным актом для государств участников СНГ. Этот документ ориентирован на страны постсоветского пространства, как имеющие общую довольно длительную историю развития уголовного законодательства. Именно на основе указанного Модельного кодекса были разработаны базовые элементы структуры и содержания уголовных кодексов стран содружества, в том числе России. Правовые конструкции данного акта, разработаны парламентариями и лучшими учеными-юристами стран Содружества. Ключевую роль сыграл этот документ и при создании института освобождения от уголовной ответственности, в связи с примирением с потерпевшим в уголовном праве вышеуказанных государств, учитывая, что ранее примирение с потерпевшим не закреплялось ни в одном Уголовном кодексе СССР.

Модельный уголовный кодекс содержит статью 75, согласно которой лицо, совершившее преступление небольшой тяжести, может быть освобождено от уголовной ответственности, если оно примирилось с потерпевшим и возместило причиненный потерпевшему вред [6].

Как в уголовном судопроизводстве России, так и Казахстана, примирение с потерпевшим возможно только по ходатайству или заявлению самого потерпевшего. Никто не вправе заставить потерпевшего примириться с лицом, совершившем преступление. Основания примирения с потерпевшим указаны в законе четко, и расширительному толкованию не подлежат. Примирение с потерпевшим возможно как на стадии предварительного следствия, так и в ходе судебного разбирательства. Обзор судебной практики показывает, что институт примирения с потерпевшим является эффективным инструментом уголовной политики в современное время.

Законодатели различных стран используют свою формулировку понятия примирения потерпевшего с лицом, совершившим преступление.

Так, Уголовно-процессуальным законодательством Российской Федерации одним из оснований для прекращения уголовного дела и уголовного преследования является примирение с потерпевшим. Суд, а также следователь, с согласия руководителя следственного органа, или дознаватель, с согласия прокурора, вправе, на основании заявления потерпевшего или его законного представителя, прекратить уголовное дело в отношении лица, подозреваемого или обвиняемого в совершении преступления небольшой или средней тяжести, в случаях, предусмотренных статьей 76 Уголовного кодекса Российской Федерации, если это лицо примирилось с потерпевшим и загладило причиненный ему вред [4]. На основании заявления лица, совершившего преступление, уголовное дело не может быть прекращено при отсутствии заявления потерпевшего. Даже если обвиняемый, подсудимый полностью возместит, загладит причиненный ущерб, но потерпевший будет против примирения, прекращение уголовного дела по данному основанию недопустимо.

Согласно ст. 68 Уголовного Кодекса Республики Казахстан, лицо, совершившее уголовный проступок или преступление небольшой или средней тяжести, не связанное с причинением смерти, подлежит освобождению 
от уголовной ответственности, если оно примирилось с потерпевшим, заявителем, в том числе в порядке медиации, и загладило причиненный вред. Несовершеннолетние, беременные женщины, женщины, имеющие малолетних детей, мужчины, воспитывающие в одиночку малолетних детей, женщины в возрасте пятидесяти восьми и свыше лет, мужчины в возрасте шестидесяти трех и свыше лет, впервые совершившие тяжкое преступление, не связанное с причинением смерти или тяжкого вреда здоровью человека, могут быть освобождены от уголовной ответственности, если они примирились с потерпевшим, заявителем, в том числе в порядке медиации, и загладили причиненный вред. При освобождении от уголовной ответственности к несовершеннолетнему применяются принудительные меры воспитательного воздействия. В случаях, когда уголовным правонарушением причинен вред охраняемым законом интересам общества и государства, лицо, указанное в части первой или второй настоящей статьи, может быть освобождено от уголовной ответственности, если оно чистосердечно раскаялось и загладило вред, причиненный охраняемым законом интересам общества или государства.

Положения настоящей статьи не распространяются на лиц, совершивших преступления по неосторожности, повлекшие смерть человека либо смерть двух и более лиц, коррупционное преступление, террористическое преступление, экстремистское преступление, преступление, совершенное в составе преступной группы, преступление против половой неприкосновенности малолетних [5]. Данная норма развернута, включает в себя несколько частей.

Анализируя вышеуказанные положения Уголовного законодательства Республики Казахстан и Российской Федерации, можно сделать вывод, что в Республике Казахстан невозможно примирение потерпевшего с лицом, совершившим преступление, повлекшее смерть человека, даже по неосторожности. Но при этом, законодатель Республики Казахстан предусматривает примирение потерпевшего с лицом, впервые совершившего тяжкое преступление, не связанное с причинением смерти или тяжкого вреда здоровью человека, для отдельных категорий лиц: несовершеннолетних, беременных женщин, женщин, имеющих малолетних детей, мужчин, воспитывающих в одиночку малолетних детей, женщин в возрасте пятидесяти восьми и свыше лет, мужчин в возрасте шестидесяти трех и свыше лет.

Уголовным законодательством же Российской Федерации предусмотрено примирение потерпевшего с лицом, впервые совершившего преступление небольшой или средней тяжести. К указанной категории преступлений, относятся преступления, повлекшие смерть человека по неосторожности (а также смерть двух и более лиц). В частности, такие статьи Уголовного Кодекса РФ, как ст. 106 УК РФ - убийство матерью новорожденного ребенка, ч. 1 ст. 107 УК РФ - убийство, совершенное в состоянии аффекта, ч. 2 ст. 107 УК РФ - убийство двух и более лиц, совершенное в состоянии аффекта, ч. 1 ст. 109 УК РФ - причинение смерти по неосторожности, ч. 2 ст. 109 УК РФ - причинение смерти по неосторожности двум и более лицам.

Вместе с тем, в отличие от уголовного законодательства Республики Казахстан, в Российской Федерации невозможно примирение потерпевшего с лицом, совершившего тяжкое преступление. Статья 25 Уголовно-процессуального кодекса четко предусматривает только две категории преступлений, по которым возможно примирение с потерпевшим: это преступления небольшой и средней тяжести.

При этом следует отметить, что прекращение уголовного дела в связи с примирением с потерпевшим, при наличии всех имеющихся для этого оснований, это право суда, но не обязанность.

Говорить о гуманности, либо, напротив, о строгости положений уголовного законодательства Российской Федерации и Республики Казахстан в части примирения потерпевшего с лицами, совершившими преступления, нельзя, поскольку в любом случае, законодатель предоставил лицу, совершившему впервые преступление, осознать вину, загладить причиненный материальный и моральный ущерб, вред здоровью потерпевшему, примириться с последним.

Отдельным нормативно-правовым актом Республики Казахстан, регулирующим отношения между потерпевшим и лицом, совершим преступление, является Закон Республики Казахстан от 28.01.2011 г. «О медиации». Согласно ч. 1 ст. 1 указанного Закона, сферой применения медиации являются споры (конфликты), возникающие из гражданских, трудовых, семейных и иных правоотношений, с участием физических и (или) юридических лиц, а также рассматриваемые в ходе уголовного судопроизводства по делам о преступлениях небольшой и средней тяжести, если иное не установлено законами Республики Казахстан [8].

Предложение стороне обратиться к медиации может быть сделано по просьбе другой стороны, судом или органом уголовного преследования. Указанная процедура медиации является добровольной, судьи и должностные лица органов, осуществляющих уголовное преследование, не вправе в какой-либо форме принуждать стороны к медиации. Проведение медиации осуществляется по взаимному согласию сторон и при заключении между ними договора о медиации.

Статья 24 вышеуказанного закона посвящена особенностям проведения медиации, проводимой в ходе уголовного судопроизводства. В частности, факт участия в медиации не может служить доказательством признания вины участником судопроизводства, являющимся стороной медиации.

Федеральным законом Российской Федерации от 27.07.2010 г. №193-Ф3 «Об альтернативной процедуре урегулирования споров с участием посредника (процедуре медиации)» регулируются отношения, связанные с применением процедуры медиации к спорам, возникающим из гражданских правоотношений, в том числе в связи с осуществлением предпринимательской и иной экономической деятельности, возникающим из трудовых правоотношений и семейных правоотношений [7]. То есть, указанным законом не предусмотрена процедура медиации в сфере уголовного судопроизводства. 
Полагаем, что в указанный закон необходимо включить процедуру медиации и в сфере уголовного судопроизводства по делам о преступлениях небольшой и средней тяжести, поскольку это приведет к возможному примирению лица, совершившего преступление, с потерпевшим и скорейшему разрешению дела. Прекращение уголовного дела в связи с примирением с потерпевшим возможно только по ходатайству потерпевшего или его законного представителя, поэтому суд не вправе самостоятельно разрешать указанный. Но при наличии процедуры медиации в сфере уголовного судопроизводства, суд вправе будет предложить сторонам обратиться к данной процедуре.

Кроме того, необходимо расширить уголовно-процессуальные основания примирения потерпевшего с лицом, совершившим преступление, указать, что входит в понятие «примирилось с потерпевшим» и «загладило причиненный потерпевшему вред», поскольку его можно различно толковать. Постановление Пленума Верховного Суда Российской Федерации от 27.06.2013 г. №19 «О применении судами законодательства, регламентирующего основания и порядок освобождения от уголовной ответственности» указывает, что способы заглаживания вреда, которые должны носить законный характер и не ущемлять права третьих лиц, а также размер его возмещения определяются потерпевшим [13]. Действительно, потерпевший является лицом, которому преступлением причинен физический, материальный, моральный вред, и только он вправе по личному волеизъявлению примириться с лицом, совершившим преступление. Ни следователь, ни суд не вправе понудить или заставить потерпевшего примириться с лицом, совершим преступление. И только сам потерпевший определяет способ заглаживания вреда. Между тем, размер возмещения вреда, я полагаю, может быть указан в законе, поскольку потерпевшим он может быть значительно завышен и несоразмерен ущербу и последствиям в результате совершенного преступления.

Одной из главных проблем рассмотренного в указанной статье института примирения потерпевшего с лицом, совершившим преступление, это возможность такого примирения сторон, если наступила смерть потерпевшего, как с процессуальной точки зрения, так и с моральной. Некоторые исследователи считают, что представитель умершего потерпевшего не вправе заявлять о примирении, поскольку фактически не является потерпевшим. Однако представитель потерпевшего является стороной в уголовном судопроизводстве, в связи с чем имеет право на такую процедуру.

С моральной точки зрения также имеются расхождения. Несомненно, смерть потерпевшего является большой утратой для семьи потерпевшего, а также утратой для общества. Вместе с тем, законодателем России предусмотрена возможность примирения с потерпевшим по делам о преступлениях, вследствие которых наступила смерть потерпевшего.

Также, одной из проблем указанного института является тот факт, что лицо, которое ранее привлекалось к уголовной ответственности, было осуждено, и судимость которого в установленном законом порядке была погашена либо снята, может при вновь совершенном преступлении примириться с потерпевшим, имея при этом погашенную судимость. То есть такое лицо нельзя назвать «впервые совершившим преступление». Поэтому суды при рассмотрении заявлений о прекращении уголовного дела в связи с примирением с потерпевшим, учитывают и принимают во внимание личность лица, совершившего преступление, привлекалось ли оно ранее к уголовной ответственности.

Что касается примирения с потерпевшим по делам частного обвинения, по которым уголовное и возбуждается и прекращается по желанию потерпевшего, определенных особенностей процедуры примирения по делам частного обвинения не имеется. Уголовные дела частного обвинения могут прекращаться за примирением сторон. Потерпевший по таким делам самостоятельно определяет, насколько сильно нарушены его права, также определяет размер причиненного ему материального или морального вреда.

Прекращение уголовного дела или уголовного преследования за примирением с потерпевшим не относится к числу реабилитирующих оснований для освобождения лица от уголовной ответственности. Однако, лицо, совершившее преступление, освобождается от уголовной ответственности, судимость у него отсутствует, и в случае совершения нового преступления, оно будет считаться совершившем преступление впервые, как бы парадоксально это не звучало.

\section{Литература}

1. Конституция Российской Федерации : принята всенародным голосованием 12.12.1993 (с учетом поправок, внесенных Законами РФ о поправках к Конституции РФ от 30.12.2008 № 6-ФКЗ, от 30.12.2008 № 7-ФКЗ, от 05.02.2014 № 2-ФКЗ, от 21.07.2014 № 11-ФКЗ) // Российская газета. 1993. 25 дек. № 237.

2. Уголовно-процессуальный кодекс Российской Федерации: федер. закон Рос. Федерации от 18 дек. 2001 г. № 174-Ф3; ред. от 23 июля 2013 г. № 245-Ф3 // СЗ РФ. 2001. № 52. Ч. 1. Ст. 4921; 2013. № 30. Ч. 1. Ст. 4078.

3. Уголовно-процессуальный кодекс Республики Казахстан от 4 июля 2014 года № 231-V [Электронный pecypc]. URL: http://online.zakon.kz/Document/?doc_id=31575852\&doc_id2=31575852\#pos=14;-22\&sub_id2=80000\&sel_link=1004101022_2 (дата обращения: 27 марта 2016).

4. Уголовный кодекс Российской Федерации от 13.06.1996 № 63-Ф3 (ред. от 30.12.2015) // Собрание законодательства Российской Федерации. 1996. 17 июня. Ст. 2954.

5. Уголовный кодекс Республики Казахстан [Электронный pecypc]. URL: http://online.zakon.kz/Document/?doc_id= 31575252\&doc_id2=31575252\#sub_id=1004096036\&sub_id2=680000\&sel_link=1004096036 (дата обращения: 27 марта 2016 ).

6. Модельный уголовный кодекс - принят на седьмом пленарном заседании Межпарламентской Ассамблеи государств - участников Содружества Независимых Государств (постановление № 7-5 от 17 февраля 1996 года) (с изменениями на 16.11.2006 г.) [Электронный ресурс]. URL: http://docs.cntd.ru/document/901781490 (дата обращения: 27 марта 2016). 
7. Об альтернативной процедуре урегулирования споров с участием посредника (процедуре медиации) : Федеральный закон Российской Федерации от 27.07.2010 г. № 193-Ф3 [Электронный pecypc]. URL: http://mediators.ru/rus/about_mediation/home_law/193-fz (дата обращения: 27 марта 2016).

8. O медиации : Закон Республики Казахстан от 28.01.2011 г. [Электронный pecypc]. URL: http://mediators.ru/rus/about_mediation/international_law/kazakhstan_1 (дата обращения: 27 марта 2016).

9. Анишина Ю.А. Потерпевший по уголовным делам частного и частно-публичного обвинения // Российский следователь. 2011. № 21 [Электронный ресурс]. URL: http://base.consultant.ru/cons/cgi/online.cgi?req=doc;base=CJI;n=58548 (дата обращения: 27 марта 2016).

10. Артамонов А. Н. Прекращение уголовного дела (уголовного преследования по нереабилитирующим основаниям) [Электронный pecypc]. URL: http://base.consultant.ru/cons/cgi/online.cgi?req=doc;base=CJI;n=93875

11. Головко Л. В. Закон об имплементации примирительных процедур (медиации) в судопроизводство Республики Казахстан: имитация деятельности или первый шаг? [Электронный pecypc]. URL: http://online.zakon.kz/m/Document/?doc_id=30583782 (дата обращения: 27 марта 2016).

12. Научно-практический комментарий к Уголовно-процессуальному кодексу Российской Федерации (постатейный) / отв. ред. В. М. Лебедев, рук. авт. кол. В. А. Давыдов [Электронный pecypc]. URL: http://base.consultant.ru/cons/cgi/online.cgi?req=doc;base=CMB;n=17882 (дата обращения: 27 марта 2016).

13. О применении судами законодательства, регламентирующего основания и порядок освобождения от уголовной ответственности : Постановлением Пленума Верховного Суда Российской Федерации от 27.06.2013 № 19 [Электронный реcypc]. URL: http://www.consultant.ru/document/cons_doc_law_148355/ (дата обращения: 27 марта 2016).

14. Обзор судебной практики прекращения районными судами Самарской области уголовных дел в связи с примирением с потерпевшим и деятельным раскаянием [Электронный pecypc]. URL: http://oblsud.sam.sudrf.ru/modules.php?name=docum_sud\&id=297 (дата обращения: 27 марта 2016).

15. Останина В.В. Освобождение от уголовной ответственности в связи с примирением с потерпевшим: учеб. пособие. Кемеровский госуниверситет. 2004 г. [Электронный ресурс]. URL: http://lib.sale/ugolovnoe-pravo-rossii/osvobojdenieugolovnoy-otvetstvennosti-svyazi-50122.html (дата обращения: 27 марта 2016).

16. Палатурьян Г. Г. Прекращение уголовного дела в связи с примирением сторон - проблемы применения на практике [Электронный pecypc]. URL: http://www.moluch.ru/conf/law/archive/113/4628 (дата обращения: 27 марта 2016).

17. Ресурсный центр медиации [Электронный ресурс]. URL: http://mediators.ru/rus/about (дата обращения: 27 марта 2016).

18. Синенко С. А. Примирение с потерпевшим по делам частного и публичного обвинения [Электронный ресурс]. URL: http://base.consultant.ru/cons/cgi/online.cgi?req=doc;base=CJI;n=65689 (дата обращения: 27 марта 2016).

19. Словарь Даля. [Электронный ресурс]. URL: http://slovardalja.net (дата обращения: 27 марта 2016).

20. Смахтин Е. В., Ларионова А. А. К вопросу о примирении сторон в уголовном процессе // Вестник Пермского Университета. Вып. 1 (19) [Электронный ресурс]. URL: http://cyberleninka.ru/article/n/k-voprosu-o-primirenii-storon-v-ugolovnomprotsesse (дата обращения: 27 марта 2016).

\title{
Криминалистическая характеристика лиц, совершаемых преступления, связанные с незаконным оборотом наркотиков в России и Китае: сравнительно-правовой аспект
}

\author{
(C) C. H. Cухеев \\ магистрант 2 года обучения юридического факультета \\ ФГБОУ ВО «Бурятский госуниверситет» \\ Россия, г. Улан-Удэ
}

Криминалистическая характеристика лиц совершаемых преступления, связанные с незаконным оборотом наркотических средств и психотропных веществ имеет важное теоретическое и практическое значение. Несмотря на то, что к уголовной ответственности за преступления, связанные с незаконным оборотом наркотиков, ежегодно привлекается более 100 тыс. человек, практически во всех регионах страны наблюдается расширение оборота наркотиков, возрастание уровня наркотизации населения, особенно молодежи. В России выявлено 2 млн. наркозависимых, это молодые люди в возрасте от 14 до 30 лет (около 80\% всех наркоманов); неквалифицированные рабочие (23\%) либо лица, не занятые общественно полезным трудом (около 62\%); учащиеся (5,3\%); лица, ранее совершавшие преступления (23\%).

Ежегодно выявляются 150-200 тыс. наркопотребителей. Незаконный оборот наркотиков сопровождается нелегальное обращение сильнодействующих, психотропных и ядовитых веществ. Практически еженедельно появляется новый вид наркотиков.

Сведения о лицах совершивших наркопреступления, просто незаменимы, особенно на первоначальном этапе расследования, когда следователи и оперативные работники вынуждены действовать в условиях дефицита информации:

1) пол, возраст, род занятий, образование, семейное положение;

2) поведение по месту работы, учебы, по месту жительства;

3) судимость, ранее совершенные административные правонарушения.

Как отмечает Э.Ф. Побегайло, контингент участников преступлений, связанных с незаконным оборотом наркотиков, отличается неоднородностью. В 2010 году 739 чел., совершивших преступления в сфере незаконного оборота, имели постоянный источник дохода: работали, обучались в образовательных учреждениях. 
Криминальная активность РФ в сфере незаконного оборота наркотиков в частности на территории Республики Бурятия обусловлена, в первую очередь, наличием значительных очагов дикорастущей конопли. Природно-климатические условия республики благоприятны для естественного произрастания и культивирования данного наркосодержащего растения[2].

Ежегодно 98-99\% от общей массы изъятых правоохранительными органами республики наркотиков составляют наркотики каннабисной группы.

Произрастание конопли в общедоступных местах, особенно вблизи населенных пунктов, вдоль автомобильных дорог приводит к вовлечению населения в изготовление наркотических средств.

Современные социально-экономические условия в Республике Бурятия характеризуются низким уровнем жизнеобеспечения значительной доли населения Республики Бурятия. Количество трудоспособных неработающих и не учащихся среди лиц, совершивших наркопреступления, за последние 10 лет возросло в 12 раз.

По итогам 2013 года Росстат РФ опубликовал данные по итогам обследований населения по проблемам занятости, Республики Калмыкия, Бурятия и Тыва вошли в число регионов с самым высоким уровнем безработицы. Так, официальный уровень безработицы в Бурятии составил 7,7\%, в Калмыкии - 11,9\%, в Тыве - 18,2 процентов.

Всего в стране около 1 млн. человек находятся на учёте в центрах занятости населения. Количество экономически активного населения страны - около 77 млн. человек [3].

Увеличивается доля психически больных и маргинальных лиц. Все это порождает социальные конфликты, обусловливает потерю ориентации, дезадаптацию и деморализацию части наших сограждан, особенно характерную для несовершеннолетних и молодежи.

Влияние последствий афганской войны и чеченского конфликта (заражение военнослужащих традициями бытового потребления наркотиков, приобщение к незаконным операциям с ними, привыкание раненых и инвалидов к употреблению наркотических лекарств для снятия болей).

Для безработных сельских жителей сбор дикорастущей конопли стал образом жизни, так как является одним из основных источников дохода. Количество лиц без постоянного источника доходов, совершивших наркопреступления в 2010 году составило 1065 чел. или 70,8\% от общего количества наркопреступников (в 2009 году - 1070 лиц или 69,9\%, в 2008 году - 992 и 62 \% соответственно). При этом, 94\% от общего количества лиц, задержанных за совершение наркопреступлений, достигли совершеннолетия (от 18 до 29 лет - 750 чел., старше 29 лет - 669 чел.), то есть совершали преступления осознанно[1].

Также, имеет место совершения преступлений лицами, имеющими судимость, освободившимися от отбывания наказания в местах лишения свободы условно досрочно, имеющими условную меру наказания.

Лица, злоупотребляющие наркотиками, в конечном итоге становятся на преступный путь: либо сами занимаются распространением наркотиков, либо совершают преступления против собственности, чтобы завладеть имуществом и деньгами для приобретения наркотиков, либо совершают насильственные преступления в состоянии наркотического опьянения [3]. Есть лица, занимающейся наркобизнесом, не потребляя наркотиков, для получения высоких доходов. При характеристике лиц занимающихся незаконным оборотом НС и ПВ имеет место такие понятия как:

1) какое время занимается наркобизнесом (каким именно);

2) имеет ли судимости;

3) знаком ли с навыками оперативной работы;

4) место и время сбыта наркотиков (квартира, улица);

5) схема продажи наркотиков (напрямую, через посредников);

6) является ли сам потребителем;

7) образ жизни (семейное положение, наличие детей, место работы, денежный доход и др.).

Эти сведения, которые зачастую получены в результате проведения оперативно-розыскных мероприятий, помогут в установлении и составлении психологического портрета преступника, в разработке тактики допроса и других следственных действий, а также - выдвинуть версии о мотиве и цели преступления, о способе совершения и сокрытия преступления, о месте нахождения искомых объектов [1]. Данные, характеризующие особенности структуры групп, имеют большое криминалистическое значение.

Таким образом, одним из основных элементов криминалистической методики расследования преступлений является его криминалистическая характеристика, которые включают в себя информацию, предопределяющую деятельность органов предвари тельного расследования и дознания по собиранию, проверке и оценке доказательств в целях установления обстоятельств, которые необходимы для правильного принятия решения по уголовному делу.

Китай является одной из самых развитых стран Азии, как и в любых других развитых странах, кризисом двадцатого столетия для Китая можно смело назвать проблему наркомании. Китай в прошлом был крупнейшим потребителем и производителем наркотиков, последствие двух опиумных войн «сделали свое дело» с конца 18 века до прихода коммунистов огромное количество китайского народа пострадали от наркомании [4]. В 1949 г. правительством страны принят жесткий закон о наказании преступлении связанные с наркотиками, в итоге значительную массу наркотиков были уничтожены. КНР стремительно вырос в сфере торговли, параллельно с экономикой страны растет количество потребителей наркотиков быстрее, чем в остальных странах. Проблема наркомании имеет особое место в общественном отношении этой древней нации.

КНР занимает особое географическое положение, только с Россией имеет около 4000 км. пограничной зоны также морского выхода на другие страны. Производители «Золотого треугольника», известного на весь мир 
производителя и продажи наркотиков в юго-восточной Азии производят и выращивают опиум вблизи юго-западной границы Китая в связи с этой близостью, появились транспортные каналы через всю страну [2].

Из-за Афганской войны появились беженцы вдоль афганских и пакистанских границ поток наркотиков, пошел из области «Золотого полумесяца». С улучшением общественной и экономического уровня жизни, резко увеличилось потребление и изготовление наркотиков в Китае.

Основные криминалистические личности, вовлеченные в наркопреступность начинали свое «становление» с 70-х годов двадцатого столетия с ростом торговых и международных отношений между Китаем и близлежащих стран [5]. Наркобизнес стал одним из самых главных социальной проблем коммунистической страны. Применение жестких уголовных мер в отношению наркоторговли и потребителей не останавливает рост преступлений. Если гражданина Китая или иностранца поймали с более чем 50 г героина, то ему применяется уголовное наказание в виде смертной казни.

Основные сбытчики наркотиков на территории КНР являются уйгуры. По неофициальным данным торговлей наркотиками занимаются примерно 20-25 тысяч уйгуров. Около 100 тысяч из них живут на доходы от наркоторговли. Даже беременные женщины, дети и престарелые занимаются этим бизнесом [5]. Рассчитывать на помилование могут беременные и кормящие матери с грудными детьми младше 6 месяцев и дети, не достигшие 14-летнего возраста.

Молодежь 16-18 лет наркозависимых составляет $6.6 \%$, 3.8\% - старше 18 лет, а 40.8\% наркоманов впервые укололись, не достигнув 18 -летия.

Обычно, сбывать наркотики предлагается девушке 15-25 лет подработать курьером за заманчивую оплату. Под контролем профессиональных наркоторговцев девушка проглатывает 400-500 грамм наркотиков, упакованных в резину или пластик, а затем летит в другую часть Китая, как бы с целью найти работу. Прибыв, она принимает слабительное, чтобы извлечь пакет.

Наркозависимостью чаще всего встречается среди малообразованных людей около 5.5\% наркоманов неграмотны, 21.3 \% окончили начальную школу, 59.4 \% имеют диплом о неполном среднем образовании, $12 \%$ закончили среднюю школу, а $1.1 \%$ - выпускники вузов.

Наркотики употребляют обычно безработные или люди без постоянного места работы в настоящее время, 56.6 \% наркоманов безработны, 4.4 \% являются сезонными рабочими, 25.5 \% работают на себя, 7.7 \% - крестьяне, а $5.5 \%$ служат в государственных и совместных предприятиях. $30.2 \%$ безработных среди наркоманов, на самом деле, занимаются проституцией или работают в близких к ней предприятиях сервиса [5]. Остальные это, большей частью, безземельные крестьяне, которые продали свою землю.

Наркотики используют обычно холостые среди наркоманов 81.7 \% составляют холостые, и только 18.3 \% женатые. Среди женатых 37.5 \% разведены или ожидаю решения о разводе.

Большинство наркозависимых принимают наркотики в течение длительного срока и имеют тенденцию к сохранению привычки, несмотря на попытки бросить

Статистические данные говорят, что 27.7 \% наркоманов принимают наркотика в течение 1-2 лет; 60. \% - п более трех. 30.5 \% дважды принимали попытки бросить наркотики как по своей воле, так и в принудительном порядке; 12.7 \% наркоманов трижды пытались бросить, $24.4 \%$ - более четырех раз[4]. Перестав принимать наркотики, многие в скором времени снова подсаживаются на иглу, согласно исследованиям, 82.2 \% наркоманов пытались бросить принимать наркотики; 77.4 \% возвращались к пристрастию в течение трех месяцев (среди них, 12.8 \% в течение недели, 20.2 \% - 15 дней, $18.2 \%$ - 1 месяца, $14.4 \%$ - 2 месяцев, $12.2 \%$ - трех месяцев). 16.2 \% бросавших возобновляли прием наркотиков через 4-6 месяцев, и только 6 \% после 1-2 лет. 96.3 \% бросивших по своему желанию после перерыва снова начинают прием наркотиков; из тех, кого заставили сделать это силой, 88.5 \% вернулись к прежним привычкам, а из тех, кто оказался в исправительно-трудовом лагере, $66.1 \%$ снова сел на иглу.

Многие наркоманы заражаются различными заболеваниями из-за приема наркотиков, среди которых ВИЧ и СПИД. 72.6 \% женщин в исправительно-трудовых лагерях состояли в браке, 30.2 \% занимались проституцией, а также имели случаи занятия сексом с женщинами [1]. Медицинские обследования показали, что 87.6 \% наркозависимых среди женщин являются носителями инфекций, передающихся половым путем. 5.36 \% наркоманов заражены сифилисом.

\section{Литература}

1. Андреева Ю. Наркоконтроль // Федеральная Служба Российской Федерации по контролю за оборотом наркотиков. M., 2005.

2. Криминология: учебник / под ред. В. Д. Малкова. М., 2005

3. Преступления, связанные с незаконным оборотом наркотиков // Невское время. 1998. № 146.

4. Степенко В. Е., Войтишана О. А. Особенности криминалистической характеристики лиц, участвующих в преступной деятельности - незаконном обороте наркотиков // Криминология / под ред. Н. Ф. Кузнецовой, В. В. Лунеева. М.: Волтерс Клувер, 2004. С. 418-428.

5. Шестопалов С. В. Краткая криминологическая характеристика преступности в сфере незаконного оборота наркотических средств и психотропных веществ и лиц, их употребляющих // Российский следователь. 2012. №18. С. 44-47. 


\title{
Сравнительно-правовой анализ статуса прокуратуры РФ и США
}

\author{
(C) Л. В. Танхаева \\ студентка 2-го курса юридического факультета \\ ФГБОУ ВО «Бурятский госуниверситет» \\ Россия, г. Улан-Удэ \\ Tanhaeval@mail.ru
}

Институт прокуратуры начал свое существование еще в XIV веке во Франции, когда король Филипп издал Ордонанс 25 марта 1302 года об учреждении прокуратуры в качестве органа, представляющего интересы монарха. На тот период функции прокуратуры не сводились к регулированию только правовой сфере общественных отношений и, в силу того, что тогда во Франции существовал инквизиционный процесс, статус прокуратуры носил обвинительный и карательный характер. Являясь, в первую очередь, представителем интересов короля, она обладала довольно обширными полномочиями, например, с ее помощью монарх мог регулировать управление всего государственного механизма.

В России прокуратура возникла как институт контроля Верховной власти за деятельностью других органов государственной власти. В истории существует мнение, что первая попытка создания системного контроля деятельности государственного аппарата со стороны Верховной власти принадлежала Алексею Михайловичу Романову, когда во второй половине XVII века создал Приказ тайных дел, для того, чтобы «его царские мысли исполнялись все по его хотению, а бояре и думные люди о том ничего не ведали» [3]. Из этого следует, что основными функциями Приказа тайных дел были представительство интересов царя.

Следующий, не менее важный, этап развития отечественной прокуратуры было учреждение прокураты как фискальной службы. 2 марта 1711 году Указом Петра I, в обязанности которой входило: тайно осуществлять надзор от имени государства за деятельностью органов власти и наблюдать за судами, а также сбор казны и прочего. Во главе фискальной службы стоял Генерал-фискал.

В Америке, изначально, не было юридического ведомства, и прокурор осуществлял деятельность единолично. Его статус определялся Законом о судоустройстве 1789. В обязанности прокурора входило только представительство на суде и лишь в 1870 году, когда Министерство юстиции начало свое существование, у прокурора появился свой подчиненный орган и значительно расширился круг полномочий. Решение о создании департамента юстиции было принято по предложению спикера Конгресса Уильяма Лоуренса, а в 1871 году атторнейскую службу наделили полномочием по руководству федеральными тюрьмами.

Сейчас прокуратура США, в отличии от России, входит в Министерство юстиции в виде, так называемых атторнеев США, которые представляют собой государственных служащих, обладающие полномочиями, связанные с уголовным преследованием и аналогичными функциями прокуратур в других странах, например, таких, как Япония и Франция. В США не имеют института прокурорского надзора за законностью в сфере государственного управления и в отличие от прокуроров России, американские атторнеи - активные политические фигуры, добивающиеся политических постов с помощью избирательных кампаний, предвыборных собраний.

В России прокуратура представляет собой, согласно статье 1 Федерального закона «О прокуратуре Российской Федерации», единую федеральную централизованную систему органов, осуществляющих от имени Российской Федерации надзор за соблюдением Конституции РФ и исполнением законов, действующих на территории РФ, в целях обеспечения верховенства закона, единства укрепления законности, защиты прав и свобод человека и гражданина, а также охраняемых законом интересов и государства[2]. Прокуратура России не относится ни к одной из ветвей власти, а является самостоятельным органом в системе государственного аппарат. Статья 159 Конституции Российской Федерации определяет особый статус прокуратуры. В отличие от Америки, прокуратура которой является частью исполнительной власти, Конституция США не определяет правового статуса атторнейской службы, также и в законодательстве не выработано единого нормативно-правового акта, определяющего функции, задачи и правовое положение данного органа.

Следует отметить, что правовая основа России относиться к романо-германской правовой системе, где основным источником права является Закон, напротив, США относиться в англо-саксонской правовой системе, основным источник которой является правовой прецедент, несмотря на то, что в стране есть единый основной закон, однако, как уже отмечалось, Конституция США не определяет статуса прокуратуры. В виду этого, деятельность прокуратуры США и статус ее работника определяется обычаем, прецедентным правом и нормами профессиональной этики.

Система прокуратуры США не имеет единого центрального аппарат, она состоит из трех уровней атторней, взаимодействующих между собой с помощью координационной связью.

1. Высший уровень в системе органов прокуратуры занимает Генеральная прокуратура США. Она возглавляется Генеральным прокурором (атторнеем), который также является Министром юстиции США, назначается Президентом США, перед которым он несет ответственность за свою деятельность, и утверждается Сенатом.

В компетенции Генеральной прокуратуры США относятся разрешение вопросов, связанные с обжалованием решений федерального суда первой инстанции, а также имеющие основания для обжалования в Верховный суд США. 
2. Средний уровень представляется прокуратурой штатов. В США каждый штат имеет свою прокуратуру, возглавляемую Генеральным прокурором штата, который избирается непосредственно населением штата.

В компетенцию прокуратур штатов относится осуществление юридического представительства штата по делам, рассматриваемым в апелляционных инстанциях, а также правомочны возбуждать уголовное преследование по некоторым категориям преступлений[3].

3. И последнее низшее звено занимают окружные прокуратуры. Их правовое положение является уникальным, так как, в отличии от других уровней, окружные атторнеи осуществляют свои публичные функции от имени всего штата, также, как и прокуроры штатов, избираются гражданами графства и несут ответственность только перед жителями графства.

Структура прокуратуры Российской Федерации, согласно статье 11 Федерального закона о Прокуратуре Российской Федерации, состоит из:

1. Генеральной прокуратуры РФ, как высшее звено системы органов прокуратуры, которую возглавляет Генеральный прокурор РФ.

2. Прокуратуры субъектов РФ, как второе звено образуются с учетом административно-территориальным устройством России, а также приравненные к ним военные и другие специализированные прокуратуры.

3. Низшее звено представляют прокуратуры городов и районов, другие территориальные, военные и иные специализированные прокуратуры[4].

Цели деятельности прокуратуры Российской Федерации и США определяются законами этих стран. Так, статья 1 Федеральный закон о прокуратуре Российской Федерации определяет основные цели прокуратуры РФ:

- обеспечение верховенства закона;

- единство и укрепление законности;

- защита прав и свобод человека и гражданина, а также охраняемых законом интересов общества и государства.

Цели, поставленные перед прокуратурой США, схожи с целями прокуратуры РФ. Однако, имеются некоторые различия в сфере компетенции прокуратур двух, рассматриваемых стран. Федеральная прокуратура Америки является одним из главных звеньев при производстве расследований по уголовным делам, и прокурор имеет право инициировать уголовное преследование и вести расследование преступлений. Тогда, как, согласно российскому процессуальному законодательству, прокурор во многом ограничен на стадии возбуждения уголовного дела, прокурор может направлять материал в органы расследования для решения вопроса, касающихся уголовного преследования.

Что касается полномочий прокуратур России и США, касающихся судебного заседания, можно говорить о том, что они схожи - это выполнение функций государственного обвинителя. Основной смысл данной функции заключается в обеспечении законности проведения правовой процедуры.

Для достижения той или иной цели прокуратуры решают различные и многочисленные задачи. Основные задачи прокуратуры Российской Федерации можно разделить 3 крупные группы:

1. Общие задачи прокуратуры - это задачи, выполнение которых осуществляется всеми органами прокуратуры независимо от уровня и специализации, вида осуществляемой деятельности. К общим задачам можно отнести:

- необходимость достижения в процессе осуществления той или иной деятельности наибольшей эффективности;

- формирование в обществе атмосферы неприятия фактов противоправного поведения;

- создание среди населения образа прокурорского работника как должностного лица, проявляющего принципиальность в вопросах укрепления законности, защищающего права и законные интересы не только государства и общества в целом, но и конкретных индивидов.

2. Специальные задачи прокуратуры - задачи, вытекающие из содержания конкретной функции, направления (участка) деятельности, осуществляемой органами прокуратуры. Так, к специальным задачам надзорной деятельности относятся:

- полное выявление в ходе проверок имеющих место нарушений законов;

- установление виновных в совершении нарушений законов лиц и лиц, при попустительстве которых совершаются нарушения закона;

- принятие надлежащих мер к устранению выявленных нарушений закона и способствующих им обстоятельств, наказанию виновных лиц и возмещению причиненного нарушениями закона ущерба.

Специальными задачами при участии прокурора в правотворческой деятельности являются:

- своевременное выявление имеющихся недостатков в правовом регулировании тех или иных сфер общественных отношений;

- подготовка юридически грамотных и обоснованных предложений по совершенствованию законодательства;

- принципиальная позиция при направлении проекта документа в уполномоченный на то орган государственной власти или местного самоуправления и отстаивании его при обсуждении в таких органах.

3. Частные задачи прокуратуры - задачи, которые ставит перед конкретным прокурором вышестоящий прокурор или текущая оперативная обстановка. Например, прокурору района может поступить от прокурора субъекта РФ поручение. Частные задачи отличаются от общих и специальных, прежде всего, конкретизированностью и характеризуются оперативностью их выполнения. Эти задачи, как правило, не являются постоянными, они многочисленны и разнообразны. 
Во многом, задачи, выполняемые Министерством юстиции аналогичны с задачами прокуратуры РФ. Но в виду того, что атторнейская служба имеет трехуровневую систему, каждый уровень которой осуществляет свою деятельность в большинстве случаев отдельно, можно выделить следующие отличительные задачи:

- организационно-административное обеспечение разносторонних функций, возложенных на федеральную атторнейскую службу;

- дача рекомендаций президенту относительно кандидатов на должности федеральных судей, включая членов Верховного суда.

- координация всех федеральных программ правоохранительной деятельности и предупреждения преступности;

- надзор за местами заключения (бюро тюрем).

Таким образом, прокуратура РФ является органом государственной власти, обладающий особым статусом. Многие авторы отмечают роль прокуратуры как органа «сдержек и противовесов» в системе разделения властей, потому как прокуратура не относится ни к одной из ветвей власти.

Прокуратура США, являясь частью государственного управления и входя в состав исполнительной ветви власти, наряду с реализацией основной задачи - борьбой с преступностью, осуществлением уголовного преследования, поддержания обвинения в суде приобретает и многие надзорные функции, особенно в деле охраны прав человека, и таким образом, в определенной степени становится и своеобразным органом надзора за исполнением законов.

В заключении, нужно отметить, что прокуратуры РФ и США исторически развивались в разных плоскостях, в разное время и образовывались при различных обстоятельствах.

\title{
Литература
}

1. Винокуров Ю. Е. Прокурорский надзор : учебник для вузов / под общ. ред. Ю. Е. Винокурова. 11-е изд., перераб. и доп. М.: Юрайт, 2013. С. 404.

2. Ершов В. В. Суд и правоохранительные органы : учебник для вузов / под общ. ред. В. В. Ершова. 2-е изд., перераб и доп. М.: Юрайт, 2014. С. 333.

3. Капинус О. С. Прокурорский надзор : учебник для вузов / под общ. ред. А. Ю. Винокурова. М.: Юрайт, 2013. С. 25.

4. О прокуратуре [Электронный ресурс] : закон Рос. Федерации от 17 янв. 1992 г. : (с изм. и доп. от 10 февр., 19 нояб. 1999 г. ; 2 янв., 27 дек. 2000 г.) // Энциклопедия российского законодательства : весна 2002 : спецвып. справ. правовой системы «Гарант» : регион. вып. - Электрон. дан. M., 2002. 1 CD-ROM.

5. Рамазанов А. А. Правовое положение прокуратуры Российской Федерации и Соединенных Штатов Америки: сравнительно-правовой анализ // Законность и правопорядок в современном обществе. 2013. № 16. С. 97-100.

\section{Институт адвокатской тайны по законодательству России и Китая}

\author{
(C) А. П. Филиппова \\ магистрант 2 года обучения юридического факультета \\ ФГБОУ ВО «Бурятский госуниверситет» \\ Россия, г. Улан-Удэ \\ cherry-15.89@mail.ru
}

Защита граждан от необоснованного вмешательства государства в частную жизнь, наверное, является одним из наиболее успешных условий создания правового государства и формирования гражданского общества в любой стране. Кроме этого, приоритетное значение личных интересов над публичными устанавливает оптимальное соотношение между ними путем эффективного повышения уровня юридической защищенности граждан. На наш взгляд, это касается возможных вторжений в личную жизнь граждан.

В силу самых различных жизненных обстоятельств, граждане доверяют свои личные тайны представителям определенных профессий, в частности тем, кто осуществляет их юридическую защиту, и необходимым атрибутом которых является сохранность доверенных им тайн.

В современном мире, каждое государство имеет уже сформировавшийся институт адвокатской тайны. Адвокат является субъектом адвокатской тайны и играет одну из ключевых основ в формировании ее института, ведь в переводе с латинского, «адвокат» означает «заступник, ходатай».

Отношение к адвокатской тайне, в нашей стране, всегда было неоднозначным. Объяснить это можно, только пониманием самой роли адвокатуры и задач, стоящих перед адвокатом.

Институт адвокатской тайны в России установлен в 2002 году, с момента принятия Федерального закона от 31.05.2002 № 63-Ф3 "Об адвокатской деятельности и адвокатуре в Российской Федерации" (далее Закон об адвокатуре) и был закреплен в Кодексе профессиональной этики адвоката, принятый 31 января 2003 года на первом Всероссийском съезде адвокатов (с последующими изменениями и дополнениями) [7].

П. 1 ст. 8 Закона об адвокатуре РФ установил понятие адвокатской тайны, согласно которому, адвокатской тайной являются любые сведения, связанные с оказанием адвокатом юридической помощи своему доверителю $[4$, c. 6]. Другими словами, для адвоката адвокатской тайной является любая разновидность информации, полученная им в связи с оказанием им юридической помощи гражданам. Если смотреть более подробно, то час- 
тично круг сведений, входящих в адвокатскую тайну, вытекает из Кодекса профессиональной этики адвоката: сам факт обращения к адвокату, включая имена и названия доверителей; все адвокатское производство по делу; все собранные адвокатом в ходе подготовки к делу доказательства и документы; сведения, полученные адвокатом от доверителя; личная информация о доверителе, ставшая известной адвокату в процессе оказания юридической помощи; содержание правовых советов, данных непосредственно доверителю адвокатом или ему предназначенных; условия соглашения об оказании юридической помощи, включая денежные суммы между адвокатом и доверителем; а также любые другие сведения, связанные с оказанием адвокатом юридической помощи гражданам [7, с. 3]. Данный перечень, конечно, не является исчерпывающим, а это значит, что он может включать в себя также и иные сведения, связанные непосредственно с оказанием адвокатом юридической помощи гражданину [9, с. 17].

Казалось бы, в России на законодательном уровне вопрос о защите адвокатской тайны достаточно четко урегулирован, что в некоторой мере даже превосходит правовые институты других стран. В частности интересен опыт развития института адвокатской тайны в странах Азиатско-Тихоокеанского региона, а именно Китая. В последние годы, с развитием экономики Китая, наблюдается динамичное развитие такого института гражданского общества как адвокатуры. Обратим внимание, что по законодательству Китайской Народной Республики (далее КНР), адвокат - это лицо, которое по закону получило сертификат на право осуществлять непосредственно адвокатскую деятельность и оказывать юридические услуги обществу.

Основными нормативно-правовыми актами, регулирующими адвокатскую деятельность и адвокатуру в «поднебесной» являются : во-первых, Закон КНР "Об адвокатской деятельности и адвокатуре" от 1 января 1997 г. (в ред. от 29 декабря 2001 г.); во-вторых, Постановление Минюста КНР "О профессиональной нравственности и требованиях к адвокатской деятельности" от 27 декабря 1993 г.; в третьих, Постановление Минюста КНР от 1 января 1995 г. "О порядке регистрации адвокатских контор и о порядке управления адвокатскими конторами" [6, с. 3]

Четко установленного законом определения «адвокатской тайны» в законодательстве Китая не усматривается, но само понятие закрепляется на законодательном уровне. Например, в Законе КНР «Об адвокатах и юридическом представительстве», вступивший в законную силу 7 января 1997 г., прямо указывается на обязанность адвоката хранить государственную тайну и коммерческие секреты участника тяжбы, ставшие известными во время ведения дела, и не раскрывать тайн сторон, участвующих в тяжбе.

По законодательству КНР, сведения, входящие в адвокатскую тайну могут составлять «коммерческие секреты» участника тяжбы, ставшие известными адвокату в процессе оказания юридической помощи по делу. Хотелось бы заметить, что в наши дни адвокаты в КНР играют все большую роль в экономической деятельности участников рыночных отношений, как в самом Китае, так и за его пределами. После вступления Китая во Всемирную торговую организацию (ВТО), все более актуальной становится адвокатская деятельность по разрешению споров, связанных именно с торговлей в рамках ВТО, и непосредственно тайну частной жизни.

Из всего вышеперечисленного, складывается мнение, что адвокатская деятельность состоит не только в оказании юридической помощи по уголовному, гражданскому и арбитражному процессу, но и в юридической поддержке, консультировании бизнеса и ведении именно деловых переговоров.

Другой вопрос, как обстоит дело с защитой самих сведений, указанных в законодательстве КНР, которые стали известными адвокату непосредственно от своего доверителя. На этот факт указывает, статья 36 УПК КНР, где закреплено право адвоката-защитника иметь свидания и вести переписку с находящимся под стражей подозреваемым в совершении преступления, но при всем при этом, данная статья не гарантирует конфиденциальности таких встреч и бесед. Так, статьей 96 УПК КНР предусмотрено, что при свидании адвоката-защитника с находящимся под стражей подозреваемым в совершении преступления следственные органы, исходя из обстоятельств дела и необходимости, могут послать своего работника для присутствия при свидании. Одну, не маловажную особенность играет, что по УПК КНР не предусмотрено право адвоката присутствовать при допросе подозреваемого.

В первую очередь, это говорит об отсутствии так называемой свидетельской защиты самого адвоката, как защитника, по законодательству КНР. Так, ст. 48 УПК КНР закрепила обязанность каждого лица, которому стали известны обстоятельства дела, выступать в качестве свидетеля. Единственным исключением из этого правила является лицо, которое в силу своих физиологических, душевных недостатков либо в силу малолетства не в состоянии отличить правду ото лжи, четко выражать свои мысли.

Представляет определенный интерес и норма статьи 306 УК КНР, где говорится «об адвокатах уголовного права», а именно: «свидетельские показания и иные улики, предъявленные привлеченными к судебному процессу адвокатами, представителями истца и свидетелями, оказавшиеся не соответствующими истине, но не подделанные умышленно, не считаются ложными и поддельными». Вместе с тем, зная о том, что ст. 33 Закона об адвокатуре КНР закрепила обязанность адвоката хранить государственную тайну и коммерческие секреты участника тяжбы, ставшие известными во время ведения дела, и не раскрывать тайн сторон, участвующих в тяжбе, небезынтересным представляется вопрос о мерах юридической ответственности адвоката. Так ч. 6 ст. 44 Закона об адвокатуре КНР содержит право юридического отдела органов власти провинции, автономной области, муниципалитета или города, имеющего районы, наложить дисциплинарное взыскание на адвоката, раскрывшего коммерческую тайну или тайну личной жизни доверителя.[6, с. 4]

Теперь посмотрим, как обстоят дела с защитой сведений по российскому закону. Возможно, выделить несколько аспектов: 
1. В статье 6 Закона об адвокатской деятельности и адвокатуре России, указано: «адвокат не вправе разглашать сведения, сообщенные ему доверителем в связи с оказанием последнему юридической помощи, без согласия доверителя» $[7$, с. 4].

2. Ст. 56 УПК РФ указывает, что адвокат, защитник подозреваемого, обвиняемого не подлежит допросу в качестве свидетеля об обстоятельствах, ставших ему известными в связи с обращением к нему за юридической помощью или в связи с ее оказанием. [2, с. 51].

3. ст. 8 Закона об адвокатской деятельности и адвокатуре, прямо указывает, что адвокат не может быть вызван и допрошен в качестве свидетеля об обстоятельствах, ставших ему известными в связи с обращением к нему за юридической помощью или в связи с ее оказанием. [7, с. 6].

4. Проведение оперативно-розыскных мероприятий и следственных действий в отношении адвоката (в том числе, в жилых и служебных помещениях, используемых им для осуществления адвокатской деятельности) допускается только на основании судебного решения. Полученные в ходе оперативно-розыскных мероприятий или следственных действий сведения, предметы и документы могут быть использованы в качестве доказательств обвинения только в тех случаях, когда они не входят в производство адвоката по делам его доверителей, об этом говорится в ст. 8 Закона об адвокатской деятельности и адвокатуре.[5, с. 10].

5. Негласное сотрудничество адвоката с органами, осуществляющими оперативно-розыскную деятельность, запрещается.

6. Подозреваемым и обвиняемым предоставляются свидания с защитником с момента фактического задержания. Свидания подозреваемого или обвиняемого с его защитником могут иметь место в условиях, позволяющих сотруднику места содержания под стражей видеть их, но не слышать.

Все вышеперечисленное говорит о том, что адвокат должен сохранять конфиденциальность по отношению к любому клиенту, независимо от того является ли клиент постоянным или обращается за оказанием разовой помощи. Эта обязанность продолжает существовать и после прекращения взаимоотношений по юридическим вопросам, и не ограничивается моментом прекращения оказания правовой помощи клиенту, независимо от того какие между клиентом и адвокатом могут возникнуть разногласия.

Все же, несмотря на законодательное закрепление института адвокатской тайны, и гарантий, обеспечивающих ее охрану, нарушения адвокатской тайны продолжаются. Так, за нарушение адвокатской тайны самим адвокатом действующее законодательство РФ не предусматривает уголовной или административной ответственности адвоката. В этой связи, за разглашение сведений, составляющих адвокатскую тайну, адвокат может быть привлечен к дисциплинарной ответственности советом адвокатской палаты, либо к гражданско-правовой ответственности. Мерой дисциплинарной ответственности адвоката за совершенный проступок может быть замечание, предупреждение, прекращение статуса адвоката, иные меры, установленные собранием (конференцией) соответствующей адвокатской палаты, либо штраф и компенсация морального вреда по решению суда.

Наступление уголовной ответственности для адвокатов по законодательству Китая наступает в случаях, если адвокат:

- раскрыл государственную тайну;

- предлагал взятку судье, государственному прокурору или третейскому судье или другим ответственным лицам либо подстрекал своих доверителей к даче взятки;

- представил фальшивые улики, скрыл важные факты, принуждал либо уговаривал других, обещая при этом получение выгоды.[6, с. 4]

Сам по себе напрашивается вывод, что действующий УПК КНР, при всех изменениях и поправках, все же сохранил свою сущность. Следует отметить, что в уголовном процессе КНР на первом месте стоят интересы государства, а личность, по своей сути, находится всего лишь на втором плане. Поэтому, сейчас в Китае общая численность адвокатов выглядит незначительной, и это с учетом количества населения Китая, который занимает первое место в мире. Большой проблемой является неравномерное распределение численности адвокатов в пределах страны. Преимущественно, адвокаты выбирают местом оказания правовой помощи большие города, мегаполисы, и, конечно же, экономические центры.

Вместе с тем, в отличие от законодательства России, законы КНР не наделяют адвоката так называемым «свидетельским иммунитетом», что, на наш взгляд, прямо искажает смысл защиты, и может повлечь существенное ухудшение положения подозреваемого, так как одним из главных проявлений свободы в правозащитной деятельности является охранение адвокатом тайны доверителя. Поэтому, является необходимым совершенствование законодательства КНР в области «адвокатской тайны». В современном Китае, законодатель мало внимания обращает на положение адвоката и его полномочия, что обусловлено, в первую очередь, историческими причинами.

Изучение института адвокатской тайны двух стран, показало, что института адвокатской тайны требует усовершенствования. В первую очередь, необходимо начинать с нормативно-правового регулирования данного института. В частности, нарушение адвокатской тайны в уголовном процессе, является несовершенством законодательства обеих стран. Действующие правовые нормы не обеспечивают в полной мере защиту адвокатской тайны, а так называемый «адвокатский иммунитет» от нарушений со стороны третьих лиц. Исправить сложившуюся ситуацию возможно путем усовершенствования действующих нормативно-правовых актов, а также принятия новых норм, регламентирующих институт адвокатской тайны. 


\section{Литература}

1. Конституция Российской Федерации : принята всенародным голосованием 12.12 .1993 (с учетом поправок, внесенных Законами РФ о поправках к Конституции РФ от 30.12.2008 № 6-ФКЗ, от 30.12.2008 № 7-ФКЗ, от 05.02.2014 № 2-ФКЗ, от 21.07.2014 № 11-ФКЗ) // Российская газета. 1993. 25 дек. № 237.

2. Уголовный кодекс Российской Федерации от 13.06.1996 № 63-Ф3 (ред. от 30.12.2015) // Собрание законодательства Российской Федерации. 1996. 17 июня. Ст. 2954.

3. Уголовно-процессуальный кодекс Российской Федерации: федер. закон Рос. Федерации от 18 дек. 2001 г. № 174-Ф3; ред. от 23 июля 2013 г. № 245-Ф3 // СЗ РФ. 2001. № 52. Ч. 1. Ст. 4921; 2013. № 30. Ч. 1. Ст. 4078.

4. Об адвокатской деятельности и адвокатуре в Российской Федерации» : Федеральный закон от 31 мая 2002 № 63 -Ф3 (в ред. от 13.07.2015) [Электронный ресурс]. URL: http://www.consultant.ru/document/Cons_doc_LAW_36945 (дата обращения 29.03.2016).

5. О содержании под стражей подозреваемых и обвиняемых в совершении преступлений : Федеральный закон от 15 июля 1995 г. № 103-Ф3 (в http://www.consultant.ru/document/cons_doc_LAW_7270 (дата обращения 29.03.2016).

6. Гуськова А. П., Дашицыренова О. Г. Институт адвокатской тайны по законодательству России и Китая // Вестник ОГУ. 2010. №103 (109).

7. Кодекс профессиональной этики адвоката (принят Первым Всероссийским съездом адвокатов 31.01.2003) (ред. от 22.04.2015) [Электронный pecypc]. URL: http://www.consultant.ru/document/cons_doc_LAW_44841 (дата обращения 29.03.2016).

8. Коломиец А. Адвокатская тайна. Некоторые проблемы правового регулирования и правоприменения // Хозяйство и право. 2005. №1. С. 109-110.

9. Смирнов В. Н., Смыкалин А. С. Адвокатура и адвокатская деятельность: учеб. пособие. М.: Проспект, 2014.320 с.

10. Смоленский М.Б. Адвокатская деятельность и адвокатура в России. Курс адвокатского права: учебник. М.: Феникс, $2015.331 \mathrm{c}$.

\section{Особенности производства дактилоскопических экспертиз в России и Монголии: сравнительно-правовой анализ}

(C) A. В. Фоминых студентка 3-го курса юридического факультета ФГБОУ ВО «Бурятский госуниверситет»

Россия, г. Улан-Удэ nastix.fominix@yandex.ru

В последние годы в России происходит кардинальное реформирование всех систем, в том числе и правоохранительных органов. Как мы знаем, в 2011 проводилась реформа в Министерстве внутренних дел Российской Федерации, которая позволила вывести на новый уровень эффективность борьбы с преступлениями. Но на последних двух заседаниях коллегии МВД РФ президент России В.В. Путин говорил о совершенствовании работы по раскрытию и расследованию преступлений [2]. Одним из составляющих этой работы выступает повышение уровня экспертного обеспечения стадии досудебного производства по уголовным делам. Именно экспертные заключения помогают сотрудникам быстро и качественно расследовать дела.

Дактилоскопия и дактилоскопическая экспертиза широко применяется в правоохранительной деятельности как научно-техническое средство раскрытия и расследования преступлений - практически 50\% от общего числа экспертиз. В основе данной экспертизы лежит дактилоскопическая информация, т.е. кожные узоры руки человека, которые у всех людей индивидуальны.

В Монголии же дактилоскопическая экспертиза в настоящее время является самым развитым видом криминалистической экспертизы [4, с. 495].

Вообще термин «дактилоскопия» (от греч. daktylos - палец и skopeo - смотрю) впервые предложен аргентинским публицистом доктором Франциском Латцина вместо термина «икнафалангометрия», используемого создателем первой дактилоскопической классификации Хуаном Вучетичем (1858 - 1925) [3, с. 3].

Для производства дактилоскопических экспертиз необходимы качественные объекты, представленные на экспертизу, которые в свою очередь должны быть правильно обнаружены, зафиксированы и изъяты во время проведении осмотра места происшествия. В основном этим занимаются криминалисты Экспертно-криминалистических центров МВД РФ. Они также проводят фотосъемку и видеозапись места происшествия.

Для обнаружения следов пальцев рук в современном мире существует множество способов. Таких как, применение химических веществ в газообразном и порошкообразном состоянии, лучей лазера [6, с. 41]. Химические вещества в газообразном состоянии представляют собой пары йода и пары цианакрилатов, которые применяются для обнаружения невидимых отпечатков пальцев рук. Химические вещества в порошкообразном состоянии представлены различными порошками, обладающими магнитными, адгезионными и сорбционными свойствами [1, с.111]. Как правило, выявленные следы пальцев изымаются вместе с предметом-носителем. Копирование производится только в тех случаях, когда изъять предмет-носитель невозможно или это может повлечь за собой повреждение следа. Следы, выявленные дактилоскопическими порошками, можно копировать с помощью дактилоскопической пленки. Также применяются различные аэрозольные следокопирующие составы, силиконовые пасты, образующие в последующем резиноподобный слепок. Фиксация обнаруженных следов 
пальцев рук производится путем фотографирования и подробного описания в протоколе осмотра места происшествия.

Монгольские правоохранительные органы используют практически те же методы обнаружения, фиксации и изъятия следов пальцев рук при осмотрах, но половина следов, представленных на исследование признается непригодными для идентификации. Причем, эти следы изымаются с таких объектов как нож, пистолет, топор, т. е. с объектов, которые являются орудиями преступления. В большинстве случаев, для обнаружения следов пальцев рук применяются дактилоскопические порошки, но в последнее время криминалисты прибегают к помощи передовых технологий, заключающихся в обнаружении следов парами цианакрилата и использованием силиконовых слепочных масс, применяемых в стоматологии. В основном правоохранительные органы Монголии перенимают опыт работы экспертов в России. [4, с. 496]

Правовую основу экспертной деятельности в России определяют Уголовно-процессуальный кодекс Российской Федерации, Федеральный закон «О государственной судебно-экспертной деятельности в Российской Федерации» и множественные локальные акты Министерства внутренних дел. Так в соответствии с Федеральным законом «О государственной судебно-экспертной деятельности в Российской Федерации» основаниями производства судебной экспертизы являются определение суда, постановления судьи, лица, производящего дознание, следователя [9, ст. 19]. В постановлении обязательно должны быть указаны:

1) основания назначения судебной экспертизы;

2) фамилия, имя и отчество эксперта или наименование экспертного учреждения, в котором должна быть произведена судебная экспертиза;

3) вопросы, поставленные перед экспертом;

4) материалы, предоставляемые в распоряжение эксперта. [8, ст. 195]

В основном перед экспертом ставятся 2 группы вопросов:

1. Вопросы, относящиеся к характеристике следов и к определению механизма их образования, а именно:

- имеются ли на объекте следы рук и, если да, то пригодны ли они для идентификации личности человека?

- каким пальцем какой руки оставлен данный след?

- в результате каких действий: касание, нажим, захват оставлены данные следы?

2. Вопросы, связанные с идентификацией:

- не оставлены ли данные следы рук конкретным лицом?

- не оставлены ли следы рук одним лицом?

- не принадлежат ли отпечатки пальцев рук на дактилокарте трупа конкретному лицу?

Для дактилоскопической экспертизы присущи следующие стадии исследования объектов: предварительное исследование; детальное исследование; оценка результатов исследования и формулирование выводов; оформление результатов исследования. Предварительное исследование заключается в ознакомлении эксперта с постановлением о назначении экспертизы. После этого производится фотосъемка упаковки объектов, самих объектов, поступивших на исследование. Одновременно, эксперт определяет пригоден ли отпечаток для проведения сравнительного исследования.

Детальное исследование объектов дактилоскопической экспертизы производится в два этапа, которые условно подразделяются на:

- раздельное исследование - подробное, всестороннее исследование всех следов и их признаков;

- сравнительное исследование - производится сравнение следов между собой и с отпечатками (оттисками) рук на дактилокарте.

На стадии оценки результатов и формирования выводов эксперт решает совпадают или нет предоставленные след и отпечаток пальцев рук. Для обоснования вывода о том, что след и отпечаток образованы одним и тем же пальцем руки, необходимо определить, что образуемая совокупность признаков строения папиллярного узора в следе и отпечатке индивидуальна, а поэтому и неповторима.

Оформление результатов исследования производится исходя из правил, установленных УПК и Федеральным законом «О государственной судебно-экспертной деятельности в Российской Федерации». В заключении эксперта

- или комиссии экспертов должны быть отражены:

- время и место производства судебной экспертизы;

- основания производства судебной экспертизы;

- сведения об органе или о лице, назначивших судебную экспертизу;

- сведения о государственном судебно-экспертном учреждении, об эксперте (фамилия, имя, отчество, образование, специальность, стаж работы, ученая степень и ученое звание, занимаемая должность), которым поручено производство судебной экспертизы;

- предупреждение эксперта в соответствии с законодательством Российской Федерации об ответственности за дачу заведомо ложного заключения;

- вопросы, поставленные перед экспертом или комиссией экспертов;

- объекты исследований и материалы дела, представленные эксперту для производства судебной экспертизы;

- сведения об участниках процесса, присутствовавших при производстве судебной экспертизы;

- содержание и результаты исследований с указанием примененных методов;

- оценка результатов исследований, обоснование и формулировка выводов по поставленным вопросам. [8, ст. 204] 
Все зафиксированные и изъятые следы пальцев рук заносятся в автоматизированную дактилоскопическую информационную систему (АДИС) «Папилон», которая позволяет вести дактилоскопический учет для дальнейшего быстрого раскрытия и расследования преступлений. [7, с. 423]

Как было отмечено раньше дактилоскопические экспертизы являются самыми развитыми и поэтому часто применяются. Так, например, на представленном графике мы можем увидеть число экспертиз, произведенных в экспертных подразделениях г. Улан-Батора.

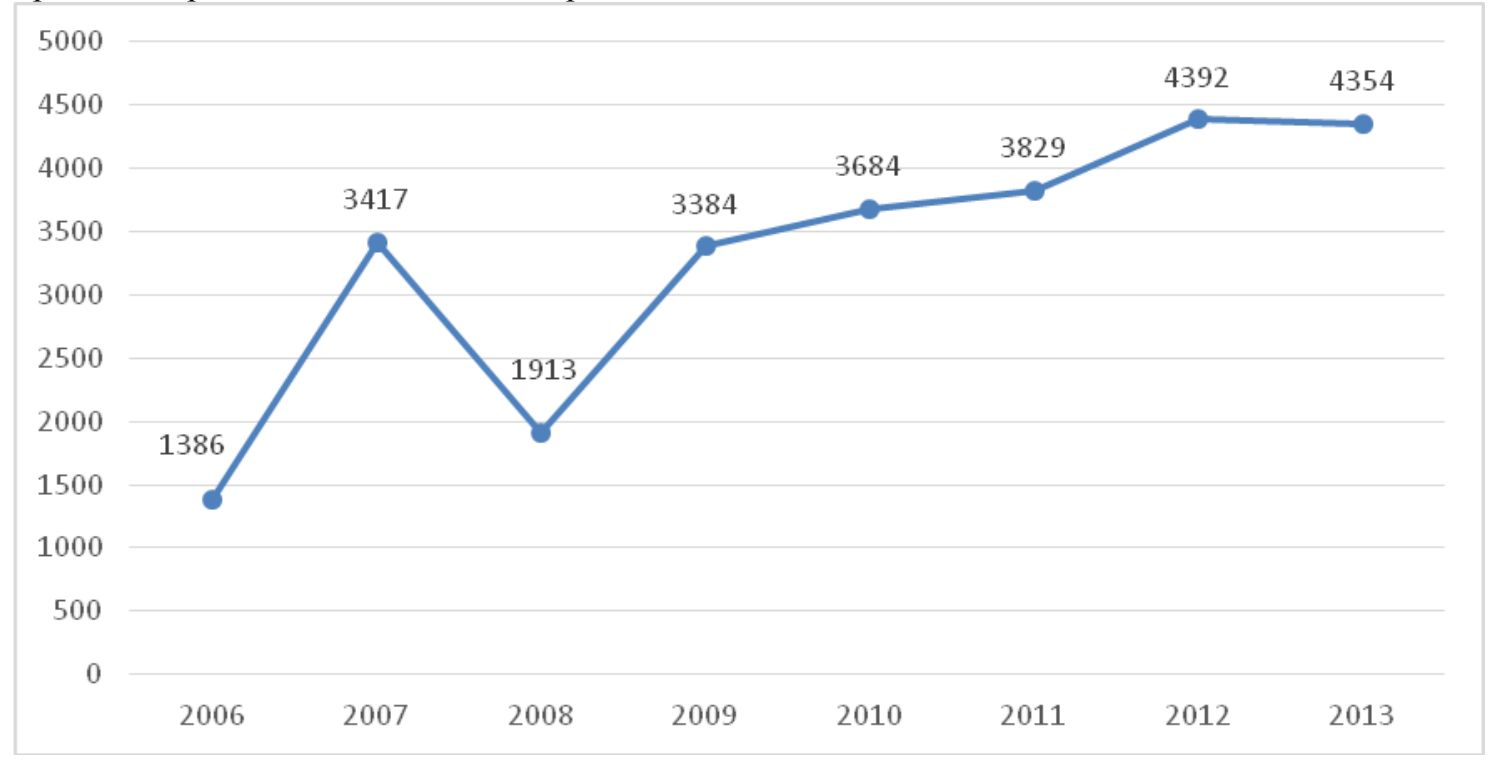

Но у монгольских экспертов возникают трудности при обнаружении, фиксации и изъятии следов папиллярных узоров, на предметах, изъятых в ходе осмотра места происшествия. Поэтому все чаще экспертные подразделения Монголии прибегают к помощи российских коллег, так, например, Волгоградская академия МВД России имеет устойчивые долгосрочные контакты с Академией полиции ГУП Монголии (г. Улан-Батор), которые помогают монгольским курсантам обучаться, стажироваться в академии. Все чаще академия проводит международные конференции по судебной экспертизе, по итогам которых выходят сборники научных трудов [5].

Сегодня монгольские сотрудники пользуются такой же системой дактилоскопической регистрации, как в России, - это АДИС «Папилон». Данная система помогает хранить множество дактилоскопических карт, а также решать следующие задачи:

- установление личности по отпечаткам пальцев и ладоней;

- установление личности по следам пальцев и ладоней;

- идентификация неопознанных трупов;

- объединение по следам преступлений, совершенных одним и тем же лицом. [4, с.495]

Таким образом, мы видим, что Россия и Монголия тесно сотрудничают в сфере судебной экспертизы, а именно дактилоскопической. Обмен опытом между сотрудниками экспертных подразделений позволяет быстро и качественно раскрывать и расследовать преступления, что в современном мире необходимо для общества.

\section{Литература}

1. Афанасьев И. Б., Дружинин Ю. А., Васильев В. А., Ермакова Т. А., Крылов А. А. Возможности методов анализа поверхности в исследовании дактилоскопических порошков // Судебная экспертиза: российский и международный опыт: сб. науч. тр. II Междунар. науч.-практ. конф. (Волгоград, 21-22 мая 2014 г.). Волгоград: ВА МВД России, 2014. С. 111-115.

2. Владимир Путин принял участие в расширенном заседании коллегии Министерства внутренних дел [Электронный peсурс]. Режим доступа: http://kremlin.ru/events/president/news/51515 (дата обращения: 26.03.2016)

3. Ивашков В.А. Особенности составления заключения эксперта при выполнении дактилоскопических экспертиз: учеб. пособие. М.: Изд-во ЭКЦ МВД России, 1999. 240 с.

4. Курин Г. И., Бардаченко А. Н., Попов А. И., Номин Б. Проблемы обнаружения, фиксации и изъятия следов рук с мест происшествия в Монголии // Судебная экспертиза: российский и международный опыт: сб. науч. тр. II Междунар. науч.практ. конф. (Волгоград, 21-22 мая 2014 г.). Волгоград: ВА МВД России, 2014. С. 495-497.

5. Международное сотрудничество Волгоградской академии МВД России [Электронный ресурс]. Режим доступа: http://va-mvd.ru/modules.php?name=Content\&pa=showpage\&pid=12 (дата обращения: 26.03.2016).

6. Осмотр места происшествия: практ. пособие / под ред. А. И. Дворкина. М.: Юристъ, 2000. 336 с.

7. Сафонов А. А. Алгоритмизация формирования и ведения экспертно-криминалистического учета следов рук // Судебная экспертиза: российский и международный опыт: сб. науч. тр. II Междунар. науч.-практ. конф. (Волгоград, 21-22 мая 2014 г.). Волгоград: ВА МВД России, 2014. С. 421-427.

8. Уголовно-процессуальный кодекс Российской Федерации от 18.12.2001 N 174-Ф3 (ред. от 30.03.2016) // Собрание законодательства РФ, 24.12.2001, N 52 (ч. I), ст. 4921

9. Федеральный закон от 31.05.2001 N 73-Ф3 (ред. от 08.03.2015) «О государственной судебно-экспертной деятельности в Российской Федерации» // Собрание законодательства РФ, 04.06.2001, N 23, ст. 2291 


\title{
Коротко об адвокатской деятельности и адвокатуре в КНР
}

\author{
(C) Чэжан Цзиньхуэй \\ адвокат, научный сотрудник \\ Ассоичиации российской правовой системы и права, \\ зам. начальника секретариата, \\ Китай, г. Цииикар \\ 1114024039@qq.com
}

Закон КНР «Об адвокатах и юридическом представительстве» вступил в силу 7 января 1997 года. Это первый закон об адвокатской деятельности и адвокатуре в Китае, так что система адвокатов Китая была беспрецедентным улучшением. В 2001 году были внесены изменения, утверждено положение о порядке сдачи квалификационного экзамена по юриспруденции, улучшая тем самым требования к профессионализациям адвокатов, что соответствует современным социально-экономическим требованиям эпохи глобализации. В 2007 и 2012 годах, ВСНП были внесены комплексные изменения в указанный закон, в том числе изменения о формах адвокатских образований, надзоре за адвокатами и т.д. И система адвокатов сделалась более совершенной и стандартизованной [1].

До конца 2015 года во всей стране всего 297000 адвокатов, из них 1445 депутатов ВСНП, 4033 членов НПКСК, более 86000 членов партии. В Китае учредили около 24000 адвокатских контор, всего учредили 330 представительств из 256 адвокатских контор из 21 стран и регионов, в том числе 265 представительств из иностранных стран, 65 из города Гонконг, 9 представительств в городе Сямыне и Фучжоу из Тайваня. А китайские адвокатские конторы учредили более 50 представительств за границей.

В статье 2 Закона КНР «Об адвокатах и юридическом представительстве» устанавливается Термин «адвокаты», используемый в данном законе, подразумевает лиц, получивших лицензию на занятие адвокатской практикой в соответствии с законом и оказывающих юридические услуги гражданам [2]. По клиентам, в зависимости от оказываемых адвокатами услуг, выделяются: социальные адвокаты; адвокаты компаний; адвокаты правительств; адвокаты армий. По рабочему режиму выделяются: адвокаты-основники; адвокаты-совместители; адвокаты по особому приглашению и т.д.

Формами адвокатских образований являются:

1. Адвокатская контора на основе партнерства. Партнеры несут неограниченную и совместную ответственность за эту адвокатскую контору.

2. Адвокатские конторы, финансируемые государством.

3. Адвокаты могут образовать кооперативную адвокатскую контору и отвечать по своим обязательствам всем своим имуществом. Эти адвокатские конторы должны учреждены органами Юстиции.[3]

Адвокаты оказывают судебные и внесудебные услуги. В том числе участвуют в качестве представителей или защитников доверителя в гражданском и административном или уголовном судопроизводстве; беспрепятственно встречаются со своим доверителем наедине; собирают и представляют предметы и документы, которые могут быть признаны вещественными и иными доказательствами; дают консультации и справки по правовым вопросам; составляют заявления, жалобы, ходатайства и другие документы правового характера и т.д.

Ассоциация адвокатов является юридическим лицом общественной организации и организацией самоконтроля адвокатов. Существует общенациональная Всекитайская ассоциация адвокатов, местные ассоциации адвокатов созданы во всех провинциях, автономных областях и муниципалитетах. Адвокаты обязаны вступить в местную ассоциацию адвокатов по месту расположения своих адвокатских контор. Адвокаты, вступившие в одну из местных ассоциаций адвокатов, автоматически становятся членами Всекитайской ассоциации адвокатов. Органы Юстиции по Закону КНР «Об адвокатах и юридическом представительстве» контролируют и руководствуют адвокатами, адвокатскими конторами и ассоциациями адвокатов. В настоящее время, органы Юстиции и ассоциации адвокатов совместно управляют адвокатами [4]. Адвокаты несут административную и дисциплинарную ответственность за нарушение прав в ведении адвокатской деятельности. Как правило, власть органов Юстиции выше ассоциаций адвокатов.

В настоящее время, еще нужно улучшать систему адвокатов. Кроме решений проблем о трудности во встрече с подозреваемыми, в осмотре документов, в сборе доказательств, еще нужно решить проблемы о трудности задавания вопросов, представления доказательств в судебном заседании, и трудностей в дискуссии. И еще необходимо гарантировать права адвокатов; повышать социальный статус; поощрять адвокатов активно участвовать в политике, выполнять функции Ассоциации адвокатов; укрепить профессиональные подготовки молодых адвокатов; углубить реформы системы адвокатов, чтобы адвокаты играли важную роль в управлении государством на правовой основе.

\section{Литература}

1. Чэнь Вэйдун. Наука о китайских адвокатах. Пекин: Изд-во Китайского народного университета, 2008.

2. Статья 2 Закона КНР «Об адвокатах и юридическом представительстве» от 07.12.1997// Собрание законодательства КНР. 04.07.1999. № 42. Ст. 243.

3. Статьи 15、16、20 Закона КНР «Об адвокатах и юридическом представительстве» от 07.12.1997// Собрание законодательства КНР. 04.07.1999.№ 42. Ст. 247.

4. Ту МинХуэй. Сравнительный анализ о адвокатской системе США и КНР // Законодарность и общество. 2013. 


\section{Примирение сторон по уголовным делам в Китае}

(C) Ши Мэн

магистрант Политико-юридического университета,

Китай, г. Пекин

14 марта 2012 в Пекине завершилась 5-я сессия Всекитайского собрания народных представителей (ВСНП) 11-го созыва, где приняли проект поправок к Уголовно-процессуальному кодексу КНР. Обобщая ранее приобретенный опыт и пользуясь многими научными достижениями в этой области, новый Уголовно-процессуальный кодекс КНР предусматривает особые процессуальные процедуры, предусмотренные отдельными разделами кодекса [1]. Данные новеллы являются безусловным совершенствованием уголовно-процессуального института КНР. Примирение сторон по уголовным делам является одной из четырех особых процессуальных процедур примирения сторон. Рассматриваемая процедура применяется по уголовным делам, для разрешения спора между сторонами, как по делам частного обвинения, так и по делам государственного обвинения. В то же время, новый Уголовно-процессуальный кодекс КНР строго ограничивает сферу дел государственного обвинения, к которым можно применить примирение сторон по уголовным делам:

- преступления, возникшие в связи с гражданскими спорами, касающихся преступлений, предусмотренных 4 и 5 главами особенной части Уголовного Кодекса КНР [2], за которые назначаются наказания лишения свободы на срок менее трех лет.

- преступления по неосторожности, за которые наказание - лишение свободы на срок менее семи лет.

Создание примирения сторон по уголовным делам в новом Уголовно-процессуальном Кодексе КНР способствует: разрешению споров, уменьшению судебных расходов и своевременному восстановлению общественных отношений и порядка. Ограничение сферы использования примирения сторон по уголовным делам, в свою очередь, гарантирует торжественность и обязательность назначения наказания и справедливость такого наказания в судебной деятельности.

Касаясь вопроса сферы и условий применения процедуры примирения сторон по уголовным делам отметим предложение Верховной Народной Прокуратуры «О примирении сторон по уголовным делам небольшой тяжести» от 29 января 2011 г. N 2 [3]. Данное предложение распространяется на дела государственного обвинения, за которые согласно закону предусмотрены санкции в виде лишение свободы на срок менее трех лет, аресту, надзору или штрафу в качестве самостоятельного наказания.

Уголовные дела в вышесказанных пределах должны одновременно соответствовать следующим условиям:

1) преступление должно быть совершено умышленно и причинять вред определенному потерпевшему, кругу лиц, или преступление совершенное по неосторожности, совершаемое в отношении конкретного потерпевшего;

2) должны иметься ясно установленные факты преступления, присутствовать достоверные и достаточные доказательства;

3) подозреваемый или обвиняемый признает свою вину в содеянном, и фактически исполняет условия соглашения о примирении сторон. В случае невозможности исполнения соглашения сторон в установленное время предусмотрена обязанность согласования и утверждения гарантии исполнения обязательств, вытекающих из соглашения о примирении.

4) стороны дел уже примирились и договорились друг с другом по вопросам возмещения причиненного материального и морального вреда, приведения в прежнее состояние и принесения извинения и др.

5) потерпевший и его агент или близкий родственник прощают подозреваемого, или обвиняемого, просят или соглашаются смягчить наказание согласно закону.

Таким образом можно выделить обязательные условия прихождения к соглашению и возможности заключения такого соглашения:

- принесение извинения;

- возмещения причиненного материального и морального вреда;

А так же, должны наличествовать:

- исполнение обязательных работ;

- доклады о своих мыслях, предоставляемые с периодичностью в органы прокуратуры, предполагающие мысли о раскаянии и недопустимости совершения подобных преступных действий в последствии.

Рассматривая роль Народной Прокуратуры в процессе примирения сторон по уголовным делам необходимо отметить, что в отношении уголовного дела, по которому органы общественной безопасности обратились за разрешением на арест, если обстоятельство данного дела соответствует сфере и условиям применения примирения сторон по уголовным делам, тогда это считается важным условием для неисполнения ареста и Народная Прокуратура зачастую может принять решение об отказе в применении в отношении подозреваемого, обвиняемого ареста.

В отношении мелкого уголовного преступления, предусмотренного пунктом 2 статьи 170 Уголовно-процессуального кодекса КНР, по которому органы общественной безопасности направляют его на расследование, и обстоятельства данного дела соответствуют сфере и условиям применения процедуры примирения сторон по уголовным делам, то возможно принятие решения об отказе от дальнейшего предъявления обвинения. 
В отношении других мелких уголовных преступлений, если они соответствуют сфере и условиям применения примирения сторон по уголовным делам, которые считаются незначительными, нет необходимости приговаривать нарушителя к уголовному наказанию и возможно принятие решения о не выдвижении обвинения. В отношении дел, требующих выдвижения государственного обвинения, возможно подать предложение о смягчении наказаний Народному суду в пределах, предусмотренных законом.

Если лицо, против которого не было выдвинуто обвинений, должно подвергнуться административному штрафу или административным санкциям, или его незаконные доходы должны быть конфискованы, то Народная прокуратура должна сделать соответствующие предложения об этом, и передать дело на рассмотрение в компетентные органы.

В отношении дела, по которому достигнуто примирение и принято решение о выдвижении обвинения, на стадии до момента публичного объявления решения об отказе выдвижения обвинения, Народная прокуратура должна снова принять во внимание мнение сторон о примирении и установить, что подозреваемый уже искренне раскаялся, соглашение о примирении уже осуществилось, существует действующая гарантия для осуществления соглашения о примирении или Народный суд уже утвердил соглашения о примирении.

В отношении дел, по которым лицо в соответствии с законом может быть приговорено к лишению свободы на срок свыше трех лет и стороны уже примирялись, при выдвижении государственного обвинения, Народная прокуратура может подать предложение о смягчении наказаний Народному суду в пределах, предусмотренных законом.

Касаясь практики применения примирения сторон по уголовным делам необходимо отметить, что некоторые районные судебные органы, районные органы прокуратуры, заимствовали опыт иностранных стран и положили начало реформы правил примирения сторон по делам государственного обвинения во многих формах. Они активно работают над вопросами примирения сторон и поощряют примирения по незначительным уголовным делам.

В 2002 году прокуратура района Чаоян города Пекина предусмотрела специальный порядок разбирательства дел о преступлениях, последствиями которых является причинение легкого вреда здоровью, что является их первым шагом в практике примирения сторон в уголовном деле. После этого, города Чжэзянь, Шанхай и другие города разработали нормативно-правовые акты, которые регламентируют процедуру примирения сторон по уголовным делам.

Обобщая ранее приобретенный опыт, Верховный Народный Суд в 2010 году внес предложения «О вопросах глубокого внедрения правил о приоритете примирения и сочетании примирения с приговором» [4]. Статьей 5 гласит: «Необходимо активно работать над уголовным примирением и посредничеством». Практика показывает, что окончание дела путем примирения сторон - хорошая защита прав потерпевшего и помощь ему в получении максимальной суммы компенсации материального и морального вреда - это позволяет уголовной политике сочетать наказания со снисходительностью, способствует решению конфликтов и уменьшению судебных расходов.

Примирение сторон по уголовным делам имеет большое значение и является поворотным в рассмотрении уголовных дел. В Уголовно-процессуальном Кодексе КНР уже установлены статьи о примирении сторон, что является ключевым моментом и первым шагом создания, а так же дальнейшего совершенствования применения процедуры примирения сторон в правоприменительной практике Китая. Таким образом предоставляются законные основания и гарантии для применения упрощенной процедуры при разрешения конфликтов.

В последние годы статистика показывает, что количество преступлений пребывает на высоком уровне, поэтому система правосудия нагружена, что не может не сказывается на качестве его отправления. Законодательное закрепление примирения сторон в настоящем Уголовно-процессуальном кодексе КНР несомненно улучшает существующее положение. Примирение сторон акцентирует внимание и реализует на практике восстановление нарушенных прав и законных интересов и возмещение вреда, причиненного непосредственно преступлением вместо применения санкций, наказаний и мщения. Это соответствует концепции уголовно-правовой политики КНР - «человек и защита прав человека превыше всего». Примирение сторон по уголовным делам активно и позитивно решает споры между сторонами и ставит заботу о гражданах на первое место. Разумеется, порядок применения рассматриваемой процедуры нужно совершенствовать. Конечно многие уголовные дела не могут быть решены путем примирения сторон из-за их противоречивости. Именно поэтому примирение сторон играет вспомогательную роль в системе уголовного права. Все же необходимо глубже изучить примирение сторон по уголовным делам, чтобы оно эффективно выполняло свою функцию.

\section{Литература}

1. Уголовный Кодекс КНР // Принят на 5-й сессии Всекитайского собрания народных представителей шестого созыва, 1997 год.

2. Уголовно-процессуальный Кодекс КНР// принят на 2-й сессии Всекитайского собрания народных представителей пятого созыва, 1979 год (с поправками, внесенными Постановлением, принятым на 4-й сессии Всекитайского собрания народных представителей восьмого созыва 17 марта 1996 года «О внесении изменений в «Уголовно-процессуальный кодекс КНР Китайской Народной Республики»). KHP.

3. О примирении сторон по уголовным делам небольшой тяжести // N 2011 г., 2, Верховная Народная Прокуратура

4. О вопросах глубокого внедрения правил о приоритете примирения и сочетании примирения с приговором // 2010, Верховный Народный Суд КНР. 


\section{К вопросу об эффективности проведения очной ставки: сравнительный анализ норм УПК РФ и УПК Китая}

() М. А. Щербина

курсант 3 курса

ФГКОУ ВО «Крымский филиал Краснодарского университета

Министерства внутренних дел

Российской Федерации»

Россия, г. Симферополь

Главная цель каждого уголовного дела - это выяснение всех обстоятельств совершенного преступления, а также установление виновного в совершении преступления. Для выявления лица, совершившего преступление, сотрудники следственных подразделений проводят ряд определенных следственных действий: допросы, осмотры, следственный эксперимент, проверку показаний на месте и др. В соответствии со ст. 192 УПК РФ [2] следователю предоставлено право проведения очной ставки.

Очная ставка является одним из значимых процессуальных действий в уголовном процессе РФ, которому обычно отводится значительная часть времени на предварительном и судебном следствии. Однако и до настоящего времени спорным остается вопрос, самостоятельное ли это следственное действие или разновидность допроса.

Разделяем точку зрения тех ученых, которые относят очную ставку к самостоятельному следственному действию.

Допрос является одним из самых распространенных процессуальных действий в уголовном процессе РФ, его суть заключается в получении от допрашиваемого лица устных сведений (показаний), т.е. устной речевой информации об обстоятельствах и фактах, имеющих значение для разрешения уголовного дела.

Хотелось бы проанализировать правовые нормы РФ и Китая, регламентирующие указанные следственные действия.

В РФ порядок проведения допроса регламентирован ст.187 УПК, а в Китае тактика проведения допроса закреплена в ст. 91-96 УПК [3].

В УПК РФ порядок проведения допроса предусматривает право допрашиваемого выбирать язык, на котором языке желает давать показания. В УПК КНР данная норма отсутствует, однако считать это существенным пробелом в законодательстве не считаем необходимым, т.к. возможность участия в уголовном судопроизводстве переводчика не исключается как в РФ, так и в Китае.

Можно обратить внимание на особенность нормы УПК Китая, которая закрепила порядок проведения допроса с лицами, имеющими ограниченные физические возможности. Так, в ст.94 УПК Китая говорится, что, если необходимо допросить лицо, страдающее глухотой или немотой, то должен принимать участие чиновник, хорошо владеющий письменным языком, и данные обстоятельства должны быть отмечены в протоколе. В УПК РФ подобная норма отсутствует, что заставляет следователя самостоятельно регулировать такие вопросы, основываясь только на внутреннем убеждении в правильности содеянного, что не всегда имеет положительный результат.

Что касается процесса проведения допроса, то в УПК РФ сказано, что при проведении данного следственного действия запрещается задавать наводящие вопросы, а в остальном следователь свободен при выборе тактики его проведения. В УПК Китая более четко прописан процесс его осуществления. Так, в ст.93 УПК Китая говориться, что при допросе подозреваемого следователи должны спросить подозреваемого, совершил ли он какие либо уголовные деяния, и дать ему возможность объявить обстоятельства, касающиеся его вины или объяснить свою невиновность, после чего они могут задавать ему вопросы. Подозреваемый должен правдиво отвечать на все вопросы, но он имеет право отказа от ответов на вопросы, не имеющих отношения к данному делу.

Можно заметить, что в данной норме указано, что подозреваемый «должен» правдиво отвечать на поставленные вопросы, логично будет поставить вопрос о возможности подозреваемого лица вообще отказаться от дачи показаний при допросе. В РФ дача показаний предполагает собой право подозреваемого, а не обязанность, отказ от дачи показаний и дача заведомо ложных показаний подозреваемым уголовной ответственности не влечет, что не умоляет прав подозреваемого.

Не совсем ясной для нас является урегулированная в ст.91 УПК Китая норма о том, что в допросе должны принимать участие не менее двух следователей. В УПК РФ вопрос о количестве участников допроса в виде следователей не регламентирован, а значит, четкого ограничения нет. Однако, открытым остается вопрос о роли второго следователя при допросе. Возможно, обязательное участие двух следователей обосновывается психологическим воздействием на подозреваемого, что понуждает его давать правдивые показания.

В отличие от допроса назначением очной ставки является устранение противоречий в показаниях ранее допрошенных лиц. Очная ставка может быть проведена между свидетелями, потерпевшими, подозреваемыми, обвиняемыми в любом сочетании. Из этого четко прослеживается цель данного следственного действия, которая не соответствует целям допроса.

Бытует мнение о том, что при подготовке и проведении очной ставки «применимы общие положения тактики допроса и тактические приемы, используемые при допросе» [1, с.399]. Практика, однако, показывает, что 
механическое перенесение правил допроса на очную ставку отрицательно влияет на раскрытие преступлений и расследование уголовных дел. Имеются случаи, когда очные ставки, проведенные по общим правилам допроса, не достигают своих целей, в связи с чем следователи отказываются от проведения данного следственного действия. Именно различные цели очной ставки и допроса позволяют выделить очную ставку в самостоятельное следственное действие, требующее разработки самостоятельной тактики его производства.

Изучая процессуальное законодательство Китая, можно отметить, что там отсутствует данное следственное действие, вне зависимости от формулировки названия данного следственного действия. Существенным будет вопрос о том, как в Китае при осуществлении расследования по делу следователи устраняют противоречия, ведь отсутствие противоречий в показаниях практически невозможно. Не устраняя противоречия в показаниях лиц при расследовании дела, следствие, при осуществлении своей деятельности может зайти в тупик.

В заключении хотелось бы сказать, что по нашему мнению, проведение такого следственно действия, как очная ставка значительно упрощает процесс расследования преступлений и помогает следователю выяснить данные, которые при простом допросе лиц выяснить не представляется возможным. Очная ставка, которую мы рассматриваем как самостоятельное следственное действие, требует дальнейшей научной разработки. Однако использовать опыт Китая по данному вопросу, к сожалению, не представляется возможным по причине отсутствия в уголовном процессе Китая такого следственного действия. Полагаем, что дальнейшее совершенствование действующего уголовно-процессуального закона РФ, регулирующего очную ставку, возможно с использованием практики иных государств, что представляет собой большое поле деятельности как для отечественных, так и для зарубежных ученых.

\title{
Литература
}

1. Криминалистика / под ред. С. П. Митричева, М. П. Шаламова. М., 1966. С. 399.

2. Уголовно-процессуальный кодекс Российской Федерации : Федеральный закон от 18.12.2001 г. № 174-Ф3// Российская газета. 2001. № 249.

3. Международная научно-практическая конференция "Сравнительное правоведение в странах АТР" [Электронный реcypc]. URL: http://www.bsu.ru/university/departments/faculties/uf/13244 (дата обращения 27.03.2016).

\section{Некоторые особенности тактики производства осмотра места происшествия в странах АТР}

\author{
(С Г.Ц. Эрдынеев \\ магистрант 2 года обучения юридического факультета \\ ФГБОУ ВО «Бурятский госуниверситет» \\ Россия, г. Улан-Удэ \\ garmazhap_2011@mail.ru
}

В целях обнаружения следов преступления и установления обстоятельств, имеющих значение для дела, производится осмотр места происшествия, в противном случае найденные фактические данные не смогут приобрести доказательственную силу. «Осмотр места происшествия - одно из самых важных следственных действий, поскольку позволяет не только обнаружить и зафиксировать материальные следы преступления, но и уяснить обстановку правонарушения, его механизм и масштаб» [1]. В зависимости от того, как умело следователь провел следственное действие, зависит качество и объем получаемой в ходе его производства информации, что в свою очередь вызывает правильный выбор средств и методов решения задач начального этапа расследования. В параграфе 4 главы 2 УПК КНР предусмотрен порядок проведения осмотра и освидетельствования при совершении преступления.

«Как известно, осмотр - понятие обобщающее. Оно объединяет в себе несколько видов этого следственного действия»[2].

Некоторые авторы считают, что местом происшествия в уголовно-процессуальном законе называется место, где произошло преступление, которое расследуется, либо то, которое в начале расследования принимается за место совершения преступления. Поэтому установление действительного места происшествия и его осмотр следователем имеют важное значение для расследования определенного преступления. Своевременный осмотр позволяет следователю получить ясное представление о характере события, причастности лиц и других обстоятельствах, подлежащих доказыванию.

Тактика осмотра места происшествия содержится в приемах, способах проведения осмотра места происшествия.

Существует несколько этапов проведения осмотра места происшествия (подготовительный, рабочий, заключительный). Осмотр места происшествия как часть процесса расследования связан не только с выявлением фактических данных, имеющих отношение к исследуемому событию, но также и с их фиксацией. Осмотр места происшествия - это неотложное следственное действие, заключающееся в непосредственном, визуальном обозрении лицом, ведущим предварительное расследование, каких-то материальных объектов, результаты которого отражаются в соответствующем протоколе. Фиксация результатов осмотра имеет исключительно большое значение для раскрытия преступлений и объективности следствия. Какие бы ценные доказательства следо- 
ватель ни выявил во время осмотра, они не будут иметь доказательственной силы без надлежащей фиксации. Точное и полное закрепление всего обнаруженного является обязанностью лиц, производящих осмотр места происшествия.

Закрепление обнаруженных данных при осмотре имеет две стороны: криминалистическую и процессуальную. Оно должно производиться на высоком научно-техническом уровне при строжайшем соблюдении норм уголовно-процессуального закона. Фиксация доказательств как определенное действие может осуществляться в начале, в ходе осмотра и в его заключительной части.

Уголовно-процессуальным законом предусмотрено, что в целях обнаружения следов преступления, а также выяснения других обстоятельств, имеющих значение для расследования уголовного дела, возможно проведение осмотра местности, помещения, предметов и документов, причем в случаях, не терпящих отлагательства осмотр места происшествия может быть проведен до возбуждения уголовного дела (ст. 176 УПК).

Таким образом, можно выделить цели следственного осмотра:

1. «непосредственное изучение следователем отдельного объекта (например, документа), совокупности или комплекса объектов (например, технологического оборудования, на котором производилась неучтенная продукция или с которым связаны преступные нарушения техники безопасности и охраны труда;

2. получение исходной информации для выдвижения типичных, общих и частных версий о событии, его механизме, участниках, личности преступника (а в необходимых случаях - и личности потерпевшего) и других обстоятельствах, подлежащих установлению по делу;

3. получение данных для организации розыска преступника по так называемым горячим следам и проведения других необходимых оперативно-розыскных мероприятий»[3].

Р. С. Белкин указывает на «возможность производства при осмотре места происшествия простейших действий опытного характера, направленных на уяснение обстановки на месте происшествия и решения других задач» [4].

Особенностью тактики производства осмотра места происшествия в России является то, что ему уделяется большое значение как процессуальному действию. От своевременного и правильного проведения осмотра зависит дальнейшее расследование совершенного преступления. В УПК КНР же осмотр рассматривается вместе с освидетельствованием, хотя в УПК РФ выделяет, что осмотр производится на местности, в помещении, на территории, а освидетельствование проводится в отношении живых лиц.

\title{
Литература
}

1. Уголовно-процессуальный кодекс Российской Федерации от 18.12.2001 г. № 174-Ф3 (с изм. и доп. вступ. в силу с 15.02.2014)// Справочно- правовая система «Консультант плюс».

2. Смирнов А. В., Калиновский К. Б. Уголовный процесс: учебник / под общ. ред. А. В. Смирнова. 4-е изд., перераб. и доп. М.: Кнорус, 2008. С. 393-394.

3. Тактика уголовного преследования и профессиональной защиты от него. Следственная тактика: науч.-практ. пособие / О. Я. Баев. М.: Экзамен, 2003. С. 75-76.

4. Белкин Р. С. Сущность экспериментального метода исследования в советском уголовном процессе и криминалистики. М.: ВШ МВД РСФСР, 1960.

\section{Типология производств о применении принудительных мер медицинского характера России и Китая на фоне западного права в свете нового Уголовно-процессуального кодекса КНР 2012 года}

() Юань И

кандидат юридических наук, дочент Политико-юридического университета Китая, научный руководитель магистрантов,

\begin{abstract}
Производство о применении принудительных мер медицинского характера в отношении лица, страдающего психическим расстройством, в Уголовно-процессуальном кодексе КНР 1979 года и поправке Уголовно-процессуального кодекса 1996 года ранее не существовало. В 2012-ом году это производство появилось на фоне без каких-либо мнений как самостоятельная глава, она с другими тремя главами вместе составила пятый раздел особый процесс, который станет одной новой независимой системой после раздела «Исполнение». Это разбило традиции линейной структуры Уголовно-процессуального кодекса, что считается прецедентом уголовно-процессуального права 2012 года.

По указанной причине изучение характера производства о применении принудительных мер медицинского характера очень мало. В настоящее время некоторые учёные предпочитают просто причислить его к числу предупредительных мер безопасности также, как в Германии и Италии. Например, учёный уголовного права КНР подчеркнул, что «на фоне реформы нового уголовно-процессуального права можно рассматривать предупредительные меры безопасности лица, страдающего психическим расстройством, определенные уголовным кодексом, то есть для этого уже есть достаточные юридические аргументы». Также некоторые учёные уголовнопроцессуального права тоже отметили: «принудительная медицина есть предупредительные меры безопасно-
\end{abstract}


сти». В связи с этим мы считаем, что необходимо обсуждение онтологии новопостроенного производства о применении принудительных мер медицинского характера. Ниже мы будем сравнить с реальным доказательством других соответствующих стран вышеописанные ошибочные мнения. Также мы будем обсуждать сущность производства принудительных мер медицинского характера КНР и РФ.

Во-первых, со стороны назначения кодекса приёмная система в отношении лица с психическим расстройством в уголовном законодательстве Германии, Италии и других стран континентальной ветви права является частью концепции «Предупредительных мер безопасности». Кроме принятия лица с психическим расстройством, в Германии эта система включает в себя принятие ещё преступника, у которого пристрастия к алкоголю или наркотику, и принятие рецидива преступлений. В Италии в систему включаются не только принятие в судебно-психиатрическую больницу - в Италии ссылались на преступников, у которых пристрастия к алкоголю или наркотику, в сельскую местность или место трудового перевоспитания, и отправляли рецидив преступлений и профессионального преступники в судебный исправительный дом. А в Китае и в России производство о применении принудительных мер медицинского характера в отношении лица с психическим расстройством является частью концепции «особого порядка», и не существует системы «надзорных мер» и системы «ненадзорных мер» уголовной системы, которая является частью концепции «Предупредительных мер безопасности» в Германии и Италии. В Китае и России тоже не существует двухколейной системы - меры традиционного наказания стоят рядом с «Предупредительными мерами безопасности», которые являются частью уголовной системы Германии и Италии. Более важно, что вместе с производством о применении предупредительных мер медицинского характера производства по уголовным делам в отношении несовершеннолетних и другие «особые порядки» не характеризуются «Предупредительными мерами безопасности». Это очевидно отличается от законодательных традиций в Германии и Италии, в которых мера принятия лица с психическим расстройством стоит рядом с «Предупредительными мерами безопасности» в одном ряду.

Во-вторых, по традиции Китая в сфере наказания относятся к рецидиву преступлений более строгим наказанием. Таким же образом Россия сохраняет эту традиционную идею наказания. В соответствии со статьей 18 УК РФ о рецидиве преступлений «Рецидив преступлений влечет более строгое наказание на основании и в пределах, предусмотренных настоящим Кодексом». В соответствии со статьей 68 о назначении наказания при рецидиве преступлений - «При назначении наказания при рецидиве, опасном рецидиве или особо опасном рецидиве преступлений учитываются характер и степень общественной опасности ранее совершенных преступлений, обстоятельства, в силу которых исправительное воздействие предыдущего наказания оказалось недостаточным, а также характер и степень общественной опасности вновь совершенных преступлений». А в Германии и Италии наказание для рецидивиста относится к концепции «Предупредительных мер безопасности». Иными словами, по характеру эти две меры принятия лица с психическим расстройством и принятие рецидива преступлений одинаковы, и оба относятся к концепции «Предупредительных мер безопасности».

Так как концепция «Предупредительных мер безопасности» совсем отличается от традиционной концепции наказания, предпосылка и предел наказания по традиционной концепции наказания есть ранее совершенные преступления, а под концепции «Предупредительных мер безопасности» в отношении лица с психическим расстройством в состоянии невменяемости, рецидива преступлений, преступники, у которых пристрастия к алкоголя или наркотику, и лица с психическим расстройством в состоянии ограниченной вменяемости, все имеют основы соответствующих наказанию «Предупредительных мер безопасности», т.е. по норме «опасность личности». Под этой концепции не могут быть привлечены к ответственности за ранее совершенные преступления и не наказываются за преступное действие. В то же время не существует предела наказания - по всей строгости, и лица с психическим расстройством и рецидивисты преступлений могут получать бессрочное наказание.

В-третьих, исходя из эволюции истории, можно кратко свести развитие и эволюцию применения принудительных мер медицинского характера России в «постепенный переход из принудительного заключения в применение принудительных мер медицинского характера». Это проиллюстрировано примерами: в 1801-ом году было принято бессрочное заключение к душевнобольным, потом в 1827-ом году превратилось в пятилетнее заключение; а впервые понятие применения принудительных мер медицинского характера было включено в пятнадцатый том «Свода законов Российской империи» 1832 года. УПК РСФСР 1922 г. дал специальную установку: «Если судом будет признано, что подсудимый во время совершения приписываемого ему деяния находился в невменяемом состоянии, то суд выносит определение о прекращении дела, причем входит в обсуждение проблем о необходимости принятия по отношению к подсудимому мер социальной защиты». На релевантной судебной практике существовали серьёзные проблемы в обеспечении данного права, например, следователи всегда самовольно принимали меры медицинского характера без решения суда, суд прямо решал принять меры медицинского характера без судебной экспертизы, психиатры самовольно разрешали отменять меры социальной защиты без решения суда, это привело к тому, что в первых 6 месяцах применения мер медицинского характера половина умалишённых больных вышли из больницы, среди которых одна из третьих сами сбежали из больницы). А впервые целой главой в УПК РСФСР 1960 г. установлено производство о применении принудительных мер медицинского характера (этот институт ещё несовершенный, русские учёные принимают целый судебный процесс лишь формальный и издеваются над протоколом судебного заседания в нескольких строчках). В УПК РФ 2001 г. полностью усиливали право на участие в судебном процессе для законного представителя, защитника и самого умалишённого больного и рационализировали процесс в области прекращении, изменения и продления при исполнении мер. 
Применение принудительных мер медицинского характера России развивается по закономерности «с наказания к лечению». Постепенно нормализовали процедуру и повысили процессуальное право умалишённого больного. Но не обратили внимание на метод и результат определения «опасности личности», только постепенно ослабляли его принудительный акцент и подчёркивали цель развития - «лечение занимает первое место, а принуждение является вспомогательной мерой». Профессор Игорь Леонидович Петрухин, ведущий учёный в области уголовного процесса России, подчёркнул в его произведении «Теоретические основы реформы уголовного процесса в России», что ключевое слово в словосочетании «применения принудительных мер медицинского характера» является «медицинским характером» и основная ценность этой меры заключается именно в лечении умалишённого больного. А все эти сильно отличаются от законодательной цели в «приёмных мер психиатрической больнице» в предупредительных мерах безопасности в Германии, которое не предпочитало лечение умалишённого больного, как основная цель, а предпочитало охранение общества от опасности, как своя цель. И при этом постепенно совершенствуется механизм определения будущей опасности личности преступника.

Из всего сказанного выше вытекает, что производство о применении принудительных мер медицинского характера, установленное Уголовно-процессуальным кодексом РФ 2001 года и Уголовно-процессуальным кодексом КНР 2012 года отличается от «Предупредительных мер безопасности» в западных странах. Мы считаем, что Производство о применении принудительных мер медицинского характера в КНР и России ещё не обладает функцией и ценностью «Предупредительных мер безопасности» по направлению процессуального права, его сущность представляет собой уточнённое медицинское производство в цели обеспечения лица с психическим расстройством. Не случайно выбрали создавать такое уточнённое медицинское производство, а потому, что это совпадает со способностью внутреннего убеждения судьи России и Китая. Именно из-за того, что судьи обеих стран не могут решать проблему об определении будущей опасности личности, приходится склоняться сделать законодательство в такую процедуру, которая лишь формально отражает обеспечение права человека.

\title{
Литература
}

1. Ши Яньань. Скрытая двухколейная система : анализ предупредительных мер безопасности в Уголовном праве. Изучение по юриспруденции. - 2013. - № 3.

2. Чень Вэйдун. Создание особенных уголовно-процессуальных производств с китайской спецификой. - Китайская юриспруденция. - 2011. - № 6.

3. Новейший уголовный кодекс Италии. Переводчик Хуан Фэн С, 81 Издат, 2007, Юридическое издательство.

4. В Уголовном кодексе РФ не существует специального положения о принудительных мерах безопасности, действующий Уголовный кодекс РФ 1996 года только устанавливает отдельный специальный раздел в соответствии с Уголовно-процессуальным кодексом, и называется этот раздел «Предупредительными мерами медицинского характера» и дальше другими мерами уголовного свойства, с начала до конца, всегда следовал традиции одинаковой системы.

5. Ст. 326 УПК РСФСР 1922г.

6. Глава 33 Уголовно-процессуального кодекса РСФСР.

\section{Analysis of the Evolution of Criminal File Transfer System in China}

\author{
(C) Bu Yangyang \\ Ph.D candidate from China University \\ of Political Science and Law
}

\begin{abstract}
In terms of the selection of criminal file transfer mode, the Criminal Procedure Law in China has experienced a cycle evolution, from the transfer of all files to the transfer of main evidence copied, and then back to the transfer of all files again. In the views of some scholars, the return to the all files transfer mode before trial confirmed in the revision of Criminal Procedure Law in 2012 is a retrogression, falling back to the initial state in 1979, which means the failure of the reform of limiting the file scope from the procuratorates before trial in 1996. It also leads to the pretrial prejudgment inevitably, deteriorating the nomination of court trial. Therefore, in order to fully understand and fairly judge the current file transfer system in China, it is necessary to make an in-depth study and reflection on the "twists and turns" of criminal file transfer system in China.

Key Words: File transfer, transfer of all files, transfer of copies of main evidence, pre-trial prejudgment

I. All File Transfer System in 1979's Criminal Procedure Law

In order to reestablish the socialist legal system, after the end of Cultural Revolution in 1979, the first criminal procedure code was issued after the establishment of new China. Under this code, the procuratorates shall transfer all the files to the court to initiate a public prosecution, and the court shall perform the public prosecution review and prepare for the court based on the files. In the same time, the court has the power to investigate and verify the facts and evidences outside court during the public prosecution review. During the public prosecution review, the judge has power to arraign the defendant and verify the evidence through inquisition, inspection and authentication. On the basis of all file review and investigation and verification outside the court, the trial procedure will only initiate under clear facts and sufficient evidences; while for the cases with unclear facts and insufficient evidences, the court can send back to the procuratorates for supplementary investigation. So to speak, the all file transfer system in 1979's Criminal Procedure Law has a strong inclination of public prosecution with strong $\mathrm{d}$ color of functions and powers doctrine.
\end{abstract}


On one hand, as a component part of state authority dominant litigation model in civil law system, the all file transfer system gives the judge more opportunities to get a full picture of the facts and evidences and enough time to prepare for the court, so that the criminal task as crime punishment can be fulfilled more efficiently; on the other hand, in most cases, the judge who carries out the public prosecution review and the presiding judge is the same one, so if the all file transfer system is adopted in these cases, the primary opinion of the judge based on the files sent by the procuratorates was easy to form a pre-trial prediction. More importantly, starting the trial procedure on the basis of clear facts and sufficient evidence which needs to go through a substantive examination of the case actually implies that the judge takes the defendant as guilty with convinced heart [2, P. 16-21]. if a case is decided as to be up to the hearing standard. Under this system, it is hard to ensure the neutrality and impartiality of the hearing. Also, the all file transfer system is not only a pre-trial prediction, even worse, it is a pre-trial judgment, which making the hearing a mere formality [3, P. 238]. Therefore, the all file transfer system is inevitably connected with problems of pre-trial prediction, judge by hearing, and the formality of hearing. It is exactly based on these considerations that more and more opposing voices were aroused against the all file transfer system.

At the same time, with the opening and reform going deep, the two legal systems in the world begin to show trends of integration. The same things happen in criminal law. More and more eyes were put on the development of criminal procedure law outside China. More and more studies were carried with expectations to absorb and draw lessons from the advantages of the adversarial system in common law system so as to make a reform of the all file transfer system in China. According to the mainstream views at that time, the all file transfer system reform shall go along with the way to abolish the pre-trial substantive examination, in order to avoid records reading before hearing [1]. Therefore, the Indictment-Only Doctrine which possesses the typical traits of common legal system was accepted with appreciative applause in China.

II. Major Evidences Copied Transfer System in the reform of trial mode in 1996.

In1996, responding to the judicial reality, the legislature made an extensive modification and improvement of the 1979's Criminal Procedure Law in 1979m specific to the problems in the 20 years, so as to fulfill the goal of trial mode reform. In a sense, this modification of the criminal procedure law was based on learning and absorbing the advantage of the Adversary System with a purpose to raise the importance of the parties and reduce that of the judge, so as to form a new litigation mode with more counter argument between the two parties [1]. In particular in the pre-trial file transfer system, the substantively review was replaced by formal examination and the All File Transfer System was turned to Major Evidences Copied Transfer System. To be exact, when the procutatorates present a public persecution, the court shall decide whether to hear the case based on a formal examination, which only needs to see whether the files presented include crime facts, evidence list, witness list and the copies of major evidences, rather than a substantive review which ask a standard of clear crime facts and sufficient evidences. At the same time, the judge's power to investigate and verify the evidence was abolished, so as to clear the pre-trial procedure and the hearing procedure and prevent the normalization and generalization of the investigation and verification power.

Actually, Copy Transfer System is a mixed system with Chinese characteristics, which incorporate the investigation of judge with counter argument in a court. The design of this system, on one hand, refrain from the problem of prediction and judgment before hearing of the substantive review and all file reading; on the other hand, it ensures the rights to information of the judge, making preparation for the hearing and the control of the court's procedure. However, this litigation mode without matching system will lead to many problems in the criminal judicial practice.

First, the unilateralism in define of the major evidences makes the judge far from a fair and clear heart. According to the Regulations on Issues of the Enforcement of Criminal Procedure Law (Hereinafter referred to as Regulations of Six Ministries) issued in 1998, the People's Procuratorates can decide the scopes of the «major evidences»; however, the People's Court cannot refuse to hearing a case based on insufficient evidences.

Second, the Copies Transfer System seriously impedes the efficiency of the court's proceeding, from which a adaption system was from, that is File Transfer System after the Hearing. In China, judge in criminal court was used to prepare for the hearing by reading and studying file-transcripts. However, the partiality, arbitrariness and flexibility of the Procuratorates's definition on the Major Evidence cannot meet the physical and working needs of the judge in criminal court, which make it hard for the judge to prepare for the hearing. The court investigation and argument will hereby be influenced when the focus of disputes was not so clear. At the same time, the Copies Transfer System objectively restricts the lawyer's reading right before the trial which makes the judgement can only be based on the selected file transcripts and sectional court reading of the procuratorates. Under the integrated influence of pursuing substantive justice and system of judge account for the case, judge in criminal court is hard to make judgment, so can he only resort to investigation and verification outside the court or within the court, which badly affect the efficiency of the trial.

III. The Return of All Files Transfer System in 2012's Criminal Procedure Lawю

In 2012, the legislature again made a big amendment of the 1996's Criminal Procedure Law. To be specific in file transfer system, aiming at the problems brought by the Copies Transfer System, the 2012's Criminal Procedure Law return to the All Files Transfer System before the trial. That is when the Procuratorates initiates a public prosecution, all the files about the case shall be transformed to the court. The "twists and turns" legislation on the file transfer system again aroused a great debate between the scholars. The return of the All Files Transfer System still faces the criticism of prediction and the formalization of the trial. Since the All Files Transfer System established in the 1979's Criminal Procedure Law was full of defeats and problems, it is confusing that the legislature chose to come back to this system.

On one hand, the All Files Transfer System ensures the needs of judge to read all the files before hearing, which give the judge more time to prepare for the trial and better control of the court's proceeding. As previously mentioned, 
in the criminal justice practice in China, the judge who carries out the public persecution review will also be responsible for the hearing of the case, who also have the adjudicative right on the decision of the facts and the legal application. If the judge cannot read all the files of the case before hearing, only with the copies of the major evidences obviously the judge cannot fully understand the claims of the two parties and the focus of the dispute. In turn, the procedure problem which is irrelevant to the conviction and sentence of a case cannot be completed before the hearing, which will easily lead to the undue delay of the case and fragmentary of the trial. At the same time, the fail to prepare for the trial based on the reading of all files makes it hard for the judge in criminal court to control the court investigation, defense and the hearing of the case.

On the other hand, the return and reestablishment of the All Files Transfer System before the trial gives the lawyer right to read the files. The defense lawyer's right to read the files, the fundamental and conditional right of the defense lawyer, plays an important role in the defense. The reading right makes a big difference on the preparation of the defense, and further influences the advice of the lawyer. However, the Copies Transfer System in 1996's Criminal Procedure Law is not only a deprivation of the reading all files of the judge, but also a limitation of the defense lawyer's reading right.

\title{
Bibliography
}

1. Above $\mathrm{n} 1$.

2. Chen Ruihua, Development and Thinking on the File Transfer System [J]. Forum of Politics and Laws, 2012(5), 16-21.

3. Li Xinjian, Study on the Structure of Criminal Procedure [M]. China University of Political Science and Law Press, 1992,238 .

\section{On Jurisdiction of Terrorism Crime Lawsuit in China}

\author{
(C) Gui Mengmei \\ Doctor of laws \\ China University of Political Science and Law
}

\begin{abstract}
As a serious crime affected by multiple factors, the criminal proceedings of terrorism crime possesses certain particularity. For instance, some important issues of contentious jurisdiction, witness protection and the construction of the criminal special proceedings procedure are worth of more attentions. This paper analyzes the terrorism crime jurisdiction from two perspectives of international law and domestic law, and further puts forward improvement measures of Chinese legislation to facilitate the understanding on relevant problems of terrorism crime jurisdiction in view of the government by law.

Keywords: terrorism crime, jurisdiction, legal provisions, improvement

Aiming at the new situation and new characteristics of violent terrorist crimes in recent years and summarizing the struggle experience against this type of crime, the punishment on terrorism and extremism crimes has been strengthened in Chinese Ninth Amendment to Criminal Law to maintain public security. On December 27th, 2015, the eighteenth meeting of the Twelfth National People's Congress Standing Committee approved Anti-Terrorism Act of the People's Republic of China (hereinafter referred to as Anti-Terrorism Act), which will be put into force from January 1 st, 2016. This act includes ten chapters and 97 clauses in total. The main contents include general principles, identification of terrorist organization and personnel, security protection, intelligence information, investigation, response and disposal, international cooperation, safeguard measures, legal liability and supplementary provisions. The important contents involved in criminal proceedings include that intermediate and above people's court with jurisdiction right can legally recognize terrorist organizations and personnel, require terrorist suspects to comply with one or more constraint measures and provide one or more protective measures for the witnesses and their close relatives in the process of criminal cases trial. Jurisdiction is the first problem to be solved in criminal proceedings. The analysis on jurisdiction system of terrorism crime from two aspects of international law and domestic law is conductive to understanding and grasping the status and complete idea of Chinese proceedings jurisdiction of terrorism crime.
\end{abstract}

1.The connotation of terrorism and terrorism crimes

It is the necessary prerequisite to correctly understand terrorism for interpretation of terrorist crimes. However, the international applicable legal concept for terrorism hasn't been formed yet. In 2001, Shanghai Cooperation Organization Member States signed Shanghai Convention on Combating Terrorism, Separatism and Extremism, which defined "terrorism" in the international scope for the first time. The convention includes two aspects: One is the act identified and defined as crime by one of the ten anti-terrorism treaties listed in the Convention annex. The other is the act will lead to death or serious personal injury on civilian and other personnel who don't actively participate in military actions or heavy losses on substance target under armed conflicts, behaviors of organizing, planning, conspiring or instigating above activities. This provision can clearly explain the basic connotation of terrorism.

There are also different understandings on the definition of terrorism crime. International society carried out the first legislative practice of terrorism in Convention on the Prevention and Punishment of Terrorism in1937. Terror is directly opposed to a certain country, the purpose and nature of which are to commit horrible crimes among individuals, groups or the public. Furthermore, the convention lists various terrorism acts. Concise Encyclopedia Britannica also gives a general explanation for terrorism. European Convention on the Prevention of Terrorism promulgated in 1977 
lists a few kinds of terrorism crimes including illegal aircraft hijacking, kidnapping, hostage hijacking, applicable bomb endangering personal safety, etc [3]. Chinese theory and practice circles have also experienced a deepening process of understanding on the terrorism crime. For instance, the terrorism crime is understood as a criminal offence with serious social harmfulness, rather than a political crime, or even without political purpose. The non political definition is more conducive to reaching agreement on the understanding of terrorism crime for international community. Some scholars pointed out that the terrorism crime had evolved from the treaty crime regulated by domestic criminal law to "international crimes" under the "international law". Many countries and scholars believe that its judiciary should be carried out by judicial organs at the international level [4]. Although the theory circle and practice circles haven't reached an agreement on the definition of the terrorism crime, its basic element can also be summarized as follow: Firstly, the terrorism crime possesses the political intention to convey information to the government or the international community. Therefore, some scholars called it as "political violence". Of course, other purposes such as "philosophical, ideological or religious" shouldn't be excluded. [8, P.144]. Secondly, under the background of globalization, terrorism crime generally possesses "internationality". Its organization, support and implementation can often spread across borders. Thirdly, the victims are also uncertain, which is conducive to making unpredictable terror atmosphere and triggering a massive social panic. Finally, the terrorism crime often possesses a certain organization, which is from the individual and loose ordinary criminal offence.

Article 3 of Chinese Anti-Terrorism Law clearly defines terrorism crime as the proposition or behavior which will perpetrate social panic, endanger public security, violate personal property or threaten national agency and international organization to realize political and ideology by means of violence, destroy and threat.

2.The provisions of international law on terrorism criminal jurisdiction

Basing on the long-term judicial practice, international law has covered a series of principles including territorial jurisdiction, personal jurisdiction, protective jurisdiction, flag state jurisdiction and universal jurisdiction. Since terrorism crime is an international crime, since 1960s the universal jurisdiction principle has been explicitly stipulated in more than ten multilateral international conventions on anti-terrorism approved by the United Nations including International Convention on Stopping Terrorist Explosions and International Convention on Severing Financial Aid to Terrorism to maintain the overall interests of human beings and the litigation function of jurisdiction principle itself. This principle is also embodied in Article 9 of Chinese Criminal Law. The so-called universal jurisdiction principle, also known as the "cosmopolitanism", takes the protection of the common interests of all countries as the standard. It considers that for all crimes which infringe the common interests of all countries stipulated in international treaty shall, the contracting states or acceding states can exercise criminal jurisdiction once they find the crime within their field regardless of offender's nationality or the property of the guilty place [9, P. 96]. The application of the universal jurisdiction principle in international law is of great significance for the punishment of terrorism crime.

After the Rome Statute of the International Criminal Court (hereinafter referred to as Rome Statute) went into effect in 2002, the permanent organization of international criminal court was set up. More and more experts and scholars have advocated bringing the international terrorism crime into their jurisdiction. According to the provisions of the statute, the jurisdiction of the International Criminal Court is only limited to the four categories of serious crimes attracting the most attentions from international community including crime of genocide, crimes against humanity, war crimes and aggression crime, whereas terrorism crime is not included. This has become an obstacle for jurisdiction on terrorism crime by International Criminal Court to a great extent. Despite these problems, there are some countries including Russia, India, Turkey, Libya suggest that the statute should make stipulations on the terrorism crime. Some Chinese scholars have pointed out, since political factors may be involved in the international terrorism crime, it's a better choice to submit it to the international criminal court, rather than extraditing the suspect to his country. This is undoubtedly" a more elegant solution". The author believes with the continually increasing non-traditional security threatening under the background of globalization, it has been necessary to take the International Criminal Court as an alternate subject of international terrorism crime jurisdiction at least. In fact, in the applicable universal jurisdiction principle litigation, the basis of substantial law is the domestic criminal law rather than international treaties. Because the international treaty doesn't provide legal punishment for crimes, but require the contracting states or acceding states to stipulate the crimes listed in international treaties as the crimes in domestic criminal law.

3.The jurisdiction mode of domestic law on terrorism crime

The terrorism crime is generally stipulated in criminal substantive law and procedural law by each country. Therefore, in the whole criminal proceedings process of registration, criminal investigation, prosecution, trial and execution, there is often some special experience and practices in each country. For example, after the outbreak of 9.11 attack, on the one hand, America stipulated the terrorism crime jurisdiction in criminal law or anti-terrorism special law, on the other hand, the specialized jurisdiction mode different from the ordinary legal case was formed. In the aspect of criminal substantial law, some countries make stipulation for terrorism crime jurisdiction in criminal laws, such as French Criminal Law and Italian Criminal Law. Some countries have made specific anti-terrorism laws to further explicit or supplement the jurisdiction of terrorism crime, such as Singapore and Australia [5].

There are three typical patterns of terrorism crime jurisdiction system in criminal procedural law all over the world: The first one is the "dual-track system" jurisdiction pattern represented by America. The second one is the specialized court jurisdiction pattern represented by Spain and India. The last one is the common court jurisdiction pattern represented by France and Germany. The so-called "dual-track system" refers to the jurisdiction pattern with the coexistence of common court and the special court martial. After the outbreak of 9.11 attack, the United States adjusted the trial jurisdiction of terrorism crime committed by foreign citizens. The terrorism crimes committed by citizens from any 
countries are governed by common courts before, which was converted to that non American citizens would accept exclusive jurisdiction by the anti-terrorism military court. For the purpose state security and crime control, this jurisdiction mode deviates from modern judicial ideas of a considerable degree of deviation from the trial publicly, equal confrontation and human rights protection to a great extent [1, P. 200]. Spain and India set up a special court to carry out terrorism crime jurisdiction in the judicial system. In Spain, the national high court has an exclusive jurisdiction over terrorism crime cases. In India, the central and local government can specify special court to give a jurisdiction over the terrorism crime cases. In France and Germany, the common courts have jurisdiction over terrorism crime cases. In France, the trial jurisdiction of terrorism crime which constitutes a misdemeanor of is more flexible. Either the regional misdemeanor court or Paris misdemeanor court can have jurisdictions over terrorism crime cases. As for the terrorism crime which constitutes heavy offense, Paris felony court will has exclusive jurisdiction. In Germany, the regional, local and federation common court will have terrorism jurisdiction over terrorism crime. However, comparing with the ordinary criminal offence, the countries adopt common court jurisdiction will generally consider improving the trial level to ensure the stable trial of complex and sensitive terrorism crimes.

4.The stipulation and improvement of Chinese contentious jurisdiction over terrorism crime

Due to the spread of terrorism in the world, terrorist activities in China have entered into the active period, even the "local war" period, which could be sufficiently proved by violent and terrorist cases in Xinjiang and Kunming [6]. In order to effectively punish terrorism crime, Anti-Terrorism Law has been formulated in China. The crime terrorism jurisdiction has achieved more attentions. However, there are still some defects of the stipulations on crime terrorism and its jurisdiction in Chinese criminal law to be further improved.

Chinese criminal procedure code and related judicial interpretation (such as Opinions on Several Issues Concerning the Application Law of Violent Terrorism and Religious Extremist Criminal Cases in 2014) stipulate the litigation issues of terrorism crime. However, the current criminal procedure law hasn't given special provisions on the jurisdiction of the terrorism crime. In Criminal Procedure Law modified in 2012, the terrorist activities are classified into the first instance jurisdiction of the intermediate people's Court. Thus the trial level of terrorism crime has been promoted, which is similar to the jurisdiction mode of foreign common courts. The author believes that on the basis of circuit court jurisdiction and cross-district court jurisdiction put forward under the current judicial reform, the terrorism crime could be judged either by cross-district concentration jurisdiction or local higher people's court. Furthermore, its investigation and prosecution should be under the jurisdiction of provincial department. Of course, it's not suitable for China to follow the example of American specialized anti-terrorism crime military tribunal to carry out exclusive jurisdiction for terrorism crime.

\title{
Bibliography
}

1. Chen Guangzhong. Recent Development of Criminal Procedure Law Outside Mainland China in the 21st Century [M]. China University of Political science and Law Press, 2004.

2. Decision on Amendding the Criminal Procedure Law of the People's Republic of China in accordance with the decision. Beijing University Press[M], 2012.

3. Gou Xin. Studies on Counter-terrorism Policy of EU After 9/11 Terrorism Attacks. China Renmin University Press, 2009. 2007.

4. Huang Wenxu. On the International Criminal Court's Jurisdiction on the Crime of Terrorism[J]. Jiangxi Social Sciences,

5. On December 4th, 2014, Austrilia introduce new Anti-Terrorism Law, which stipulates terrorism crime litigation jurisdiction; Singapore Anti-Terrorism Law also stipulates crime jurisdiction.

6. Refer to Xinjiang Public Security Department Offer a Reward of 50,000-100,000 yuan to Search Clues of Terrorism Crime, media reports that anti-terrorism situation in xinjiang is in a state of "war period", and the armed police bear serious anti-terrorism task.

7. 2. www.npc.gov.cn. Shanghai Convention on Combating Terrorism [M], Article 2.

8. 5. Zhao Bingzhi. Thematic Exploration on International Criminal Law and International Crime[M]. Press of People's Public Security University of China, 2003.

9. 6. Zhang Mingkai. Science of Criminal Law[M]. Law Press of China, 2011.

\section{Application of Detention in Crimes of Drug Trafficking in China}

\author{
(C) Wang Shaojia \\ Ph.D candidate in China University \\ of Political Science and Law
}

\begin{abstract}
Based on the characteristics of drug trafficking offenses and their own shortcomings of criminal detention, detention may no longer apply to the crime of lightweight drug trafficking. The first-time offender who trafficking in heroin, methamphetamine less one gram or considerable number of drug, may be sentenced to more than one year to two years of public surveillance, focusing on personal freedom constraint to prevent recidivism; while for repeated offenders, the starting point of sentence may be upgraded more than one-year imprisonment, in order to enhance the function of education and reform. Thereby forming a progressive way of punishment combining constrained freedom and Education Reform function.
\end{abstract}

Keywords: crimes of drug trafficking; detention; renovation. 
1. The origin of the problem.

In recent years, China's drug-related crimes continued to show a growth trend, and spread to small cities and regions. While the drug problem is invading the southeast coast and the Southwest area of China, the Northwest Territories has gradually become the hardest hit area by drug crime [3]. Drug crime is beginning to show a situation of «everywhere». China is always in a high-pressure situation in fighting against drug-related crime, but it does not seem to bear fruit.

At present, the ratio of drug crime reoffending and recidivism are very high. From 2007 to 2013, among all the offenders of drug crimes, there are 59,899 offenders who are drug reoffending, accounting for 12.69 percent, which is a high proportion. Among drug reoffending, some offenders commit drug-related crimes again during the period of probation, parole test or temporary execution outside prison [2]. According to the situation informed by Chengdu Intermediate People's Court, the ratio of drug crime reoffending in 2014 is $11.45 \%$, while the ratio of drug crime recidivism is 6.32 percent [4].

By collecting and observing cases of the crime of drug trafficking, we find: At present, for the crime of drug trafficking are mostly used on summary judgment, and in most cases are sole-judge trial; in sentencing, the ratio of detention in punishment of lightweight drug trafficking is high. Summary procedure, punishment of detention, sole-judge trial, and brief judgment documents, etc., these trial characteristics have shown that the trials of small quantities of drugs trafficking tend to be simply and rapidly. The problem is that the courts' quickly acting on and sentencing penalties to drug trafficking through judicial proceedings, has met the requirements in time penalty, but a lot of offenders select to return to prostitution after their sentences of three or four months of detention, the ratio of drug trafficking recidivism is still high. This makes us to doubt whether the current punishment system in Penal Code can really play the role of prevention and punishment in the crime of drug trafficking or not, and in Chinese drug trafficking penalties, the question whether the application of detention is appropriate is worth to review.

2. Reservations of the detention in crimes of drug trafficking.

There is a very clear conclusion about the question that whether the criminal detention should be abolished from the whole the punishment system, most people, including myself, believe that criminal detention is indispensable in China's detention punishment system. The most important reason is: detention punishment is an important part of the transition from light to heavy punishment, it makes the whole punishment system to be strict and intact, so that we can meet the basic principles of Chinese Criminal Law that «the punishment must fit the crime», so that we can avoid the disconnect between different kinds of punishment.

Meanwhile, although the detention is short deprivation of liberty punishment, but it is still different with imprisonment, for example, offenders who are sentenced criminal detention have the right to return home to visit relatives and so on. Therefore, the Supreme Court is very cautious and denies the alternative execution between criminal detention and imprisonment or other punishment. In the «Telephone Reply of Supreme People's Court Research Department on Implementation of Imprisonment When Found Guilty in Concealing the Crime during the Implementation of Probation», the Supreme People's Court said that «we cannot agree to convert the fixed-day deprivation of liberty punishment of criminal detention to complete deprivation liberty penalty of imprisonment, this question may leave to be resolved by the NPC Standing Committee». Therefore, abolishing the criminal detention punishment from Chinese criminal punishment system is not feasible. However, whether criminal detention is fit to drug crimes, or only fit to the crime of drug trafficking, we still have doubt on this question. We need to discuss this issue by returning to drug crimes' own characteristics and the detention's own shortcomings.

There are two main reasons for the high rate of drug trafficking crime reoffending: First, drug-related crimes can bring economic benefits to the drug traffickers, many offenders choose trafficking drugs as source of income for their lives, the interests drive them to choose their old way of survival or «making money» after their punishment of shortterm freedom. Meanwhile, drug trafficking has characteristics of easy be hidden and difficult to be detected. Drug offenders often use the way of «small quantity, many times, mobile way» to traffic drug, they divide the drug into small bags at the standard of less than one gram per package, and set a price for per package [3]. If the offenders have not been identified as the suspect in advance, these crimes behaviors are hardly to be noticed. This has exacerbated the tendency of the drug crimes «favored» by the offenders compared to other classes of property crimes. Therefore, not only there are many drug crimes, but also there are many reoffenders.

Second, the punishment of criminal detention is not enough for the transformation for the crime of drug trafficking. For which the criminal detention has always been criticized, and for which the reason to abolish the punishment of crimes detention is that the effect of too short period of freedom punishment in transformation is not enough. In 1968, a group of fourteen criminal law teacher in Federal Republic of Germany published «Alternative Draft of Penal Code», advocated the abolition of imprisonment less than six months, since a shorter period of time than it is impossible to achieve the purpose of transforming the offenders from bad to good. After the rise of the penal reform movement worldwide, many countries have realized the shortcomings of such a short-term freedom punishment just like criminal detention [1].

Criminal detention focuses on short-term deprivation of liberty, and so as a punishment. The punishment is not complete isolation, and is executed by the nearest public security organ in the detention place, and the offenders can go home for one or two days per month. Criminal detention is weaker compared to prison in the effect of education and reform, and interruption of isolation brought by going home to visit relatives will cause an interruption of transformation effect. And the period of criminal detention is short, making it only be the protection measures to limit the offend- 
ers from reoffending the crime of drug trafficking within several months. Thus, criminal detention is not preferable for the crime of drug trafficking in the punishment system.

3. Approach for lightweight drug trafficking punishment.

The prevention and transformation of lightweight drug crimes should focus on the supervision and education to offenders, and we cannot achieve the goal simply by limiting the effect of personal freedom. The author believes that the effect of short-term freedom punishment is focused on the punishment effect on minor disciplinary offenses, and is more suitable for minor criminal negligence and violent crime, for such crimes have less characters of persistent and reoffending on criminal intent, and the probability of reoffending is little after the short-term freedom punishment. It is not entirely due to the transformation function of short-term freedom punishment, but mainly depends on the features of this crime. In contrast, short-term freedom punishment cannot play a role in long-term prevention of crimes like drug crimes. Light punishment can only be used to transform offenders whose inferiority are minor, and for offenders whose inferiority are large, the goal of transformation may only be achieved by severe punishment to exert complete deterrent, or by long-term transform education to complete the transformation of offenders' ideology.

Under the trend of light punishment in the penalty, it is clearly contrary to the trend to not apply criminal detention to the crime of drug trafficking but lifting a scale of punishment to imprisonment, besides, a minimum sentence of imprisonment is six months, and too short term cannot achieve the goal of transformation, while too long term is not fit for the social harmfulness of drug crimes and also be contrary to the principle of suiting punishment to crime, and this is not desirable.

In view of the above situation, the author suggests to regard control as a common punishment for lightweight crimes of drug trafficking, and the punishment may directly upgrade to more than one-year imprisonment for drug reoffenders. The reasons are as follows: First, the term of control is long to two years, which is an ideal education correction period. Second, the control punishment is lighter, and is fit for the social harmfulness of lightweight crime of drug trafficking, and conform to the trend of light punishment. Third, to the offenders who are sentenced to control, we can prohibit them from being engaged in specific activities, going to specific areas, accessing to specific people during the implementation. We can also achieve the function of protection by limiting offenders going into bars, Internet cafes and other drug trafficking prone areas. Fourth, offenders sentenced to control shall be subject to community correction, which can not only prevent cross infection caused by the execution of criminal detention, but also avoid the maladaptation caused by punishment of depriving freedom when the offenders return to society. At the same time, it is conducive to the education effect by contacting with positive information and human groups in the social. Fifth, sentencing the reoffenders of drug trafficking to more than one-year imprisonment, on the one hand, is because there is an earlier punishment of control, which is a warning to the offenders, on the other hand, more than one year imprisonment is to ensure improvement effects of education sustained, so as not to make the punishment of depriving freedom only be the protection measures to limit the offenders from reoffending the crime of drug trafficking within several months.

\section{Bibliography}

1. Deng Youtian, Deng Xiuming. «On the abolition of detention punishment», law Research, August 23, 1989.

2. Gao Guijun, Ma Yan, Li Jingran: «The main features of the current Chinese drug crime and suggestions to strengthen the anti-narcotics work», People's Court News, June 26, 2014.

3. Kun Dulun District Court network, «2012 - 2014 Drug Crime White Paper»,
http://kdlqfy chinacourt org/public/detail.php?id=699.

4. Sichuan News Network, «Severe drug crimes in Chengdu reduced and drug recidivism is at a high rate», http://scnews.newssc.org/system/20150624/000575552.html.

\section{Reform and Development of China's Prosecutor's Case Handling Responsibility System}

(C) Zhang Zichao Ph.D in law

The prosecutor's case handling responsibility system literally means the system in which prosecutors and their case handling organization are responsible for the cases they are handling. However, in reality, in procuratorial work, the prosecutor's case handling responsibility system involves prosecutors as the basic case handling organization, the organization mode and case handling mechanism formed by prosecutors during case handling, and the job security and supervision mechanism securing prosecutors to independently perform their duties.

1. Reform of China's prosecutor's case handling responsibility system.

The prosecutor's case handling responsibility system has undergone a process of constant exploration and development. At the end of the 20th Century, some local procuratorial organs proposed ideas about reform of the case handling responsibility system. After investigation and demonstration, the Supreme People's Procuratorate adopted the main-suit prosecutor's case handling responsibility system[1]. In 1999, Working Scheme Concerning Trial Implementation of the Main-Suit Prosecutor's Case Handling Responsibility System was printed and distributed, and was experimentally implemented in 10 provincial or municipal procuratorates. In January 2000, the Supreme People's Procuratorate issued Working Scheme Concerning Full Implementation of the Main-Suit Prosecutor's Case Handling Responsi- 
bility System in the Department Responsible for Examination before Prosecution, which began to be implemented across China. Initially, good results were achieved; some regions also sought to introduce chief handling prosecutors in other business departments. In May 2000, the Supreme People's Procuratorate issued Suggestions on Experimentally Implementing the Chief Handling Prosecutor's Case Handling Responsibility System in the Investigation Departments of Procuratorial Organs, and experimentally implemented the chief handling prosecutor's case handling responsibility system in the investigation departments of some procuratorial organs[2]. Later, as supporting measures were not sufficient and also due to some other factors, these reforms largely stagnated, but some regions are still continuing with these reforms.

According to the requirement of the central government in the recent reform of the judicial system that «the handler of a case should be held responsible for the case, and the maker of a decision should be held responsible for the decision», in December 2013, the Supreme People's Procuratorate proposed the reform scheme of «improving case handling organization, and enhancing prosecutors' responsibility for case handling», and printed and distributed Scheme for Pilot Reform of the Prosecutor's Case Handling Responsibility System, deciding to experimentally implement the head prosecutor's case handling responsibility system [3] in 17 procuratorates in 7 provinces and establish the prosecutor's case handling responsibility system based on the head prosecutor system. In the first half of 2014, the Central Politics and Law Committee experimentally implemented four reforms of the judicial system: «improving the judicial responsibility system, improving the system for classified management of judicial personnel, improving judicial personnel» job security system, and promoting unified management of human, financial and material resources in local courts and procuratorates under the provincial level. A major reform measure was to promote the policy of appointing a specified number of prosecutors that account for not more than $39 \%$ of the establishment of judicial, procuratorial, and public security organs. After the implementation of this policy, this specified number of prosecutors have become comparatively elite, highly corresponding to the experimental practice of selecting around $1 / 3$ of existing prosecutors as head prosecutors. Therefore, with the implementation of this policy, the head prosecutor's case handling responsibility system has been identified as the prosecutor's case handling responsibility system.

2. The current situation of the reform of China's prosecutor's case handling responsibility system

Based on experiments across China, in September 2015, the Supreme People's Procuratorate printed and distributed Opinions about Improving the Judicial Responsibility System of People's Procuratorates. This is an important guiding document developed to improve the exercising mechanism of procuratorial powers and the judicial responsibility system of procuratorial organs, mainly covering:

The prosecutor's duty and extent of power

«Powers must be specifically vested by law, and duty must be performed within the legal extent of power»[4]. A prosecutor performs his/her duty according to law and as delegated by the chief procurator. As to what powers a chief procurator can delegate to a prosecutor, a provincial procuratorate can develop lists of the powers of the prosecutors in the jurisdiction based on procuratorial business types and forms of case handling organization to delegate some of the powers of a chief procurator to other prosecutors. Prosecutors are major roles in judicial case handling, though judicial case handling cannot be fulfilled only by prosecutors, and require the involvement of diversified procuratorial personnel[5]. However, some important case handling related matters shall be done by prosecutors personally to better secure legal validity, better meet the requirement of personal judicial experiencing, and ensure judicial case handling quality.

Procuratorial organs' judicial case handling organization.

Case handling organization is a vehicle for the exercise of procuratorial powers, the basis of the judicial responsibility system. There are two forms of case handling organization: the sole prosecutor, and the case handling group of prosecutors. The case handling group can be either relatively fixed or be organized on a case by case basis. The responsible person of a case handling group is the head prosecutor who is responsible for organization, direction, coordination and management of case handling group members, and for decision making concerning case handling related matters or for giving suggestions for case handling.

Modes of procuratorial business operation.

Logically, reform of the prosecutor's case handling responsibility system involves two interacting basic aspects: the positioning of a prosecutor (namely, the power and responsibility of a prosecutor) and ways of procuratorial case handling[6]. China's procuratorial organs have not only the right to ratify an arrest, the right of public prosecution, and the right of investigation, but also the right of legal supervision, the right to judicial remedies and the like. Procuratorial powers are judicial, administrative and supervisory. Therefore, different types of procuratorial business should be operated differently:

1. Cases of reviewing an arrest and reviewing prosecution can normally be handled by sole prosecutors. However, in case of important, difficult and complicated case, such cases can be handled by case handling groups of prosecutors. In these cases, business department heads no longer examine and approve the cases; sole prosecutors and head prosecutors are directly responsible to chief procurators.

2. Cases placed on file for investigation and prosecution by a procuratorate are normally handled by a case handling group of prosecutors. A simple case can also be handled by a sole prosecutor. Decisions regarding the preliminary investigation, filing, conclusion of investigation and the like of these cases are provided with suggestions by head prosecutors or sole prosecutors, examined by the head of the duty-related crime investigation department and then made by the chief procurator. In these cases, the handling power and the decision-making power are separated because investigation is very administrative, and many cases are complicated and sensitive, objectively requiring necessarily hierarchical leadership and centralized, unified direction. 
3. Lawsuit supervision and other legal supervision cases, which are complicated, can be handled by sole prosecutors or case handling groups of prosecutors; sole prosecutors and head prosecutors, responsible to the chief procurator, make decisions on case handling related matters. Suggestions on correcting offences, procuratorial suggestions, suggestions on ceasing to examine, on not supporting application for supervision or on counterappeal to be made in the name of a people's procuratorate should be made by the chief procurator or the procuratorial committee after the head of the business department examines or holds a meeting to discuss them and then reports.

Confirmation and bearing of judicial responsibilities.

«Possession of powers can negatively lead to power expansion and corruption»[7]. The integration of and consistency between power and responsibility is the key to fully implementing the prosecutor's case handling responsibility system. Judicial responsibilities include the responsibility for deliberately violating laws and regulations, the responsibility for gross negligence, and the responsibility for supervision and management. Confirmation of judicial responsibilities should first stress the consistency between subjective fault and objective behaviour. Procuratorial personnel should be held responsible when deliberately violating laws and regulations no matter consequences are caused or not. However, they should be held responsible for gross negligence only when serious consequences are caused. Also, they should be held responsible for supervision and management only when they are deliberate or have gross negligence, and cause serious mistakes in judicial case handling. An accusation against a prosecutor, after being investigated and verified by the discipline supervision and inspection organ of a procuratorate which believes that the prosecutor should be held responsible, should be reported to the chief procurator for making a decision and referring it to a neutral prosecutors disciplinary committee to deliberate and offer a proposal.

The bearing of judicial responsibilities involves the following situations: 1) for a case handled and decided by a sole prosecutor, the sole prosecutor should be held responsible; 2) for a case handled by a case handling group of prosecutors, the head prosecutor and other prosecutors should be held jointly responsible; the head prosecutor should be responsible for the decisions made within his/her powers, and other prosecutors should be responsible for their respective behaviour; 3) a prosecutor who is responsible for examination and checking when auxiliary procuratorial personnel are involved in judicial case handling should bear corresponding responsibility; 4) for matters to be decided by the chief procurator or the procuratorial committee, prosecutors are responsible for the facts and evidence, and the chief procurator or the procuratorial committee, for deciding the matters. If a prosecutor, when reporting a case to the chief procurator or the procuratorial committee or when handling a case, deliberately conceals or distorts the facts, or omits important facts, evidence or circumstances, leading to the chief procurator or the procuratorial committee's wrong decision making, the prosecutor should bear the responsibility; 5) in the event that a prosecutor reviews and changes the original opinion as required by the chief procurator, the prosecutor and the chief procurator should jointly bear the responsibility; 6) the chief procurator, if changing a prosecutor's decision, should be responsible for the changed part; 7) a member of the procuratorial committee is not judicially responsible for the opinions passed by him/her according to his/her knowledge of law when discussing and deciding a case on the procuratorial committee. A member of the procuratorial committee, if deliberately violating laws and regulations or committing gross negligence causing the procuratorial committee to make wrong decisions, should bear corresponding judicial responsibilities.

3. Development and improvement of China's prosecutor's case handling responsibility system.

The prosecutor's case handling responsibility system is systematic. Besides defining a prosecutor's duty and extent of power, case handling organization and mode and the judicial responsibility system and addressing other important issues, the system must be continuously improved to integrate reform of the prosecutor's case handling responsibility system, the system for classified management of judicial personnel, the policy of appointing a specified number of prosecutors, enhancement of prosecutors' job security and the like, and necessary mechanisms must be established, and supporting measures must be launched. They include, among others:

Establishing a case undertaking confirmation mechanism.

Case distribution is an important judicial management activity. A scientific, reasonable case distribution mechanism plays an important role in securing judicial justice and improving judicial credibility. In most countries, judicial case handling judges and prosecutors are appointed randomly. Therefore, a case undertaking confirmation mechanism primarily based on random distribution of cases and complementarily based on assignment of cases combined with unified handling of cases by the case management department should be established. The specified number of prosecutors, including the chief procurator, the deputy chief procurator, and full time members of the procuratorial committee, should be included in the list of handling prosecutors. A case will be randomly distributed by the case management system to the sole prosecutor or the case handling group of prosecutors. An important, difficult and complicated case can be handled by a case handling group of prosecutors or a sole prosecutor appointed by the chief procurator. To alter the result of random distribution of cases, the reason should be explained.

Improving the prosecutors' performance appraisal system.

«Sound operation of a system needs human support»[8]. A scientific performance appraisal system can effectively encourage and increase prosecutors' willingness to work and sense of responsibility, impelling prosecutors to legally perform their duties. Fair, reasonable appraisal of prosecutors' performance is very important to enhancing management of the specified number of prosecutors and promoting the implementation of the judicial responsibility system. The existing appraisal system is imperfect, and the appraisal procedure and method need improvement. It is needed to follow the law of judicial case handling and the characteristics of procuratorial work, and file the judicial records of procuratorial personnel to establish a prosecutor performance appraisal system primarily based on performance of duties, numbers of cases handled, quality and effect of cases handled, judicial skills, external appraisal and the like. 
Establishing the working mechanism of the prosecutors disciplinary committee

It is needed to properly design the institutions of the disciplinary committee, especially its constitution, working mechanism, deliberation procedure and the like, based on accurate identification of its role. In practice, three points should be heeded: 1) the prosecutor selection committee[9] and the disciplinary committee should preferably be separated, consist of different personnel, and follow different deliberation procedures. As the selection committee and the disciplinary committee have totally different functions, when the same committee both selects and discipline, it is functionally conflicting, and this may impede prosecutors' legal performance of their duties; 2) the disciplinary committee system and the existing discipline supervision and inspection system of procuratorial organs should be properly integrated. The disciplinary committee primarily considers whether or not a prosecutor deliberately violates laws and regulations or commits gross negligence, and then suggests irresponsibility, dissolution of responsibility, or discipline. Investigation of judicial responsibilities and the like are still to be decided by the Party committees of discipline supervision and inspection organs and procuratorates, the chief procurators' meeting and the like according to existing rules and procedures; 3 ) it is needed to make the most of the role of the disciplinary committee. A procuratorial organ should value and respect the disciplinary committee's suggestion for irresponsibility, dissolution of responsibility, or discipline; when the disciplinary committee's suggestion is not adopted, the reason should be fully explained and properly communicated to uphold the due authority of the disciplinary committee.

Enhancing prosecutors' job security.

Only when a sound mechanism for protecting judicial personnel in performing their legally mandated duties is established to fully protect judicial personnel in legally, independently and justly exercising their judicial powers, can they be reasonably held responsible for misjudged cases[10]. In September 2015, the Leading Group for Deepening Reform Comprehensively under the Party Central Committee examined and approved Scheme for Pilot Reform of Providing Judges and Prosecutors with Independent Classes of Positions and Scheme for Pilot Reform of the Judges and Prosecutors' Pay Systems, which stress the professional characteristics of judges and prosecutors, and provide judges and prosecutors with special policies, independent classes of positions differing from those for other government employees and a payroll distribution mechanism closely related to their duties, performance and contributions. The Fourth Plenary Session of the 18th CPC Central Committee proposed that "a sound mechanism for protecting judicial personnel in performing their legally mandated duties be established, and judges and prosecutors should not be transferred, dismissed, demoted or otherwise punished without legal causes and procedures". Currently, the Central Politics and Law Committee is developing opinions about improving the judicial personnel' duty performing protection mechanism. With the deepening of reform of the judicial system and the successive launching of relevant reform measures, the system to ensure that procuratorial personnel can perform their duties will be considerably improved.

\section{Literature}

1. The main-suit prosecutor's case handling responsibility system, implemented in the department responsible for examination before prosecution, is a prosecutors' case handling system in which the main-suit prosecutor, under the leadership of the chief procurator, is the main responsible person.

2. The chief handling prosecutor's case handling responsibility system is a case handling system in which the chief handling prosecutor, under the leadership of the chief procurator and the head of the investigation department, is the directly responsible person having full authority to decide matters within the scope of his/her duty.

3. The head prosecutor's case handling responsibility system is a system in which under the leadership of the chief procurator, a case handing group consisting of the head prosecutor and a number of prosecutors independently exercises the power to decide cases within the scope of authority and is responsible for case handling.

4. Sun Qian: «Keeping to the path of socialist rule of law with Chinese characteristics», in Criminal Science, no. 3, 2013.

5. According to the scheme for classified management of judicial personnel confirmed by the central government, procuratorial personnel include prosecutors, auxiliary procuratorial personnel (including assistant prosecutors and clerks) and judicial administrative personnel.

6. Shao Hui: «An academic analysis of the reform of China's prosecutor's case handling responsibility system», in Hebei Law Science, no. 12, 2015.

7. Zhang Shuming: «On the development of the right of public prosecution under the control of powers», in Criminal Science, no. 3, 2014.

8. Li Jia: «Substantive rule of law and trust», in Jinan Journal (Philosophy and Social Science Edition), no. 4, 2014.

9. The prosecutor selection committee, normally consisting of deputies to the National People's Congress and members of the Chinese People's Political Consultative Conference who are law graduates or have experience in legal work, as well as legal scholars, lawyers, prosecutors and the like, is a neutral third party organization that selects professional prosecutors fairly and transparently.

10. Wang Minyuan: «Enhancing the building of prosecutors' job security system», in Procuratorial Daily, December 30, 2014. 


\section{СОДЕРЖАНИЕ}

Предисловие

\section{І. КОНСТИТУЦИОННО-ПРАВОВЫЕ И АДМИНИСТРАТИВНО-ПРАВОВЫЕ ИНСТИТУТЫ СТРАН АТР: СРАВНИТЕЛЬНО-ПРАВОВОЙ АСПЕКТ}

Алексеева Е.С. Развитие страхования в Китае.

Аюшиев Д.Б. Сравнительно-правовой анализ конституционного статуса глав государств Республики Казахстан и Российской Федерации

Багдуев Р.А. Проблемы развития демократии в конституционной доктрине США и Российской Федерации.........

Баиров С. А. Сравнительный анализ системы налогового администрирования Японии и Российской Федерации...

Баннова Ю.А. Бюджетный процесс в России и КНР.

Бернадская К.М. Сравнительно-правой анализ защиты социальных прав на примере Российской Федерации и КНР

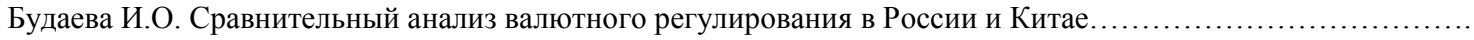

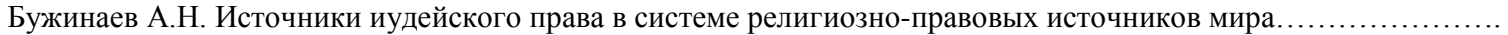

Васильева Н.Л. Административно-территориальное устройство КНР и РФ: сравнительно-правовой анализ..........

Гатаулина О.А. Вопросы параллельного импорта в Евразийском экономическом союзе.

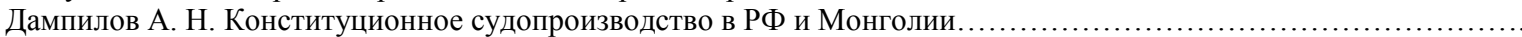

Дондупова Л.Э. Бюджетный федерализм в Российской Федерации.

Жамбалова О.С. Сравнительный анализ правового статуса Народного Банка Китая и Центрального Банка Российской Федерации

Зуева В.Е. Адаптация опыта США при привлечении к ответственности за налоговые преступления в России......

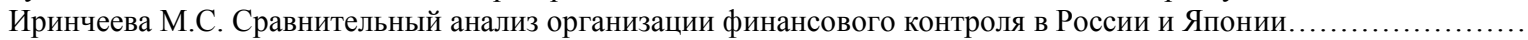

Капустина Д.П. Повышение правовой культуры молодёжи: пути и способы решения (на материалах Республики

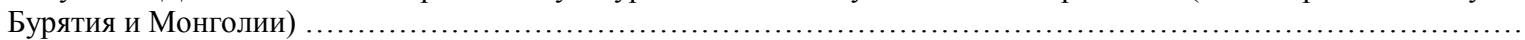

Клементьев А.В. Сравнительный анализ некоторых аспектов федерализма Малайзии и России.........................

Красикова К.В. Досудебное урегулирование налоговых споров в КНР.

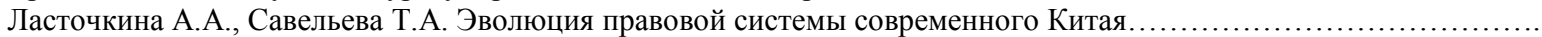

Павлова И.А. Сравнительно-правовой анализ налогообложения Сингапура и России. .

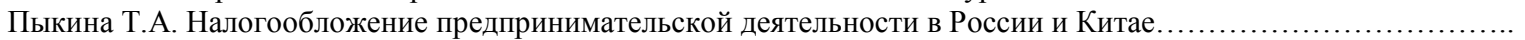

Санжижапов Р.-Д.С. Формирование и развитие Азиатско-Тихоокеанского регионализма..

Санжицыбиков К.Д. Системы регистрации прав на недвижимое имущество в странах Азиатско-Тихоокеанского

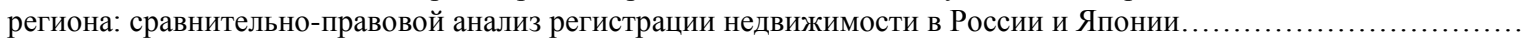

Сверкунов С.П. Воздействие на экосистему озера Байкал при строительстве ГЭС «Шурен» на территории Монголии....

Тетерин А. Н. Краткая характеристика реализации свободы выражения мнения в Австралийском союзе...............

Тышкенова А.Г. Правовой статус государственного служащего в Российской Федерации и Монголии (сравнительное исследование).....

Цыбикова Б.Ч. Конституционные основы организации денежного обращения в Российской Федерации и странах АТР...

Шайдорова М. М. Транспарентность государственных органов в России и Канаде: сравнительно-правовой анализ..

Wang Ru, Guan Fengrong. The Perfection of Financial Transfer Payment System in the Perspective of The Equalization of

Basic Public Service.

\section{ІІ. МЕЖДУНАРОДНОЕ ПРАВО И МЕЖДУНАРОДНЫЕ ОТНОШЕНИЯ}

Алексеева В.А. Военно-техническое сотрудничество России и Китая.

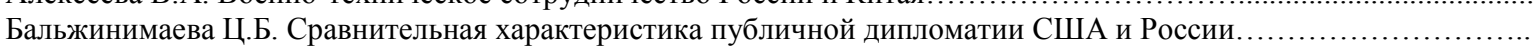

Варнакова М.М. Институт права частной собственности в Риме в доклассический и классический периоды.........

Галецкая Г.С. Азиатская и Европейская конвенции по правам человека: сравнительно-правовой анализ.

Ганхуяг Алтандош. Орос монголын хоорондын харилцаа хx-хі-p зуунд: дипломат харилцааны гэрээ байгуулсанаас өнөөг хүртэл.

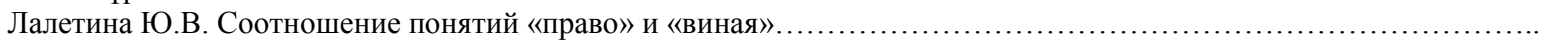

Мадаев Е.О. Соотношение национальной доктрины Российской Федерации с международной доктриной............

Максарова Р.И. Проблема правового регулирования авторского права в России и Китае................

Цыденова А.В. Практика предоставления дипломатического убежища в странах АТР. ....

Чимитдоржиева В.Ж. Сравнительный анализ экологического законодательства РФ и КНР

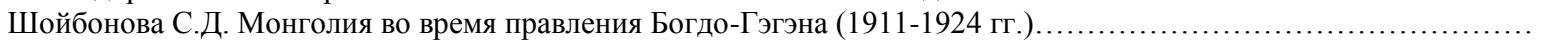

Южикова Е.А. Конфликт интересов США и КНР в Азиатско-Тихоокеанском регионе.

\section{ІІІ. ГРАЖДАНСКО-ПРАВОВЫЕ ПРОБЛЕМЫ СРАВНИТЕЛЬНОГО ПРАВОВЕДЕНИЯ В СТРАНАХ АТР}

Баиров С.А. Перспективы введения в России института частных судебных приставов на примере стран АТР.........

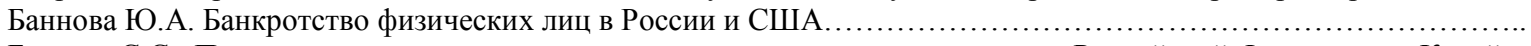
Батуева С.С . Правовое регулирование трудового договора в законодательстве Российской Федерации и Китайской Народной Республики..

Домшоева В.С. Правовое регулирование труда несовершеннолетних работников: сравнительный анализ РФ и Китая....

Жамбалова О.С. Порядок раздела общего имущества супругов в России и странах Азиатско-Тихоокеанского региона....

Иринчеева М. С. Предоставление земельных участков из государственных и муниципальных земель в России и Монголии: сравнительный анализ. 
Ковалёва А.А. Институт усыновления по русскому праву и обычному праву монголов: сравнительный анализ.....

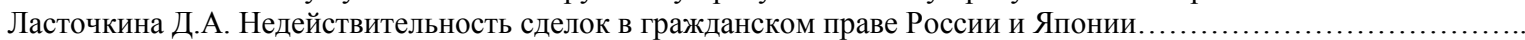

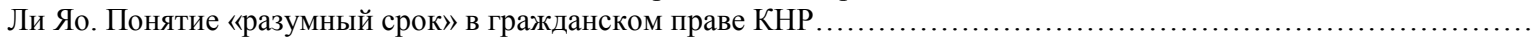

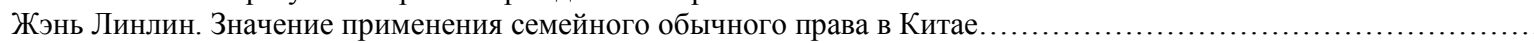
Лосева Ю.К. Особенности несостоятельности (банкротства) физических лиц в России и Южной Корее............... Мантатова С.М. Сравнительно-правовой анализ договора аренды земельного участка в России и Китае...............

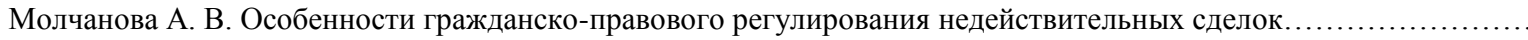
Мункуева С.Ц. Правовое регулирование страхования ответственности туристических агентств в КНР.... Очирова Э.С. Сравнительный анализ суррогатного материнства в Российской Федерации и Китайской Народной Республики..

Павлова И.А. Актуальные проблемы осуществления личных неимущественных прав супругов на примере России и США Петрова Е.Ю. Юридическая процедура покупки «жилой» недвижимости нерезидентами в Российской Федерации и Социалистической Республике Вьетнам: сравнительно-правовой анализ.....

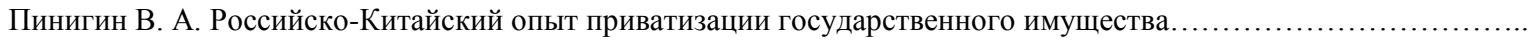
Побежимов Д.М. Сравнительно-правовой анализ посреднических договоров по законодательству Российской Федерации и Китайской Народной Республики......

Пыкина Т.А.Правовое регулирование товарного знака в России и Китае.

Самсонова В.О.Особенности режима труда работников, воспитывающих ребенка-инвалида по трудовому законодательству России, Узбекистана, Туркменистана и Таджикистана.....

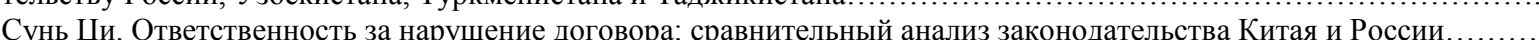
Трофимова Е.П. Сравнительно-правовое исследование права собственности на недвижимость в зарубежных странах на примере Монголии и Южной Кореи.....

Фань Цзинчжао. Сравнительно-правовой анализ между Россией и Китаем: примерные условия в договоре куплипродажи.

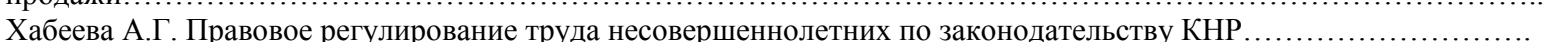

Цыденова В.С. Имущество должника в рамках исполнительного производства России, США, Китая и Японии....... Цыденова О.Ч. Частная собственность на землю в России и Монголии: сравнительный анализ.......................

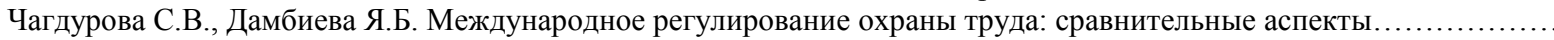
Чжао Лэ. Краткий анализ настоящего положения о защите персональных данных граждан в КНР....

Чэнь Си. Раздел недвижимости супругов при разводе по закону КНР......

Шагдаров Т.Н. Ипотечное кредитование в России и Индонезии: сравнительно-правовой анализ.....

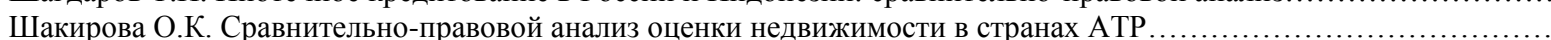
Юй Хай, Лумбунова М.Э. Сравнительно-правовой анализ правового регулирования в области ограничения недобросовестной конкуренции в России и Китае.

\section{IV. УГОЛОВНО-ПРАВОВЫЕ И КРИМИНОЛОГИЧЕСКИЕ ПРОБЛЕМЫ СРАВНИТЕЛЬНОГО ПРАВОВЕДЕНИЯ В СТРАНАХ АТР}

Байкалов А.С. Профилактика коррупции в образовании: опыт Китая.

Балаганская А.С. Анализ опыта легализации оружия в США и право на ношение оружия в России: сравнительноправовая характеристика..

Батоев Б.Б. Актуальные проблемы противодействия коррупционной деятельности в Российской Федерации и Китайской Народной Республике.

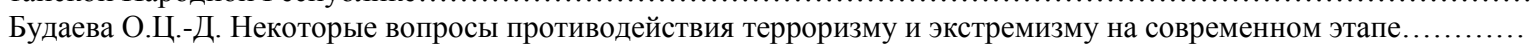

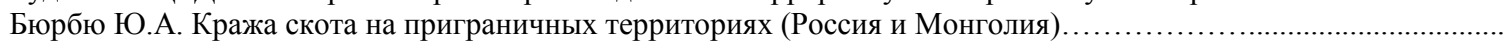

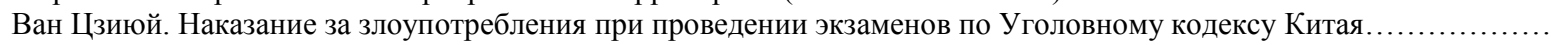

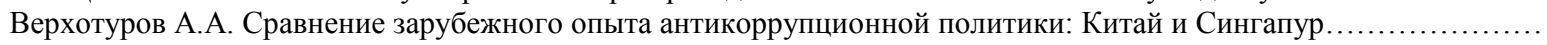

Вторушина А. С. Особенности уголовной ответственности за мошенничество по законодательству России и Китая

Гао Япэн. К вопросу профессионального запрета в Уголовном кодексе КНР....

Гасанова Э.М. Генезис уголовной ответственности за похищение человека по законодательству России и Азербай-

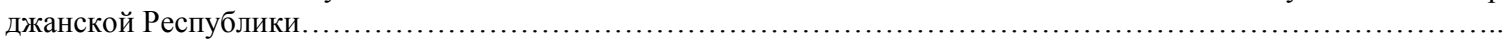

Григорьева С.В. Особенности уголовной ответственности за мошенничество в сфере кредитования по законодательству России и США.....

Дашинимаев Б.Б. Уголовная ответственность за совершение дорожно-транспортнох происшествий (сравнительноправовой анализ законодательства России и Китая)......

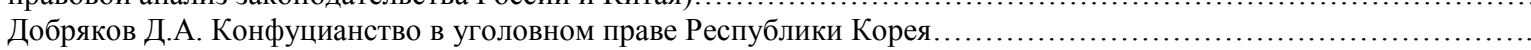

Дондокова А.Л. Сравнительно-правовой анализ уголовного законодательства о преступлениях против половой неприкосновенности несовершеннолетних России и США...

Дондокова Д.В. Особенности уголовной ответственности и наказания несовершеннолетних в уголовном праве России и Китая.

Дондупова Ж.Б. Международный терроризм и способы борьбы с ним в крупнейших странах АТР (на примере Китая, США и России)......

Доржиева А.Г. Незаконный оборот наркотических средств и психотропных веществ и противодействие ему в Российской Федерации и Китайской Народной Республике..

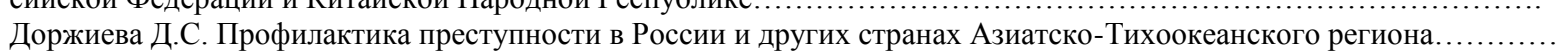
Доржиева Х.Ю. Применение условного осуждения по уголовному законодательству России и Японии: сравнительно-правовой анализ.

Дружинина Л.В. Виктимологическая профилактика насилия в России и Японии: сравнительно-правовая характеристика.... Зуев П.П. Преступность в России и США: сравнительный анализ......

Ижийт Баатар Баясгалан. Реформы в системе уголовного наказания Монголии. 
Кобылкин А.В. Сравнительный анализ наказаний за преступления, носящие террористический характер в РФ, Ки-

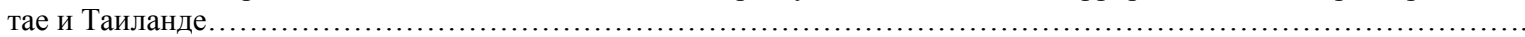
Латыпова К.С. Особенности уголовной ответственности за дорожно-транспортные преступления: сравнительно-

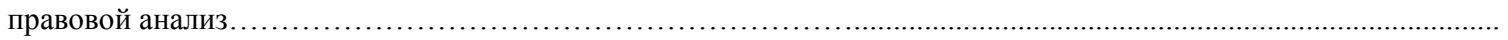

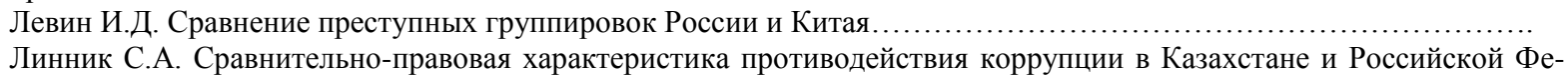
дерации.

Манзыев С.Б. Сравнительно-правовой анализ квалификации дачи, получения взятки в России и Китае.

Мохосоева Е.А. Проблема соблюдения прав женщин, содержащихся в исправительных колониях: опыт некоторых стран АТР.

Мурзинова О.А. Нелегальный оборот наркотических средств, психотропных веществ в странах АТР: основные направления борьбы и их результаты (на примере КНР).

Найданова Е.В. Международный правовой опыт назначения наказания с учетом гендерных признаков по законодательству стран АТР.

Оболов Л.Т. Опыт борьбы с коррупцией в странах АТР

Сапарбаев Д.С. Законодательная конструкция грабежа в уголовном законодательстве Китая, Кыргызстана и России Сахинов В.А. Развитие системы наказаний в уголовном праве некоторых стран АТР.

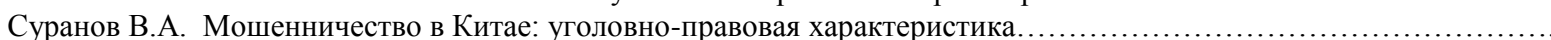

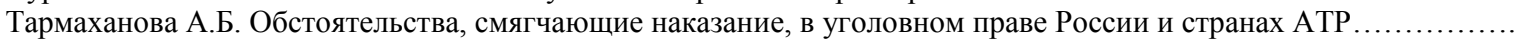
Телятников Е.В. Сравнение института ограниченной вменяемости в уголовном законодательстве РФ и ряде других стран.

Хармаева Э.Ю. Использование зарубежного опыта в повышении эффективности предупреждения правонарушений среди несовершеннолетних (на примере Монголии и Японии).

Цзан Цземэй. Обзор «Закона о борьбе с терроризмом» Китая.

Цыцыков А.В. Неисполнение обязанностей по воспитанию несовершеннолетнего по уголовному законодательству

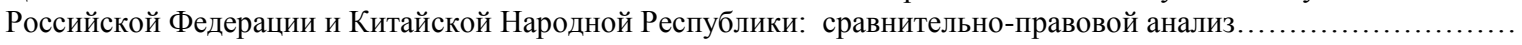

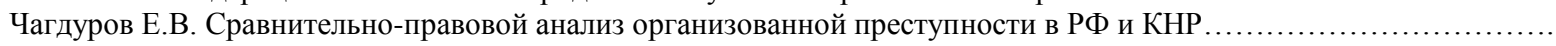
Чернышев И.А. Кибертерроризм.

Чжан Синь. О преступлении против порядка судебного заседания.

Чимитдоржиева Г.Т. Сравнительно-правовой анализ судебного толкования уголовно-правовых норм в Российской

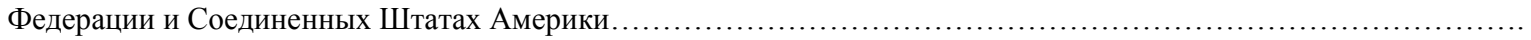

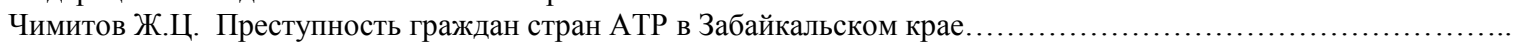
Шаргакшанова 3.Ж. Уголовная ответственность военнослужащих в России и США: сравнительно-правовой анализ Яковлев О.Д. Незаконное проведение искусственного прерывания беременности: сравнительно-правовой анализ субъекта состава преступления по УК РФ и УК Японии..

Chen Na. Criminal law interpretation of «firearms» in firearms-related crimes in China on behavior regulation of firearmsrelated crimes.....

Guo Donglei. On the death penalty with reprieve.

\section{V. УГОЛОВНО-ПРОЦЕССУАЛЬНЫЕ И КРИМИНАЛИСТИЧЕСКИЕ} ПРОБЛЕМЫ СРАВНИТЕЛЬНОГО ПРАВОВЕДЕН ИЯ. ПРАВООХРАНИТЕЛЬНЫЕ ОРГАНЫ В СТРАНАХ АТР

Аносова С.И. Особенности процессуального положения свидетеля в процессе РФ и США...... Бродникова А.В. Право подозреваемого на защиту в уголовном судопроизводстве Китайской Народной Республики и Российской Федерации...... Будникова К.О. Сравнительно-правовой анализ американской сделки о признании вины и особого порядка судебного разбирательства российского уголовного судопроизводства.

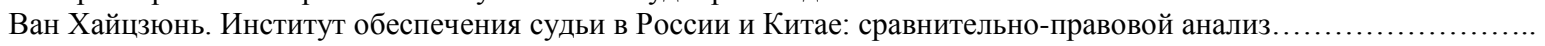
Васильев Б.И. Особенности производства допроса подданных Японии.....

Викулов О.В. Достоверность как основное условие использования результатов оперативно-розыскной деятельности в доказывании.

Гатилова А.М. Сравнительный анализ доказывания в уголовном судопроизводстве на стадии предварительного

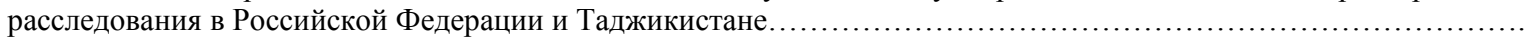
Дармаева М.В. Особенности расследования убийства матерью новорожденного ребенка в некоторых странах АТР...

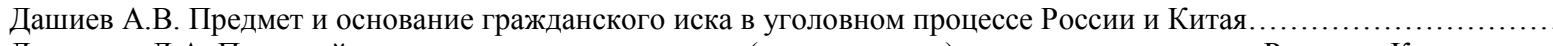
Доржиева Д.А. Правовой статус жертвы преступления (потерпевшего) в уголовном процессе России и Казахстана.. Дымбрылова В.В. Сравнительно-правовой анализ использования видеоконферецсвязи в уголовном процессе РФ и США Каминский Д.Я. Законодательство РФ и Китая, регламентирующее институт защиты в уголовном процессе: сравнительный анализ.

Коровин Н.К., Крахмалёва К.И. Особенности методики расследования вымогательства в России, Казахстане и Китае....

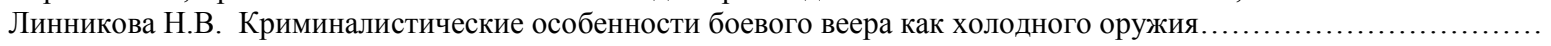
Лумбунова М.Э. Сравнительно-правовой анализ регулирования в сфере недопустимых доказательств............... Мамаева Р.О. Сравнительный анализ уголовно-процессуального законодательства Российской Федерации и стран СНГ на предмет обеспечения прав и законных интересов участников уголовного судопроизводства, имеющих физические недостатки.

Хойд Баатар Мунхбаатар. Некоторые правовые вопросы по обеспечению психологической помощи в уголовноисправительной системе Монголии.....

Петрова Е.Ю. Полномочия прокурора в досудебном производстве по уголовно-процессуальному законодательству России и Вьетнама. 
Потапова А.В. Сравнительный анализ правового статуса показаний подсудимого в уголовно-процессуальном законодательстве США и РФ....

Раздрогин А.В. Процессуальные особенности производства по уголовным делам о преступлениях несовершеннолетних в РФ и КНР: сравнительно-правовой анализ.

Редикальцева Н.Н. Особенности примирения с потерпевшим в уголовном законодательстве России и Казахстана...

Сухеев С.Н. Криминалистическая характеристика лиц, совершаемых преступления, связанные с незаконным оборотом наркотиков в России и Китае: сравнительно-правовой аспект......

Танхаева Л.В. Сравнительно-правовой анализ статуса прокуратуры РФ и США.

Филиппова А.П. Институт адвокатской тайны по законодательству России и Китая.....

Фоминых А.В. Особенности производства дактилоскопических экспертиз в России и Монголии: сравнительно-

правовой анализ.

Чжан Цзиньхуэй. Коротко об адвокатской деятельности и адвокатуре в КНР...

Ши Мэн. Примирение сторон по уголовным делам в Китае.

Щербина М.А. К вопросу об эффективности проведения очной ставки: сравнительный анализ норм УПК РФ и УПК Китая.

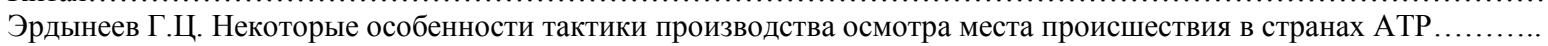

Юань И. Типология производств о применении принудительных мер медицинского характера России и Китая на фоне западного права в свете нового Уголовно-процессуального кодекса КНР 2012 года

$\mathrm{Bu}$ Yangyang . Analysis of the Evolution of Criminal File Transfer System in China.

Gui Mengmei. On Jurisdiction of Terrorism Crime Lawsuit in China.

Wang Shaojia. Application of Detention in Crimes of Drug Trafficking in China........

Zhang Zichao. Reform and Development of China's Prosecutor's Case Handling Responsibility System.

Научное издание

\section{СРАВНИТЕЛЬНОЕ ПРАВОВЕДЕНИЕ В СТРАНАХ АЗИАТСКО-ТИХООКЕАНСКОГО РЕГИОНА - VII}

Материаль международной научно-практической конференциии молодых ученых, аспирантов, магистрантов и студентов

(Улан-Удэ, 15 апреля 2016 г.)

Компьютерная верстка Ж. В. Галсановой

Свидетельство о государственной аккредитации № 1289 от 23 декабря 2011 г.

Подписано в печать 18.09.16. Формат 60x84 1/8. Уч.-изд. л. 43,91. Усл. печ. л. 39,76. Тираж 200. Заказ 204. Цена договорная.

Издательство Бурятского госуниверситета 670000, г. Улан-Удэ, ул. Смолина, 24 а riobsu@gmail.com

Отпечатано в типографии Бурятского госуниверситета 670000, г. Улан-Удэ, ул. Сухэ-Батора, 3 a

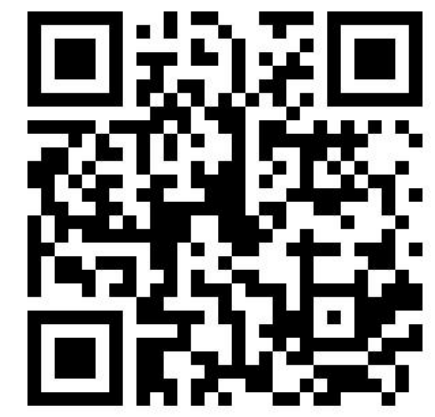

